\title{
MEMORIA E INNOVACIÓN EN EL MUSEO DE ARTE
}

TESIS DOCTORAL

Autor:

Director:

Programa:

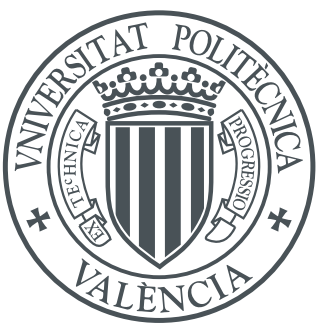

\section{Manuel Portaceli Roig}

Arquitecto y Profesor Titular de Escuela Universitaria.

Jorge Torres Cueco

Doctor Arquitecto

Catedrático del Departamento de Proyectos Arquitectónicos.

Proyectos Arquitectónicos

Proyectar desde el territorio una mirada moderna

\section{Escuela Técnica Superior de Arquitectura}

Universidad Politénica de Valencia

Valencia, Septiembre de 2012

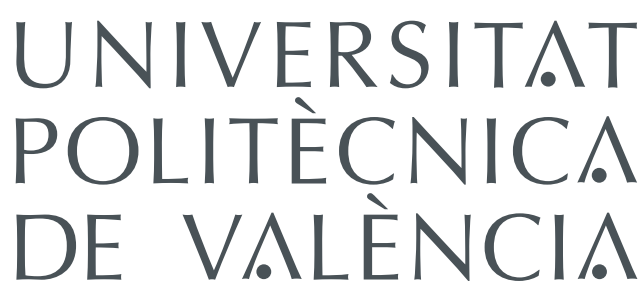


.. MEMORIA E INNOVACION

EN EL MUSEO

DE ARTE

TESIS DOCTORAL

Manuel Portaceli Roig.

Escuela Técnica Superior de Arquitectura. UPV 


\title{
MEMORIA E INNOVACIÓN EN EL MUSEO DE ARTE SUMARIO
}

\section{El proyecto de arquitectura desde el tema-programa}

\section{y el lugar}

\author{
1.1. Un planteamiento $1-5$ \\ 1.2. Una lectura del contexto 1-8 \\ 1.3. Necesidad de una forma de acercamiento 1-12 \\ 1.4. La Historia como fondo $1-15$ \\ 1.5. El proyecto de arquitectura 1-18 \\ Notas $1-24$
}

\section{Una concreta experiencia proyectual}

2.1. Introducción 2-1

2.2. Cómo intervenir, cómo reconvertir, cómo ver el arte 2-4

2.3. La intervención en edificios históricos.Criterios 2-5

2.3.1. Ampliar edificios históricos 2-8

2.4. Reconfiguración de espacios urbanos 2-9

2.5. El museo: evolución y desarrollo 2-12

2.6. Los cinco museos 2-13

2.6.1. Palacio del Marqués de Campo (1984-1989) 2-13

2.6.2. El Almudín de Xátiva (1983-1989) 2-15

2.6.3. Las Atarazanas de Valencia (1979-1993) 2-17

2.6.4. Rehabilitación y Ampliación del Neues Museum de Berlín 2-21 (1993-95)

2.6.5. Rehabilitación y Ampliación del Museo de Bellas Artes de 2-24 Valencia (1985-1996)

2.7. A modo de conclusión 2-28

Notas $2-30$

\section{El Museo de Arte}

3.1. El museo y el pensamiento llustrado 3-1

3.2. Necesidad del Museo 3-2

3.3. Definición y objetivos del Museo de Arte 3-5

3.4. Redefinición del Museo de Arte 3-8

3.5. El primer museo público. Su impacto social 3-10

3.6. Importancia del Museo de Arte en el debate arquitectónico 3-13

3.6.1. El museo define ciudad 3-15

3.6.2. El museo en contextos históricos 3-16 
3.6.3. El museo y la relación entre lo nuevo y lo viejo 3-16

3.6.4. El museo como arquitectura autónoma 3-18

3.6.5. El museo y la definición del lugar-ambiente 3-19

3.7. Breve génesis de los espacios expositivos 3-20

3.7.1. Antecedentes 3-20

3.7.2. Durand y el Gran Museo del siglo XIX 3-31

3.7.3. El Museo de Arte y los "pioneros del Movimiento Moderno" 3-47

3.7.4. El Contenedor 3-54

3.7.5. Louis Kahn: una nueva impostación 3-60

3.7.6. El nuevo programa del Museo de Arte 3-66

3.7.7. Museo de Arte: Programa y organización 3-76

3.7.8. Los grandes museos del último cuarto del S. XX 3-81

3.7.9. Pequeños museos atentos al lugar 3-101

Notas 3-109

\subsection{Museo de la Ciudad: Restauración y Rehabilitación del Palacio del Marqués de Campo}

4.1.-1

4.1.2. Breve historia del lugar y del edificio

4.1.-2

4.1.2.1. Origen del palacio

4.1.-2

4.1.2.2. El palacio y el lugar

4.1.-3

4.1.2.3. La residencia del Marqués de Campo

4.1. -5

4.1.3. Año 1983. El palacio antes de la intervención

4.1.-9

4.1.4. El proyecto de intervención: Objetivos y criterios

4.1.-13

4.1.5. La intervención

4.1.-18

4.1.5.1. El patio y las fachadas del Palacio del Marqués de Campo

4.1. -26

4.1.5.2. El espacio interior. Planta Baja

4.1.-27

4.1.5.3. El espacio interior. Planta Noble

4.1.-27

4.1.5.4. Plantas ático

4.1.-29

4.1.5.5. El invernadero

4.1. -29

4.1.6. De Palacio del Marqués de Campo a Museo de la Ciudad.

4.1.-30

Criterios organizativos. Usos y accesos

4.1.6.1. Programa: Usos y accesos

4.1.-30

4.1.6.2. Recorridos y relación espacio interior-espacio exterior

4.1.-34

4.1.6.3. Visuales

4.1.-37

4.1.6.4. La iluminación

4.1.-37

Notas

4.1.-38 


\subsection{Rehabilitación del Almudín de Xàtiva para Museo \\ Municipal}

4.2.1. Breve historia del lugar y del edificio 4.2-1

4.2.2. El edificio antes de la rehabilitación 4.2-3

4.2.3. Objetivos y criterios de intervención 4.2-6

4.2.4. Descripción de la intervención 4.2-18

\subsection{Rehabilitación de las Atarazanas}
4.3.1. Introducción
4.3-1
4.3.2. Breve historia del lugar y del edificio
4.3-2
4.3.2.1. Origen de las Atarazanas
4.3-2
4.3.2.2. El lugar
4.3-3
4.3.3. Descripción del edificio
4.3-6
4.3.4. Antes de la intervención
4.3-10
4.3.5. Criterios de intervención
4.3-15
4.3.6. El proyecto de intervención. Objetivos
4.3-16
4.3.6.1. La liberación del espacio gótico
4.3-16
4.3.6.2. La plaza y el pabellón de servicios
4.3-18
4.3.6.3. Liberación del volumen primigenio. La fachada principal y
$4.3-20$
un porche de acceso
4.3.7. La intervención: Criterios constructivos y acciones. Criterios
$4.3-26$
constructivos
4.3.8. El espacio expositivo de las Atarazanas
4.3-30
Notas
4.3-35

\subsection{Neues Museum de Berlin}
4.4.1. Introducción
$4.4-1$
4.4.2. El programa museístico
4.4-2
4.4.3. Breve historia del edificio y el lugar
4.4-3
4.4.4. Descripción general del edificio
4.4-7
4.4.5. Estado del edificio y del entorno
4.4-8
4.4.6. Criterios de la intervención y descripción del proyecto
4.4-10
Notas
4.4-30 


\subsection{Museo de Bellas Artes de San Pío V}

4.5.1. Introducción 4.5-1

4.5.2. Breve Historia del Edificio 4.5-1

4.5.3. El lugar 4.5-6

4.5.4. Descripción del edificio. Estado anterior a la restitución 4.5-8

4.5.4.1. Descripción general del edificio 4.5-8

4.5.4.2. El estado del edificio antes de la intervención 4.5-10

4.5.5. Objetivos de la intervención 4.5-14

4.5.6. Criterios de intervención 4.5-16

4.5.7. Antecedentes del proyecto 4.5-18

4.5.8. Descripción de la intervención. 4.5-34

4.5.8.1. Relaciones entre lo nuevo y lo viejo 4.5-34

4.5.8.2. La necesaria eliminación de elementos impropios 4.5-34

4.5.8.3. La recuperación del espacio cupulado: el núcleo del 4.5-34

nuevo museo

4.5.8.4. La organización del nuevo Museo 4.5-36

4.5.8.5. Claustro y alas claustrales 4.5-37

4.5.8.6. El bloque lineal y las salas de exposición temporal 4.5-38

4.5.8.7. La ampliación y la exposición permanente 4.5-39

4.5.8.8. Los usos internos 4.5-42

Plantas: Usos, Recorridos y Visuales 4.5-43

4.5.9. Criterios organizativos. Usos y accesos 4.5-52

4.5.9.1. Programa: Usos y accesos 4.5-52

4.5.9.2. Recorridos y relación espacio interior-espacio exterior 4.5-53

4.5.9.3. Visuales 4.5-54

4.5.9.4. La iluminación 4.5-55

Notas

\section{Museos: Una antología personal}

6. Bibliografía 


\section{UNA JUSTIFICACIÓN}

El presente trabajo tiene su origen en la sucesiva, y a veces simultánea realización de proyectos relacionados con la exposición y conservación de obras de arte. Museos, cinco en total, galerías de arte y algunas casas para coleccionistas privados constituyeron, desde finales de la década de los 80 del siglo pasado, el fondo del escenario, un ciclorama, de mi actividad como arquitecto y como docente. $Y$ todo ello, en la mayoría de los casos, ligado a arquitecturas que el tiempo nos había legado, testimonios en un estado, en general, deplorable, reflejo quizás de una triste historia centenaria.

Los diferentes procesos proyectuales comportaban una investigación en diversas direcciones que explico más adelante en este trabajo.

A la búsqueda de la definición del museo, de sus objetivos y de su génesis, se une un auscultar la producción arquitectónica que se prolonga más allá de las fechas concretas de los proyectos realizados hasta alcanzar casi nuestros días, lo necesario para permitir que la reflexión que posibilita la distancia en el tiempo convierta en juicio razonado lo que surge de un acercamiento mediante el gusto.

Una antología personal del museo de arte, incluida en esta tesis, junto con unas fichas elaboradas sobre diferentes ejemplos contemporáneos fruto de mi continuado interés sobre el tema, completan el presente trabajo. Estas últimas han sido ideadas

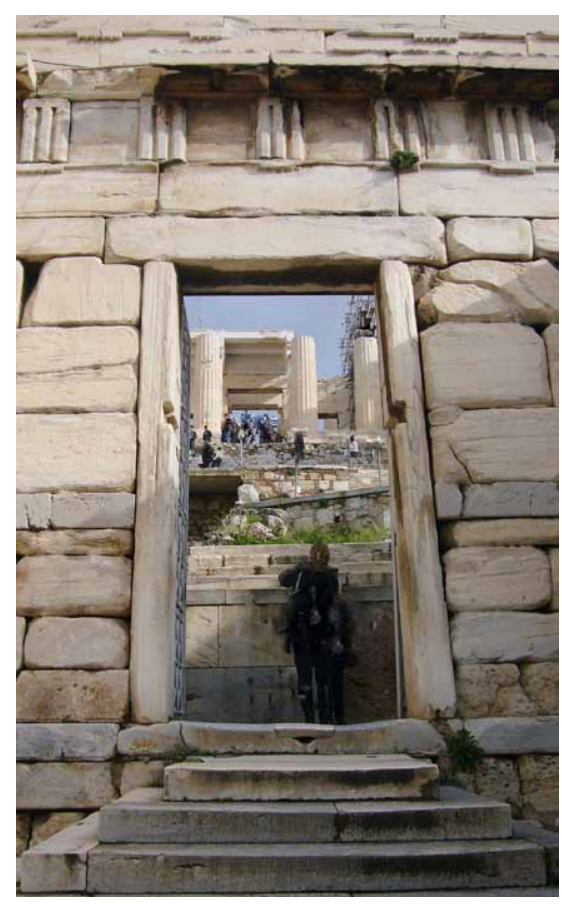


durante mi actividad como docente en asignaturas optativas, en las que en colaboración con los estudiantes se han desarrollado casos ejemplificados en la selección incluida en el anexo del presente estudio.

Una aproximación al apasionante e inagotable tema del proyecto de museo de arte constituyó, y constituye, la base de esta reflexión, llevada a cabo desde la soledad del "que hace". Acercamiento, por tanto, forzosamente personal. No en vano comienzo mi actividad formativa cuando el difuso existencialismo de la generación anterior ha provocado cambios radicales en la crítica arquitectónica, cuando la arquitectura se ve necesariamente comprometida con los datos pre-existentes, cuando triunfan la historia y las cualidades particulares. Anuncio quizás, todo ello, de la caída de los principios generales y de la fe en el progreso y de la necesidad de un compromiso particular que apuntale una radical inseguridad. Para alcanzar nuestros días, cuando redacto este trabajo, en la angustiosa y presurosa espera de que lo objetivo, por el que tanto hemos luchado, y lo subjetivo, sobre el que volvemos una y otra vez, se encuentren en un pliegue, el "pli" de los pensadores actuales que se produce, además y según ellos, por un desajuste de la realidad.

\section{Y UNA ADVERTENCIA}

“Toda cita realiza el sentido último de cualquier discurso con unos mínimos de conspicuidad: ser repetido". Tomo esta frase de Gombrovicz para tratar de justificar la aparición, a lo largo de este trabajo, de citas de las que no se menciona su procedencia, incluso algunas veces, ni su autor. Quisiera explicar esta circunstancia aclarando que han sido extraídas de cuadernos, lo que los ingleses llaman un common place book, en los que voy anotando frases que expresan con la palabra justa juicios, intuiciones, ideas que no había sido capaz de verbalizar cabalmente.

Walter Benjamin siempre abrigó el deseo de escribir un libro de citas. Al hacer suyos conceptos, experiencias de otros expresados en el marco de la cultura y tradición europeas, a la 
que, según él, había que volver con un sentido crítico y libre de perjuicios, liberaba a la cita de su contexto original impulsándola a ofrecer un nuevo sentido y una actualidad que iluminaba el camino del conocimiento.

A su vez y de forma complementaria, Wallace Stevens afirmaba que las citas tienen un interés especial ya que uno es incapaz de citar algo que no sea sus propias palabras, quienquiera que las haya escrito, en cualquier época, bajo otras circunstancias. Se trata pues de una apropiación creativa de lo que está ahí, en la palabra pública, para hacerla propia, para que pase a la palabra privada en aras de expresar con justeza lo que se quiere plantear.

Deseando, desde mi modestia, siquiera rozar en mi exposición lo que Juan Ramón Jiménez pretendía en aquel delicioso poema:" Intelijencia, dame/ el nombre esacto de las cosas! / que mi palabra sea/ la cosa misma,/ creada por mi alma nuevamente." (1) 


\section{MEMORIA E INNOVACIÓN EN EL MUSEO DE ARTE}

\section{El proyecto de arquitectura desde el tema- programa y el lugar}

\subsection{Un planteamiento}

En su libro "Seis propuestas para el próximo milenio" (2) Italo Calvino dedica el apéndice a "el arte de empezar y el arte de acabar", referido a la preparación de una conferencia. Leído hace ya varios años esperando, recuerdo, la salida muy retrasada del avión que me traería de Marsella, tuve la impresión de que con su agilidad y concreción habituales, Calvino sintetizaba, desde su experiencia como escritor y ensayista, la angustiosa, y gozosa a la vez, situación que se produce cuando los arquitectos, al iniciar

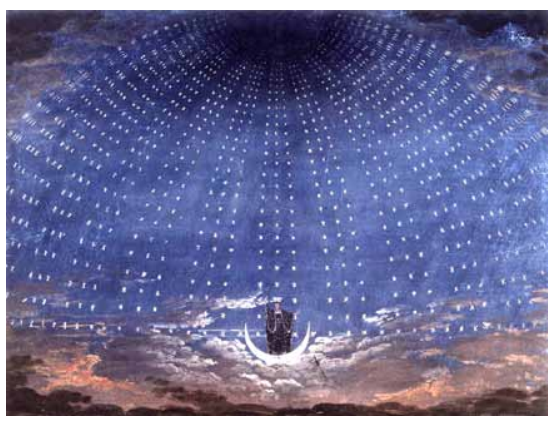

K.F. Schinkel: La Flauta Mágica de Mozart. Escenografía un nuevo proyecto, nos enfrentamos a la hoja en blanco.

Subrayé con el lápiz, doblé la esquina superior de la página, y creo que, además, coloqué después la tarjeta de embarque.

Considero que este "arte de empezar", objeto de tan señalado fragmento, es muy útil, todavía hoy, para mostrar el planteamiento del que se parte para el desarrollo del presente trabajo y de su mano desgranar una serie de consideraciones. En la nota a pie de página se incluye el texto completo para mayor información del lector.

“Empezar (...) es el instante de la elección: se nos ofrece la posibilidad de decirlo todo (...); y tenemos que llegar a decir algo". Podemos estar de acuerdo en que una arquitectura debe saber encontrar la respuesta adecuada a una situación concreta. Pero: ¿qué necesitamos para iniciar la acción de empezar?

Ante esta situación sentimos, en ocasiones, una sensación de ahogo, cierta angustia ante la hoja en blanco (el ordenador más tarde, por favor) pero: "La vida es siempre un naufragio,-nos advierte José Ortega y Gasset- pero naufragar no es ahogarse" (3). Y nos aclara que el necesario movimiento de brazos que llevamos a cabo para no ahogarnos es la cultura.

El campo que nos ofrece la cultura es prácticamente 
ilimitado: "Tenemos a nuestra disposición el mundo -el que para cada uno de nosotros constituye el mundo, una suma de datos, de experiencias, de valores- el mundo dado en bloque, sin un antes y un después, el mundo como memoria individual y como potencialidad implícita" y además "disponemos de todos los lenguajes: los elaborados por la literatura, los estilos en los que se han expresado civilizaciones e individuos en todos los siglos y países, y también los lenguajes elaborados por las disciplinas más dispares, los concebidos para alcanzar las más variadas formas de conocimiento."

La información de que disponemos hoy en día puede, en su abundancia y en su carácter indiferenciado, bloquear la acción de elegir si no disponemos de un criterio de selección. Criterio que es consecuencia de cómo y con qué hemos construido nuestro universo personal. Calvino lo indica con claridad: la elección la llevamos a cabo desde ese universo que cada uno de nosotros se ha construido, fruto de "una suma de datos, de experiencias, de valores".

Hasta aquí "el mundo como memoria individual", pero ¿cómo saber responder, en nuestro caso, al problema de proyectar en un momento en el que no existen criterios fijos, ni certeros con los que aproximarse a la producción arquitectónica? ¿En qué nos basamos para poder elegir entre toda la ingente información que recibimos?

Disponemos "sin un antes y un después", continua Calvino, de todos los lenguajes, estilos, de las aportaciones de otras disciplinas, elaborados "en todos los siglos y países". En suma, de una visión sincrónica de la historia; pero la historia al fin y al cabo. Pero al día de hoy, que en muchas ocasiones se da la espalda a la historia que parece volver a considerarse como una disciplina para especialistas sin apenas relación con nuestro presente, considero vigente la advertencia de Ortega sobre si "lo" que tenemos que comenzar, el futuro, "es el horizonte de los problemas, el pasado (es) la tierra firme de los métodos". (4)

A nuestra disposición está toda la experiencia de la historia pero carecemos de unas reglas aceptadas para acercarnos a 
ella. En esta situación la única pauta la proporciona el talento personal, la capacidad del individuo de confrontarse con la historia. En el trabajo de proyectar, el arquitecto contemporáneo debe establecer las bases de su relación con el devenir histórico. Frente al ingente patrimonio que le antecede su decisión será desde su soledad. Será una respuesta exclusivamente individual, producto de la lectura de todo el arsenal heredado.

Además, para mayor tensión, esa elección individual para producir algo que todavía no existe y que "que podrá existir sólo por medio de la aceptación de los límites y las reglas" se produce contemporáneamente a la ausencia de un acuerdo colectivo que sirva de fundamento a actividades como la producción arquitectónica, artística o literaria (el mundo desde el que nos habla Calvino), que son siempre manifestación de las ideas dominantes en el seno de una civilización.

Por tanto, sin categorías universales, sin valores comúnmente aceptados, el "empezar" lo llevamos a cabo desde el universo individual que nos hemos construido, y de las ilimitadas opciones que ofrece hemos de ser capaces de extraer algo, lo adecuado a lo que demanda el objeto del proyecto. De ahí la necesidad de un instrumento, de un criterio que tenemos que fabricar nosotros mismos, un ingenio intelectual que nos permita abordar consecuentemente los objetivos de proyecto.

La historia se constituye en el segundo soporte de estas reflexiones. Se nos ofrece sincrónicamente en todas sus manifestaciones culturales y hemos de saber acercarnos a ella, pues constituye, en su devenir, un arsenal de respuestas a requerimientos no demasiado diferentes a los que ahora se nos presentan. Necesitamos aprender a "leer", a conocer las razones de las respuestas que la arquitectura ha dado a lo largo del tiempo, para poder alcanzar una propuesta desde la raíz del problema. No debemos olvidar, como afirmaba Félix de Azúa: "Quien no sabe leer, no sabe escribir y no sabe hablar, y quién no sabe hablar es un loco que está a merced de los demás".

El planteamiento del proyecto de arquitectura, la tercera pata del trípode en que se apoyan estas reflexiones, es consecuencia 
del criterio que hemos construido desde nuestra experiencia, desde nuestro "mundo" para ser capaces de insertarnos en el suceder del tiempo, en el decurso histórico, a través del cual adquiere un preciso significado.

Y todo ello lo hacemos, inevitablemente desde un contexto, desde una situación de la disciplina arquitectónica en la que inexorablemente estamos inmersos y que re-escribimos con nuestro trabajo.

Empecemos con una sucinta introducción a estos apartados.

\subsection{Una lectura del contexto}

La civilización global y la intercomunicación mundial en la que vivimos parecen provocar una uniformización, no sólo en los comportamientos y los gustos sino también en la arquitectura que le sirve de escenario, todo ello unido a una rápida obsolescencia de las tendencias y modas.

El desarrollo imparable de las ciudades que en las últimas décadas se ha producido, y cuyas consecuencias son ahora visibles, ha dejado un panorama ciertamente desolador. La crisis de los centros históricos, la proliferación de la periferia definida por el vacío y la indiferenciación, la construcción de grandes complejos de ocio y comerciales que producen artefactos descontextualizados, confirman esta situación. Las ciudades ya no poseen un carácter diferenciado y podemos comprobar cómo los lugares donde "habitan" los seres humanos se repiten en sus características en uno u otro lugar. En cuanto a la concepción central de la ciudad cuyo perímetro está definido, en donde se reconoce un centro y un extrarradio, podemos afirmar su obsolescencia, pues ni hay un único centro ni sus límites son precisos y definibles.

En una entrevista al diario El País, Francisco Jarauta afirmaba: "La globalización determina también una homologación cultural del mundo tanto en los modos de vida como en las formas de pensamiento. Contra este movimiento de homologación se encuentran los fenómenos de resistencia 
territorial de la identidad"(5). En este sentido, entendemos que la respuesta que la arquitectura puede ofrecer ya no es universal, sino una respuesta particular a situaciones que en cada ocasión piden una forma adecuada a sus condicionantes. Siguiendo a Ignasi de Solà-Morales ${ }^{(6)}$, ya no podemos entender el desarrollo de la arquitectura actual como un árbol de cuyo tronco común parten los diferentes brazos o ramas; por el contrario, ante la ausencia de criterios fijos y certeros con los que aproximarse de algún modo a la producción arquitectónica, se entiende que una arquitectura que da respuesta a una situación concreta se presenta, por tanto, con un carácter singular.

En el tiempo de la homogeneización, la resistencia, y por tanto la creación, están siempre del lado de lo singular. Una singularidad que no procede del tipo de edificio sino de la capacidad de hacer saltar de un asunto aparentemente corriente una chispa de entendimiento y de afección que en todos los otros casos parece haber pasado desapercibida. Sólo desde este punto de vista puede haber una salida "al único oscurantismo vivo: el progreso", como diría Octavio Paz.

El progreso, como objetivo del desarrollo indiscriminado, fue denunciado en diversas ocasiones como fuente de los males que acucian a la sociedad. Considero de notoria actualidad lo que Charles Eliot Norton escribió en una carta fechada en 1869: "El futuro de Europa es incierto (...) Que nuestro período de economía de empresa, libre concurrencia e ilimitado individualismo represente el estadio más alto del progreso humano es más que dudoso". Y concluye: "Nadie que de verdad conozca lo que es la sociedad en nuestra época puede creer que merezca la pena conservarla sobre sus fundamentos actuales".

En el campo del pensamiento cabe recordar la distinción que Ernst Jünger efectúa entre progreso y "humanitarismo civilizatorio", o la denuncia que Walter Benjamín hace del progreso como destructor del equilibrio de la naturaleza y expoliador de sus recursos, hasta la dureza de Karl Kraus cuando espeta "el progreso hace monederos con la piel de los trabajadores". Desde el punto de vista del arquitecto, analizado el progreso en relación 
a la construcción de la ciudad y la vertebración del territorio, podemos establecer conclusiones de dudoso optimismo.

El desarrollismo, que ha aniquilado la idea clásica de ciudad, se presenta como un hecho objetivo e innegable; la desestructuración de una teoría general que no ha resistido el impacto de las nuevas circunstancias, y su incapacidad de explicar y orientar la producción contemporánea, implica irremisiblemente una desorientación y desconfianza. Lo que afecta a la vocación claramente urbana de la arquitectura.

Por otro lado, es pertinente reconocer que el hecho de que diferentes procesos y cambios se desarrollen con simultaneidad, fuerza a que una hipotética visión de conjunto sea sencillamente eso: hipotética. Y si, desde nuestra percepción individual de los fenómenos simultáneos, deseamos extraer conclusiones generales, estamos destinados, con seguridad, al fracaso.

En cuanto a las nuevas arquitecturas que difunden los media, eludiendo el complejo entramado de la situación de la sociedad del siglo XXI, éstas no tienen más objetivo que la creación de iconos ignorando la necesaria reflexión razonada sobre el hábitat y sus habitantes en la búsqueda de una construcción equilibrada de la ciudad. Sin una razón de ser que los justifique podemos afirmar que los iconos que se construyen son siempre adecuados al simbolismo exigido por los poderes que los generan, casi siempre despreocupados de las consecuencias concretas para los habitantes de la ciudad. A pesar de ello, entusiasman a muchos ciudadanos, incluidos arquitectos. Arquitectura volcada al espectáculo, en la sociedad que en su día teorizó Guy Debord (7) envuelta en una sofisticada tecnología, que busca los efectos especiales, ajena al lugar donde se ubica y por supuesto a las necesidades de sus habitantes.

El ciudadano asiste inerme, pero queda abducido por el impacto que le produce la visión del artefacto, lo que le impide razonar, entre otras cosas, sobre la oportunidad del mismo, la adecuación a las características del lugar, a sus necesidades.

Se habla de arquitectura globalizada y deslocalizada. ¿No leemos muchas veces estos adjetivos aplicados al mundo de la 
producción ligado a los intereses de las gigantescas empresas multinacionales?

A pesar de, o mejor, desde la obligada singularidad de las respuestas concebimos la arquitectura como un arte útil, al servicio de la sociedad. $Y$ nos interesa aquella en cuyo planteamiento y desarrollo de los programas, en la peculiaridad de cada situación urbana o periférica, en la proposición de imágenes diferentes y adecuadas para el trabajo, el habitar, la representación del poder o la comunicación pública, es capaz de expresarse con plenitud, alcanzando la respuesta profunda y singular necesaria.

Arquitecturas atentas a la lectura y al estudio del programa, a la peculiaridad del lugar donde se va a desarrollar ese programa, y a la propuesta de la forma que da respuesta a ese estudio del programa en el lugar.

Continuando con las ideas enunciadas por Ignasi de Solà-Morales, hablamos de las arquitecturas que resisten la trivialización de lo que está ya codificado, pero no a través de la extravagancia o de los golpes de efecto, sino de la respuesta razonada, adecuada, única y singular, a un espacio concreto y diferente según sea un espacio de trabajo, de habitar o público.

Se trata al fin, de resistir a la uniformización para que más allá de situaciones convencionales, conocidas y culturalmente establecidas, alguien sea capaz de profundizar y poner en evidencia el problema con sus condicionamientos fundamentales a los que la obra tiene que responder.

Los momentos de crisis y desorientación ante nuevas situaciones son constantes históricas. Lo cual no significará que no intentemos descubrir qué sucede y cómo se desarrolla; solamente desde una actitud activa y crítica podemos hacer frente a la angustia y a una fragmentación más que palpable, sin olvidar que habrá que asumir, siguiendo a Deleuze, el recorrer el tiempo actual con todas sus tensiones y sus gritos.

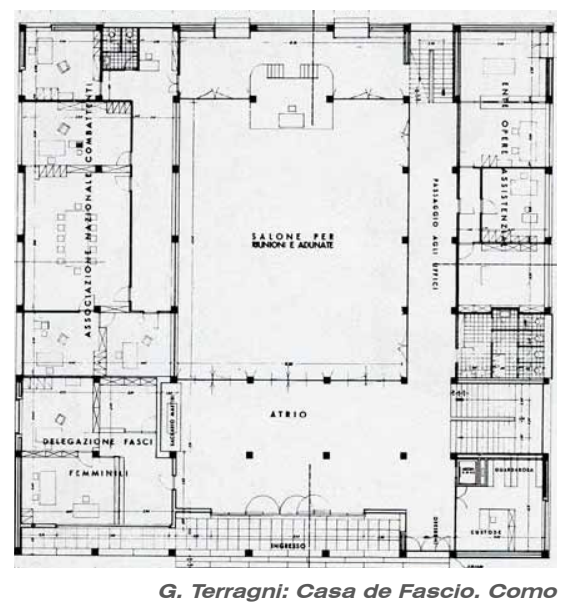




\subsection{Necesidad de una forma de acercamiento}

Theodor Lipps afirmaba que nada actúa sólo por sí mismo sino en función de lo afín que hay en nosotros. Efectivamente nuestro acercamiento a las cosas, a los objetos, al arte, a la arquitectura, lo llevamos a cabo a través de la simpatía que despiertan en nosotros. Por empatía como lo denominaría el mismo autor.

Los arquitectos, al proyectar, disponemos, como hemos visto, de todo un arsenal, de todas las obras que respondiendo a determinados condicionantes jalonan esta antiquísima actividad. Es decir: poseemos toda la experiencia histórica. Pero nuestra respuesta al problema que se nos plantea la damos desde nuestro "mundo individual", que hemos de construir y que quedará constituido por una selección personal extraída de aquel todo. Si logramos razonar el por qué de la elección podremos, a partir de ese momento, actuar.

El tantasvecesmal interpretadoysinembargoimprescindible arquitecto y teórico francés Eugène Viollet le Duc nos recordaba, en el siglo XIX, que en numerosos casos el razonamiento explica el juicio que el gusto ha pronunciado. Según Viollet el sentimiento del gusto no es más que un razonamiento involuntario, y cultivar el gusto no es más que acostumbrarse a lo bello y a lo bueno. Para lo cual es necesario saberlo encontrar, escoger, y para esta elección llamamos en ayuda nuestra al razonar. ${ }^{(8)}$

Y para acostumbrarse a lo bello y a lo bueno, ¿cómo saber lo que es bello y lo que es bueno? Evidentemente el arte no pertenece al campo del conocimiento científico. En las ciencias naturales el conocimiento es objetivo. Expuesta una hipótesis, la demostración empírica la confirma. Y podríamos repetir el experimento cuantas veces quisiéramos obteniendo siempre el mismo resultado. Confirmada una segunda hipótesis que modifica la anterior, queda aquélla sustituida por ésta.

Sin embargo, en el campo del arte donde la disparidad de criterios abunda: ¿qué criterio o regla utilizaremos para discernir la calidad de una obra de arquitectura? Para David Hume, en "La norma del gusto", "no hay otro criterio que el veredicto unánime 
de jueces con gusto delicado, libres de prejuicios, dotados con capacidad de comparación y auxiliados por una práctica constante". (9)

El "veredicto unánime" nos ofrece un elenco de buenas arquitecturas en el cual, por ejemplo, la Villa Rotonda está junto a San Carlo alle Quatro Fontane, la iglesia Unitaria de Oak Park y la Villa Savoye. No con todos ellos el sujeto se siente a priori identificado. Con los que lo haga buscará el discernimiento, el por qué de este interés. Un razonamiento que, como hemos dicho, al reconocer las cualidades del objeto arquitectónico explica el juicio que el gusto ha pronunciado. Por tanto cultivar el gusto, hacerlo razonable, y por tanto transmisible, demanda una actitud crítica que implica diversos estadios cuyo recorrido permite establecer unos criterios de certeza.

Thomas Stearns Eliot en su libro "Función de la poesía y función de la crítica", nos habla de la necesidad de partir de una profunda experiencia para poder distinguir la buena poesía. Y establece una referencia para acercarse a ella, (léase la arquitectura en nuestro caso): partir de lo que personas de reconocida exigencia han considerado "buena arquitectura". Punto de partida no muy lejano de la reflexión de Hume.

Arriesgándonosconun paralelismoentrelasconsideraciones que sobre la búsqueda de la buena poesía lleva a cabo T. S. Eliot y la formación de nuestro criterio acerca de la arquitectura, podemos intentar una manera de alcanzar este discernimiento, de lograr un método que nos permita determinar a priori la buena arquitectura de la que no lo es.

Para llegar a ello, el autor inglés por elección, como recuerda Gil de Biedma (traductor minucioso de parte de su obra), reflexiona sobre la necesidad de la crítica, entendida como toda actividad intelectual encaminada bien a averiguar qué es arquitectura, cuál es su función, por qué se construye y se disfruta, bien a apreciar lo que es la buena arquitectura. ${ }^{(10)}$

Las preguntas: ¿Qué es la arquitectura? ¿Es esta una buena arquitectura?, constituyen las dos metas teóricas de toda labor crítica. No hay entusiasmo teórico que baste para responder a

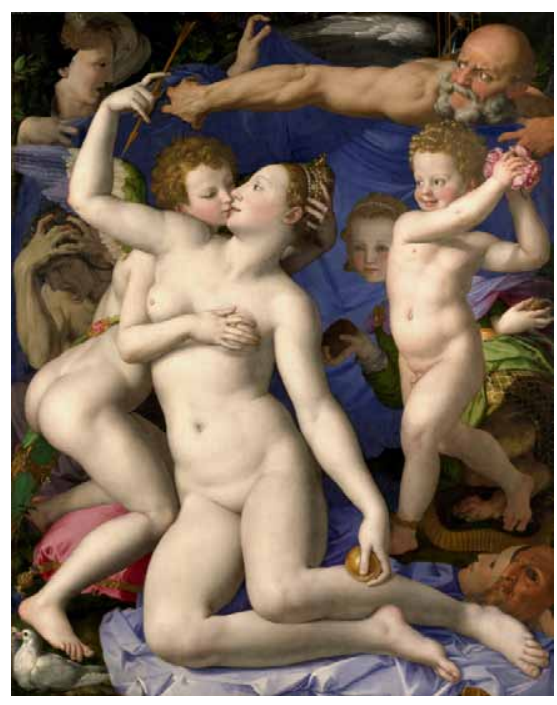

II Bronzino. Allegoria del trionfo di Venere 
la segunda cuestión, porque no hay teoría que vaya lejos si no se funda en una experiencia directa de la buena arquitectura. Parafraseando al escocés Ivor Armstrong Richards -citado por T.S. Eliot-, se requiere un conocimiento apasionado de la arquitectura y una actitud para el análisis desapasionada.

Conocemos lo que es la arquitectura "leyendo" su representación en los libros, visitándola, lo que supone recorrerla, percibirla en el lugar donde surge. Cuantas más veces llevemos a cabo estas incursiones, cuantas más arquitecturas disfrutemos, mayor será nuestra capacidad de escoger o rechazar, pues "el conocimiento se origina en la experiencia sensible, trascendiéndola puesto que ofrece un conocimiento de la realidad que supera los límites de la experiencia sensorial" (11).

La experiencia de la arquitectura no solo consiste en la suma de lecturas y vivencias: requiere su comparación y ordenación. Cierto es que "nadie nace dotado de un gusto infalible, nadie lo adquiere súbitamente". Pero existen muchos individuos con aptitud de gozar y capacidad de clasificar, y al comparar las experiencias entendemos cada una con mayor profundidad de forma que "el goce se profundiza en apreciación, que añade una fruición intelectual a la originaria intensidad del sentimiento". De este modo, continua Eliot: "Cuando no nos contentamos con escoger y rechazar, sino que ordenamos lo escogido, hemos llegado a un segundo estadio en nuestro conocimiento".

"Y podría hablarse de un estadio tercero, o de reordenación de todo el material almacenado, en el que el lector descubre un nuevo criterio con el cual considerarlo" (12). La racionalización de los resultados de este acercamiento permite, en relación a las obras con las que nos sentimos identificados, objetivar sus aportaciones, mientras que con aquellas que no generan en nosotros empatía alguna este estadio nos posibilita discernir su calidad y su contribución específica, independientemente del juicio negativo experimentado en su apreciación sensible. Un criterio, en suma, que permite reconocer la calidad, "la bondad y la belleza" del material acumulado y a partir de ello construir una propuesta que, desde su aislamiento y las pequeñas certezas 
logradas, partirá de lo aprehendido para alcanzar una acción, inevitablemente individual, pero desde una cierta madurez.

Karl Friedrich Schinkel afirmó que "el trayecto de un aprendizaje auténtico debe ser difícil, pero en última instancia se reduce a la formación de una sensibilidad, que en arquitectura abraza un campo muy amplio"(13). De la mano de T. S. Eliot hemos atisbado cómo lograr un criterio personal de acercamiento crítico a la arquitectura. Desde la sensibilidad alcanzamos la racionalidad de un acto, la construcción de la arquitectura, cuyo componente artístico la convierte en un factor basilar.

Necesario es reunir sentimiento y razón, pues en la racionalidad interna y específica de la arquitectura descansa su capacidad de comunicación, comprensión y transmisibilidad, para llevar a cabo nuestra acción como arquitectos en "el mundo moderno (...) el mundo del fragmento, del resto, de la dispersión y de la multiplicidad (donde) no hay lugar para la reconstrucción de la unidad y el sentido" y en el que "tal vez podemos encontrar hoy momentos en los que "el fragmento y el desperdicio tal vez puedan dar razón de casi todo lo perdido, lo ganado y lo por venir" (14).

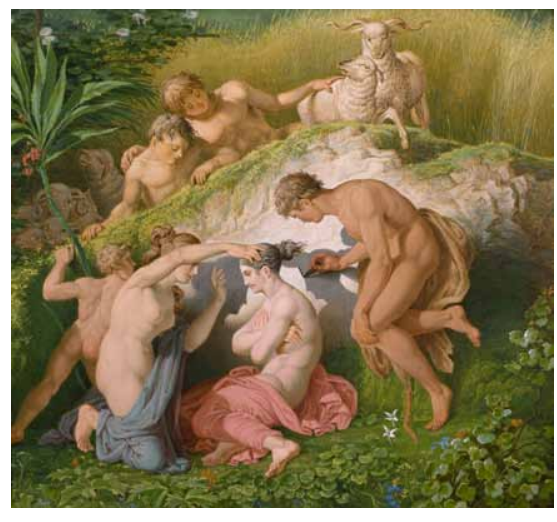

K.F. Schinkel. El origen de la Pintura

\subsection{La Historia como fondo}

Si convenimos que cada proyecto de arquitectura se mide con un mundo expresivo que ha existido y continua existiendo, podemos deducir el interés por el conocimiento de la experiencia de la arquitectura, por la necesidad de su historia no como fuente de información general, ni mucho menos listado de obras maestras de determinadas épocas, sino como herramienta indispensable en la búsqueda de la formación de un juicio sobre la experiencia de la disciplina, que nos posibilite la adopción de un criterio motivado sobre la arquitectura en toda su complejidad a partir del cual podamos construir una propuesta que se insertará en el devenir del tiempo.

Giorgio Grassi, en un texto sobre la escuela y las condiciones de nuestro trabajo de arquitectos, enlaza el argumento del apartado anterior con el papel de la historia: "Lo más importante 
para un estudiante hoy es la formación de un juicio motivado y coherente sobre la arquitectura en su complejidad. (...) En este sentido un paso fundamental del aprendizaje es el juicio sobre la experiencia histórica."(15)

La experiencia de la historia surge como fuente de entendimiento y convivencia, como banco de pruebas donde se reflejan los éxitos y los fracasos que alimentan nuestro trabajo. La Historia de la Arquitectura, testimonio de un pasado más o menos remoto, se convierte en material de nuestro trabajo cuando alcanzamos a discernir el por qué de las respuestas que se han dado con anterioridad a determinados problemas.

El pensador francés Alain Finkielkraut afirmaba que "la misión de la escuela es integrar a los estudiantes, en un mundo que es mucho más viejo que ellos, para tejer los lazos entre los vivos y los desaparecidos"(16) y no sólo por el hecho innegable de que "los muertos son mucho más numerosos que los vivos", como expone su conciudadano el director de cine François Truffaut a propósito de su film "La chambre verte", sino porque dicha misión nos recuerda que la historia es componente básico para la comprensión de la realidad, y en nuestro caso, como legitimación de la disciplina. La arquitectura que se va construyendo a lo largo de la historia se erige como corpus disciplinar de tal manera que el objeto arquitectónico cobra legitimidad, y un significado preciso, introducido en el decurso histórico.

Porque "tejer los lazos" tiene como consecuencia un desvelar las respuestas que la Arquitectura ha dado a las diferentes preguntas que se le han planteado a lo largo de su suceder. Problemas del hombre moderno que, según aseveraba un vanguardista como el director de cine Michelangelo Antonioni, son los mismos que los del hombre de la época de Homero.

El devenir histórico nos muestra las respuestas que ha dado la Arquitectura a lo largo del tiempo, y de su conocimiento podemos extraer "un juicio sobre la experiencia histórica", un criterio que nos permite acercarnos críticamente a ella, constatando que en cada momento la arquitectura proporciona 
unas respuestas a problemas que esencialmente no están tan alejados de los que hoy se nos plantean.

Se podrá aducir que en una situación cultural como la actual, que ha olvidado la experiencia de la historicidad, el necesario juicio sobre la experiencia histórica se torna una acción individual que trata, quizás utópicamente, de mantener un hilo conductor con aquella.

Diversos pensadores acuden a resolver nuestras dudas y angustias. De un lado T. S. Eliot que, como nos recuerda Gil de Biedma (17), al examinar la Historia de la poesía "no cae en la embriagadora tentación de pronunciar excomuniones y conceder salvoconductos; se contenta con hacer valer aquellas observaciones y experiencias del pasado que todavía son útiles y con poner en claro la continuidad -y necesidad- de un proceso histórico".

Continuidad y necesidad que expone Giorgio Grassi en diferentes escritos y para quien la historia se plantea como un continuum insistiendo en que la arquitectura, a lo largo de la historia, siempre plantea las mismas preguntas, y nuestras respuestas se relacionan con las que le han precedido.

La inserción de nuestras obras en la larga experiencia de la arquitectura es uno de los factores que les otorgan su razón de ser. Las grandes arquitecturas se reconocen porque se inscriben en ese devenir, en continuidad. La calidad específica de nuestra propuesta forma parte "de una construcción más amplia y unitaria: la construcción de la arquitectura en el tiempo, la larga experiencia de la arquitectura en el curso del tiempo" (18).

Construir en y desde la historia no es una acción novedosa. El pensador José Ferrater Mora afirmaba hace ya décadas que los que modifican sustancialmente el futuro son aquellos que viven enraizados en el pasado y son conscientes de las implicaciones de la historia, de lo que las acciones pasadas pueden comprometer aquello que está por venir. En el inevitable acercamiento individual a la historia sentimos como si el tiempo se achatara, la diacronía se torna sincronía. Sobre la mesa y analizadas las diferentes respuestas producidas a lo largo del 
tiempo, mediante el criterio que, al menos, hemos empezado a pergeñar, elegimos la acción que queremos ejecutar.

No sin razón Heidegger escribió que "sólo cuando nos volvemos con el pensar hacia lo ya pensado nos ponemos al servicio de lo por pensar". (19) Pero al hacerlo no podemos soslayar la situación de la que partimos. Cierto es que disponemos de todas las lecciones de la historia, que a través de un proceso logramos disponer de un criterio de lectura, y de elección aunque, hoy en día, estamos privados de unas reglas aceptadas, de cualquier pauta que no sea la del talento personal, por lo que lograr estos objetivos se convierte en "el resultado exclusivo de una operación que empieza y acaba en el sujeto, que nos transmite, desde su soledad la angustiada situación de alcanzar una propuesta hecha desde la distancia insalvable de su condición contemporánea“(20).

Inevitable contemporaneidad que no evita, más bien confirma, que existen unas arquitecturas que recordamos, que nos interesan porque al volver a visitarlas siempre aportan una luz en el vertiginoso suceder de nuestras vidas. Arquitecturas que se imponen por su necesidad "como si estuvieran allí siempre". Arquitecturas cuya razón de ser nos incita a la reflexión, a la extracción de nuevas conclusiones con las que enriquecer nuestra experiencia, nuestra capacidad de respuesta ante un proyecto de arquitectura.

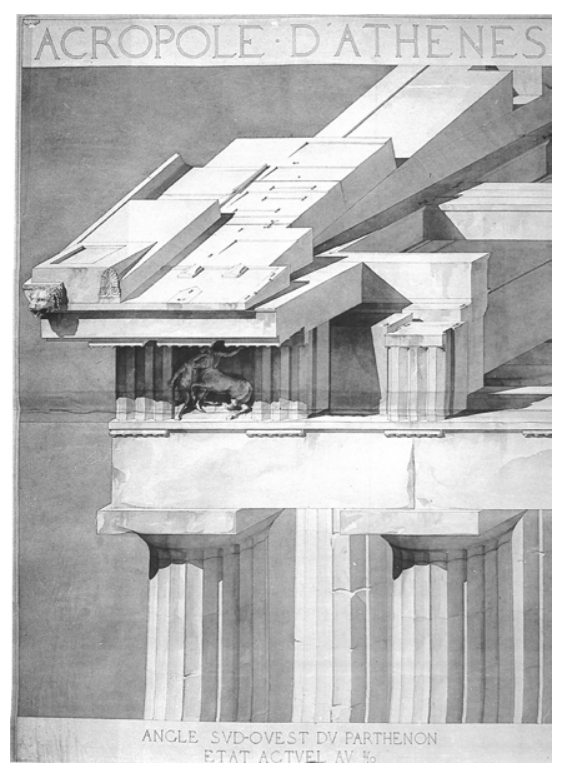

\subsection{El proyecto de arquitectura}

Diversos son los factores que integran el panel de datos previo y necesario a la realización de un proyecto de arquitectura; tras su análisis e interpretación podemos plantear los objetivos del mismo. De entre aquéllos, el estudio del tema-programa y el análisis del lugar son, para muchos de nosotros, arquitectos, parámetros fundamentales a los que debe dar respuesta el proyecto a sabiendas de que nuestra propuesta, respondiendo a unas necesidades, se introduce en un lugar concreto, con sus características propias, para modificarlo.

El proyecto es una declaración de principios, es la respuesta 
al desafío de producir una arquitectura que se tiene que medir con un mundo expresivo que ha existido y existe, con el que tiene que confrontarse. Un mundo tan antiguo como el hombre, quien a lo largo del tiempo ha buscado respuestas a los problemas del habitar, entendido como el mundo de las formas que abarca desde la casa hasta los lugares de trabajo y encuentro que configuran nuestro universo construido.

El proyecto de arquitectura no es un gesto, ni un ejercicio meramente formal. Desde los parámetros mencionados constituye la expresión de un juicio sobre la arquitectura y la ciudad (el lugar usual donde se desarrolla), la respuesta a un análisis de la misma, de cómo es, era y podría ser. De los problemas que planteó antaño y los que afloran modificados, actualizados podríamos decir, por las circunstancias del momento de la actuación.

Es decir: parte de un lugar, la ciudad, con su presente y su pasado, para constituirse en lo que quiere ser, pide ser, en el futuro.

El proyecto contesta a preguntas como: ¿Qué hace esta arquitectura aquí, en esta parte de la ciudad, construyendo un lugar, definiendo un paisaje? ¿Qué quiere proponer-decir- este proyecto en este lugar, con determinado programa hoy, en la actualidad? Y la propuesta no agota la respuesta a todos los problemas, siempre quedarán preguntas, situaciones, que el proyecto pone en evidencia.

El tema-programa, al que debe dar respuesta el proyecto de arquitectura constituye lo que Grassi denomina el objeto práctico del proyecto.

Objeto práctico cuya definición es un punto de partida para poner en claro su razón de ser, sus condiciones actuales, enriquecidas por nuevas expectativas. En la consecución de este "objeto práctico" del proyecto el tema-programa se reinterpreta, e incluso transgrede, como recuerda Louis Kahn: "Creo que lo primero que un arquitecto debe hacer es tomar el programa que le dan y cambiarlo. La arquitectura es una mediata creación de espacios (...) No es adaptar funciones en áreas dimensionadas. 


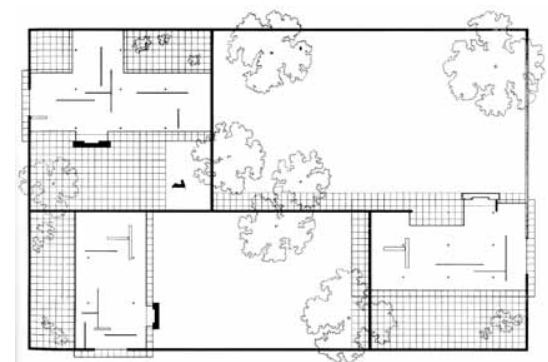

Mies Van der Rohe. Tres casas patio
Es creación de espacios que evoquen una atmósfera del uso al que están destinados. Espacios que se forman en armonía con la función que el edificio debe resolver" (21).

El objeto del proyecto, su objetivo práctico, debe clarificar el tema-programa, llegar a alcanzar su razón de ser para conocer los límites y posibilidades de su aplicación en la creación de esos espacios que evocan su adecuación. Adecuación al uso para el que se conciben y que se insertan en un lugar interpretándolo y modificándolo. No en vano en nuestro diálogo con las arquitecturas que nos han precedido, y nos emocionan, observamos su confrontación con la naturaleza transformada y, también, su adecuación a las condiciones materiales, a las singulares condiciones del programa. En consecuencia el temaprograma introduce el proyecto tanto en el campo historiográfico como en el campo teórico. Si conocer las respuestas que con anterioridad se han dado a problemáticas similares es reflexión necesaria para obtener conclusiones válidas, no debemos olvidar que aquéllas, ejemplos históricos que hemos estudiado, son sólo un estímulo, un indicio a partir del cual nosotros, inexorablemente, debemos "fabricarnos" nuestra forma de acercarnos al problema. Nos construimos el "cómo" resolverlo desde las condiciones que en el momento que vamos a actuar se nos plantean.

En resumen, toda arquitectura, como construcción de un espacio, se desarrolla en un lugar y establece mediante la resolución del tema-programa, una serie de relaciones que el arquitecto debe conocer para llevar a cabo una propuesta congruente con la realidad física en la que se inscribe. El encuentro entre ambos parámetros origina unas conclusiones que se ordenan para alcanzar la forma de la propuesta.

La geografía y la historia comparecen en el punto que, de este modo, determina de manera precisa la idea general de espacio y tiempo estableciendo una continuidad en el proceso de la arquitectura. Su vocación es la de servir al descubrimiento de lo que ya existe previamente, como un fondo permanente del cual la arquitectura ilumina sus condiciones, sus invariantes y 
también lo que ha evolucionado en el tiempo.

Ignasi Solá-Morales resume con contundencia el encuentro entre el tema-programa y el lugar: "La arquitectura actúa trazando límites a cielos y tierras que tienen cualidades determinadas. Estas dimensiones cualitativas son esenciales. La tarea de la arquitectura es recolectarlas, hacerlas visibles, solidarias, ponerlas en el universo de la palabra. Si el hombre es el cuidador de las palabras y sólo de ellas emerge el sentido de las cosas, la arquitectura tiene un cometido preciso: hacer de las condiciones ya dadas de cada lugar palabras que signifiquen las cualidades de la existencia, y que desvelen la riqueza y los contenidos que en ellas se contienen potencialmente.

Es una labor que no se hace con principios generales, ni desde el vacío de la innovación. Surge, por el contrario, de tierras y cielos, de luces y sombras, de imágenes e historias que existen antes de la arquitectura, que son literalmente ancestrales. La obra de arquitectura es sólo un paciente reconocimiento, un laborioso cultivo de semillas que sólo esperan la mano de quien será capaz de hacerlas crecer y fructificar" (22).

El lugar se constituye como unos de los parámetros básicos del proyecto de arquitectura. "Por esto el construir, porque instala lugares, es un instituir y ensamblar espacios" nos recuerda Heidegger. Si la tarea de la arquitectura es la de edificar lugares para el habitar, el lugar es por tanto una de las condiciones que influyen de manera decisiva en la elaboración del proyecto al hacer visibles su existencia histórica, sus aportaciones particulares y concretas, la riqueza de sus contenidos mediante el juicio al que los sometemos para construir nuestra propuesta. Pero un lugar no se hace presente antes de "construido". Mediante su construcción, por ella, surge el lugar. "Es cierto que antes de que esté puesto el puente, a lo largo de la corrienteexplica Heidegger- hay muchos sitios que pueden ser ocupados por algo. De entre ellos uno se da como lugar, y esto ocurre por el puente. De este modo (...) por el puente mismo, y sólo por él, surge el lugar" (23). No hay lugar sin construcción y al mismo tiempo no hay acción del construir que no suponga modificación 


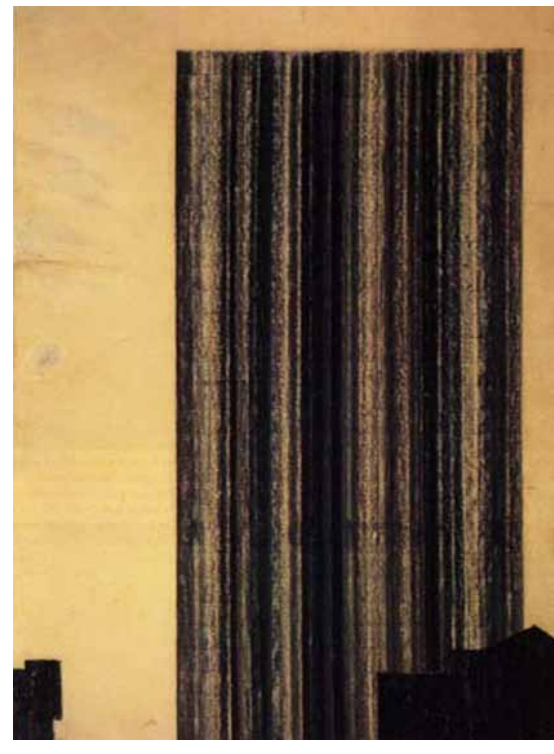

Mies Van der Rohe. Rascacielos de vidrio 1920-1921 del territorio para convertirlo en un lugar.

El necesario análisis de la realidad física donde el proyecto se inserta constituye la primera reflexión al abordar la propuesta. Por otro lado, la realidad exterior no dice nada si no se interpreta desde una clara intencionalidad recurriendo a pautas analíticas para alcanzar el conocimiento necesario. El lugar es el espacio físico en donde proyectamos un objeto que lo modificará y dotará de significado. El análisis de esta fase del proyecto tendrá que responder de cómo ha sido ese lugar, cuáles han sido las razones por las que ha llegado a ser de concreta manera; y el proyecto determinará ineludiblemente en qué sentido se tiene que transformar a partir de la intervención.

Si los apartados de programa y lugar pueden ser objeto de debate para establecer una serie de conclusiones en base a unos parámetros objetivables y trasmisibles, la formalización del proyecto pertenece a la esfera individual pues supone una interpretación de aquéllos que darán lugar a la forma. Y esta acción, en ausencia de criterios fijos, de referentes aceptados, se convierte en un salto al vacío que el individuo, en su soledad lleva a cabo mediante la interpretación de dichas conclusiones generales a través de analogías que le permiten establecer una forma de actuación de carácter individual.

Nos hemos referido con anterioridad a la ciudad como lugar usual de la arquitectura. La ciudad, que se presenta como hecho global construido, es el campo al que se refiere y donde se reconoce. Dado que las intervenciones se producen generalmente en ella, será importante que tal como la entendemos en la cultura europea, la estudiemos en el contexto e historia que dieron lugar a su forma actual.

Cómo ha sido la ciudad, cuál ha sido su evolución. Al destacar las arquitecturas que la definieron y definen, relacionando su forma con las técnicas de construcción utilizadas, los usos a los que estaban destinadas y con la evolución de todo ello, comparecen factores propios de otras disciplinas que informan el proceso investigador: históricos, arqueológicos, sociales, a los que se añaden los técnicos, constructivos, y aunándolos a 
todos, la razón de ser de todos ellos, el por qué y el cómo de su comparecencia.

La noción de lugar aparece indisolublemente ligada a la noción de tiempo. El lugar como fundamento, aquello que está debajo, que pertenece a culturas que encuentran la identidad luchando contra el paso del tiempo. Los lugares de las culturas históricas han sido, casi siempre, desafíos al tiempo, acumulan la memoria combatiendo el olvido, contienen evocaciones permanentes y preguntas que se renuevan, a las que el proyecto busca dar respuesta.

Y el proyecto de arquitectura desde el tema y el lugar enunciará una propuesta que será diferente en cada caso, dado que "la experiencia nos da seguridad de juicio, confianza en los medios, pero (...) poner de nuevo cada vez todo en discusión es en realidad una condición necesaria del proyecto; incluso podríamos decir que esta lección procede de la buena arquitectura, esa arquitectura que cuanto más segura y definitiva parece, en mayor medida demuestra que la tentación académica es completamente extraña a ella" (24). 


\section{NOTAS}

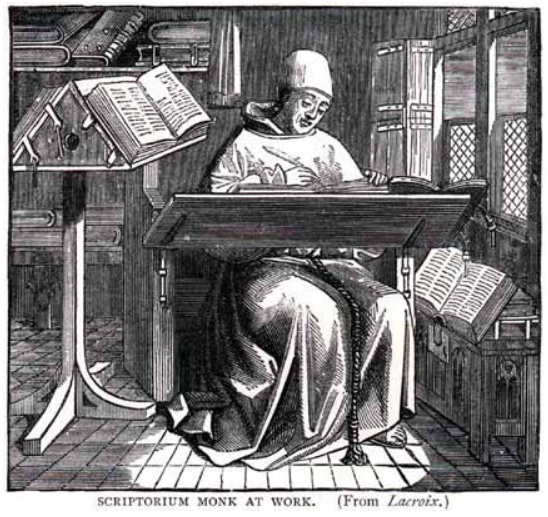

(1)

Jiménez, Juan Ramón, Antología Poética 1917-1935, Volumen 2, Madrid, Alianza Editorial, 1984, pp. 18

Calvino, Italo, Seis propuestas para el próximo milenio, Madrid, Ed. Siruela, 1998, pp.125. A continuación, se reproduce el texto íntegro:

Empezar una conferencia, o mejor dicho un ciclo de conferencias, es un instante crucial, como cuando se empieza a escribir una novela. Es el instante de la elección: se nos ofrece la posibilidad de decirlo todo, de todos los modos posibles; y tenemos que llegar a decir algo, de una manera especial.

Así pues, el punto de partida de mis conferencias será ese instante decisivo para el escritor: el distanciamiento de la potencialidad ilimitada y multiforme para dar con algo que todavía no existe y que podrá existir sólo por medio de la aceptación de los límites y las reglas. Hasta el instante previo al momento en que empezamos a escribir, tenemos a nuestra disposición el mundo -el que para cada uno de nosotros constituye el mundo, una suma de datos, de experiencias, de valores-, el mundo dado en bloque, sin un antes y un después, el mundo como memoria individual y como potencialidad implícita; y lo que queremos es extraer de este mundo un argumento, un cuento, un sentimiento: o, tal vez más exactamente, queremos llevar a cabo un acto que nos permita situarnos en este mundo. Disponemos de todos los lenguajes: los elaborados por la literatura, los estilos en los que se han expresado civilizaciones e individuos en todos los siglos y países, y también los lenguajes elaborados por las disciplinas más dispares, los concebidos para alcanzar las más variadas formas de conocimiento. Y lo que nos proponemos es extraer de ellos el lenguaje más apropiado para contar lo que queremos contar, un lenguaje que "sea" aquello que queremos contar.

El principio es también la entrada en un mundo completamente distinto: un mundo verbal. Fuera, antes del principio, existe, o se supone que existe, un mundo completamente distinto, el mundo no escrito, el mundo vivido o vivible. Pasado este umbral se entra en otro mundo, que con aquél puede entablar relaciones que se deciden en cada ocasión, o ninguna relación. El principio es el lugar literario por excelencia porque el mundo de fuera es continuo por definición, no tiene límites visibles. Estudiar las zonas fronterizas de la obra literaria es observar los modos que en la labor literaria comporta reflexiones que van más allá de la literatura pero que sólo la literatura puede <expresar>.

(3) Ortega y Gasset, José, Carta a un alemán pidiendo un Goethe desde dentro, Madrid, Biblioteca Nueva SL, 2004, pp.43. 
(4) Ortega y Gasset, José, op cit., pp.45

(5) Verdú, Vicente, "Entrevista a Francisco Jarauta", El País, 15 de Septiembre de 1999.

(6) Solà-Morales, Ignasi, "Diferencia y límite: individualismo en la arquitectura contemporánea", Diferencias. Topografía de la arquitectura contemporánea, Barcelona, Ed. Gustavo Gili, 2003, pp.119.

(7) Debord, Guy, La sociedad del espectáculo. Pre-textos. Valencia, 1999.

(8) Viollet le Duc, Eugene, Entretiens sur l'architecture, París, Ed. A. Morel, 1863, pp.466.

(9) Gomá Lanzón, Javier, "La vanidad literaria", El País, 21/01/12, Suplemento Babelia.

(10) Eliot, Thomas Stearns, Función de la poesía y función de la crítica, Gil de Biedma, Jaime (prol.), Barcelona, Ed. Tusquets, 1999, pp.44

(11) Marí, Antoni, La vida de los sentidos. Fragmentos de una unidad perdida, Barcelona, Ed. Tusquets, 2006, p.11.

(12) Eliot, Thomas Stearns, op. cit., pp.47.

(13) Grassi, Giorgio, "Escoger a los propios maestros", Giorgio Grassi. Obras y proyectos 1962-1993, Edición a cargo de Pilar Insausti y Amando Llopis, Valencia, Ed IVAM- Electa, 1994

(14) Marí, Antoni, Op. cit., p.11.

(15) Grassi, Giorgio. Un parere sulla scuola. Domus n0714, pag.58. Milan, 1989, incluido en Grassi, Giorgio, "Una opinión sobre la escuela y las condiciones de nuestro trabajo (1989)" en Arquitectura lengua muerta y otros escritos,edición a cargo de Martí Arís, Carles, Barcelona, Ediciones del Serbal, 2003

(16) Martí, Octavi, "Entrevista a Alain Finkielkraut, filósofo" El País, 24 de Agosto de 1999

(17) Gil de Biedma, Jaime. "Prólogo", en: Eliot, Thomas Stearns, Función de la poesía y función de la crítica, Barcelona, Tusquets Ed., 1964, pp.16

(18) Grassi, Giorgio, op. cit., pp. 59

(19) Heidegger, Martin, "Construir, habitar, pensar", Conferencias y artículos, Barcelona, Ediciones del Serbal, 1994, pp. 139

(20) Solà-Morales, Ignasi, op. cit., 2003, pp.121

(21) Weiss, Barbara, "American museums: three examples", Lotus n 35. Ed. Electa, Milano, 1982, pp. 101

(22) Solá-Morales, Ignasi. "Lugar: permanencia o producción" en Diferencias. Topografía de la arquitectura contemporánea. Barcelona, Ed. Gustavo Gili. 2003, pp.106

(23) Heidegger, Martin, op.cit., pp. 134

(24) Grassi, Giorgio. Cuestiones de proyecto, en Arquitectura lengua muerta y otros escritos, edición a cargo de Martí Arís, Carles, Barcelona, Ediciones del Serbal, 2003, pag.33 


\section{Una concreta experiencia proyectual}

\subsection{Introducción}

Entre 1978 y 1996 sobre mi mesa de trabajo se suceden y simultanean en algunos momentos, los proyectos y la realización de cinco Museos, que junto a dos galerías de arte y la casa para un importante coleccionista, comportan una serie de consideraciones relacionadas con la exhibición de obras de arte. El desarrollo de estos trabajos suscita mi interés en el conocimiento de los diferentes espacios expositivos generados a lo largo de la experiencia de la arquitectura, aún

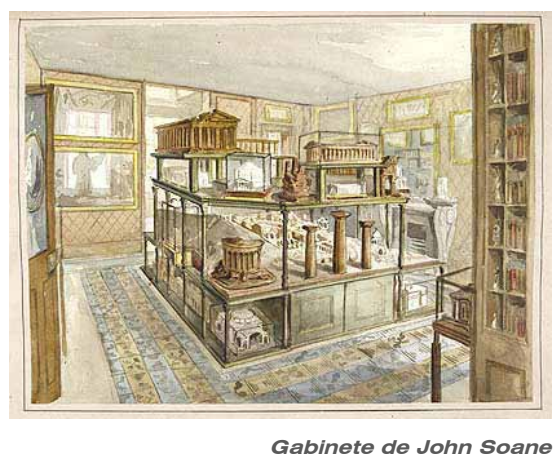
antes de la aparición del museo como tal. También supone una indagación en los modos de exposición de las piezas de arte: las posibles diferencias entre espacios que acogen una exposición permanente o una temporal, la mejor disposición de las obras para su contemplación y disfrute o la importancia de las visuales y del recorrido. Todo ello se une al actual entramado de exigencias que, junto a los espacios de uso público, plantean los usos internos, como administración, acceso de las obras, su conservación y almacenaje, talleres o las necesidades del personal vinculado a estos servicios. La reflexión que se realiza sobre el programa y sobre los cambios que se producen en él a lo largo del tiempo, no puede olvidar las sofisticadas instalaciones que un museo necesita.

El presente estudio se concreta en los cinco trabajos en 
edificios históricos que se rehabilitan, replantean, ordenan o amplían a partir de sus viejas fábricas o de sus instalaciones totalmente obsoletas o deterioradas, incluso destruidas parcialmente por la guerra, con la conclusión final de su utilización como museo.

De este grupo cabe destacar que tres de ellos, el Almudín de Xàtiva, el Neues Museum de Berlín y el Museo de Bellas Artes de San Pío $V$ de Valencia, eran o habían sido antes de su destrucción, como el Neues Museum, museos. En cuanto a las Atarazanas y al Palacio del Marqués de Campo, ambos en Valencia, había que recuperarlos para que pudieran ser reutilizados como tales.

En dos de ellos se presenta otro factor de ineludible responsabilidad. Tanto el Neues Museum como el San Pío V presentan una ineluctable componente urbana en la resolución del proyecto: construyen y definen ciudad y la relación con ella es un factor capital que se debe tener en cuenta en el proyecto y en la intervención.

$Y$ todos ellos, los cinco edificios citados, deben dar respuesta al nuevo programa de museo de arte que a partir de la década de los sesenta del siglo pasado se impone y que supone una inversión radical de los términos que para el uso museístico planteó el siglo XIX. De los cinco museos, tres de ellos respondían de uno u otro modo al obsoleto programa decimonónico, aunque con limitaciones. El Neues Museum, parcialmente destruido durante la segunda guerra mundial, asumía una respuesta museística basada en el desarrollo lineal y acumulativo de la exposición de obras de extensas y diversas colecciones y carecía de infraestructuras adecuadas de apoyo y de servicios. Por otro lado, los museos de San Pío $V$ y del Almudín de Xàtiva aunaban a la acumulación de obras la más absoluta falta de criterios expositivos, todo ello agravado por la indiscriminada colonización de diferentes espacios preexistentes caracterizados por la inadecuación de sus condiciones de exhibición.

Podemos resumir en cinco apartados los problemas que 
plantea y que comporta la investigación objeto del presente trabajo.

En primer lugar los criterios de intervención. Juan Luis Trillo de Leyva define con justeza el término intervención: "Toda intervención proyectual se realiza sobre los sedimentos de las anteriores construcciones. En la ciudad origen y custodia de la cultura, la memoria del pasado se transforma en una materia del proyecto arquitectónico. No es tanto la tradición constructiva y popular como inercia formal, cuanto la capacidad de interpretar las prexistencias físicas y los conocimientos de nuestro pasado, en un continuo regurgitar". (1)

El lugar donde se ubican, la ciudad, guarda el germen de lo acaecido y adentrándonos en ella nos descubre un ingente material que nos permite una lectura crítica de las prexistencias que se nos presentan ante nosotros y tras cuyo estudio son activa materia del proyecto. Se convierten en basilares en la redacción del mismo. Lo que no quiere decir que, aún situadas en la misma ciudad, las conclusiones sean las mismas para todos los edificios objeto de intervención

Cada uno de los edificios objeto de intervención plantea una problemática concreta producto de sus circunstancias. De su concreta realidad física, de las conclusiones que su estudio permite obtendremos una respuesta proyectual adecuada a cada caso y por tanto diferente al resto. Como Ambrogio Annoni enunciaba allá por el año 1928, cada uno de ellos ofrece una lectura de su realidad física, histórica, urbana, etc. que demanda una solución "caso por caso".

Un segundo apartado hemos de tener en cuenta: He avanzado que dos de los proyectos interpretan un importante papel en la definición de la forma de la ciudad. Si los grandes museos del siglo XIX habían intervenido en la configuración de la misma observamos que, ya entrados en el siglo $X X$, el interés por el estudio y revalorización de la ciudad europea lleva al museo a retomar su compromiso, como "catedral laica", en la redefinición de la misma. Tanto el Neues Museum de Berlín, como el Museo de Bellas Artes de Valencia representan un importante papel en 
la redefinición urbana.

Un tercer factor es su destino común. Su nuevo uso como museo plantea una dialéctica entre las exigencias del nuevo uso y la capacidad de respuesta del viejo edificio. Es decir, pondera la capacidad tipológica de cada uno de ellos para responder a la complejidad del uso expositivo, y en esta relación museomonumento habrá que adecuar las necesidades de éste a las posibilidades de aquel.

La cuestión que el museo formula lleva implícita el conocimiento de su problemática actual inexorablemente vinculada a su desarrollo a lo largo de la historia de las formas arquitectónicas, cuarto apartado que confluye en la resolución de estos trabajos: me refiero a la necesidad de un juicio sobre la experiencia histórica. Para ello hay que conocer la génesis del museo, el origen de los diferentes espacios expositivos que a lo largo del tiempo se van generando hasta la aparición del museo como institución, tal y como lo entendemos hoy. Ello no impide olvidar la evolución radical de su programa de necesidades, que a partir de la segunda mitad del siglo $X X$, queda explicitado en museos que admiramos y que supone un giro de $180^{\circ}$ en relación al museo desarrollado en el siglo XIX que disfrutamos en las grandes ciudades europeas y americanas.

De estos apartados hablaremos a continuación, no sin antes establecer unas claves para la comprensión del punto de partida del presente trabajo.

\subsection{Cómo intervenir, cómo reconvertir, cómo ver el arte}

El cómo intervenir en un edificio histórico, el cómo convertirlo o reconvertirlo en museo de arte junto al cómo se "lee", contempla, se disfruta el arte, se apoya en una misma idea enunciada por Ernest Gombrich. El profesor austríaco lo explicó en una entrevista que me resultó clarificadora y que atañe a los tres "cómo": "El arte es como un ser vivo cambia conforme lo hace el espacio social en el que se mueve, su propia ecología”. (2)

A lo largo de la historia de nuestra cultura, la pintura, la 
poesía, el teatro, la arquitectura, nunca han sido contemplados, leídos, vistos, experimentados en la misma manera, pues como prosigue el historiador: "La Historia del Arte es una constante exploración en las formas de la visión."

El uso del color, la textura, el ambiente de un cuadro de Velázquez puede mantener vivo, para algunos de nosotros, el valor de la pintura de este maestro del siglo XVII; contemplando el retrato de Madame d'Hausonville de Ingres, podemos subrayar la descomposición de las partes, la importancia del dibujo, la ausencia de profundidad, cubismo sesenta años antes del cubismo o, cambiando de disciplina, nos emociona Shakespeare por esos valores universales, esos conceptos que todavía nos hacen reflexionar, poniendo entre paréntesis el contexto histórico que le sirve de soporte o la estructura argumental en la que se engarzan.

El espacio social del arte cambia y con él, nuestros intereses, y también nuestra forma de acercarnos no sólo al arte contemporáneo sino también, y por supuesto, al del pasado. Si han llegado hasta nosotros es porque siempre han planteado unos problemas, unas preguntas, algo que mantiene un nexo del pasado con el presente, que hace que su estudio, su lectura, su desentrañamiento, manifieste ese "continuum" entre los valores históricos y los actuales.

\subsection{La intervención en edificios históricos. Criterios}

La arquitectura, como arte, es también un fenómeno vivo: cambia, evoluciona según su "espacio social" se produce. Y cambia, evoluciona nuestra relación con las arquitecturas del pasado.

Nuestros cinco proyectos, que tienen en común su relación con estructuras ya existentes no sólo de forma visual o física, se tienen que enfrentar a una verdadera interpretación del material histórico con el que se miden, de modo que este material ha de ser objeto de una auténtica lectura que acompañe explícita o implícitamente a la nueva intervención en su global significación. 
En la búsqueda de esa significación global ninguno de los cinco proyectos pretende, ni puede hacerlo, establecer un sistema de resolución de la puesta en relación de lo "nuevo" con lo "viejo"; sí, en cambio, intentan mostrar las dudas y certezas que aparecen en el recorrido. Cada uno de los proyectos tiene su historia, su razón de ser y también su problemática específica y además, como recuerda Giorgio Grassi: "Empezar de nuevo desde cero es, en realidad una condición fija del trabajo de la arquitectura; ya que las condiciones no son nunca las mismas (...) La experiencia nos da la seguridad de juicio, pero poner todo de nuevo, cada vez, en discusión es en realidad una condición necesaria del proyecto" (3)

Partiendo de que "no existe restauración, intervención, que no requiera de un proceso de toma de decisiones similar al de cualquier acto creativo, por lo que no es posible intervenir en bienes patrimoniales sin crear sin proyectar, al igual que no es posible proyectar ninguna arquitectura, sin afectar a bienes patrimoniales" (4).La recuperación de los edificios históricos, la confrontación con las fábricas del pasado en relación a los valores y necesidades actuales, ha producido y produce diferentes actitudes que dan lugar a formas de intervención diversas. Denominamos, en este escrito, intervención a cualquier acción de restauración, repristinación, rehabilitación, que siempre supone un cambio morfológico.

Estudiar un edificio, su historia, sus caracteres, elementos constructivos, evolución, relación con el lugar, estudios comparativos, etc., proporciona un cuadro de datos cuya interpretación se produce a través de los valores, criterios, con los que nos acercamos a él, en absoluto ajenos al "zeitgeist" desde el que trabajamos. Pues como ha indicado en repetidas ocasiones el historiador y arquitecto Ignasi de Solá-Morales: "Todo problema de intervención es siempre un problema de interpretación de la obra de arquitectura".

Esta interpretación es, la que a través de un proyecto de arquitectura, nos establece las pautas de la intervención. Por supuesto la manera en que se interprete el monumento dará 
lugar a diferentes formas de intervención, a diferentes proyectos, y esa diversidad en la interpretación la posibilita precisamente, la riqueza de aportaciones que encierra un monumento vivo.

Porque intervenir en el Patrimonio Arquitectónico no es sólo un problema historiográfico, arqueológico, sociológico, técnico, o documental. Estos factores, estas disciplinas, son las que ineludiblemente están presentes en ese panel de datos del que hemos de partir para resolver el problema, que es un problema de arquitectura y sólo desde ella se puede dar la respuesta que propicie que en los monumentos, testimonio del pasado civil, la sociedad actual siga reconociendo unos valores colectivos.

Proyecto como respuesta concreta a la lección extraída del estudio del Monumento, porque como decía Ambrogio Annoni: "Sólo si se penetra en los meandros de las antiguas construcciones y se deja que expresen su inmutable palabra los ladrillos, las piedras, las vigas, las pinturas (...), sólo así el monumento revela su razón de ser". El mismo recordaba: "El monumento es el maestro y toda intervención se determina en cada caso particular a partir de él." (5)

Muchas de las actuaciones que, nostálgicamente, han intentado recrear el carácter antiguo del monumento, lo hacen para eludir una lectura, una decidida actitud, ante el rico material que su estudio proporciona, enmascarando esta ausencia con el "panem et circenses" de los caracteres estilísticos. Por muy eruditos que éstos puedan ser, no pueden establecer el puente necesario e ineludible entre la cultura del pasado y del presente que hace que la arquitectura actual se mida y enriquezca con la histórica, comprendiéndola y replanteándola.

Más allá de consideraciones estilísticas ajenas al pensamiento actual, cercano desde mi punto de vista a esencias y conceptos, la comprensión e interpretación de la razón de ser, de la lógica de la arquitectura en la que hemos de actuar, es un punto de partida desde el que llevar a cabo la intervención. Se establece de este modo un nexo, una continuidad, entre el presente y el pasado y su interpretación y plasmación en un proyecto de arquitectura. Al fin y al cabo, en la búsqueda de lo 
que el edificio "quiere ser", su futuro, "descubrimos el pasado como arsenal, (...) el pasado la tierra firme de los métodos" como nos recordaría Ortega y Gasset. (6)

El estudio del pasado nos ofrece conocer el edificio como hecho histórico y físico, sus vicisitudes y su vinculación a los sucesos que dan origen a la configuración del lugar tal como se nos presenta. Pero también nos permite descubrir los "métodos": el cómo la arquitectura ha dado respuesta a requerimientos y problemas semejantes que se han planteado a lo largo de los siglos. Las sucesivas respuestas que proporciona la relación con su propia arquitectura y con la arquitectura del lugar donde se instala y que modifica, constituyen una base necesaria para ese partir de cero que, como hemos dicho, es característico del proyecto de arquitectura.

Junto a estos rasgos generales que plantea definir una actitud ante la restauración de edificios históricos añadiría una apuesta, necesaria desde mi punto de vista: el valor del conocimiento, ineludible si estamos de acuerdo en que el patrimonio es un fenómeno vivo que con su historia, su interpretación, su uso, aporta luz a nuestro presente para la construcción de nuestro futuro. Se trata de sustituir el valor de vetustez, de lo viejo porque es antiguo, del que habla Riegl (y no precisamente en sentido positivo), por el esfuerzo del conocer lo característico de cada época, por considerar la aportación de cada momento histórico al desarrollo de nuestros monumentos y de nuestra memoria. La apuesta por el conocimiento y deleite de nuestra Historia debe partir necesariamente de una sensibilidad formada razonablemente.

\subsubsection{Ampliar edificios históricos}

Como se ha mencionado con anterioridad dos de los cinco proyectos introducen una variable respecto a los otros: se requiere su ampliación.

Juan Luis Trillo de Leyva sitúa con justeza el problema: “El concepto de ampliación es sugerente ya que parece resolver el problema de la continuidad, la arquitectura anterior no es algo 
que precise reanimación, sino sólo su inserción en una nueva situación proyectiva (...) El concepto de ampliación puede hacer entender el proyecto creativo que comprende en una misma acción lo nuevo y lo viejo, integrando ambos."

En el Neues Museum las trazas de la aduana que Schinkel plantea a espaldas del Altes Museum son el punto de partida para la resolución de la ampliación solicitada, como si el bloque lineal schinkeliano se encontrara allí antes de la construcción del Neues. Antes también de la enormemente densa trama de los museos que definirán la isla menospreciando la claridad de la ordenación propuesta en su día por Schinkel.

En el museo de Bellas Artes de Valencia, la ampliación, por necesidad de superficie junto a la incapacidad del edificio conventual para asumir el nuevo uso museístico dan lugar a una propuesta consecuencia de la lectura del complejo original, de sus sistemas compositivos, basada en un esquema contrastado en las propuestas de arquitectos "racionalistas radicales".

La ampliación de un edificio histórico supone: "En resumen aceptar la continuidad de la arquitectura en el tiempo y en el espacio" (7)

\subsection{Reconfiguración de espacios urbanos}

Las ampliaciones desarrolladas en dos de los cinco proyectos objeto de este estudio introducen una nueva problemática: a) la relación del volumen ampliado con el monumento existente y b) la relación del conjunto resultante con la ciudad. Si bien es cierto que el primer apartado pertenece al campo de los criterios de rehabilitación, el segundo hace aflorar el problema de la capacidad del museo para reconfigurar perfiles urbanos.

El papel específico que el museo-monumento ha asumido en relación con la ciudad lo encontramos con anterioridad en el momento de su primera eclosión. Aunque criticado, el programa cultural del museo del XIX que se pretendía como lugar de conservación de piezas, el ser un lineal, enciclopédico templo del conocimiento, ha sabido, sin embargo, crear áreas de centralidad y partes completas de la ciudad. El hecho de erigirse 
como punto central imprescindible en la composición de los conjuntos monumentales nos lleva a recordar el Ring vienés, el eje Unter der Linden berlinés rematado por el conjunto formado por el Palacio, la Catedral y el Altes Museum, (Lustgarten), o en el elemento generador de barrios cuya cualidad visual-urbana ha sido renovada, como observamos en Otto Wagner.

Es cierto que el museo del siglo XIX definió partes de la ciudad convirtiéndose en hito urbano que articula conjuntos de relieve en el tejido de la misma. Baste recordar el "rôl" que representa la no excesivamente brillante National Gallery de Wilkins (iniciada en 1833) en la definición de Trafalgar Square, pero no hemos de olvidar que su lenguaje académico se engloba en el eclecticismo con el que se construye la ciudad desde el siglo XIX hasta bien avanzado el siglo XX. (8)

En el caso de reutilización del edificio histórico, elemento primario de la ciudad y depositario de la memoria colectiva, como indica Rossi, la reconsideración de su capacidad de reconfiguración urbana da lugar a su revitalización a través de su conversión en museo, restituyendo así con nuevos contenidos su papel articulador de la urbe.

A partir del último cuarto del siglo $X X$ encontramos que, como consecuencia de la relectura y revalorización de la ciudad europea, el museo retoma su compromiso con la construcción de la misma. No sin agrias polémicas, dado que se trata de intervenciones cuyo lenguaje, inequívocamente contemporáneo, se relaciona en general por contraste $\mathrm{y}$, en las intervenciones menos "duras" por analogía con el contexto. Recordemos la intervención en la Staatsgalerie de Stuttgart donde Stirling privilegia con cuidadas y estudiadas cadencias la relación con la tradición y con el pasado sin caer en superficiales modas. Mientras, Venturi, que amplia el edificio de Wilkins, se diluye formalmente, en su desarrollo, conforme se aleja de la plaza de Trafalgar, como podemos observar en su conocido dibujo a tinta.

En consecuencia, muchas ciudades vuelven a asignar a los museos el logro de saber redimir la realidad de territorios urbanos desestructurados y deshilachados. Nuevos museos 
nacen con la intención de renovar el plano de la ciudad con la restitución de relaciones, la reconstrucción de frentes y el descubrimiento de estratigrafías olvidadas. Un ejemplo de ello lo encontramos en la construcción en Viena, de dos museos en el área comprendida en las inmensas caballerizas de Fischer von Erlach, operación que ha vuelto a proponer un siglo después la terminación del Ring.

De igual modo merecen destacarse las actuaciones en Frankfurt. En la orilla del río Meno, sus villas y muros son recuerdo olvidado de la antigua y bella imagen perdida. Una nueva secuencia de museos, en diálogo con las históricas construcciones, restaura y restituye el nuevo-antiguo frente urbano. Su revitalización y puesta en valor representa así un elemento fundamental de la composición urbana, elemento reconocible de los mejores momentos de su tradición clásica ejemplarizada y enriquecida con la recuperación lograda. En su centro histórico bombardeado en 1944, la ciudad utiliza un museo, un centro de arte, para restañar las heridas abiertas en lo que era la ciudad medieval. El proyecto, -el enésimo después de diversas tentativas como el concurso de 1953, ganado por Hebebrand, colaborador de Ernst May en la Neue Frankfurt, seguido de un segundo en 1963, en el que participan arquitectos de la talla de Gropius, May, Scharoun, Candilis-Josic, y Jacobsen - plantea unir el Ayuntamiento y su plaza, con la catedral ante la cual los bombardeos han sacado a la luz restos romanos y carolingios cuya conservación se pretende, mediante un complejo cultural que se ordena a base de un elemento lineal que enlaza a modo de un stoa ambos recintos.

Recientemente el aparentemente aislado Kunsthalle de Peter Zumthor, en Bregenz, asume en la complementación del Wasserfront una toma de posición clara y formalmente refinada en la redefinición del espacio urbano. 


\subsection{El museo: evolución y desarrollo}

Los edificios objeto de actuación comparten una finalidad: convertirse en museos. El conocimiento de la institución museo, su origen y objetivos y las diferentes respuestas que la arquitectura ha dado a su resolución es un camino cuyo recorrido debe ser paralelo al de la lectura crítica del edificio de partida.

Sus objetivos básicos de transmisión de conocimiento, salvaguarda de la memoria y disfrute, pertenecen a su sistematización a finales del siglo XVIII, como museo, institución cívica que nace en estas fechas.

Pero con anterioridad, el afán de coleccionismo y su exposición, ya sea como disfrute o como instrumento de poder, ha generado una serie de espacios arquitectónicos, un vocabulario, que aguarda al replanteamiento realizado por la sociedad burguesa en el Siglo de las Luces, que los sistematiza $y$ articula en una sintaxis generadora del edificio museo. A partir de la segunda mitad del siglo XX lo que era un espacio de cultura y reflexión burgués se convierte en elemento de instrucción y entretenimiento de las masas.

La profunda transformación vivida por el museo como institución da lugar a un cambio de necesidades en su programa. Ello comporta la dilucidación de la validez y de la permanencia de los espacios de exposición hasta entonces utilizados y la posibilidad de su manejo en nuestras propuestas.

Ha cambiado el museo, su programa, y han cambiado las condiciones del entorno. De la resolución arquitectónica de las necesidades que plantea, hablaremos más adelante, exponiendo cómo a lo largo de los siglos se ajustan las respuestas de la arquitectura a los cambios y a la evolución del programa museístico. Por supuesto la historia acudirá para informarnos de la génesis de los espacios expositivos que están en la base del museo moderno y para constatar la relevancia de un edificio que no sólo por su contenido, sino por la importancia simbólica del mismo, constituirá hitos urbanos en la construcción de la ciudad europea y americana.

Podemos avanzar que la aparición de nuevos espacios 
de exhibición extraídos de otros campos de la disciplina arquitectónica y su introducción en el repertorio museístico, no supone una obsolescencia de los modelos organizativos que se han venido usando hasta ahora, es más, no actúa en contraposición. El proyecto actual de museo mostrará la validez de las diferentes tipologías espaciales sistematizadas por Durand, agregándose y recomponiéndose con el "container" proveniente de las exposiciones universales decimonónicas, con el objeto de alcanzar el fin específico de una institución que hasta la llegada, a caballo entre siglos, del edificio icónico, daba forma y significado a la ciudad y aportaba información y entretenimiento a la sociedad.

\subsection{Los cinco museos}

Enunciemos sucintamente cómo se presentan ante nosotros, en el momento de la redacción del proyecto, los cinco edificios, es decir, lo que llamamos en la jerga arquitectónica su "estado actual."

\subsubsection{Palacio del Marqués de Campo (1984-1989)}

Un palacio en forma de "U", cuyo origen se remonta al siglo XVII, en el centro histórico de Valencia, cercano a la catedral, a la antigua Casa de la Ciudad y al palacio de la Generalidad, definidor del frente norte de una plaza cuyo lado sur cierra el Palacio Arzobispal, como se observa en el plano de la ciudad del Padre Tosca de 1704

En el siglo XIX la reestructuración del Maestro Ferrando, para residencia del nuevo propietario el futuro Marqués de Campo, lo convierte en edificio de patio central y fachada principal a la citada plaza al cerrar la planta en U original del siglo XVII. Esta configuración la ofrecía el palacio en el momento de plantear la intervención.

De los criterios de intervención en el entonces denominado Palacio de Berbedel hablaré más adelante. Solamente avanzaré la asunción, como juicio de valor, de la forma decimonónica que ofrece el edificio, como punto de partida para llevar a cabo una

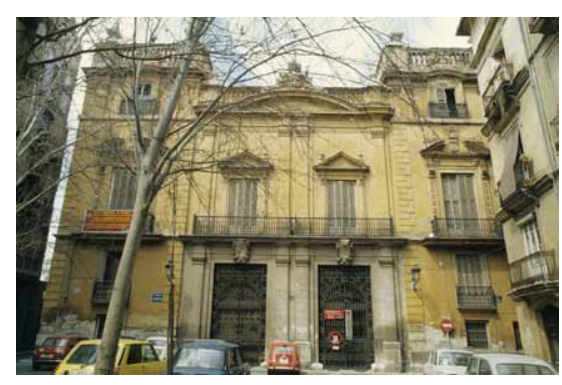



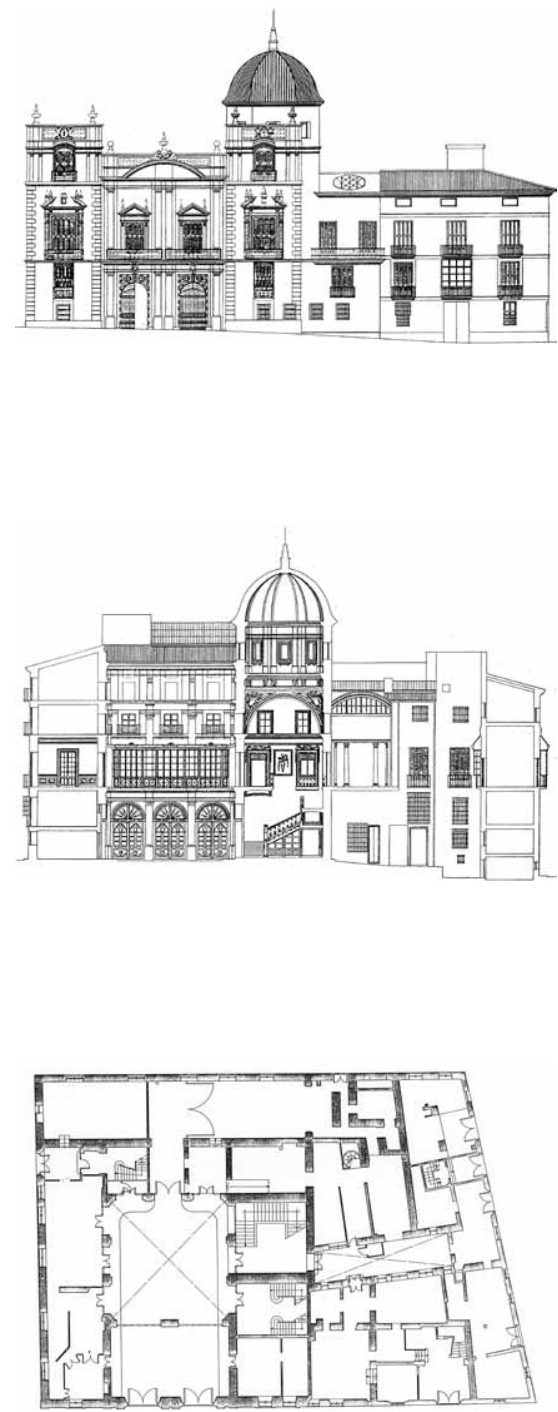

restitución que devuelva con mayor claridad y transparencia algunos de sus más genuinos valores. Siendo consciente que restituyendo no se salva todo el pasado, ni todas las vicisitudes que el edificio ha sufrido a lo largo del tiempo se asume el riesgo de interpretar lo que es fundamental, separándolo de lo accesorio, haciendo legible la congruencia compositiva lograda tras la intervención del siglo XIX.

La idoneidad y compatibilidad de edificios nacidos para funciones diversas a las que se proponen en el momento de la actuación no son obstáculo en el caso que nos ocupa.

Veremos más adelante como el museo nace en el palacio, donde se muestran las colecciones de sus propietarios. En el palacio Marqués de Campo, el poner de manifiesto, según el criterio de restitución citado, la estructura del siglo XIX, lleva a la obtención de secuencias de espacios aptos para exposición pictórica en un recorrido que la tipología de patio propicia.

Como última consideración como edificio monumental capaz de asumir el papel de museo, el palacio debe responder a la necesaria relación espacio-obra de arte-espectador.

En cuanto al uso del edificio como museo se considera fundamental: la independencia de accesos, que eviten superposición de usos, el recorrido del espectador, por las exposiciones temporales y las permanentes y las posibles visuales que la secuencia espacial implícita en estos recorridos ofrece. El visitante del museo establece una relación con la obra de arte en su contemplación. A través del factor tiempo, el recorrido es un elemento primordial en la visita a un museo. Debe permitir la sucesiva contemplación reposada de las obras expuestas y la consecución fluida de las diferentes muestras que la institución propone a lo largo de los diferentes espacios.

Por supuesto que para los usos internos la propuesta debe propiciar espacios razonados y ordenados que en este caso se reducen drásticamente, pues estarían ubicados la mayor parte en la segunda fase, como he indicado.

La planta baja se considera idónea para las exposiciones temporales. La propuesta proyectual posibilita, mediante la 
transparencia de los grandes acristalamientos, establecer no solo la incorporación visual del patio al recorrido de los visitantes, sino también su inclusión en la exposición cuando las obras a exponer lo permitan.

Al final del recorrido de la exposición temporal propuesto en planta baja el visitante puede, si lo desea, continuar la visita del museo accediendo a las exposiciones permanentes ubicadas en las plantas superiores. Los diferentes salones en enfilade de la planta noble propician un recorrido a través de los espacios recuperados conectado, mediante una escalera de nueva traza (no existía conexión original entre plantas), con los áticos. En ellos un lenguaje abstracto, permitido por la ausencia de pre-existencias, articula diferentes espacios que, apoyados en la variada altimetría proporcionada por el edificio, organizan el claro recorrido museístico.

\subsubsection{El Almudín de Xátiva (1983-1989)}

En el centro histórico de Xàtiva, junto al eje definido por la calle Corretgeria, se encuentra esta alhóndiga conformada alrededor de un delicado patio de un temprano estilo jónico. Destinada al depósito, contratación y venta de cereales, se trata en realidad de la ampliación de la primitiva. Aprobada en 1530 por el Consejo de la Ciudad, su ejecución se realiza entre 1545 y 1548. "L' obra del present Almodi fon acabada en MDXLVIII” reza la inscripción coronada del acceso. En 1918, con la inclusión de una pequeña pinacoteca cívica, se convirtió en museo municipal.

El conjunto se ofrecía a nuestros ojos como un elenco de materiales diversos entre los que había elementos de indudable valor arqueológico. Las piezas estaban colocadas sobre los muros de la planta baja y alrededor del patio se ubicaban y almacenaban, sin orden alguno, fragmentos de arquitecturas procedentes de demoliciones. En la planta superior se colgaban pinturas de diferentes épocas, entre ellas un gran retablo, para cuya ubicación se alteró el impluvium de la cubierta original. El "vell Almodí" debía ser rehabilitado y sistematizado, posibilitando en cuanto museo lugar adecuado a la colección pictórica y la 

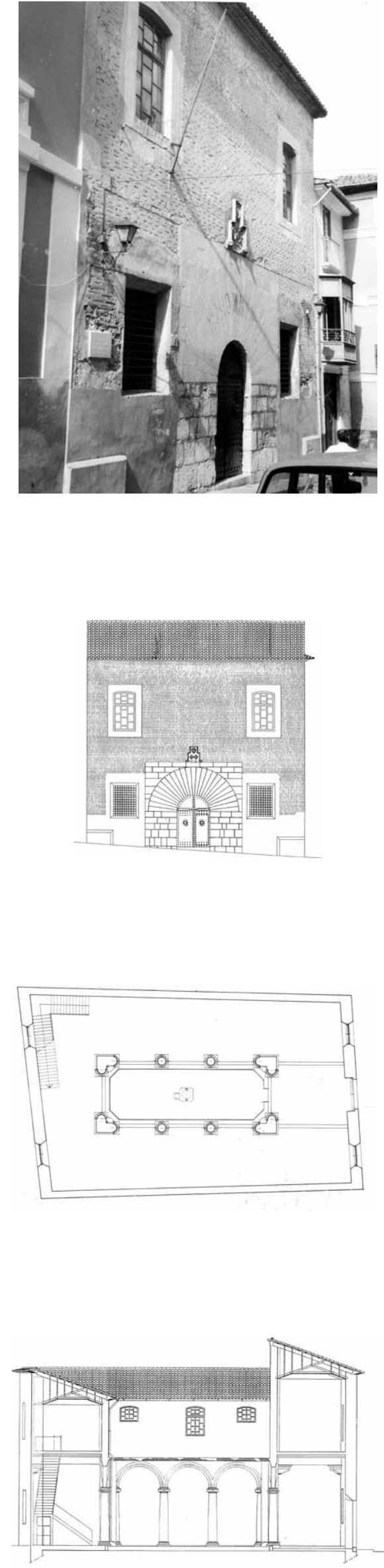

exposición y puesta en relieve de sus piezas arqueológicas y arquitectónicas más significativas depositadas en él.

La intervención, realizada con el Prof. Girgio Grassi, parte como no podía ser de otra forma de la lectura del edificio y de cómo éste se presenta inmediatamente antes de la actuación. Resultado de las alteraciones sufridas a lo largo del tiempo, el Almodí aparece como un bloque compacto, de dos plantas, cerrado entre dos muros de fachada que dan a estrechas calles paralelas. Se desarrolla alrededor de un pequeño patio porticado en planta baja con columnas jónicas (cuyos capiteles se presentan curiosamente girados 90\%) y arcos de piedra, en relación de tres a uno (11x4m aproximadamente).

La planta superior, muy transformada, adolece de los elementos como cornisas, impostas y de una ordenación de huecos que la relacionen con el orden jónico inferior. Constituye una ampliación del edificio de planta baja, realizada en atención al uso museístico que se otorgó al edificio. Carece de la calidad de la arquitectura de la planta baja y no posee relación alguna con ella; incluso su cubierta, transformada, había anulado la figura originaria del impluvium. Una escalera de madera, de considerable longitud, permitía la conexión entre la planta baja y la planta primera.

En consecuencia, el objetivo de la intervención es conseguir la unidad del espacio claustral relacionando ambas plantas a partir del orden establecido por la arcuación renacentista que lleva a ordenar axialmente a ésta la nueva fenestración pautada por las correspondientes impostas y cornisas que se maniefiestan en negativo ante la imposibilidad de caracteres estilísticos de la arquitectura actual.

La adaptación del edificio al programa actual museístico cuestiona, de nuevo, la idoneidad en la adaptación funcional del edificio histórico al nuevo uso. La colección se organiza en atención al recorrido, que en planta baja dispone de unos corredores elevadosque permiten el acercamiento delespectador a las obras de arte expuestas a modo de antiquarium. Estas pasarelas posibilitan pues una contemplación más cercana de 
las obras para los estudiosos y son clave en la resolución de la conexión entre plantas. La escalera antigua, añadida e impropia en una esquina del deambulatorio del patio, presentaba una gran longitud, debido a la considerable altura que debía salvar; la nueva escalera de comunicación, vinculada a uno de las pasarelas, permite un discreto ascenso a la planta primera. En ésta, las obras se exhiben sobre los muros perimetrales, bajo la cubierta de madera restaurada y con su impluvium recuperado.

La posterior reforma y adecuación como museo del antiguo Banco de España, edificio adyacente, ha modificado la circulación e itinerario del Museo del Almodí. A la planta superior se accede desde el contiguo edificio aislándola de su relación con la planta baja, el delicioso patio del antiguo Almudín.

Interesa en este proyecto la relación espectador-obra de arte-recorrido: no solo los numerosos fragmentos arqueológicos y arquitectónicos son objeto de contemplación y aprecio; también el propio edificio -a través de su arquitectura y orden recuperados- se muestra como un objeto valioso cuyo injusto olvido reclama, hoy, nuestra valoración en un recorrido integrado: Desde las pasarelas de planta baja, cuya materialidad se distancia claramente de la obra antigua, se aprecia desde un punto de vista elevado e inédito el pequeño claustro renacentista que, mediante el adecuado tratamiento de sus paramentos interiores y la ordenación de los huecos y elementos arquitectónicos de la planta primera, aparece revalorizado en toda su magnificencia.

\subsubsection{Las Atarazanas de Valencia (1979-1993)}

Su construcción se remonta al 27 de agosto de 1338 cuando el Consejo de la Ciudad, a raíz de una solicitud del Rey Pedro el Ceremonioso para la construcción de unas galeras, acordó construir una casa en la que "velas, remos, (...), puedan guardarse convenientemente". Consta su terminación en Agosto de 1391.

En 1802, para satisfacer la deuda que la ciudad tenía con ella, las Atarazanas pasan a manos de la Real Hacienda, que las utiliza como almacén de sal. A partir de entonces la conservación
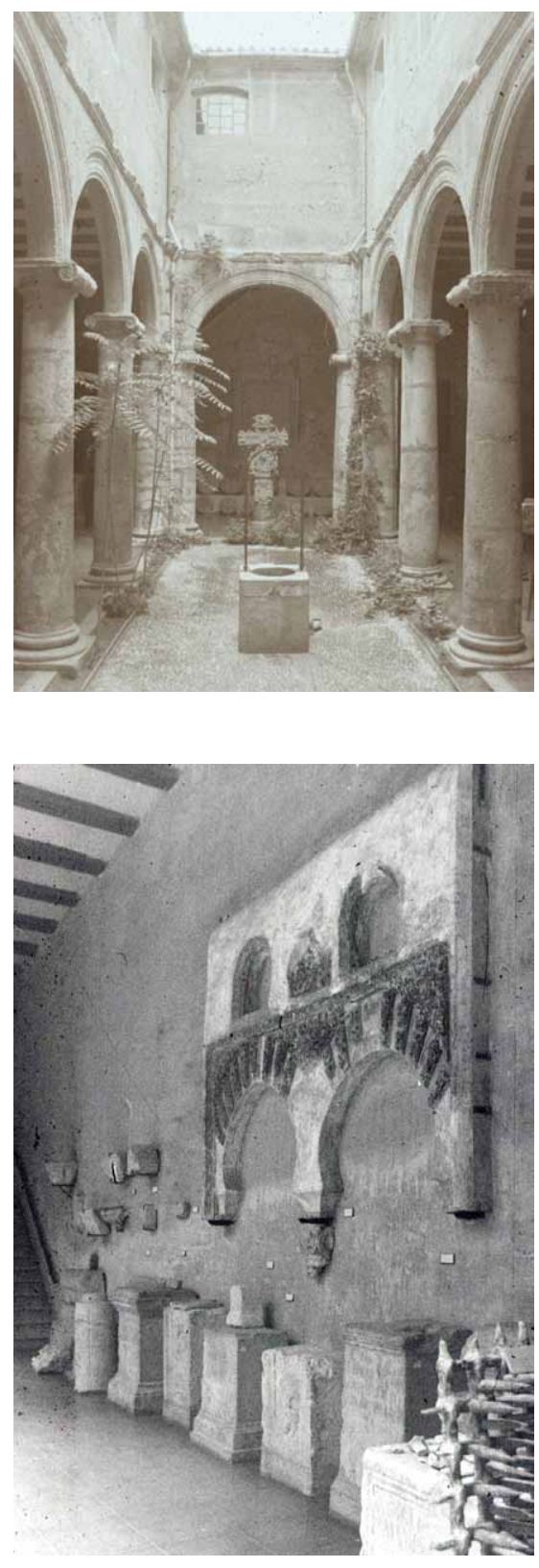


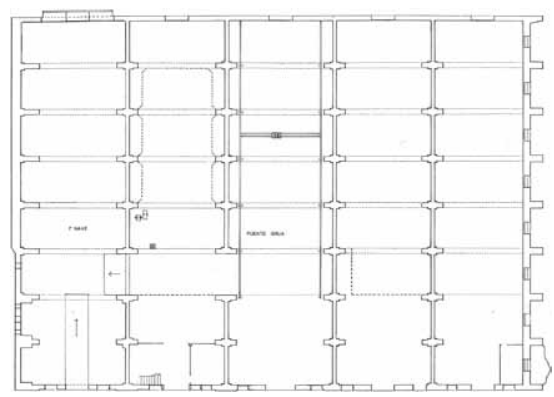

y mantenimiento del monumento caen en el olvido. El 9 de septiembre de 1840 se privatiza la propiedad del Monumento, y las cinco naves de que consta son independizadas y pasan a albergar diferentes usos: almacén, sala de cine, viviendas, oficinas, talleres de fundición y de maquinaria naval, son las diferentes funciones a las que se somete el monumento con las alteraciones y agresiones implícitas en usos tan dispares.

Vinculadas históricamente al mar, hoy día aparecen tras la imponente muralla del frente urbano portuario, conformada por los edificios de siete plantas construidos en la segunda mitad del siglo pasado.

En 1978, iniciado el proceso de estudio, previo al proyecto de arquitectura, el edificio se ofrece como un conjunto de planta sensiblemente rectangular integrado por cinco grandes naves de una longitud de 49,50 m. y anchura media de 13,20 m. cada una de ellas. Las naves están formadas por 9 arcos diafragma en sentido longitudinal de perfil apuntado arriostrados por 8 arcos formeros; toda la fábrica evidencia su construcción en ladrillo. Las cinco cubiertas son a dos aguas, de teja moruna en origen. Las aguas pluviales se recogen en unas gárgolas de piedra caliza que en su parte inferior poseen esculpido el escudo de la ciudad. Estos elementos se han conservado hasta nuestros días, tanto los correspondientes a la fachada principal como a la posterior.

Accediendo en el edificio, por gentileza de la propiedad

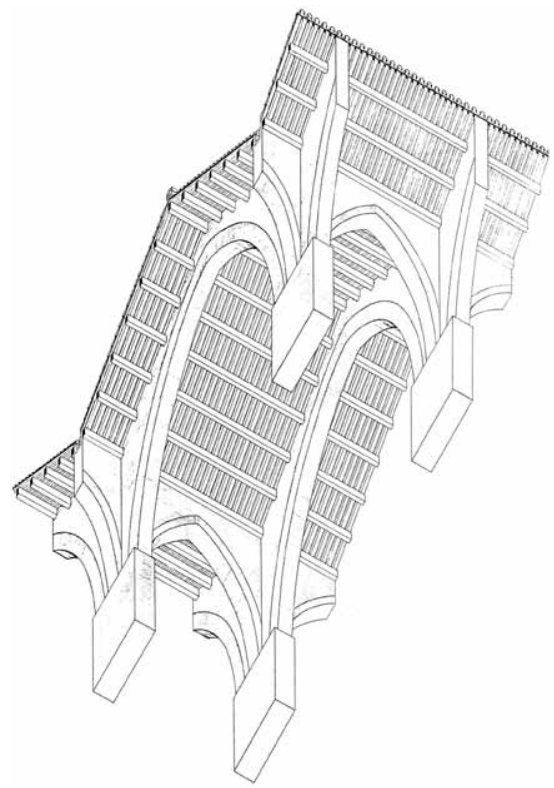
(privada) observamos: Los arcos transversales se encuentran macizados, bien sea por límite de propiedad bien sea por los diferentes usos a los que se someten las naves. Las cubiertas han sido descuidadamente perforadas para dejar paso a la luz en busca de la iluminación de los espacios de trabajo. La nave central dispone de balcones apoyados en la imposta de los arcos -los palcos del antiguo cine Alhambra-; para permitir el paso, se perforan los riñones de los arcos. Puentes grúa se empotran en las fábricas antiguas para facilitar el trabajo de fundición. Un arco ha sido cortado para construir un altillo en el que se instalan unas oficinas; otro, en la fachada de la cuarta atarazana (desde el sur), para construir una vivienda de aire, sólo aire, modernista. 
Soleras de hormigón en los pavimentos. Brevísimo resumen de casi 200 años de abandono. A grandes rasgos así se presentan las atarazanas de Valencia a finales de la década de los setenta del siglo XX.

Pero la arquitectura del edificio se "escuchaba", latía entre las brutales agregaciones y mutilaciones. Había que "dejar hablar al edificio" como decía hace casi un siglo Ambrogio Annoni, que continuaba: "El monumento es el maestro".

El espacio que propician la articulación de los arcos diafragma y los formeros era, tras años de reflexión y pequeñas operaciones de "inspección", la gran clave de la intervención. El mínimo necesario, a nuestro entender, para que el monumento manifieste todo su esplendor. En consecuencia, la intervención en las Atarazanas de Valencia se plantea a partir de la decidida recuperación del espacio gótico que definen las cinco naves comenzadas a construir en siglo XIV, a base de simples, elementales, bellísimos, arcos diafragma de ladrillo, con su tradicional cubierta de madera.

La articulación definida espacialmente por el arco diafragma y sus transversales de arriostramiento es el elemento cuya repetición da lugar a la rica secuencia espacial que proporciona el monumento, una vez liberado de los añadidos, producto de las agresiones que padece desde que pasa a manos privadas en 1840 .

Se podrá argüir que es posible que nunca el espacio interior fuera diáfano, que desconocemos este particular. Pero también hay que recordar que nunca la pintura, la arquitectura, la música, las artes han sido interpretadas de la misma manera, en épocas diferentes. El arte, decía Gombrich, tiene su propia ecología: su percepción cambia conforme evoluciona el modo de acercamiento y lectura. La historiografía arquitectónica del pasado siglo nos ha mostrado el valor del espacio como elemento definidor de la arquitectura. Cómo todos los elementos que definen la forma de la arquitectura solo tienen sentido en cuanto configuran espacio. Él es el protagonista, definidor y diferenciador de la disciplina respecto de las demás artes.

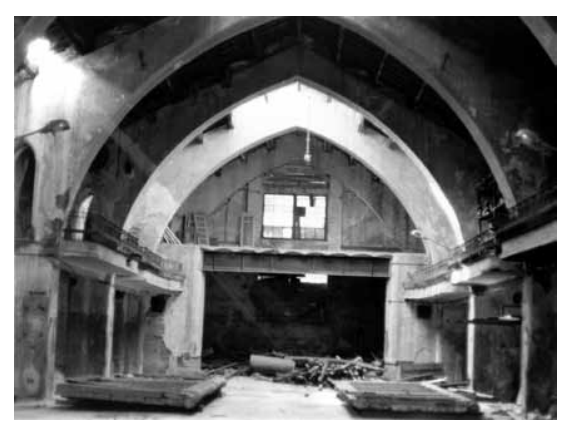


Todos los elementos que definen el proyecto junto con el porche, las cristaleras, con sus transparencias, las diferentes carpinterías, las instalaciones, pavimentos, etc. tratan de hacer hincapié en su simplicidad, en el tema abstracto que entendemos desde la mentalidad de hoy: el espacio gótico, su potencia, su razón de ser y también su magia.

La capacidad tipológica del espacio recuperado para dar respuesta a las necesidades expositivas es el segundo apartado que se considera. El contenedor como tipo arquitectónico expositivo había tenido su consagración, una década antes de comenzar las intervenciones en las Atarazanas, con la construcción del Centro Pompidou en París. Una mirada a la historia de la arquitectura nos lleva a los edificios-contenedores de las grandes exposiciones universales: desde el Crystal Palace de Paxton de 1851, hasta la Gallerie des Machines de 1889, entre otros.

El gran espacio que se genera proporciona flexibilidad en la adaptación de diferentes exposiciones mediante proyectos específicos y adecuados para cada caso. Las Atarazanas ofrecen un espacio de más de $3000 \mathrm{~m} 2$ modulado por rectángulos de aproximadamente $6,50 \times 13,50 \mathrm{~m}$. En ellos se pueden instalar diferentes elementos, bien sean vitrinas o mamparas que soporten la exhibición de las obras, siempre -claro está- en relación a la estructura del edificio: a $3 \mathrm{~m}$ de altura aparecen las impostas de los arcos. La exposición se apoya en el espacio arquitectónico, de modo que ambos se potencian mutuamente. El monumento muestra su capacidad de respuesta y su esplendor mediante un uso que el Consejo de la Ciudad de 1338 nunca hubiera imaginado, cuando ordenó el levantamiento de un edificio -industrial o funcional diríamos hoy- para la construcción y almacenaje de galeras y enseres de la mar. 


\subsubsection{Rehabilitación y Ampliación del Neues Museum} de Berlín (1993-95)

El primer premio, en el concurso convocado en 1993, para la realización del proyecto y obra de rehabilitación y ampliación del Neues Museum de Berlín se obtuvo en colaboración con el profesor Giorgio Grassi. Diversas circunstancias -cuyo relato no es propio de este texto- cancelaron el contrato, finalmente adjudicado al equipo, encabezado por David Chipperfield, que había obtenido el segundo premio y que ha rehabilitado el histórico edificio.

El edificio fue diseñado por Friedrich August Stüler, discípulo de Schinkel, en la llamada isla de los Museos (Museumsinsel) y su construcción se lleva a cabo a mediados del siglo XIX, durante casi veinte años. En el conjunto de la isla de los Museos se organizan, con mayor o menor fortuna, cuatro edificios de uso expositivo a espaldas del Altes Museum: La Alte Nationalgalerie, obra también de Stüler (1841), basada en un croquis del emperador Guillermo IV y construida entre 1866-1876; El Bode Museum, antiguamente Kaiser Friedrich-Museum, cuyas puertas se abrieron en 1904; El Pergamonmuseum, construido entre 1910 y 1930 según diseño de Alfred Messel y el Neues Museum, cuya rehabilitación y ampliación requerían las bases del concurso convocado.

Cinco aspectos fundamentales se requerían. El primero atañe a la reconstrucción del museo; los graves bombardeos acaecidos durante la Segunda Guerra Mundial supusieron la pérdida de dos alas del noroeste del edificio -que limitaban uno de los dos patios que definen el museo-, de la torre del ángulo sureste así como del cuerpo central de escaleras que articulaba ambos patios.

Una segunda exigencia, suscitada ya en fase de concurso y muy cuestionada durante el desarrollo del proyecto, reclamaba una conexión aérea -mediante la reconstrucción del puente destruido que había sido realizado también por Stüler- con el Altes Museum, que desfiguraba la exenta y canónica concepción del edificio de Schinkel.

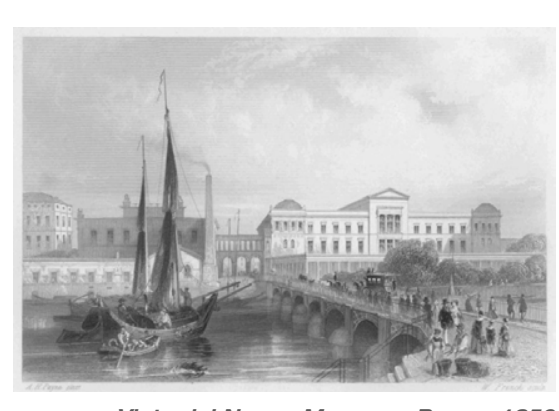

Vista del Neues Museum. Payne, 1850

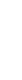




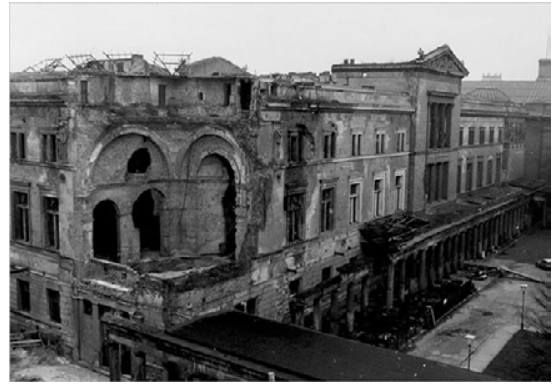

.
La tercera cuestión que se planteaba demandaba la ampliación del edificio original en atención a la extensa colección objeto de exposición. De este extenso elenco -cuarto requerimientos- cabía destacar la exhibición de dos obras maestras: el busto de Nefertiti y los restos del templo de Tel el Amarna.

Una quinta exigencia exigía la creación de un recorrido integrado entre el Neues Museum y el Pergamon Museum: la propuesta debía resolver un recorrido breve que procurase una visita exclusiva a las piezas más relevantes de ambos museos y que puede resumirse de este modo: Templo de Tel El Amarna y el busto de Nefertiti -en el Neues Museum- y la Calle de las procesiones, Puerta de Ishtar, Puerta del mercado de Mileto, Altar de Pérgamo y la fachada de Mschatta -en la secuencia canónica del Pergamon-.

La propuesta del proyecto se puede dividir en dos partes: La primera trata de los criterios de reconstrucción del Neues y de su ampliación cuya problemática plantearé sucintamente; la segunda, no menos relevante pues afecta a la definición de ciudad, se refiere al complejo de los museos y es el resultado de la lectura crítica de su condición actual, de sus recíprocas relaciones y de su vinculación con la ciudad. El tratamiento de los problemas que surgen -cuya complejidad y extensión así lo aconsejan- se explicitan más adelante.

Con respecto al Neues Museum, se propone una reconstrucción en atención a la trama implícitamente contenida en el actual trazado del museo, como si se tratase por un lado de sus fragmentos destruidos y por otro del antiguo Packhofsanlage diseñado por Schinkel a espaldas del Altes Museum. Estas dos referencias guían la estrategia de proyecto del nuevo edificio e incluso determinan la expresión estilística del mismo, de modo que tanto la reconstrucción de los fragmentos derruidos como la ampliación (que pretende expresarse como estos), se liberan de todo ornamento y se definen mediante un material pobre, como el ladrillo cara vista, otorgando una apariencia incompleta. Su ampliación, necesaria por la gran cantidad de obras objeto 
de exposición, se enfrenta al hecho de la altamente masificada Isla de los Museos; la propuesta debe por tanto conciliar en la medida de lo posible esta contradicción.

Apoyándose en la tipología edilicia de edificio con un cuerpo central -el imponente espacio del antiquarium- y un patio a cada lado, la propuesta plantea dicho volumen como elemento que ordena el complejo espacial. El vaciado del antiguo hueco de escalera se destina a antiquarium de los elementos decorativos del anterior espacio bombardeado. Estos restos arquitectónicos, fragmentos y calcos evocan con su disposición en los paramentos que los contuvieron la memoria de un espacio desaparecido que ya no existe. La potencia de este espacio sirve para referencia y orientación del visitante, organizando las diversas colecciones que dentro del Neues Museum pueden ser contempladas. Los dos patios divididos por el gran espacio central, denominados originariamente patio egipcio y patio griego, se cubren con cristal y, fácilmente accesibles en planta baja, se proponen como salas de exposiciones temporales.

Desde el recuperado acceso que recae a la Kolonnadenhof, el eje ordenador de los espacios principales se prolonga -en planta baja- para enlazar con el edificio de ampliación que discurre paralelo al Kupfergraben. De este modo, se establece una secuencia formada por el vestíbulo, el antiquarium y una sala de considerable altura e iluminación cenital, cuyo objeto de exhibición es una de las piezas clave del Museo Egipcio: el Templo de Tel el Amarna. Este cuerpo transversal con iluminación cenital enlaza con el volumen lineal de la ampliación, junto al canal, que evoca la aduana proyectada por Schinkel en ese lugar -la Packhofanlage-, ajustada en su longitud a la del Neues Museum, del que es ampliación. En el eje de enlace se sitúa, como no podía ser de otra manera, la joya de la colección: el impresionante y exquisito busto de Nefertiti.
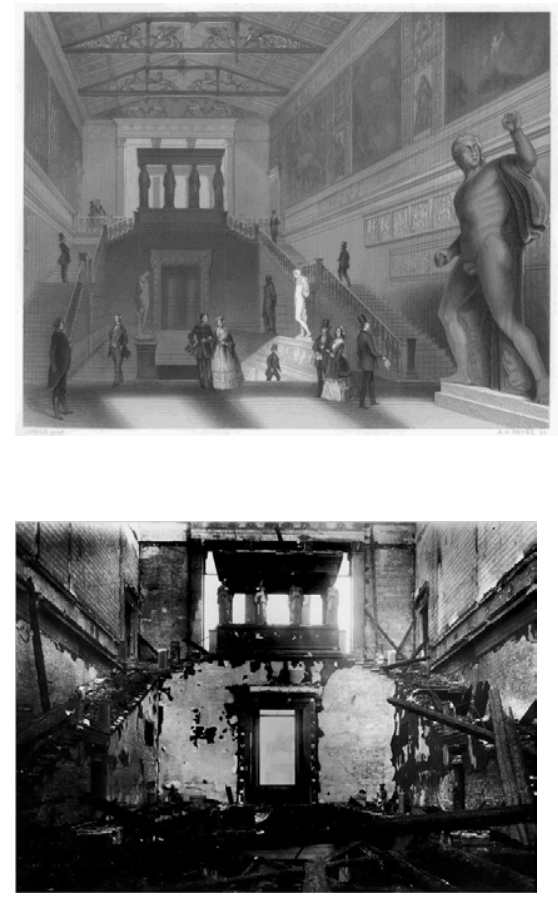


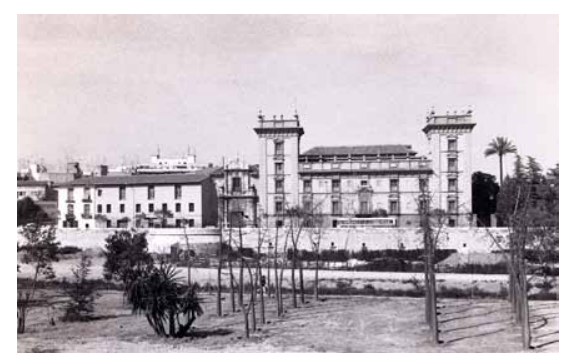

2.6.5. Rehabilitación y Ampliación del Museo de Bellas Artes de Valencia (1985-1996)

El antiguo convento y colegio de San Pío V, convertido en Museo de Bellas Artes en 1946, se presentaba en 1985, cuando recibí el encargo de su rehabilitación y ampliación, como una confusa aglomeración de edificaciones que enmascaraban el edificio original que en el siglo XVII construyó Juan Bautista Pérez Castiel. Su situación en el margen izquierdo del río Turia entre el Palacio Real, demolido en 1811, sus jardines y el convento de la Trinidad, se enmarca entre los bellos puentes góticos del Real

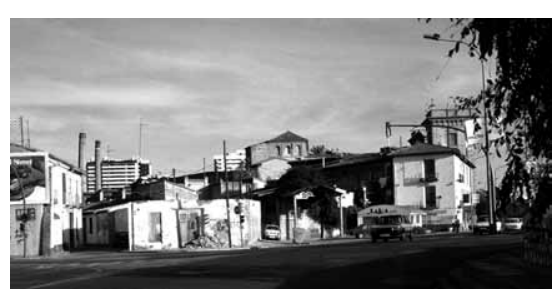
(en alusión al palacio) y de la Trinidad, definiendo un perfil urbano, frente a la silueta de la ciudad histórica con sus innumerables torres y campanarios, que se observa en diversos grabados.

El edificio histórico consta de tres partes diferenciadas: el claustro y sus alas perimetrales -en el flanco este-, la iglesia cupulada de planta octogonal -en el centro-y un edificio de planta rectangular añadida a ésta -en el oeste-. A las trazas originales se le añadieron, a lo largo del tiempo, un conglomerado informe de volúmenes sin más criterio que la construcción de edificios adosados funcionales y sin más límite que el que establecía la acequia de Mestalla en su discurrir de norte a oeste. La iglesia exhibía el vacío provocado por la inexplicable demolición de su cúpula a inicios del silgo $X X$, de modo que la composición del conjunto adolecía de su tradicional remate, la gran cúpula cubierta con teja azul vidriada. La decidida recuperación del perfil histórico del edificio, cuya memoria perduraba a través de los grabados antiguos de la ciudad, es uno de los axiomas del proyecto, que reflexiona $-y$ emite un juicio materializado en la propuesta- acerca de la importancia del monumento en el

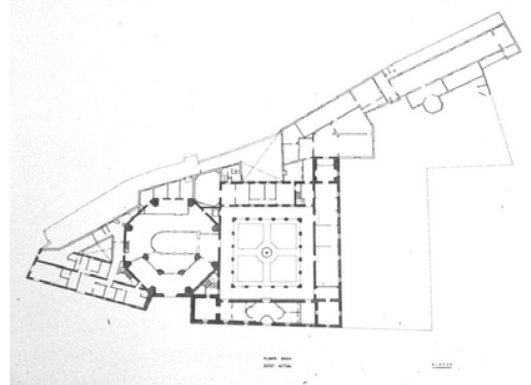
tejido urbano y de la trascendencia de su recuperación como protagonista de la escena urbana.

El desorden y la aleatoriedad en la exhibición de las colecciones, la insuficiencia de sus instalaciones y la inadecuación de sus espacios expositivos, la falta generalizada de almacenes adecuados y de servicios llamados internos, entre otros, 
emparentaban al museo de 1984 con un museo decimonónico en estado de abandono.

El proyecto de rehabilitación y ampliación del Museo de Bellas Artes San Pío V, plantea como objetivo básico la dotación de una unidad lógica al conjunto resultante de la intervención en las trazas originales del edificio; la resolución del nuevo programa de museo de arte debe proporcionar los espacios de exposición necesarios así como los servicios propios de un museo, a partir de las reglas, las pautas que del estudio y lectura del monumento se establecen.

Una primera decisión clave es la restitución del espacio definido por la cúpula, que se restituye tanto por ser el núcleo del nuevo museo como su por significación urbana. Cesare Brandi en su Teoría de la restauración nos decía que, en el momento en que los elementos desaparecidos hayan sido monumentos en si "el ambiente deberá ser reconstruido en base a los datos espaciales, no a los formales, del monumento desaparecido. Así se debía reconstruir un campanario en San Marco, pero no el campanario caído; se debía reconstruir un puente en la Santísima Trinidad, pero no el puente de Ammanati."(9) A los ejemplos citados podemos añadir la reconstrucción del Palacio de los Sforza en Milán, incluida la "licencia" que se permite Beltrami con la reconstrucción de la torre del Filarete. En conclusión: la restitución del papel urbano de la cúpula era una acción decisiva.

Este espacio recuperado se convierte en el núcleo del nuevo museo donde se cruzan los dos ejes principales de la intervención: El longitudinal, en el sentido norte-sur del acceso nuevo al museo por la fachada retablo de la antigua iglesia, enlaza con la ampliación, convertida en el elemento fundamental para exposición y servicios. El transversal, secundario, enlaza el antiguo claustro alrededor del cual se ordenan funciones permitidas por sus escasas dimensiones con el denominado patio de escultura, que articulaba a su alrededor tanto el bloque lineal convertido en edificio administrativo como las nuevas salas de exposiciones temporales y el salón de actos.

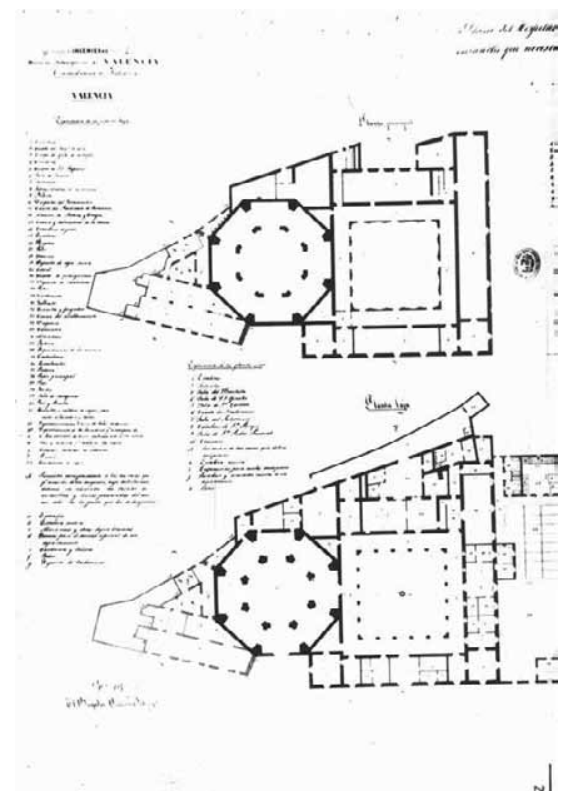

La ampliación del Museo se plantea mediante un esquema 


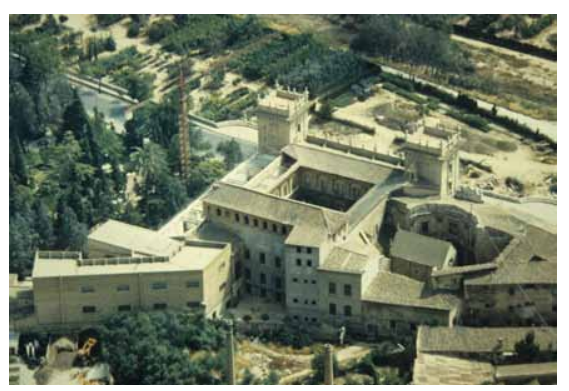

aditivo de partes reconocibles y diferenciadas, de forma análoga al procedimiento del edificio histórico. Éste estableció en proyecto una ele inicial, formada por las crujías este y sur -con sus torreones-, que se cerró en una planta cuadrada con un claustro central. Posteriormente, en el siglo XVIII, se añadió la iglesia octogonal y el bloque lineal, adosado a uno de los muros de esta última. Cuadrado, octógono y rectángulo, tres figuras plenamente reconocibles con entidad propia, formaron el conjunto primigenio reconocible en su fórmula aditiva. La nueva propuesta se alinea con este criterio de composición y hunde sus raíces formales en la apreciación de la arquitectura histórica de la ciudad, esencialmente en aquella que se caracteriza por la masividad de sus muros y por el ritmo que le confieren sus contrafuertes, que emergen de los mismos y pautan su lectura.

La tipología en peine, que tan buenos resultados ha aportado en la arquitectura del siglo $\mathrm{XX}$ a la resolución de proyectos de uso público, es la escogida como base de la ampliación. Baste recordar la propuesta de Hans Schmidt y Paul Artaria para el concurso de la biblioteca cantonal de Berna, en 1927. El brazo principal, en el eje Norte-sur proporciona una gran galería longitudinal en la que albergar los grandes retablos que atesora el museo y que nunca pudo exhibir completos debido a sus grandes dimensiones. Su anchura corresponde a la dimensión

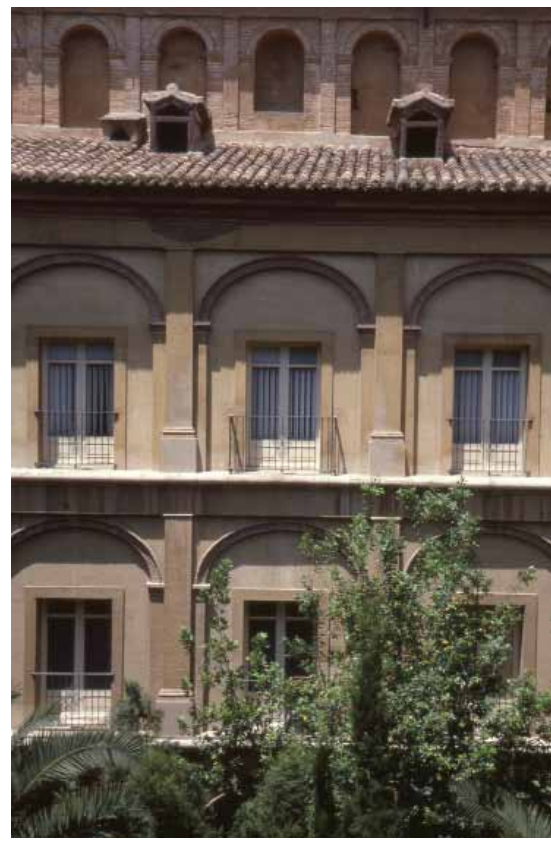
del lado del octógono y su altura viene limitada por la cornisa de la antigua iglesia, lo que da pie a una sala a doble altura, iluminada con luz cenital; en consecuencia los brazos perpendiculares del peine se entregan al eje principal dando lugar a una galería en el primer nivel en la que se pueden contemplar los retablos desde un punto de vista más alto.

Un itinerario subyace implícito en la planta. Al fondo de la gran galería longitudinal se ubica el núcleo de comunicaciones verticales que da acceso a la planta superior, donde los brazos proporcionan amplias salas con iluminación cenital que arrancan de la citada galería abierta al gran espacio longitudinal. Al final de su recorrido, se alcanza el bloque claustral, en el que se visitan las galerías, abiertas al patio, que liberadas de fraccionamientos 
se ajustan a las dimensiones del claustro y permiten su comprensión.

El eje Este-oeste resuelve problemas diferentes. En su lado occidental, el claustro acoge programas relacionados con la Real Academia de Bellas Artes de San Carlos. En el otro extremo se sitúa la cafetería y librería (también con entrada desde el vestíbulo octogonal). Las galerías de exposición temporal se desarrollan según el mismo esquema compositivo y están dotadas de iluminación cenital; también permiten unir su recorrido mediante un corredor acristalado, abierto al jardín, que al tiempo permite una necesaria evacuación. La recuperación del espacio abovedado de la antigua iglesia, hoy vestíbulo y gran acceso al nuevo museo, se refuerza con la ubicación de la biblioteca en la galería superior.

¿Y qué ocurre con los servicios requeridos por el museo moderno? Definitivamente los almacenes profundos, los talleres de restauración y demás servicios se ubican en la ampliación. Envolviendo el bloque de sus salas, se organiza un sector especial, en forma de " $L$ ", en el que se sitúan en su parte norte los almacenes y taller de restauración en dos alturas, y los pequeños talleres de apoyo -electricidad, carpintería, marquetería, desinsectación, entre otros- en su parte este solamente en planta baja. Amén de otros servicios que se pormenorizan más adelante, en el último apartado de este escrito.

En el nuevo museo proyectado accesos y recorridos son elementos fundamentales. El público accede por el nuevo vestíbulo del museo: el espacio cupulado. La Academia disfruta también de un acceso propio en el cuerpo claustral. Las entradas de servicio, tanto de personal como de material o piezas de exposición se plantean absolutamente independientes del público. Así la administración y el personal disponen de un acceso independiente en el bloque lineal. Los servicios de cargadescarga para las exposiciones temporales o permanentes por la parte posterior del conjunto conectan con sus almacenes respectivos y su conexión con las salas queda asegurada.

En resumen, el proyecto del nuevo museo de Bellas

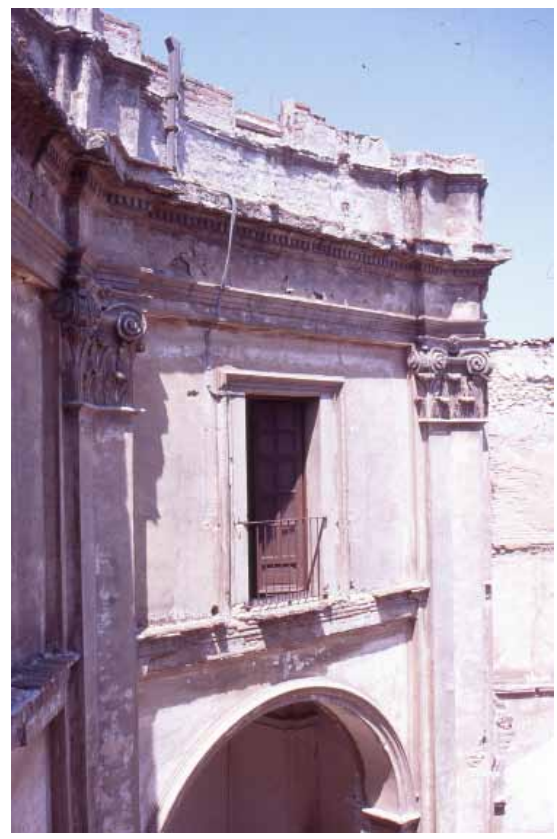


Artes de San Pío V de Valencia, aprobado por el Ministerio en 1996, recoge desde la óptica museográfica, los elementos que considero necesarios en todo edifico de este uso: clara distinción de usos, accesibilidad y recorridos claros y una iluminación que permita el aprovechamiento, y control, de la luz natural, que apoyada con la artificial, ofrezca unas óptimas condiciones para la exhibición de obras de arte, razón de ser del museo.

\subsection{A modo de conclusión}

La elaboración de los proyectos citados ha generado una serie de preguntas tales como: qué es un museo, cuándo nace, a qué necesidades responde, cuál ha sido su evolución hasta llegar al momento actual o si ha cambiado su rôl social, que subrayan, entre otras, el protagonismo del museo como institución social y su capacidad para representar los valores cívicos por excelencia.

El interés de la arquitectura que da respuesta a sus exigencias actuales pone sobre el tapete teórico el contraste y discusión sobre ideas básicas del debate arquitectónico, tales como: las relaciones entre lo viejo y lo nuevo, la intervención en contextos históricos, la reflexión acerca del carácter monumental de la arquitectura, la investigación formal, la autonomía de la arquitectura, la valoración de la calidad pura y simple de la arquitectura con ausencia de cualquier relación entre forma y contenido. Complejidad que se ejemplariza en la afirmación de Vittorio Magnago Lampugnani: "El museo es un sismógrafo que registra con extrema sensibilidad las oscilaciones de la cultura arquitectónica."

Dos apartados, fruto de la investigación llevada a cabo para realizar los proyectos citados, merecerán especial atención en el presente trabajo.

En primer lugar el papel específico que el museo ha asumido en relación con la ciudad y con el ambiente circundante. Muchos de los nuevos museos nacen con el intento de insertarse en el lugar, ser proyecto urbano, restituir relaciones, reconfigurar frentes, desvelar estratigrafías olvidadas. En los casos más 
comprometidos las propuestas han sabido resarcir fragmentos heridos de la ciudad.

Por último, en el campo tipológico, en la resolución del complejo programa actual del Museo de Arte, reflejada en el gran número de ellos que se han construido en los últimos 50 años, podremos observar como la sabia utilización de las diferentes partes expositivas que integran un museo tipificadas por J.N.L.Durand en1802, están en la base de las respuestas más adecuadas que se han aportado a la historia de la proyectación arquitectónica. pero no a través de la inadecuada contraposición entre el contenedor y la galería que circunda el patio de "durandiana" memoria ,sino entendiendo que los mejores ejemplos contemporáneos muestran que sólo a través de un proceso de agregación de diferentes tipologías espaciales, desmembrando y recomponiendo sin restricciones ni sistemas preconcebidos, puede la arquitectura dar respuesta a los fines específicos de una institución cuyo éxito popular ha puesto paradójicamente en crisis los objetivos para los que fue creada. 


\section{NOTAS}

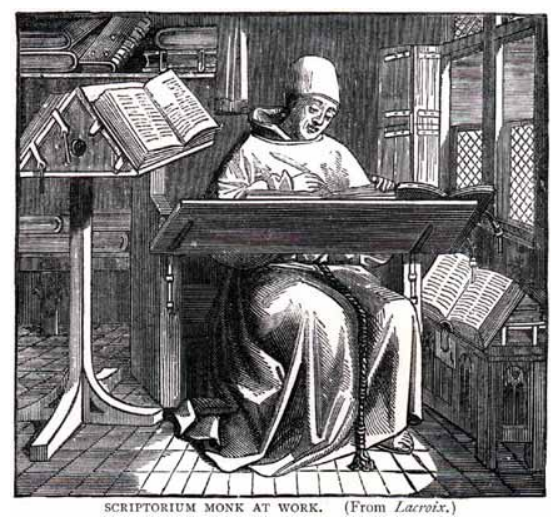

(1) Trillo de Leyva, Juan Luis, "Huellas pisadas", Argumentos sobre la contigüidad en la Arquitectura, Universidad de Sevilla.IUCC. Sevila, 2001., pp.116

(2) Murillo, Enrique, "Entrevista a Ernst Gombrich", El País, 19/10/1991 Suplemento Babelia

(3) Grassi, Giorgio, "Cuestiones de proyecto", Arquitectura lengua muerta y otros escritos, Martí Arís, Carlos (prol.), Barcelona, Ediciones del Serbal, 2003 pp. 39

(4) Trillo de Leyva, Juan Luis. Argumentos sobre la contigüidad en la Arquitectura. Sevilla, Universidad de Sevilla. IUCC. 2001.pp 146

(5) Annoni, Ambrogio. Scienza e Arte del Restauro Architettonico, Milano, Ed. Artistiche Framar, 1946, pp.30

(6) Ortega y Gasset, José, Carta a un alemán pidiendo un Goethe desde dentro, Madrid, Biblioteca Nueva SL, 2004.pp.43.

(7) Trillo de Leyva, Juan Luis. Op.cit.pp131-33.

(8) Summerson, John, Architecture in Britain 1530-1830, London, Penguin Books, First Paperback Edition, 1970, pp. 502

(9) Brandi, Cesare, Teoria del Restauro, Torino, Piccola Biblioteca Einaudi, 1977, pp.46 


\section{El Museo de Arte}

\subsection{El museo y el pensamiento llustrado}

La creación del museo público en el Siglo de las Luces es una consecuencia lógica de la renovación de la sociedad que se pretende desde el pensamiento llustrado. Tanto la organización del estado a partir de instituciones al servicio del ciudadano, como la sistematización del conocimiento en todas sus ramas desde un prisma científico y por tanto objetivo, están en la base de la sociedad burguesa nacida de la Revolución Francesa. El antropocentrismo esbozado en el Renacimiento en sustitución del teocentrismo medieval se asienta liberado de dogmas y supersticiones que trababan el avance y el estudio de las diferentes disciplinas que con la llustración, adquieren su propia autonomía y desarrollo al servicio del conocimiento y por tanto del ciudadano. En el campo de la arquitectura son elocuentes las propuestas de los arquitectos llamados "revolucionarios" de edificios públicos que dan respuesta a las necesidades de la nueva sociedad junto a la proliferación de tratados de arquitectura que rastrean sus orígenes, lenguaje y organización de la misma y la difusión de los modelos distributivos de estos nuevos tipos edilicios en manuales de amplia distribución.

La unidad primordial definida por el triángulo sensibilidad

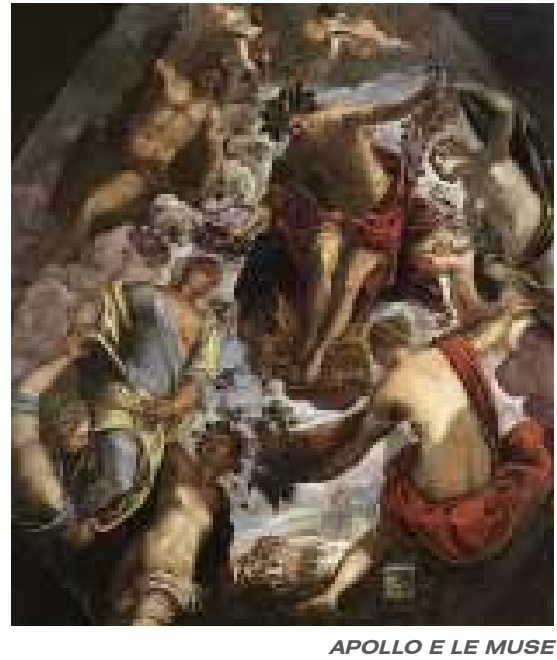

JACOPO ROBUSTI IL TINTORETTO, C.1560 
/ razón / historia, desarrollada desde los griegos como requisito para todo conocimiento es retomada en la llustración y mantiene su vigencia hasta la última modernidad. Mas el museo, que nace con unos definidos objetivos, es un fiel reflejo de los cambios que la sociedad experimenta que le llevará a profundizar en sus posibilidades didácticas, con la ampliación de la oferta, el estudio de la relación entre la obra expuesta y los espacios del museo o la generación de nuevos usos como respuesta a la demanda de un público creciente.

De los cambios en la resolución arquitectónica del museo que estas circunstancias plantean, hablaremos más adelante, exponiendo cómo a lo largo de los siglos se ajustan las respuestas de la arquitectura a estos cambios y a la evolución del programa museístico. Por supuesto la historia acudirá para informarnos de la génesis de los espacios expositivos que están en la base del museo moderno y para constatar la relevancia de un edificio que no sólo por su contenido, sino por la importancia del mismo, constituirá hitos urbanos en la construcción de la ciudad europea y americana.

Podremos razonar lo que ello afecta a nuestra tesis acerca de la arquitectura de los Museos de Arte, aunque baste por el momento su enunciado para no olvidar que escribimos estas reflexiones en un momento en el que el fragmento, la dispersión y la multiplicidad están en la base de la vida actual, por lo que quizás, el Museo de Arte, proporciona hoy uno de los resquicios desde los que se atisba ese momento de privilegio que da una razón de ser a la vida y a la existencia.

\subsection{Necesidad del Museo}

El afán de coleccionar objetos es tan antiguo como la humanidad. De la colección personal a su exposición al público, de la contemplación sensitiva o simplemente curiosa de las piezas se llega a un estudio sistemático de las mismas, tan científico como los conocimientos de la época lo permiten. 
Fruición, estudio, comparación con otros objetos de diferentes procedencias o momentos históricos, difusión de los análisis llevados a cabo, es el elemental proceso que está en la base de lo que denominamos museo. Las colecciones, cualquiera sea el grado de desarrollo en que se encuentren, se albergan en una arquitectura -se argüirá que en estado embrionario su contenedor fue un baúl o un armario- abriéndose así el campo que estudia su aparición, forma y evolución desde las primeras colecciones hasta el museo que hoy conocemos.

Existe el coleccionismo y con él el interés por la

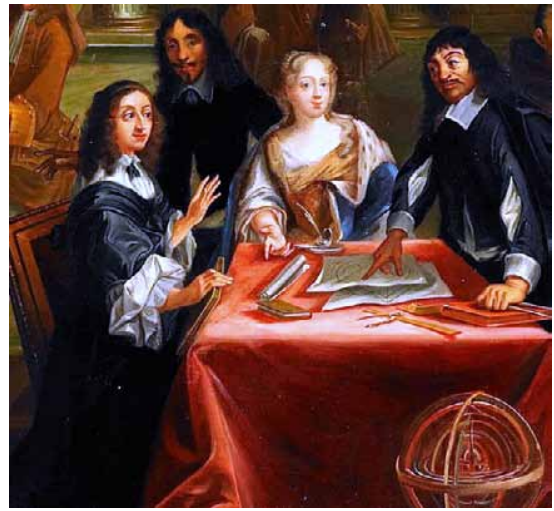

DESCARTES EN LA CORTE DE LA REINA CRISTINA DE SUECIA (DETALLE) PIERRE-LOUIS DUMESNIL contemplación de los tesoros que colman studiolos y galerías, no sólo como símbolo de poder sino, en el campo del arte, como la posibilidad de disfrutar de unas piezas poseedoras de una armonía de valores, de un aura que el concepto de arte -que ya desde siglos atrás se desarrolla y se difunde- les confiere.

La incipiente burguesía desea contemplar las obras de arte y muestra un interés patente en la nueva sociedad ilustrada del siglo XVIII. Sin embargo, este empeño ya se había puesto de manifiesto con anterioridad, cuando en diferentes cortes europeas ciertos sectores de la población presionaban para poder admirar las importantes colecciones que sus gobernantes habían atesorado. Colecciones producto del trueque, compra o fruto de específicos saqueos -e incluso guerras- que se promovían para la obtención de tan preciadas piezas. Como ejemplo de la insaciabilidad coleccionista podemos recordar toda la actividad política, económica, intrigante de cualquier pelaje, que se teje en toda Europa, de la que destacamos los siguientes episodios: los intentos para la obtención por cualquier medio de las colecciones del rey inglés Carlos I y de reputados coleccionistas de su Corte, como los Arundel, ejecutados durante la revolución de Cronwell; la postergación de la firma del Tratado de Paz de Westfalia, por parte de la reina Cristina de Suecia, también importante coleccionista, hasta conocer que sus tropas han tomado y saqueado el castillo de Rodolfo I en Praga que contenía su importante colección, sin olvidar las campañas de 
Napoleón que proporcionaron fabulosos fondos al recién creado Museo del Louvre.

Al valor intrínseco de la obra de arte se le añade un nuevo significado: su vinculación a un sentimiento ciudadano, que se evidencia en un ejemplo: la salida de los Países Bajos del Descendimiento de la Cruz de Rubens se lleva a cabo bajo la protección de los Tercios de Flandes, que lo escoltarán hasta España.

Podemos entender lo dicho anteriormente desde una evolución de la necesidad del arte por parte de la sociedad, que del coleccionismo individual desemboca en la necesidad de un lugar de exposición pública que denominamos museo. Pero junto a este factor, diríamos, de evolución interna, no podemos olvidar el factor externo definido por las circunstancias políticas, económicas y sociales que propician y condicionan la aparición y evolución del mismo. En el Siglo de las Luces la nueva realidad se llama Racionalismo, la conciencia política de clase de la burguesía llustración, el culto al Progreso deísmo.

Esta actitud racionalista es abstracta, no necesita de las visuales representaciones religiosas del barroco, le bastan los principios y los símbolos. Estos principios se manifiestan, como sucede en todos los períodos, en el arte. David, frente a lo que él denomina "la irresponsabilidad, extravagancia e impertinencia del Barroco" propone el énfasis en la estructura del cuadro haciendo hincapié en el valor del plano frontal y la temática grave, cívica, de su pintura, que se representa no con los suaves pasteles del frívolo rococó sino con la valoración del papel del dibujo y el orden compositivo. La inspiración clásica responde a la búsqueda de una formulación que responda a la realidad de una época burguesa, racionalista y abstracta. Y el romanticismo, en el que muchos estudiosos ven el germen de la cultura de la modernidad del siglo XX, no es sino la otra cara de la moneda. La realidad sometida al imperio de la razón deja en el olvido el valor del recóndito yo. Y lleva a tratar la naturaleza, purificada por los clásicos, fuente del conocimiento, con la más implacable 
idealidad neoclásica. El yo es razón y sentimiento y la naturaleza no se la conoce recortada como en los jardines de Le Nôtre, sino liberada a su genio como hay que liberar al yo de los esquemas silogísticos que matan el corazón.

Pero Denis Diderot, ilustrado, escritor, teórico, co-redactor de la Encyclopèdie, no olvida las dos facetas que definen al individuo; más bien hace hincapié en ello cuando nos recuerda "que todo conocimiento, originándose en la experiencia sensible, la trasciende al ofrecer una visión de la realidad y del mundo que va más allá de la experiencia sensorial, (...) lo que establece la base de dicha existencia plena: la vida de un hombre civilizado".

El valor y extensión del conocimiento son componentes de esta nueva sociedad. Y el museo de arte es una consecuencia de ello: como formación y disfrute de todos los ciudadanos. El nuevo puritanismo civil y progresista en su exaltación de la legalidad, el orden y la razón encuentra en el museo un instrumento para la educación de sus ciudadanos sin distinciones de clase o formación y en él se mostrará la producción sensible del espíritu humano plasmado en las obras de arte.

\subsection{Definición y objetivos del Museo de Arte}

El museo nace con la tarea de proteger, conservar, catalogar y exponer el inmenso material del que dispone para disfrute y formación de sus visitantes. Como exhibición ordenada de obras de arte, abierta al público, con una función a la vez didáctica y gratificante, el museo, tal como lo concebimos hoy, es fruto de las sociedades nacidas de la revolución francesa.

Podemos afirmar que, en el siglo XVIII, el museo se puede entender como la institución en la que los sentidos, el conocimiento y la historia se aúnan en la contemplación de las piezas magistrales que expone. De hecho, los objetivos del museo de arte como transmitir conocimiento, educar, salvaguardar la memoria y el disfrute de la belleza de las obras expuestas, no hacen sino recoger la idea clásica de que sensibilidad, memoria 
y razón, fundamentos del arte, de la historia y de la filosofía, son atributos relacionados entre sí y origen de una vida plena.

El deseo de captar científicamente el mundo y el interés por la historia dan lugar, en el siglo XIX, a un afianzamiento del papel educador del museo. La puesta de relieve por el romanticismo de los valores relativos a las identidades nacionales y su reverencia por el arte dan lugar a la proliferación de museos nacionales de todo tipo apoyados en la constitución y desarrollo de nuevas áreas de conocimiento.

La gran estima existente hacia las colecciones de obras de arte confiere a este museo nacional una particular relevancia. El omnipresente interés por la historia en el siglo XIX, no modifica los objetivos del museo enumerados sino que hace hincapié en su papel de salvaguarda de los tesoros acumulados necesarios para la investigación y su aplicación en el momento, convencidos de que el conocimiento del pasado es imprescindible en un presente caracterizado por continuos cambios.

El museo favorece la formación del individuo y su contemplación le proporciona un disfrute, una fruición que se apoya en el desarrollo del gusto estético, por el que se interesaba la filosofía desde el siglo XVII y que ahora, con el advenimiento de la nueva clase social, adquiere especial relieve al considerarse un objetivo más de la función social del museo.

Los objetivos del museo que se mantienen a lo largo del siglo XIX y principios del XX, no evitan su distanciamiento de la sociedad. Asumido que el arte necesita ser visto bajo el prisma ordenador de la historia y que de ella derivan la formación moral y las virtudes cívicas, el subsiguiente proceso conlleva una tensión entre la historicidad y el valor intrínseco de la obra de arte. La acumulación de material en exposición apenas permite al visitante individualizar la pieza de un artista. En realidad se está poniendo en crisis la exposición a base de innumerables piezas que cubren el muro de soporte en toda su extensión, del modo en que las pinturas de Tenniers, el Joven, o de Panini ya 
nos habían mostrado en el siglo XVIII.

Con el Art Nouveau y los movimientos Arts and Crafts se plantea la presentación conjunta, en las salas del museo, de las artes mayores y las menores. El problema objeto de resolución era, de nuevo, que la abundancia de material se debía organizar de manera que no redujera el valor individual de las piezas. El ambientalismo que se genera en la definición de los espacios expositivos se arrastra hasta prácticamente los años 50 del siglo pasado y no logra conectar con el público.

Hacia 1930, Wilhem de Bode plantea en el entonces Kaiser Friedrich Museum (hoy denominado Bode Museum), en la Isla de los Museos berlinesa, una forma de exposición en la que las piezas se sitúan sobre fondo neutro distanciadas unas de las otras, con lo que se puede apreciar el valor intrínseco de cada una de ellas. Pero las salas "ambientadas" siguen teniendo gran predicamento, bien renovadas en clave "moderna" por la Bauhaus o "clasicista" en el período nazi. Alejado del debate y de la reflexión, el museo, cortada su relación con el presente, se convierte de templo del arte en mausoleo del mismo.

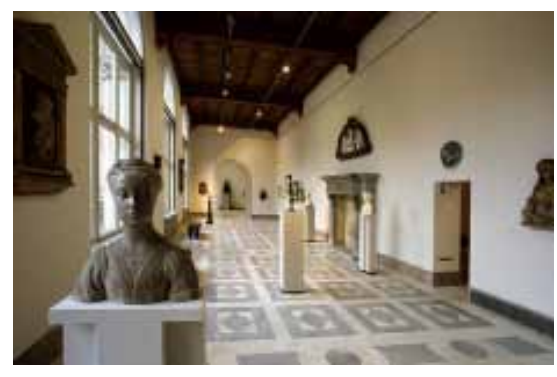

BODE MUSEUM, BERLIN

Como podemos observar, desde finales del siglo XIX hasta bien entrado el siglo $X X$, el museo de arte se debate en las estrategias de exposición sea la acumulación histórica o la ambientación de componente más estética. Tanto una como otra no afectan a la arquitectura del museo, que sigue siendo el modelo decimonónico que todos conocemos. Ignasi SoláMorales lo apunta con claridad: "De la misma manera que la museología como ciencia no existe, puesto que ella no es otra cosa que la mera ordenación de prácticas de gestión del museo que cambian en función de los cambios culturales que el museo asume, del mismo modo la arquitectura del museo no existe como un tipo establecido en la medida- iafortunada!- en que el hacerse del museo y su arquitectura participaban de una misma aventura cultural".

Efectivamente, como veremos, la arquitectura museística 


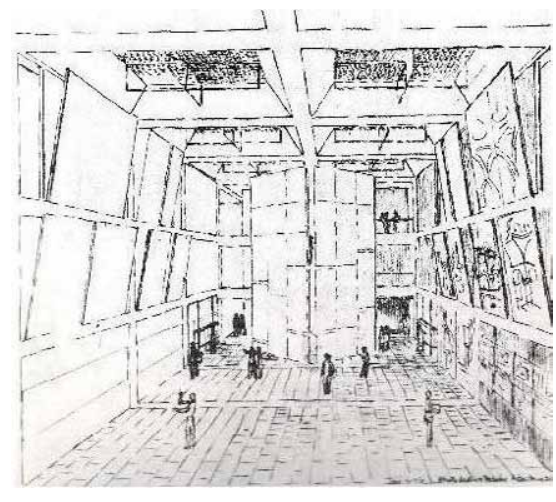

YALE CENTER FOR BRITISH ART, HALL ENTRADA. DIBUJO vivirá más adelante con los cambios de planteamientos y ampliación de necesidades un replanteamiento en el que el museo durandiano manifestará su capacidad de transformación.

\subsection{Redefinición del Museo de Arte}

Es comprensible, con la perspectiva que el tiempo otorga, el distanciamiento que, en algunos, produce el museo "acumulativo" que perdura hasta casi la primera mitad del siglo XX. El mismo Louis Kahn, cuando se enfrenta al primero de los tres magníficos proyectos de museo que lleva a cabo se plantea superar la impresión que de él guardaba: "Cuando pensé por primera vez en un museo lo primero que recuerdo es la sensación de cansancio que me producía nada más entrar en él”. Lo que no hace sino reflejar una cierta parálisis de una institución que se aleja de la sociedad del momento

Quizá no se habían puesto en crisis los objetivos para los que fue creado y nadie ponía en duda el valor intrínseco del museo. Éste había quedado encerrado entre investigaciones eruditas en el marco de la historia pero ajenas a la realidad, visitado por copistas que en su obsoleta actividad repetían composición, estructuras, formas de unas épocas en las que ya no se miraba la pintura que en el siglo XX estaba incorporando otras experiencias y que se liberaba de su tiranía llegando a negar, como reacción, el sacrosanto valor de la historia en la creación de las nuevas obras.

En la década de los 50 del siglo pasado los expertos en arte y museos se replantean la finalidad del mismo, en especial los dedicados al arte moderno. Las revueltas estudiantiles del 68 aceleran la transformación del museo en centro de debate, intercambio de ideas y lugar de aprendizaje: un museo para la sociedad del mañana que genera, aún hoy, reflexiones que oscilan entre el escepticismo y el optimismo.

El patrocinio -o "esponsorización"- de las actividades del museo y su necesidad de la industria turística para su 
mantenimiento lo introduce en las leyes de eficacia comercial, ausentes hasta el momento, que lo aproxima al peligro de convertirse en una especie de parque temático.

Existen hoy más museos que los que han existido en cualquier momento histórico y tienen mayor número de visitantes que nunca. Lo que era ante todo lugar de observación, cultura y contemplación para un público burgués seleccionado y especializado, constituye hoy un elemento de instrucción y entretenimiento de masas. El profundo cambio sufrido por la institución amplía considerablemente el panel de requerimientos a los que tiene que dar respuesta un proyecto de Museo de Arte.

En realidad no cambian los objetivos primordiales para los que el museo fue creado. En primer lugar el museo es el lugar donde las obras de arte son conservadas y expuestas. También el lugar para aquellos que desean observar, con la máxima concentración posible, las obras de arte situadas, para ello, en espacios adecuados que constituyen el fondo neutro y protector para su disfrute. Pero el visitante no sólo necesita dicho espacio tranquilo y reservado para la contemplación y deleite.

Al gran museo del último tercio del siglo $\mathrm{XX}$ pertenecen, además de los espacios expositivos tradicionales, las salas de exposiciones temporales, el auditorio, o la biblioteca-mediateca, todos ellos elementos que lo convierten en el lugar de actividad, debate e intercambio de ideas que se demanda. A ello se añade, por supuesto, un gran acceso público, espacio de acogida, que

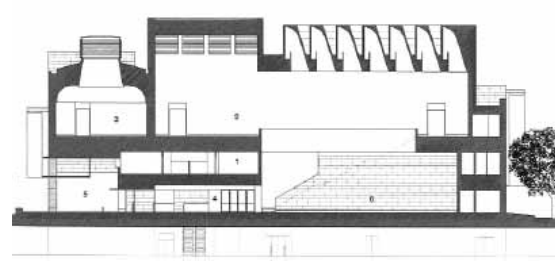
MUSEO DE BELLAS ARTES DE HOUSTON ESPACIO DE ACOGIDA. SECCIÓN debe cumplir una misión similar a la del foyer del teatro: acoger al público que afluye al museo, y ofrecerle la oportunidad de comunicación y socialización, junto a la necesaria orientación e identificación de lo que la institución le ofrece. La importancia del espacio de acogida se constata, ya, en algunos museos de corte decimonónico, baste recordar el vestíbulo del Metropolitan de Nueva York o el del Victoria and Albert Museum. Sin embargo ahora se vincula a espacios públicos como la tienda, que amplia su oferta, restringida antes a publicaciones y reproducciones de los fondos, a objetos de lo más variado, y al restaurante, lugar de 
encuentro y descanso.

Permítanme una anécdota sobre la importancia que adquieren estos elementos en el mantenimiento del museo: hace una decena de años leí que el Museo Smithsonian recibía un media anual de cuatro millones de visitantes. Cada uno de ellos gastaba en la tienda un promedio de 10 euros.

De trascendental importancia es la nueva disposición de accesos suficientes para los diferentes, y funcionalmente independientes, usos públicos, semi-públicos e internos y de una organización interior que impida el cruce de sus respectivas circulaciones, que además permita y posibilite la accesibilidad de todos los ciudadanos en términos universales. La creciente demanda de espacios de almacenamiento y de talleres de restauración, aunada a la implantación de las políticas educativas y didácticas que conforman un nuevo horizonte cultural, solicitan una considerable superficie dentro del museo. Estas necesidades rebasan ampliamente y desbordan la concepción museográfica decimonónica, obsoleta y abandonada, y que dará lugar a la consecución de los nuevos objetivos que debe alcanzar el proyecto de esta institución y que veremos plasmados en relevantes ejemplos que comentaremos más adelante, donde podremos analizar las respuestas que ofrecen a la nueva problemática del museo de masas.

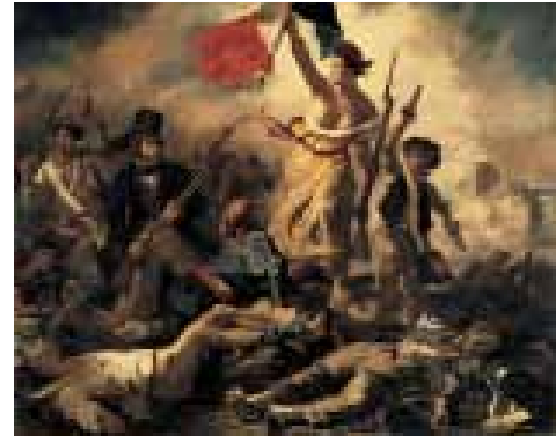

LA LIBERTAD GUIANDO AL PUEBLO EUGĖNE DELACROIX, 1830

\subsection{El primer museo público. Su impacto social}

Según la Grande Encyclopèdie, el primer museo en el sentido moderno del término (colección pública y propiedad estatal) fue fundado en Francia el 27 de julio de 1793 por la Convención Republicana. El museo de arte nace con la tarea de proteger, conservar, catalogar y exponer el depósito colosal de riquezas que posee, para disfrute y formación de sus visitantes. Las colecciones de piezas pertenecían a la nación, a los ciudadanos y debían darse a conocer, para lo que se publican catálogos y guías de apoyo a su primordial función educativa. 
La nueva institución se ubica en el palacio del Louvre, para lo que los arquitectos Percier y Fontaine llevan a cabo diversos trabajos de adecuación. El museo es visitado por un público seleccionado de connaisseurs, pintores, copistas, estudiosos y diletantes en los días laborables, abriendo sus puertas al público en general los domingos.

El museo es el lugar donde el visitante, desplazándose a través de los diferentes espacios, aprehende la realidad cambiante de la historia interpretada por el artista a través de unas formas y técnicas específicas para cada momento. Es también lugar de recogimiento, de reflexión ante la obra de arte.

La historia, la belleza, la reflexión; la creación y difusión de la institución provoca tal impacto social que hace escribir a George Bataille en 1930 lo siguiente: "El desarrollo de los museos ha superado las esperanzas más optimistas de sus fundadores. No solo el conjunto de los museos del mundo representa un depósito colosal de riquezas sino sobretodo el conjunto de visitantes de los museos del mundo representa sin duda alguna el espectáculo más grandioso de una humanidad liberada de

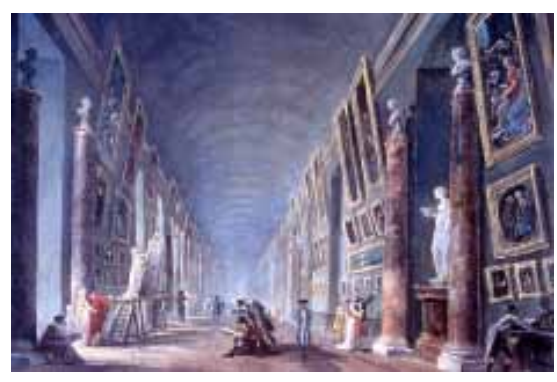

PROJET D'AMENAGEMENT DE LA GRANDE GALERIE DU LOUVRE HUBERT ROBERT, 1796 las preocupaciones materiales absorbida en su contemplación. (...) Un museo es como el pulmón de una gran ciudad; la muchedumbre afluye cada domingo al museo como la sangre, y sale purificada y fresca. (...) El domingo, a las 5, a la salida del Louvre, es interesante admirar el flujo de visitantes visiblemente captados por el deseo de ser como las celestiales apariciones que han cautivado sus ojos".

Bataille nos habla del cúmulo de riquezas que contiene el museo público, al servicio de los ciudadanos que quedan "absorbidos en su contemplación", y de la necesidad del mismo como "pulmón de una gran ciudad." Su acción vivificadora y regeneradora se traduce en la contemplación, disfrute y reflexión ante las obras de arte. Y se sorprende gratamente de la gran afluencia de visitantes, anotando que son ellos lo que diferencia al museo público, logro social, de una colección privada. 
Lo que era espacio de cultura, observación y reflexión para unos pocos se convierte en instrumento de educación y disfrute de las masas. "iUn arte para cambiar la vida!" clamaba Arthur Rimbaud. ¿Hemos logrado lo que los firmantes del grupo Arbeitsrat für Kunst pretendían cuando escribían en 1919: "El arte ya no ha de ser placer para unos pocos sino que ha de ser vida y felicidad de las masas."

Casi un siglo después, en la década de los 80 del siglo XX otra nueva generación de museos, cuyo conjunto supera ampliamente en número la eclosión del siglo anterior, renueva y afianza la acogida que el público rinde a tales instituciones.

Contenido y continente, museos antiguos y museos nuevos; la toma de posesión por el público europeo de sus venerables y polvorientos templos de las musas es debido, por un lado, a un profundo cambio de los valores sociales junto a una mayor disponibilidad en la aceptación de los valores culturales consolidados como compensación a la pérdida de las tradicionales señas personales de orientación.

Lo que Benjamín había diagnosticado como avidez preocupante, en cuanto resultante de una consideración del arte como mercancía, ha tomado la forma de un crecimiento sin parangón del consumo. Durante decenios sociólogos, historiadores, directores de museos han intentado en vano una democratización "desde arriba" de la cultura. Hoy, si pudieran, revocarían el consumo "social", provocado por ellos mismos, de sus preciados objetos presentados ahora de forma demasiado atractiva, convertidos en una moda.

Un par de datos y una anécdota para ilustrar el éxito de público: La National Gallery de Londres recibía 300.000 visitantes a principios de siglo, tras la inauguración de la ampliación llevada a cabo por Robert Venturi en 1988 su número alcanza los cuatro millones de visitantes. El museo de la ciudad alemana de Stuttgart ocupaba el puesto 56 en las estadísticas de museos más visitados de Alemania, después de la inauguración de la 
Neue Staatsgalerie de James Stirling, es catapultado al segundo lugar. Y la anécdota: en marzo de 2007, fue llevada a Tokio el cuadro La Anunciación, de Leonardo da Vinci. La pintura fue admirada por 10.000 personas al día durante tres meses: cada visitante dispuso de tres segundos para la contemplación de la obra.

Posiblemente una de las causas profundas de la enorme aceptación del museo radique en la situación del hombre actual, enfrentado continuamente a la ambivalencia de las cosas, constreñido a la excitación de su vertiginoso "aparecer" y "desaparecer" que encuentra en el museo, en la visión de una colección de arte, en un orden que detenga ese vivir el presente como un eterno fragmento.

El museo muere de éxito, sus millones de visitantes y las consecuencias que ello conlleva pueden poner en crisis los objetivos para los que el Museo de Arte fue creado.

\subsection{Importancia del Museo de Arte en el debate arquitectónico}

Desde 1970 hasta nuestros días la proliferación de museos construidos, que se inicia en Alemania y Estados Unidos y se extiende a Francia, Inglaterra y España principalmente, constituye uno de los acontecimientos más interesantes acaecidos en el campo de la arquitectura.

Se puede observar, en esta producción de arquitectura para museos, una alternativa enunciada hace algunos años, por Helen Searing (1) y que continúa siendo parcialmente válida: de un lado parte de los museos llevados a cabo en este período, surge de la institución pública definida a caballo de los siglos XVIII y XIX con las obras de Soane, Schinkel o Von Klenze; de otro encontramos museos que se basan en el contenedor, en el gran espacio vacío indiferenciado nacido en la temática ochocentista de las machine à exposer cuyo prototipo surge en Londres, en 1851, en el Crystal Palace de Paxton. A la primera categoría 
pertenece la Staatsgalerie de Stuttgart, a la segunda el Centre Pompidou de Paris. Una respuesta mixta la ofrecería la Neue Galerie de Berlín.

A estos apartados, habría que añadir la familia de museos de menor dimensión, que se inicia también con la renovación museística alemana del último cuarto del siglo XX y que alcanza nuestros días. Conjunto de museos resultado de la agregación de diferentes tipologías espaciales consolidadas que, rompiendo la sintaxis que las estructuraba en su origen, se desmiembran y recomponen sobre el plano y dan lugar a nuevas propuestas que responden a los requisitos del museo actual.

Se trata de una operación que retoma alguna de las técnicas que las vanguardias pictóricas habían practicado: descomponer los diferentes elementos que definen el tema del cuadro y recomponerlos, reconstruirlos, desde valoraciones diferentes a las que primaban en la anterior manera de analizar la realidad, configurando así una nueva imagen.

Junto a la búsqueda del edificio que se adapte a las continuas y dispares propuestas del arte contemporáneo, el museo urbano pertenece a una de las pocas familias edilicias que marcan la experiencia de la ciudad. El museo vuelve a definir ciudad, se constituye en hito que reconstruye partes degradadas de la misma o se convierte en foco de renovación de tejidos degradados. También el paisaje, el ambiente natural se convierte en lugar, en sentido heideggeriano; sin olvidar lo que supone de aportación al enriquecimiento del repertorio lingüístico arquitectónico.

De todo ello podemos concluir que la respuesta a los complejos requerimientos y exigencias que se plantean al museo en el último cuarto del siglo $X X$ da lugar a un programa espacial excepcionalmente variado reflejado en nuevas arquitecturas que participan en la construcción de la ciudad y del paisaje. Su interés radica en la puesta sobre el tapete teórico del contraste y discusión sobre ideas basilares del debate arquitectónico 
cuyo significado se refleja en el aserto del Profesor Magnago Lampugnani que no puedo evitar repetir dada su exactitud: "la arquitectura de los museos se asemeja a un sismógrafo que registra precozmente y con extrema sensibilidad las oscilaciones de la cultura arquitectónica".

Veamos los apartados que considero relevantes en referencia al trabajo que aquí se desarrolla.

\subsubsection{El museo define ciudad}

El museo de arte, desde su consolidación en el siglo XIX, pertenece a la familia de edificios, monumentos, elementos "primarios", depositarios de la memoria colectiva, que definen ciudad. A modo de ejemplos, baste recordar el papel que representó en Berlín el triángulo definido por la catedral, el Palacio y el Altes Museum al final del Unter der Linden; la definición del frente norte de Trafalgar Square por parte de la débil obra de Wilkins, la National Gallery de Londres; el Museo del Prado y su relación con el Paseo de su nombre; y finalmente, la participación de los museos de Semper en la definición del Ring vienés, en un conjunto, por cierto, recientemente completado con la construcción, en las enormes caballerizas de Fischer Von Erlach, del complejo de museos realizados por Örtner y Örtner.

En algunos casos el museo recompone el tejido destruido de la ciudad como se observa en la ciudad de Frankfurt, caso ejemplar, donde entre 1980-90 se manifiesta la capacidad del museo de recoser un tejido y de recrear un diálogo con antiguas formas en la reconstrucción de parte del centro histórico. El Römerberg, cuyo bombardeo en la Segunda Guerra Mundial dejó a la vista restos de la ciudad romana, fue resuelto con un edificio, el Kulturschirn de Bangert, Jansen, Scholtz y Schultes; su complejo programa cultural se organiza a lo largo de una stoà que enlaza la catedral con la plaza del ayuntamiento, poniendo además en valor las ruinas. En la misma ciudad, a través del museo, se recupera el sentido de algunas partes históricas significativas destruidas por la guerra, como la orilla del río Meno,

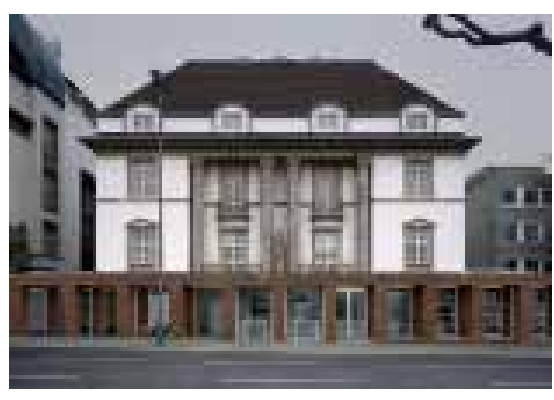

DEUTSCHE ARCHITEKTURMUSEUM, FRANKFURT 


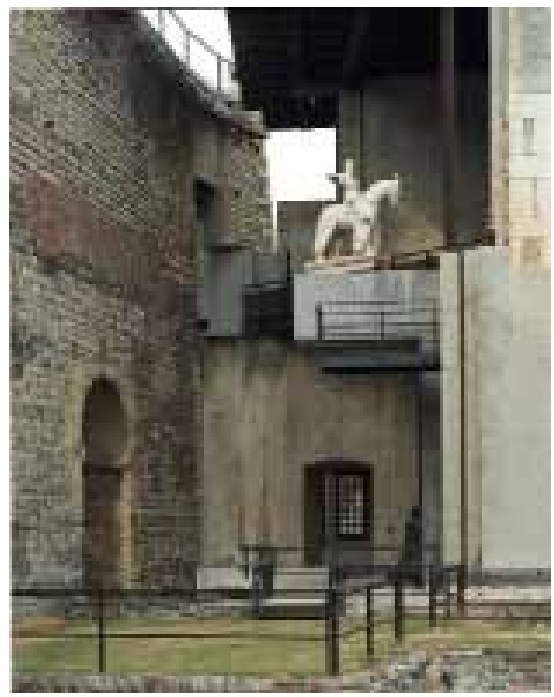

con sus villas y muros. De la serie de museos que se instalan en ese lugar cabe recordar, entre otros, el Museo de la Arquitectura de Oswald Mathias Ungers -que trabaja dentro de los restos de una de las villas, en una suerte de arquitectura dentro de la arquitectura- o el de las Artes Aplicadas de Richard Meier que amplía otra de ellas-. Este conjunto de pequeños museo restituye uno de los mejores momentos de la tradición clásica de la ciudad, recuerdo olvidado de esta bella y consolidada imagen, que vuelve a representar un elemento fundamental de la composición urbana.

\subsubsection{El museo en contextos históricos}

Los ejemplos anteriores sirven también para ilustrar el papel del museo en la recuperación de la ciudad histórica. A menor escala, podemos recordar en el Centro Gallego de Arte Contemporáneo y sus jardines de Santiago de Compostela, el cuidadoso entretejido de piedras, de muros de cierre interrumpidos, el trazado del jardín, la volumetría que enlaza con el antiguo convento y evoca partes desaparecidas y recompuestas del contexto. El edificio que Alvaro Siza propone parece haber pertenecido siempre a aquel lugar.

Sin la carga de significado que la historia otorga, en la Fundación Menil que realiza Renzo Piano en un barrio residencial de Houston, el arquitecto adopta una horizontalidad formal y un uso de materiales, como la madera, para ponerse en relación con el contexto, persiguiendo una atmósfera doméstica similar a la de las viviendas colindantes.

\subsubsection{El museo y la relación entre lo nuevo y lo viejo}

La conversión de edificios históricos en museos es un argumento recurrente en el debate del papel del museo en la revitalización de edificios pre-existentes. La experiencia italiana de los años 50 del pasado siglo logra resultados muy afortunados, desde las complejas intervenciones de BBPR en el Palazzo Sforza de Milán; las celebradas intervenciones en Castelvecchio y Palazzo Abbatelis de Carlo Scarpa, sin olvidar 
su ampliación de la Gipsoteca de Canova; las intervenciones de Franco Albini en Génova, Palazzo Bianco y Palazzo Rosso, entre otros. Estas actuaciones tienen gran difusión en Europa, donde descuellan las cuidadosas propuestas de Hans Döllgast y Josef Wiedemann para, respectivamente, la Alte Pinakcotek y la Glyptothek de Munich, ambas obras originales de Leo von Klenze, o el menos conocido Museo de Historia de Hanover de Dieter Oesterlen.

En muchas ocasiones este tipo de actuación constriñe al museo en espacios en los que la memoria de su uso es excesivamente patente, como sucede en el Museo D'Orsay donde Gae Aulenti hace esfuerzos por articular un museo en un espacio que podría estar mas emparentado con una gallerie des machines abierta, indiferenciada, que con unos recorridos e instalaciones propios de espacios expositivos consolidados históricamente.

El alemán Josef Klaus Kleihues, en lo que evidentemente es la capital alemana de los museos -Frankfurt- muestra su enorme habilidad y conocimiento en el Museo de Prehistoria y de la Protohistoria de 1985. La nueva construcción debía integrar, y por supuesto integrarse en el contexto urbano, los restos de un convento destruido durante la guerra, incluidas una iglesia y una capilla carmelitas. La respuesta que da el arquitecto renuncia en gran medida a una presencia urbana y el edificio nuevo se articula más bien como un anexo que reconstruye la rudimentaria área del convento. Fracturas, curvas y brazos jerarquizan de modo casi imperceptible los sectores funcionales del museo, creando volúmenes de memoria gótica. Con esta actuación Kleihues delinea una tendencia que, con un dispendio reducido y con una importante impostación didáctica unifica elementos de la tradición alemana, la fascinación por las ruinas y la readaptación racionalista, con unos resultados que no han tenido la difusión que su interés y sabiduría merecían.

En el museo de Bellas Artes de A Coruña, Manuel Gallego resuelve con claridad y sencillez, tanto el problema de relación

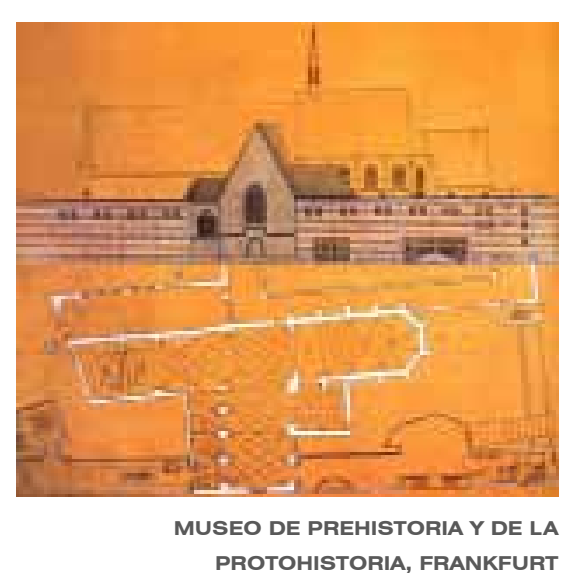

PROTOHISTORIA, FRANKFURT 


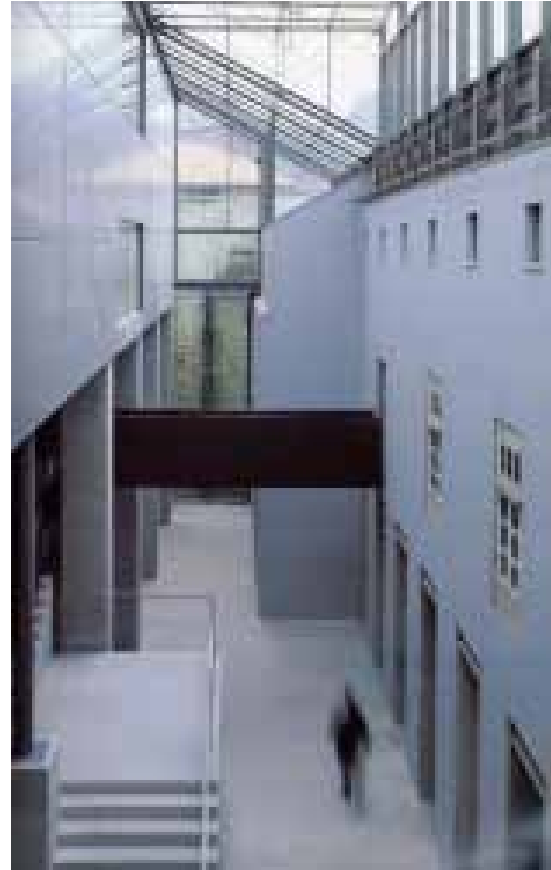

MUSEO DE BELLAS ARTES DE A CORUÑA

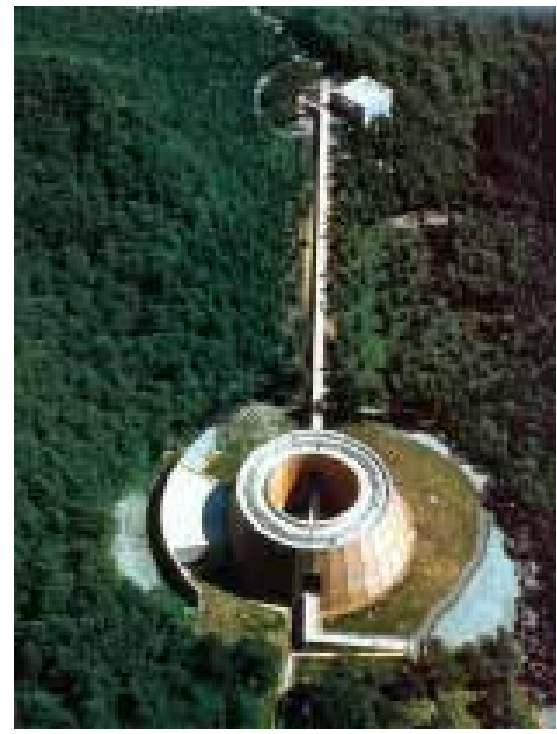

MUSEO DEL BOSQUE DE LAS TUMBAS, КUМАMOTO con la ciudad como su relación con un edificio histórico. El museo articula la ciudad nueva y la antigua y además se apoya y utiliza, físicamente, los restos del antiguo convento de las Capuchinas que le sirve para enlazar con lo "viejo" coruñés. De las medidas del viejo edificio extrae la modulación de la nueva intervención que articula lo "nuevo y lo viejo" mediante un vestíbulo a lo largo de la iglesia del antiguo convento. Las zonas de exposición se ordenan en dos bloques cuyos diferentes niveles generan salas superpuestas iluminadas cenitalmente, con la inteligencia y sensibilidad que caracterizan al arquitecto.

Otra forma de insertarse y de relacionarse con un contexto histórico se observa en la figura extrema de columnas rehechas y alineadas a una secuencia preexistente, neoclásica y tradicional, en la National Gallery de Londres, que reviste el ala Sainsbury de la ampliación de Venturi en la que si la planta parece hablarnos de un diálogo con el vecino, la sección está todavía dentro del museo del ochocientos.

\subsubsection{El museo como arquitectura autónoma}

La constatación de la existencia de una arquitectura que valora su calidad simple y pura, sin intención de otorgarle significado, se revela como paradigma de la este tipo de arquitectura, que muestra la ausencia de cualquier relación entre forma y contenido.

Podríamos citar la obra de dos importantes y diferentes arquitectos: Tadao Ando y Frank Gehry. Para el primero cada obra es un experimento autónomo, como refiere Solà-Morales ${ }^{(2)}$ : "Las propuestas no obedecen al contexto. No imitan la tradición. Si se refieren a la cultura local, lo hacen como ausencia, como vacío, como cancelación de toda afirrmación. Son artefactos que ebemos experimentar psicofísicamente en su realidad y que no nos son dados a través de su representación ni siquiera de sus imágenes." Como sucede en Kumamoto, en el Museo del Bosque de las Tumbas, donde con sus propias palabras explica: "He buscado un modo de trascender una simple relación con el 
espacio y expresar la unión de dos estructuras (el yacimiento de las antiguas tumbas Iwaburu y la construcción del museo que las contiene) en la dimensión del tiempo."

Mas introduce el ambiente: "En el rico ambiente natural circundante los visitantes entran en coloquio con la foresta, terreno fértil generador de vida, y con el aire puro; y son inducidos a pensar en la armonía con la naturaleza de la que los antepasados gozaban cotidianamente."

La obra de Gehry procede de un creador plástico y su método de configuración se aproxima a los procedimientos de creadores de otros campos de la plástica. "Sus obras son lo que son y no se refieren a otras obras distintas" (3). Sus obras están -como sigue explicando Solà-Morales- "en el polo opuesto de cualquier arquitectura contextual" y cada una de ellas, podemos decir, se agota en sí misma. En el Museo Weisman de Minneápolis y también en el Guggenheim bilbaíno, como en otras ocasiones frente a la imagen unívoca, escoge el reflejo y la fractura multiplicada de un signo sin aparente orden ni relación con el lugar.

\subsubsection{El museo y la definición del lugar-ambiente}

El importante elenco de museos resultado de las grandes operaciones auspiciadas por los poderes públicos, se ha visto complementado por pequeños museos atentos al lugar cuyas estrategias oscilan entre la integración silenciosa y la generación de pequeñas arquitecturas autónomas que revalorizan entornos indiferenciados o suburbanos.

Renzo Piano en el museo para la colección Beyeler en Basilea, manifiesta una estimable sensibilidad con el ambiente circundante. Plantea una delicada inserción en un paisaje de cultivos a través de unos muros paralelos que van salvando el desnivel de ascenso. Muros de piedra sin desbastar que se coronan con una sofisticada cubierta técnica. Unión entre necesidad técnica y papel simbólico que tanto gusta al arquitecto.

También Tadao Ando trabaja sobre la capacidad del museo

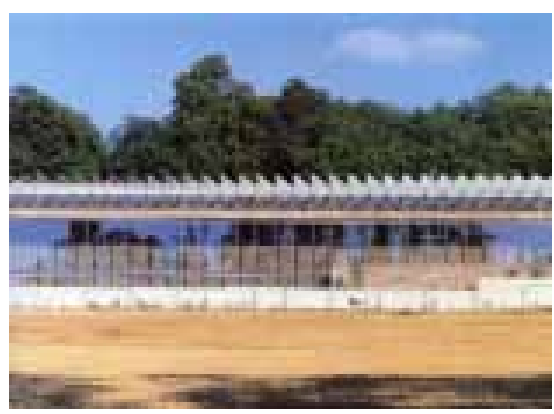

MUSEO PARA LA OLECCIÓN BEYELER,

BASILEA 


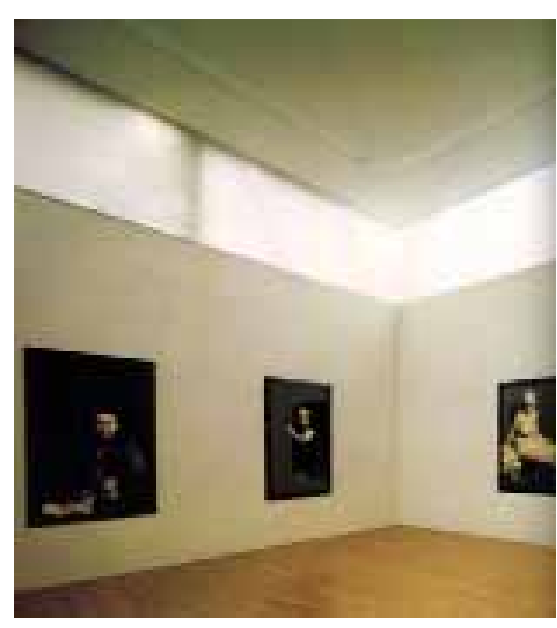

GOETZ ART GALLERY, MUNICH de reorganizar y definir el ambiente natural. Aún incluido en el grupo de la arquitectura autónoma, el Museo del Bosque y de las Tumbas, en Kumamoto, no puede negar en su inserción en el lugar la búsqueda de un gesto fundamental, una delimitación desde la que poder contemplar una naturaleza estetizada.

Pero son, quizás, los pequeños museos que se producen en especial a principios del siglo XXI, los que merecen una merecida atención en cuanto presentan de forma sencilla el genius loci. La cabaña primitiva, el laberinto, la rotonda, el muro recorrible comparecen en una triada arte-naturaleza-arquitectura.

Así, Herzog y de Meuron, en una parcela suburbana y entre abedules y coníferas, vuelven al tema del puro museo en el pabellón Goetz: tres salas tradicionales, blancas, cuya iluminación perimetral se repite en la sala del sótano que aprovecha la franja acristalada de la aparente planta baja, de acuerdo con el ingenioso artificio que crea la sección.

La obra de Gigon y Guyer muestra sensibles ejemplos. El Museo Kirchner, en Davos, se inserta en la trama suburbana de la ciudad y se ajusta a su escala partiendo de la fragmentación de volúmenes concebidos como figuras prismáticas, planas, similares a las viviendas de la zona para constituir un conjunto que articula libremente la tipología ya conocida de salas de exposición alrededor del espacio de comunicación. Conjunto "cristalizado" por el material utilizado que resuelve las necesidades del museo insertándose en el lugar y reutilizando espacios expositivos consolidados.

\subsection{Breve génesis de los espacios expositivos}

\subsubsection{Antecedentes}

Se puede establecer que al principio era la casa, el palacio del coleccionista, el origen espacial del Museo. El afán coleccionista que se manifestaba en la Antigüedad en las poco frecuentes pinakothekae se hace notorio en el siglo XV. 
Se colecciona todo tipo de curiosidades, huesos, manuscritos, hallazgos diversos junto a pintura y escultura. Según el profesor J.Rykwert: "Se guardaban en tesoros y cajas especiales, además de exponerse en ocasiones solemnes, como en la organizada por la reina María de Hungría, viuda del Rey Luis II y hermana del emperador Carlos $\mathrm{V}$, que comprendía todo un altar festivo dispuesto para exhibir objetos preciosos" El afán propio del coleccionismo, según el autor, concluye con "la formación de colecciones tan amplias que supuso la aparición de edificios especiales para albergarlas." (4)

Un espacio de coleccionista, característico en la Italia del siglo XV es el studiolo. Hacia 1470, el bello retrato de Federico de Montefeltro (Fig.1), realizado por Piero de la Francesca, nos representa a este fiero soldado poseedor de un delicioso studiolo en Urbino (Fig.2), cuya ejecución se atribuye a Bramante. En su interior, junto a obras pictóricas de maestros como Botticelli y Giorgione, se observan instrumentos de precisión de la época, minerales, fragmentos de elementos exóticos y libros producto de la recién inventada imprenta. Otro reputado gabinete de la época lo lleva a cabo Mantegna en el Palacio Ducal de Mantua para Isabella D'Este, que departía con un escogido grupo de intelectuales y artistas del momento.

En 1471, el papa Sixto IV, hizo trasladar para su exposición en el Palazzo dei Conservatori del Capitolio, obras escultóricas clásicas como La gran cabeza y La mano del emperador Constantino, la Loba Capitolinay el Muchacho sedente sacándose una espina que fueron expuestas en el patio interior, como un primer atisbo de museo. Las obras de arte salieron por primera vez de su reducido círculo de gabinetes, cofres, tesoros, etc. para mostrarse al público, no en el sentido que lo entendemos hoy sino desde el punto de vista de ampliar su visión a un cierto número de personas no incluidas en los círculos cortesanos o íntimos.

La historia del museo como edificio comenzó en el Renacimiento. En 1508 el Papa Julio Il encargó al más importante 


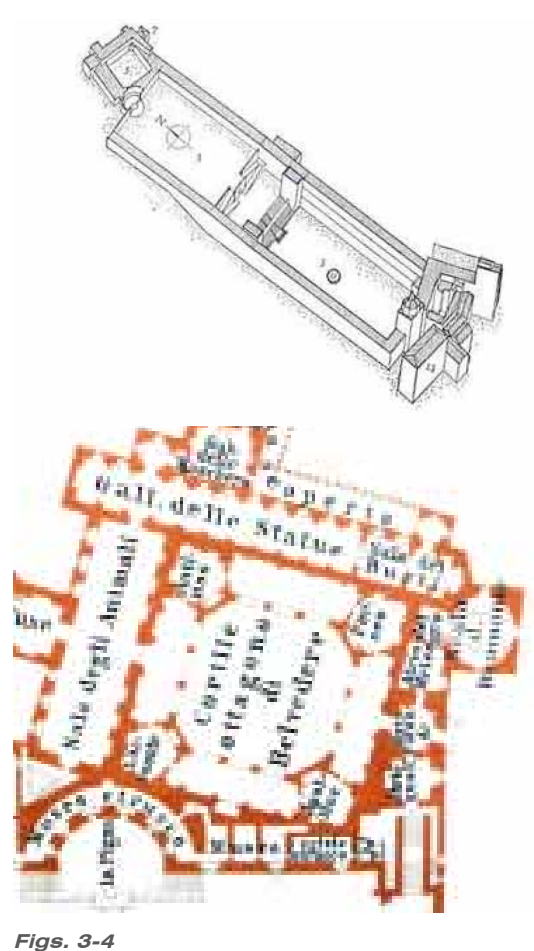

Figs. 3-4 arquitecto del momento, Donato Bramante, la construcción, en un extremo de su inacabado Belvedere, de un espacio de nueva planta para mostrar parte de la colección de escultura que poseía (Figs.3-4). Se trata de un patio de planta cuadrada, en cuyos vértices achaflanados dotados con hornacinas se colocaron las más prominentes esculturas clásicas, que todavía permanecen en él, como el Apolo del Belvedere, (que Julio II, entonces cardenal Giuliano della Rovere compra tras su hallazgo y traslada al Vaticano) y el Laocoonte, hallado en las ruinas de las termas de Tito en 1506. El Patio de las Estatuas, donde, según testimonios de la época, Julio II hizo instalar dichas piezas para inspiración de "sus" artistas Miguel Angel y Rafael, y denominado significativamente, por sus contemporáneos, el Atrio del Piacere, fue sin embargo alterado posteriormente.

Similares patios de estatuas, de planta cuadrada la mayoría de ellos, se construyeron en diversos palacios y villas romanos siguiendo las huellas establecidas por el papa. Este espacio expositivo formará parte de los proyectos de museo realizados a partir de la Revolución Francesa, y se convertirá en componente fundamental de los mismos.

Más adelante, junto al citado patio, a la manera del potente templo de Agripa, se construyó la Rotonda, circundada de nichos para ubicar escultura clásica. En 1590, Sixto V articuló el Belvedere en diversos espacios para instalar su creciente biblioteca y acomodar sus colecciones. Cabe recordar que desde la Antigüedad era usual relacionar biblioteca con obras de arte. La construcción de espacios destinados a usos expositivos a partir de la enorme estructura bramantesca del Belvedere srvió de base, como veremos, del futuro Museo Pío-Clementino, embrión de los futuros Museos Vaticanos.

También el siglo XVI contempla la aparición de un nuevo espacio expositivo: la galería. Conforme se afianza históricamente el coleccionismo se construyeron o adecuaron en otras partes de Europa estos espacios específicos para exposición. En Francia, Francisco I mandó construir en Fontainebleau, en 1540, 
galerías de exposición cuyos grandes huecos abiertos en uno de sus laterales iluminaban las obras de arte dispuestas en los paramentos opuestos ${ }^{\text {(Fig.5). }}$

En 1559, en Florencia, Giorgio Vasari, por encargo de Cosme I de Médicis, proyectó una imponente implantación urbana, en

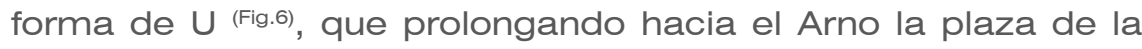
Signoria, creó el famoso balcón sobre el río, donde albergar las dependencias administrativas y judiciales, Uffizi, ubicadas en Palazzo Vecchio. Traslado que por circunstancias diversas no se llegó a efectuar, por lo que pronto se convirtió en un espacio donde guardar las curiosidades y rarezas coleccionadas por los Médicis, así como obras de arte.

La fábrica de los Uffizi, destinada definitivamente a guardar colecciones de arte, se enriqueció con nuevas salas. En 1574, Buontalenti fue el responsable de convertir la planta superior del edificio en las galerías visitables que hoy conocemos (Fig.7) para albergar la rica colección de pintura, toscana fundamentalmente, que los Medicis habían atesorado. Para ello, configuró una secuencia de espacios rectangulares de gran dimensión servidos por otra de espacios reducidos con una pequeña fenestración. El mismo Gran Duque Francesco I encargó al arquitecto la construcción, en el ala este de la famosa Tribuna, un espacio octogonal cubierto por una cúpula, concebido como alegoría del universo con sus cuatro elementos; lo que convierte la Tribuna en piedra angular de la arquitectura de museos es el tratamiento de la luz que se hace a través de una claraboya central. Este elemento se convertirá en un importante medio de iluminación desde la perspectiva de la tecnología museística.

En 1570, Vespasiano Gonzaga hizo construir la Galleria della Mostra ${ }^{(F i g .8)}$ como espacio de exposición de estatuaria en el Palacio Ducal de Mantua y, entre 1584 y 1586, una galería de $300 \mathrm{~m}$ de longitud en Sabionetta, con la misma función. Contemporáneamente, en Roma, alrededor de 1580, Bartolomeo Ammanati construyó y adecuó con fines expositivos la Villa Medicis.

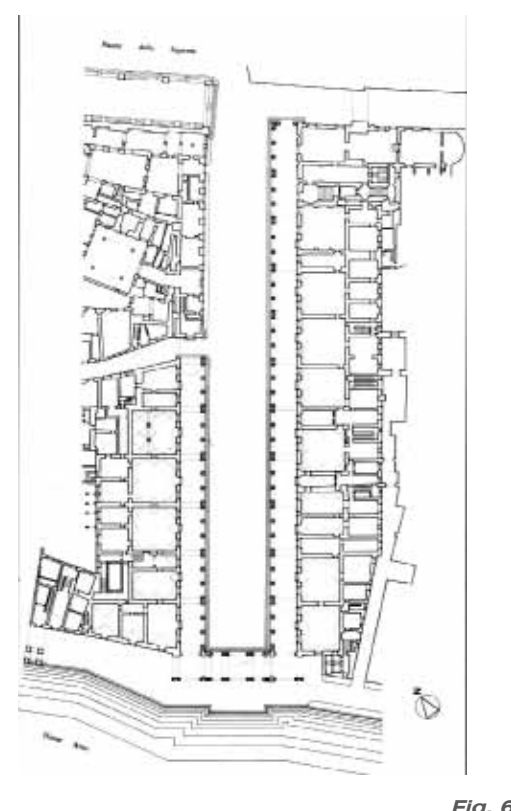

Fig. 6
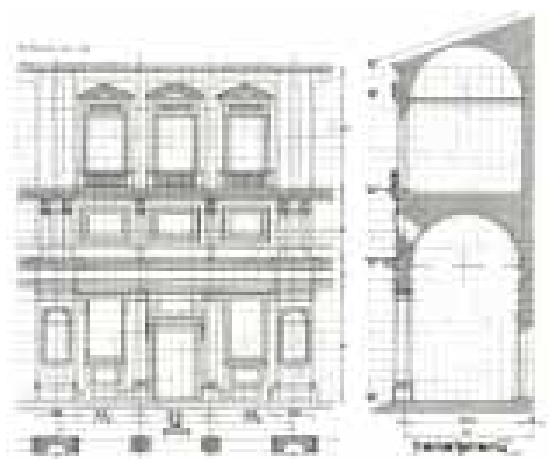

Fig. 7

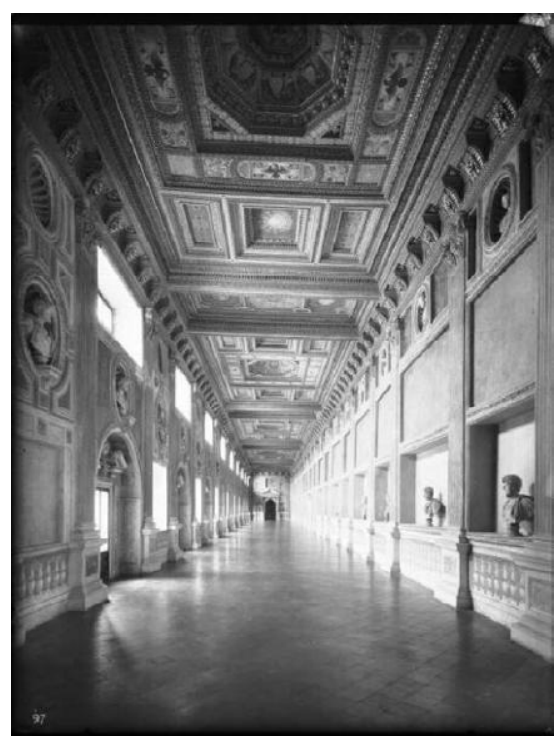

Fig. 8 


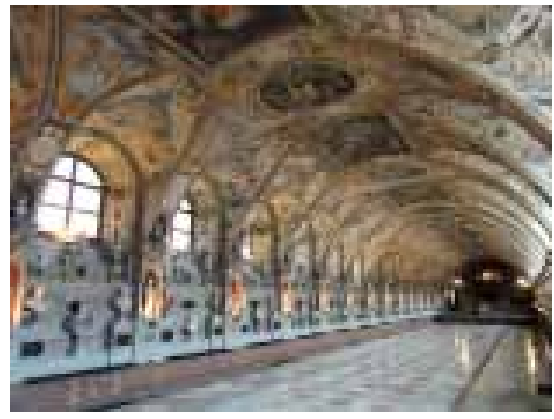

Fig. 9

Una muestra coetánea de estas inquietudes expositivas la encontramos en el gran Antiquarium (Fig.9) que realizó Wilhem Egkl en 1568. Esta galería y gabinete (o cámara del tesoro) sita en la residencia real en Munich del Duque Alberto $V$ de Baviera, ofrece la particularidad de proporcionar una iluminación natural, mediante la perforación de la bóveda de cañón que cubre sus $66 \mathrm{~m}$ de longitud, con huecos altos a cada lado que difunden la luz y permiten una mejor apreciación de las cualidades de las esculturas expuestas.

El siglo XVII es el del afianzamiento del coleccionismo. Felipe IV en España, Enrique IV en Francia, la reina Cristina de Suecia, Rodolfo I en Praga, Carlos I de Inglaterra y la pléyade de aristócratas coleccionistas de su corte, constituyeron parte del elenco de reputados, y ansiosos, amantes del coleccionismo artístico. Tal consolidación conllevó el desarrollo de arquitecturas que permitieron la exhibición de las colecciones, lo que implicó el estudio de mejoras en los modelos distributivos. Esta investigación afianzó el uso, como espacios expositivos, de las galerías -cortas, largas, planas o abovedadas- que se proyectan de nueva planta o se ubican en salones adaptados a tal fin en palacios existentes. También la iluminación de las piezas, para una correcta contemplación de las obras, comienzó a ser, en especial en Inglaterra, objeto de estudio.

Ejemplo elocuente de la aparición de estos espacios específicos de exposición son los retratos de Thomas Howard de los reputados coleccionistas Lord y Lady Arundel (Fig.10), que ofrecen una interesante diferenciación: El fondo del retrato del aristócrata muestra una galería de escultura, iluminada por un lado mediante una secuencia de ventanales y cubierta con bóveda de cañón, mientras que en el retrato de su esposa el espacio dedicado a pintura se representa mediante una galería, con la misma fuente de iluminación en un lateral, pero con cubierta plana.

En 1601, Enrique IV de Francia ordenó construir la Grande Gallerie, en el palacio del Louvre, junto al patio denominado Cour 
Carrée. Tras el asesinato del rey, su esposa María de Medicis, con la intención de alejarse de un Louvre que seguramente juzgaba tosco y medieval, mandó la construcción de su residencia -entre 1615 y 1630- en el palacio de Luxemburgo (Fig.11). En ella dispuso la primera galería a doble altura para exposición de las obras de arte de su colección que incluía, entre otras, la serie de 24 telas alegóricas de su reinado, pintadas por Rubens.

La expectación y el interés por las obras de arte de los coleccionistas demanda su contemplación y la necesidad de una institución que lo articule se hacen palpables. Un ejemplo de ello lo observamos en Oxford, en 1683, con el establecimiento de un reglamento para hacer visitable por el público el contenido del Ashmolean Museum, propiedad de la universidad.

El siglo XVII aportó un espacio expositivo de gran interés para determinadas circunstancias y necesidades: el gabinete de pintura. Los cuadros de David Tenniers, el Joven nos detallan sus características. En uno de ellos (Fig.12) (1651) vemos al Archiduque Leopoldo Guillermo de Habsburgo, tocado con sombrero, al pintor y demás personajes, protocolariamente descubiertos, por supuesto, observando unas piezas que cubren en su totalidad los muros del gabinete. Piezas que el pintor reproduce con total exactitud. En este caso las piezas representadas son parte de la colección de pintura italiana del Archiduque. Tal es la precisión de la reproducción que, dichos cuadros de Tenniers, se utilizaron como catálogo para la venta o trueque de piezas entre coleccionistas de la época.

El siglo XVIII alumbró el nacimiento del museo tal como lo entendemos hoy. Hemos observado en el siglo anterior gestos que anunciaban la necesidad de la institución. De hecho la reina Cristina de Suecia ya permitía a sus súbditos la visita a las galerías de palacio que exhibían su colección, (se exigía ir calzado con zapatos limpios). La divulgación de las colecciones privadas, mediante accesos restringidos y condicionados, discurrió en paralelo a la reorganización de las colecciones y a la introducción de criterios expositivos. En Roma, en la citada Villa
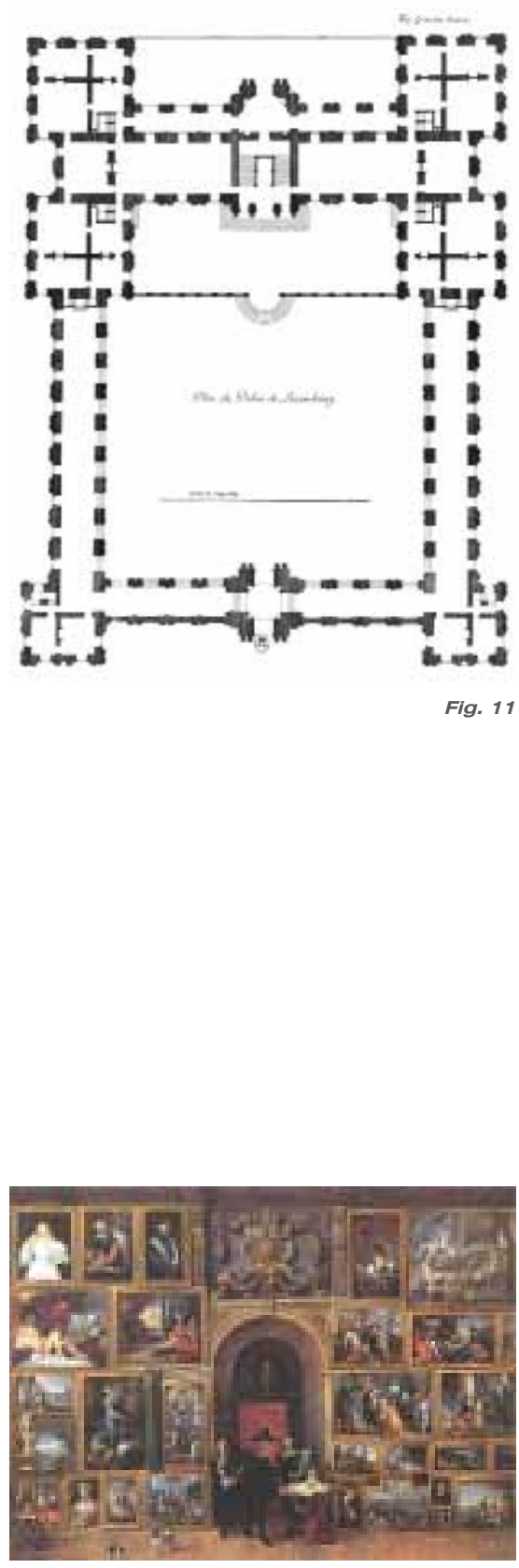

Fig. 12 .

.



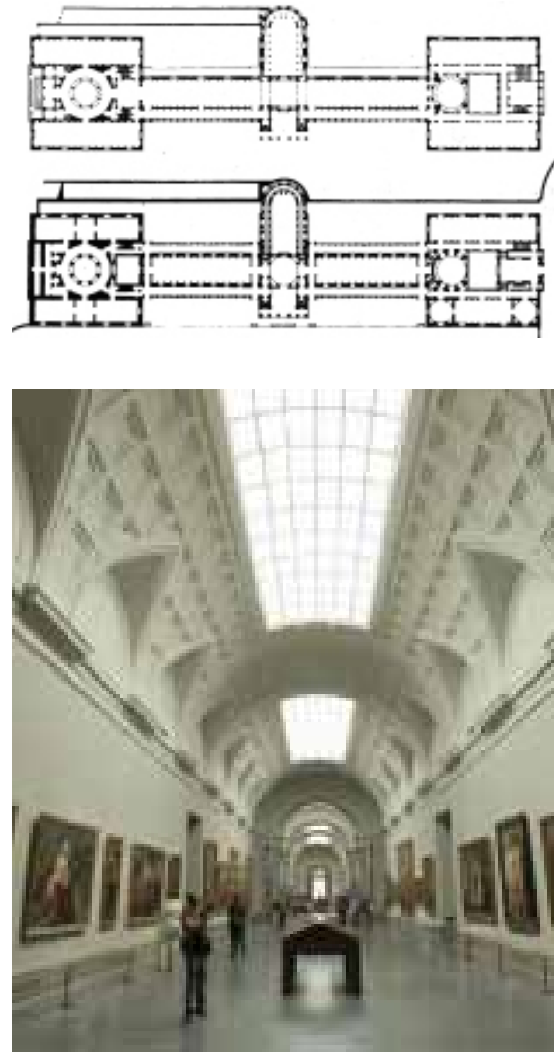

Figs. 13-14

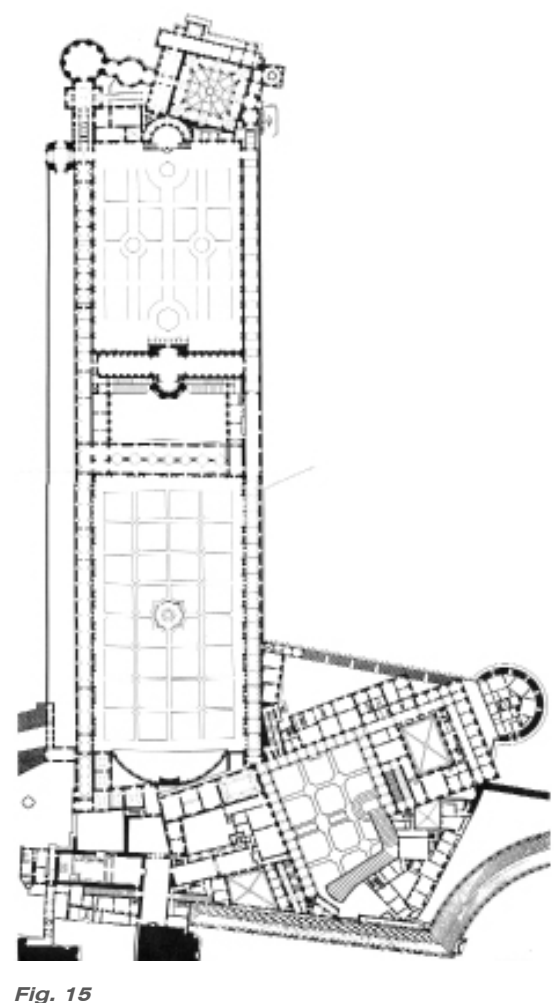

Borghese, concebida como una villa cuyo objeto fundamental era la exposición de obras de arte y el recreo, se reordenó la colección y se redecoraron sus salas.

En 1784, Juan de Villanueva proyectó el Prado (Figs.13-14), destinado en origen a la Academia de Ciencias Naturales y al Real Gabinete de Historia Natural. La concepción original del edificio aprovechaba el desnivel entre sus accesos para destinar la planta baja a la primera institución y la planta primera a la segunda. Su pronta mutación de uso al de Real Museo de Pinturas y Esculturas aprovechó la organización lineal del recorrido primigenio para la disposición, cronológica, de las obras de arte; la pintura se alojaba en la planta primera, que adquiere así un carácter de planta noble, mientras que la escultura se reservaba para la planta inferior.

Como un ejemplo entre muchos de la construcción de edificios con el objetivo de albergar y exponer obras de arte cabe citar Villa Albani. El interés del edificio construido en 1758 por Carlo Marchionni, coetáneo de Simonetti, es relativo, pues se trata en su exterior de una villa barroca al uso. Es muy relevante, sin embargo, el hecho que su propietario el Cardenal Albani, sobrino del papa que bendijo a Cristina de Suecia, en aquel momento coleccionista en el exilio, tenía por bibliotecario al padre de la Historia del Arte Joham Joachim Winkelmann. Juntos habían logrado exponer las piezas de la forma más fiel, elegante y fructífera.

En 1787, Pío VI inauguraba el nuevo Museo Vaticano (Fig.15) iniciado por su predecesor Clemente XIV. De esta manera las colecciones de estatuaria clásica seleccionadas años antes por el Prefecto de Antigüedades J.J. Winckelmann disponían de una sede permanente. La construcción del museo en el extremo norte del complejo Vaticano fue encomendada al arquitecto Michelangelo Simonetti, que tuvo que optar por actuaciones drásticas, como la demolición de la capilla de S. Juan, pintada por Mantegna, para disponer de espacio suficiente para su edificación. 
El museo fue concebido en función de un recorrido a través de una secuencia de espacios (Fig.16), que especificaremos a continuación, proyectados para la exposición de las colecciones. Una gran escalinata de un solo tiro, que lleva el nombre del arquitecto, enlaza el museo profano con los nuevos espacios que enumeramos en orden de recorrido: la sala de cruz griega, la rotonda, la sala de las Musas, y el patio que fue de Bramante; junto a él, la galería de estatuaria y las salas de bustos. Todo un repertorio de espacios expositivos extraídos del vocabulario palaciego, o de grandes ejemplos de la época clásica, como la rotonda y que constituirán la base del museo como institución y cuya validez perdura aún en nuestros días.

Las intervenciones de Camporessi y Simonetti, a caballo entre la remodelación y la nueva planta, centraron su intervención en torno al patio cuadrado de Bramante (Figs.17-18), modificado según diseño de Giacomo de Pietrasanta. En él se prosiguió la exhibición de esculturas clave de la Antigüedad: el Apolo de Belvedere, el Laocoonte, el Hermes de Praxíteles, a los que se añadió un moderno Perseo de Canova. El conjunto, de honda influencia en la arquitectura museística posterior, representa un elenco codificado de espacios expositivos que se utilizarán disciplinarmente con diverso éxito: la rotonda (Fig.19), de más de 21 metros de diámetro, que evoca al Panteón de Agrippa o la sala de cruz griega, cuya empleo en futuros espacios expositivos conocerá una menor fortuna, etc. Pocos años después Camporessi diseñó la Sala delle Muse, cuya impronta longitudinal se matiza con la introducción en su parte central de
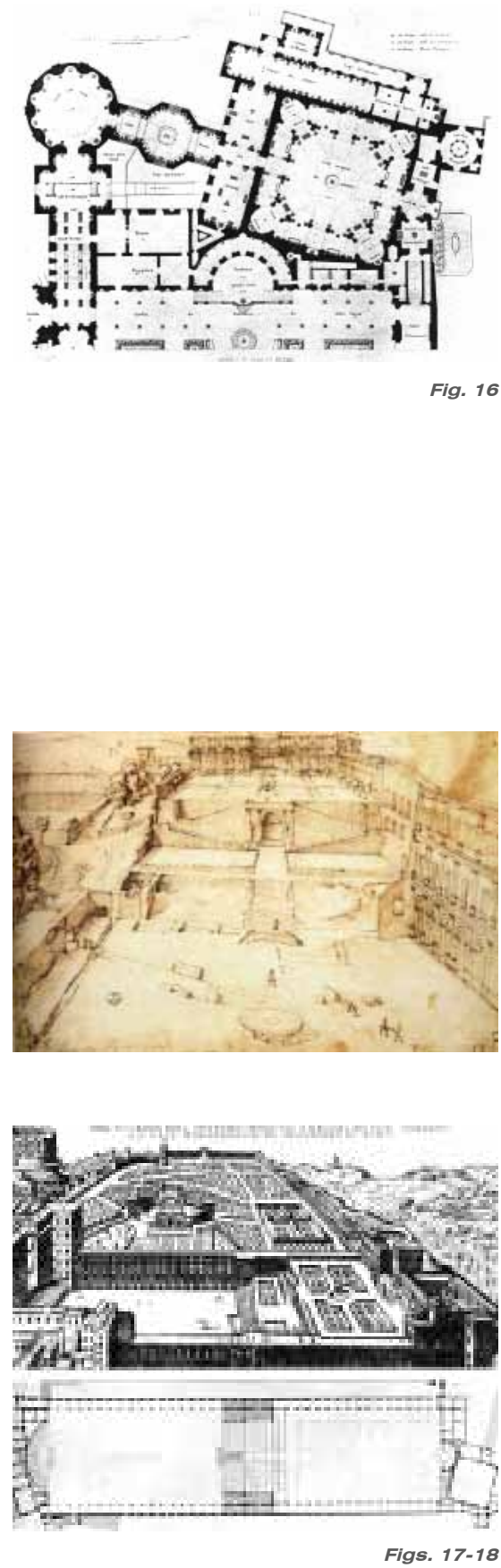
un octógono cupulado con copias romanas de las nueve musas de talla helenística provenientes de Villa Adriana, presididas por un Apolo Musagetes moderno. Estas instalaciones se abrieron al público de forma restringida en 1787 tomando el nombre de sus promotores, Museo Pío-Clementino.

Nueve años después de la inauguración del museo, en 1796, las tropas napoleónicas irrumpieron en el norte de Italia. La invasión napoleónica provocó un importante expolio. En el 


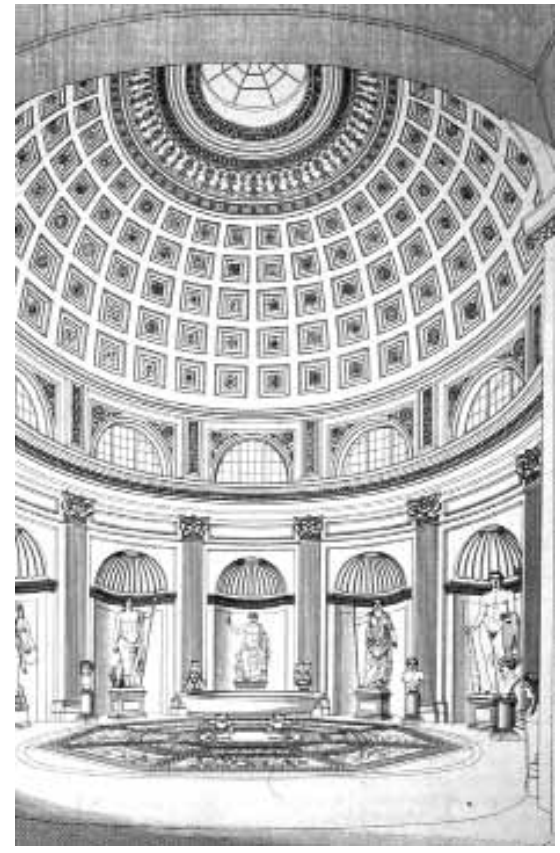

Fig. 19 mes de mayo Napoleón solicitó a París el envío de conocidos artistas como apoyo científico para seleccionar las obras objeto del latrocinio que decidió acometer. En virtud de los tratados de Campo Formio y Tolentino, Venecia y el Vaticano vieron consumado el robo de obras de arte llevado a cabo por las tropas bonapartistas. En 1798 tuvo lugar en París la "entrada triunfal de los monumentos de las ciencias y de las artes" eufemismo con el que se nombraba al botín artístico italiano. Una única voz se alzó contra esta acción, la del arqueólogo e historiador Quatremère de Quincy que consideró que el espíritu de conquista era absolutamente contradictorio con el espíritu de libertad de la Revolución Francesa.

El papa Chiaramonti, Pío VII, ante el vaciado napoleónico del museo, promovió excavaciones y adquirió piezas que Canova, Inspector General de Bellas Artes y Monumentos de los Estados Pontificios, dispuso ocupando el ala norte del corredor del Belvedere bramantesco, por lo que se denominó Museo Chiaramonti.

Antonio Canova, tan buen escultor como ferviente revolucionario bonapartista, fue enviado a París en 1802 por el Papa Pío VII en respuesta a la invitación hecha por Napoleón para realizar bustos y estatuas, con el velado objetivo de persuadir al emperador de la bondad de la devolución a Roma de las colosales maravillas que se había llevado a Francia como botín de guerra. Este viaje, además de cimentar su fama, le permitió conocer las obras realizadas en el Louvre por Percier y Fontaine y, trasladándose a Inglaterra, visitar el British Museum, sito en Montagüe House, donde pudo admirar los mármoles del Partenón que Lord Elgin había traído a Londres. Es posible que conociera también de primera mano todo el trabajo de investigación que los arquitectos ingleses efectuaron respecto de la iluminación cenital de las salas de exposición. Esta labor arranca en el siglo XVIII y tendrá una influencia en el continente muy importante, como veremos más adelante.

Su reconocido prestigio, su profunda militancia neoclásica, 
su ideología, afín a la de Jean Nicolas Louis David con el que fue firme candidato a la dirección del Louvre, su condición de discípulo de Mengs y de Winckelmann: a Canova se le abrieron todas las puertas del mundo artístico europeo del momento.

En 1815, terminado el largo Congreso de Viena que pone fin al dominio napoleónico de Europa, salieron del Louvre más de 2.000 cuadros y 300 estatuas, junto a bronces, esmaltes y otras piezas valiosas: entre ellos los principales tesoros vaticanos.

Ante el retorno de tan codiciadas piezas, la ampliación del museo se tornó perentoria. Fue Canova el que optó porque la ampliación de los museos fuese de nueva planta. La nueva construcción se ubicó en el patio del Belvedere uniendo las salas Este y Oeste de Bramante.

El gran patio quedó dividido en tres partes (Fig.20), el Patio de la Piña, el de la Biblioteca y el Belvedere -en el siglo XVI ya se había construido el Salón Sixtino que había partido en dos el gran espacio-. El Pontífice encargó para ello, en 1817, a otro ilustrado, el arquitecto Rafaello Stern, la citada galería de enlace. El arquitecto, ferviente seguidor de Winckelmann y con una sólida formación en la arquitectura clásica (había llevado a cabo la restauración del Arco de Tito y del Coloseo), acometió la construcción del Braccio Nuovo ${ }^{(\text {Figs.21-22-23) }}$ en la tradición de las grandes galerías: tramo central cubierto con cúpula que divide la galería en dos espacios, cuyos paramentos interiores presentan una serie de nichos; la disposición de la cúpula da lugar a un ábside en el alzado sur y a un pórtico octástilo en el norte. La iluminación es cenital a la manera de la solución de Percier y Fontaine en la Grande Gallerie del Louvre, realizada en 1805. Con esta galería terminada en 1822, se cerraron las obras del Museo Pío Clementino, posteriormente denominado Museos Vaticanos.

La idoneidad, en la definición del museo Museo Pío Clementino, de espacios expositivos como el patio de escultura, la rotonda, las salas, las galerías largas, cortas, y el antiquarium,
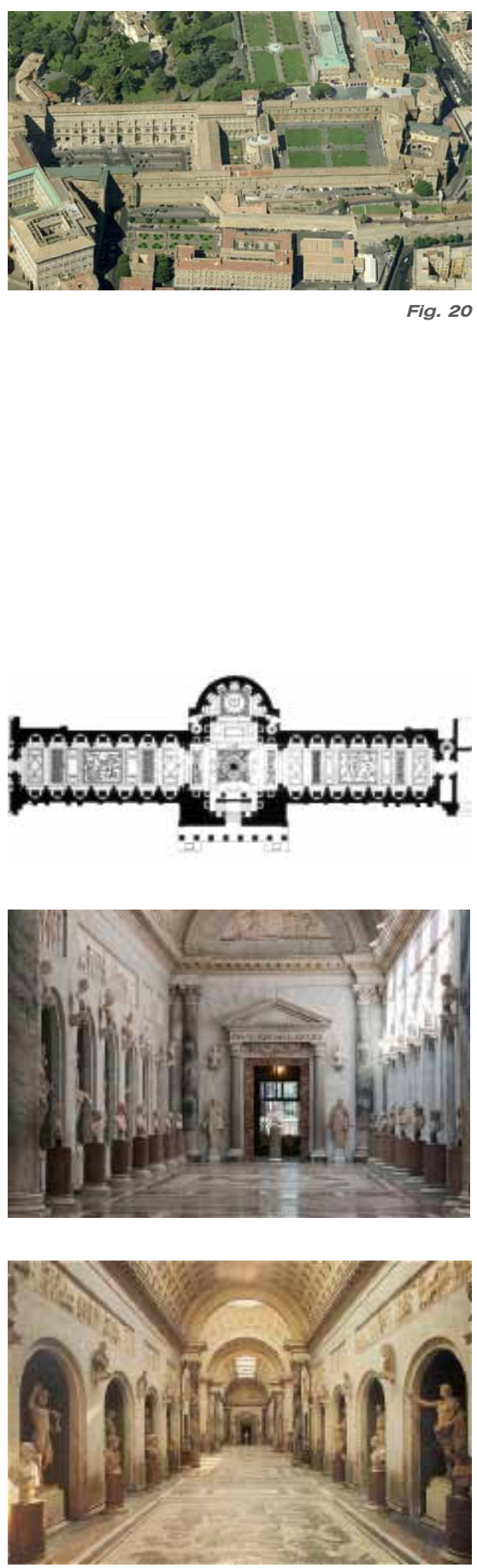

Figs. 21-22-23 

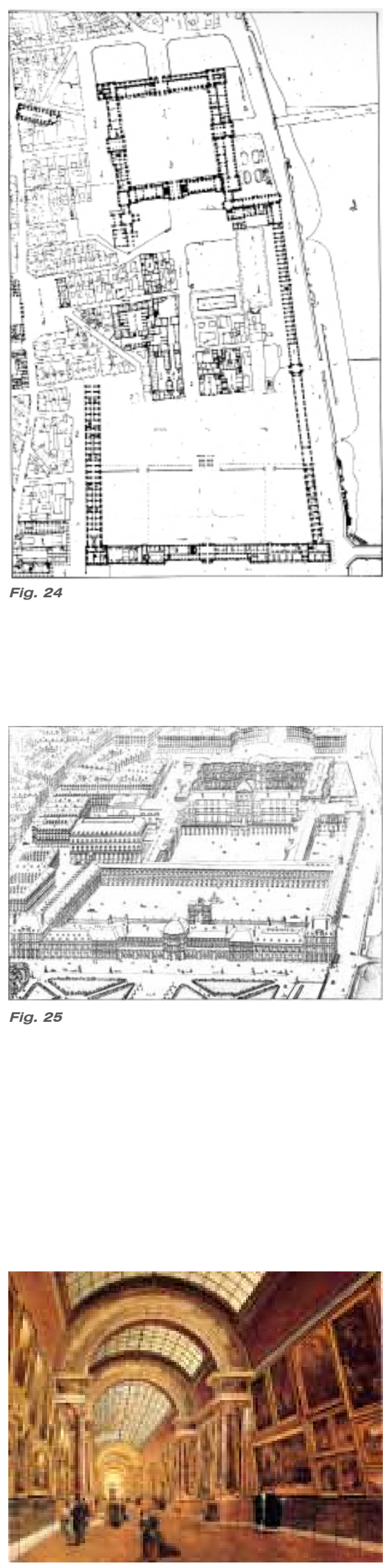

Fig. 26 confirman su valor como elementos arquitectónicos que constituyen la base en la definición del gran museo del siglo XIX.

El 27 de julio de 1793, la Convención Republicana fundó el primer museo en sentido moderno del término: una colección pública en un museo estatal. La elección del Palacio del Louvre como primer museo estatal podemos leerla como un síntoma: el museo público creado por la Convención se instala en la casa del coleccionista: el palacio. Otros edificios institucionales de la época han alcanzado situaciones más consolidadas, gracias a la estabilidad de las relaciones espaciales que en ellos deben producirse. No es el caso del museo, todo en él obra moderna, donde la exhibición ordenada de obras de arte, abierta al público, con una función a la vez didáctica y gratificante, es producto de las aspiraciones de las sociedades nacidas de la Revolución Francesa.

Las obras de adecuación del Palacio del Louvre, que se acometieron para su conversión en museo público, tienen numerosos antecedentes, en especial desde inicios del siglo XVII. Bajo el mandato de Enrique IV, se comenzó la construcción de la Grande Gallerie. Ésta, de 450 metros de longitud, tenía como principal cometido la conexión entre las dependencias del Louvre y de las Tullerías (Fig.24); la contemplación de las vistas sobre el Sena se completaba con la exhibición de obras de la colección real. Hacia 1610, año del asesinato del monarca, se habían concluido gran parte de los trabajos. Con la creación del Museo del Louvre, casi 200 años después, los arquitectos Percier y Fontaine (Fig.25) llevaron a cabo los trabajos de adecuación de los que destaca su actuación en la Grande Gallerie. La decisión fundamental de esta remodelación consistió en la perforación de la bóveda y la disposición de huecos que permitieron la iluminación cenital, tal y como se refleja en el celebrado cuadro

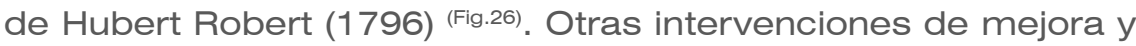
adaptación del inmenso palacio, de menor calado cuya reseña se obvia, lo convirtieron así en el primer museo público estatal. 


\subsubsection{Durand y el Gran Museo del siglo XIX}

En un momento de definición tipológica en el campo de la arquitectura, como es el Siglo de las Luces, el museo no disponía de modelo. Podemos hablar de tipos de edificios cuando la experiencia histórica de un cierto programa funcional se resuelve técnicamente en un sistema espacial estable, del cual la arquitectura podrá establecer múltiples variantes. No es el caso del museo.

Durante el siglo XVIII, y en la transición de éste al siguiente, los espacios expositivos como rotondas, patios, galerías -larga o corta-, salas, gabinetes, aportados a lo largo de etapas anteriores, constituyen un vocabulario asumido en el desarrollo de los futuros museos.

A pesar de que se continua trabajando sobre este repertorio de espacios, como es el caso de los decisivos estudios sobre la iluminación de dichas piezas realizados, en especial en instituciones o galerías privadas inglesas -baste recordar los estudios de Wilkins sobre la luz cenital en Somerset House (1787), de Tanhan en Castle Howard (1801) y en Blockesby (1807), sin olvidar a George Dance, maestro de John Soane, en 1805, en la biblioteca del Royal College of Surgeons-, a este conjunto de palabras le falta una sintaxis que lo articule y establezca las necesarias relaciones de unas respecto de las otras. ${ }^{(5)}$

Conviene insistir en que se trata de elementos espaciales ya existentes en el campo de la arquitectura; las galerías provienen del palacio, básicamente, así como el patio; la rotonda posee el ejemplo colosal del Panteón, amén de encontrarse en otros restos clásicos que ya con Rafael son objeto de estudio y análisis. Una novedosa manera de proceder a su ensamblaje y una renovada utilización desde una óptica codificada suponen el importante cambio que se producirá en los inicios del siglo XIX, vinculado inevitablemente a los cambios sociales ejemplificados en el desarrollo de las ideas de la Convención Republicana y a la formación de los estados modernos. Se trata, sin duda, de 
DES MUSÉUM.

Dans les grandes villes il peut y avoir plusieurs Musénm, les uns destinés à renfermer les productions les plus rares de la nature, les autres à contenir les chefs - d'oeuvre des arts. Dans les villes peu considérables, un même Muséum peut servir à-la-fois à ces divers usages. On pourrait même pour plus d'économie, y réunir la bibliothèque. Mais quell que soit l'étendue de ces édifices, quel que puisse être le genre des objets quils doivent renfermer, la conservation et la communication d'un trésor précieux étant toujours le motif qui les fait élever, ces édifices doivent être composés dans le même esprit que les bibliothèques. Ce que non avons dit de général it l'égard de celles-ci peut donc leur êtrie appliqué; la seule différence qui devrait avoir lieu dan leur disposition est que les bibliothèques ne renferment dans leur intérieur qu'un même genre d'objets, n'étant desthe de nées dans toute lour étendue qu h́ mé mage, une seule entree peut lour son la shio que les Musean, meme ceux qui seraient aniquent destinés a renfermer les productions des arts, contenant des objets de différente espèce, étant composées de parties destinées à des études différentes, doivent, pour que le calm qui doit régner dans chacune ne soit pas troublé, offrir outre l'entrée principale, autant d'entrées particulières qu'ils contiennent de parties distinctes. On nous dira, peut-être, que cette multiplicité d'ouvertures nuirait à la sûreté : on peut voir dans le projet, planche II, comment, au moye de vestibules communs, chaque partie serait parfaitement dégagée, sans qu'il fût nécessaire d'ouvrir un grand nombre de portes à l'extérieur. Voyez de plus les planches $15,{ }_{1} 6$ 17 et 18 du Choix des projets.

Fig. 27 aportaciones que abocan a una codificación de elementos que, a comienzos del siglo XIX, establecerá J.N.L. Durand en sus Prècis des leçons d'Architecture.

Jean Nicolas Louis Durand, teórico y profesor de la École Polytechnique durante más de tres décadas, fue el autor, en 1802, de un importantísimo compendio: Prècis des lessons d'Architecture (Fig.27). Lecciones de Arquitectura cuyo objeto era la enseñanza del ejercicio de la arquitectura a los estudiantes de ingeniería.

Imbuido de las ideas renovadoras de la Revolución, el objetivo fundamental de sus materiales docentes era el proporcionar a sus alumnos un método instrumental que permitiese, desde una óptica racional, económica y utilitaria, la realización de proyectos en respuesta a las concretas exigencias derivadas de la función que debían satisfacer. En el método que define Durand, los elementos (soportes, muros, aberturas, cimientos, bóvedas, techumbres y terrazas) se combinan entre sí con objeto de formar las diversas partes de los edificios: pórticos, porches, vestíbulos, escaleras, salas, etc. La lógica aditiva que preside este procedimiento implica la adición de estos fragmentos como potente herramienta configuradora de los edificios: son éstos pues el resultado de la adición de pórticos, vestíbulos, escaleras, salas, cúpulas, entre otros. Del análisis de sus lecciones, apreciamos claramente la preferencia por las formas geométricas simples, el auxilio de la cuadrícula cartesiana en la combinación de elementos y partes así como la racionalidad y simetría de las estructuras resistentes: "No se debe luchar por hacer un bello edificio -cita Peter Collins- ya que preocupándonos únicamente por conseguir resolver las necesidades prácticas, es imposible que sea feo." Así, el profesor británico concluye: "La doctrina del funcionalismo no se puede exponer con más fuerza $\mathrm{y}$, ciertamente, nunca ha sido mejor explicada ni siquiera en los últimos años." (6)

En conexión con el apartado anterior, comprobamos que los espacios museísticos desarrollados en los siglos anteriores, 
fundamentalmente en los siglos XVII y XVIII, reaparecen en un procedimiento combinatorio, que reafirma su vigencia y que les proporcionará una larga pervivencia. Por otro lado, cabe resaltar que Durand no solo establece un método compositivo en abstracto, sino en referencia a programas funcionales, algunos de reciente creación revolucionaria, entre los que se encuentra el Museo Público.

El Museo de Durand (Fig.28) se inscribe, en planta, en un cuadrado. Ordenado por dos ejes de simetría ortogonales, sus cuatro fachadas son idénticas y constan de un pórtico de 48 columnas flanqueado por dos paramentos macizos orlados con relieves. Cuatro patios perforan el cuadrado primigenio, resultando un cuerpo edilicio en forma de cruz, con disposición central, enmarcado por las crujías perimetrales. En la confluencia de los dos brazos de la cruz, aparece una rotonda, cuyo aspecto reseñado en la sección nos evoca no solo el Panteón de Agrippa, sino también la sala expositiva que diseñó Camporessi en el Museo Pío Clementino. Por otro lado, la intersección en planta de la cruz con la construcción perimetral suscita los vestíbulos de ingreso, que son cuatro, de planta cuadrada y que constituyen salas cuya solución es análoga a las del encuentro que las esquinas de las diferentes alas provocan. Observamos la articulación de salas cortas y largas, alternadas con pequeños espacios de transición que responden a un orden secundario en el que aparecen los gabinetes para los artistas. Mientras las galerías se cubren con bóvedas aristadas, se reserva la techumbre plana para los gabinetes.

Establecidos en sus Prècis los esquemas organizativos de Durand, la construcción del museo se produce a través de la conjunción de figuras que se proponen como dispositivos adecuados a la visión de las obras de arte. Figuras que provienen del antiguo coleccionismo (gabinetes, galerías, cámaras del tesoro...) o de la moderna arquitectura palaciega (pórticos, rotondas, galerías...); referencias que aparecen en la construcción del museo como repertorios alternativos a los que

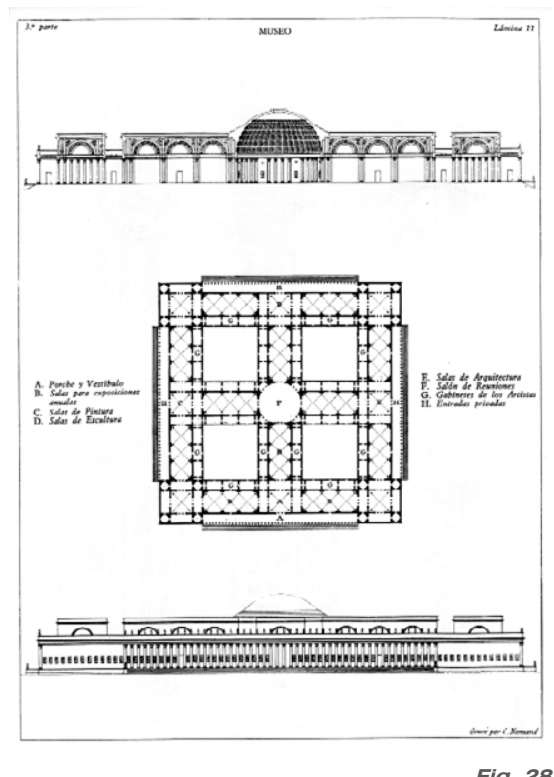

Fig. 28 
puede referirse este lugar civil privilegiado por la cultura ilustrada.

Rafael Moneo, citando a H.R. Hitchcock, explica clarividentemente como los principios manifestados por Durand "eran los responsables de buena parte de la arquitectura del norte y del centro de Europa en el primer tercio del siglo XIX, período que tiene como máximas figuras a arquitectos de la talla de K. F. Schinkel y Leo von Klenze". (7)

La honda influencia que ejerce Durand en los arquitectos de su época trasciende los objetivos meramente académicos que motivaron la redacción y publicación de sus lecciones. Estos planteamientos, cuya memoria revive, áulica, están presentes en todos aquellos bellísimos proyectos que vienen a la mente pensando en la relación que une programa edilicio y construcción, que se van desgranando conforme avanza el siglo XIX: en 1811, la Dulwich Gallery de John Soane, en 1815 la Glyptotek en Munich de Leo von Klenze y en 1823, el más durandiano de los grandes proyectos de arquitectura de museos, el Altes Museum. En él, Karl Friedrich Schinkel, pauta, desde una contundente relación con el lugar (el Kupfergraben, el río Spree y el Lutsgarten) la definición del gran Berlín prusiano.

Los nuevos ideales que surgen como consecuencia del proceso ilustrado, que abogan por la instrucción popular y por un acceso democrático a la cultura, propician en Europa y Estados Unidos, la reproducción de muchas de las modernas instituciones desarrolladas a partir de la Revolución Francesa y durante el período Napoleónico. Este es el caso del Museo Público, institución que en algunos de los casos aúna la voluntad de modernización de los estados con el deseo de exposición de los tesoros que, sustraídos, fueron recuperados tras la definitiva derrota de las tropas bonapartistas. Las aspiraciones de la naciente burguesía, la incipiente creación de los estados modernos y el desarrollo del nacionalismo, todo ello unido al importante desarrollo alcanzado por ciencias como la Historia del Arte -de cuyo "fundador" Winckelmann, considerado como tal por la historiografía, ya se ha hablado anteriormente-, explican 
de manera fundamental la gran fortuna que experimenta el programa del Museo Nacional, cuyo desarrollo en el siglo XIX no solo se circunscribe a Europa, sino que dará el salto al continente americano como veremos posteriormente.

Uno de los más importantes y precoces Museos que con carácter nacional se crearon fue el Altes Museum de Berlín. Tuvo un poderoso antecedente: la galería que Federico el Grande mandó erigir en Sans-Souci, en Potsdam, entre 1755 y 1763, a cargo de Johann Gottfried Büring. Esta galería, concebida de nueva planta como un pabellón aislado (Fig.29), tenía por objeto exponer las colecciones reales. Éstas se consideraban en el proyecto de arquitectura parte de la decoración, que se debía integrar, y el carácter exento y la fastuosidad del edificio que las contiene mostraban y reforzaban la idea del poder real. ${ }^{(8)}$

De una sola planta, consta de un espacio único, rectangular, coronado en su centro por una cúpula; con iluminación natural por su fachada sur, reserva la opuesta-ciega- para la exhibición de pintura ${ }^{(F i g .30)}$. La escultura se dispone al exterior, entre los vanos, articulando la relación entre el edificio y el jardín que es tratado como espacio museístico. En su interior, la pintura se organiza fundamentalmente por procedencias y escuelas. La creciente importancia y tamaño de la colección aconsejaron su unificación y reordenamiento en un espacio de superior capacidad, que dio paso así a la creación del Altes Museum, que puede considerarse como el primer Museo Nacional Alemán.

El primer proyecto diseñado lo realizó el profesor de Arte Alois Hirt en 1798. Responde a la ubicación actual de la Neue Wache, junto al edificio de la Zeughaus -actualmente Museo de Historia Alemana-, y consiste en dos crujías edificadas en torno a un patio rectangular. Su esquema, de cierta pobreza conceptual, consiste en la agregación en torno a un patio de reducidas salas, de planta cuadrada, rectangular o en torpe forma de L. El vestíbulo, inscrito en uno de estos escuetos espacios, permite el inicio del recorrido a través de las salas de planta baja o la ascensión a la planta primera mediante una escalera encajada
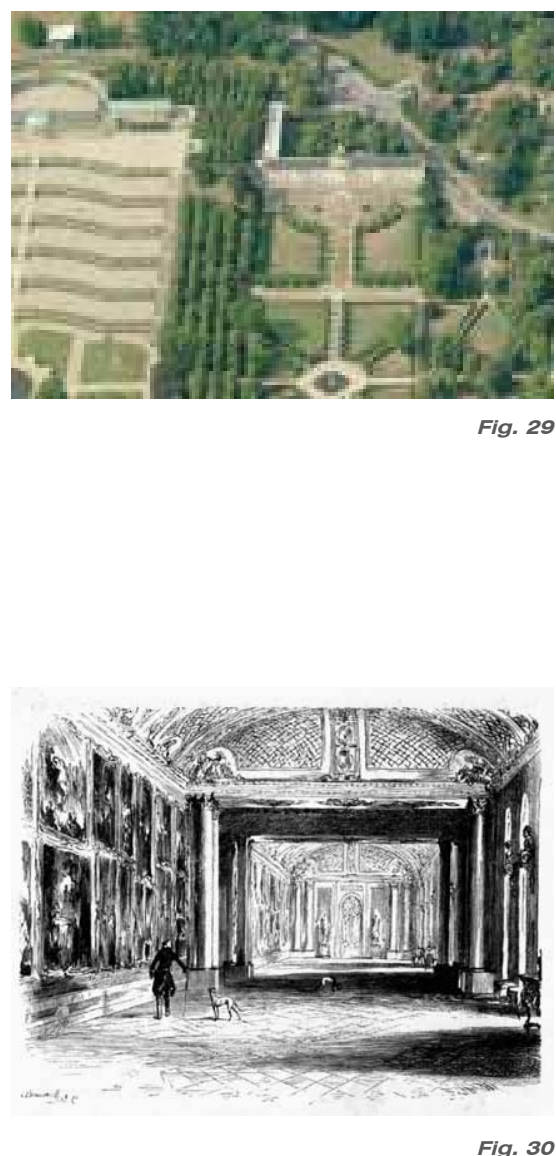

Fig. 30 


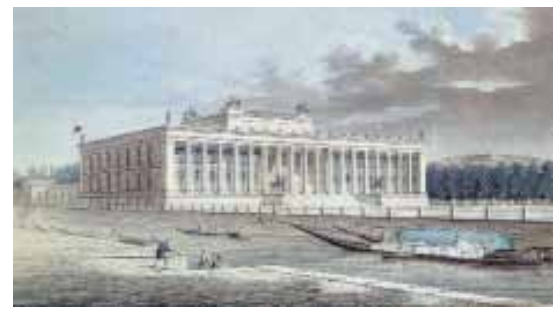

Fig. 31

entre muros. El alzado conservado muestra un basamento con rústico almohadillado y una primera planta ordenada con pilastras de orden dórico, que sostienen un mínimo arquitrabe que da paso al faldón de cubierta, de considerable inclinación, que se muestra sin ningún tipo de rubor.

La descripción de este primer proyecto, afortunadamente no realizado a favor del propuesto por Schinkel, no pretende ser una gratuita muestra de erudición, sino establecer una pequeña reflexión acerca de las razones que aconsejaron la elección de una propuesta y de las dudas que en todo proceso creativo se producen.

El Altes Museum de Schinkel (Figs.31-32) es un edificio paradigmático en el que se puede apreciar con mayor nitidez la impronta "Durandiana" en su composición y resolución del nuevo programa de Museo. Esta influencia ha sido indicada por varios autores, de modo que su demostración no es objeto de este texto. ${ }^{(9)}(10)$

El Museo que Schinkel diseña, cuya construcción se data entre 1823 y 1830, responde también a una estrategia urbana de mejora de los espacios representativos del poder real. Su ubicación en el Lustgarten, frente al Palacio Real, adyacente al Zeughaus -o arsenal- del cual lo separa el canal Kupfergraben, representa una clara operación de modernización del inicio de la Avenida de Unter den Linden.

Inspirado en el stoa ateniense, un pórtico jónico de 18 columnas que materializan un orden gigante se enfrenta a la fachada del Palacio Real, demolido pero en vías de reconstrucción si se lleva a cabo el proyecto del italiano Franco Stella seleccionado a tal efecto. Franqueada la columnata, a la que se asciende a través de una amplía escalinata, el gran vano de acceso aparece sustentado por una nueva serie de columnas gigantes que dan paso al vestíbulo, que se desarrolla en dos alturas y permite el acceso, a través de dos escaleras simétricas enfrentadas, a la planta superior. Un importante eje 
parte de este vestíbulo y enlaza con la rotonda (Figs.33-34), situada en posición central entre dos patios, cuyo objeto es la exhibición de las mejores esculturas de la antigüedad pertenecientes a la colección. (11)

Las salas expositivas se desarrollan en el perímetro del edificio; en planta baja se sitúan las destinadas a escultura; en planta primera, las propias para la exhibición de pintura. En todas las salas, la iluminación es lateral, restando el paramento opuesto para la colocación de las obras de arte. En ningún caso se perforan a la vez muros paralelos ni se introduce la iluminación cenital que tan gran fortuna alcanza en la época en los ejemplos ingleses. Se repite el esquema utilizado en la organización de la Bildergalerie de Sans-souci.

Las salas de planta baja se articulan mediante pares de columnas de planta circular que sostienen acusados arquitrabes divididos en tres platabandas, dispuestos en el centro del espacio entre ventanas, de manera transversal al eje longitudinal de la sala. Los espacios de la planta superior, que no muestran estas columnas ni arquitrabes, repiten la disposición de elementos transversales. Se trata en este caso de mamparas que permiten introducir, por un lado, la dimensión transversal en el recorrido, y por otro ampliar la superficie expositiva superando la disposición colonizadora del paramento vertical propia del gabinete de pintura. Además, la colección se ordena por orden historiográfico y no de acuerdo con criterios propios de la iconografía (según Pevsner, éste era el criterio del Pío Clementino). Cabe reseñar que el presidente de la Comisión de creación del Museo no era otro que el gran humanista y pensador Wilhem von Humbolt; por ello, no es de extrañar que la propuesta expositiva del Altes Museum adelante, en cuanto a modernidad de los criterios expositivos, a la Bildergalerie de Potsdam y a la mayor parte de sus museos contemporáneos. ${ }^{(12)}$

La influencia que el museo berlinés tuvo en otros museos nacionales es muy grande; basta pensar, entre otros, en el Museo Nacional de Hungría, proyectado por Mihály Pollack,

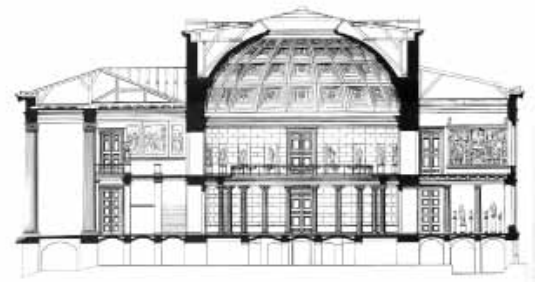

Fig. 33

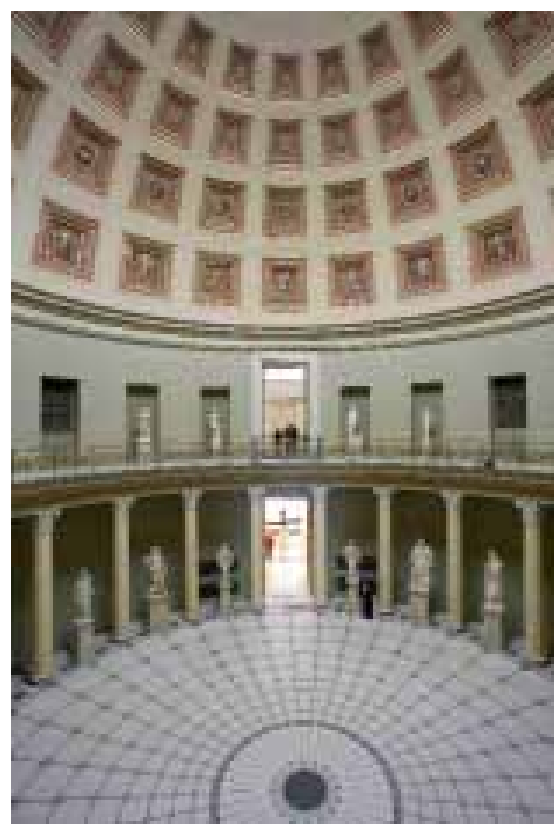

Fig. 34 

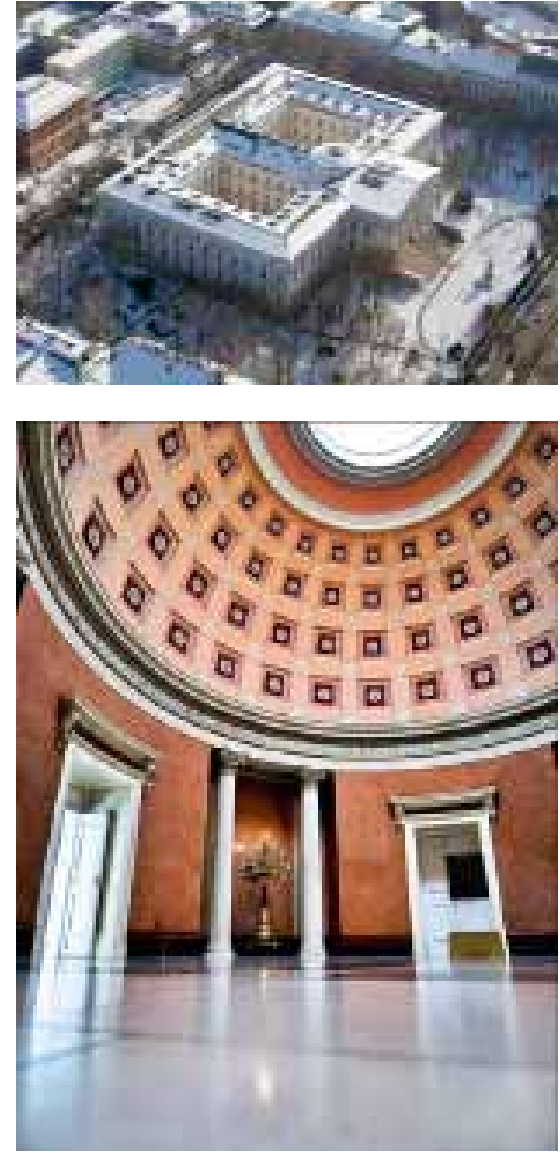

Figs. 35-36

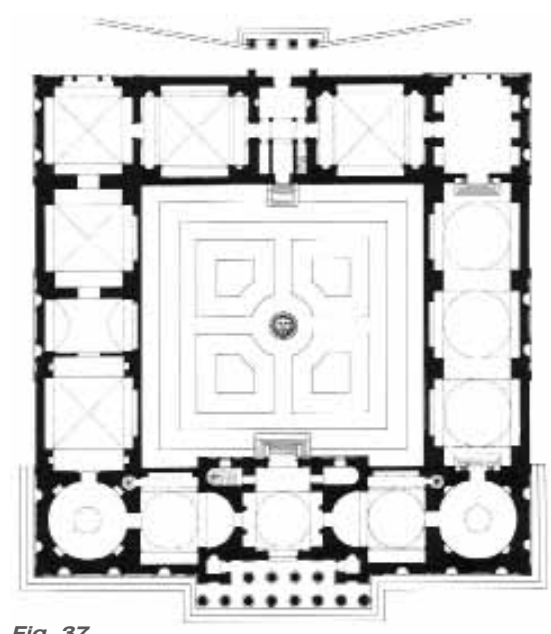

cuya construcción se comenzó en 1837. Se trata de un edificio de planta rectangular, de dos plantas, cuyo acceso se realiza a través de un pronaos articulado con un orden gigante; se repite el esquema de dos patios separados por un cuerpo central que alberga, en conexión con el vestíbulo, la exitosa rotonda expositiva (Figs.35-36).

Contemporáneo en el tiempo y cercano en el orden geográfico y cultural, en Munich desarrolló Leo von Klenze una importante tarea reflexiva y edilicia en torno al programa del Museo de Arte.

En primer lugar, diseñó en torno a 1815 la Gliptoteca de Munich, cuyo objeto era la exhibición de la colección de escultura antigua del rey Luis I de Baviera. Este pequeño museo se inscribe en el diseño de la Plaza Real a la que da frente, obra también de Klenze -en colaboración con Karl von Fischer-. Se trata de un edificio de planta baja, de planta cuadrada y patio central, cuya composición se ha asociado en numerosos estudios a la del Museo propuesto por J.N.L. Durand (Fig.37). Se accede a través de un pórtico octástilo centrado en uno de sus lados, entre dos muros ciegos pautados con la disposición de tres nichos decorados en cada uno de ellos que albergan obras de escultura. Tras varios diseños en diferentes estilos -renacentista, romano y griego- fue elegido este último, inscrito en la corriente neoclásica del momento, al parecer más del agrado del monarca.

En el interior, Klenze privilegia las salidas hacia el patio mediante el eje de entrada mientras niega la conexión entre este espacio exterior y el teórico eje transversal, de modo que establece una asimetría funcional en una planta de perfecta y académica composición. Las galerías se distribuyen en un recorrido anular alrededor del patio, con cubiertas abovedadas de diferentes modos (Fig.38). La contradicción generada por este tipo de cubrición (los griegos desconocían la bóveda), se justificó por el peligro que suponía para las obras de arte (en cuanto a un posible incendio) la cubrición de las galerías con la clásica cubierta de madera a dos aguas. Fundamental importancia reviste el 
patio en la disposición de las salas y en su iluminación, pues éstas se abren hacia el interior del mismo mediante ventanas de tipo termal y disponen, en los casos en los que se adopta la rotonda, de iluminación cenital. La iluminación interior de las salas permite la libre resolución de la fachada, que no acusa las ventanas termales, y que se resuelve mediante paramentos lisos ornados con nichos y esculturas ${ }^{\text {(Fig.39). }}$

Otro gran ejemplo que a continuación se analiza es la Alte Pinakothek que Leo von Klenze proyectó, también en Munich entre 1823 y 1824, cuya terminación se demoró hasta 1836. Fue destruida durante la segunda guerra mundial y su reconstrucción por Hans Döllgast, data de 1957. (13)

El edificio original aporta un esquema lineal de organización basado en una división de funciones entre los dos niveles que tiene el edificio; la planta baja se reserva para almacenes, biblioteca y dependencias secundarias, y la planta primera, que adquiere un carácter preeminente, es la propia de exhibición de pintura. El edificio presenta, en alzado, una planta baja con zócalo y fenestración, enmarcada en edículos, sobre un muro liso. La planta superior se articula por medio de un orden jónico en cuyos vanos se dispone una fenestración de arcos de medio punto. Dos alas flanquean la fachada, confiriendo a la planta una forma de $\mathrm{H}$ marcadamente oblonga (Fig.40). Un pequeño pórtico, que solo abarca tres vanos de la ordenada fenestración, marca el centro de la composición. Este supuesto acceso principal no funciona como tal; el acceso a la Galería se produce a través de la fachada este, donde un vestíbulo de planta cuadrada, dominado por cuatro columnas, nos lleva a la magnífica escalera que nos conducirá a la planta primera. Este modo organizativo nos recuerda al Prado que diseña Villanueva: el funcionamiento a través de un eje longitudinal, el acceso a través de las fachadas laterales, la importancia de la simetría en la composición y la división funcional entre niveles ${ }^{(\text {Fig.41). }}$

En primera planta, uno de los más novedosos tratamientos que introduce Klenze corresponde a la inclusión de la luz cenital
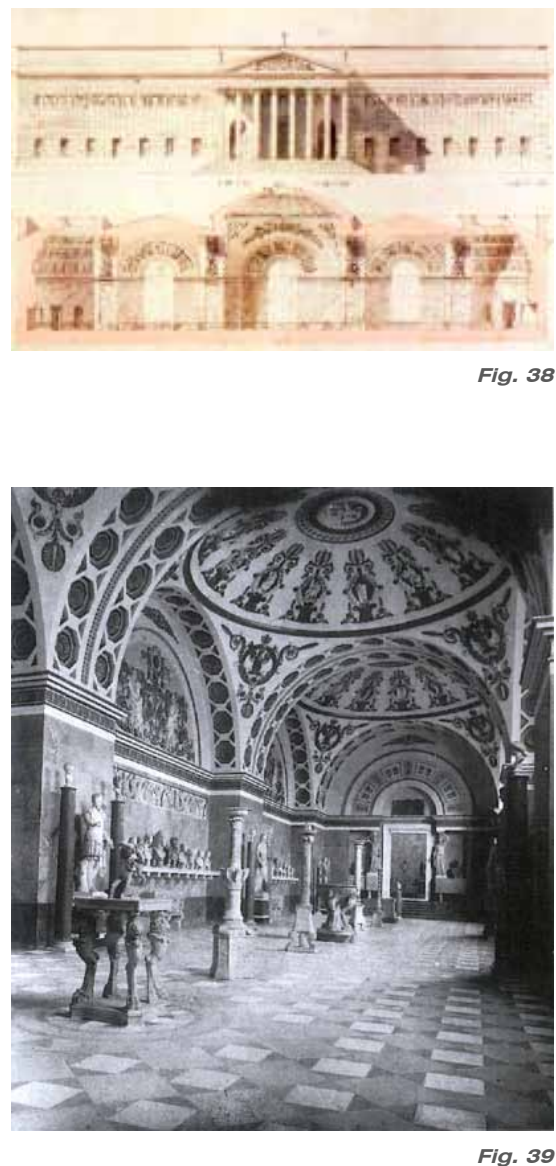

Fig. 39
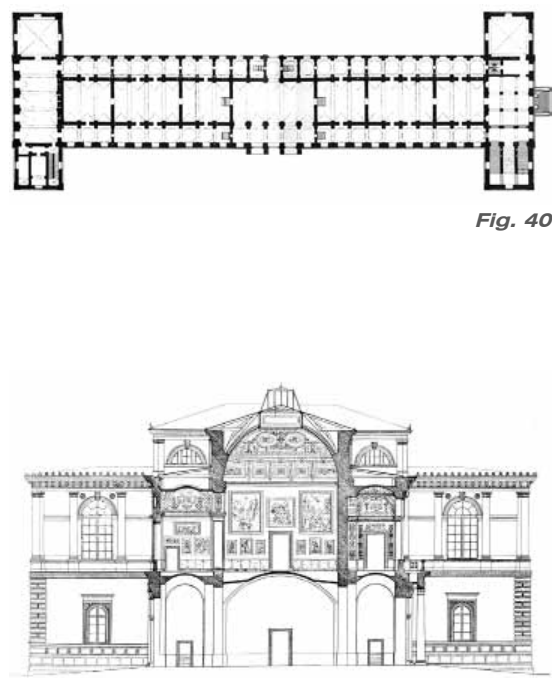

Fig. 41 


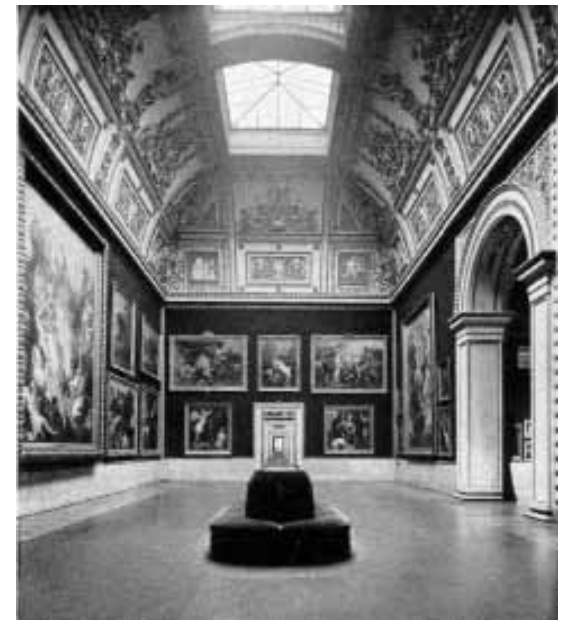

Fig. 42
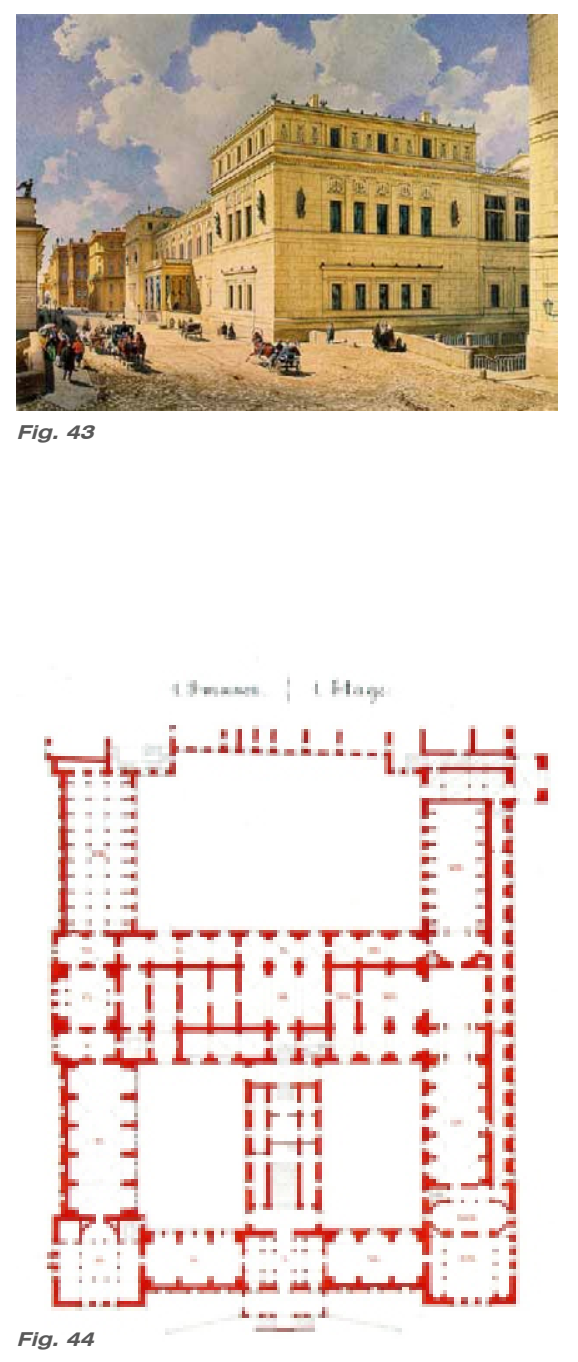

en las bóvedas de las salas expositivas. La pinacoteca se organiza a través de una triple crujía paralela al eje longitudinal. La primera corresponde a una galería de circulación, con vistas al jardín dispuesto a los pies de la fachada principal. Desde esta galería se accede a las salas, de planta rectangular, que se disponen en enfilada siguiendo el eje longitudinal y cuya iluminación se realiza a través de lucernarios, permitiendo así un aumento de la superficie expositiva (Fig.42). Una tercera crujía, de espacios de menor entidad iluminados lateralmente, corresponde a los gabinetes, cuyo acceso se produce a través de las salas, y cuyo cometido original era el albergar cuadros de pequeño formato y de importancia secundaria.

El planteamiento de Klenze lo volveremos a encontrar casi un siglo y medio más tarde. Efectivamente en muchos de los museos que se llevan a cabo desde 1970 dependencias de todo tipo, en especial de uso público, se ubicarán en la planta o entreplantas inferiores dejando la última, normalmente la segunda, para las salas de exposición, lo que permite la entrada de luz cenital en las mismas. A modo de ejemplo podemos citar la ampliación de la National Gallery de Londres, de R. Venturi, la Galería de Stuttgart de J. Stirling o el museo de Houston de R. Moneo.

El éxito de sus dos museos muniqueses le procuró en 1839 la invitación del Zar Nicolás I para diseñar el Museo del Hermitage en San Petersburgo (Fig.43), que abrió sus puertas en 1852. A tal fin, el arquitecto realizó más de 800 dibujos, en los que se reflejó no solo su arquitectura sino también acabados de las estancias e incluso mobiliario diseñado ex profeso.

La organización del Hermitage de Klenze es deudora en gran extremo de la Pinacoteca de Munich. De forma esquemática, soslayando las operaciones de reforma e inclusión de edificaciones preexistentes al norte del emplazamiento elegido (que privaron al arquitecto de proyectar sus fachadas sobre el río Neva), podemos describir en conjunto el edificio que proyecta (y reforma) Klenze como una edificación perimetral 
en torno a un patio central rectangular (Fig.44). Un primer cuerpo edificado, de tres crujías de espesor y dispuesto de forma transversal al eje dominante, divide el primer patio en dos de similar tamaño. Posteriormente, un nuevo cuerpo, esta vez dispuesto en el eje de acceso, parte el primer patio en dos de menores dimensiones. Este cuerpo pertenece al espacio de la magnífica escalinata del Museo, que inicia su ascensión desde el vestíbulo, una vez franqueado el característico pórtico de los atlantes. La escalinata nos conduce, en planta primera, al bloque de tres crujías que, como hemos comentado, corresponde a la primigenia operación de división del patio.

Una delicada atención a este bloque central de tres crujías nos permite establecer una poderosa analogía con la Pinacoteca; en efecto, el desembarco de la escalera nos conduce ineludiblemente a una galería, deambulatorio con fines expositivos, destinada a pintura antigua, cuyos tramos se abovedan mediante cúpulas rebajadas impostadas desde pechinas -al igual que en caso precedente-. Esta galería permite su recorrido así como la entrada a las salas de mayor dimensión cuya iluminación es cenital y que se destinan a la exhibición de lienzos de diferentes escuelas pictóricas: flamenca, italiana, española, etc., tal y como hemos visto en el caso de Munich. En los grabados de época, se observa cómo las obras expuestas en las salas consuman la casi completa colonización de los paramentos verticales (Fig.45). Finalmente, en la tercera crujía, aparecen los gabinetes, de reducidas proporciones, iluminados por uno de sus laterales, a los que se accede a través de las salas (Fig.46). Sin duda, Klenze introduce su exenta Pinacoteca en el corazón de un organismo de vastas proporciones y de considerable complejidad.

A diferencia de los ejemplos alemanes, concentrados en los arquitectos muniqueses, el desarrollo de los espacios expositivos de iluminación cenital alcanzó gran éxito, a fines del siglo XVIII, en las Islas Británicas. A partir de 1790 se inauguran nuevas salas expositivas, de carácter temporal o definitivo, cuyo

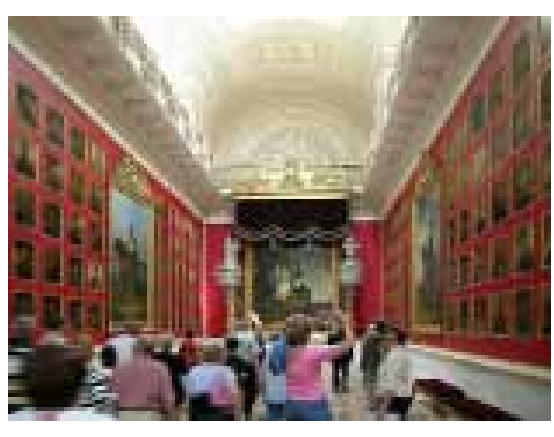

Fig. 45

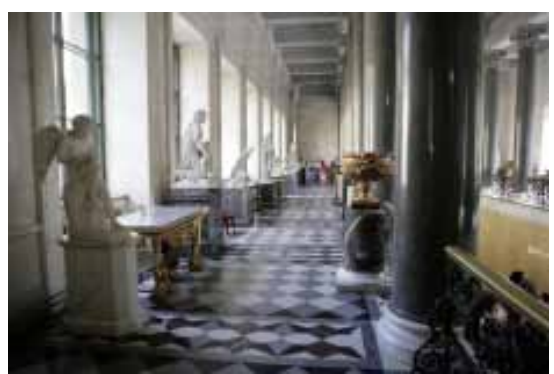

Fig. 46 


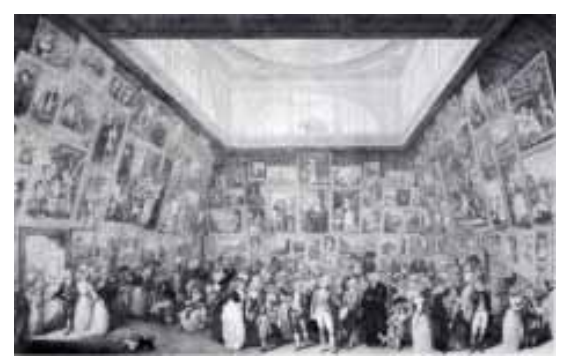

Fig. 47

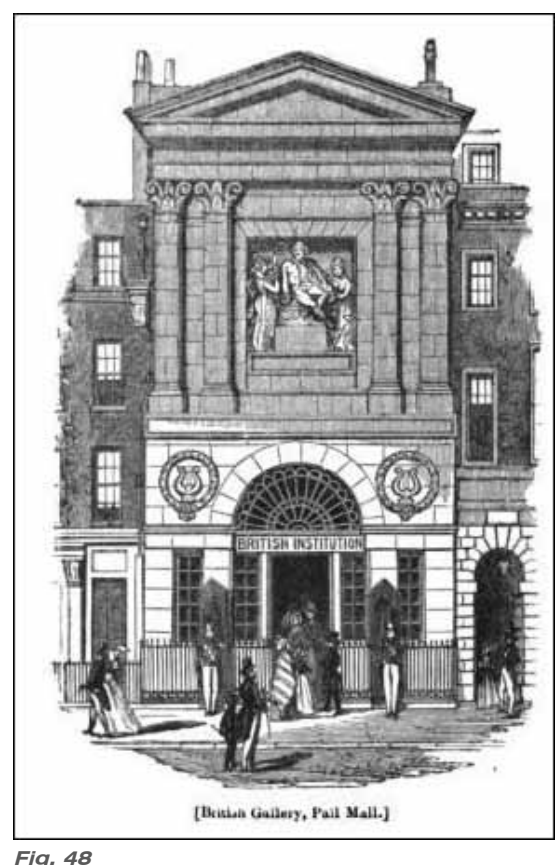

objeto era la exhibición de obras de arte. Los ideales educativos de la revolución se propagaron e influyeron de uno u otro modo en la proliferación galerías de arte. Según muestran los grabados de la época, el tratamiento vertical de los paramentos nos recuerda a los gabinetes de pintura, cuyo criterio expositivo principal radica en el aprovechamiento máximo de la superficie vertical. Los criterios de organización de las colecciones son escasísimos; las pinturas consideradas como mejores ocupan puestos visualmente accesibles, en detrimento de las obras menos valoradas cuya posición será siempre periférica respecto del observador. También muestran los grabados la gran fortuna y variedad de soluciones de iluminación cenital en estos espacios de exhibición. Los casos concretos son muy abundantes; por ello, solo citaremos un par de ellos.

Como ejemplo temprano, en 1787 Pietro Antonio Martini nos representa (Fig.47) una exhibición de la Royal Academy of Arts, institución de reciente fundación -1768-, en Somerset House, en una sala acomodada por Sir William Chambers alrededor de 1776. Por otro lado, podemos observar a través de un grabado (Fig.48) y de su descripción escrita el interior de la Boydell Shakespeare Gallery que George Dance construyó entre 1787 y 1789. Constaba de tres salas, cuya anchura aproximada era de 7,50 metros y sus longitudes variaban entre 11 y 13 metros aproximadamente, unidas en enfilada, que se conectaban mediante huecos rematados con arcos de medio punto. La iluminación, cenital, se realizaba a través de linternas de planta rectangular que cubrían gran parte de la superficie de cada una de las salas. ${ }^{(14)}$

Esta última galería se puede considerar como un precedente de la Dulwich Gallery. El destino no ha sido excesivamente benévolo con la obra de Dance, en gran medida desaparecida. Quizá por esta razón no se le ha otorgado el debido reconocimiento a su importancia, que cabe relacionar con su labor como miembro fundador y docente de Arquitectura en la Royal Academy of Arts. 
La iniciación de John Soane en la disciplina de la arquitectura se produce en el estudio de G. Dance, en el que colaboró entre 1768 y 1772. Soane está considerado por Peter Collins como uno de los arquitectos revolucionarios junto a Boullée, Ledoux y Durand, de cuyos planteamientos hace hincapié en su importante aportación a la terna vitrubiana: "la idea de espacio, que es una cualidad arquitectónica positiva y que tiene tanto o más interés

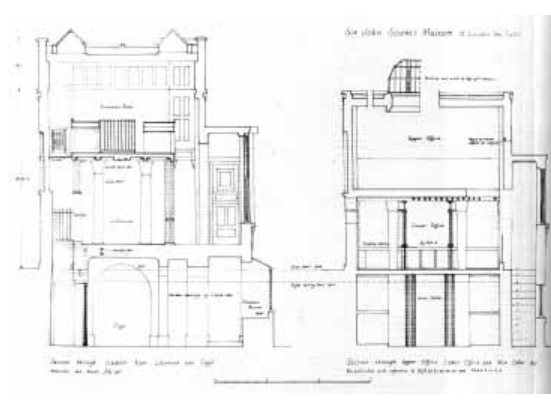

Fig. 49 que la estructura que lo limita." Además subraya, en Soane, su interés por las arquitecturas de Hawksmoor y Vanbrugh en su "búsqueda deliberada de efectos escultóricos y pictóricos." (15)

Las obras de Soane han trascendido el interés local para considerarse como referente en la evolución de los espacios expositivos. Ello se debe, sin duda alguna, al planteamiento que subyace en su casa-museo del 12 de Lincoln's Inn Fields (Fig.49) y a la exitosa Dulwich Gallery (Figs.50-51) donde además de plasmar su idea de que un edificio sólo era bello si "formaba un todo desde cualquier punto de vista de que fuese visto, como una escultura" pone de relieve la importancia del espacio en la articulación de la secuencia de salas que definen el pequeño

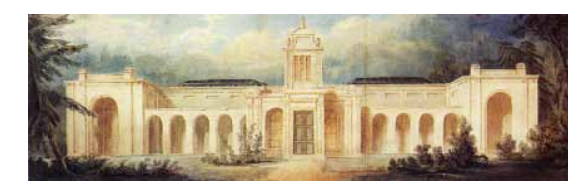
museo junto al importante papel que representa la luz en la definición de las mismas. Recordemos el paralelismo entre "los efectos arquitectónicos causados por la luz" de Boullée y la definición de Le Corbusier de "la arquitectura es el juego magistral correcto y magnífico de las masas unidas por la luz", argumento extensamente tratado por Emil Kaufman en su obra De Ledoux a Le Corbusier de 1933.

La galería Dulwich, posee el doble objeto de permitir la exposición de una importante colección privada y servir como mausoleo de su promotor. Esta colección, dirigida y realizada por Sir Francis Bourgeois y Noel Desenfans, respondía inicialmente a un encargo del rey de Polonia, Estanislao Augusto, que pretendía la formación de una colección nacional polaca. La abdicación del rey y la partición de su país en 1795 frustraron las aspiraciones iniciales, que se encaminaron a la preservación y ampliación de la colección original, que Desenfans conservó hasta su muerte

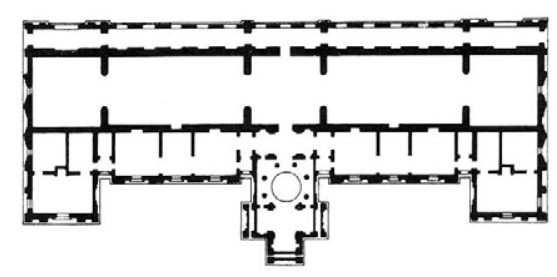

Figs. 50-51

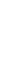




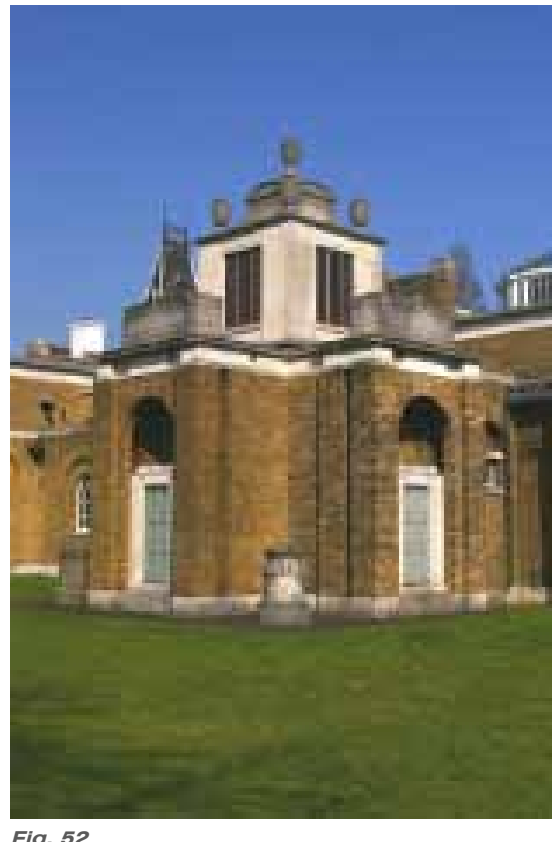

Fig. 52

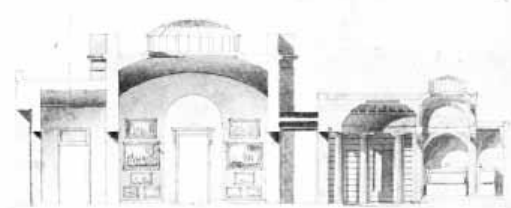

Fig. 53 en 1807. Éste legó la colección a Bourgeois, que posteriormente la donó a la caritativa institución propietaria del Dulwich College.

El edificio de la nueva galería, inaugurado en 1817, fue confiado por Bourgeois a John Soane, a quién le unía una gran amistad (de hecho el arquitecto no cobró honorarios de su trabajo e incluso llegó a costear parte de la ejecución de la obra). Soane incluyó en el programa el mausoleo para los benefactores que en principio debía ser construido en el cercano colegio.

Después de diversos proyectos y tentativas, cuyo largo proceso no procede aquí explicar, la Dulwich se construye en ladrillo común (Fig.52), como el utilizado en sus impresionantes caballerizas del Chelsea Hospital, y presenta análogas formas primitivistas, con las incisiones en los elementales arcos de ladrillo, la ausencia de elementos estilísticos y el uso de la piedra de Portland en zócalos y bases de los citados arcos a las observadas en las citadas caballerizas y en su casa. El uso del ladrillo visto relaciona al edificio con su entorno, aunque con una particularidad: muestra claramente, por primera vez en occidente, el funcionamiento del interior en su forma exterior. Afirma Hitchcock: "Pero es exactamente opuesto al resto de galerías de escultura de su tiempo desde la Gliptoteca de Munich, de Klenze, al Thorvaldsen Museum de Copenhague, de Bindesböll. Tampoco son muchas las afinidades con las galerías de pintura de la época, del Altes Museum de Schinkel a la Alte Pinakothek." (16)

La galería consiste en un cuerpo longitudinal en cuyo centro se dispone, perpendicularmente, el mausoleo. Protagonista del ambiente central, está cuidadosamente trabajado en los materiales citados y bañado mediante un lucernario que proporciona, junto a las cristaleras en color, la lumière espirituel que tanto admiraba Soane de las pequeñas iglesias góticas francesas. Una crujía paralela a la principal, de menor entidad, albergaba en origen dependencias funcionales y de carácter logístico ${ }^{(F i g .53)}$. Las salas, en número de cinco, se disponen en enfilada, alternando la planta cuadrada y la rectangular, mediante 
un ritmo armónico A-B-A-B-A. Las dimensiones de éstas ultimas 6,5×12,5 metros, son muy similares a las hemos visto que $G$. Dance construyó para la Boydell Shakespeare Gallery, como similar es el tratamiento de los huecos de paso entre las salas, centrados y acabados en arcos de medio punto. La iluminación cenital de la galería, que en dibujos preliminares constaba de un óculo que bañaba una bóveda vaída, finalmente se resolvió mediante lucernarios de planta rectangular y esquinas ochavadas que emergían de la cubierta (Fig.54), que si bien algún testimonio de la época, como Harrington de la Royal Academy, consideraba inadecuada, aún hoy en día permite la contemplación correcta de las piezas. Tras numerosas ampliaciones y reconstruida parcialmente de los daños producidos por los bombardeos de la segunda guerra mundial, la Dulwich Gallery ha llegado hasta nosotros conservando la esencia del proyecto de Soane.

Merece al menos una sucinta mención el Thorvaldsen Museet, abierto en Copenhague en 1848 según proyecto de Bindesbøll. En él se alberga, junto a la producción del artista danés del que toma su nombre, las piezas de arte clásico que éste atesoró durante su estancia en Roma. El edificio, que aprovecha una antigua estructura anterior, fue construido entre 1839 y 1848, y se constituyó en el primer museo público de Dinamarca. Se organiza en torno a un patio central, con un corredor interior perimetral que establece un recorrido expositivo (Fig.55). La disposición de las salas en enfilada permite un nuevo recorrido que es independiente de la galería interior, al contrario que lo que había establecido Klenze en su Pinacoteca. Las salas carecen de iluminación cenital: todas reciben iluminación por uno de sus laterales, mediante una fenestración en la parte superior del muro. Si bien Bindesbøll diseñó, durante su estancia en Roma, diversos proyectos de carácter más ambicioso, en la reforma que llevó a cabo de las antiguas caballerizas vinculadas al Palacio de Cristianborg centró su talento creativo en los delicados diseños de pavimentos, motivos geométricos decorativos de bóvedas y techos y en una sabia y exquisita utilización del color (Fig.56).

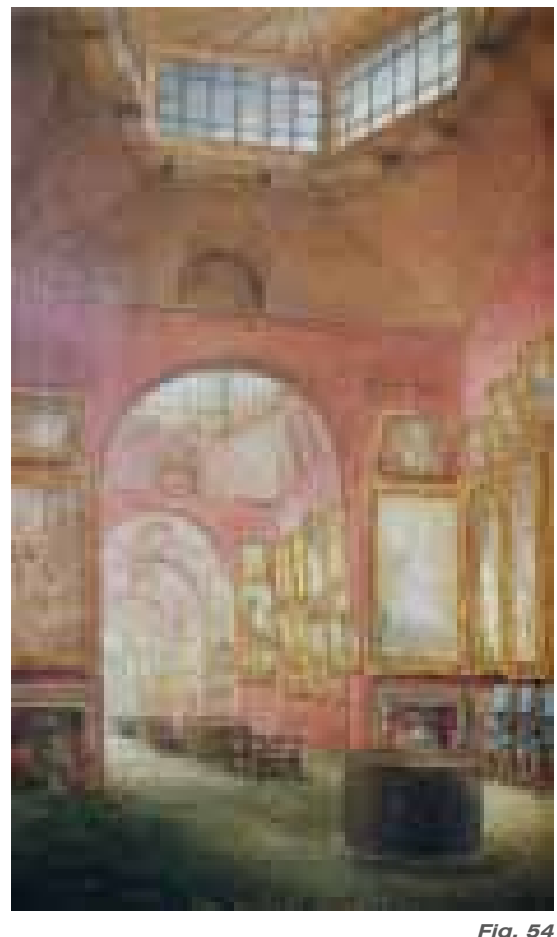

Fig. 54
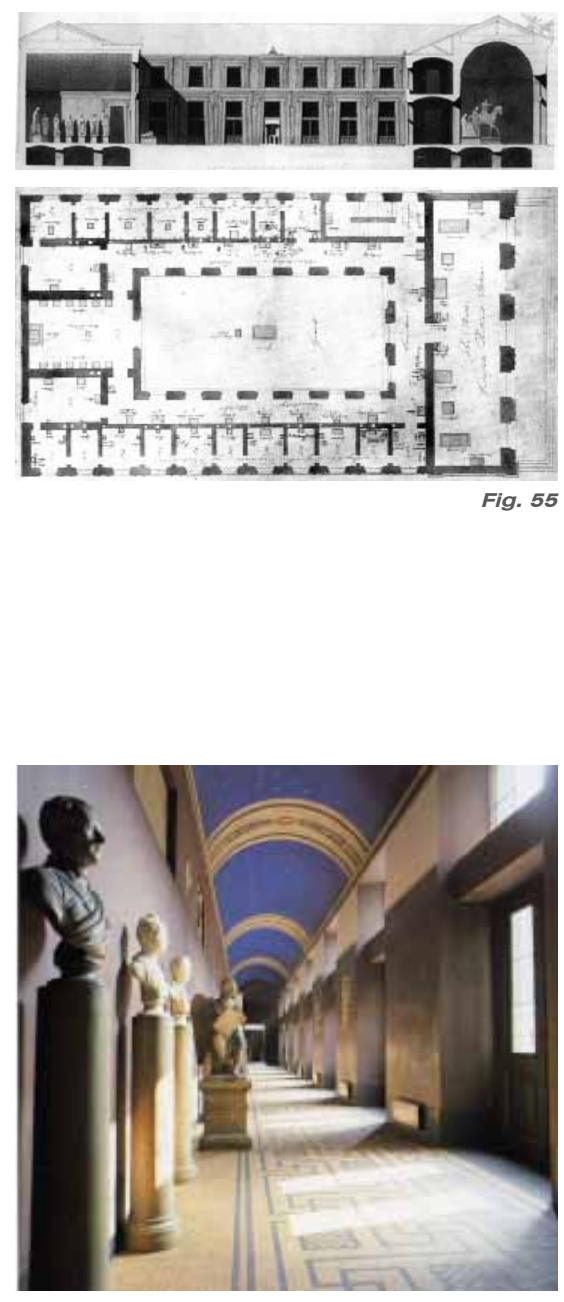

Fig. 56 


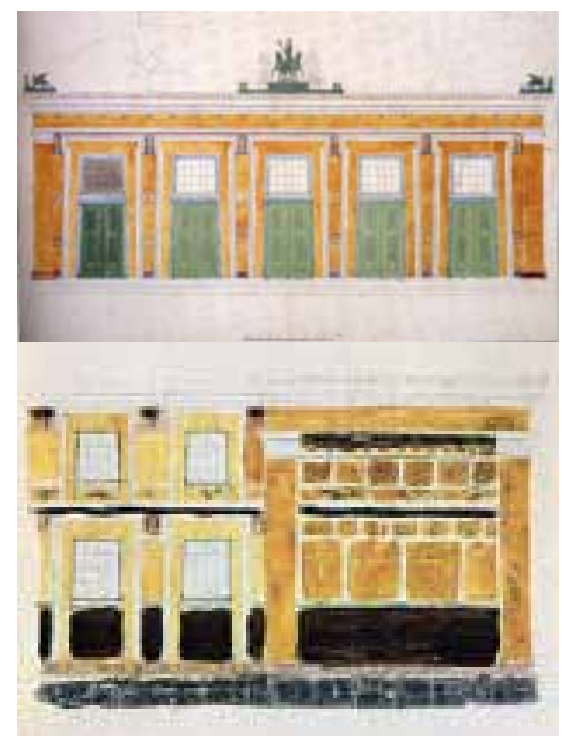

Figs. 57-58
Con la rica decoración de los techos y la poderosa coloración de sus paramentos, Bindesbøll procuró establecer un delicado contraste con las esculturas de su amigo Thorvaldsen. Durante su período romano, el estudio de las decoraciones de las villas de Pompeya y Herculano (excavadas a medidos del siglo XVIII) sirvió como modelo plasmado en su trabajo para este museo que evoca un edificio de la antigüedad (Figs.57-58).

Se abre, así un período que a partir de las obras clave citadas, la Gliptoteka de Von Klenze, la Dulwich Gallery de Soane y el Altes Museum de Schinkel, alcanza hasta el siglo XX.

Consecuencia de ello es el alud de museos que se produce a partir de la creación de estos precedentes pioneros. Baste mencionar, entre otros: en 1831-37 la National Gallery de William Wilkins, en Londres; en 1840-45 el Neues Museum de August Stüler, en Berlin; en 1847-55, la Gemäldegallerie de Gottfried Semper en Dresde; en 1823-47 el Museo Británico de Smirke, en Londres; en 1855 el Museo Nacional de Estocolmo, también de Stüler; en 1880 el Metropolitan de Nueva York; en 1895 el Rijsmuseum de Pierre Cuypers, en Amsterdam, fundado en 1800, entre otros. Conviene recordar, por último, que John Russell termina en 1948 la National Gallery de Washington lo que nos muestra la pervivencia, hasta mediado el siglo $\mathrm{XX}$, de unos esquemas museísticos cuyo origen hemos expuesto.

El gran museo del XIX europeo es el resultado de la utilización caleidoscópica de imágenes museísticas en las que la idea de organización del edificio -lineal, central, con recorrido simple o doble, etc.- sirve de soporte a una inclusiva citación de iconos: imágenes que tienden a interpretar la noción del museo como "palacio de la cultura", "templo de las artes", "gabinete del conocimiento" o "sede de la felicidad civil".

Las grandes ciudades levantan el fabuloso conjunto de edificios que constituyen el gran museo decimonónico europeo y americano. Será, como veremos, en la segunda mitad del siglo $\mathrm{XX}$, cuando replanteado el museo de arte, a partir de unas nuevas 
necesidades surgidas de unos profundos cambios sociales, se producirá una segunda eclosión en la construcción de museos parangonable a lo aquí sucintamente expuesto.

Pero antes conviene hacer un breve repaso de las aportaciones a nuestra reflexión llevadas a cabo por los que Pevsner denominó "pioneros" del Movimiento Moderno.

\subsubsection{El Museo de Arte y los "pioneros del Movimiento Moderno"}

La negación del valor de la historia por parte de los diversos manifiestos que ven la luz en los primeros 20 años del siglo $\mathrm{XX}$ hay que entenderla desde la lógica de las vanguardias. La vanguardia es ruptura por definición aunque si bien esta ruptura se explicita en alguno de estos manifiestos, también es cierto que algunos de sus protagonistas como Le Corbusier, Hilberseimer, Mies van der Rohe o Gropius, por citar algunos nombres, muestran una, diríamos, inevitable sensibilidad hacia la arquitectura que define la ciudad histórica. Le Corbusier, que en su Viaje a Oriente sube a la Acrópolis de Atenas todas las mañanas de su estancia a observar, medir, dibujar el Partenón, al plantear el Plan Voisin menciona la revalorización de los edificios históricos que dicho plan conlleva. Gropius construye el edificio de la Bauhaus en Dessau desde su relación visual con el centro histórico de la ciudad. Lo mismo podríamos recordar de Mies con sus rascacielos de vidrio en el centro urbano de Berlín al igual que Hilberseimer en sus propuestas para el centro urbano.

La lista no acaba aquí y podríamos extenderla a arquitectos que la historiografía tradicional (Giedion, Pevsner, Hichcock, Zevi) denominan pre-modernos, léase Adolf Loos, Auguste Perret, Bruno Taut o Hans Poelzig, por citar algunos. A los que hay que añadir a Oud, que se separa del rupturismo neoplástico cuando se enfrenta al problema de definir la ciudad de Róterdam.

Hay que constatar sin embargo y en primer lugar el lógico cansancio provocado por una arquitectura que escapa a su responsabilidad en la búsqueda de unas nuevas formas ligadas 
a una sociedad que desde la Revolución Industrial protagoniza cambios radicales en el pensamiento y en el modo de actuar. En innumerables casos, nuevos edificios muestran antiguos lenguajes; se produce así el agotamiento de los historicismos.

De la necesidad de unas nuevas formas de expresión surge el interés por otras culturas no occidentales y por tanto "no contaminadas". Baste recordar el retorno al arte japonés, argumento recurrente, pues ya lo habíamos observado en la etapa Art Nouveau, o a las culturas africanas que tanto influirán en la pintura y escultura de vanguardia. Incluso hallazgos arqueológicos como las civilizaciones pre-helénicas, enriquecen el repertorio de los nuevos artistas.

En segundo lugar: vanguardia significa ruptura y denuncia de estos hechos. Renuncia a la historia tal como se ha entendido hasta ese momento incluso de forma militante como se observa en el Manifiesto Futurista de 1909, en el que Marinetti entre otros firmantes, equipara los museos a los cementerios y la secuencia de cuadros a los féretros colocados uno al lado del otro.

Al fervor iconoclasta acompaña en ciertas ocasiones una inconcreción de objetivos, de propuestas alternativas frente a las que se consideran obsoletas, como en el conocido debate sobre el teatro de vanguardia en el que frente a la clara objetivación de los problemas por parte de Louis Jouvet, reconocido y eminente hombre de teatro, opone Le Corbusier, con su irrefrenable inclinación a épater casi antes que la reflexión mesurada, una equiparación entre Teatro y Vida que anula absolutamente las conclusiones sobre cómo se debe enfrentar la arquitectura a la necesidad que los nuevos usos teatrales manifiestan. Gropius, sin tanta estridencia, lo plasmará en su proyecto de Teatro Total.

Los gritos de esta vanguardia necesaria, incluido el sano épater le bourgeois, no evitan que analicemos con fruición algunas aportaciones sobre el museo de "los pioneros del Moviendo Moderno."

El éxito que suponen las iniciativas de creación de Museos 
que los poderes públicos ejecutan en las primeras décadas del siglo XX soslaya la presencia y participación de los arquitectos abanderados del Movimiento Moderno. Por tratarse del ámbito geográfico inmediato en el que Le Corbusier desarrolla su actividad, haremos un breve comentario de la situación francesa, ejemplarizada en París, y que puede extrapolarse, no sin sustanciales reservas, a otros lugares.

En los años treinta la capital francesa ve edificar varios museos: El Museo de Obras Públicas, obra de August Perret y al cual dedicaremos unas breves notas; el Museo de las Colonias, obra de Albert Laprade, de clásica composición y lenguaje heredero de las Artes Decorativas; el Museo de Arte Moderno de la Villa de París y del Estado, iniciativa conjunta de dos administraciones que dispondrán de sendos edificios, de pétreas y rigurosas fachadas, unidos por un clásico peristilo; el Palais Chaillot (Figs.59 y 60), cuyo clasicismo simplificado fue obra de Boileau, Carlu y Azéma, y que albergó diversos museos (de la marina, del hombre, etc.). En todo caso, se observa la clara predilección por las arquitecturas cuya imagen y organización respondía a la disciplina que sus artífices habían adquirido durante su académica formación, y que, en definitiva, no era otra que la que la sociedad burguesa reclama para la construcción de la ciudad. La exclusión de la vanguardia se pudo deber, además, a su incapacidad para la exitosa resolución de problemas concretos.

Cabe mencionar, por su importancia en la historia de la arquitectura, la figura de Auguste Perret; pionero del empleo del hormigón armado en la arquitectura pública y residencial. Si bien Anatole de Baudot ya había ensayado en su Iglesia de Saint Jean de Montmartre entre 1897 y 1904 una suerte de ladrillo armado con varillas de hierro, la contemporánea y actual solución de un "hormigón armado" que Perret emplea en los apartamentos de la Calle Franklin entre 1902 y 1903 se extrapola a vastos edificios de importante programa y significación urbana, como el Teatro de los Campos Elíseos o el Museo de Obras Públicas (Figs.61-62 y 63),
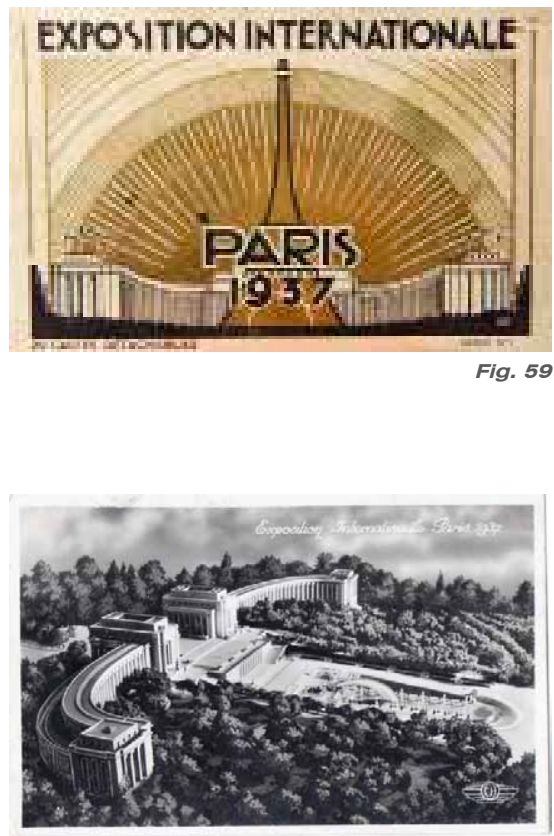

Fig. 60

MINISTERE DES TRAVAUX PUELICS MUSEE Des IRAVAUX PUBLICS IACADE PLACE D' IENA.

$\mathbf{6}^{-\infty}$
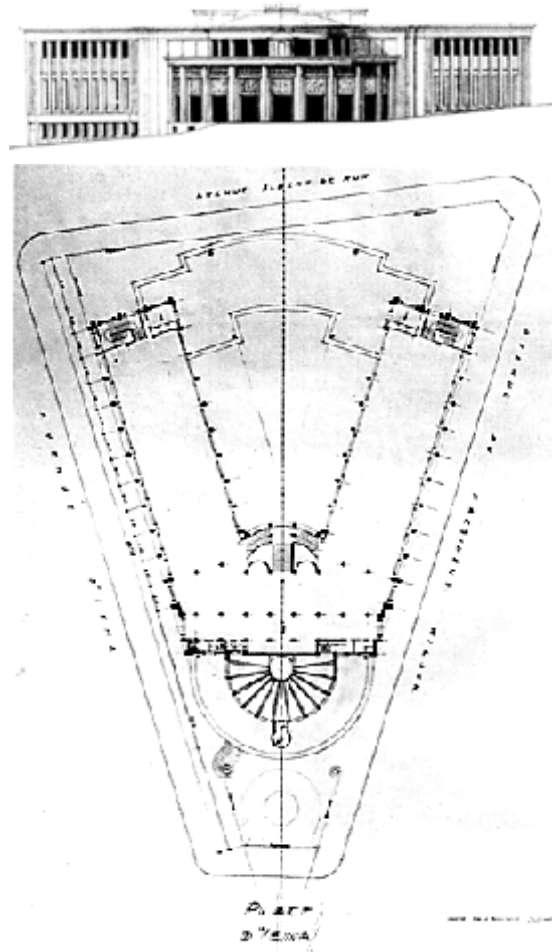

Figs. 61-62 


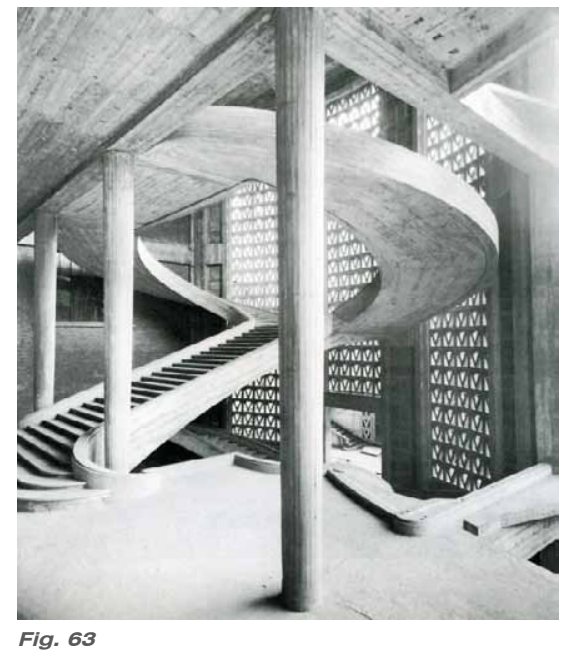

Fig. 63

terminado por los discípulos del arquitecto. Este último edificio posee una planta en forma de $\mathrm{V}$; alberga una sala de conferencias en su vértice y dispone de salas en sus brazos. La iluminación de las salas es lateral y el ancho de la crujía se divide por medio de dos columnas estriadas que sostienen un arquitrabe, todo ello de clásica impronta y estudiadas proporciones. Esta disposición nos recuerda, por su claridad y composición, a la que Schinkel materializó en las salas de escultura correspondientes a la planta baja del Altes Museum de Berlín, como ya hemos visto. Perret explica así la simbiosis de la concepción de la estructura con el diseño del espacio interior: "La composition de cette ossature est très importante, car elle est au bâtiment ce que le squelette est à l'animal, il ajoute même que si la structure n'est pas digne de rester apparente, l'architecte a mal rempli sa mission." (17)

Esta afirmación la podrían suscribir nuestros pioneros y también aquellos que la historiografía tradicional casi olvida como André Lurçat o Mart Stam, por citar dos arquitectos de países protagonistas de la nueva arquitectura. La voluntad de Perret, preocupado por la claridad estructural de la que el edificio hace gala, se complementa con la buscada neutralidad del espacio expositivo ante el protagonismo de las obras expuestas, reflejando así una idea central en el debate museístico de los años treinta claramente expuesta por Louis Hautecoeur en 1933: 'Lornement est possible dans un théâtre, dans une maison particulière : mais, dans un musée, dont chaque salle contient des oeuvres d'un style différent, ce sont les œuvres elles-mêmes qui constituent le décor du musée." (18)

Ante los titubeos y escasa capacidad técnica que Le Corbusier y otros arquitectos vanguardistas muestran en sus primeras propuestas, el desarrollo de las técnicas de construcción por parte de otros profesionales -algunos de significativo renombre y propios de una generación anterior- anticipará y contribuirá al desarrollo de la arquitectura moderna. Es en este contexto en el que Le Corbusier comienza a desarrollar sus propuestas; a lo largo de 25 años trabaja en diferentes tipos de 
museo, haciendo contemporáneos y presentes el racionalismo radical del zigurat del Musée Mondialen Ginebra de 1929, seguido conceptualmente por el Museo de Arte Contemporáneo de Paris

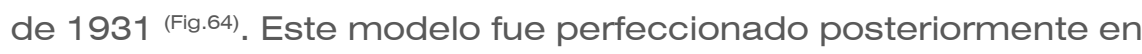
el proyecto de Museo de Crecimiento Ilimitado (1939) y en la planta del Museo de Ahmedabad, en el que además la luz es protagonista.

En el Mundaneum de Ginebra, Le Corbusier plasma un esquema de proyecto que desarrollará y perfeccionará a lo largo del tiempo. Situemos la gestación de esta propuesta y la agria polémica que suscitó mediante la lectura que nos proporciona Jorge Torres: "El Mundaneum tenía que constituir una Ciudad Mundial de la Cultura, un centro intelectual de cooperación y unión de los hombres, patrocinado por el mecenas belga Paul Otlet. (...) El elemento más discutido fue sin duda el Museo Mundial, organizado por un recorrido en espiral que rememoraba los zigurats precolombinos y babilónicos." (19)

La crítica del arquitecto y ferviente militante vanguardista Karel Teige incide, siguiendo al profesor Torres, en "las formas áulicas y trazados reguladores del que deriva su gran falsedad: el error de Le Corbusier en el Mundaneum es la monumentalidad". Le Corbusier, como certeramente recuerda Torres, se defiende con el ataque a la Neue Sachlichkeit por haber matado, en su opinión, los conceptos Baukunst (arquitectura) y Kunst (arte). El arquitecto suizo en esta época programática, a la que tanto ha contribuido incluso con un considerable número de dogmas, no puede abiertamente hablar de monumentalidad. Calmadas las aguas vanguardistas el monumento, evocador y sintetizador de la memoria, volverá a comparecer una vez depositadas en el anaquel las soflamas rupturistas. (20)

La espiral de planta cuadrada es la figura que inspira al Museo de la Civilización Mundial (Fig.65), que el arquitecto suizo identificará, con cierta dosis propagandista, con formas de enorme impronta histórica, lejanas a la cultura occidental, como el zigurat o las pirámides mayas escalonadas de Chichén Itzá. En
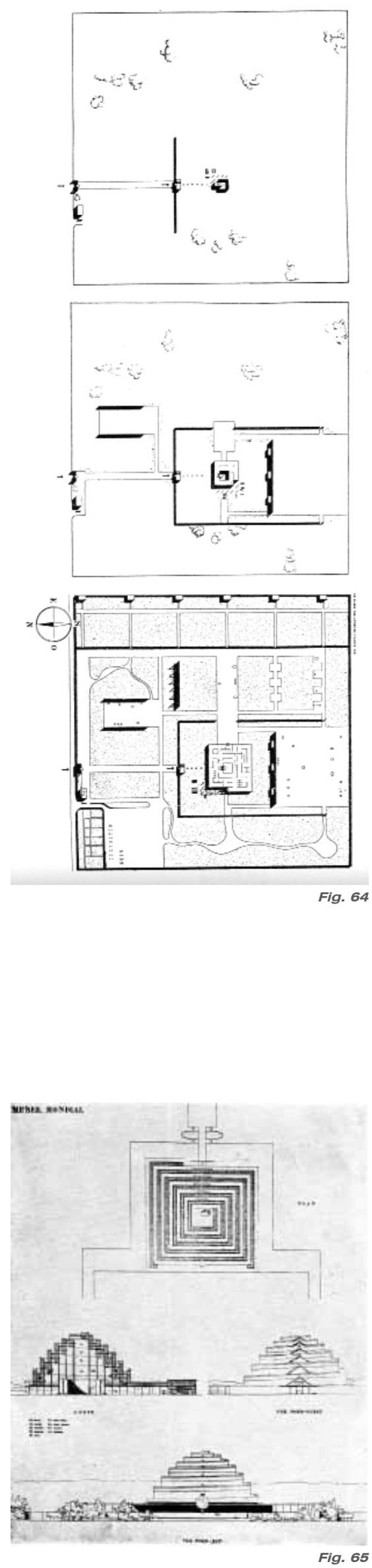


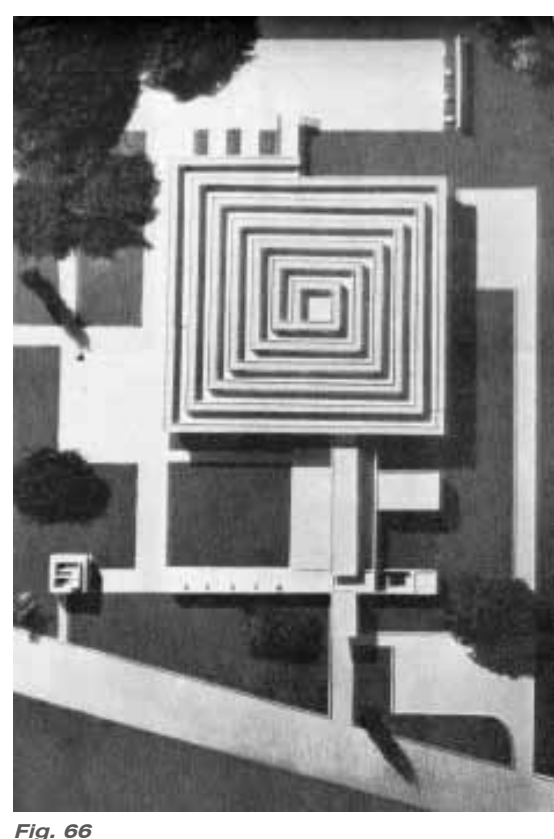

Fig. 66

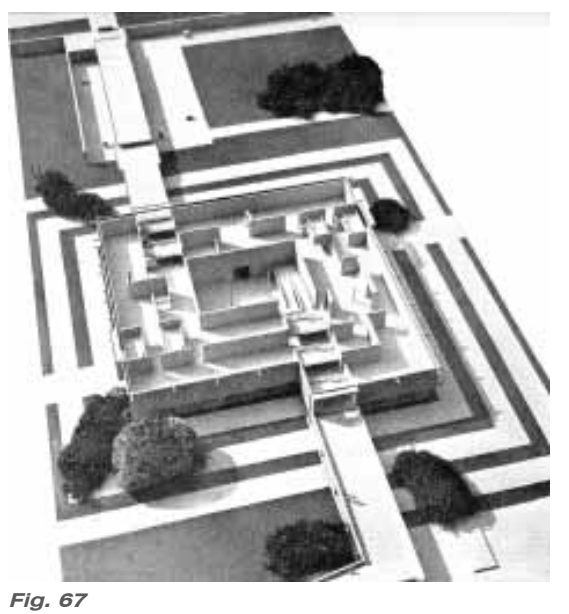

este museo, una primera rampa exterior nos conduce a la cima, desde donde se inicia un recorrido descendente por una galería -segunda rampa dispuesta bajo la primera- cuya iluminación prevista es de tipo cenital. El espacio central queda como un gran vacío aparentemente sin uso: para subir directamente a la cumbre de la pirámide sin recorrer su espiral exterior, cabe tomar tantos ascensores como "saltos" o escalones muestra el zigurat, según se aprecia en los croquis que Le Corbusier muestra en su obra completa.

¿No recrea, en esta propuesta, la tradicional gran rotonda de acogida enmarcada por la secuencia de galerías en movimiento descendente? Quizás la rotonda muestra a su vez las numerosas dudas y titubeos del proyecto. No explicita su función ni centra los elementos de comunicación vertical, que en el caso de los ascensores, son más bien en este inicial proyecto elementos de "comunicación diagonal". Además, el carácter cerrado de las salas parece negar conexiones y vistas con el gran espacio central, de forma que soslaya el potencial espacial que éste tiene. Podríamos aseverar, en fin, que es resultado de la imponente escenografía que Le Corbusier imagina para la forma de su Museo Mundial como una pieza más de la composición abierta que, propia de sus convicciones urbanísticas, diseña para la Ciudad Mundial. (21)

Cabrá esperar al desarrollo de nuevos proyectos de Museo para reconocer propuestas más elaboradas y menos programáticas. El Museo de Arte Contemporáneo que propone Le Corbusier en 1931 para Paris anticipa el Museo de Crecimiento Ilimitado de 1939 (Figs.66-67), que comentaremos de forma algo más amplia. Ya en 1931 el zigurat desaparece, de modo que la espiral cuadrada se desarrolla en el mismo nivel y su acceso principal se efectúa desde el centro; a partir de éste, la adición de un modulo que sigue la directriz de la espiral cuadrada origina el museo, cuyo tamaño puede extenderse, en palabras de Le Corbusier, "a voluntad".

El modelo de 1939 que Le Corbusier plantea nos permite, 
no obstante, establecer algunos paralelismos con el método de composición de Durand: pilares, vigas, tabiques, fachadas -aunque tildadas de provisionales-, y techos con iluminación cenital, conforman una unidad constructiva -el fragmento ediliciocuya adición constituye el conjunto: el museo de crecimiento ilimitado. No se trata aquí de pórticos, rotondas, galerías, sino de un espacio de planta rectangular de $7 \times 7$ metros y altura aproximada de 4,5 metros, que se eleva del suelo sobre pilares. Sin embargo, la forma de presentación que de su propuesta hace Le Corbusier se distancia de las estrategias disciplinares del proyecto de arquitectura del momento; la asociación de imágenes e interdisciplinariedad propias de la vanguardia, unida a una astucia propagandística inédita y desconocida hasta el momento, permitirá a este proyecto -cuarto de una saga hasta el momento de infructuosa comercialización- trascender el anonimato e influir en posteriores producciones.

Desde el espacio central, se desarrolla una serie de salas que, siguiendo la directriz de la espiral cuadrada, configuran la planta del museo. Unos entresuelos -cuya disposición se efectúa según una esvástica en planta, orientan al visitante hacia el espacio central o hacia el exterior que se muestra por medio de una gran superficie vidriada. La planta libre de las salas, cuya tabiquería puede disponerse de forma libre e independiente de la estructura, constituye uno de los axiomas de este museo; la iluminación cenital de las salas representa otro. Cabrá esperar a 1957, fecha en la que Le Corbusier proyecta el Museo Nacional de las Artes Occidentales de Tokyo (Figs.68-69) para comprobar una aplicación concreta de estas propuestas.

Tras el precedente que establece el Centro Cultural de

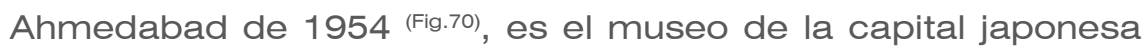
el que centra la atención de estas notas, donde los sucesivos estudios y tanteos realizados se materializan finalmente de esta manera: el gran espacio de acogida (abierto, sobre pilotis) extraído de sus estudios sobre el museo de desarrollo ilimitado, se cierra parcialmente para proteger el acceso, y posibilitar la

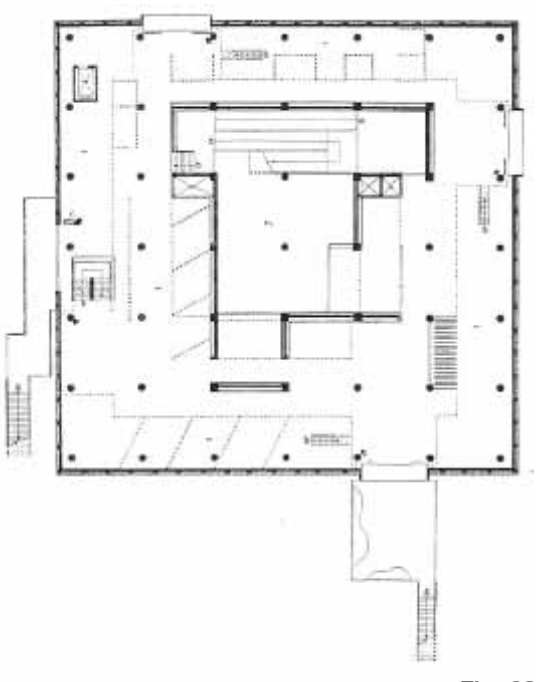

Fig. 68

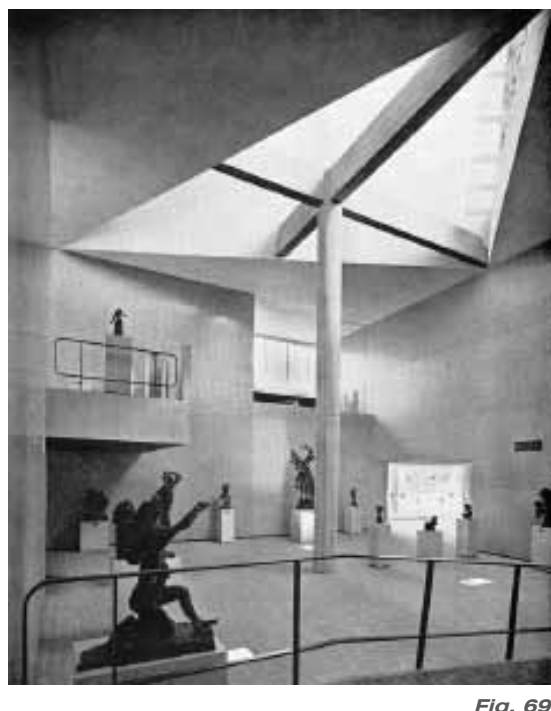

Fig. 69

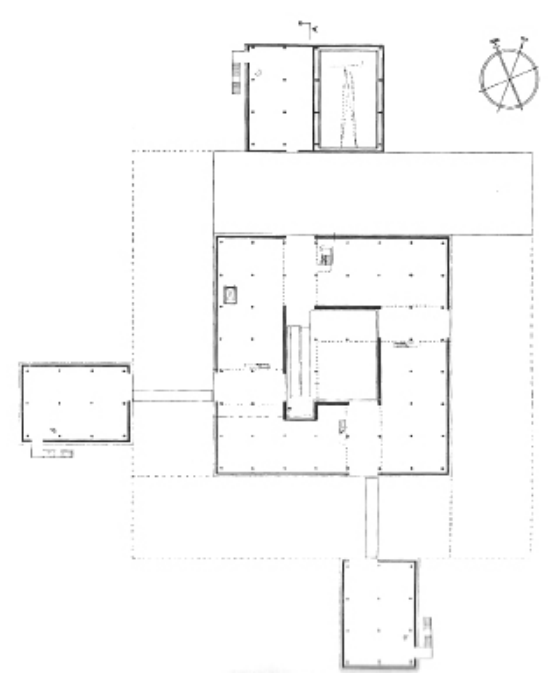

Fig. 70 


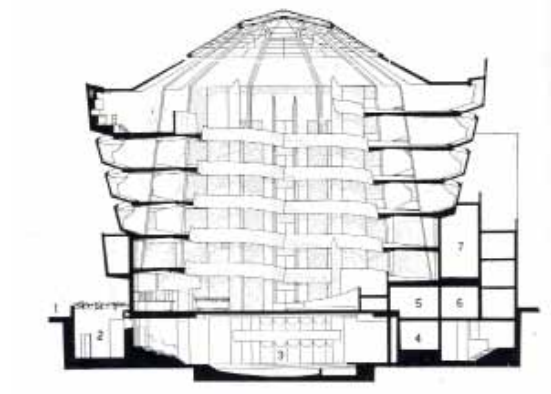

Fig. 71

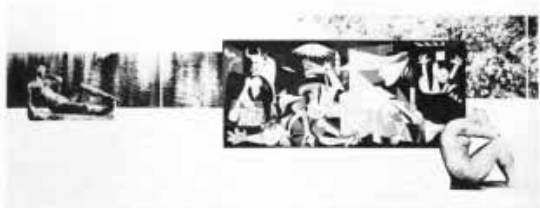

Fig. 72

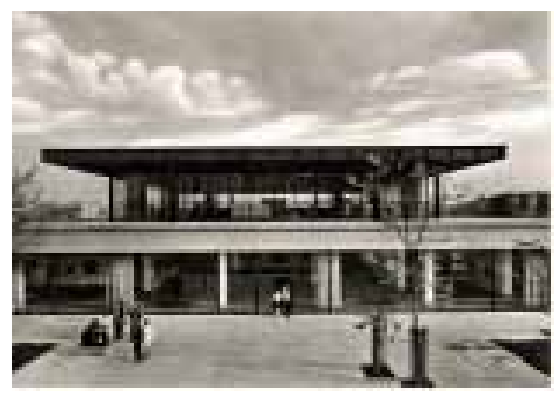

Fig. 73 carga y descarga. Tras franquear la recepción, se abre el gran espacio central de acogida, que se cubre mediante un lucernario triangular y que da origen a la rampa que nos conduce hasta la primera planta. Arranca así el movimiento ascendente del recorrido por la enfilada de salas, estudiadas para el uso de la luz cenital natural.

En 1959 se inaugura, en Nueva York, el Museo Guggenheim. Al final de su extensa y apasionante biografía, con esta potente imagen frente a Central Park, Frank Lloyd Wright evoca la clásica rotonda de acogida enmarcada, en este caso, por la galería en espiral (Fig.71). El arquitecto introduce así el sacrosanto movimiento, la cuarta dimensión de los cubistas que tanto interesó a Le Corbusier para su promenade architectural, la potente fuerza dinámica del recorrido con posibilidad, también, de crecimiento ilimitado. Toda una síntesis de quien se consideraba, a sí mismo, el origen de la arquitectura moderna.

\subsubsection{El Contenedor}

De los llamados maestros o pioneros del Movimiento Moderno por parte de la historiografía tradicional, Mies van der Rohe elabora la propuesta más radical con su Proyecto de un Pequeño Museo (Fig.72) (1942): su planta diáfana, absolutamente libre, constituye un espacio único, transparente; concepto que desarrolla más tarde, de 1962 a 1968, en la Neue Nationalgalerie de Berlín (Fig.73), donde la colección permanente se ubica en un oscuro semisótano, ordenada en una secuencia de salas enterradas en su basamento abierto en un lado al patio de esculturas.

Al espacio vacío donde se ubican las obras libremente y según sus necesidades, que está en la base de las propuestas que el arquitecto alemán plantea en ambas obras por medio de su reconocido refinamiento, se denominará en la literatura arquitectónica al uso "el Contenedor", cuyos precedentes nos proponemos analizar y establecer.

A partir de los años 50 se produce un cambio de 
paradigma que tiende hacia una nueva concepción del espacio museístico: el contenedor. En él se ha visto un afán de apertura y democratización que cubre varias vertientes: la social-educativa, la artística y la arquitectónica. La primera de ellas, radica en la concepción del museo como un espacio lúdico y educativo, que incorporará nuevos elementos en su programa destinado al disfrute y educación de todas las clases sociales: surgen nuevos requerimientos como la tienda, la librería, la cafetería, etc. Por otro lado, la vertiente que hemos Ilamado artística, suscita una apertura a otro tipo de manifestaciones y contenidos expositivos. El arte de vanguardia y las nuevas formas de expresión artística se enraízan y se instalan en los espacios expositivos; valga de ejemplo la exhibición que Wolf Vostell realiza en 1959 en Colonia, percusora del video-arte. Todos estos cambios de orden social y artístico tendrán su correlación en la arquitectura, en la generación de una tipología expositiva que corresponde a lo que hemos denominado como Contenedor.

Una de sus características fundamentales consiste en la pretensión de ofrecer una imagen moderna, obtenida a través del empleo de las nuevas tecnologías y de punteros materiales, del alarde estructural, de la minuciosidad del detalle e incluso conseguida mediante el protagonismo de las instalaciones. Otro rasgo de capital importancia es la pretendida flexibilidad espacial. La planta libre permite la capacidad redistributiva, cuya importancia es secundaria y adjetiva; lo esencial es la creación de un espacio a modo de contenedor en cuyo interior se desarrolle, posteriormente, el programa museístico.

Este tipo de edificio tiene su origen en experiencias arquitectónicas anteriores que arrancan en el Crystal Palace de Paxton (Fig.74), edificio construido para la primera Exposición Universal de Londres en 1851. Paxton estaba muy familiarizado con la construcción de invernaderos metálicos o serres, tipología muy de moda en los años 40 y 50 del siglo XIX, y es conocida

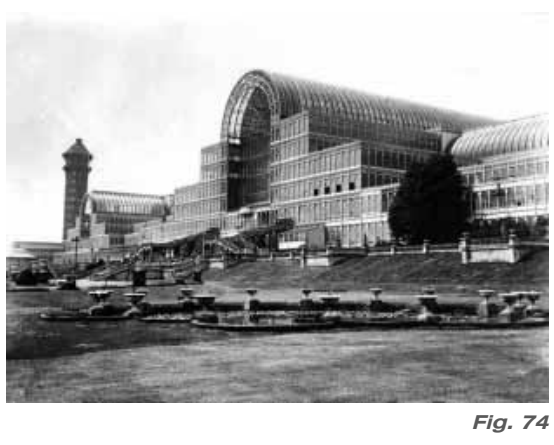
su participación en negocios especulativos relativos al desarrollo del ferrocarril. Su propuesta del Palacio de Cristal, presentada 
como postrera variante y finalmente aceptada, resulta no solamente un logro desde el punto de vista estructural, sino una verdadera hazaña con respecto a la esmerada planificación de su construcción y su estricto cumplimiento de los plazos de ejecución, razón definitiva de la obtención del encargo, en la que se implicaron importantes constructores y metalúrgicos de la industria ferroviaria. Sin embargo, el gran mérito para nosotros reside en otro aspecto, que reseña acertadamente Leonardo Benévolo: "La importancia del Palacio de Cristal no se debe a la solución de importantes problemas estáticos, ni tampoco a la novedad de los procesos de prefabricación y a los detalles técnicos, sino a la nueva relación que se establece entre los medios técnicos y las finalidades representativas y expresivas del edificio." (21)

Asentada la Revolución industrial, el nuevo tipo de edificio, surge con el principal cometido de cubrir un terreno con el doble objeto de generar un espacio interior a la vez que conferir un carácter monumental y representativo. La "confrontación comercial pacífica" que significa la exposición universal requiere una imagen suficientemente representativa del poderío de la sociedad organizadora del evento. El hierro y el uso masivo del vidrio, como nuevos materiales de construcción, y la osadía, a ojos de sus contemporáneos, de su esbelta estructura, las importantes dimensiones de la misma (unos 560x130 metros aproximadamente), entre otros, son factores que desde 1851 se repetirán en este tipo de edificios.

Por otro lado, Owen Jones realizó el diseño del espacio

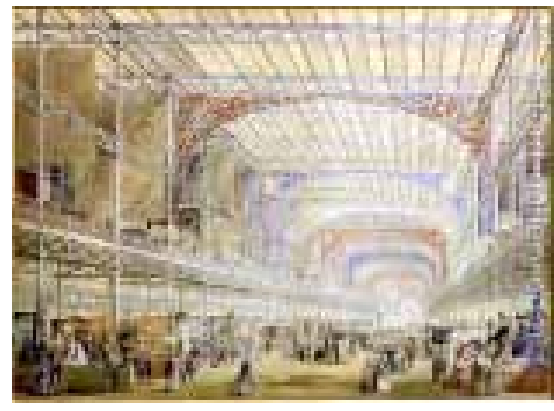
interior, tal y como muestran sus exquisitos dibujos conservados (Fig.75). La exposición interior es posterior e independiente del edificio que la contiene. La aplicación, en la decoración y disposición interior del Cristal Palace, de sus estudios acerca del color y de la ornamentación basados en el estudio de la Alhambra y de la policromía de la antigüedad griega supondrá para Jones un enorme éxito. Reconocimiento que será independiente y adquirirá una autonomía respecto al propio Crystal Palace. 
Es tal el éxito de esta primera exhibición y del edificio que la contiene que dará lugar a sucesivas Exposiciones Universales para las cuales se construirán grandes contenedores. Es destacable la exposición específica de arte efectuada en Manchester pocos años después de la de Londres, en 1857: la Art Treasures Exhibition. La construcción de un edificio similar al londinense tuvo sus correspondientes proyectos de adecuación interior para la exhibición de las casi 16.000 obras de arte que, al parecer, fueron expuestas. John Gregory Crace, afamado diseñador que trabajó, al igual que Paxton, para el sexto duque de Devonshire, se encargó de la adecuación de algunos espacios como salas para la exhibición de pintura y escultura, dado el elevado número de obras que se pretendía exponer y que exigía la construcción de numerosos paramentos verticales aptos para su presentación. (22) (23)

Un nuevo tipo de contenedor, basado en la tipología de las estaciones ferroviarias, inició su desarrollo en París con motivo de la Exposición Internacional de 1889. El gran hangar de la Galerie des Machines, obra de Dutert i Contamin, cubre mediante sus arcos triarticulados la importante luz de 115 metros (Fig.76), de forma que supera con creces los 60 metros de la St. Pancras Station de Londres, estructura de referencia hasta el momento. El alarde estático y cuantitativo, pues se trató del edificio de hierro y vidrio más grande de su época, fue acompañado de los posteriores proyectos de adecuación y decoración interior, como hemos visto en ejemplos precedentes.

Retornando a la Neue Nationalgalerie de Mies, ésta se convierte en paradigma del contenedor como tipo arquitectónico, cuya pureza espacial viene garantizada por su inadaptación funcional; su uso como enorme vestíbulo eclipsa la convencional resolución del programa museístico y de exhibición en lóbregas salas, sin iluminación natural y de intrincado itinerario, ubicadas en el sótano. Numerosos autores han pretendido establecer asociaciones entre el carácter clásico del edificio-con evocadores y delicados paralelismos- y su dialogo con la arquitectura

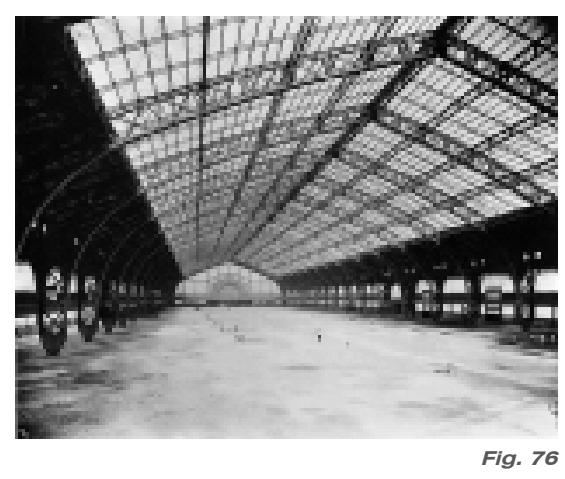

Fig. 76 
berlinesa de Schinkel. Olvidan quizá que sólo casualmente el edificio se encuentra en Berlín, y no en Santiago de Cuba o en Schweinfurt, donde para usos similares o totalmente opuestos presentó con anterioridad Mies idénticas respuestas por medio de muy similares proyectos.

Numerosos ejemplos posteriores recogen el testigo de este modelo de museo cuyo éxito fue arrollador. Como establece Helen Searing, en sucesivas propuestas de arquitectos "miesianos", la caja de cristal se revierte corrigiendo la opacidad de sus muros. Como ejemplo, cita el Munson-Williams-Proctor Institute que diseña Philip Johnson en la década de los 60 o el Amon Carter Museum of Art, del mismo autor, entre otros. Mención aparte merece el Yale Arts Center, de Louis Kahn, cuyo análisis pormenorizado estableceremos en otro apartado. (24)

El prototipo del museo miesiano encontró su realización más radical en la plurifuncionalidad multiplicada del Museo de Arte de São Paulo (MASP, 1957-1968) de Lina Bo Bardi (Fig.77). La primera sede del MASP, que Bo Bardi adecua en 1947 en el interior de un edificio de oficinas, muestra en la planta superior, destinada a uso expositivo, una completa diafanidad. Las obras de arte se exponían colgadas sobre mamparas, dispuestas de forma azarosa según dos direcciones perpendiculares en el interior del gran espacio. Éste está marcado por la retícula del falso techo que alberga en su interior un sistema de iluminación fluorescente cuyo efecto es la uniformización del espacio interior. La libertad de elección del recorrido y la falta de pautas para la contemplación de las obras se relaciona, en este caso, con posiciones ideológicas izquierdistas. El gran edificio del MASP participa de estos caracteres: planta libre y diáfana, exhibición independiente de la arquitectura del edificio mediante peanas y mamparas, alternativa y multiplicidad de recorridos e indiferencia en el tratamiento de la iluminación.

El nuevo tipo de machine à exposer, cuyo origen en el Cristal Palace nos conduce hasta la refinadísima Neue Nationalgalerie, encuentra una adecuada y celebrada versión en el Centre 
Pompidou (Fig.78), realizado en Paris entre 1971 y 1977, por Piano y Rogers. Participa de los grandes espacios sin configuración, abiertos, que requieren en su interior proyectos de adecuación a los fines expositivos concretos. El edificio, definido por Alan Colquhoun como "un supermercado del arte", ofrece una gran capacidad de adaptación. La disposición de una estructura formada por grandes vigas que evita los soportes interiores, así como la traslación a la fachada delantera de la escalera principal y a la fachada posterior del grueso de las instalaciones -vistas-, permite una amplia capacidad de respuesta para exposiciones temporales (Fig.79). No ocurre lo mismo en lo referente a la exposición permanente, base de un museo, que requirió un proyecto posterior de adecuación expositiva. Posiblemente, una

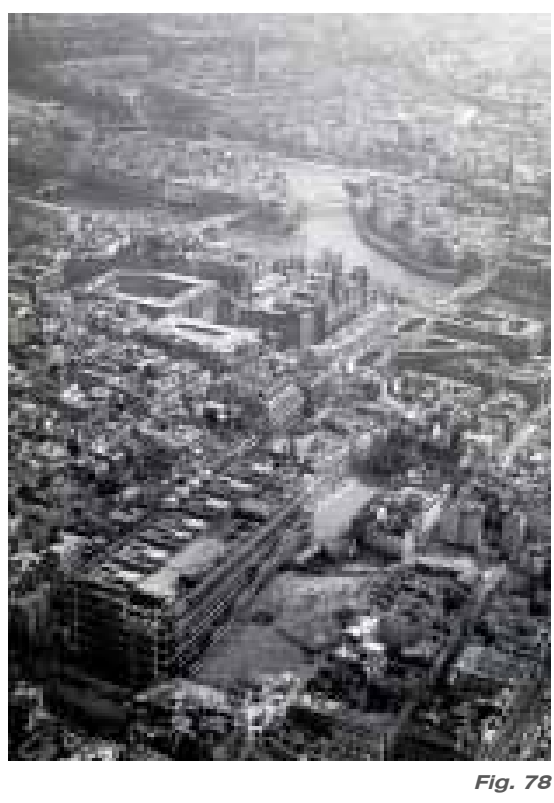
de las grandes virtudes del Pompidou haya sido la generación de un amplio espacio público frente a la fachada principal, cuyo éxito de utilización por parte del público ha popularizado, sin duda alguna, este museo. Sin embargo, el sistema original de paneles colgados del techo que no llegaban al suelo fue abandonado por las dificultades expositivas que presentaba. En 1985, Gae Aulenti es llamada para ubicar las colecciones en espacios tradicionales, secuencia de salas, diseñados por la arquitecta, que había realizado ya en Paris la adaptación de la estación del

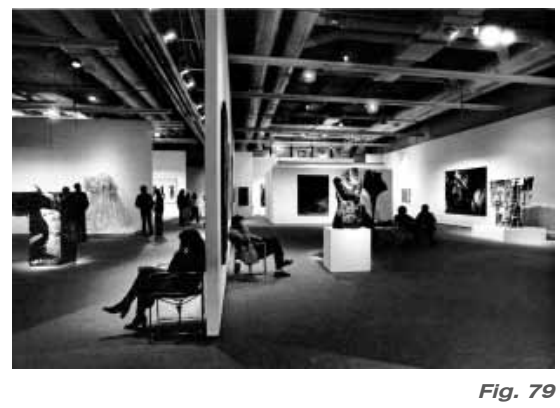
Quai d Orsay para museo del silgo XIX y del Impresionismo.

Más tarde, con motivo de las obras de mejora que se realizaron entre 1997 y 2000 , Jean François Bodin, en colaboración con Renzo Piano, reestructuró las salas de nuevo, mediante el enésimo proyecto de adecuación interior, que prueba la flexibilidad del espacio interior, permitida por su sólida estructura y por sus eficientes instalaciones, a la vez que la inadecuación como espacio expositivo del gran contenedor vacío.

Todos estos ejemplos demuestran la confianza en el hecho de que un contenedor de planta libre, un fuerte soporte tecnológico y la máxima plurifuncionalidad son la mejor respuesta al carácter mutante y complejo del museo. En los últimos años se ha pasado de la caja tradicional a la caja electrónica, continuando con la 
fortuna de la tradición racionalista y abstracta y pasando por la eclosión del edificio masa, del que es muestra el museo parisino.

La inevitable dependencia que el contenedor posee de un proyecto de exposición para cada evento programado, los controles de iluminación, tanto natural como artificial requeridos, junto a otras exigencias, producen la crisis del espacio indiferenciado como la única respuesta adecuada a las necesidades expositivas actuales. Esta experiencia, muy válida en determinadas circunstancias, no se convierte en "única" para la resolución del proyecto del Museo de Arte. Adecuada en determinadas condiciones, se añade al repertorio de espacios expositivos tradicionales sin anularlos.

\subsubsection{Louis Kahn: una nueva impostación}

En su larga carrera, de 1901 a 1974, el maestro realizó sólo tres museos. Dos de ellos, ambos en New Haven, el Yale Arts Center de 1951 y el Yale Center for British Arts (1969-77), se encuentran uno frente a otro en Chapel Street. La distancia de 20 años que separa su construcción muestra con claridad la evolución de sus ideas en relación al museo de arte. El tercero, el Kimbell Art Museum de Fort Worth (1966-1972) se halla cercano a los planteamientos del Yale Center for British Arts, y ambos expresan la madurez de ideas e intereses de Lou Kahn.

En el Yale Arts Center (Fig.80) Kahn, en trance de abandonar la ortodoxia del Movimiento Moderno, vuelve su mirada hacia al clasicismo y sobre todo a Viollet le Duc para el que, como recuerda Jorge Torres, "la morfología de una arquitectura que es racional (...) no estaba determinada por su taxonomía de "formas" históricas, sino por un sistema de funciones internas inherentes a esas mismas formas. Estas debían ser derivadas directamente de la estructura del edificio y de los principios técnicos que la hacen posible." (25)

Se vincula al monumentalismo norteamericano de postguerra pero desde unos planteamientos que lo alejan de las mastodónticas embajadas que en aquellos momentos se llevan 
a cabo, subrayando el papel de los componentes secundarios, como paredes, techos, y suelos. Tanto en el Yale Arts Center como en su vecino para las Artes Británicas, el papel de los materiales, el tratamiento de los huecos, diluyen la simetría estructural miesiana.

En este museo una hermética fachada de ladrillo crea el frente a la calle y en su retranqueo con respecto a la alineación

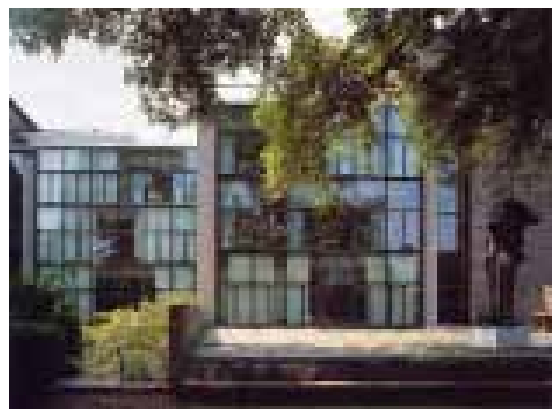

Fig. 81 del edificio existente genera el acceso, cuyo paramento -en contraposición- se resuelve mediante un muro cortina de acero y vidrio ${ }^{(F i g .81)}$. El interior viene definido por una malla de pilares rectangulares de hormigón y el marco tetraédrico del mismo material que define suelo y techos y que muestra la influencia de Bucky Fuller, con el que además, parece ser, Kahn mantenía una buena relación personal. Realizado en hormigón armado aligerado incorpora techos, suelos y servicios en un solo sistema de tetraedros huecos ${ }^{\text {(Fig.82). }}$

La organización del espacio interior muestra una faja central donde se ubican los elementos de comunicación y servicio y a cada lado los espacios diáfanos de exposición. En este espacio rectangular Kahn introduce por primera vez el cilindro, donde se sitúa la escalera. Con el cilindro como "servidor" y el rectángulo como "servido" se observa la dialéctica de lo que será su teoría arquitectónica.

Parece ser que Kahn no quedó satisfecho con el resultado de los espacios diáfanos para exposición. Entiendo que esta percepción se refuerza por la aguda crítica que el arquitecto realizó de la planta libre, considerando que creaba un vacío ante el que, según él, Mies reaccionaba con poca inspiración y Le Corbusier lo eludía corriendo hacia la forma. Pero la observación que del espacio realiza Reyner Banham enfoca, desde mi punto de vista, el hecho de que el arquitecto de Filadelfia dejara de lado la planta indiferenciada: "No surgía un paseo arquitectónico significativo del ritmo de la retícula estructural, o al menos no uno que de algún modo trascendiera la disposición esporádica y siempre cambiante de las particiones de la galería." (26)

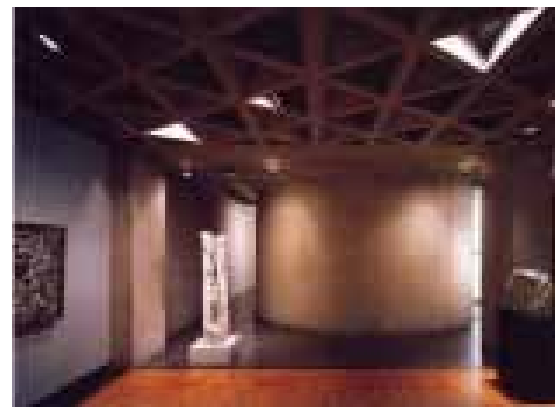

Fig. 82 particiones de la galeria:" 

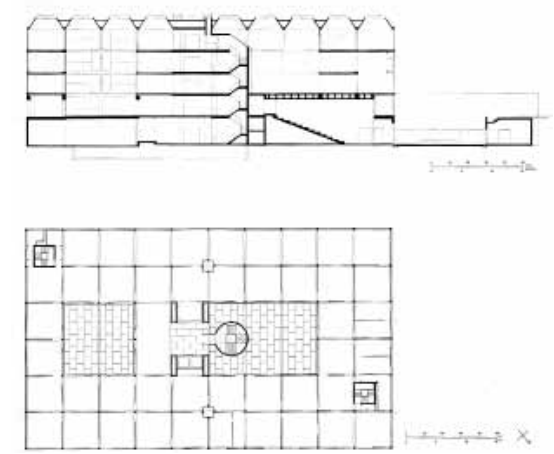

Fig. 83

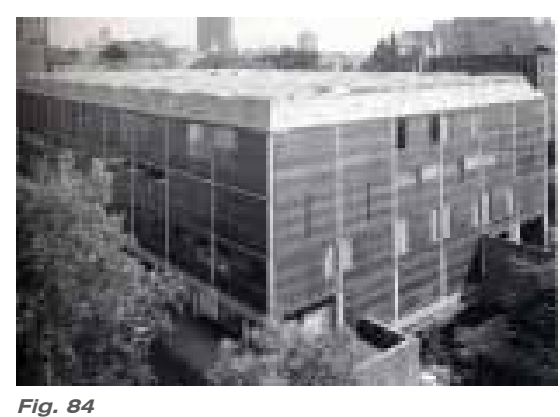

Fig. 84
"Of course- afirma Kahn- there are some spaces which should also be flexibles, but there are also some which should be completely inflexible. They should be sheer inspiration... just the place to be, the place which does not change, except for the people who go in and out..." Las salas, rooms, con su connotación doméstica constituirán el espacio mental del que partirá Kahn en la definición del espacio del museo. (27)

En relación al lugar, tanto el Kimbell como el Center for British Arts, manifiestan su carácter de monumentos públicos que albergan colecciones privadas. A la importancia del edificio en términos urbanos se une el tratamiento íntimo, doméstico, que proporciona a la exhibición de las colecciones.

El museo del Yale Center for British Arts ${ }^{(\text {Figs.83) }}$ es un edificio que mantiene alineación, altura de cornisa y proporción de los edificios colindantes (Figs.84). Su exterior muestra la potente estructura de hormigón cuyos vanos se macizan con paneles de acero tratado, que cambian de tono conforme a la atmósfera circundante y posee una fenestración de forma y ubicación que responde a la necesidad del espacio interior. Allí donde hay dobles alturas, éstas se evidencian en fachada con la ruptura de la cuadrícula estructural. El resultado es una fachada densa, enfática, que continua el carácter esencial de la calle. No es un plano abstracto, sus materiales muestran su realidad. Frente a algunos comentaristas que lo consideraron un edificio miesiano, quedándose superficialmente en su planeidad y simplicidad formal y en su mostrar la estructura, el Center for British Arts es arquetípico, un edificio público, monumental. Su imagen no deriva de su construcción: es "forma”, significa museo.

La solución de fachada que le otorga un aspecto silencioso y austero, manifiesta su vinculación a la primigenia idea del arquitecto de tratar el exterior como un palacio del renacimiento, con sus bajos abiertos a la actividad urbana, y con una modulación, proporcionada por la estructura, que da escala al conjunto. De hecho se dice que en el estudio de Kahn al proyecto se le denominaba Palazzo Mellone (en atención a Paul Mellon, 
donante del edificio y de su contenido a la Universidad de Yale donde había estudiado).

El Kimbell Museum (Fig. ${ }^{85)}$ ofrece en su relación con la zona suburbana de Fort Worth, Texas, un aspecto menos severo, dada la fragmentación del elemento generador del mismo que junto a su baja altura, una planta, lo armoniza con el espacio circundante.

En conjunto la imagen del Kimbell es informal y relajada debido por un lado al aire de vivienda que el autor pretendía y, por otro, a la naturaleza de la vida provinciana de Texas.

El elemento básico es la galería cubierta con bóveda de cañón: dieciséis espacios abovedados que se adaptan, en su interior, a los diferentes requerimientos funcionales. Todos ellos son idénticos, excepto los que se abren a patios y cuya articulación no hace sino confirmar la idea de Kahn: "un módulo no es la repetición de un motivo sino la expresión de un principio arquitectónico".

El principio lo extrae de la arquitectura romana, pero no de la monumental sino de las villas rodeadas de jardín y perforadas por patios. Mediante el uso repetitivo de la bóveda cicloide sobre pilares de hormigón, que liberan la bóveda del tradicional muro de carga, une la grandeza de uso y la arquitectura romana sin olvidar la escala humana. Un museo suburbano para disfrute de sus visitantes.

En relación al programa del museo, al que otorga una importancia basilar, Kahn aporta, también en la definición de sus museos, su particular visión del mismo: "Creo que lo primero que tiene que hacer el arquitecto es cambiar el programa que le entregan: La arquitectura es una meditada creación de espacios. No es seguir las instrucciones del cliente. No es adaptar funciones a áreas predimensionadas. Es la creación de espacios que evoquen la atmósfera del uso a que son destinados. Espacios que se formen en armonía con la función que el edificio debe resolver." (28)

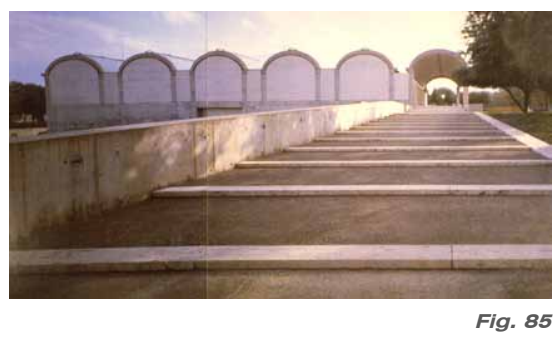

Fig. 85 
Giorgio Grassi en Arquitectura, realidad y vanguardia citaba grosso modo a Georg Lukacs en la definición de la particularidad de la arquitectura, enlazando evocación, adecuación y el devenir histórico, conceptos todos ellos cercanos a las ideas de Kahn: "La arquitectura crea un espacio real y adecuado, destinado a evocar visualmente adecuación. (...) Así, en el proyecto, la definición de "espacio adecuado" dependerá del grado de profundización de la noción misma de adecuación que es, por otra parte, el objeto específico de la adecuación. De aquí la relación recíproca y fatal que liga las arquitecturas en el tiempo." (29)

"Evocar la atmósfera de uso" va vinculado a la escala del museo; sus espacios se plantearán desde la búsqueda de una atmósfera íntima, doméstica, en la que las piezas se encuentren como en su espacio original y los visitantes, inmersos en ese ambiente, disfruten de ellas.

El dilema del contraste que presenta el carácter de las colecciones y la importancia del edificio en términos cívicos, es resuelto por el arquitecto con la creación de dicha atmósfera, que nos revela el por qué de su interés por la escala. Sus museos albergan pequeñas colecciones cuyas zonas de exposición son interrumpidas por áreas de estudio y de lectura, que evitan así la inexorable sucesión de espacios expositivos que encontramos en muchos museos. De este modo Kahn supera la impresión que guardaba del museo tradicional: "Cuando pensé por primera vez en un museo lo primero que recuerdo es la sensación de cansancio que me producía nada más entrar en él”. (30)

La estructuración de las salas tantro del Kimbell como del Yale British muestra la fuerte convicción de Louis Kahn de que la habitación es el principio de la arquitectura y que la planta es "una sociedad de habitaciones" (society of rooms). Y el carácter de estas "habitaciones" es terminado de definir mediante la luz: "He insistido en la luz natural y la relación entre naturaleza y hombre (...) Pensé también en el pintor que pinta con luz y las formas cambiantes de la pintura bajo la luz natural. Deseaba crear salas donde las pinturas y esculturas se encontraran adaptadas y a su 
gusto."

En Kimbell retomó, como hemos visto, el ideal de galería con bóveda de cañón (Fig.86), y en el espesor de los muros (Fig.87) resolvía las instalaciones y los espacios resultantes se bañan mediante un exquisito sistema de iluminación natural. Luz cenital que resbala por la superficie de la bóveda e ilumina las piezas de manera que la mirada desciende desde la entrada de luz hasta el cuadro proporcionando un aislamiento perceptivo del mismo superior al que presentaría una división espacial tradicional.

En el Yale Center for British Arts logró, Kahn, la convivencia en una sola propuesta de la gran planta fijada 150 años antes con la sección de un moderno centro cultural. Todo ello se realiza sin renunciar a elegantes reproposiciones de figuras clásicas como enfilades (Fig.88) que se cruzan, gabinete de cuadros, de retratos, sala de bustos, en una planta de módulo cuadrado, de $6 \times 6 \mathrm{~m}$, que permite cierta flexibilidad dentro de la escala y ambientes que pretende evocando su carácter doméstico. Por ejemplo el tratamiento de los muros con madera de roble del patio interior (Fig.89) está destinado, como indica Scully, a mostrar el carácter inglés del programa sugiriendo viejos empanelados, librerías ducales, etc. No en vano Louis Kahn se refería al patio llamándolo hall. La idea de mansión en el campo se subraya con la imprevista separación entre el patio de acceso del nivel inferior y la secuencia de estancias del plano superior. Las diferentes plantas aparecen compartimentadas, pero Kahn evita la repetición con la introducción en cada nivel de un suceso particular, como la biblioteca o la gran galería en la parte posterior. Aunque cada planta aparece diferente se mantiene la idea de totalidad del edificio mediante las recurrentes vistas al patio de acceso. Subrayando la idea de mansión que subyace en el proyecto, Scully nos recuerda la idea del arquitecto de introducir elementos tan poco ortodoxos en un museo como las chimeneas, lo que indica la relación con la casa y el confort en el sentido de las grandes mansiones inglesas abiertas graciosamente al público.
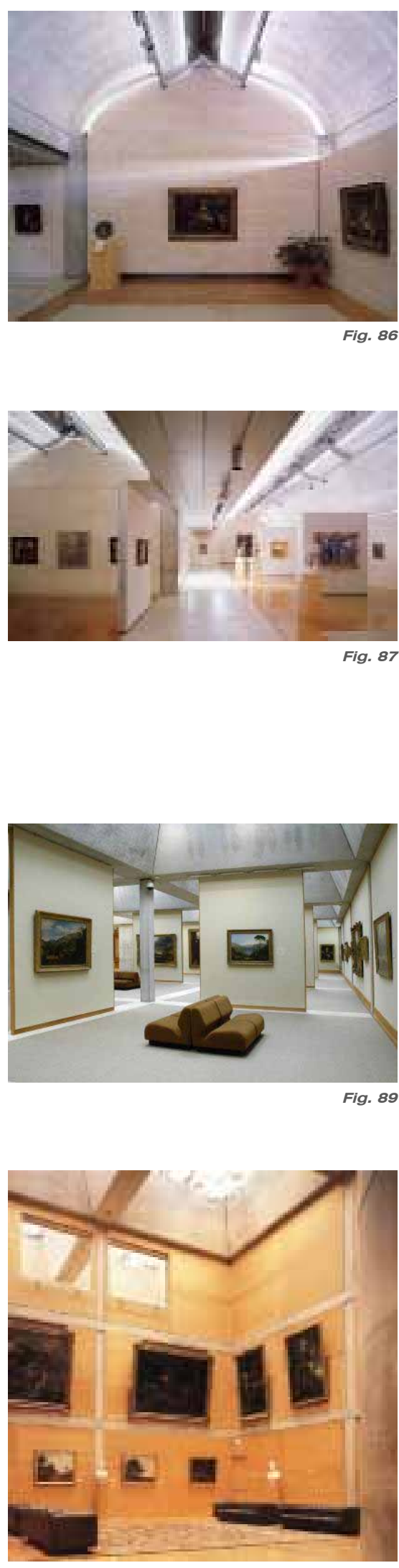

Fig. 90 


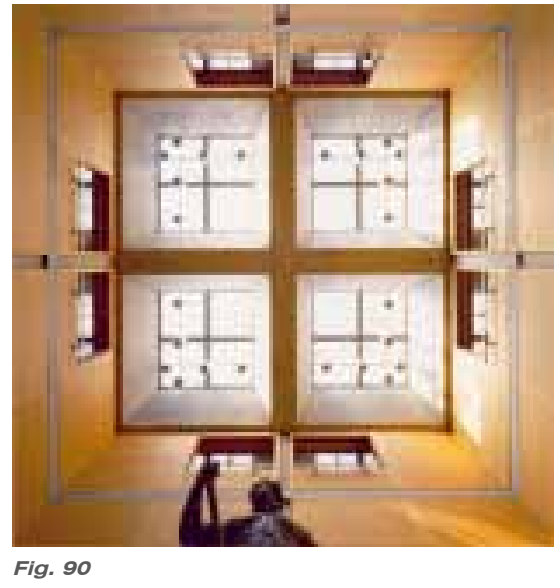

Fig. 90

El lucernario que diseñó para todo el edificio (Fig.90), que ajustado al módulo estructural de 6x6m perfora el conjunto, sirve tanto para el tratamiento de los espacios expositivos de la última planta como para bañar de luz los impresionantes patios que articulan el conjunto.

Podemos concordar que el arquitecto de Filadelfia era un experto constructor de habitaciones (salas) y la vitalidad del Kimbell Art Museum y del Yale Centre for British Arts deriva de la habilidad de Kahn en el juego de la ambientación doméstica en la escala pública. Dado que esta arquitectura se basa en geometrías y soluciones simples y repetitivas, el museo puede acoger las más variadas colecciones sin parecer caótico.

Podemos decir que Lou Kahn estuvo tentado obsesivamente por alcanzar en el museo un carácter de intemporalidad, lo que no es nuevo. Baste recordar a los futuristas incluyendo el museo en sus ataques y comparándolo con el cementerio: las obras de arte están, como los cadáveres en la morgue, una al lado de otra. La tumba como el museo es un lugar sin tiempo, si bien esta imagen funeraria desaparece en Kahn quien conscientemente trata de acomodar el pasado y el presente enriqueciendo con su imaginación, la imaginación del público.

En 1982, el historiador Vincent Scully nos describió de esta forma el resultado: "Creo que es maravilloso. Tan tranquilo, tan silencioso, tan eterno. Es todo silencio y luz, algo de lo que Lou siempre había hablado".

\subsubsection{El nuevo programa del Museo de Arte}

Entrados en la década de los años 60 del pasado siglo, una generación de museos se abre camino, superado el demagógico eslogan de espacios presuntamente de planta libre, indefinidos, flexibles, distanciándose del gran contenedor, en realidad limitado y poco disponible. En ellos, incluso en los ejemplos más distantes de la tradición, hay un repensar sobre formas reconocibles. Casi se puede afirmar que el museo ochocentista, superado en el plano cultural por la investigación de Max Weber, 
por las reflexiones de la Escuela de Frankfurt, por la renovación de las ciencias sociales y de la historiografía de la última mitad del siglo XX, mantiene sin embargo una gran inercia en el plano del tipo y de la forma.

El análisis de conspicuos ejemplos construidos en los últimos treinta años del pasado siglo ofrece una multiplicidad de articuladas tipologías claramente identificables con la tradición de los espacios expositivos reflejados en la historia de las formas arquitectónicas. Esta variedad de respuestas no se ajustan a un esquema de raíz durandiana, a la manera de los grandes museos del siglo XIX, sino que plantean simultáneamente experiencias diversas que enriquecen y transforman las tradicionales trazas del museo.

La eclosión en la producción de edificios para museos que se produce esos años responde a estos nuevos planteamientos. Lo que en un principio fue lugar de contemplación, cultura y reflexión para un público burgués seleccionado se constituye, desde ese momento, en elemento de instrucción y entretenimiento de las masas. El nuevo templo laico del arte, adaptado a estas exigencias, vive una profunda transformación como institución. Las nuevas necesidades configuran un programa y por tanto unos requerimientos a los que tiene que dar respuesta. Ha cambiado el rol del museo, las condiciones de su entorno y en consecuencia su programa. Los términos del debate sobre el museo se truecan tras el apabullante éxito popular de dicha institución.

Robert Venturi en su conferencia De la invención a la convención, (31) impartida en 1988 a propósito de la realización de su proyecto de ampliación de la National Gallery de Londres, la Sainsbury Wing (Fig.91), establece los parámetros de la nueva situación que a continuación repasamos para enunciar, después, el nuevo programa que ha de observar un museo de arte y que explica su transformación.

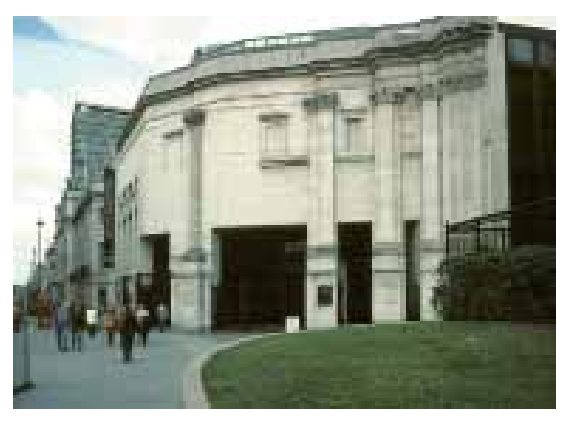

Fig. 91

Comienza su conferencia afirmando el papel del museo en 
la reconfiguración de los centros urbanos: "El Museo Popular de Arte en el centro de la ciudad, es un fenómeno actual ampliamente reconocido; viene a ser el arquetipo arquitectónico del momento, como lo fue la catedral en la antigüedad (...) para Sylvia Lavin existe en cada época una tipología en la cima de la jerarquía arquitectónica, que está relacionada con los valores culturales del momento: la religión en el renacimiento o la vivienda en el movimiento moderno. Actualmente, debido a la complejidad de los valores occidentales, el museo es el edificio que mejor muestra los valores culturales de la época. Su valor institucional hace que este edificio afronte además diferentes fenómenos políticos y sociales".

El arquitecto norteamericano prosigue recordando que el incremento en el número de visitantes, vinculado a la ubicación de la institución en el centro urbano, conlleva un replanteamiento de sus necesidades: "Otro rasgo que ha variado en el museo es la afluencia de visitantes. El museo que antes estaba destinado a un cierto sector cultural se ha ampliado a diferentes gustos, culturas, nacionalidades,... en el caso concreto de la National Gallery, la afluencia ha pasado de 500.000 visitantes a 3.000.000 este año (1988). En esta promoción tiene una gran importancia el acercamiento del museo al centro histórico de la ciudad. Mediante este acercamiento se facilita el acceso del público al museo al tiempo que crea un vínculo museo-comercio que facilita la relación del mismo con la vida cotidiana. Ahora, este acercamiento del museo a la ciudad, con su densidad y complejidad, se convierte en un desafío arquitectónico".

A partir de lo expuesto, Venturi desgrana los parámetros de proyecto que se desprenden de la relación con el contexto, haciendo hincapié por un lado en la escala del edificio y del otro el "cómo" relacionarse con aquel. Si esta relación se puede lograr mediante la analogía o el contraste, Venturi, coherente, por supuesto, con sus ideas, elegirá ambos criterios - "both, and"-: "Otra consideración sería la situación urbana. Un museo en el centro de una ciudad moderna esta rodeado de edificios 
mayores. Además, el museo no acostumbra a situarse en un fondo de perspectiva, sino a lo largo de una calle (Whitney (Fig.92), Guggenheim (Fig.93), MoMa,...). Por tanto, para que un edificio menor en tamaño mantenga su carácter Institucional, debe emplear una escala mayor que el edificio de mayor tamaño, pero combinada con la escala menor, para crear también un aspecto familiar (otros museos prefieren la combinación de varios pabellones de media escala de modo que el público se encuentre callejeando por entre los pabellones, cambiando la escala del entorno). Otro punto importante es el contexto. En el diseño del edificio cabe destacar la concepción del mismo de fuera hacia adentro, pero también de dentro hacia fuera, algo que obviaron los arquitectos modernos. La armonía con el contexto se consigue por analogía o por contraste. La analogía permite un diálogo con el contexto, mientras que el contraste lo enriquece por cuanto introduce nuevos elementos, de modo que la armonía también se consigue por la combinación entre ambos conceptos. En este aspecto, la National Gallery es una ampliación y por tanto es concebida como una continuación del antiguo edificio como así se evidencia en la repetición de las pilastras y la permanencia de las alineaciones, formando una unidad con el edifico de Wilkins, pero del mismo modo, la ampliación es un edificio de esta época, y por tanto también se establece un contraste, más evidente entre las dos fachadas de la ampliación, y que responde a una relación de analogía con el diferente contexto de la parte posterior".

Se extiende añadiendo unas consideraciones sobre "la apariencia exterior" del museo entre las que cabe destacar el papel de los huecos en fachada: "sin huecos la apariencia es hostil, como una cárcel, mientras que los huecos dotan al edificio de un carácter simpático, de modo que Wilkins hizo bien en la National Gallery, con nichos que se identifican como ventanas y con el pórtico exterior que invita a entrar".

Junto a las citadas reflexiones sobre la relación museociudad y las consecuencias proyectuales que conlleva en
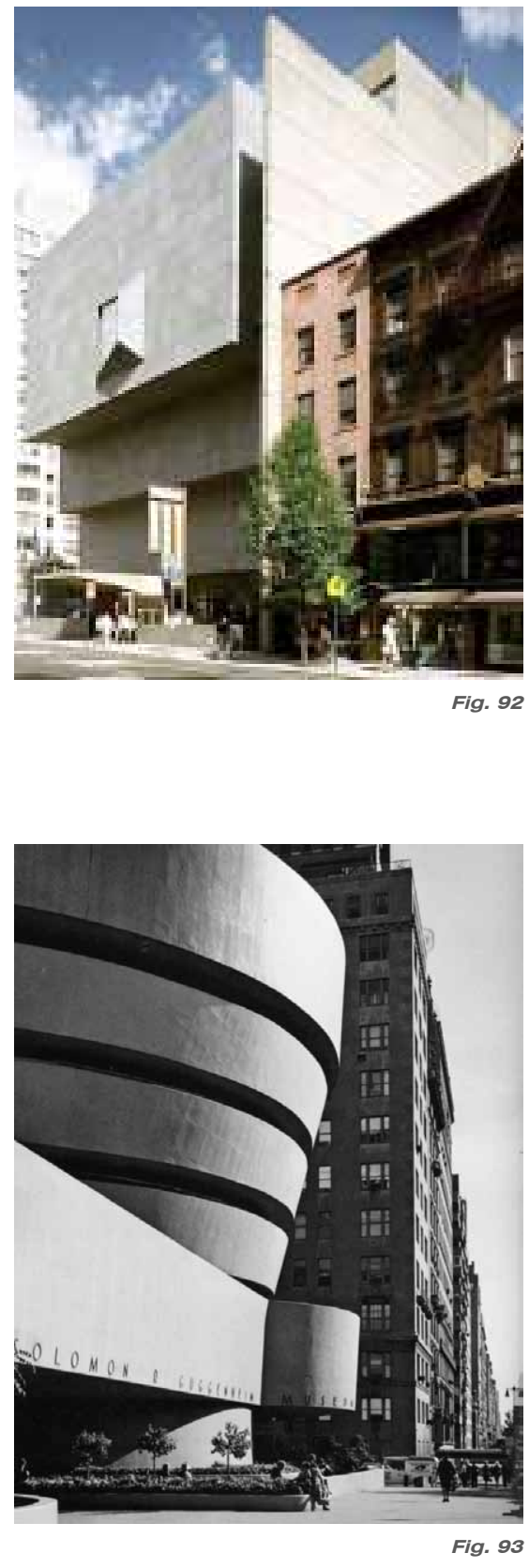

Fig. 92

Fig. 93 
relación a escala y lenguaje, conviene que nos detengamos en el nuevo programa del museo y en sus consideraciones sobre los espacios de exposición y el papel de la luz en su definición. Como Venturi nos explica: "El museo no es un simple contenedor para custodiar y exponer obras de arte, sino una institución cultural con una precisa función didáctica, dotada de ambientes para informar mediante conferencias, proyecciones, televisión, ordenadores y libros; alberga un personal numeroso (al tradicional se añaden los adscritos a los nuevos programas); dispone de una tienda y un restaurante con cocina; a menudo dispone, especialmente en América, de un espacio recreativo, de un ambiente agradable y monumental adecuado a inauguraciones y otras ceremonias -y considera- En cuanto a concebir el museo como un espacio didáctico, con todos sus complementos, complica en gran medida el diseño. Por un lado hay que encajar las piezas como en un puzzle chino; antiguamente el museo era una sucesión de salas de parecidas dimensiones, ahora se trata de combinar diferentes tipos de salas, junto con un programa complementario muy complejo en un edificio denso en el centro de la ciudad (entrada de camiones sobre el teatro, bajo la sala de ordenadores que a su vez esta debajo de la sala de los Masaccios, al lado de las oficinas de seguridad por un lado y de la tienda del museo al otro), cumpliendo además con las estrictas normas de seguridad y con una estructura muy exigente. Pero lo complicado no es encajar las piezas, sino distribuirlas sin cansar al público". Por tanto prosigue: "Los problemas que se producen son: el laberinto que tiene que atravesar el público hasta llegar a las salas de exposición, que le produce una desorientación que no le permitirá apreciar lúcidamente las obras de arte, la arquitectura de arquitecto, que en ocasiones compite con las propias obras de arte y la pérdida del sentido institucional que se produce al entrar en un museo en el que a primera vista te encuentras con una recepción, un guardarropa, la caseta de seguridad, la tienda...".

En la ampliación de la National Gallery la resolución de 
estos complejos requerimientos se realiza mediante "claridad y escala". Lo explica así: "La forma en que se resuelven estos problemas en la National Gallery es la jerarquía, la superposición de órdenes: un orden de gran escala y simplicidad destinado a dotar de carácter institucional al edificio al tiempo que clarifica el acceso a las obras de arte mediante la gran escalera, y otro de menor escala, más intrincado, con todos los servicios y complementos del museo (Figs.94-95). En resumen, es una cuestión

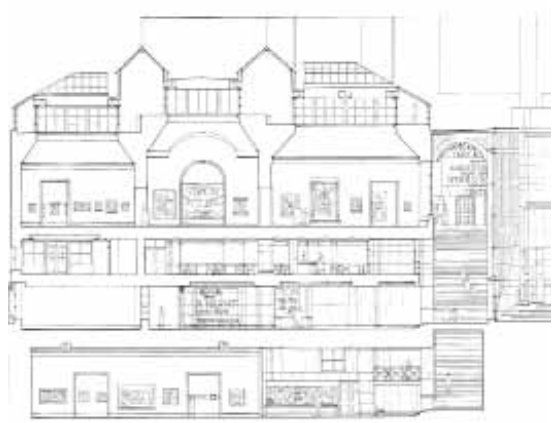
de claridad y escala: claridad para acceder directamente al arte, y escala para dotar de carácter institucional y unificar el programa funcional, en vez de yuxtaponer diferentes elementos de escala media donde se pierde la tensión propia de la buena arquitectura."

Mostrada la forma de articular tan complejo programa sin perder de vista el carácter institucional del nuevo museo, Robert Venturi, tan agudamente realista como siempre, invierte la relación entre sus espacios expositivos y los espacios administrativos y logísticos que lo complementan: "En los museos decimonónicos la relación entre área expositiva y área destinada a actividades

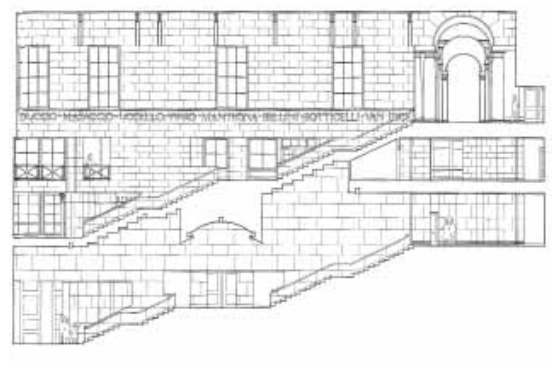
auxiliares era circa 9:1; hoy la relación tiende a ser de 1:2, lo que significa dedicar a las obras de arte solo un tercio del área del complejo." Esta inversión de los términos pone radicalmente en crisis el tradicional programa del museo de arte-que permanecía gracias a una enorme inercia- mediante el enunciado de nuevos contenidos que integrarán a partir de ahora el programa del museo de masas.

Veamos como el arquitecto plantea el espacio expositivo del nuevo museo: "Dar forma e identidad a un edificio museístico en un ambiente urbano denso plantea notables problemas arquitectónicos, derivados en parte de la necesidad de reexaminar el carácter que hoy significa la exposición de obras de arte. Mientras en el pasado las colecciones eran relativamente estables, hoy tienden a ser mutables, por ampliación de adquisiciones, por la difusión de exposiciones temporales o la exposición de piezas de arte actual, lo que requiere mayor o 

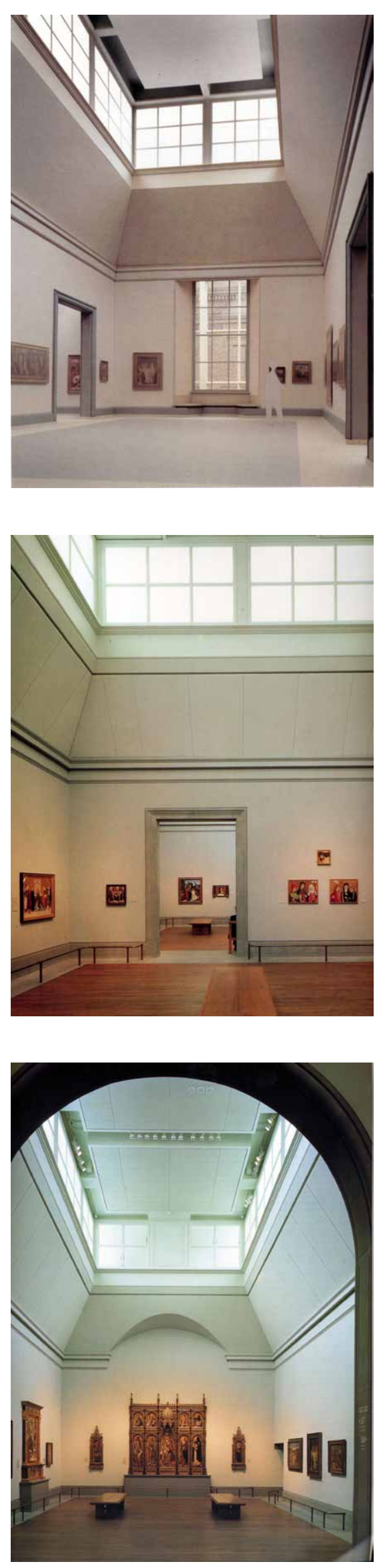

Figs. 96-98 menor flexibilidad en la configuración espacial y en las formas de iluminación, y favorece una pluralidad de soluciones arquitectónicas que puedan valerse de espacios simbólicamente neutros, históricos o modernamente tecnicistas, espacios estáticos o fluidos." Y al examinar de nuevo el significado actual de la exposición de obras de arte es inevitable una acotación sobre su iluminación: "en el diseño se juega con la luz natural (mejor cromatismo) y la artificial (mayor control), pero siempre con especial cuidado en la protección de las obras de los rayos ultravioletas, muy dañinos para los pigmentos." Y concreta de esta forma los criterios para la iluminación de las salas: "Para la iluminación se tienen en cuenta varios puntos: 1.La iluminación natural no debe ser directa para evitar los rayos ultravioleta. 2. La luz natural se complementa con luz artificial para iluminar en mayor medida la zona baja de la pared donde se exponen las obras. (Figs. 96-98) 3. Evitar la regulación mecánica de la luz. 4. Hacer reconocible la luz del día, la luz de la tarde o la luz de invierno, mediante el uso de claraboyas. 5. Introducir el símbolo de la ventana (normalmente no hay por razones de seguridad, espacio y protección solar), para crear el ambiente de "habitación" y para que el público pueda puntualmente echar un vistazo al exterior. En las habitaciones interiores, una ventana interior se hace corresponder con la ventana exterior de la habitación contigua, consiguiendo una mayor protección solar". (31)

¿Hace falta destacar la aparición del concepto kahniano de "habitación" (room) en la definición del carácter del espacio expositivo? Conviene recordar la colaboración de Venturi en el despacho de Kahn hasta su separación por motivos ideológicos (en el campo de la disciplina arquitectónica).

En esta conferencia Robert Venturi sintetiza la problemática proyectual que el museo de arte ofrece en el último tercio del siglo XX. Refleja, como ya he comentado en otras partes de este trabajo, la relación de la institución con el centro urbano, que vuelve a ser objeto de estudio, y su capacidad de revalorización. Los problemas que en la redacción del proyecto se plantean 
sobre las formas de inserción del edificio en contextos, cargados las más de las veces de fuertes connotaciones históricas, estilísticas y significativas.

En relación a los espacios expositivos, habida cuenta de la diversidad de posibilidades que deben ofrecer, los clasifica e insiste en la importancia decisiva de la iluminación, natural y artificial, que en estos momentos se hacen coincidir dando lugar a la conjunción de ambas en la resolución de las diferentes salas. Hay que recordar que en las décadas anteriores, en especial los años 40 y 50 , se confiaba, en la mayoría de los casos la iluminación de las salas al uso de la luz artificial. Un ejemplo de ello será el museo Whitney, que Marcel Breuer llevó a cabo en el centro de Manhattan.

Pero la gran afluencia de público a esta institución, fruto del éxito obtenido, que junto a sus fines expositivos desarrolla un papel didáctico y también de entretenimiento de las masas que la visitan, da lugar a un complejo programa que Venturi, no exento de cierta ironía, enuncia someramente.

Junto a las salas de exposición, el gran museo del último tercio del siglo $X X$ incluye también salas para exposiciones temporales, auditórium, librería y biblioteca, mediateca, bar y restaurante así como una tienda del museo. A esto se añade, naturalmente, un gran vestíbulo (Fig.99), un espacio de acogida con similares funciones a las del foyer de un teatro: acoger a las personas que acuden al museo y ofrecerles la oportunidad de socialización y comunicación mientras se orientan entre lo que la institución les ofrece.

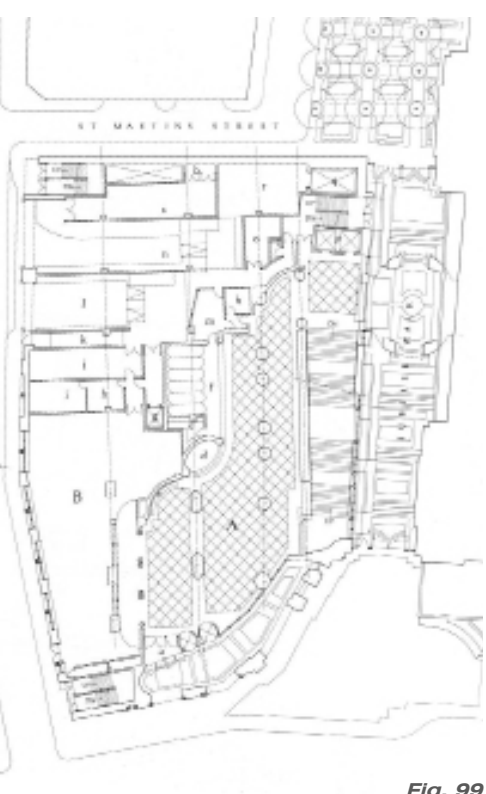

De todo ello nace un programa funcional y espacial excepcionalmente variado que se refleja en nuevas estructuras arquitectónicas que realmente se constituyen como expresión de la cultura contemporánea del proyecto arquitectónico. Baste señalar como ejemplo la Neue Staatsgalerie de Stuttgart (19771984), proyectada y construida por James Stirling y Michael Wilford. Este paradigmático museo incluye en su programa 
un espacio de exposiciones temporales -cuya importancia y demanda de superficie seguirá creciendo de forma paulatina en los museos de arte-, 142 plazas de aparcamiento, una biblioteca de $500 \mathrm{~m} 2$ (incluida el área de personal), una sala de conferencias de 480 plazas, tienda-librería, administración, depósito de obras -de 1400 m2-, cafetería, y por supuesto, salas de exhibición permanente de la colección. En resumen, de los aproximadamente $14.000 \mathrm{~m} 2$ construidos, la superficie expositiva que corresponde a las salas de exposición permanente y temporal, junto a la terraza y rotonda de exposición de escultura, apenas alcanza los $4.000 \mathrm{~m} 2$, lo que representa un $27 \%$ de la superficie del edificio. El resto del total de la superficie se reparte entre la destinada a usos públicos (36\%) y la correspondiente a usos internos (37\%). Y los espacios de acogida alcanzan los 900 m2 de superficie. (32)

Las distintas partes que integran tan complejo programa las podemos englobar, de manera simplificada, en tres apartados: espacios de uso público, espacios semipúblicos y espacios internos. Según los estudios realizados sobre los museos que acompañan a modo de adenda este trabajo, continuadores de los elaborados por el arquitecto Carlos Baztán (responsable de museos del Ministerio de Cultura hasta 1999, quien suministró el programa que adjunto simplificado al final de este capítulo estos tres tipos de usos que integran el nuevo museo), la superficie de las citadas zonas se divide en partes aproximadamente iguales, de modo que la relación superficial de cada una de ellas respecto al todo es de 1:3, lo que da idea del cambio de relaciones, su articulación y su concurrencia en la elaboración de un proyecto de museo.

Los espacios de uso público engloban las salas de exposición permanente y temporal, el espacio de acogida con sus servicios al visitante (información, guardarropía, entradas, grupos, etc.) y los usos vinculados a él, como la biblioteca-videoteca, sala de actos, cafetería, restaurante, tienda y un largo etcétera.

Se denominan espacios semipúblicos aquellos que, 
esporádicamente, pueden ser accesibles con carácter general como la administración del museo, las salas de reserva para investigadores, las salas de consulta para el estudioso especializado y los almacenes visitables.

En el grupo relativo a lo que hemos denominado "usos internos" encontramos los almacenes profundos (de acceso exclusivo del personal técnico de la institución), los almacenes de apoyo, los almacenes de tránsito (que como su nombre indica, cubren las necesidades del montaje, desmontaje y almacenamiento de las exposiciones temporales) y las cámaras junto a todos las necesidades deducibles como talleres de restauración, desinsectación, embalaje y desembalaje, talleres de carpintería- electricidad, registro, sin olvidar las salas de personal y las áreas relativas a las complejas y diversas instalaciones requeridas.

Por su interés, a continuación, se explicitan sucintamente los diversos apartados que concurren en la organización del museo de arte. 
MUSEO DE ARTE: PROGRAMA Y ORGANIZACIÓN

(A) ESPACIOS PÚBLICOS:

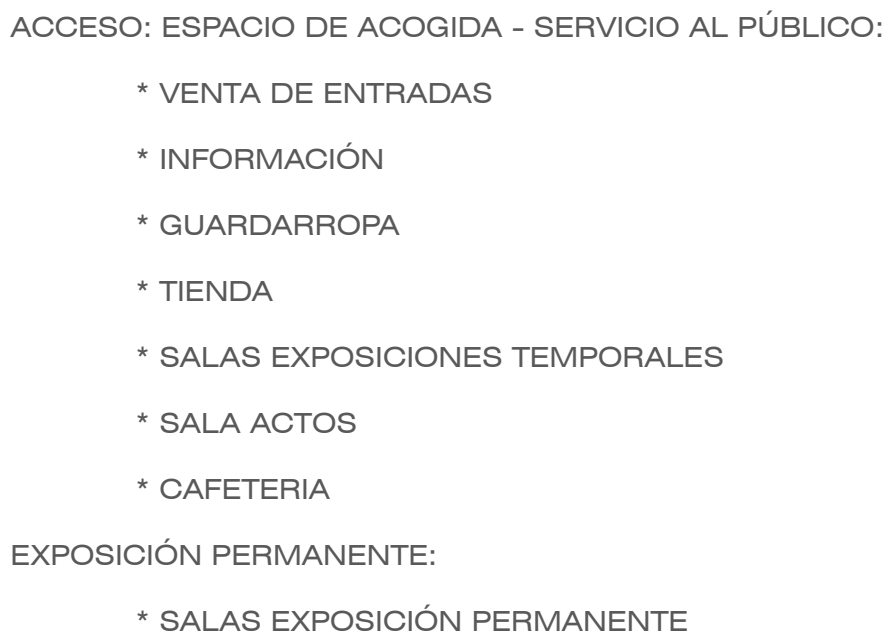

(B) ESPACIOS SEMIPÚBLICOS:

DIRECCIÓN

ADMINISTRACIÓN

ALMACENES VISITABLES

(C) ESPACIOS INTERNOS:

ÁREA DE ALMACENES DE FONDOS (RESERVAS)

ACCESO DE FONDOS Y ALMACENES DE TRÁNSITO (SI PROCEDE)

ÁREA DE TALLERES DE MANTENIMIENTO

ÁREA DE PERSONAL SUBALTERNO C(1)

ÁREA DE INSTALACIONES C(2) 


\section{(A) ESPACIOS PÚBLICOS:}

SERVICIOS AL PÚBLICO

(DE POSIBLE FUNCIONAMIENTO A EXPOSICIÓN PERMANENTE CERRADA)

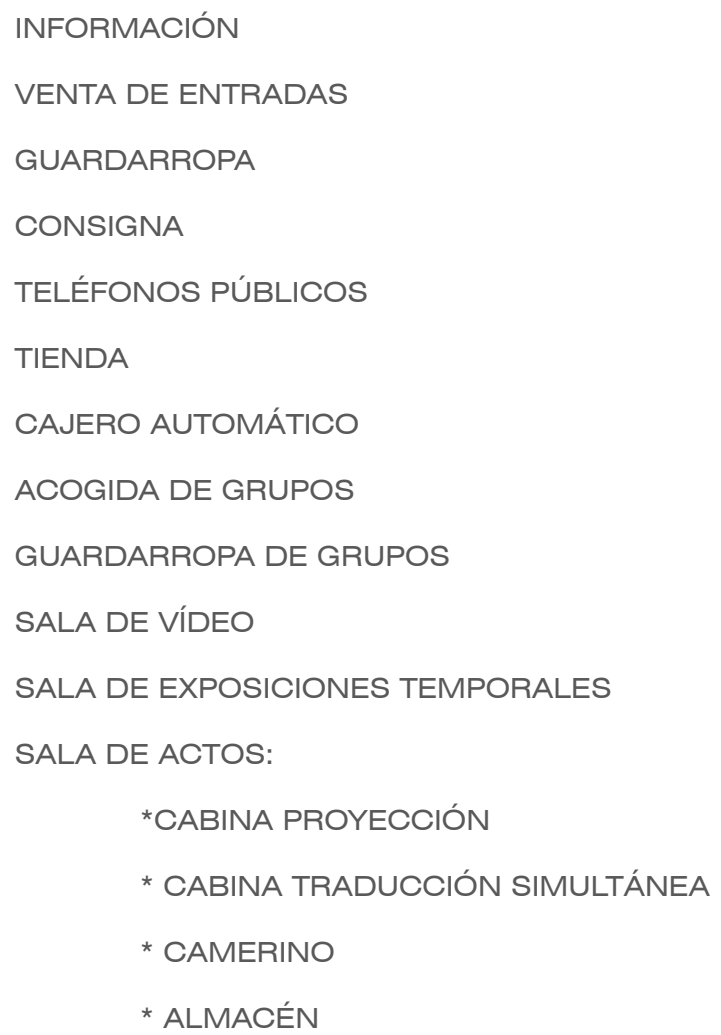

* ALMACÉN 


\section{(B) ESPACIOS SEMIPÚBLICOS:}

USOS INTERNOS CON EVENTUAL ACCESO POR PARTE DEL VISITANTE

DIRECCIÓN:

* SECRETARía

* ESPERA

* DESPACHO DIRECTOR

* SALA DE JUNTAS

* ASEO

ADMINISTRACIÓN:

* DESPACHO ADMINISTRADOR O GERENTE

* SECRETARía

* ESPEA

* DESPACHOS ADMINISTRATIVOS

* ARCHIVO

* ASEOS

RESERVAS VISITABLES - ALMACÉN VISITABLE:

(CONECTAR CON ACCESO INVESTIGACIÓN)

* CONTROL

* SALAS DE RESERVAS VISITABLES

* salas de consulta 


\section{(C) ESPACIOS INTERNOS:}

USOS INTERNOS CON ACCESO EXCLUSIVO DEL PERSONAL DEL MUSEO

ÁREA DE ALMACENES DE FONDOS (RESERVAS):

(CONECTAR CON EXTERIOR)

(CONECTAR CON MANTENIMIENTO)

* ACCESO DE FONDOS

* EMBALAJE Y DESEMBALAJE

* DESINSECTACIÓN Y DESINFECCIÓN

* CONTROL DE REGISTRO

* ALMACENES

* POSIBLE PLATÓ FOTOGRÁFICO

ÁREA DE ALMACENES DE TRÁNSITO:

(CONECTAR CON EXTERIOR)

(CONECTAR CON EXPOSICIONES TEMPORALES)

(CONECTAR CON MANTENIMIENTO)

* ANDÉN DE CARGA Y DESCARGA

* CONTROL

* EMBALAJE Y DESEMBALAJE

* ALMACENES DE TRÁNSITO

* ALMACENES DE APOYO

ÁREA DE TALLERES DE MANTENIMIENTO:

(CONECTAR CON EXTERIOR)

(CONECTAR CON MANTENIMIENTO)

* RESTAURACIÓN

* Laboratorio

* ASEOS con lavaojos

* ALMACÉN PRODUCTOS TÓXICOS

* RAYOS $X$

(SIGUE) 
C(1) ÁREA DE PERSONAL SUBALTERNO :

(CONECTAR CON EXTERIOR)

(CONECTAR CON EXPOSICIONES PERMANENTES)

(CONECTAR CON ESPACIO ACOGIDA)

* VESTUARIOS (MASC. Y FEM.)

* ASEOS Y DUCHAS (MASC. Y FEM.)

* Área de estancia

C(2) ÁREA DE INSTALACIONES:

* INSTALACIONES ELÉCTRICAS:

- CUARTO DE CONTROL INFORMÁTICO

- ESPACIO PARA TRANSFORMADOR

- CUADRO DEL GENERADOR

- ACOMETIDA Y CUADRO GENERAL:

CUADRO DE CONTADORES

CUADRO ELÉC. POR PLANTAS O ZONAS

CUADRO DE ILUMINACIÓN

* INSTALACIONES DE ASCENSORES O ESCALERAS

MECÁNICAS:

- CUARTO DE MAQUINAS

* INSTALACIONES DE CLIMATIZACIÓN:

- CUARTO DE CONTROL INFORMÁTICO

- SALA DE CLIMATIZADORES

- SALA DE BOMBAS

- ESPACIOS DE CONDUCTO REGISTRADO

* INSTALACIONES DE FONTANERÍA Y CALEFACCIÓN:

- CUADRO DE ACOMETIDAS Y LLAVES GENERALES

- LLAVES POR ZONAS

- CUARTO CALDERA AGUA CALIENTE

* INSTALACIONES DE DETECCIÓN DE INCENDIOS:

- CUARTO DE CONTROL

- DEPOSITO AGUA EXTINCIÓN

- CUARTO DE BOMBAS

* INSTALACIONES DE TELEFONÍA

* INSTALACIONES DE ORDENADORES

* INSTALACIONES DE SEGURIDAD (CENTRALITA CONTROL) 


\subsubsection{Los grandes museos del último cuarto del $\mathrm{S}$. XX}

Las pequeñas intervenciones y las estrictas y funcionales ampliaciones de los diferentes museos, en las cuarta y quinta décadas del siglo pasado, ceden el paso, a finales de los años 70, a la construcción de grandes museos. La nueva orientación didáctica y de aprendizaje para el público que ofrece la institución se une a las necesidades de servicios logísticos inexistentes en los museos "decimonónicos" y motiva este cambio que también obedece a operaciones de amplio calado político y social. El prestigio de la institución del Museo aparece ligado a políticas culturales ambiciosas que trascienden el carácter preferentemente local que hasta entonces los proyectos de museos ostentaban. Se celebran grandes concursos públicos de ámbito internacional en los que participa asiduamente una élite de arquitectos de amplio y reconocido prestigio. Éstos se convierten, de una manera adaptada a su tiempo, en especialistas cuya colaboración garantiza a los poderes públicos un éxito -en ocasiones solo mediático- en su política cultural, en un procedimiento similar al ejemplarizado por los poderes decimonónicos, en un extremo, y por los arquitectos Leo Von Klenze o Friedrich August Stüler, en el otro, durante el siglo XIX.

Entre estos arquitectos de finales del último cuarto del siglo XX cabe destacar a Hans Hollein, Robert Venturi, Richard Meier, James Stirling, leoh Ming Pei, Arata Isozaki o Rafael Moneo, entre otros. Como ejemplo de esta nueva situación, baste reseñar la inauguración del Museo de Orsay y del Gran Louvre como paradigma de la política cultural de François Mitterrand, promotor asimismo de la gran Biblioteca Nacional -diseñada por Dominique Perrault-. No debemos olvidar, aunque no es objeto de nuestro discurso, a la biblioteca como programa edilicio de enorme éxito, complementario del Museo en la definición de las grandes políticas culturales.

De todos los edificios que se construyen y de todos los proyectos que se diseñan en los numerosos concursos convocados, algunos de ellos tienen especial trascendencia por su significación en el desarrollo de los espacios expositivos 


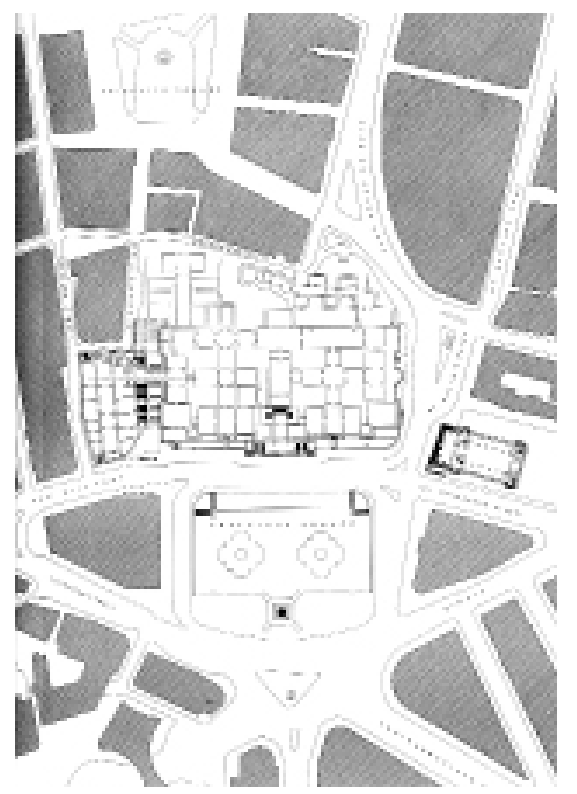

Fig. 100 definidos y en la configuración de espacios urbanos, por lo que procederemos a su análisis sucinto.

Hablaremos de Robert Venturi, siguiendo el hilo de las citas superiores. La ampliación de la National Gallery que Robert Venturi y Denise Scott Brown construyen en Londres entre 1986 y 1991 representa, de acuerdo con Charles Jencks, el primer gran encargo realizado en las Islas Británicas a un arquitecto norteamericano. Este proyecto, cuyo concurso convocó en su fase final a importantes arquitectos como Stirling o Pei, debía resolver no solo la adecuación al nuevo programa museístico sino también el cierre del flanco oeste de la Trafalgar Square (Fig.100) y el cosido de una vieja herida en la trama urbana londinense. En efecto, la destrucción del edificio que ocupaba el solar objeto de concurso, el Hampton Furniture Building, durante la segunda guerra mundial permitió, gracias al mecenazgo de la familia Sainsbury, la disposición de los terrenos necesarios. El nuevo edificio debía responder no solamente a la National Gallery de Wilkins, sino también a los dos edificios neogriegos que Smirke proyectó enfrentados: la Canada House, en el flanco oeste de la plaza, y a la South Africa House, en el extremo opuesto. La columna central de Nelson y la iglesia de Sant Martin in the Fields, situada en el extremo noreste de la plaza, cierran el elenco de objetos arquitectónicos de profundo arraigo en la memoria visual colectiva de la ciudad que configuran el entorno de la nueva galería. (33)

La implantación que Venturi ofrece es, a nuestro modo de ver, brillante. Entre las operaciones urbanas que realiza destaca, en primer lugar, la alineación con Whitcomb Street en detrimento de los ejes ordenadores del edificio original. La siguiente acción consiste en el avance de la masa de su edificio respecto al histórico edificio de Wilkins, junto a la "erosión" de la esquina adyacente al mismo y a la plaza, hecho que permite el acceso al nuevo museo. Desde esta entrada, y en paralelo al Jubilee Walk, flanco oeste de la National Gallery, una escalinata de un tramo asciende y nos muestra el muro del antiguo edificio, introducido visualmente en el espacio de nueva construcción. Finalmente, 
se remata la fachada con una gradación de elementos del orden clásico de Wilkins, concentrados en la esquina más cercana a éste y cuya desaparición gradual hacia el Pall Mall East se corrobora con las modernas fachadas de Whitcomb street y de St. Martins Street. En definitiva, este es un ejemplo más de cómo el nuevo edificio del Museo se erige como configurador de frentes en delicadas operaciones urbanas que en la ciudad histórica requieren especial atención y sensibilidad. (34)

Por otro lado Venturi, en relación al aspecto formal de su arquitectura, justifica su "manierismo" en atención a la naturaleza innovadora que en su opinión siempre ha caracterizado el clasicismo y que, dentro de la tradición británica, viene representada en su vertiente más transgresora por arquitectos de la talla de Iñigo Jones, Nicholas Hawksmoor o el propio John Soane. El equilibrio entre las operaciones de proyecto basadas en la analogía y en el contraste representa, en palabras del autor, el método de aproximación formal a la resolución del objeto arquitectónico. No obstante, no persigue este discurso el análisis formal de esta arquitectura; sí su relación con los espacios expositivos.

Las salas expositivas (Fig.101), generalmente de planta rectangular, son espacios expositivos tradicionales que se disponen en la última planta, lo que permite su iluminación cenital. Se estructuran por medio de tres ejes paralelos a Whitcomb Street; las salas centrales se disponen en enfilada "enfatizando", en palabras de Moneo, "el espacio perspectivo"; en los otros casos, las enfiladas están interrumpidas de tal modo que se produce un mayor número de visuales hacia las obras de arte en detrimento de la apreciación global del espacio longitudinalmente organizado. En sentido perpendicular solamente un eje tiene una entidad parangonable a los tres anteriores: se trata del eje que, de modo oblicuo a la alineación general del edificio, conecta las tres series de salas con el vestíbulo previo y la rotonda de comunicación con el edificio primigenio (Fig.102-104). El resto de conexiones son pasos de menor entidad e importancia. ${ }^{(35)}$

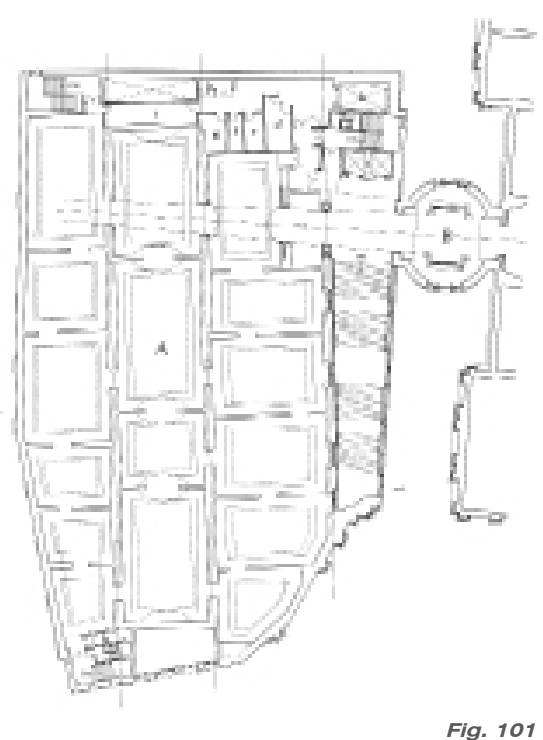

La conexión con el edificio original se realiza a través de 


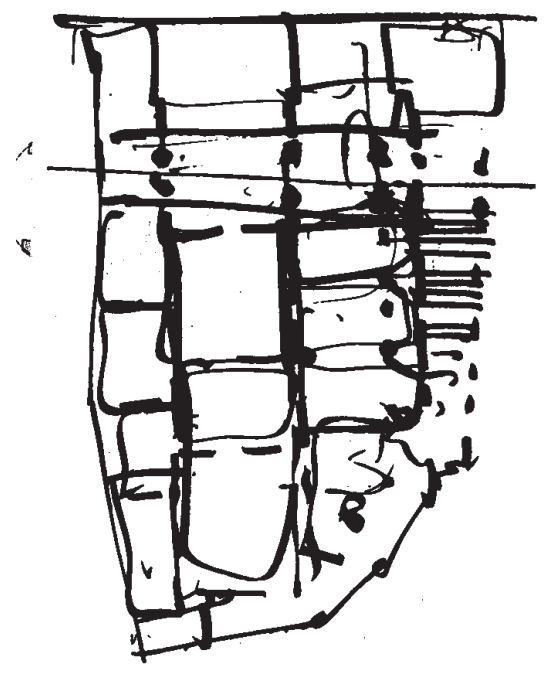

una sala circular evocadora de la rotonda, comunicada con el vestíbulo, punto de inicio del recorrido expositivo, donde desemboca la gran escalinata, que adquiere una fundamental trascendencia. Al igual que en el precedente museo de Seattle, permite también el acceso al restaurante, parte del programa que se intercala en el tránsito entre el vestíbulo de acogida y las salas de exhibición. El gran protagonismo que adquiere la escalera nos evoca, por un lado, las escalinatas de acceso a los grandes museos históricos nacionales, como el Altes Museum. La escalera, cuyo efecto perspectivo se amplía en su cota más elevada, posee parentescos clásicos, como la Scala Regia de Bernini o también nos acerca, de una forma más literal, a la gran escalera longitudinal que Leo Von Klenze diseña para el Hermitage

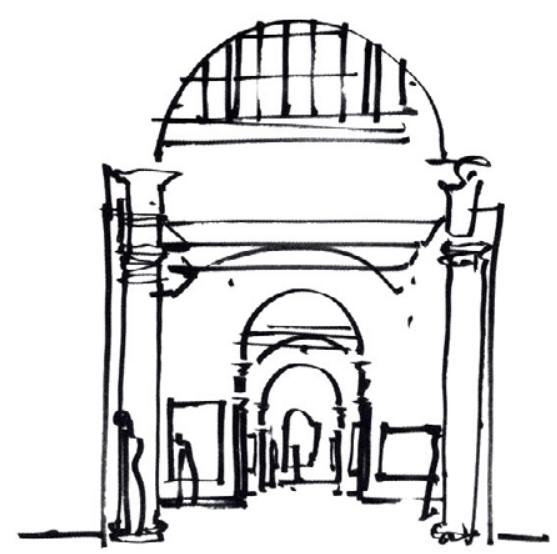
o a las que Hans Döllgast construyó en su rehabilitación de la Alte Pinakothek.

La cuestión que plantea la monumentalidad de las escaleras no siempre se ha resuelto de un mismo modo. Baste considerar su resolución en el Museo que Venturi desarrolla en Seattle (Fig.105) unos años antes de ganar el concurso de la Sainsbury Wing. En este museo, Venturi plantea una escalera monumental longitudinal que reproduce el perfil de una avenida en pendiente, permitiendo diversas salidas y conexiones con un espacio público generado por el retranqueo del edificio respecto de la alineación establecida. Esta escalera, que también permite

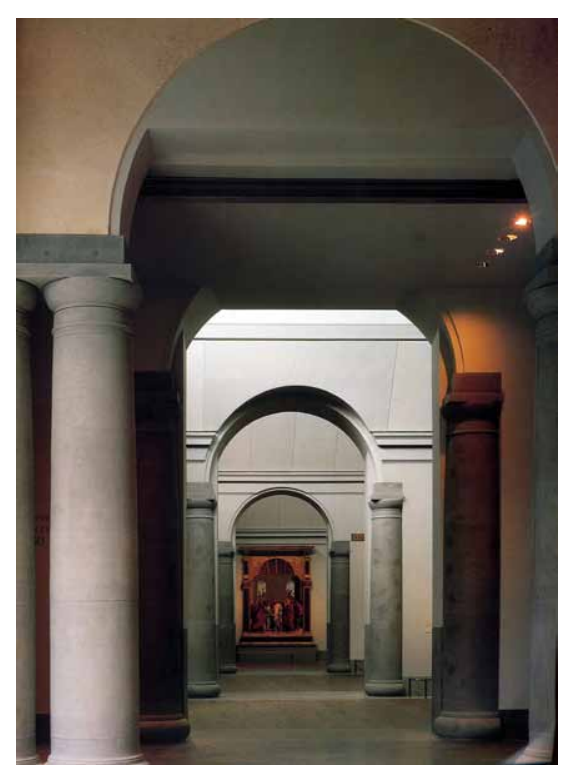
el acceso a la mezzanine que alberga al restaurante -misma solución que en Londres-, desemboca en el vestíbulo de acceso a la primera planta, a partir del cual se desarrolla la exposición. A las dos plantas superiores, sin embargo, se accede a través de pequeñas escaleras funcionales e impersonales ascensores, de manera que se usa la gran escalinata como un tránsito de acceso a los espacios de las colecciones, cuya posterior organización vertical es totalmente independiente de la misma. Venturi nos relata que esto responde a requerimientos del cliente, cuyo programa prevé el acceso y la visita autónoma de partes de la exposición. En todo caso, el resultado espacial es pobre e indiferenciado. (36) 
Otro de los grandes arquitectos que abordan la resolución del nuevo programa de museo en la década de los setenta y ochenta es James Stirling. En esta etapa irrumpen ciertas alternativas en el debate teórico y en la producción edilicia que marcarán profundamente el devenir de la arquitectura de los museos: los estudios sobre la ciudad de la Tendenza italiana,

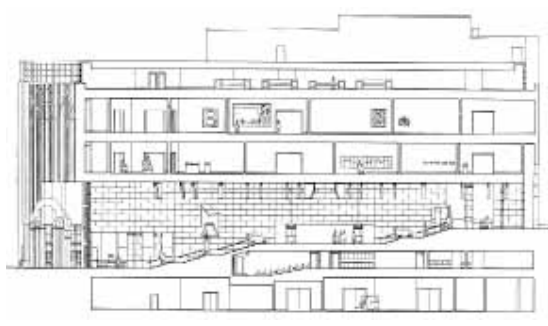

Fig. 105 los escritos de Venturi que priman lo singular y una idea de arquitectura que reclama realismo y complejidad.

Stirling realizó numerosos proyectos relacionados con la exposición de obras de arte; su producción se caracteriza por la indagación acerca de los espacios expositivos tradicionales y por la reflexión sobre la integración y yuxtaposición con el contexto urbano, a través del recorrido, que suscita la relación Museo-Ciudad.

Destaca entre sus primeras obras del programa Museo de Arte la propuesta, no construida, para el Nordrhein-Westfalen Museum (Figs.106-107) que desarrolla para la ciudad de Düsseldorf en 1975. El proyecto debe completar parte de una manzana destruida durante la segunda guerra mundial, atendiendo a la escala de los edificios del entorno, al viario peatonal que se establece en el interior de la manzana y a la decidida conservación de las ruinas y de fragmentos de edificios preexistentes. Para ello, plantea la creación de un podio en la Grabbeplatz, desde el cual se puede o bien acceder al vestíbulo del museo, o bien descender por debajo del mismo cruzando un jardín circular para alcanzar una calle posterior (la Ratinger Mauer) o finalmente atravesar el eje de la Mühlenstrasse mediante una pasarela peatonal que comunica con la Kunstverein Düsseldorf, galería de arte municipal. También estaba prevista la creación de un porche, lugar de encuentro y de espera para grupos, así como

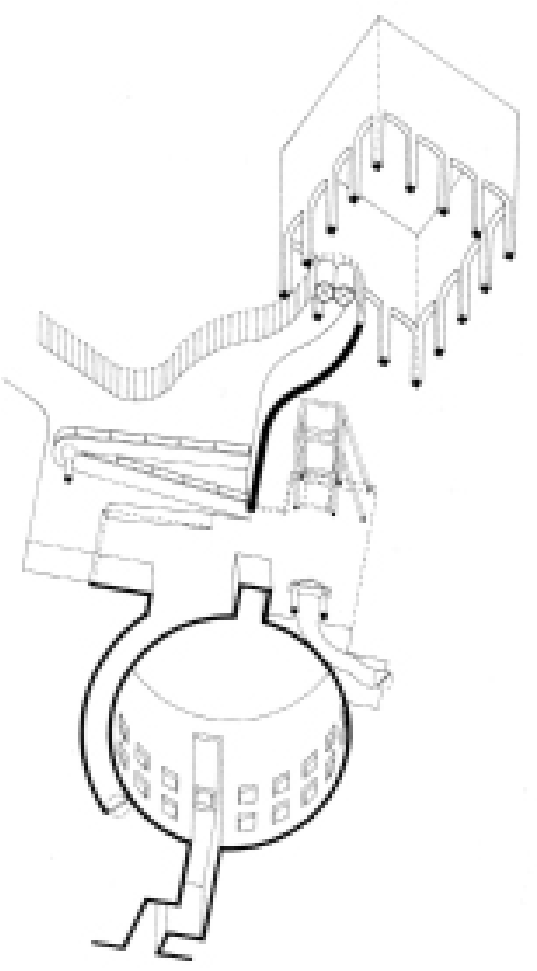
recorridos secundarios a través de los jardines situados en el flanco occidental del emplazamiento. La implantación urbana de este edificio no solamente restaña la herida abierta en la ciudad histórica: genera unos recorridos, plantea unas alternativas, que la enriquecen, mejoran y cualifican.

Rafael Moneo lo describe así: "Proyecto con una 


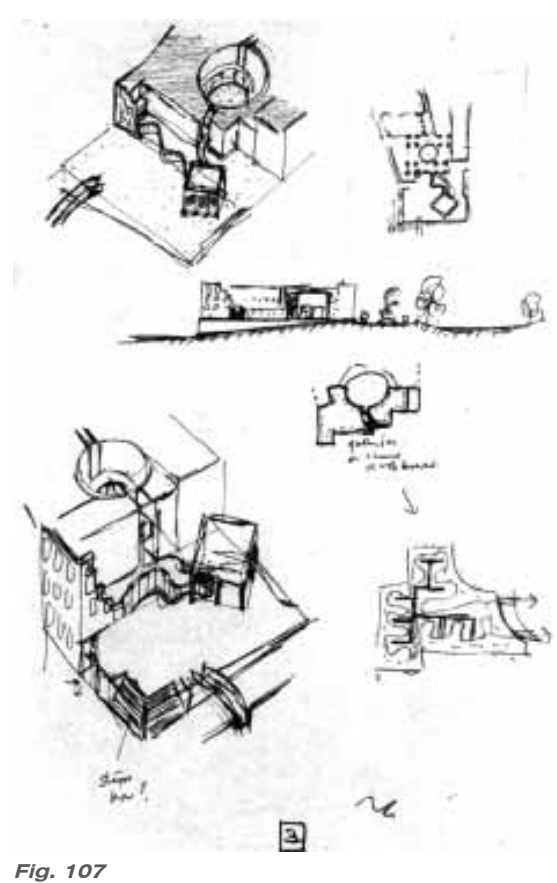

Fig. 107 exhuberancia no ajena a la fronda postmoderna que reclama una mayor complejidad de trazados y una mayor libertad para que cohabiten elementos diversos, episodios autónomos que intervienen en la definición de este paisaje arquitectónico más que edificio. Por primera vez aparece el cilindro, el patio circular como elemento clave, todos los demás elementos, personajes del drama, se medirán con él". (37)

Finalmente el edificio construido por Hans Dissing y Otto Weiling adolece y es desafortunadamente ajeno, en su rotunda volumetría y sus perfiladas aristas, a estas consideraciones urbanas.

Por otro lado, interesa la disposición de las salas expositivas en la última planta así como la organización de la colección en dos áreas expositivas. Alrededor del gran cilindro hueco se organizan perimetralmente una sucesión de salas divididas por elementos fijos o por mamparas, cuya iluminación es siempre cenital (Fig.108). El arquitecto británico niega la posibilidad de paso entre salas, de modo que se impide la generación de enfiladas tradicionales. Para pasar de una sala a otra, cabe ineludiblemente regresar al espacio de circulación que se establece de modo perimetral en torno al patio cilíndrico; pequeñas ventanas, situadas a ras de pavimento, permiten iluminar este recorrido sin afectar a las obras expuestas. Introducen así en el itinerario una conexión visual con el paseo peatonal que cruza de norte a sur el museo, a través de la rotonda vacía, de forma que interrelaciona la contemplación de las obras de arte con la visualización de su idea de itinerario dentro de la ciudad histórica. Además, permite la orientación del visitante que puede tomar como referencia este eje norte-sur que atraviesa, por una planta inferior, el museo. Por otro lado, Stirling organiza la colección Paul Klee - Julius Bissier en una sala expositiva independiente de planta circular y que se desarrolla en dos niveles. Aparece así un espacio inspirado en la rotonda, que se ilumina mediante un óculo que se reproduce en la perforación del forjado de la entreplanta. También se produce, a tenor de los dibujos y maquetas conservados, una voluntaria muestra de este volumen circular, inscrito entre los restos murarios conservados 
de una antigua edificación bombardeada, en la planta de cubierta. La elección de esta forma, que genera en planta un importante poché, no pasa desapercibida, y entronca con la utilización, renovada y readaptada, de los espacios expositivos tradicionales.

Otro de los grandes conjuntos museísticos que proyecta Stirling y sus asociados, el Wallraf-Richartz Museum de Colonia, en 1975, ejemplariza el tratamiento sensible que muestran nuestros arquitectos en respuesta a la política de creación de grandes museos en áreas deterioradas o devastadas de la ciudad histórica. La Catedral de Colonia, a cuyo ábside debía responder esta propuesta, actúa como referente fundamental, junto con la estación del ferrocarril -y su playa de vías- y la margen derecha del río Rin. De esta propuesta mencionaremos el atento análisis del lugar y el tratamiento paisajístico de los volúmenes propuestos. En efecto, podemos citar la asunción en su proyecto de las terrazas peatonales a distinta cota propias de la sensibilidad de postguerra, la reflexión ajardinada de los márgenes de las inmensas extensiones de vías férreas o el tratamiento de los dos cubos que, a modo de puerta, flanquean el Hohenzollernbrücke y generan una antesala a la imponente vista del ábside de la catedral. Todo ello se imbrica en el recorrido que tanto preocupaba a nuestro arquitecto, quien tuvo que esperar unos años más para ver materializado uno de sus proyectos de museo de arte, de cercano parentesco y geografía, que corresponde con la Nueva Galería Estatal y Teatro de Cámara de Sttutgart, cuyo concurso ganó en 1977 y cuya construcción finalizó en 1984.

En la Neue Staatsgallerie de Stuttgart, Stirling, cuya maestría en el uso de la sección en proyectos anteriores es indiscutible, consolida definitivamente en esta obra el papel de la planta que, en este caso es la que dicta el proyecto.

Este proyecto supone una continuidad en la línea de investigación iniciada por los correspondientes a Düsseldorf y Colonia, y en él se puede apreciar-de nuevo- cómo Stirling y sus compañeros no solo saben cómo es y cómo funciona este retazo 


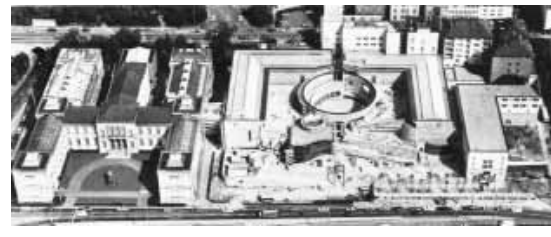

Fig. 109

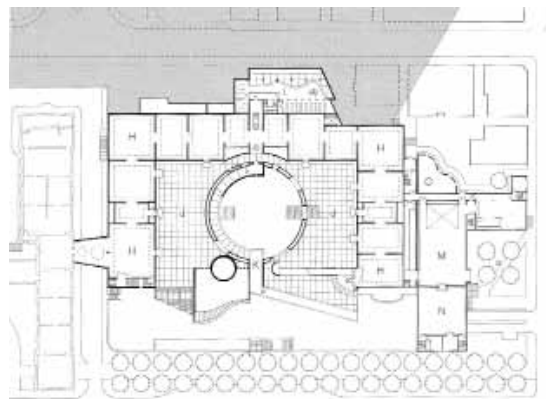

Fig. 110

de ciudad, sino que además vislumbran cómo puede y debe ser. Cabe establecer que el edificio responde a un complicado emplazamiento (Fig.109) y que, a pesar de su autonomía, es una ampliación de la Alte Staatsgalerie. En atención a la importancia e influencia que en el debate arquitectónico ha tenido este edificio, vamos a proceder a la realización de una somera descripción de sus características esenciales y de sus más importantes decisiones de proyecto.

El emplazamiento confiere cierta complejidad al proyecto; en primer lugar, se trata de un solar rectangular que presenta un importante desnivel entre sus lados de mayor longitud; en segundo, implica la inscripción de la nueva galería en un contexto de arquitecturas de alto componente representativo y monumental conservadas: la Alte Staatsgalerie -a la que debía conectarse (Fig.110), y al frente, al otro lado de una densa arteria de circulación, el Staatstheater; por último, esta vía de circulación, casi una autovía que se comienza a soterrar frente a la nueva galería de arte, imposibilita la aproximación frontal y la conexión peatonal con el Teatro Estatal. Asimismo, el solar está condicionado por requerimientos de índole municipal: se requiere la elevación de la plataforma de entrada al vestíbulo del museo con objeto de albergar en planta baja un aparcamiento de vehículos. Desde esta plataforma se debe, además, establecer un recorrido peatonal que cruce el solar y que permita la comunicación entre el nivel inferior -la "autovía" de la Konrad Adenauer Strasse- y el superior representado por la Urbanstrasse.

En consecuencia la propuesta se aparta de la autopista y levanta un podio bajo el cual se ubica el aparcamiento. La aparición de este basamento se convierte en genérica ya que el aparcamiento aparecerá ya en todos los programas de los nuevos museos. Como comenta Rafael Moneo: "El viejo podium de la arquitectura clásica hace de nuevo su aparición. En esta ocasión son los coches quienes lo rescatan".

Sobre él se construirá un paisaje urbano: El círculo y la "U" invertida dan estabilidad a la escena y establecen la relación con 
el edificio académico, la antigua galería neoclásica. Queda así definida la trama de referencia sobre la que se aplican episodios muy queridos por Stirling.

Como en todos los proyectos que hemos visto diseñados por el magnífico arquitecto de Glasgow, una de sus claves está en la brillante resolución de la sección, que ya mostró en su etapa anterior, pero que en este caso surge de la clara apuesta por la planta en la que se plantea el complejo entramado del proyecto y es en ello donde radica, fundamentalmente, gran parte del interés espacial de la Neue Staatsgalerie; podemos incluso afirmar que la radical modernidad que caracteriza el trabajo de Stirling frente a otros arquitectos contemporáneos -de habitual empleo de lenguaje historicista y de amplia proclividad hacia la cita arquitectónica erudita- consiste en esta interesante concepción espacial del proyecto de arquitectura.

Entretanto, se resuelve un programa de cierta complejidad que, además de los usos ya comentados y habituales desde el último cuarto del siglo $X X$, engloba una escuela de música y un Teatro de Cámara cuyo funcionamiento puede ser conjunto o independiente. La resolución del proyecto de Stirling en la que lugar y programa son sus puntos de partida es recogida con agudeza por Moneo que lo define de esta manera: "No es tanto un edificio como un paisaje arquitectónico", por lo que la propuesta se integra en la ciudad de forma que puede ser difícil distinguir la arquitectura de la ciudad y la de Stirling.

El edificio de la Staatsgalerie se organiza en torno al vaciado de un cilindro (Fig.111) cuya posición central nos recuerda al proyecto de Düsseldorf y en cierta manera al Altes Museum de Schinkel. Este espacio articula el recorrido peatonal y público producido mediante un sistema de rampas de conexión entre los diferentes niveles y plataformas en el que se organiza el conjunto. El nivel del pavimento del patio circular está elevado respecto al del vestíbulo del museo y no es accesible desde el recorrido peatonal, que lo bordea de forma tangencial al ascender por una rampa desde la que se domina visualmente. En el interior del museo, la rotonda se integra en el recorrido que parte del

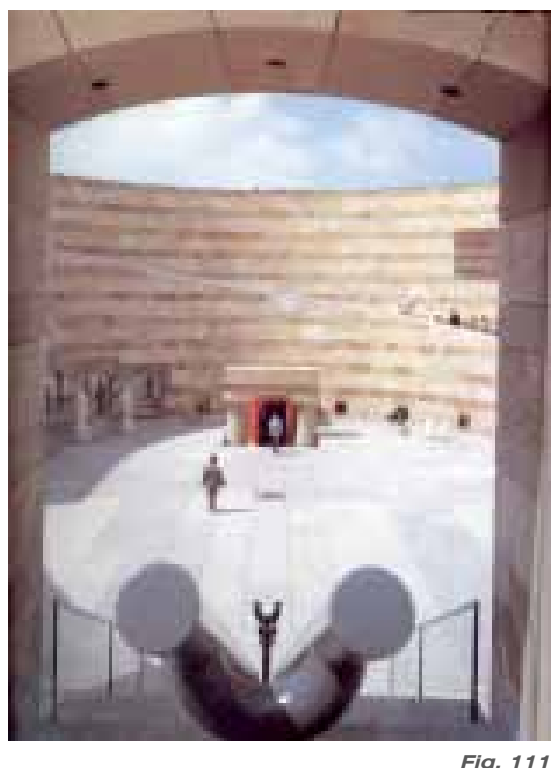

Fig. 111 (n) 


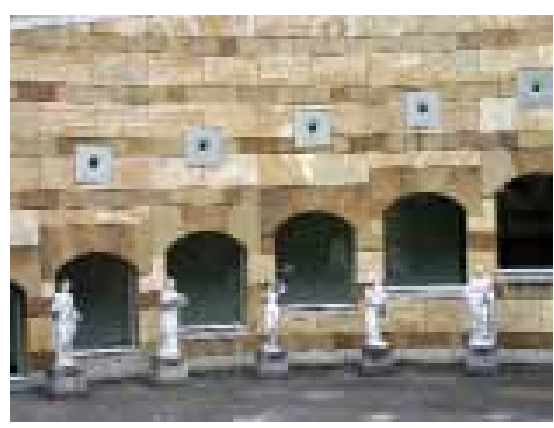

Fig. 112 vestíbulo y -bordeando $180^{\circ}$ del perímetro de esta rotonda- nos conduce a la sala de exposiciones temporales (cuyo acceso se enfrenta a la salida al patio) y a una escalera secundaria que permite la ascensión a las salas de exposiciones permanentes; por otro lado, su espacio ha sido conscientemente apartada del ascenso por la rampa y por el ascensor principal a la exposición permanente.

Si la rotonda fue en los ejemplos más importantes del museo decimonónico el gran espacio de orientación y distribución de recorridos, en este caso no sucede así: sus accesos no son frontales y sus visuales -que ofrecen variedad de puntos de vista desde itinerarios tanto internos como externos- han sido cuidadosamente seleccionadas. Se crea de este modo una ambigüedad relevante, que diferencia el museo de Stuttgart de sus precedentes compositivos, en tanto en cuanto caracteriza como periférico y accesorio un elemento que, por su componente simbólica histórico-colectiva, poseía en los museos tradicionales carácter central.

El baldaquino señala el punto desde el que el visitante puede subir al podio por escalera o por rampa. Es el umbral de la fruición de la arquitectura como experiencia plástica, visual. "Todo es arquitectura". Se disfruta a partir de ese punto de un paisaje al que no se es ajeno: el muro "ondulante que configura el acceso; el encuentro del mismo con el plano oblicuo que soporta la rampa que da pie al paso a través del edificio -disfrutando así de la escena del cilindro vacío- es muestra de este diseñar desde los opuestos tan frecuente en la obra del arquitecto inglés". Al itinerario que Moneo describe, podríamos añadir el gran patio circular enriquecido con una rampa encastrada en la pared interna del cilindro para recoser el complejo de espacios, alcanzando un dominio pleno sobre un contenido lenguaje monumental idóneo para representar la analogía entre los lugares escogidos para la celebración del recuerdo y los monumentos funerarios (Fig.112).

Hablamos siempre de la planta: con ella se trabaja, se teje y desteje la arquitectura. La sección está presente en cuanto que contribuye a escribir el paisaje. Desde ella la obra exhibe 
en su diagramática complejidad la precariedad de un hacer, consciente de las contradicciones, atento a los límites, pero que no renuncia a confrontarse con el cúmulo de imágenes del tiempo que cada ubicación urbana ofrece.

Respecto a las salas del museo, es pertinente hacer una serie de consideraciones. En la sala de exposiciones temporales, se opta por un espacio de planta rectangular con seis columnas ordenadas con respecto a sus ejes de simetría. Se trata de un espacio vacío que permite su adaptación para cada exposición temporal, que solamente posee luz artificial, cuya ubicación en

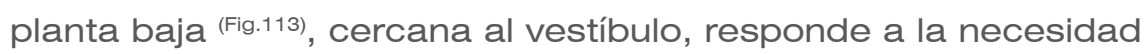
de una mayor accesibilidad que acorte el recorrido. En la planta superior, las salas de exposición permanente representan, como apunta Alan Colquhoun, "orden y serenidad en contraste con los espacios públicos de acogida y circulación. De diferente proporción y planta (el programa requería salas de 65 a 250m2 y de 4 a 6 metros de altura) se enlazan en enfilada a lo largo de tres brazos que conforman una planta en $U$. Ello permite la apertura de la terraza de escultura hacia el valle dominado por el emplazamiento. Las salas poseen iluminación cenital, resuelta mediante una entreplanta técnica que permite el control lumínico y el tendido y registro de todas las instalaciones. Al interior, se muestra un panel reticulado de vidrio translúcido (Fig.114), cuya imagen nos recuerda a la iluminación de los museos alemanes de finales del siglo XIX y principios del XX." (38)

Para Francesco dal Co (39) la arquitectura resultante es de gran complejidad al hacer convivir ideas tan diversas, contradictorias, como las nociones lecorbusieranas y el estatismo de formas clásicas que recuerdan a Schinkel. La planta, según el crítico italiano, es el resultado de incluir esta diversidad que da lugar a que en ella vivan a un tiempo simetrías y rupturas: figuras perfectas como el círculo y el cuadrado con ondulantes trazados pseudo-orgánicos; imágenes de la arquitectura histórica con otras ligadas a la tradición moderna como la importancia que se da a la iluminación cenital del museo. Junto a ello la innegable habilidad de Stirling en el juego de los deslizamientos y de las

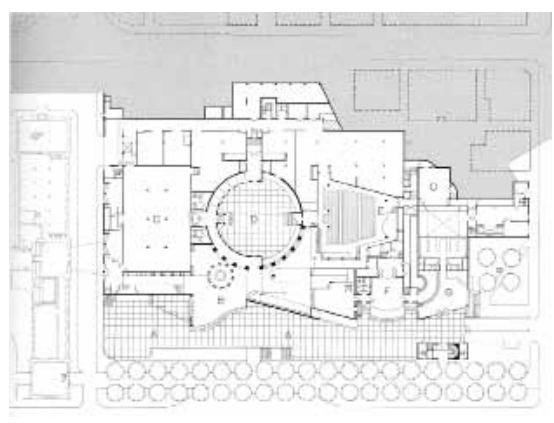

Fig. 113

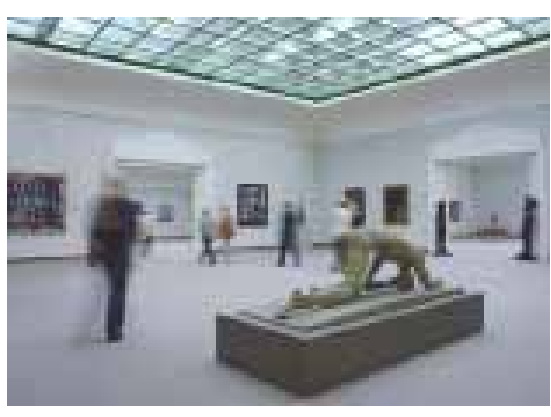

Fig. 114 s. 
distorsiones, en el uso de la ironía, citas, nuances, alusiones; continuidades espaciales que no son nunca miméticas sino alusivas y metafóricas.

El edificio cumple con su misión pero también participa en la redacción del texto que es la ciudad. Stirling busca como Rossi, que arquitectura y ciudad sean una misma cosa, pero de forma diferente.

Otro de los grandes arquitectos que se ha ocupado de la resolución del programa del Museo en diversas ocasiones es Rafael Moneo. Su amplia y dilatada experiencia incluye edificios tan significativos como el Museo Nacional del Arte Romano de Mérida (1980-1986), La Fundación Pilar i Joan Miró de Palma de Mallorca (1987-1992), el Museo Thyssen-Bornemisza de Madrid (1989-1992), el Davis Museum, Wellesley College en Wellesley -Massachussets- (1989-1993), el Museo de Arte Moderno y Arquitectura de Estocolmo (1991-1998), el Museum of Fine Arts, edificio Audrey Jones Beck, en Houston -Texas- (1992-2000) o la reciente ampliación del Museo del Prado en Madrid (19982007). Esta extensa experiencia se verá pronto enriquecida con la construcción del proyecto de Museo de Arte de la Universidad de Navarra, que albergará la colección donada por María Josefa Huarte en 2008 así como el legado del fotógrafo José OrtizEchagüe.

De entre sus numerosos museos y proyectos, vamos a describir solamente algunos de ellos, en sus aspectos relacionados con la tesis expuesta en estas líneas: la pervivencia y adaptación de los espacios expositivos tradicionales. Nos interesan de la arquitectura de Rafael Moneo tres aspectos fundamentales: el razonamiento disciplinar de acercamiento al proyecto, los sensibles vínculos que establece con el lugar y la utilización de espacios expositivos definidos e iluminados cenitalmente.

El Moderna Museet de Estocolmo representa un proyecto de ampliación de un primitivo museo construido en 1958. Se halla en la isla de Skeppsholmen (Fig.115), en el antiguo enclave 
tradicionalmente ocupado por la armada sueca; su posición privilegiada permitía la defensa de la ciudad. Durante el siglo XX perdió importancia, debido fundamentalmente a los cambios en las estrategias defensivas navales. El museo que Moneo proyecta forma parte de una operación cuyo fin es la revitalización de la isla por medio de un uso público y cultural. Como veremos, el análisis ordenado y metódico del entorno es una de las principales estrategias de acercamiento a la resolución del proyecto de arquitectura en Rafael Moneo. En este caso, en el que nos extendemos algo más por considerarlo paradigmático, dos aspectos suscitan un arranque del proceso: la accidentada superficie de la isla y la multiplicidad de arquitecturas exentas cuyo conjunto presenta una fragmentada volumetría (Fig.116). En palabras de nuestro admirado arquitecto: "Construir en Skeppsholmen desde la interpretación de la ciudad implicaba respetar la condición pabellonaria de la arquitectura de la isla, por que lo sustantivo de aquella arquitectura radicaba en su autonomía, en su capacidad de situarse en las escarpadas laderas como edificios exentos. Pero la dimensión del museo que se deducía del programa no daba pie a proyectar un edificio exento de proporciones reducidas, un edificio que cupiera asociar a un único pabellón". (40)

Nos atraen la coherencia y claridad de los depurados razonamientos de Moneo y el carácter indisociable de sus arquitecturas respecto de sus emplazamientos; también la reflexión acerca del carácter disciplinar de la arquitectura y de la aproximación metódica al problema que plantea siempre la hoja en blanco del proyecto de arquitectura. La inclusión de esa hoja en blanco en un texto que otros ya han escrito con carácter previo es una característica de una arquitectura que, atenta a los condicionantes del emplazamiento y del programa, propone una continuidad cultural y evita la arquitectura puramente autónoma, fuente de innumerables dislates y desencuentros con la ciudad histórica. El trabajo del arquitecto navarro arranca de la realidad y valora la tradición como fuente de experiencia y conocimiento, cuya investigación evita la malversación del gran acervo cultural

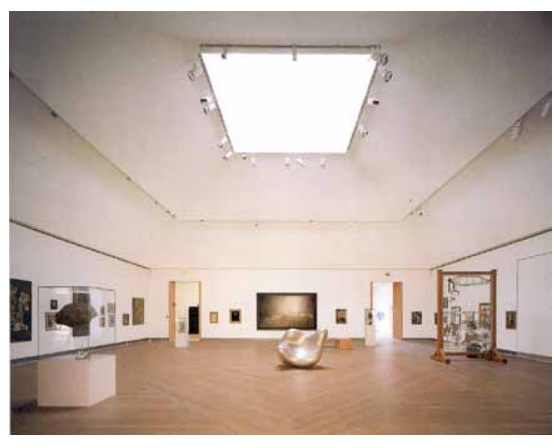

Fig. 116 


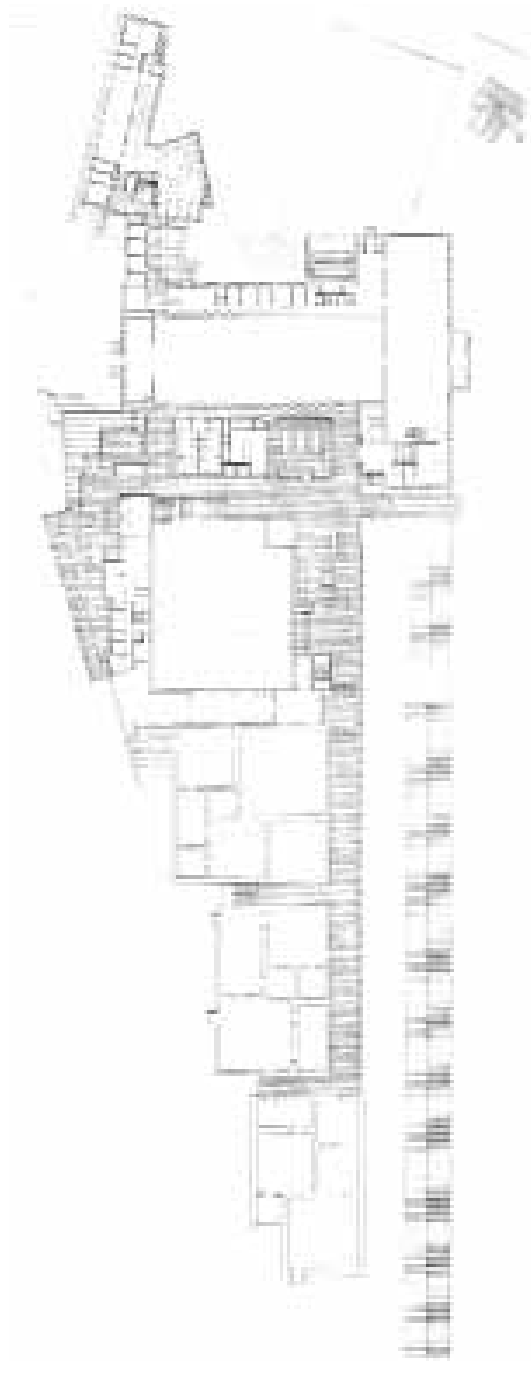

Fig. 117 arquitectónico adquirido históricamente. Adscritas a este procedimiento, las salas de exposición de Estocolmo evocan, mediante los lucernarios y por medio de la diversidad de tamaños y formas en planta (Fig.117), a aquellas legadas por la Historia de la Arquitectura. El lucernario del museo de Estocolmo, en palabras del autor, no es solo un sistema que permite la iluminación del interior de las salas; representa un mecanismo formal por el cual se permite tanto fragmentar el volumen para su adaptación a los objetivos establecidos en el análisis como para resolver la transición entre los paramentos verticales y las cubiertas. Es destacable el hecho de que en su última publicación, Apuntes sobre 21 obras, Moneo disponga junto a la imagen de las salas de su museo de Estocolmo el dibujo de la sección transversal de la casa-museo de John Soane (en concreto aquella realizada por los espacios expositivos), así como una fotografía de la cubierta de dicho espacio y otra fotografía de la enfilada central de salas de la Dulwich Picture Gallery. No olvida el arquitecto que, apoyados en la constatación de que el origen del Museo se halla en el Palacio del coleccionista, la sucesión de salas y su preferente disposición regular están en la base de los espacios expositivos, como bien entendieron maestros como sir John Soane. Esta concepción ya la había considerado Moneo en anteriores proyectos: véase, al respecto, la nueva distribución interior del Palacio de Villahermosa para albergar el Museo ThyssenBornemisza. Tras el vaciado interior del edificio perpetrado en los años 70 del siglo $\mathrm{XX}$, no dudó nuestro arquitecto en producir un orden de salas expositivas que evocaran, pues no podía ser de otra manera, el palacio del coleccionista, mediante un sistema formado por muros, pasos entre ellos y una cubierta que permitiese la iluminación cenital.

En la propuesta que desarrolla para el Museo de Bellas Artes de Houston, entre 1992 y 2000, el arquitecto reflexiona acerca de los tipos de salas y de sus formas de iluminación. De acuerdo con el análisis del lugar, opta por una arquitectura de tipo compacto, cuyos lienzos de fachada se alinean con los límites de propiedad. En cubierta, sin embargo, es donde despliega su 
máxima capacidad expresiva; la variedad y disposición de los volúmenes de los lucernarios ofrece un interesante contraste

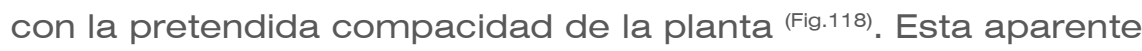
eventualidad del aspecto de la cubierta posee una necesaria ligazón con la distribución de la planta, que se vislumbra a través de las relaciones que se producen entre sus emergentes cuerpos. Las salas, dispuestas en la planta baja y en la planta primera, albergan las exposiciones temporales y permanentes, respectivamente.

Una gran variedad de formas en planta y en sección (Fig.119) conforman un conjunto de espacios expositivos cuyas estudiadas secuencias son fruto de la existencia de tres colecciones diferentes, cuyos itinerarios expositivos, implícitos en la planta, no son evidentes en una primera apreciación. Las salas, a menudo en enfilada, ofrecen una visión canónica y codificada, ampliamente reconocible, del espacio de más honda tradición expositiva junto a la rotonda: la galería. La organización expositiva, como se muestra en algunas fotografías del interior del museo, ha acentuado la contemplación de algunas piezas relevantes colocándolas sobre peanas en el eje de la enfilada. No obstante, la apreciación secuencial del espacio es ineludible y sus referencias a la arquitectura expositiva inglesa es insoslayable. En todo caso, un examen del corte longitudinal del museo de Houston nos rememora la sección, tan presente en el tablero del arquitecto, de la casa del 12 de Lincoln's Inn Fields.

La resolución formal de una arquitectura que organiza sus espacios mediante muros -en cuyo adicional espesor se inscriben las necesarias instalaciones ocultas- confía la resolución de la iluminación de los espacios expositivos a cuidadísimas y estudiadas soluciones que, como las instalaciones que permiten el funcionamiento del edificio, se ocultan a los ojos del visitante. Alejado de exhibicionismos tecnológicos y pseudo-industriales, la arquitectura de Moneo cede así todo el protagonismo a la razón de ser del museo: la adecuada exhibición y contemplación de las obras de arte.

La arquitectura de Rafael Moneo siempre suscita una

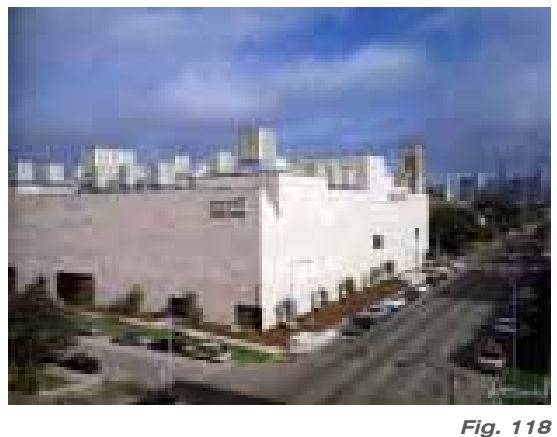

Fig. 118
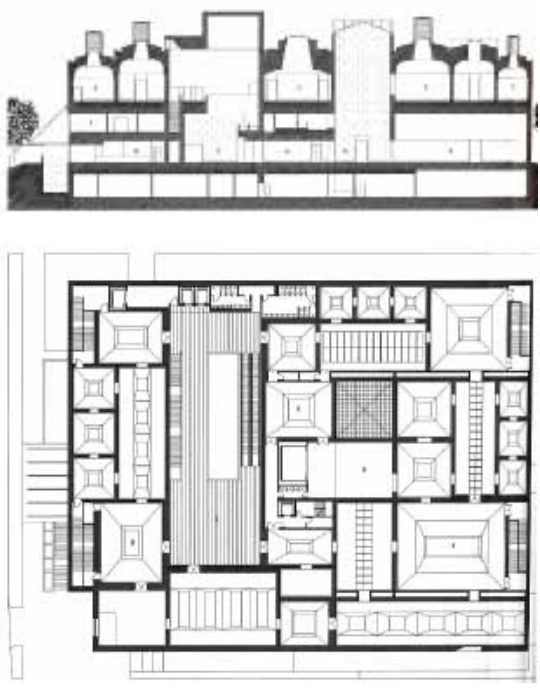

Fig. 119 
reflexión acerca de los valores culturales e históricos que posee la arquitectura. Sus proyectos se inscriben en el devenir de la disciplina: establecen un juicio sobre la arquitectura anterior y proponen una arquitectura para el presente en cuya base está presente una razonada elección entre las numerosas posibilidades que el proyecto de arquitectura ofrece y sugiere.

Recordamos, a modo de breve escolio, que contemporáneo al Museo de Estocolmo fue construido e inaugurado el Museo Guggenheim de Bilbao, ejecutado según proyecto de Frank Ghery. Ambos museos fueron paradigmas de diferentes quizás opuestas- vías de aproximación a la arquitectura y su comparación tuvo incluso hondos efectos mediáticos. Como ejemplo, valga señalar que ambos museos fueron tratados de modo monográfico en el primer número de una nueva revista sobre arquitectura que nació en noviembre de 1998. Se trata de la revista Pasajes, Arquitectura y crítica, que tomó en consideración ambas propuestas como reclamo iniciativo de su ya fructífera trayectoria. Contrariamente a lo que algún lego pudiera suponer, en la portada no figuró el nuevo museo bilbaíno: en primer plano de la portada, apareció un muro de ladrillo, con una pequeña abertura, tras el cual emergía un remate de una de las salas expositivas del museo de Estocolmo. Una imagen que elude la representación de lo monumental y sugiere un modesto carácter, que vaticinaba -a mi entender- el espíritu de la revista: una gran economía de medios aunada a una amplia riqueza conceptual.

En la línea de lo que comentamos, anotemos una breve mención de los espacios expositivos del Guggenheim: el desbordado movimiento, la complejidad volumétrica y la irregularidad que sus torzonadas superficies metálicas inducen en los espacios internos, se concentra en los espacios de acogida -el atrio- y en los servicios que con carácter periférico se adosan a las salas de exposición, cuyo tradicional carácter y rectangular geometría son eludidos en la difusión y publicidad que del museo se realiza: no aparecen el las fotografías del célebre y aclamado museo. Tan solo la gran sala longitudinal 104 Arcelor-Mittal -ampliamente fotografiada y difundida-, 
presenta una cierta irregularidad que se muestra, de una forma capciosa, como paradigma de una modernidad formal -todo que ficticia- de los espacios expositivos del museo. En realidad, las grandes dimensiones de la sala (en la que se puede inscribir aproximadamente un rectángulo de $30 \times 130 \mathrm{~m})$, hacen que sus pretendidas irregularidades sean absolutamente superfluas en el correcto funcionamiento de una tradicional galería iluminada -aunque de forma pobre y escasa- de forma cenital.

La ampliación de la National Gallery de Londres, la nueva Staatsgalerie de Stuttgart y el Museo de Bellas Artes de Houston son tres ejemplos que pertenecen a un periodo de gran actividad en la construcción de museos. Estos tres ejemplos comportan una revalorización de los espacios expositivos definidos, acotados y reconocibles.

Especializado en la construcción de museos, aparece otro relevante arquitecto del cual ya hablamos cuando explicamos algunas de las propuestas que suscitaron la aparición del llamado "contenedor". Renzo Piano, está vez sin su compañero del Centro Pompidou Richard Rogers, ha construido numerosos edificios en la resolución del programa de museo. El primer encargo que Piano construye en los estados Unidos corresponde al Menil Collection Museum, edificio cuyo objeto es la conservación y exhibición de la colección privada de John y Dominique Menil. El matrimonio, exiliado en Estados Unidos a causa de la ocupación nazi de Francia durante la segunda guerra mundial, estableció su residencia en Houston, donde actuó como patrono y animador de la vida cultural de la ciudad. A la vez que John y Dominique ampliaban su colección de obras de arte, patrocinaban a los arquitectos "modernos", como Louis Kahn o Philip Johnson. El interés de los mecenas en el arte contemporáneo, en las antigüedades clásicas mediterráneas y bizantinas, así como en los objetos de arte y artesanía de culturas africanas y de Oceanía, orientaron la creación de esta importante colección. En el año 1972 encargaron a Louis Kahn el diseño de una galería de arte, proyecto que se vio truncado por la muerte del mecenas y, poco tiempo después, del arquitecto. Hubo que esperar a la década 
de los ochenta del pasado siglo para que Dominique de Menil retomara la idea original del museo, que fue encargado a Piano.

Años de reflexión suscitaron un tipo de museo que por un lado se integra en su contexto urbano y por otro responde a una concepción museográfica que difumina los límites entre la exhibición temporal y permanente.

El museo se emplaza en un contexto suburbano, definido por una serie de calles ortogonales arboladas en las que existen una serie de "bungalows", viviendas unifamiliares, de los años 20-30, que fueron compradas por la propiedad junto a una gran extensión de terreno, en el que se suceden diversas arquitecturas y conjuntos escultóricos al aire libre. Destacan en el conjunto la Rothko Chapel, obra de Philip Johnson, la Bizantine Fresco Chapel Museum o la Cy Twombly Gallery, también diseñada por Piano en 1995. El edificio que proyectó Piano responde pues a la pequeña escala de las viviendas unifamiliares tanto como al carácter representativo que la secuencia de edificios de uso público establece.

Se trata de un edificio de planta rectangular que se desarrolla

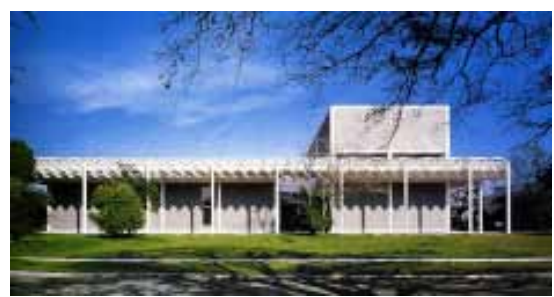

Fig. 120 principalmente en planta baja; su carácter horizontal se refuerza con la alineación paralela al vial al que da frente por medio de un pórtico que suaviza el cambio de escala con respecto a las

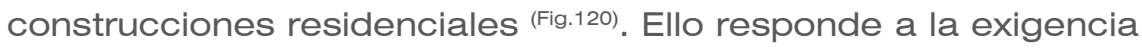
de la promotora, resumida en su conocida fórmula "a museum that would look small on the outside, but be as big as possible inside". El carácter exento y períptero del edificio refuerza también la condición de homogeneidad en el tratamiento de las fachadas, que no distingue entre principales y secundarias. Esta elección revierte en la falta de monumentalidad -matizada como explicaremos- y redunda en el carácter doméstico del edificio, que se muestra también, por ejemplo, en el tamaño y forma de las ventanas de las oficinas del cuerpo longitudinal de planta primera.

Dado que el edificio se integra en un campus o conjunto de edificios y espacios abiertos que complementan sus funciones, 
se aligeran las exigencias del programa. En planta baja, el volumen paralelepípedo se organiza en tres franjas paralelas: exhibición, circulación y servicios como biblioteca o recepción (la tienda está fuera del edificio, en las edificaciones que se hallan en el itinerario que desde el aparcamiento conduce

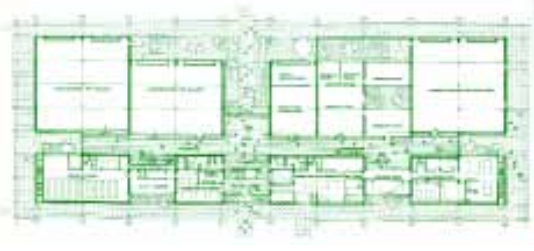

Fig. 121 al acceso principal) (Fig.121). Posee una planta sótano que tiene unos almacenes generosos así como talleres de restauración y otros usos internos. Finalmente, la planta primera alberga oficinas propias de la institución. El acceso se produce de forma perpendicular a las franjas organizadoras de la planta, casi en su punto medio -no puede ser centrado en un pórtico que presenta once columnas y diez vanos-, y en él se establece un recorrido que viene marcado por una sucesión de elementos: el paso encintado de piedra, el pórtico cubierto, el patio descubierto, un nuevo espacio cubierto de antesala y las puertas de acceso, totalmente acristaladas y dispuestas en un plano avanzado al propio del espacio de circulación.

En relación al modo de exposición de las piezas, la

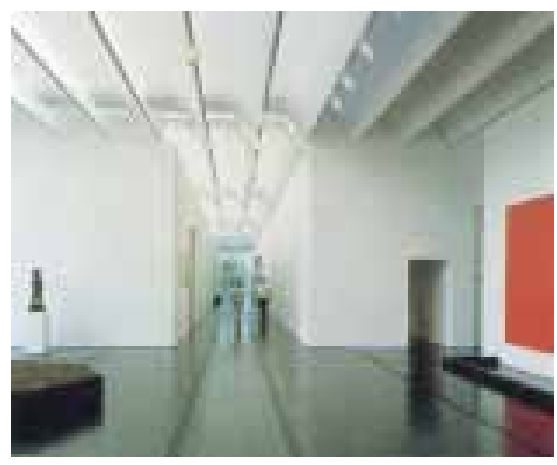
propiedad deseó un tipo de museo con iluminación natural de alta calidad en el que las piezas de la colección permanente se exhibieran de modo temporal, resultando una forma de exhibición cambiante. Para conseguir esta iluminación, Piano diseñó una lama orientable de ferrocemento en la que se integra la estructura de cubierta, el acceso y control de la luz natural, la iluminación artificial y otras instalaciones (Fig.122). La disposición -en sección- de la planta primera sobreelevada sobre la cubierta de la planta baja permite la iluminación cenital de toda la planta baja a través de la disposición repetida del elemento configurador de cubierta; las salas de exposición, de planta rectangular e iluminación cenital, responden a espacios expositivos tradicionales ejecutados con modernas técnicas constructivas. Algunos críticos han sugerido evocadoramente que el edificio se genera a partir de la repetición de un solo elemento "tecnológico", lo que, a tenor de la complejidad del conjunto ideado por los Menil, es inexacto, superficial e injusto. No cabe duda de que la lama se utiliza de manera insistente 


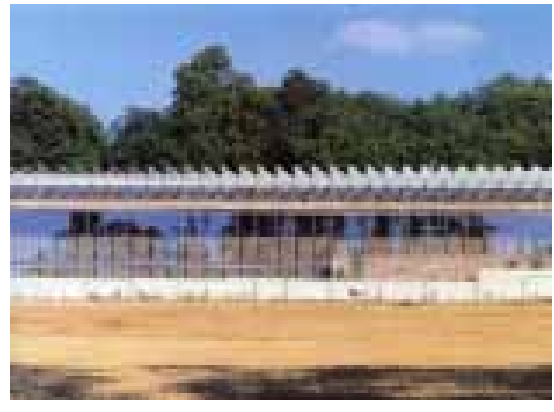

Fig. 123 en la resolución formal del edificio, y de que voluntariamente su forma representa e identifica al Museo, a modo de icono del mismo. No obstante, lo que sí es cierto es que la repetición de este elemento permite la resolución de la cubierta de la planta baja del edificio y una esmerada respuesta -quizá excesiva- al requerimiento de iluminación cenital para la exhibición de obras de arte de una galería expositiva tradicional.

El museo Beyeler, proyectado y construido por Piano en Basilea, puede considerarse como una evolución del esquema en planta ideado para Houston. Se trata de un volumen prismático apaisado (Fig.123), organizado por medio de tres líneas paralelas: una estrecha franja de servicios, un espacio de circulación ensanchado en su parte central aproximada- y una crujía de mayor anchura global en la que se disponen las salas. Éstas también responden a espacios definidos, regulares, acotados, de planta rectangular; sus variadas dimensiones responden a la utilización de un módulo constructivo, y se insertan o pervierten la lógica que establecen los cuatro muros revestidos de pórfido de la Patagonia. En opinión del arquitecto, sus diferentes medidas responden a la voluntad de evitar un "recorrido monótono". Las salas se iluminan cenitalmente y, del mismo modo que en la Menil Collection, presentan un lucernario continuo en toda su superficie de cubierta. El sofisticado sistema se erige en protagonista, y configura una quinta fachada vítrea, ampliamente mostrada por Piano en las diversas publicaciones sobre su obra.

No podemos dejar de lado la relación del edificio con el lugar que se realiza mediante una serie de muros de piedra paralelos y alargados que van salvando la suave pendiente en ascenso del pintoresco enclave. Desde esta evocación de las terrazas de cultivo mediterráneas la inserción arranca de unos campos de cereales hasta alcanzar el parque natural. Los paramentos de pórfido, coronados por "espinas" de vidrio no hacen sino recordar nuestras antiguas tapias coronadas de fragmentos de cascos de botella.

Finalmente, en el centro de arte Botín en Santander, proyecto de reciente finalización, Piano vuelve a proponer dos 
grandes salas a doble altura cuya funcionalidad expositiva se confía a proyectos de adecuación para cada muestra, utilizando al respecto paneles y mamparas móviles. De nuevo, como acaeció en 1971 en París, el arquitecto italiano apela al concepto de "flexibillidad" como garantía de éxito en la exhibición de piezas de arte contemporáneo.

\subsubsection{Pequeños museos atentos al lugar}

Desde los años ochenta del siglo XX y hasta la actualidad se produce, en paralelo al desarrollo de grandes programas públicos de museo, un importante auge de pequeñas galerías y reducidos museos que alcanza hasta esta segunda década del siglo XXI. Diversos motivos han propiciado el importante aumento de su número: muchos de ellos corresponden a iniciativas de pequeños municipios alejados del circuito artístico, que en ocasiones surgen vinculados a una colección de algún personaje que la lega a una institución, compuesta en gran medida por la producción de un artista, local o relacionado con este lugar; otros manifiestan la voluntad de un pequeño coleccionista privado de exhibir, bien sea de forma semipública o bien de manera privada, la selección de obras que atesora; también son fruto de la iniciativa de un artista concreto y algunos casos pertenecen al conjunto de exquisitas ampliaciones producidas en reducidos museos de ciudades secundarias.

Uno de los edificios paradigmáticos es la Goetz Art Gallery (Fig.124), que diseñaron en torno a 1989 los arquitectos Herzog y de Meuron en Munich, Alemania. Se trata de un edificio exento en el jardín de una vivienda unifamiliar suburbana. Es un volumen rectangular de extremada sencillez y delicados acabados; su alzado se divide en tres franjas, siendo la central -opaca, de paneles de contrachapado de abedul- de doble anchura que las bandas superior e inferior, ambas construidas en vidrio mate. El

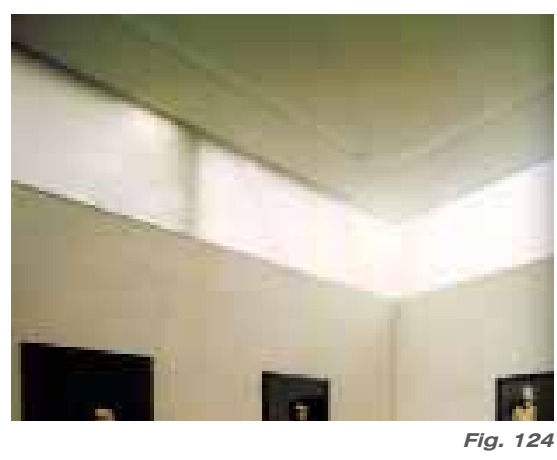
pequeño edificio alberga, en su interior, dos niveles principales que corresponden a sendas salas expositivas. La clave del proyecto está en su sección: mediante dos breves escaleras de un tiro, idénticas y dispuestas la una sobre la otra, se accede a las dos salas citadas: una en el sótano y otra en la planta primera. 


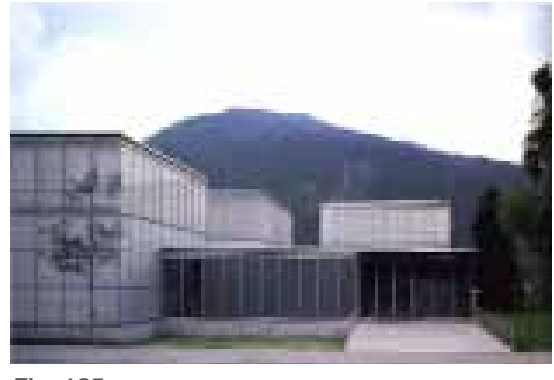

Fig. 125
Ambas tienen doble altura (entre 4,50 y 5,00 metros), adecuada para la exhibición de obras de arte; en ambos casos se iluminan casi cenitalmente a mediante la franja de vidrio mate perimetral aludida en la descripción de sus alzados. La sala superior se divide en tres espacios de similares dimensiones; la correspondiente al sótano en dos de diferente planta. Desde estas salas se puede acceder a los dos almacenes. El acceso se dispone en planta baja, en una suerte de mezzanine o entreplanta, que vincula las escaleras a este reducido espacio de acogida. La celebrada Galería Goetz propone una reflexión sobre la pequeña escala y su apuesta por los espacios expositivos tradicionales y contenidos bascula la fuerza expresiva del proyecto a la resolución formal y constructiva de sus escaleras y del exterior de su volumen.

También de exitosa crítica y gran aceptación fue el museo Kirchner de Davos (Fig.125), diseñado por el equipo suizo Gigon \& Guyer en las mismas fechas que el anteriormente comentado. En este caso, se trataba de construir un pequeño museo para la exposición de la obra del pintor expresionista Ernst Ludwig Kirchner. Fundador de Die Brücke, se retiró en esta pequeña ciudad suiza en 1917 y pasó en ella el resto de sus días. Se trata de un pequeño edificio de planta baja y sótano, que como hemos visto en otros museos, duplica su superficie mediante una planta enterrada. Este procedimiento persigue el doble objetivo de presentar un volumen reducido (en referencia a su superficie) por consideraciones de adecuación al entorno, de modo que permite también el tratamiento libre del volumen del edificio, como en el caso que nos ocupa. En efecto, el Museo de Davos se configura a partir de la disposición sobre el plano del suelo de seis paralelepípedos separados, que corresponden a cuatro salas de exhibición y a dos de menores dimensiones que albergan servicios del museo; su posición relativa define los espacios públicos de acogida y circulación, de modo que son los cerramientos vidriados del perímetro los que los terminan de acotar y definir. En volumen, las salas muestran el protagonismo que tienen en la composición de la organización funcional del museo y emergen del plano de cubierta que define el espacio 
de circulación. La iluminación de las salas es, también, cenital. Interesa este caso por la estrategia de proyecto que, en vez de unir salas a través de diversos ejes compositivos, establece la posición y magnitud de las salas como hipótesis inicial sobre la que se asienta el resto del museo.

Siguiendo con la experiencia centroeuropea, el centro Pasquart (Figs.126-127) proyectado por Diener und Diener se inserta en este conjunto de pequeños museos ubicados en reducidas ciudades. Se trata de una ampliación proyectada en el año 2000 , de un edificio longitudinal construido en dos fases, 1866 y 1955 , a lo largo del Faubourg du Lac en la localidad suiza de Bienne. Un volumen cúbico, aristado, que contiene las salas expositivas, se alinea con la edificación existente frente al vial principal; en la parte

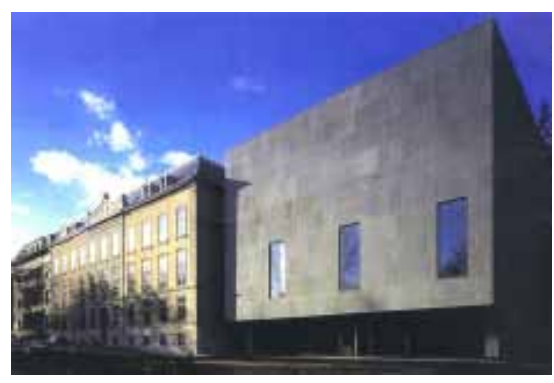

Fig. 126 trasera, se resuelven los espacios de servicio y de comunicación vertical. Como en muchos otros ejemplos, la sección representa un papel crucial en la resolución del programa. La introducción del sótano permite cumplir con las previsiones de usos internos requeridos sin provocar un aumento del volumen exterior y la supresión de uno de los tres niveles de la edificación original resultando pues dos en el bloque ampliado- permite una altura de sala de alrededor de 6 metros, adecuada para los usos expositivos. Las salas proyectadas responden a un programa de exhibición temporal. Es por ello que las de la planta primera iluminadas por un lateral- corresponden a la división tripartita del rectángulo de la planta, mientras que en planta segunda -con luz cenital- una única sala de $365 \mathrm{~m} 2$ permite la adaptación de instalaciones artísticas que incorporan nuevas tecnologías.

Inscrito en el conjunto de pequeños museos europeos de finales de los ochenta e inicios de los noventa, cabe citar

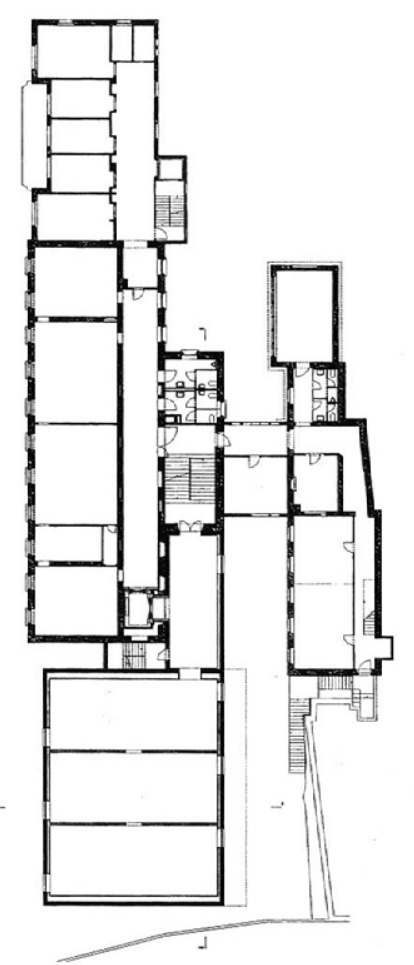
el celebrado Museo de Arte de Breguenz (Figs.128-129), obra de Peter Zumthor. Representa un ejemplo icónico de un tipo de arquitectura de volúmenes puros y de gran contención formal, cuyo reducido repertorio de materiales empleados obliga a una resolución esmerada del detalle constructivo. Consta de dos edificios autónomos, cuyas funciones y materialidad están claramente diferenciadas. Un volumen rectangular apaisado 


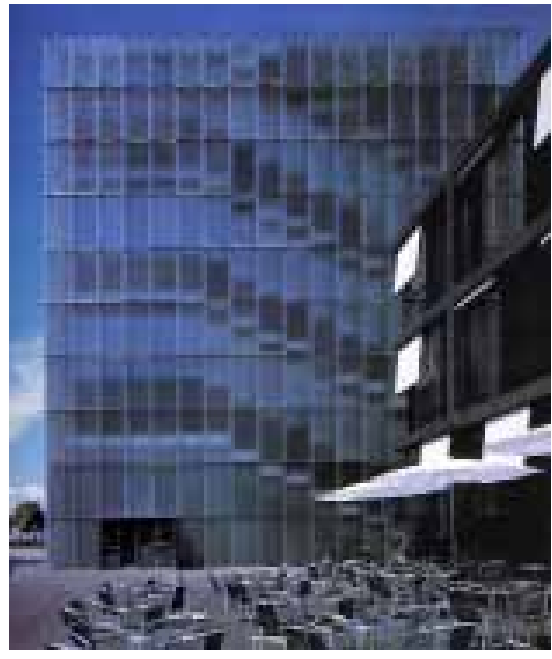

Fig. 128

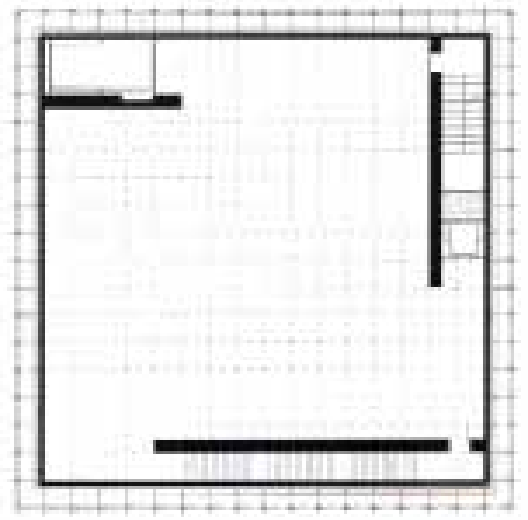

Fig. 129 alberga los usos administrativos -en plantas altas- y los usos de cafetería y librería en la planta de acceso; está compuesto según un esquema de lleno-macizo que otorga al vano la mitad de la superficie de fachada, mientras muestra claramente mediante fajas horizontales sus tres plantas. Su color negro busca un contraste con el otro volumen autónomo del edificio, de proporción vertical, que corresponde con la imagen más difundida del museo: un prisma vítreo, de gélidas reminiscencias, que da frente al puerto deportivo y paseo existentes a orillas del lago Constanza. De absoluta claridad y limpieza en su dibujo, su planta parte de un cuadrado el que la posición de tres muros resuelve la estructura sustentante y los núcleos de comunicación vertical, que de forma centrífuga se inscriben en el perímetro del edificio. Los cerramientos se constituyen con una doble capa de vidrio; una exterior que configura la imagen del edificio y cuyos paneles de vidrio se imbrican solapándose, permeables a la circulación e intercambio con el exterior del aire de la cámara; una piel interior aísla el espacio museístico y es la garante del confort y de las prestaciones requeridas. Una única sala por planta ocupa el espacio central del cuadrado y dispone de unos muros de hormigón perimetrales que no alcanzan la altura libre del mismo; la diferencia entre su cota de coronación y la correspondiente a la cara inferior del forjado permite una iluminación, -a través de un falso techo de vidrio opal- controlada, de carácter difuso y homogéneo, que recrea y rememora la iluminación cenital de los espacios expositivos tradicionales. Estos muros, además, permiten una ampliación de la superficie vertical expositiva y muestran -en una suerte de sinceridad constructiva y recato formal-la superficie del hormigón en la que están construidos. En todo el edificio se genera un rechazo a la acumulación de elementos constructivos estratificados de función única, de modo que se procura la reducción de su número con el objetivo de formalizar una arquitectura de líneas y planos puros que minimice la presencia de la junta constructiva.

El museo de Arte de Liechtenstein en Vaduz (Figs.130-131), proyectado por Morger, Degeloo \& Kerez, significa dentro de los 
museos de pequeñas ciudades uno de los que mayor atención han prestado al recorrido. Se trata de un volumen prismático, de aristas vivas, que presenta una uniforme y opaca superficie. En una de sus esquinas sitúa una superficie acristalada que nos informa del acceso, en la única relación visual entre el interior y el exterior del edificio. Desde este vestíbulo se establecen dos alternativas de visita y recorrido: o bien se visitan las dos salas de exposición temporal de planta baja y se asciende a través de una escalera lineal a las salas de exhibición permanente de la planta primera, o bien se asciende por otra escalera lineal de igual dirección y distinto sentido que nos conduce a la visita de la colección permanente del museo. Estas dos escaleras, cuyo superficial análisis nos podrían llevar a adjetivar como simple gesto formal, son el realidad la clave de la elección de los itinerarios de visita y por lo tanto no son accesorias sino fundamentales. La rotundidad de su forma, la regularidad de las salas, la claridad de su composición en planta, la limpieza en el trazado de las instalaciones y la exquisitez en la elección y proceso de los materiales empleados, hacen de este pequeño museo uno de los más brillantes y paradigmáticos del conjunto en el que se inserta, en el que la moderación expresiva y la contención formal son consideradas como virtudes basilares del proyecto.

Otro de los pequeños museos que han considerado el recorrido como un axioma de proyecto es el Museo de Arte y Diseño de Ingoldstadt (Fig.132), diseñado por Gigon \& Guyer en el año 2000, y que contempla una ampliación de un antiguo edificio defensivo al que se le añadió un depósito de agua. Justificado en atención a la ciudad de Ingolstad, los arquitectos plantean un recorrido circular para el volumen capaz de contener los nuevos espacios expositivos. Los usos administrativos y comerciales se disponen en el edificio histórico mientras que la función expositiva se reserva para la nueva edificación. Ésta se materializa por medio de dos prismas de orientación vertical que, situados en las esquinas opuestas de un rectángulo en planta, unes sus bases y sus coronaciones por medio de dos cuerpos en forma

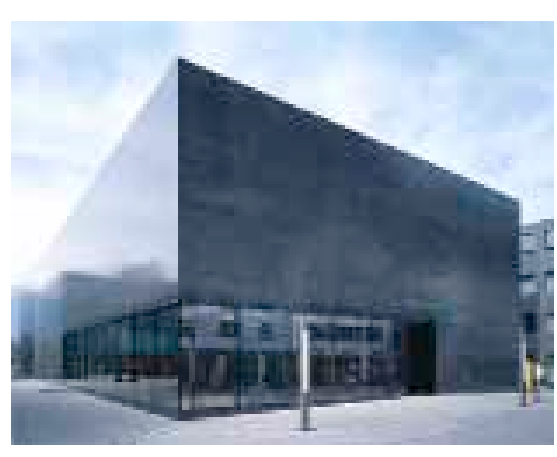

Fig. 130
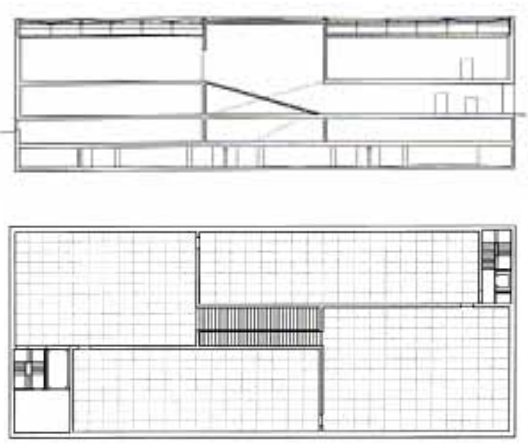

Fig. 131

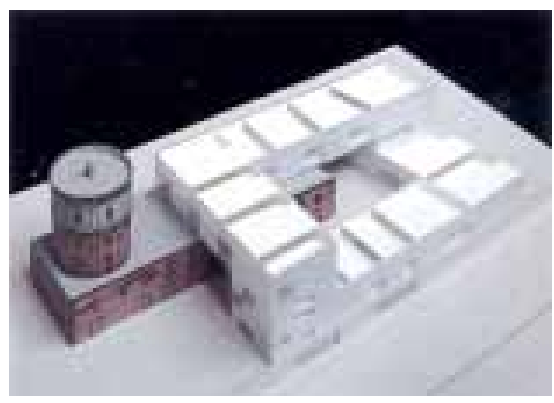

Fig. 132 
de ele, situados lógicamente a diferente altura: la primera $L$ en planta baja conecta sus bases; una segunda en planta cuarta comunica sus testas, de modo que una apreciación cenital del conjunto ofrecería la figura de un rectángulo. El nuevo edificio establece una relación volumétrica intensa con el viejo, al disponer volado sobre el mismo el segundo bloque en forma de L. El recorrido se inicia en una de las "torres", en su planta baja, y nos indica el itinerario a través de la primera "L" hasta llegar a la base del segundo prisma. Un núcleo de comunicación vertical nos permite el ascenso a las plantas segunda y tercera, en las que existen dos pequeñas salas en cada una de ellas. Una vez ascendidos a la cuarta sala, seguimos el recorrido a través de la siguiente "L", cuyo fin corresponde al remate del primer prisma. Descendiendo por la escalera o ascensor situados en este punto, regresamos al punto de acceso. Las salas de este museo, de reducidas dimensiones, nos recuerdan a los gabinetes acotados cuya función correspondía a la exhibición de obras de arte de pequeño formato. Sus modos de iluminación, lateral o cenital, mantienen la tradicional diferencia entre los modelos originales alemanes e ingleses.

Por último, el museo Ibero-Camargo (1998-2008) que ha construido Álvaro Siza en Portoalegre es una muestra de la trascendencia del recorrido en la resolución del proyecto y de la pervivencia y reinterpretación de los espacios expositivos codificados. De gran complejidad y de una potencia formal inusual, la gran escultura que el exterior de este edificio nos muestra se debe a tres factores primordiales, que pasamos a enumerar: la creación de un recorrido espacial en torno a un espacio central, vacío, que nos evoca a la rotonda "en negativo" que Stirling diseñó para Stuttgart; la imbricación de las salas de exposición y de unas suaves rampas de ida y vuelta en el itinerario, de modo que las salas tienen el doble de altura libre que el espacio interior de las rampas; y por último, la alternancia en el paseo desde el acceso de un recorrido horario en la visita a la primera planta, un recorrido antihorario en la segunda y finalmente un nuevo recorrido horario en la visita a la tercera 
planta. Las salas, rectangulares, espacios canónicos de exposición, son ajenas a las orgánicas formas que las rampas de conexión entre niveles organizan junto al vacío del espacio de acogida. Sin embargo, a diferencia de otros ejemplos de vano formalismo, sus salas participan en el recorrido, de suerte que la ondulante forma exterior se genera por las alternancias en el sentido de los itinerarios que las incluyen. Esta estrategia de proyecto, que a la resolución formal de un impecable trabajo de

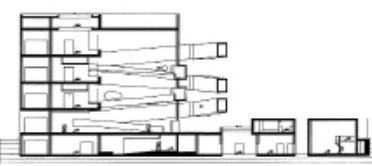
planta aúna una brillante sección (Fig.133), inscribe con naturalidad los espacios expositivos como una premisa de proyecto y no como una posterior adición necesaria a complejas geometrías, fruto de decisiones formales apriorísticas, en las que las dibujadas aristas de las salas expositivas inscritas con posterioridad laceran y zahieren las voluptuosas y exuberantes formas de una pretendida arquitectura redentora.

En los casos observados se reconoce una multiplicidad de articuladas tipologías de forma claramente identificable que, sin ajustarse a un esquema preconcebido, se plantean simultáneamente en experiencias diversas que enriquecen y transforman las tradicionales trazas del museo.

La arquitectura del nuevo templo laico del arte, adaptado a los parámetros actuales, al contribuir a la interpretación de las obras de arte -dándoles el entorno adecuado a la lectura que de ellas se propone- queda directamente comprometida en la operación cultural que el museo representa, debiendo asumir, al mismo tiempo, la precariedad de las hipótesis desde las que trabaja y la insuficiencia de cualquier pretendido fundamento científico a su labor técnica. 


\section{NOTAS}

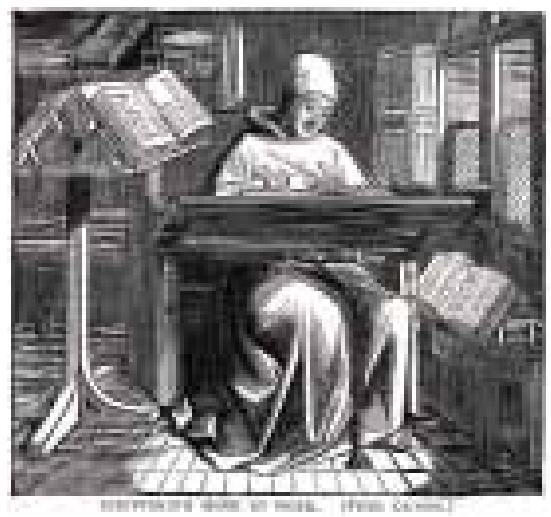

(1) Searing, Helen, "Ipotesi sullo sviluppo delle tipologia del museo", Lotus International 55, Nouvi Musei, Ed. Electa, Milano, 1988, pp. 118

(2) Ignasi de Solà-Morales, "De la autonomia a lo intempestivo", Diferencias, topografia de la arquitectura contemporánea, Barcelona, Editrial Gustavo Gili, 2003, pp. 97

(3) Ignasi de Solà-Morales, "De la autonomia a lo intempestivo", Diferencias, topografia de la arquitectura contemporánea, Barcelona, Editrial Gustavo Gili, 2003, pp. 98

(4) Rykwert, Joseph, "El culto al museo, del tesoro al templo", en Arquitectura y Vivienda (AV) 18, MayoJunio1998, pp. 4-11

(5) Waterfield, Giles, Palaces of Art, Art Galleries in Britain 1790-1990, London, Ed. Dulwich Picture Gallery, 1991

(6) Collins, Peter, "Arquitectura Revolucionaria", Los Ideales de la Arquitectura Moderna; su evolución (17501950), Barcelona, Editorial Gustavo Gili, 1970, pp. 20

(7) Moneo, Rafael, "Prólogo", J.N.L. Durand. Compendio de Lecciones de Arquitectura, Parte Gráfica de los Cursos de Arquitectura, Prólogo de Rafael Moneo, Madrid, Editorial Pronaos, año 1981, pp. VI

(8) Streidt, Gert, Potsdam, Köln, Editorial Könemann, 1996

(9) Posener, Julius, Schinkel: Arquitecturas 1781-1841, Madrid, Ed. Ministerio de Obras Públicas, 1989

(10) Pevsner, Nikolaus, Historia de las Tipologías Arquitectónicas, Barcelona, Ed. Gustavo Gili, 1979, pp. 151

(11) Semino, Gian Paolo, Schinkel, Bologna, Ed. Zanichelli, 1997

(12) Snodin, Michael, Karl Friedrich Schinkel: A universal Man, New Haven and London, Yale University Press, 1991 
(13) AAVV, München 5 Architekten, Sevilla, Ed. Junta de Andalucía, 1994

(14) Sheppard, Francis Henry Wollaston, Survey of London: volumes 29 and 30, Francis Henry Wollaston Sheppard Editor, London, 1960, pp. 336

(15) Collins, Peter, "Arquitectura Revolucionaria", Los Ideales de la Arquitectura Moderna; su evolución (17501950), Barcelona, Editorial Gustavo Gili, 1970, pp.

(16) Hitchcock, Henry-Rusell, L'Architettura dell'Ottocento e del Novecento, Torino, Giulio Einaudi Ed., 1971, pp.92

(17) Perret, Auguste, "Le musée moderne", Mouseion n9, 1929, pp.229-230

(18) http://archiwebture.citechaillot.fr/awt/

(19) Torres Cueco, Jorge. Le Corbusier, Visiones de la técnica en cinco tiempos, Barcelona, Colecció Arquithemas No 13, Ed. Fundacion Caja de Arquitectos, 2004, pp.221-223

(20) O’Byrne Orozco, María Cecilia, "El origen de la unité de Bâtisse: El proyecto para el Hospital de Venecia de Le Corbusier", Tesis doctoral inédita, Director: Josep Quetgals. Universidad Politécnica de Catalunya, Cuaderno III, Página 14

(21) Benévolo, Leonardo, Historia de la Arquitectura Moderna, Barcelona, Ed. Gustavo Gili, 1998, pp.131

(22) Parkinson-Bailey, John J., Manchester: an architectural history, Manchester, Manchester University Press, 2000

(23) Pergam, Elizabeth A. Manchester Art Treasures Exhibition of 1857: Entrepreneurs, Connoisseurs and the public, Surrey, Ashgate Publishing Limited, 2011

(24) Searing, Helen, Art Spaces, The Architecture of four Tates, London, Tate Publishing, 2004

(25) Torres, Jorge, op. cit., pp. 41

(26) Frampton, Kenneth, Historia crítica de la arquitectura moderna, Barcelona Editorial Gustavo Gili, 1987, pp. 246

(27) Weiss, Barbara, "American museums: three examples-From the cloisters to Michael Graves", Lotus n 35. Ed. Electa, Milano, 1982, pp. 101: Por supuesto que existen espacios que necesitan ser flexibles, pero otros necesitan ser espacios absolutamente inflexibles. Deberían ser inspiración pura (...) espacio que no cambian excepto por las personas que entran y salen.

(28) Weiss, Barbara, op. cit., pp. 102

(29) Grassi, Giorgio, "Arquitectura, Realidad y Vanguardia", En: AAVV, Arquitectura y Ciudad: vanguardia y continuidad, Llorens, Tomás, Mira, Rafael, Portaceli, Manuel, Sanchez-Robles, J. Cecilio, (Editores), Valencia, Ed. Colegio Oficial de Arquitectos de Valencia y Murcia, 1980pp. 49-58

(30) Weiss, Barbara, op. cit., pp. 102 
(31) Venturi, Robert, "From invention to convention in architecture". En: $10^{\text {th }}$ Thomas Cubitt Lecture, Royal Society of Arts, (Londres, 8-4-1988), RSJ Journal, Enero 1988.

(32) AAVV, Neue Staatsgalerie und Kammertheater Stuttgart, Stuttgart, Finanzministerium Baden-Würtemberg, 1984

(33) Venturi, Robert; Vaughan, David; Jencks, Charles, "National Gallery-Sainsbury Wing. An interview", Architectural Design, n 91, 1991, pp. 48-57

(34) Baker, Geoffrey, "The Sainsbury at the Nacional Gallery by Venturi, Scott Brown and Associates", Architectural Design, n 94,1991 , pp. 16-17

(35) Moneo, Rafael, Inquietud teórica y estrategia proyectual en la obra de ocho arquitectos contemporáneos, Barcelona, Actar, 2004

(36) Abrams, Janet Y., "Contemplazione e rituale nel museo d'arte per il gran pubblico. Due progetti di Venturi, Rauch \& Scott-Brown ", Lotus International 55, Nouvi Musei, Ed. Electa, Milano, 1988, pp. 85

(37) Moneo, Rafael, op. cit., pp. 37

(38) Colquhoun, Alan, "Un monumento para la ciudad", Los Museos de James Stirling, Michael Wilford y Asociados, Colección de Arquitectura, Milán, Electa, 1992, pp. 124-127

(39) Dal Co, Francesco, "Hallazgos alusivos. James Stirling 1950-1980", Los Museos de James Stirling, Michael Wilford y Asociados, Colección de Arquitectura, Milán, Electa, 1992, pp. 17

(40) Moneo, Rafael, Apuntes sobre 21 obras, Barcelona, Gustavo Gili, 2010, página 415 


\subsection{MUSEO DE LA CIUDAD: RESTAURACION $Y$ REHABILITACIÓN DEL PALACIO DEL MARQUES DE CAMPO}

Valencia (1983-1989)

\subsubsection{Introducción}

El Palacio del Marqués de Campo, también llamado Palacio de los Condes de Berbedel (nombre tomado de sus últimos propietarios), fue adquirido a éstos por el último ayuntamiento franquista en el año 1974. El encargo de los trabajos de recuperación (no de otra manera se pueden denominar, dado el avanzado estado de degradación en que se encontraba el conjunto en 1983) se realizó durante la primera legislatura municipal democrática, encabezada por una coalición de socialistas y comunistas preocupados por la dispersión del patrimonio municipal, ausencia de un inventario riguroso y el mal estado de las piezas -pintura en su mayor parte-. La colección estaba distribuida anárquicamente, en dependencias de todo tipo, sin ninguna protección respecto a la temperatura y la

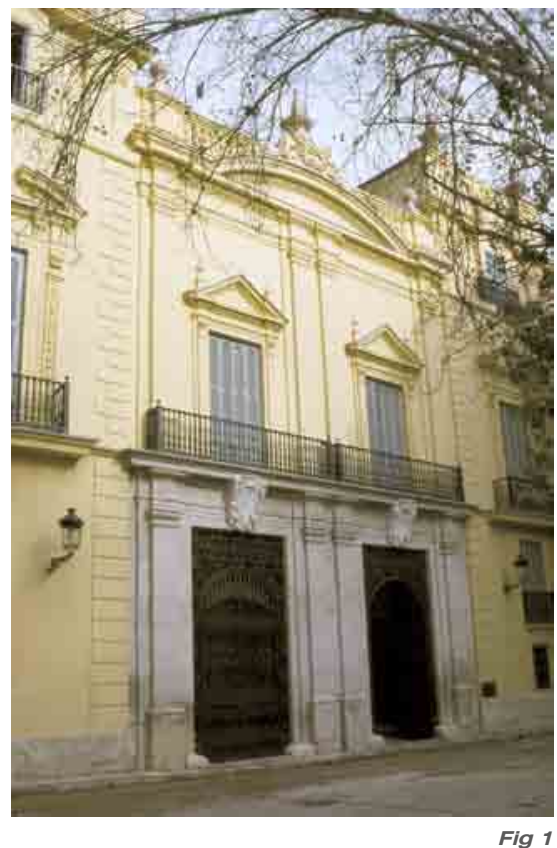
humedad.

Si muchas son las anécdotas sobre sus ocupantes, citadas por los cronistas de la ciudad, escasos son, como suele suceder, los datos históricos y arquitectónicos que proporcionen un cierto conocimiento del origen y evolución históricos del citado inmueble. 
La documentación existente sobre la importante intervención realizada, en 1857, por el maestro de obras Manuel Ferrando permite confirmar que la apariencia que ofrecía en 1983, momento en que comienzan los estudios previos al proyecto de restitución, corresponde a la intervención decimonónica.

\subsubsection{Breve historia del lugar y del edificio}

\subsubsection{Origen del palacio}

Enclavado en pleno corazón de la Valencia medieval, junto
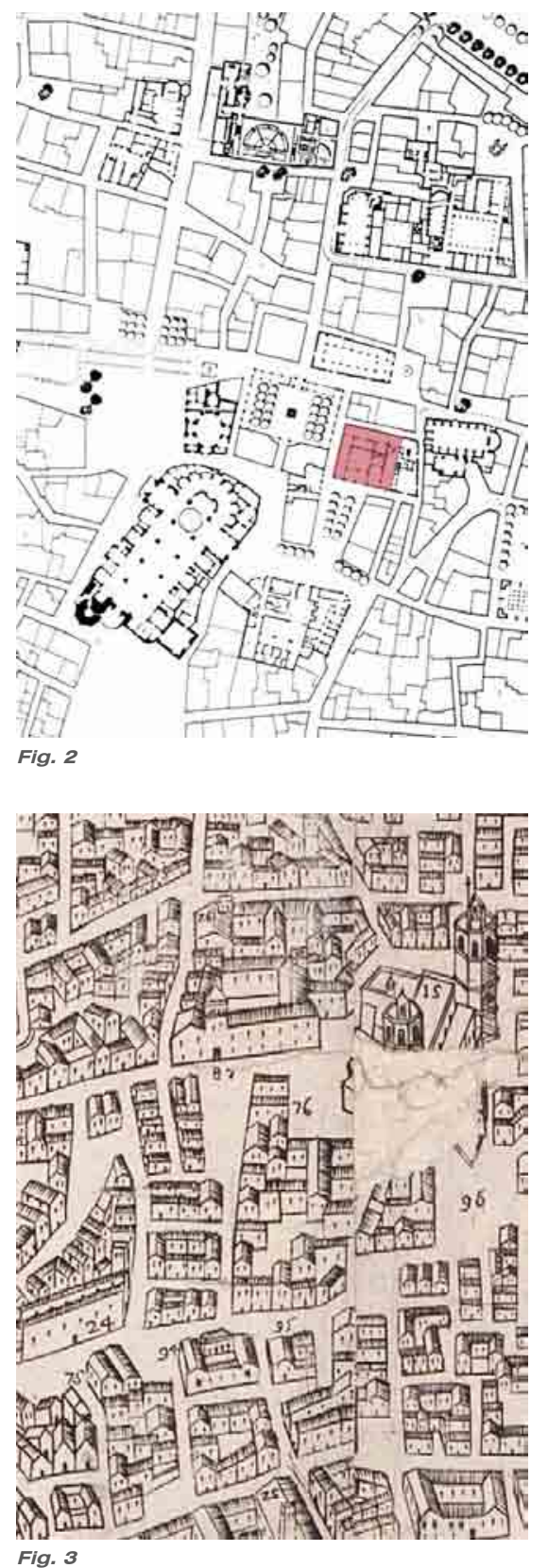

al conjunto formado por la Catedral, la Basílica de la Virgen, el palacio de la Generalidad y la antigua Casa de la Ciudad hoy desaparecida (Fig.2), el Palacio del Marqués de Campo está situado, en palabras de Tormo, "en la plaza del Arzobispo (al norte del Palacio), la casa señorial de los Condes de Olocau, duques de Villahermosa, más tarde del famoso Marqués de Campo, y ahora del Conde de Berbedel, restaurada en el siglo $\mathrm{XIX}$, y donde residieron los capitanes generales de trágico destino Elío y Méndez Vigo".(1)

Su adscripción por parte de algunos cronistas antiguos al duque de Villahermosa es un hecho no contrastado. Se sabe que fue sede de la Capitanía General del Reino entre 1810 y 1840 y que cayó, al parecer, en el abandono hasta su compra por parte del Marqués de Campo.

En el plano de la ciudad de Valencia de Antonio Manceli, de $1608^{(2), ~ e l ~ l u g a r ~ q u e ~ o c u p a ~ h o y ~ l a ~ m a n z a n a ~ q u e ~ c o n t i e n e ~ e l ~}$ palacio está formado por dos manzanas residenciales con sus correspondientes viales ${ }^{\left(\mathrm{Fig}^{3} \text { ). }\right.}$. Sin embargo en los planos de la ciudad del Padre Tosca ${ }^{(3)}$, de abril de 1704 y 1738 (circa), se percibe un importante cambio en la morfología urbana.

Las dos manzanas que se apreciaban en el plano de Manceli corresponden en el de Tosca ${ }^{(\text {Fig.4) }}$ a una de grandes dimensiones en la que se observa el edificio, que en forma de "U" se abre a la plaza llamada hoy del Arzobispo, de la que le separa un muro de cierre. En la vertiente de la calle de los Venerables, vial que ya se 
observa en el citado plano del siglo XVII, se supone la existencia de viviendas adosadas, a tenor del dibujo de Tosca, que en este aspecto parece sugerir este hecho.

De la lectura de la cartografía histórica citada se desprende que el palacio y la configuración de la manzana que lo contiene fueron realizados entre 1608, año de redacción del plano de Manceli y 1704, fecha del primer plano de la ciudad del Padre Tosca, donde ya aparece la configuración embrionaria del Palacio actual. Podemos por ello concluir que el núcleo original del Palacio se construyó durante el siglo XVII.

\subsubsection{El palacio y el lugar}

El conjunto de la manzana se aprecia en el plano axonométrico de la ciudad del siglo XVIII realizado por el Padre Tosca. En el mismo se distinguen los siguientes elementos característicos: el cuerpo del palacio en forma de $U$, con una cúpula levantada sobre el brazo este y el muro de acceso que lo cierra con respecto a la plaza. Cabe señalar el considerable espesor de la crujía este, dibujada quizá con cierta desproporción si suponemos que la cúpula indicada por Tosca corresponde -en tamaño y posición- con la actual. En este último caso, la delineación de la crujía este obvia (o estrecha en demasía) el caserío adosado al Palacio por este lado.

Nótese, a efectos de evitar confusiones, que tanto el Plano de Mancelli como el del Padre Tosca invierten el norte y el sur. La plaza a la que se abre el palacio nos remite al historiador Vicente Boix cuando en su Valencia Histórica y topográfica. Antigua y Moderna (1863) al hablar de la Plaza de la Farina dice:

"Llamábase de la Farina, la plaza que entre otros nombres antiguos se llama actualmente del Arzobispo. Se denomina de la Farina en un bando publicado en 8 de Julio de 1530, y así también en un acta de Cortes y por real privilegio de Felipe II. EI origen de ésta denominación se expresa en el mismo privilegio disponiendo que "se tanque la porta del Pes de la Farina que hix á dita plasa, extremos, por otra parte, no comprobados."
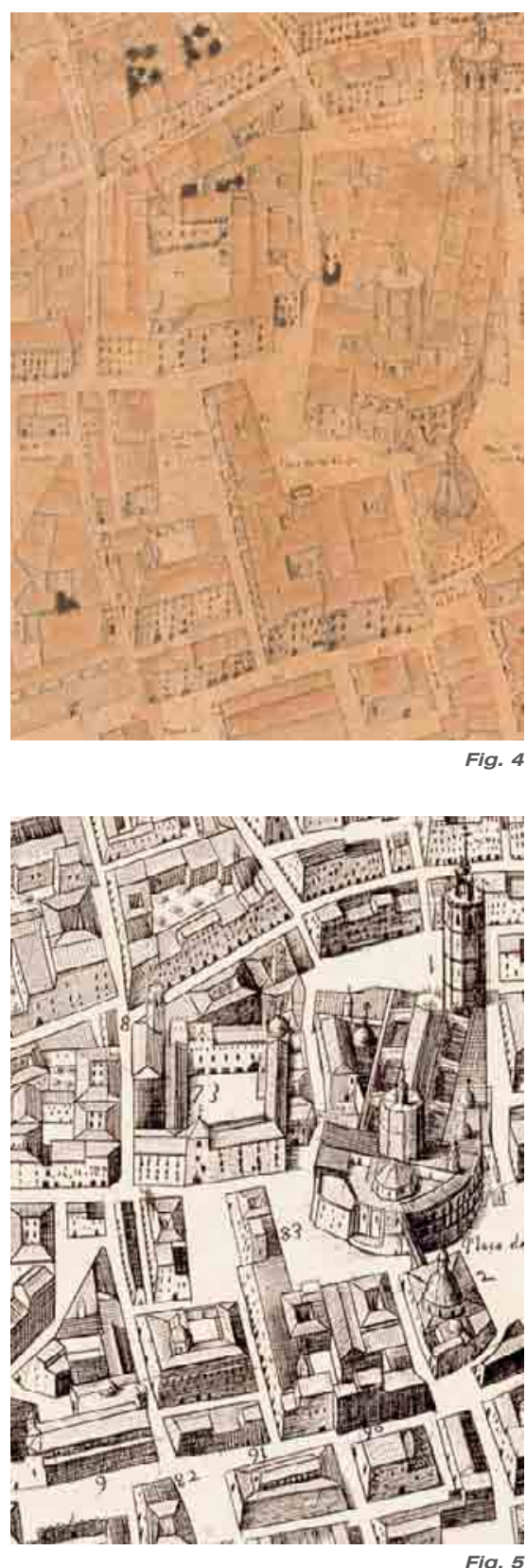
El mismo Boix había confirmado un año antes su localización: "Ya antigua, esta denominación que tiene la plaza -del Arzobisposituada enfrente del palacio arzobispal, del opulento capitalista D. José Campo y de la Fonda del Cid (...) no es la primitiva pues existe la circunstancia de no haber sido elevada nuestra catedral al rango de metropolitana hasta 1492, por gracia del papa Inocencio VIII, a instancia de mi paisano D. Rodrigo de Borja, después Papa Alejandro VI. Su nombre anterior era Plasa de la Farina (por los años 1530), y antes Plasa de les Olles y Plasa de la Fruita, porque se vendería allí, tal vez, el vidriado negro y también la fruta, según se dirá en sus respectivos títulos". (4)

Así pues la plaza del Arzobispo, antes de la Farina, por la que se accede al Palacio del Marqués de Campo, se cerraba en su extremo sur, como se observa en el plano, por el palacio arzobispal, edificio que presidía la plaza con una torre (Fig.5). De remoto origen, alhóndiga en período musulmán, pasó a propiedad del obispo en 1241. Ampliado en 1357 se instaló en él, más tarde, la biblioteca pública de D. Andrés Mayoral con más de cincuenta mil volúmenes y rico monetario.(5) En el sitio de la ciudad, en 1812, sufrió un importante incendio que la afectó gravemente así como a gran parte del edificio arzobispal. Destruido -aunque parcialmente- de nuevo por un incendio en

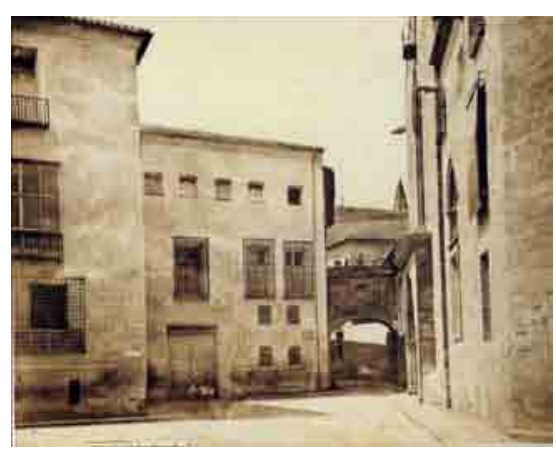
Fig. 6

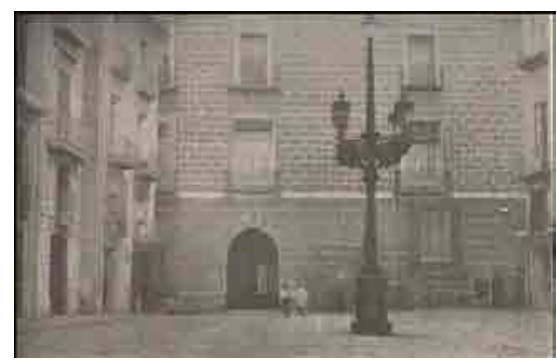

1936, se demolieron sus restos (Fig.6 y Fig. 7) y se construyó de nueva planta entre 1941 y 1946. El nuevo edificio presenta un retiro de la línea de fachada primigenia, que creó un ensanchamiento en el tramo final de la antiquísima calle del Palau, integradora junto a la calle Caballeros del Decumanos de la implantación romana. No podemos olvidar que esta parte de la ciudad vieja coincide con la ciudad romana. El nuevo palacio arzobispal fue proyectado, en estilo casticista, por el arquitecto de Castellón Vicente Traver, que se había formado con Aníbal González, autor del proyecto y parte del conjunto de la Feria Ibero-Americana de Sevilla de 1909. Traver lo sustituyó tras su muerte tanto en la redacción de proyectos como en la ejecución de numerosos edificios para dicho evento.

En el lado norte, la plaza, de dimensiones y escala 
contenidas, se remataba con el antiguo palacio, en forma de "U", con sus brazos unidos mediante un muro en el que se producía su acceso, a la manera del hôtel francés -tipológicamente hablando-. La ejecución de este cierre, al parecer, no ostentaba pretensión arquitectónica alguna, sino que consistía en una respuesta meramente funcional. La fachada actual del Palacio del Marqués de Campo a la mencionada plaza del Arzobispo es el resultado de la intervención llevada a cabo a mediados del siglo XIX, como se verá más adelante.

\subsubsection{La residencia del Marqués de Campo}

El edificio fue adquirido por D. José Campo Pérez, prototipo del burgués emprendedor, con amplios intereses mercantiles en especial en los transportes marítimos y el ferrocarril. Es recordado especialmente como figura pública: alcalde de la Ciudad, diputado a Cortes y senador vitalicio. La impronta de sus intervenciones se manifestó en una ciudad que le adeuda la modernización de sus infraestructuras: el adoquinado de sus calles, la instalación de agua potable y gas, la mejora del puerto y la creación del asilo de beneficencia que lleva su nombre. Todo ello le hizo merecedor de la dignidad de marqués que en 1875 le concedió Alfonso XII.

La elección, por parte del Marqués de Campo, del inmueble que posteriormente transformó en su Palacio, respondió a razones de diversa índole. Entre otras, su preferente ubicación en el Cuartel del Mar, donde la burguesía incipiente comenzó a establecer sus residencias; la excelente posición frente al Palacio Arzobispal; su situación en el centro de la vida política, militar y religiosa de la ciudad; el carácter exento del edificio, que ocupaba una manzana entera, como símbolo inequívoco del poder económico de su propietario.

En 1857, D. José Campo encargó al Maestro de Obras Manuel Ferrando una importante reforma del palacio ${ }^{(F i g .8)}$, que lo transformó sustancialmente, para convertirlo en su residencia, con el resultado formal que básicamente el palacio ofrece en

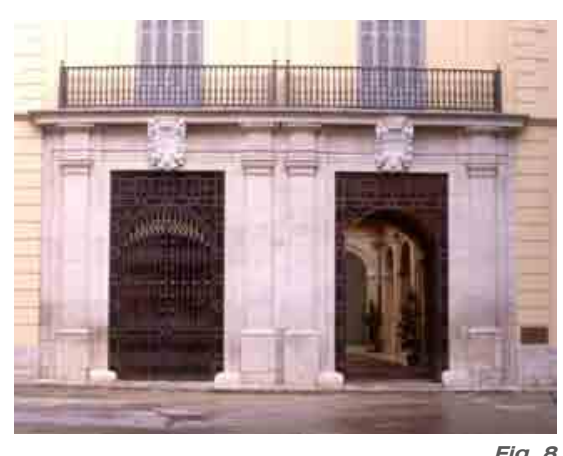




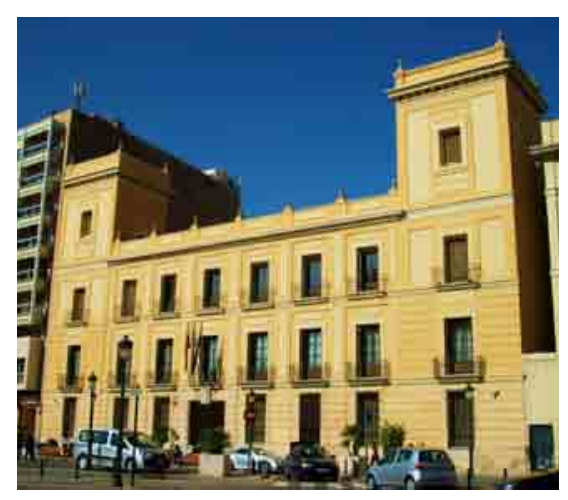

Fig. 9

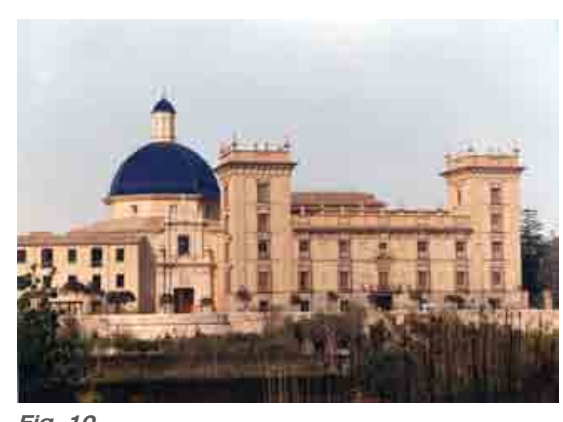

Fig. 10

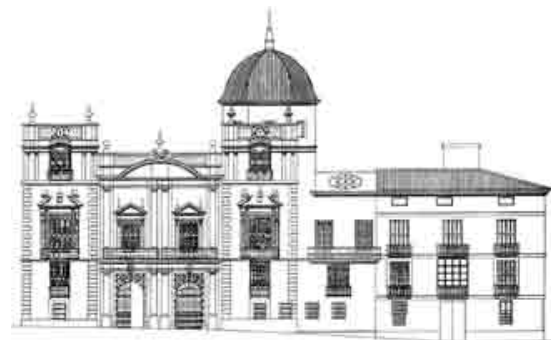

Fig. 11 nuestros días. La operación consistió, esencialmente, en el cerramiento de la $U$ original, mediante un cuerpo de una crujía de profundidad, de menor altura que los originales, de manera que se configura así un patio central alrededor del cual se organizan los diferentes espacios y niveles del palacio.

Este cuerpo, de nueva creación, define la nueva fachada principal mediante un juego de dos puertas en piedra, blasonadas, sobre las que se apoya un balcón corrido en bronce dorado perteneciente a lo que será el espacio principal de la planta noble: el salón de baile. Los testeros de los brazos de la antigua $U$, de mayor altura, se convierten en torres que flanquean el nuevo cuerpo siguiendo una típica composición académica (Fig.11), muy utilizada en diversos edificios de la ciudad como, entre otros, la Antigua Casa de la Ciudad, el Palacio de Cervelló (Fig.9),

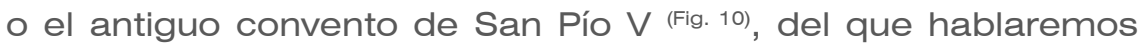
más adelante. Esta disposición clásica aporta la particularidad de la división mediante dos vanos del cuerpo central, que aparece coronado con amplio y rebajado frontón curvo. Éste centra el nuevo cuerpo de cierre del palacio, a su vez flanqueado simétricamente por las torres de nueva creación.

De hecho, en aras de una correcta composición canónica, se fuerza el dibujo de la torre este a efectos de conseguir una fachada principal homogénea y simétrica. Las torres disponen en sus esquinas de un almohadillado decorativo en la planta baja y noble. Visualmente, la diferencia de anchura de las crujías oeste y este habría repercutido en la falta de simetría y correspondencia entre ambas torres, lo que habría generado un resultado estético no deseado. Por ello, el almohadillado de la torre este se dispone de forma asimétrica en su alzado hacia la plaza, de modo que se separa de su esquina sur-este. En uno de sus flancos falta pues este almohadillado, que se dispone en el interior de la torre: su anchura percibida coincide así con la de la torre oeste. El remate de la torre este se ciñe, pues, a la anchura definida por el almohadillado y corresponde, lógicamente, con el de la torre oeste. Se consigue así el necesario efecto óptico que enmascara la falta de simetría de los volúmenes mostrados en 
fachada.

Por otro lado, este doble acceso, de rica cerrajería con las puntas en lanza de bronce dorado, proporciona una inusitada y rica transparencia del patio creado. Se conforma así un patio central estructurado a base de tres órdenes de pilastras superpuestos que articulan los tres frentes iguales originarios (probablemente pertenecientes a la construcción del siglo XVII) (Fig.12). La planta baja se modula mediante tres arcos de medio punto en cada frente, enmarcados entre pilastras. Este orden tripartito se extiende verticalmente a los niveles superiores, y se transforma en un orden gigante que abarca la planta noble y el primer nivel del ático. Los huecos del primer ático, de pequeña altura, poseen barandillas de forja que simulan balcones; el nivel del forjado que divide los áticos es muy bajo y repercute en la escasa dimensión de los huecos. La cornisa de este orden gigante sirve de apoyo al segundo ático, que posee pequeños huecos articulados por un tercer orden de pilastras. Una importante cornisa, que recoge los faldones de la cubierta inclinada de teja, remata el conjunto.

El cuarto lado producto de la intervención del XIX, de menor altura, se resuelve en planta baja con la creación de un ámbito cubierto, caracterizado por su permeabilidad. Las dos puertas de acceso al Palacio se cierran, como hemos visto, mediante rejas. El alzado interior se compone por dos arcos, de trazado carpanel (Fig.13), que restan abiertos y cuyos centros se sitúan en el eje de las puertas. Sobre ellos se abren los ventanales del salón de baile que ocupa el cuerpo de nueva creación. Una cornisa recoge el faldón de la cubierta del citado cuerpo, de menor altura, como ya se ha dicho, en relación con los otros tres lados del patio.

Conviene añadir que todos los huecos de la planta noble que se abren al patio lo hacen a través de un balcón corrido en el que se construyó un mirador. Éste consistía en una complicada talla de madera de lenguaje ecléctico que aunaba rasgos góticos con elementos de un cierto aire rococó a tono con la carpintería que en planta baja cerraba todos sus huecos.
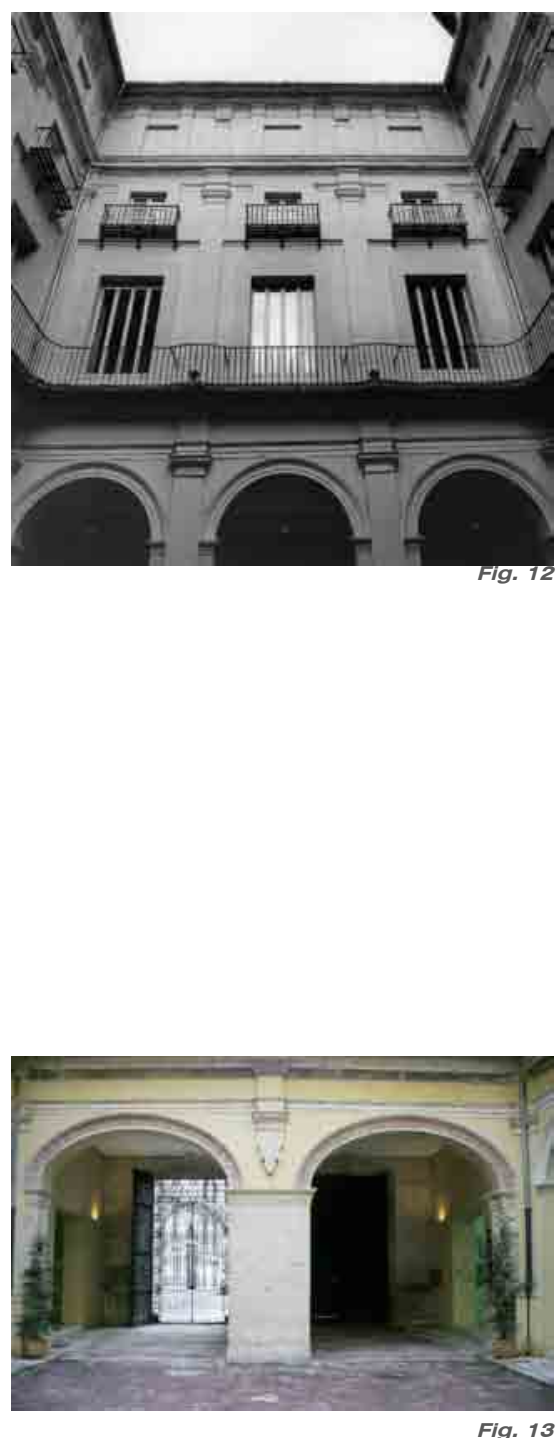
Campo confirió al edificio un uso mixto residencial y terciario de forma que en planta baja albergó oficinas, vinculadas a negocios propios, mientras que las plantas altas, los áticos, acogieron, al parecer y entre otros, a inquilinos relacionados con el periódico La opinión -en cuya cabecera se proclamaba Diario político, literario y de intereses materiales- del que fue propietario.

Configuran el resto de la manzana dos casas colindantes que recaen a la calle Venerables (una de ellas gira la esquina abriéndose también a la calle Vergara), y una tercera con acceso por la calle Llimera, prolongación de la nueva fachada principal del palacio. Estos edificios fueron adquiridos, parece ser, por José Campo y convertidos parcialmente en otras dependencias de la residencia, como el baño oval en mármol de Carrara. Cabe destacar del mismo su tratamiento con las piezas en dicho material y su coronación con una cúpula de cristal que invadía la última planta del inmueble Venerables-Vergara. Otra dependencia notable es la Capilla, en la primera planta de la casa de la calle Llimera, a la que se accedía desde el invernadero, del que hablaremos más adelante. Se ubicaron también en estos edificios viviendas de acceso independiente, en una operación de simple apropiación que no afectaba arquitectónicamente a la unidad definida por el palacio a partir de su reestructuración con

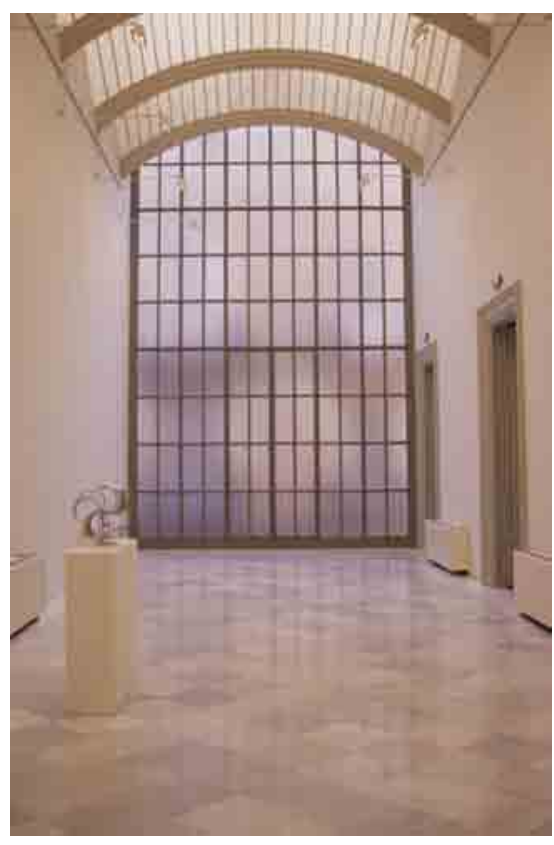
patio central.

Articulando el bloque propio del palacio, ahora con patio central, con las citadas casas se encuentra en planta noble una pieza de singular interés en boga en aquella época: un invernadero que se produce a partir de la existencia de un "atzucat" (Fig.14), hipótesis no confirmada, basada en que las fachadas del patio interior que deja esta estancia tienen el mismo tratamiento en su fenestración, con sus curiosos balconesmirador curvos, de madera, que aparecen en el exterior de la casa de la calle Venerables-Vergara. De hecho, en el antiguo Palacio de los Borja, Borgia en su denominación italiana, existía un pabellón de hierro fundido y vidrio, a modo de invernadero, atribuido al ingeniero Beatty. Este pabellón, muy celebrado en la 
época y hoy desaparecido, se adentraba en el frondoso jardín, y respondió con seguridad a las obras de remodelación para la transformación del antiguo Palacio en residencia del Conde de Benicarló, coetáneas con la reforma de Campo.

El invernadero, la serre según la denominación afrancesada de moda entre los cronistas de la época, se resuelve mediante

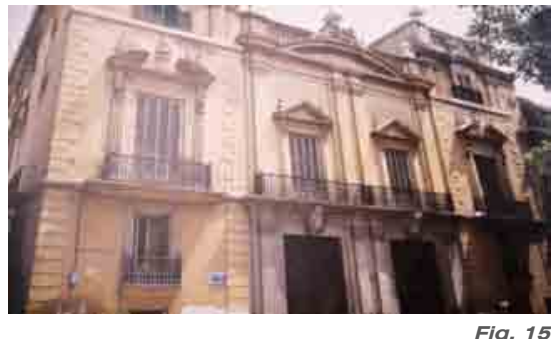

Fig. 15 una compleja y brillante cubierta acristalada a base de cerchas curvas de madera tallada, con armadura metálica, por supuesto en diente de sierra. Esta luminosa y espaciosa pieza de creación decimonónica se planteará en proyecto como elemento bisagra entre la fase primera de intervención, el palacio propiamente dicho, y la segunda, que ya no realizaré.

Toda esta parte del complejo se encontraba en muy malas condiciones en 1983, de tal modo que, comenzadas las obras, ordené su apuntalamiento a efectos de evitar su hundimiento.

\subsubsection{Año 1983. El palacio antes de la intervención}

El edificio principal del Palacio del Marqués de Campo (Fig.15) ocupa parte de la manzana delimitada por la Plaza del Arzobispo, y las calles de la Harina, Vergara, de los Venerables y Llimera. A estas tres últimas, que corresponde al flanco este de la manzana, se adosaban al cuerpo principal del Palacio dos edificios de viviendas, como he mencionado en diversas ocasiones, en considerable estado de degradación en 1983 (Fig.18), cuando se produce el encargo de su restauración y adecuación.

El cuerpo principal del Palacio tiene un patio central (Fig.16) delimitado por una crujía simple en sus lados este, sur y oeste, y por una crujía doble en su lado norte. Tiene el edificio tres niveles principales; planta baja, planta noble y ático. Existía también entresuelo y el espacio del ático se hallaba, en algunas partes, subdividido en dos niveles (Fig.17). Este último hecho trascendía incluso al alzado, en especial al correspondiente a la calle de la Harina.

Empujando la oxidada rejería de una de las dos portadas del palacio se accedía al patio. Las complicadas carpinterías
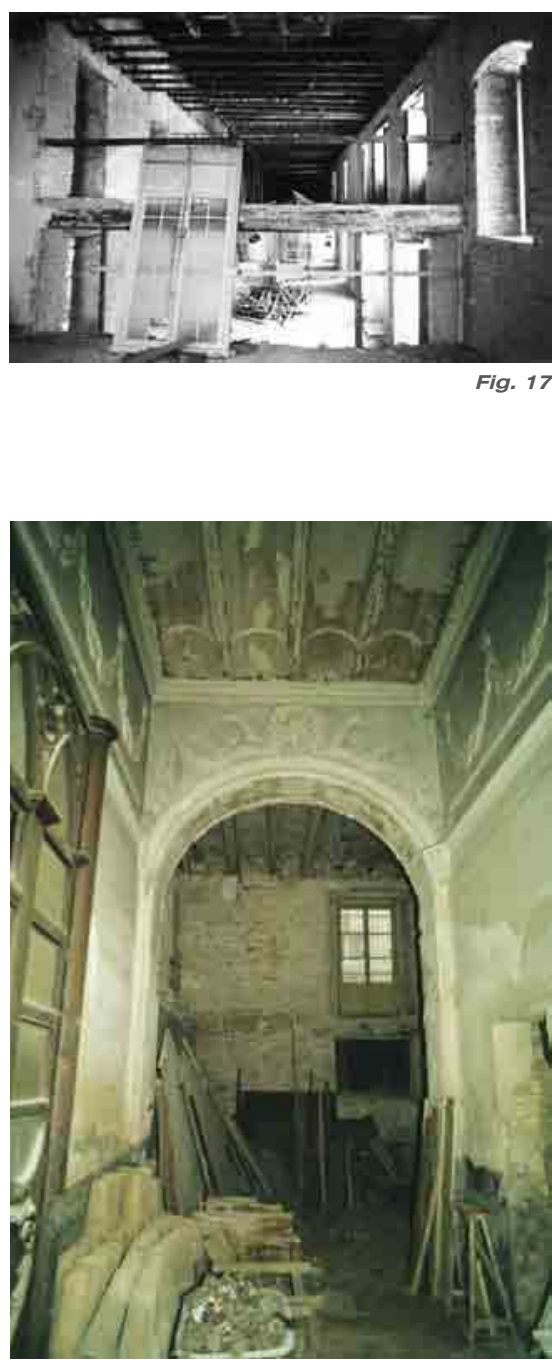

Fig. 18 


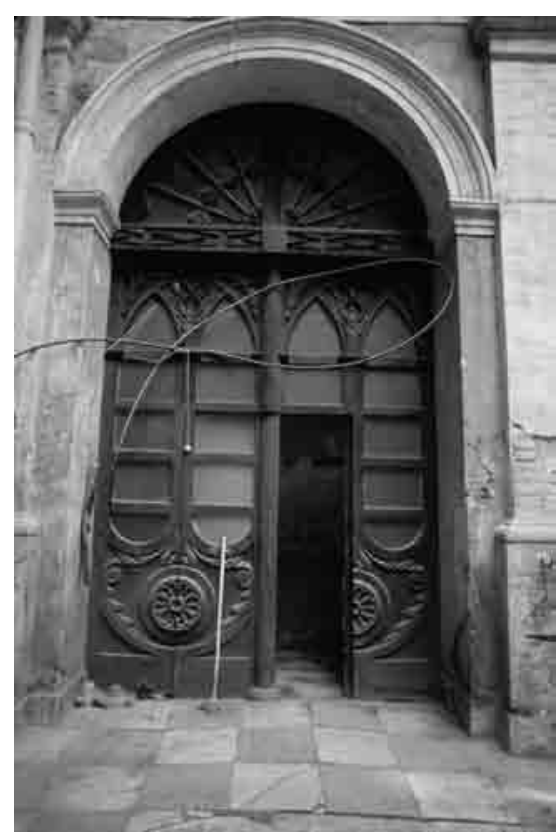

Fig. 19

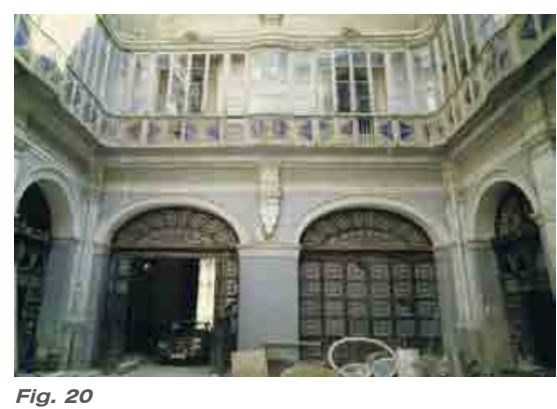

Fig. 20

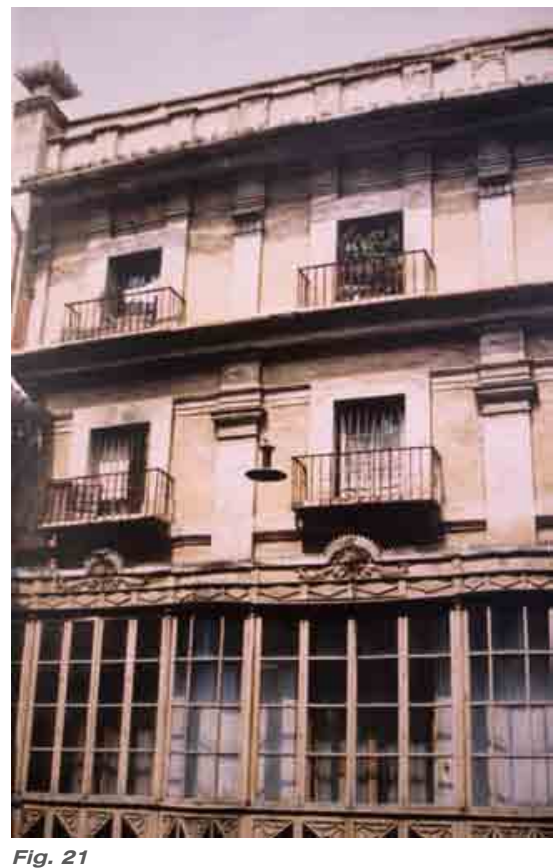

que cerraban los huecos -rematados con arcos de medio punto de planta baja- estaban en franca descomposición por la acción del agua y del vandalismo. Sus cristales mostraban que el dibujo que los tornaba opacos, como si estuvieran tratados al ácido, no era más que papel dibujado a modo de un vinilo actual, que ocultaba forjados de altillos que cortaban su altura, estancias

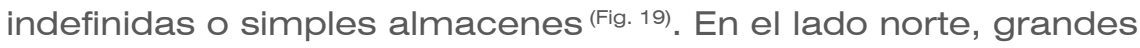
portalones abrían el acceso a las caballerizas.

El mirador de madera que envolvía la planta noble estaba prácticamente destrozado por las termitas y la acción de los elementos. Su mal estado permitía observar como ocultaba la esbeltez del orden gigante del que hemos hablado, que ordenaba el ritmo y jerarquizaba el patio. Por el lado este el hueco central daba paso a la escalera principal. Este espacio, coronado con una bien dibujada cúpula que por sus trazas parece anterior al siglo XIX. ¿Se trataba de la cúpula observada en los planos de Tosca? Muy probablemente.

Merece destacar que el primer tramo de escalera se desarrollaba junto a uno de los huecos del patio, con su carpintería y sus vidrios de papel pintado. El trazado de la escalera suscitaba problemas de encuentros con los vanos del patio. La zanca del primer tramo de la escalera interfiere con la fenestración y es visible a su través. La desaparición de la carpintería y del papel que recubría sus vidrios permitía observar el lateral de la bóveda y su arranque, que no estaba previsto para su visión y consistía en un macizado, mezcla de ladrillo, cascote y cal. Se planteaba pues la duda de cuál era el uso original de este espacio cupulado. No parece lógico que se ubicara allí la escalera principal cuya construcción había que ocultar mediante papeles pintados adheridos a las cristaleras de la carpintería exterior. Por otro lado, comprobamos que el peldañeado de la escalera estaba primorosamente ejecutado en una magnífica y bien conservada madera de caoba.

El patio disponía de un adoquinado de piezas de rodeno de tamaño medio enmarcado por una deliciosa acera con bordillo del mismo material y un damero de piezas de piedra 


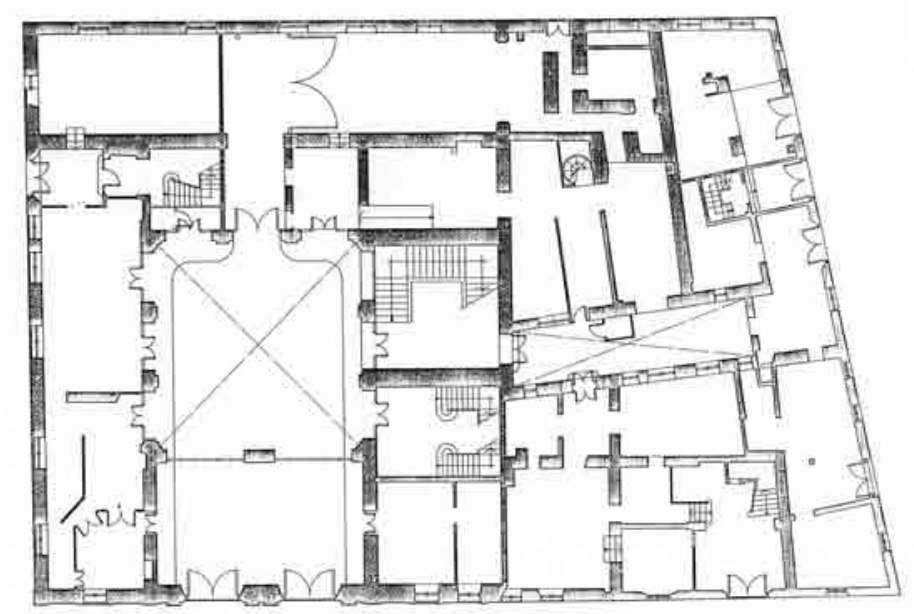

Estado anterior. Planta baja

gris y rosa (Fig. 20), que se curvaba funcionalmente para permitir el acceso de los carruajes desde el exterior y para entrar a las caballerizas. Hay que recordar que el rodeno, piedra arenisca rojiza, abundante en nuestras tierras, es muy difícil de escuadrar debido a su formación a base de lajas. No obstante he podido observar, en otras intervenciones, su utilización histórica, como en este caso en piezas cuadradas para pavimentos exteriores en patios.

La planta baja del cuerpo del palacio en su ala oeste, estaba fraccionada en diferentes dependencias y disponía de altillos, alguno de los cuales, como se ha dicho, se entregaban en las carpinterías de cierre al patio, lo que obligaba a abrir puertas de pequeñas dimensiones en ellas. En el último tramo perteneciente a la calle de la Harina, un portal rompía la ya alterada fenestración de los muros originando un acceso a una escalera que, al atravesar la planta noble, alcanzaba los áticos de pequeñas viviendas. En la doble crujía norte se encontraban las caballerizas, al fondo de las cuales se había construido un refugio durante la Guerra Civil.

En el lateral este junto a la escalera principal se hallaba una segunda que llevaba a la planta superior de la casa de la calle Llimera, con unas dependencias que comunicaban con la residencia del Marqués. En las casas adosadas se observaban espacios de uso desconocido, conectados con el palacio (Fig.22), plantas bajas abiertas a la calle Venerables, amén de escaleras

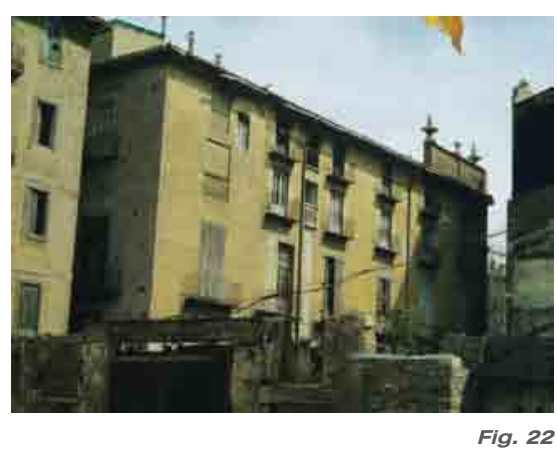




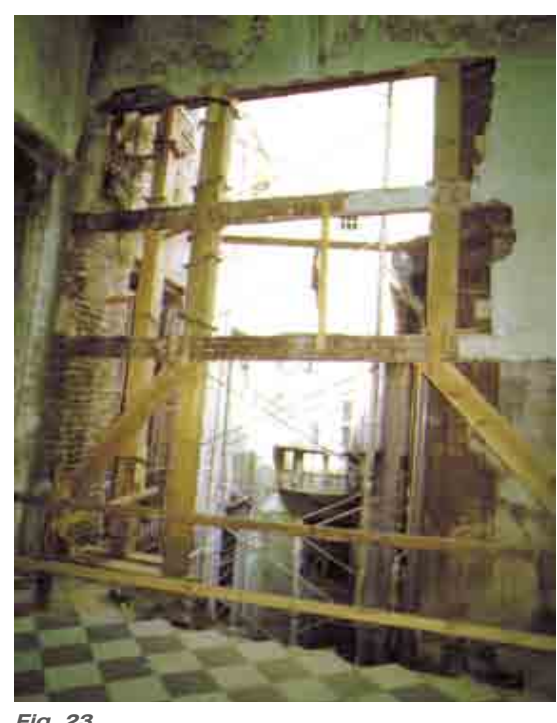

Fig. 23

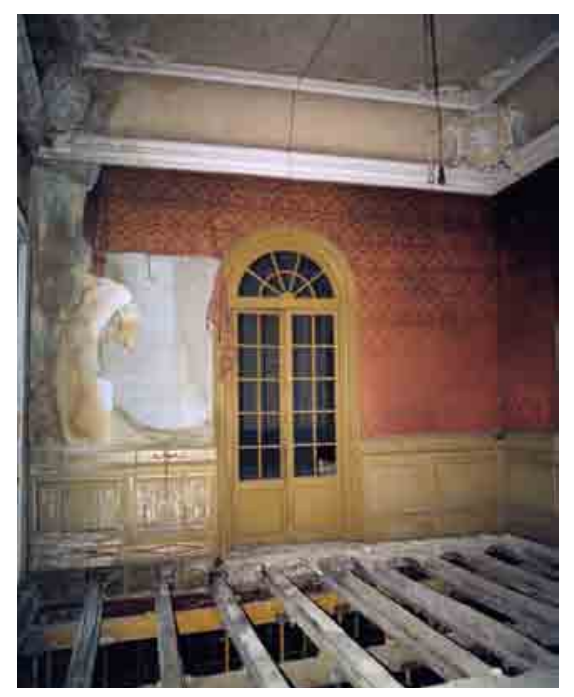

Fig. 24

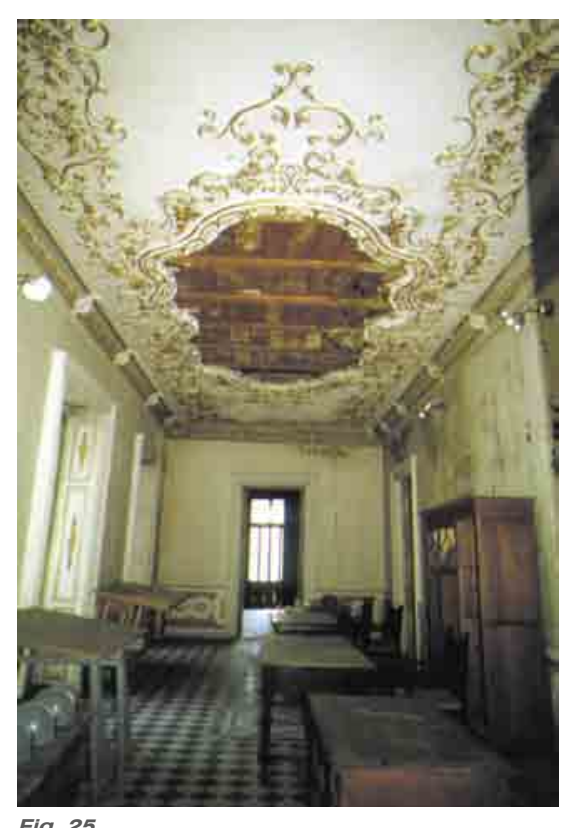

Fig. 25 y escalerillas, con sus accesos a través de portales, uno en la calle Llimera y un segundo en la calle Venerables.

En primera planta, la noble, Palacio y vivienda se maclaban entre sí, extendiéndose las estancias del palacio hacia las viviendas adyacentes. La suite de salones alrededor del patio se encontraba en un alto estado de degradación (Fig.23y Fig.24). No existía ninguna de las chimeneas cuya huella cada sala mostraba en sus paramentos. Las purpurinas en oro o plata habían recubierto lo que parecía que en su origen había sido pan de oro o plata, provocando su oxidación e irreparable deterioro.

A pesar de ello los oficios de escayolista y de carpintero, de larga tradición, mostraban su buen hacer en la decoración de los salones, con un tratamiento estilístico diferente en cada uno de ellos y en sus elaboradas carpinterías, muy diferentes del trabajo vulgar de los cerramientos de planta baja y el mirador superior del patio. ¿Quiere decir esto que pertenecían a dos momentos diferentes? Seguramente.

El llamado salón isabelino mostraba un gran plafón central vacío (Fig.25), donde debió de existir una pintura al óleo claveteada en su estructura de madera que quedaba a la vista, probablemente del tipo de los medallones del salón de baile que se conservaban, aunque manchados y al parecer acuchillados. Su mala calidad y su mal estado aconsejó sustituirlos en ambos salones, siguiendo el planteamiento del proyecto de intervención.

Los acabados que encontramos confirmaban lo que la Academia de San Fernando escribió, el 19 de noviembre de 1982, en su informe para la declaración del palacio como monumento de carácter local: "Por lo demás el resto del edificio es de una vulgaridad asombrosa y su decoración tiene todo el mal gusto de la época que lo produce". Sin embargo, algunos de los restos que se apreciaban a través de los desconchados mostraban una mayor exquisitez. Valga el ejemplo del uso del estucado, ejecutado, por supuesto, en caliente en un escogido color gris con las molduras en pan de plata. El estucado estaba por desgracia agrietado y gravemente afectado por las capas de pintura superpuestas y mostraba la ya citada oxidación del pan 
de plata.

Los pavimentos eran de mármol, damero blanco y negro en piezas de pequeña dimensión, donde no habían sido sustraídos. Solamente el salón de baile disponía de un delicioso pavimento en "trompe l'oeil" en blanco negro y gris.

Por su crujía norte los salones nobles se prolongaban en la vivienda de Vergara-Venerables mediante unas estancias entre las que se encontraba el baño oval de Carrara cuya cúpula de cristal ocupaba un espacio de la planta superior. En comunicación con la "serre" se encontraba la capilla y alguna estancia. Forjados hundidos, revestimientos arrancados. La acción de los elementos atmosféricos completó el mal estado del conjunto. Respecto al invernadero, este importante espacio ofrecía parte de su cubierta acristalada hundida; los cristales, por supuesto, rotos. Seguramente la reiterada entrada de agua era la causa de la ruina de sus cerchas de madera tallada con el alma metálica y el desplome de parte de su muro de cierre correspondiente a las viviendas.

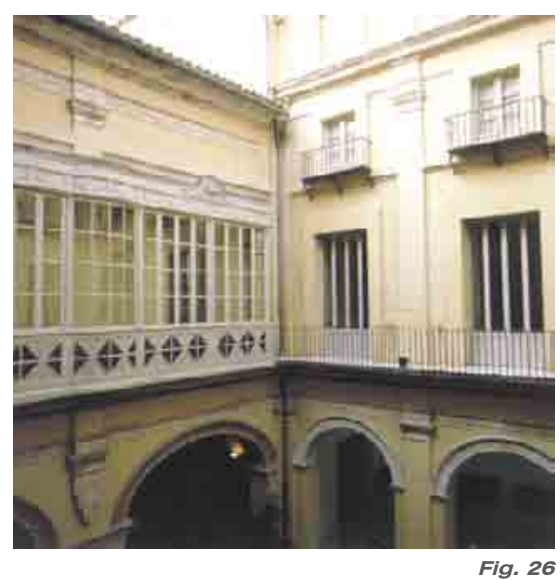

\subsubsection{El proyecto de intervención: Objetivos y criterios}

Los criterios básicos de la intervención parten de la convicción de que el monumento es un testimonio de una multiplicidad de razones que convergen en la forma del edificio. Su mantenimiento en la vida de la ciudad, su reutilización en un nuevo tiempo, sólo se consigue a través de la constante reconsideración de lo que está ínsito en su fábrica y de la continuada elección de aquellas posibilidades que su compleja estructura es capaz de permitir.

Tras una lectura del edificio, tal como nos ha sido legado, junto a los datos históricos, origen y evolución en el tiempo, el sistema constructivo utilizado, los materiales que informan sus acabados, sus características, texturas, colores, etc., viene configurado un panel de datos desde cuya interpretación se establecerán los criterios de intervención de los que partir para alcanzar los objetivos del proyecto de arquitectura, sin olvidar la

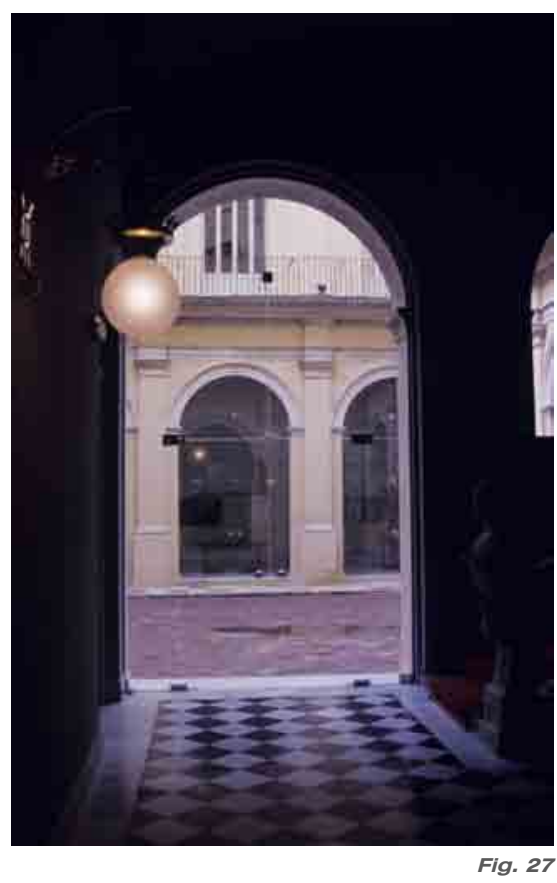




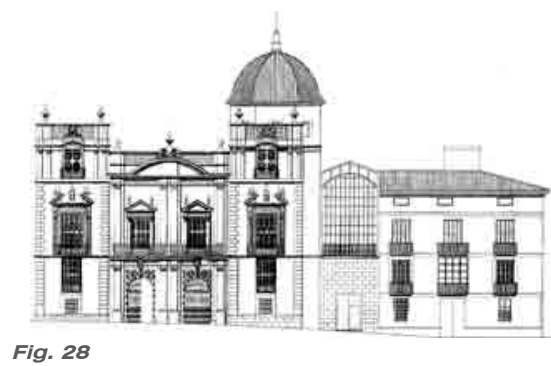

Fig. 28 posibilidad de respuesta a la necesidad expositiva que el nuevo uso demanda y que dará nueva vida al edificio abandonado.

El primer criterio que se establece es el punto de partida de la intervención. El palacio en su origen, el siglo XVII, se estructuraba en forma de $U$ (Fig.26), con un muro de cerramiento de la misma, totalmente funcional. De ambos solo tenemos noticias extraídas de los planos de la ciudad mencionados. Ningún otro documento nos permite siquiera conocer alguna de sus características. Solamente la aparición de una cúpula, que pervive hasta nuestros días, introduce un elemento arquitectónico cuya razón de ser desconocemos.

Si volver al origen, a la forma de $U$ ofrecía serias dificultades, la historicista intervención de Manuel Ferrando en 1857 -que transformó sustancialmente la tipología del edificio con su nueva configuración de patio central- permite en su resolución la lectura parcial de elementos estilísticos y constructivos de los dos momentos clave de su construcción, los siglos XVII y XVIII. A la vez que la jerarquización que imprime en sus frentes, en especial respecto a la definición de una fachada principal a la plaza con sus torreones y acceso doble coronado con amplio y rebajado tímpano curvo (Fig.28), el proyecto de Ferrando ofrece una arquitectura clara fruto del momento de su construcción, frente al indefinido muro de cierre de la $U$ originaria.

La aceptación de la intervención del siglo XIX del Maestro Ferrando, aún a sabiendas de que es un juicio de valor que implica desechar otras hipótesis, es el primer punto de partida de la actuación. Poner de manifiesto tal estructura constituye el objetivo fundamental de la restauración, lo que en consecuencia lleva a la obtención de secuencias de espacios aptos para exposición pictórica en un recorrido que la tipología de patio propicia.

Restitución, denomina Ignasi de Solá Morales esta actuación que define con estas palabras: "La operación llevada a cabo debería llamarse una restitución, es decir, el trabajo por el cual al edificio se le devuelven con mejor claridad y transparencia algunos de su más genuinos valores. Restituyendo, ciertamente, 
no se salva todo el pasado ni todas las vicisitudes que el edificio ha sufrido en el tiempo. Se toma el riesgo de interpretar lo que es fundamental y separado de lo que sólo es accesorio. (...) Para este palacio podía haber razones para volver a la originaria forma de $U$ anterior a la reforma de mediados del siglo XIX. Pero en vez de hacer este viaje a los orígenes se acepta la congruencia compositiva que, de un modo un tanto "historicista", llevará a cabo Manuel Ferrando al dar forma de patio cerrado y fachada jerárquica entre dos torreones a aquello que nunca la tuvo. (6)

La segunda decisión fundamental es la asunción de la división tripartita, manteniendo un carácter principal para el primer piso y no para la planta baja como sería propio de la sensibilidad actual.

Se recupera diáfano el gran espacio de planta baja, con la demolición de oficinas, despachos y escaleras de acceso a las viviendas superiores y se da un carácter completamente nuevo a los espacios del ático, antes ocupado por viviendas, ahora transformado en un sistema libre y fluido de espacios expositivos. La eliminación de los huecos adventicios abiertos en las fachadas, tanto en la fachada principal como en las correspondientes a las calles de la Harina y Vergara, clarifica la comprensión de esta división tripartita, reflejo de la organización interna de los diferentes espacios que integran cada nivel: en planta noble, donde se conserva el gusto de la época en la secuencia recuperada de los diferentes salones; en planta baja en la que se libera la altura establecida por el orden inferior del patio, lo que posibilita en su generosidad espacial la creación de itinerarios expositivos conectados con él; y finalmente los áticos totalmente alterados en el momento de realizar el proyecto y que son despojados de fragmentaciones.

Una mención especial merece el invernadero, la "serre", objeto también de la intervención que se convierte en el límite físico del proyecto, como elemento articulador con la futura segunda fase de la intervención, que debía consistir en la dotación de las dependencias necesarias para un óptimo funcionamiento del museo, tales como administración, sala de 


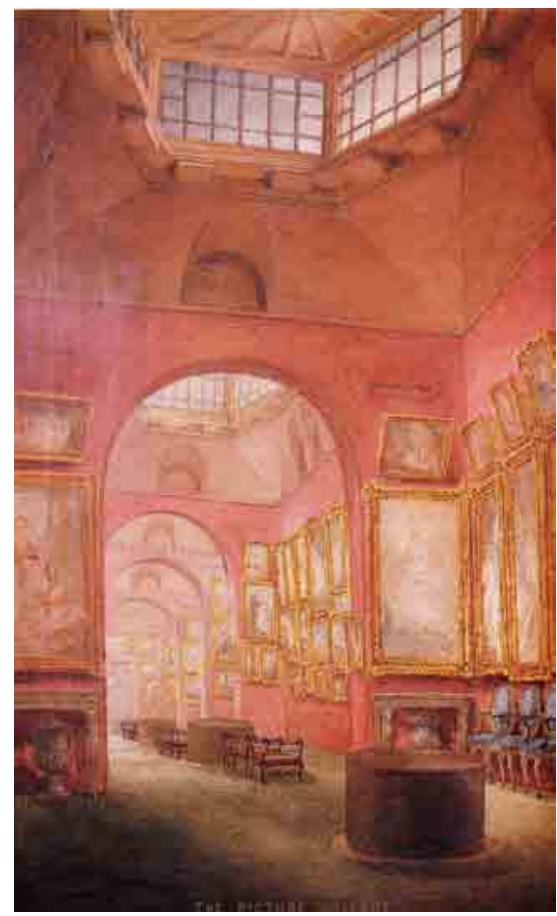

Fig. 29

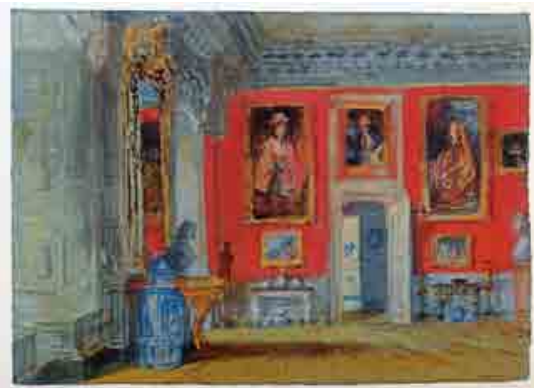

Fig. 30

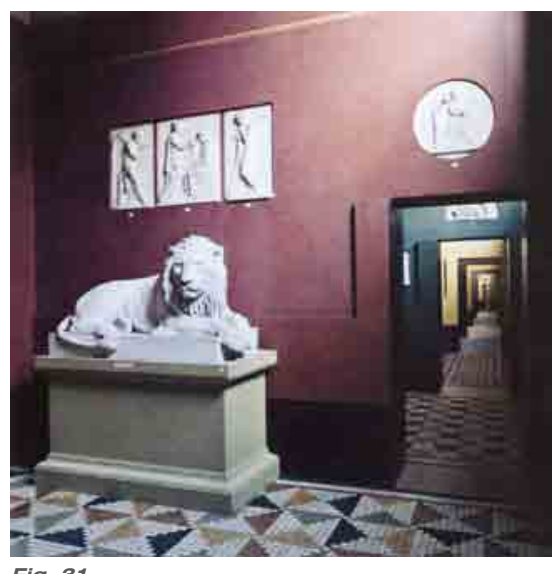

Fig. 31 conferencias, video, hemeroteca, talleres, laboratorios, etc., disparidad de requerimientos que se pueden satisfacer con la disposición de los nuevos locales en el espacio definido por las casas adyacentes, lo que no afecta a la unidad característica del noble edificio original. De su resolución hablaremos en el apartado de la intervención.

La tercera decisión, clave para definir el juicio establecido en la misma operación restauradora, es la del tratamiento de los espacios interiores. Como hemos afirmado, en su presencia exterior el edificio recompone el carácter mantenido desde la reforma decimonónica, forzando la regla clasicista que le servía de soporte y eliminando las casuales apariciones de elementos no controlados. Armada pues la estructura espacial del edificio a través de las opciones planimétricas y altrimétricas ya comentadas -la elección y mantenimiento del tipo de edificio de patio central, con escalera como cuerpo autónomo y división vertical tripartita- se aborda el problema de la epidermis, del acabado.

Se trata de establecer en este plano, un juicio, una interpretación, que permita la lectura de la secuencia de espacios, "enfilade", con la que se estructuran los salones de la planta noble, única huella que llega hasta nuestros días de las trazas del palacio, del gusto de una época, de la aplicación de refinados oficios en la definición de los caracteres estilísticos, cada uno diferente al otro, que conforman los diferentes salones a los que se accede por la gran escalera, bajo la cúpula recuperada. La intervención en los salones de la planta noble oscila entre la recuperación de las características de aquellos bien conservados y la intervención por analogía en los que se hallan en pésimo estado de conservación, estableciendo así un diálogo entre la semejanza y la diferencia.

Frente a la aceptada neutralidad del fondo blanco, la experiencia de museos como la National Gallery londinense, el Rijsmuseum, o la Wallace Collection de Londres, muestra cómo la utilización de colores intensos en los muros pone en valor la obra expuesta. A partir de esta constatación, el uso del color 
se determina en el proyecto como una acción, que contrastada históricamente su validez, que permite económicamente -dado el escaso presupuesto con que se contaba- y con calculada secuencia subrayar las diferencias de los tratamientos estilísticos que muestran los salones.

Los referentes históricos son abundantes y de gran trascendencia: la casa de John Soane (Fig.29), cuya serie de salas muestran diferentes colores; el museo Thorvaldsen de Copenhagen (Fig.31), construido entre 1839 y 1848 por Bindesböll, o en el Faaborg Museum, diseñado por Carl Petersen en 1915. El descubrimiento, en el siglo XVIII, de los colores empleados en las estancias de Pompeya (Fig.32), es un precedente que azuza la pasión grecorromana de la sociedad inglesa de la ilustración y que se aplicará en diversas residencias de aristócratas y burgueses (Fig.33), embrión muchas de ellas de importantes galerías expositivas, como se refleja en deliciosas acuarelas de Turner ${ }^{(\text {Fig.30) }}$ o en minuciosas representaciones de salones burgueses a cargo de Fortuny.

Las plantas baja y áticos, liberadas de oficinas y viviendas, permiten el uso de un lenguaje más espacialista y más abstracto en la tradición moderna. La planta baja aporta unas espaciosas salas diáfanas cuyo tratamiento de huecos recuerda el introducido por Albini en intervenciones como el Museo del Palazzo Bianco de Génova (1950-1951) o la Galería del Palazzo Rosso (Fig.34), de la misma ciudad (1961). En ambos casos se establece una relación visual con el patio a través de cierres vidriados que no afectan a la lectura del orden arquitectónico. Esta solución permite un uso expansivo de las salas de exposición de planta baja, que pueden extenderse, merced a esta conexión visual suscitada, al espacio abierto del patio.

La planta ático es el resultado de la lectura de la variedad altimétrica que presentan los techos de la planta noble, interpretados de modo que se produzcan una serie de conexiones espaciales, de visuales y de recorridos, acordes con la sensibilidad propia de la arquitectura moderna.

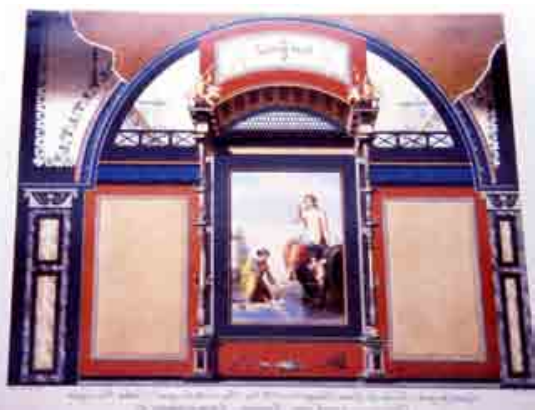

Fig. 32
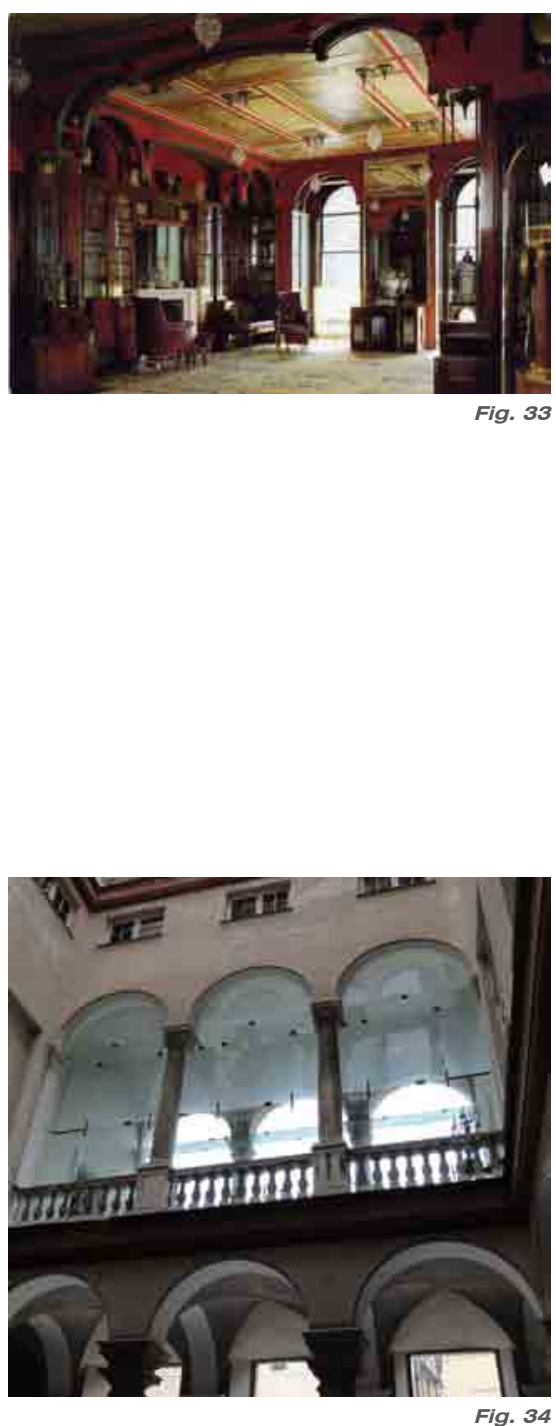
ESTADO ANTERIOR A LA INTERVENCIÓN

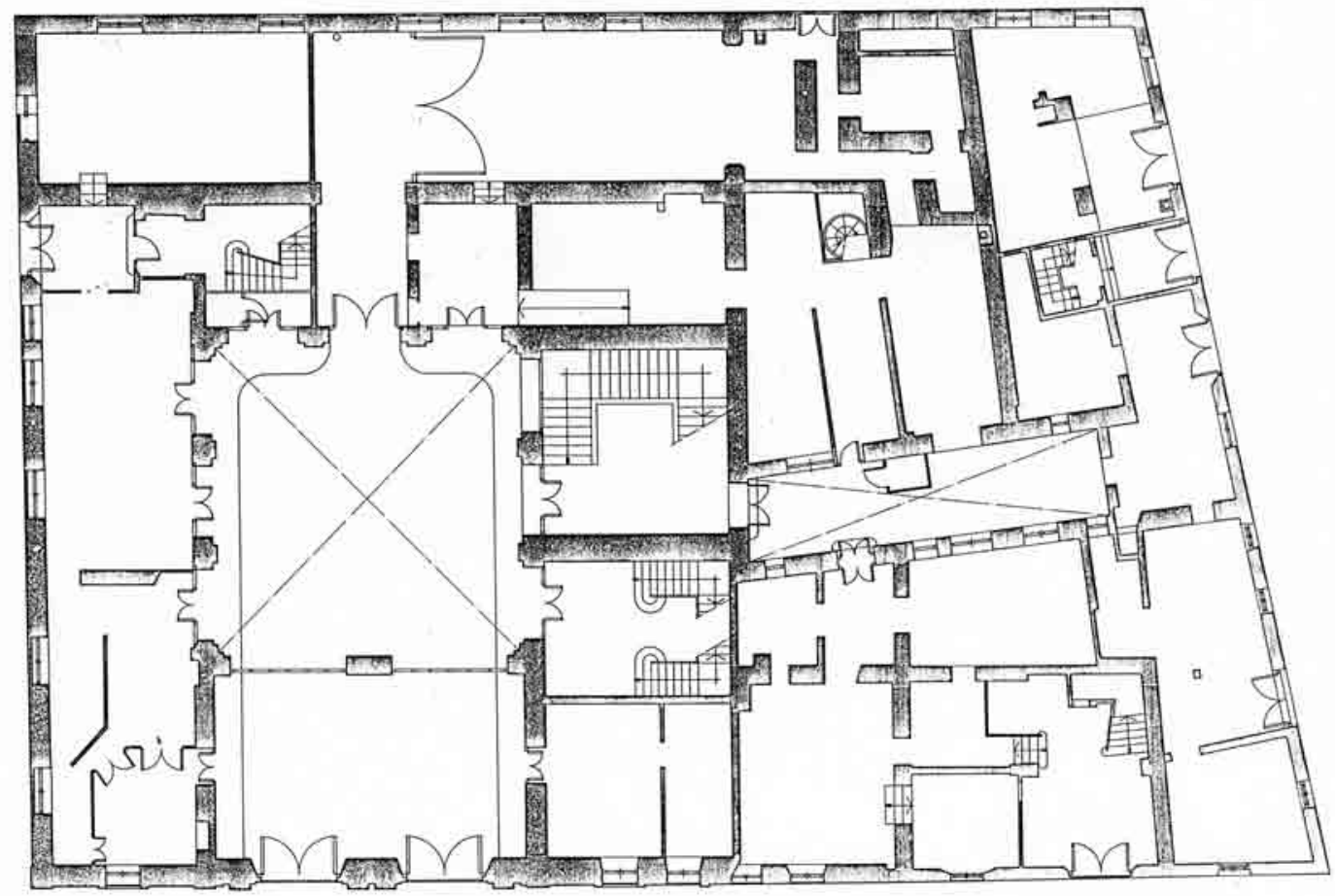

Estado anterior. Planta baja

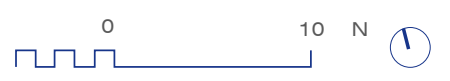


PROYECTO DE INTERVENCIÓN
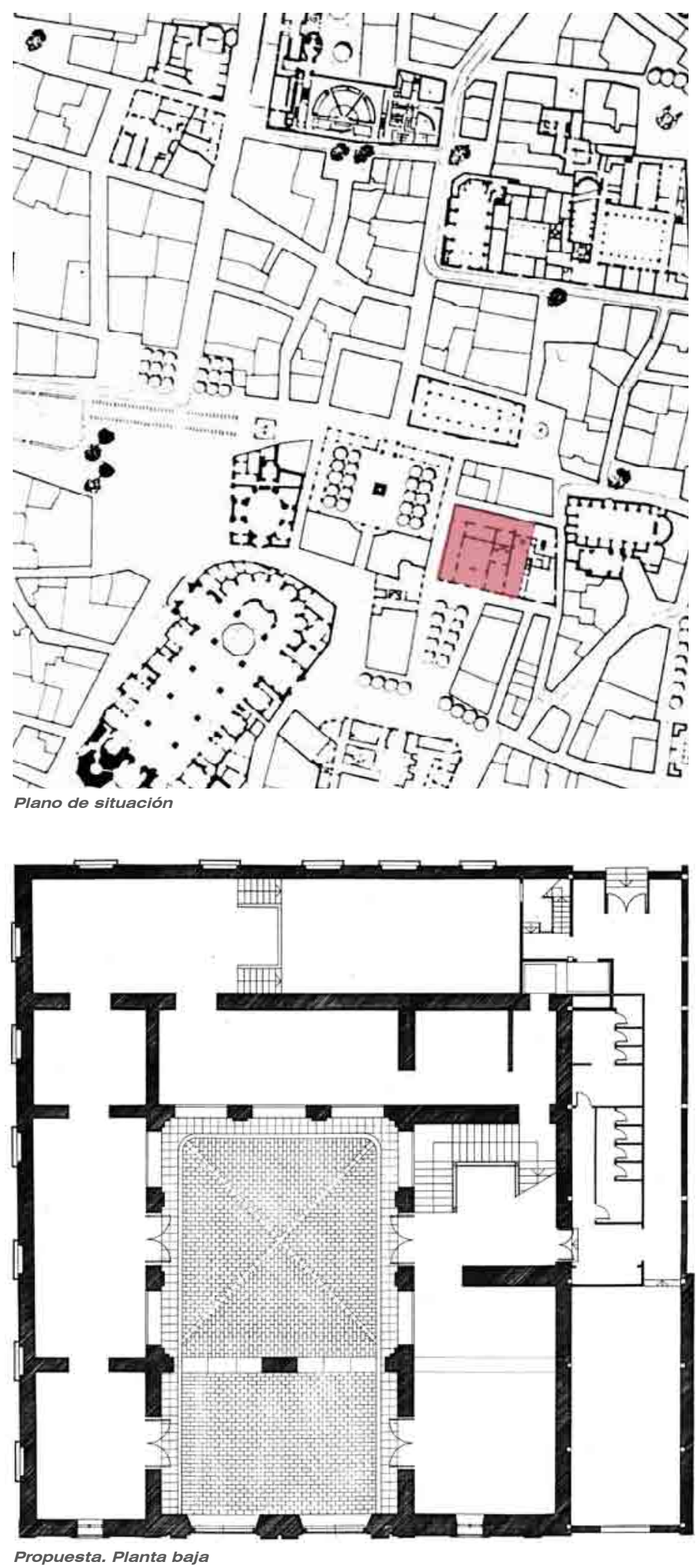

$\sqcap$ 


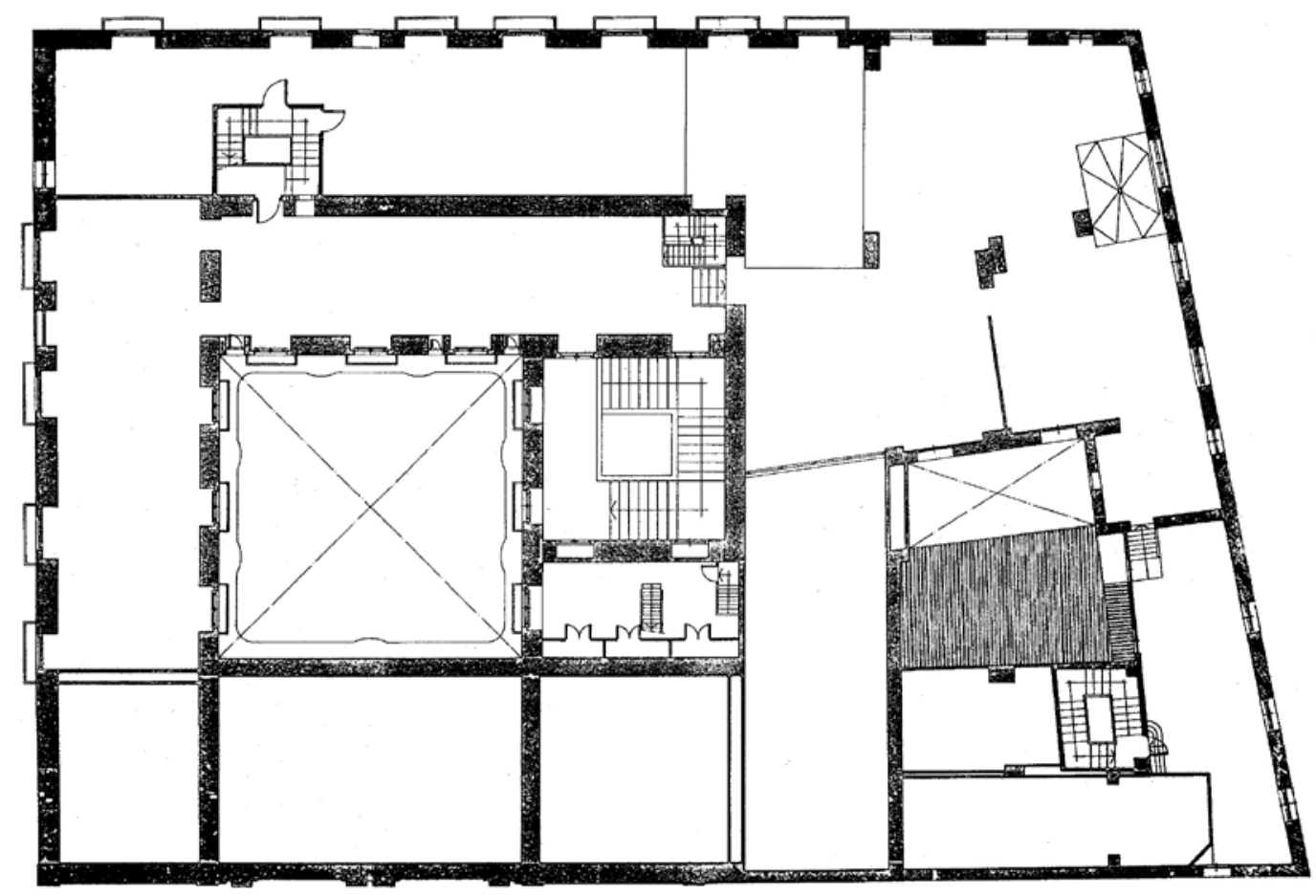

Estado anterior. Planta altillos

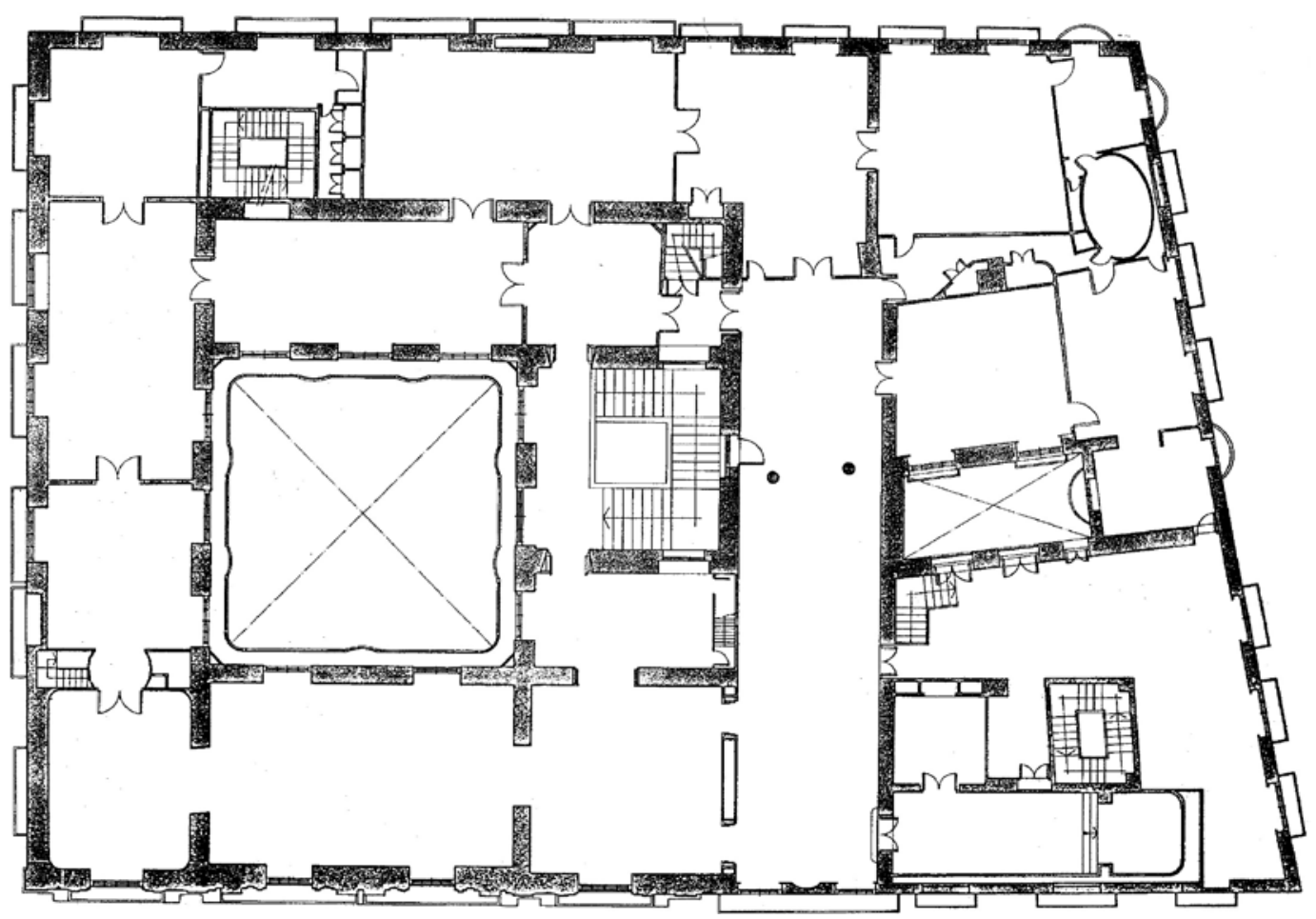

Estado anterior. Planta noble

$$
\text { Пำ ن }
$$




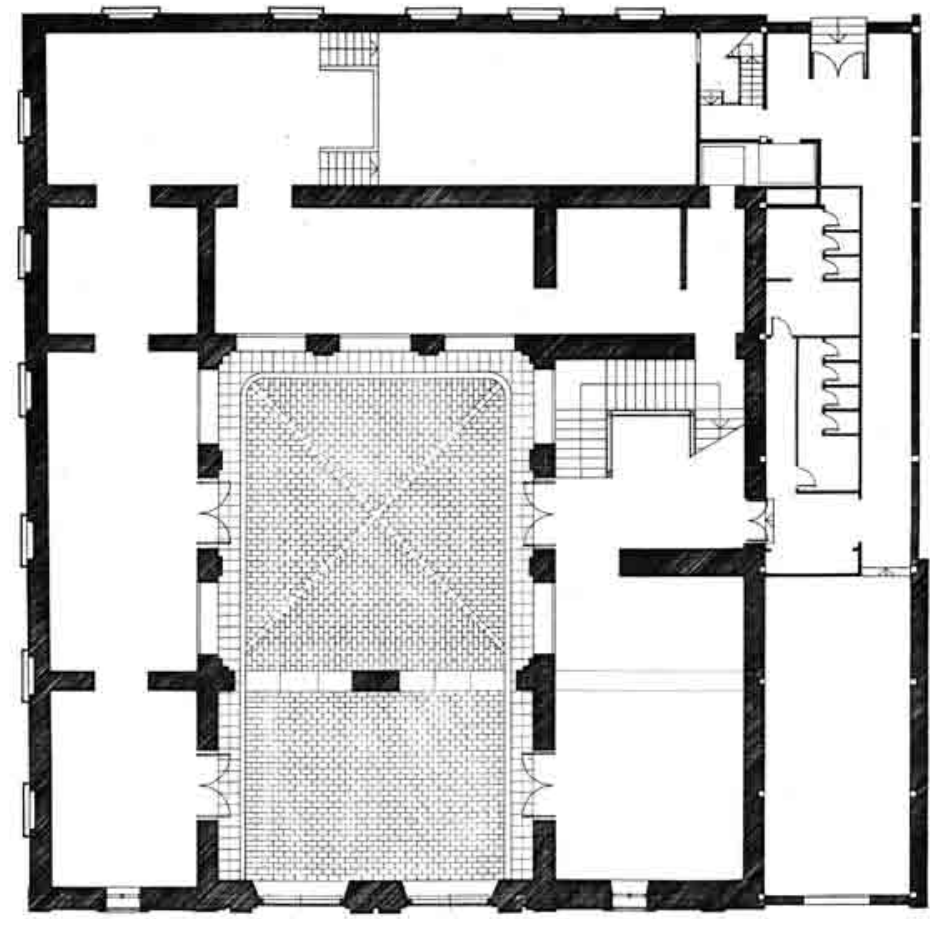

Propuesta. Planta altillos

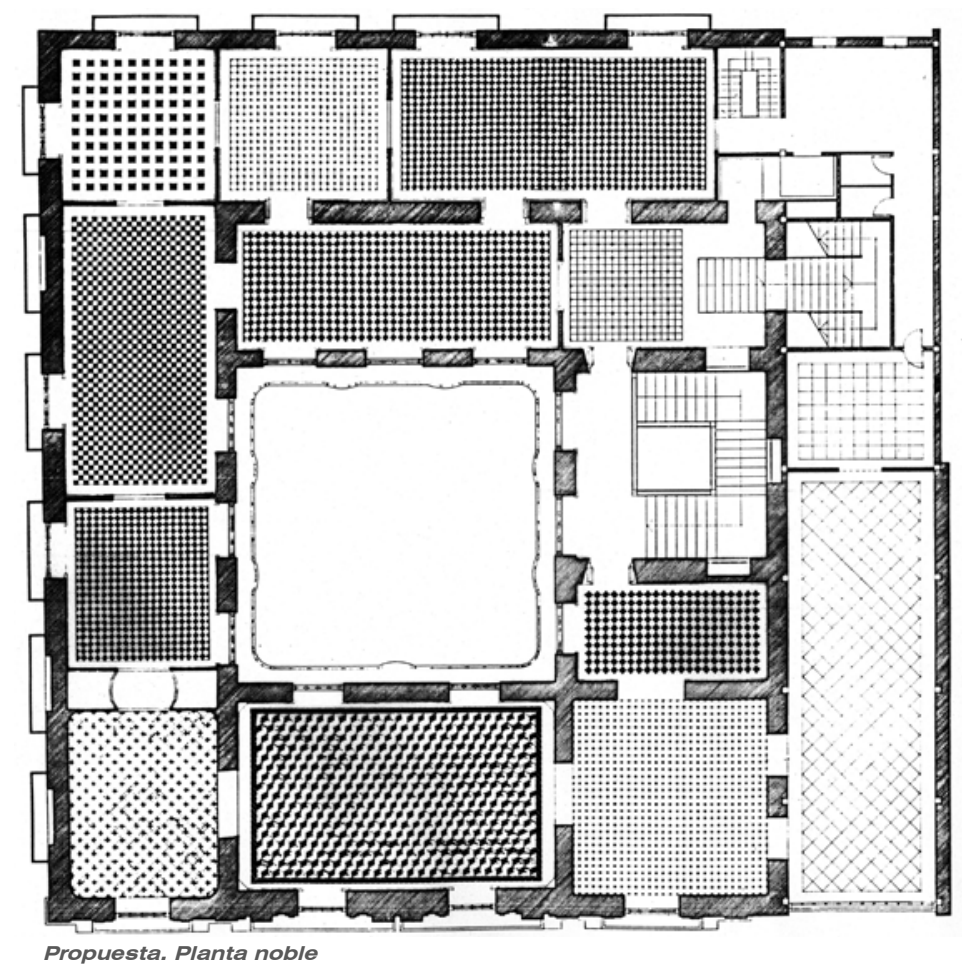

ロோ $10 N($ 


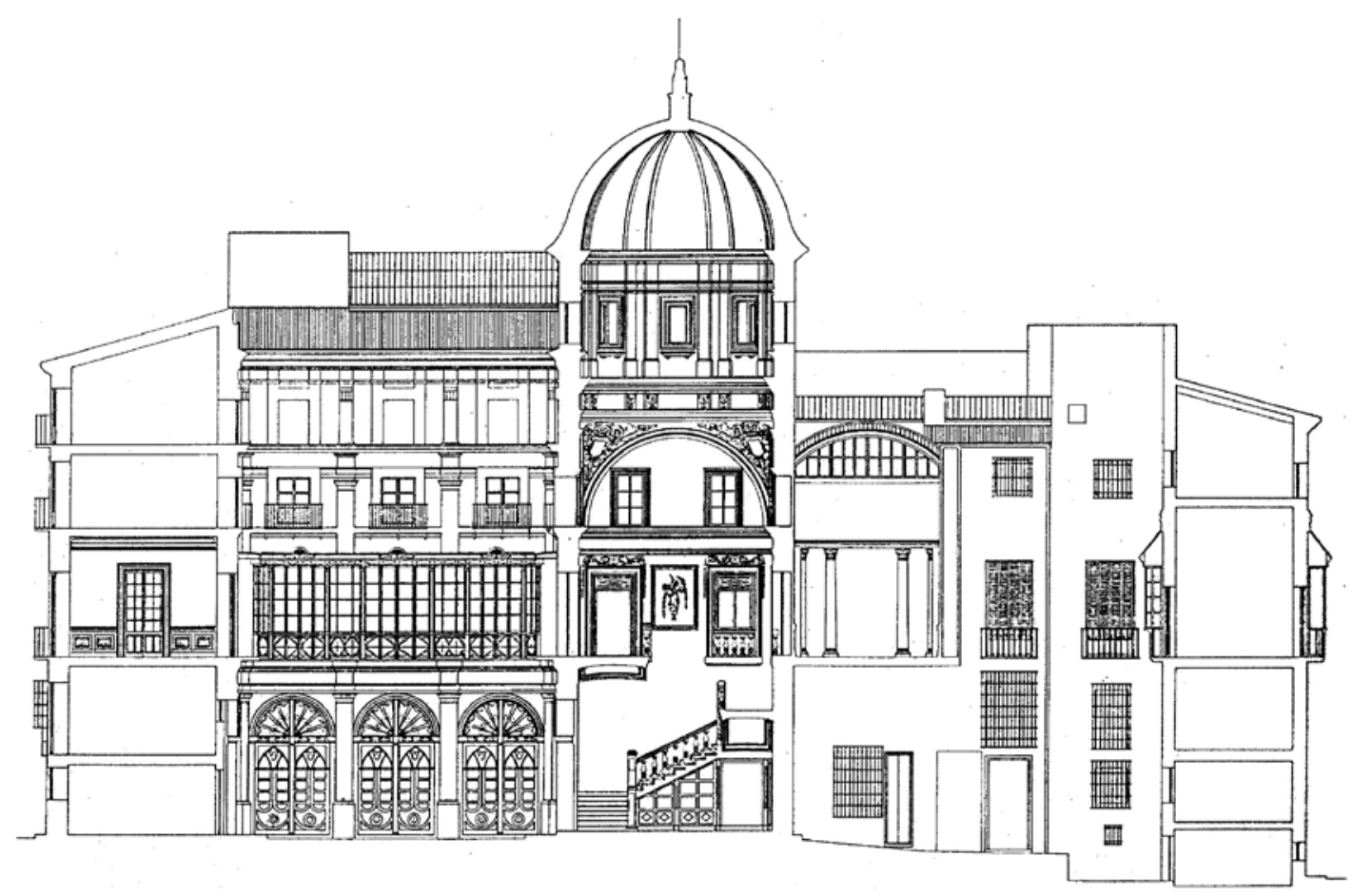

Estado anterior. Sección principal

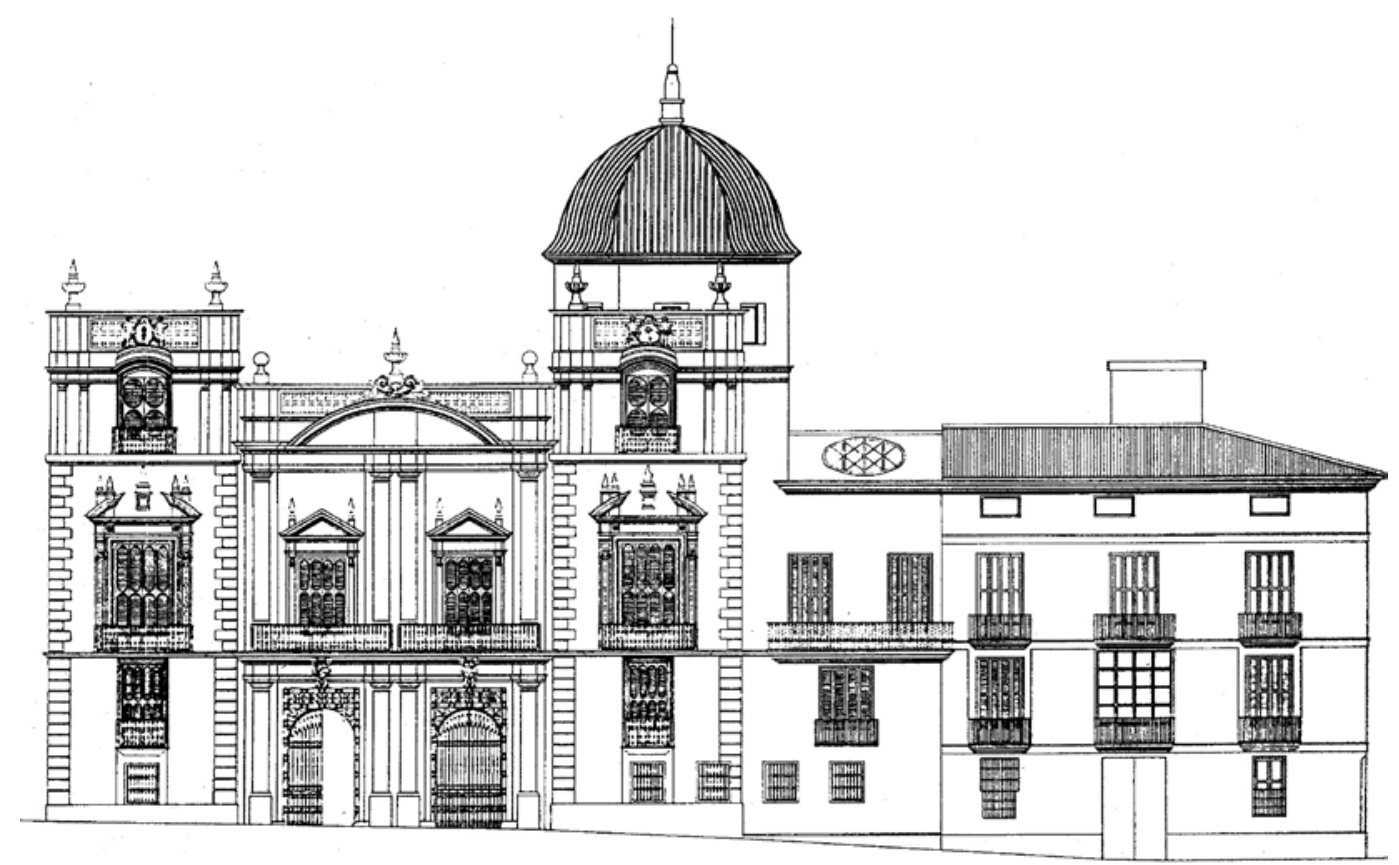

Estado anterior. Alzado principal

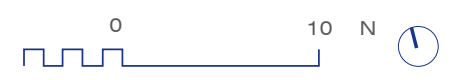




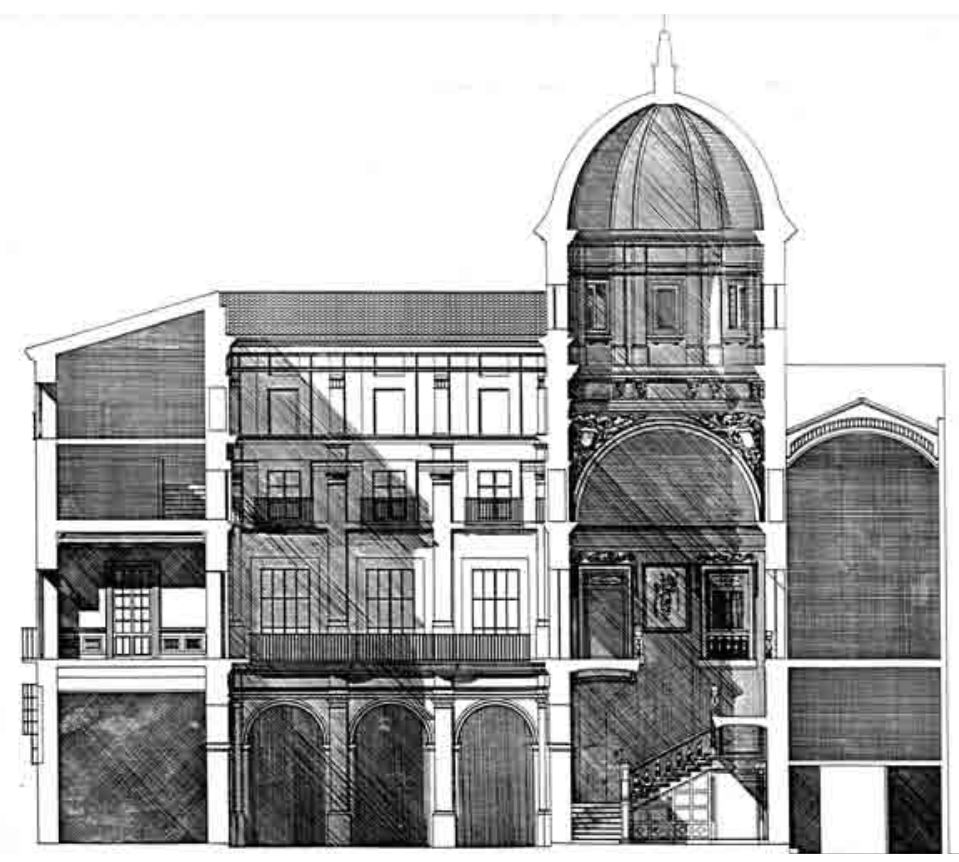

Propuesta. Sección principal

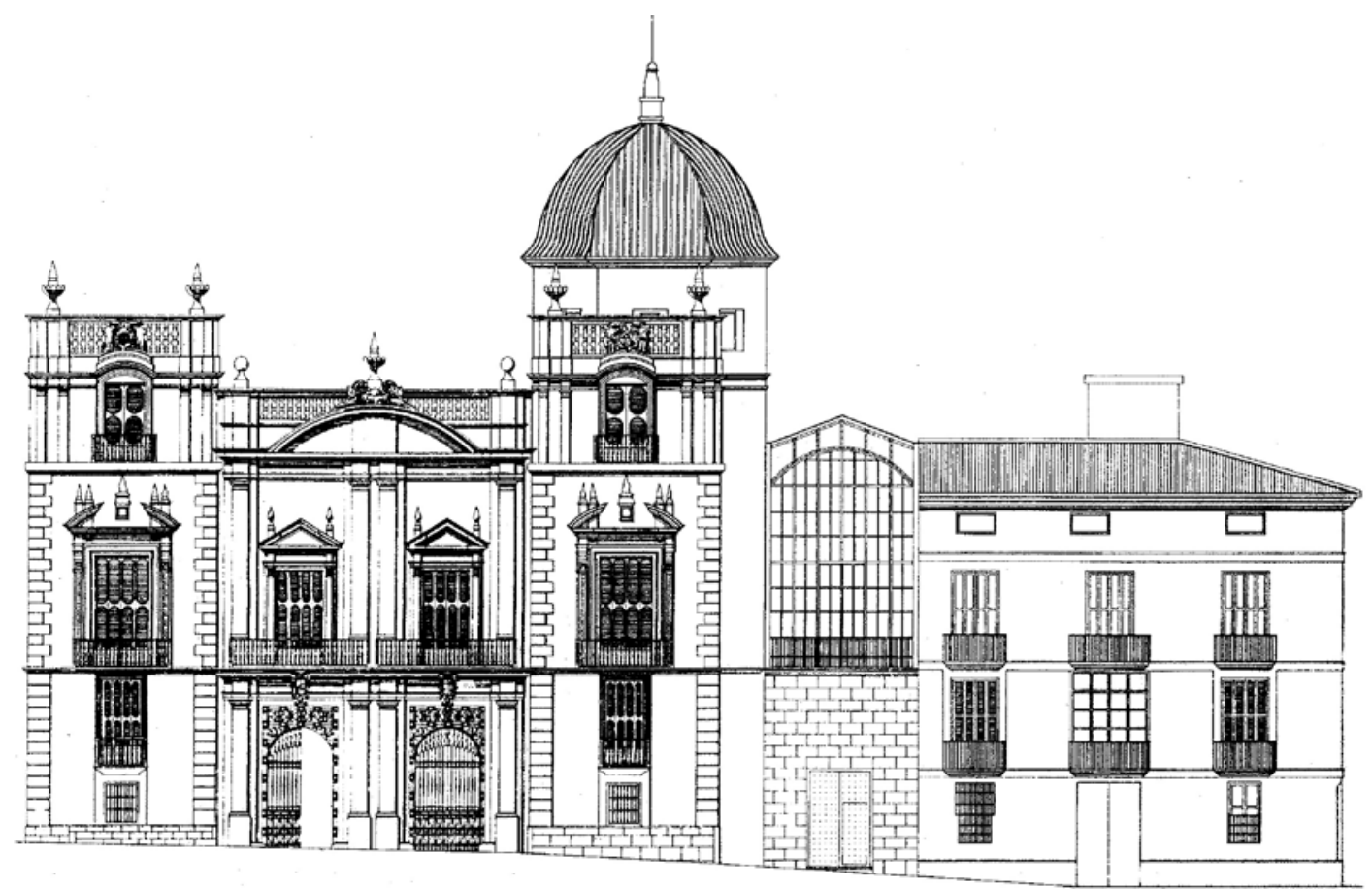

Propuesta. Alzado principal

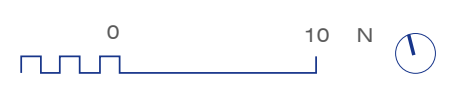




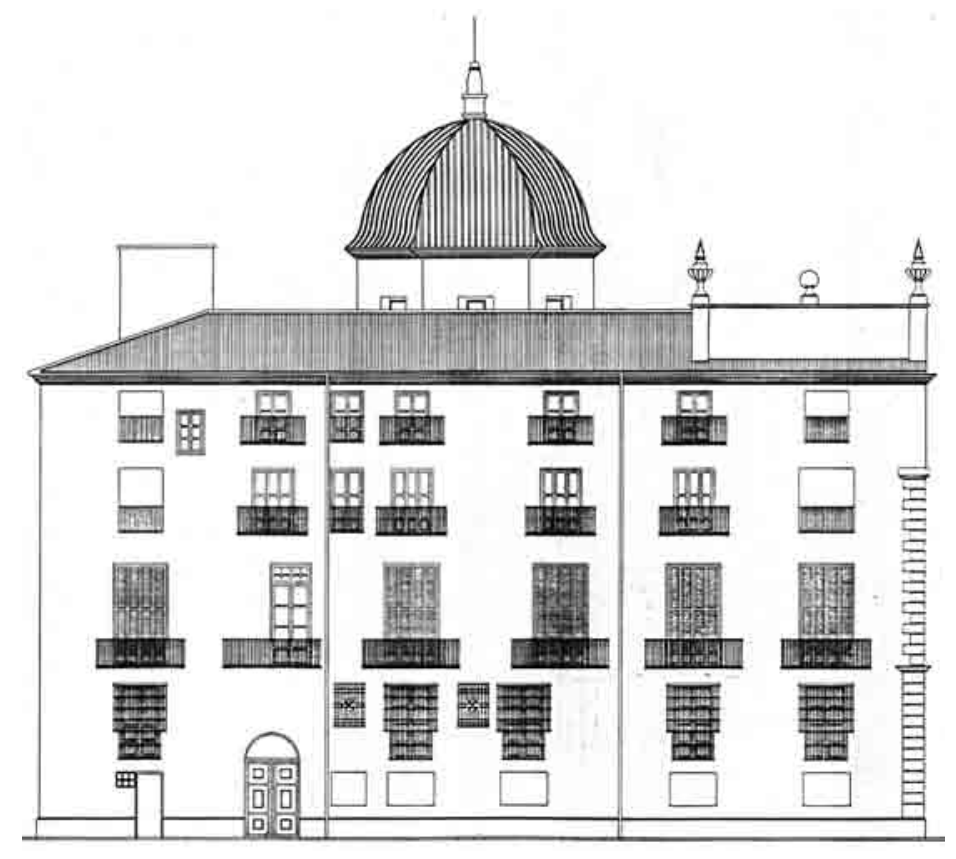

Estado anterior. Alzado a la Calle de la Harina

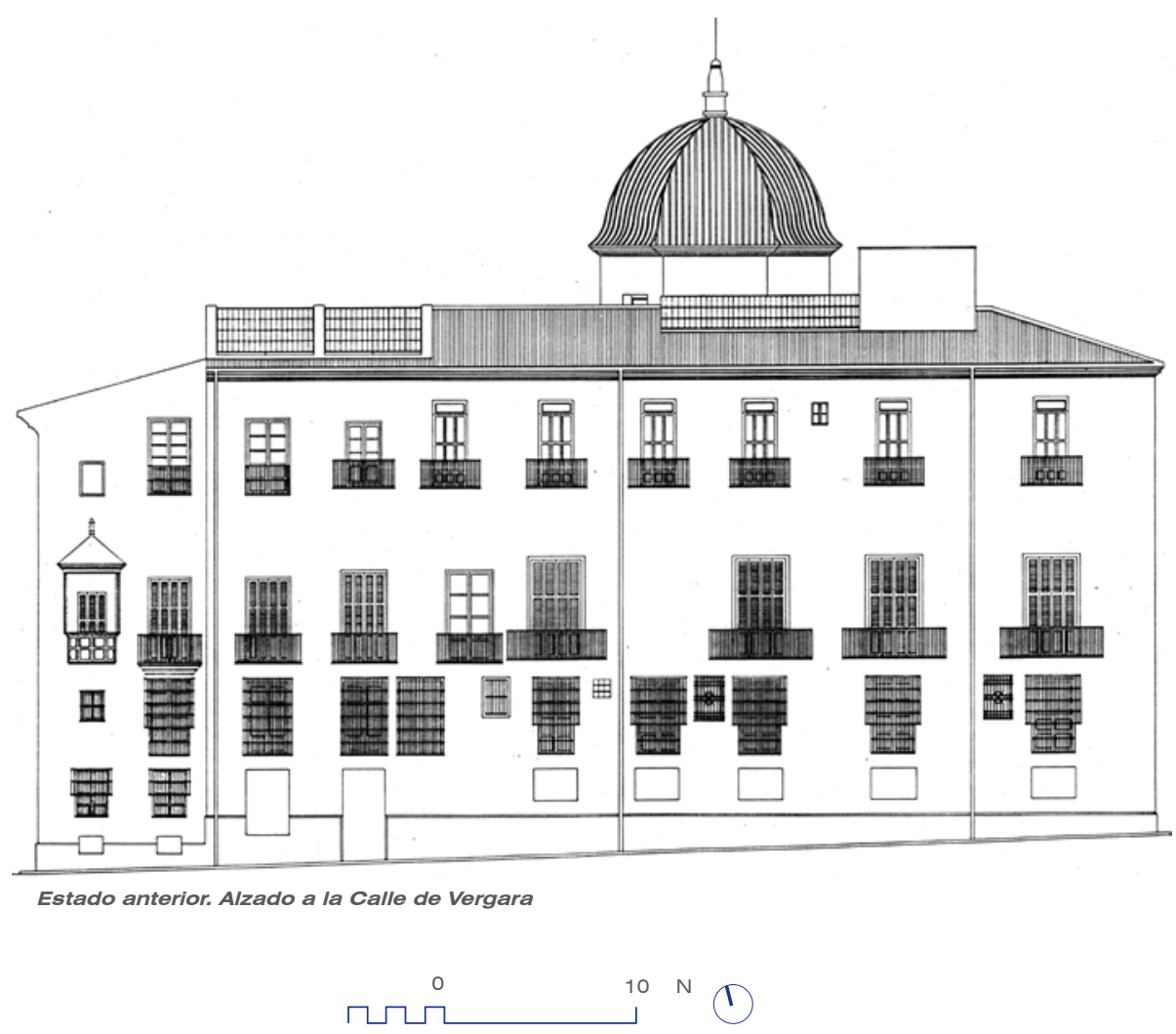




\section{PROYECTO DE INTERVENCIÓN}
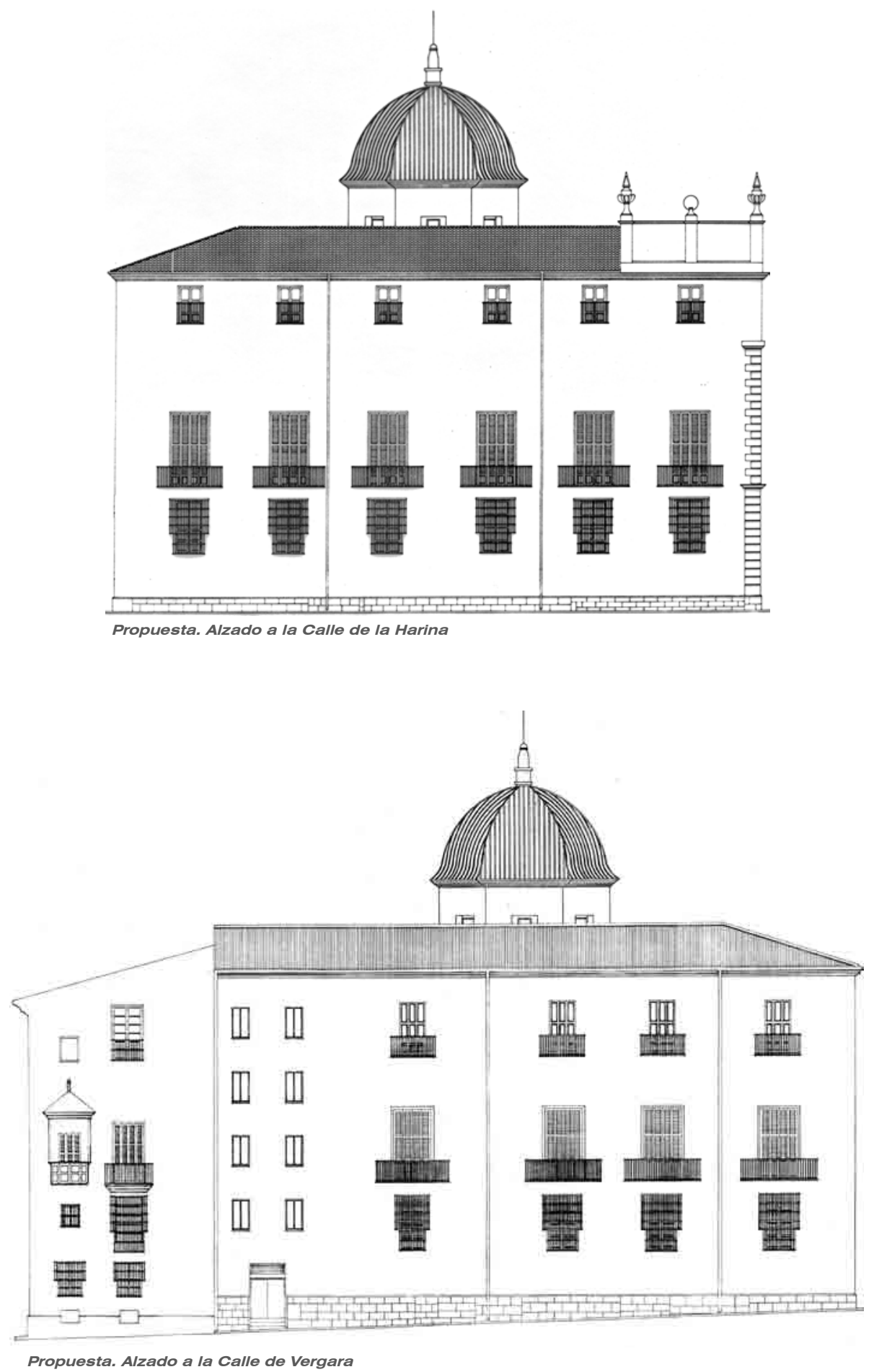

ேோ ${ }^{10} N(1)$ 


\subsubsection{La intervención}

Pasemos, pues, a especificar la aplicación en el proyecto de intervención en el Palacio del Marqués de Campo, de los criterios de actuación expuestos en el apartado anterior.

\subsubsection{El patio y las fachadas del Palacio del Marqués de Campo}

La restitución del patio se centró en la asunción del orden de pilastras gigantes sobre arcos de medio punto, en sus tres frentes del siglo XVII, y de la puesta en valor de su cuarta vertiente, la decimonónica, que cierra la $U$ original y se divide mediante dos arcos de tipo carpanel en planta baja. El mirador que recorría en planta primera todo el perímetro del patio, en muy mal estado de conservación, rompía la visión del orden gigante y unificaba torpemente los diversos frentes cronológicamente diferenciados.

Para hacer más clara la lectura del edificio, se reconstruye el mirador en el costado decimonónico (Fig.36) y se libera del mismo los costados del s. XVII (Fig.35), dejando visibles las pilastras y mostrando lo que la limpieza de los paramentos ha descubierto: las cornisas, impostas y capiteles cerámicos que quedan vistos para enriquecer con su textura la ordenación del conjunto. Carpinterías y cerrajerías, que enseñan la calidad de los oficios, se restauran utilizando en aquéllas un tono de grises basado en la tradición arquitectónica valenciana que nunca dejará la madera natural vista, sino protegida por una capa de pintura. Siguiendo la tradición, los paramentos se pintan a la cal con ocres naturales para conseguir un noble envejecimiento.

La estructura tripartita, base, planta noble y ático, clara en

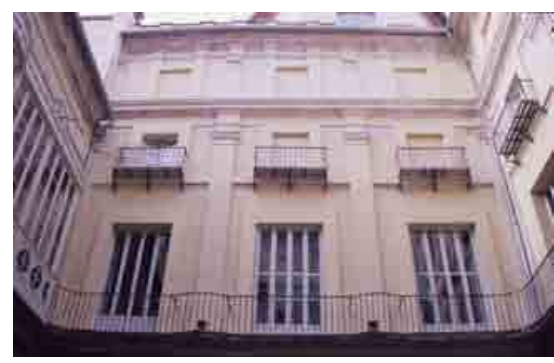
el patio, deberá informar también el exterior. La fachada principal viene definida por la intervención de 1857, como se ha dicho. Los testeros de la $U$ del siglo XVII, convertidos en torres, enmarcan el acceso. Tras la restauración de cantería, cerrajería (en bronce patinado) y carpintería, su tratamiento con un estuco a base de silicatos ocre se diferenciará, con su textura, del tratamiento de 
las otras fachadas para indicar el diferente momento histórico en que se construyeron; las de la calle Vergara y Harina en el siglo XVII y la principal en el XIX. Apreciación, quizás para eruditos, pero que hace visible esa matización cronológica.

Las fachadas de la calle de la Harina y Vergara, una vez eliminada la fenestración adventicia reseñada, se tratan con un enlucido de ocre natural y se restauran sus cornisas, carpinterías y cerrajerías.

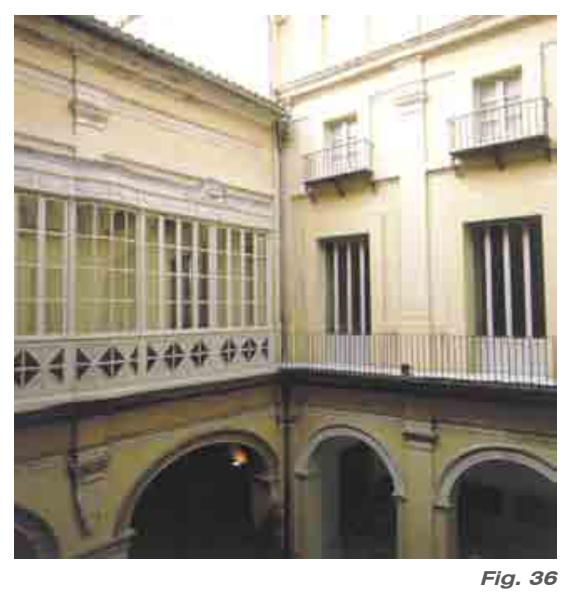

\subsubsection{El espacio interior. Planta Baja}

La planta baja, claramente delimitada en el patio mediante el orden citado había sido, en su interior, gravemente alterada con altillos y nayas. Los trabajos de limpieza y de demoliciones parciales llevados a cabo antes de que se produjera el encargo de proyecto impiden conocer exactamente su disposición y funciones. Era evidente que la apertura de huecos se había hecho sin más orden que el marcado por la necesidad. La demolición de los restos todavía existentes, una vez estudiados, lleva a una recuperación de su escala y dimensiones dando lugar a una secuencia de espacios de generosa altura y gran potencia, que por su situación y conexión con el patio posibilita una independencia funcional del resto del edificio (Fig.37 y Fig.38).

A través de la escalera principal, cuyo peldañeado de madera de caoba fue restaurado, se accede a la planta noble. Esta planta es la única que conserva volúmenes, espacios, escayolas y demás elementos característicos del gusto del siglo XIX.

\subsubsection{El espacio interior. Planta Noble}

En la planta noble, la actuación se centra en conservar -y recuperar en su caso- el espíritu decimonónico de sus espacios, volúmenes y acabados: pavimentos, escayolas, etc.... Se presta especial atención al tratamiento de color de los paramentos y a los pavimentos para resaltar la sucesión de salones eclécticos en esta planta. Todos ellos, excepto los de la doble crujía del fondo, están situados a caballo entre el patio y la calle.
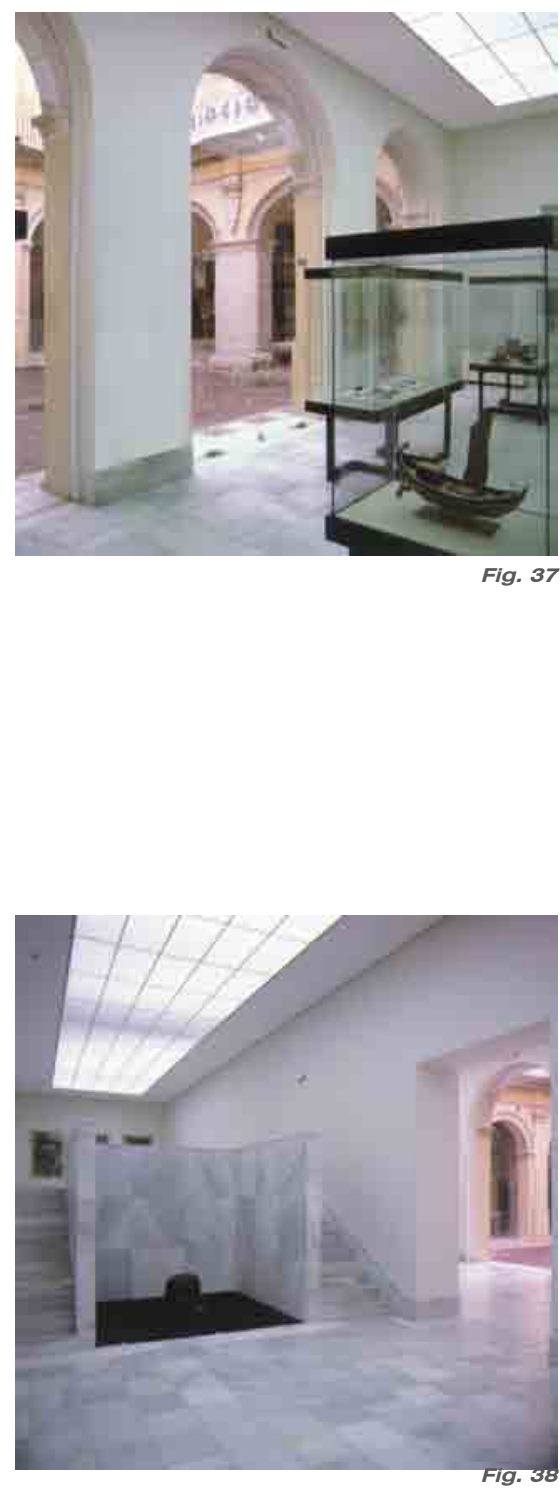


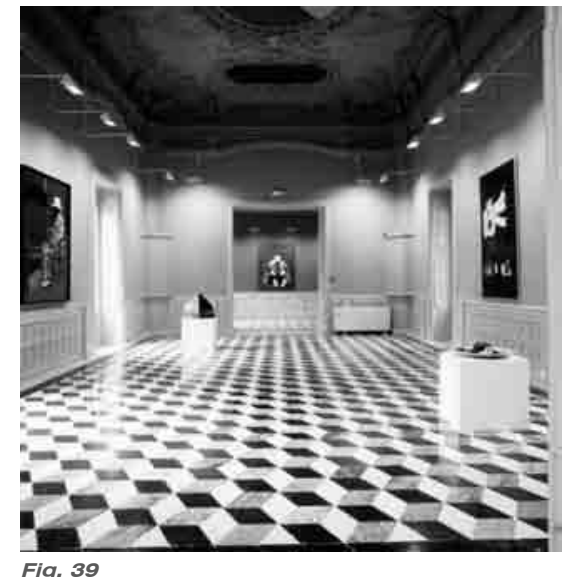

Fig. 39

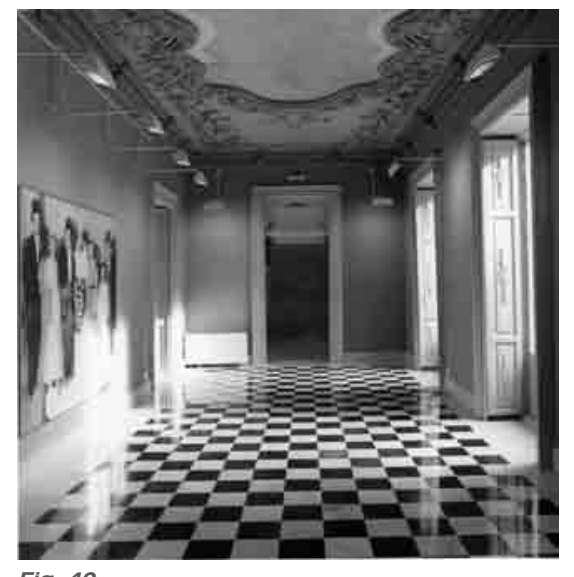

Fig. 40

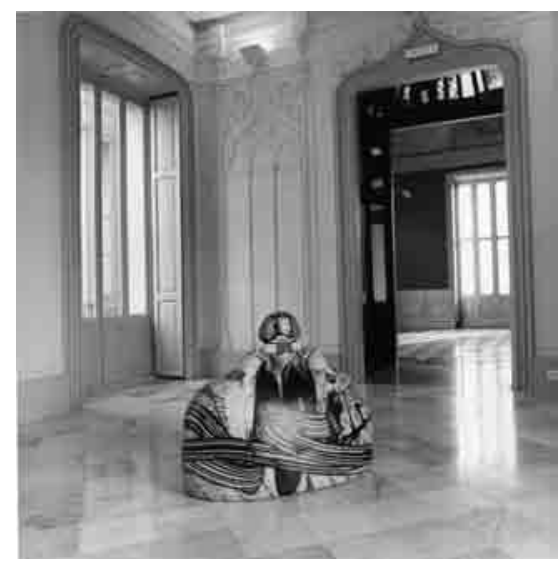

Fig. 41

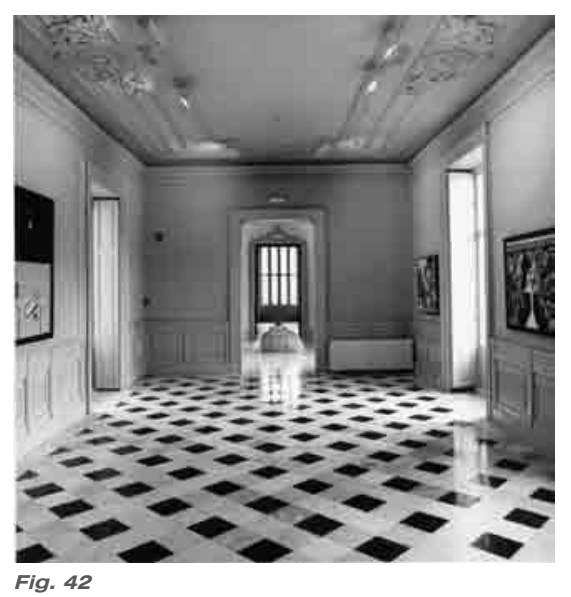

La recuperación y puesta en valor de la secuencia ecléctica de los distintos salones, su calidad espacial y ornamental, representa una operación primordial de acuerdo con los criterios básicos expuestos de la restauración: pavimentos, escayolas, carpinterías que han llegado hasta nuestros días deben mostrar todos sus caracteres así como contribuir al restablecimiento de las características de la enfilade de la planta noble (Fig.39-42).

Merecen reseñarse tres aspectos de la intervención en la planta noble. En referencia al tratamiento de los pavimentos, se propone la conservación de los dameros en blanco y negro de los distintos salones que han Ilegado hasta nosotros. En aquellos en los que el pavimento fue sustraído, se coloca un solado de mármol blanco que distingue el momento de la intervención del original decimonónico. Este mismo tratamiento se hace extensivo a los solados de las plantas baja y ático de nueva ejecución. Por otro lado, las sucesivas capas de pinturas y purpurinas que a lo largo del tiempo recubrieron paramentos, molduras y carpinterías, habían arruinado los paramentos estucados -que no representaban la totalidad de los salones-y los elementos originales de pan de oro y plata, haciendo imposible su recuperación. Los jirones de tela que exhibía algún salón demostraban la existencia de antiguos tapizados totalmente perdidos e irrecuperables.

La introducción del color en el tratamiento de los diversos salones que integran la secuencia espacial de la planta noble permite la lectura de los mismos desde el exiguo presupuesto del que se dispone. La estudiada gama subraya la secuencia de las diversas salas; potencia el espacio y la calidad de los oficios que lo configuran (representada en algunas de las escayolas y carpinterías, como las del salón de baile) así como la variedad de carácter definida en cada espacio; variedad apoyada en la diversidad de los pavimentos originales recuperados. Finalmente, los salones de Baile e Isabelino disponen de unos techos decorados por lienzos que hay que completar para devolverles su carácter. Una pintura actual, como actual fue la intervención del Maestro Ferrando en 1857, que potencie con la valoración del color, de la textura y de la veladura, los 
valores formales del salón donde se ubican, es la planteada para cerrar la restauración de esta noble planta. A sugerencia del arquitecto, el Ayuntamiento de Valencia encarga esta actuación al reconocido pintor valenciano Jordi Teixidor, quien mediante el color, la textura y la veladura de una pintura actual ayuda a resaltar la atmósfera minuciosa del espacio arquitectónico.

\subsubsection{Plantas ático}

En el caso de las plantas ático, tras la eliminación del

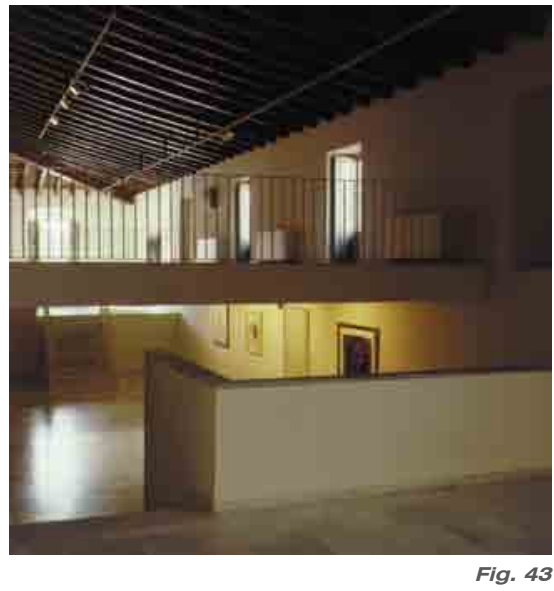
fraccionamiento que su uso como vivienda había producido, se procede a su fusión. Con el aprovechamiento de la variedad altimétrica, se produce un juego de niveles en el que se desarrolla un nuevo recorrido expositivo bajo la única cubierta de madera recuperada (Fig.43 y Fig. 44).

\subsubsection{El invernadero}

Con respecto al invernadero ${ }^{(F i g .45)}$, la serre, el proyecto plantea su reconstrucción filológica a partir de las pocas cerchas que se encuentran en buen estado. Pero su fachada enturbiaba su comprensión al realizarse como simulador de la diferente dimensión que presenta la torre colindante, en relación a la composición del frente principal. De ahí que se configure como una fachada acristalada, a la manera del siglo XIX, que muestre

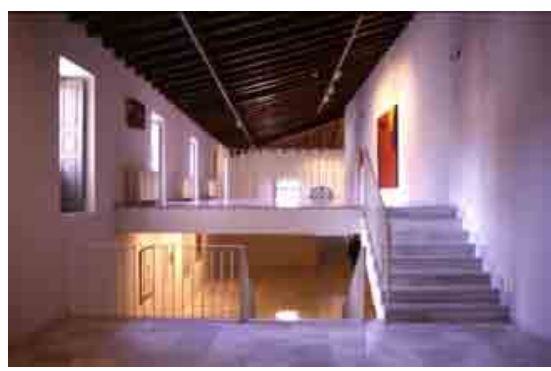

Fig. 44 al exterior su contenido, apoyada sobre un zócalo de piedra de Borriol que configura el paramento de planta baja. En ella, un gran portalón, revestido de cinc claveteado como otros portones del centro histórico, facilitará la carga y descarga indispensable en un museo.

Los muros que limitan la serre se prolongan hasta la calle Venerables. De esta forma se muestra con claridad el bloque palaciego y el bloque de viviendas. Se obtiene de esta manera un acceso de personal -que es al mismo tiempo necesaria salida de evacuación- y una serie de plantas de servicio que conectan éste con los niveles del palacio. Se propician así dependencias para el personal del museo que no afectan al espacio palaciego.

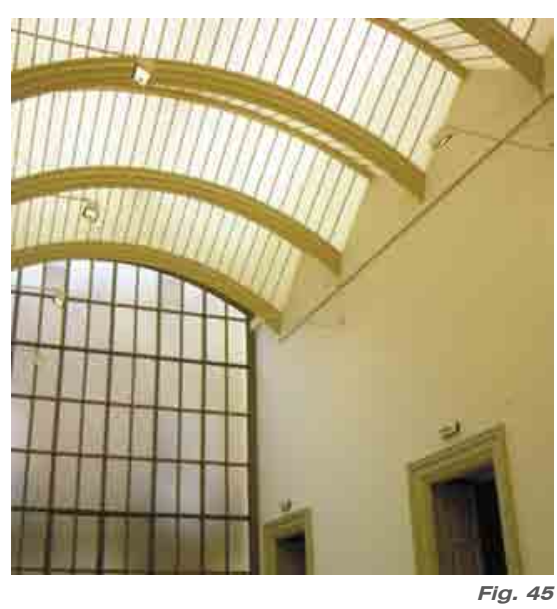




\subsubsection{De Palacio del Marqués de Campo a Museo de la Ciudad. Criterios organizativos. Usos y accesos}

\subsubsection{Programa: Usos y accesos}

El nuevo Museo de la Ciudad responde a un programa municipal -de alcance moderado- cuyo cometido primordial es el albergar la colección de arte de la ciudad. Creado en 1927, la primitiva institución tenía por objeto la recopilación de cuantos elementos valiosos tuviese el consistorio $y$, en dicho momento originario, no disponía de personal ni de sede propia. Esta recopilación de elementos destacaba por su carácter heterogéneo, por su importante dispersión y por la ausencia de un criterio eficaz de clasificación. Había sido, además, desperdigada por diversos locales y su exhibición parcial se había realizado en locales mal acondicionados e insuficientes. Con la rehabilitación de este edificio, el Ayuntamiento pretendía no solo mostrar ordenadamente y con criterio museológico sus más valiosas obras de arte, sino también propiciar un espacio de exhibición temporal que aumentara el interés que por el nuevo museo pudieran manifestar los ciudadanos.

Podemos establecer que el programa de necesidades de un museo actual se organiza en tres apartados: espacios públicos, semipúblicos y espacios para uso interno del museo. La primera fase de rehabilitación del edificio, que contempla solamente el núcleo palaciego, afecta básicamente al primero y segundo.

Eneste proyecto de arquitectura losespacios representativos propios del palacio se consideran los idóneos para exposición;

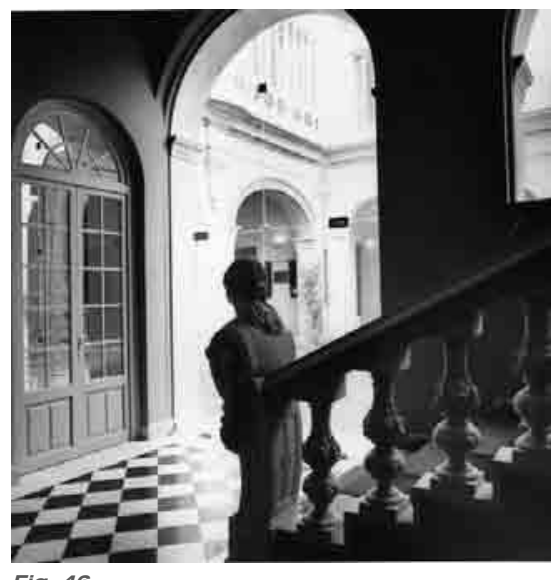
no en vano, como hemos comentado, el museo nació en el palacio, la residencia del coleccionista. La secuencia de salones generada alrededor del patio se convierte en el lugar adecuado para exhibición de las obras, decisión reforzada por el significado que le confiere la recuperación de las estancias históricas. Por las dimensiones y definición de las salas, se propone en la planta noble la exhibición de la colección permanente, cuyos requerimientos superficiales precisarán también la ocupación de las plantas áticos. 
Por otro lado, se propone para la planta baja el uso de exposición temporal, por su generosa altura, accesibilidad exterior y por la posibilidad que el patio permite en cuanto a la expansión del uso expositivo. Asimismo, se ha sopesado la autonomía de uso que, en un momento dado, puede poseer esta planta inferior.

El acceso del público se produce por la doble puerta principal del antiguo Palacio; a la mera funcionalidad se le añade el carácter representativo que la pétrea portada da al uso público y educativo de la institución museística.

Por tanto el palacio propiamente dicho es de uso expositivo en las tres plantas, excepto un espacio de recepción ubicado en planta baja que funciona como vestíbulo de las plantas superiores y que comunica con la escalera principal (Fig.46). El núcleo original del palacio resulta exclusivamente de uso público y se concluye por ello que el resto de funciones que necesita un museo -a las que hemos denominado usos internos-, aún siendo como este de pequeñas dimensiones, requieren la ocupación de una considerable superficie. Estos usos se debían ubicar, en una segunda fase de intervención, en el espacio ocupado antaño por las viviendas colindantes anteriormente descritas, cuyo interés histórico y artístico es mucho menor. Finalmente, esta previsión no se llevó a cabo y se privó al museo de una adecuada y mínima infraestructura para su correcto funcionamiento.

Con objeto de articular el espacio museístico del Palacio con los servicios previstos en la segunda fase de intervención -por otra parte, reiteramos, no realizados- la crujía definida por el ancho de la serre, sirve para albergar el mínimo de servicios internos que permiten el funcionamiento del museo hasta la conclusión de las obras de la segunda fase. Estas funciones corresponden al área de carga-descarga de piezas y materiales, que se ubicó debajo del invernadero y cuyo acceso se permitía mediante el portón creado a tal efecto, abierto hacia la calle Llimera junto a la plaza del Arzobispo, cuya accesibilidad rodada y generosa altura permitía el acceso y salida de embalajes de cierta dimensión. A través del vestíbulo de los servicios públicos 

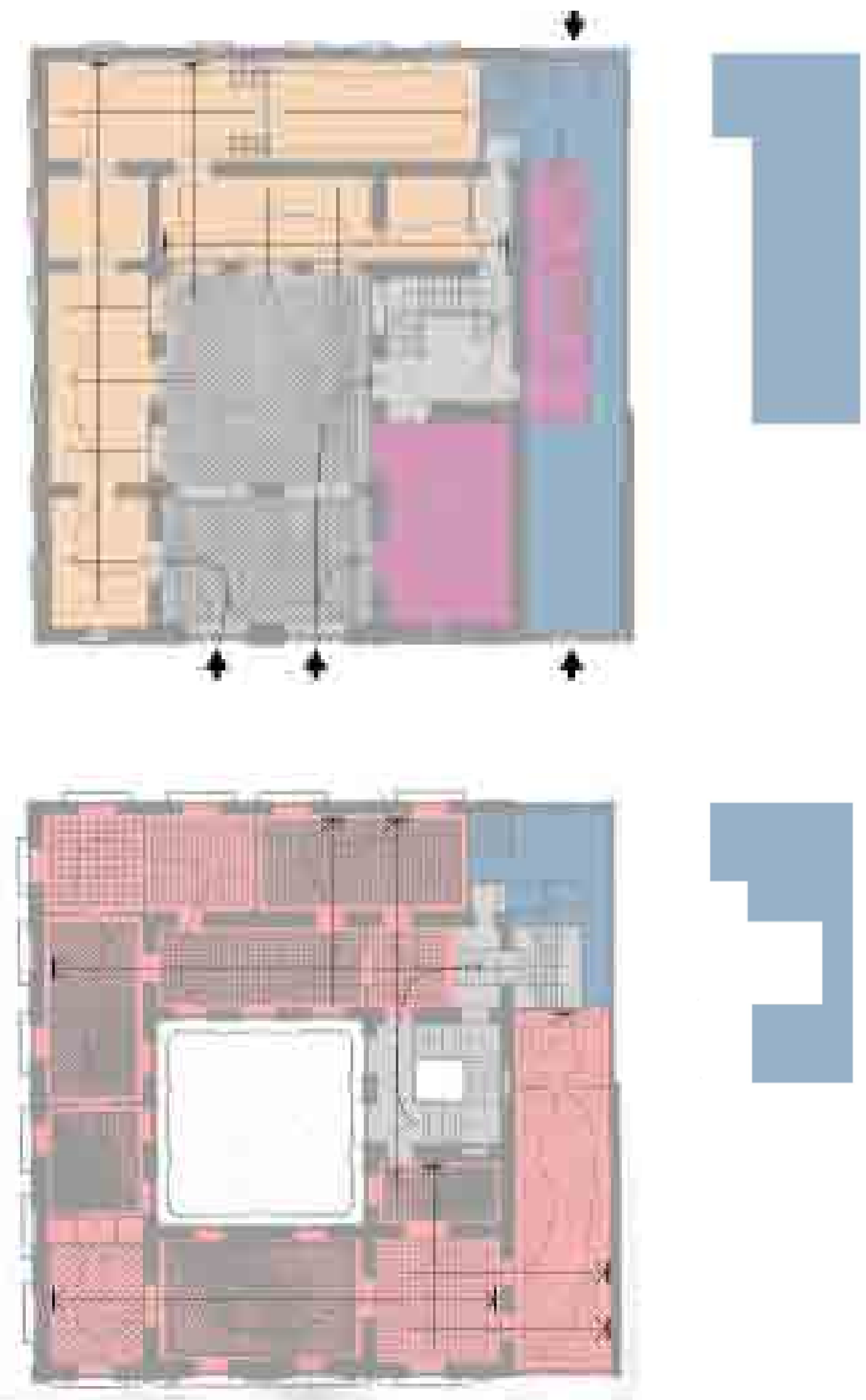

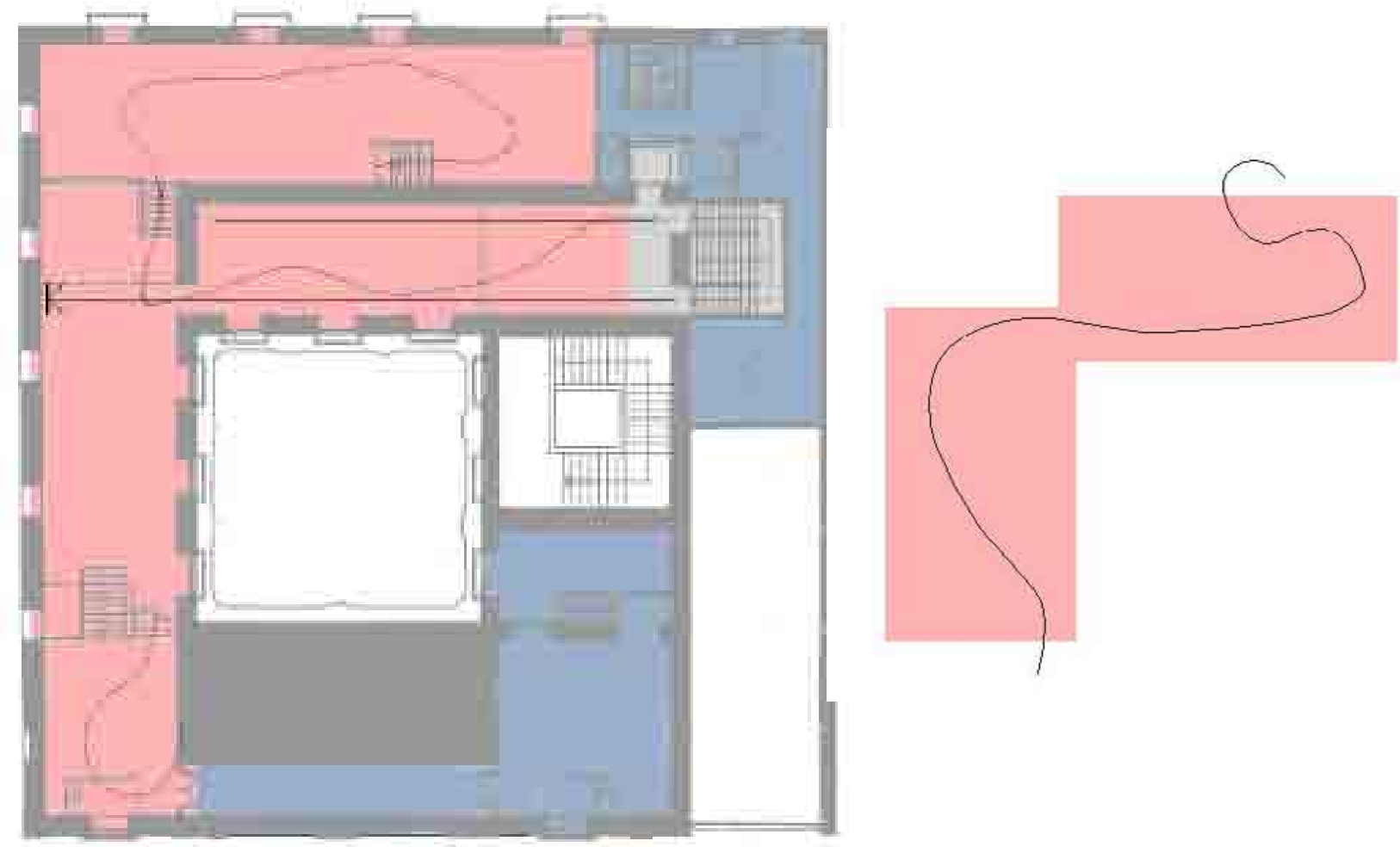

\section{ESTIMACIÓN DE SUPERFICIE}

$m^{2} \quad \%$

$\begin{array}{lcc}\text { Superficie Expositiva total } & 1800 & \mathbf{7 1} \\ \text { Superficie de Usos Públicos } & 150 & \mathbf{6} \\ \text { Superficie de Usos Internos } & 570 & 23 \\ \text { Superficie Total } & 2520 & 100\end{array}$
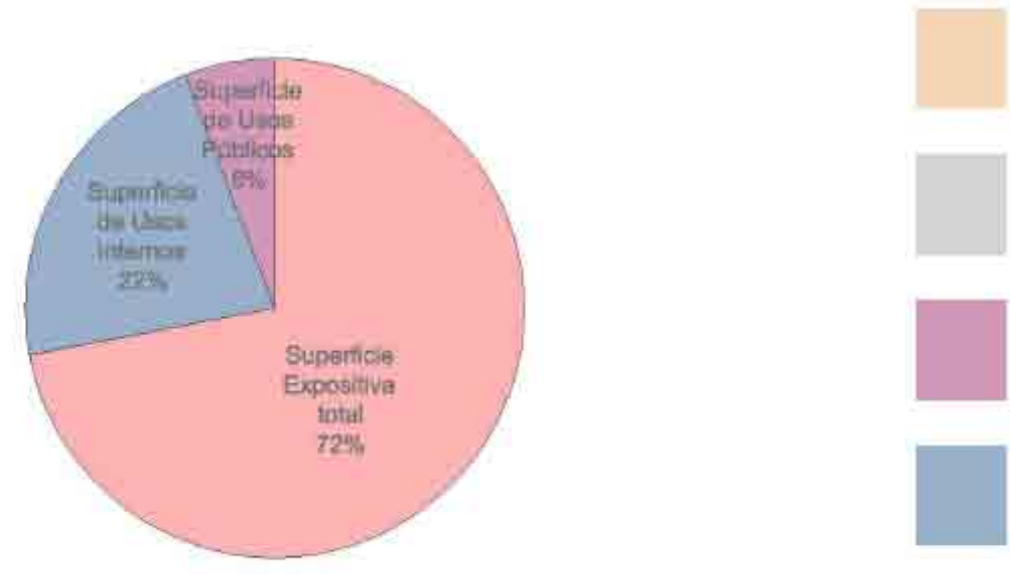

EXPOSICIONES
PERMANENTES

EXPOSICIONES

TEMPORALES

CIRCULACIÓN Y

VESTíBULOS

USOS PÚBLICOS

USOS INTERNOS 
se enlazaba con el montacargas y con las diversas plantas de exposición. Tras este espacio se ubicaban dependencias de personal cuya entrada independiente por la calle Vergara permitía, con su consideración de salida de evacuación, la satisfactoria resolución de la seguridad frente a incendios. Desde este acceso de personal, se permite además de la entrada e inspección al aljibe contra-incendios, la ascensión a través de la escalera secundaria a las diversas plantas y entreplantas de oficinas y espacios para la administración del museo.

Con todo ello se resuelve una cuestión considerada primordial en el proyecto: la claridad e independencia de los accesos a un museo de sus diferentes funciones y el establecimiento claro de recorridos que eviten las interferencias entre ellas.

\subsubsection{Recorridos y relación espacio interior-espacio exterior}

Se considera, por todo lo dicho anteriormente, que los recorridos son un factor fundamental en el planteamiento del museo. Exposiciones temporales y permanentes son los dos bloques de uso público que deben permitir su uso independientemente y a la vez, su integración en un recorrido que englobe el conjunto expositivo del museo. Ambos usos están servidos por un pequeño espacio de acogida situado cerca de la entrada, en el lado este de la planta baja, que se conecta con la escalera principal de acceso a las colecciones permanentes. Representa un espacio mínimo de servicios al público: información, entradas, catálogos y guardarropía.

\section{La exposición temporal}

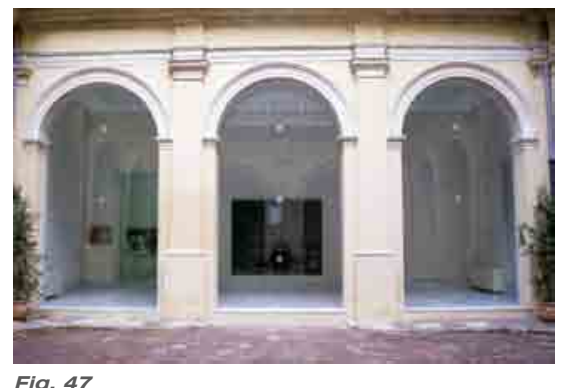

El recorrido arranca en planta baja desde el espacio cubierto tras las puertas de acceso. En este punto se accede a la sala que existe bajo la torre oeste, lugar donde comienza la secuencia de espacios para exposiciones temporales. Una "enfilade" de salas, que proporciona la tipología del edificio, recorre el ala oeste 
(calle de la Harina). Este brazo, de generosa altura, permite en su segunda sala una conexión con el patio, a través de sus tres vanos rematados por arcos, que sugieren una posible inclusión de aquel como lugar de exposición o posterior descanso (Fig.47). Al fondo de estos luminosos espacios, de blancas paredes, solados de mármol blanco Macael e iluminados artificialmente mediante unas importantes claraboyas que albergan también las instalaciones, se accede a la doble crujía que conforma el lado norte del palacio. Mediante el completado de los muros estructurales se genera en una "tercera sala" un espacio que actúa de antesala del gran espacio que ocupa todo el lado norte (calle Vergara), que presenta dos niveles. Su justificación se apoya en una prescripción de seguridad: El edificio necesita un aljibe para garantizar el suministro de sus servicios contra incendios. Su ubicación en este lugar resuelve, en primer lugar, su accesibilidad desde la zona de acceso de personal y por tanto desde el exterior, mientras que en segundo lugar clarifica el itinerario expositivo de planta baja. Efectivamente el desnivel que genera en el plano de exposición da lugar a un recorrido de ida y vuelta que enlaza con la crujía paralela, que da frente y se abre al patio. Al final de su recorrido, un ascensor de uso público posibilita la subida a la planta noble y un vano nos permite un tránsito que enlaza, por debajo de la bóveda de la majestuosa escalera, con el espacio cupulado que la contiene y que también permite el ascenso a través de la misma a las salas de exposición permanente. También, desde este punto, se puede salir al patio, lugar propicio para el descanso, o bien dar por terminada la visita y salir al exterior.

La colección permanente: La planta noble y la planta ático.

Llegados a la planta noble del palacio, integrada por los salones recuperados, el recorrido se apoya en la secuencia que ofrecen los mismos alrededor del patio (Fig.48). Un simple cierre de puertas en la doble crujía norte permite un itinerario ordenado que lleva a la escalera, de nueva creación, de acceso a la planta

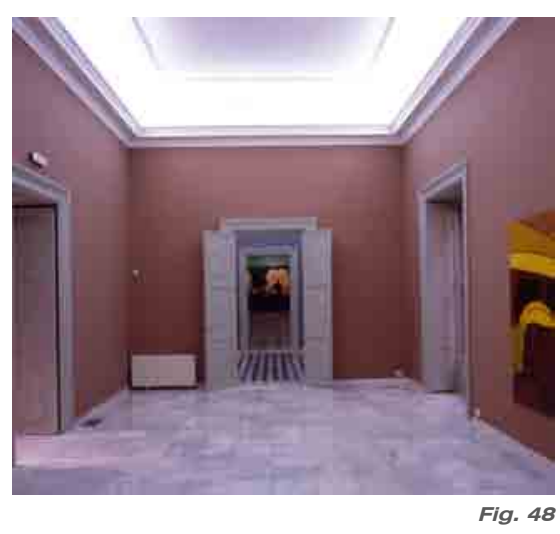




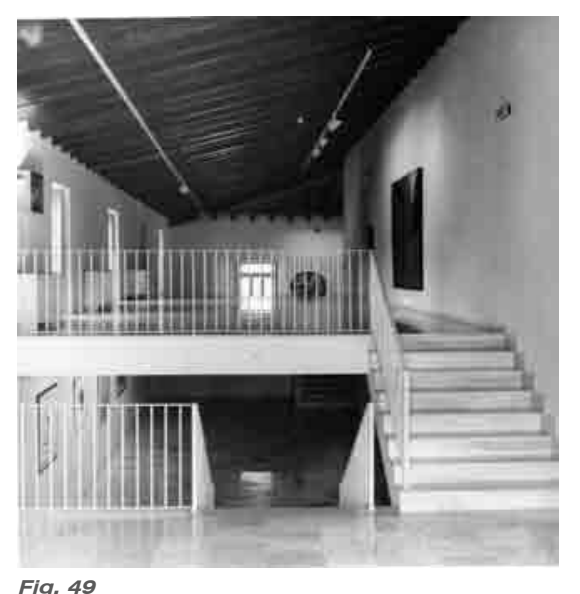

Fig. 49 ático. Cabe recordar que la última planta del palacio constaba de dos niveles cuya fenestración abierta al patio generaba una primera planta englobada en el orden gigante de la planta noble y una segunda hilera de huecos que actuaban a modo de ático. Además, conviene hacer hincapié en que esta planta tiene forma de $L$ y solamente recae a la calle de la Harina (oeste) y a su perpendicular, Vergara (norte). La configuración del antiguo palacio no permite la circulación alrededor del patio, pues está interrumpida en su vertiente este por el espacio cupulado de la escalera y en el sur por la menor altura que presenta la crujía de la fachada principal, que en este nivel no dispone de espacios habitables. En consecuencia, el espacio de planta segunda de la torre este resultaba prácticamente inaccesible; se podía ascender a él por una enorme escalera manual de madera sita en un armario de la planta noble que salvaba un desnivel de aproximadamente 7 metros. A esta dependencia se le asigna en el proyecto un uso interno del museo, como espacio de trabajo para el personal, y su acceso se resuelve por medio de un paso previsto a través del espacio bajo cubierta del cuerpo central de la fachada principal.

El itinerario por los espacios generados en el proyecto se apoya en la diferente altimetría consecuencia de las diferentes alturas libres de los salones de la planta noble y los niveles del segundo ático que se recuperan según el recorrido del mismo. Se busca, de esta manera, una visita que arrancando de la escalera de comunicación con la planta inferior, recorra los diferentes niveles hasta regresar al punto de partida. Los huecos de fachada se abren donde manifiestan la estructura tripartita vertical del palacio, sean la fachadas de las calles Harina y Vergara o un nivel del ático que recae al patio, macizando el resto para conseguir superficies de cuelgue. Dobles alturas y salas de diferentes dimensiones jalonan, bajo la cubierta de madera recuperada, el itinerario que finaliza en el mismo punto donde empezó (Fig.49). De nuevo el ascensor y la escalera permiten descender al patio y, o bien el descanso, o bien la salida del edificio. 


\subsubsection{Visuales}

Dada la configuración que los muros originales del palacio establecen, las visuales vienen por ellos condicionadas así como por la apertura de los huecos hacia el patio. Dos tipos básicos de visuales se establecen: las que longitudinalmente recorren una secuencia de salas (Fig.50) y las que permiten vistas transversales entre diferentes alas a través del patio. El recorrido longitudinal en planta baja, pautada la dimensión de las salas por los muros de carga estructurales, permiten básicamente la colocación de pintura en un lateral mientras que el opuesto los grandes huecos comunican el espacio interior con el patio central. Hemos comentado la razón de ser del desnivel que presenta la crujía norte, el ascenso a este nivel superior permite disfrutar de un espacio expositivo carente de huecos por lo que las piezas pueden colocarse, y contemplarse, permitiendo una confortable contemplación de las mismas.

El recorrido, en planta noble, marcado por la secuencia de salones posibilita una tradicional exposición de pintura, amén de posibles piezas de escultura o vitrinas en las zonas centrales. El recorrido por los diferentes niveles de la planta ático presentan, en muchas ocasiones paramentos ciegos, generalmente del lado del patio interior y aberturas al exterior en los opuestos, lo que tiene como consecuencia el mostrar la ordenación tripartita de las fachadas.

\subsubsection{La iluminación}

La iluminación y tendido de las instalaciones adquieren una importancia en su resolución derivada de su supeditación al orden que establece la arquitectura del monumento. En planta baja, se propone en cada sala de un falso techo dotado de una gran cristalera que a modo de lucernario ilumina las salas con la intensidad requerida para la exposición de pintura. Un carril permite la disposición de proyectores que refuercen, si es necesario la intensidad lumínica o iluminen puntualmente piezas

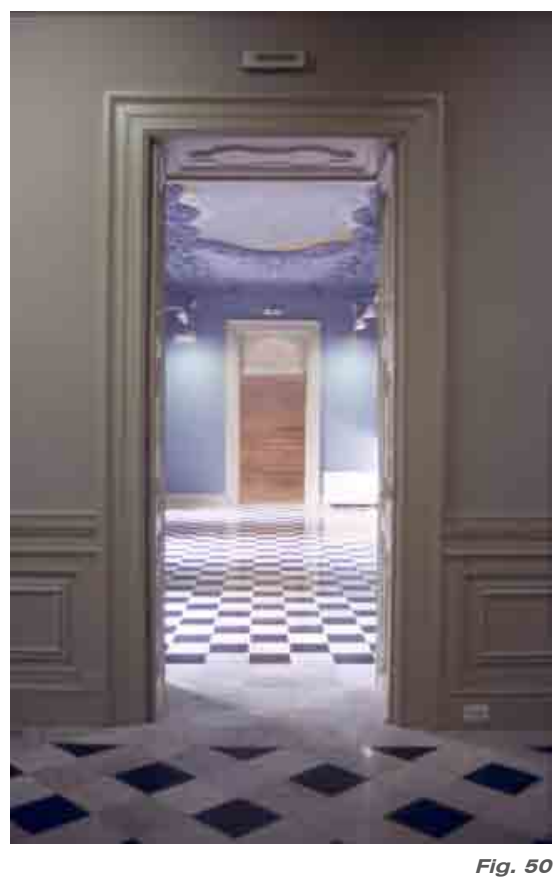




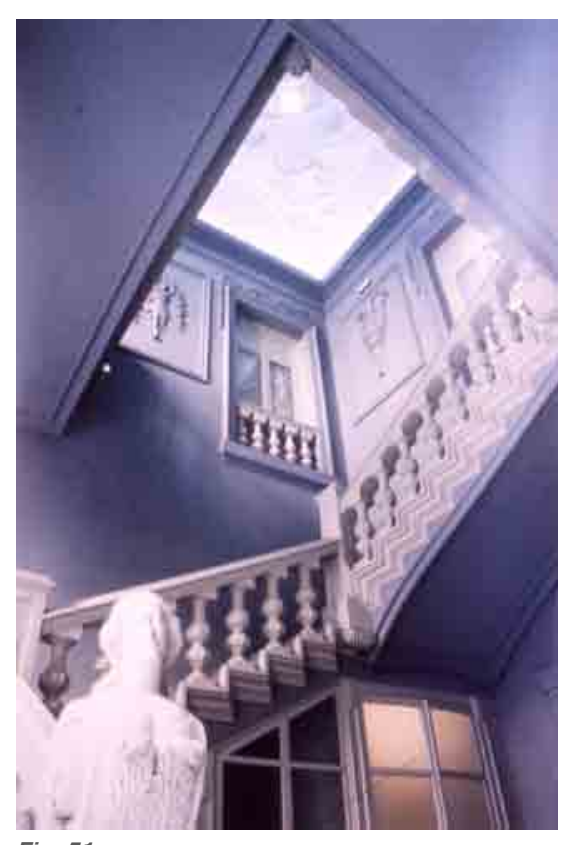

Fig. 51 colocadas en medio de las salas. Todas las instalaciones de la planta noble discurren ocultas por este techo: la salvaguarda de techos, pavimentos y parte de sus paramentos obliga a este trazado, no siempre el más cómodo o idóneo desde el punto de vista del trazado y cálculo de las instalaciones.

En planta noble, el sistema utilizado depende de las características del salón: en unos se utiliza la potente cornisa para la introducción de una luz de fluorescencia que, por reflexión, ilumina, con los luxes requeridos, todo el salón; en otros casos, como en el salón de baile y en el isabelino, correspondientes con los más decorados, se diseñan unos elementos que incorporan bañadores de luz. Éstos posibilitan la adecuada iluminación de los paramentos en los que se exhiben las obras, con una mínima incidencia en su orden y decoraciones cuya conservación se exige desde los planteamientos teóricos de proyecto.

En planta ático, restaurado su elemento más notable, la cubierta de madera, se diseñan y disponen unos soportes de carriles de iluminación para bañadores de luz de las distintas superficies expositivas que solucionan la iluminación de una planta que, dada su histórica configuración, apenas recibe luz natural.

En resumen en la restitución del Palacio del Marqués de Campo como Museo de la Ciudad se ha planteado comprender el pasado del edificio, se ha pretendido que su historia, a través de su interpretación, siga presente y que en sus espacios reencontrados el ciudadano disfrute de la hermosa colección que su institución ha atesorado. 


\section{NOTAS}

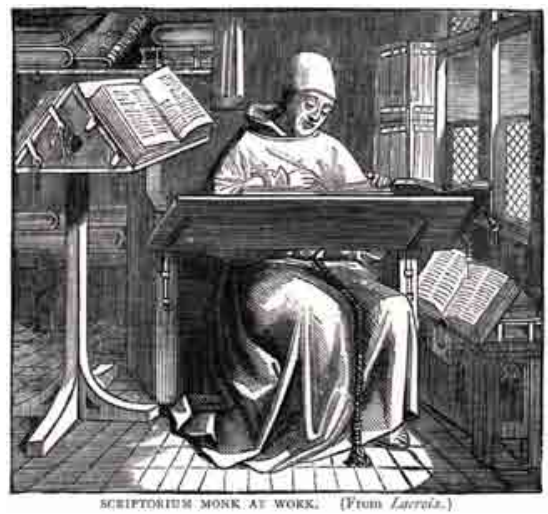

(1) Tormo, Elías, Levante (Guía regional), Madrid, Espasa Calpe, 1923, pp. 132. Información relativa al Palacio del Marqués de Campo se puede encontrar también en Cruilles, Marqués de, Guía Urbana de Valencia, Valencia, Imprenta de José Rius, 1876, pp. 60 así como en Almela y Vives, Francisco, "El Marqués i les seues residències", El Marqués de Campo, Capdavanter de la burguesia valenciana (1814-1889), Valencia, Ajuntament de València, 1989, pp.73

(2) Llopis Alonso, Amando; Perdigón Fernández, Luis, "Plano P1 de Antonio Mancelli", Cartografía de la Ciudad de Valencia, 1608-1944, Valencia, Universidad Politécnica de Valencia, 2010

(3) Llopis Alonso, Amando; Perdigón Fernández, Luis, "Plano P2 y P3 del Padre Tosca", Cartografía de la Ciudad de Valencia, 1608-1944, Valencia, Universidad Politécnica de Valencia, 2010

(4) Boix, Vicente, Valencia histórica y topográfica. Relación de sus calles, plazas y puertas, origen de sus nombres, hechos célebres ocurridos en ellas, y demás noticias importantes relativas á esta capital, Tomo I, Valencia, Imprenta de J. Rius, Editor,1862, pp. 75

(5) Boix, Vicente, Manual del viagero y Guia de los forasteros en Valencia, Valencia, Imprenta de J. Rius, Editor, 1849, pp. 8-9

(6) Solà-Morales, Ignasi, "Una restitución, un riesgo", Palacio del Marqués de Campo, Museo de la Ciudad, Valencia, Ajuntament de València, 1989, pp. 36 


\subsection{REHABILITACIÓN DEL ALMUDÍN DE XÀTIVA PARA MUSEO MUNICIPAL}

XÀTIVA. VALENCIA. 1983-1985

\section{Introducción}

El almudín, destinado en su origen al depósito, contratación y venta de cereales, se transformó por medio de este proyecto en parte del Museo Municipal de Xàtiva. El programa museístico se desarrolla en dos edificios anexos: el antiguo Banco de España, en el que se ubica el acceso principal y la exposición del grueso de la colección, y el edificio del antiguo Almudín, cuyo proyecto realizado con el arquitecto Giorgio Grassi se desarrolla a continuación.

\subsubsection{Breve historia del lugar y del edificio}

El edificio histórico del Almudín (Fig.1), enclavado entre medianeras, da frente a dos calles secundarias que descienden hacia la parte baja del casco histórico y son perpendiculares al importante eje urbano que representa la Calle Corretgeria. Esta

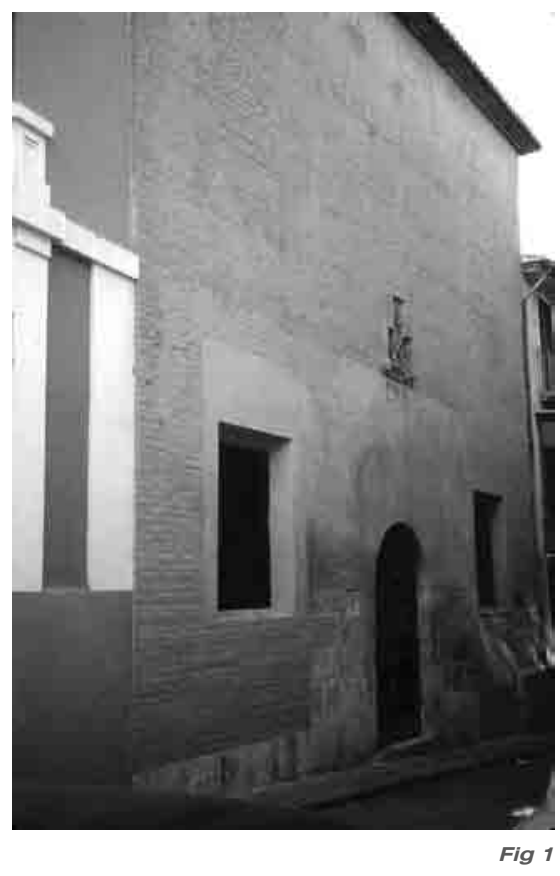
importante vía se identifica como el eje fundamental este-oeste que cruza y vertebra la ciudad histórica; aparece interrumpida por la Colegiata, edificio de grandes dimensiones, de modo que la bordea y atraviesa la Plaza de la Seo, antiguo centro cívico y religioso, a la que la Colegiata y el antiguo Hospital de Pobres abren sus fachadas principales. 


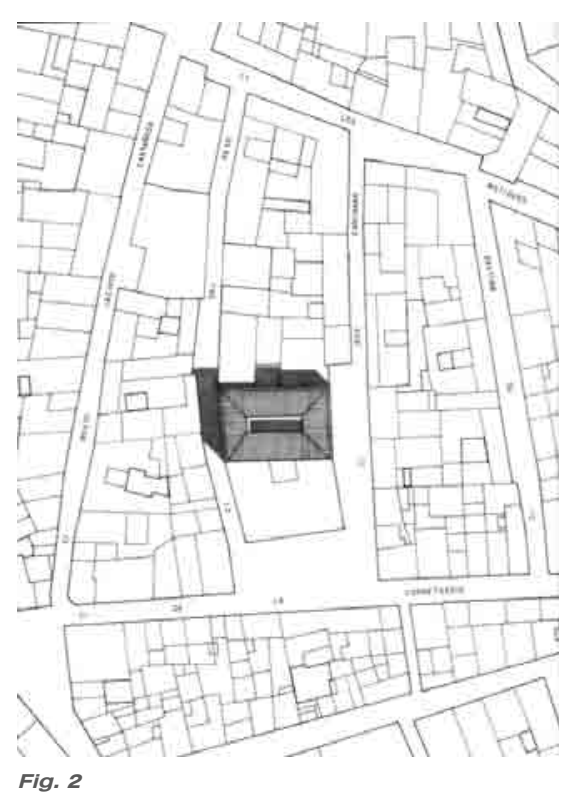

El antiguo Hospital de Pobres, institución fundada por el Rey conquistador Jaime I, es un edificio que ocupa una manzana entera y que se presupone originario del siglo XV; su interior fue arrasado durante la guerra de sucesión y posterior incendio de la ciudad por parte de las tropas borbónicas en 1707. Destaca en su fachada principal su portada de acceso, renacentista, y su capilla tardo-gótica.

La Colegiata de la Seo, asentada sobre el solar de una iglesia gótica anterior que se sobrepuso a la antigua mezquita, se comenzó a construir en el siglo XVI. De grandes dimensiones, similares a las de la Catedral de Valencia, consta de tres naves, crucero y girola. Es destacable la utilización del lenguaje clásico, con dobles pilastras dóricas que pautan y articulan su interior.

La arquitectura popular del caserío de Xàtiva muestra en el entorno inmediato viviendas de acaudalados propietarios. Se caracterizan por una división tripartita en alzado, en el que la planta noble tiene una altura muy considerable y el ático -o andana-, que se destinaba a almacenaje de productos agrarios, posee un orden de ventanas rectangulares o en arcada, cuyo número a menudo se multiplica. El predominio del macizo sobre el hueco y las proporciones verticales de sus vanos nos informan del carácter másico de esta arquitectura, conservada con loable uniformidad hasta nuestros días en el casco histórico de la población.

El actual museo ocupa, además del Almudín en el que se desarrolló nuestro trabajo, el antiguo edificio del Banco de España -que no fue objeto de nuestro proyecto-, que preside una plazuela, fruto de un ensanche de la calle Corretgeria (Fig.2). Este edificio fue muy transformado en los años 20 del pasado siglo mediante una intervención del arquitecto Luis Menéndez Pidal, que elevó una planta y reformó completamente la fachada. El autónomo tratamiento de la misma, poco integrado en referencia a la arquitectura tradicional, data de esta época y se caracteriza por sus cerrajerías ampulosas, blancas cornisas 
descontextualizadas y complejos remates piramidales.

El origen del edificio objeto de restauración se halla en el siglo XVI. En 1530 el consejo de la ciudad decidió la ampliación del primitivo almudín -sito en el emplazamiento del antiguo edificio del Banco de España-, probablemente para separar el depósito del trigo del de los otros cereales. El nuevo edificio se construyó junto al antiguo y en conexión con él, pues en el muro medianero se aprecian resto de puertas que los unían en los dos niveles en que se desarrollaba. Los trabajos se iniciaron en 1545 y duraron tres años. En la enseña de piedra que está sobre el portal se lee la inscripción: "L'obra del present Almodi fon acabada en MDXLVIII".

A finales del siglo XIX se convirtió este edificio en museo arqueológico con la disposición en su interior, entre otros, de las piezas y restos procedentes de los sucesivos derribos que se llevaron a cabo en la ciudad histórica. En 1918, con la inclusión de una pequeña pinacoteca cívica, se convirtió en museo municipal. Con este motivo se reconstruyeron las paredes perimetrales de la planta superior y se abrieron ventanas, tanto hacia al patio como cara a las dos fachadas; la fenestración, de diferente posición y variadas dimensiones, se abrió según las necesidades de lo expuesto. Se invirtió también la pendiente de la cubierta (en origen en impluvium) hacia la fachada principal para consentir la colocación de un gran retablo gótico. Durante esta intervención, se construyó además una escalera de madera de dos tramos, de pronunciada pendiente, que enlazaba los dos niveles que poseía el edificio.

\subsubsection{El edificio antes de la rehabilitación}

El edificio se presentaba como un bloque compacto y cerrado entre dos muros de medianería y dos muros de fachada vinculados a estrechas calles paralelas. Se desarrollaba alrededor de un pequeño patio porticado en planta baja con columnas jónicas y arcos de piedra, en relación de tres a uno $(11 \times 4 m$ aproximadamente). Los capiteles se presentaban curiosamente girados $90^{\circ}$ (Fig.5).
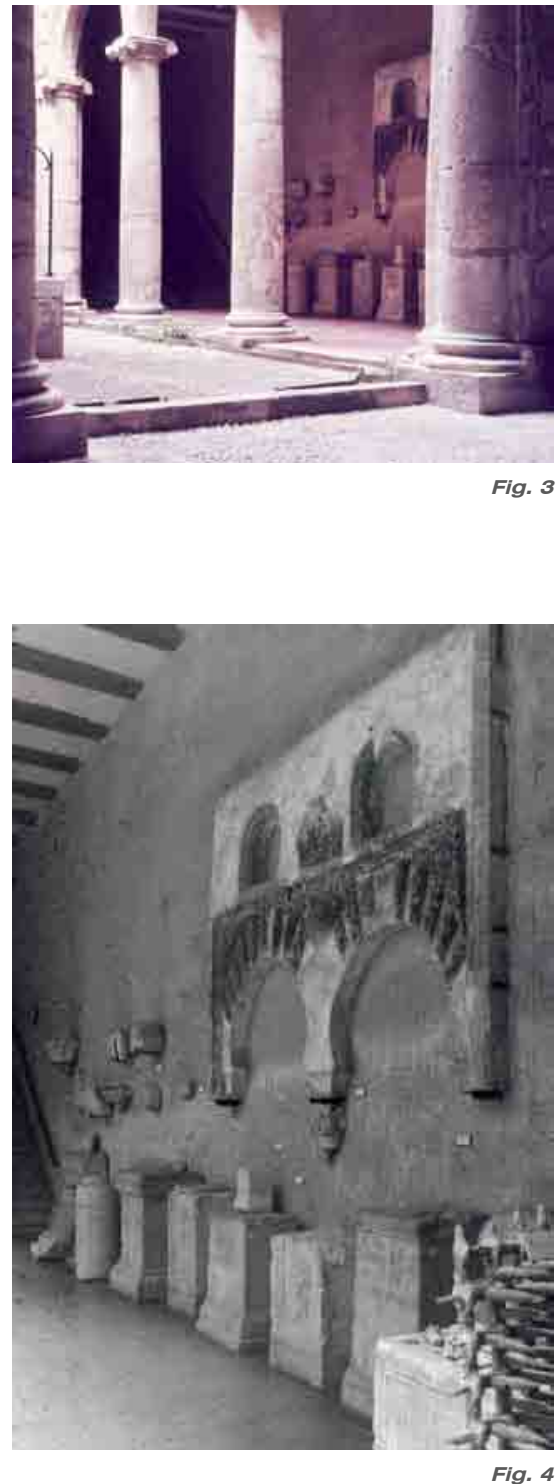

Fig. 4

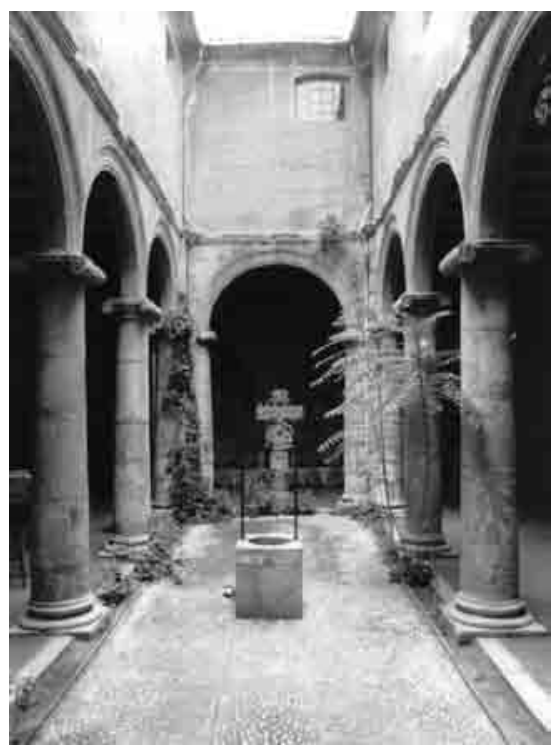

Fig. 5 


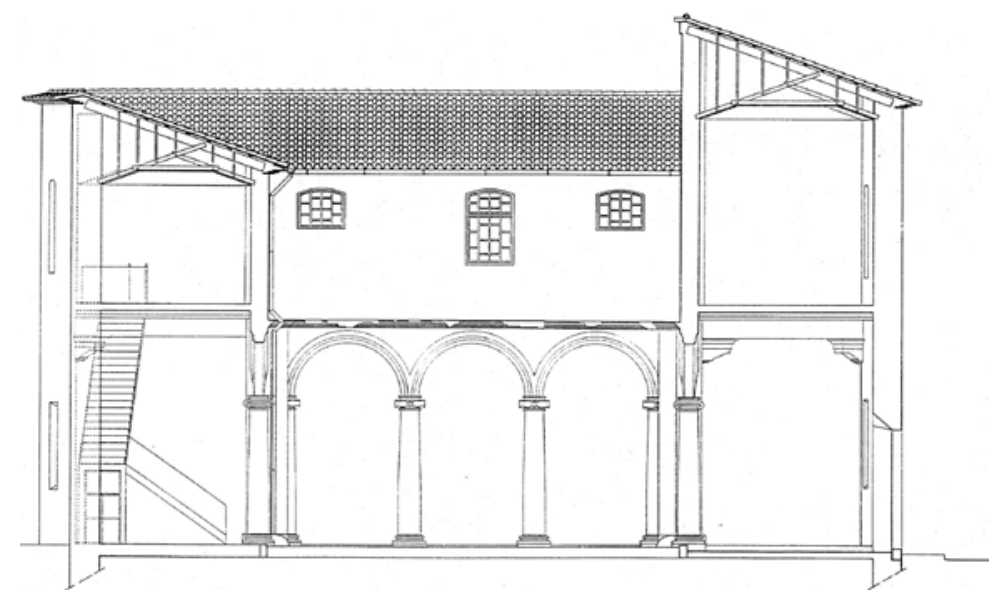

Sección del estado anterior

Se sabe bien poco de cómo fue en origen la planta superior. Este recrecido fue tal vez notablemente transformado, debido a las necesidades de espacios expositivos determinadas por la conversión del monumento en museo. Los muros exteriores (hacia el patio) de la primera planta se construyeron con una fábrica de tapial (de peor calidad que la que se utilizó en las fachadas). Después de las últimas intervenciones anteriores a nuestra labor, se presentaba falto de cualquier elemento arquitectónico que pudiera ponerla en relación con el orden que se manifestaba en la planta inferior (Fig.6); además, carecía por completo de la cornisa de articulación con la cubierta en pendiente. Por lo demás, como se ha dicho, el cambio de pendiente de parte de la cubierta hacia la fachada principal, cuya consecuencia fue la elevación de la altura del correspondiente frente sobre el patio,

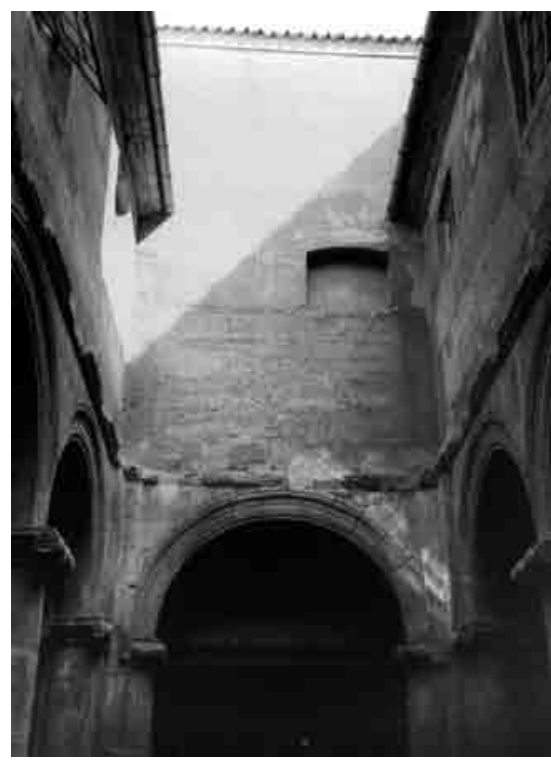
había anulado completamente la figura originaria del impluvium. Finalmente, cabe destacar que la cornisa que separa la planta baja de la primera está anómalamente situada a unos $50 \mathrm{~cm}$. por debajo del nivel superior del forjado.

El tapial de la fachada principal, trabado con ladrillo macizo, abarcaba los dos niveles. Sin embargo, entre los huecos de planta primera y baja, las diferencias en el tipo de hueco y en la resolución de las carpinterías mostraban su pertenencia a distintas épocas ${ }^{(F i g .7)}$. En la planta superior, carpinterías endebles, de madera pintada, cuyo despiece solamente permitía alojar pequeños vidrios; en la inferior, la carpintería robusta, con sus huecos enrejados, no tenía vidrio y poseía una contraventana 


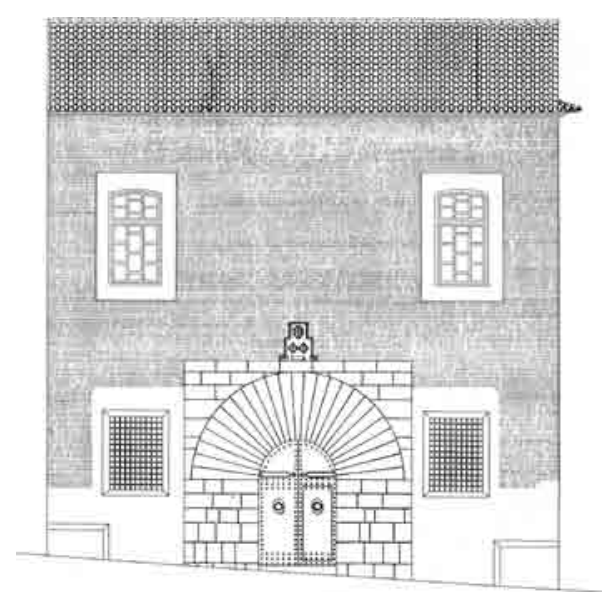

Alzado principal del estado anterior

interior de madera (allí se les denominaba "catalanas").

Por todo ello, la resolución del cierre de los huecos de planta primera, tanto al patio como a vía pública, constituía una respuesta meramente funcional a las necesidades de iluminación y ventilación, carecía de relación con las carpinterías de planta baja y adolecía de cualquier interés e intención en el detalle de su ejecución.

El forjado de planta primera estaba formado a base de grandes vigas de madera, empotradas en los muros, cuyo apoyo en el paramento interior de la fábrica del patio se situaba claramente por encima de la cornisa interior de remate del orden renacentista. La cubierta de madera se encontraba en relativo buen estado de conservación, dado que el edificio estaba en uso; bajo ella se exponían, además del retablo, otras obras pictóricas, en general de pequeño formato. Esta cubierta estaba oculta por un falso techo de cañizo y escayola.

En planta baja, la organización museística tenía cierto carácter caótico: se apiñaban las piezas como fragmentos arquitectónicos (fruto de derribos de edificios históricos) junto con esculturas y piezas arqueológicas organizadas sin ningún criterio aparente. Algunas de las piezas eran de sustancial importancia: cabe mencionar la pila árabe, ejecutada en mármol, del siglo $\mathrm{XI}$, y los fragmentos del Palacio árabe de Pinohermoso. En los muros destacaban las inscripciones en las que se reflejaba la fecha y cantidad de grano depositado.

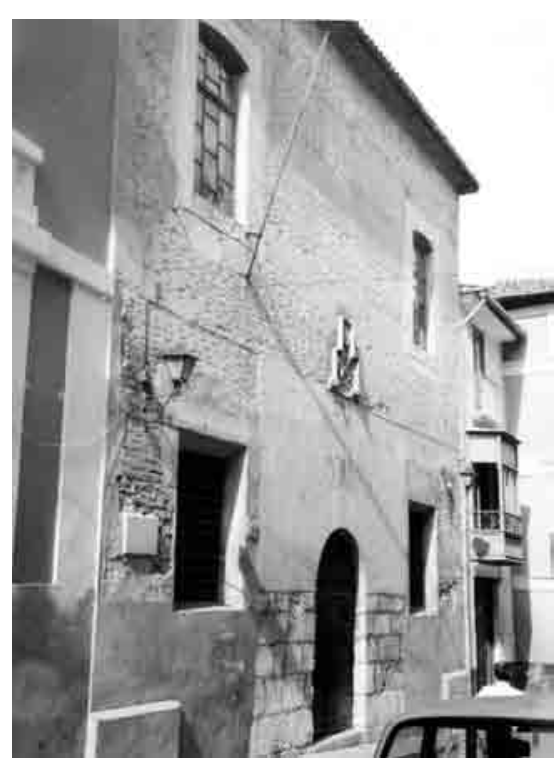




\subsubsection{Objetivos y criterios de intervención}

En lo que concierne al proyecto, cabe apuntar dos anotaciones preliminares:

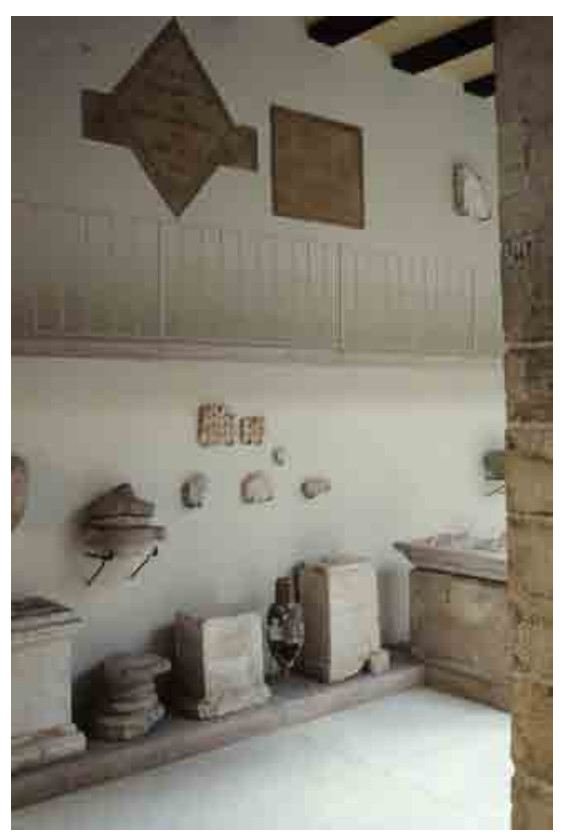

1. El único elemento que evoca la función histórica del edificio son las inscripciones, pinturas o "graffiti" en la parte alta de los muros perimetrales del pórtico, que muestran la fecha, la cantidad y el precio del grano que se encontraba depositado en aquel momento en ese lugar (la más antigua es de 1614). El conjunto de esas inscripciones, de gran valor documental, y su colocación en alto, ha sido precisamente el punto de partida para la ordenación, en dos franjas expositivas, separadas por una estrecha galería, del Antiquarium en la planta baja. (Fig.8)

2. La cornisa de piedra (muy desgastada) que remata el orden inferior y marca la separación entre los dos niveles del patio se encuentra cerca de $50 \mathrm{~cm}$. por debajo del correspondiente forjado: este aspecto extraño de la construcción ha sido sin embargo el dato de partida para la composición de la fachada interna, para el establecimiento de las dimensiones de las aberturas y para la definición de los vierteaguas.

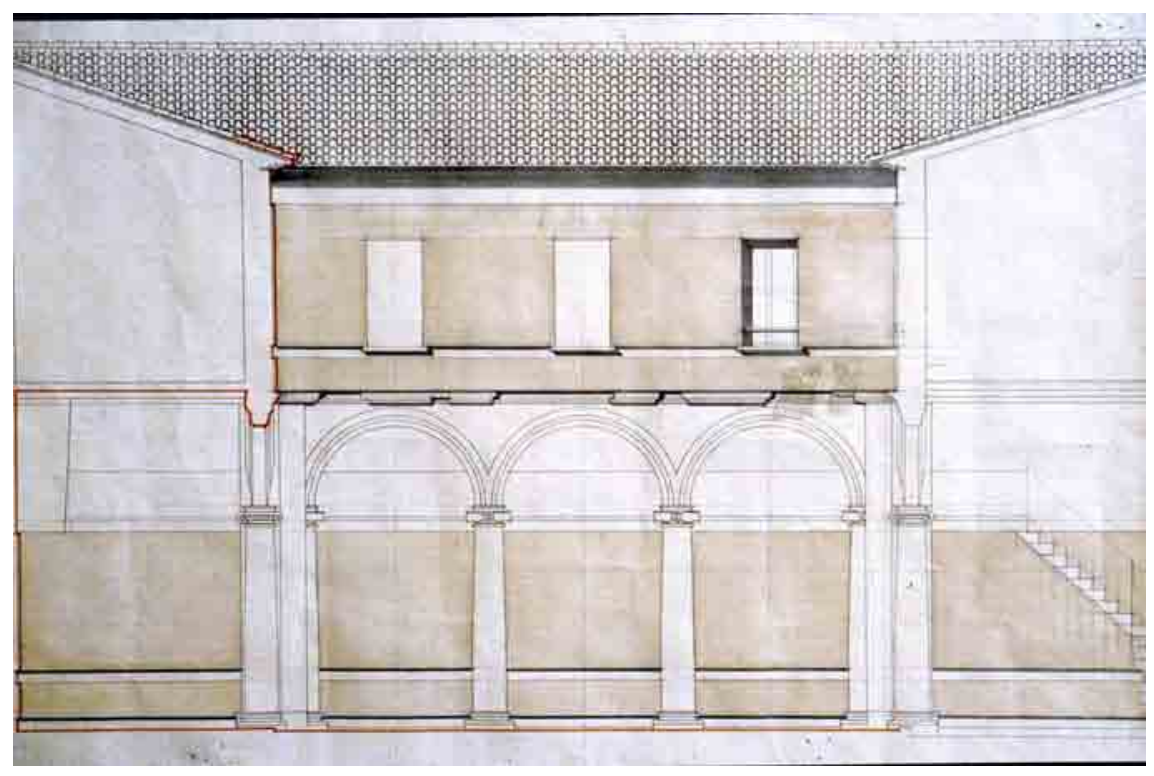


El objetivo fundamental de la intervención es, en definitiva, conseguir la unidad del espacio claustral con la puesta en relación de ambas plantas mediante la recuperación del orden tipológico del patio renacentista (Fig.9 y Fig.10).

Consecuentemente, el proyecto de restauración y reestructuración prevé, además del saneamiento y consolidación de las estructuras existentes, la reconstrucción de la cubierta como era en origen -en impluvium y el cerramiento de las ventanas del primer nivel en la fachada principal del edificio. La consideración de la fenestración de la planta primera (tanto a la vía pública como al interior del patio) como elemento impropio implica la remodelación del frente interior del patio, en una operación que revaloriza la planta baja, identificada como elemento de gran valor patrimonial cuyo orden debe establecer

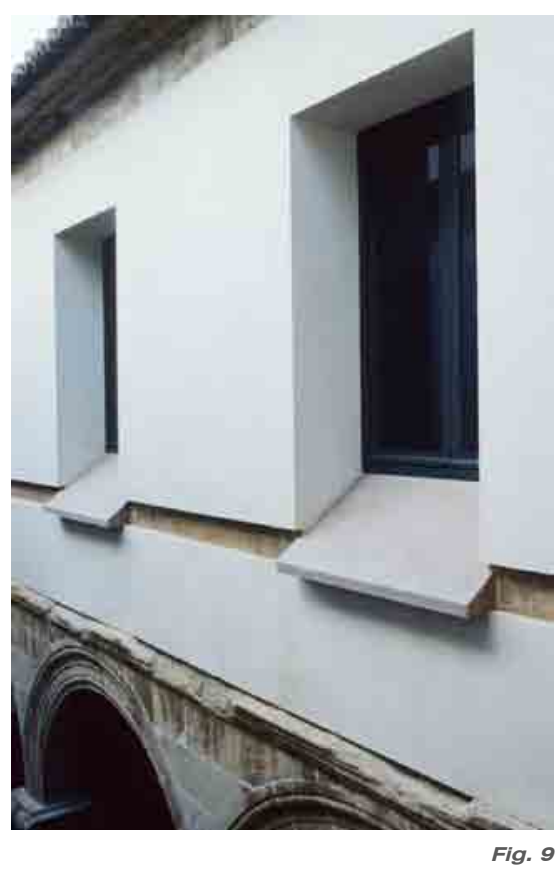
las pautas de la intervención.

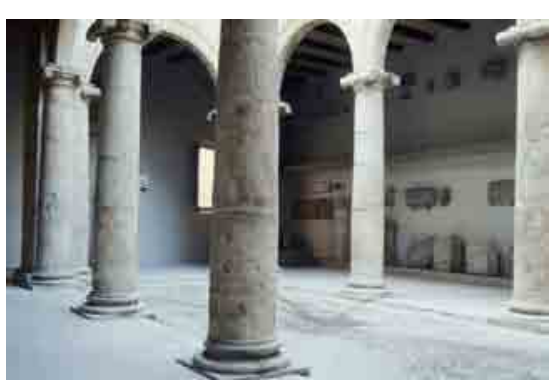

Fig. 10 
ESTADO ANTERIOR A LA INTERVENCIÓN

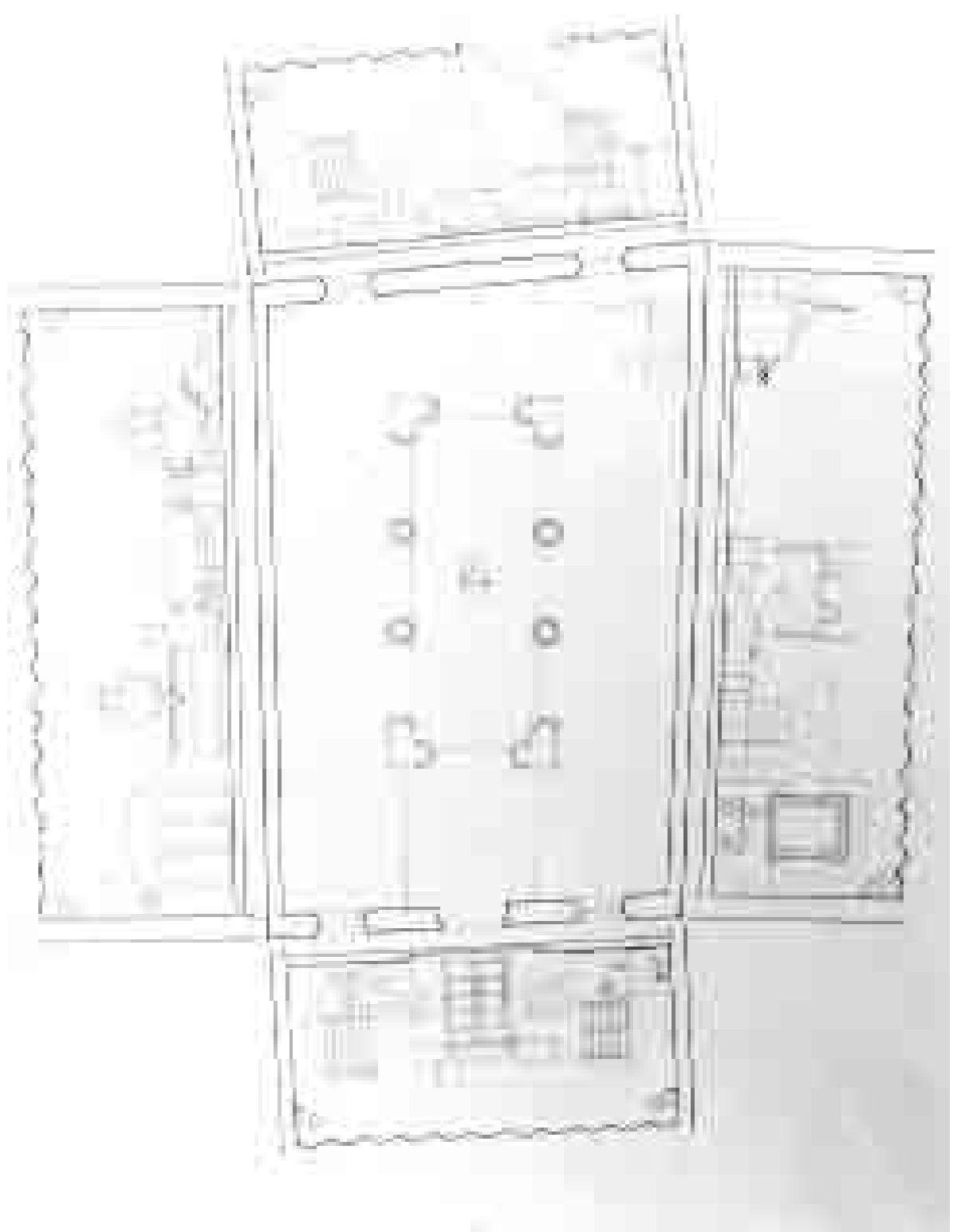

Estado anterior. Antiquarium. 


\section{SITUACIÓN}

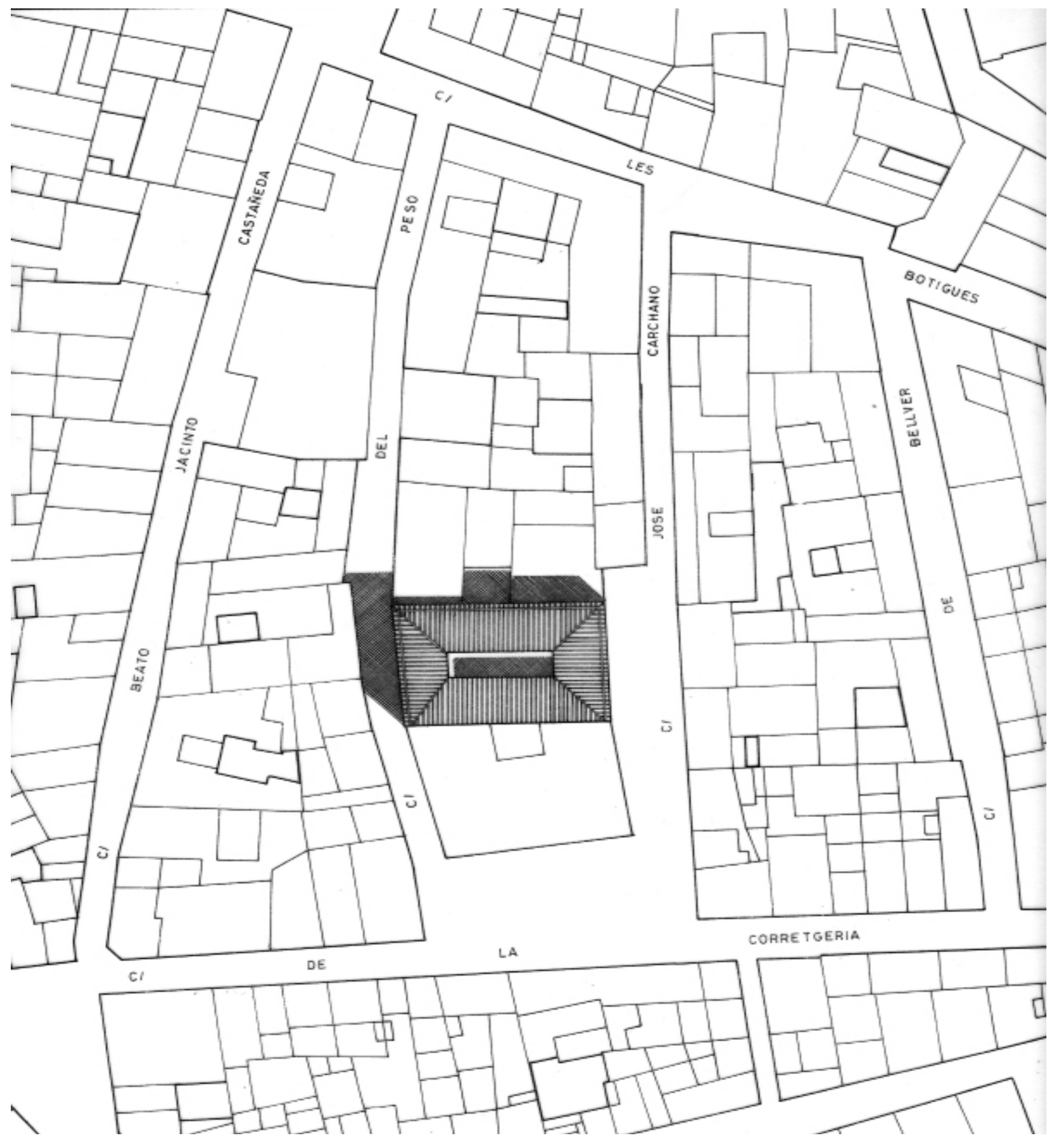

Situación 
ESTADO ANTERIOR A LA INTERVENCIÓN

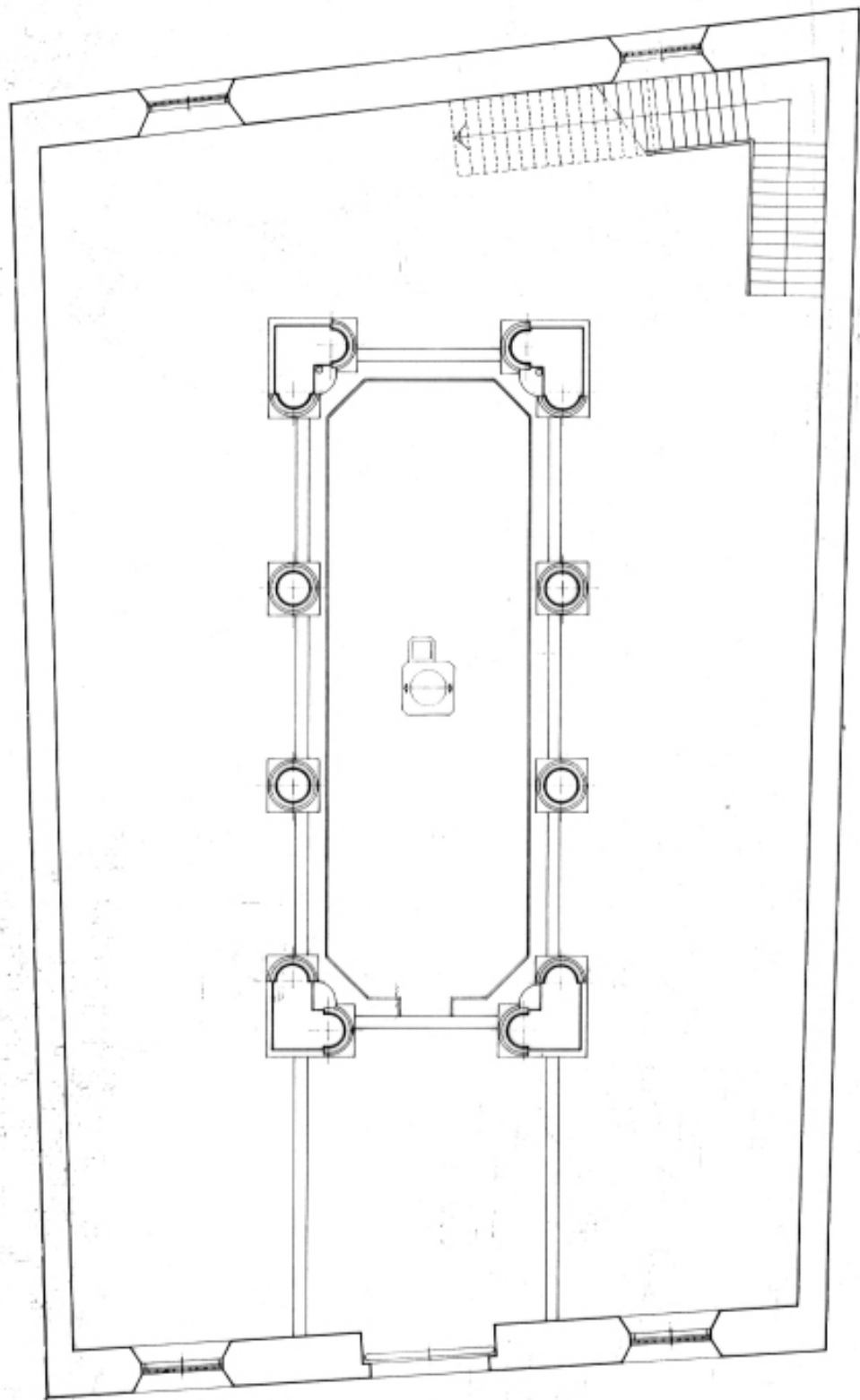

Estado anterior. Planta baja

$\sqcap\left\llcorner น^{\circ} \mathrm{S}^{\mathrm{N}} \Theta\right.$


PROYECTO DE INTERVENCIÓN

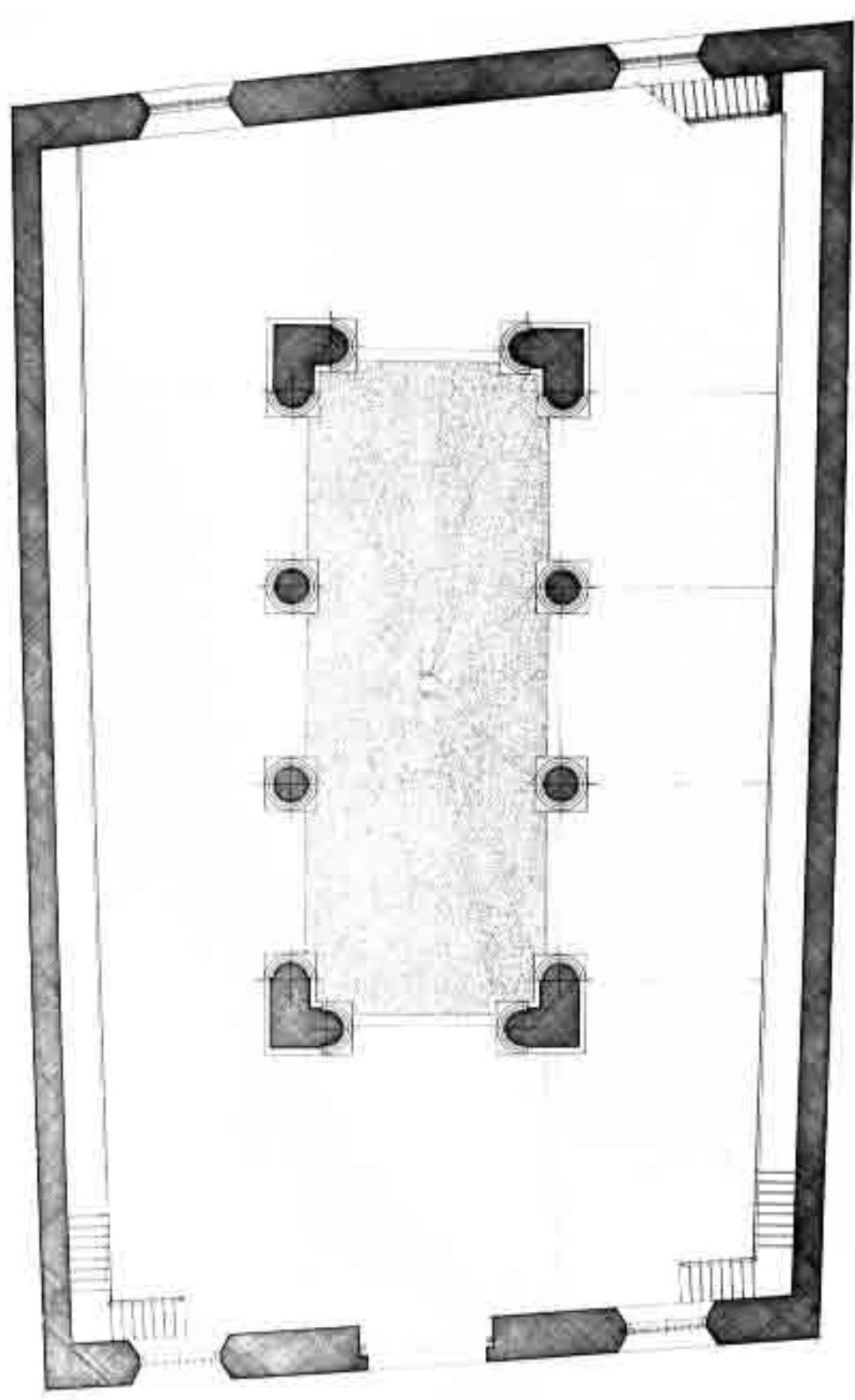

Propuesta. Planta baja

舟


ESTADO ANTERIOR A LA INTERVENCIÓN

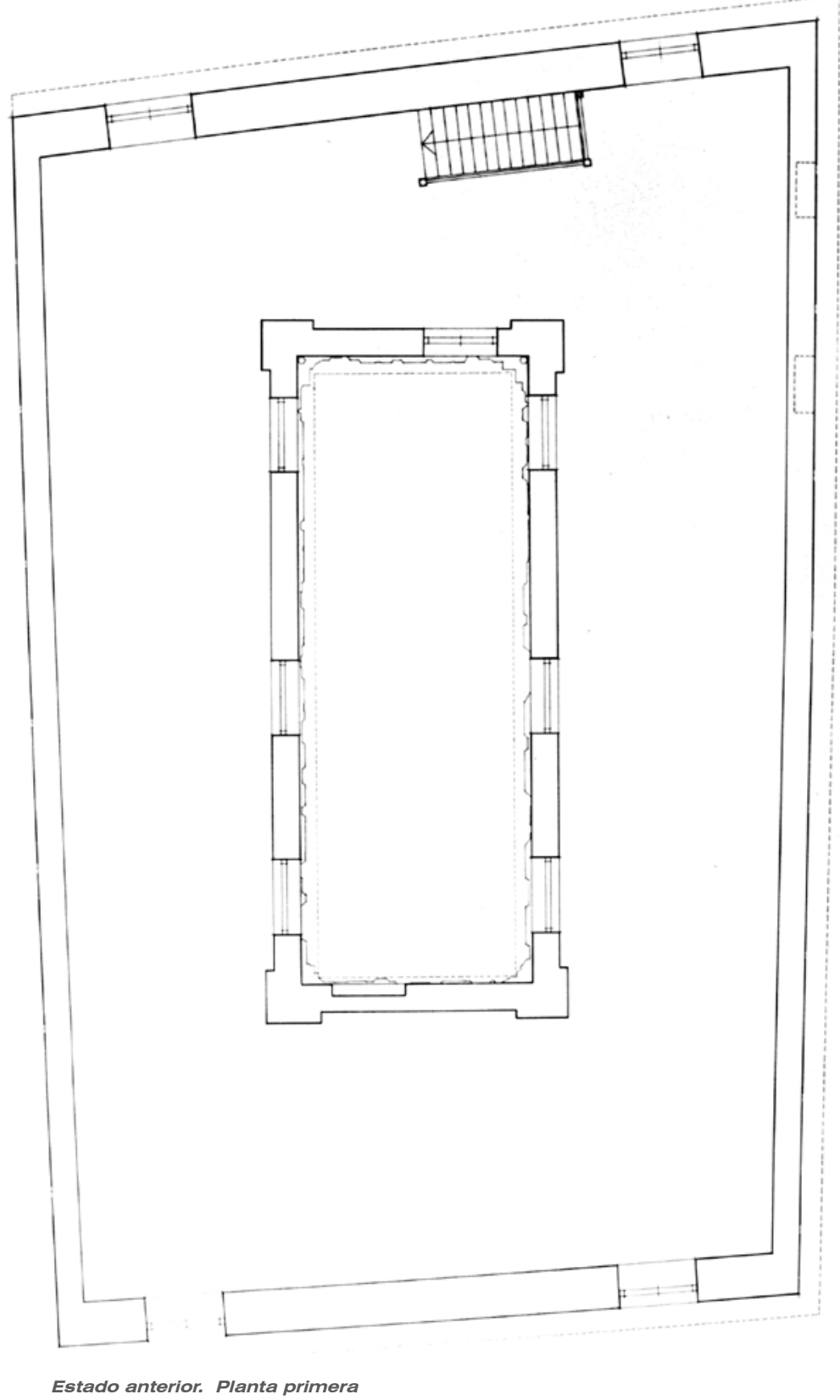

$\sqcap\left\llcorner น^{\circ} \mathrm{S}^{\mathrm{N}} \Theta\right.$ 
PROYECTO DE INTERVENCIÓN

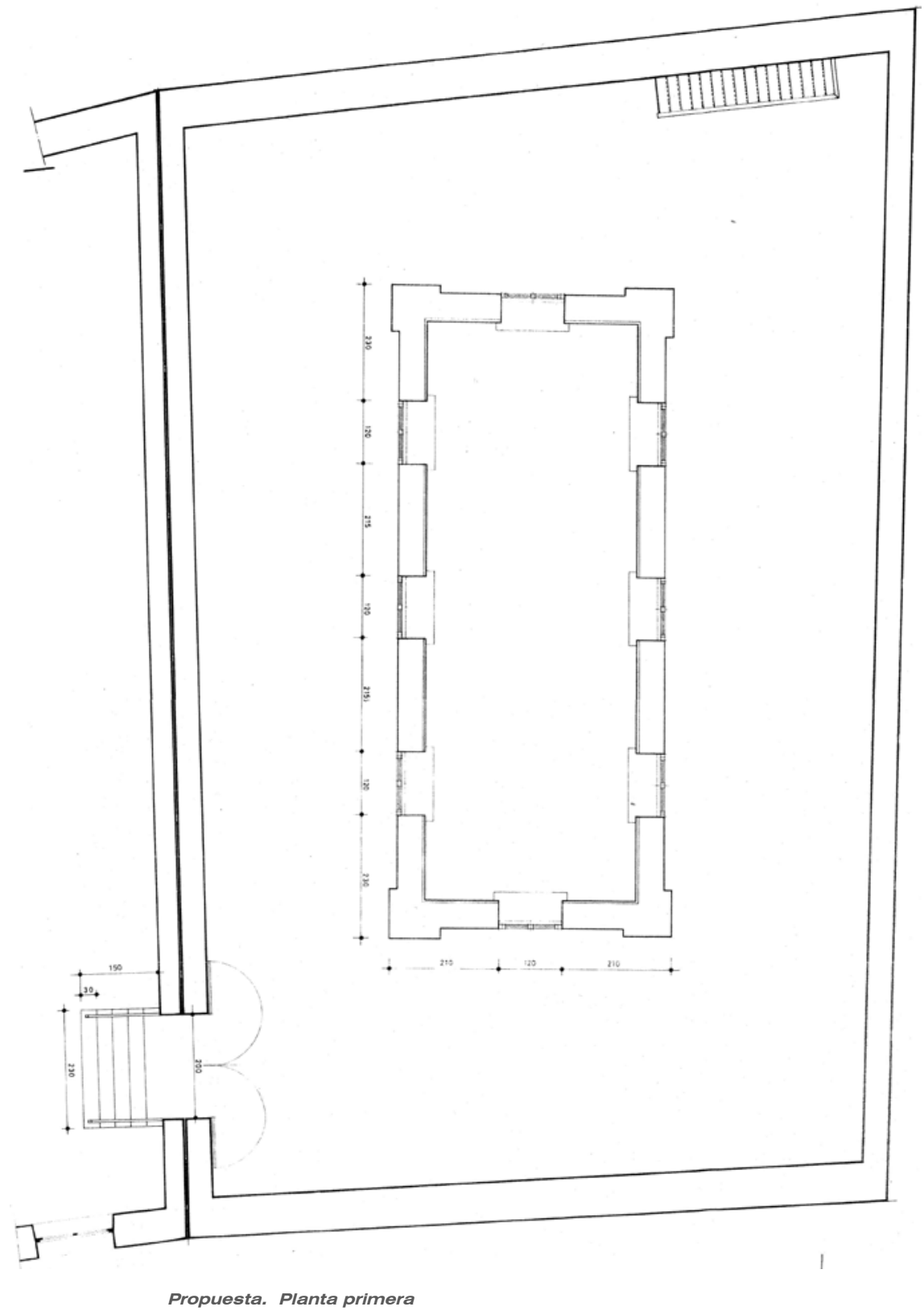

レடீำ ${ }^{5} \mathrm{~N} \theta$ 


\section{ESTADO ANTERIOR A LA INTERVENCIÓN}

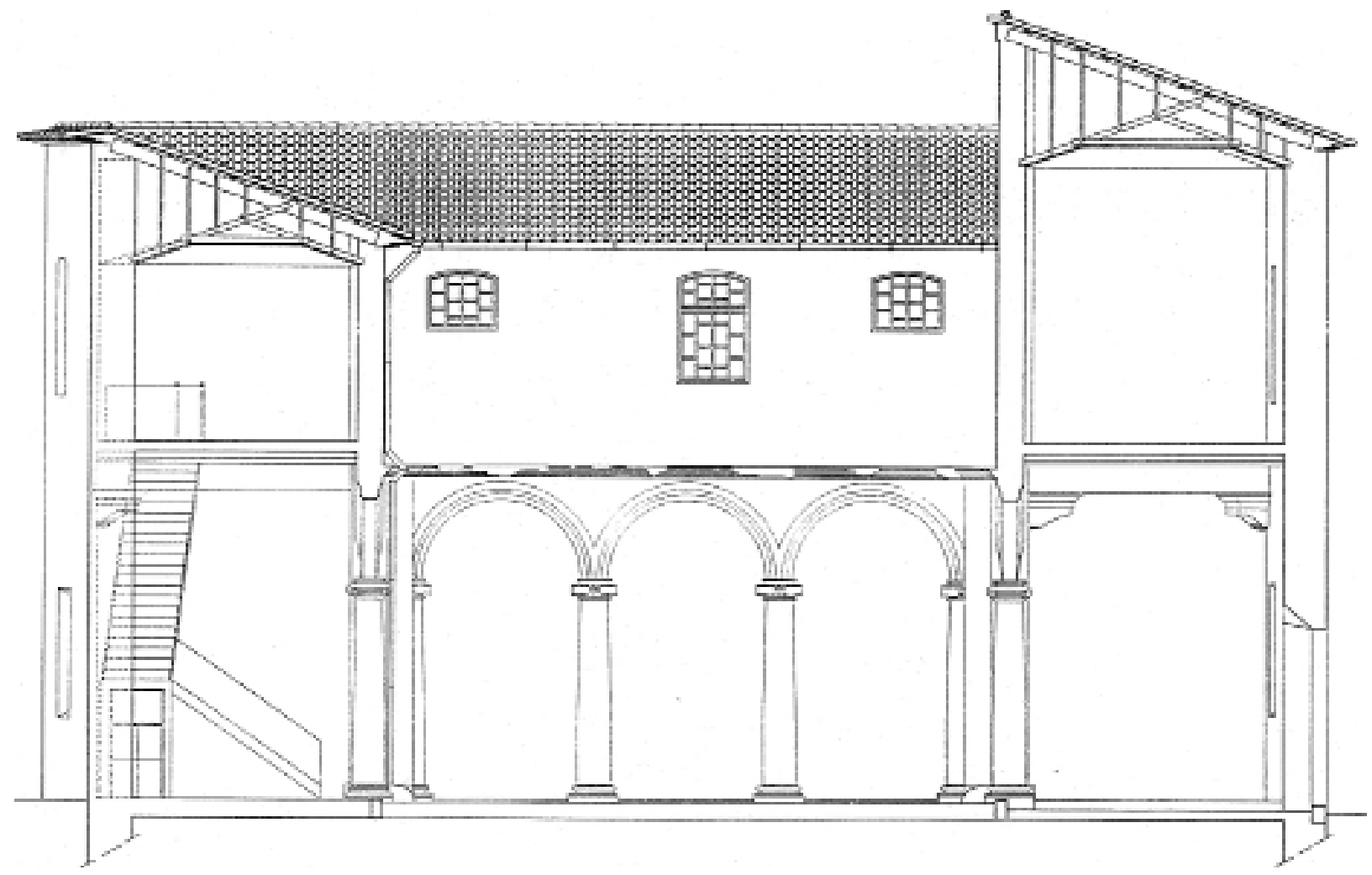

Estado anterior. Sección lon itundimal

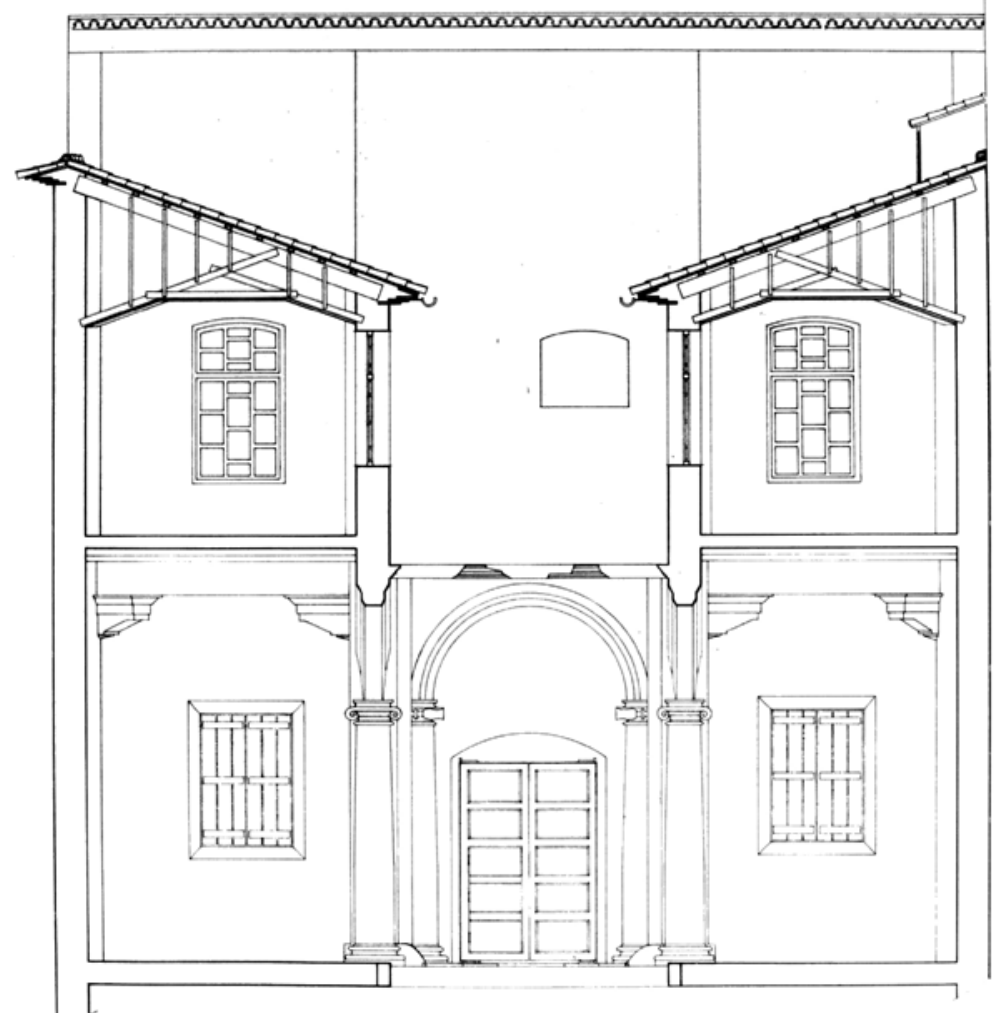

Estado anterior. Sección transversal

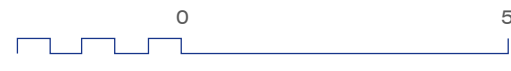


PROYECTO DE INTERVENCIÓN

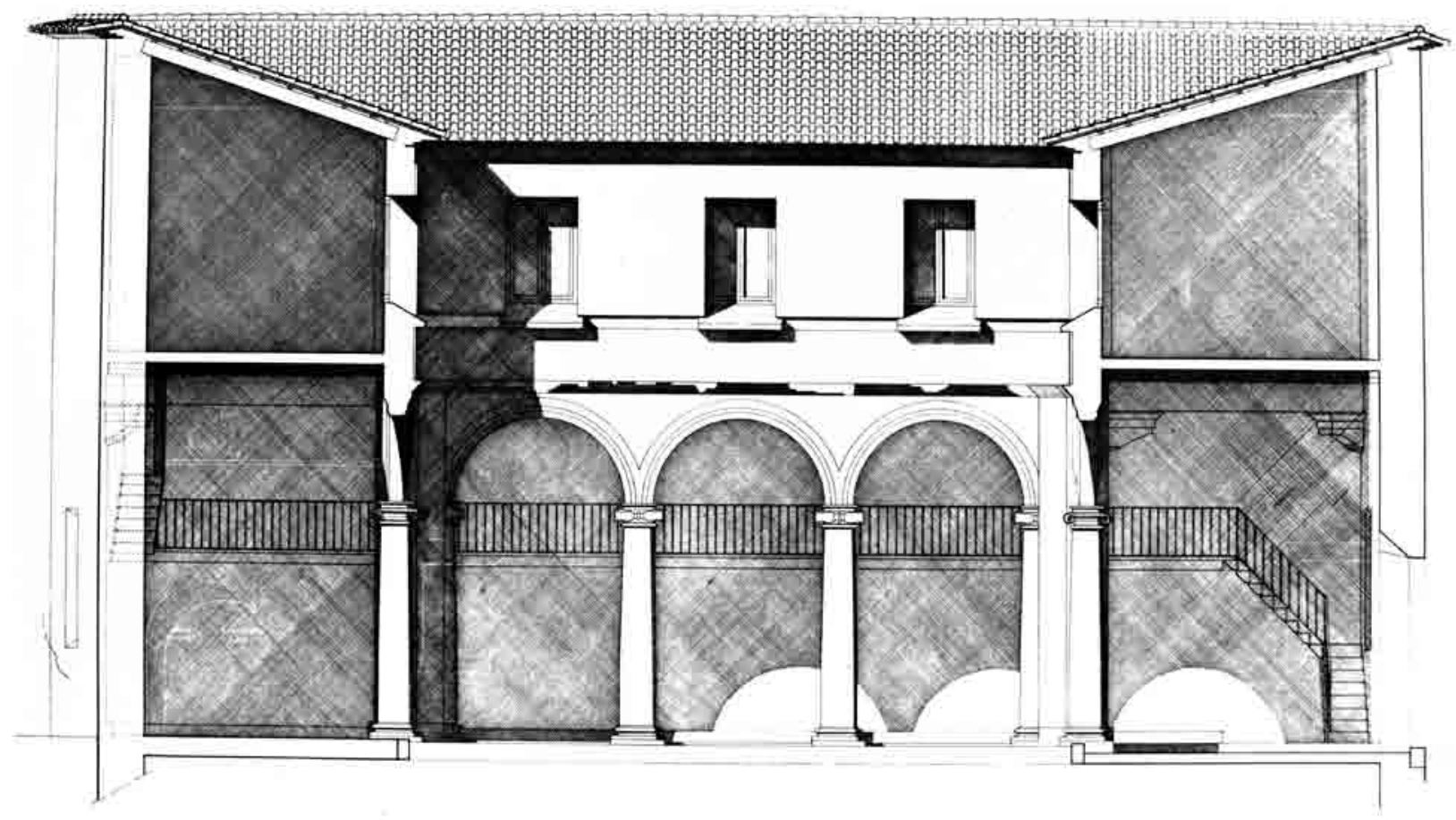

Propuesta. Seccion longitundinal

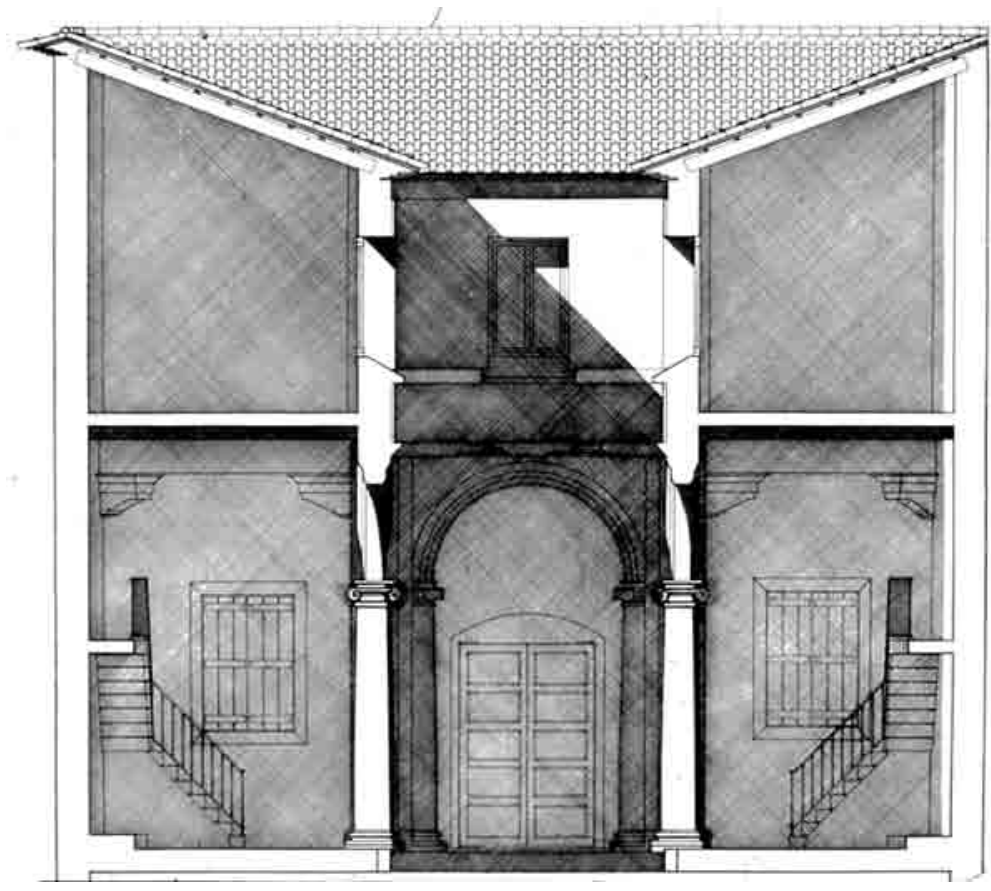

Propuesta. Sección transversal

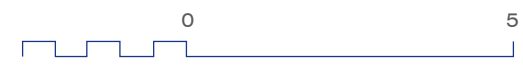




\section{ESTADO ANTERIOR A LA INTERVENCIÓN}

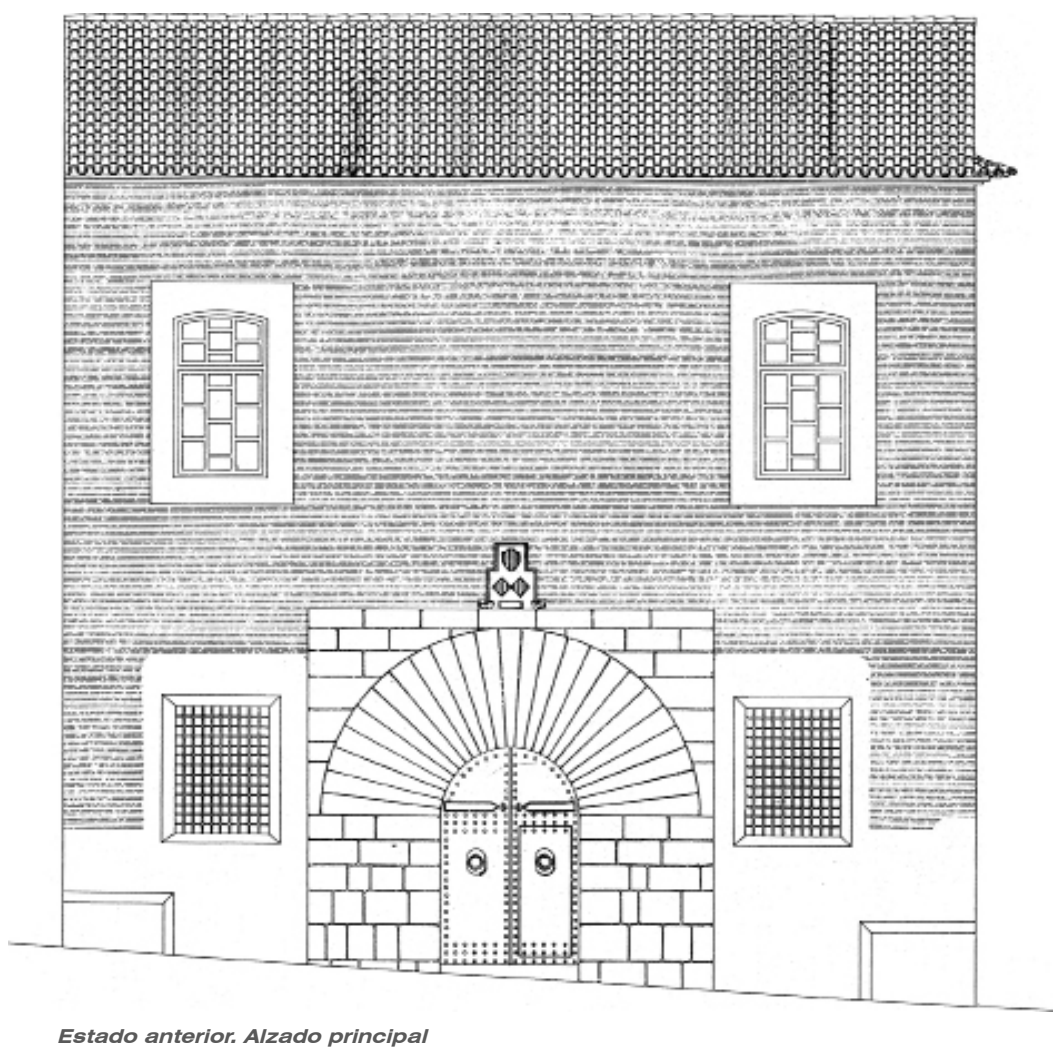




\section{PROYECTO DE INTERVENCIÓN}

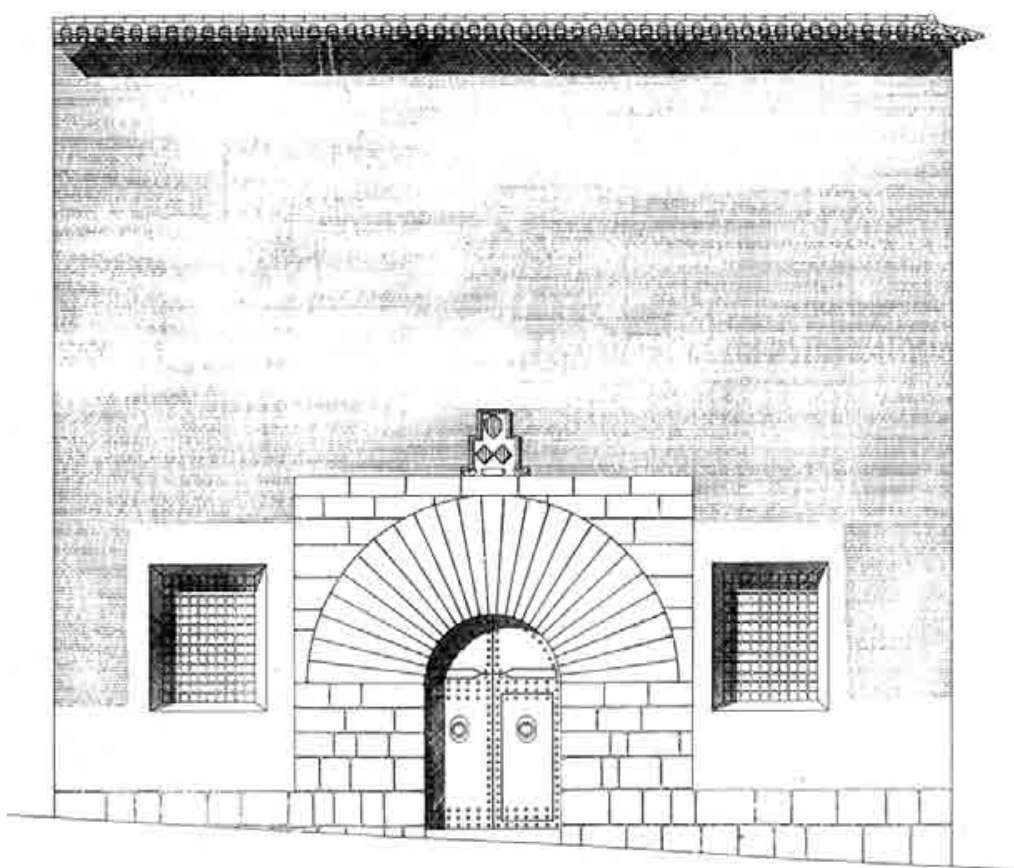

Estado anterior. Alzado principal

$\neg \vdash$




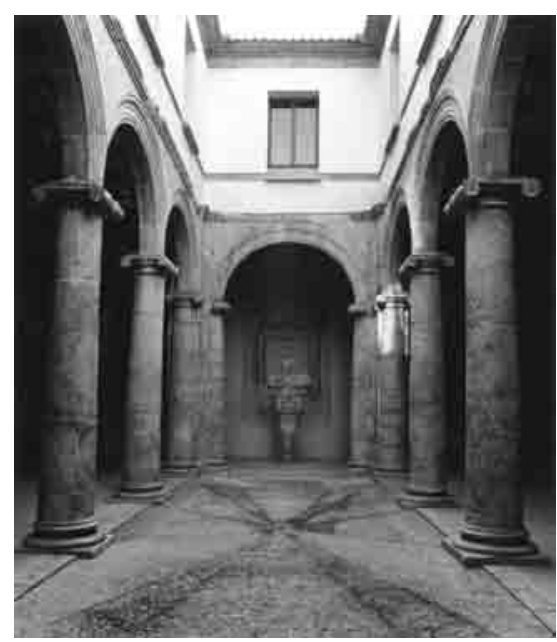

Fig. 11

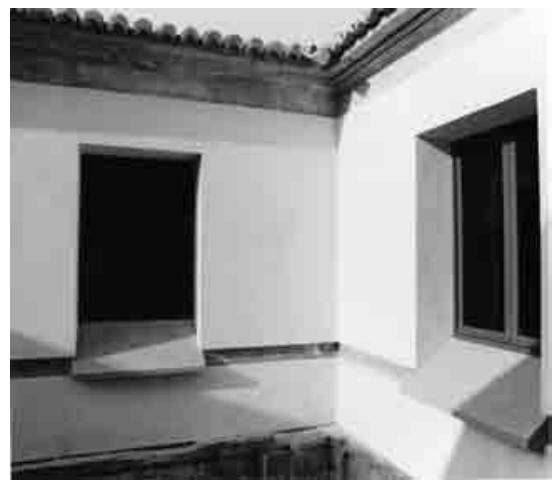

Fig. 12

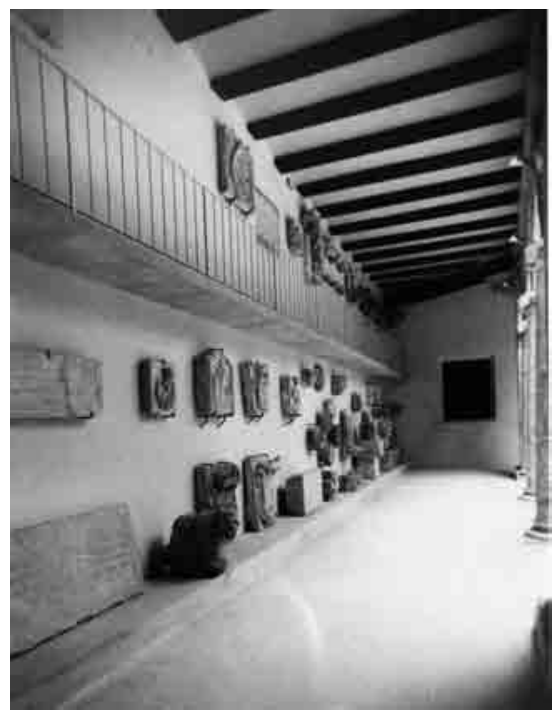

Fig. 13

\subsubsection{Descripción de la intervención}

Con objeto de otorgar al claustro renacentista el orden tipológico pretendido, se procede a la eliminación de la azarosa fenestración adventicia, que se substituye por nuevos huecos ordenados axialmente con respecto a sus respectivas campatas. La articulación de estos huecos se produce a través de la cornisa existente -sobre la que se apoya el cuerpo superior-, la imposta que ortodoxamente debía ligar las aberturas en su plano de apoyo, y la cornisa de remate, donde se entrega la cubierta. Estos dos últimos elementos inexistentes se presentan en "negativo", de forma que evocan el orden superior, sin manifestarse formalmente dada su inexistencia.

En el proyecto, las ocho ventanas están unidas entre sí por la línea continua del alféizar que, para estar correctamente proporcionada en relación con la línea de la cornisa inferior de piedra y con la de una supuesta cornisa superior, resultaría en una posición mucho más baja que la de un antepecho normal. Esta desviación se resuelve con la realización de grandes alféizares, cuya fuerte inclinación ( $45^{\circ}$ ) es capaz de absorber en el espesor del muro la diferencia de cota. (Fig.11y12)

Las partes sobresalientes de los alféizares no son, sin embargo, elementos aislados. Se unen entre sí por una acanaladura continua, de la misma altura: punto de apoyo o de engaste aparente de dicho elemento incompleto de continuidad. De este modo, los cortes horizontales "en negativo" de la nueva fachada permiten leer, además de la ausencia de imposibles molduras sustitutivas, también el acabado del viejo muro de tapial: un muro moldeado de tierra, con grava de diferentes tamaños, endurecido con una capa exterior de cal.

El paramento exterior de la planta primera se realiza con un estucado de arena amarilla y cal que confiere un espesor adicional de 5 centímetros a la fábrica original Este acabado es compatible con la calicostra o capa exterior caliza del tapial que le sirve de soporte, a la vez que permite una coloración adecuada en relación con el monumento, dado el aspecto natural que su técnica tradicional le confiere. Este paramento 
comienza allí donde termina la cornisa de piedra del orden inferior -evidenciando las mermas-, se interrumpe en relación con la franja cuya cota establece el alféizar de la fenestración y termina en la línea en la que debería comenzar el arranque de la cornisa desaparecida, que remataría el alero de la cubierta en impluvium. (Fig.14y15)

En la planta baja de acceso, la intervención del proyecto concierne casi exclusivamente a las paredes perimetrales del pórtico. Las antiguas inscripciones halladas en lo alto sugieren una división de las paredes de los dos lados largos en dos zonas de exposición. Éstas se separan por una estrecha galería que permite una visión cercana del material expuesto arriba; a la galería le corresponde en el plano de planta baja un podio, de similares dimensiones, destinado a sostener las piezas apoyadas en el suelo.

El Antiquarium que de tal modo se llega a formar sigue un

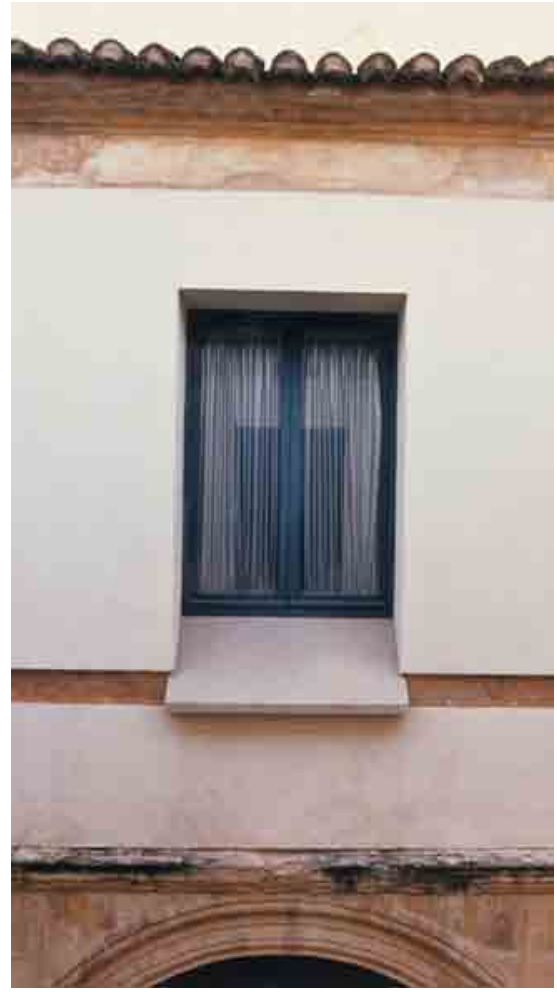

Fig 14 principio expositivo cronológico (de derecha a izquierda: de los hallazgos romanos hasta los del siglo XVII-XVIII) así cig como un principio de lógica distributiva, por llamarlo de algún modo, en el sentido de que en la parte baja de los muros se distribuyen las piezas que ya tenían originariamente esta colocación (estatuaria, bases de columnas, cipos) y recíprocamente sucede en la parte alta de los mismos donde se sitúan capiteles, frisos, claves, ménsulas. (Fig.13)

En cuanto a las fachadas se ciegan los huecos superiores en ambas fachadas mediante la utilización del mismo tipo de tapial, trabado con piezas de ladrillo macizo que ha perdurado hasta entrados el siglo XX. Esta actuación tiene un doble objetivo: mientras que las fachadas recuperan su aspecto y composición original, en la planta superior, eliminados los huecos coetáneos del patio, se obtiene un recorrido perimetral expositivo, dedicado a la pintura, alrededor de la secuencia de la nueva fenestración ya comentada. Se refuerza esta fuente de luz natural con luz artificial dirigida en el mismo sentido.

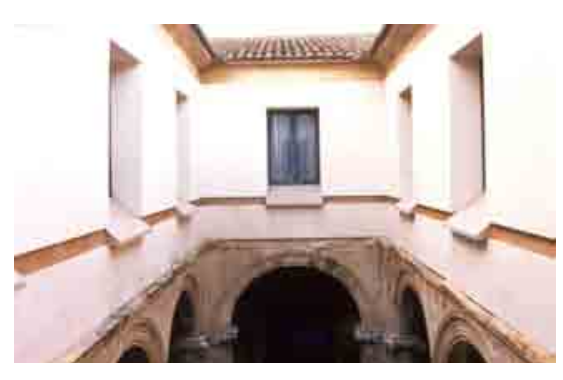



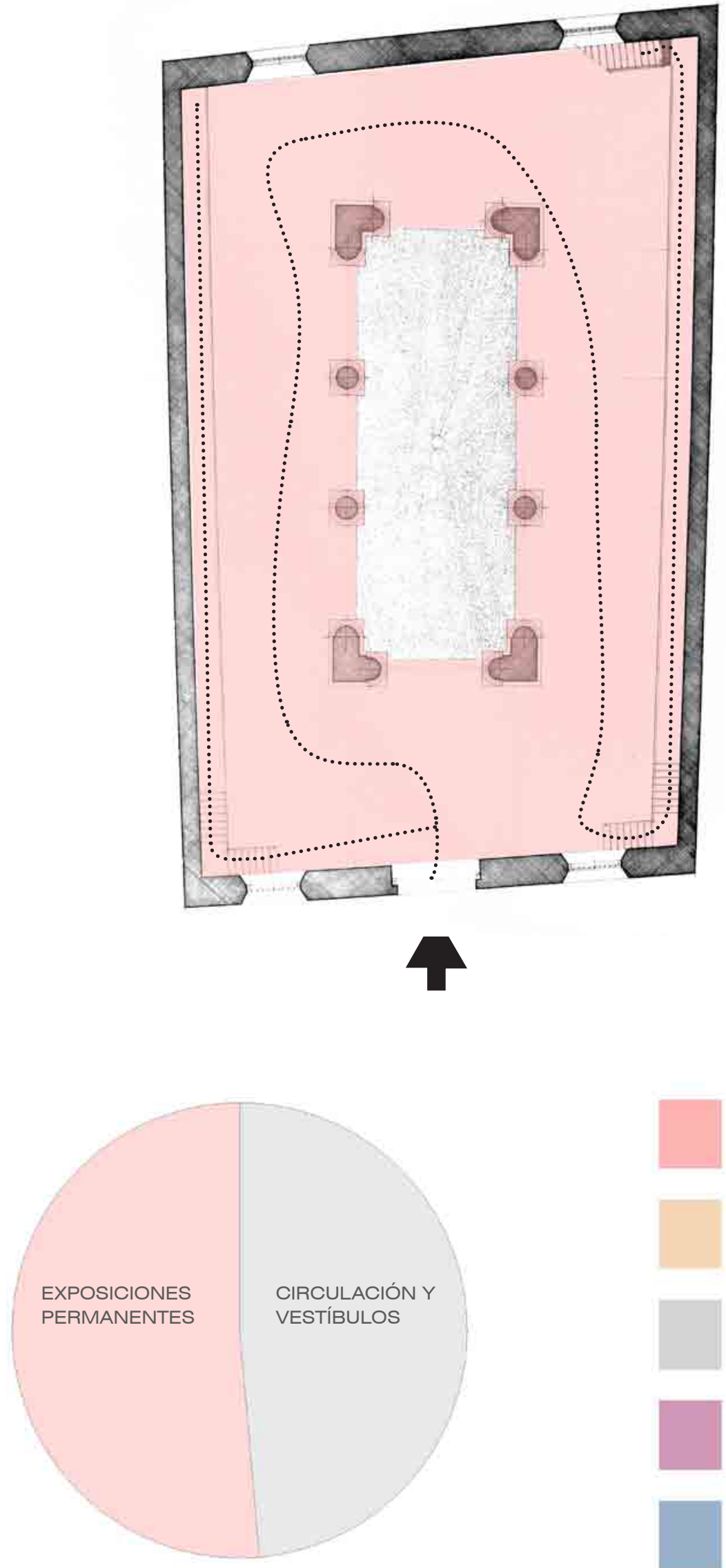

EXPOSICIONES PERMANENTES

EXPOSICIONES TEMPORALES

CIRCULACIÓN Y VESTíBULOS

usOS PÚBLICOS

USOS INTERNOS 


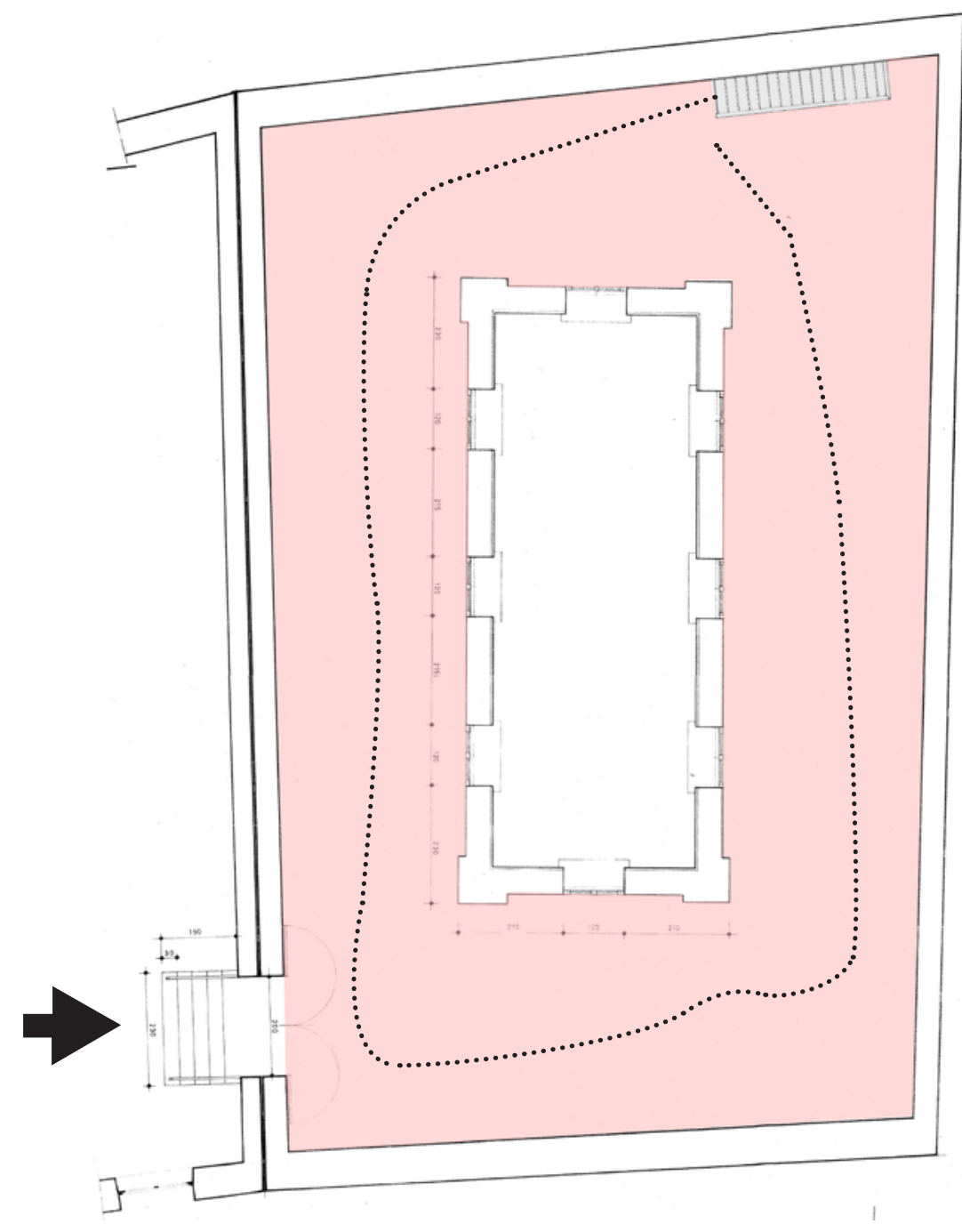

ESTIMACIÓN DE SUPERFICIE

\begin{tabular}{lcc}
\hline & $\mathrm{m}^{2}$ & $\%$ \\
SUPERFICIE EXPOSITIVA & 440 & $92 \%$ \\
SUPERFICIE DE USOS PÚBLICOS & 35 & $8 \%$ \\
SUPERFICIE DE USOS INTERNOS & 0 & $0 \%$ \\
\hline TOTAL & & \\
\hline
\end{tabular}




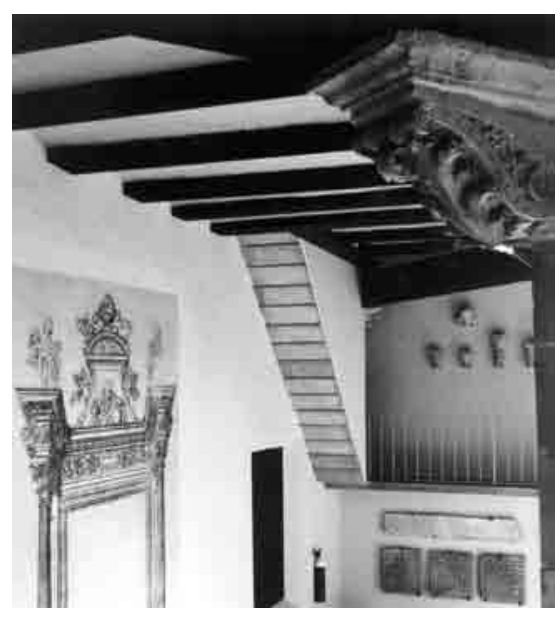

Fig. 16

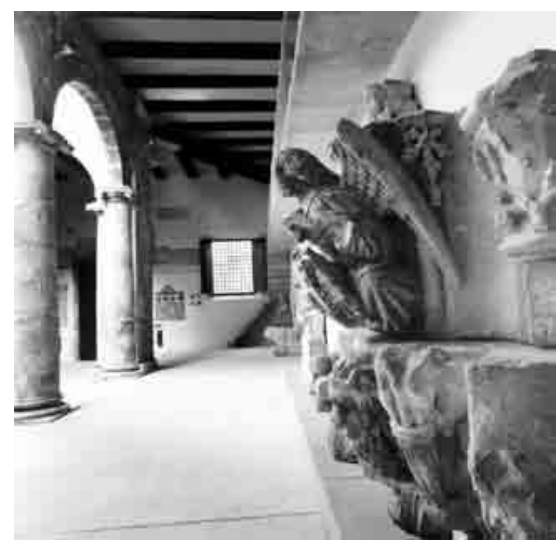

Fig. 17

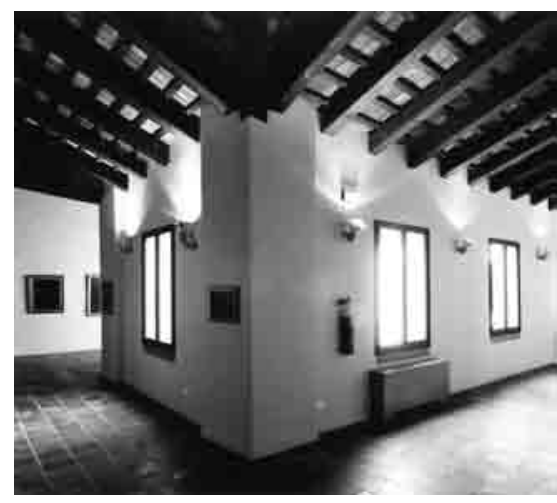

Fig. 18

\section{Materialidad}

Con una manifiesta voluntad de economía de medios y de contención expresiva, todos los materiales empleados permiten un fácil mantenimiento. En el patio, se recupera el pavimento de guijarros o enmorrillado. En el deambulatorio de la planta baja, el hormigón "in situ" conforma no solo el pavimento, ligeramente pulido, sino que materializa también las bases de las piedras y corredores de piedra artificial, que confieren un color y una textura unitarios a los elementos de nueva ejecución. En la planta superior, el pavimento corresponde a la tradicional baldosa de barro cocido, tratada para su limpieza y acorde con el aspecto doméstico de la planta que muestra su forjado de madera visto.

A las galerías se accede por medio de pequeñas escaleras en voladizo, realizadas en piedra artificial (la misma que se ha utilizado para los alféizares, las galerías y el podio). En el extremo de la derecha se encuentra la escalera de servicio que comunica con la pinacoteca en la primera planta. Esta escalera también está realizada en piedra y encerrada por una caja de madera aljofarada y pintada (Fig.16,17 y 19).

\section{Iluminación}

Respecto a la iluminación, las características del edificio original condicionan sumamente la solución. En la galería superior, los cuadros se ubican en los muros perimetrales y la luz natural entra por los huecos de nueva creación que responden al orden inferior del patio. Se sitúan en ellos cortinillas anti-radiación, cuyo objeto es la protección de las obras de arte respecto del soleamiento y de la iluminación excesiva. En respuesta al criterio de contención expresiva y de subordinación de las instalaciones a las pautas que establece el edificio histórico, la iluminación, tanto artificial puntual como ambiental, se coloca junto a las ventanas, en el perímetro de los muros de cerramiento con respecto al patio. En estos paramentos se concentran, asimismo, las instalaciones de climatización, electricidad y protección contra incendios. (Fig. 18) 


\section{Usos}

La planta baja dispone de su acceso histórico, desde la calle José Carchano, que responde a la gran portada original del siglo XVI. Usualmente y motivado por la facilidad de control de accesos y de la seguridad del museo, se entra en el patio desde el edificio principal del museo, por medio de una pequeña puerta ubicada en una esquina del deambulatorio.

La modificación más relevante que se produjo en el funcionamiento del Almudín corresponde al requerimiento que establece la independencia de usos entre la planta baja y la

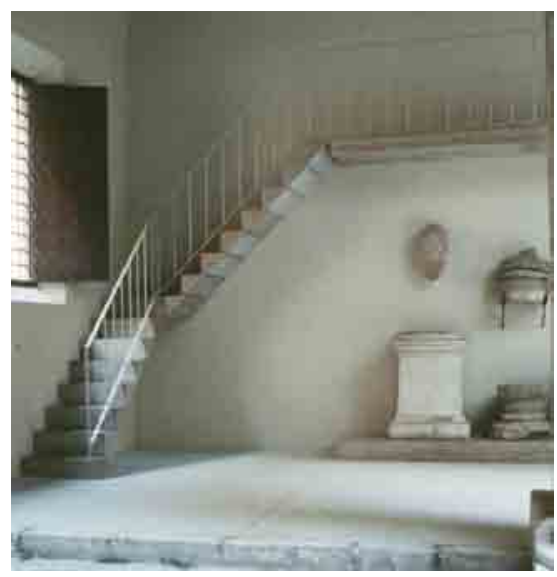
primera. Dado que en el nuevo museo la pinacoteca posee su acceso al público desde el edificio adyacente, se elimina la escalera de madera de dos tramos que viene sustituida por una de servicio -también en piedra artificial- encerrada en una envolvente, a modo de caja, de madera pintada que arranca al final del recorrido por la galería de la derecha. 


\subsection{REHABILITACIÓN DE LAS ATARAZANAS}

Valencia. 1979-1993

\subsubsection{Introducción}

El Ayuntamiento democrático de Valencia, encabezado por el socialista Ricard Pérez Casado -antiguo profesor de Urbanismo de la Escuela Técnica Superior de Arquitectura de Valencia-, interesado por la recuperación de las Atarazanas, a la sazón en manos privadas y en avanzado estado de deterioro, estableció un convenio con el Ministerio de Cultura para su recuperación. Según el mismo, el Ayuntamiento procedería a la expropiación

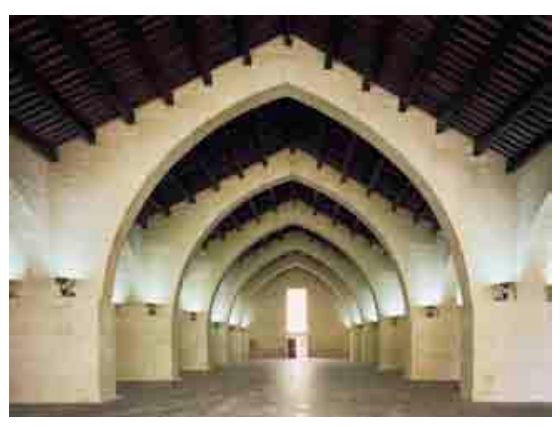
de las naves a sus diversos propietarios -proceso posible dado el carácter de Monumento Nacional que ostentaba el edificio desde 1949-, mientras que el Ministerio llevaría a cabo su rehabilitación. Consecuencia de ello, el proceso de rehabilitación se realizó, en base a una concepción unitaria, por fases, a medida que el proceso administrativo de la expropiación iba avanzando.

En 1978 el Ministerio encargó al autor el proyecto de restauración del monumento, adaptado a las diversas fases que culminarían con la última del año 1993. 


\subsubsection{Breve historia del lugar y del edificio}

\subsubsection{Origen de las Atarazanas}

El edificio de las Atarazanas del Grao de Valencia se encuentra en dicha barriada marítima, separada del mar (puerto) por una hilera de casas de nueve plantas construidas en los últimos cuarenta años (Fig.2). Estos edificios de desproporcionado tamaño le han quitado la comunicación natural que, por la función originaria del monumento, lo vinculaba al mar privándole, por otra parte, de la hermosa vista que desde el puerto ofrecía, como se observa en los grabados del siglo XVIII del estudio de Cavanilles sobre el reino de Valencia.

Su construcción se remonta al 27 de agosto de 1338 cuando el Consejo de la Ciudad, a raíz de una solicitud del Rey Pedro el Ceremonioso para la construcción de unas galeras, acordó construir una casa en la que velas, remos, (...), puedan guardarse convenientemente. Almela y Vives afirma que el 17 de agosto de 1391 se adoptó un acuerdo para la terminación y armado de dos galeras que a la sazón se hallaban en las atarazanas; ello nos lleva a pensar que, al menos, dos de sus naves ya habían sido construidas.

El mismo cronista duda de la posibilidad de la construcción de las atarazanas mediante un plan preconcebido: "Por lo demás, las Atarazanas no debieron de construirse con arreglo a un plan previamente establecido y de una sola vez, sino poco a poco y conforme a las exigencias de la necesidad y a las recomendaciones de la práctica". (1)

La lógica aditiva que configura el edificio por medio de arcos diafragma y arcos formeros, que se repiten en sentido longitudinal y transversal, viene referida por una orden que el Consell establece en 1388, en referencia al modo de la construcción de nuevas porchadas de ampliación del edificio: "Per avant poguessen

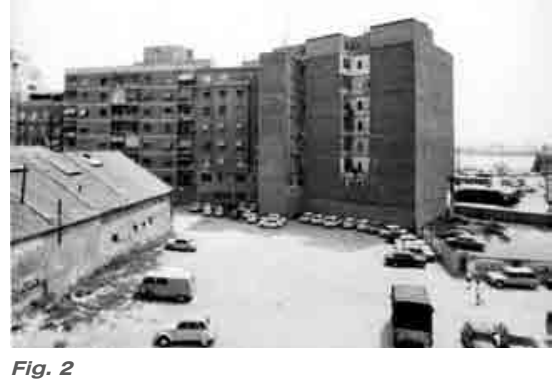
aiudant Déu esser continuats e fets més porches per a les Galeres en la dreçana". (2)

En reunión de dicho Consejo, en noviembrzve de 1409, se encargó a Francesc de Tona, cantero de Valencia, la construcción de un "bell portxe" con tres arcos de piedra para completar la 
obra, insistiendo no solo en su belleza sino en su utilidad ya que, como se indicaba, protegería las mercancías que depositaban los barcos siendo obra provechosa y conveniente al honor de la ciudad. Según Almela y Vives, esta intervención no se llevó a cabo.

Se tienen noticias de numerosas reparaciones efectuadas en las Atarazanas durante el siglo XVI. Un inventario realizado el 16 de noviembre de 1512 nos permite deducir dos partes en el edificio: una interior, donde estaban comedores y estudios con su mobiliario, y otra parte abierta, el porche, donde se almacenaba material.

En 1687 se rehicieron las cubiertas de las Atarazanas así como las canales estropeadas. En 1802, las Atarazanas pasaron a manos de la Real Hacienda, para satisfacer la deuda que la ciudad tenía con ella, que las utiliza como almacén de sal. A partir de entonces la conservación y mantenimiento del monumento caen en el olvido.

El 9 de septiembre de 1840 se privatizó la propiedad del Monumento. Las cinco naves de que consta, separadas por el macizado de los arcos transversales, sufrieron diversas modificaciones debido a la diversidad de usos. Almacén, sala de cine, vivienda, oficina, taller de fundición y de maquinaria naval, corresponden con las diferentes funciones a las que se sometió al monumento, con las alteraciones y agresiones implícitas en usos tan dispares.

El 24 de noviembre de 1949, las Atarazanas fueron declaradas Monumento Histórico Artístico de carácter Nacional. Hay que esperar a 1980 para que el Ayuntamiento de Valencia comience el proceso de expropiación del monumento, a la vez que el Ministerio de Cultura se comprometa a su restauración (Fig.3 y Fig.4).

\subsubsection{El lugar}

Las atarazanas se ubican en la Vila Nova del Grao (Fig.5), núcleo de fundación cristiana asentado sobre posibles restos de una alquería musulmana. La ciudad de València, eminentemente fluvial e instalada durante la época romana en un promontorio
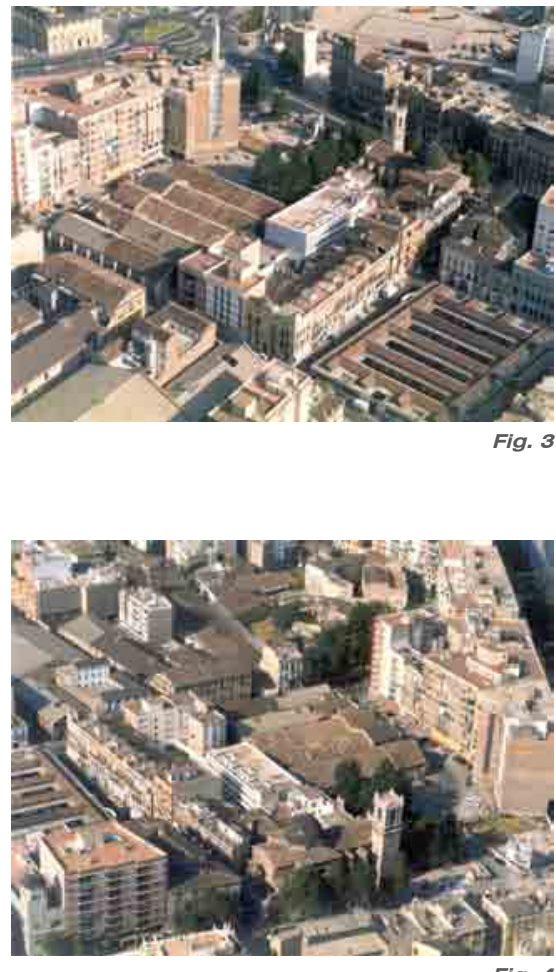

Fig. 4

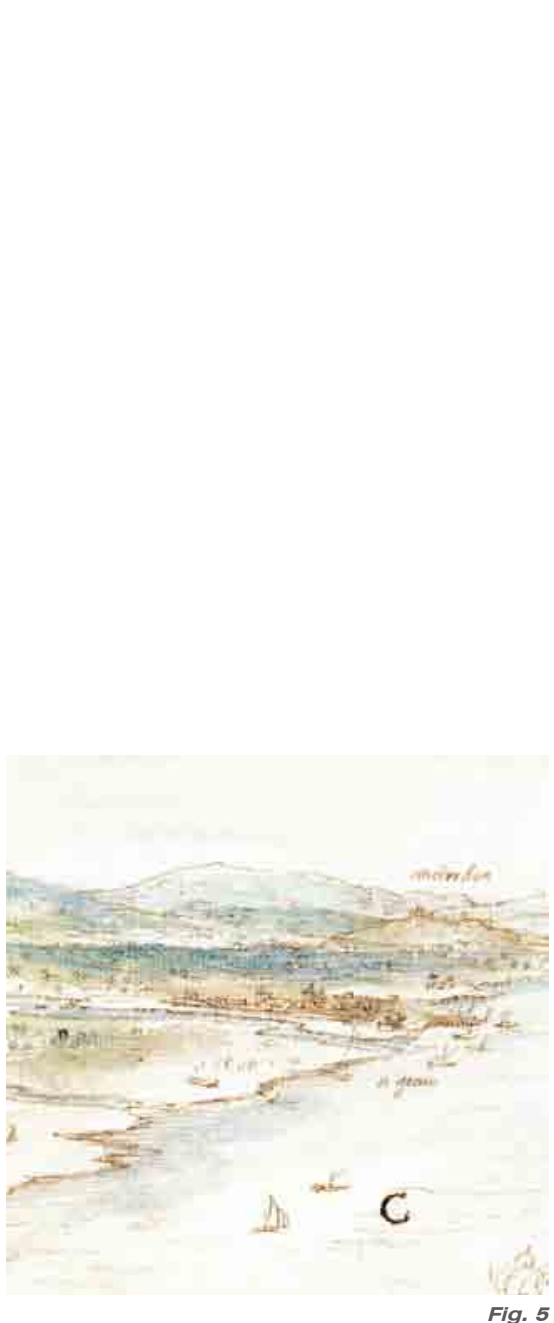




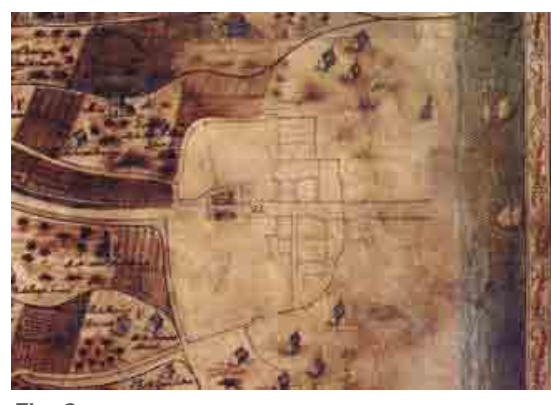

Fig. 6

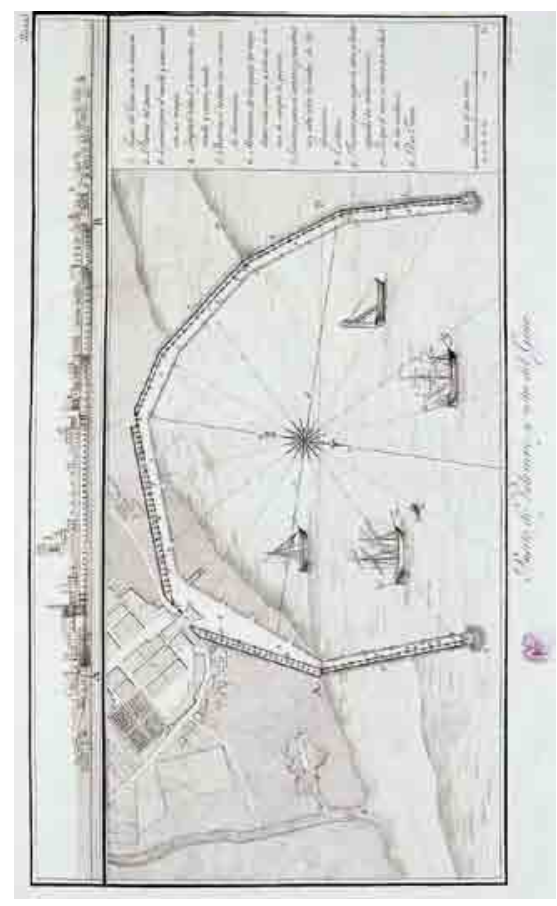

Fig.7 entre dos brazos del río Turia, dista tres kilómetros de su desembocadura, y por tanto, del mar.

La necesidad del control de este importante punto estratégico y la escasa aptitud del río Turia para la navegación instaron a los conquistadores cristianos a la creación de un núcleo permanente de población que garantizara una mínima infraestructura portuaria, en su doble vertiente comercial y defensiva.

La Vilanova del Grau estuvo, al menos, parcialmente fortificada desde sus inicios; no parece que tuviera una muralla propiamente constituida, pudiendo el propio caserío asumir las funciones de la misma. En el siglo XVI, la torre de vigilancia medieval fue reforzada por la construcción de un baluarte, y las puertas que poseía el recinto fueron reforzadas.

Las atarazanas, situadas en posición excéntrica respecto del núcleo originario de la Vilanova, significaban su límite norte (Fig.6). En esta línea se disponía, a tenor del informe de recomendaciones para el refuerzo de fortificaciones de Giacobo Palearo Fratín, del año 1576, una puerta de acceso al recinto del Grao: "A la puerta del ataraçanal hazia la mar, sirviéndose de tres de los pilares que saltan fuera y sirven para contrafuerte de la ditha ataraçana". (3)

En la esquina noreste del edificio se dispuso un cuerpo en forma de bastión, que muestra el plano de Boudin de 1739 y cuyos cimientos son todavía visibles en el primer contrafuerte de la nave norte de las Atarazanas. En dicho plano se aprecia todavía libre el espacio de la conexión de las atarazanas con la playa y el mar.

La pérdida de importancia de las Atarazanas en el devenir de su existencia se hace palpable en el plano redactado en 1796 con objeto de regularizar la trama urbana de los poblados

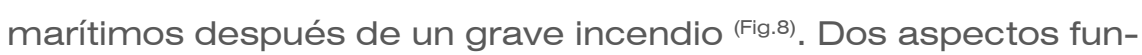
damentales podemos reseñar de la observación de este plano. El primero de ellos constata la construcción del brazo norte de la dársena del puerto y la disposición perimetral de una edificación de planta baja que impide la directa conexión de las atarazanas con el Mediterráneo. Esta apreciación se corrobora con el exa- 
men del grabado de Cavanilles de fecha de 1795 y nos permite ratificar el importante menoscabo de la función marítima originaria de las atarazanas (Fig.7). Además, si se le presta debida atención, se confirma que dicho grabado soslaya a las atarazanas en su descripción del puerto. Si bien las representa en el alzado, en el que muestra los cinco testeros destacados en el perfil de la ciudad, en la planta y su aneja leyenda son obviadas; solo circunstancialmente se grafía un ángulo del conjunto edilicio. ${ }^{(4)}$

Por otro lado, es destacable en dicho plano de 1796 que la propuesta ilustrada -y no realizada- de reedificación del poblado de pescadores considere la línea de la fachada este de las Atarazanas como una traza de proyecto: alineada a ésta, se dispone en sustitución del anárquico caserío anterior un cuerpo edificado de planta rectangular subdividido en parcelas regulares. Este cuerpo enlaza con la trama de manzanas rectangulares y calles rectas y ortogonales del Cabañal mediante un bloque curvo que establece la necesaria transición entre la alineación de las atarazanas y la del nuevo Cabañal propuesto. No cabe duda de que el proyecto de reconstrucción del frente marítimo de la ciudad, de corte académico y con preocupaciones de índole estética, ponía en valor y establecía un positivo juicio, con la decisión de este trazado, del histórico edificio de las Atarazanas.

Cabe mencionar, para la comprensión de las circunstancias históricas del edificio, que el Grao de Valencia, cuyo puerto no es natural, no poseía instalaciones portuarias permanentes. Su falta de calado dificultó la navegación y el comercio; hasta finales del siglo XVIII no se procedió al comienzo de las obras de la primera dársena del actual puerto. Las obras fueron costosas y se interrumpieron constantemente, prolongándose de forma notoria hasta bien entrado el siglo XIX. Las Atarazanas, por aquel tiempo, se utilizaban al parecer como almacenes del comercio portuario: trigo, sal, etc.

En referencia a la conexión del puerto con la ciudad, cabe reseñar que la actual Avenida del Puerto -que regulariza el camino histórico entre la ciudad y el mar- continuaba en los años 80 siendo su eje principal de conexión. La trama histórica de la

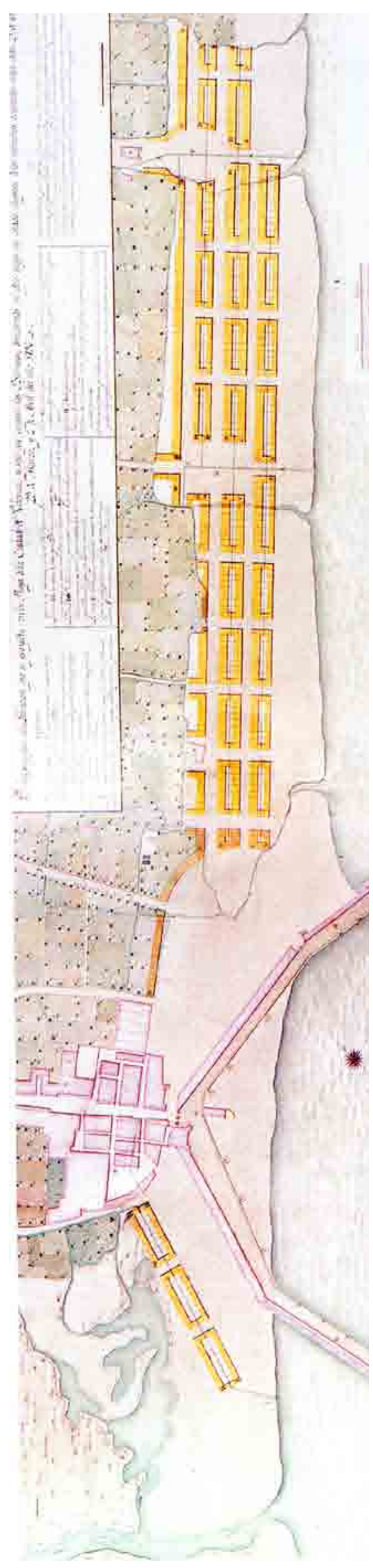



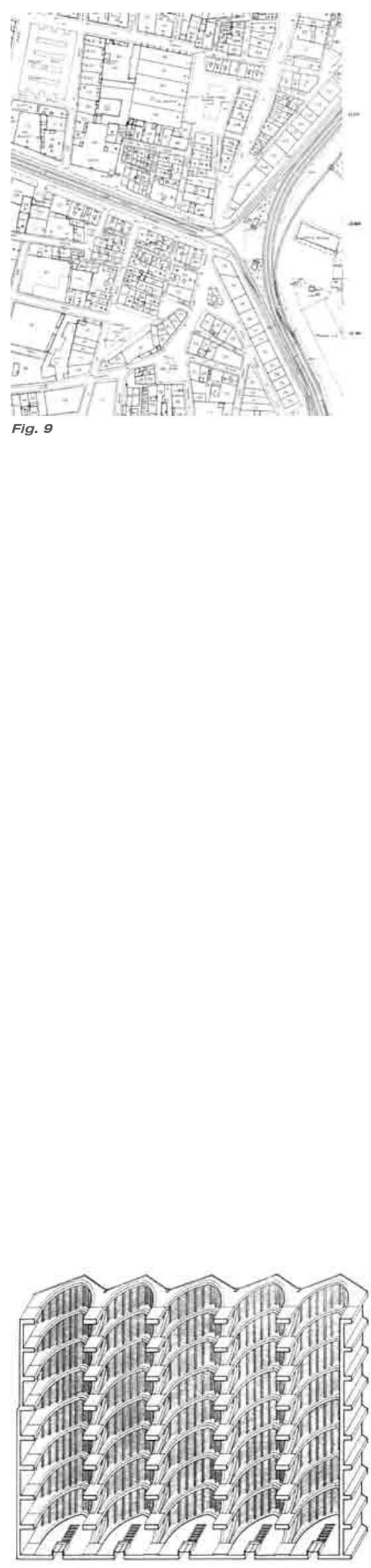

Fig. 10
Vilanova ha sido radicalmente transformada por operaciones urbanísticas de reforma interior, aceleradas sin duda debido al mal estado de los edificios consecuencia de los reiterados bombardeos realizados por el ejército golpista, llamado bando nacional, del puerto de Valencia. La Iglesia de Santa María del Mar, de única nave, con contrafuertes, cúpula en el crucero y capilla de la comunión, es el edificio más destacado del entorno. El templo actual se asienta sobre uno anterior de época medieval, y su construcción comenzó, según los cronistas, en 1683. Su alineación coincide con la de las Atarazanas, y comparte con éstas la pérdida de la escala urbana de su entorno inmediato y la descontextualización histórica (Fig.9).

La anexión de la Vilanova del Grao en 1897 por parte de la ciudad de Valencia y las importantes transformaciones urbanísticas, algunas muy desafortunadas, han terminado de romper el histórico vínculo de las atarazanas con el Mediterráneo. Hoy restan empequeñecidas y descontextualizadas, frente a edificios de 5 a 9 alturas y junto a una plaza lateral de nueva creación, ordenada con unos jardines que sustituyen a antiguas viviendas.

\subsubsection{Descripción del edificio}

El conjunto de las Atarazanas consta de 5 naves de 8 tramos. De planta sensiblemente rectangular, tienen cada una de ellas una longitud de 49,50 $\mathrm{m}$ y anchura media de $13,20 \mathrm{~m}$. Su luz libre entre arcos responde a aproximadamente 10,30 metros. Cada una de las cinco naves está determinada por la sucesión de 9 planos diafragma, perpendiculares a su eje, que se perforan por medio de arcos de perfil apuntado. Separan las diferentes naves 8 arcos formeros que arriostran los arcos diafragma a la vez que permiten la comunicación entre ellas (Fig.10).

El conjunto se define espacialmente por medio de dos planos verticales dispuestos de modo ortogonal; el primero está perforado por 5 arcos diafragma apuntados, cuyos límites superiores acusan la impronta triangular de la cubierta a dos aguas de cada nave; el segundo, transversal, se constituye por una serie de 8 arcos apuntados, cuyo límite superior de coronación 
horizontal alberga una canal de recogida de aguas, resultado de la limahoya que definen los faldones opuestos de las cubiertas de dos naves adyacentes.

Se puede asimismo concebir este conjunto como la adición en planta, según un sistema de ejes cartesianos, del espacio delimitado entre dos arcos diafragma apuntados, en una de sus direcciones, y 2 arcos formeros en la otra; los primeros rematan su extradós mediante dos líneas convergentes a modo de frontón y entre ambos se dispone un entramado de vigas y correas de madera que sostiene un tablero cerámico de cubierta a dos aguas, que forma el límite vertical de esta unidad espacial; los segundos, paralelos, establecen la separación entre diafragmas y sirven de apoyo a la canal que recoge las aguas. De este modo, cinco espacios en una dirección y 8 en la ortogonal configuran el conjunto (Fig.11).

La construcción de las Atarazanas se concibió, podríamos decir, a la romana: un alma de tapial, constituida mediante tierra apisonada con cal, piedra y algunos ladrillos macizos, toma forma por medio de una piel exterior de ladrillo macizo manual. Esta construcción, sin duda de notable economía, evidencia el carácter funcional e industrial del edificio. El ladrillo, manual de $3 \mathrm{~cm}$ de espesor, es el material que predomina y caracteriza la imagen colectiva de las Atarazanas. Perfila su construcción, dibuja su traza y define sus aristas y curvas. Además, no solo moldea la forma del tapial, sino que se dispone en los puntos más delicados de la construcción: aristas y cambios de plano, zócalos, trazado y formación de arcos así como constitución de los frontones con sus numerosos y precisos cajeados que albergan las vigas de cubierta. Los arcos, tanto diafragmas como formeros, y los soportes, se definen con este ladrillo macizo de dimensiones $3 \times 15 \times 30 \mathrm{~cm}$. La fábrica muestra llagas de considerable espesor -sobre los $5 \mathrm{~cm}$ - realizadas con mortero de cal reforzado con grava, llamado popularmente perdigoná de moro. Solamente en los cierres de los muros norte y sur, aparece la mampostería, de forma ocasional, como describiremos más adelante.

La aplicación concreta del sistema constructivo descrito no

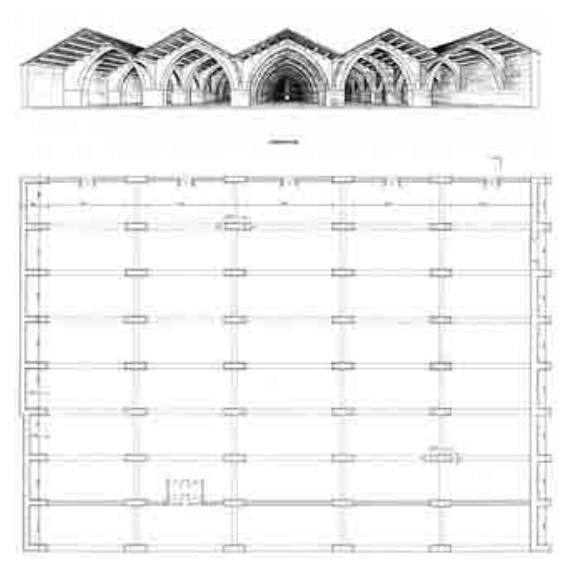




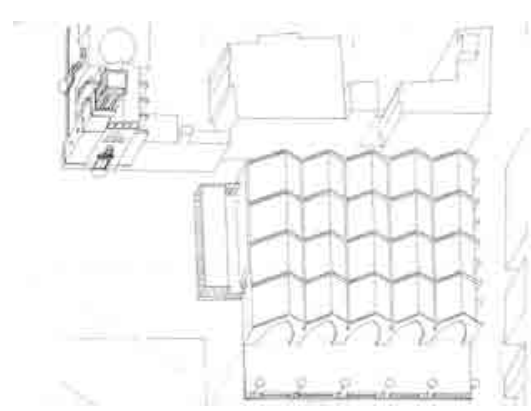

Fig. 12

es totalmente uniforme: la ejecución del conjunto de la obra es desigual. Su examen muestra falta de trabazón entre algunas de sus partes, diferente esmero en la realización de las fábricas, así como la afloración del tapial en los riñones de algunos arcos diafragma. Este último hecho evidencia cierta despreocupación estética al enseñar partes de la fábrica realizada con un material reservado para el núcleo de la construcción. Ciertamente resulta más fácil y económica la ejecución del irregular espacio en cuña de los riñones mediante un material plástico que permita la superación de la modular rigidez del ladrillo. En todo caso, y de nuevo, este proceder ilustra tanto como recalca el carácter utilitario del edificio.

Las cinco cubiertas de las naves son a dos aguas, revestidas con teja moruna en origen, de tal modo que se generan dos aleros que vierten el agua al exterior -fachadas laterales norte y sur- y cuatro canales interiores. En los extremos de cada una de ellas, la salida de aguas se realiza a través de dos gárgolas, una en cada fachada. Están realizadas mediante bloques de piedra caliza, dispuestos en voladizo, y en su parte inferior aparece esculpido el escudo de la ciudad (Fig.12). Estos elementos se han conservado hasta nuestros días, tanto en la fachada principal como en la posterior.

La periférica disposición de las Atarazanas en el norte del recinto de la Vilanova del Grao nos informa acerca de los diferentes tratamientos de sus fachadas laterales. La fachada norte acusa al exterior los pilares de los arcos diafragma, recrecidos hasta la altura del alero de cubierta a modo de contrafuerte. Este cierre servía de límite del recinto murado de la Villa portuaria. La razón última de la decisión de situar los contrafuertes "extramuros" nos es desconocida. Sin embargo, se constata que de este modo, al disponerlos al exterior, el alero de cubierta puede situarse a una cota superior y elevar la altura del muro -antiguo cierre de la Vilanova-, que se robustece visualmente por medio de los contrafuertes. Esta disposición corresponde con la histórica y es un hecho constatado en la cartografía histórica que desde el siglo XVIII representa la Vila Nova del Grao. Por otro 
lado, la fachada sur no acusa el seriado ritmo estructural y se nos muestra con caracteres indiferenciados: los pilares quedan absorbidos en el espacio interior (Fig.10). En este alzado, además, se exhibe un quiebro que remarca la diferencia entre la fábrica de mampostería con verdugadas de ladrillo macizo del muro de cierre de las tres primeras crujías y la fábrica de ladrillo macizo de las restantes. La excavación arqueológica realizada durante la intervención confirmó la existencia del quiebro en las cimentaciones originales. Se atribuye a la existencia de antiguas vías y plazas, así como edificios o propiedades anteriores del caserío intramuros de la Vilanova, las causas de esta disposición, cuyo objeto de estudio excede el cometido de este texto. Por otro lado, las fachadas este y oeste acusan el perfil apuntado de las arcos diafragma y de los testeros de las cubiertas a dos aguas, elementos formales característicos de las Atarazanas.

La marcada dirección longitudinal que se percibe mediante los arcos diafragma, que corresponde con la profundidad total

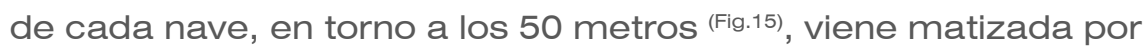
la importancia que adquiere la dirección transversal. Ésta prevalece en magnitud a la primera: la supera, con sus aproximados $70 \mathrm{~m}$, en casi 20 metros. Además, la fábrica de los pilares sobre los que apoyan los arcos diafragma, es más gruesa que los anchos de los mismos. Ello genera un soporte apantallado en la dirección del plano de los arcos diafragma, cuyas dimensio-

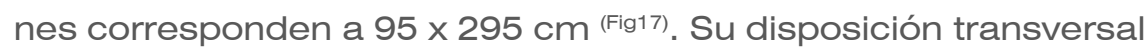
refuerza la importancia de la dirección perpendicular al eje de las naves. Por otro lado, el tratamiento del plano que contiene los arcos formeros contribuye a una percepción de máxima permeabilidad de la dirección transversal. Los arcos formeros se impostan desde pilares cuya mayor sección en la base evita su reconocimiento como perforación de un muro que hubiese reforzado el carácter longitudinal de la nave (Fig.16). Se reconoce así una clara intencionalidad de "desmaterialización” de este muro transversal, que viene corroborada mediante el trazado de los arcos formeros: éstos salvan la luz completa entre pilares y su clave alcanza la máxima cota posible, tangente a las maderas

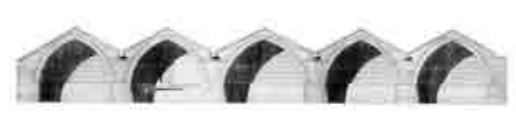

Fig. 14
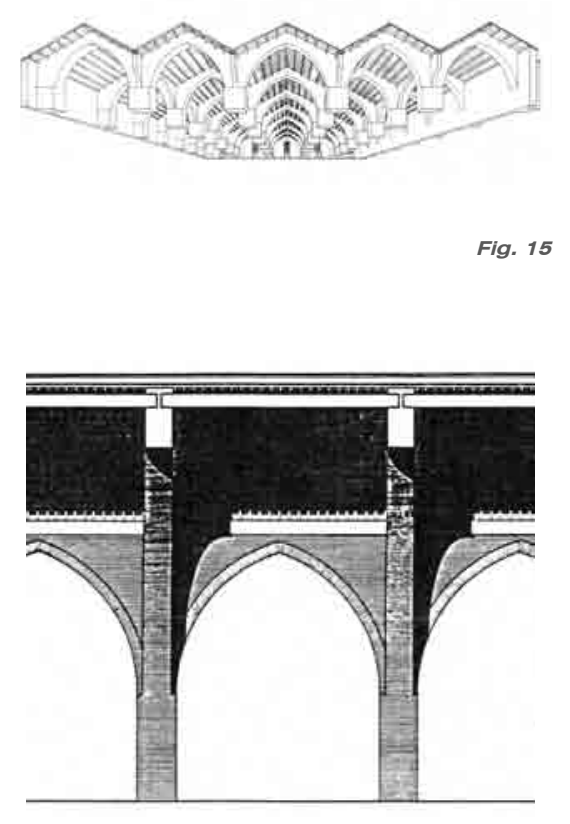

Fig. 16

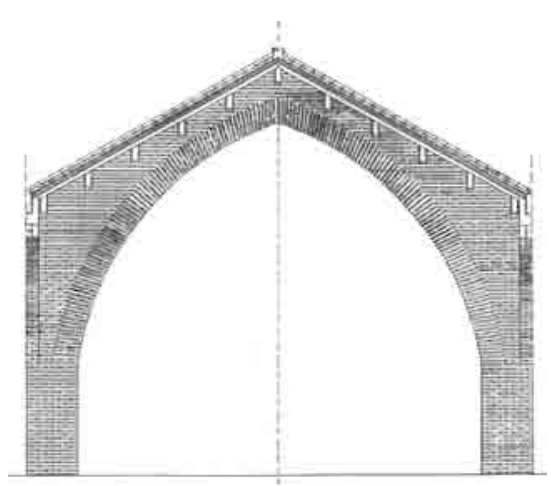

Fig. 17 


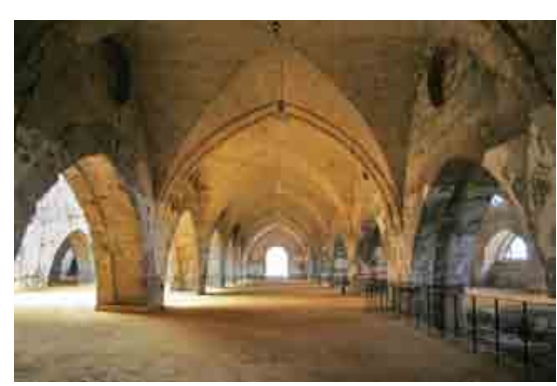

Fig. 18

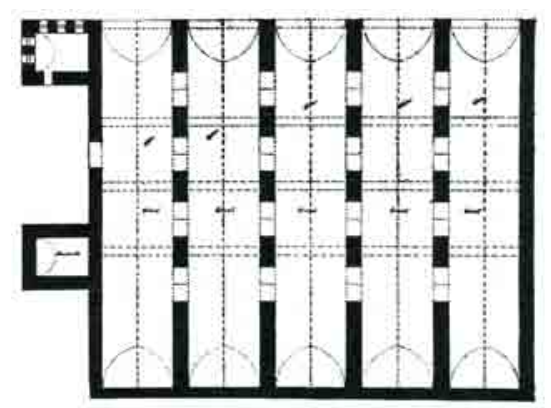

Fig. 19

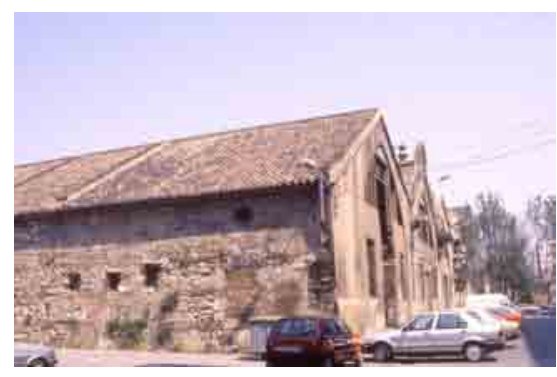

Fig. 20 de cubierta. Diferente sin duda hubiese sido este espacio con un muro, acaso perforado con arcos formeros de escasa luz y menor altura de clave; la visión de este muro enfatizaría ineludiblemente la dirección longitudinal. A modo de ejemplo, piénsese en el espacio de las naves de las Atarazanas sevillanas, cuyo espacio interior acentúa la dirección longitudinal, o en el de la ciudad turca de Alanya (Fig.18 y Fig.19).

No obstante, bien es cierto que no podemos hablar de un espacio isótropo, independiente de su dirección: las mayores altura y luz salvadas por los arcos diafragma frente a las de los formeros jerarquiza ineludiblemente una dirección frente a la otra. La disposición de los elementos resistentes de cubierta y la dirección de su cumbrera también refuerzan la línea longitudinal. Sin embargo, la disposición apantallada transversal de los pilares y el arranque desde ellos de unos formeros que sustituyen al muro, tal como se ha descrito, matiza esta importancia y permite la creación de un espacio que tiende hacia la isotropía. En efecto, esta disposición, intencionada en el proyecto primigenio, voluntad de sus artífices, realza las visuales entre las distintas naves y lima la tendencia de percepción anisótropa del espacio.

La tendencia a la neutralidad y homogeneidad espacial en la arquitectura gótica de los antiguos territorios mediterráneos de la Corona de Aragón, definida por la ambivalencia de los ejes en planta, la isotropía de los espacios generados, la constante altura, la importancia de las visuales diagonales y la uniformidad de sus soportes, dará como ejemplo culminante el espacio de la Sala de Contratación de la Lonja de Valencia. Las Atarazanas, construidas con una antelación de casi una centuria, no pueden sino considerarse como un precedente espacial en la ciudad, de excepcional importancia, del gran espacio característico de la Lonja valenciana.

\subsubsection{Antes de la intervención}

El estado en el que se encontraba el monumento a finales de los años 70 era muy preocupante ${ }^{(F i g .20)}$. La privatización que del mismo se realizó en el siglo XIX había determinado una dis- 


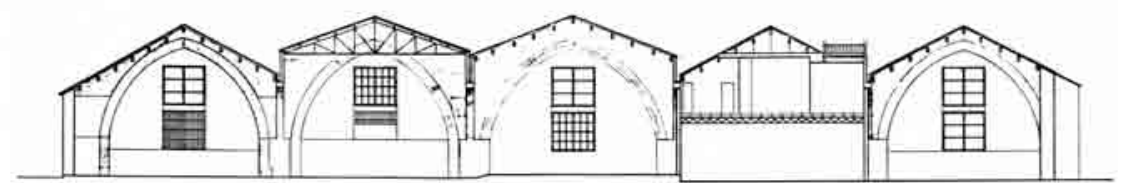

tinta suerte para cada una de las naves.

En general, los arcos formeros habían sido cegados con la privatización decimonónica de las 5 atarazanas. Éstas tuvieron, posiblemente y en dicho momento, cinco propietarios diferentes. El gran espacio gótico, fragmentado y subdividido, había sido privado de sus cualidades espaciales esenciales. En 1980 las tres primeras naves estaban comunicadas parcialmente, mientras que la cuarta y la quinta restaban independientes.

De este modo, la primera nave (la meridional) albergaba un taller de maquinaria naval, que ocupaba asimismo la segunda y la tercera nave. En la primera se habían colocado unas vigas metálicas en sentido transversal al eje de la nave, en cajeados efectuados tanto en los muros sobre los arcos formeros como en las roscas de los arcos diafragma (Fig.22). En la segunda nave quedaban los vestigios del antiguo cine Alhambra: las pilastras de los arcos habían sido perforadas, a la altura de sus riñones, a efectos de generar un paso a través de los palcos volados, independientes entre sí, de cierto aire modernista, dispuestos en sus crujías quinta, sexta y séptima (Fig.21). La nave tercera presentaba un puente grúa, que se sostenía mediante ménsulas de acero empotradas en cajeados impropios, realizados en el intradós de los arcos. En estas tres naves se había sustituido parte de la cubierta originaria por una placa ondulada translúcida, con objeto de ampliar el nivel de iluminación de la zona de trabajo del taller.

Las naves segunda y tercera presentaban altillos en sus dos primeras crujías. Se había procedido a elevar sus cubiertas respecto de sus niveles originales, mediante la disposición de cuchillos metálicos. Asimismo, se constató la ausencia del segundo arco diafragma de la segunda atarazana, degollado en su arranque, seguramente por exigencias funcionales del altillo correspondiente a las oficinas principales de la industria naval,
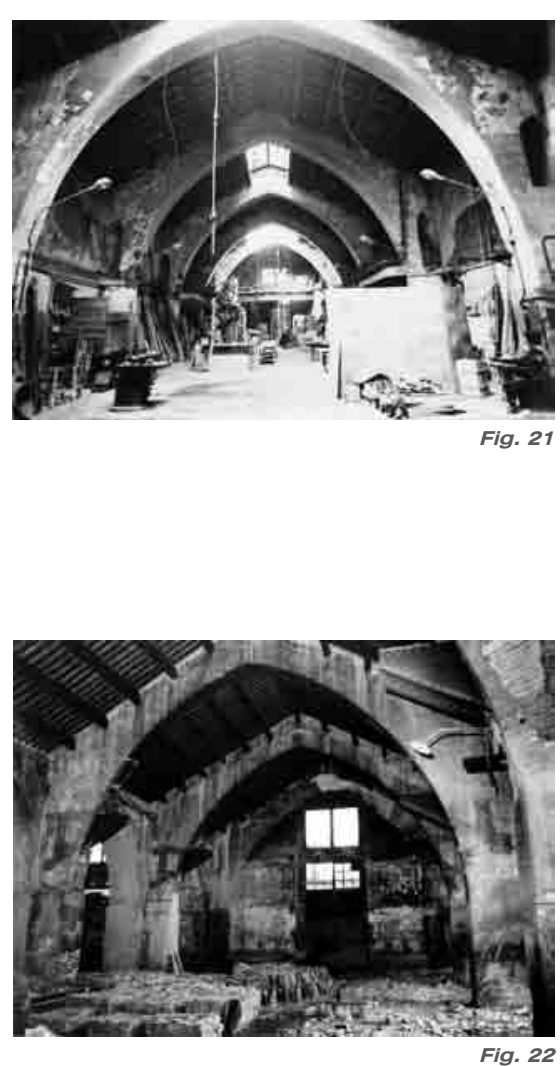


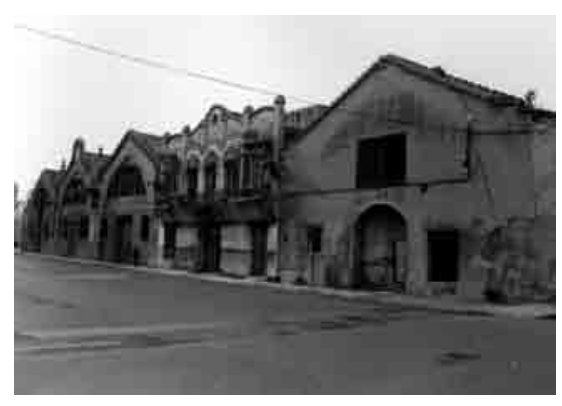

Fig. 23

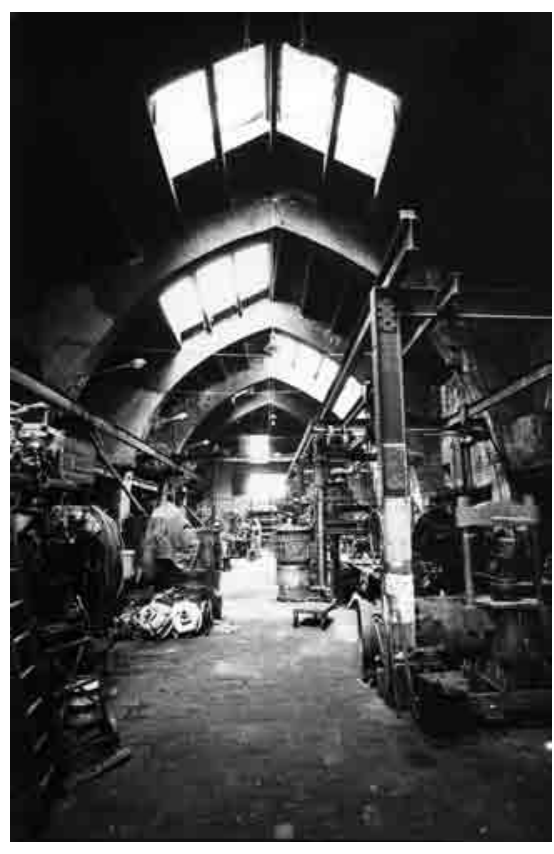

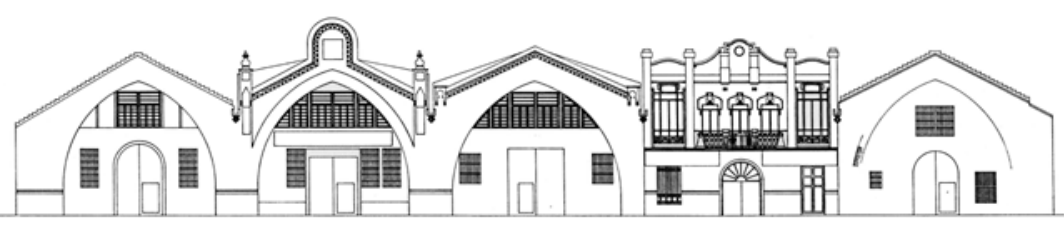

talleres Illueca.

En la cuarta nave se había habilitado una vivienda, en una planta primera de nueva invención, en su parte correspondiente a la fachada principal o de levante. Dicha vivienda, de principios de siglo $\mathrm{XX}$, tenía su acceso en planta baja por medio de una puerta situada en el lateral derecho de la nave, que daba paso a un zaguán y una escalera de tres tramos. El lenguaje decorativo de la fachada correspondía a la arquitectura popularizada en la exposición regional de 1909, y no presentaba ningún trabajo de interés destacable. Su construcción significó la demolición y pérdida del arco de fachada, que fue sustituido por una nueva fábrica cuyo alzado se compuso con cinco vanos, tal y como se aprecia en las fotografías (Fig.23). Además, supuso esta nueva organización variaciones de la cubierta de las dos primeras crujías respecto del perfil original. Se crearon varias terrazas y cuerpos emergentes que desvirtuaban el volumen primigenio y el acabado original, de teja árabe, de gran parte de las cubiertas de esta nave había sido sustituido por teja plana alicantina. En planta baja, una puerta central, abierta gracias a un arco de medio punto, permitía el acceso a su interior. Las dos primeras crujías tenían una altura inferior, debido a la presencia de la vivienda reseñada. El interior de la nave, a partir de su tercera crujía, recuperaba su altura original.

Finalmente, la quinta nave, la septentrional del conjunto, albergaba un almacén de maderas. Presentaba vigas metálicas colocadas en dirección transversal a la nave, solución análoga a la de la primera nave. Las tejas de cubrición de la cubierta habían sido substituidas, casi en su totalidad, por teja alicantina, como en la nave cuarta. Según muestra el fotoplano de Valencia, de la Compañía Española de Trabajos Fotogramétricos Aéreos de 1944, publicado por Amando Llopis y Luis Perdigón ${ }^{(6)}$, las primeras crujías de esta atarazana habían perdido su cubierta 
durante los bombardeos efectuados por la aviación alemana durante la guerra civil. Este hecho puede explicar el cambio del material de cobertura original por el descrito. Además, por esta misma causa, uno de sus arcos había sido totalmente destruido. Su reconstrucción posterior, informada por vecinos del lugar, acusa esta reparación: fue ejecutada con ladrillo contemporáneo tipo cara vista, dispuesto con juntas de mortero de inferior espesor, como corresponde a una intervención del momento. En fin, el continuo funcionamiento de esta nave hasta el momento de la expropiación contuvo su deterioro, que fue algo menor que en las otras partes (Fig.25 y Fig.26).

De acuerdo con la lógica de su privatización y cambio de funcionalidad, en todas las naves se había procedido al macizado del primer arco diafragma. El alzado principal mostraba la heterogeneidad propia de la fragmentación de la propiedad. Las tres primeras naves acusaban el arco diafragma; no la cuarta, que lo había eliminado, y apenas la quinta, cuyo revoco lo ocultaba. Las naves primera y quinta enseñaban los perfiles originales del testero de cubierta; en las restantes se habían producido recrecidos y alteraciones volumétricas y de fachada. Realmente, el enfoscado de sus alzados así como de la mayor parte del interior debía de ser, seguramente, un acabado usual y funcional que asegurara la protección tanto del ladrillo como de las fábricas de tapial, los cuales, dejados vistos, producirían graves problemas de mantenimiento.

En las tres primeras naves, propiedad de Talleres Illueca (Fig.24), se jerarquizaba la composición de las mismas al disponer en la central, aprovechando el recrecido para la ubicación de sus oficinas, de un remate en el que se situaba el logotipo de la empresa. El aspecto compositivo y decorativo denotaba una intención de superar el carácter meramente funcional de la construcción; en la segunda nave se coronó la fachada mediante un remate curvo que se sostenía, a ambos lados, por dos faldones inclinados, resaltados con molduras, que partían de dos machones volados, decorados con azulejos de motivos geométricos, todo ello rematado con abombados pináculos (Fig.27). Finalmente,
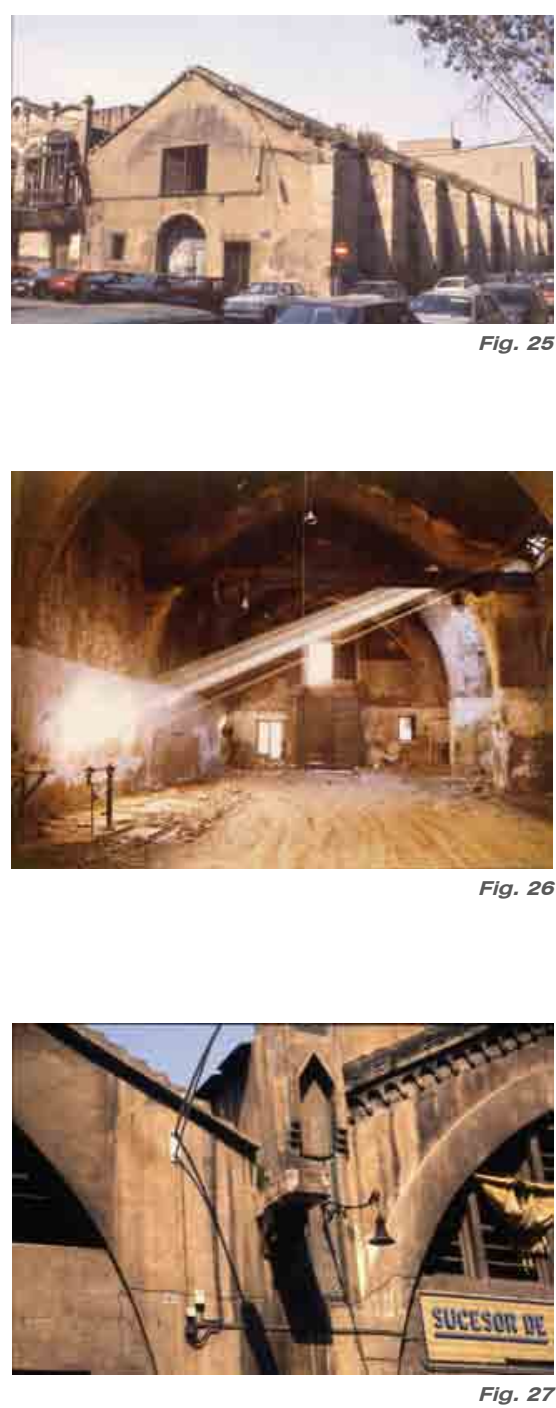


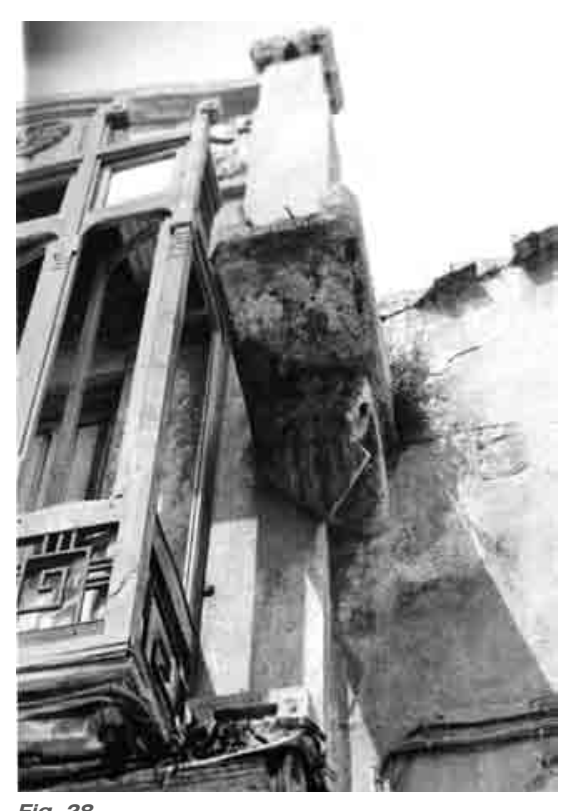

Fig. 28
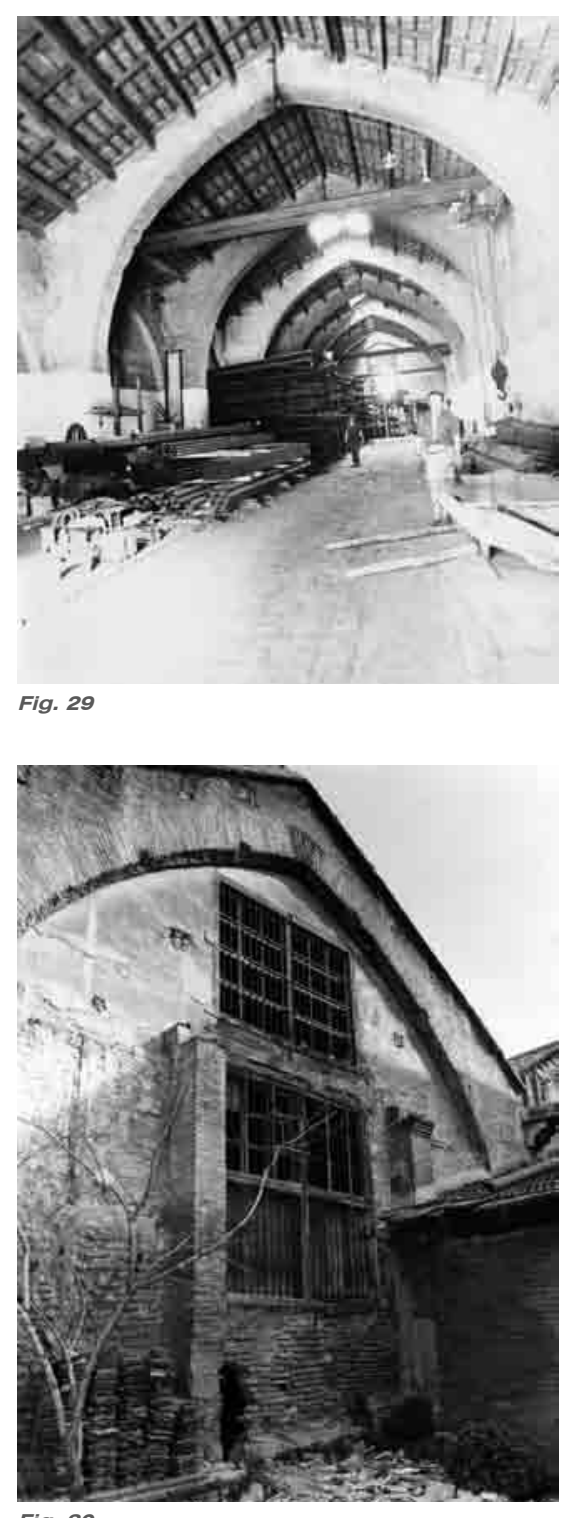

Fig. 30 la distribución de huecos, cuyos alféizares y dinteles estaban en las tres naves a una misma altura, y el dibujo de sus carpinterías, respondían a criterios meramente funcionales sin excesiva intención compositiva.

Respecto de la fachada de la cuarta nave, cabe mencionar que en ésta se dispuso un orden de cinco vanos que significó, como hemos dicho, la destrucción del argo diafragma de fachada. De estos cinco huecos, los tres centrales daban a un balcón corrido, recogido en sendos miradores de madera, dispuestos a cada extremo. Los remates propios de la arquitectura ecléctica, presentes en la vivienda, eliminaron el arco gótico y desfiguraron el dentado perfil del conjunto de las atarazanas (Fig.28).

$\mathrm{Ni}$ siquiera la iluminación municipal, constituida por brazos empotrados en el muro que sostenían un farol, cuyo cableado surcaba impunemente la fachada, guardaba relación con ésta. Su disposición aleatoria, sin respetar el orden de las cinco naves, informa del poco aprecio y la escasa consideración que se le había prestado, hasta el momento, al conjunto monumental.

El mal estado generalizado de los elementos constructivos y el carácter común de la mayor parte de la patología de la construcción permite su reseña global para todo el conjunto edilicio.

Presentaba el edificio, en general, numerosas alteraciones de las fábricas originales, como abertura y cegado de huecos, cajeados para ubicar altillos y forjados interiores, presencia de dinteles de madera en desuso, tendido de instalaciones y anclaje de todo tipo de elementos impropios, carencia o pérdida de los morteros, etc.

Las cubiertas estaban en muy mal estado de conservación. Las canales de evacuación de aguas se hallaban obturadas y con una falta generalizada de mantenimiento. Todo ello había producido humedades cuyo resultado fue la presencia y ataque de xilófagos que acarreó la posterior pudrición de la madera. Tanto las vigas como los cabios se hallaban en pésimo estado de conservación. Además, parte del tablero cerámico había sido sustituido por lucernarios constituidos por una placa translúcida (Fig.29). En una parte importante de la cubierta se había sustituido la teja 
original por teja plana alicantina.

Los huecos y vanos tenían un carácter impropio y añadido; sus carpinterías, de marcado carácter utilitario (Fig.30), evidenciaban un pésimo estado de conservación. La fachada posterior no era más que un claro ejemplo de aleatoriedad y nulo mantenimiento.

Finalmente, cabe resaltar la demostración de la más que suficiente capacidad resistente de la estructura, vistos los diversos usos y cargas que adicionalmente solicitaron el conjunto de arcos y soportes. Sin duda, su fortaleza frente a los diversos maltratos que ha sufrido ha permitido la llegada hasta nosotros de este bello edificio.

\subsubsection{Criterios de intervención}

La idea básica de esta restauración es dejar hablar al edificio. En otras ocasiones hemos afirmado que un proyecto de arquitectura establece una elección entre las diferentes posibilidades que se plantean en la resolución de un programa de recuperación. Los arcos diafragma con el espacio que propician es la pequeña y gran clave de la intervención. Es el fruto de años de reflexión y el mínimo necesario, a nuestro entender, para que el monumento manifieste toda su riqueza

La intervención en las Atarazanas de Valencia se plantea a partir de la decidida recuperación del espacio gótico que definen las cinco naves comenzadas a construir en siglo XIV, a base de simples, elementales, bellísimos, arcos diafragma de ladrillo, con su tradicional cubierta de madera.

La articulación definida espacialmente por el arco diafragma y sus formeros de arriostramiento es el elemento cuya repetición da lugar a la rica secuencia espacial que proporciona el monumento, una vez liberado de los añadidos, producto de las agresiones que padece desde que pasa a manos privadas en $1840^{\text {(Fig.31). }}$

No cabe duda de que la resolución formal del espacio interior de las Atarazanas no responde a simples criterios utilitarios y funcionales, sino que posee una clara intencionalidad relacionada con la percepción de su espacio interior.

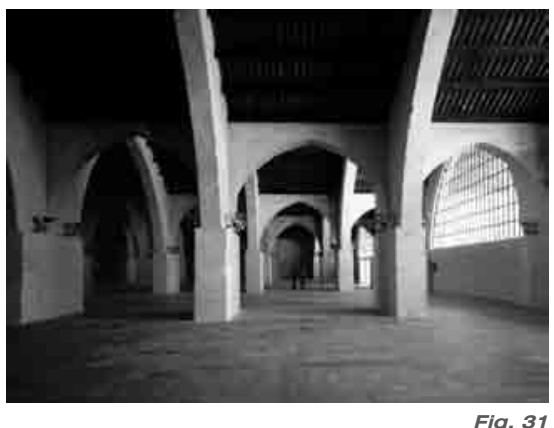




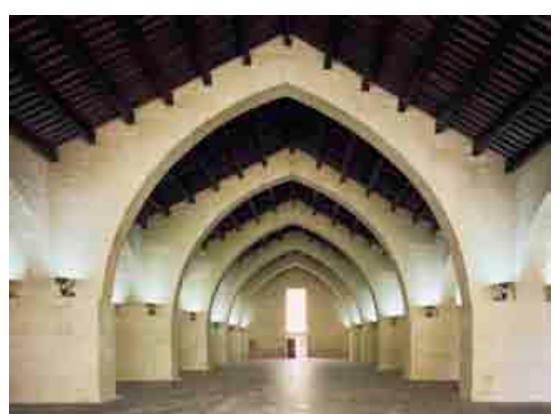

Fig. 32

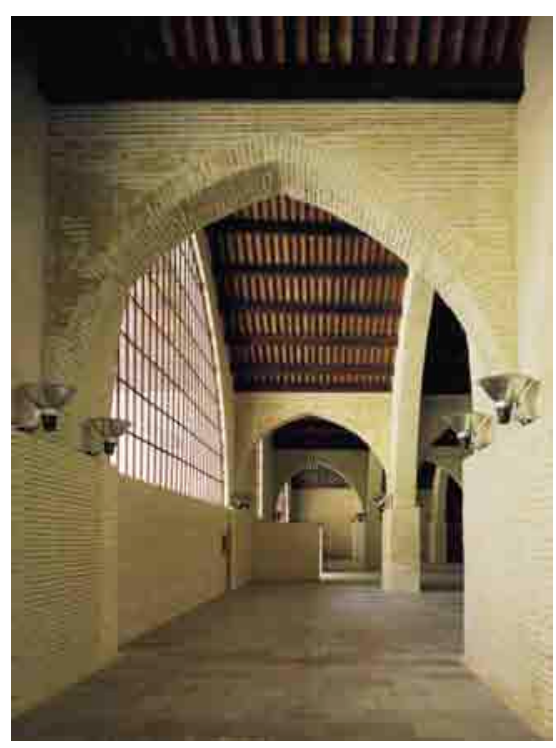

Como conclusión básica la intervención que se pretende posee un carácter de mínimo necesario, de búsqueda de lo esencial, cuyo último objetivo es restablecer toda la riqueza inherente al monumento.

Toda la obra, los elementos, el porche, las cristaleras, las carpinterías buscan hacer hincapié en su simplicidad y, con sus transparencias, en el tema abstracto que entendemos desde la mentalidad de hoy, el espacio gótico, su potencia, su razón de ser y también su magia.

\subsubsection{El proyecto de intervención. Objetivos}

\subsubsection{La liberación del espacio gótico}

Se pretende la recuperación del conjunto monumental a partir de la lógica aditiva que lo configuró en su origen, tal y como expresó el Consell de la ciudad en 1388, que aconsejaba esta disposición de tal suerte que pudiera ampliarse el edificio mediante la añadidura de nuevos módulos. Las operaciones de repetición y adición de arcos diafragma y de arcos formeros, con una cubierta de madera y cerámica a dos aguas, generan el gran espacio interior de las Atarazanas, cuya recuperación, como se ha mencionado, constituye la clave de la intervención (Fig.32). La definida articulación por medio de dos planos ortogonales, el plano diafragma y el plano de evacuación de aguas, da lugar al potente espacio interior que posee el monumento (Fig.33).

Se ha venido a dar por supuesto, fundamentalmente por parte de algún estudioso y de múltiples aficionados locales, que la configuración espacial y constructiva descrita hasta ahora de las Atarazanas corresponde con aquellas primigenias para las que en el siglo XIV la ciudad obtuvo privilegio real, y para las cuales el proyecto que aquí se describe no fue sino un mero instrumento de repristinación de una verdad conocida y universalmente aceptada, cuyo objeto fue eliminar la pátina de suciedad que la enmascaraba. No poseemos ninguna certeza de que este espacio haya sido originariamente, en el siglo XIV, del modo en el que el proyecto lo recupera y, en cierto modo, podríamos decir que es intrascendente desde el punto de vista de la vertiente disciplinar 
de nuestro trabajo, la arquitectura, cuyo objeto final es otro.

Mediante la comparación con otras Atarazanas del ámbito mediterráneo, se ha constatado la existencia de variedad de soluciones y de respuestas individuales a un mismo programa; algunas de ellas resolvieron sus cubiertas mediante cuchillos de madera, técnica familiar para los constructores de embarcaciones; en otras, como las correspondientes a la ciudad de Sevilla, existen indicios de la presencia de patios de iluminación, realizados mediante la parcial falta de cubierta en las naves, cuyo objeto era iluminar las zonas de trabajo y que podían cubrirse en caso de necesidad mediante entoldados. En Barcelona, las naves se interrumpieron, en un momento dado, para generar un patio transversal que permitía la iluminación. También podemos apuntar la existencia de cierta incertidumbre acerca de la original percepción del gran espacio de las Atarazanas; no resultaría extraño el aislamiento de unas naves respecto de otras ni el tabicado y subdivisión de dependencias, fruto de la satisfacción de necesidades derivadas del uso que incluía, no lo olvidemos, el

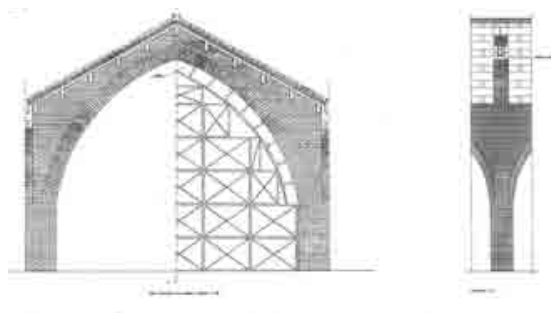

Fig. 34 depósito y guarda de armas, materiales y utensilios (arsena). De hecho, algunos arcos formeros aparecieron cegados antes de la intervención con fábricas adosadas, de factura idéntica a la de la construcción original (ladrillo macizo y perdigoná de moro). Este hecho, debido a la pervivencia de las técnicas constructivas tradicionales, ofrece lógicamente diversidad de interpretaciones y serias dudas con respecto a su datación.

En todo caso, no es objeto del proyecto obtener una respuesta erudita a estas cuestiones, cuya resolución final pertenece a otros especialistas. El proyecto resuelve un problema de arquitectura, y no una mera cuestión de índole histórica, y para ello formula una hipótesis coherente con la lógica constructiva del edificio. Sabemos que la arquitectura es, siempre, un sistema espacial. Es el espacio y su posibilidad de recorrido el que la distingue de las demás artes. El sistema espacial que se vislumbraba en los primeros vaciados de los rellenos de los arcos formeros, en los primeros años de la intervención, comenzaba a mostrar la necesidad de la aprehensión del conjunto, tanto en el plano de

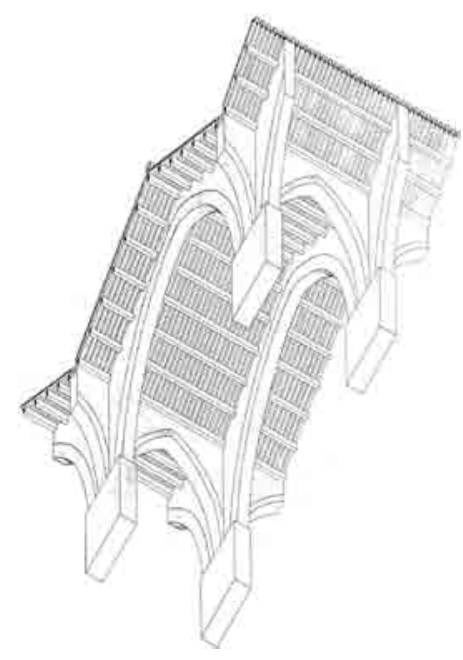

Fig. 35 
información de un espacio gótico, el de las Atarazanas de Valencia, como en el referente a la capacidad de disfrute que ofrece. Comprensión y fruición son, al fin y al cabo, las dos caras de la moneda del arte.

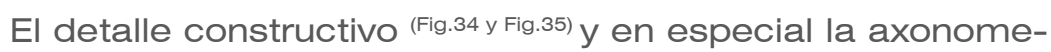
tría del proyecto que muestra el módulo formado por dos arcos diafragma y sus formeros manifiestan gráficamente el objetivo primordial de la intervención: Hacer visible el imponente espacio de las Atarazanas propiciado por la secuencia del citado módulo, procediendo a la unificación, al fin, de un espacio cuyos principales ejes visuales longitudinales se ven enriquecidos con las múltiples relaciones espaciales que de modo transversal y diagonal se ofrecen, en un espacio que, como se ha dicho, tiende a la isotropía.

La necesaria eliminación de elementos impropios y la pertinente restitución de los elementos desaparecidos es la consecuencia directa de este principio rector y objetivo primordial del proyecto, la liberación del espacio interior.

\subsubsection{La plaza y el pabellón de servicios}

En consonancia, la potencia que ofrece la diafanidad del espacio y su fruición asociada, obliga a que los servicios mínimos necesarios para el funcionamiento del edificio como sala de exposiciones se dispongan en un edifico anexo, comunicado con el monumento. La propuesta plantea redefinir la plaza (limitada al oeste por la iglesia, abierta a la histórica Avenida del Puerto) con un pequeño volumen de una planta (Fig.36 y Fig.37). Éste evita
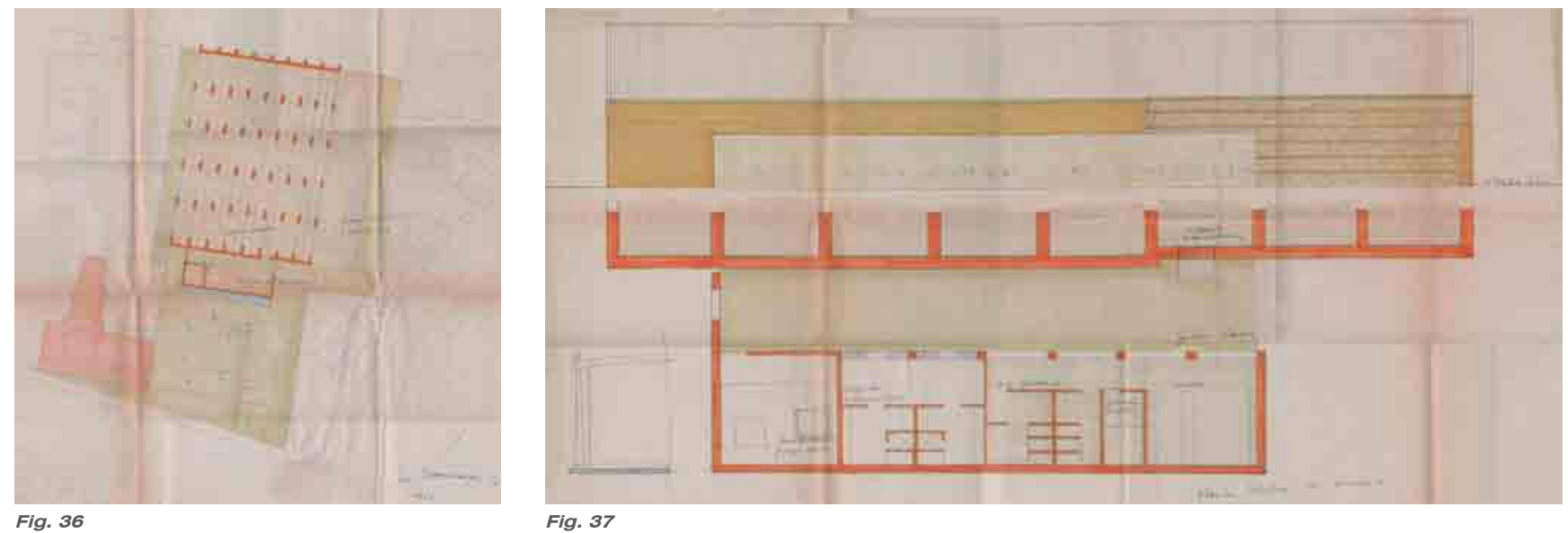
atracarse al monumento y desvirtuar la traza de su cierre sur, de modo que la situación de un pequeño patio ajardinado permite esta articulación. El nuevo volumen contiene servicios funcionales como tienda, aseos, limpieza y mantenimiento, dependencias del personal, centro de instalaciones, etc (Fig.37). Acabado en piedra, y a modo de reclamo desde la avenida, se talla en toda su altura $(3,50 \mathrm{~m})$ el nombre del edificio: Drassanes.

Este procedimiento logra la liberación total del espacio gótico, asegura la existencia fundamental de estos servicios, configura la plaza y proporciona una llamada de atención al viandante que recorre la avenida, ya que desde ella la visión del monumento, un muro de una nave, no permite sugerir la riqueza que encierra. Además, recordemos que la fachada principal ya había sido ocultada detrás de vulgares construcciones que impiden su vista y su relación con el mar.

La propuesta, cuya ejecución recaía en el Ayuntamiento, habiendo cambiado éste de signo político, no fue considerada y el monumento se abrió en ausencia de todo servicio, con fraccionamientos del espacio mediante mamparas desmesuradas, ausencia de mantenimiento y de servicios higiénicos. Para este último menester, un carromato se dispuso durante muchos años en la calle trasera. La posterior apertura de ésta y la clausura de parte del espacio gótico por medio de paneles y mamparas, suscitan pesimistas conclusiones en la reflexión acerca de la ubicación de los aseos higiénicos, si es que actualmente los hay. Una patente muestra de insensibilidad e incultura.

En conclusión, se define así un imponente espacio, de carácter diáfano, enmarcado en la tradición gótica mediterránea, de adireccional connotación en su percepción, que participa de la cierta isotropía y que propicia un libre recorrido y una experimentación de las complejas relaciones que se establecen entre sus dos ejes ordenadores. En definitiva, un espacio acorde con la sensibilidad actual y adecuado para su posterior distribución museográfica.

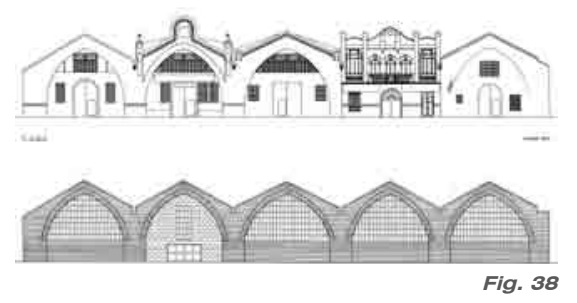




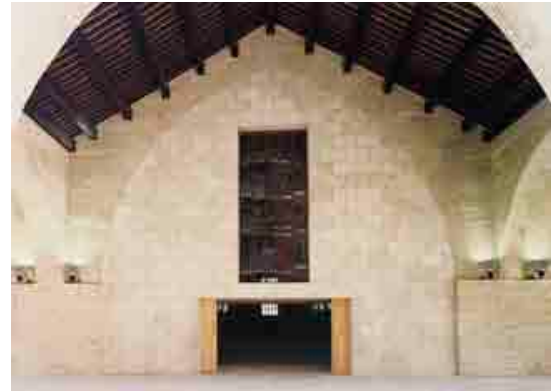

Fig. 39

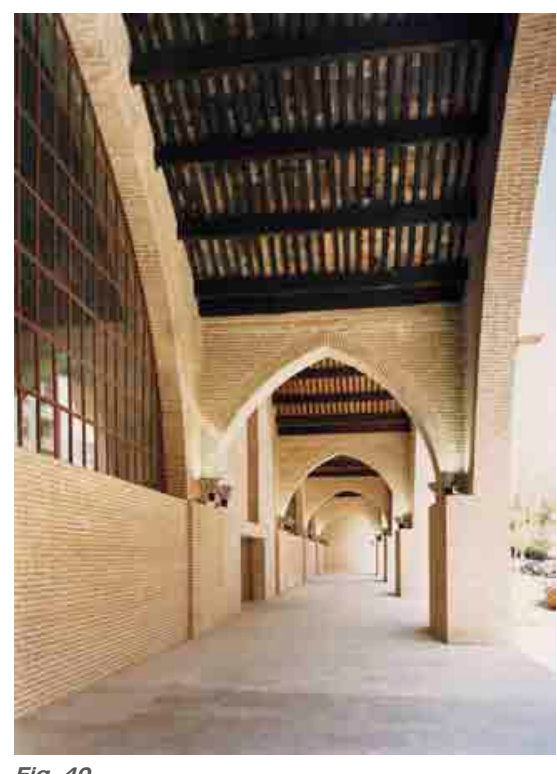

Fig. 40

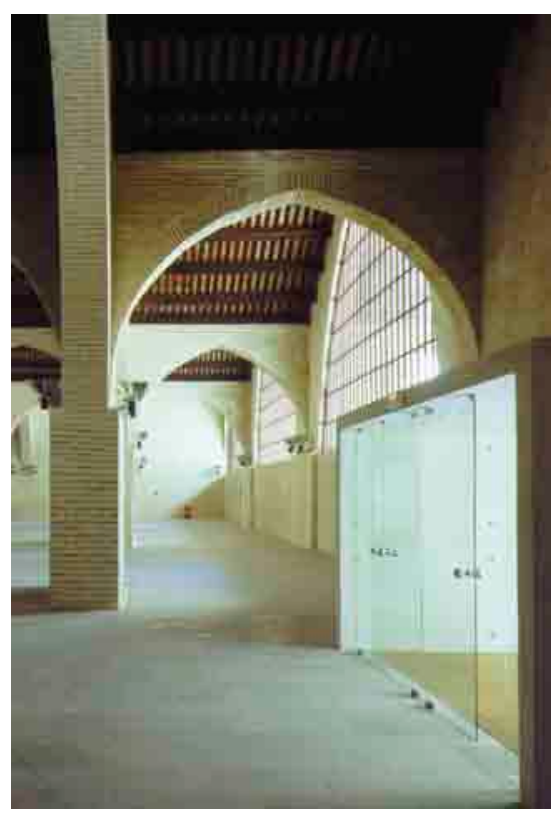

Fig. 41

\subsubsection{Liberación del volumen primigenio. La fachada} principal y un porche de acceso

Consecuencia de la liberación y recuperación del espacio interior, se devuelve al edificio su volumetría y su imagen urbana. Este es el segundo objetivo, corolario del primero. Los alzados frontales

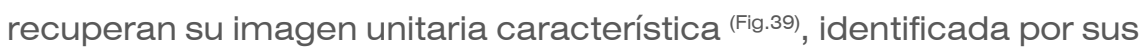
apuntados arcos y por el perfil definido por sus frontones que acusan las cubiertas a dos aguas. Éstas se despojan de los cuerpos elevados y protuberantes, impropios y ajenos. Las operaciones de demolición se complementan con las indispensables de reconstrucción para la recuperación de una imagen que acuse el modo de construcción de su espacio interior. Los trabajos de limpieza para la recuperación de la fábrica de ladrillo, su necesario retaqueado una vez eliminados los perfiles metálicos y puentes grúa introducidos para las actividades que se desarrollaban en el edificio, junto con la reconstrucción de los dos arcos desaparecidos, se comentan en un sub-apartado posterior.

Un tercer criterio que responde a las cuestiones establecidas por el nuevo tratamiento de su alzado principal -este-, se origina debido a la recuperación del aspecto derivado de la construcción interior y que precisa un necesario cierre emanado de las nuevas exigencias funcionales.

La configuración de este alzado manifiesta una severa contradicción histórica, que se establece en la contraposición entre el carácter abierto y el cerrado (Fig.38). Por causa del uso de construcción y depósito de embarcaciones, se precisa una conexión directa a la playa y al mar, de modo que el alzado presente una necesaria permeabilidad. Por otro lado, el carácter defensivo propio de su constitución como límite de un recinto murado, así como la función de depósito de armas, pertrechos y herramientas en general, fuerzan la pertinente condición cerrada del alzado. No disponemos de imágenes ni de referencias de la primitiva configuración de este frente. O mejor dicho, de sus primeras y posteriores configuraciones, que sin duda fueron variables y dependieron de la importancia relativa que adquirió cada uso en cada momento, basculando entre el peso de su función naval -abierto- y los correspondientes a sus destinos 
como arsenal y como cierre defensivo de la Vilanova -cerrado-.

Este proceso nos lleva hasta bien entrado el siglo XVIII, en el que en el grabado de Cavanilles, ya citado, nos sugiere como macizado el espacio libre entre los arcos diafragma de fachada. Una fenestración de proporción rectangular se abre, ordenadamente, en el eje de cada nave, iluminando el espacio interior, que se supone cerrado. En esta época ya parece, como se ha comentado, que las Atarazanas habían perdido su uso naval y es por ello que necesariamente debió de ser cerrado su frente principal, siguiendo el elemental criterio de máximo aprovechamiento del espacio interior.

En atención a la descontextualización de las atarazanas, iniciada con la construcción de la dársena del puerto a finales del siglo XVIII y rematada por la construcción de una "muralla" de edificios en los años 70 del siglo XX, se requiere una decidida respuesta formal en la recuperación del alzado este. La desproporción y falta de escala de los nuevos edificios es manifiesta. Su epidermis es propia de la más anodina y vulgar arquitectura de bloque de vivienda plurifamiliar de la época, que se nos revela como impropia e indigna de establecer un diálogo con el monumento. Es por ello que el proyecto requiere una paulatina transición entre el gran espacio interior recuperado y la escasa plaza de acceso que lo precede, cerrada y definida por estas mediocres construcciones. Ello lleva a la adopción de la solución que propugna la retirada del cerramiento del nuevo espacio museístico al segundo plano diafragma (Fig.40 y Fig.41). Prolongada la plaza, se liberan los arcos del primer plano del diafragma, cuyo cierre, desde el punto de vista de la resolución del detalle arquitectónico, hubiese debido satisfacer condiciones funcionales y de seguridad de difícil conciliación con su poderosa geometría y materialidad.

El espacio de transición entre el exterior y el interior del monumento debe contener el acceso al recinto de exposiciones (Fig.42). La estructura de las atarazanas no jerarquizaba nave alguna, por lo que el proyecto evoca, como cita metafórica, el bello porche de piedra, encargado al cantero Francesc de Tona en 1409, del que no se encontró huella alguna durante la intervención. Así, lo rememoramos mediante un aplacado de piedra que se dispone en el vano definido por el trazado del arco de la segunda atarazana.

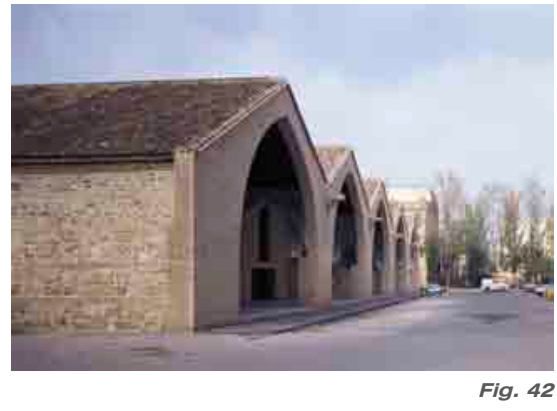

Fig. 42 
ESTADO ANTERIOR A LA INTERVENCIÓN
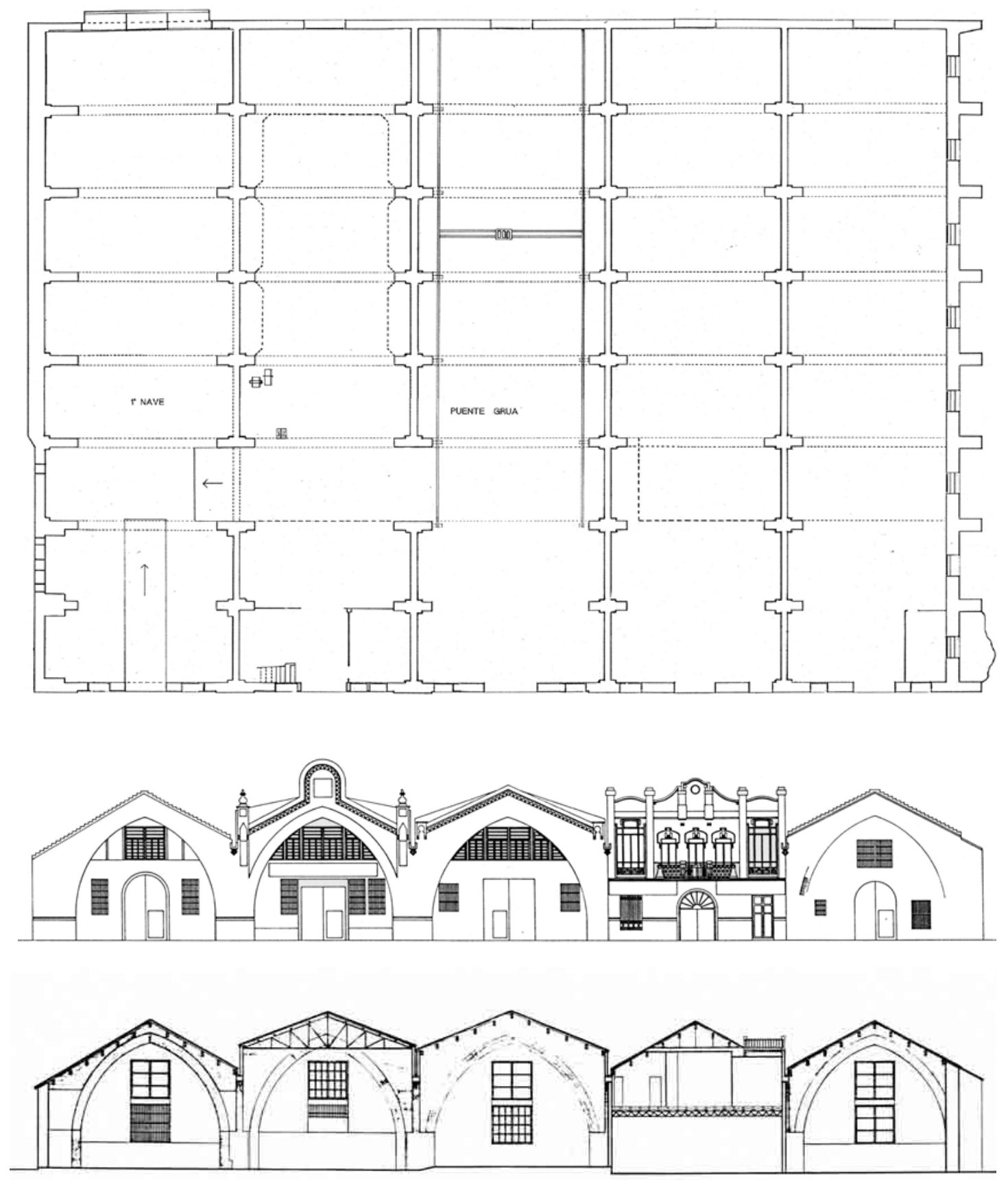

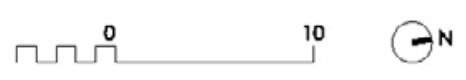



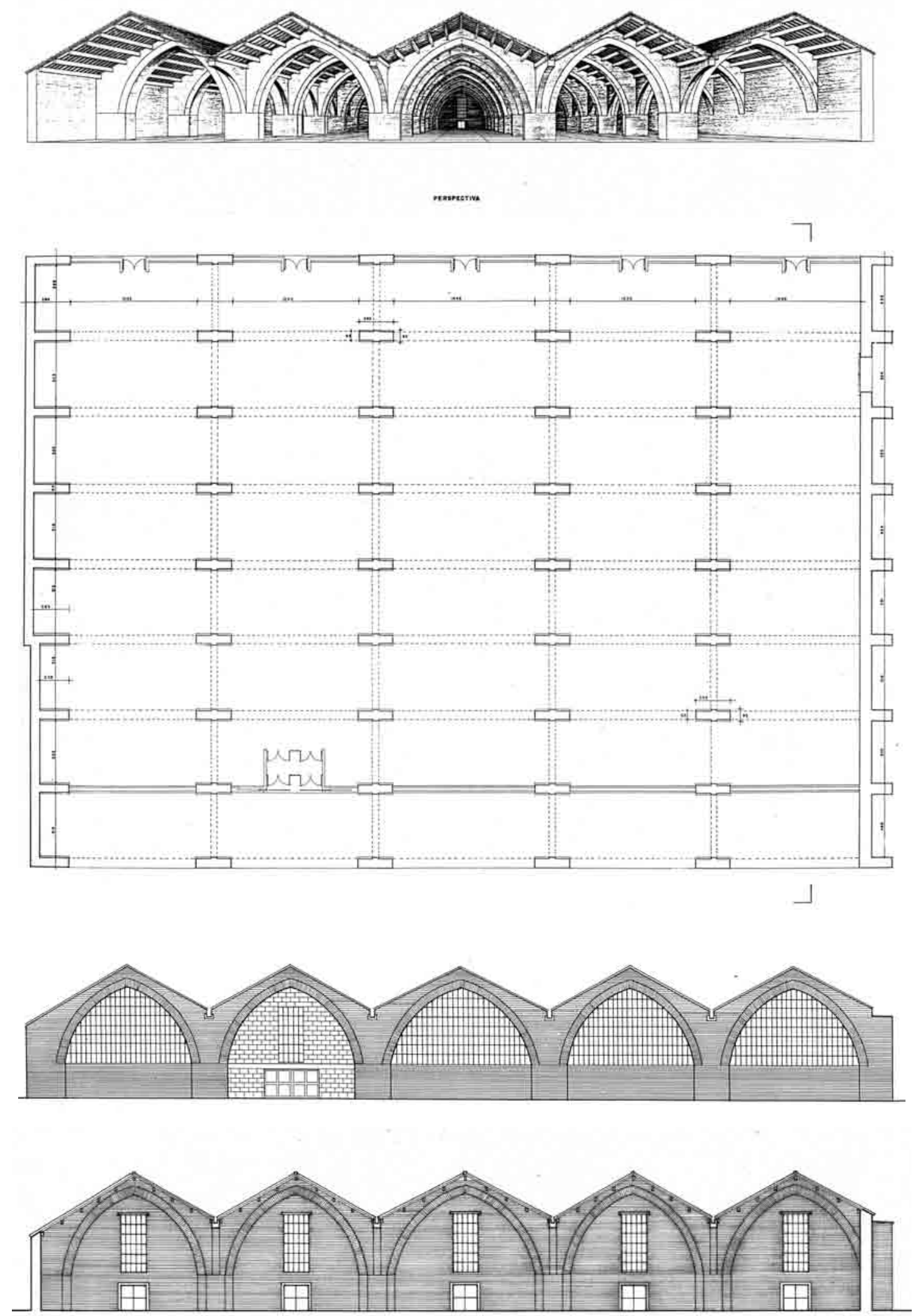

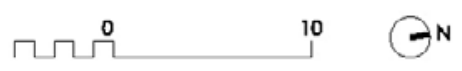




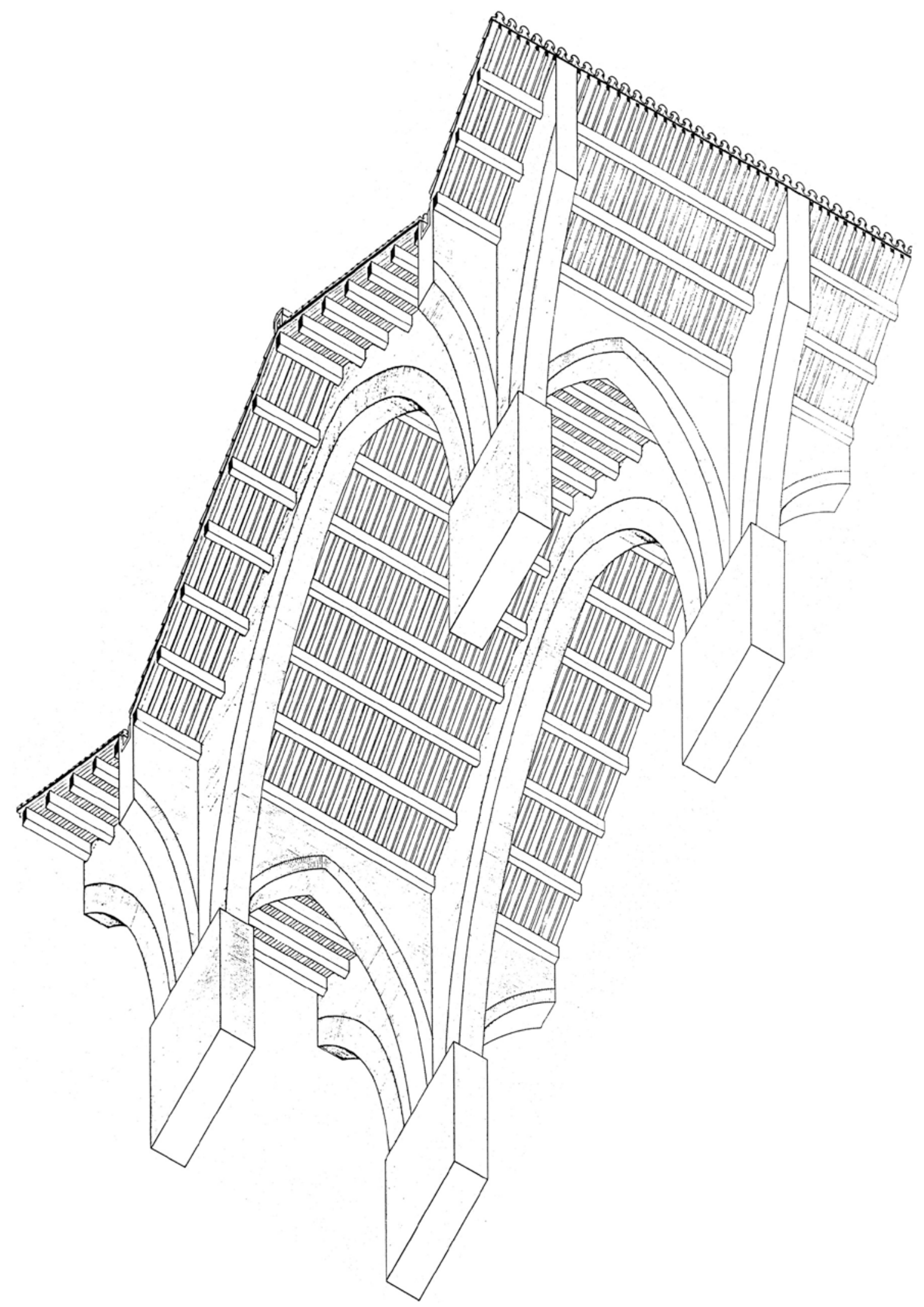



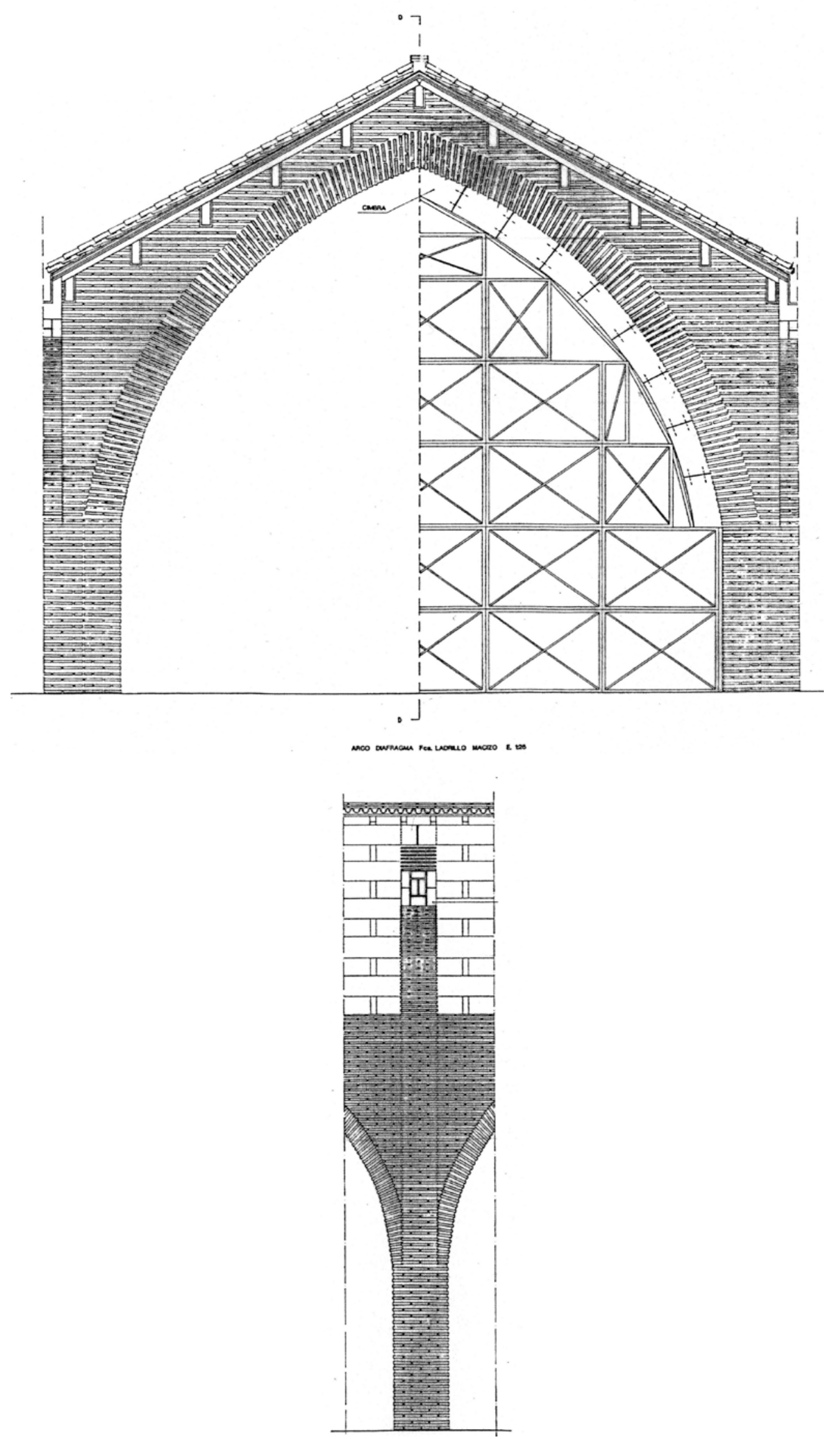


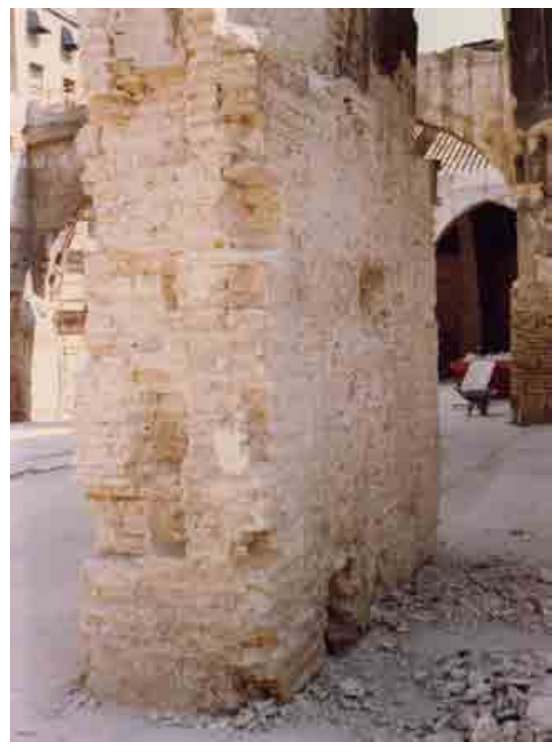

Fig. 43

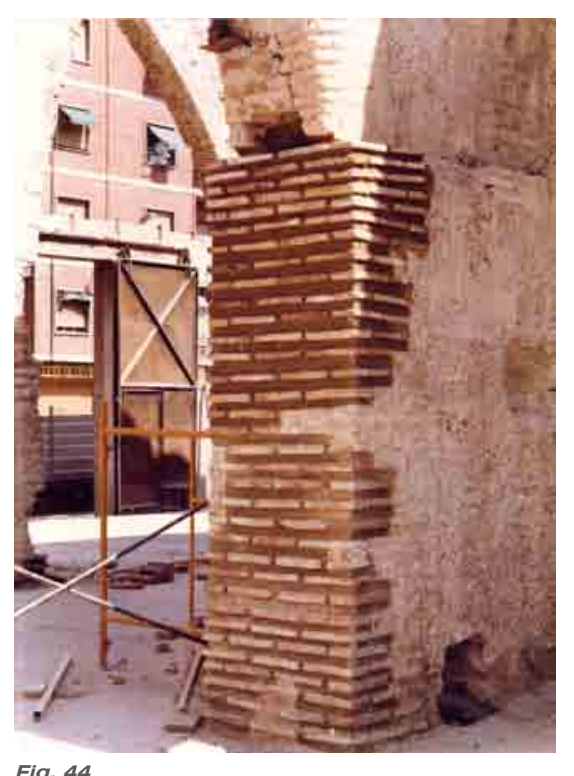

4.3.7. La intervención: Criterios constructivos y acciones Criterios constructivos

Cabe destacar los criterios que determinan la reconstrucción de las partes arruinadas y de nueva ejecución. Como hemos venido observando, la pervivencia en el tiempo de las técnicas y materiales que conforman la construcción primigenia aconseja su adopción en la restitución de las partes desaparecidas. No en vano hasta el primer tercio del siglo XX se encuentran obras ejecutadas con estas características. Ladrillo manual de similar formato y mortero de cal recomponen las partes dañadas y forman los retacados que restañan las heridas y cicatrices de los maltratados paramentos. De igual manera el llagueado, de mortero de cal con grava en avanzado estado de descomposición, se repone con las mismas características técnicas de los existentes. Una sutil diferencia en el tratamiento de la junta posibilita, por otro lado, la distinción de las partes reconstruidas para el especialista (Fig.43 y fig. 44). Lo mismo podríamos decir del tapial utilizado y restituido.

La recuperación del espacio gótico contenido en el edificio demanda la reconstrucción de los dos arcos demolidos, el correspondiente a la fachada de la tercera atarazana, donde se había construido una vivienda, y el segundo de la segunda nave donde se ubicaban las oficinas de la industria náutica (Fig.49). Se proyectan y construyen de acuerdo con el procedimiento histórico: cimbra, ladrillo al exterior y alma de hormigón en masa. EI ladrillo macizo manual es del mismo tipo y dimensión del histórico utilizado pues su fabricación, aún en la actualidad, perdura. Solamente la junta (el llagueado), de un espesor mayor que el del propio ladrillo (unos $5 \mathrm{~cm}$ ) en los paños originales, manifiesta con sus $2 \mathrm{~cm}$ la actualidad de la ejecución.

En su reconstrucción se pondera la primacía del espacio interior frente al criterio que establece el asumir la desaparición de dos de estos arcos, elementos por otro lado semejantes a los conservados y por lo tanto perfectamente conocidos. Entendemos que la unidad potencial del monumento, de la que nos habla Brandi en su Teoria del Restauro, aconseja la restitución de 
estos fragmentos perdidos (Figs.45-49).

En cuanto a la cubierta, sus elementos resistentes-vigas y cabios- se reponen, con similares escuadrías a los existentes (el porcentaje entre sustitución y reposición por ausencia alcanza un mínimo del 75\%) y se trata contra el ataque de xilófagos ${ }^{(\text {Fig.48). }}$ Se recupera también la cobertura original del conjunto, realizada mediante teja cerámica moruna sobre tablero cerámico; una impermeabilización bituminosa protege todo el conjunto.

Los cerramientos planteados en proyecto demandan una especial consideración. Las puertas al edificio responden a dos requerimientos. El acceso al monumento, al Museu de les Drassanes, se sitúa lógicamente en la fachada principal, bajo el nuevo porche que actúa de espacio abierto de acogida; la puerta de carga-descarga, lo hace en la fachada norte (en la única vía apta para el tráfico rodado, la calle de las Atarazanas) y al fondo del edificio encontramos las preceptivas cinco salidas de evacuación.

El tratamiento y definición de la puerta de acceso y de las de evacuación se extrae del sistema constructivo del edificio. El ladrillo de los muros actúa, en todo el sistema constructivo del edificio, a la manera romana, es decir, como encofrado perdido del hormigón de relleno. Este surge al exterior para convertirse en los elementos en forma de $U$ que deben albergar la carpintería de las puertas, delimitar su ubicación en el plano de cerramiento y proteger la necesaria apertura hacia el exterior de las puertas

Los nuevos cierres, carpinterías, lámparas de iluminación, etc., reflejan de algún modo el carácter industrial o fabril que la construcción del edificio original nos evoca.

\section{Acciones}

Las intervenciones llevadas a cabo entre 1980 y 1993, basadas en los criterios de intervención descritos, propiciaron la actual configuración del espacio interior y permitieron al edificio su reversión a una imagen urbana consonante con la tipología que lo posibilita.
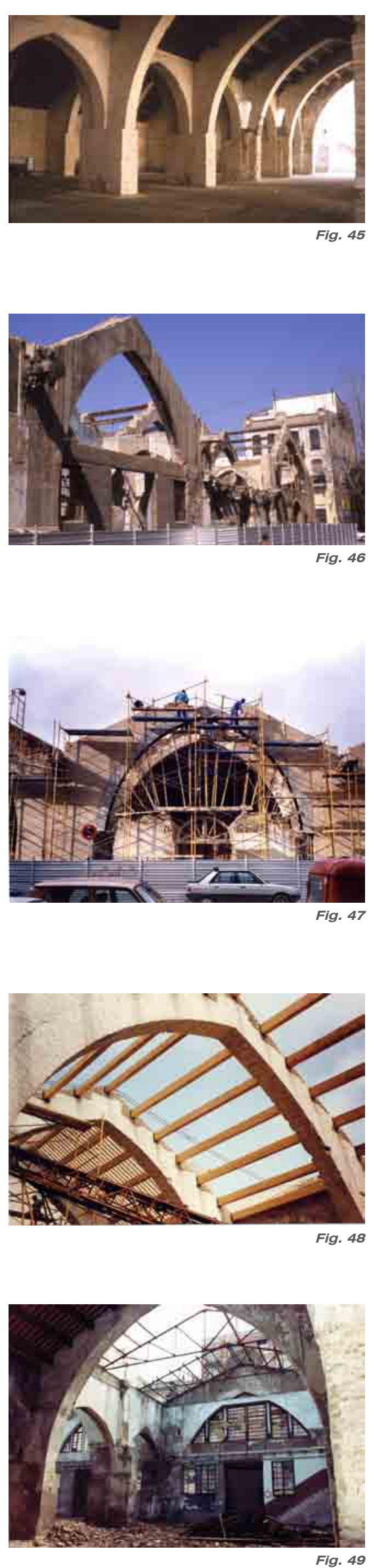


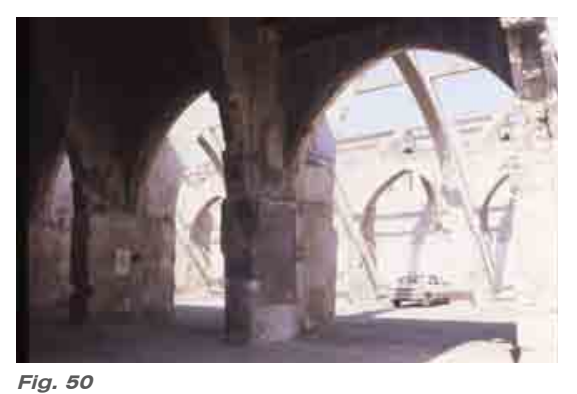

El trabajo consistió, inicialmente, en la demolición y eliminación de los numerosos elementos impropios descritos en apartados anteriores: cierres de formeros, cerchas metálicas y recrecidos volumétricos, altillos y diversidad de forjados, escaleras, levantado completo de instalaciones, de los puentes grúa, antiguos dinteles, soleras industriales de hormigón, vestigios del antiguo cine Alhambra, carpinterías, capas de pintura y enlucidos de todo tipo, etc.

La demolición de los rellenos de los arcos formeros que fraccionaban el espacio permitía vislumbrar el tesoro oculto que el edificio poseía: el impresionante espacio gótico conformado por las cinco hileras de arcos diafragma, 45 en total, y los 32 formeros, transversales, que los comunicaban (Fig.50).

La reconstrucción de los elementos definitorios desaparecidos y el retacado de los numerosos huecos y mermas que presentaban paramentos, soportes y arcos, mediante técnicas tradicionales y mismos procesos constructivos, determinó la recuperación anhelada del espacio interior. Las pequeñas intervenciones permiten delimitar un cuadro de patologías que se fue resolviendo y que se cierra con la última intervención. No obstante, ésta no cubre la resolución de un problema aparecido en 1990, por tanto no incluido en el último proyecto, y que vale la pena mencionar por sus características.

A la primera atarazana, resuelta en su interior en la primera fase de estas primeras intervenciones, se le aplicó un tratamiento antihumedad a base de electro-ósmosis, electro-foresis cuyos positivos resultados movió a generalizarlo al conjunto del edificio. Durante el cierre del edificio entre los años 1985 y 1990, algunos desaprensivos entraron en su interior con objeto de saquearlo. Entre las huellas que dejaron se observa el corte y hurto parcial de todos los cables de la instalación antihumedad. El resultado ha sido la disgregación de los morteros utilizados en la restauración de la primera nave y el deterioro de las estructuras de madera, que aunque tratadas contra el ataque de xilófagos, han sufrido una acción química que, según análisis realizados, descompone sus elementos. En el proyecto de 1990, no se con- 
templa la restauración de esta cubierta de la primera nave, agredida salvajemente en el período de paralización del proceso de restauración, con efectos de cristalizaciones producto del salitre (además de su proximidad al mar, el edificio fue almacén de sal durante décadas).

Las fachadas principal (Este) y posterior se limpian y restituyen eliminando los remates y demás elementos añadidos, lo que permite observar al exterior la estructura que informa el conjunto. En la fachada Oeste, secundaria, se crea un orden centrado en el eje de la nave con ventanas de proporción vertical, cerradas con una cristalera-reja de perfiles en frío pintado, dispuestas sobre puertas de salida -o de carga y descarga-, que disponen un cierre ordenado, académico, como el sugerido por el antiguo grabado de Cavanilles.

En la fachada principal la actuación implica la demolición de los elementos que configuran la fachada de la industria instalada en las tres primeras naves. La fachada de la vivienda fue demolida en su totalidad, así como el relleno del arco diafragma de la quinta nave. En esta fachada principal se retira el cerramiento al segundo plano diafragma, en el límite entre la primera y segunda crujía, con objeto de permitir una transición entre un exterior poco amable y el magnífico espacio gótico. Se crea así un porche que además sirve como antesala, vestíbulo semi exterior, que a su vez configura un espacio protegido y resguardado de acceso.

El relleno de los vanos de los arcos correspondientes a la fachada principal y posterior se realiza con el mismo tipo de ladrillo manual de $30 \times 15 \times 3 \mathrm{~cm}$. pero con llaga enrasada de 1,5 $\mathrm{cm}$ (Fig.55). En la fachada Oeste, se crean ventanas verticales cerradas con una cristalera-reja de perfiles en frío pintados. En la fachada principal, el mismo tipo de muro se construye hasta el arranque de los arcos. A partir de él una reja vidriera cierra todo el hueco del arco formero, estableciendo una transparencia visual que integra la primera crujía destinada a porche.

El acceso se lleva a cabo en la segunda nave (empezando por el lado sur) mediante grandes puertas correderas hori-

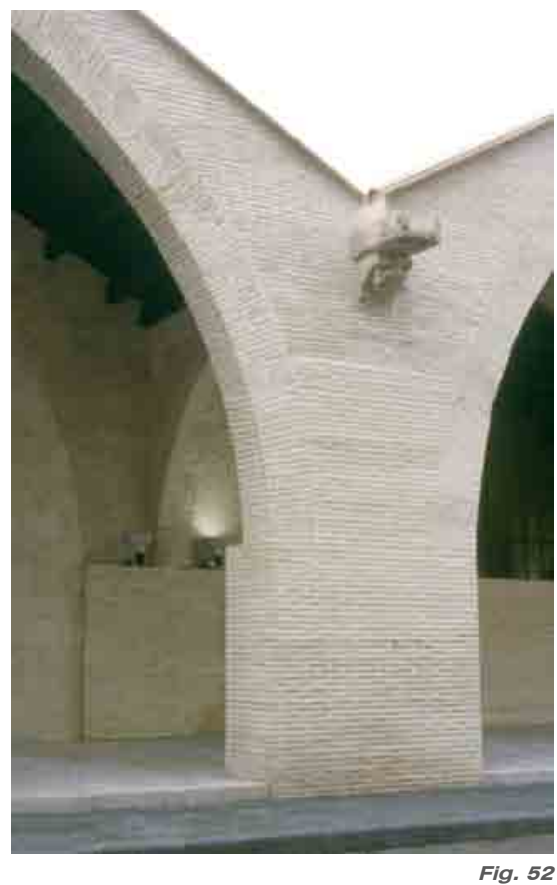




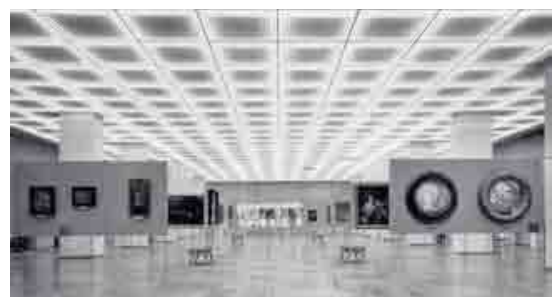

Fig. 53 zontales de madera que dan paso a una doble puerta acristalada. Todo ello contenido, como en las salidas de emergencia de la fachada posterior, en una "U" de hormigón blanco visto. Las restantes naves se cierran mediante un muro de ladrillo manual cuya cota máxima corresponde a la imposta de los arcos diafragma. A partir de este nivel, una carpintería de perfiles de hierro laminados en frío dibuja un cierre acristalado que integra mediante la transparencia y la conexión visual el porche con el interior del espacio.

Para subrayar el acceso se aplaca el vano del arco con caliza travertínica (la llamada piedra de Godella, usual en los monumentos de la ciudad) en evocación del bell portxe de piedra -ya mencionado- con el que la ciudad quiso enriquecer el edificio en 1409 y que nunca se ejecutó.

No habiéndose reconocido en las excavaciones arqueológicas niveles de pavimento original, se lleva a cabo el solado a base de losas de piedra de Borriol, cortada a sierra. Dicho pavimento, a modo de tapiz, no se entrega a la fábrica del monumento y deja un foso perimetral en los muros y bases de arcos originales que destacan su traza.

Ante la falta de definición de usos del espacio rehabilitado, se dota al edificio de una iluminación ambiental general y una malla de infraestructura eléctrica, debajo del pavimento, a la que se accede a través de unas pequeñas placas rectangulares de acero atornilladas al mismo que permiten la conexión de elementos de iluminación aptos para diversas instalaciones (sean "boxes", vitrinas, etc.).

\subsubsection{El espacio expositivo de las Atarazanas}

El espacio gótico recuperado se configura como marco de las actividades expositivas previstas. Se muestra como un contenedor (Fig.53 y Fig. 54), un amplio espacio pautado por el ritmo que le imprimen las bases de los arcos diafragmáticos, en el que se debe llevar a cabo, en cada ocasión, un proyecto de adecuación. Éste debe responder a las necesidades del concreto programa expositivo, y al mismo tiempo, permitir la fruición del espacio. 
Es por ello que la instalación concreta del montaje expositivo -distinto para cada caso como hemos dicho- debe responder a una serie de cuestiones de modo que permitan una adecuada lectura de la arquitectura gótica recuperada. Una de ellas, fundamental, se centra sobre la percepción ininterrumpida de las cubiertas como elemento que unifica un espacio en el que, en planta baja, se deben disponer diversos elementos y objetos. A mi entender, existe un límite que corresponde con la altura de las bases de los arcos, 3,5m, por encima de la cual el espacio fluye. Los elementos que, con carácter puntual, tuviesen una mayor dimensión, lo puntearían y enriquecerían en una disposición cuidadosa. Otras preguntas estriban sobre el hecho de que, mediante la situación de paneles y mamparas, se puede transformar el espacio de modo que prime la dimensión longitudinal sobre la transversal y viceversa. El tratamiento de las vistas perspectivas, de las diagonales, o la separación de los elementos expositivos de las bases de los arcos, son factores que también deben ser considerados.

Estas reflexiones surgen al hilo de que en un momento de la redacción del proyecto -en torno al inicio de la década de los noventa-, el entonces Director General de Patrimonio Tomás Llorens, planteó la posibilidad de crear un Museo de la Romanización con sede en el edificio. La idea basilar del museo consistía en la organización de una exhibición de carácter didáctico que explicase el origen romano de la ciudad (Fig.55). A través de pequeñas piezas, objetos, fragmentos, junto a maquetas y algún elemento de mayor dimensión, se mostraría al visitante cómo la ciudad había evolucionado desde su fundación. La propuesta de organización de la colección establecía una reflexión sobre estos aspectos e introducía los elementos auxiliares de modo que respetasen la contemplación del gran espacio gótico mostrado a través de sus cubiertas. Para ello situaba en la primera y quinta atarazana dos elementos lineales desarrollados a dos niveles, semienterrados, que evocaban, mediante la utilización de la madera, el primigenio uso del edificio como atarazana (Fig.56). Las pequeñas piezas -monedas, fíbulas, ídolos, y sobretodo fragmen-

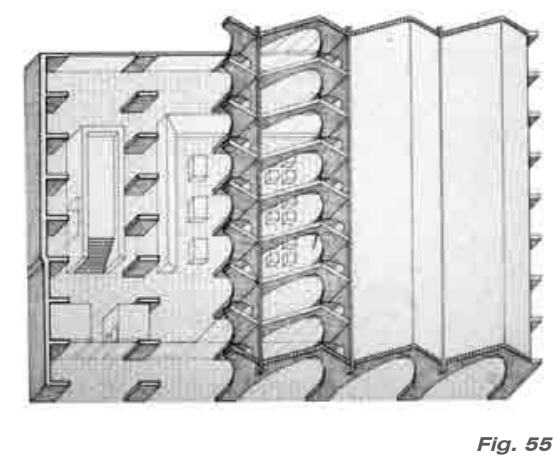

Fig. 55

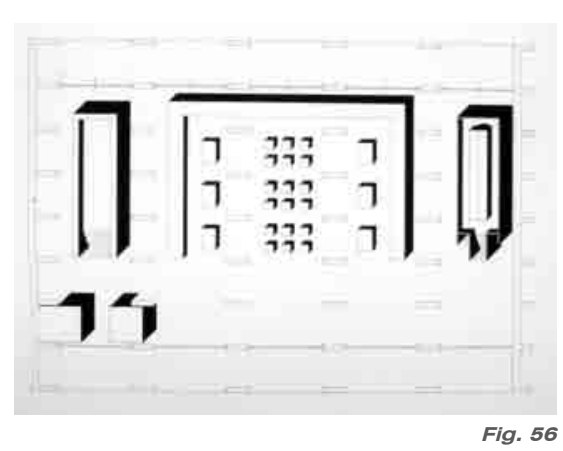


tos- se ubicaban en unos mostradores perimetrales (que también servían como barandilla del primer nivel) dispuestos al efecto. La altura máxima de dichas construcciones correspondía con la línea de imposta de los arcos $(3,5 \mathrm{~m})$, de forma que desde el primer nivel se podía disfrutar del conjunto del espacio recuperado de las Atarazanas. En las otras naves, diversos elementos de carácter mueble -esculturas, maquetas y paneles explicativos- colonizaban, de una forma un tanto aleatoria, el resto del espacio, atendiendo a criterios tanto didácticos como de establecimiento de visuales preferentes.

\section{Criterios organizativos}

El edificio, en su elementalidad, ofrece a través del proyecto realizado un acceso público, de características ya citadas, al que le precede un espacio cubierto, el porche, como antesala del gran espacio. Dispone de un acceso de material para exposición por la calle de las Atarazanas y otro de personal a través del pequeño jardín que articula el monumento con el pabellón de servicios que debía contener los elementos de apoyo y servicios que el espacio gótico no tolera. Esta claridad y elementalidad de accesos es el único requisito para, desde mi punto de vista, permitir el uso y disfrute del espacio gótico de las Atarazanas.

No cabe hablar de circulaciones, ya que responderá en cada caso al montaje de la correspondiente exposición.

\section{La iluminación}

Se plantea una iluminación general, por reflexión, mediante luminarias, de tipo industrial, como entiendo que corresponde al carácter del edificio. Bajo el pavimento de piedra de Borriol, descrito como un tapiz que enmarca con un foseado los elementos estructurales del monumento, se dispone un sistema de canaletas con instalación eléctrica que permiten la conexión de vitrinas u otro elemento que responda a las necesidades de lo expuesto. Se manifiesta al exterior mediante una malla de pequeños cuadrados de acero que salpican rítmicamente el pavimento. Dichas trapas se alzan y permiten la conexión de las instalaciones que el proyecto expositivo considere en cada caso. 


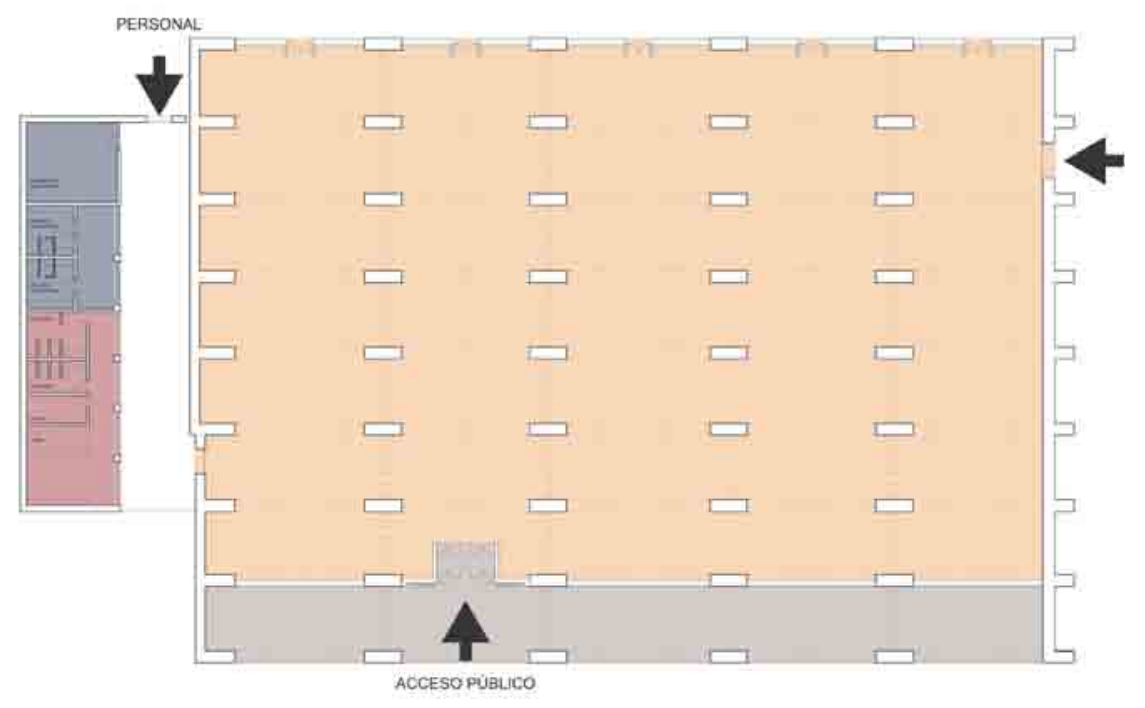

EXPOSICIONES

PERMANENTES

EXPOSICIONES

TEMPORALES

CIRCULACIÓN Y

VESTIBBULOS

USOS PÚBLICOS

USOS INTERNOS

\section{ESTIMACIÓN DE SUPERFICIE}

$\mathrm{m}^{2} \quad \%$

Superficie Expositiva total $\quad 3025 \quad 78$

Superficie de Usos Públicos 128

Superficie de Usos Internos 124

Vestibulo y Circulaciones $\quad 595 \quad 16$

Superficie Total

3872

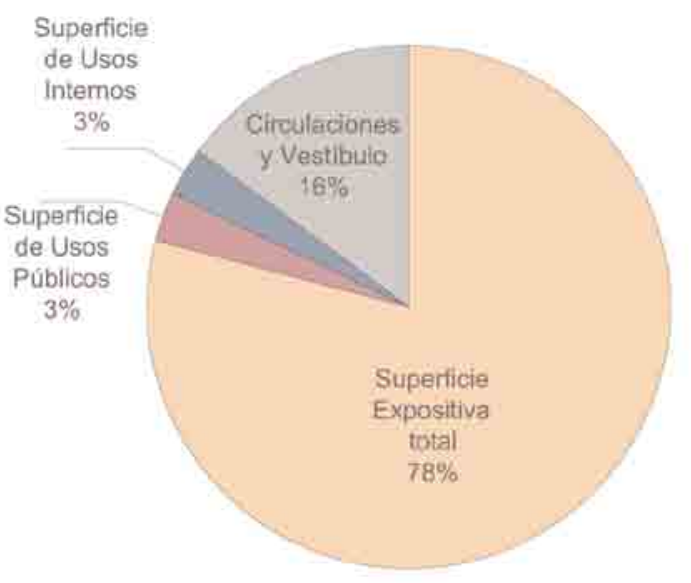




\section{Relaciones de uso}

En el punto anterior, hemos comprobado como las relaciones entre los diversos espacios que concurren en la definición del museo (expositivo, público e interno) corresponden, en cuanto a la superficie ocupada, a un tercio del total.

En el caso de las Atarazanas, no se puede establecer un paralelismo con un museo articulado, puesto que se trata de un gran espacio, indefinido desde el aspecto de su uso expositivo. El interior de sus cinco naves proporciona una superficie de exposición que se estructura mediante su preceptivo proyecto, a excepción del el porche previo, creado como filtro entre el interior y el terrible exterior y que sirve de acogida al público.

Estamos hablando, como se observa en el diagrama adjunto, de un porcentaje de dos tercios de la superficie total dedicada para exposición. El resto, se destina a uso público, aunque se haya contabilizado la superficie del uso de servicios del pabellón no construido.

Hoy en día, la organización interna de las Atarazanas, poco atenta a las características del monumento, escamotea al visitante el disfrute de la bella secuencia espacial producida por los 45 arcos diafragma y los 32 transversales construidos a partir del siglo XIV. 
NOTAS

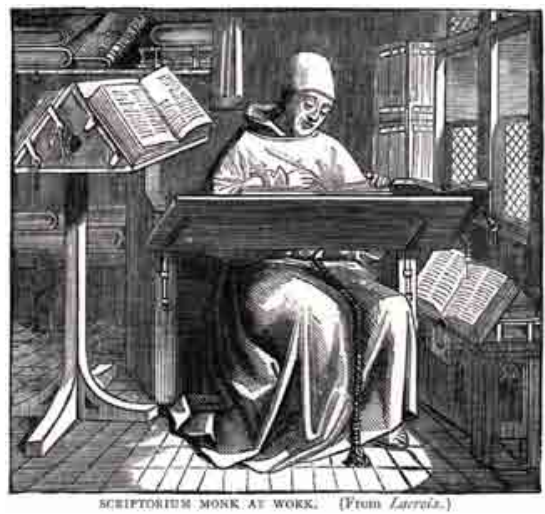

(1) Almela y Vives, Francisco, Las Atarazanas del Grao, Valencia, Revista Feriario Valencia, 1953

(2) Boira, Josep Vicent, Serra, Amadeu, El Grau de València. La construcció d'un espai urbà, Valencia, Institució Valenciana d'Estudis i Investigacióz. Generalitat Valenciana, 1994, pp.26

(3) Boira, Josep Vicent, Serra, Amadeu, Op. cit., pp. 54

(4) Antoni Joseph Cavanilles, Observaciones sobre Historia Natural, Geografía, Agricultura, Población y Frutos del Reyno de Valencia, Imprenta Real, Madrid, 1795, en: Edición FAXIMIL Biblioteca digital Valenciana, TOMO I, pp. 145

(5) Llopis Alonso, Amando; Perdigón Fernández, Luis, Cartografía de la Ciudad de Valencia, 1608-1944, Valencia, Universidad Politécnica de Valencia, 2010 


\subsection{NEUES MUSEUM DE BERLIN}

BERLIN 1993

\subsubsection{Introducción}

El primer premio, en el concurso convocado en 1993, para la realización del proyecto y obra de rehabilitación y ampliación del Neues Museum de Berlín, se obtuvo en colaboración con el profesor Giorgio Grassi. Diversas circunstancias -cuyo relato no es propio de este texto- cancelaron el contrato, finalmente adjudicado al equipo encabezado por David Chipperfield, que había obtenido el

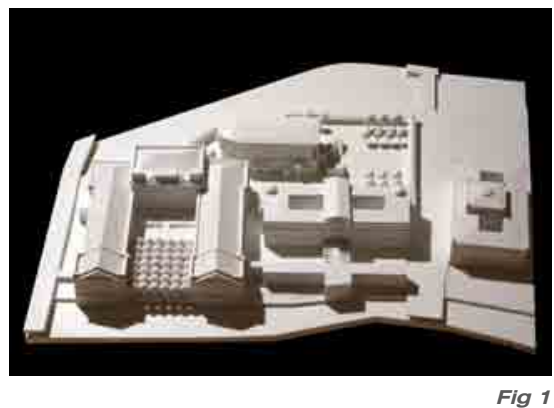
segundo premio en este concurso y que ha rehabilitado, finalmente, el histórico edificio.

El edificio fue diseñado por Friedrich August Stüler, discípulo de Schinkel, en la llamada isla de los Museos (Museumsinsel) (Fig.1) y su construcción se llevó a cabo a mediados del siglo XIX, durante casi veinte años. En el conjunto de la isla de los Museos se organizan, con mayor o menor fortuna, cuatro edificios de uso expositivo a espaldas del Altes Museum: La Alte Nationalgalerie, diseñada también por Stüler (1841) y basada en un croquis del emperador Federico Guillermo IV, construida entre 1866-1876; El Bode Museum, antiguamente Kaiser Friedrich-Museum, cuyas puertas abrieron en 1904; El Pergamonmuseum, construido entre 1910 y 1930 según diseño de Alfred Messel y finalmente el Neues Museum, el primero en ser construido de todo el elenco mencionado, cuya rehabilitación y ampliación requerían las bases del concurso convocado. 


\subsubsection{El programa museístico}

Las estrictas y concisas bases del concurso trazaban un requerimiento general para el conjunto de la isla de los museos; referidas con una gran precisión, incorporaban incluso -para sorpresa de meridionales- una exhaustiva relación del elenco expositivo, que enumeraba pormenorizadamente los nombres de las piezas, su tamaño, su material, y cuantos datos de interés expositivo fueran relevantes.

El proyecto debía responder a los diversos requerimientos funcionales que rebasaban y diluían ampliamente los límites físicos del antiguo Neues Museum. En primer lugar, el programa establecía un recorrido breve (Kurzrundgang) cuyo objeto era la sucinta visita a las más célebres piezas del PergamonMuseum (Fig.2) y del Museo Egipcio inscrito en la planta baja -y en su ampliación asociada- del Neues Museum. La preferente ubicación del templo de Tel el Amarna y del celebérrimo busto de Nefertiti (Fig.3), y su cuidada inserción en el Kurzrundgang, constituía un específico e ineludible requerimiento del programa propuesto.

Seguidamente, recordamos que las obras exhibidas en el Neues Museum no conforman una única colección; grosso

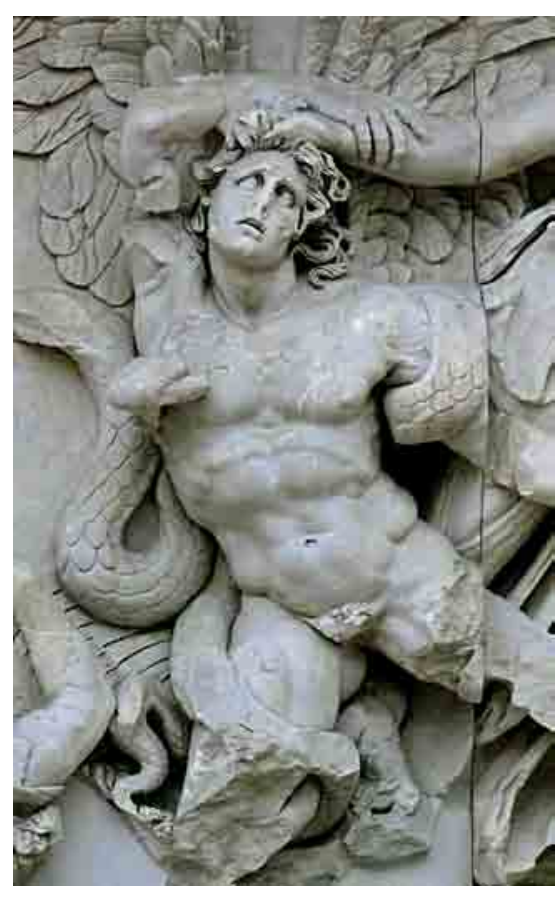
modo, dentro del edificio -una vez recuperado- se debe ubicar el Museo Egipcio, el Museo de Prehistoria y el Museo de Historia Antigua así como la colección de piezas primitivas griegas y romanas. La inserción en un solo edificio de esta mezcolanza de objetos y colecciones, por otro lado tan decimonónica, parece inducir cierta confusión en la forma en que se nombra: se denomina al conjunto por el nombre del Museo -Neues Museum o Museo Nuevo- y no por lo que hay dentro, que como se verá, al carecer de la necesaria ligazón, impide el establecimiento de un itinerario que aúne edificio y exhibición.

Un tercer aspecto, cuya explicación acometeremos de forma separada, atañe a la confusa y caótica organización de la Museumsinsel, que especialmente agrava la absurda disposición del Pergamon Museum. La necesaria intervención en éste, que 
permita un acceso razonable desde el Kolonnadenhof, debe integrar el Kurzrundgang que atañe a la organización conjunta del itinerario entre el Neues Museum y el Pergamon.

La reconstrucción de las partes arruinadas del Neues Museum y la rehabilitación de sus espacios para albergar un uso museístico actual es el cuarto requerimiento que en este breve escolio se reseña. El proyecto, atento a la ausencia de elementos -decorativos y ornamentales- provocada por la destrucción a la que fue sometido el edificio, evocará, a través del vacío y de la utilización de materiales pobres que dejen sus fábricas desnudas, sus antiguos espacios a través de la imposibilidad, de su reproducción material, paralela, por otro lado, a la conservación de la memoria histórica.

Otro aspecto importante -el quinto-que resumimos aquí es el relativo a la ampliación -solicitada por las bases- cuyo objeto principal es el aumento de la superficie destinada a espacios expositivos. Esta ampliación debe responder al dilema que establece la nueva demanda edilicia en un área caracterizada por la saturación y por la escasa cualificación de sus espacios libres. Para ello, el proyecto rememora las antiguas aduanas proyectadas por Schinkel, a través de la disposición de una pieza lineal junto al Kupfergraben, en una suerte de elemento previo, como si se tratase de una construcción precedente a la inserción de los museos en la isla.

En sexto lugar, la recuperación del acceso original al Neues Museum y la inversión del acceso del Pergamon-Museum permiten la decidida recuperación del Kolonnadenhof, único espacio libre de la isla cuyo carácter positivo y no residual le confiere una identidad y representatividad que, a nuestro juicio, cabía potenciar.

\subsubsection{Breve historia del edificio y el lugar}

La actual isla de los museos inicia su destino museístico con el, a la sazón, Neues Museum que Schinkel diseña frente al Palacio Real; como podemos observar en el plano de Schleuen de 1748 , la isla seguía resultando un espacio extramuros -con

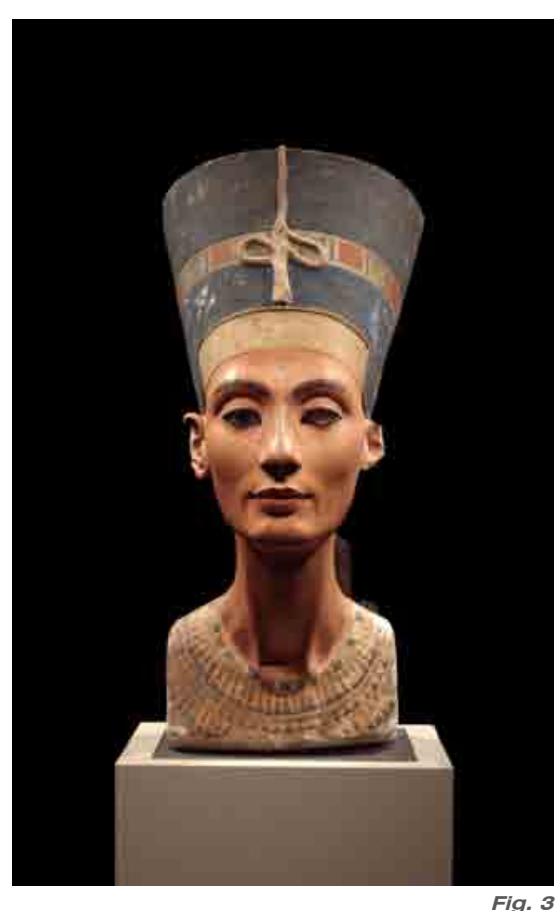


seguridad pantanoso- en el que un bastión se inscribía de forma asimétrica.

El museo de Schinkel tuvo su origen, como hemos visto en otro apartado, en el deseo de exhibir -de una forma metódica y sistematizada- la colección real en un edificio concebido ex profeso. La galería expositiva erigida en Sans Souci a mediados del siglo XVIII, por encargo de Federico el Grande, era insuficiente; por ello, la idea de construir un nuevo museo adquirió gran fuerza y plena justificación. A la necesidad de una exhibición ordenada de las obras de arte -cuya finalidad educativa se evidencia, entre otras circunstancias, con la presencia de Humboldt en la comisión fundadora- se unió el deseo de embellecimiento de la ciudad. El lugar designado para la construcción constituiría, a partir de ese momento, no solamente el centro político ejemplarizado en la residencia del poder real, sino también un centro cultural y de ocio en el que la nueva institución museística poseería un carácter preeminente. El nuevo museo -nótese que en aquella época Schinkel rotula como Neues Museum lo que ahora conocemos como Altes Museum- iba a ofrecer un potente hito urbano cuyas fachadas, junto a las del Berliner Dom -Catedral- y las del Palacio Real, redefinirían y cualificarían el espacio del Lustgarten, jardín de ocio y de placer. La deliciosa arquitectura proyectada por Schinkel lógicamente dispone su

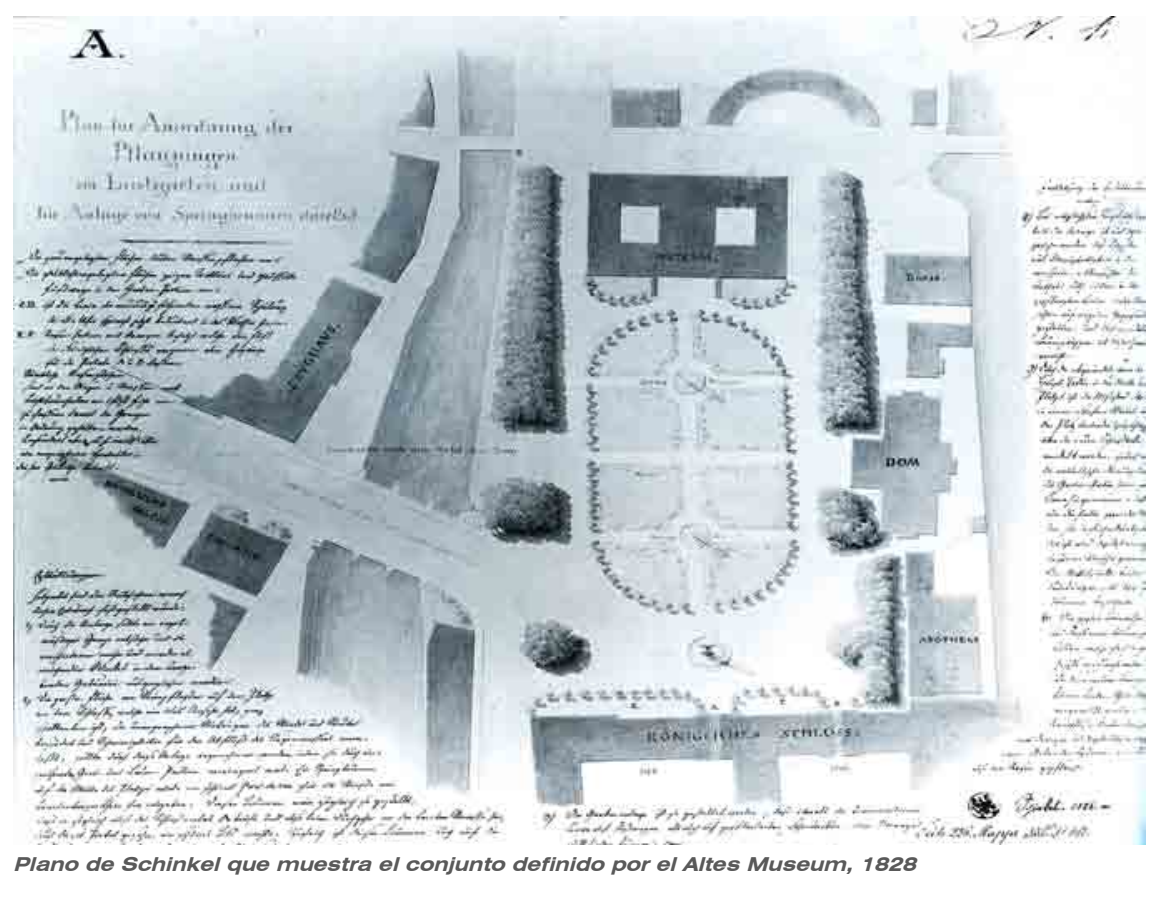


acceso principal frente al Palacio Real y ofrece su trasera a lo que, posteriormente, se conocerá como Museumsinsel, hecho que añade una mayor complejidad a la articulación de los museos de la isla con el edificio primigenio.

Al espíritu ilustrado emanado de las ideas de la Revolución, pronto se añadió un sentimiento nacional prusiano, resultado de la victoria sobre las tropas de Napoleón; en ese contexto el Emperador Federico Guillermo IV decide la conversión de la isla en "un santuario para las Artes y las Ciencias" y encarga a su arquitecto de cámara el diseño de un plan ordenador, en el que se plasmen las ideas por el monarca concebidas. En torno a 1841 -once años después de la inauguración del museo de Schinkel-, un discípulo suyo, Friedrich August Stüler, trazó unas pautas que, por diversas circunstancias, fueron violentadas y no se llevaron a cabo en su totalidad.

Del trazado de Stüler, publicado por el autor en Das Neues Museum in Berlin (1), podemos establecer una serie de consideraciones: en primer lugar, el Neues Museum se dispone a espaldas del Altes Museum, y se une a él funcionalmente por un desafortunado paso elevado sobre la calle, cuya voluntad de reconstrucción por parte de la autoridad de los museos prusianos ha sido objeto de grave controversia; un segundo aspecto estriba en que el acceso principal al Neues Museum se realiza

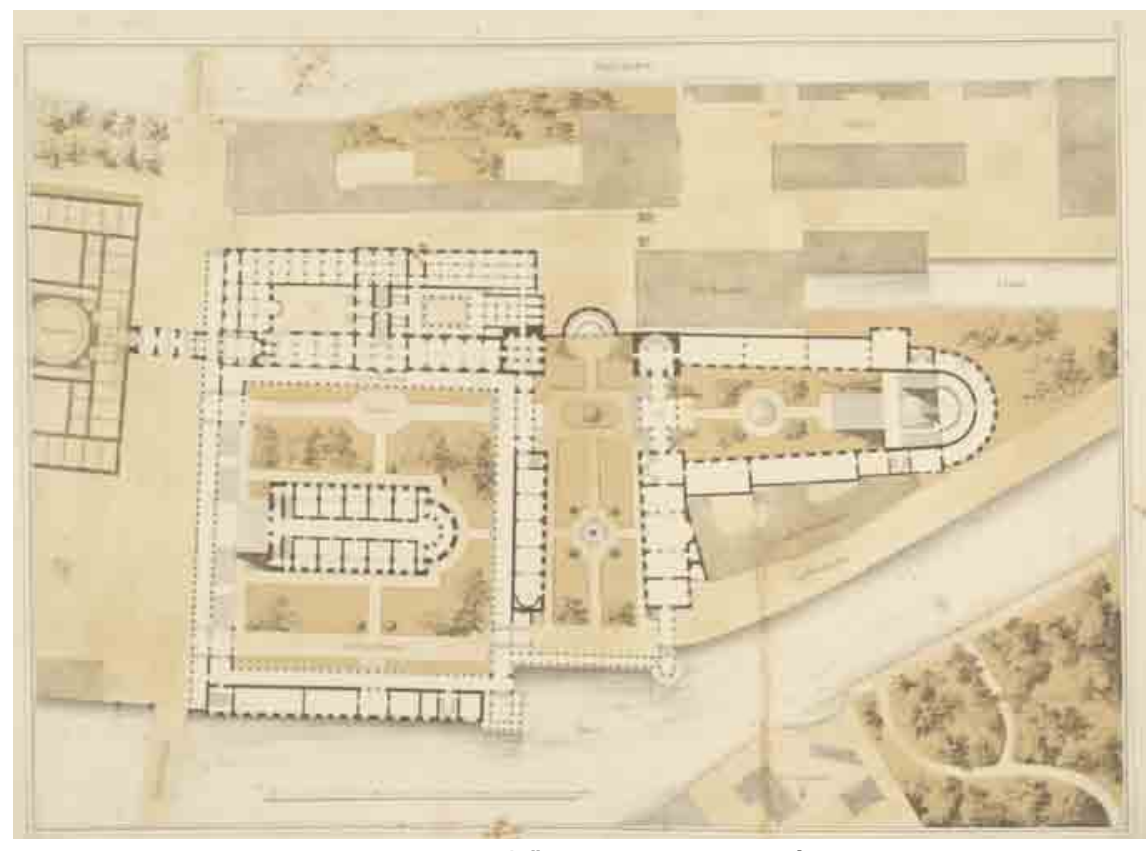

Propuesta de Stüler para la organización general de la Museumsinse 


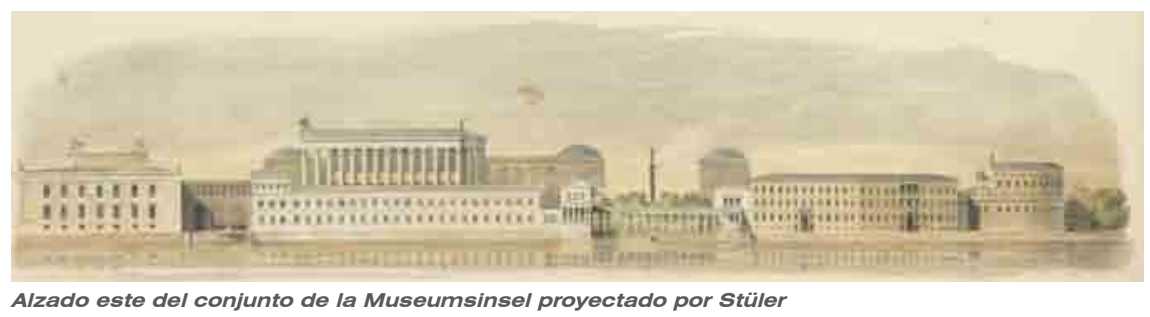

Alzado este del conjunto de la Museumsinsel proyectado por Stüler

a por su flanco este, a través de una columnata cuyo trazado en planta define un patio rectangular en cuyo centro se inscribe el edificio que corresponderá a la Galería Nacional -tercer museo del conjunto-; una tercera precisión se centra en la organización del conjunto a través de un eje longitudinal, que establece un paseo que recorre tangencialmente la Kolonnadenhof y que se remata -tras atravesar diversos elementos como escalinatas, un eje secundario transversal y una estatua ecuestre- en una suerte de exedra; por otro lado, el conjunto bascula hacia el Spree, cuarta apreciación, pues hacia el muelle del Kupfergraben existen edificios vinculados a las Aduanas que imposibilitan la ordenación por parte del plan del frente oeste del conjunto; el área norte de la isla impone su forma trapezoidal a la edificación, que además se debe adaptar a un edificio preexistente a orillas del Spree.

El trazado de Stüler, que por otro lado ofrece algunas dudas y muestra algunas indecisiones, fue desvirtuado y los cambios sufridos propiciaron en parte el aspecto caótico que los espacios libres de la isla ofrecen. Entre otras operaciones, el desplazamiento hacia el norte de la Nationalgalerie impidió el cierre del rectángulo definido en la propuesta delineada para el patio del Kolonnadenhof, cuya resolución reproduce la exedra de la parte posterior del edificio y termina inciertamente, desdibujada y dubitativa, frente a la mole de la trasera del Pergamon-Museum. Otro aspecto fundamental fue el posterior trazado ferroviario que seccionó la isla y que también impidió el desarrollo del plan de Stüler. La inserción del Bode Museum (en torno a 1905) en el extremo septentrional de la isla y la calamitosa disposición del Pergamon Museum -ejemplarmente explicada por Adolf Behnecompletaron la densa organización del conjunto. 


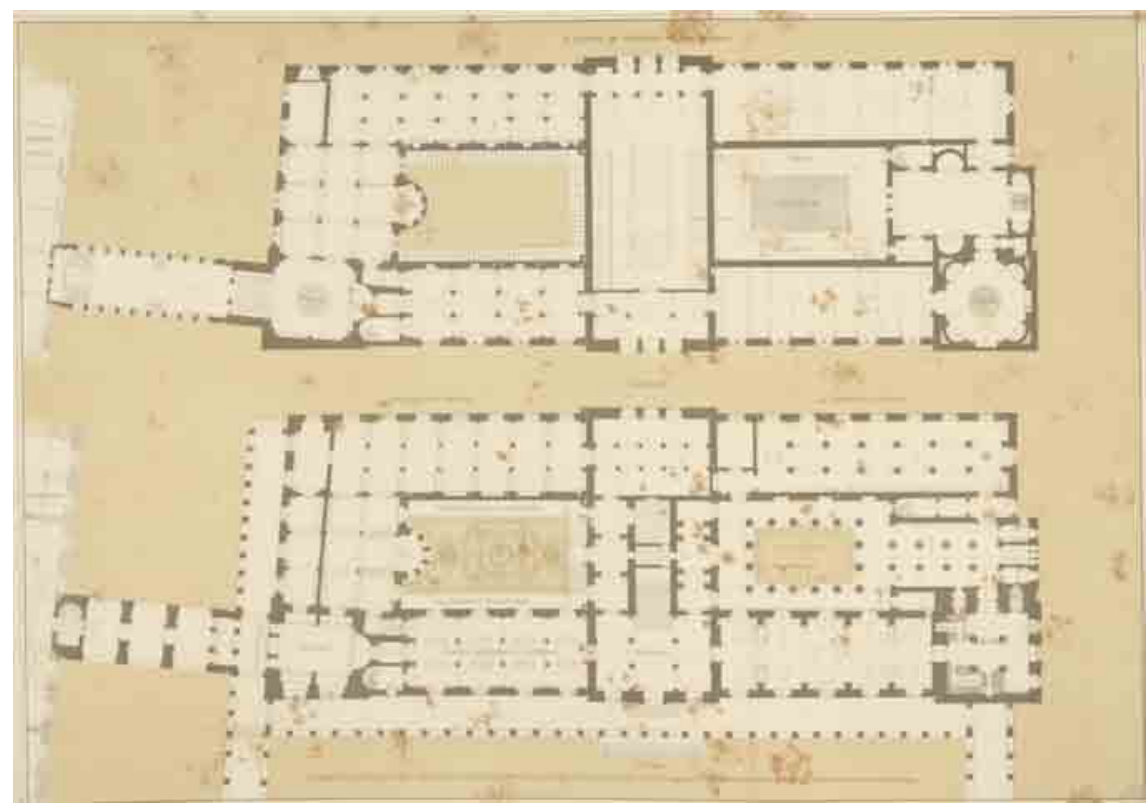

Planta primera y baja del Neues Museum proyectado por Stüler. Se aprecia, en la parte izquierda el cuerpo de enlace con el Altes Museum.

\subsubsection{Descripción general del edificio}

El Neues Museum, proyectado por Stüler, es un edificio de planta rectangular organizado en torno a dos patios que confían a la crujía que los divide el acceso y organización general de su planta. La horizontalidad que al exterior muestra el edificio se matiza por el destacamento del cuerpo central (cuya alineación avanza ligeramente y su mayor altura se remata por un frontón en ambos alzados) y, en fachada principal, por el avance de los dos cuerpos de las esquinas cuyo remate se efectúa por medio de cúpulas.

La organización interior responde a un conjunto de salas expositivas cuyo itinerario, en planta en forma de $C$, parte y regresa al espacio central en el que se disponía una gran escalinata, emparentada con los diseños de Leo von Klenze para Munich y -especialmente- San Petersburgo. La austeridad de los exteriores se matiza por la ostentosa decoración interior, que hoy día conocemos a través de las fotografías históricas y del álbum de dibujos legado por Stüler, colección gráfica de inmediata relación con el amplio elenco de dibujos y detalles que Klenze diseñó para el Hermitage. 


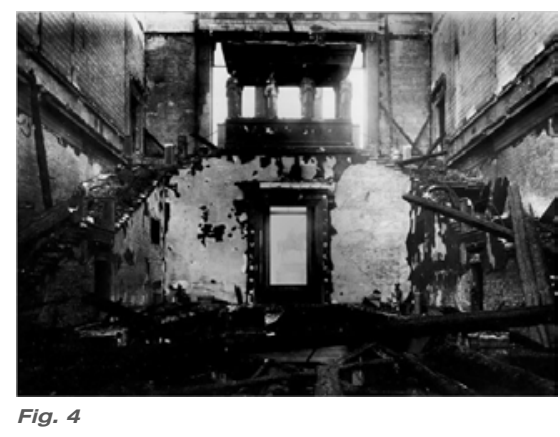

Fig. 4

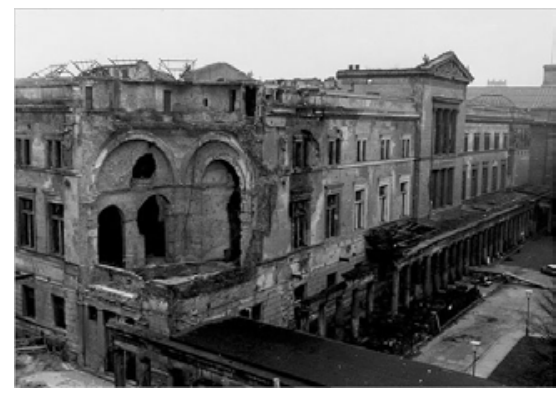

Fig. 5

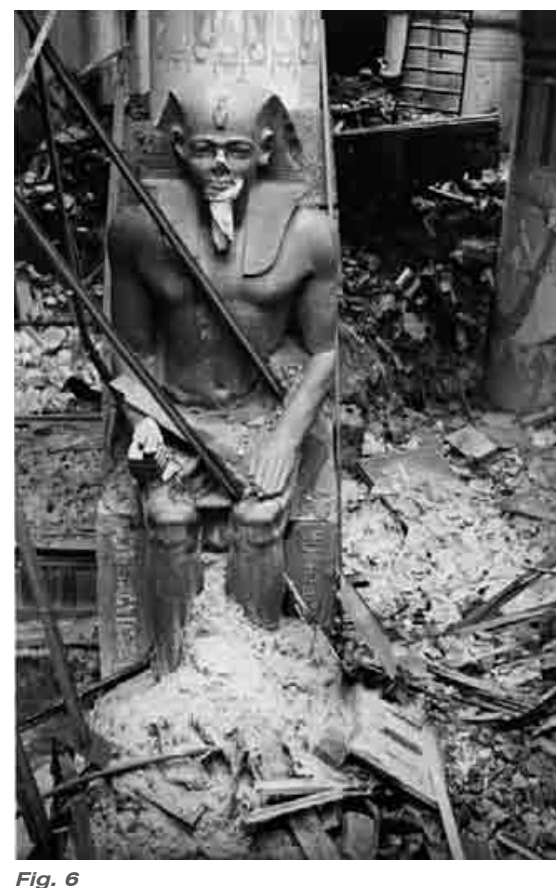

\subsubsection{Estado del edificio y del entorno}

El Neues Museum fue severamente dañado por los bombardeos realizados durante la segunda guerra mundial, entre

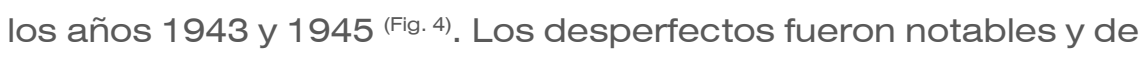
gran alcance: el ala noroeste y la torre sudeste prácticamente desaparecieron (Fig. 5); la cubierta quedó calcinada; parte de los forjados y fachadas del resto de las crujías desaparecieron bajo el efecto de los explosivos y de la metralla; la rica decoración interior del edificio también sufrió los rigores derivados de la guerra ${ }^{(\text {Fig. 6). }}$

A los efectos de la contienda, cabe añadir los no menos perjudiciales resultados que el abandono prolongado durante sesenta años produjo. Esta situación supuso la continuación del proceso de deterioro propio de los edificios abandonados y la presencia de su característica patología: humedad, presencia de vegetación, pérdida de estabilidad de las fábricas, desaparición de revestimientos de los paramentos y por tanto de sus elementos decorativos, muchos de ellos construidos en yeso o aplicados sobre los revocos (frescos), etc.

El estado en el que se encontraba a finales de los años 80 permitía una lectura clara de su realidad construida, al carecer de buena parte de sus elementos decorativos. La fábrica de ladrillo macizo, material pobre, se revestía en el edificio original, mediante pomposos y esplendorosos frescos y esculturas para mostrar toda la magnificencia con la que Prusia pretendía, también en el plano de las Bellas Artes, ejercer una suerte de hegemonía germánica y convertirse, asimismo, en una potencia cultural. Arruinados los interiores, solo quedaban vestigios y fragmentos que nos informaban de lo que fueron $y$ que atestiguaban la suma dificultad de su repristinación. Por ello, como venimos diciendo, las descarnadas fábricas, que permitían la lectura de los procesos constructivos y de la materialidad del edificio, evidenciaban la imposibilidad de revertir el edificio al estado anterior al conflicto bélico. La pérdida irreparable de sus ricos ornamentos y de sus revestimientos significaban, de un modo inexororable, la conversión del edificio en sí mismo en lo 
que los germánicos denominan Mahnmal: un monumento cuyas heridas y cicatrices nos recuerdan y advierten acerca de las aberrantes consecuencias de la guerra. El desnudo aspecto del edificio, o mejor dicho, de su construcción, arruinada o a medio hacer-como quiera que se pretenda la lectura- era el punto de partida del proyecto. Nuestra propuesta, consecuentemente, operando mediante los mecanismos de la evocación y de la ausencia, procuraba enfrentarse a un complejo entramado expresivo en el que, como ineludible advertencia, la memoria histórica del edificio reclamaba un especial tratamiento sensible y razonado.

Por otro lado, la complejidad y aleatoriedad de la actual implantación urbanística de los cuatro museos de la Museumsinsel reclamaba abordar desde el proyecto de intervención acciones de clarificación funcional y de cualificación de sus espacios libres. En atención a este hecho hay quien había opinado, sugiriendo una bella imagen metafórica, que el inacabado y desdibujado Kolonnadenhof, el eje transversal cerrado por el cuerpo central del Pergamon y por la vía férrea y el descontextualizado y herido Neues Museum, no eran más que fragmentos que participaban de una ruina de mayores dimensiones y de mayor alcance: la de aquel plan que Stüler trazó en 1862, de la que se nos muestran como arqueológicos restos, y la de las oportunidades frustradas ejemplarizadas por el escrito de Adolf Behne.

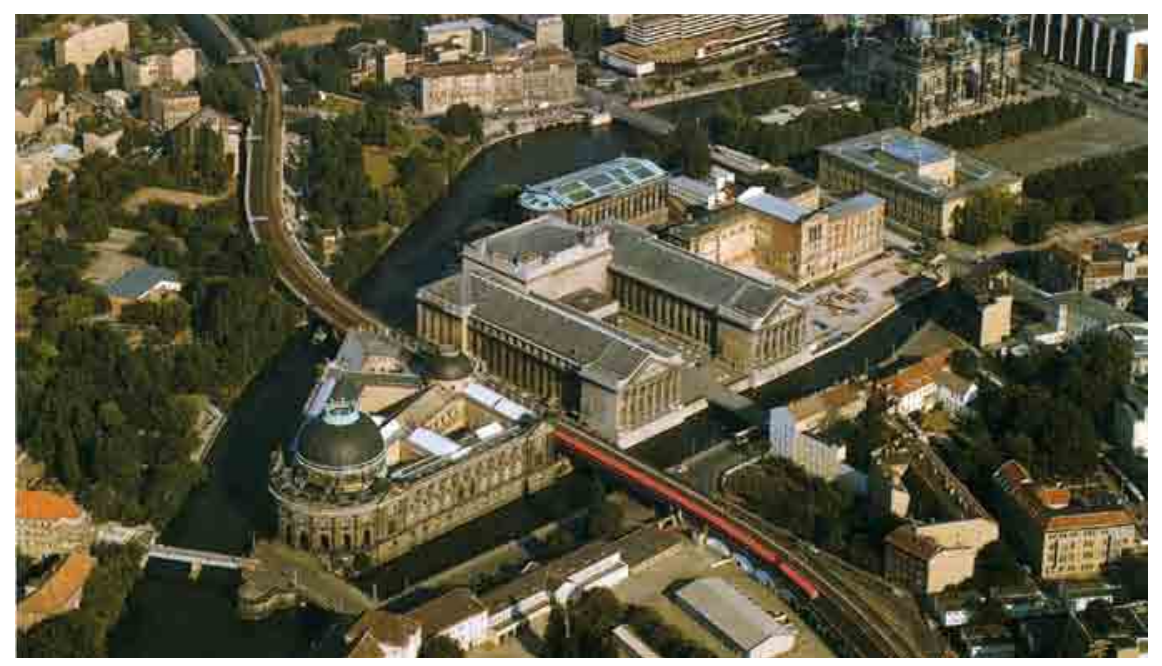

Vista de la Museumsinsel en una postal de los años 80 del siglo XX. 


\subsubsection{Criterios de la intervención y descripción del proyecto}

La respuesta del proyecto a las pretensiones del concurso se puede dividir, a grandes rasgos, en dos partes. La primera parte se refiere al complejo de los museos y es el resultado de una lectura crítica de su condición actual, de las recíprocas relaciones que entre ellos establecen y de su articulación con la ciudad. A este propósito han sido individualizados dos problemas específicos particularmente delicados: uno en relación al cuerpo edilicio que unía el Altes al Neues y, el otro, al acceso desde el Kupfergraben al museo Pergamon. Una segunda parte trata de la propia reconstrucción y ampliación del Neues Museum.

\section{El cuerpo de enlace entre el Altes Museum y el Neues Museum}

Aunque se viene reconociendo como un elemento legítimo de la herencia schinkeliana recogida por Stüler, y a pesar de que ha estado construido muchos años, en nuestra opinión el cuerpo de enlace entre ambos museos ha sido un continuo y craso error, bastante incomprensible. Siempre ha sido una violenta e injustificada manipulación de la bella y clara idea arquitectónica y tipológica del Altes Museum. Una idea, aquella de Schinkel, que no admite ampliaciones o deformaciones y, sobretodo, que no soporta ajustes funcionales camuflados de soluciones arquitectónicas, como corresponde al caso del cuerpo de enlace diseñado por Stüler (Fig.7).

Hoy este hecho resulta más evidente desde el punto de vista compositivo en esta parte de la ciudad. En el complejo de los cinco museos, el único verdadero solitäres, y sigue siendo, el Altes Museum. Los otros cuatro, demasiado cerca entre sí para establecer una mutua relación arquitectónica, están obligados por su vecindad a tomar parte, por así decirlo, en una especie de monumentalidad que entre ellos se confieren de forma recíproca. Mientras, el Altes Museum, volviendo hacia ellos la espalda (el bellísimo frente posterior), establece una relación arquitectónica 
de bien diverso cariz con otros elementos de la ciudad, como el Lustgarten, el Castillo, la Zeughaus (Arsenal) o la Catedral. Hoy que, por diversas vivencias históricas, el Altes Museum ha reconquistado su aislamiento, pensamos que es imposible proponer la idea de un cuerpo de enlace con el Neues Museum.

La respuesta de nuestro proyecto es, pues, una respuesta exclusivamente funcional: un enlace técnico, subterráneo, destinado sobretodo a facilitar el trabajo del personal de los museos.

\section{El acceso al Pergamon Museum desde el Kupfergraben}

El actual acceso al Pergamon Museum adolece de una incoherencia importante, motivada por la sorprendente decisión de desvincular la entrada principal de la isla de los museos y de crear su acceso frente al Kupfergraben, salvado mediante una pasarela. Este problema fue expuesto con lucidez por Adolf Behne, en su famoso artículo "La Isla del Museo: una tragedia de la urbanística berlinesa". En los años treinta del siglo XX, Behne escribía: "Contra toda lógica, violentando y creando una fractura entre la construcción ya existente, interrumpiendo la precedente tradición positiva, viene creado un nuevo imponente patio de honor y propio en la dirección del Kupfergraben, donde esta muestra grandiosa está condenada a permanecer bloqueada en tanto en cuanto no existe el espacio para la realización del

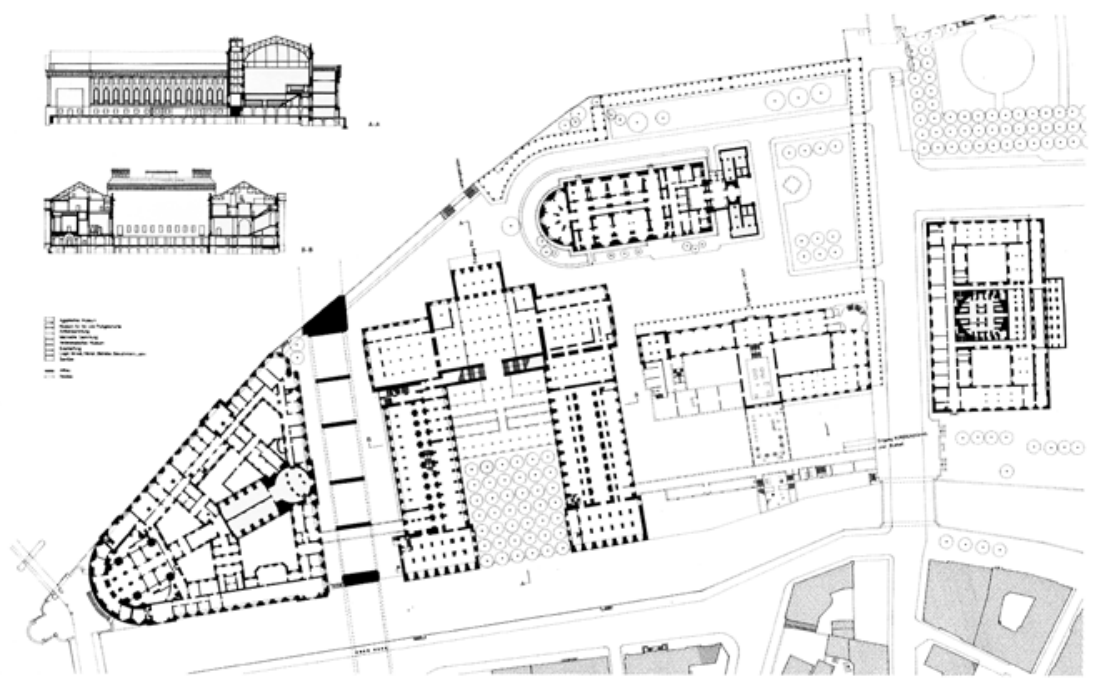

Plano de situación en el que se observa el conjunto de planta baja de la Museumsinsel 

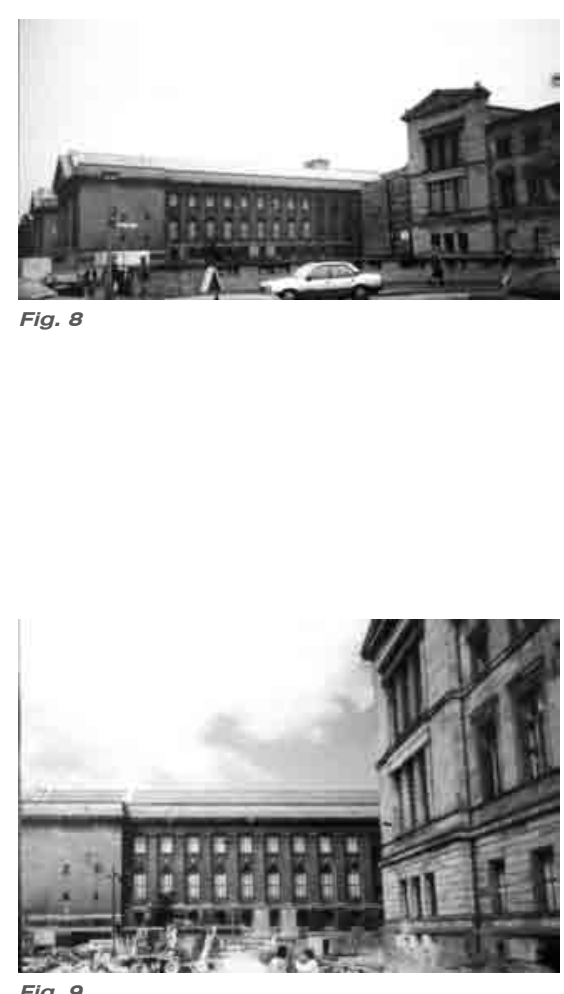

nuevo eje. iEn qué grotesca situación estamos inmersos! Y poco después, casi hablando de nuestra propuesta, continuaba: En ese intervalo, el Estado Prusiano ha adquirido el edificio junto al Kupfergraben para construir, en su puesto, el Museo Egipcio. Tal vez nacerá la posibilidad de poner a continuación un remedio a los peores efectos del descomunal error urbanístico (...) este error se puede parangonar al principio de poner un armario con la puerta vuelta contra la pared y practicar después un agujero en el exterior de la pared para poder entrar a la misma puerta. Por tanto, esta gran ocasión urbanística ofrecida hoy a la capital del estado alemán -la realización de la isla del museo- ha sido fallida, porque la manía de conferir la máxima monumentalidad al edificio en sí mismo ha abrumado el carácter colectivo de la ciudad construida. En la historia de la construcción de nuestra ciudad se repite siempre nuevamente el mismo caso: la ruptura de la tradición que Schinkel había iniciado aquí en modo casi perfecto. Naturalmente no entendemos la tradición formal, el deberse atener al "estilo" de Schinkel, sino a la tradición entendida como prosecución y cumplimiento de una herencia cultural en el sentido más amplio". (2) (Fig. 8 y Fig. 9)

En nuestra opinión, la propuesta que presentamos al concurso pudo ser la ocasión para intentar ofrecer una respuesta también a esta irresuelta cuestión. La respuesta de nuestro proyecto consiste en restituir el Kolonnadenhof en su papel de elemento distribuidor de los museos que lo circundan. Desde el Kolonnadenhof se accederá pues al Neues Museum, a la Nationalgalerie y también al Pergamon Museum. Para llevar esto a término, el acceso principal de este último se encontrará en el frente posterior del edificio (sin precisar modificaciones estructurales), en el lado que recae al Spree. En esta inversión habrá una consecuencia tipológica importante: el patio de honor se transformará en un patio posterior del edificio (Hinterhof), en la línea de los mejores ejemplos de los palacios berlineses en los que el patio posee un tratamiento ajardinado (Gartenhof).

Es por este motivo que, en nuestro proyecto, proponíamos, por un lado, la prolongación del sistema de acceso y de sus 
servicios de acogida hasta ocupar, en planta baja, una parte del actual patio de honor. También, como consecuencia de la primera decisión, se destinaba la parte remanente -aquella que da frente al Kupfergraben- a jardín arbolado, eliminando naturalmente el puente de acceso actual. La ocupación, de una sola planta, de parte del patio de honor posibilitaría un desarrollo más claro y racional del considerado "recorrido rápido" o Kurzrundgang, que atravesaría, apoyado en una estructura de servicios idónea (tienda, catálogos, lectura, cafetería, restaurante con jardín, etc.), todos los puntos relevantes del itinerario diseñado.

Esta elección (que es también, en consecuencia, una respuesta a la vieja cuestión del cuarto lado del Pergamon Museum, esto es, al planteamiento de la posibilidad del cierre circular del recorrido de la misma visita al Pergamon Museum) es, en nuestra opinión, un complemento necesario a la decisión de llevar el acceso principal del museo al Kolonnadenhof, al menos en el aspecto relativo a la elección de transformación del patio de honor en jardín arbolado abierto hacia el Kupfergraben.

\section{Restauración y ampliación del Neues Museum}

\section{La ampliación del Neues Museum}

Este apartado se refiere a la respuesta del proyecto al problema de la ampliación del Neues Museum junto al Kupfergraben.

En este caso, el problema principal radica en el hecho mismo de edificar en este lugar, en el hecho de proceder a construir sobre un área (la Museumsinsel) ya de por sí demasiado edificada, un área prácticamente saturada. Por otro lado, esta ampliación del Neues Museum parece ser un hecho necesario, bien sea desde el punto de vista de las nuevas y más amplias exigencias expositivas, bien desde el correspondiente a la racionalización y distribución del recorrido. La respuesta del proyecto, en este caso, representa sobretodo el intento de conciliar estos dos hechos evidentemente contradictorios. Hemos trabajado en una idea de ampliación del Neues Museum como si esta ampliación preexistiese a la vecindad edilicia (Fig.10)

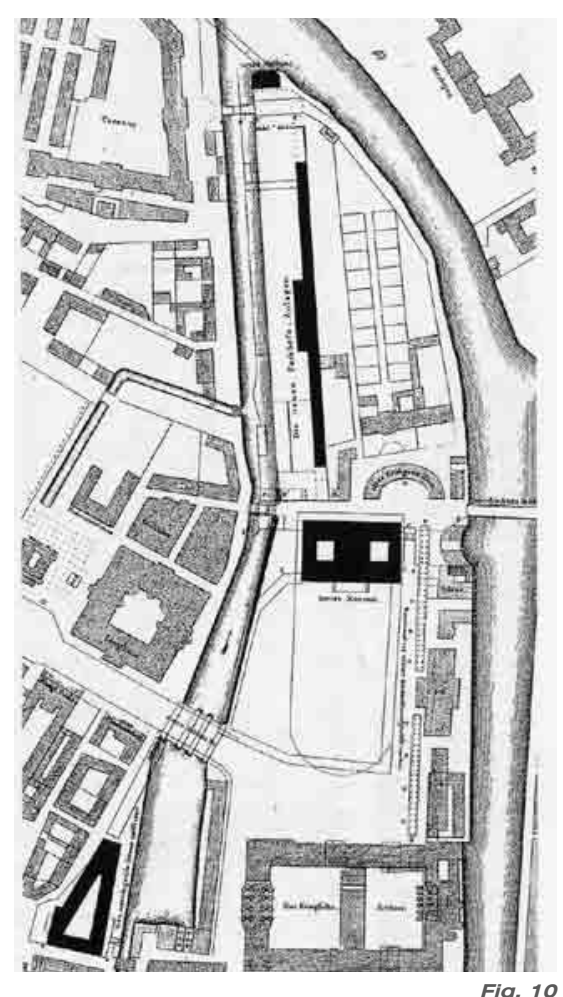




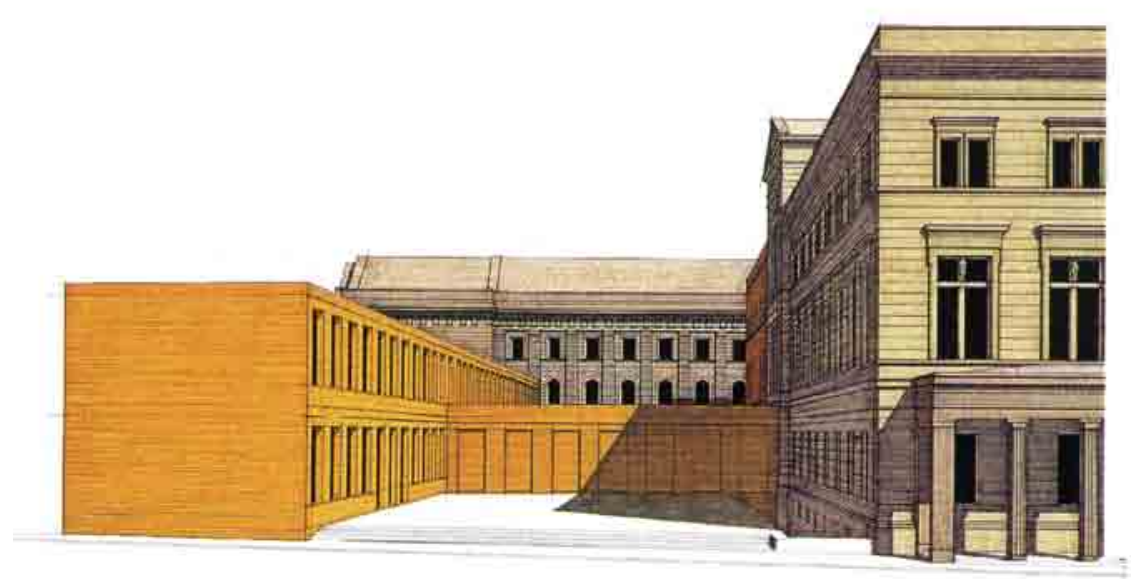

Vista del nuevo cuerpo junto al Kupfergraben

que ha conllevado tal saturación. Como si se tratase, esto es, de una construcción precedente a la inserción de los museos en la isla, como si se tratase de un fragmento de aquellos edificios del viejo Packhofanlage ideados por Schinkel a espaldas del Altes Museum. Esta definida referencia arquitectónica ha guiado los diversos momentos de nuestro proyecto: la situación del nuevo edificio, pero también sus dimensiones en planta y en altura, hasta determinar incluso la elección, por así decirlo, "estilística", el uso de los materiales pobres (ladrillo visto), los tipos de ventana (las grandes a medida de un pórtico, las pequeñas poco más que aberturas para la ventilación), la ausencia de elementos decorativos, etc.

La elección del ladrillo visto, que indica un modo usual de construir edificios técnico-utilitarios, pero que individua también el edificio sin acabados, es decir, el edificio incompleto, el edificio interrumpido, etc., ha sido extendida, con este segundo objetivo expresivo, también a aquellas partes del Neues Museum que, en nuestro proyecto, se planea reconstruir (ala noroeste y torre sudeste) y repristinar (espacio interior del gran espacio de la escalera).

Esto, naturalmente, no es el único vínculo del nuevo edificio con el Neues Museum. En cuanto a su referencia con respecto a los viejos Packhofsgebäude no se hace menos evidente su 

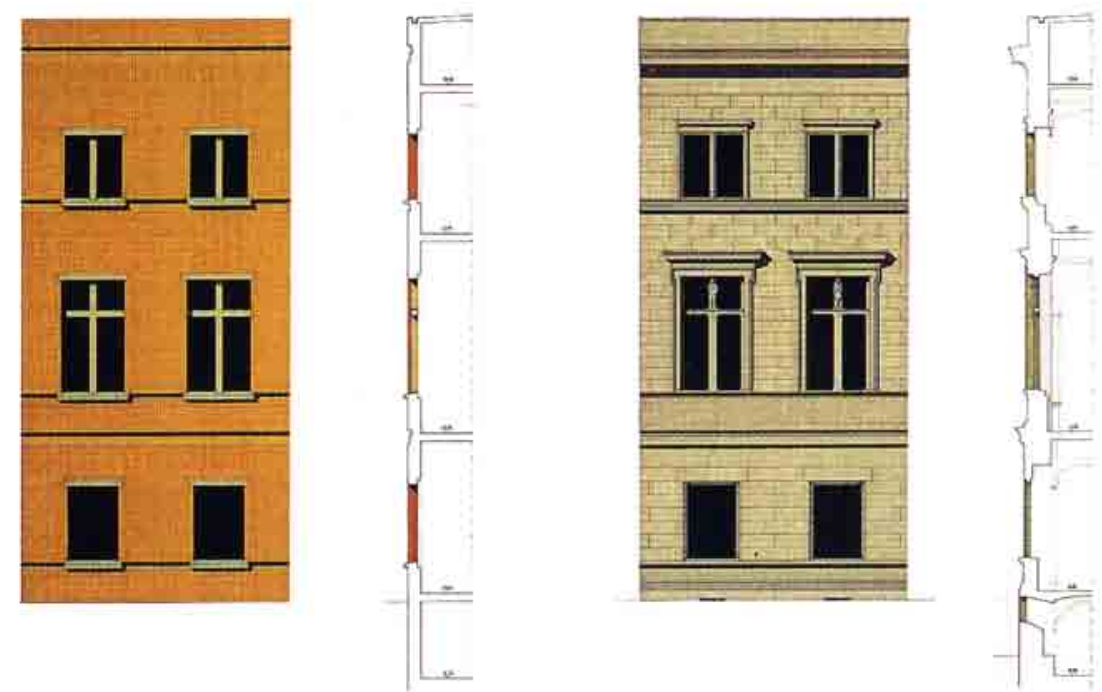

Detalle del complemento y de la repristinación

estrecha relación tipológica (planimétrica, distributiva, jerárquica) que lo une al Neues Museum, del cual queda como una expansión lógica y consecuente en el plano tipológico.

\section{Complemento y restauración del Neues Museum}

El Neues Museum se restaura, donde es posible, "como era"; las partes que se debían completar (como el brazo noroeste y la torre sudeste) repetirán los volúmenes y los espacios existentes antes de la destrucción (excepción hecha en el espacio interno de la torre, destinada a contener la escalera de acceso al Museum für Vor-und Frühgeschichte).

Las fachadas de las partes complementadas, así como la superficie interior del gran espacio de la antigua escalera, serán voluntariamente mantenidas "a lo rústico", con los muros mostrando el ladrillo visto. Se pretende dar de este modo una resolución, por así decirlo, "incompleta" del edificio antiguo, omitiendo los elementos decorativos y conservando de ellos la sola impronta en negativo. Esta solución persigue asimismo la puesta en relación con la elección constructiva ya determinada del nuevo cuerpo junto al Kupfergraben, también realizado en ladrillo y privado de elementos decorativos. En el primer caso, esta elección buscará indicar la voluntad de mantenimiento de las señales de la destrucción, su memoria histórica; en el otro, por 


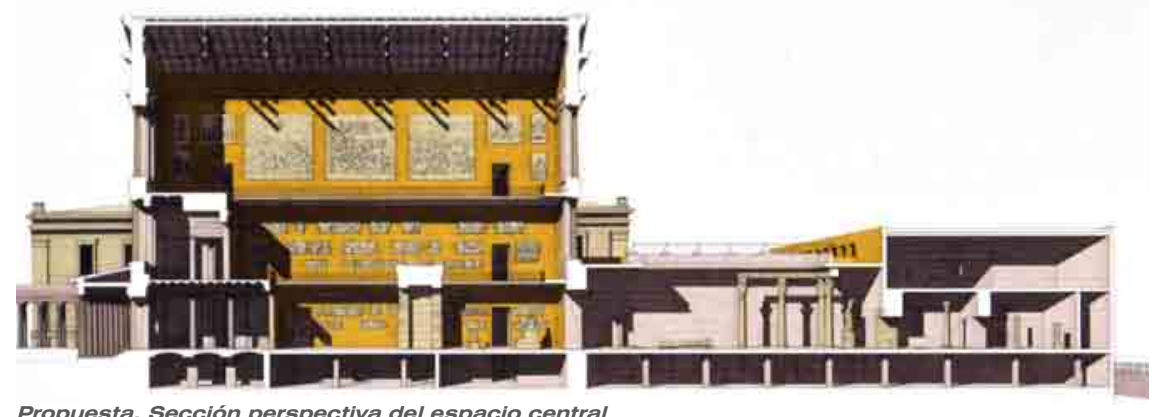

Propuesta. Sección perspectiva del espacio central

el contrario, la voluntad de reproducir la elección utilitaria de los viejos edificios schinkelianos. El espacio de la antigua escalera, junto a los patios "griego" y "egipcio", deberá desarrollar en el nuevo museo restituido al público la función de museo del edificio mismo "como era".

En este sentido, el viejo espacio de la escalera se vacía totalmente hasta el nivel del sótano y se reviste y refuerza en su perímetro con un nuevo muro de ladrillo visto, que se destina a Antiquarium de los elementos decorativos recuperados del mismo espacio (fragmentos arquitectónicos, calcos, etc. incluso posiblemente los cartones de los ciclos de frescos que han desaparecido) o de otras salas, en las que la reposición de estos fragmentos no fuera posible. El patio "griego", destinado a exposiciones especiales y cubierto con vidrio para esta tarea, será restaurado "como era" en la medida de lo posible (sin repristinar la exedra, sustituida por una ventana igual a las otras). A lo largo de la parte inferior de los paramentos se podrá desarrollar también un Antiquarium que albergue los elementos griegos del edificio de Stüler. El patio egipcio, cubierto asimismo con vidrio, se destina a exposiciones especiales. Será en parte restaurado "como era" (lado este) y de forma análoga podrá contener los fragmentos egipcios del viejo edificio dispuestos a modo de Antiquarium. 


\section{El nuevo edificio junto al Kupfergraben}

De los caracteres arquitectónicos y de los materiales de este nuevo edificio ya hemos hablado. Planimétricamente se presenta como una especie de desdoblamiento del Neues Museum hacia el Kupfergraben: un edificio longitudinal de dos plantas, compuesto por dos galerías paralelas (una abierta al este, otra cerrada al oeste e iluminada con luz artificial) y ligadas al sótano del Neues Museum mediante un cuerpo transversal -que al exterior muestra una sola altura-, colocado en el sentido del espacio de la antigua escalera del Neues Museum y de su misma longitud.

Este gran espacio transversal, en la planta sótano de los dos edificios, se destina al "Templo egipcio" y se prolonga para ello más allá del nuevo edificio hasta alcanzar el límite del agua.

En líneas generales, en las galerías abiertas al este encontrarán su lugar las piezas de escultura y bajorrelieves (ver Galería de los Uffizi), mientras que en las galerías con iluminación artificial y pequeñas ventanas a oeste, se situarán las colecciones más preciosas, sobretodo aquellas que requieren condiciones especiales de protección y adecuación.

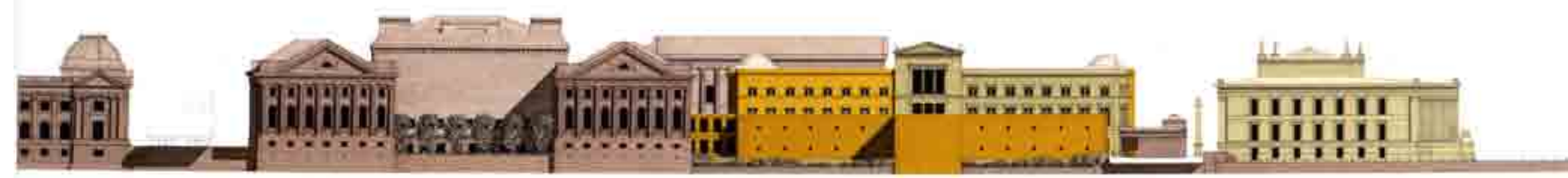


PROYECTO. PLANO DE EMPLAZAMIENTO
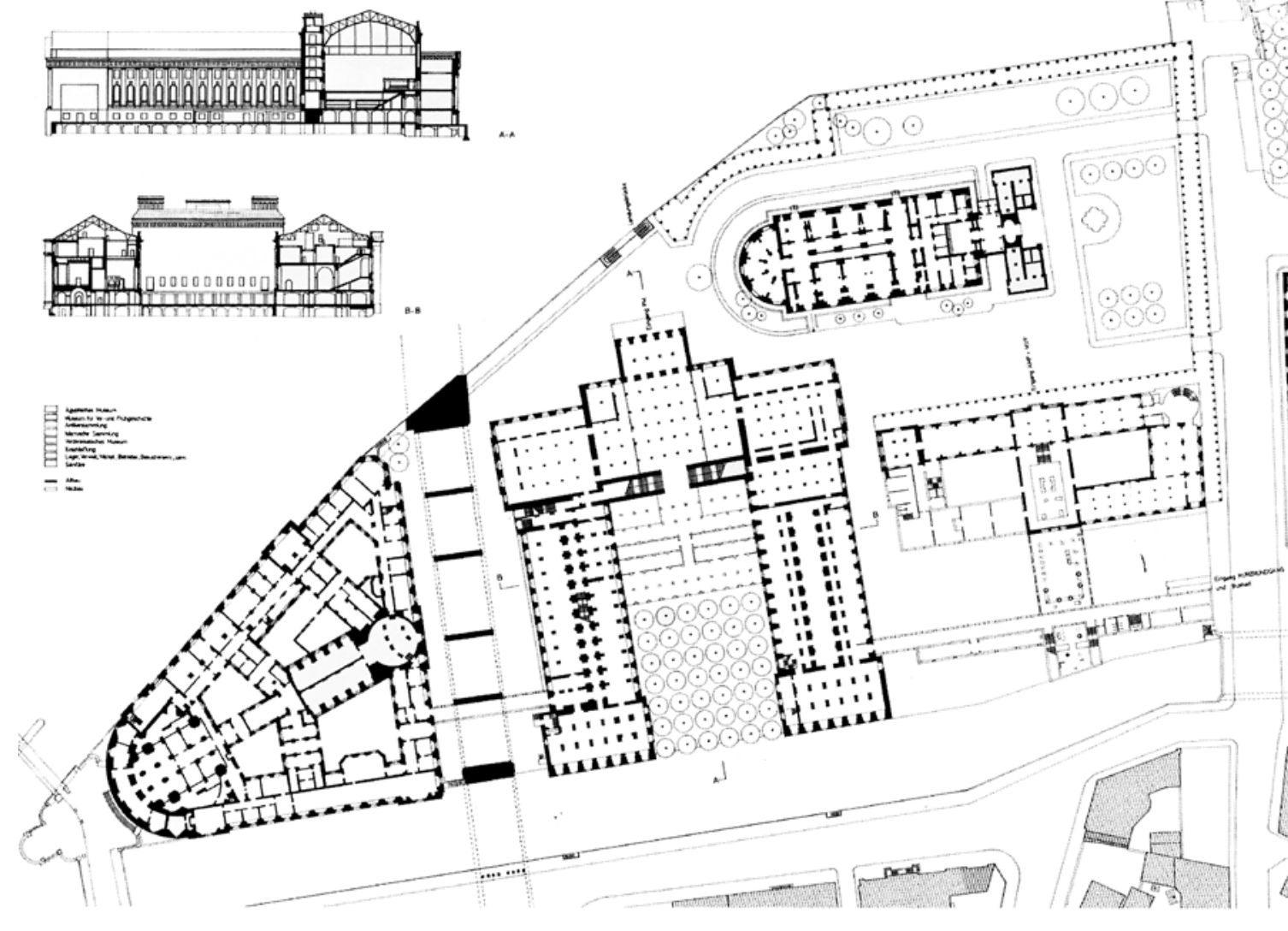
PROYECTO. PLANTA DE CUBIERTA

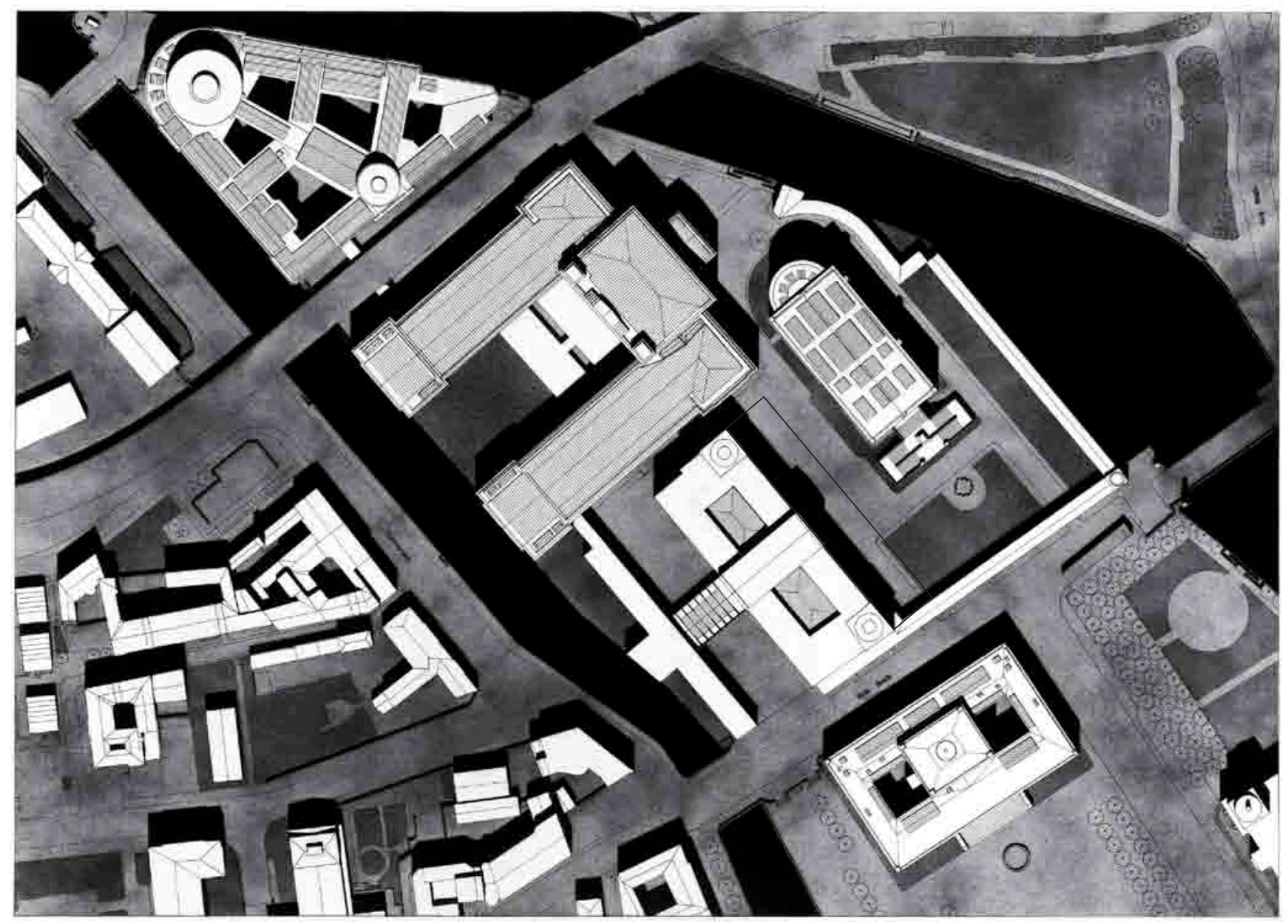




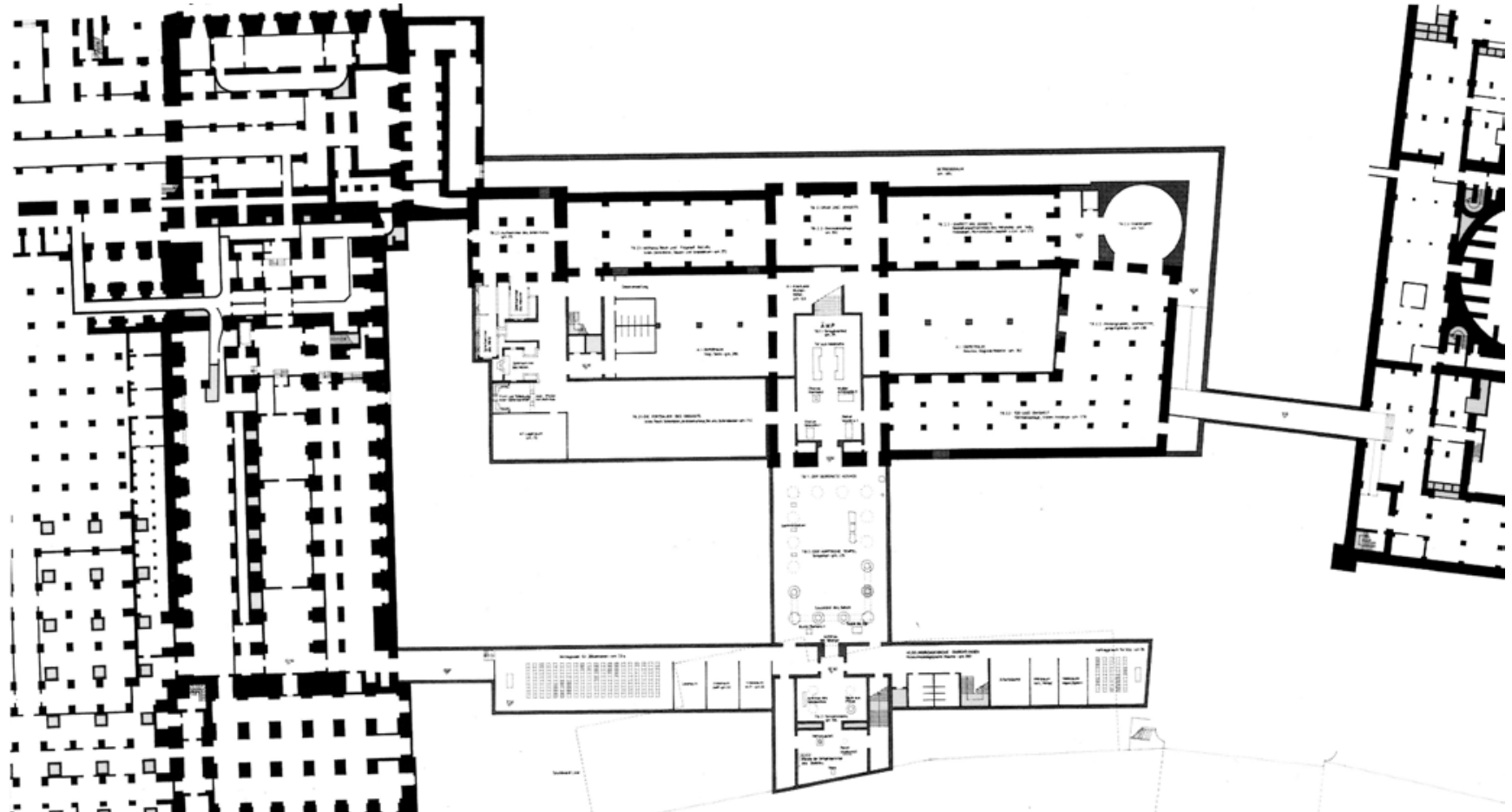

\section{: -}

Propuesta. Planta sótano
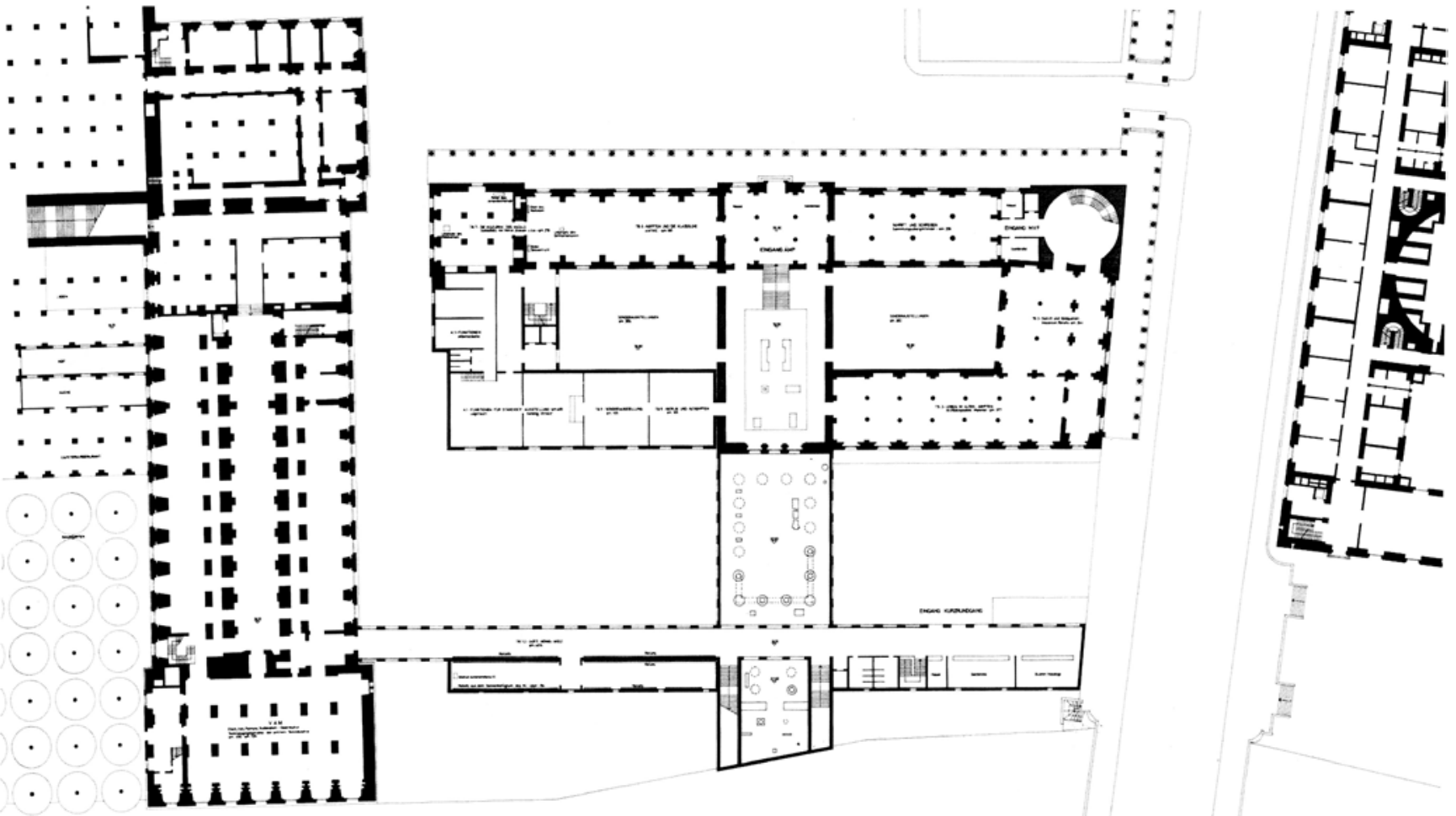

Propuesta. Planta baja 
PROPUESTA. PLANTAS
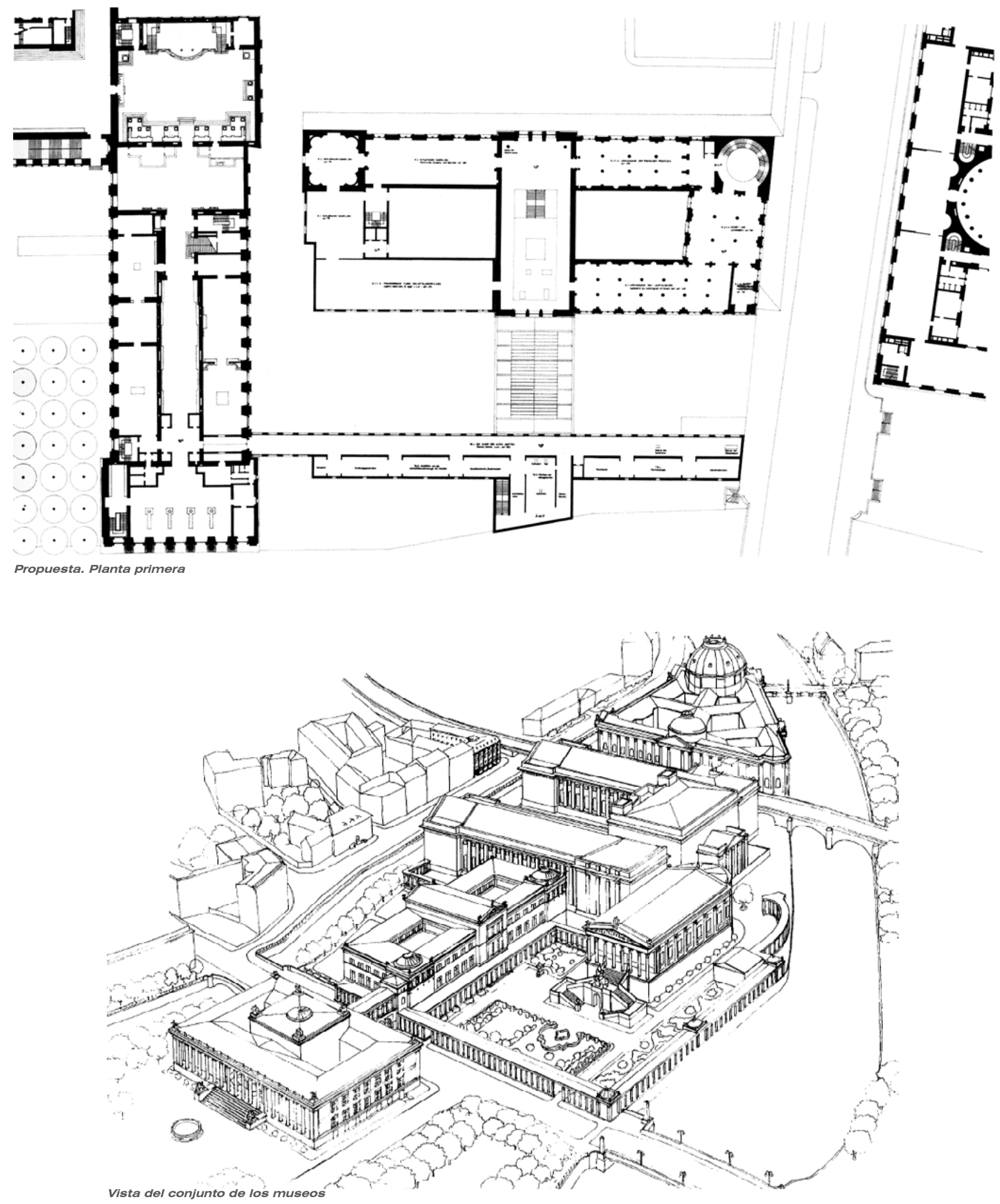

Vista del conjunto de los museos 
PROPUESTA. ALZADOS

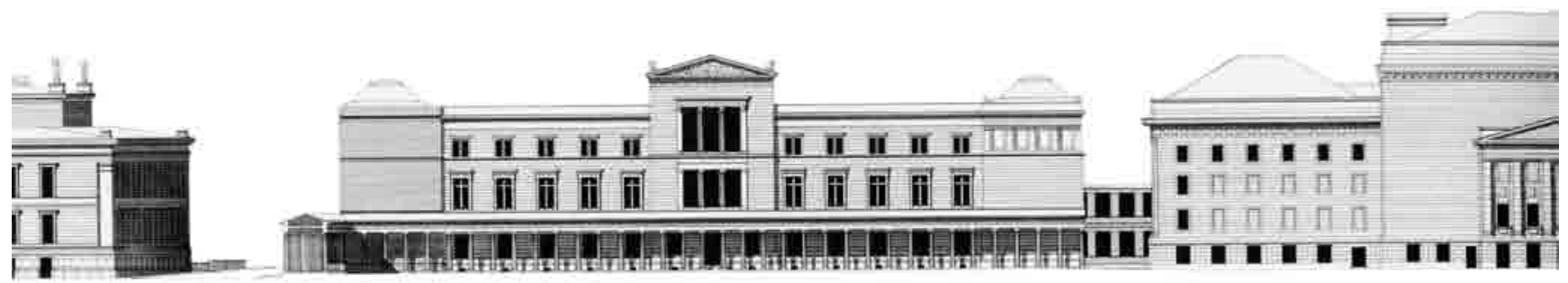

Alzado al Kolonnadenhof
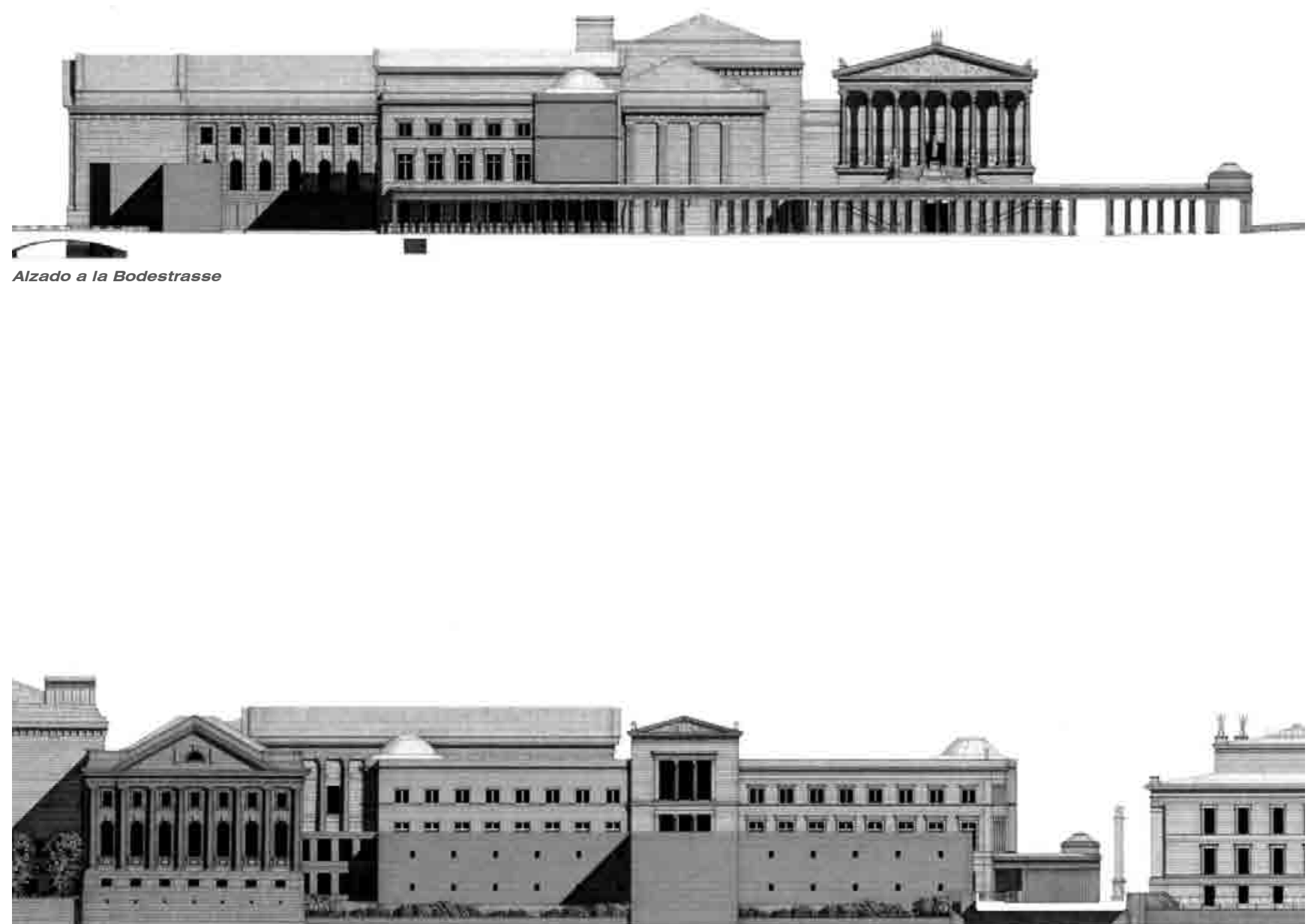
PROPUESTA. SECCIONES
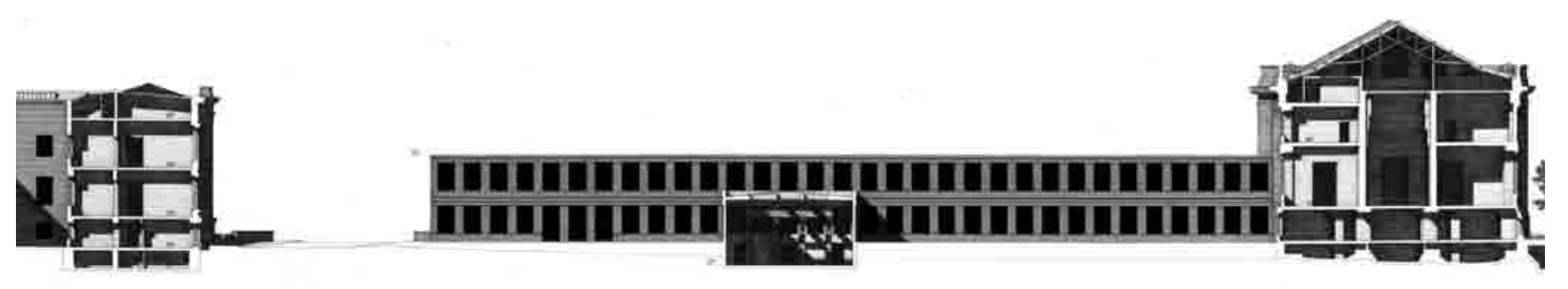

Sección CC
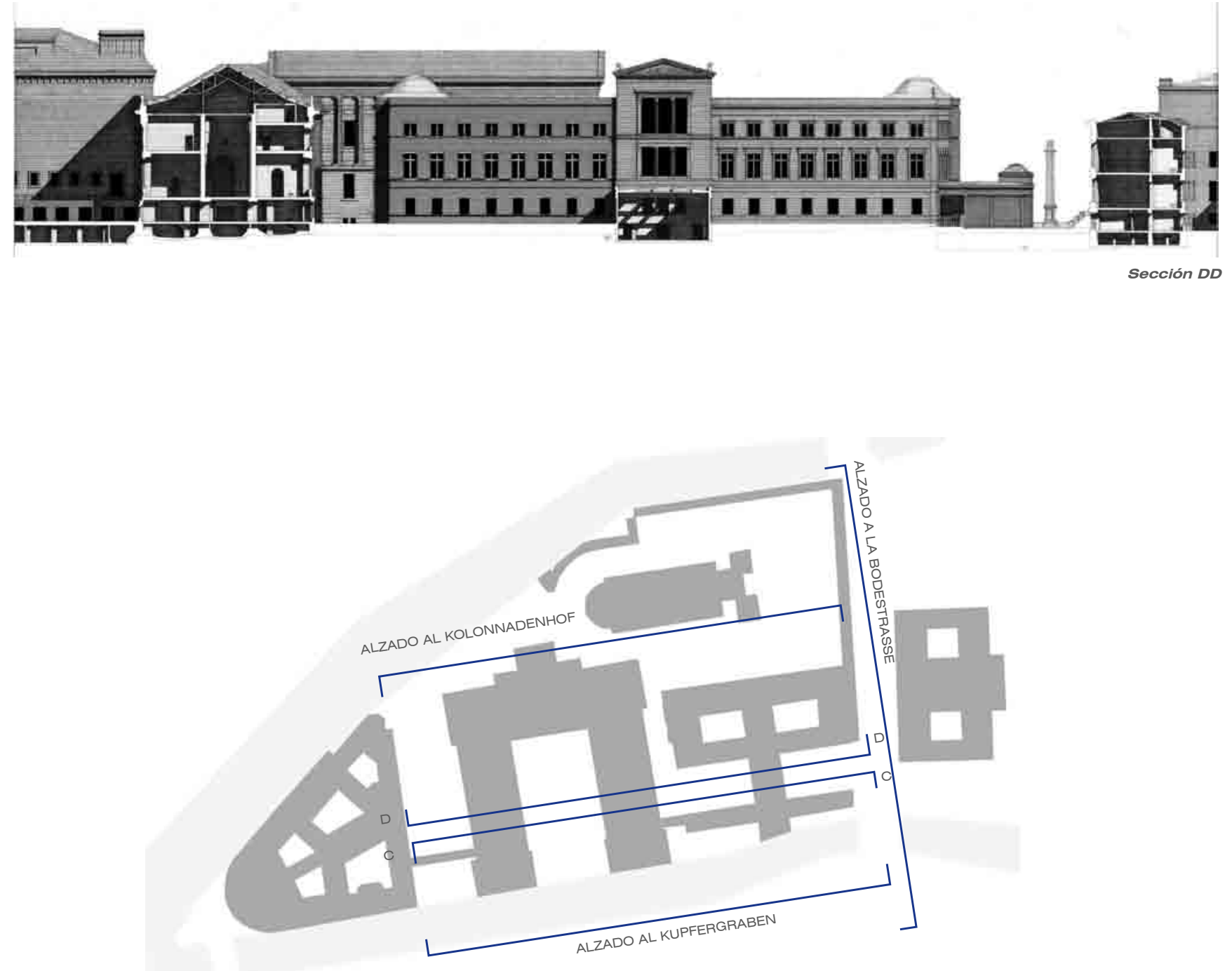

${ }^{20} N O$ 
PROPUESTA. SECCIONES

Sección GG
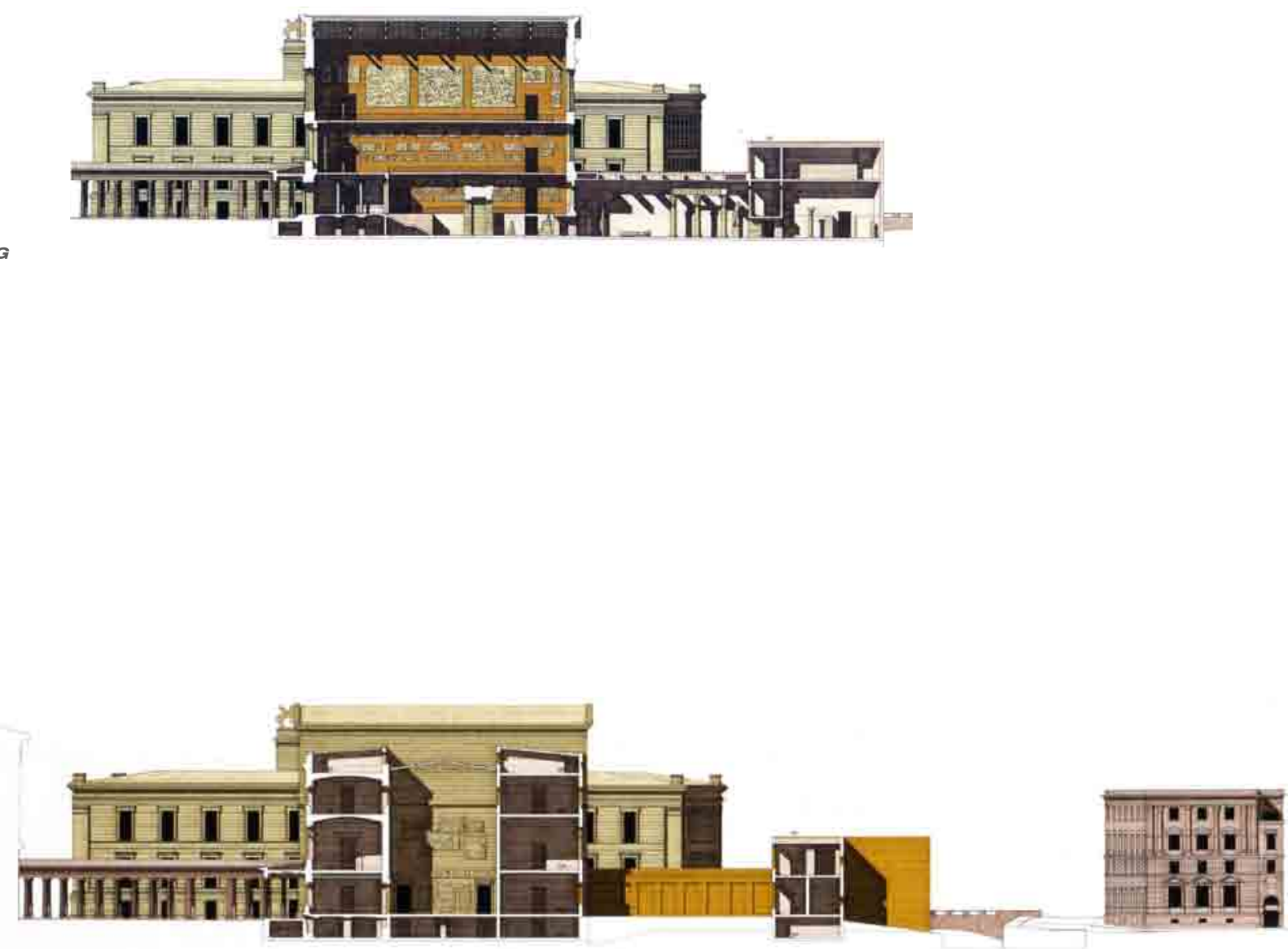
Sección EE
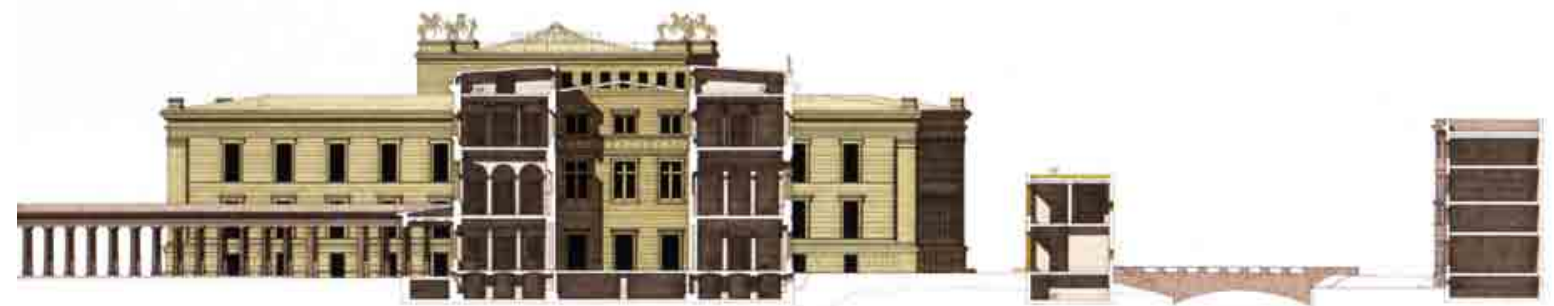

${ }^{20} N O$ 
PROPUESTA. SECCIONES

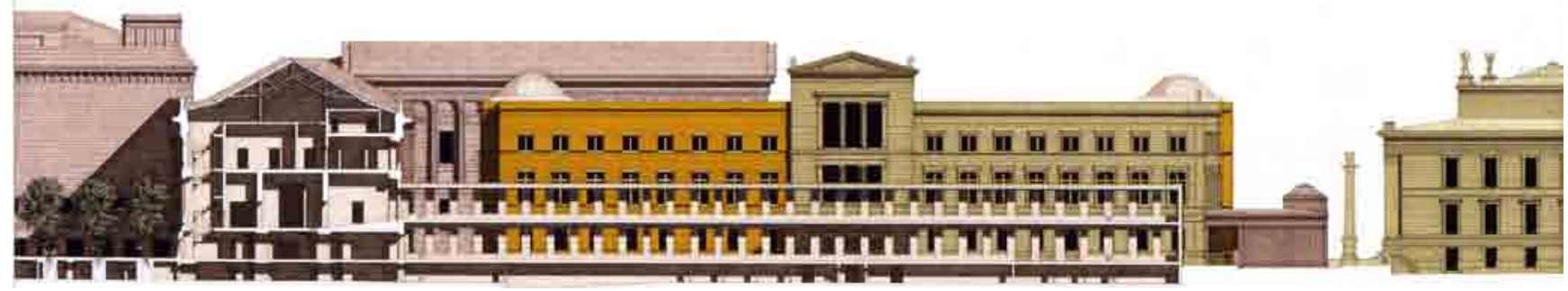

Sección AA
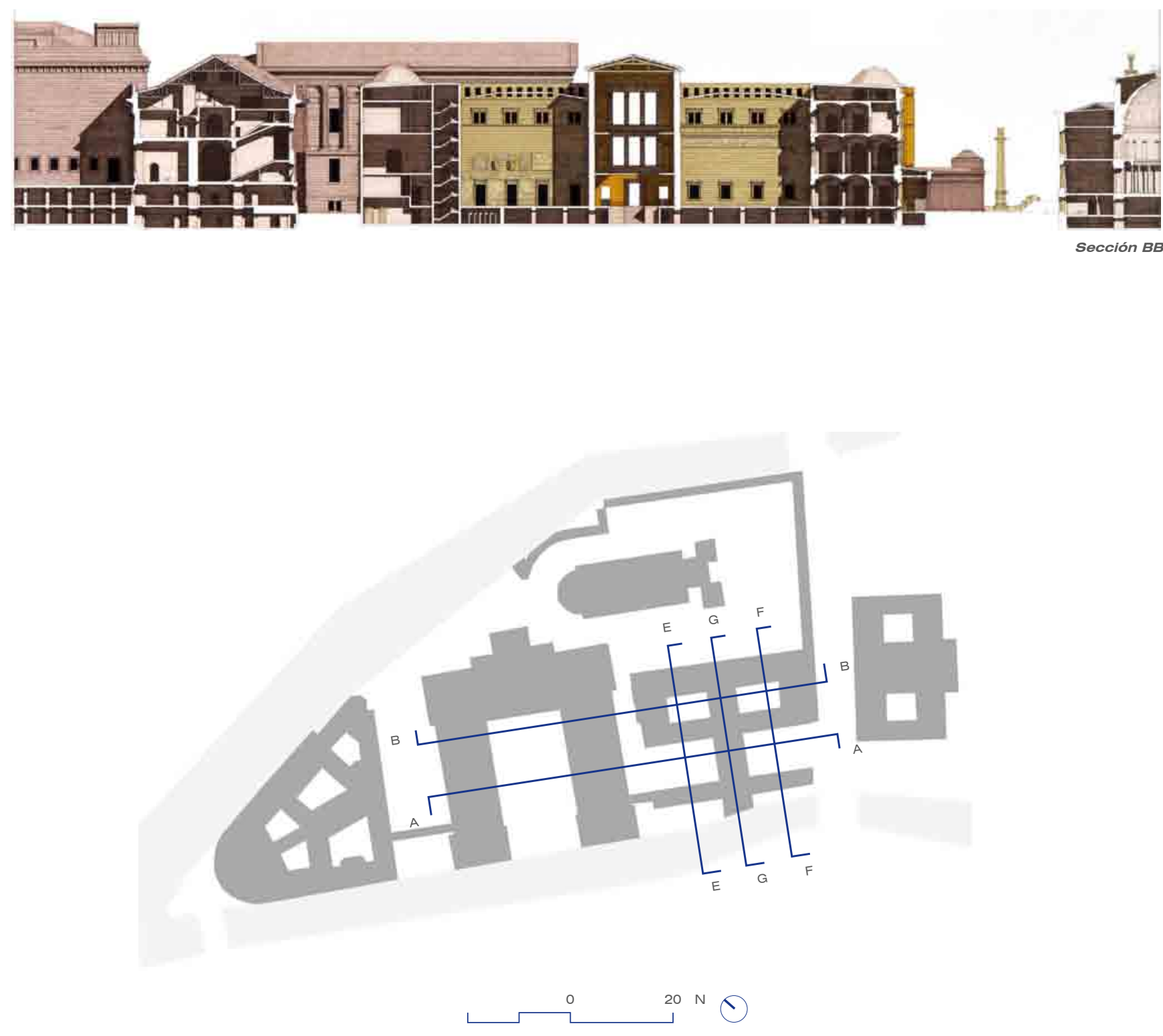


\section{El programa. Criterios organizativos. Recorridos}

Desde el punto de vista distributivo, el Neues Museum está destinado a contener parte del Museo Egipcio y todo el Museum für Vor-und Frühgeschichte. El acceso está previsto, como era, desde el Kolonnadenhof. El Museo Egipcio ocupará la planta baja y el sótano, mientras que el Museo de Prehistoria y el Museo de Historia Antigua se situarán en las plantas primera y segunda. La tercera planta está destinada a servicios generales, oficinas, etc. Al Museo de Prehistoria y el Museo de Historia Antigua se accede mediante la nueva escalera circular que se encuentra en la torre sudeste. A los diversos niveles y recorridos expositivos que se desarrollan en forma de $\mathrm{C}$ alrededor de los dos patios, se conectan entre ellos a través de galerías (de carácter funcional que sirven al Antiquarium mencionado) que, en todos los niveles, discurren a lo largo de los muros perimetrales del gran espacio de la escalera desaparecida. En la primera planta esta galería se ensancha sobre el atrio de entrada para ofrecer una zona de descanso de los visitantes, que puede, eventualmente, convertirse en una pequeña cafetería.

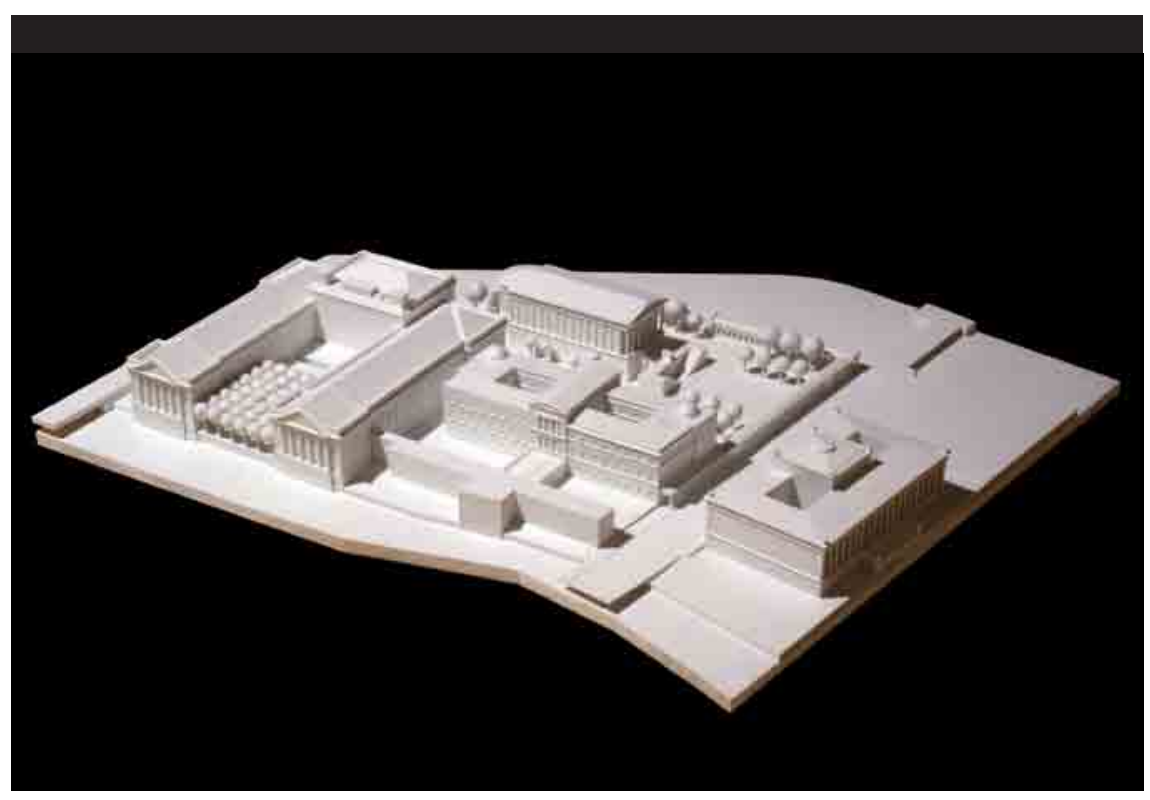




\section{El recorrido breve}

En el frente del nuevo edificio, ampliación del Neues Museum, que recae a la Bode Strasse se situará el acceso público para el Kurzrundgang o recorrido breve. A partir de el mismo, atravesando el "Templo Egipcio", el itinerario breve asciende al primer nivel donde se encuentra el busto de Nefertiti, y prosigue hacia el ala sur del Pergamon-Museum donde, tras atravesar la secuencia canónica "Calle de las Procesiones, Puerta de Ischtar, Puerta del mercado de Mileto, Altar de Pérgamo, Arquitectura Helenística y fachada de Mschatta", se desciende, de nuevo, a la planta baja $y$, atravesando el nuevo cuerpo que ocupa parcialmente el patio de honor (después de haber recorrido la zona de catálogo, lectura, cafetería, restaurante, etc.) retorna transitando en sentido inverso el nuevo edificio, al punto de partida sobre la Bode Strasse.

\begin{tabular}{lcc} 
ESTIMACIÓN DE SUPERFICIE \\
\hline & $\mathrm{m}^{2}$ & $\%$ \\
Superficie Expositiva total & 12005 & $\mathbf{6 5}$ \\
Superficie de Usos Públicos & 807 & $\mathbf{4}$ \\
Superficie de Usos Internos & 4690 & $\mathbf{2 3}$ \\
Circulaciones y Vestibulo & 1445 & $\mathbf{8}$ \\
Superficie Total & 18547 &
\end{tabular}

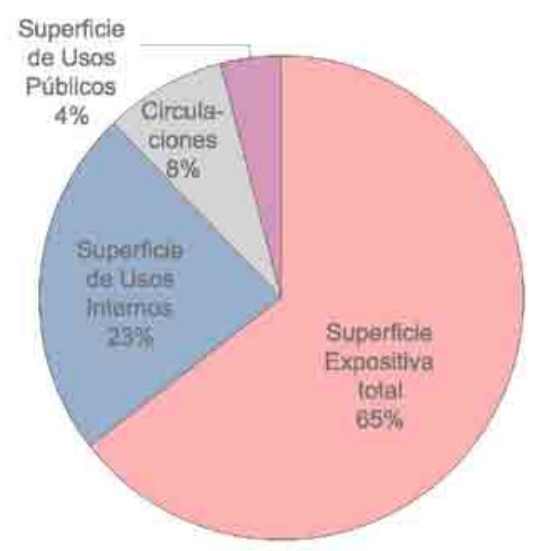



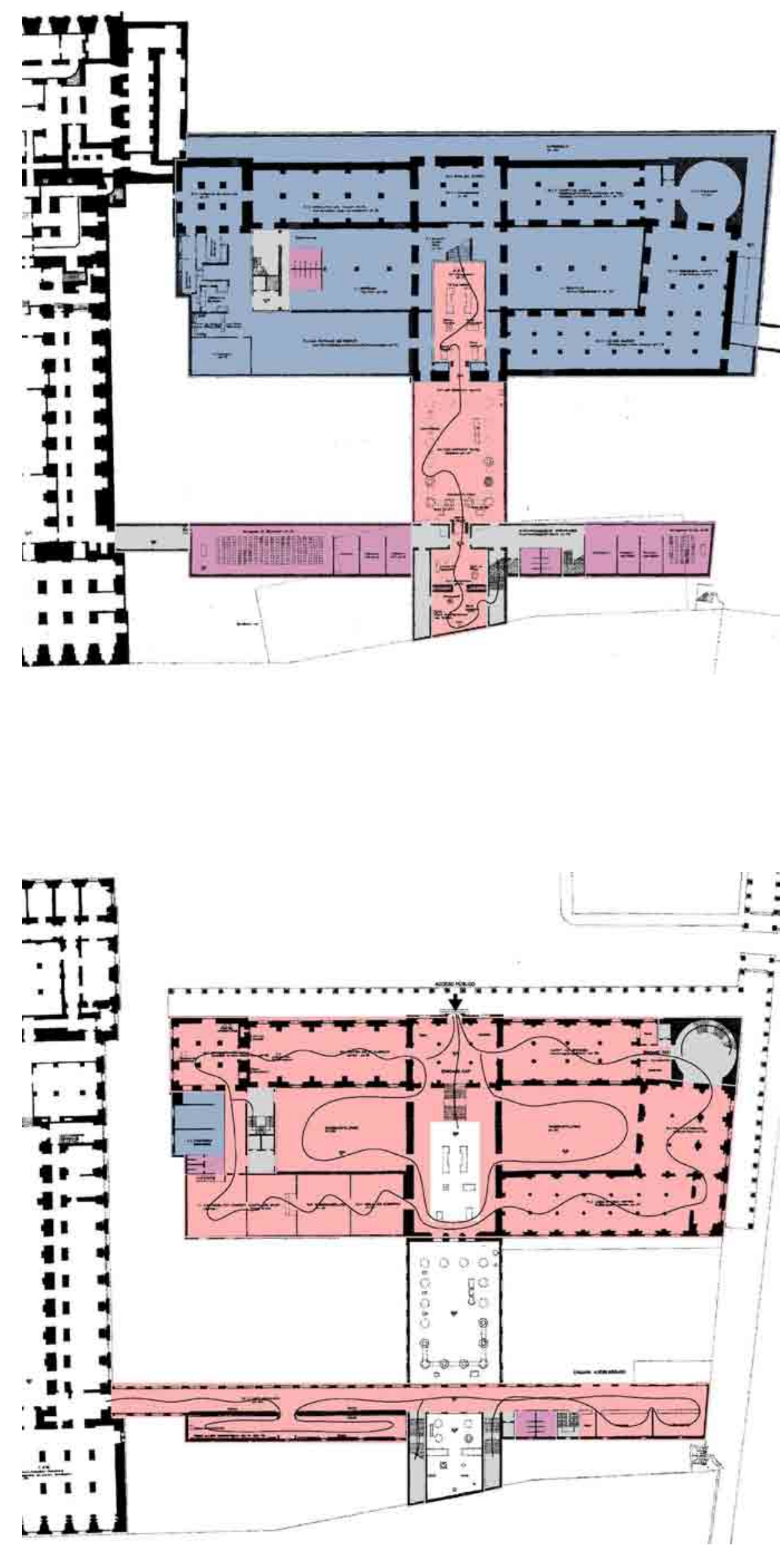

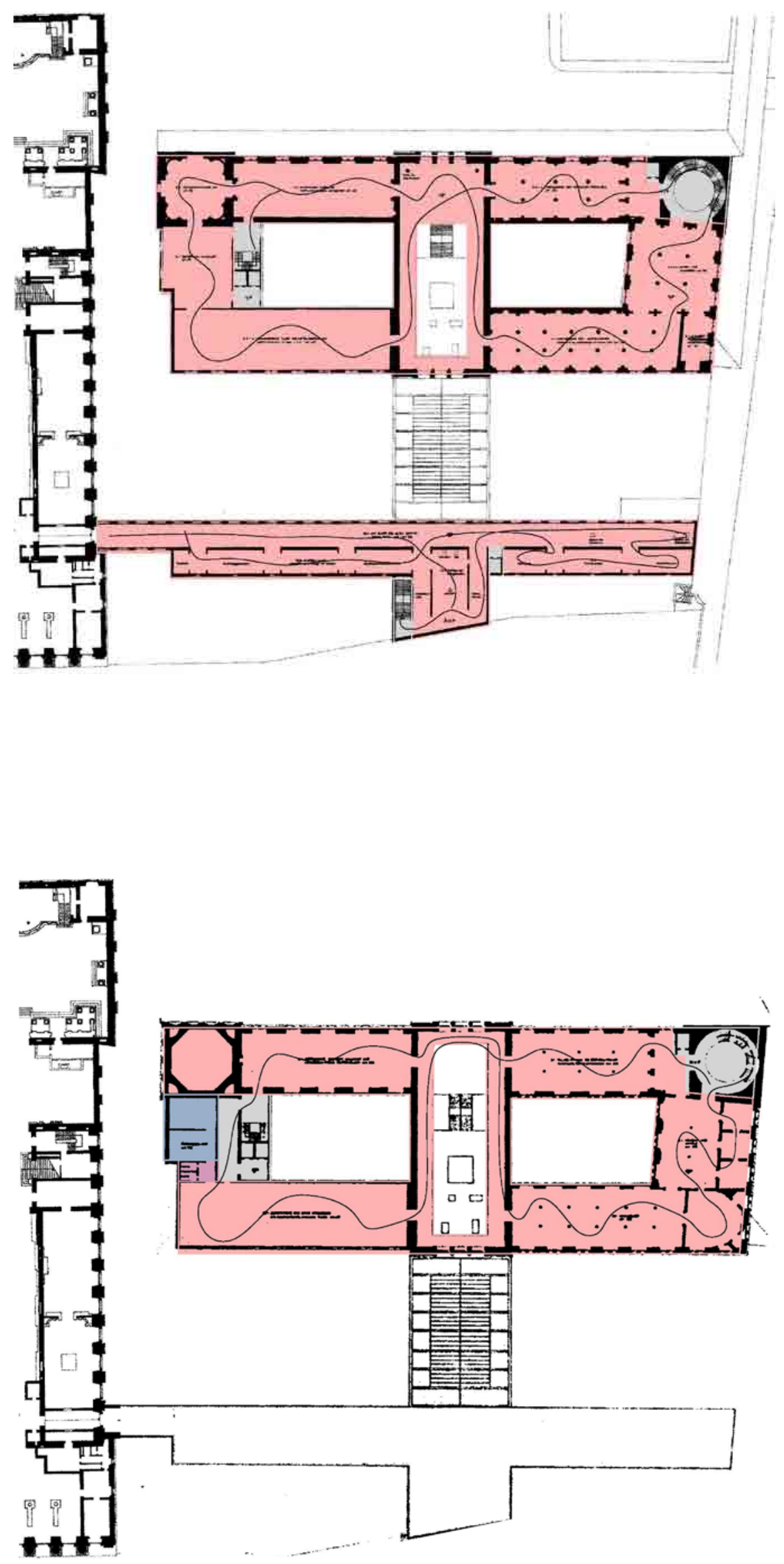

EXPOSICIONES

PERMANENTES

EXPOSICIONES

TEMPORALES

CIRCULACIÓN Y VESTÍBULOS

USOS PÚBLICOS

USOS INTERNOS 


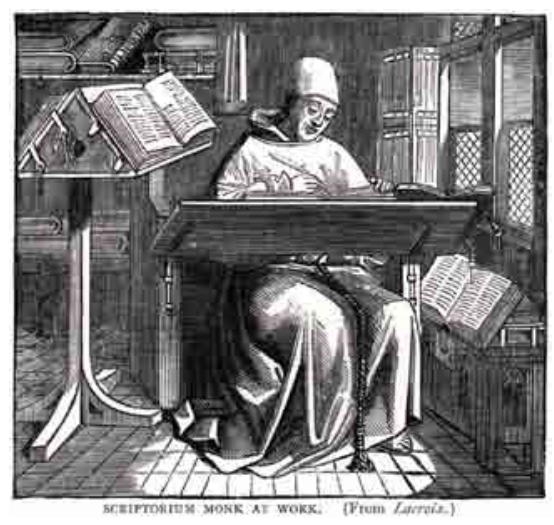

\section{NOTAS}

(1) Stüler, August, Das Neues Museum in Berlin, Berlin, Ed. Riedel, 1862

(2) Behne, Adolf, "L'isola del Museo, Una tragedia dell urbanistica di Berlino", en Grassi, Giorgio, Das Neue Frankfurt 1926-1931, Bari, Dedalo Libri, 1975, pp.312-314. 


\title{
4.5. MUSEO DE BELLAS ARTES SAN PÍO V
}

\author{
Valencia (1985-1996)
}

\subsubsection{Introducción}

El proyecto de rehabilitación y ampliación del Museo de Bellas Artes de San Pío V, realizado en colaboración con el arquitecto Álvaro Gómez-Ferrer, plantea como objetivo básico la dotación de unidad lógica al conjunto resultante de la intervención en las trazas originales del edificio, constituidas básicamente, por un cuerpo claustral, la antigua iglesia octogonal tangente a él y un bloque lineal adosado a uno de los lados del octógono, y la

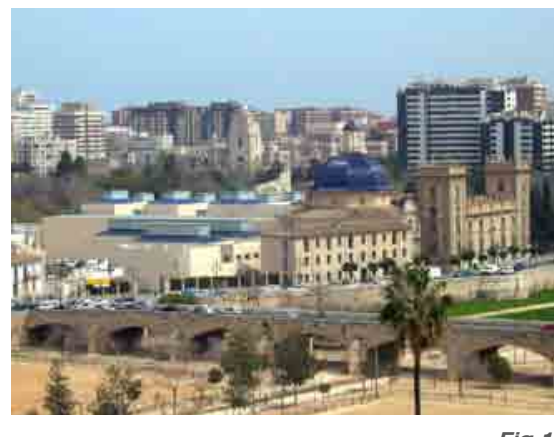
ampliación, que deberá proporcionar los espacios de exposición necesarios, así como los servicios propios de un museo, a partir de las reglas, las pautas, que del estudio y lectura del monumento se establecen, en el sentido en que habla Giorgio Grassi, en sus escritos, cuando plantea la necesidad del elemento o elementos que complementan al edificio histórico, de encontrar su base y justificación en éste, entendido como hecho físico, como construcción que la historia nos lega.

\subsubsection{Breve Historia del Edificio}

El inmueble ocupado en la actualidad por el museo San Pío $V$ fue construido entre 1683 y 1744 , según proyecto del arquitecto valenciano Juan Bautista Pérez Castiel, que también realizó algunas obras destacadas como el presbiterio de la 

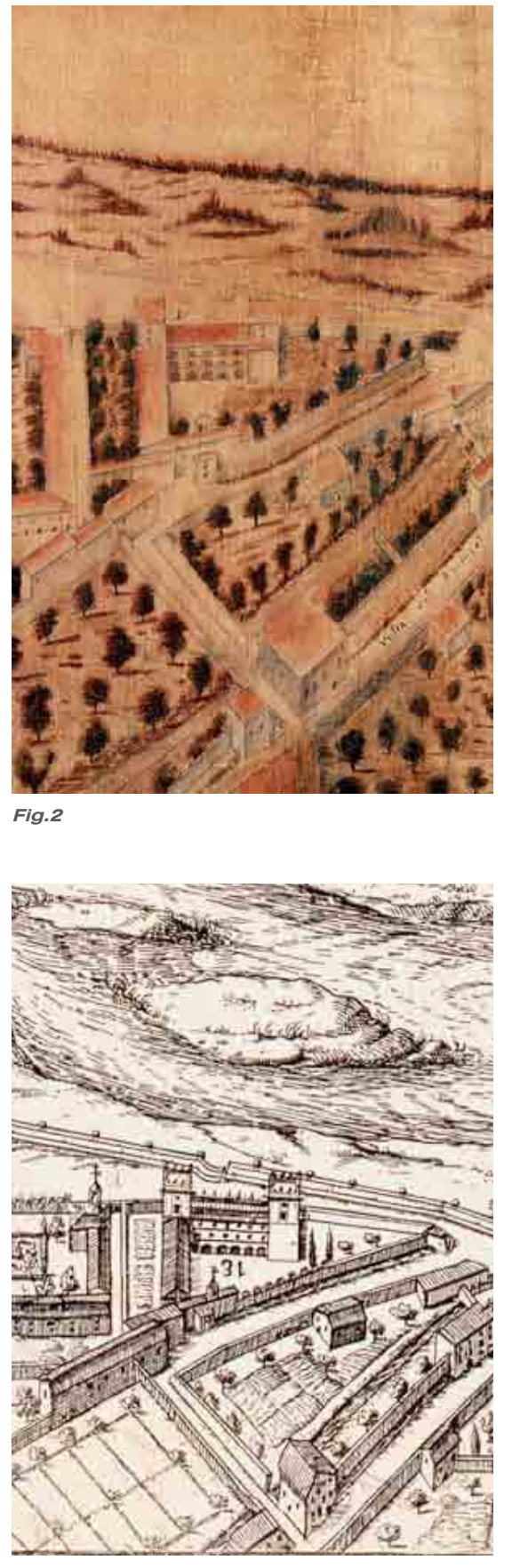

Fig.3. Grabado de Fortea (circa 1738)
Catedral, la decoración barroca de la Iglesia de San Nicolás, la torre de San Bartolomé y la fachada de la Iglesia de San Andrés, obras todas en Valencia, así como la Iglesia de Nuestra señora de la Asunción de Chelva.

En su origen, estuvo destinado a colegio seminario de clérigos menores. Fue levantado por iniciativa del arzobispo Juan Tomás de Rocaberti para residencia de "misionistas" y Colegio de Clérigos Menores. Esta fundación suscitó recelo y antipatía en amplios sectores eclesiásticos de la ciudad. Según Roca Traver, una de las más fuertes oposiciones que se dieron en la ciudad contra el establecimiento del Colegio de San Pío V fue aquella relativa a la facultad de éste de poseer una Iglesia con puerta abierta a la calle. (1) La parroquia del Salvador, cuya cercanía era la mayor del recinto, fue una de las más reticentes a dicho establecimiento, pues no deseaba perder prerrogativas, influencias ni fieles. Los pleitos con la parroquia del Salvador se alargaron hasta 1698; se firmó la concordia entre ambas partes el 7 de febrero de 1698 y felizmente se abrió la iglesia del colegio el 23 de febrero de 1698.

El inicio de la construcción se puede establecer en torno al 3 de diciembre de 1682, fecha en la que el arzobispo Fr. Juan Tomás de Rocabertí recibe de Carlos II licencia para fundar el Colegio.

Se supone que el Colegio comenzó su actividad en unas viviendas o dependencias existentes en el lugar que vinieron siendo sustituidas paulatinamente por una traza de carácter unitario y de mayor pretensión. Como afirma Roca Traver:

"Hasta dicho año de 1695 el Colegio, en proyecto, debía ser una mole de cuatro alas, con tres órdenes de ventanas, las bajas con rejas y las altas con balcones de hierro. En el momento que nos ocupa, de los cuatro cuerpos del edificio solamente estaba terminado precisamente el que daba frente al Palacio Real, cosa natural considerando que era la zona de respeto que más interesaba embellecer al constructor. Y en la esquina de esa ala, la que miraba al río, se había levantado ya una de las dos torres que había en proyecto. 
Sin embargo, el arzobispo Rocaberti mantenía ilusionados sus deseos, de forma que ya en aquella fecha de 1695 tenía enteramente terminados los cimientos de otro cuerpo de edificio, el que daba frente al mediodía, y levantada la fábrica hasta el primer piso".

Se puede concluir que entre 1683 y 1695 se debió edificar el ala oriental, y a la muerte de Pérez Castiel hacia 1708 el claustro tenía sus alas este y sur levantadas en sus tres niveles (Fig.2). El ala norte se debió construir posteriormente, pues existían edificios preexistentes a la instalación del Colegio que, suponemos, todavía eran funcionales. Por otra parte, el ala oeste se debió edificar junto a la iglesia, que debía tener acceso desde el deambulatorio del claustro en planta baja, tal y como hoy se muestra.

Juan Pérez y por José Minguez sucedieron a Juan Bautista Pérez Castiel. Éste último según algunos autores, era padre del primero y pudo ser su padre natural del segundo, del que pasaba por tío. El contrato con Minguez tiene fecha de 15 de agosto de 1728. José Minguez fue un importante arquitecto del XVIII valenciano, codificador formal del remate típico barroco de las torres campanario valencianas. (2) Al parecer, y según los contratos de obras reseñados por Roca Traver, la iglesia se debía comenzar desde la cimentación, razón por la cual se puede afirmar que es toda ella obra de Minguez, si bien la traza pudo ser heredada de Pérez Castiel. También habla Minguez de la portada del Colegio, que debía realizarse en piedra de Godella. Se supone que se refiere a la portada de la iglesia y no a la del ala Sur del Claustro, que adoleció históricamente de portada adecuada a su monumentalidad.

Según el citado contrato, la iglesia debía tener un atrio al parecer no se ejecutó- que alinearía su imafronte con el paramento de la fachada principal del Colegio. En 1744 estaba construida la iglesia y cerrado el espacio claustral. En fecha 16 de marzo de 1746 contrataron los Clérigos Menores con Hipólito Ravanals la realización de un retablo que nos hace pensar que la iglesia estaba ya terminada.

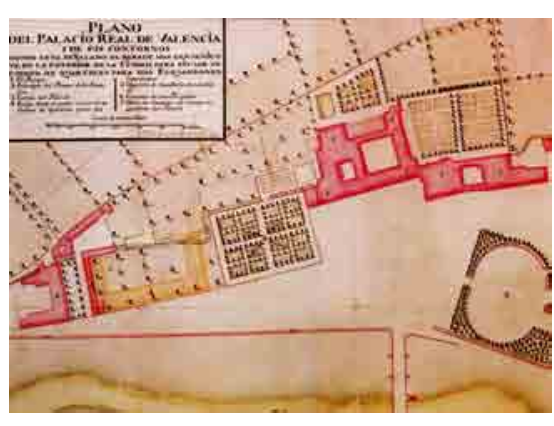

Fig.4. Plano de 1724

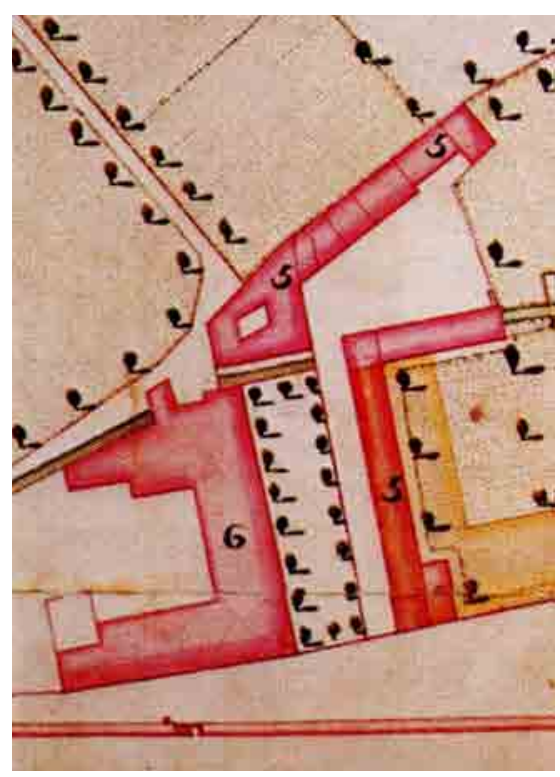

Fig.5 


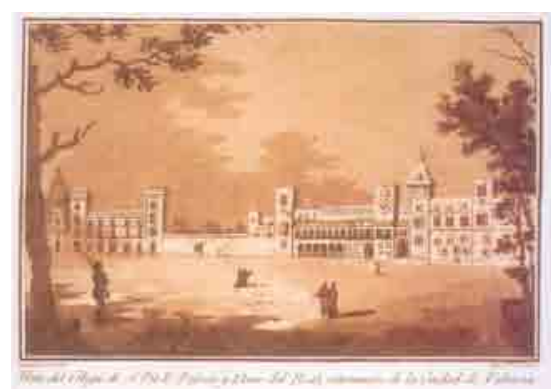

Fig.6

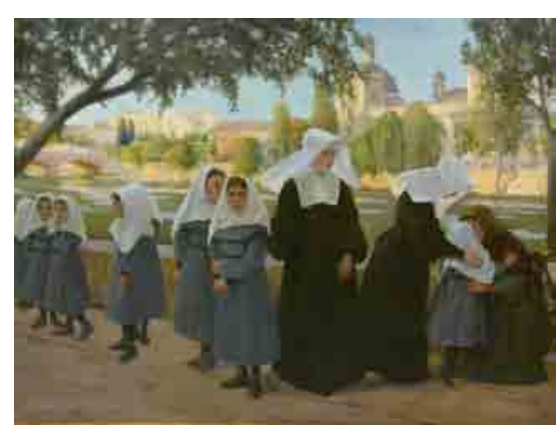

Fig. 7
Las trazas del conjunto sugieren que el proyecto era mucho más ambicioso que la obra realmente ejecutada; la precaria situación económica y los problemas surgidos con el clero de la ciudad imposibilitaron su total realización.

En fecha de 25 de marzo de 1758 encargan los Clérigos a Vicente Piñó, maestro de obras valenciano, para que eleve un proyecto y presupuesto de unas ciertas casas que pretenden levantar junto al templo del Real Colegio. Por el escaso presupuesto de contrata y por la ubicación debió de resultar una edificación modesta, que se podría identificar con el bloque lineal oeste.

En 1819 el edificio, prácticamente abandonado, fue convertido en Academia Militar de Cadetes por iniciativa del General Elío. Posteriormente, en 1820 se instaló la Casa de Beneficencia, y tras un breve período de pertenencia eclesiástica, en 1835 se desamortizó y pasó a ser propiedad del estado, que lo vinculó a usos militares hasta 1939: almacén militar de provisiones e incluso durante algunos períodos Hospital Militar.

En 1924, se ordenó la demolición del tambor y cúpula de la iglesia. De esta demolición permanecieron tres octavos del antiguo espacio octogonal, que restaron como enlace y paso cubierto entre el claustro y el edificio lineal, frente al río. Tras la guerra civil, adscrito al Ministerio de Educación Nacional, éste decide su conversión en Museo de Bellas Artes, anteriormente emplazado desde el siglo XIX en el Convento del Carmen. Los arquitectos Ricardo Macarrón, Francisco Mora y Javier Goerlich intervinieron en él entre 1940 y 1946, para lograr su adaptación al nuevo uso museístico. Fueron inauguradas las nuevas instalaciones el 3 de enero de 1946. (3)

Sucesivos proyectos parciales de reforma $y$ acondicionamiento se realizaron durante el período predemocrático. En 1947 se inauguraron las salas de escultura en planta baja y el 1948 lo fueron otras de pintura en el segundo piso. Una de las mayores intervenciones se produjo a instancias del gobernador Civil, Ramón Laporta, en torno a 1949. Se crearon varias salas, a modo de anexos al ala este del claustro, 
que recuperaban elementos arquitectónicos y pintura gótica, fundamentalmente procedentes de derribos de edificaciones antiguas. En 1950 se terminaron de abrir las galerías del segundo piso, dedicadas a pintura. En 1963 el arquitecto Francisco Javier Goerlich costeó la instalación de cuatro salas de exposición permanente, en la crujía sur de la segunda planta, en las que se exhibió la colección artística que él mismo donó al museo. Entre 1968 y 1973 se crearon salas de exposiciones temporales en la planta baja, y se reestructuraron las salas que estaban situadas en la zona que comunica el claustro con las salas de exposición permanente del ala norte - zona de acceso a la sala Laporta dedicadas a la exposición de obra de Ignacio Pinazo y Muñoz Degrain.

En 1984, en virtud del Convenio firmado entre la Administración del Estado y la Generalitat Valenciana, la gestión del Museo fue asumida por la Comunidad Autónoma y la rehabilitación del edificio por el Ministerio de Cultura, que me encargó la redacción del Proyecto "El Nou Museu Sant Pius V". (4) La operación de adecuación y ampliación del Museo se planificó en varias fases: la primera fase (1986-1991) financiada por el Ministerio de Cultura, permitió comprobar las limitaciones y posibilidades del bloque claustral y dotó al museo de un salón de actos en planta baja (para la Academia de Bellas artes) y de dos salas para exposición en las plantas superiores, integrado todo ello en el lado este del claustro. En una segunda fase (19901994) a cargo del Ministerio de Cultura, la restitución del espacio de la antigua iglesia lo convirtió en acceso principal del Museo que, siguiendo las directrices del aprobado Plan Director del nuevo museo, articulará el conjunto proyectado. La tercera fase (1995-1997), costeada por la Generalitat Valenciana, comprendió la rehabilitación del bloque lineal y el conjunto de las salas de exposiciones temporales y salón de actos alrededor del nuevo patio de escultura generado todo ello en el proyecto. En 1996, el Ministerio de Cultura aprueba el proyecto de la cuarta fase, que incluía la ampliación del museo y el resto del bloque claustral no incluido en la primera fase, que completa los requerimientos del

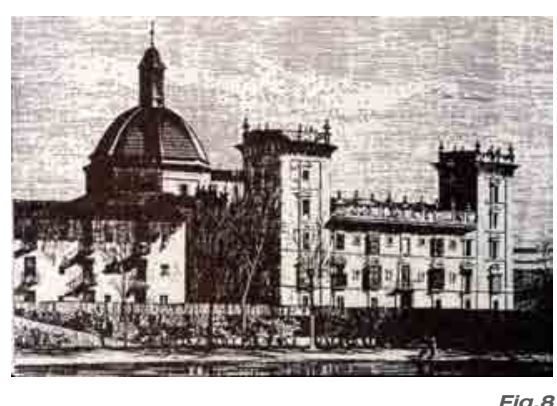

Fig.8

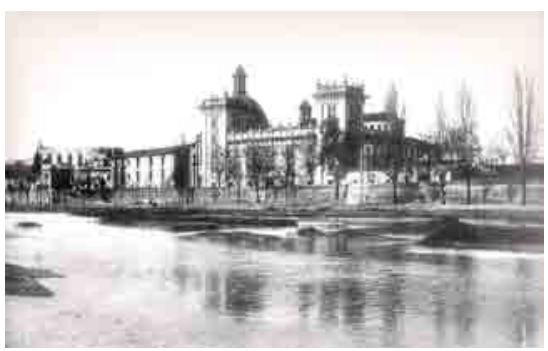

Fig.9

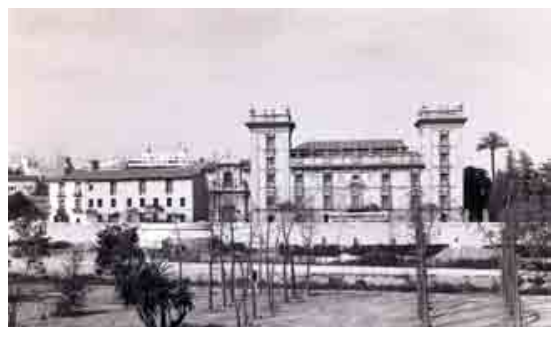

Fig. 10 
nuevo programa de museo. (5)

Tras la aprobación, la Ministra de Cultura, Esperanza Aguirre, me separó de la ejecución de la misma, rescindiéndome unilateralmente el contrato.

\subsubsection{El lugar}

La elección del solar extramuros y en la margen izquierda del río Turia para el primitivo Colegio de Misionistas parece haber sido consecuencia de diversas razones. Según Cruilles, (6) se ubicó en un origen en la plaza de Tetuán; la fuerte oposición del vecino convento de Dominicos terminó con la victoria de éstos y el desplazamiento del Colegio. Influyó seguramente la cercanía al Palacio Real en la decisión del arzobispo Rocabertí de comprar terrenos en el actual emplazamiento. Éste tenía además pozo y abastecimiento de agua, garantizado por la acequia de Mestalla, que permitía satisfacer las necesidades del Colegio y el cultivo de una huerta. Existen también noticias de la existencia de un molino vinculado al Colegio, hecho posibilitado por el curso de agua citado.

Situado en un llano (del Real) entre el puente del Real,

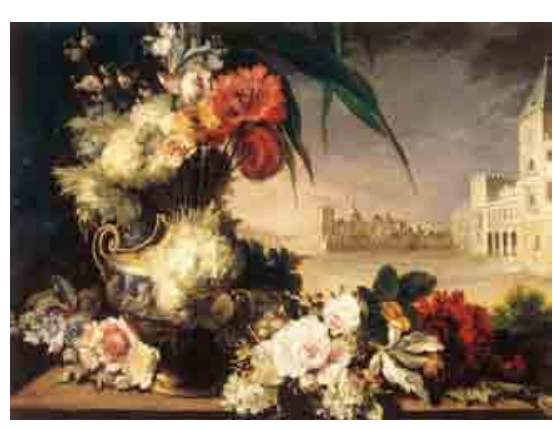
iniciado a finales del siglo XVI, y el puente de la Trinidad, que recibe su nombre del histórico convento de monjas franciscanas, este ámbito parece haber servido como lugar de esparcimiento ciudadano (llamado antiguamente "el Prado"), embrionario y predecesor del cercano paseo de la Alameda. (Fig.11 y Fig.12) El disfrute de los jardines, el festejo popular y el acontecimiento social dieciochesco que se produce en los paseos arbolados se concentraron en el área de influencia del Colegio de San Pío V.

El monasterio de religiosas franciscanas Clarisas de la Trinidad hunde sus orígenes en el siglo XIII. Ocupado por esta comunidad, durante el siglo XV fue un importante foco cultural y religioso de la ciudad de Valencia: Sor Isabel de Villena fue su primera abadesa. Destacan las depuradas líneas de su arquitectura y sobre todo la geometría de los contrafuertes de la iglesia, que emergen del muro de la nave la iglesia. La imagen 


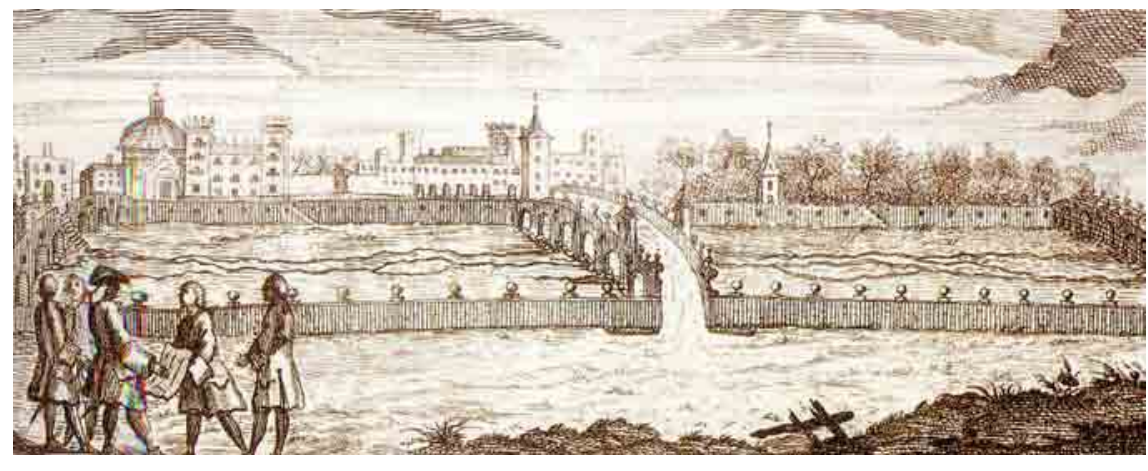

1762. Grabado de José Vergara

de los contrafuertes de las iglesias valencianas, presente en diversas parroquias, como la del Salvador entre otras, será sin duda fuente de inspiración formal del proyecto en las primeras trazas de la ampliación del Museo.

El Colegio de San Pío $V$ ha definido, con su fachada enmarcada por dos torres y con su cúpula azul vidriado, en conjunto con el Palacio Real y sus jardines, la silueta frente a la ciudad histórica y ha configurado de este modo una imagen emblemática representada en numerosos grabados y pinturas.

En el plano del Padre Tosca, de 1704, ya aparece el ala oeste y sur del claustro; falta la norte, que tampoco aparece en el grabado que Fortea realizó hacia 1738 en base al plano citado. Cabe resaltar que Fortea actualizó algunos edificios notables respecto al plano de Tosca: las torrecillas de la Alameda, la ciudadela, etc. ${ }^{(7)}$

De entre los grabados que reflejan la imagen norte de la ciudad, destaca y es quizá el más célebre, el que realizó Carlos Francia en 1762 (publicado en el libro de Fray Tomás Serrano), de la Naumaquia Real, celebrada en 1755, en cuya parte inferior aparecen enmarcadas las fachadas de ambos edificios. ${ }^{\left({ }^{8}\right)}$

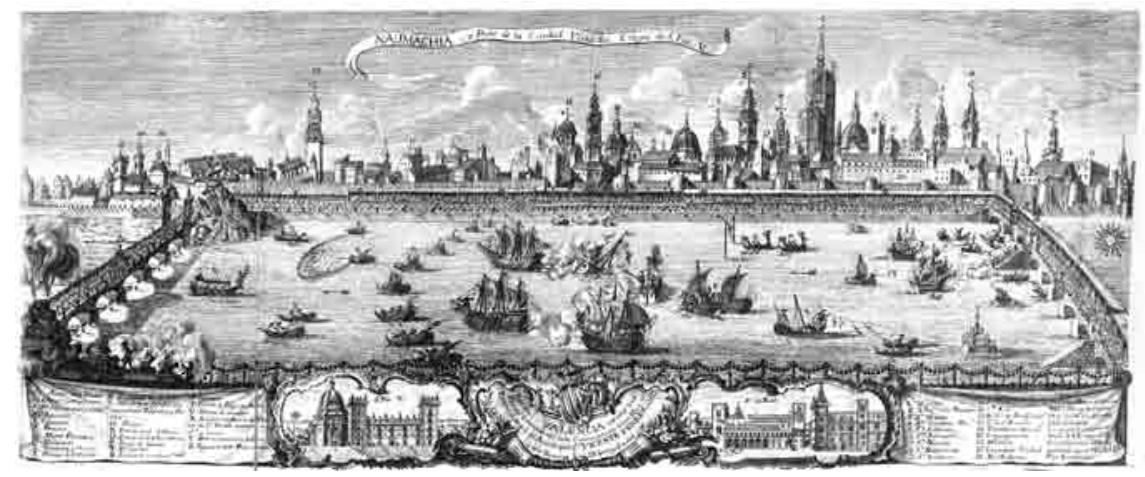

1755. Grabado de Carlos Francia 

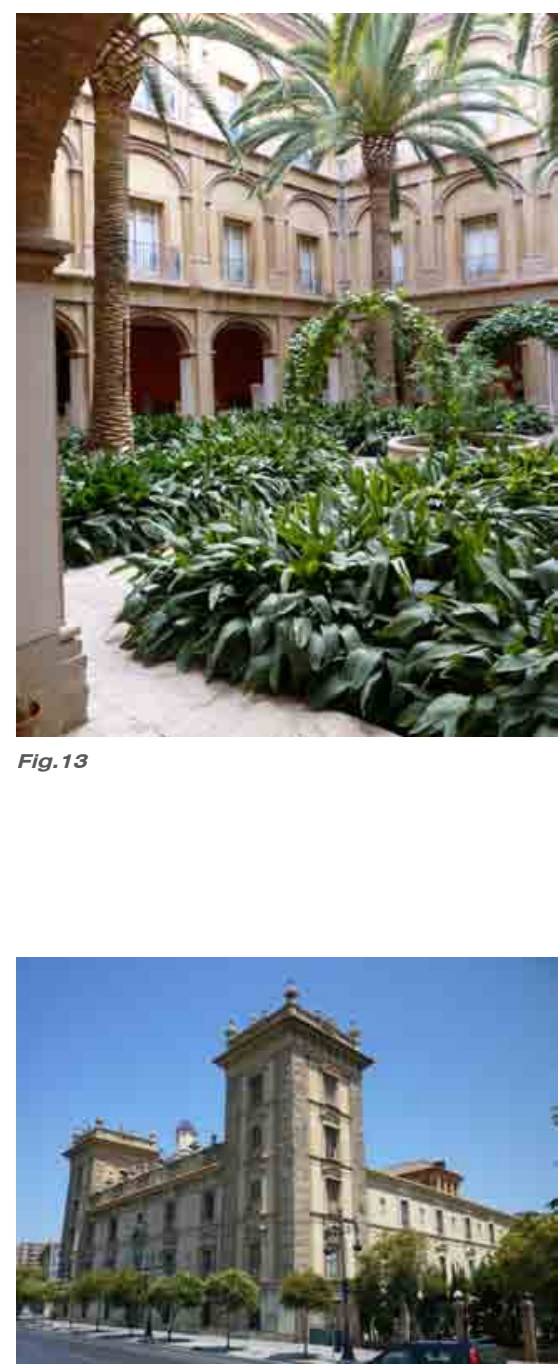

Fig. 14
4.5.4. Descripción del edificio. Estado anterior a la restitución

\subsubsection{Descripción general del edificio}

El edificio histórico del Museo de Bellas Artes se compone de cuatro cuerpos claramente diferenciados; el primero de ellos, un claustro con sus alas anexas que se distribuye en tres niveles; el segundo, una iglesia, en el flanco oeste del claustro, que se macla con su ala claustral correspondiente y posee acceso tanto desde el deambulatorio del claustro como desde el exterior; un bloque lineal oeste que parte de la iglesia y se dispone de forma paralela al antiguo cauce del río, también organizado en tres niveles; dependencias anexas en la parte norte de la parcela, añadidas, de carácter funcional y sin vinculación con las trazas de los cuerpos principales.

El claustro (Fig.13) posee cinco vanos por cada lado. En planta baja, sobre un basamento de piedra, se articula por medio de un orden simplificadísimo de pilastras con pedestal y sin capiteles. Tiene arcos rebajados realizados mediante una rosca de ladrillo aplantillado. Estos arcos se repiten en las plantas superiores y los vanos que definen están cegados y parcialmente perforados para la apertura de ventanas. Es destacable la fachada principal que recae al antiguo cauce del Turia y a la ciudad histórica (Fig.14), que corresponde al ala sur. Cronológicamente y en atención a la cartografía histórica, se debió erigir durante la dirección de Pérez Castiel. Se enmarca entre dos torreones y sigue así una tradición compositiva monumental presente en algunos ejemplos de la ciudad de Valencia: la antigua Casa de la Ciudad, el Palacio de Cerveró, entre otros. Las torres, enrasadas con el paramento de fachada, presentan sus esquinas almohadilladas, y se organizan en cuatro niveles iluminados por ventanas decoradas con frontones y molduras diversas. Los frontones se alternan en altura entre curvos y rectos. Se rematan las torres mediante una cornisa, soportada por canecillos, que culmina en un antepecho orlado de florones y bolas. Todo ello confiere a esta fachada una monumentalidad que enmascara la pobreza de medios de su 
construcción.

La iglesia, de planta central, responde a un octógono en planta. Tenía en origen deambulatorio cubierto con bóveda aristada y tribuna superior con balcones volados hacia el espacio de culto. El presbiterio estaba elevado respecto del nivel del suelo por medio de tres escalones, hoy desaparecidos, y su altura era mayor que la de las capillas del deambulatorio. El escudo del fundador, el arzobispo Rocaberti, que presidía el presbiterio, también ha desaparecido. Tres de sus lados se conservan de la construcción original, articulada en base a pilastras de orden corintio; los otros cinco-demolidos en 1924- fueron reconstruidos como lo fue la cúpula de teja vidriada azul.

La portada de la Iglesia ${ }^{(\text {Fig.15), }}$, realizada en piedra caliza, es notable. Un único vano de considerables dimensiones se halla enmarcado por dobles pilastras que recuerdan al dórico. Un proporcionado entablamento, con triglifos y metopas decoradas con motivos geométricos rectangulares, da paso a la cornisa que divide los dos cuerpos principales de la portada. En el superior, el vano que ilumina la tribuna de la planta primera también está flanqueado por dobles pilastras; éstas son de orden jónico, y de menores dimensiones que las inferiores. Se observa que la pilastra exterior del cuerpo superior está aplomada a eje de la pilastra interior del cuerpo inferior; este hecho confiere a la portada su característica composición piramidal, que se remata por medio de un frontón curvo, terminado en una cruz, que alberga el escudo del arzobispo Rocabertí, fundador del Colegio. La diferencia de dimensión entre el cuerpo bajo -de mayor anchura- y el alto se resuelve mediante la disposición de florones. Tiene esta portada un ineludible carácter vertical, suscitado por sus proporciones y por la disposición avanzada en ambos cuerpos, inferior y superior, de las pilastras de esquina; este avance se acusa en los entablamentos, cornisas y pedestales. Su parentesco con la portada de la Iglesia de Nuestra Señora de la Asunción de Foios, del mismo autor, es innegable.

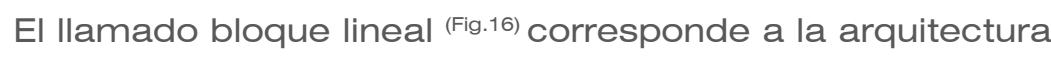
tradicional y popular de muros de carga, en la que en la
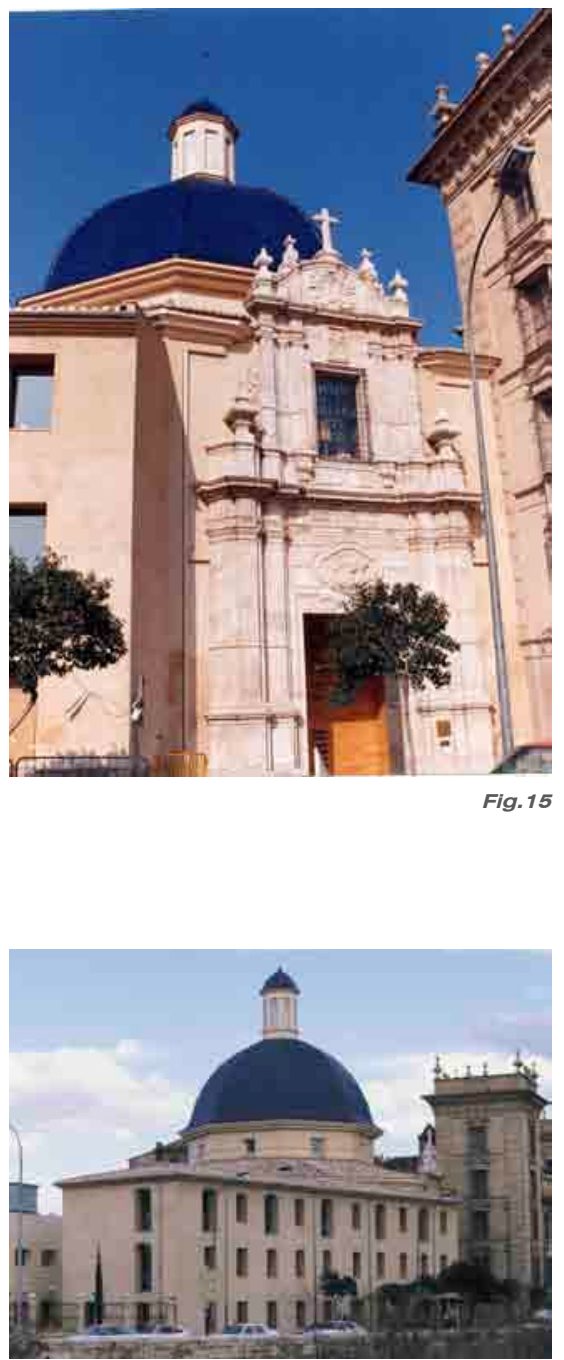

Fig. 16 
proporción hueco-macizo predomina claramente la masa frente al vano y que se halla desprovista de toda monumentalidad. La secuencia de huecos, gran ventanal con balcón y pequeña ventana, que se observa en la fachada del bloque puede indicar la ubicación de un tipo de celdas similares a las que encontramos en otros complejos conventuales como el de San Miguel de los Reyes, también en Valencia, y en algún otro ejemplo italiano. Las variaciones sufridas en su interior para su reutilización, no han permitido al respecto, confirmación alguna.

Otras dependencias auxiliares, originalmente alineadas con la acequia de Mestalla, se añaden a la construcción principal. Consideradas como cuerpos adventicios que alteraban la lectura de las trazas de sus elementos basilares, fueron eliminadas en proyecto. Durante la ejecución se alteró este planteamiento conservando parte del tanatorio del antiguo hospital, añadido que desfigura el trazado del bloque claustral y dejando una parte, el llamado Pabellón Benlliure, que en la actualidad persiste con carácter exento.

\subsubsection{El estado del edificio antes de la intervención}

El estado de deterioro en el que el edificio se encontraba en el año 1985 era, con carácter general, muy avanzado. (Fig.17) Su distribución e instalaciones eran claramente inadecuadas para cumplir con los criterios de exposición y conservación museográficos actuales: la obsolescencia de sus instalaciones; la falta de seguridad en caso de incendio; las dificultades de evacuación; las pésimas comunicaciones verticales -problema hoy agravado con la posterior introducción del Patio del Embajador Vich-; la falta de estanqueidad de parte de sus cubiertas que produjeron daños en las obras almacenadas y expuestas, etc.

La mala calidad de la construcción era generalizada. Parte de los muros de carga se habían realizado con una especie de tapial sin apenas cal que presentaba un estado avanzado de disgregación. Los forjados se hallaban en pésimo estado, con flechas excesivas. Sus elementos resistentes, de madera, no eran suficientes para resistir las cargas exigidas por la 
normativa en vigor. Las obras y reparaciones de la postguerra, fundamentalmente centradas en las cubiertas, estaban ejecutadas con una pobreza de medios ejemplar.

La Iglesia fue demolida inexplicablemente en torno a 1924. Parece ser que el motivo fue la aparición de fisuras en la cúpula, extremo no confirmado, aunque si podemos afirmar, tras las catas llevadas a cabo en el terreno previamente a la

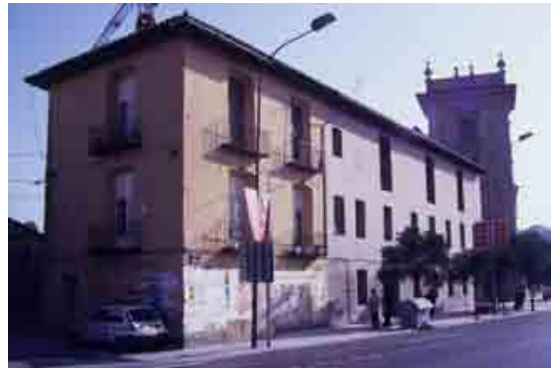

Fig. 18 ejecución de la restitución del volumen de la misma, la escasa calidad portante del subsuelo, a lo que cabe añadir los aportes de humedad debidos a la acequia colindante. (Fig.19)

Tras la demolición la antigua iglesia conservaba tres crujías, de las ocho originales, casi completas; en la más meridional de éstas se hallaba la magnífica portada, afortunadamente conservada. Restaba asimismo parte de sus muros de cerramiento y contrafuertes -interiores-, mientras que la cúpula había desaparecido. En parte del espacio central, se había levantado una pequeña capilla neogótica cuyo acceso estaba situado en el deambulatorio del claustro. El resto del espacio se utilizaba como almacén -al aire libre- y como garaje privado de los empleados del Museo. Las crujías conservadas servían de conexión cubierta entre el claustro y las dependencias del bloque lineal. (Fig.20)

El bloque lineal se hallaba fragmentado en cuanto a su propiedad (Fig.18); su extremo occidental se había enajenado del museo y constituía una residencia privada en las plantas altas y un legendario lugar de copas de la noche valenciana de los 80 en planta baja. El resto del edificio que conservaba su uso museístico albergaba el archivo y depósito de grabados de la Academia de San Carlos.

El acceso principal al Museo de Bellas Artes, con su iglesia y cúpula arruinadas y convertidas en garaje, se efectuaba a través de la puerta ubicada en fachada principal del Colegio. En la planta baja de este cuerpo y de parte de las restantes alas del claustro se encontraban diversas dependencias de la Academia $y$ en el brazo del antiguo tanatorio se depositaban fragmentos arquitectónicos, sepulcros y otros elementos de gran peso.

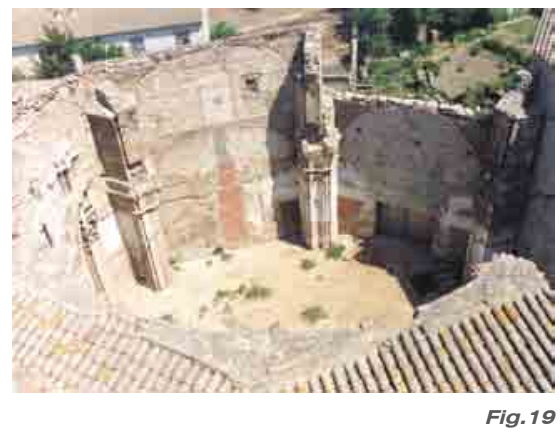

Fig. 19

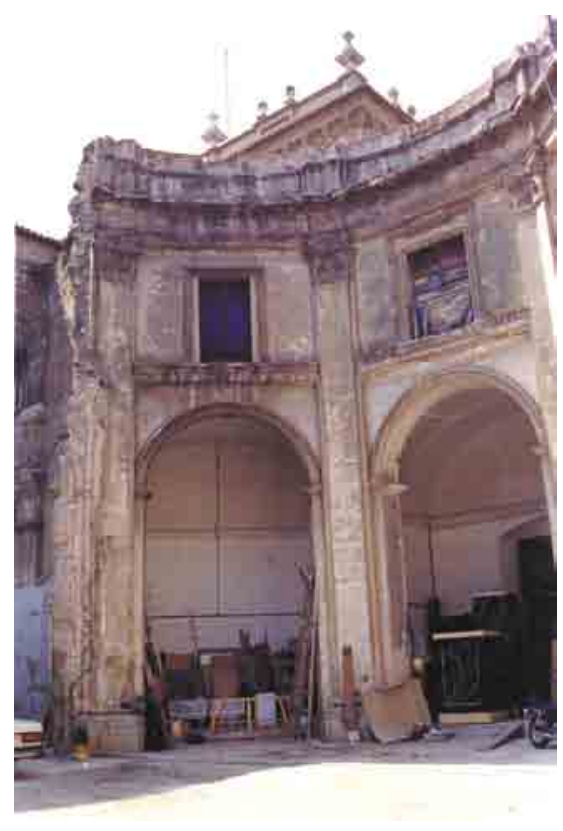




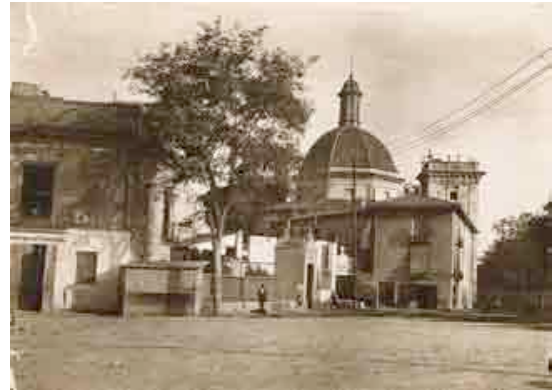

Fig. 21

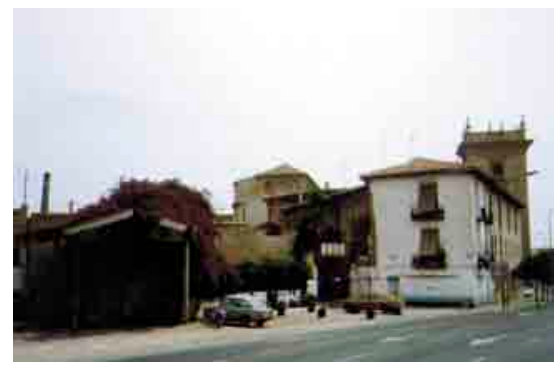

Fig.22

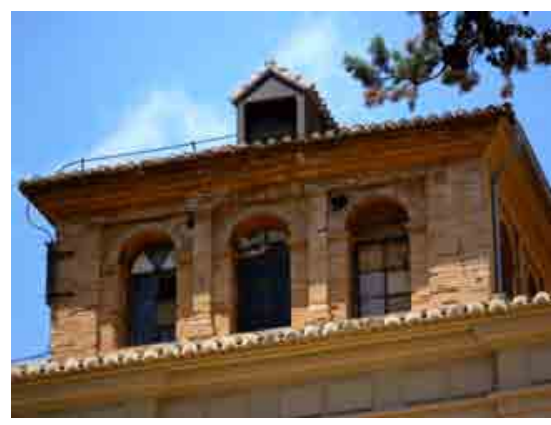

Fig.23

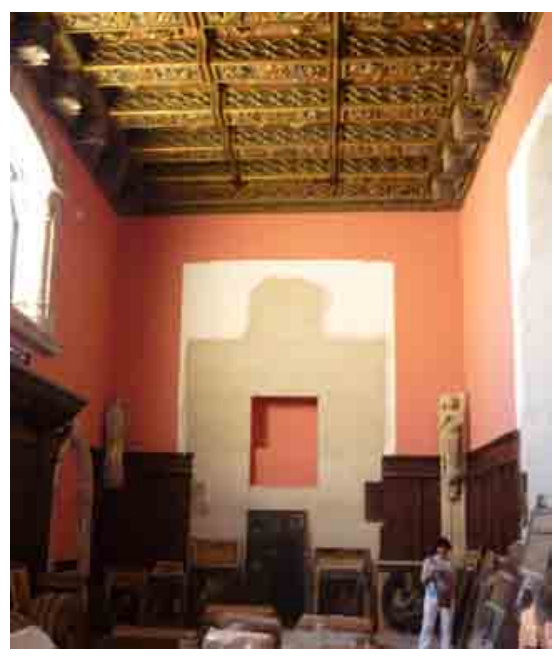

Fig.24

Las plantas superiores del claustro estaban destinadas a exposición permanente del museo. El corredor perimetral y las diversas crujías recibieron un mismo tratamiento en su fragmentación y conversión en pequeñas salas de exposición, cuya iluminación artificial consistía en tubos fluorescentes o en simples bombillas de incandescencia vistas y sin lámpara. En el espacio del Colosseo (Fig.23), en la crujía norte del claustro, estaba instalado cuadro del mismo título y que da nombre la sala; lienzo académico de considerables dimensiones, que permanecía en la única sala en la que tenía cabida. La intervención de postguerra había intentado uniformizar el aspecto de las salas, que poseían un cierto aire "estilo renacentista" muy desgastado y obsoleto. Es destacable la escasa altura libre de los niveles del edificio histórico, inadecuada para el tendido de las instalaciones necesarias y que supone una clara limitación de las posibilidades expositivas de sus espacios.

Las dos torres tenían una accesibilidad muy deficiente, representada por estrechas e incómodas escalerillas de madera. Carecían en muchos de los casos de carpintería de cierre, por lo que penetraba en su interior el viento y el sol. Se utilizaban como precarios almacenes de cuadros, en los que se depositaron muchos de los que se vieron afectados por la riada de 1957. Algunos de ellos todavía restaban colgados, "de forma provisional", de cuerdas tendidas entre paramentos, con lamentable resultado.

El conjunto de edificaciones que a lo largo del tiempo se adosaron al proyecto original desfiguraron sus trazas y originaron una confusa distribución de usos. En estas edificaciones auxiliares protuberantes se había acondicionado una serie de viviendas para operarios del Museo -que complicaron extraordinariamente la gestión del proceso de rehabilitación-, almacenes y oficinas, todo ello con gran desorden y ejemplo de provisionalidad. Fruto de las reformas llevadas a cabo tras la guerra civil, dichos edificios se enmascararon con montajes falsificadores, en los que un criterio ambientalista recreó espacios medievales (Fig.24) que conjugaban elementos originales con imitaciones que 


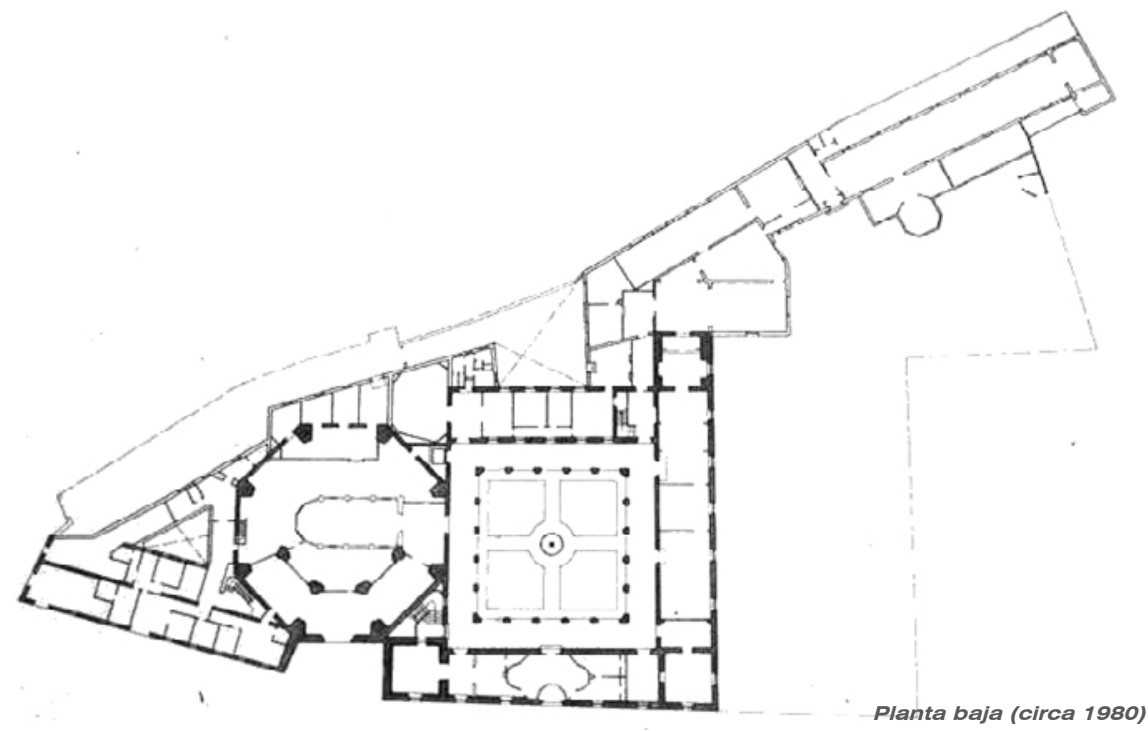

impedían distinguir lo uno de lo otro, con pavimentos hidráulicos y claraboyas "neogóticas" de escayola encerrados en tabiquillos de panderete que no prestaban la mínima protección ambiental exigida en cualquier edificio de este tipo. Por ejemplo, la sala Laporta, en planta primera, destinada a la exposición de los primitivos valencianos, había sido decorada en un ambiente medievalista, que mezclaba columnas góticas auténticas con copias de las mismas; el original artesonado, pretendidamente del período gótico, no superaba el $20 \%$ del total, que había sido reproducido y completado con carácter mimético. En su planta baja se exponían elementos arqueológicos de forma desordenada.

La primera intervención, que se centró en el ala del claustro que recae a viveros, en sus tres plantas, tuvo un carácter previo y de recopilación de datos del edificio, más propio del estudio del monumento que de su intervención (Fig.25). Importaba conocer la contracción del edificio, de su estructura -en pésimo estado-.

Se dispuso en planta baja, a petición de la Academia, un salón de actos, con un falso techo que asemejaba viguetas de madera y revoltones falsos e impropios. En la planta primera se retomó la idea desarrollada en el Museo de la CiudadPalacio del Marqués de Campo, en la que un lucernario de vidrio servía para dotar a las salas de una iluminación uniforme, reforzada por la posibilidad de instalar iluminación puntual en

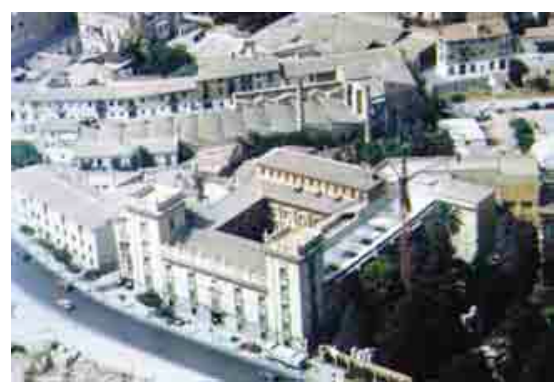


los carriles eléctricos perimetrales dispuestos para tal fin. En la planta superior segunda se eliminó el forjado plano existente y se recuperó un espacio idóneo para situar los retablos góticos con carácter provisional que, de haberse seguido el proyecto aprobado, se convertiría, posteriormente, en almacén visitable a modo de gabinete de pintura. Toda la intervención se dotó de una sofisticada (entonces) instalación de aire acondicionado a base de fancoils que controlaban temperatura y humedad; las limitaciones dimensionales y estructurales del edificio no permitían otro tipo de instalación que resultó carísima y de durabilidad reducidísima ante la ausencia de mantenimiento.

Las carencias funcionales eran numerosísimas: faltaban espacios de almacén, taller de restauración, salas de exposición temporal, salas de descanso, oficinas, biblioteca, tienda y cafetería, etc. Definitivamente, el Museo de San Pío V necesitaba una profunda intervención que pusiera en valor los elementos notables del monumento a la vez que generara las nuevas instalaciones museísticas adecuadas para sus cometidos.

\subsubsection{Objetivos de la intervención}

El proyecto de rehabilitación y ampliación del Museo de Bellas Artes de San Pío V, plantea como objetivo básico dotar de unidad lógica al conjunto resultante de la intervención en las trazas originales del edificio y la ampliación, que deberá proporcionar los espacios de exposición necesarios así como los servicios propios de un museo, a partir de las reglas, las pautas que del estudio y lectura del monumento se establecen.

La rehabilitación del edificio original, la reconstrucción de la cúpula de su iglesia octogonal y de su espacio resultante por su significación como núcleo del nuevo museo (para recuperar la imagen urbana desde el S. XVIII reflejada en multitud de grabados de la Ciudad, como el celebérrimo grabado de la Naumaquia de Carlos Francia) (Fig.26), junto a la ordenación del entorno, son importantes premisas de la actuación. La atención al entorno se considera también primordial, en una zona rica en vestigios del pasado valenciano, como los pretiles y puentes históricos del 


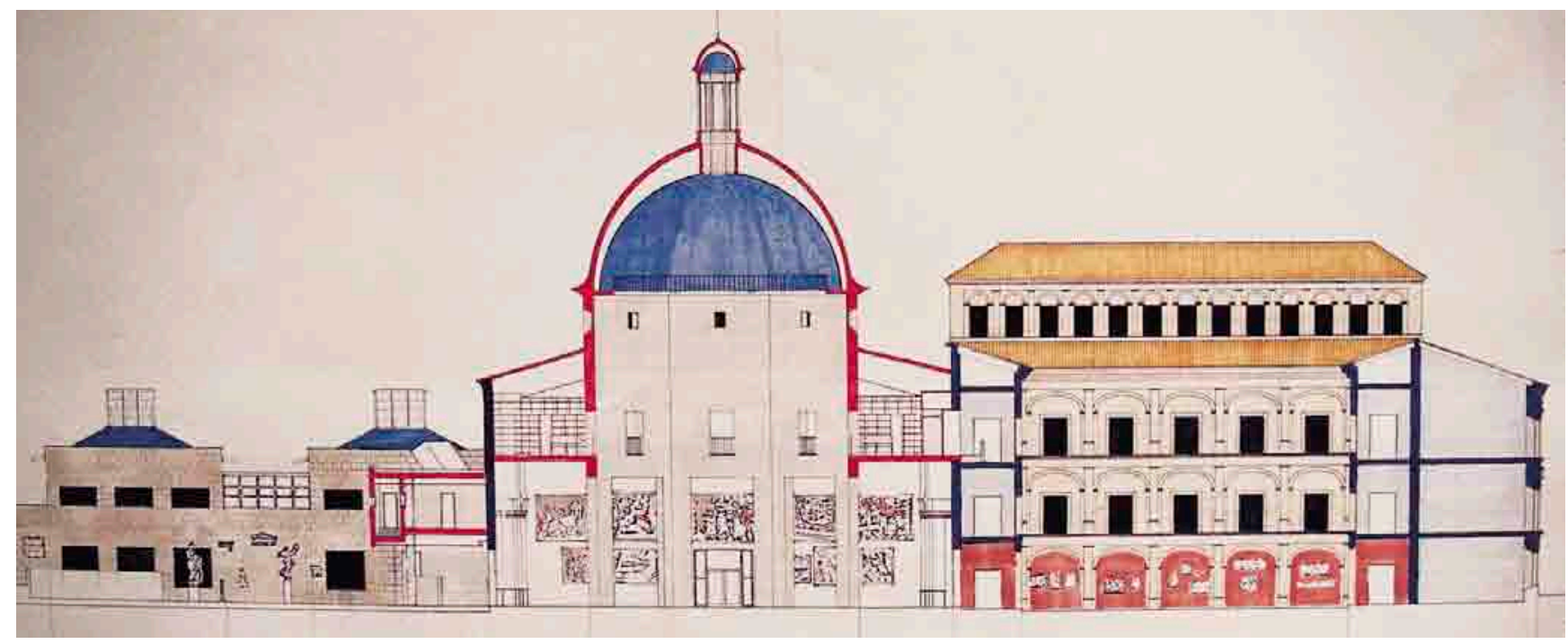

viejo cauce del Turia, el vecino convento de la Trinidad así como los antiguos Jardines del Real.

La restitución del espacio abovedado de la antigua iglesia en el punto donde se cruzan los ejes ordenadores de la rehabilitación, inicia dicho proceso con una intervención decidida para restablecer la imagen visual del antiguo convento de San Pío V, a la vez que sirve para dotar al nuevo Museo de un gran espacio de acogida que funciona a la vez como vestíbulo y como lugar de exposición de ciertas obras de considerables dimensiones y menor interés artístico producto, en general, de aportaciones de los Prix de Rome. Destino que no se llevó a cabo dedicando el espacio a exposiciones cuya visita se superponía a las circulaciones propias del acceso del museo, lo que muestra la ausencia de comprensión del gran espacio de acogida creado a tono con las necesidades del nuevo museo y la importancia de la colección que atesora. Inercia del provinciano museo que no interiorizaba las exigencias actuales del mismo en una añoranza de sus fragmentadas y polvorientas salitas.

Fundamental es la recuperación de la traza primigenia del proyecto. Para ello, se procedió a la liberación del conjunto de edificaciones que a lo largo del tiempo se adosaron -con carácter parcial y anómalo- al originario proyecto iniciado en el S. XVIII por Juan Bautista Pérez y continuado tras su muerte por Josep Minguez. Estas construcciones desfiguraron las trazas 


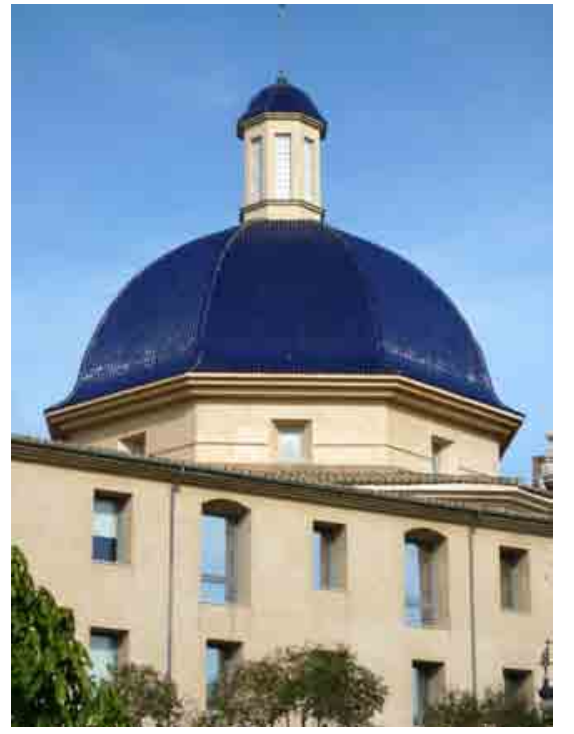

Fig. 27

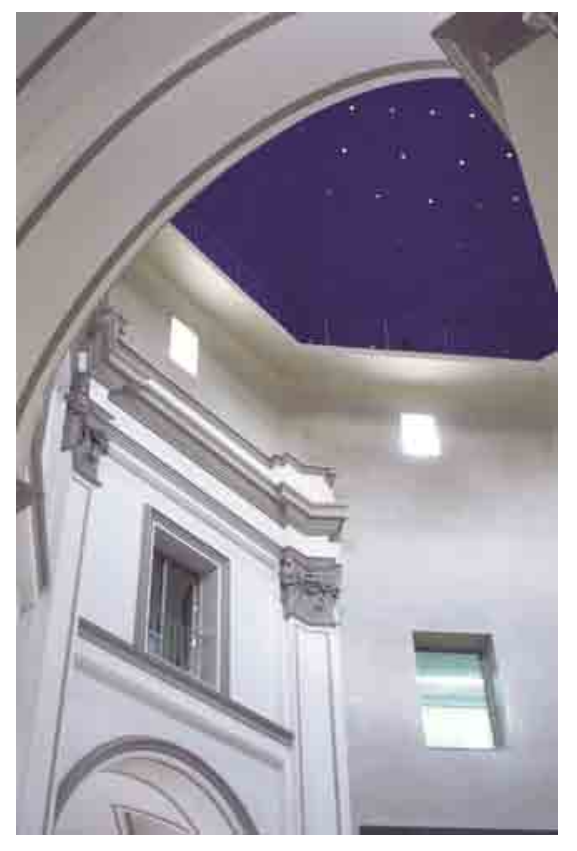

originales de aquel proyecto, sin más orden que el límite que establecía el trazado de la acequia de Mestalla, dando lugar a una confusa aglomeración de elementos que impedían su lectura y dificultaban la conveniente adecuación del edificio a los requerimientos actuales de un museo.

Todo ello se ejecutó con pleno respeto de uno de los condicionantes que ha existido siempre: el deseo de compatibilizar la situación de museo abierto al público, con las diferentes fases de las obras.

La rehabilitación de los elementos históricos y la ampliación ordenada del edificio, hasta conseguir un espacio adecuado para el museo, son los dos apartados claramente diferenciados en que se desarrolla la propuesta. Entre la diversidad y la semejanza de ambas partes, lo antiguo y lo nuevo, se tratará de establecer la relación que debe dar unidad al conjunto.

\subsubsection{Criterios de intervención}

Las pautas seguidas en este proyecto de intervención responden a una actitud clara y contundente expresada por el profesor Giorgio Grassi en coherencia con sus escritos. En ellos se recurre a una lectura actualizada de aquel escuchar al edificio de Viollet le Duc, en la que no se trata tanto el completar según una supuesta lógica estilística como el plantear la intervención a partir del conocimiento del edificio, como hecho físico, como artefacto cuya lectura establece unas formas de actuación.

Las trazas, los elementos existentes, sus sistemas constructivos, volúmenes y dimensiones establecen la pauta, mediante un proceso analógico, en la operación de intervención que plantea el proyecto. El análisis formal de este conjunto, la fragmentación y variedad de los elementos que lo integran, la dimensión de las salas resultantes alrededor del claustro, la altura de cornisa de este volumen y de la iglesia, así como sus respectivas técnicas constructivas, proporcionan los parámetros de partida para el proyecto de ampliación.

A estos factores hay que añadir, además de la necesaria lectura y evolución histórica del conjunto, su relación con la 
ciudad, la imagen urbana que definía históricamente el margen izquierdo del río y cuya restitución se considera. Se conforman así las claves de interpretación y articulación de la propuesta.

Una primera decisión clave es la restitución del espacio definido por la cúpula (Fig.27 y Fig.28), que se restituye tanto por ser el núcleo del nuevo museo como su por significación urbana. Cesare Brandi en su Teoría de la restauración nos decía que, en el momento en que los elementos desaparecidos hayan sido monumentos en sí, el ambiente deberá ser reconstruido en base a los datos espaciales, no a los formales, del monumento desaparecido. Así se debía reconstruir un campanario en San Marco, pero no el campanario caído; se debía reconstruir un puente en la Santísima Trinidad, pero no el puente de Ammanati. A los ejemplos citados podemos añadir la reconstrucción del Palacio de los Sforza en Milán, incluida la "licencia” que se permite Beltrami con la reconstrucción de la torre del Filarete. En conclusión: la restitución del papel urbano de la cúpula era una acción decisiva. (9)

Con respecto al claustro y al bloque lineal, la eliminación de las partes adventicias y la recuperación de sus trazas originales constituyen la base de la intervención.

Como hemos visto, el conjunto edilicio originario está formado por la adición de distintos cuerpos: bloque claustral, iglesia octogonal y edificio lineal. La ampliación se ordena, consecuentemente, a partir de un mismo sistema aditivo.

Se plantea la ampliación del Museo mediante un esquema aditivo de partes reconocibles y diferenciadas, que se concibe de forma análoga al procedimiento histórico. Cuadrado, octógono y rectángulo, tres figuras plenamente reconocibles y con entidad propia, formaron el conjunto primigenio resultado de su adición. La nueva propuesta se alinea con este criterio de composición y hunde sus raíces formales en la apreciación de la arquitectura histórica de la ciudad, esencialmente en aquella que se caracteriza por la masividad de sus muros y por el ritmo que le confieren sus contrafuertes, que emergen de los mismos y pautan su lectura.

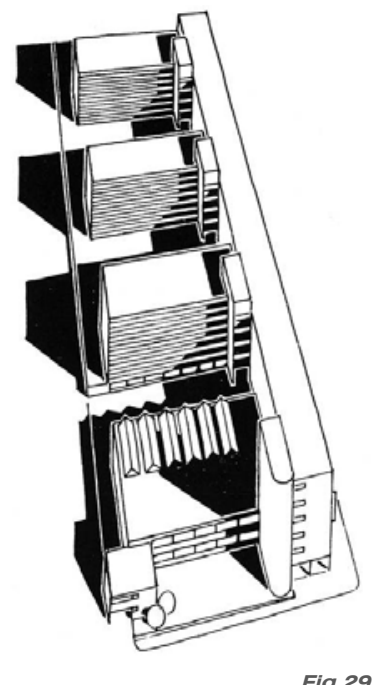

Fig.29

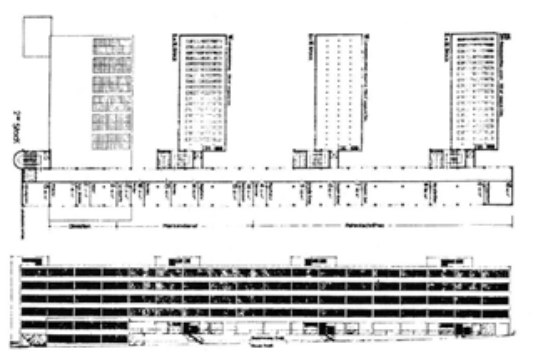


La tipología en peine, que tan buenos resultados ha aportado en la arquitectura del siglo XX a la resolución de proyectos de uso público, es la escogida como base de la ampliación. Baste recordar la propuesta de Hans Schmidt y Paul Artaria para el concurso de la biblioteca cantonal de Berna, en 1927. (Fig. 29 y Fig.30)

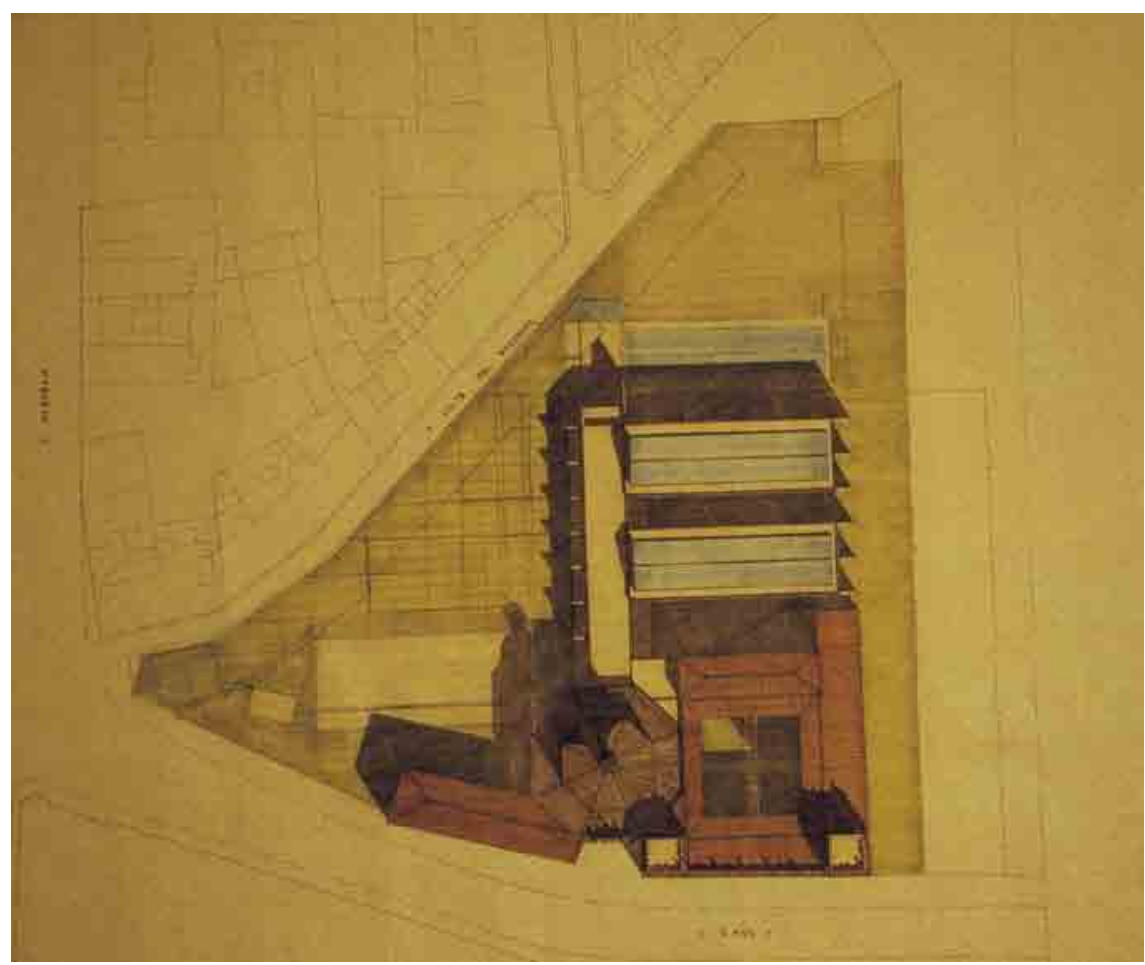

Primera versión del proyecto. Peine con dos brazos.

\subsubsection{Antecedentes del proyecto}

Se han expuesto los criterios de intervención en la rehabilitación y ampliación del Museo de Bellas Artes de Valencia, denominado incongruentemente de San Pio V, dado el dudoso interés por el arte del citado papa.

En cuanto a la formulación del proyecto que comentamos, aprobado por el Ministerio de Cultura en 1996, considero de interés hacer una breve síntesis de las propuestas que llevé a cabo con anterioridad y que tras sucesivas modificaciones y ampliaciones fraguaron en el citado proyecto.

Apenas iniciada la primera fase que a modo de "auscultación" previa del viejo edificio se lleva a cabo en el ala este del claustro, se perfila la definición del programa por parte del crítico e historiador Tomás Llorens, a la sazón Director General de Patrimonio de nuestro recién recuperado 


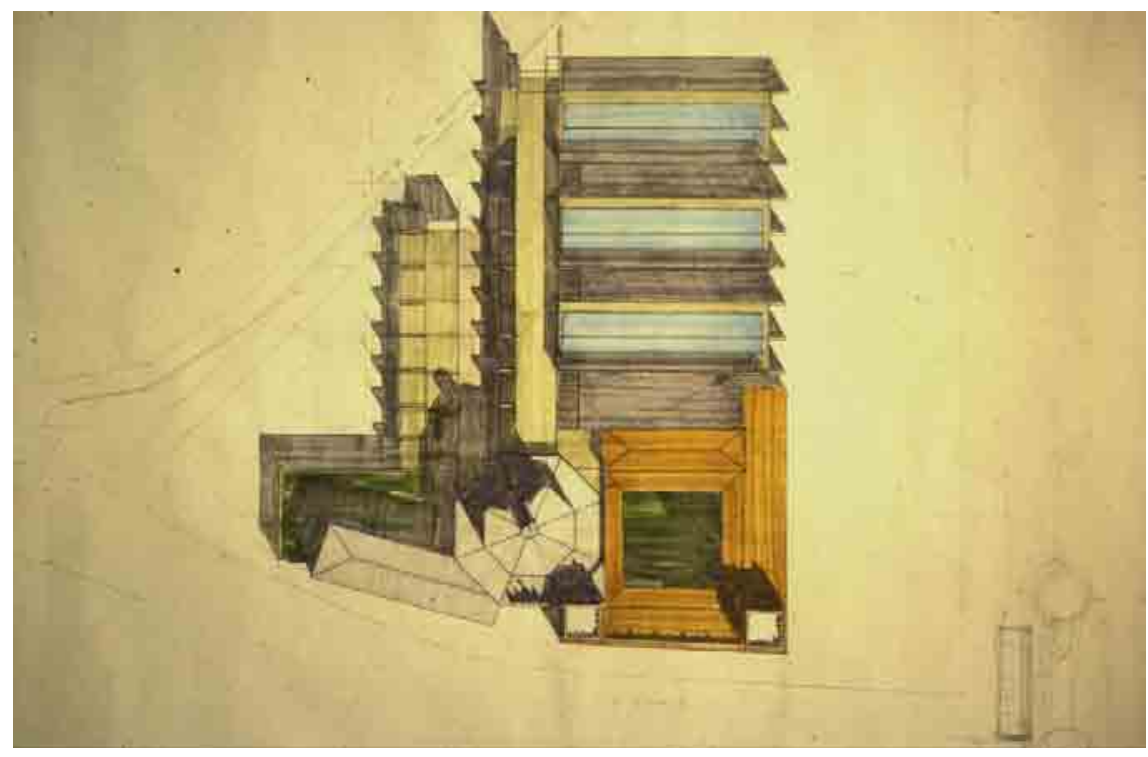

Segunda versión del proyecto. Peine con tres brazos.

gobierno autonómico, y del arquitecto Dionisio Hernández-Gil, correspondiente autoridad del Ministerio.

La primera propuesta se apoya en los criterios básicos expuestos que podemos sintetizar brevemente:

Eliminadas las construcciones adventicias que impiden la lectura de las trazas originales del conjunto, se propone recuperar la imagen urbana de la margen izquierda del rio Turia mediante la restitución del espacio definido por la cúpula de la antigua iglesia octogonal y la conversión del mismo en espacio de acogida del nuevo museo.

Los ejes, el longitudinal en el sentido del nuevo acceso y el transversal que enlaza con el bloque claustral, organizan la intervención.

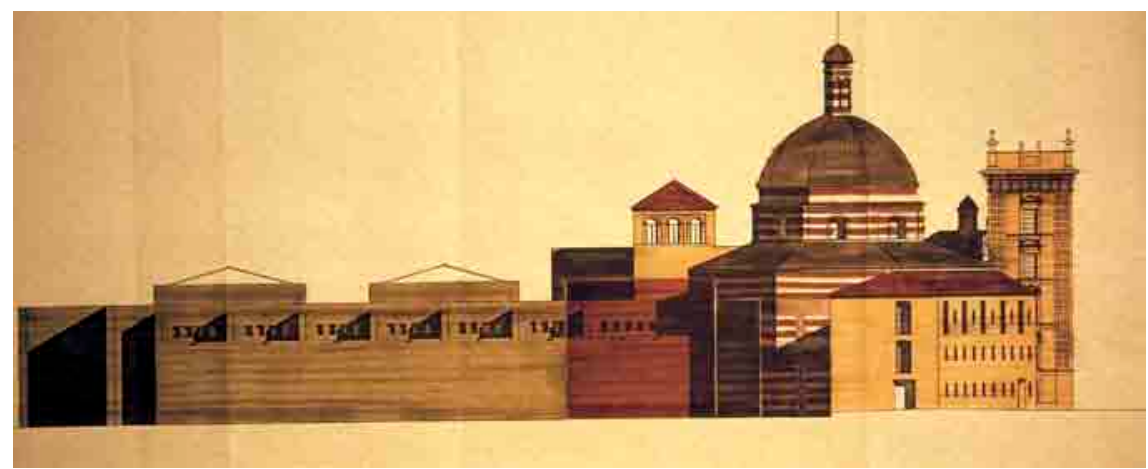

Primera versión del proyecto. Boceto del alzado oeste del conjunto del Nuevo Museo de San Pio V. 


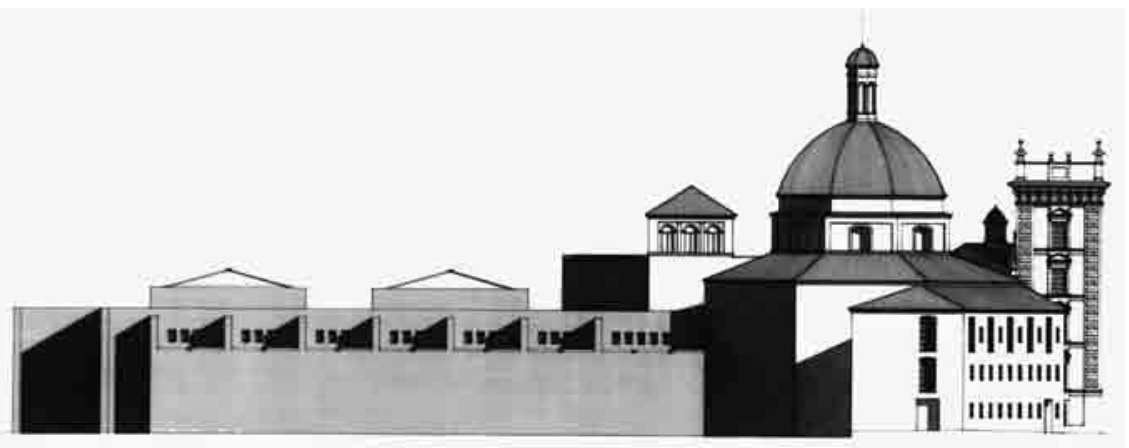

Primera versión del proyecto. Alzado oeste del conjunto del Nuevo Museo de San Pio V.

Desde el nuevo vestíbulo y en el sentido del primer eje se plantea la ampliación, a partir de la figura aditiva ejemplificada en la propuesta de Hans Schmidt. El eje principal, de anchura igual a la del lado del octógono del que arranca, se desarrolla a doble altura con el único límite físico que establece la parcela donde se ubica el conjunto. Perpendicular a él, a modo de peine, dos brazos, de la misma anchura, se desarrollan a dos niveles estableciendo la planta baja para usos internos del museo y la superior, dotada de luz cenital, producto de elementales lucernarios con cubierta a dos aguas, para usos expositivos. El recorrido es el mismo que perdurará hasta la propuesta final aprobada. (Fig.31)

En su formalización, la nave central mira las arquitecturas eclesiales que desde la toma de la ciudad por Jaime I, integran lo que se ha denominado iglesias de nueva planta, el origen de las cuales es la mezquita a la que sustituyen -de ahí que en la mayoría de los casos el acceso sea lateral, no frontal-. Su exterior se caracteriza por presentar un gran muro, ciego en la práctica totalidad de los casos, que cierra las capillas laterales y del que

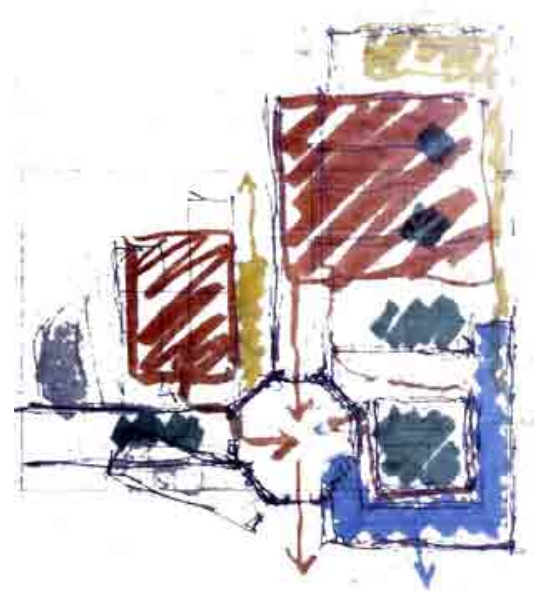
emergen potentes contrafuertes necesarios para la estabilidad de la nave central. La iglesia gótica del vecino convento de la Trinidad es una muestra de ello, aun no tratándose de una iglesia de "nueva planta". (Fig.32)

Una arquitectura de muros, que se atiranta con contrafuertes, es el resultado formal de la propuesta.

Mientras el conjunto del antiguo colegio presenta elementos de piedra de Godella en zócalos, cornisas y remates, amén de la fachada retablo de la iglesia y enfoscados en los paramentos, 
que protegen las irregulares fábricas utilizadas, la ampliación se propone a base de muros de ladrillo visto al exterior que configuran el conjunto del nuevo bloque.

Se pretende con ello no rivalizar con los acabados del monumento y recoger el aspecto elemental que ofrecía, por ejemplo, la industria de material cerámico situada junto al convento y que fue expropiada para permitir su ampliación.

Por supuesto las alturas de la ampliación no superan nunca la del conjunto al basarse, como se ha dicho, sus medidas y proporciones en las ofrecidas por el edificio histórico.

Quisiera añadir que la forma en peine de la ampliación posibilita que la vegetación de los Jardines del Real (del antiguo y vecino palacio real) se introduzca entre los brazos proyectados, integrándose ambos.

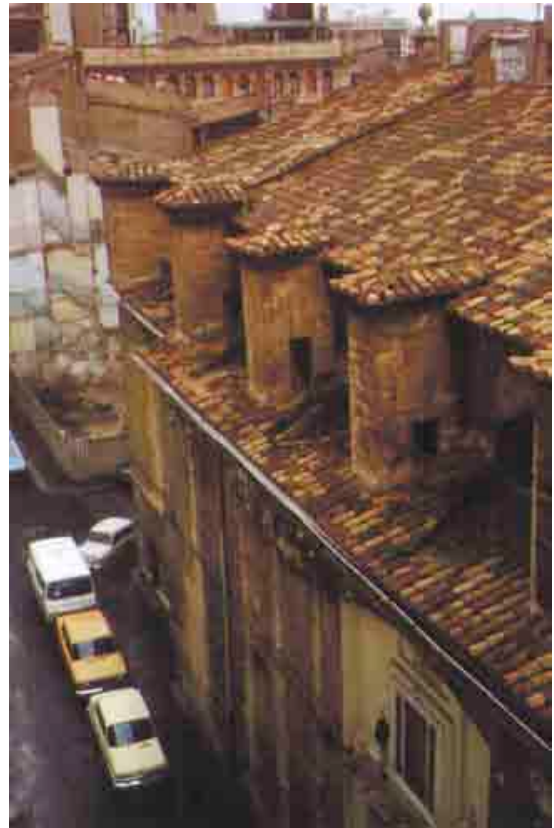

Fig.32

Posteriormente, reconsideradoel programade necesidades,

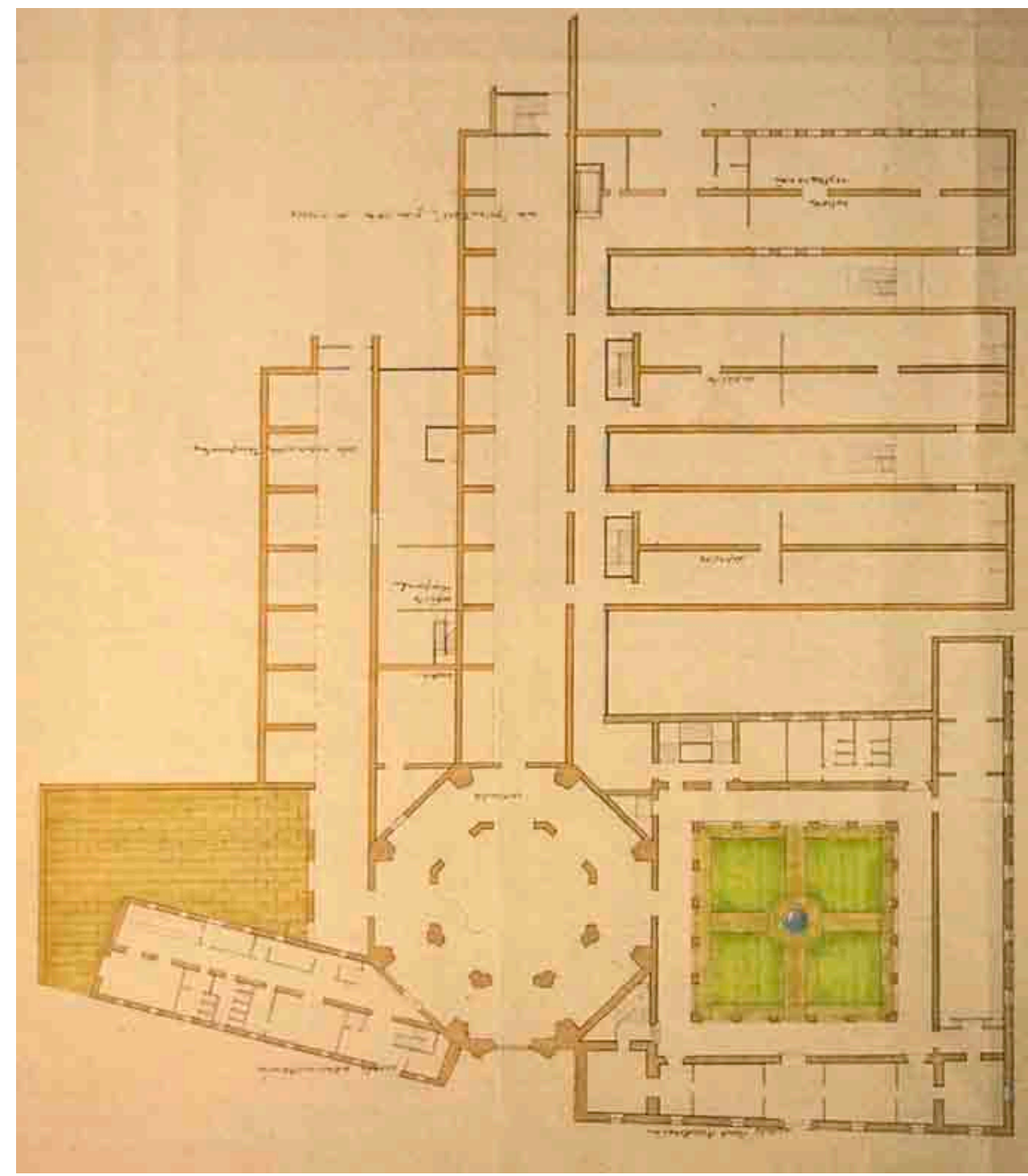

Segunda versión: peine con tres brazos. Plano de planta baja 


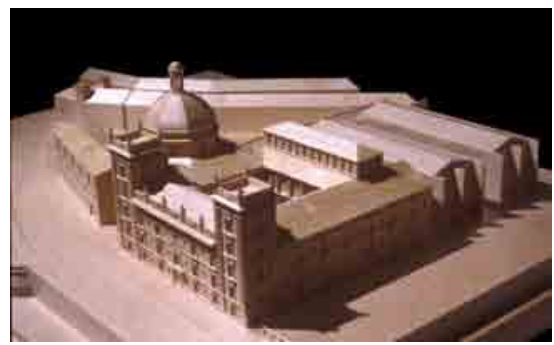

Fig.33. Peine de dos brazos

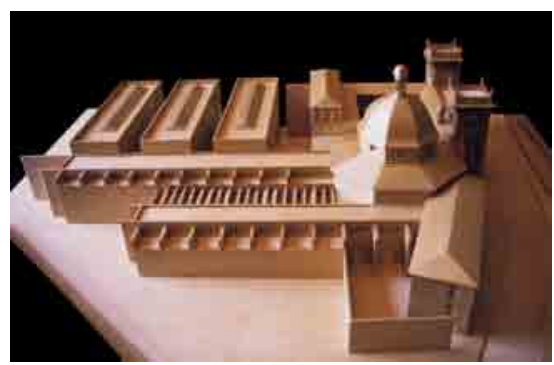

Fig.34. Peine de tres brazos

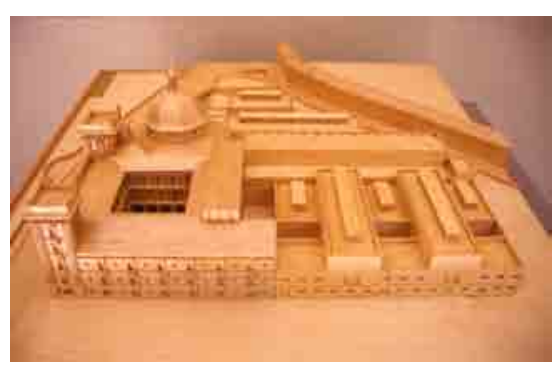

Fig.35. Propuesta final se amplia la propuesta introduciendo un brazo más en el peine, manteniéndose su imbricación con los históricos jardines.

La puesta en valor del papel de las exposiciones temporales en la dinamización de este tipo de museo, anquilosado y decimonónico, requiere unas salas para dicho uso.

Conectadas, por supuesto con el espacio de acogida según su eje transversal, en el lado opuesto al claustro se plantea un peine, definido por dos salas longitudinales de características similares a las de la ampliación principal, rematado por una sala de conferencias que, como cierre del conjunto, límite de la parcela y futura fachada oeste del nuevo museo, se configura mediante un muro curvo.

Las salas de exhibiciones temporales y de actos configuran con el bloque lineal un patio, que ya empezamos a denominar en el estudio, de escultura, opuesto al claustro. Este espacio abierto, vinculado al gran vestíbulo de acogida, permitía la realización de diversas actividades sociales relativas al museo.

Posteriormente, los requerimientos de sucesivos directores generales y del museo van densificando la implantación de la

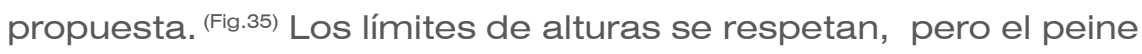
de tres brazos se maciza al introducir entre los mismos salas de exposición vinculadas al gran espacio axial, perdiéndose la lectura aditiva de los elementos y su relación con el jardín.

Los materiales se "ennoblecen" y es la piedra la que define la superficie de sus nuevos muros. Junto a ello el programa se desequilibra al primar las salas de exposición frente a los complejos servicios que necesita el museo. Los almacenes, tanto profundos como de tránsito o visitables, se reducen drásticamente.

Y desde estas nuevas premisas se redacta el proyecto objeto de este análisis. 


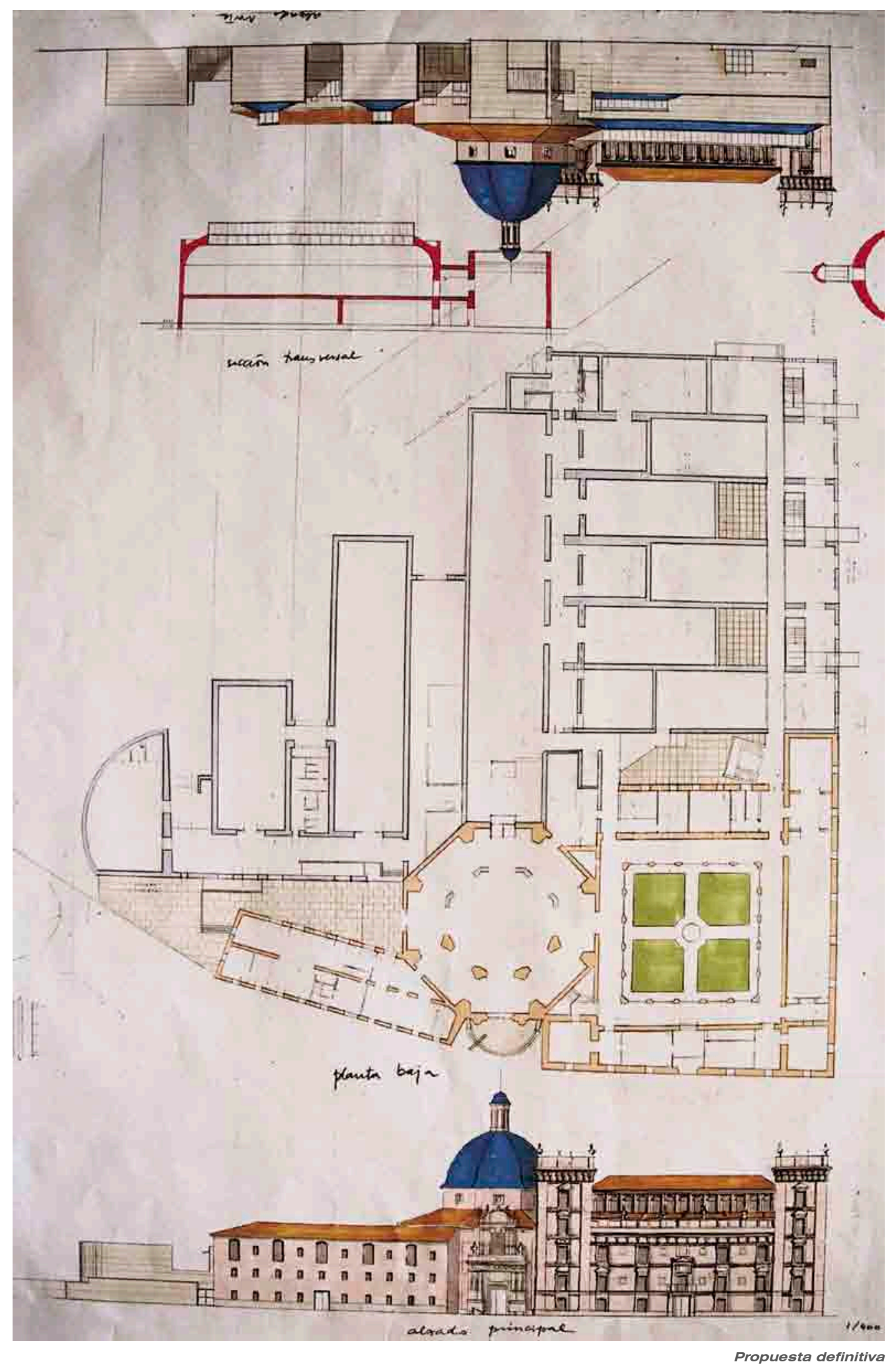


ESTADO ANTERIOR

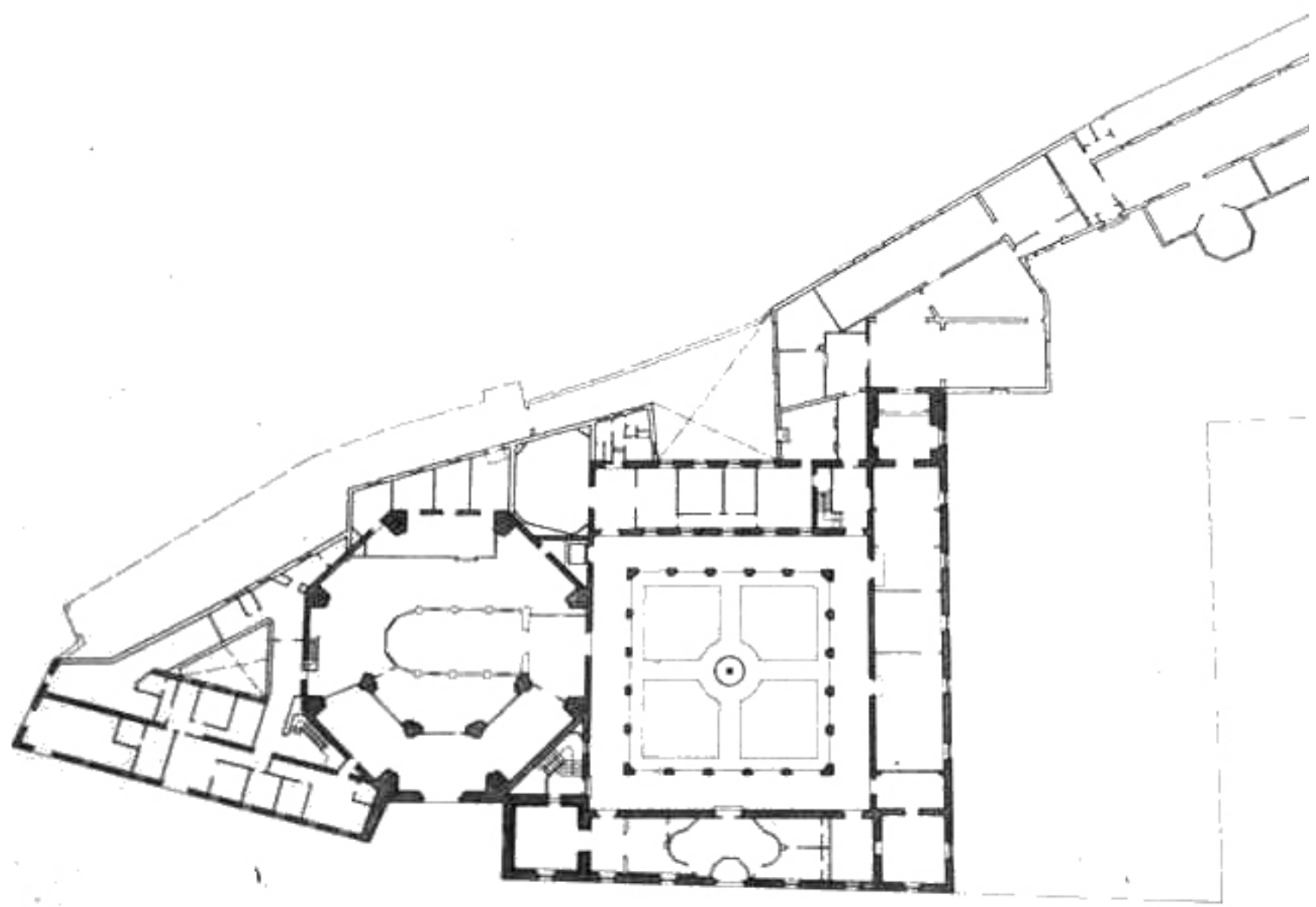

Estado anterior. Planta baja

$10 \mathrm{~N}(1$ 
PROPUESTA. PARCELA Y CUBIERTA

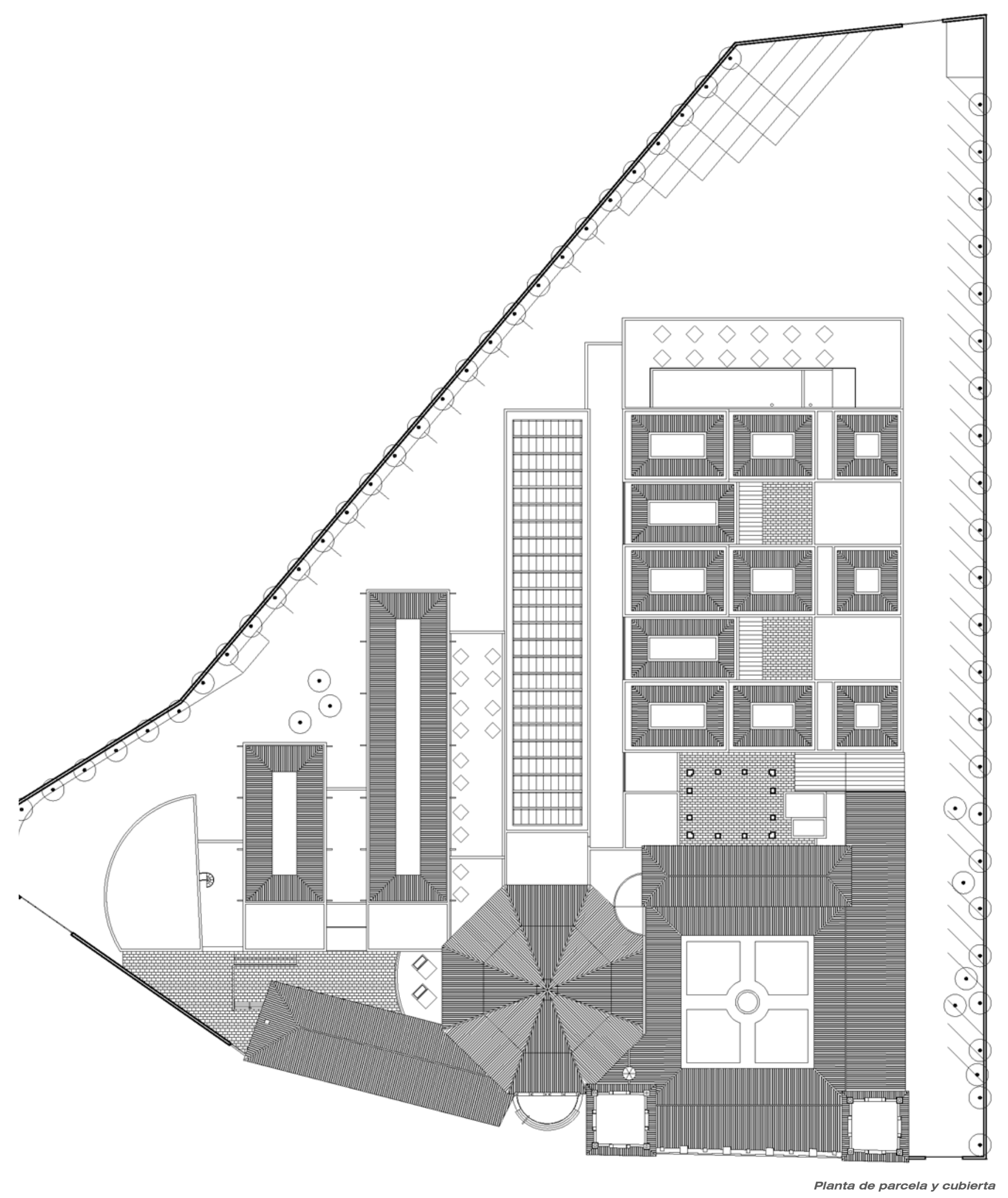

$10 \mathrm{~N}(1$ 
PROPUESTA. PLANTAS

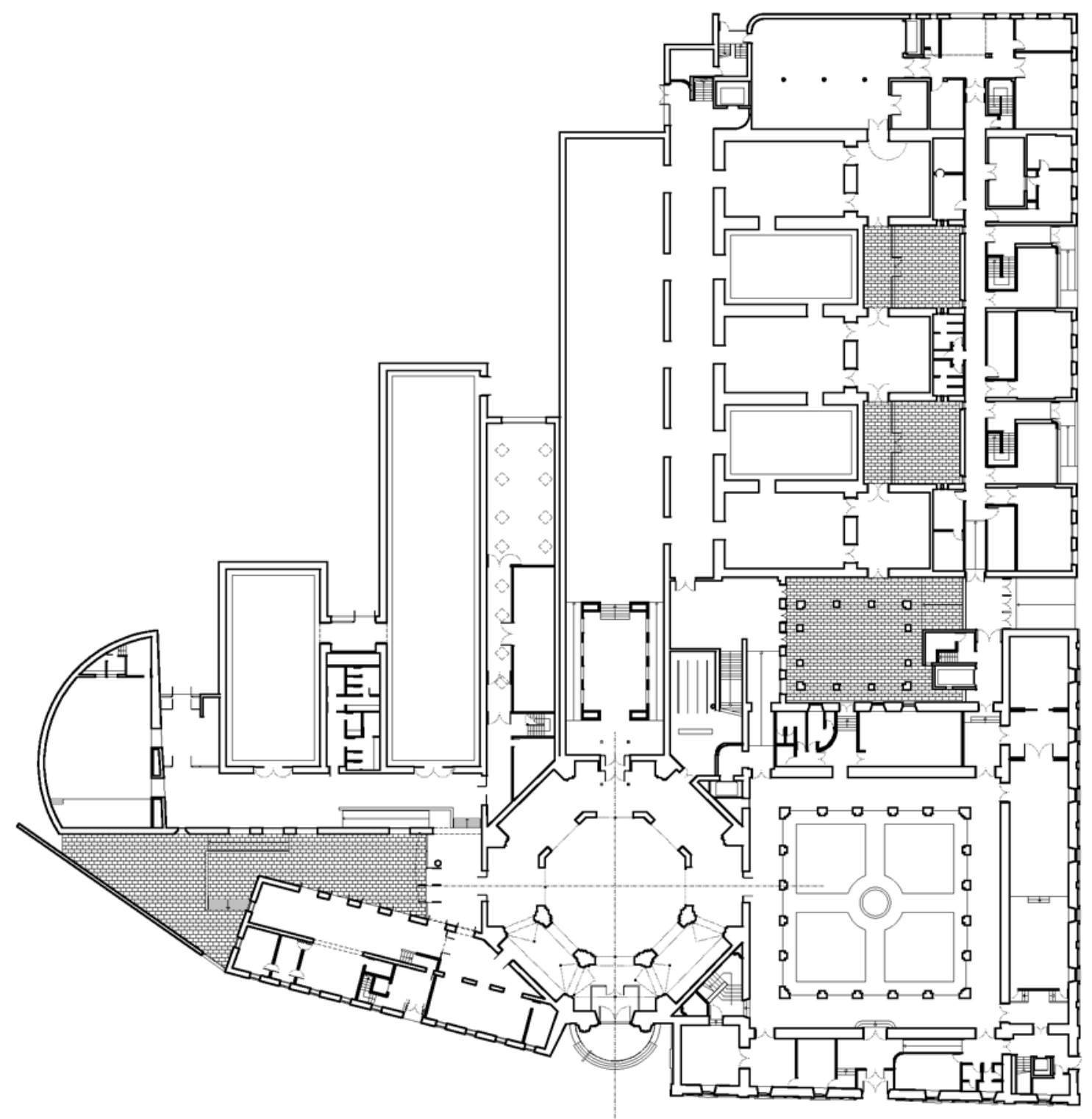

Planta Baja 
PROPUESTA. PLANTAS

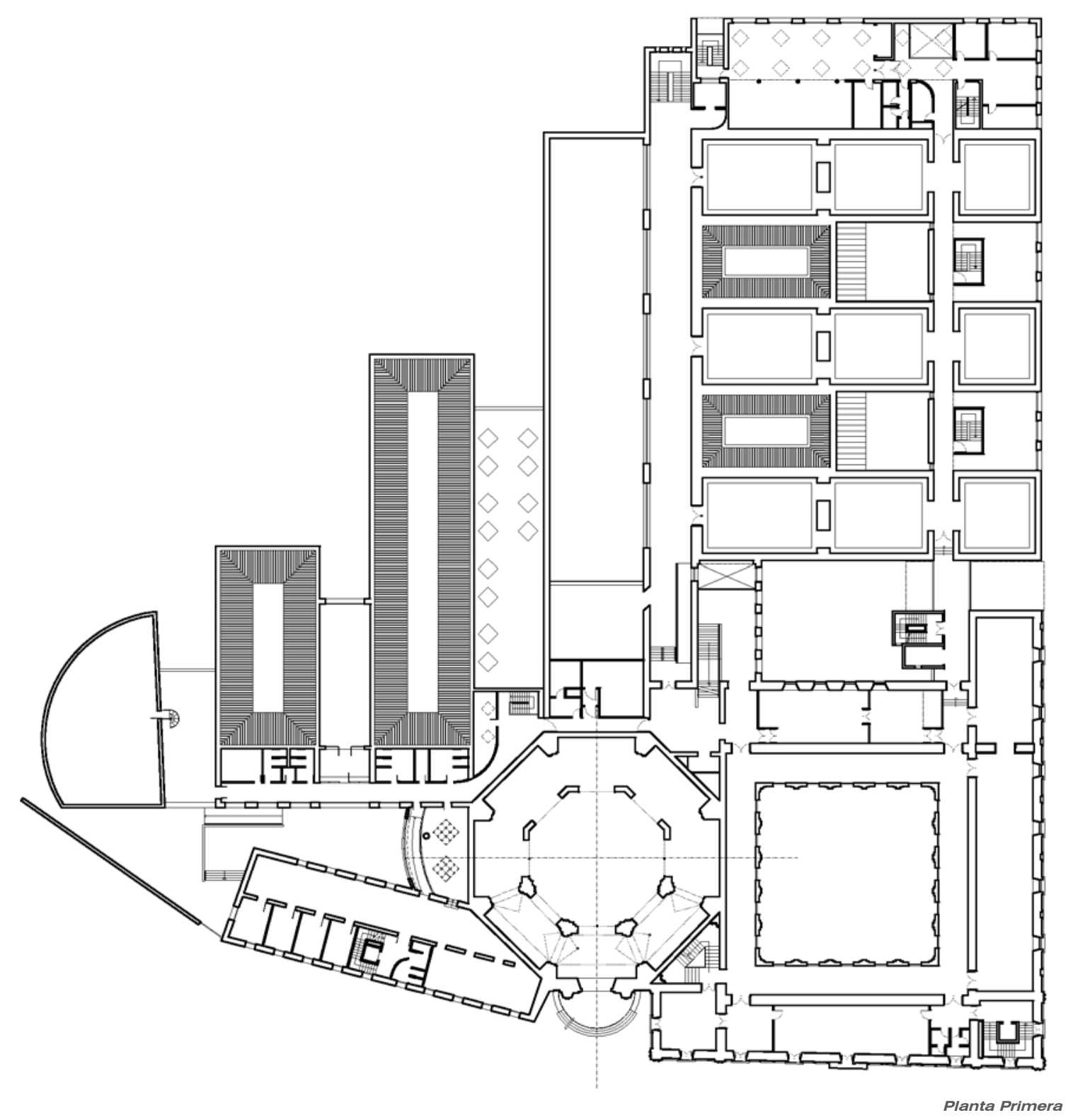

${ }^{10} N(1$ 
PROPUESTA. PLANTAS

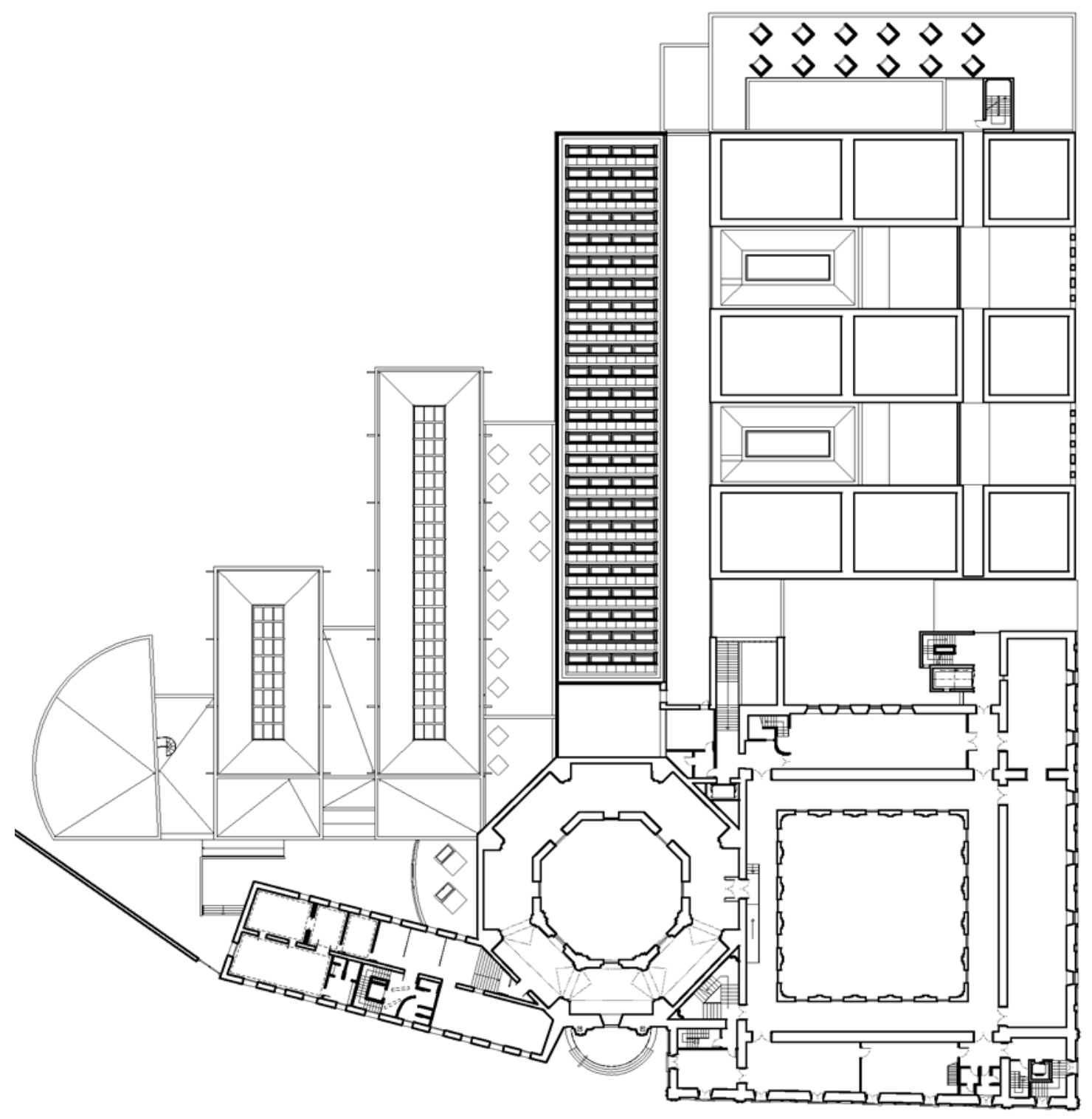

Planta Segunda 
PROPUESTA. PLANTAS

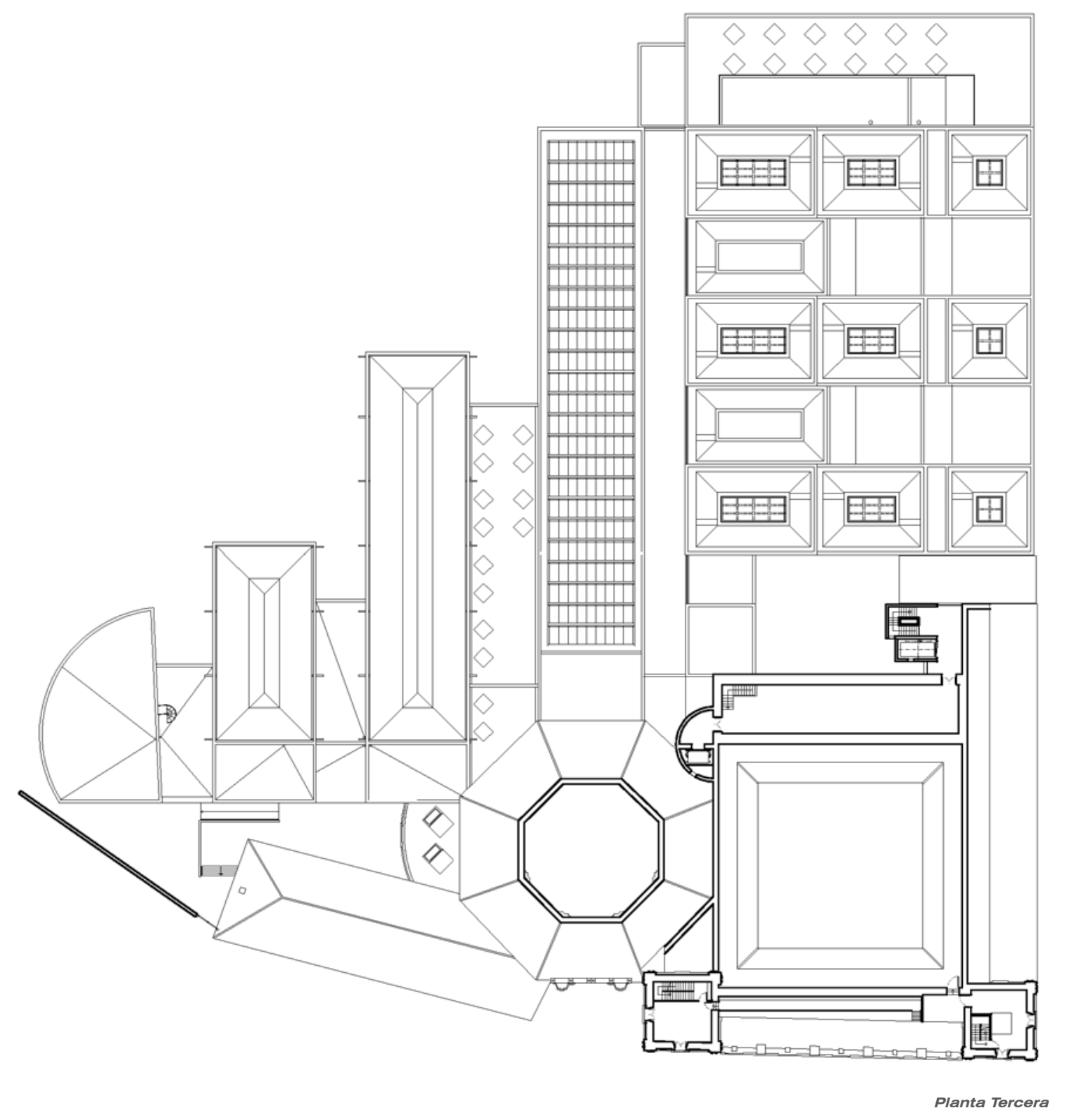




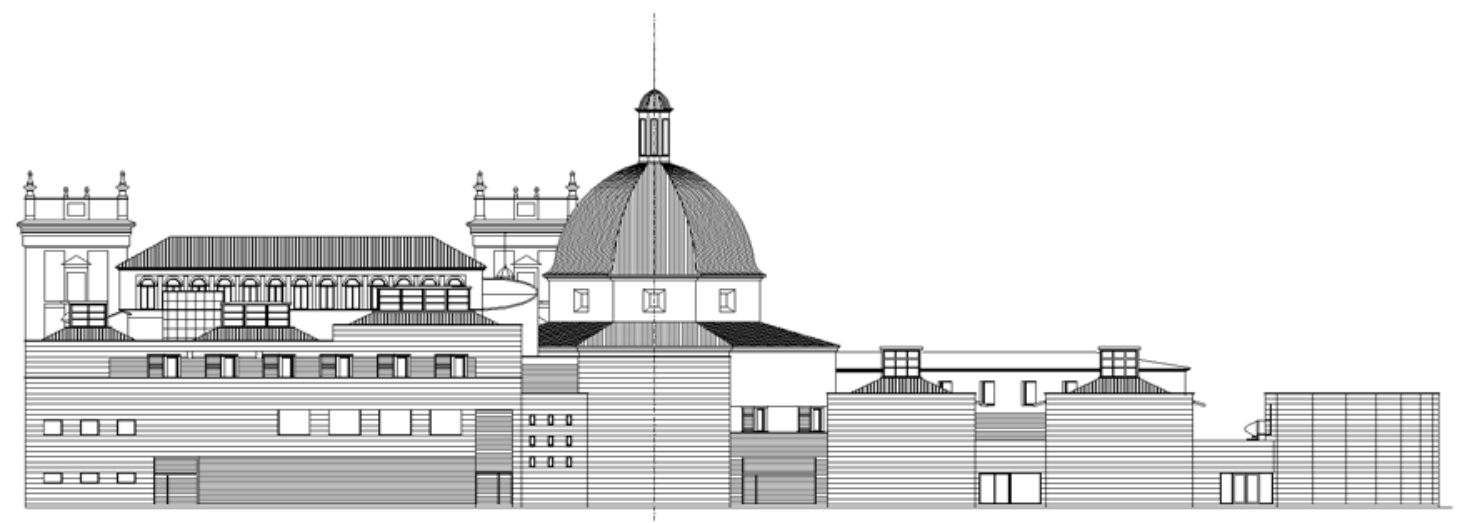

Alzado Norte
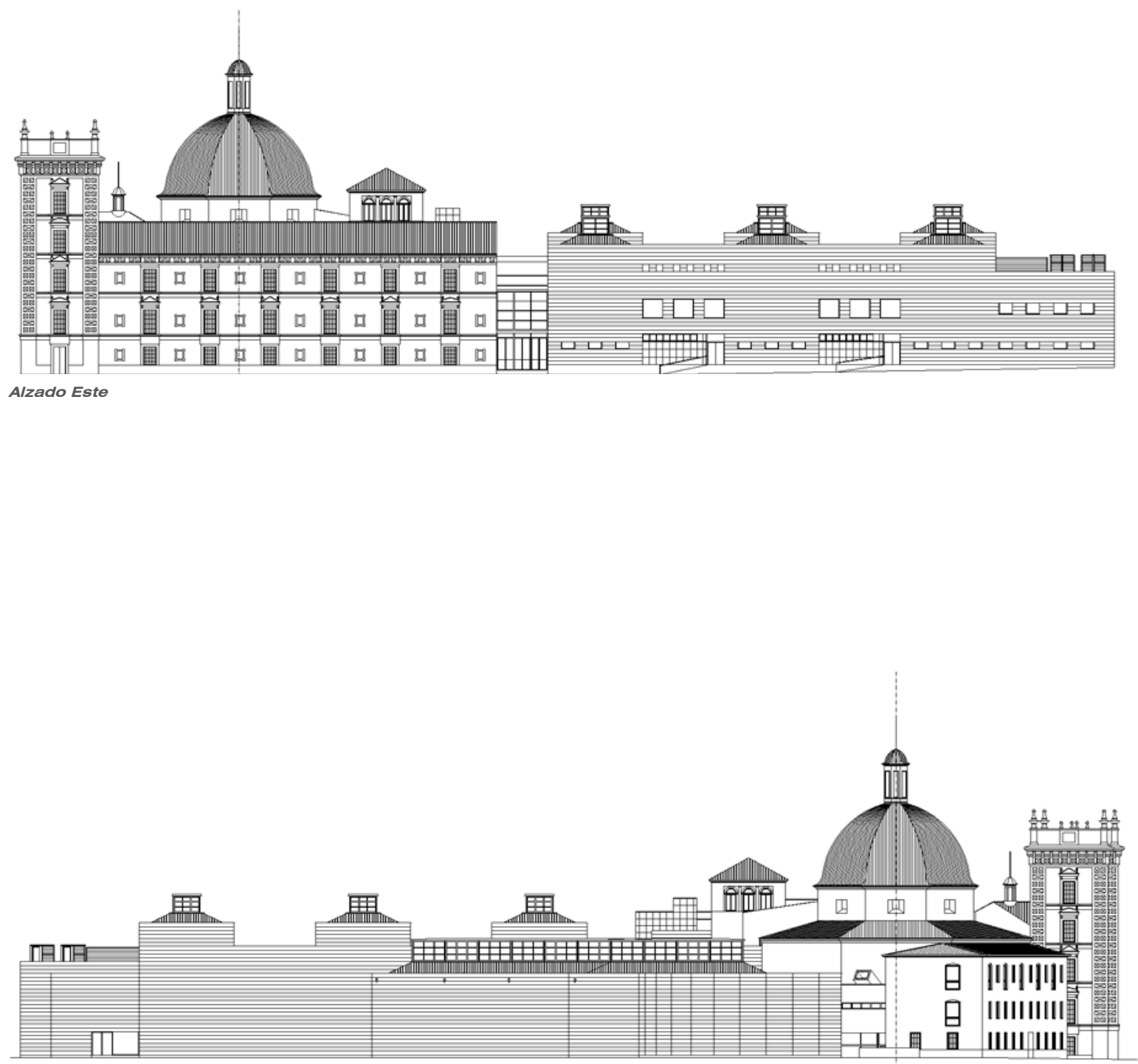

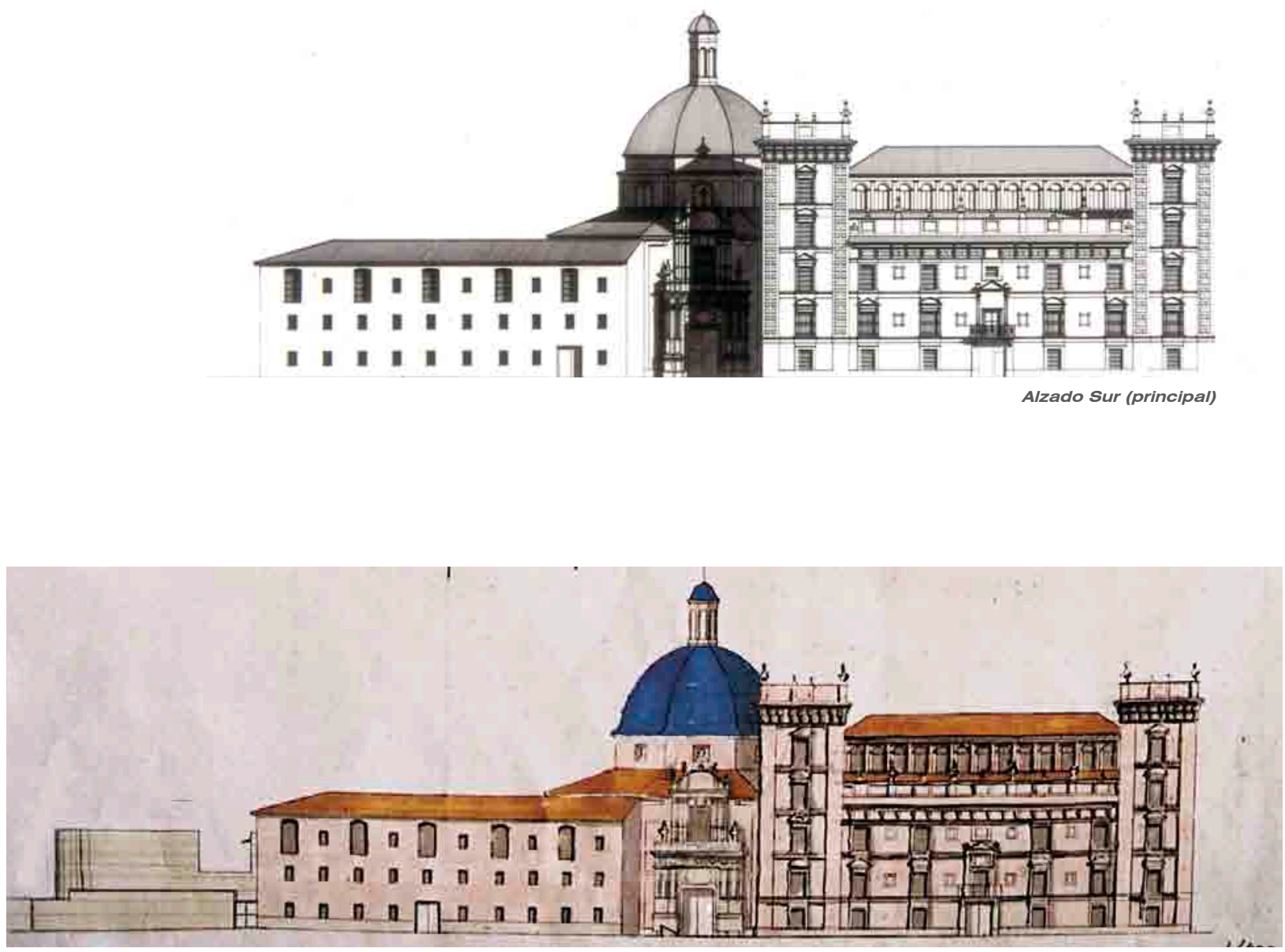

Alzado Sur (principal). Boceto de proyecto

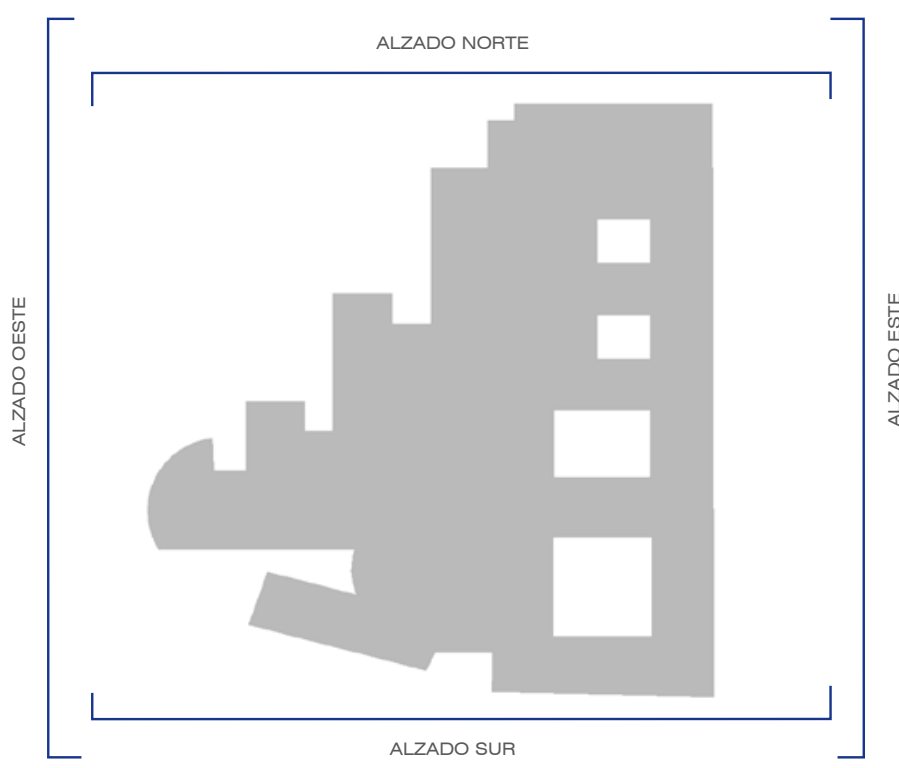

$10 N$ 
PROPUESTA. SECCIONES
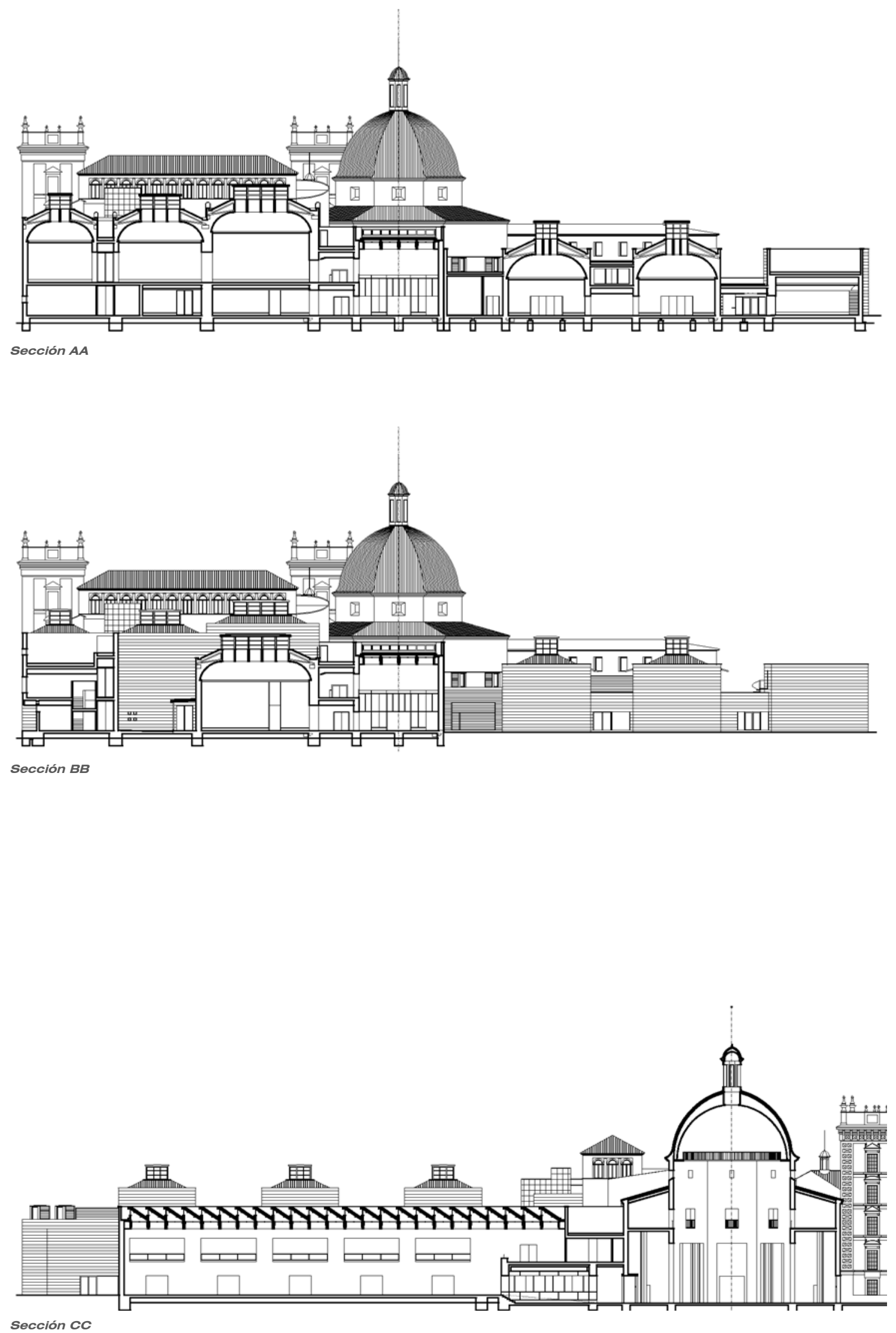
PROPUESTA. SECCIONES
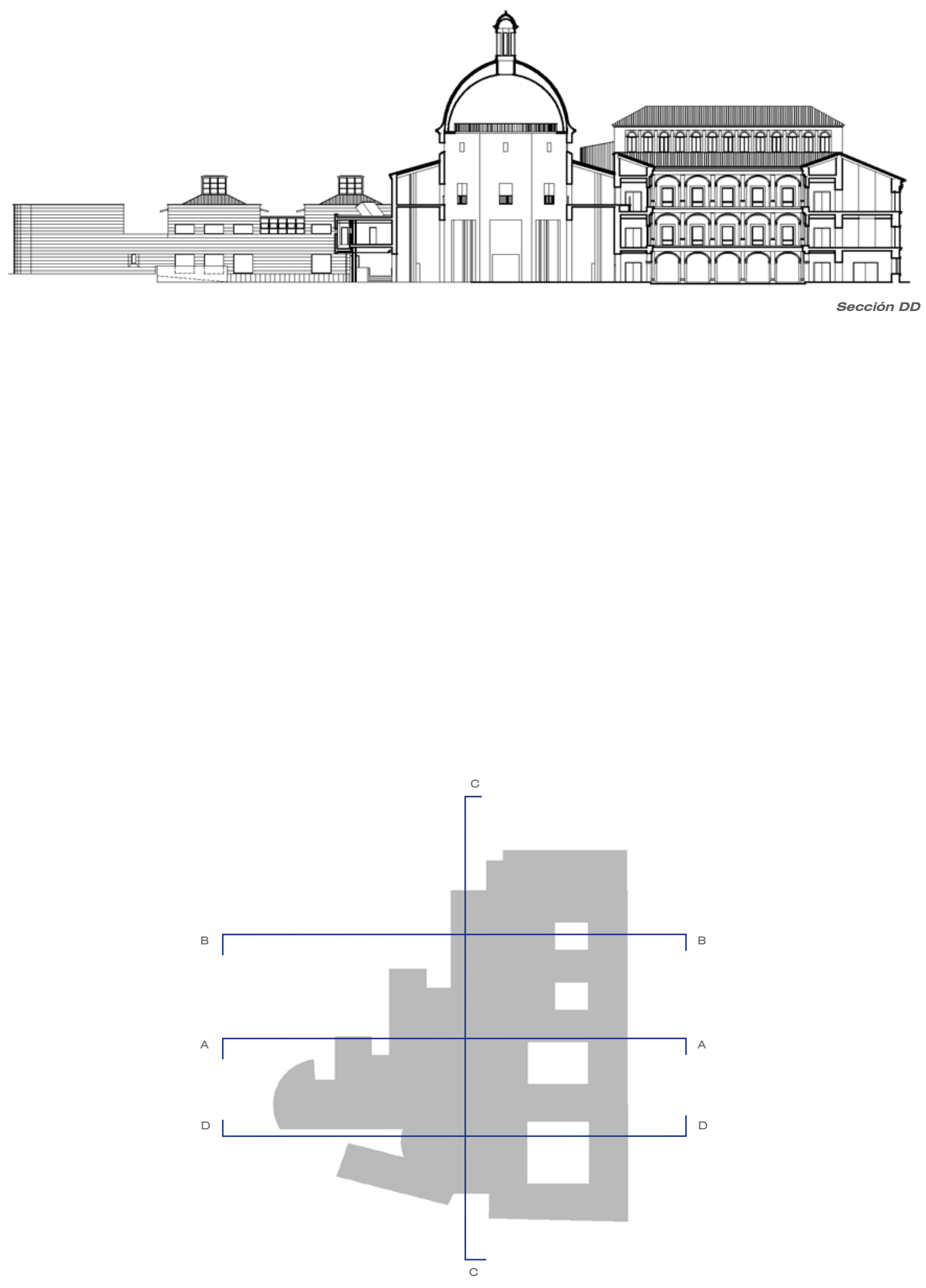

${ }^{10} \mathrm{~N} O$ 


\subsubsection{Descripción de la intervención.}

\subsubsection{Relaciones entre lo nuevo y lo viejo}

La clave fundamental que establece el proyecto de rehabilitación y adecuación museística del antiguo Colegio de San Pío V estriba en el estudio y reflexión de las relaciones que se producen entre lo nuevo y lo viejo. La consideración del monumento como expresión de la voluntad colectiva, a través de su arquitectura, así como la imbricación del mismo con su entorno y con la imagen de la ciudad que define, son expresiones claras de la memoria colectiva urbana que necesariamente se debía comprender y valorar.

Como hemos afirmado en otras ocasiones, la memoria colectiva no está constituida por formas ambientales o concretas fijas, sino que éstas varían según la evolución cultural e histórica, a partir de su origen y de su continua adecuación a la trayectoria social que genera y que a su vez actúa sobre ella.

\subsubsection{La necesaria eliminación de elementos} impropios

Las construcciones adosadas en la vertiente norte del conjunto, levantadas sin más límite ni proyecto que el de los lindes de la propiedad, junto a la pequeña capilla neogótica, que fue

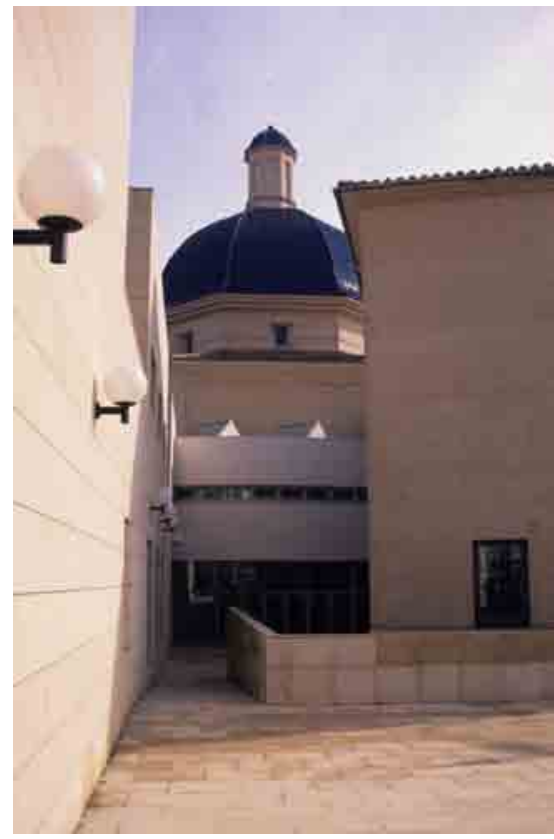

Fig.36 incluida en el espacio central del templo, demolido parcialmente en 1924, constituyen las partes adventicias que ahora se eliminan para posibilitar la adecuada lectura del conjunto original y, en consecuencia, de su tratamiento y aplicación.

\subsubsection{La recuperación del espacio cupulado: el núcleo del nuevo museo}

La recuperación del conjunto monumental y de su imagen urbana, reflejada en multitud de grabados desde el siglo XVIII, muestra como operación fundamental la reconstrucción de la cúpula de su iglesia octogonal. (Fig.36) Para ello se procedió a la eliminación de la pequeña capilla neogótica y a los adyacentes cobertizos y demás elementos impropios. 
Como resultado de esta eliminación, se procedió a la restitución del espacio cupulado de la iglesia octogonal original. Ésta se convierte en el nuevo vestíbulo del Museo; no solamente se recupera la imagen urbana perdida, sino que el espacio recuperado se constituye en el nuevo núcleo del nuevo Museo de San Pío V y sus ejes articulan el conjunto de la intervención.

El nuevo espacio de acogida se convierte así en el fulcro que articula el bloque claustral, el bloque lineal dieciochesco y la ampliación que se construye de nueva planta; sus ejes, el principal dado por la fachada-retablo de acceso y el perpendicular a él, son las directrices que ordenan no sólo las partes antiguas, sino también la nueva intervención. Se consigue de este modo la buscada imbricación entre lo nuevo y lo viejo, tanto en sus aspectos formales como en aquellos que atañen a su funcionalidad.

La recuperación del espacio cupulado del nuevo vestíbulo precisó la restauración minuciosa de las tres partes existentes y la reconstrucción del resto, que se realizó siguiendo el criterio de la clara diferenciación de lo nuevo con lo antiguo una vez repristinado. Las dimensiones y relaciones de los huecos, criterio básico del proyecto de conjunto, vienen dadas por los históricos. Pero las formas adinteladas marcan la necesaria diferencia con ellos. El tambor, todo él de nueva construcción, coronado por la cúpula y la linterna, envuelve los elementos preexistentes
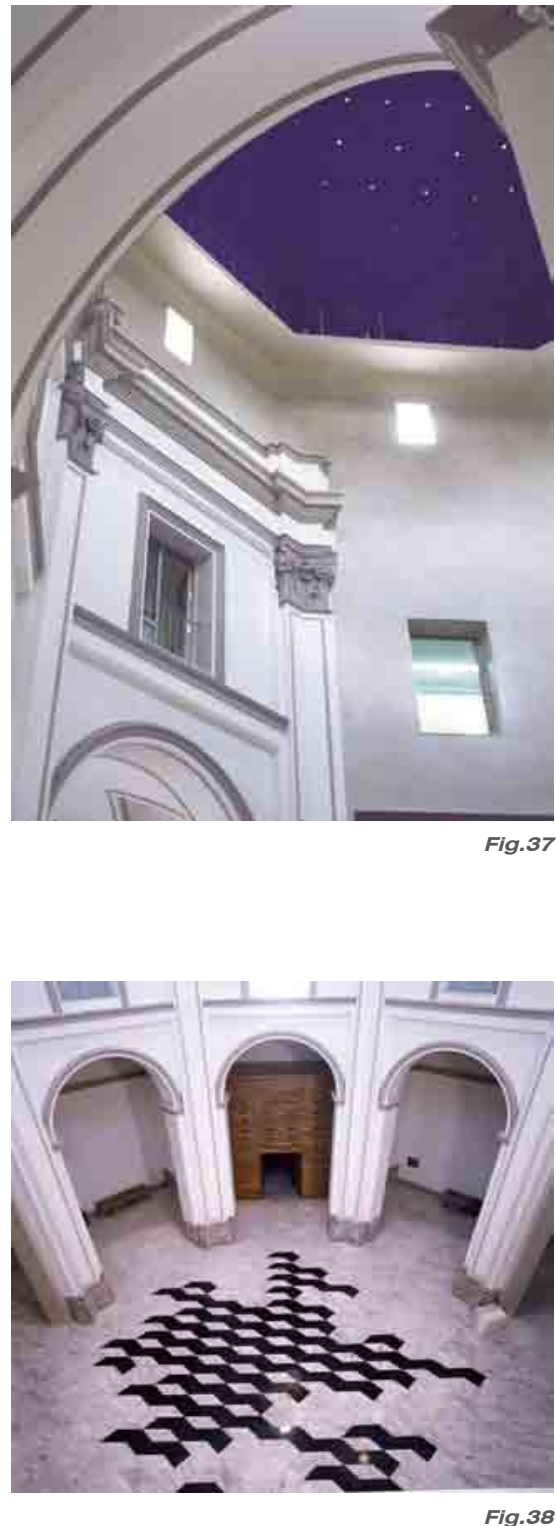
convirtiendo a éstos en un collage sobre la nueva estructura; el tratamiento formal, el acabado en estuco gris-beige del conjunto, subraya aún más esta idea de restitución espacial a la vez que valora los elementos estilísticos de los tres octavos existentes, pilastras, capiteles, cornisas, molduras, etc. (Fig.37)

El muro perimetral, fuertemente iluminado, es un deambulatorio que acoge obras de gran formato, cuyos caracteres históricos introducen al visitante en las secuencias espaciales que mostrarán los ricos fondos del museo. El tratamiento monocromático del conjunto resultante está coronado por la semiesfera de la cúpula que no puede resistir su histórica vocación de bóveda celeste. Como se produce en

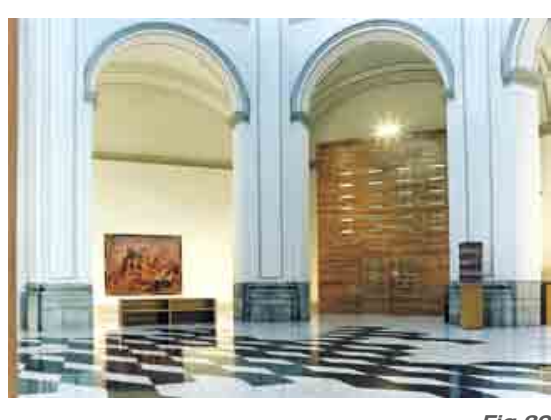


la cultura oriental, o más cerca, de acuerdo con las hipótesis del profesor Aldana para la Lonja de Valencia (10), como la cúpula original de S. Pedro en Montorio o los trabajos del siglo XVIII europeo, nuestra cúpula se reviste de añil salpicado de pequeños círculos de pan de oro. La luz controlada de la linterna, cuyos huecos en alabastro la tamizan se conjuga con la fenestración del tambor a través de los cuales los rayos de sol se entregan en el pavimento.

De mármol blanco y negro, el pavimento ofrece, en una alusión simplificada de trompe / oeil, un movimiento que subraya los ejes ordenadores del futuro museo. Siguiendo la tradición patente en algunos espacios museísticos, en la galería del vestíbulo, el deambulatorio de la primera planta recoge la nueva biblioteca del museo. (Fig.38 y Fig.39)

\subsubsection{La organización del nuevo Museo}

La forma aditiva de conformación de las trazas originales es, como hemos visto, la pauta de la propuesta. Alrededor del nuevo vestíbulo del Museo se ordenan los diferentes volúmenes que resuelven las funciones del edificio. Los ejes del octógono estructuran aquéllos permitiendo a la vez un uso diferenciado, que no interfiera las diversas actividades. Exposiciones permanentes y temporales, salas de conferencias, accesos y almacenamiento de piezas, administración, etc., son algunos de los usos que la ordenación del conjunto debe resolver sin superposiciones y así se plantea en el plano general del conjunto.

La Recuperación del espacio cupulado del recinto octogonal

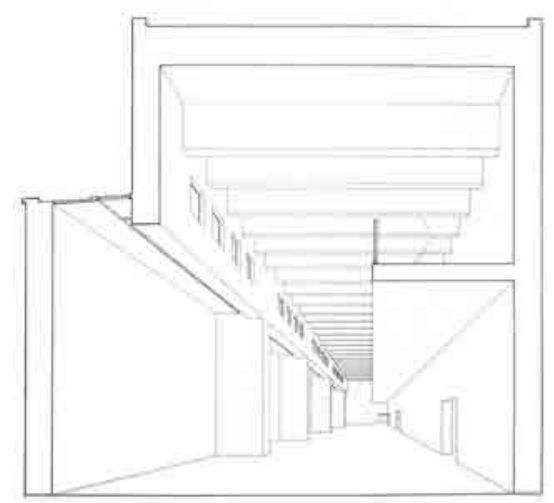

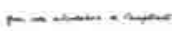
se convierte en el punto donde se cruzan los ejes ordenadores y constituye el arranque conceptual del proceso de rehabilitación.

El eje transversal, perpendicular al acceso, pone en relación el bloque lineal de oficinas y las salas de exposiciones temporales -junto con el patio de arqueología y escultura- con el claustro original y sus salas expositivas vinculadas.

El eje principal longitudinal (Fig.40) establece la directriz de la visita a las exposiciones permanentes del museo, desde el acceso por la portada de la antigua Iglesia, e indica el recorrido 
que lleva al visitante a través de todas sus salas. Este eje se desarrolla en doble altura, constituyéndose como una gran sala donde vierten perpendicularmente las salas transversales que se agrupan de manera compacta, y que a su vez se organizan en dos niveles algunas de ellas. Envolviendo el bloque de estas salas, se organiza un sector especial, en forma de "L" en el que se sitúan en su parte norte los almacenes y servicios de restauración y talleres.

La articulación entre la ampliación y el bloque claustral genera un patio en el que se ubicó, con posterioridad al proyecto, el Patio del Embajador Vich, joya de la arquitectura renacentista valenciana

\subsubsection{Claustro y alas claustrales}

La intervención en el claustro y en sus alas construidas pretende, por un lado, establecer usos compatibles con la utilización (por parte de la Academia de San Carlos) de gran parte de sus piezas y por otro, recuperar el carácter claustral de los deambulatorios, desafortunadamente tabicados para la recreación de salas expositivas.

El acceso al claustro se produce, tras la recuperación del octógono, a través del mismo. Resta en planta baja su deambulatorio para exhibición de lápidas y escultura romana y medieval (Fig.41), desde el cual se permite el acceso a las diferentes crujías. El ala norte se destinaba a aulas docentes, desafortunadamente hoy ocupadas por servicios higiénicos tras una reforma posterior. El ala este se destina, como hemos dicho, a sala de actos de la Academia, institución que ocupa fundamentalmente toda la crujía sur-fachada principal- en todas sus plantas.

En planta primera, el deambulatorio del claustro mostraba un tratamiento de sala expositiva, por el cual se segregaba espacialmente las esquinas a modo de pequeñas salas de planta cuadrada. En ocasiones, este procedimiento se extendía también a los espacios restantes, que se dividían nuevamente para la obtención de salas menos oblongas. El criterio de intervención,

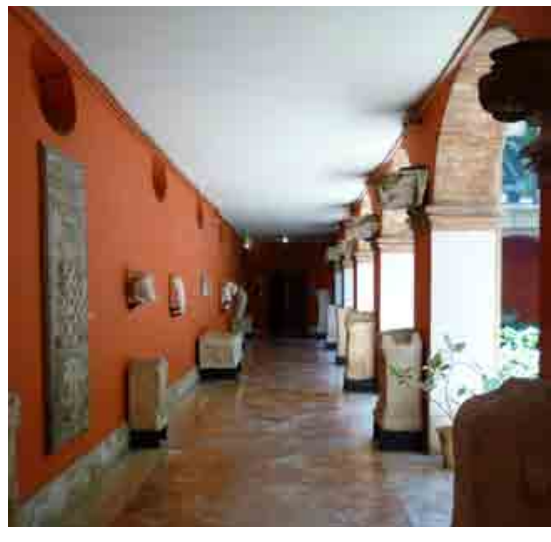

Fig.41

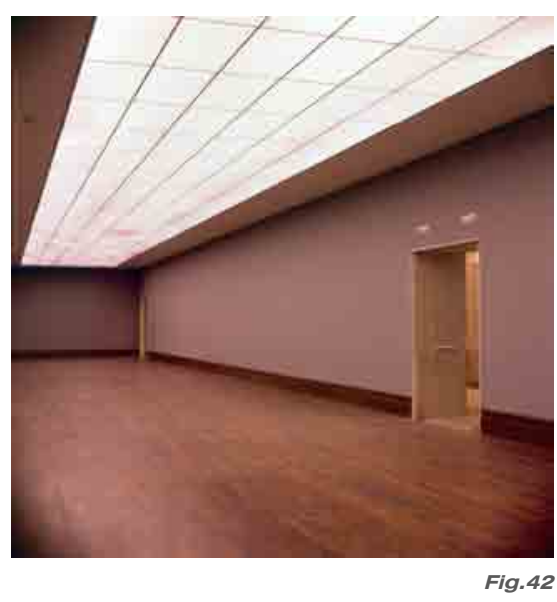


que finalmente no ha sido llevado a término en su totalidad, pretende la devolución de la continuidad espacial a este recinto mediante la recuperación de su función de deambulatorio, de modo que se permita la lectura primigenia de sus circulaciones horizontales originales. (Fig.42)

En planta segunda, se propone la creación de almacenes visitables, semipúblicos, a la manera de los gabinetes del siglo XVIII. Parcialmente realizada en el ala este del claustro, el resto de alas en las que no se ejecutó se encuentran hoy en estado de semi-abandono.

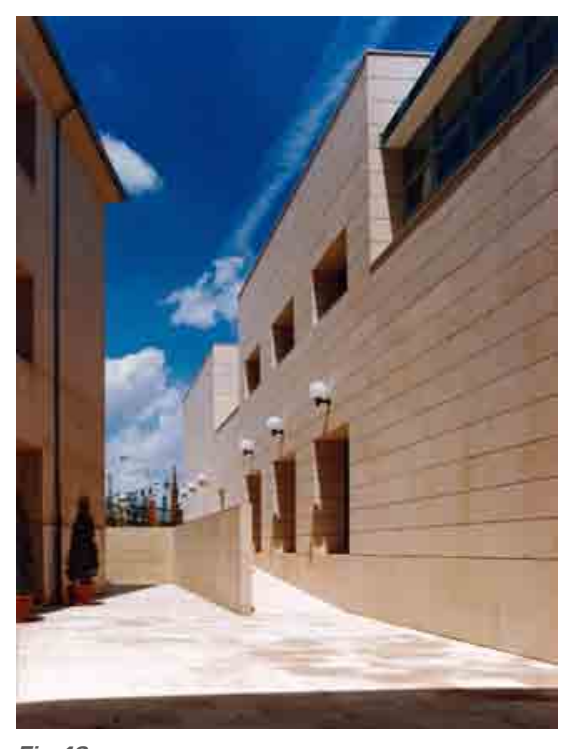

Fig. 43

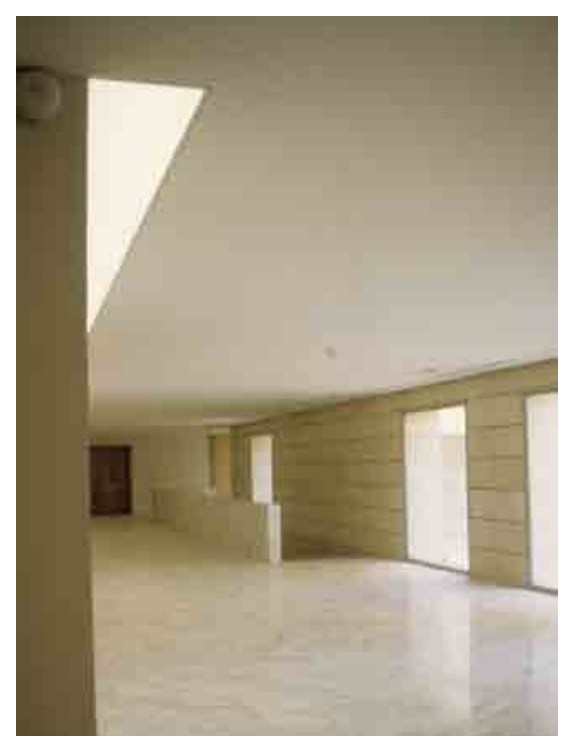

4.5.8.6. El bloque lineal y las salas de exposición temporal

El cuerpo Oeste, paralelo al río, constituido por una doble crujía de muros de carga y una cubierta a tres aguas, se recupera especialmente a partir de su sistema estructural. Sus dimensiones y su situación tangencial a la antigua iglesia lo hacen adecuado para ubicar en él las oficinas y servicios externos del museo.

En el eje perpendicular al acceso y opuesto a la conexión con el bloque claustral se ordena el acceso a la sala de exposiciones temporales, que se articula a través de un segundo patio (Fig.43) -de escultura y piezas arquitectónicas ordenadas a modo de antiquarium- que divide y separa este cuerpo de nueva creación del bloque lineal dieciochesco. Las salas de exposiciones temporales se organizan de forma análoga a la sala de exposición permanente; su dimensión responde, como en aquella, a la dictada por el lado del octógono; de su vestíbulo lineal surgen (Fig.44), al modo de la tipología del peine, las dos salas de exposición y el nuevo salón de actos del Museo, que remata y finaliza este corredor de acceso y distribución. Los servicios higiénicos, tan necesarios, se sitúan entre las dos salas de exhibición, que se conectan a través de un paso posterior y paralelo al corredor de acceso. Éste se ilumina en planta baja mediante huecos que enlazan visualmente con el patio de escultura; en planta primera, este espacio se destina a espacios 
del personal del museo, que complementan el programa administrativo ubicado en el bloque lineal.

Las salas de exposición temporal tienen una estructura formal similar a las de la exposición permanente (Fig.45); poseen iluminación cenital, con su correspondiente bóveda de reflexión, y unas dimensiones adecuadas para el uso expositivo al que se destinan. Sus longitudes se adaptan a los límites que establece la Vuelta del Ruiseñor. Ambas salas pueden utilizarse de forma independiente o conjunta, y se enlazan por medio de un espacio que conecta con el jardín a la vez que es una necesaria salida de evacuación.

Las alturas de los volúmenes de la ampliación vienen

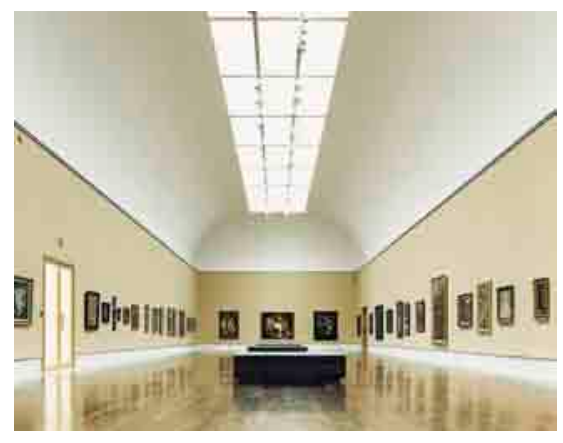
determinadas por las del edificio preexistente. La formalización de su arquitectura y los materiales utilizados evitan la confusión mimética a la vez que posibilitan la interrelación respetuosa de lo nuevo con lo viejo. El muro de piedra de Hellín es el protagonista de la ampliación en los planos verticales, frente al enlucido con color de los bloques históricos intervenidos. Al exterior, la teja azul vidriada tapiza sus cubiertas, que se rematan con lucernarios de vidrio translúcido (Fig.46).

Entre la sala de exposición temporal y la gran sala de exposición permanente se dispone el almacén de tránsito, con su correspondiente muelle de carga y descarga. La alineación retirada del volumen del almacén permite la lectura pautada de los cuerpos cuya creciente componente longitudinal responde al trazado de la acequia histórica (Fig.47): salón de actos, salas de exposición temporal y gran sala de exhibición permanente. Su tratamiento, por medio de chapa de acero, permite esta diferenciación y la articulación entre los volúmenes nuevos.

\subsubsection{La ampliación y la exposición permanente}

La exhibición permanente de la colección del museo se basa, desde los primeros bocetos, en un esquema que parte del vestíbulo octogonal mediante una gran sala, a la que se anexan de modo perpendicular otras, que poseen dos plantas, siguiendo con el procedimiento aditivo establecido para las partes nuevas.
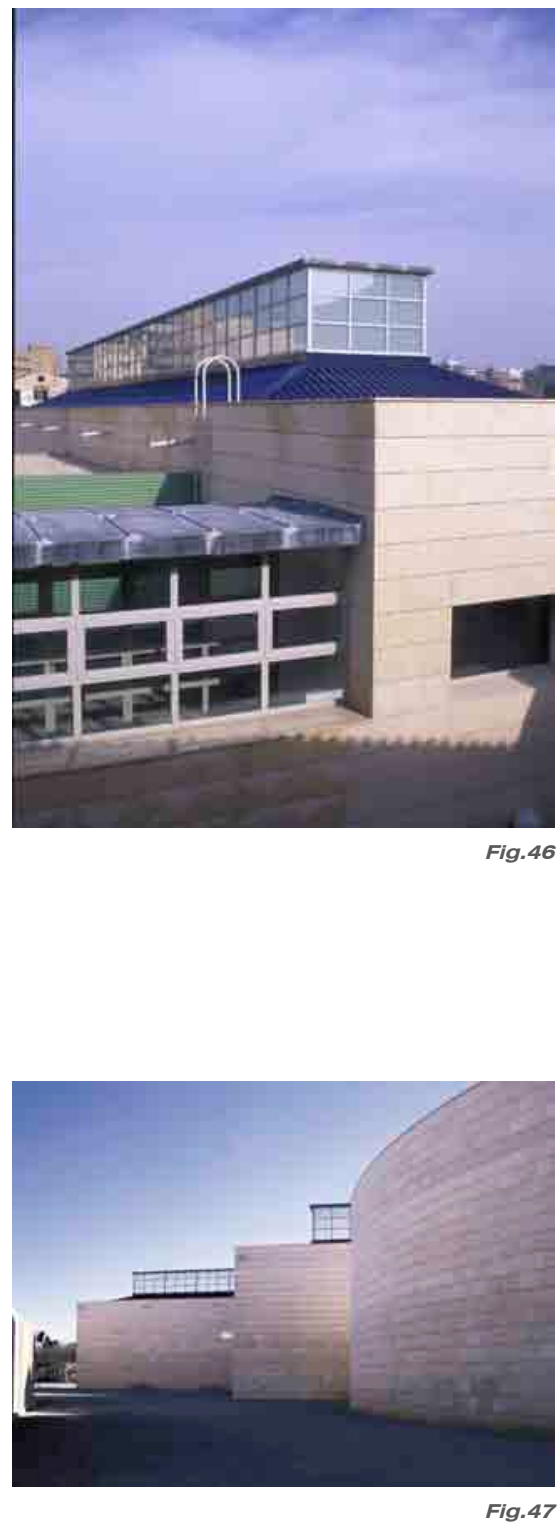


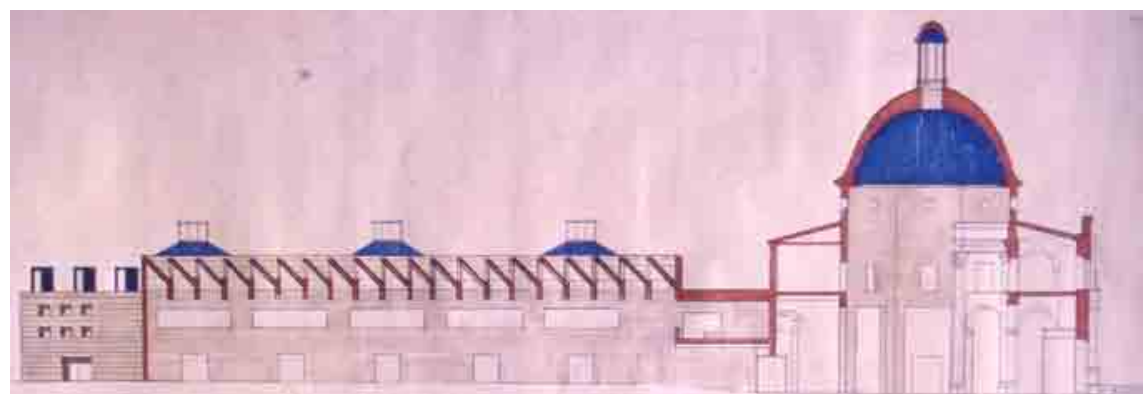

Sección longitudinal a través de la gran sala

La gran sala tiene un ancho igual al lado del octógono del vestíbulo y una altura definida por la cornisa de la antigua iglesia. Iluminada cenitalmente, tiene limitada su longitud por la alineación de la Vuelta del Ruiseñor. Su doble altura permite la exhibición de los retablos góticos de grandes dimensiones. En planta primera, paralelo a la gran sala, discurre un corredor que permite la contemplación, desde un punto de vista elevado, de las citadas tablas. Tanto desde la gran sala de planta baja como desde el mirador de planta primera parten (relacionadas espacialmente con ellos y a modo de peine), tres alas de dos plantas, de dimensiones adecuadas para la contemplación de los lienzos de pintura. Las correspondientes a la planta primera disponen de iluminación cenital, a la manera de la solución dada a las salas de exposición temporal.

El citado corredor de enlace desde el que contemplamos en altura los retablos y del que parten las citadas salas permite la conexión con el bloque claustral.

Esta organización reseñada se ha visto fuertemente alterada durante la ejecución del proyecto -de la que fui apartado- y por el modo de introducción del Patio del Embajador Vich en el patio de acceso secundario y evacuación; su irreflexiva ubicación, la resolución de sus niveles y el tratamiento de sus encuentros con la obra del Museo han generado un serio problema de accesibilidad, de comunicaciones verticales y de lectura del proceso de ampliación. Ello ha complicado -por la introducción de nuevas variables a un problema histórico- la adaptación funcional del antiguo edificio a su nueva función de museo, como a continuación se procede a explicar.

El edificio histórico en torno al claustro tiene tres niveles y 
marca una altura de cornisa determinada. Sus alturas libres son escuetas; son fruto de la precariedad de medios con los que contaron sus promotores. Estas alturas son inadecuadas para exhibir lienzos, pues o bien son insuficientes o bien no permiten una iluminación correcta. Es por ello que la ampliación, que asume la altura de cornisa del edificio original, tiene solo dos plantas; las salas que se inscriben en su interior poseen la altura libre que posibilita la exhibición de pintura en óptimas condiciones. El punto de articulación de este cambio de niveles horizontales se produce en torno al patio que, en nuestro proyecto, separaba lo nuevo de lo viejo. Se comprende que su diseño debe responder a esta cuestión de alturas y al encuentro entre las fábricas nuevas y las antiguas. La posterior introducción del Patio del Embajador Vich en el espacio de transición entre lo nuevo y lo viejo añadió, a la complejidad ya existente, dos nuevos niveles inconexos. Lógicamente, el orden renacentista de planta baja, planta noble y ático no responde a las cotas del antiguo colegio del siglo XVII ni al museo del siglo XXI, y por ello los espacios que existen entre sus fachadas y los muros que delimitaban el antiguo patio son inaccesibles y permanecen cerrados e infrautilizados.

A esto cabe añadir que en planta baja se han reproducido las bóvedas aristadas que han supuesto que tenía el deambulatorio del patio del Embajador Vich, de tal suerte que éstas interfieren y desfiguran el ritmo de huecos de la antigua fachada norte del colegio, cuya lectura era antes posible a través del patio de acceso y evacuación. Lo que en su momento fue un espacio que permitía una clara y respetuosa lectura de las pulsaciones constructivas, de articulación entre fábricas (Fig.48), se ha visto violentado por el asiento de la singular fachada del Palacio asentada parcialmente en el museo del carmen, de donde fue arrancada- que, siendo la primera en ser construida, ha sido la última en ser ubicada, circunstancia que se ha obviado y que se ha pretendido difuminar con el tratamiento de su perímetro, en una operación que podemos calificar -sin abundar en adjetivosde sumamente inadecuada y escasa sensibilidad.

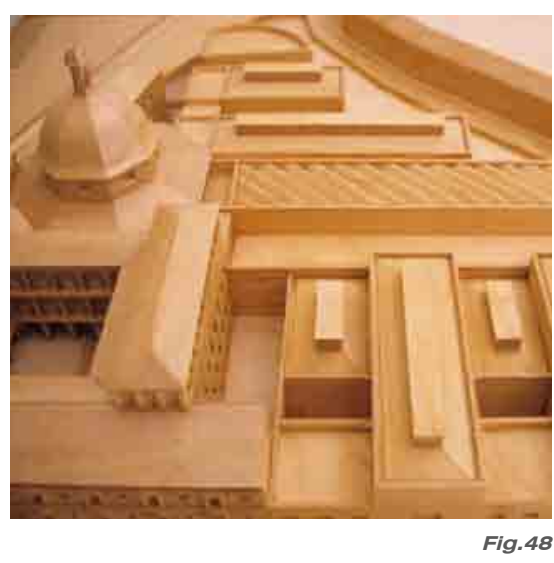




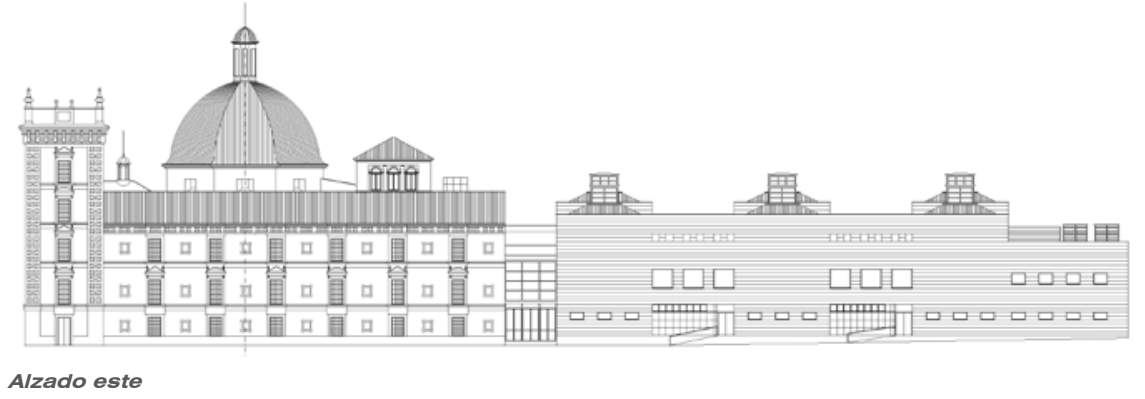

\subsubsection{Los usos internos}

Ocioso es añadir que los servicios de restauración, marquetería, etcétera, almacenes, depósitos, salas audiovisuales, de exposiciones temporales, instalaciones exigidas en un museo actual, etcétera, son atendidas en el proyecto, pero su descripción haría inacabable esta reseña, centrada más en los criterios de la intervención.

En el resto de la ampliación y desnudez del muro, el juego de sombras que propicia y sus articulaciones, son los factores que pretenden mostrar la adecuación al problema y el establecimiento de la relación no sólo con el edificio sino con cierta arquitectura de la ciudad donde se ubica, relación, en su conjunto, no sólo visual o física sino en el sentido indicado por Ignasi de Sóla-Morales: Una interpretación del material histórico con el que se miden, de modo que este material es objeto de una verdadera lectura que acompaña explícita e implícitamente a la nueva intervención en su global significación.

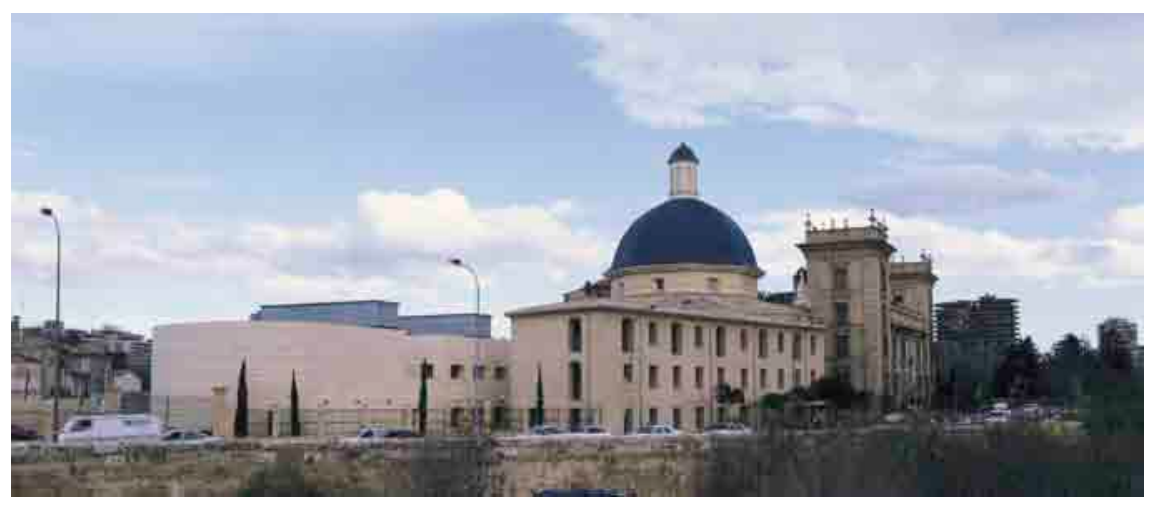

Vista final del Nou Museu de Sant Pius V 
PLANTA BAJA: USOS

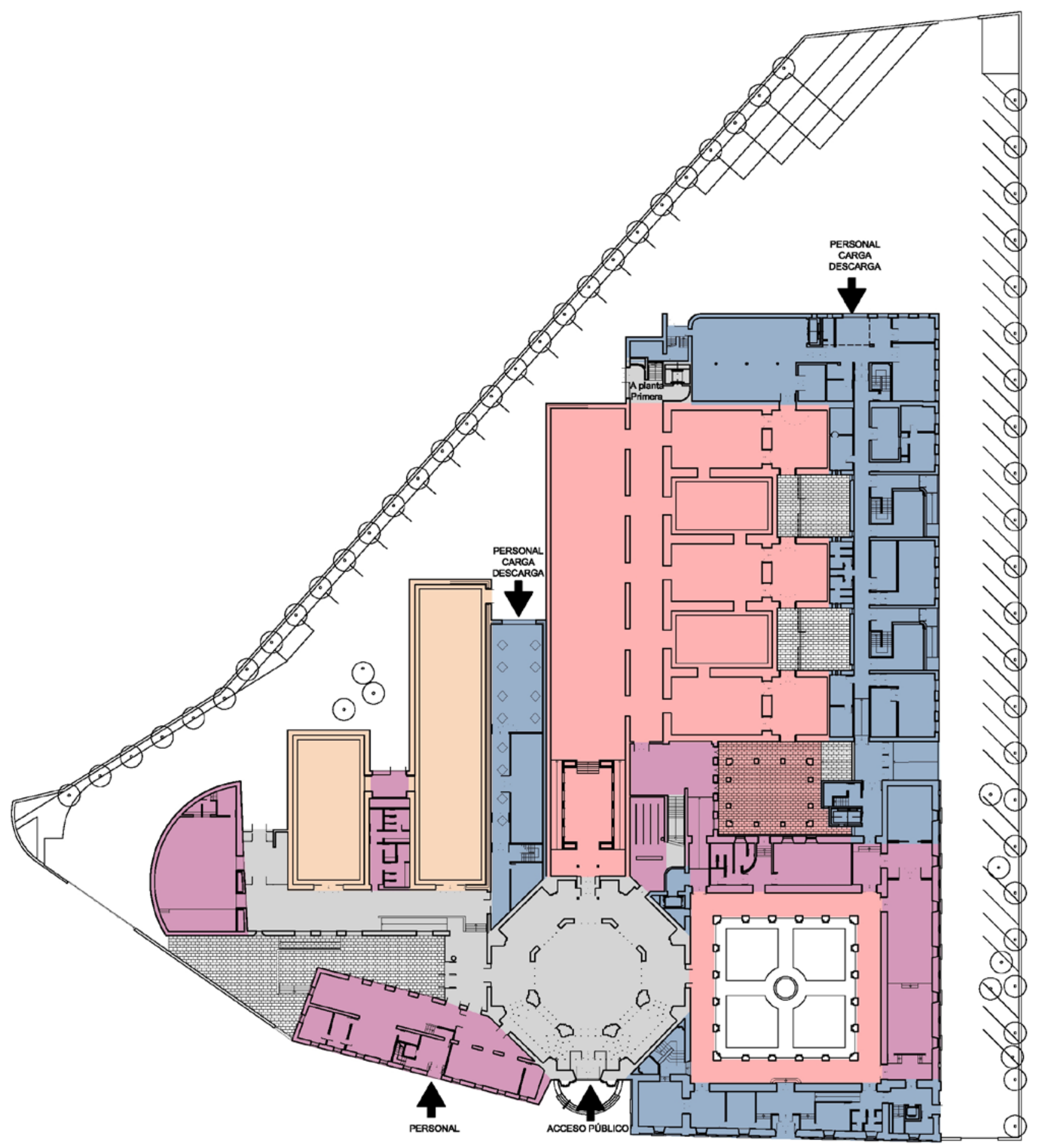


PLANTA PRIMERA: USOS

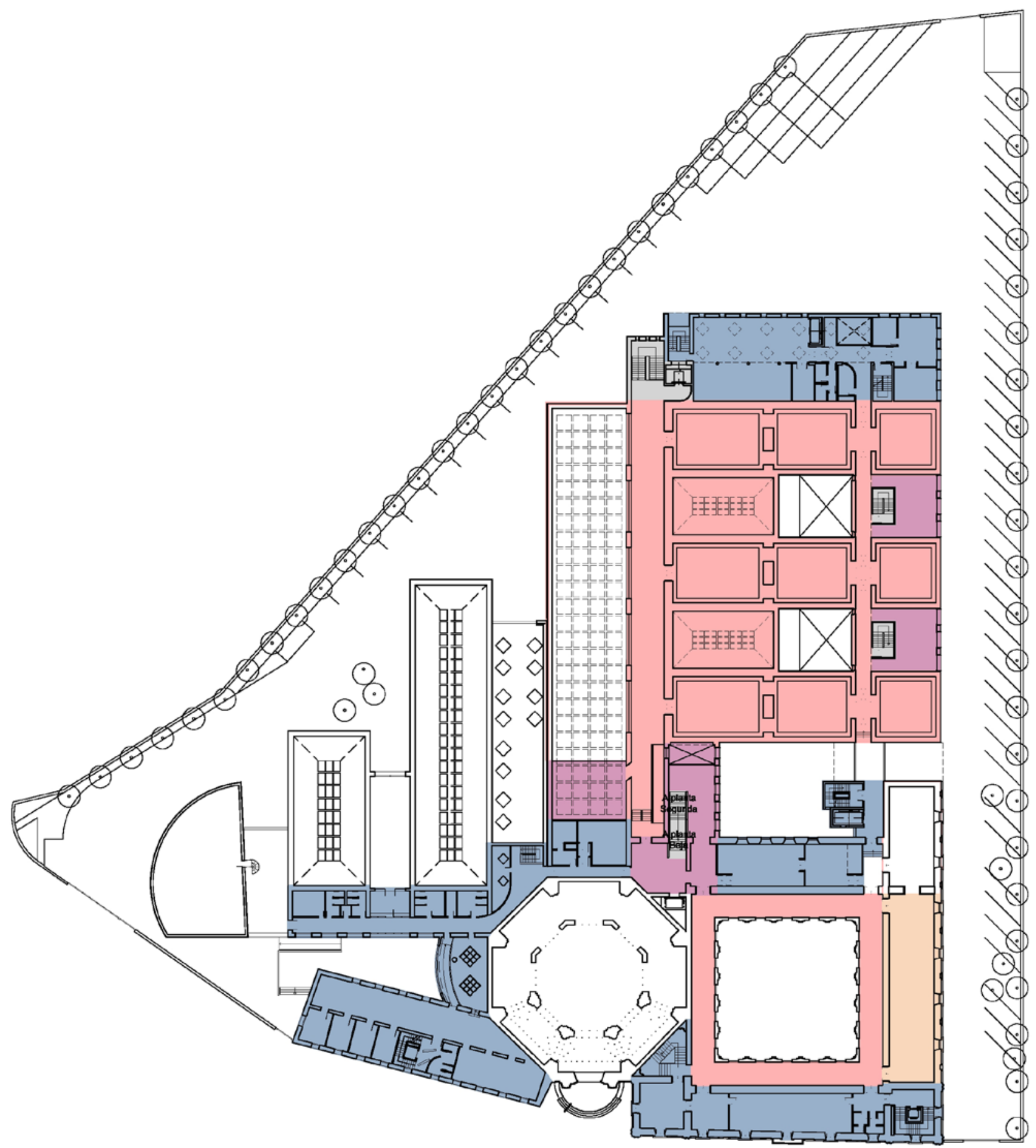


PLANTA SEGUNDA: USOS

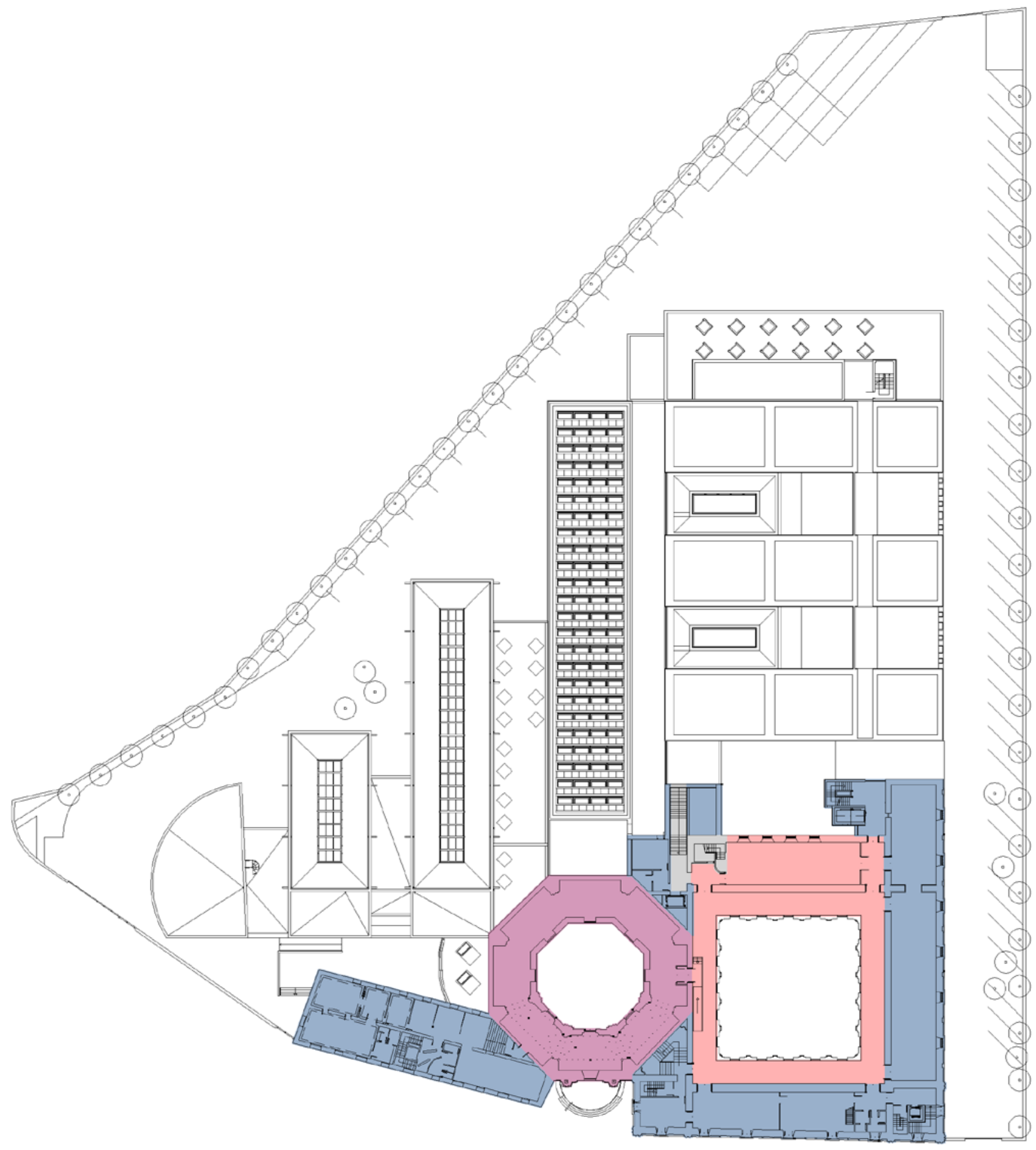


PLANTA TERCERA: USOS

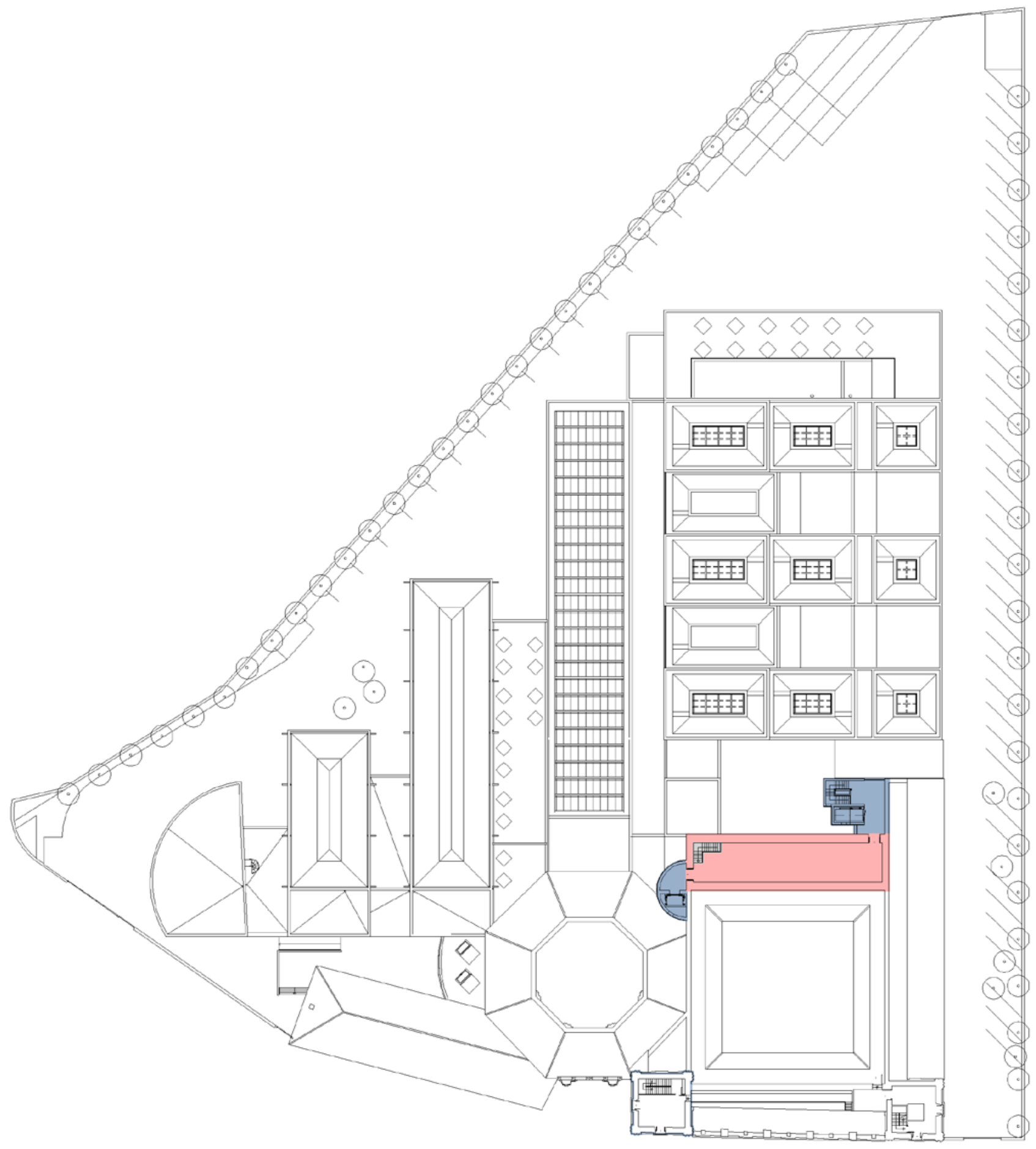


ESTIMACIÓN DE SUPERFICIE

\begin{tabular}{lcc}
\hline & $\mathrm{m}^{2}$ & $\%$ \\
SUPERFICIE EXPOSITIVA & 4.761 & $41 \%$ \\
SUPERFICIE DE USOS PÚBLICOS & 2.681 & $23 \%$ \\
SUPERFICIE DE USOS INTERNOS & 4.166 & $36 \%$ \\
\hline TOTAL & & \\
\hline
\end{tabular}

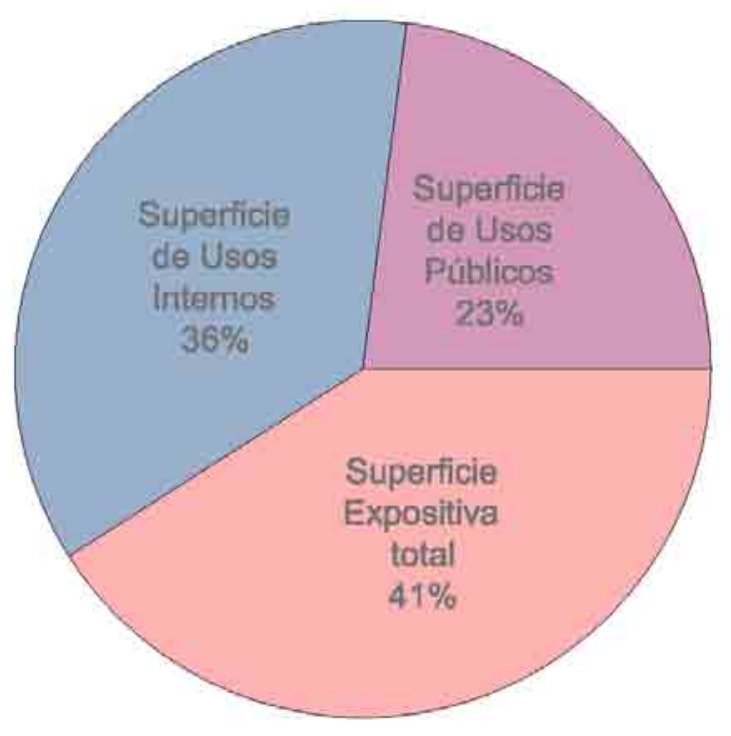

EXPOSICIONES PERMANENTES

EXPOSICIONES

TEMPORALES

CIRCULACIÓN Y VESTÍBULOS

USOS PÚBLICOS

USOS INTERNOS 
PLANTA BAJA: RECORRIDOS

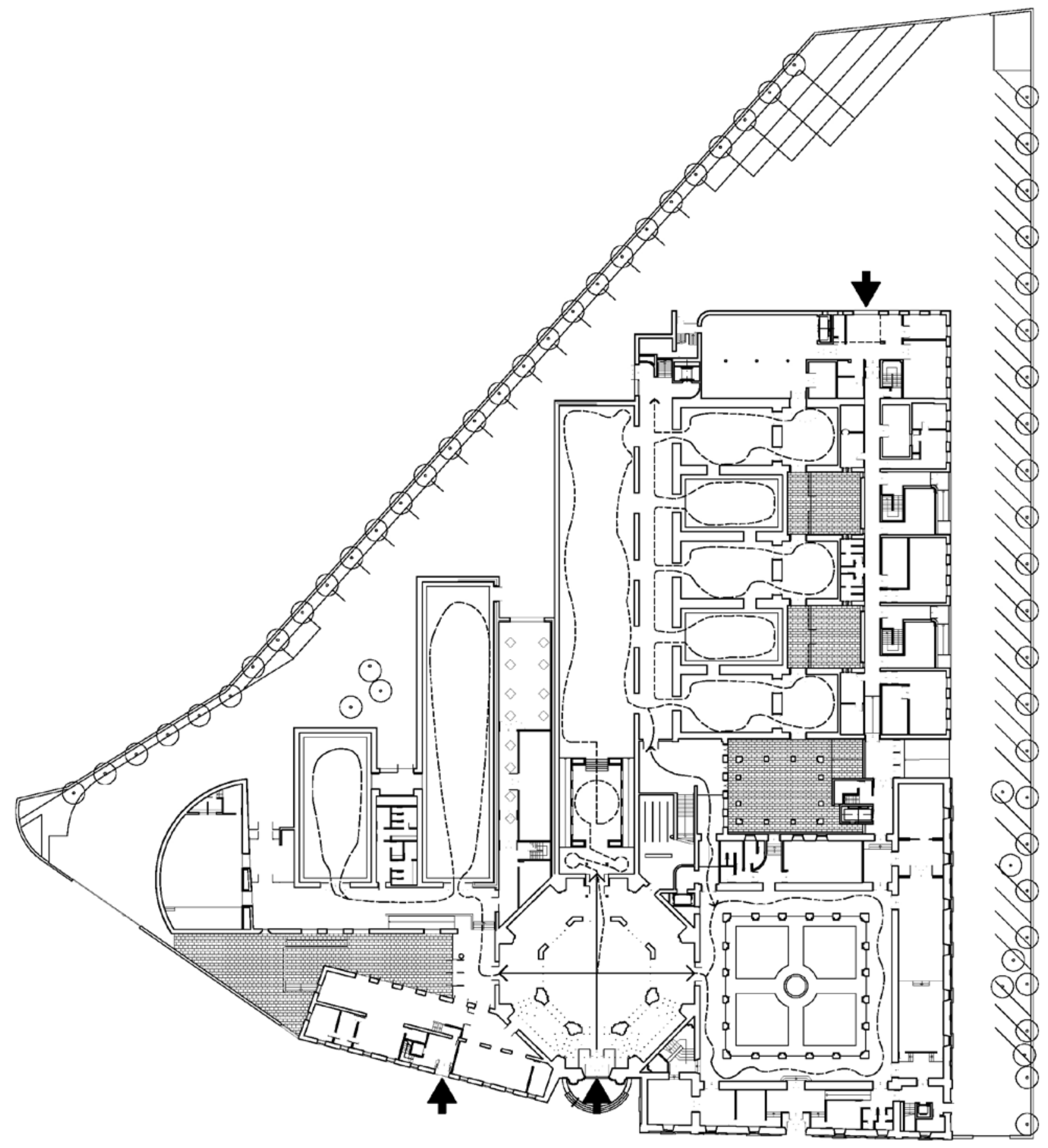


PLANTA PRIMERA: RECORRIDOS

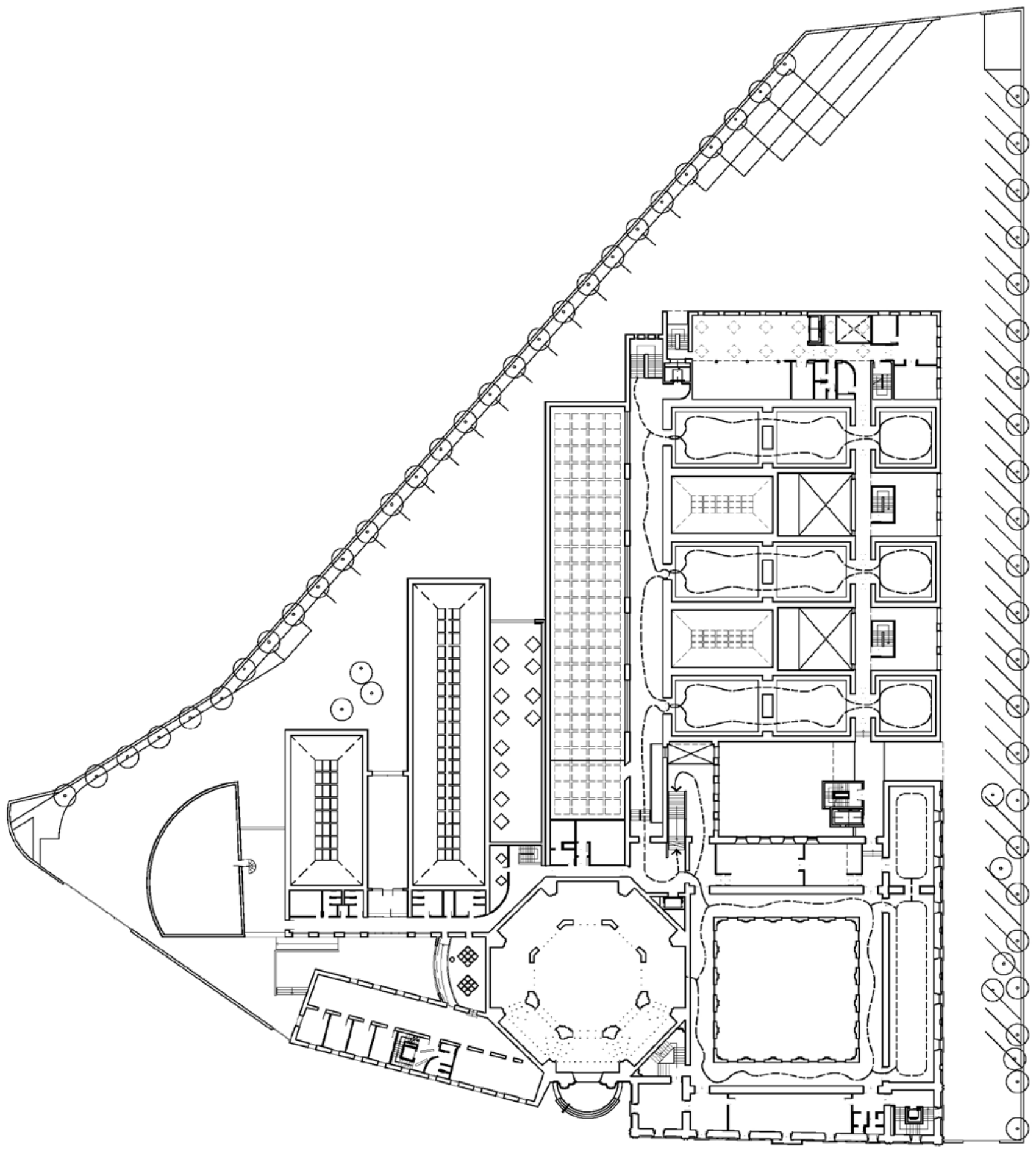


PLANTA BAJA: VISUALES

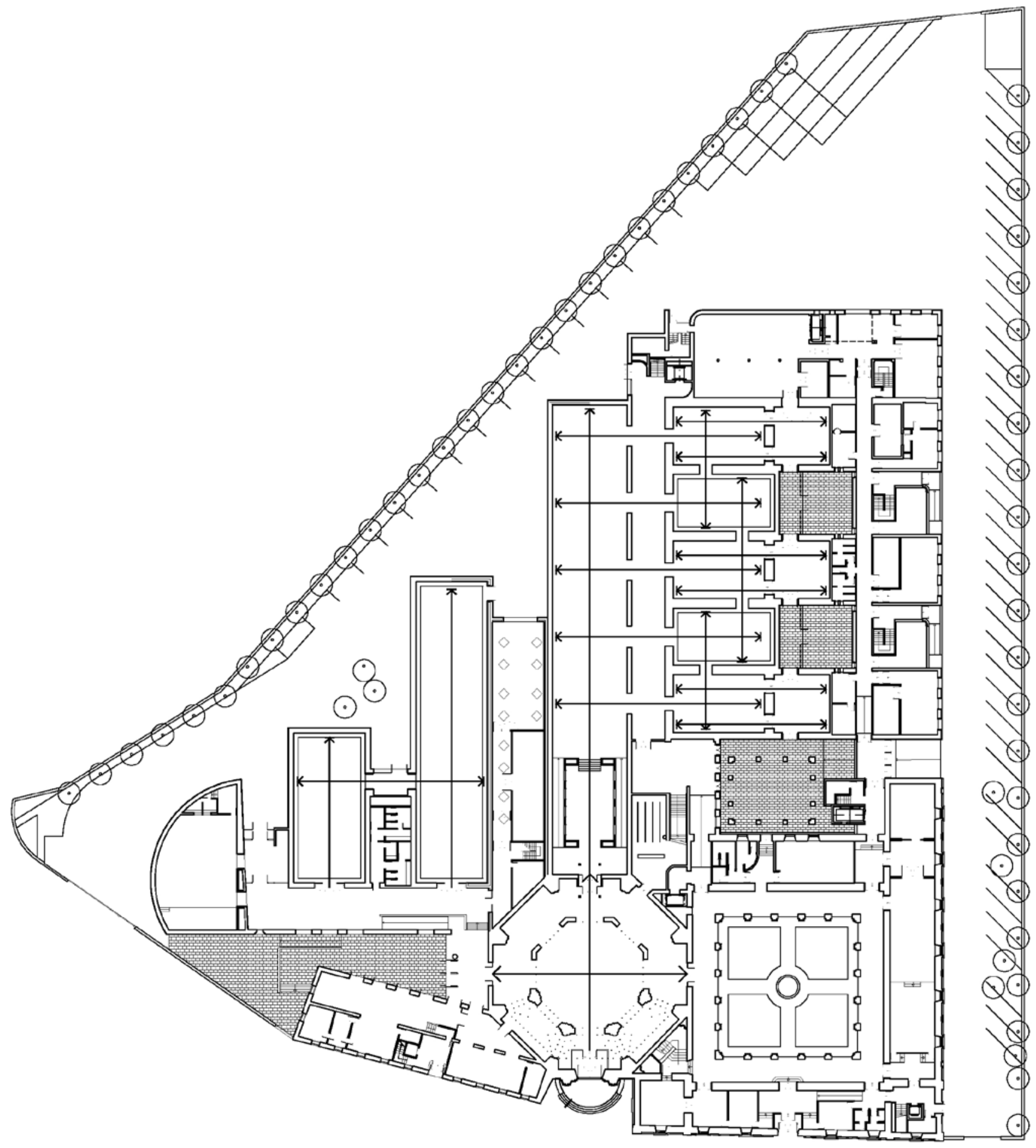


PLANTA PRIMERA: VISUALES

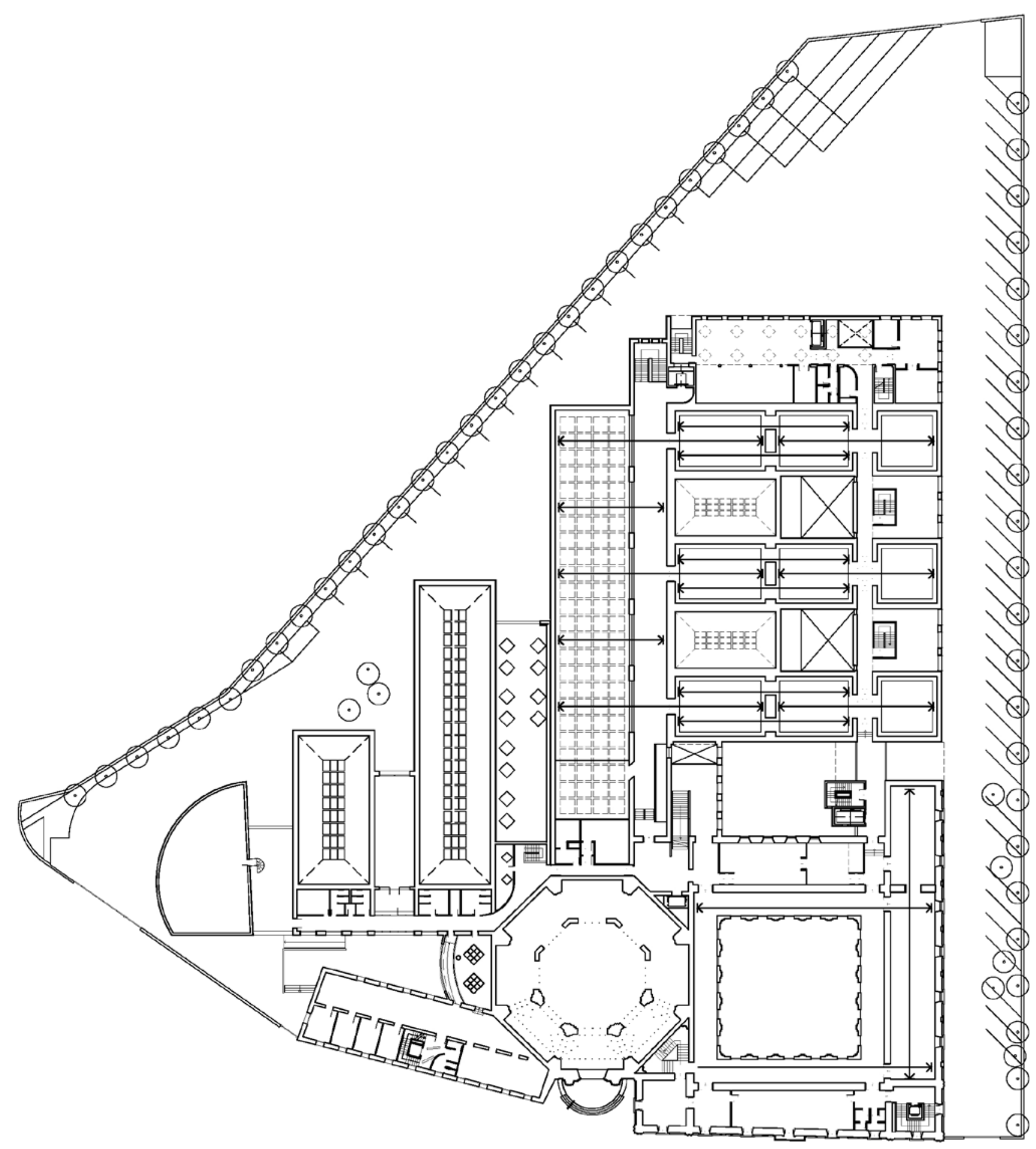




\subsubsection{Criterios organizativos. Usos y accesos}

\subsubsection{Programa: Usos y accesos}

El nuevo Museo de San Pío V pretende la organización racional y contemporánea de la exhibición de sus colecciones con la dotación de los servicios auxiliares necesarios. Los usos se inscriben en los diferentes cuerpos edificados atendiendo a la facilidad de sus accesos, a la claridad de las circulaciones y a la capacidad expositiva de sus espacios.

Desde el nuevo vestíbulo -antigua iglesia- cuyo espacio se recupera, accede el público general. El doble eje ordenador de las circulaciones permite clarificar los usos. El eje transversal permite el acceso a las exhibiciones temporales y sala de actos; también desde este vestíbulo se conectan el guardarropía en la actualidad, incivilmente suprimido- la tienda-librería y la cafetería, cuyas mesas y sillas invaden un pequeño y recogido patio de escultura. Alineado con las salas de exposición temporal, el nuevo salón de actos cierra el conjunto y define, con su paramento curvo, la nueva fachada oeste del edificio; dispone de un posible acceso independiente, a través de un pequeño vestíbulo, desde el aparcamiento interno del museo, previsto para la utilización de este espacio cuando el museo está cerrado. Este pequeño vestíbulo funciona, además, como salida de emergencia de las salas de exposiciones temporales.

El eje longitudinal corresponde con la exposición permanente, en la que se presenta la colección de una forma cronológica y razonada.

La Academia de Bellas Artes de San Carlos tiene su sede en el edificio; tradicionalmente ha ocupado parte de las alas claustrales. Su acceso independiente, por la antigua fachada sur del Colegio desde el paseo frente al río, le confiere cierta representatividad e independencia. La escasa altura libre de estas alas edificadas, junto al acceso descrito, aconsejan el mantenimiento de este uso en estos espacios, poco aptos para la exhibición de obras de arte que no sean obras de pequeñas dimensiones, como esculturas, bajorrelieves, acuarelas y dibujos. Parte de las salas que en ellas se inscriben se concibieron 
como gabinetes o almacenes visitables -hoy lamentablemente cerrados-.

El bloque lineal se reserva para las oficinas y administración en plantas altas; la baja alberga, como hemos dicho, la cafetería y la tienda. Tiene este bloque un acceso de personal desde la ronda del río, que se vincula a una escalera y ascensor de personal. Por medio de un pasillo en rampa, se puede cruzar el patio de escultura, y se alcanzan las dependencias para personal situadas sobre el corredor que da acceso a las salas de exposición temporal.

Los usos internos se sitúan en una crujía paralela al gran espacio longitudinal que expone los grandes retablos góticos; tiene un acceso independiente, vinculado al montacargas y al eje de servicio. Por este acceso, que tiene doble altura, entran y salen las obras de la colección permanente. El corredor de servicio, sobretodo el independiente de planta baja, permite la comunicación del acceso y del taller de restauración con el deambulatorio del claustro. Como hemos referido anteriormente, un almacén de tránsito sirve a las salas de exhibiciones temporales.

\subsubsection{Recorridos y relación espacio interior-espacio exterior}

La exposición permanente ofrece un recorrido cronológico: el eje longitudinal muestra los retablos góticos y tardogóticos, y permite mediante un itinerario que reproduce el "peine" conceptual de la propuesta un recorrido que alterna la gran galería con las salas de planta baja. Finalizado el recorrido en peine, se sube por una escalera a la planta primera; un corredor permite el recorrido inverso, que también se realiza a modo de peine. Desde este corredor se permiten visiones elevadas y transversales de los retablos góticos. Intercalados con las salas de exposición, dos salas con ventanas hacia el exterior permiten el descanso y reposo del visitante del museo; desde ellas descienden hacia el exterior las escaleras de emergencia, abiertas, enmarcadas por la caja de madera que las convierte 
en un objeto autónomo, inscrito en este espacio. Actualmente, se utilizan -contra lo previsto en proyecto- como lugares de exhibición, siguiendo la arraigada costumbre de censurar todo paramento desnudo, en una suerte de horror vacui impuesto como esencial criterio museográfico.

La exposición permanente desemboca en el núcleo de comunicación en el que una escalera lineal y un sistema de rampas permiten la conexión del edificio claustral con la ampliación. Desde este punto, se permitía la visita a las alas del claustro -exposición permanente en primera y segundas plantasy la subida a la llamada sala del Colosseo. Finalizada la visita, se toma un ascensor o escalera y se desciende al deambulatorio del claustro, desde el que se retorna al vestíbulo, punto de inicio del recorrido. También, en planta segunda, mediante una rampa se puede acceder a la biblioteca, por medio de un hueco abierto en el muro sur del octógono. Actualmente, estas previsiones no se llevaron a cabo, de modo que la sala del Colosseo no es accesible y la biblioteca conserva un único acceso en el poché del encuentro del octógono del vestíbulo con el cuerpo del claustro.

El recorrido de exhibición temporal es muy elemental pues consta de un espacio de circulación que se inicia desde el vestíbulo principal y que permite el acceso a las dos salas de exhibición. Las galerías de exposición temporal se desarrollan según el mismo esquema compositivo y están dotadas de iluminación cenital; también permiten unir su recorrido mediante un corredor acristalado, abierto al jardín, que al tiempo permite una necesaria evacuación.

\subsubsection{Visuales}

Se establece un planteamiento general para el conjunto de las salas de nueva planta y un planteamiento concreto para el gran espacio de exhibición de los retablos góticos. Por otro lado, se realizan una serie de precisiones sobre las salas del bloque claustral, finalmente no ejecutadas. El planteamiento visual de las salas responde a la galería tradicional: se opone 
el paramento ciego a los accesos de la sala: de este modo se rompe la enfilada en aras de propiciar una destacada visión frontal de piezas de especial relevancia. Complementariamente, el grosor de los muros que las separa, sirve para el paso de las instalaciones.

El gran espacio de los retablos marca la dirección de la visita, y su carácter longitudinal se refuerza con la disposición del corredor de planta primera; no posee ninguna subdivisión interna, salvo las que se puedan establecer de forma parcial por la posición relativa de los retablos. No obstante, la visión del lucernario continuo del techo nos recuerda a las galerías iluminadas cenitalmente cuya dimensión total se apreciaba sin interrupción alguna.

Finalmente, el deambulatorio del claustro había sido tratado como pequeñas salas expositivas, con motivos neo-renacentisas. En el proyecto, se propone la restitución del espacio continuo del deambulatorio, de forma que se devuelve al edificio el carácter anular de su circulación primigenia. Como a veces sucede, este criterio no se llegó a materializar.

\subsubsection{La iluminación}

Todas las salas de nueva planta tienen iluminación cenital, salvo las correspondientes a la planta baja de la exposición permanente, de menor altura y dimensión, ubicadas bajo las salas de planta primera. Para ello, disponen de lucernarios que iluminan los paramentos de exposición, en cuya parte inferior un zócalo de piedra alberga las rejillas de instalaciones (retorno). La impulsión se halla en la coronación de los paramentos verticales, justo antes del arranque de las falsas bóvedas que permiten una reflexión y difusión de la luz. En los senos de estas bóvedas, se colocan los aparatos de aire acondicionado, entre el espacio que encierran éstas y el forjado de cubierta. También en los arranques de las bóvedas hay una iluminación de refuerzo por reflexión y un sistema -infrautilizado- que permitía colgar cuadros con tijas; se posibilitaba así la presentación de la exposición antes del cuelgue definitivo. (Fig. 49 y 50)
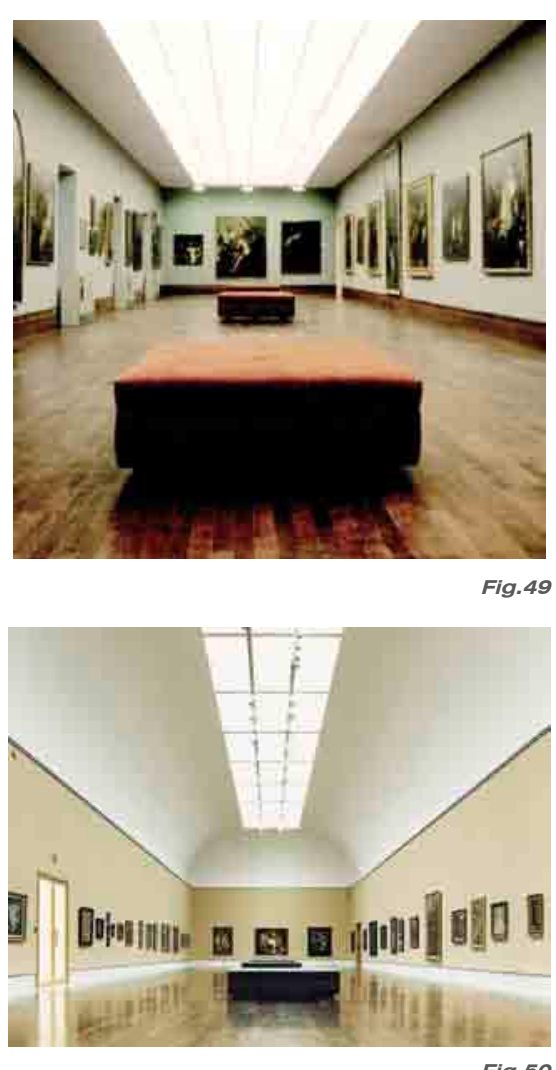
Entre cubiertas y bóvedas, hay unos parteluces dividen el hueco de las linternas que conforman el lucernario. El parteluz permite que el sol no bañe directamente las obras de arte; muy elemental, el diseño se inspira en algunos elementos análogos que diseñó Louis Kahn. Rematados en teja azul vidriada, en estos lucernarios se introducía una iluminación nocturna que desde la ciudad histórica se apreciaba como un conjunto de pequeñas linternas; inexplicablemente, esta iluminación fue respetada en los lucernarios de las salas de exposición permanente y suprimida en los relativos a las temporales: el resultado actúa a modo de resumen: motivos de difícil argumentación desfiguran y desmerecen la intención original.

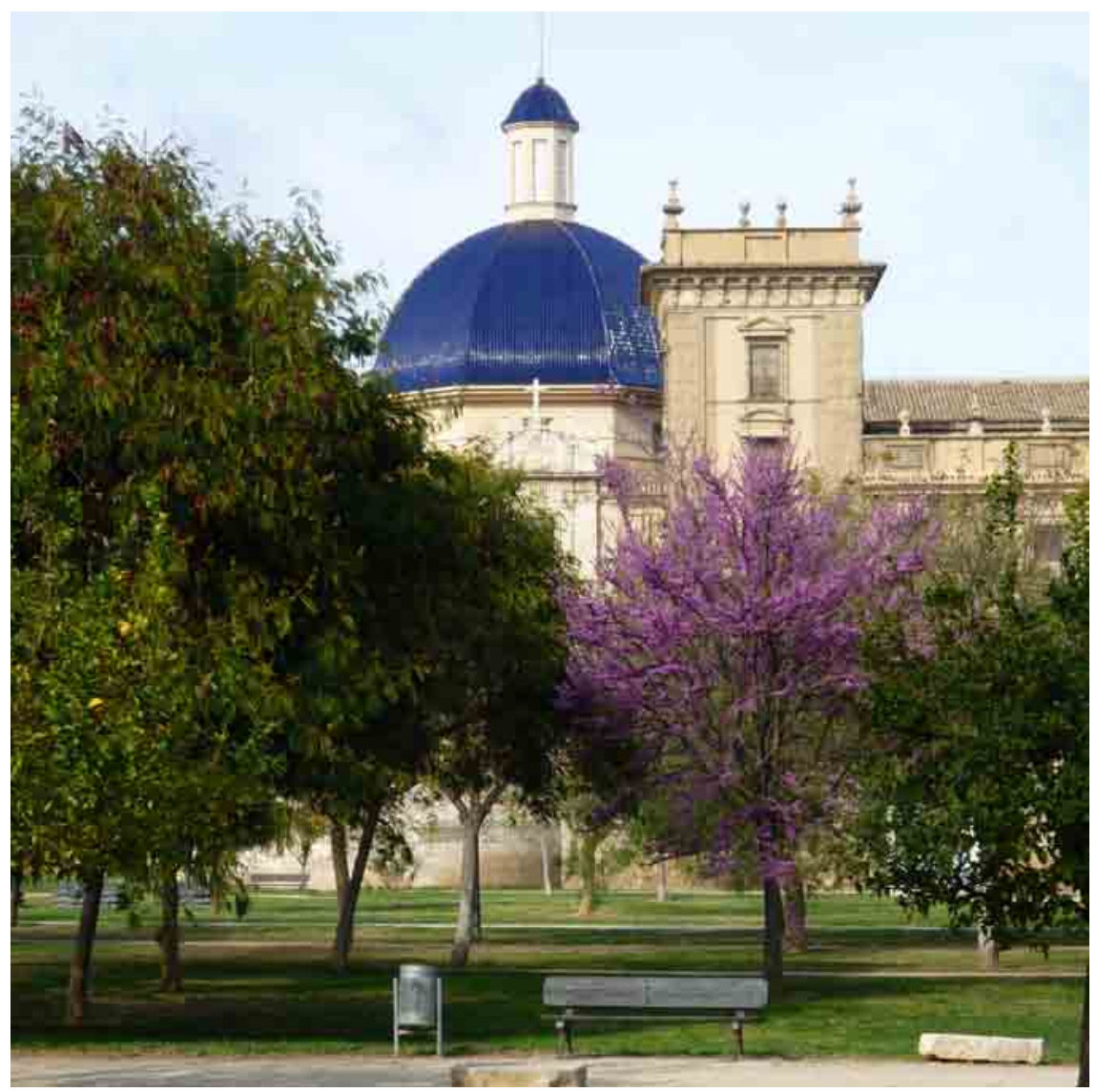


NOTAS

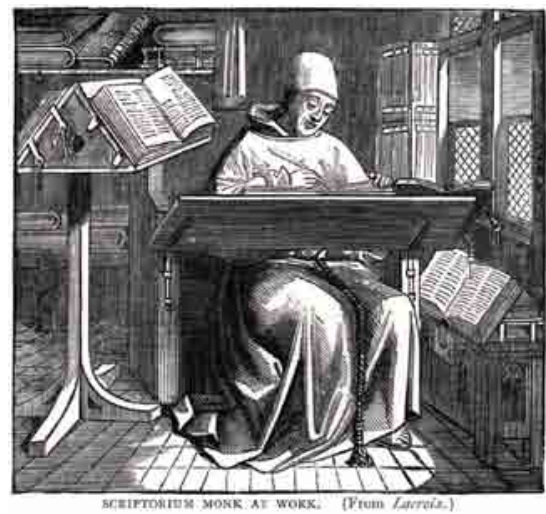

(1) Roca Traver, Francisco, El Colegio de San Pío V de Valencia, Valencia, Inédito, Copia del original en la Biblioteca del Colegio Territorial de Arquitectos de Valencia, 1969, pp. 17

(2) Juan, Francisco, Los Campanarios de José Minguez, Valencia 1700-1750, Valencia, Ediciones Generales de la Construcción, Biblioteca TC, 2000

(3) Garín Ortiz de Taranco, Felipe Ma , Catálogo-Guía del Museo Provincial de Bellas Artes de San Carlos, Valencia, Institución Alfonso el Magnánimo, 1955

(4) V.AA., "Sant Pius Ve: El Museu del 90", El Temps, 14/05/1990, año VII, Valencia,

(5) Portaceli, Manuel, Arquitecturas 1971-2001, Cuadernos TC n50, Valencia, Ediciones Generales de la Construcción, 2001

(6) Cruilles, Marqués de, Guía urbana de Valencia antigua y moderna, Valencia, Librería París-Valencia, 1979

(7) Llopis Alonso, Amando; Perdigón Fernández, Luis, "Plano P1 de Antonio Mancelli", Cartografía de la Ciudad de Valencia, 1608-1944, Valencia, Universidad Politécnica de Valencia, 2010

(8) Francia, Carlos, "Grabado de la Naumacchia", en: Serrano Pérez, Tomás, Fiestas seculares, con que la coronada ciudad de Valencia celebró el feliz cumplimiento del tercer siglo de la canonizacion de su esclarecido hijo, y angel protector S. Vicente Ferrer, Apostol de Europa / escribialas el R.P. Thomas Serrano, de la Compañia de Jesus, Valencia, Imprenta de José de Orga, 1762

(9) Brandi, Cesare, Teoria del Restauro, Torino, Piccola Biblioteca Einaudi, 1977, pp.46

(10) Aldana, Salvador, La Lonja de Valencia, Valencia, Ed. Biblioteca Valenciana, 1988 


\section{MUSEOS: UNA ANTOLOGIA PERSONAL}

01 STUDIOLO DE FEDERICO DE MONTEFELTRO, Palacio Ducal de Urbino, Urbino (Italia) - 1476

02 GALERÍA DE LOS UFFIZI, Florencia (Italia) - 1560

03 PALAIS DE LUXEMBOURG, París, Francia - Salomon de Brosse, 1631

04 MUSEO PÍO CLEMENTINO (MUSEOS VATICANOS), Ciudad del Vaticano, Roma - 1773

05 MUSEO DEL PRADO, Madrid, España - Juan de Villanueva, 1784

06 MUSEO DEL LOUVRE, París, Francia - Hubert Robert, 1786

07 PRÉCIS DES LEÇONS D'ARCHITECTURE DONNÉES À L'ECOLE POLYTHECHNIQUE, Jean Nicolas Louis Durand, 1802

DULWICH PICTURE GALLERY, Londres, Reino Unido - Sir John Soane, 1811 GLYPTOTHEK, Múnich, Alemania - Leo von Klenze, 1815

ALTES MUSEUM, Berlín, Alemania - K. Friedich Schinkel, 1823

BRITISH MUSEUM, Londres, Reino Unido - Sir Robert Smirke, 1823

ALTE PINAKOTHEK, Múnich, Alemania - Leo von Klenze, 1826

THORVALDSENS MUSEUM, Copenhague, Dinamarca - Michael Gottlieb Bindesbøll, 1848 CRYSTAL PALACE, Great Exhibition, Londres, Reino Unido - Sir Joseph Paxton, 1851

EXHIBITION HALL - ART TREASURES EXHIBITION, Manchester, Reino Unido - Francis Fowke, 1857 METROPOLITAN MUSEUM OF ART, New York City, New York (USA) - Richard Morris Hunt, 1880

GALERIE DES MACHINES - EXPOSICIÓN UNIVERSAL DE 1889, París, Francia - Ferdinand Dutert et Charles Léon Stephen Sauvestre, 1889

MUSEO FAABORG, Faaborg, Dinamarca - Carl Petersen, 1915

MUNDANEUM, Ginebra, Suiza - Le Corbusier, 1929 KRÖLLER-MÜLLER MUSEUM, Otterloo, Países Bajos - Henry van de Velde, 1937 MUSEO DE CRECIMIENTO ILIMITADO, Le Corbusier, 1939 PEQUEÑO MUSEO, Mies van der Rohe, 1942 
PADIGLIONE D'ARTE CONTEMPORANEA, Milán, Italia - Ignazio Gardella, 1953 MUSEO DE ARTE DE AHMEDABAD, Ahmedabad, India - Le Corbusier, 1954 PABELLÓN DE HOLANDA PARA LA BIENAL 1954-55, Venecia, Italia - Gerrit Rietveld, 1954 PABELLÓN DE VENEZUELA PARA LA BIENAL 1954-55, Venecia, Italia - Carlo Scarpa, 1954 MUSEO DE LAS ARTES OCCIDENTALES, Tokio, Japón - Le Corbusier, 1957 PALAZZO ROSSO, Génova, Italia - Franco Albini, 1961 PALACIO DE EXPOSICIONES EN ESTOCOLMO, Estocolmo, Suecia - Le Corbusier, 1962 KIMBELL ART MUSEUM, Fort Worth, Texas (USA) - Louis Khan, 1966 WHITECHAPEL ART GALLERY, Londres, Reino Unido - Alan Colquhoun \& John Miller, 1966 MUSEO DE ARTE WHITNEY, New York City, New York (USA) - Marcel Breuer, 1966 NEUE NATIONALGALERIE, Berlín, Alemania - Mies van der Rohe, 1968 YALE CENTER FOR BRITISH ART, New Haven, Connecticut (USA) - Louis I. Kahn, 1969 CENTRO POMPIDOU, París, Francia - Renzo Piano \& Richard Rogers, 1971 MUSEO VAN GOGH , Amsterdam, Países Bajos - Gerrit Rietveld, 1973 AMPLIACIÓN DEL MUSEO WALLRAF-RICHARTZ, Colonia, Alemania - James Stirling, 1975 THE U.S. NATIONAL GALLERY OF ART (EDIFICIO ESTE), Washington, D.C. (USA) - I. M. Pei, 1978 AMPLIACIÓN DEL MUSEO FOGG, Cambridge, Massachusetts (USA) - James Stirling, 1979 MUSEO DE ARTE ROMANO DE MÉRIDA, Mérida, España - Rafael Moneo, 1980 MUSEO DE ARTE MODERNO DE LOS ÁNGELES, Los Ángeles, California (USA) - Arata Isozaki, 1981 THE MENIL COLLECTION MUSEUM, Houston, Texas (USA) - Renzo Piano, 1982 THE NATIONAL GALLERY OF CANADA, Ottawa, Ontario (Canadá) - Moshe Safdie, 1983 NEUE STAATSGALERIE, Stuttgart, Alemania - James Striling, 1984 INSTITUT VALENCIÀ D'ART MODERN, Valencia, España - Emilio Giménez y Carlos Salvadores, 1986 CLORE GALLERY (TATE BRITAIN, Londres, Reino Unido - James Stirling, 1986 AMPLIACIÓN DE LA NATIONAL GALLERY - ALA SAINSBURY, Londres, Reino Unido - James Stirling, 1986 THYSSEN MUSEUM EN LUGANO, Lugano, Suiza - James Stirling, 1986 MUSEO DE ARTE CONTEMPORÁNEO (MACBA), Barcelona, España - Richard Meier, 1987 MUSEO DE BELLAS ARTES DE CORUÑA, La Coruña, España - Manuel Gallego, 1988 CENTRO GALLEGO DE ARTE CONTEMPORÁNEO, Santiago de Compostela, España - Álvaro Siza, 1988 GOETZ ART GALLEY, Munich, Alemania - Herzog \& De Meuron, 1989 MUSEO KIRCHNER EN DAVOS, Davos, Suiza - Gigon \& Guyer, 1989 MUSEO DE ARTE BREGENZ, Bregenz, Austria - Peter Zumthor, 1990 MUSEO DEL BOSQUE DE LAS TUMBAS, Kumamoto, Japón - Tadao Ando, 1990 SEATTLE ART MUSEUM, Seattle, Washington, (USA) - Robert Venturi, 1990 MUSEO DE ARTE MODERNO DE ESTOCOLMO, Estocolmo, Suecia - Rafael Moneo, 1991 AMPLIACIÓN DE LA NATIONAL GALLERY - ALA SAINSBURY, Londres, Reino Unido - Venturi \& Scott Brown, 1991 MUSEO PARA LA COLECCIÓN BEYELER, Basilea, Suiza - Renzo Piano, 1991 MUSEO DE BELLAS ARTES DE HOUSTON - EDIFICIO AUDREY JONES BECK, Houston, Texas (USA) - Rafael Moneo, 1992 MUSEO EN HELSINKI, Helsinki, Finlandia - Álvaro Siza, 1993 COLECCIÓN AM RÖMERHOLZ, Winterthur, Suiza - Gigon \& Guyer, 1993 AMPLIACIÓN DEL MUSEO DE ARTE DE WINTERTHUR, Winterthur, Suiza - Gigon \& Guyer, 1993 
FIGGE ART MUSEUM, Davenport, Iowa (USA) - David Chipperfield, 1995 AMPLIACIÓN DEL MUSEO DEL PRADO, Madrid, España - Rafael Moneo, 1996 MUSEO LINER, Appenzell, Suiza - Gigon \& Guyer, 1996 MUSEO DE BELLAS ARTES DE CASTELLÓN, Castellón de la Plana, España - Tuñón y Mansilla, 1997 KUNSTMUSEUM VADUZ, Vaduz, Liechtenstein - Gigon \& Guyer, 1997 TATE MODERN GALLERY, Londres, Reino Unido - Herzog \& de Meuron, 1998 MUSEO PARA LA FUNDACIÓN IBERÊ CAMARGO, Porto Alegre, Brasil - Álvaro Siza, 1998 MUSEO ARTE MODERNO DE FORT WORTH , Fort Worth, Texas (USA) - Tadao Ando, 1999

NASHER SCULPTURE CENTER, Dallas, Texas, (USA) - Renzo Piano, 1999

ART INSTITUTE OF CHICAGO, Chicago, Illinois (USA) - Renzo Piano, 1999 MUSEUM HET VALKHOF, Nimega, Países Bajos - Ben van Berkel, 1999 CENTRE PASQUART, Biel, Suiza - Diener \& Diener, 2000 KUNSTMUSEUM LIECHTENSTEIN, Vaduz, Liechtenstein - Meinrad Morger, Heinrich Degelo and Christian Kerez, 2000

CONCURSO PARA EL MUSEO DE ARTE Y DISEÑO DE INGOLSTADT, Ingolstadt, Alemania - Gigon \& Guyer, 2000

LEOPOLD MUSEUM (MUSEUMSQUARTIER), Viena, Austria - Ortner \& Ortner, 2000 MUSEUM MODERNER KUNST STIFTUNG LUDWIG (MUSEUMSQUARTIER), Viena, Austria - Ortner \& Ortner, 2000

MUSEO DE ALTAMIRA, Santillana del Mar, España - Juan Navarro Baldeweg - 2000 AMPLIACIÓN DE LA GALLERIA NAZIONALE D'ARTE MODERNA E CONTEMPORANEA, Roma, Italia - Diener \& Diener - 2000

AMPLIACIÓN DEL MUSEO PERGAMON, Berlín, Alemania - O.M. Ungers - 2000 MUSEUM DER BILDENDEN KÜNSTE, Leipzig, Alemania - Hufnagel, Pütz \& Rafaelian - 2000 ALBERS-HONEGGER DONATION, ESPACE DE L'ART CONCRET, Mouans-Sartoux, France - Gigon \& Guyer, 2000

PINACOTECA GIOVANNI \& MARELLA AGNELLI, EDIFICIO LINGOTTO, Turín, Italia - Renzo Piano - 2000 MUSEO DE ARTE CONTEMPORÁNEO DE CASTILLA Y LEÓN, León, España - Tuñón y Mansilla, 2001 PATIO HERRERIANO. MUSEO DE ARTE CONTEMPORÁNEO ESPAÑOL, Valladolid, España - Juan Carlos Arnuncio, Clara Aizpún y Javier Blanco, 2001

STUTTGART KUNSTMUSEUM, Stuttgart, Alemania - Hascher+Jehle, 2002 AMPLIACIÓN DEL MOMA, New York City, New york (USA) - Yoshio Taniguchi, 2004 MUSEO DE ARTE NELSON-ATKINS, Kansas City, Missouri (USA) - Steven Holl - 2007 
STUDIOLO DE FEDERICO DE MONTEFELTRO

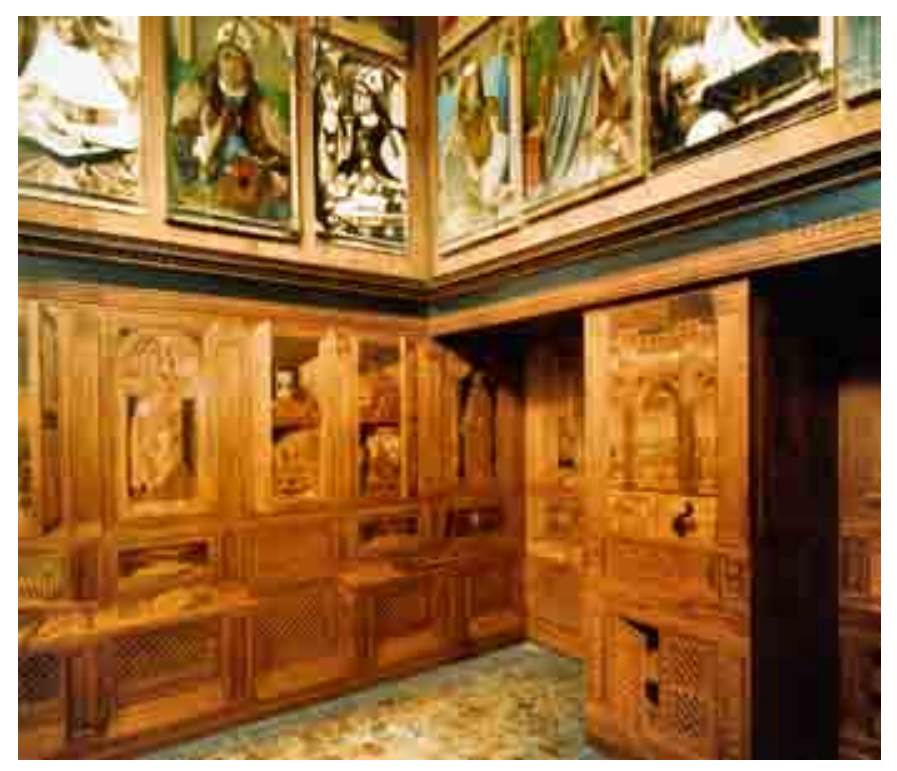

Palacio Ducal de Urbino, Urbino (Italia) - 1476
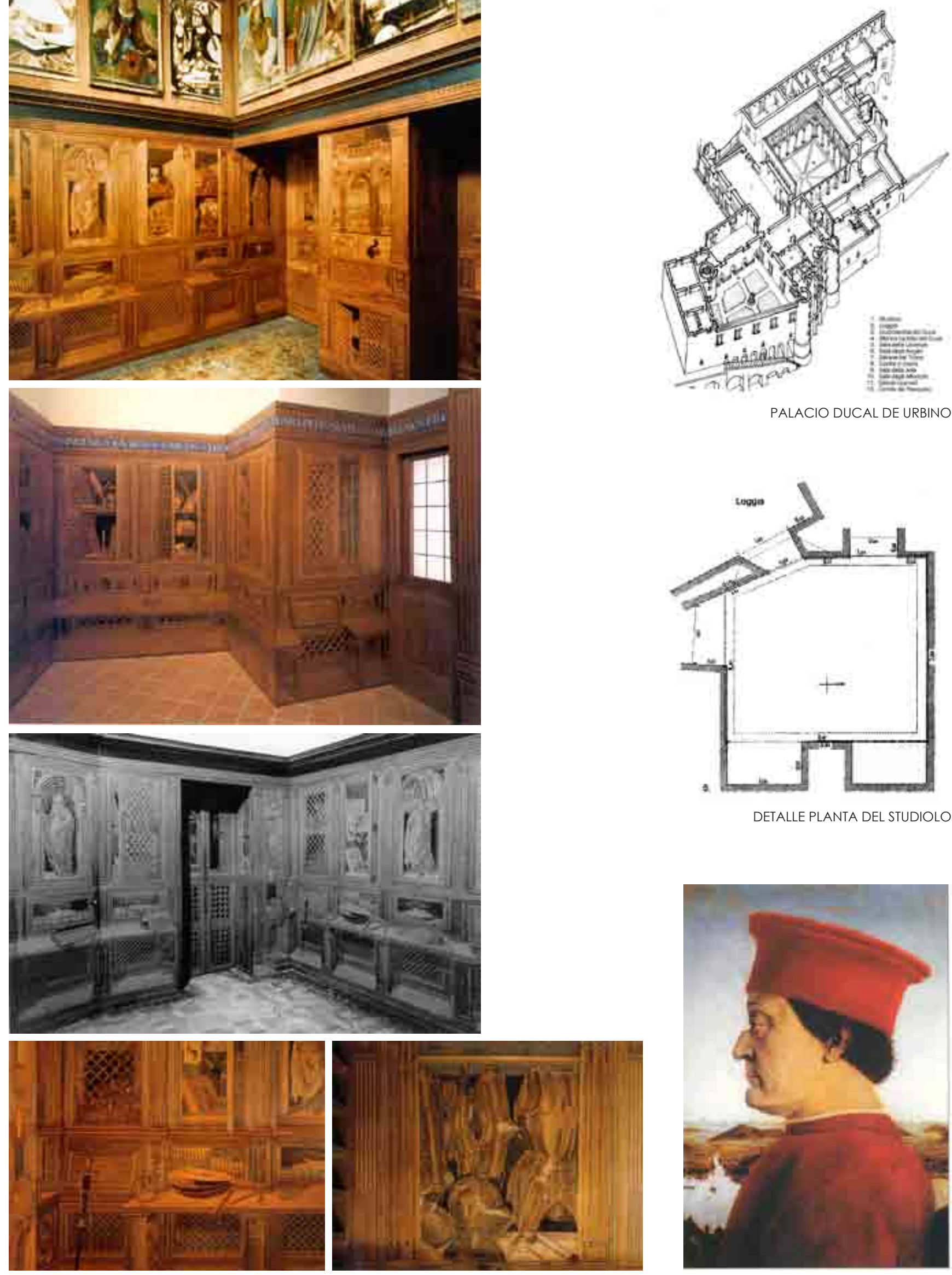

PALACIO DUCAL DE URBINO

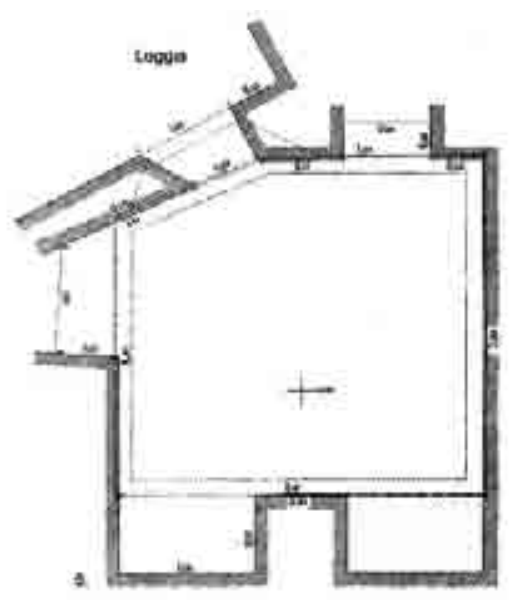

DETALLE PLANTA DEL STUDIOLO

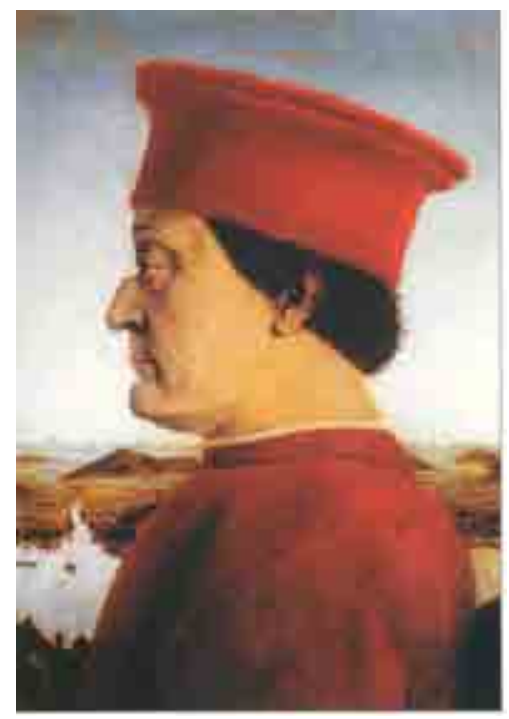


GALERÍA DE LOS UFFIZI

Florencia (Italia) - Giorgio Vasari - 1560
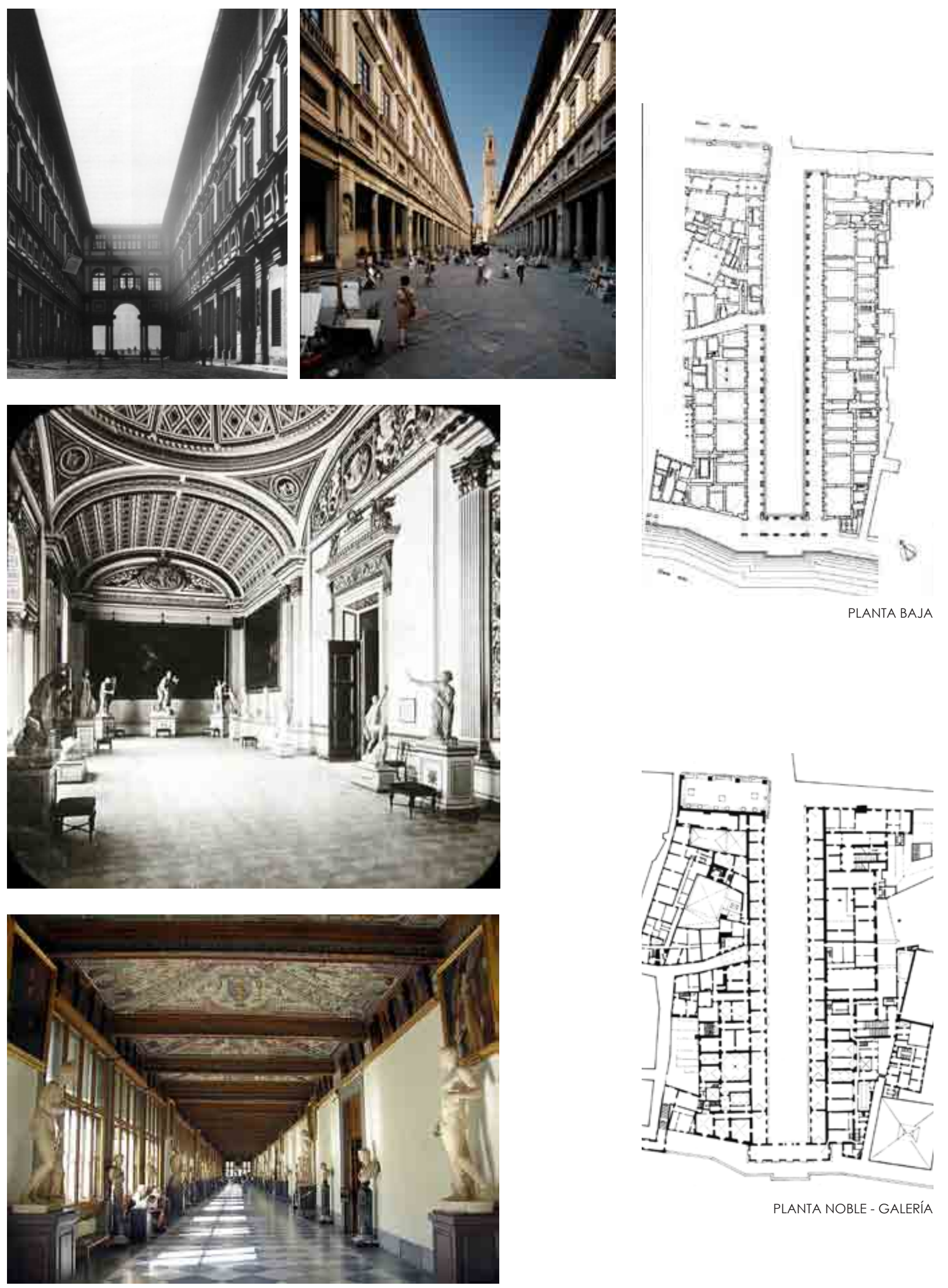
PALAIS DE LUXEMBOURG

París, Francia - Salomon de Brosse, 1631
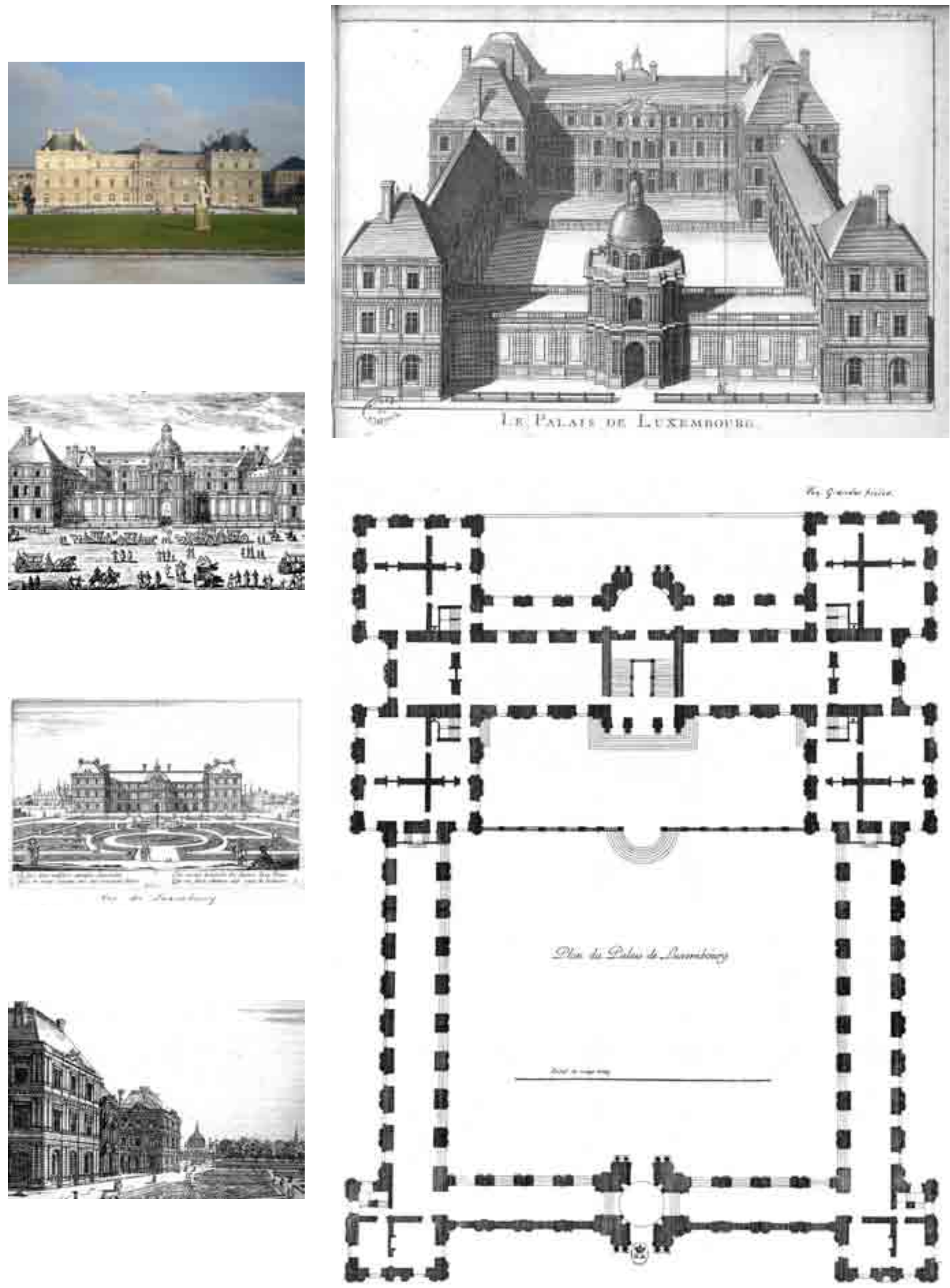
MUSEO PÍO CLEMENTINO (MUSEOS VATICANOS)

Ciudad del Vaticano, Roma - 1773
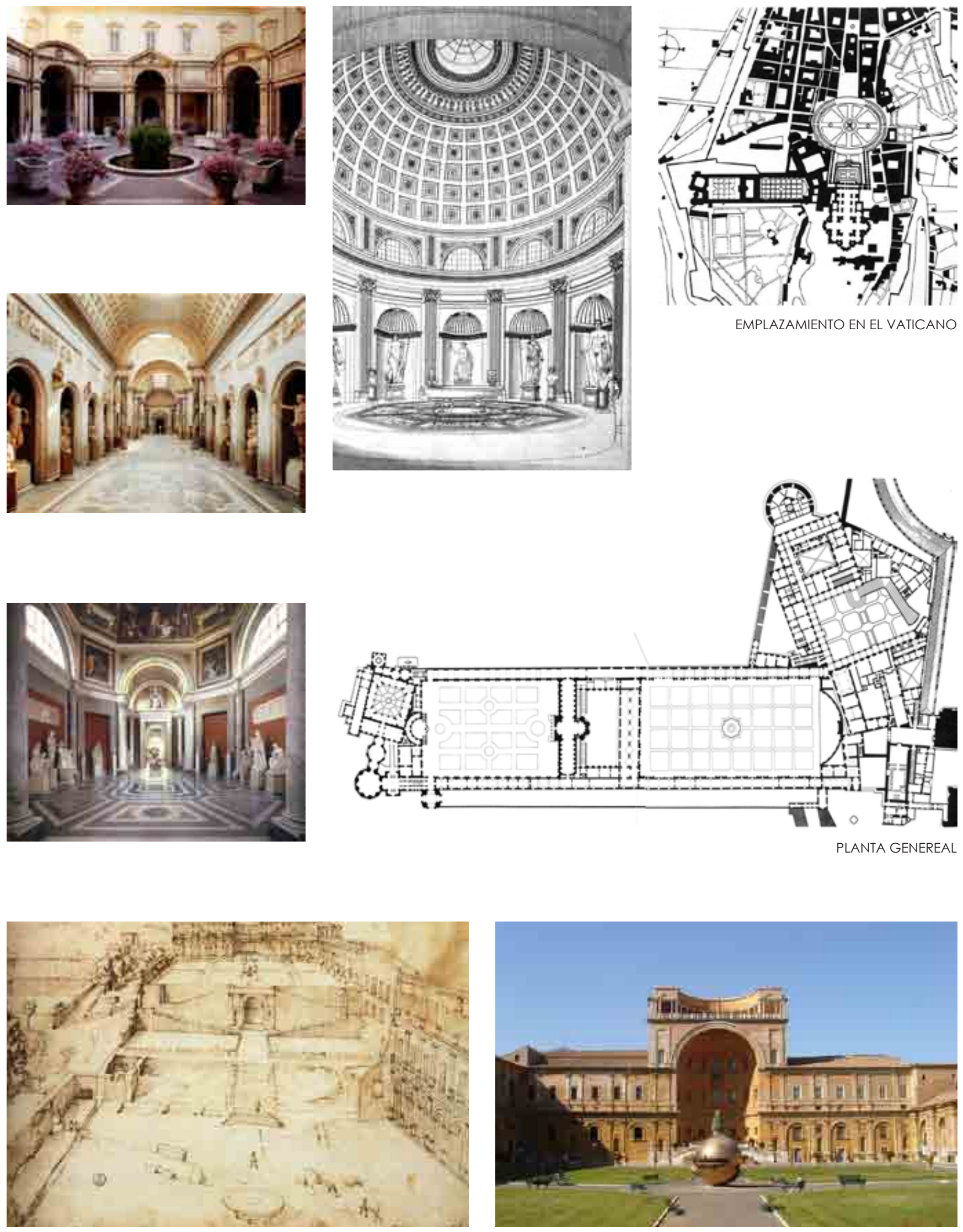


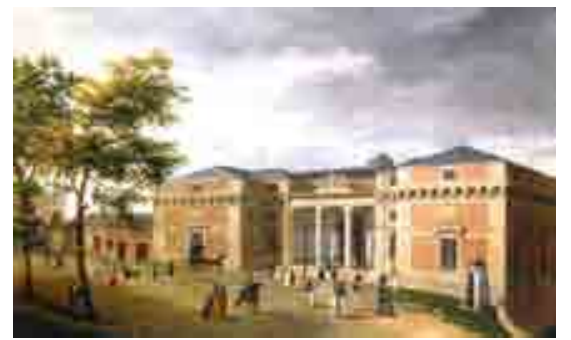

FACHADA NORTE DEL MUSEO Ferdinando Brambilla, c. 1825

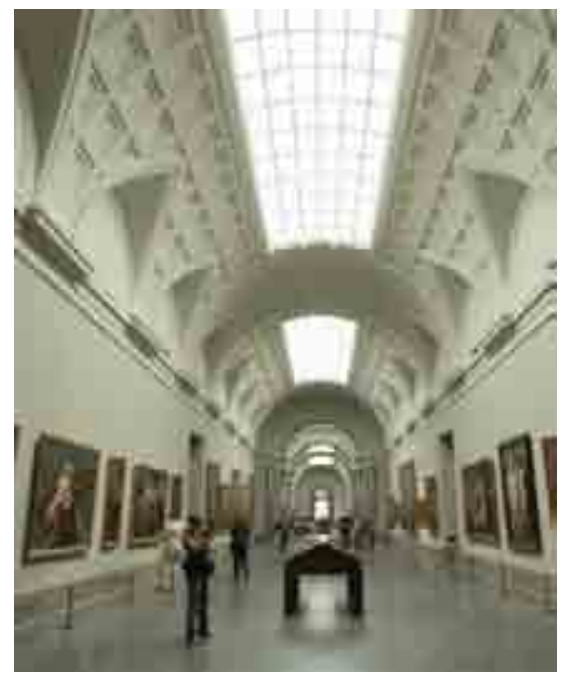

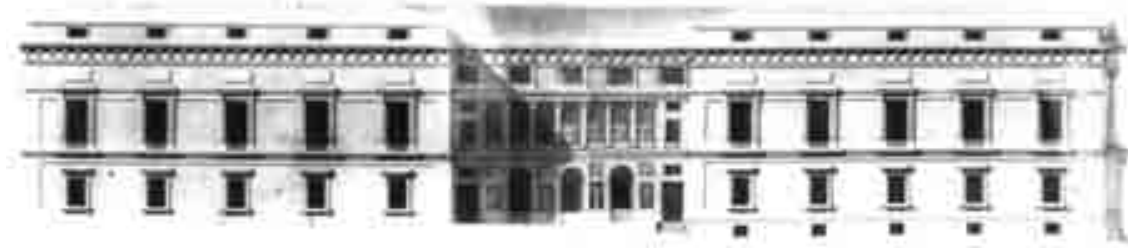

FACHADA
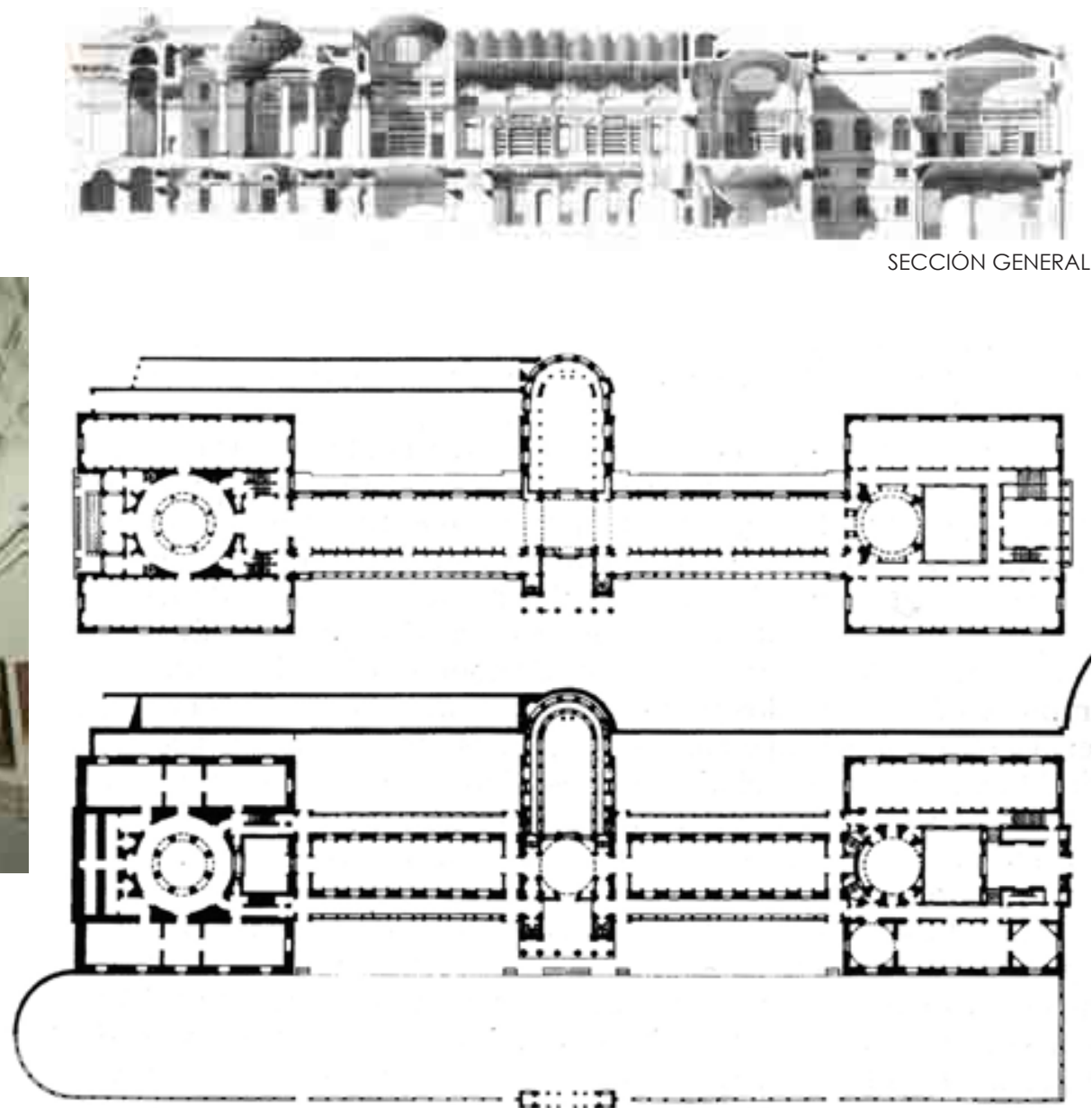

PLANTAS GALERÍAS
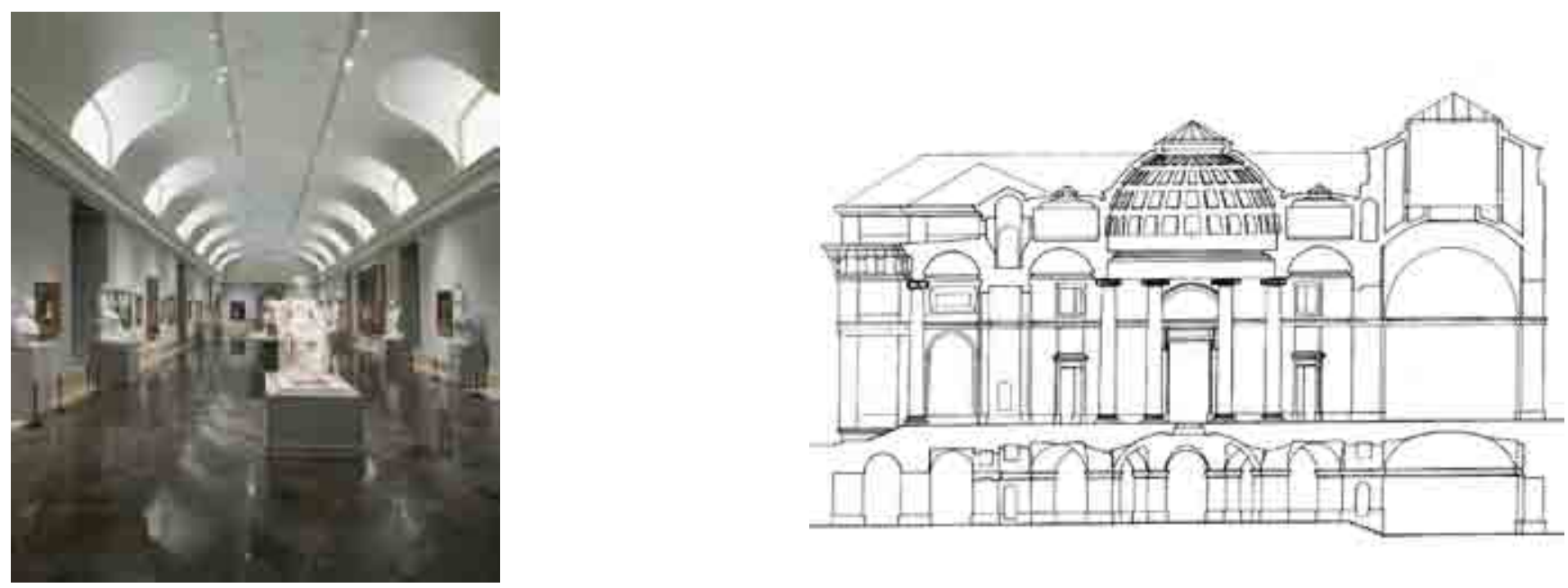

SECCIÓN - DETALLE 
MUSEO DEL LOUVRE

París, Francia - Hubert Robert, 1786

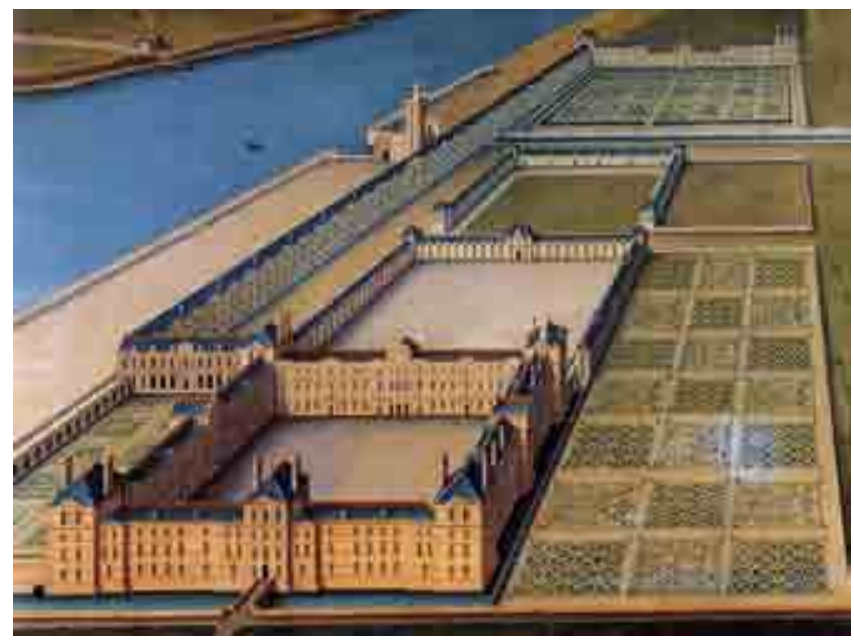

PLAN DEL LOUVRE

DE ENRIQUE IV, C. 1600

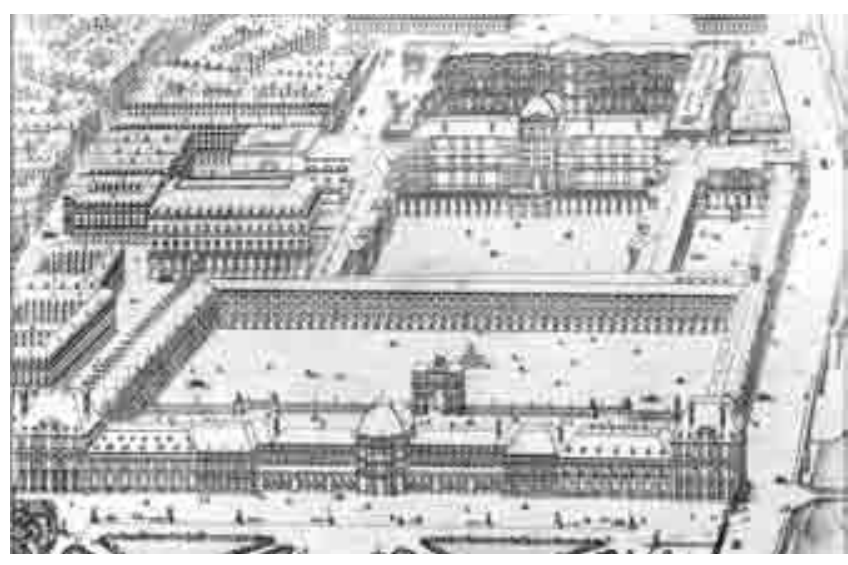

PROYECTO DEL LOUVRE

DE PERCIER Y FONTAINE, C. 1800

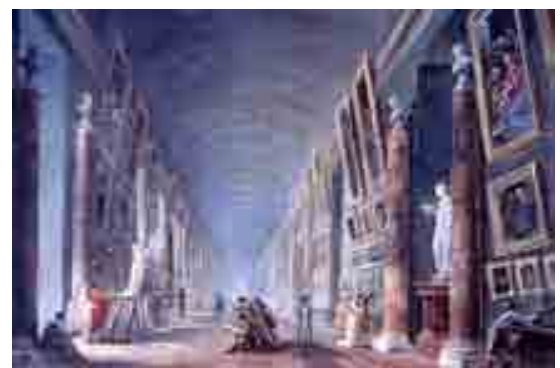

GRANDE GALERIE

Robert Hubert, C. 1786

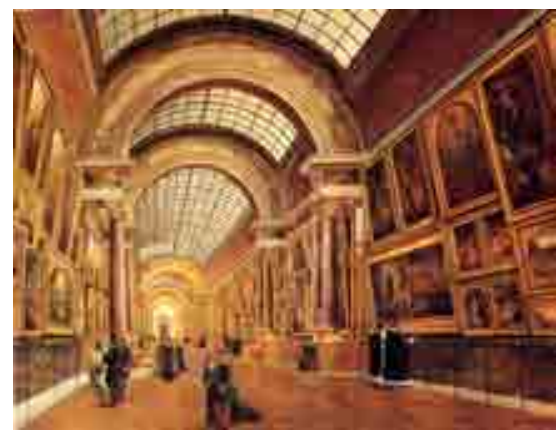

VUE DE LA GRANDE GALERIE

Victor Duval, 1880

INDEX-6

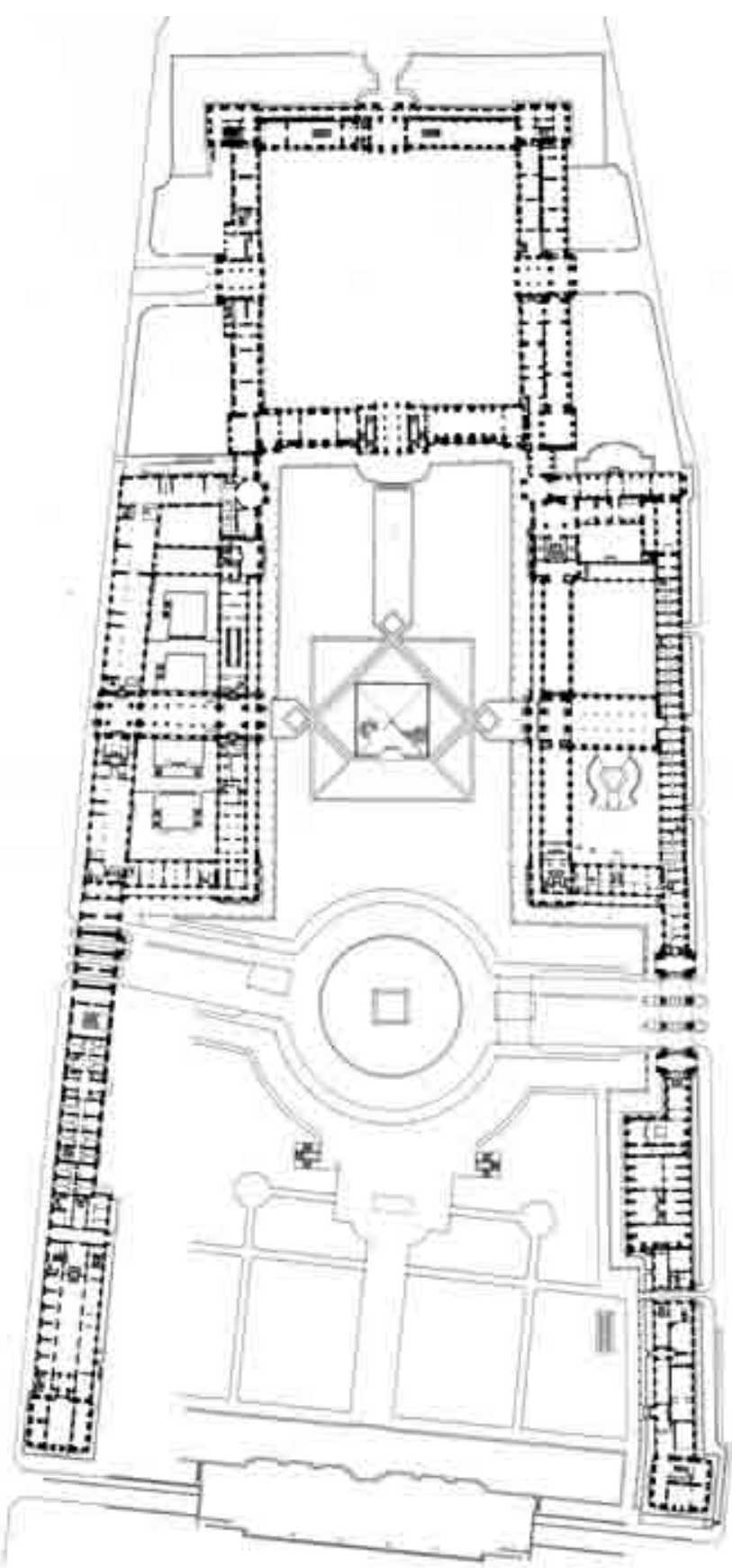

PLANTA GENERAL

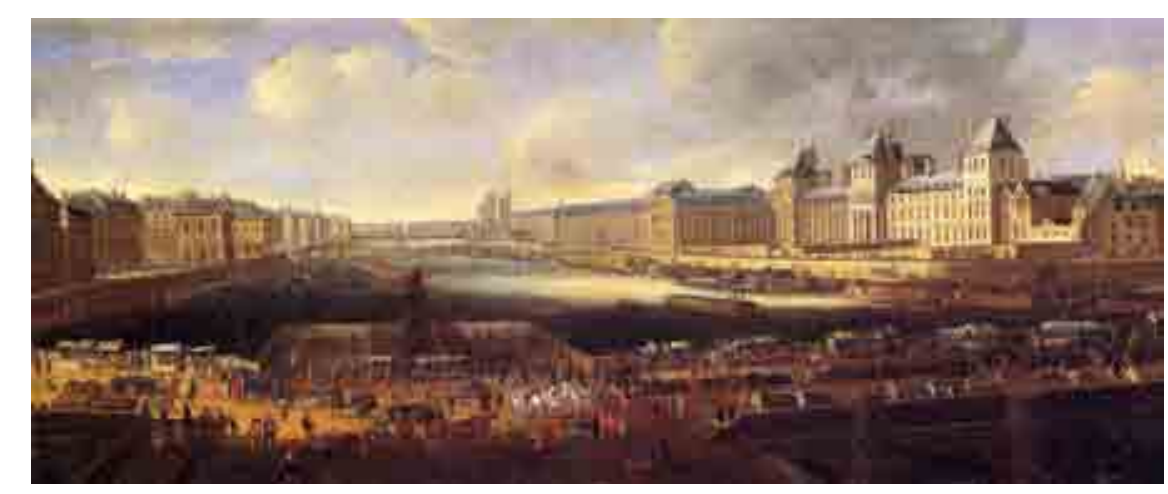

VUE DU PALAIS DU LOUVRE DEPUIS LE PONT NEUF C. 1666 
PRÉCIS DES LECCONS D'ARCHITECTURE DONNÉES À L'ECOLE POLYTHECHNIQUE Jean Nicolas Louis Durand, 1802

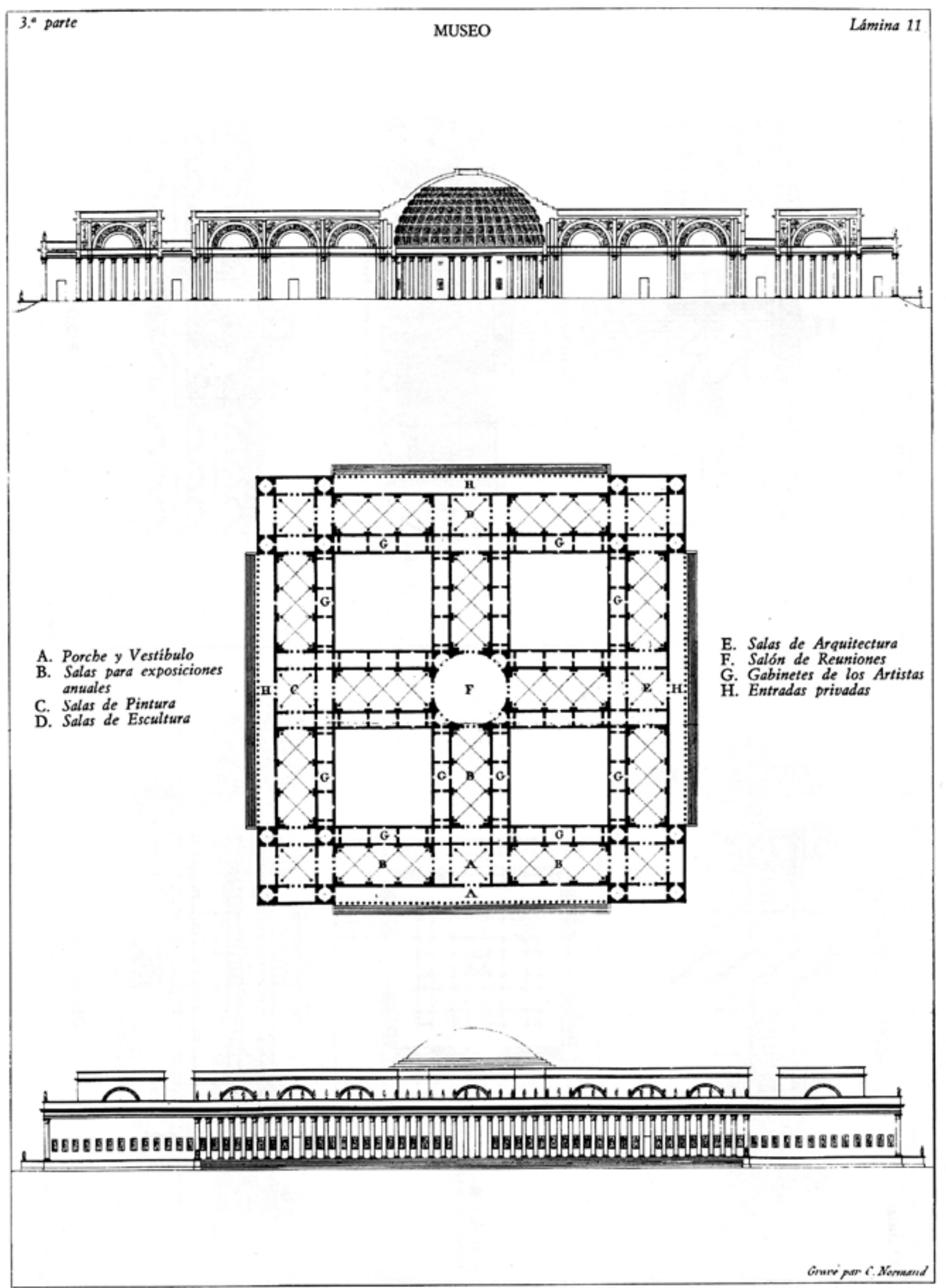


DULWICH PICTURE GALLERY

Londres, Reino Unido - Sir John Soane, 1811
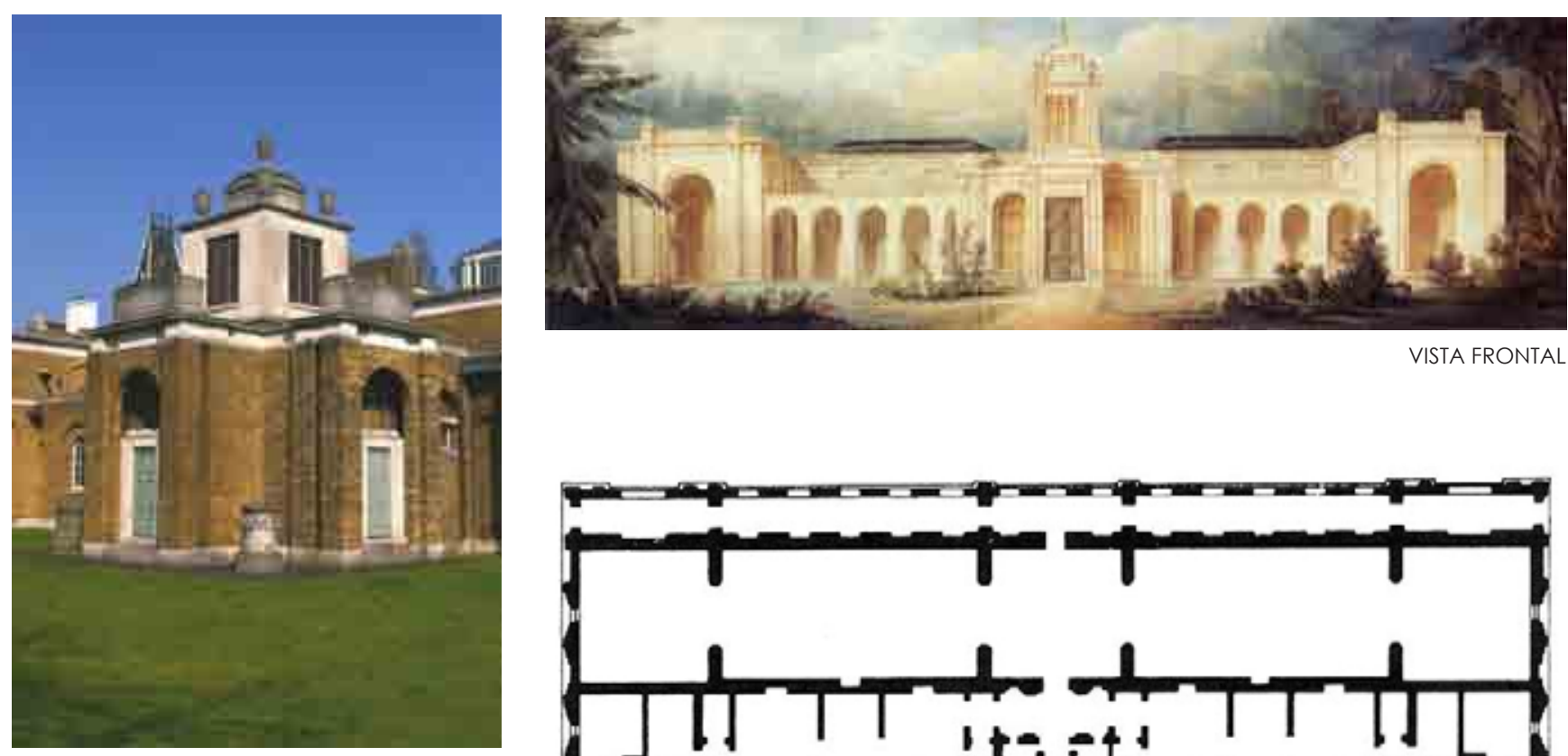

VISTA FRONTAL

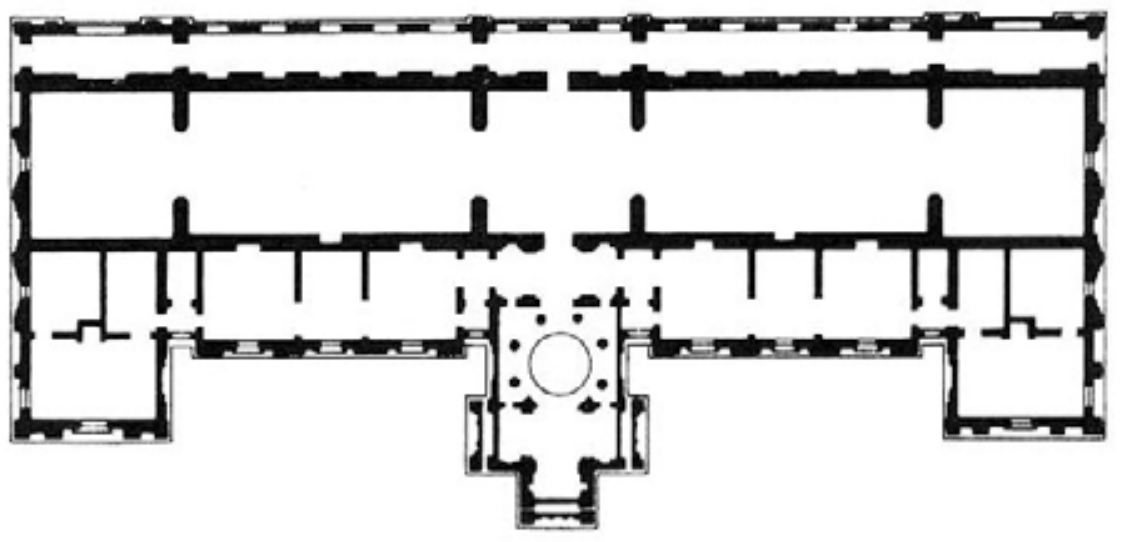

PLANTA NIVEL ACCESO
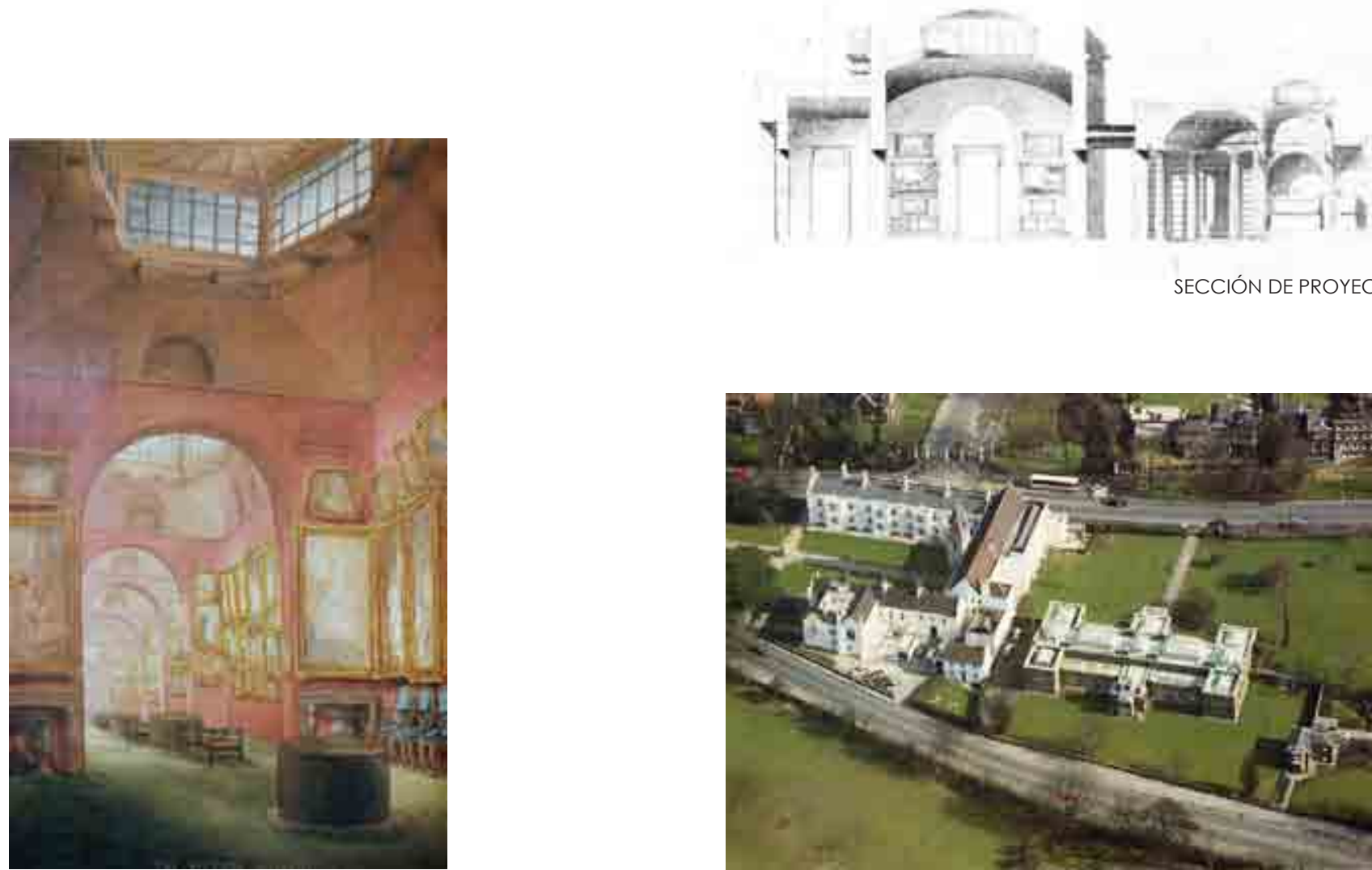

SECCIÓN DE PROYECTO

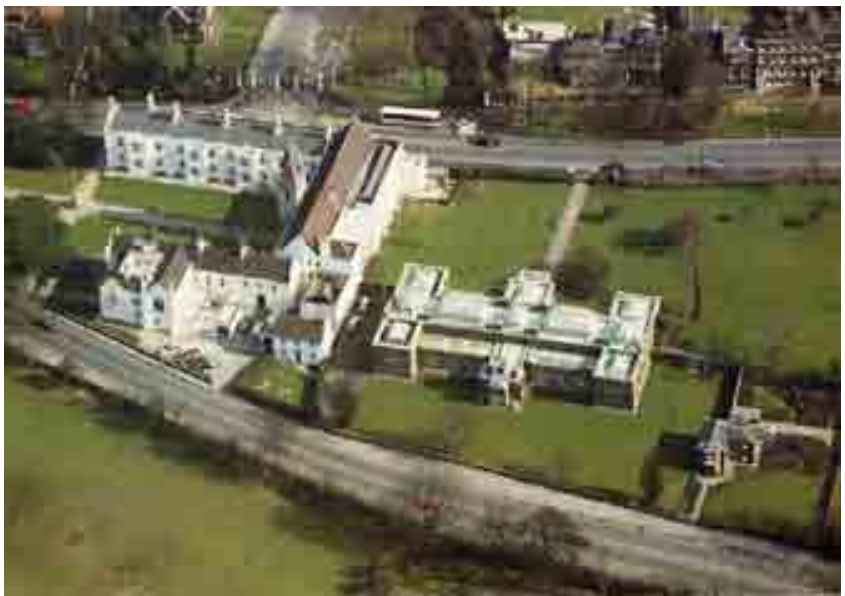

VISTA DE LA GALERÍA 

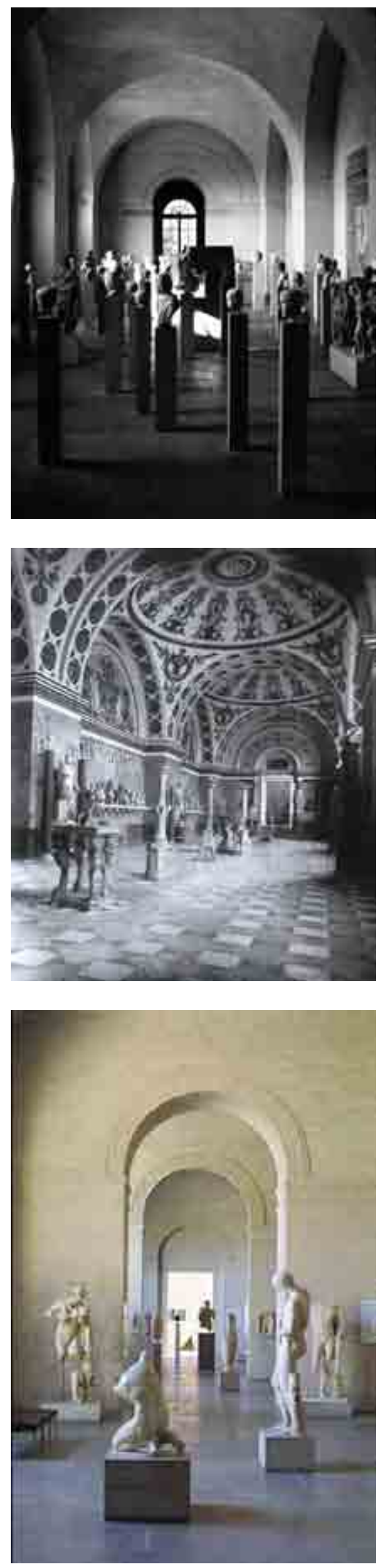

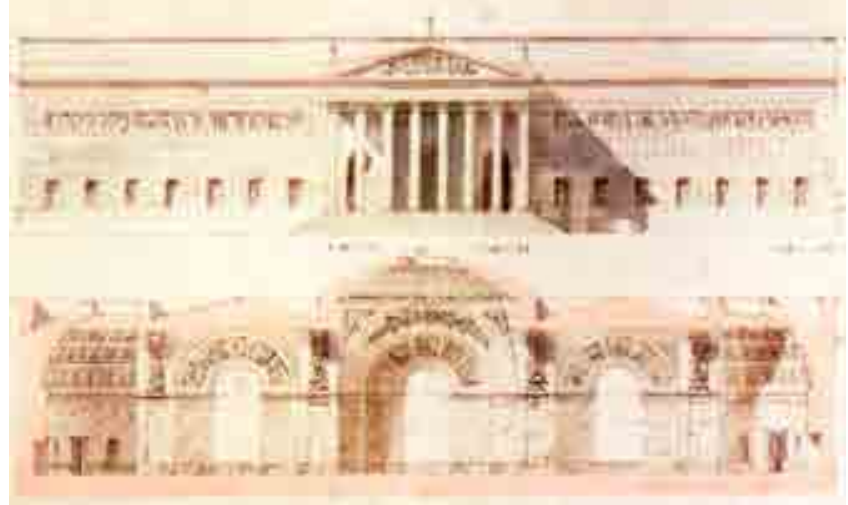

FACHADA Y SECCIÓN POR GALERÍA

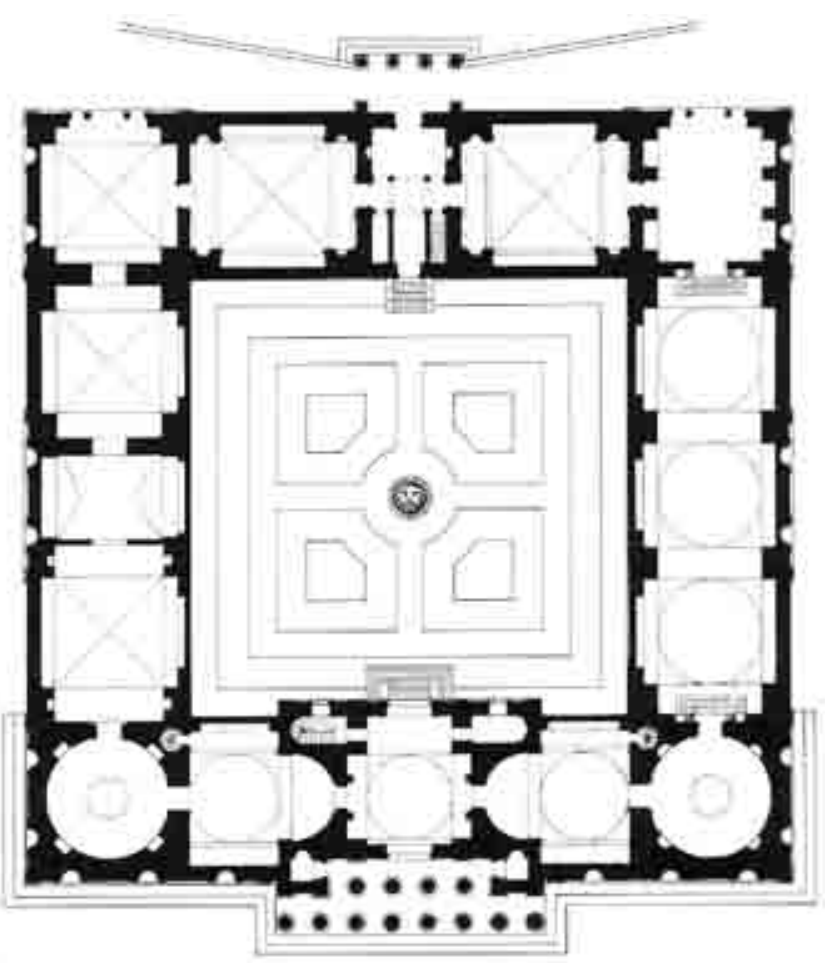

PLANTA

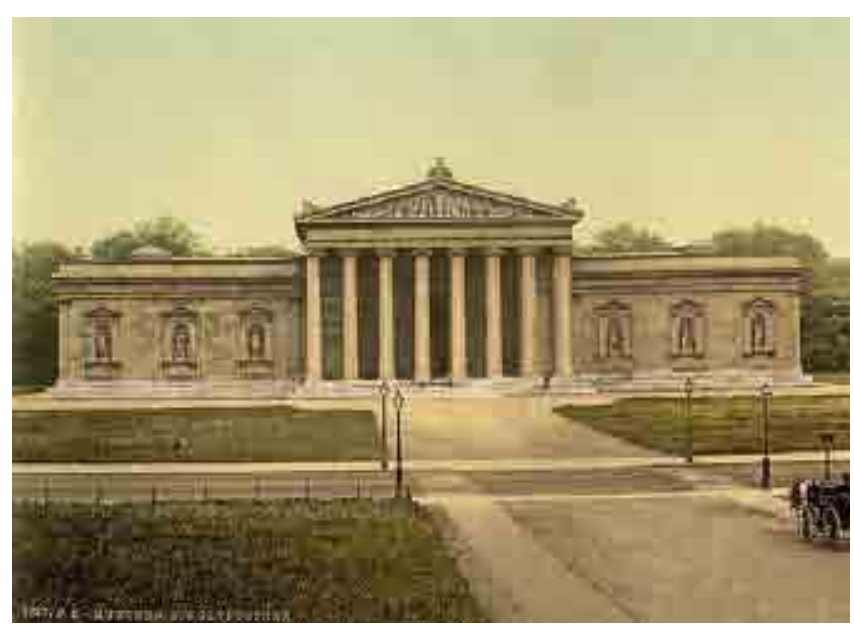

INDEX-9 
ALTES MUSEUM

Berlín, Alemania - K. Friedich Schinkel, 1823

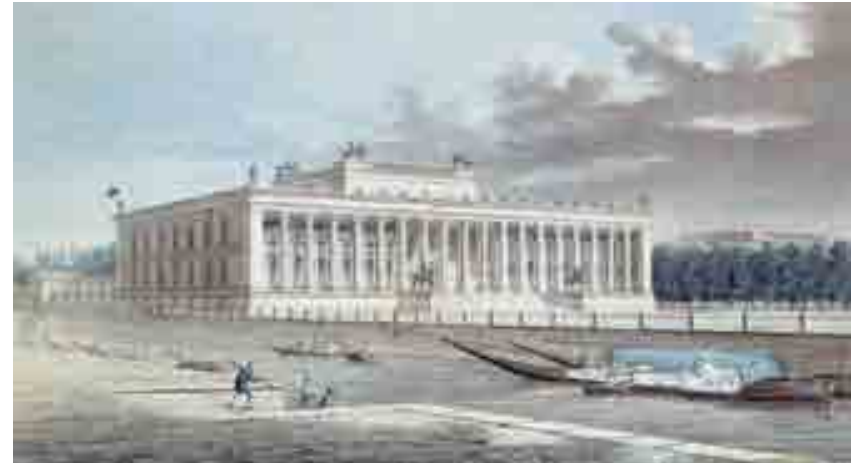

BERLIN ALTES MUSEUM

Friedrich Alexander Thiele, 1830

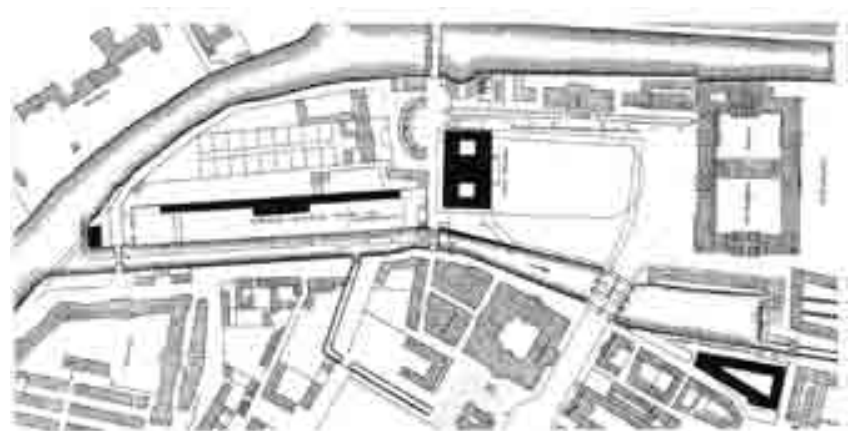

EMPLAZAMIENTO EN LA MUSEUMSINSEL C. 1823
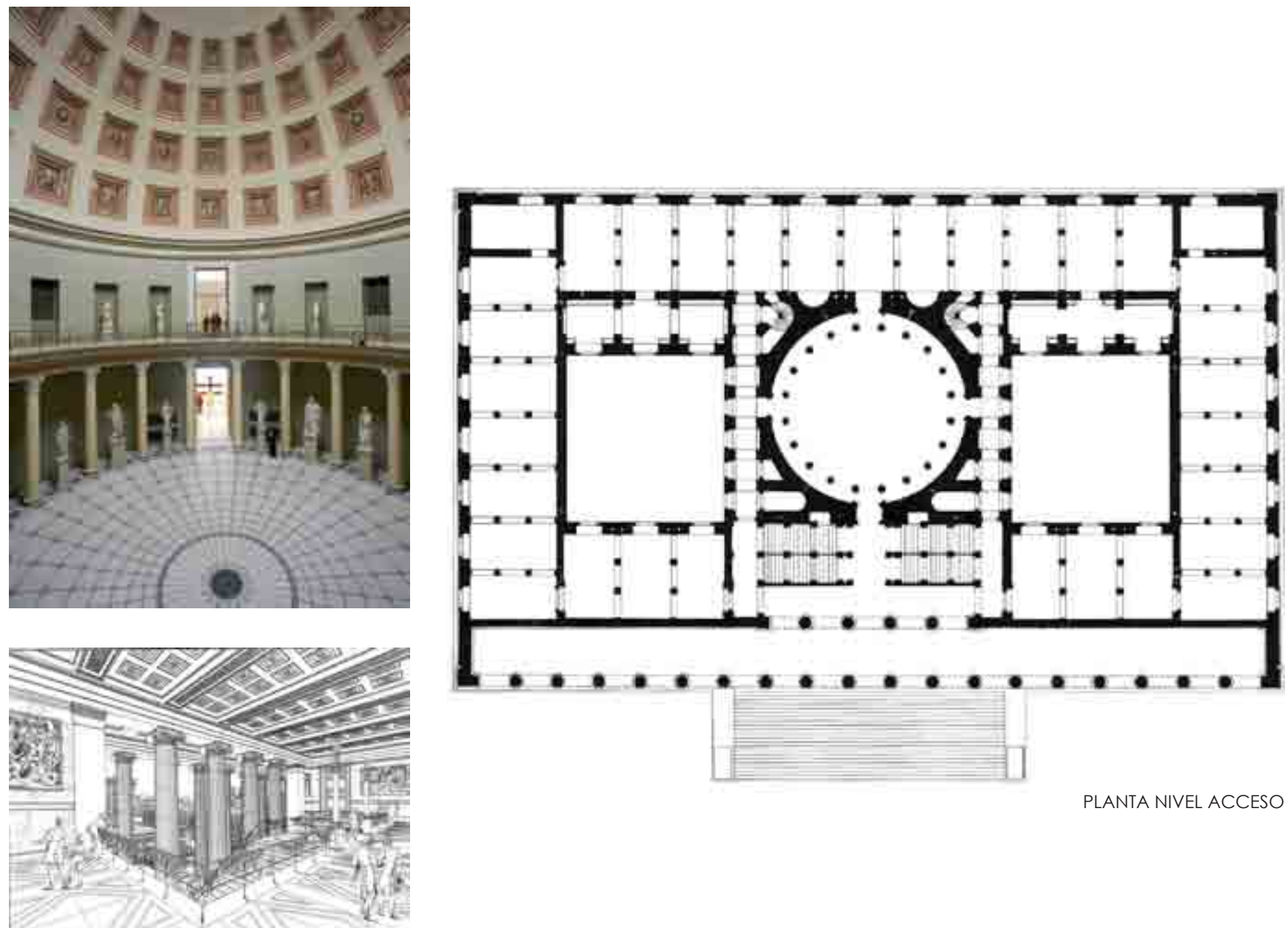

PERSPECTIVA INTERIOR DE LA ESCALERA

K. F. Schinkel, 1829
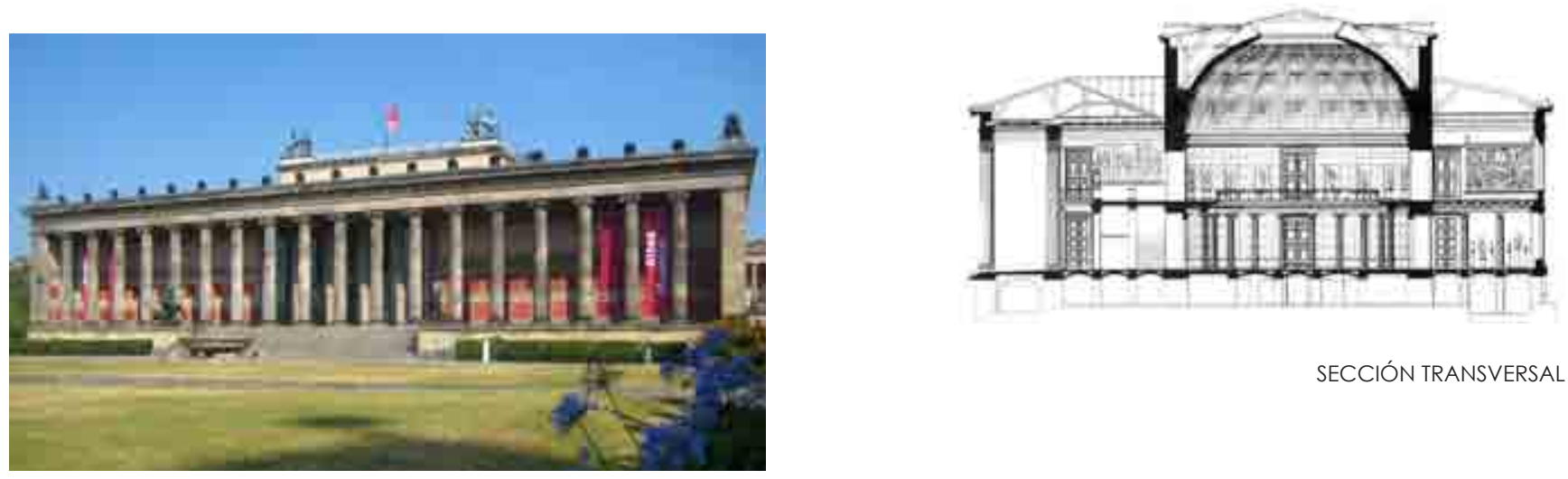

SECCIÓN TRANSVERSAL 

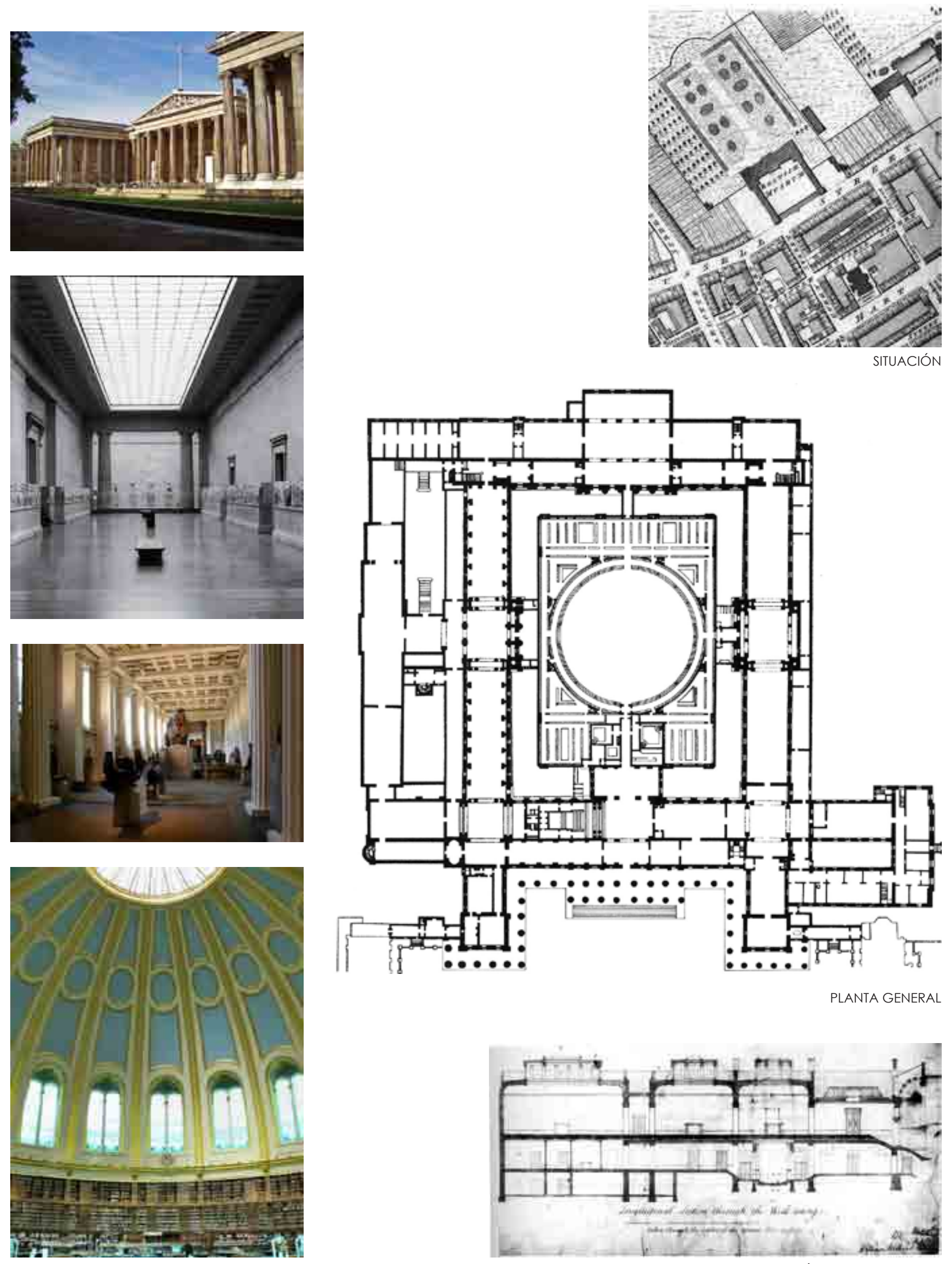

PLANTA GENERAL

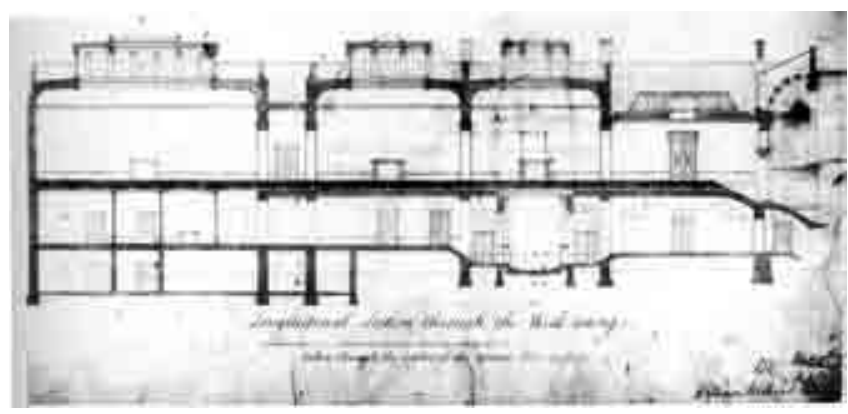


ALTE PINAKOTHEK

Múnich, Alemania - Leo von Klenze, 1826
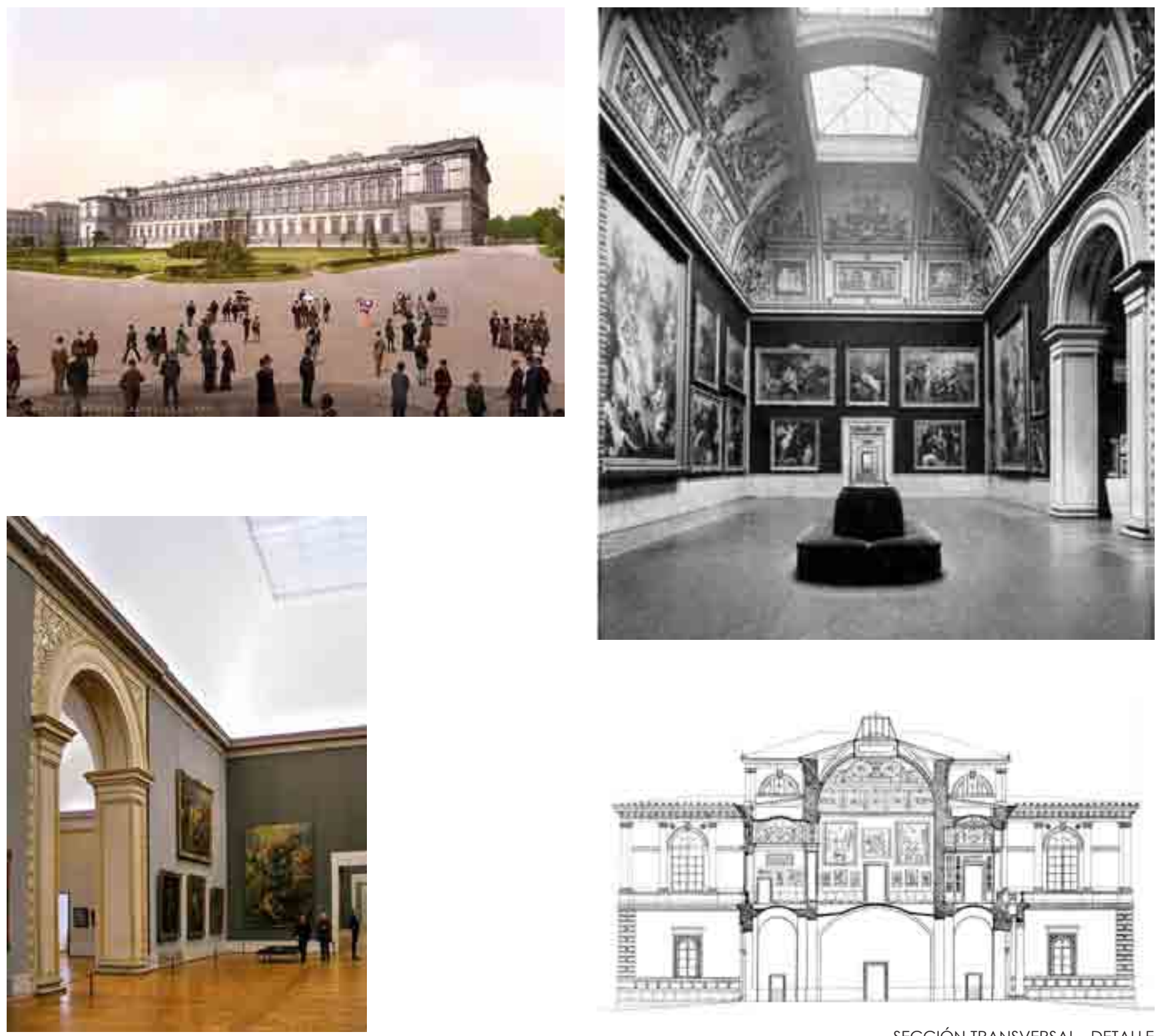

SECCIÓN TRANSVERSAL - DETALLE

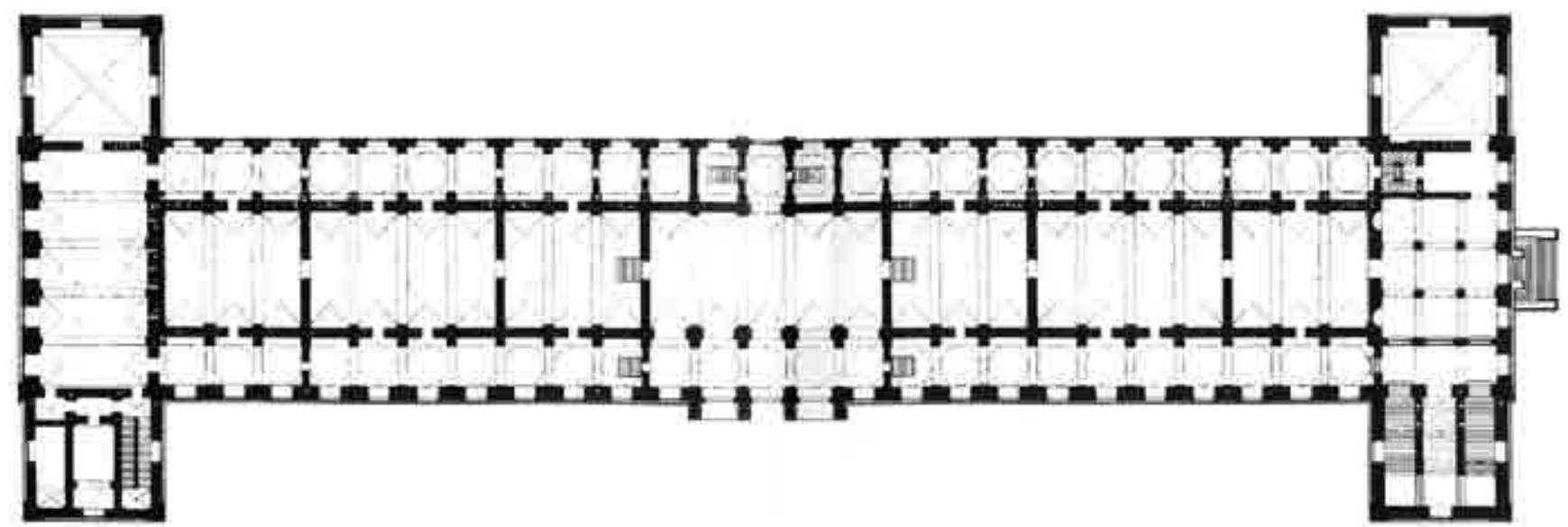

PLANTA NIVEL ACCESO 

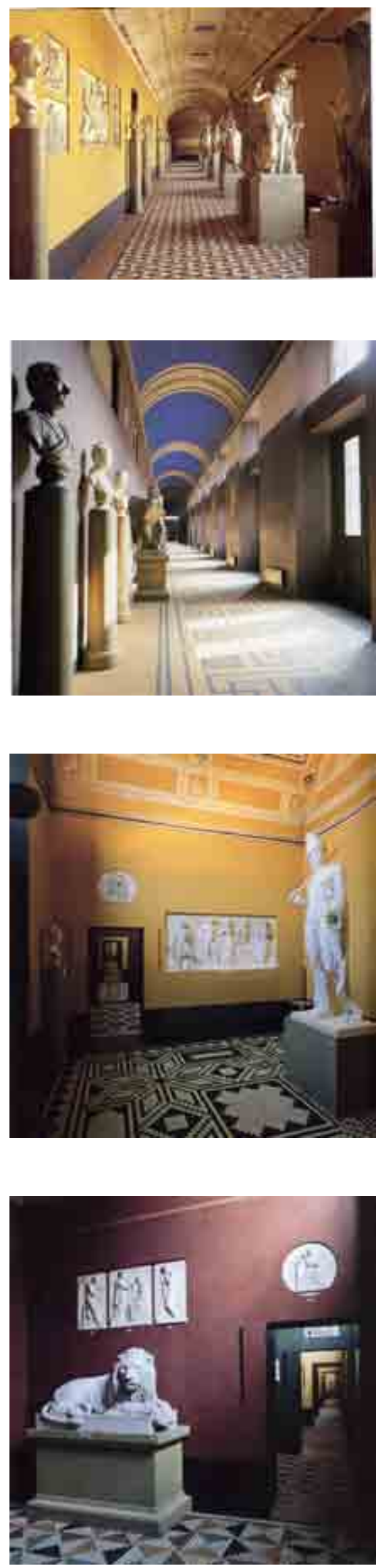
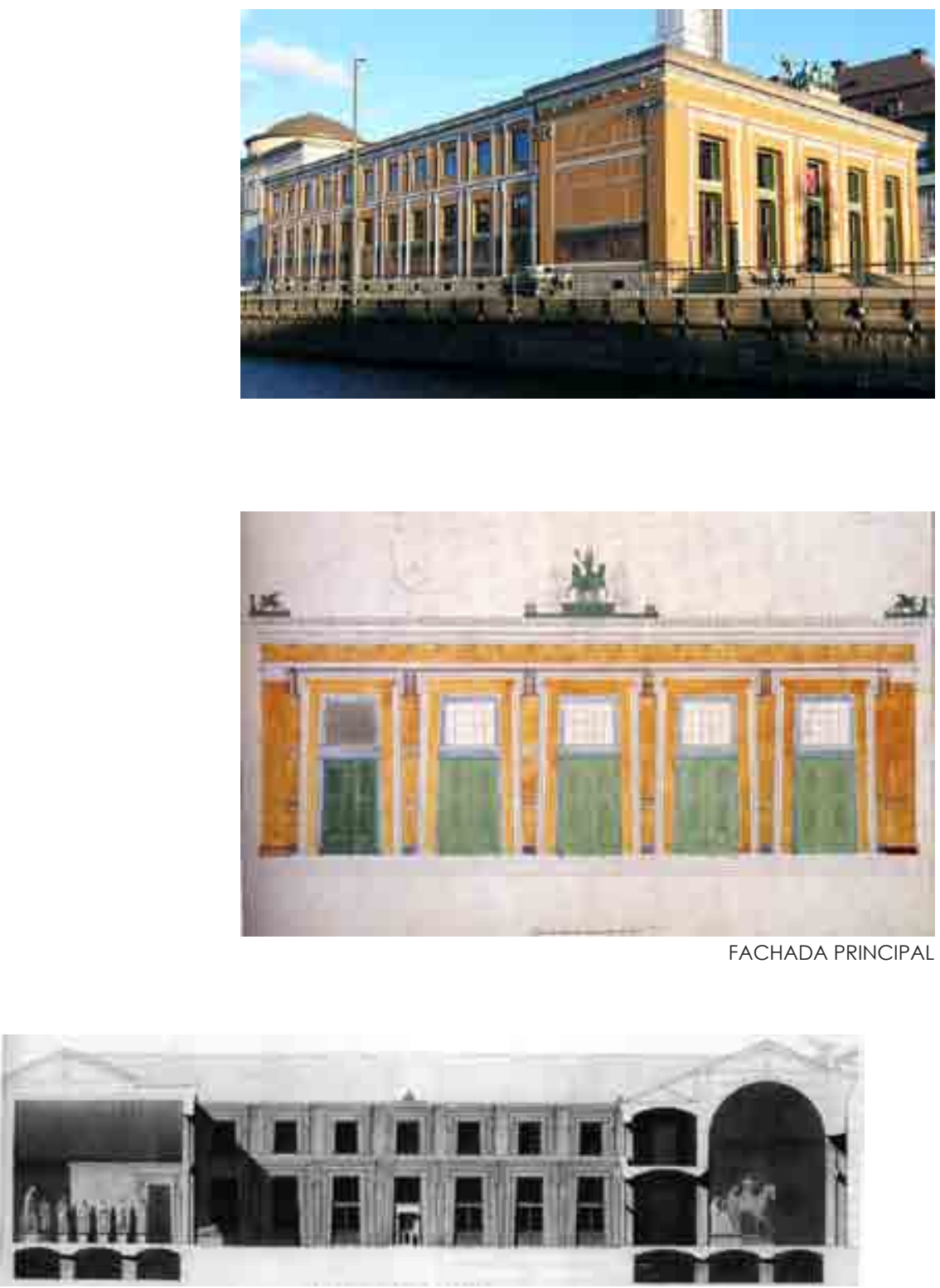

SECCIÓN LONGITUDINAL

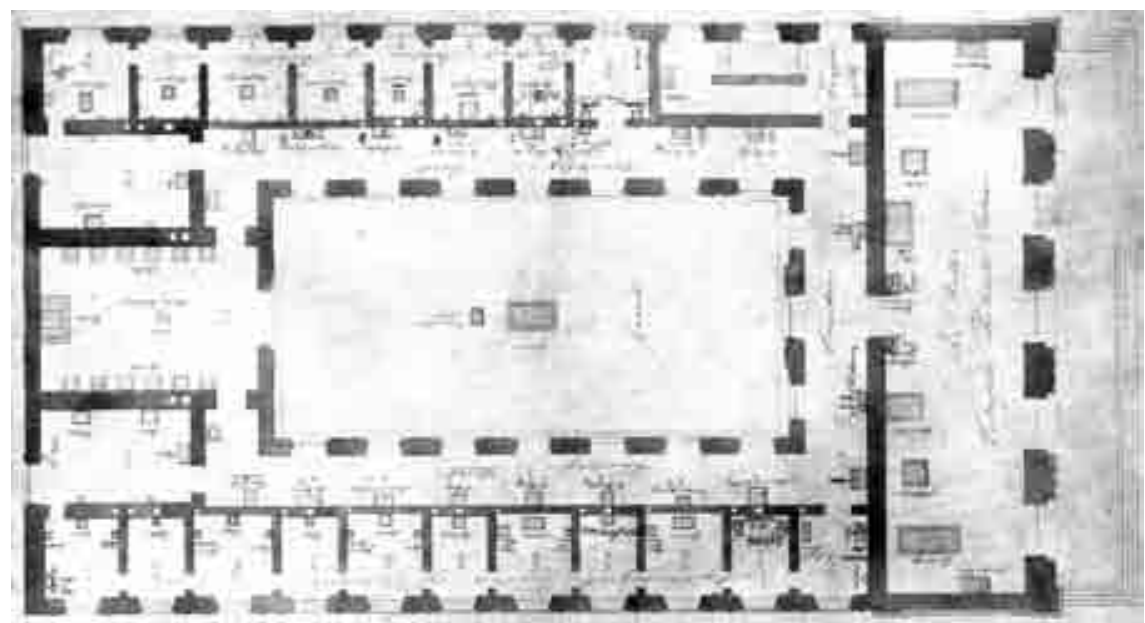

PLANTA NIVEL ACCESO 
CRYSTAL PALACE

Great Exhibition, Londres, Reino Unido - Sir Joseph Paxton, 1851
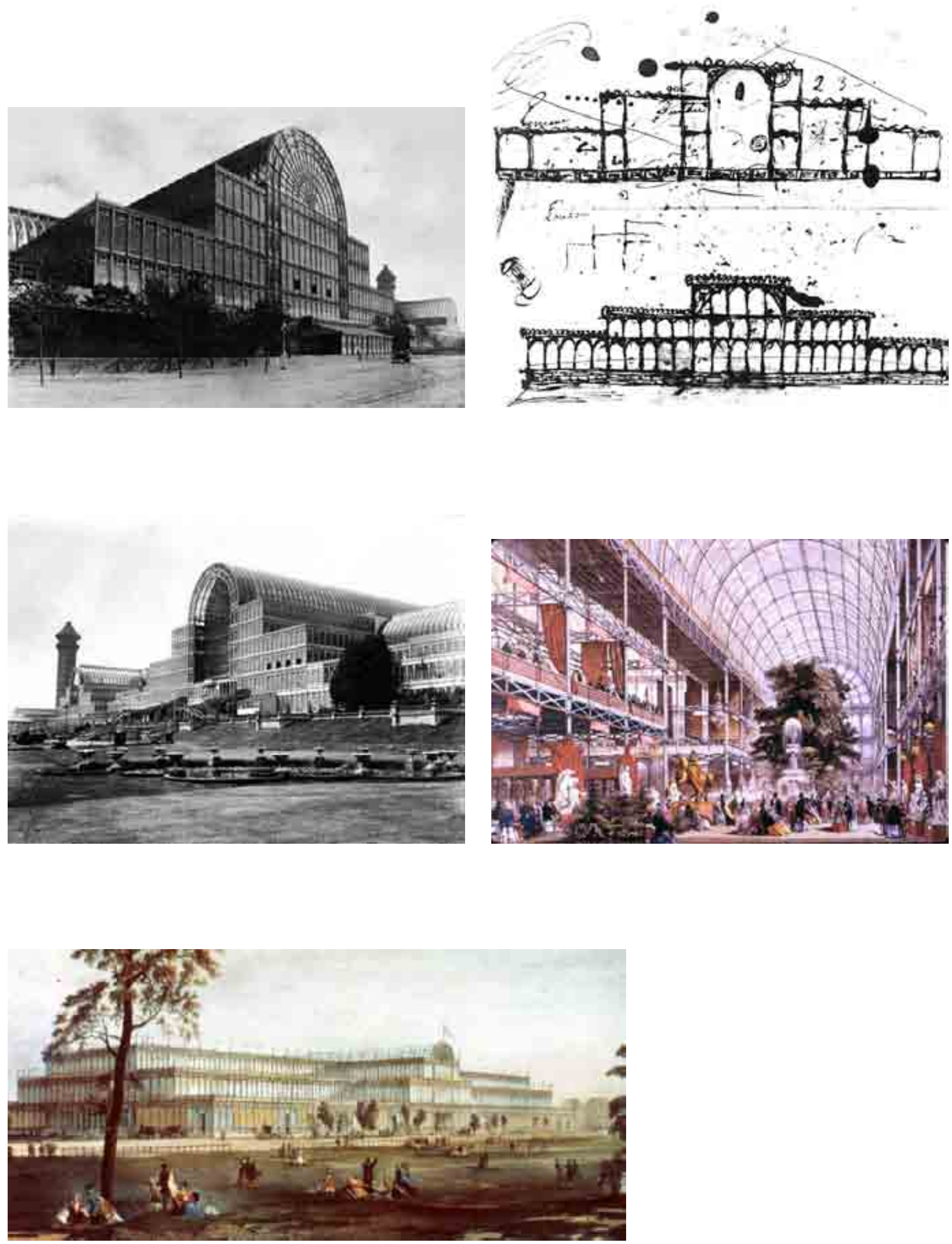

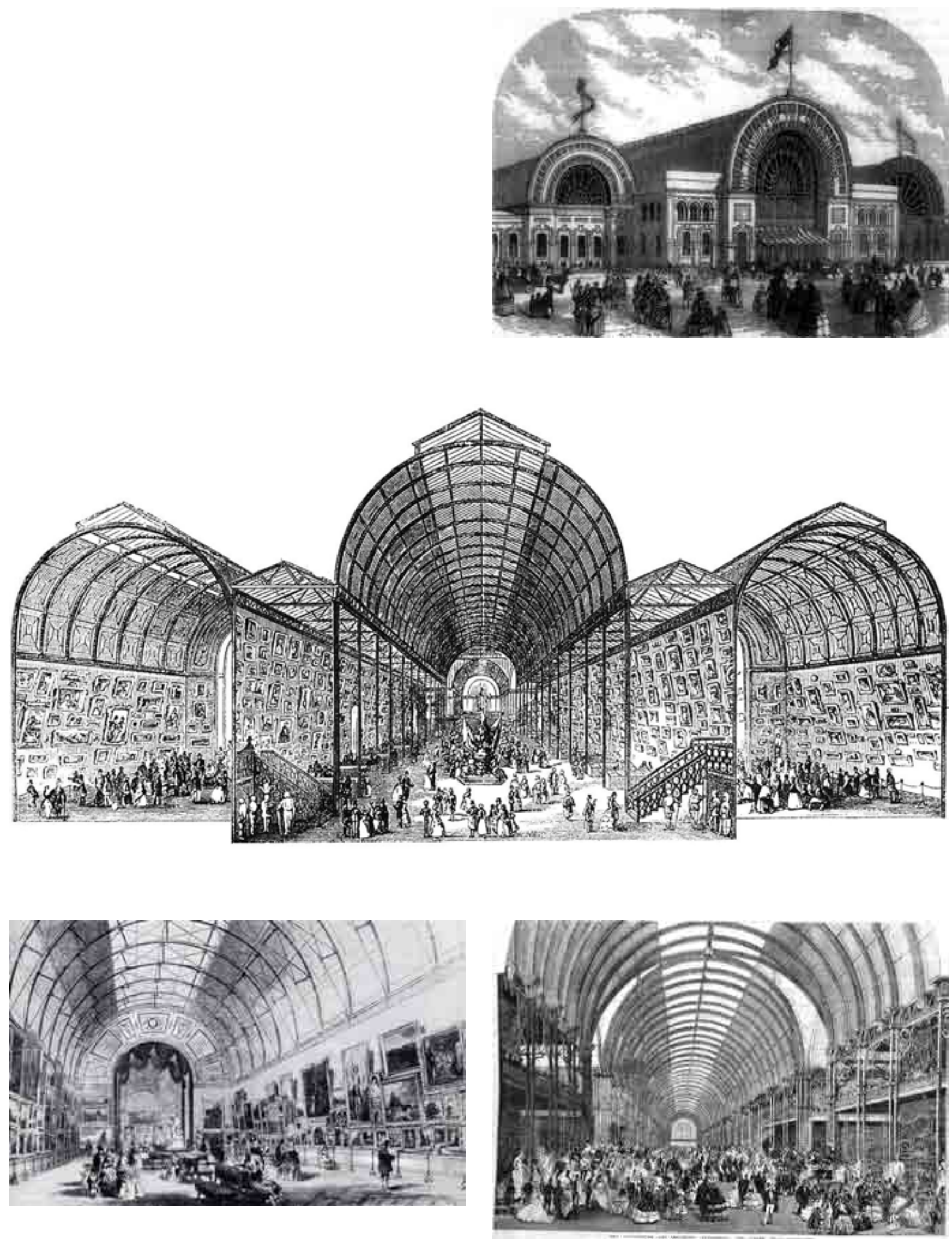
METROPOLITAN MUSEUM OF ART

New York City, New York (USA) - Richard Morris Hunt, 1880
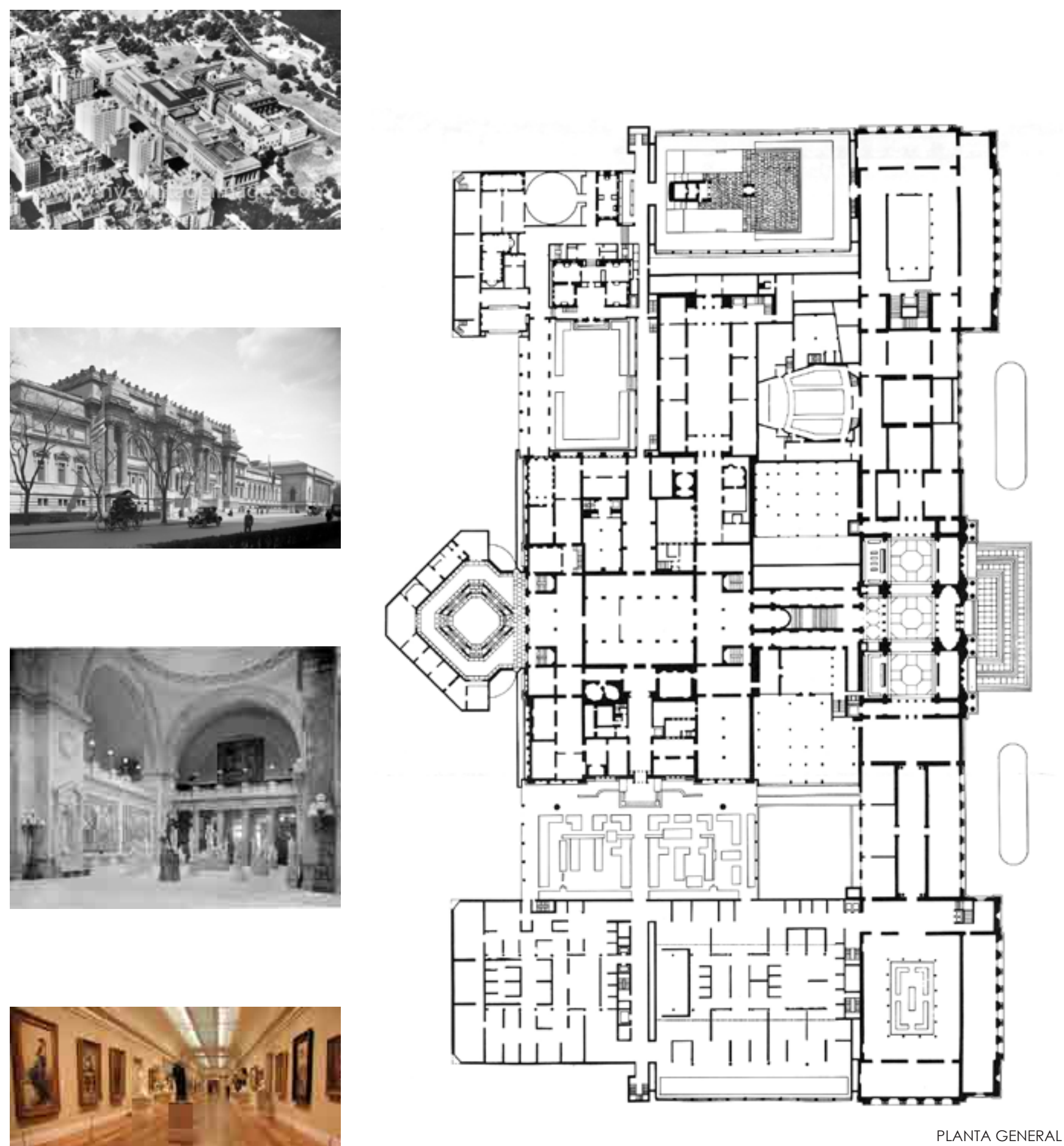
GALERIE DES MACHINES - EXPOSICIÓN UNIVERSAL DE 1889

París, Francia - Ferdinand Dutert et Charles Léon Stephen Sauvestre, 1889
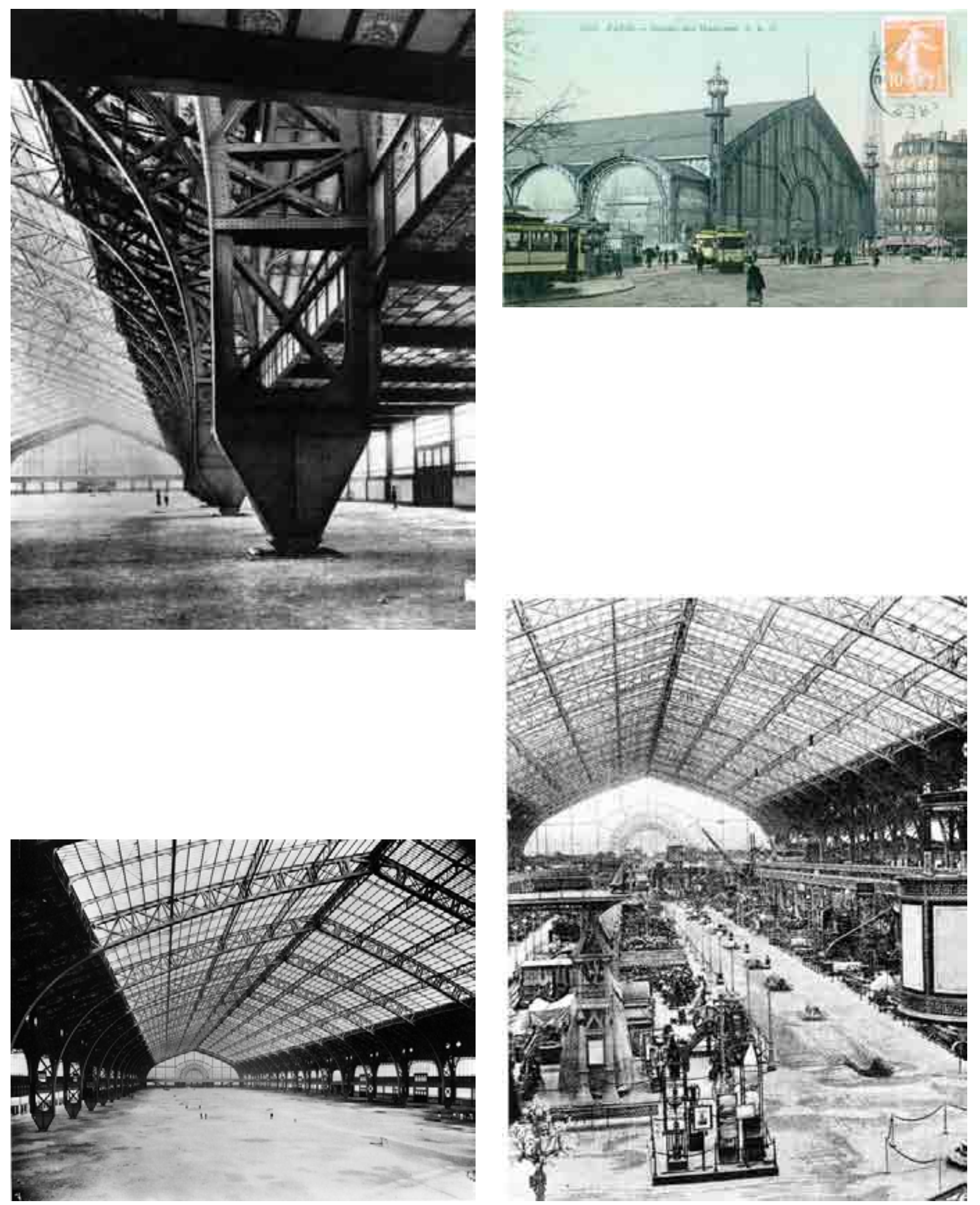
MUSEO FAABORG

Faaborg, Dinamarca - Carl Petersen, 1915
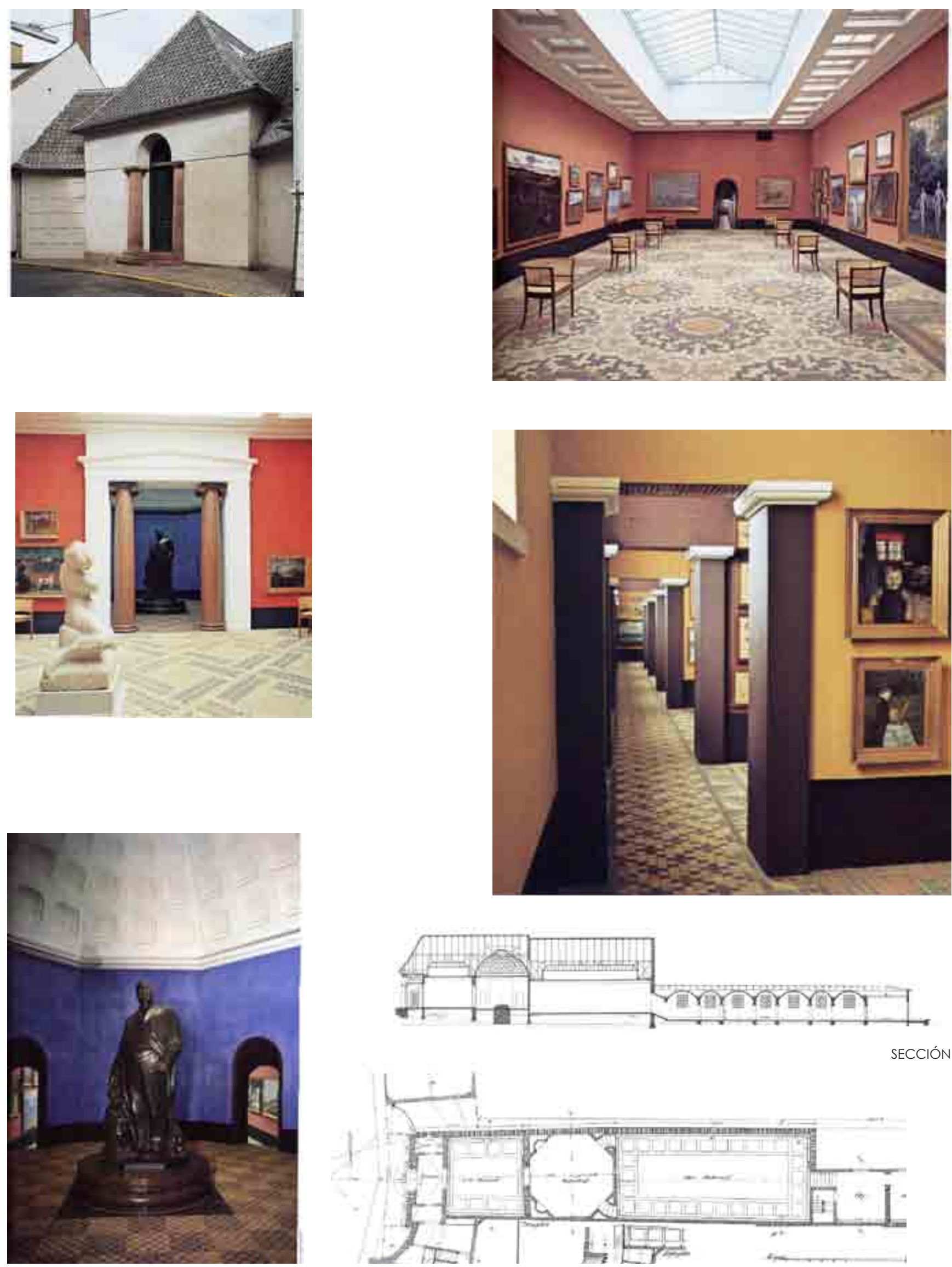

ECCIÓN

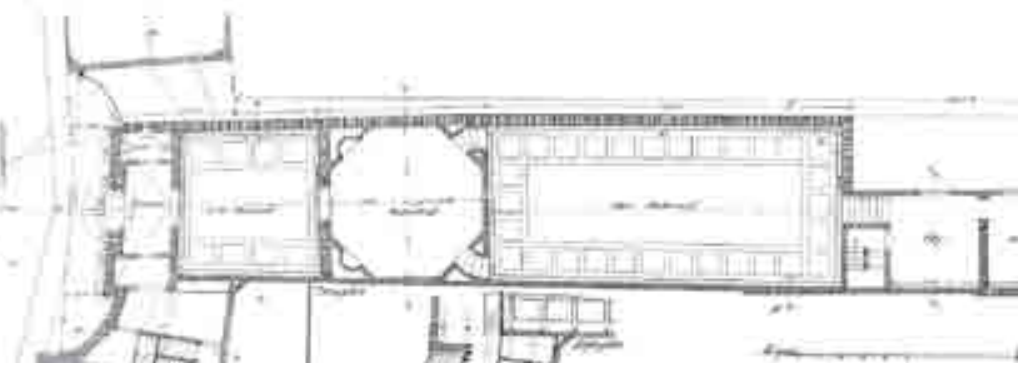



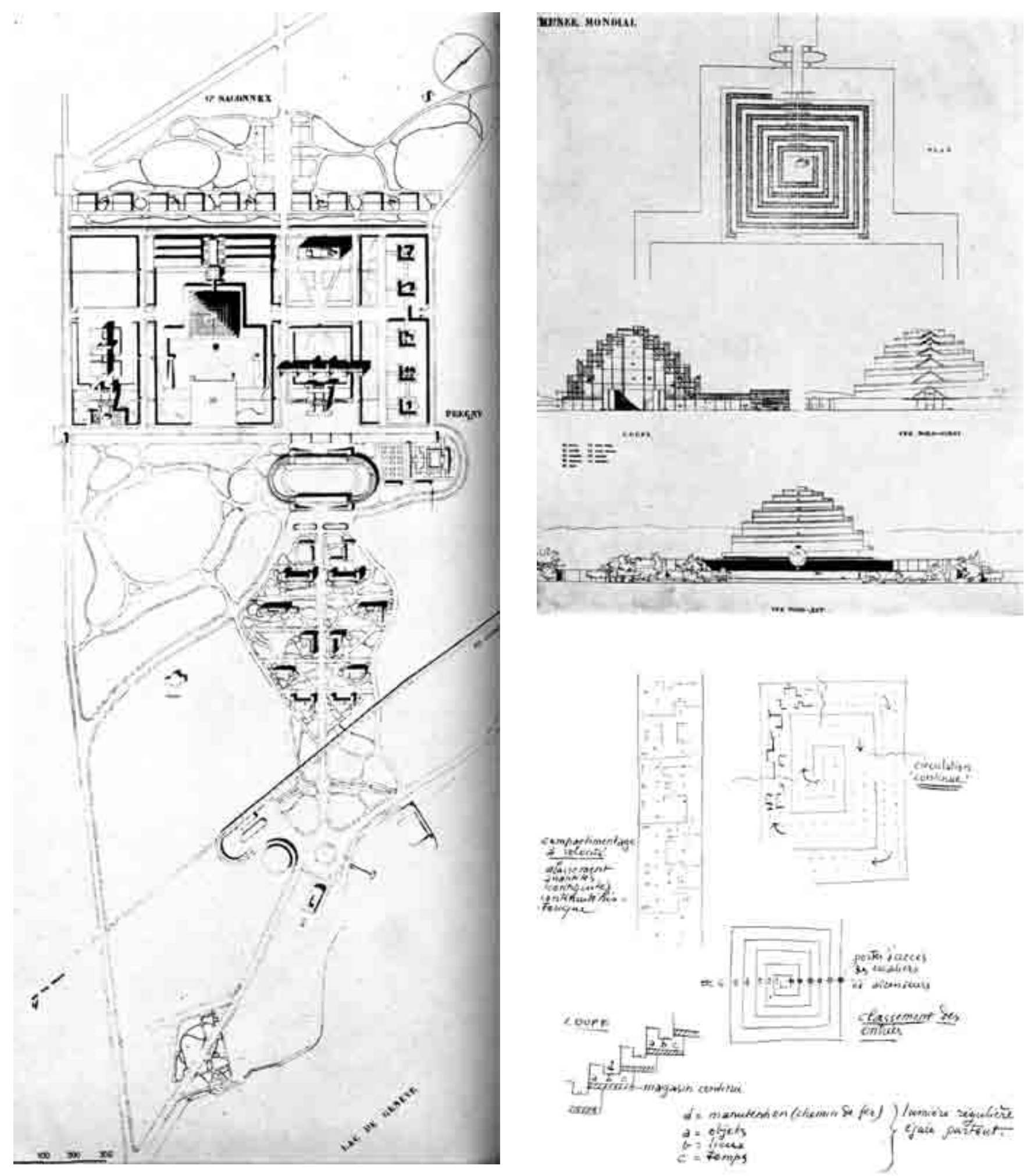
LE MUSÉE DES ARTISTES VIVANTS

París, Francia - Le Corbusier, 1931

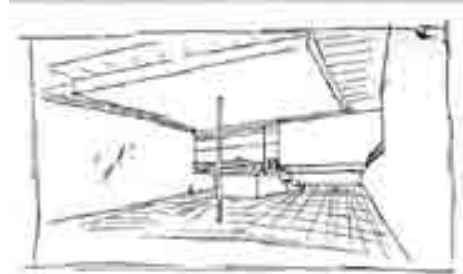

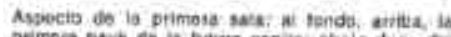
aubinernines de snitreds

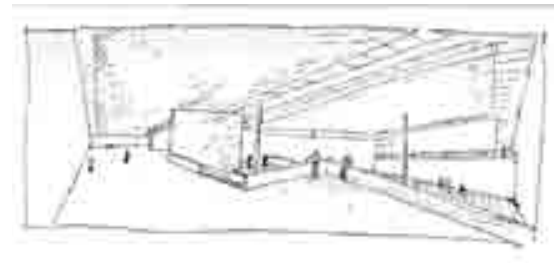

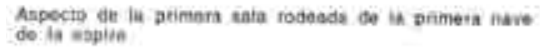

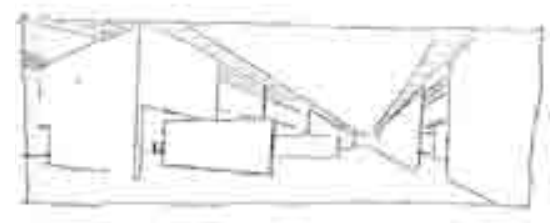

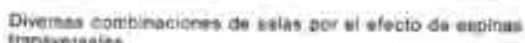
trantweraniss
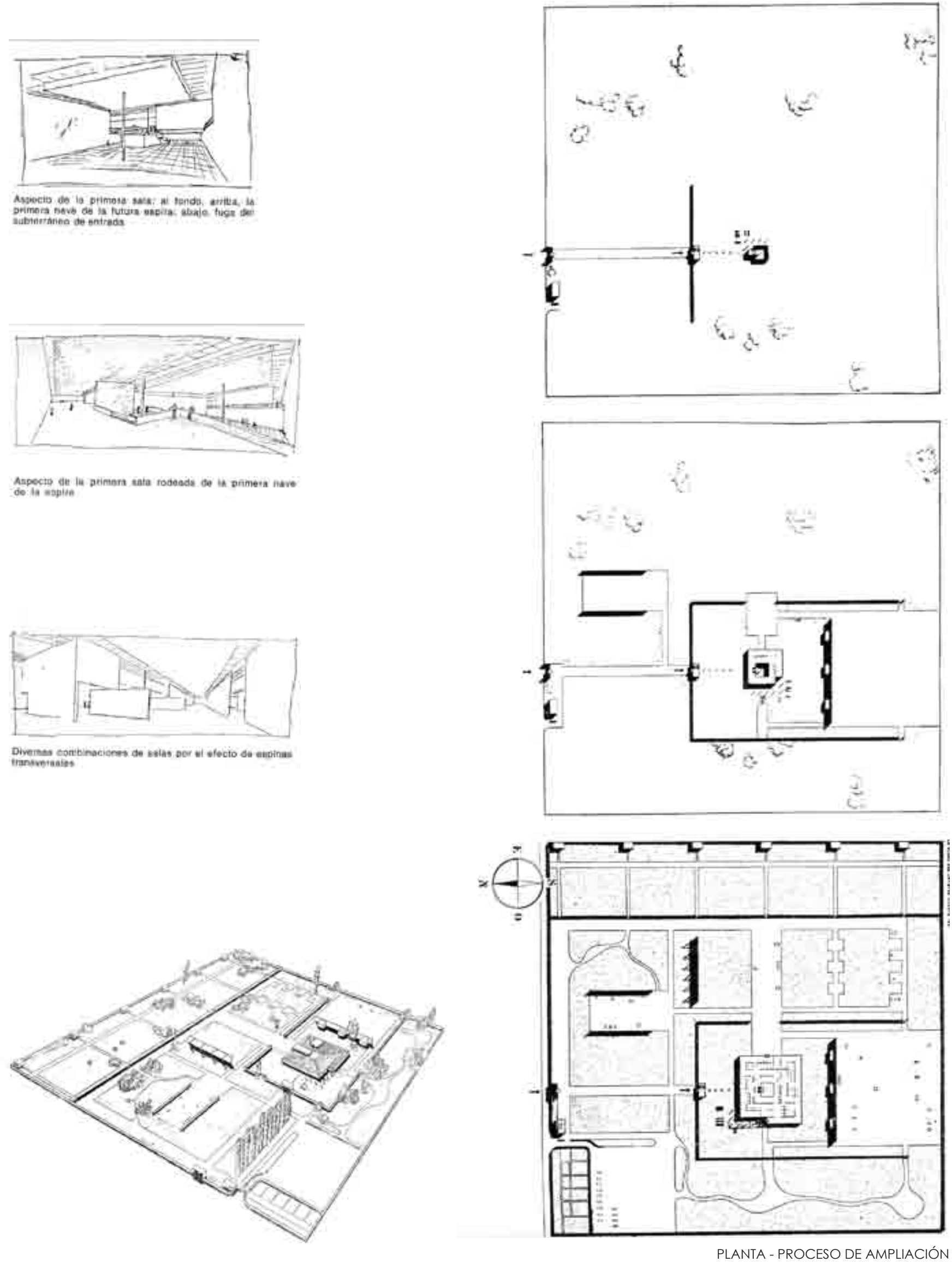

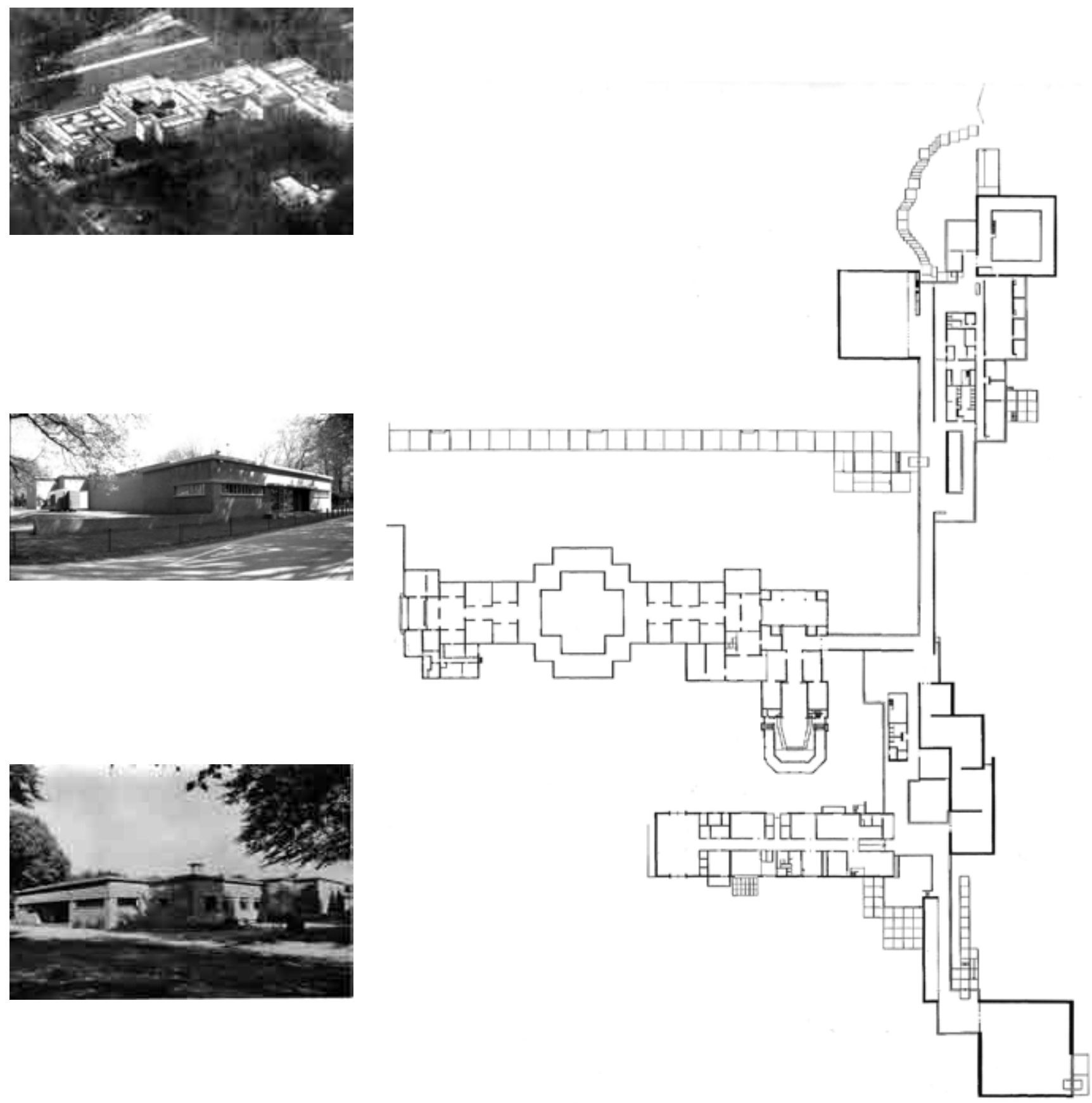

PLANTA DE CONJUNTO (INCLUYE AMPLIACIONES)

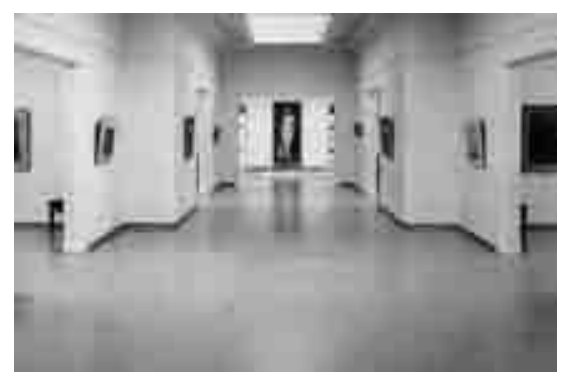


MUSEO DE CRECIMIENTO ILIMITADO

(estudio) - Le Corbusier, 1939
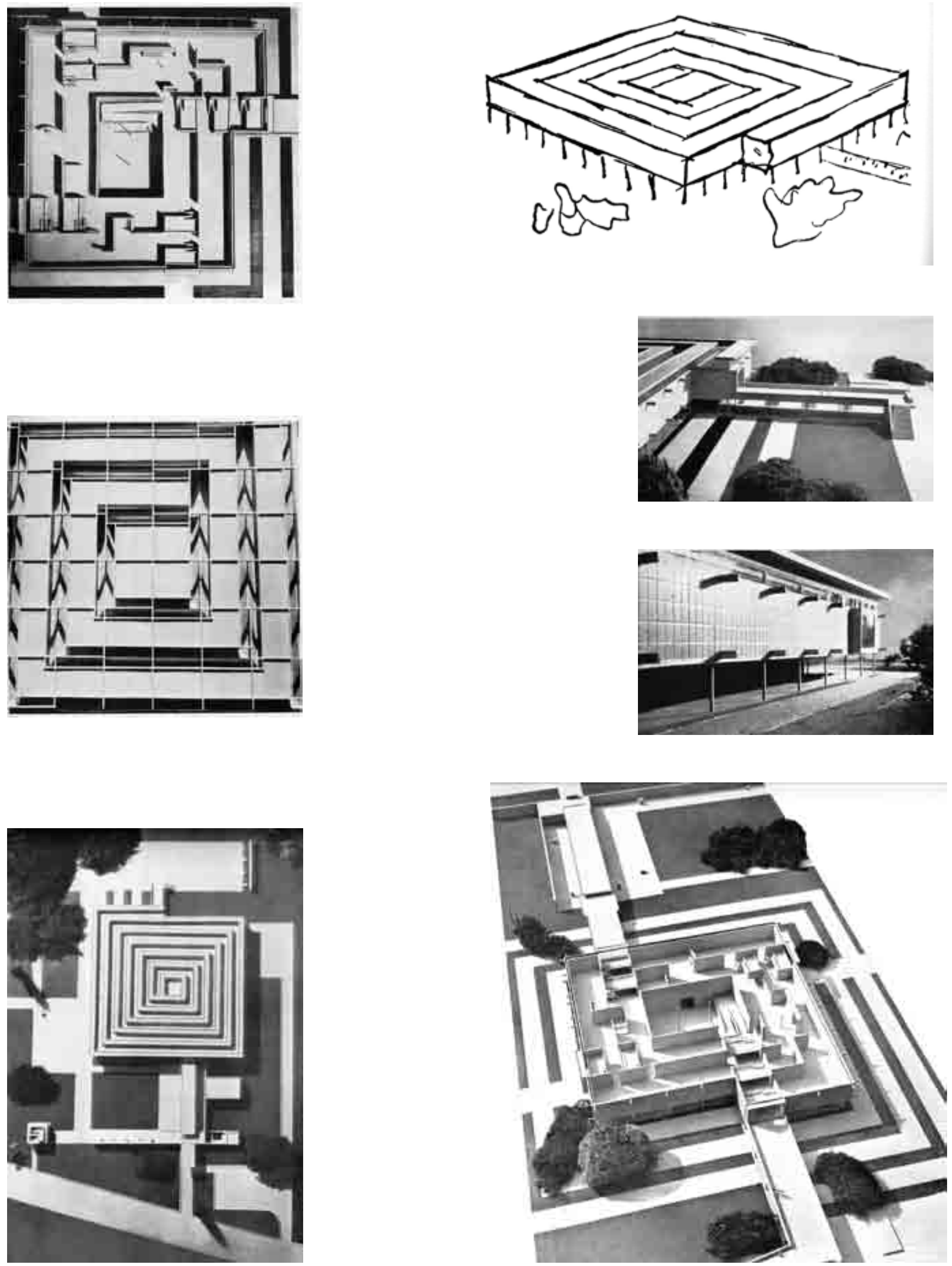

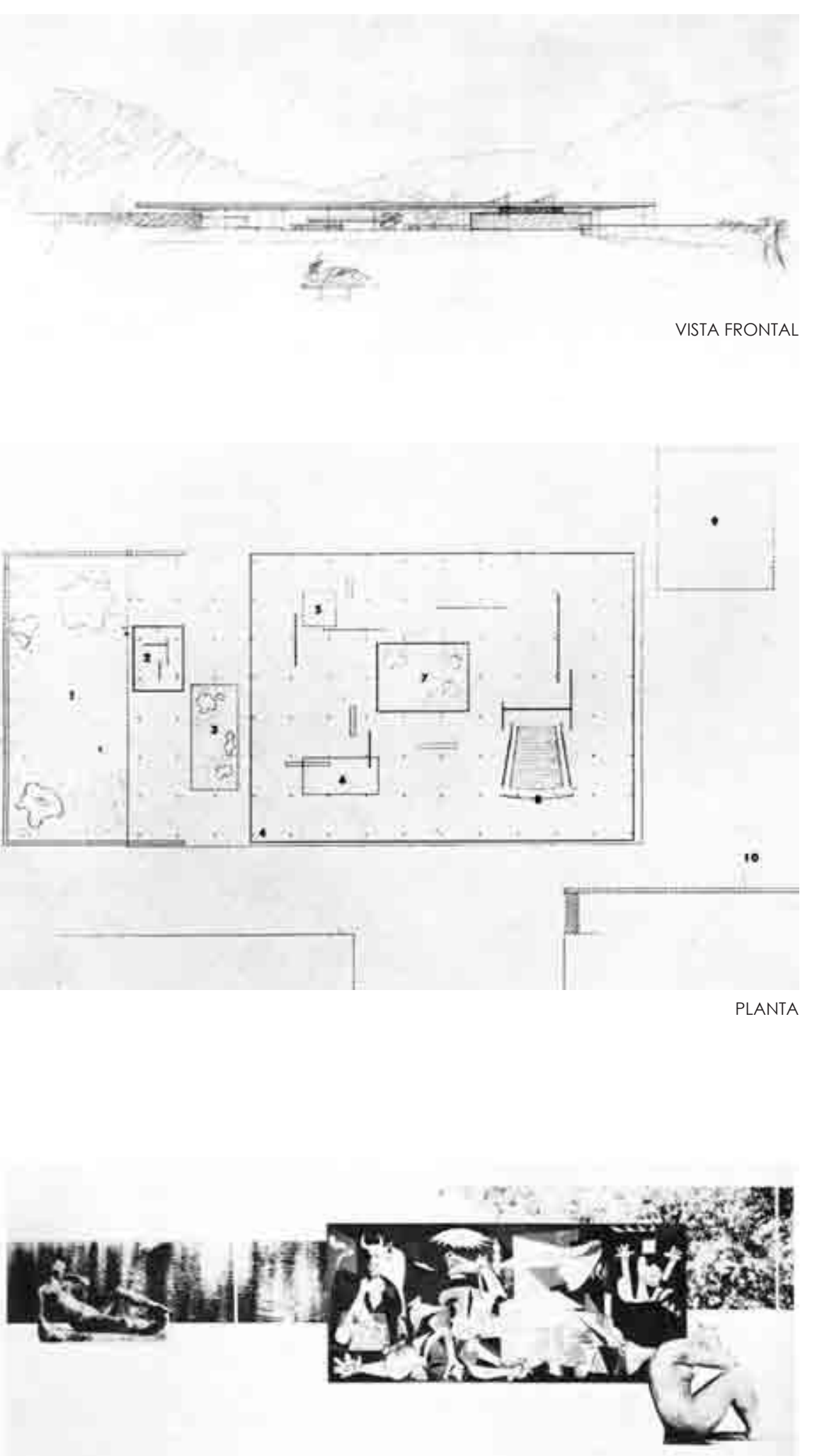
MUSEO GUGGENHEIM

New York City, New York (USA) - Frank Lloyd Wright, 1943
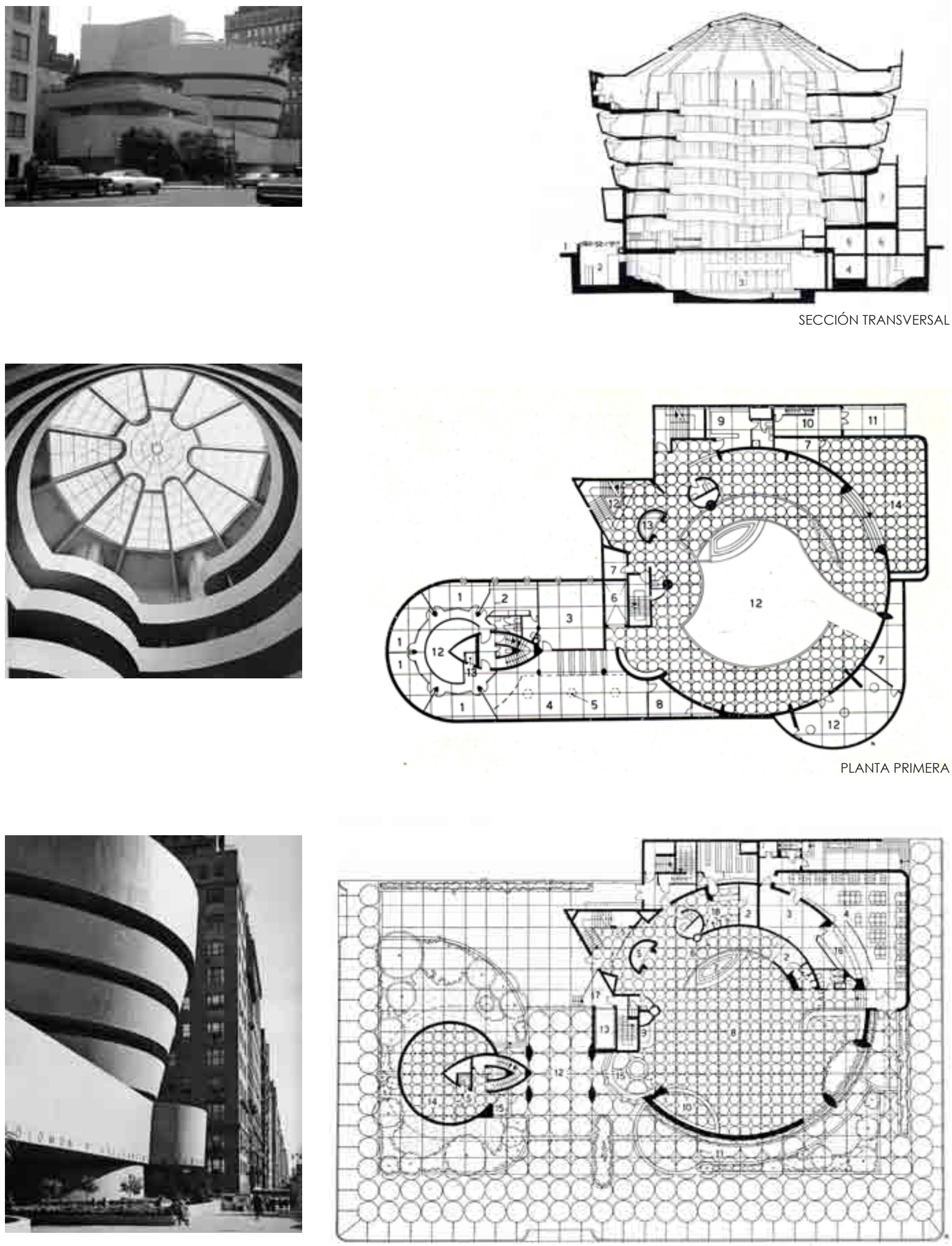

PLANTA BAJA 
MUSEO DE ARTE DE SAO PAULO

Sao Paulo, Brasil - Lina Bo Bardi, 1947
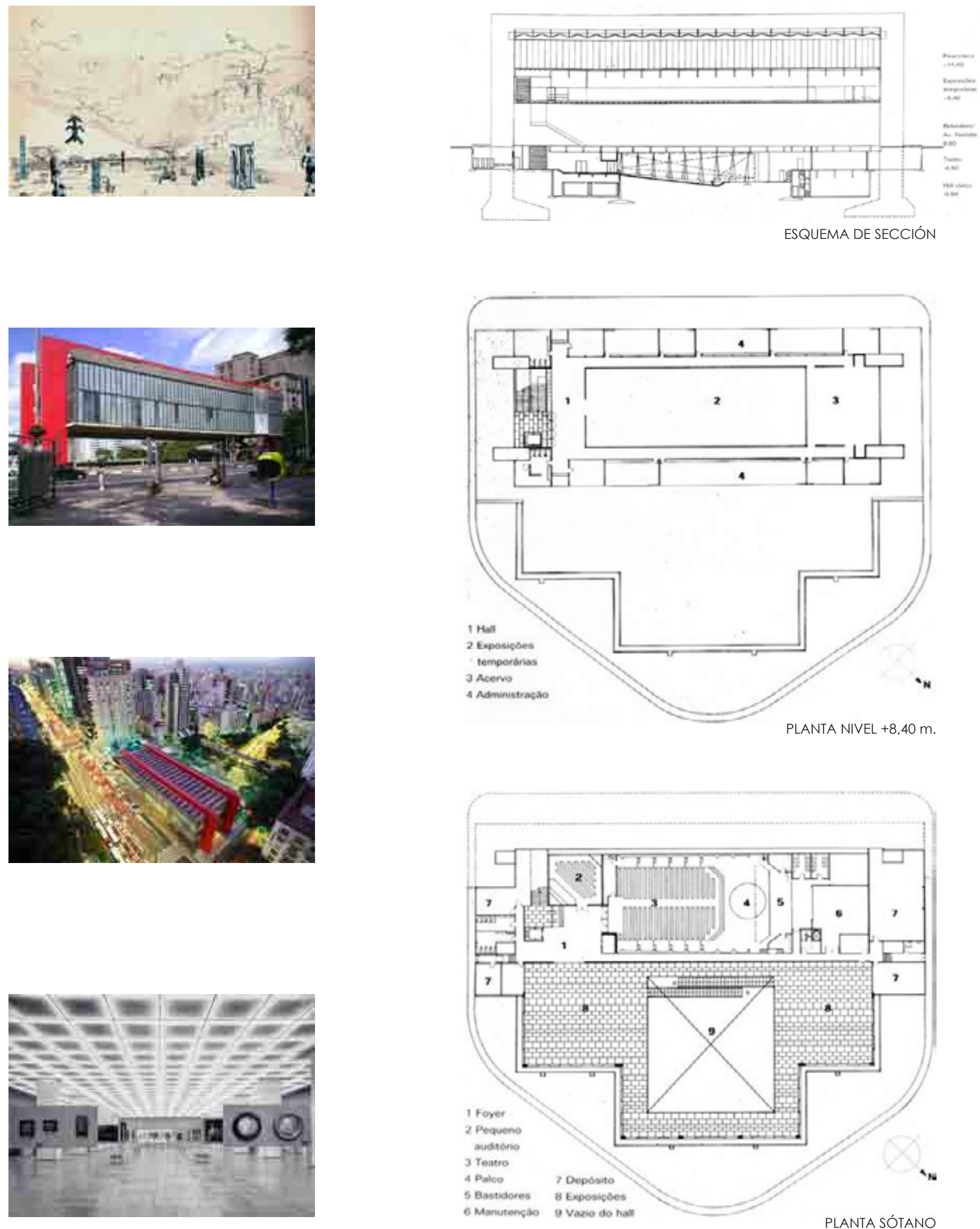
PALAZZO BIANCO

Génova, Italia - Franco Albini, 1950
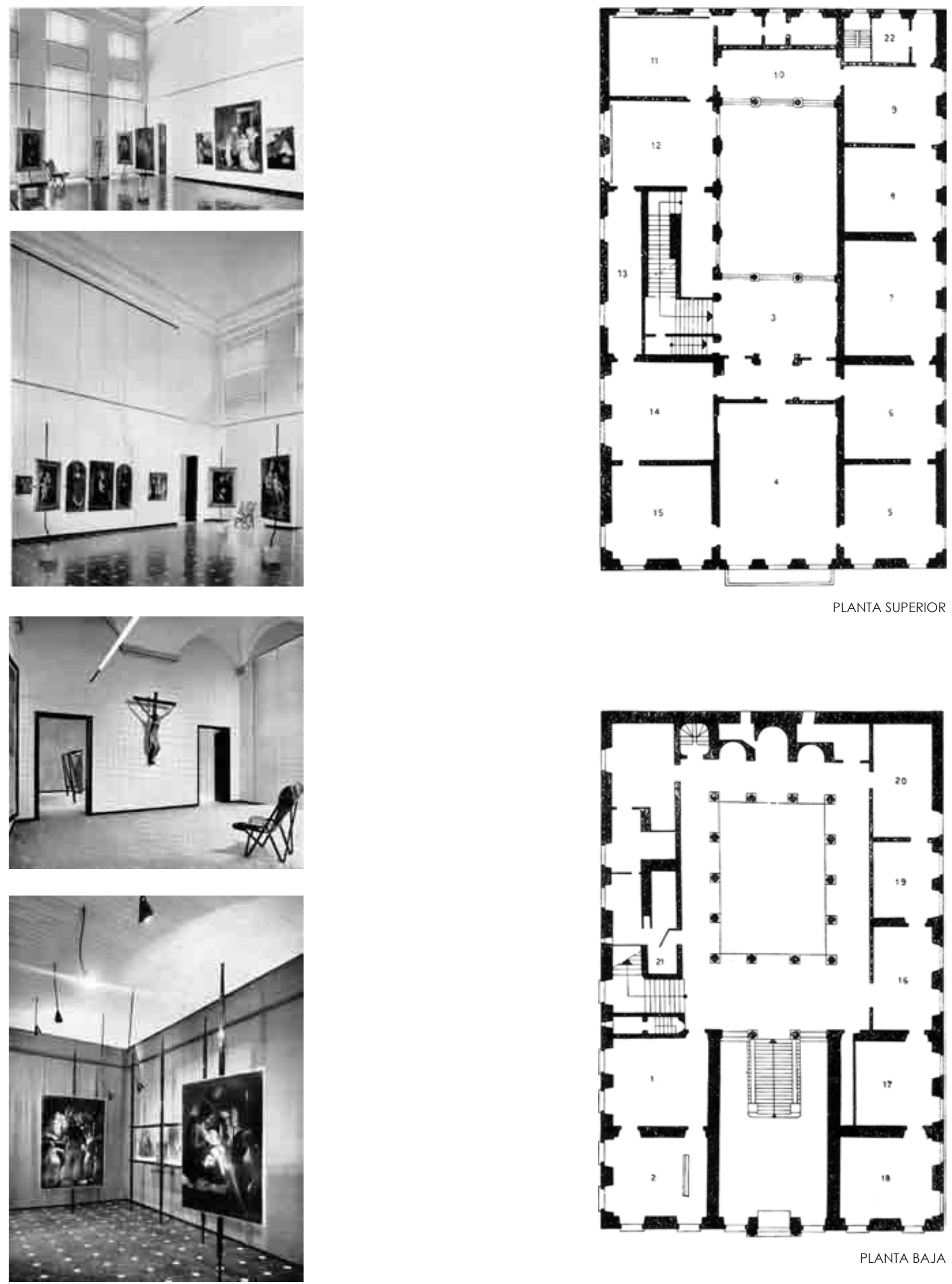
GALERÍA DE ARTE DE LA UNIVERSIDAD DE YALE

New Haven, Connecticut (USA) - Louis I. Kahn, 1951
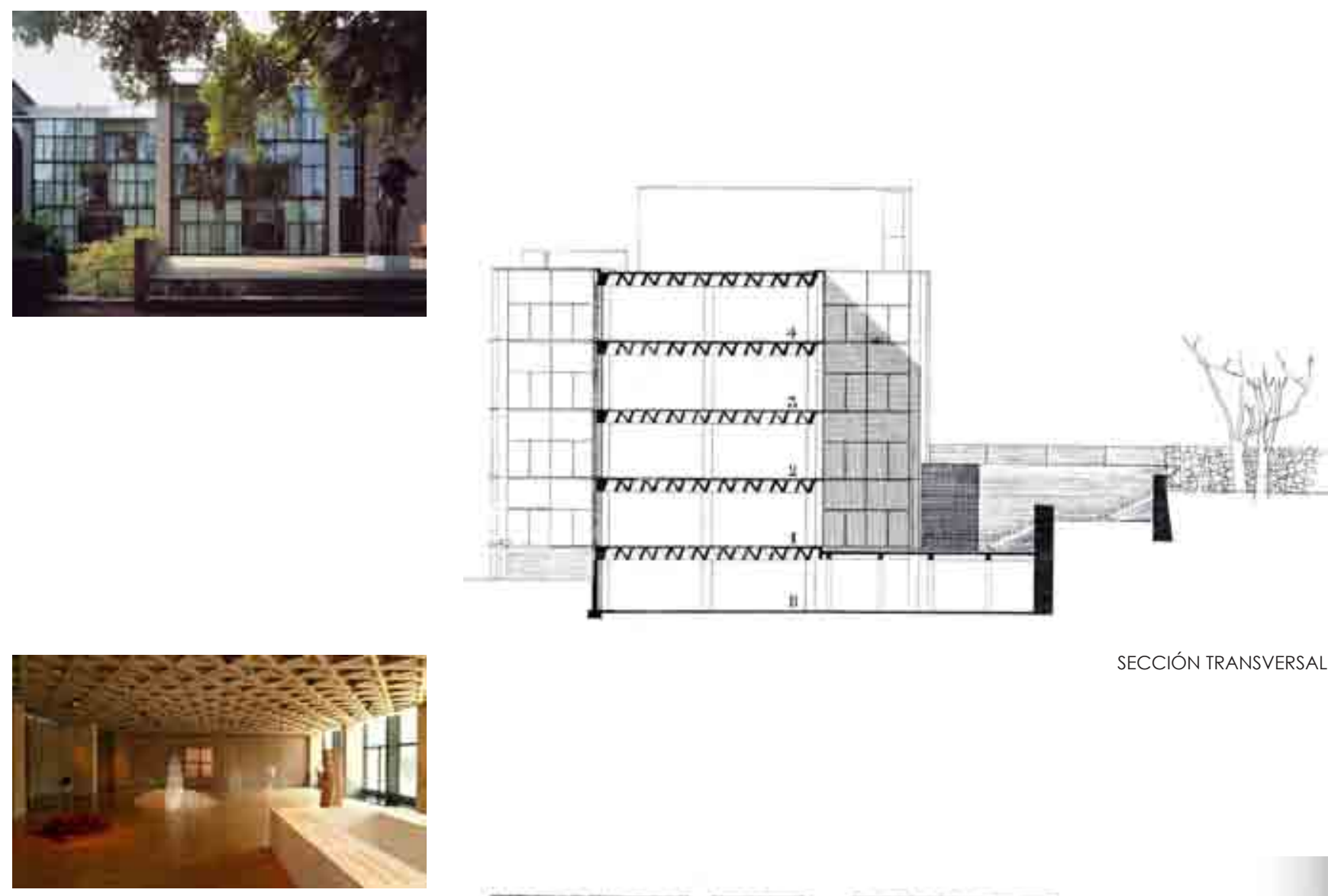

SECCIÓN TRANSVERSAL
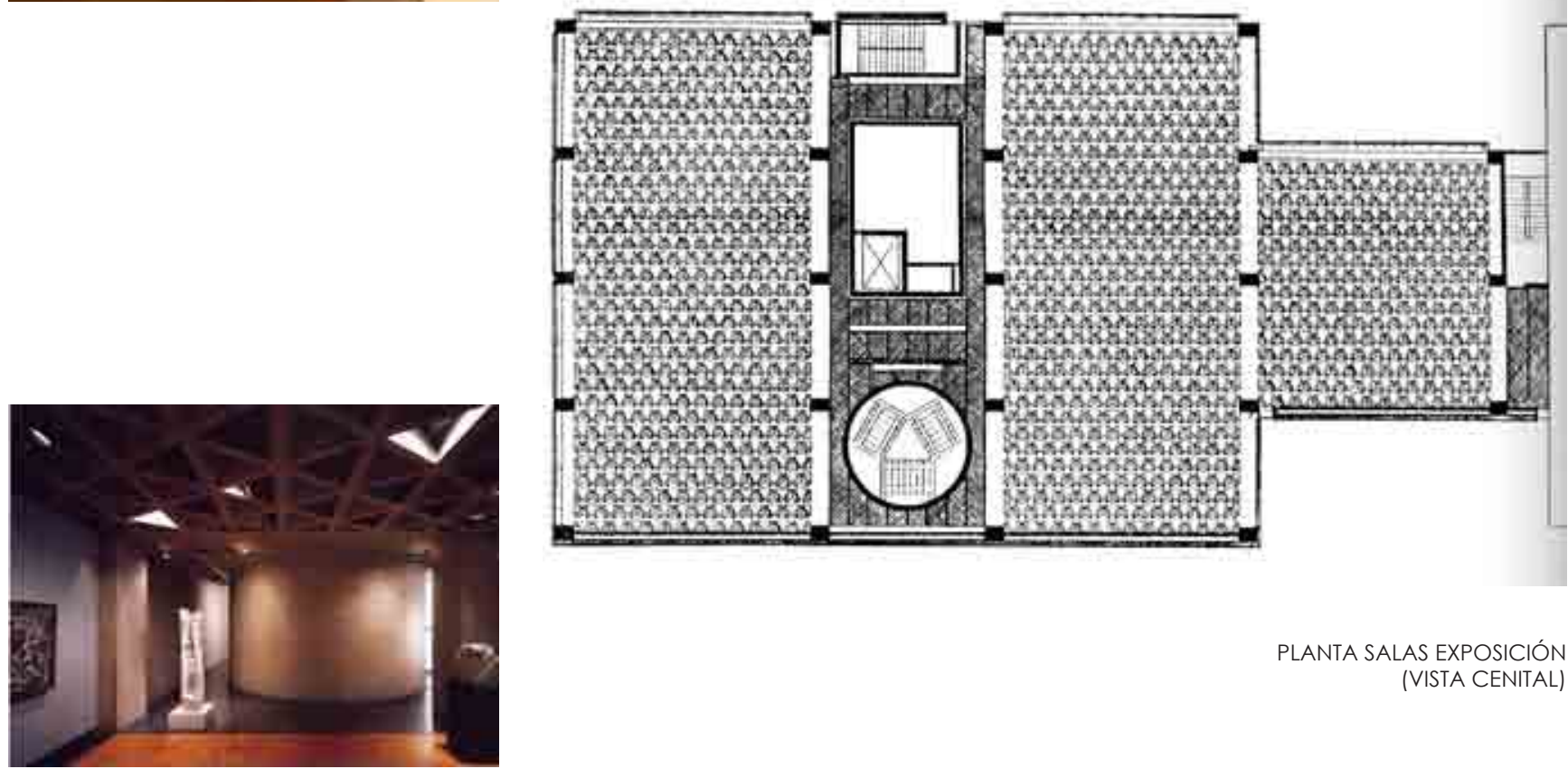

PLANTA SALAS EXPOSICIÓN (VISTA CENITAL) 
PADIGLIONE D'ARTE CONTEMPORANEA

Milán, Italia - Ignazio Gardella, 1953
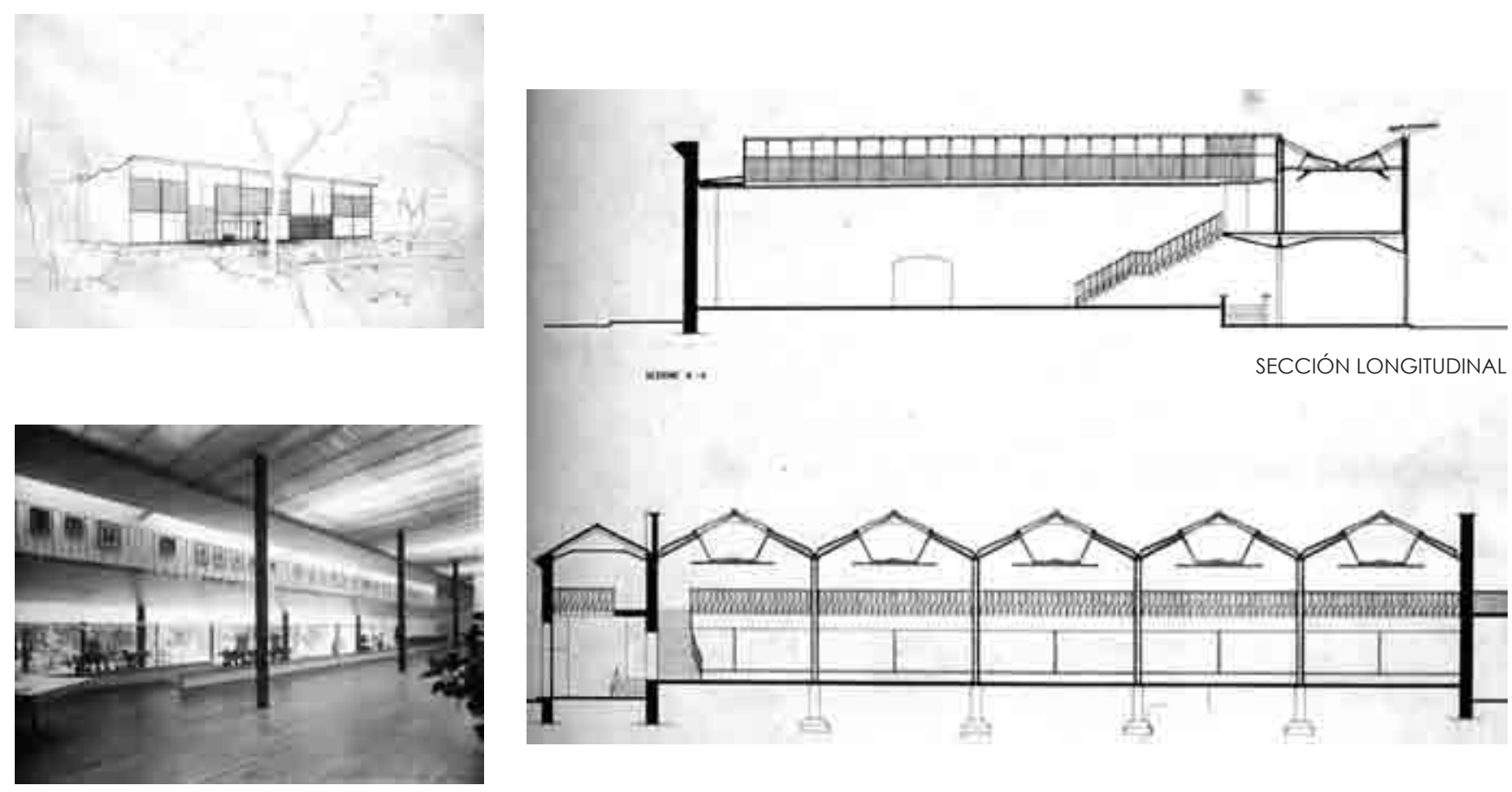

SECCIÓN TRANSVERSAL
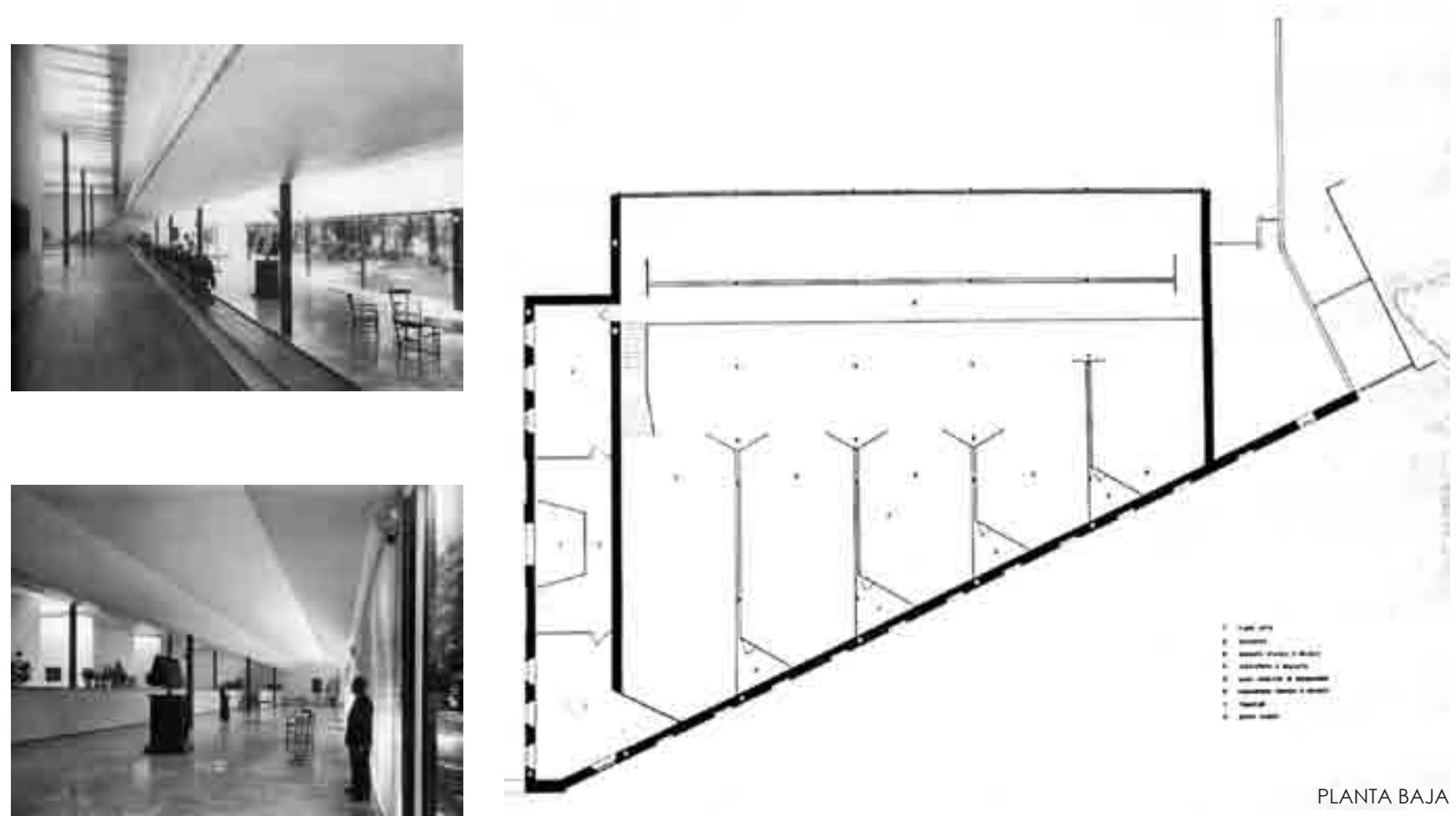
MUSEO DE ARTE DE AHMEDABAD

Ahmedabad, India - Le Corbusier, 1954
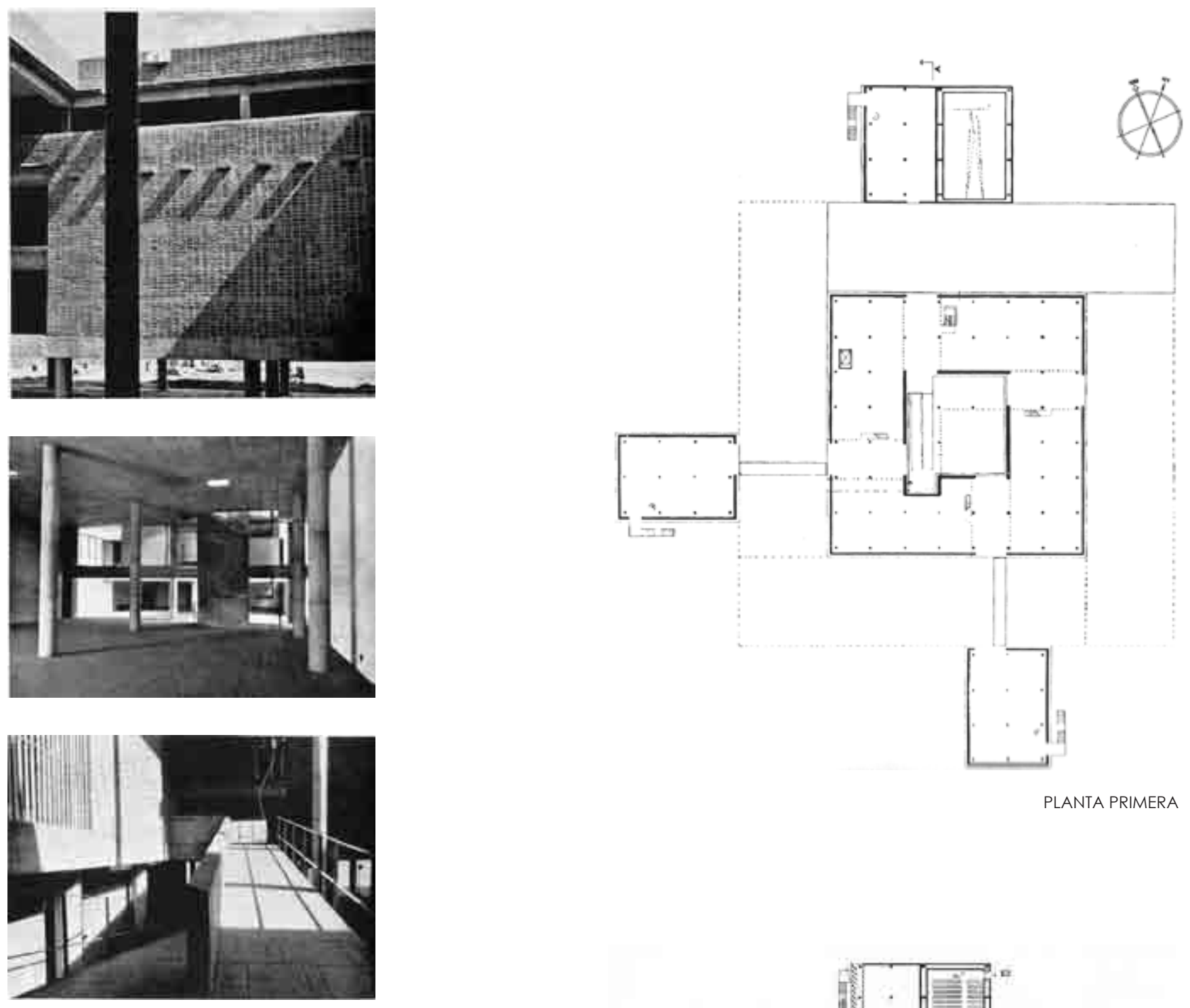

PLANTA PRIMERA
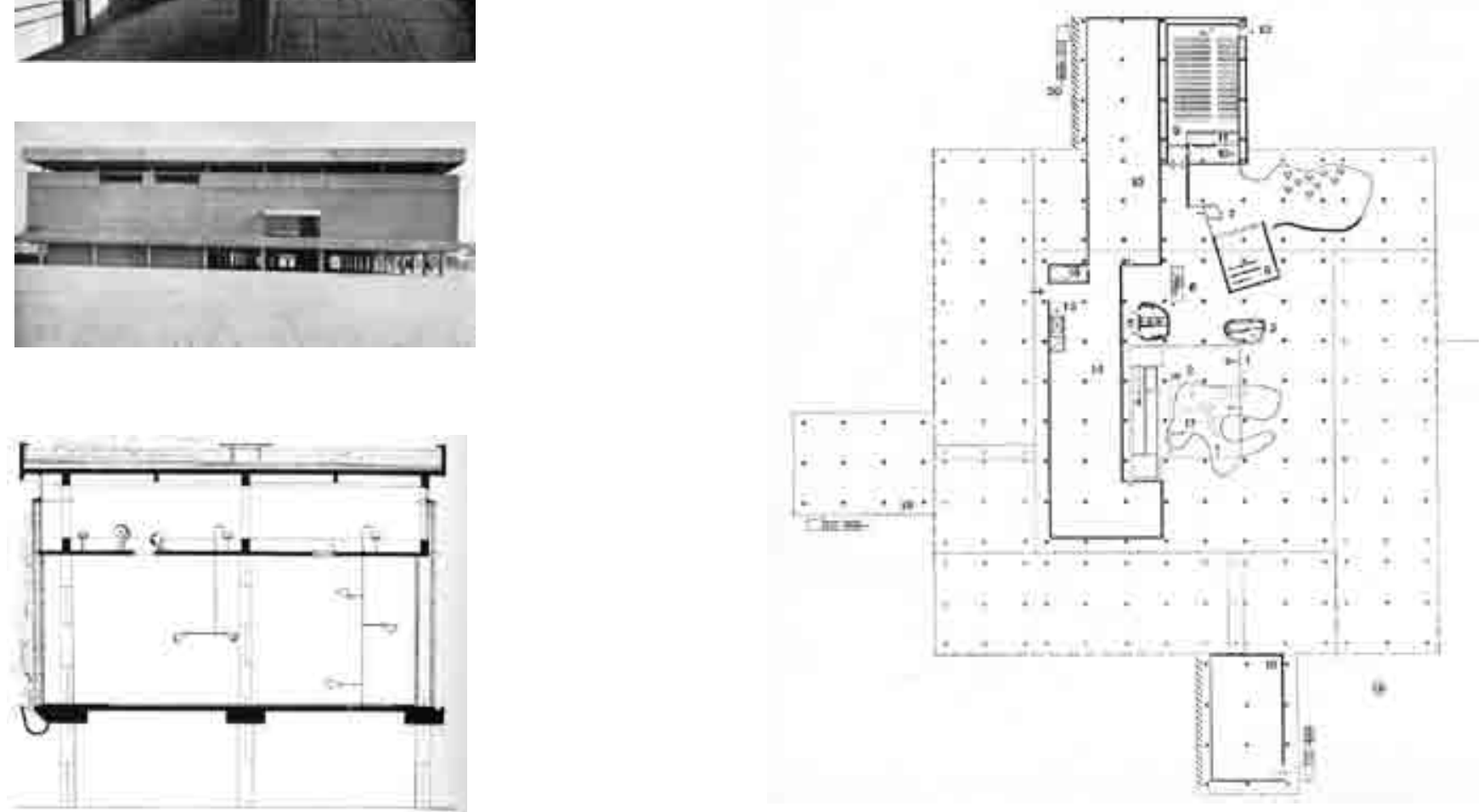

PLANTA BAJA 
PABELLÓN DE HOLANDA PARA LA BIENAL 1954-55

Venecia, Italia - Gerrit Rietveld, 1954
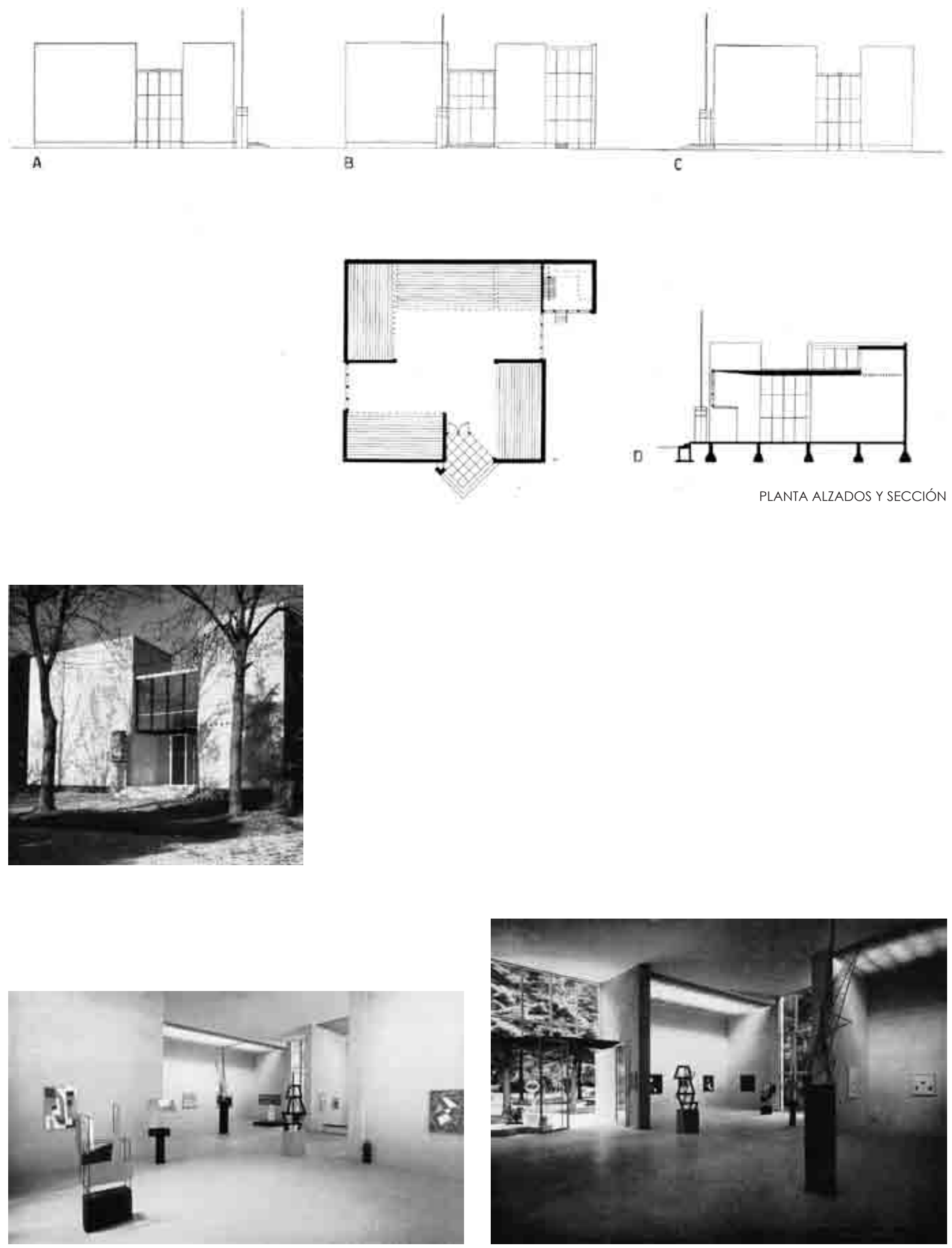
PABELLÓN DE VENEZUELA PARA LA BIENAL 1954-55

Venecia, Italia - Carlo Scarpa, 1954
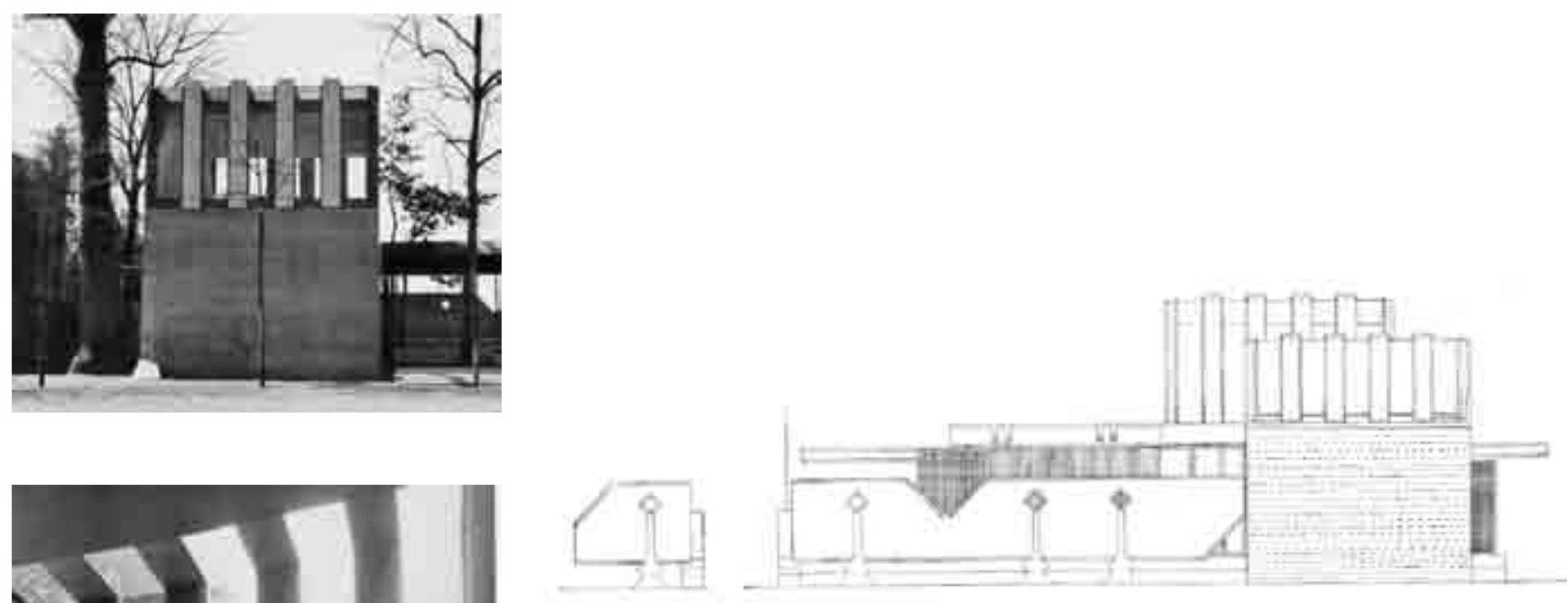

ALZADO
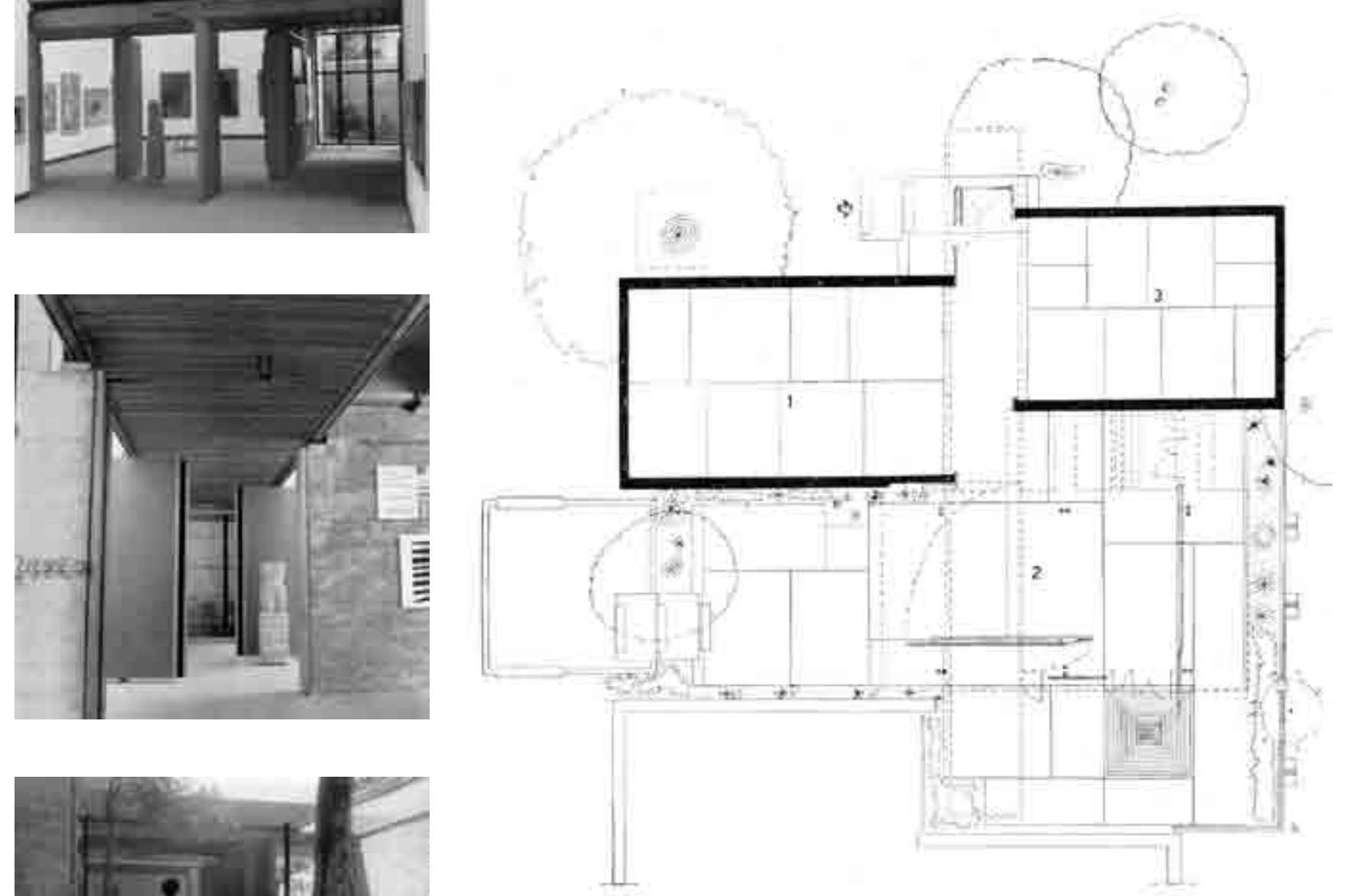

PLANTA

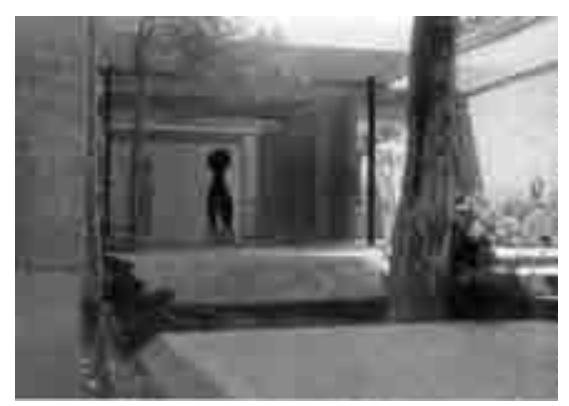


MUSEO DE LAS ARTES OCCIDENTALES

Tokio, Japón - Le Corbusier, 1957
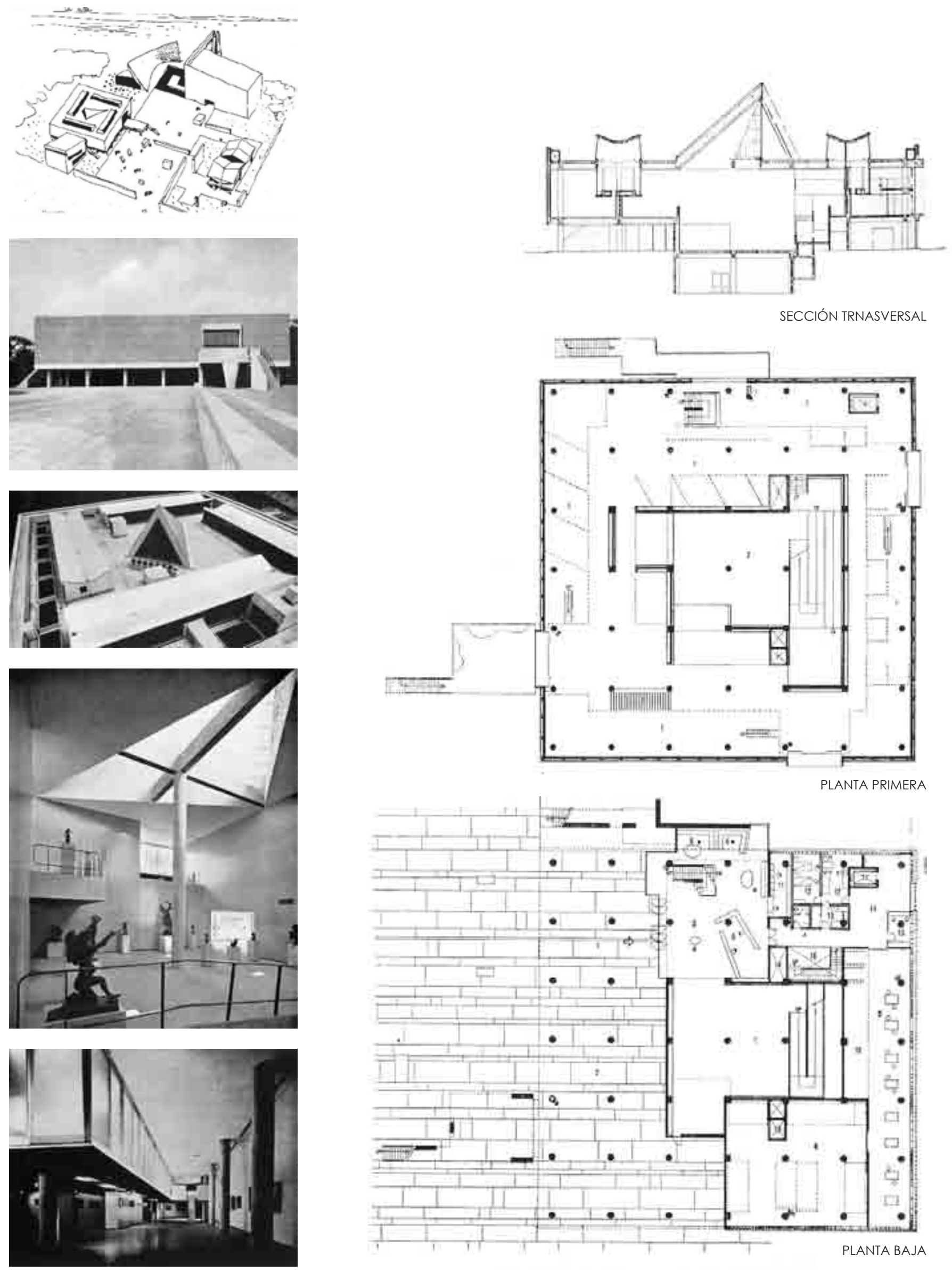

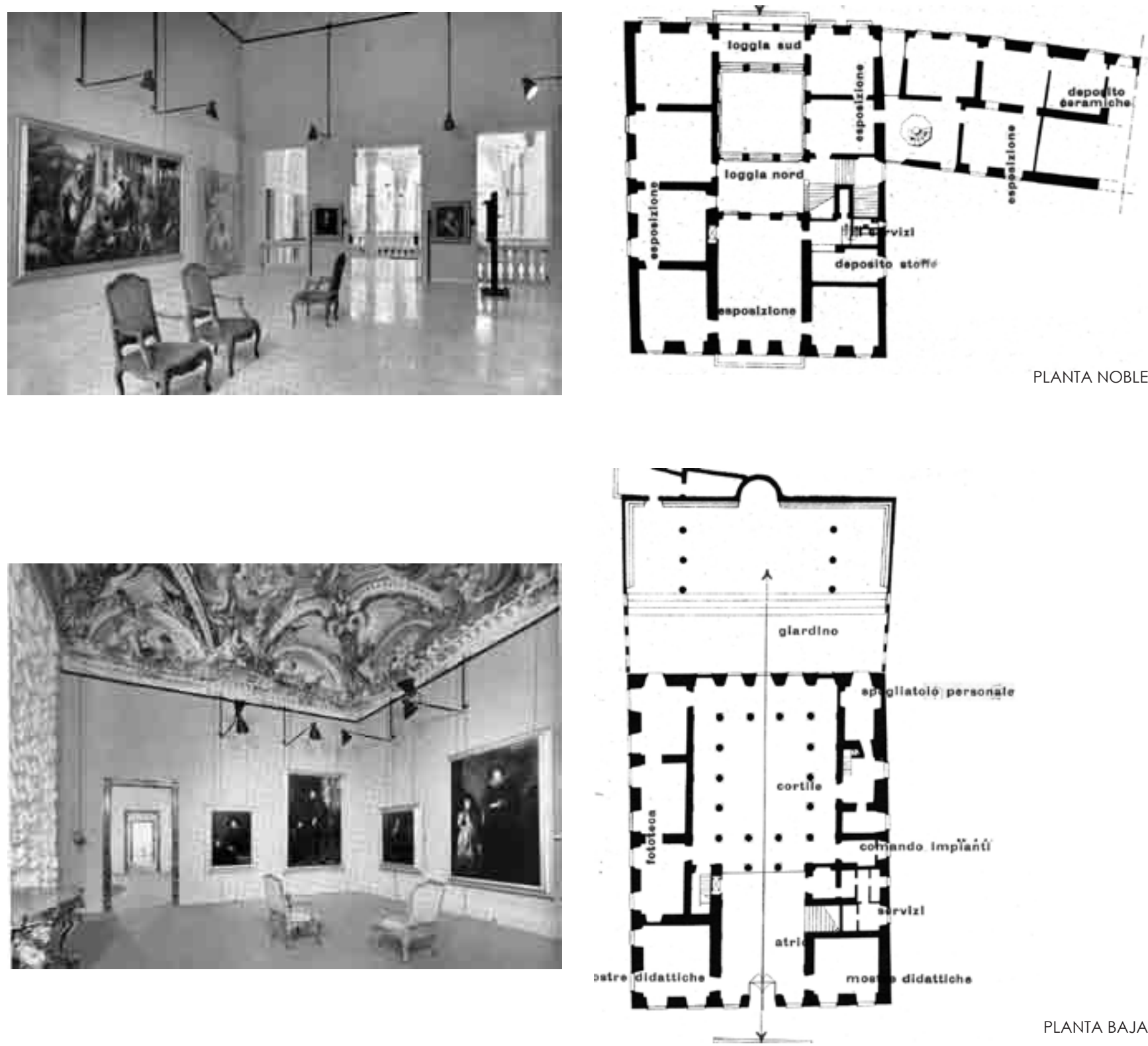

PLANTA BAJA
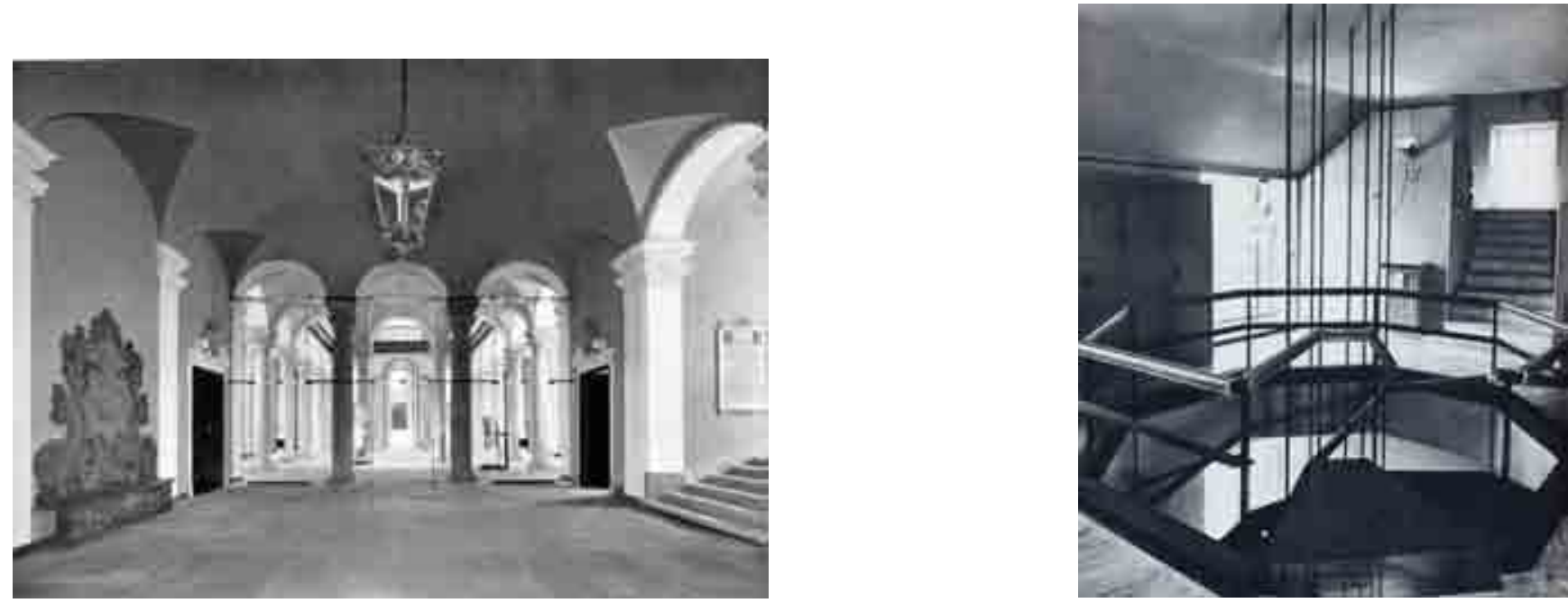
PALACIO DE EXPOSICIONES EN ESTOCOLMO

Estocolmo, Suecia - Le Corbusier, 1962

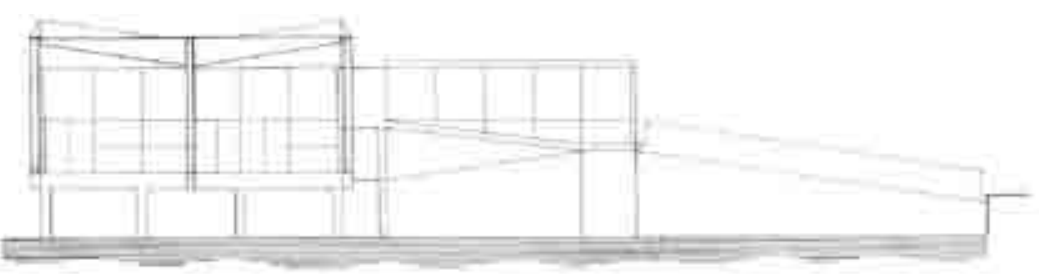

ALZADO ESTE
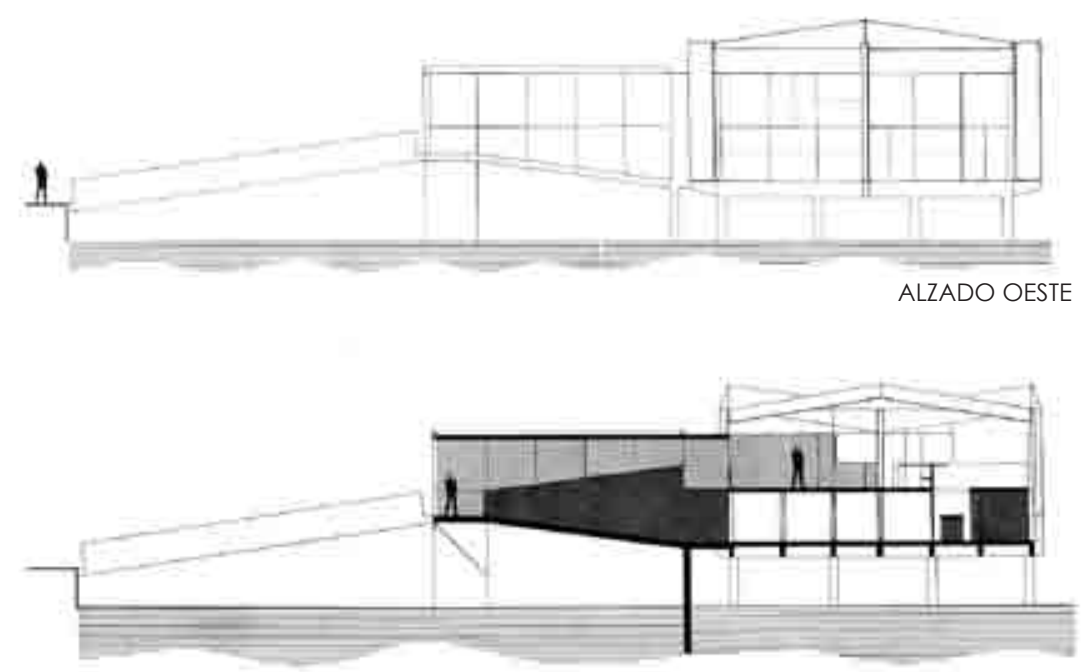

SECCIÓN TRANSVERSAL
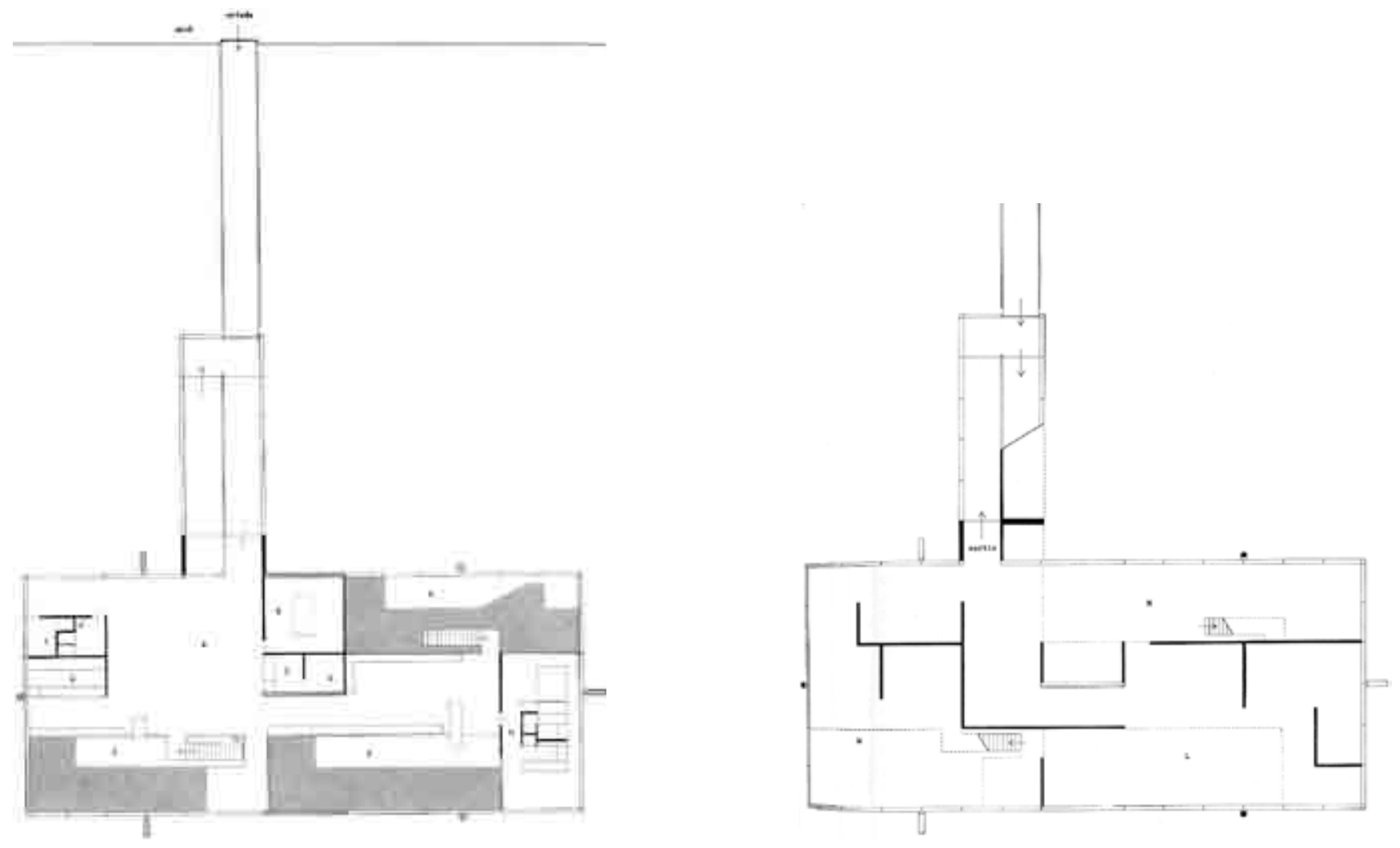

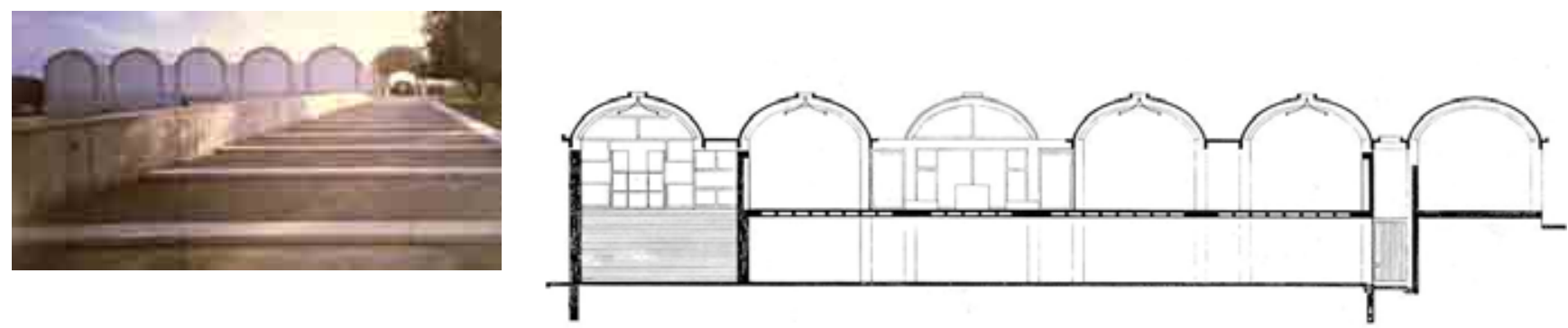

SECCIÓN TRANSVERSAL
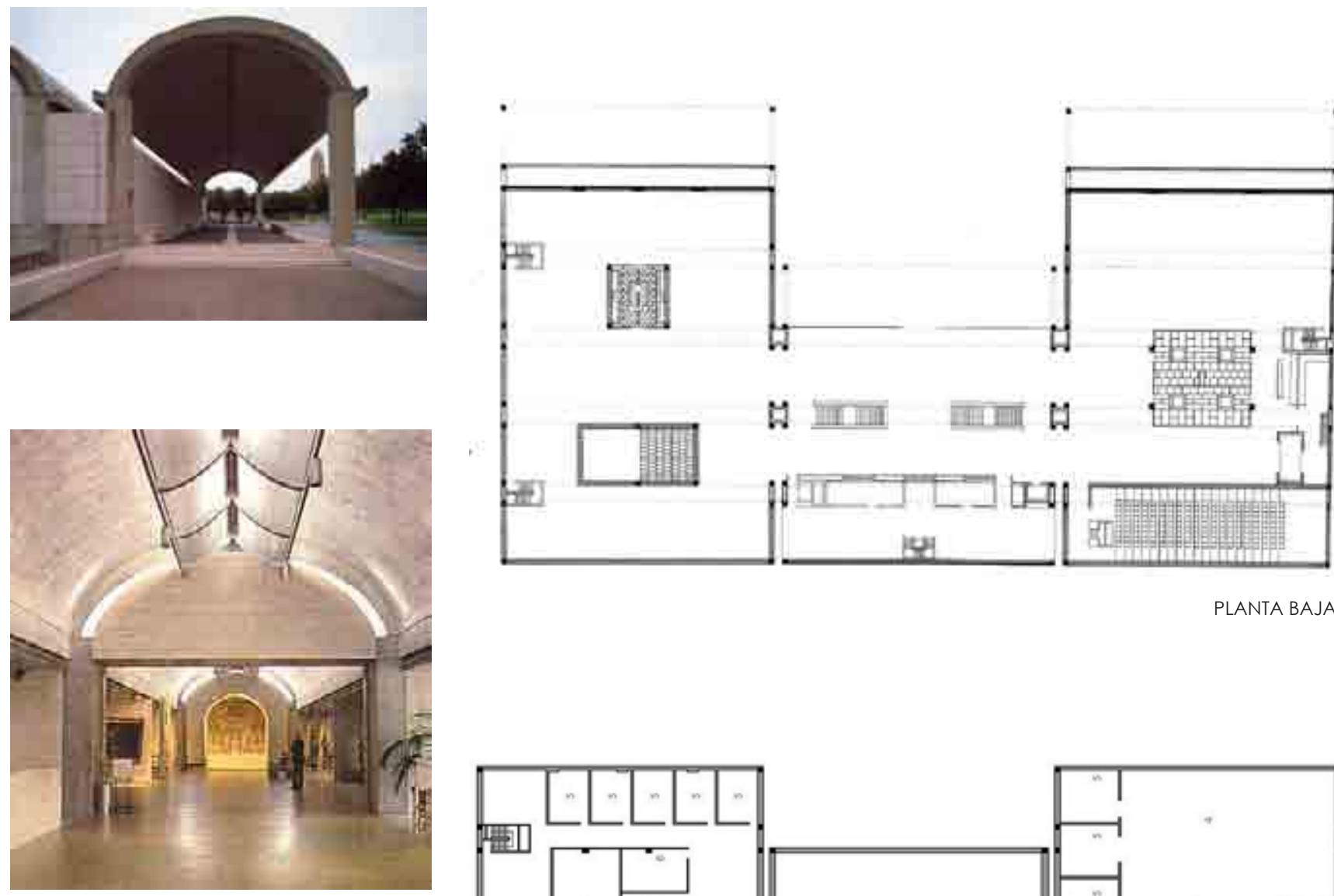

PLANTA BAJA
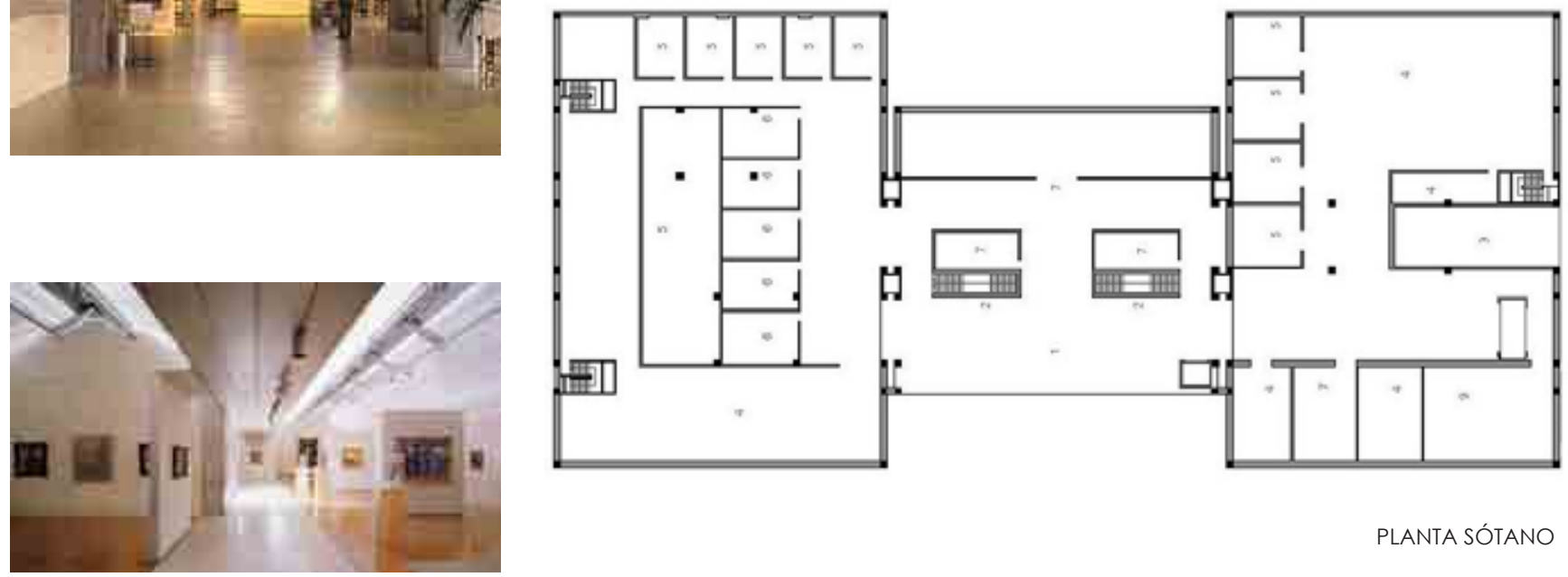
WHITECHAPEL ART GALLERY

Londres, Reino Unido - Alan Colquhoun \& John Miller, 1966
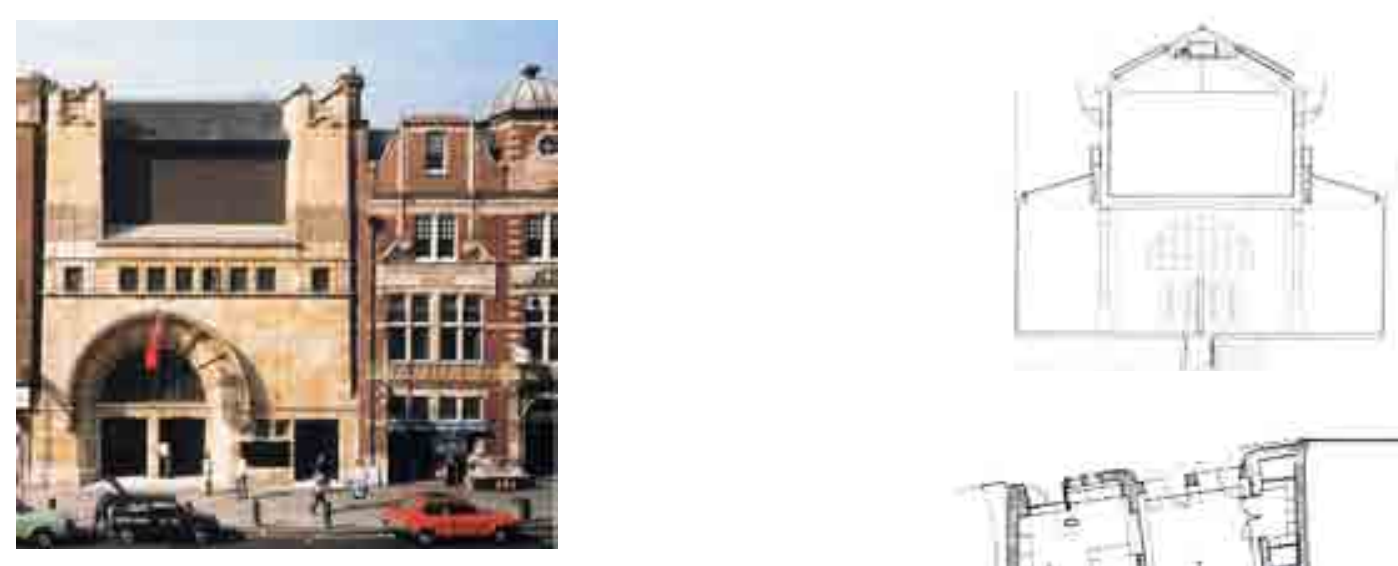

SECCIÓN POR SALA
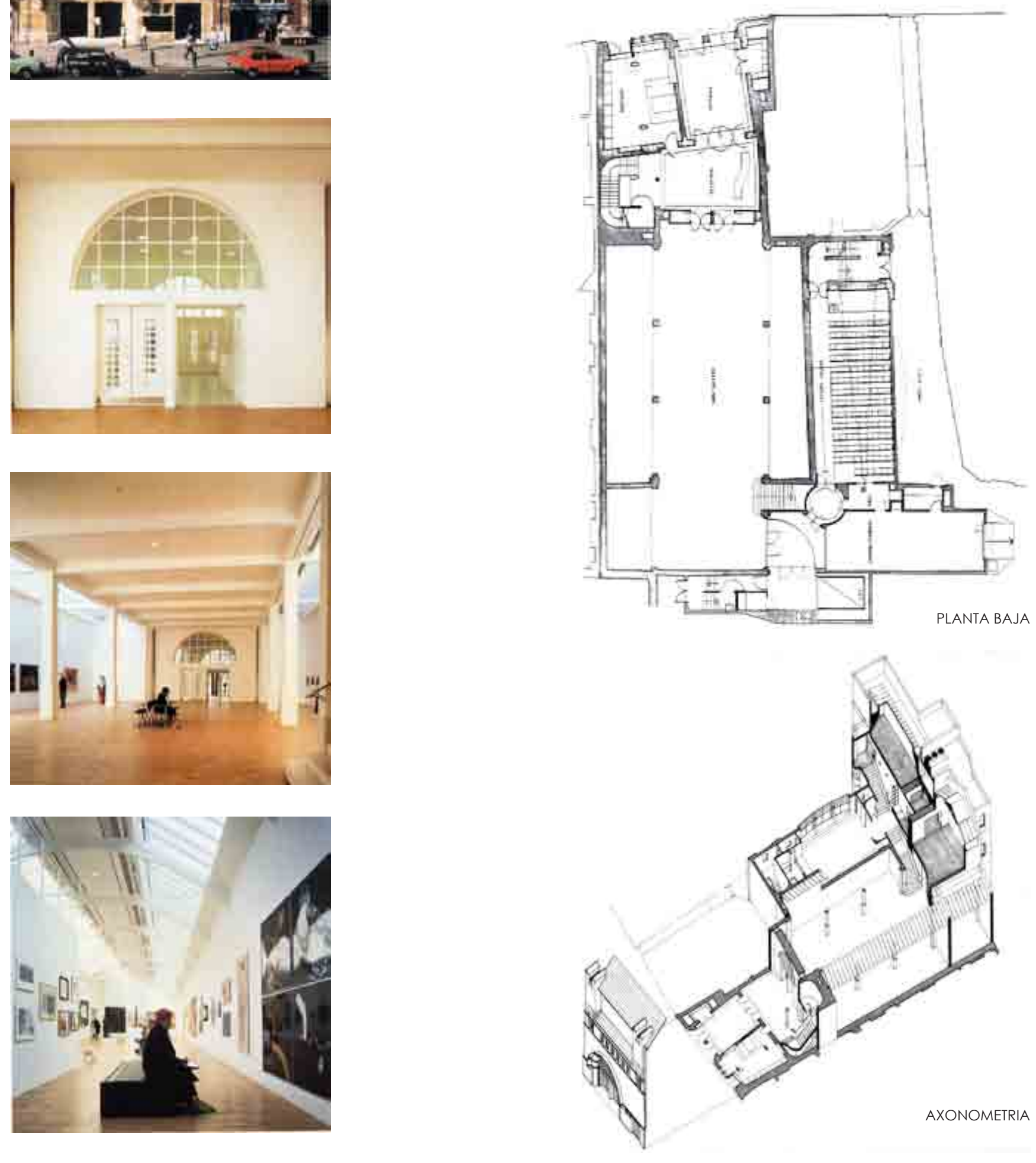

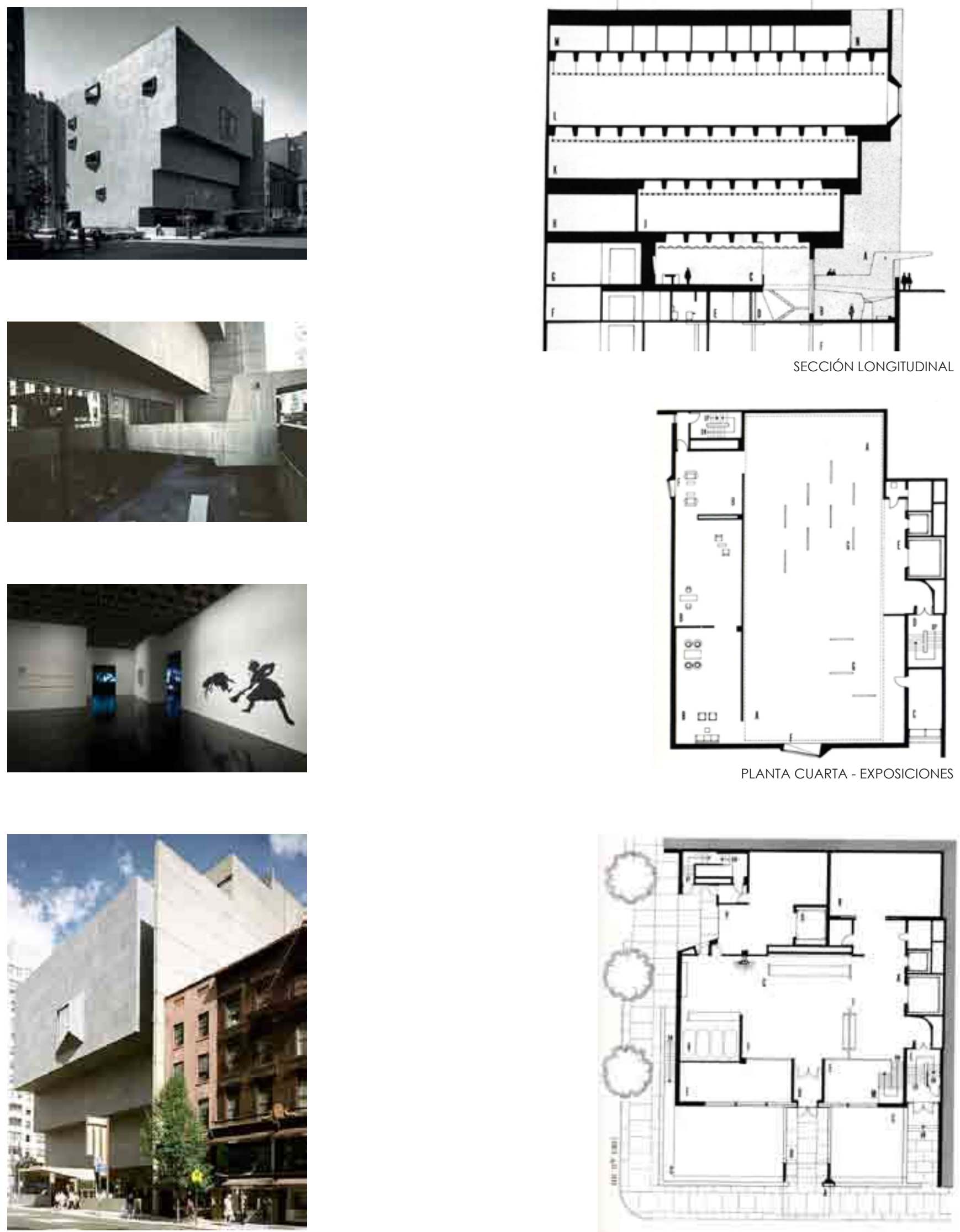

PLANTA BAJA - ACCESO DESDE CALLE 
NEUE NATIONALGALERIE

Berlín, Alemania - Mies van der Rohe, 1968
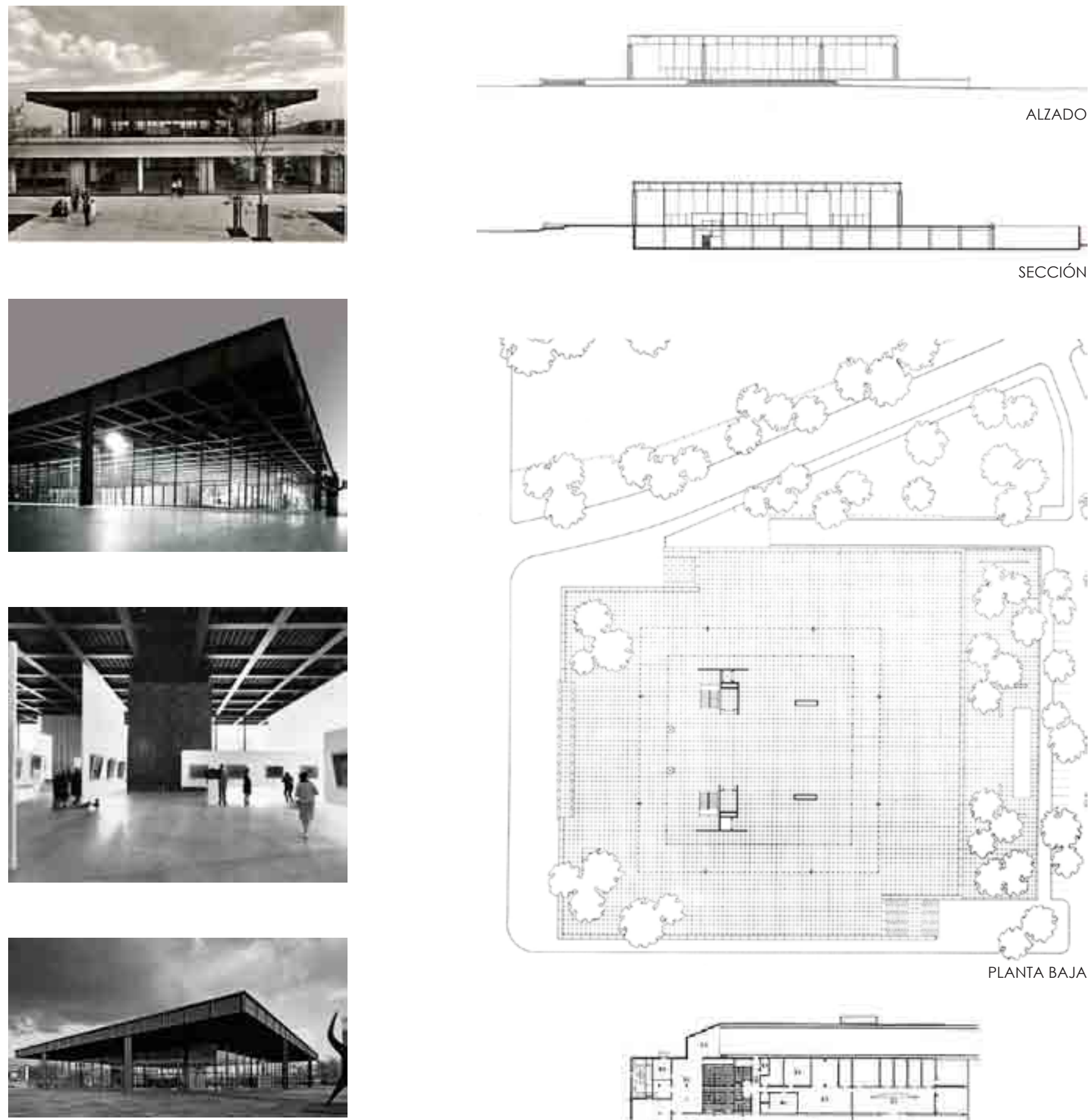

PLANTA BAJA
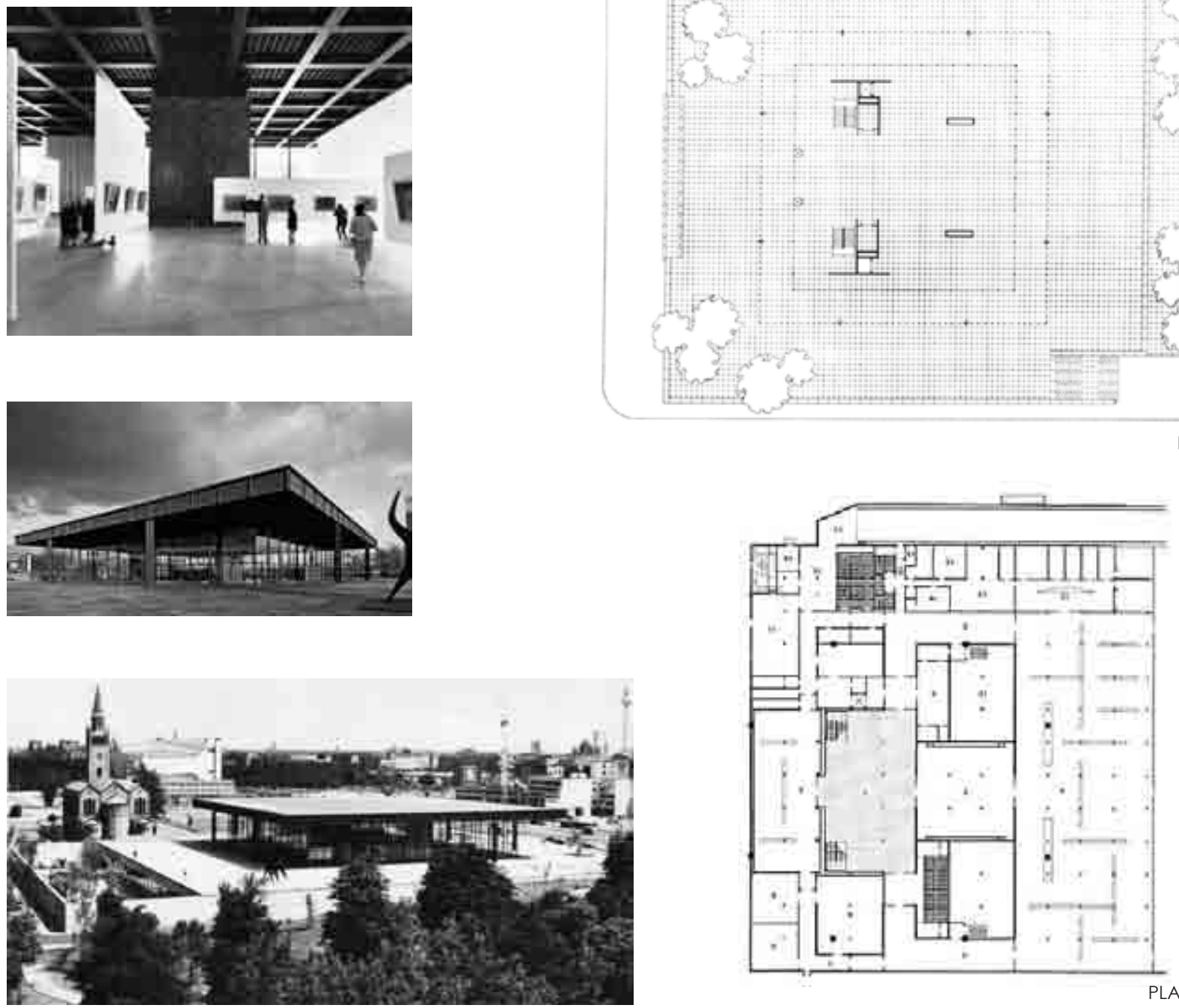

PLANTA SÓTANO 
YALE CENTER FOR BRITISH ART

New Haven, Connecticut (USA) - Louis I. Kahn, 1969
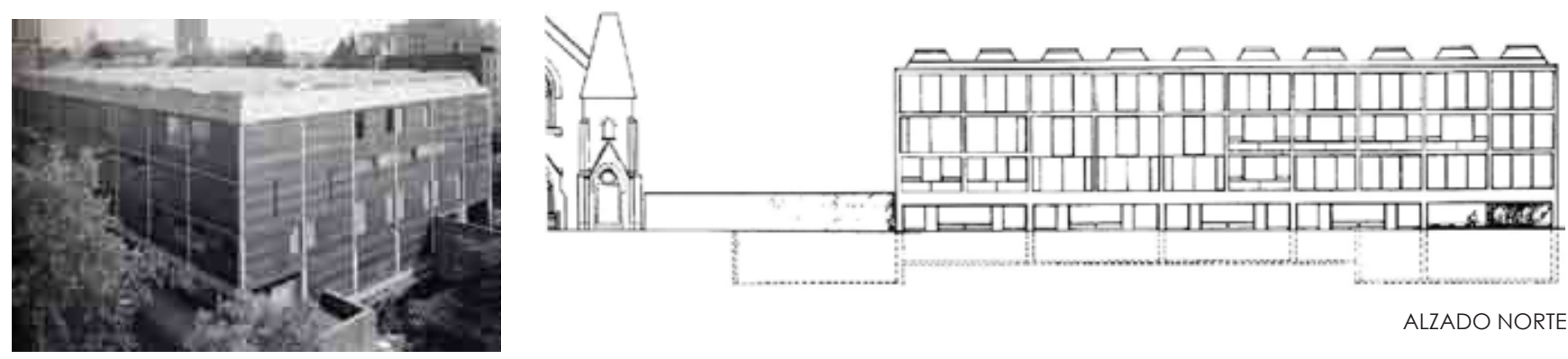

ALZADO NORTE
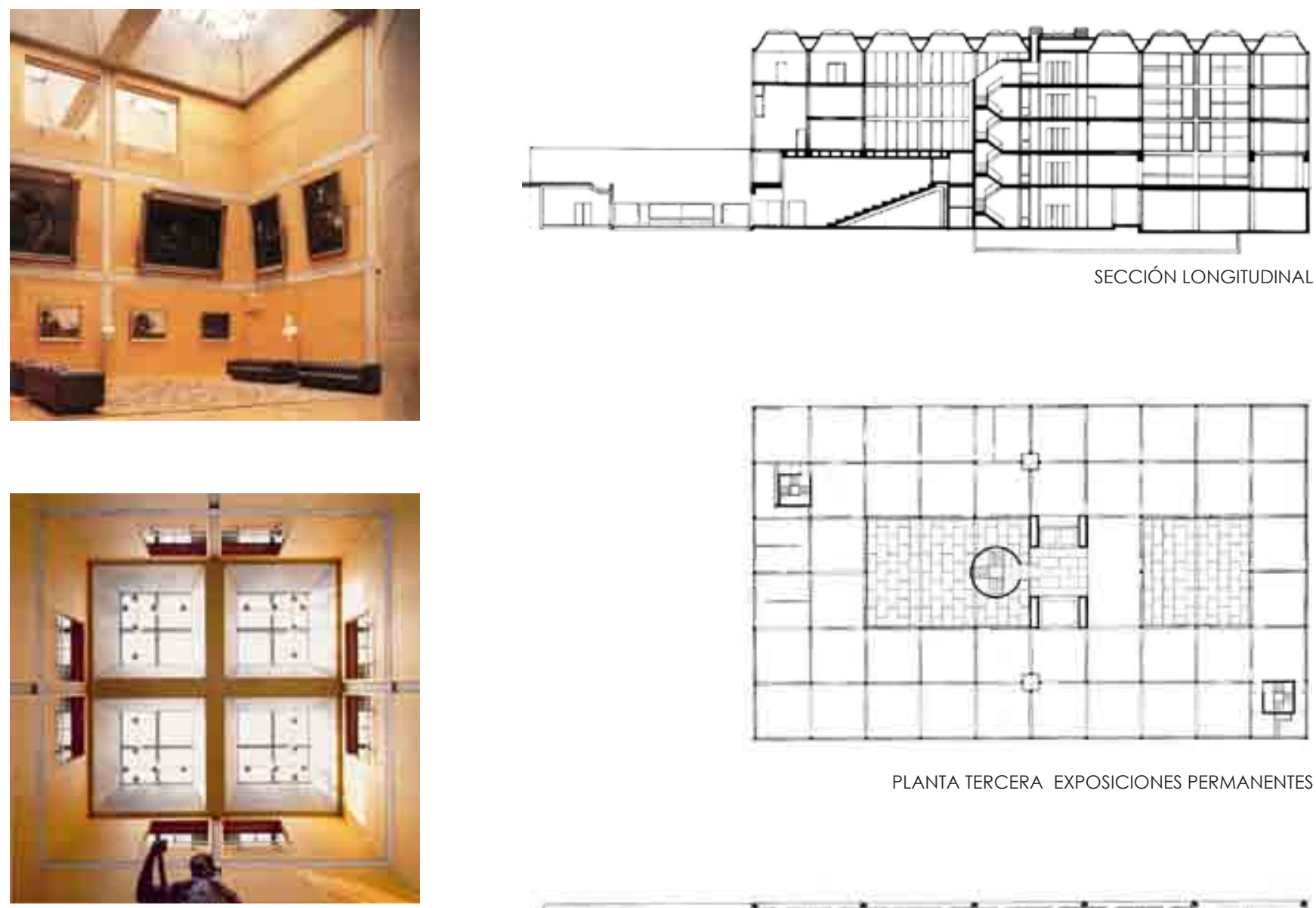

PLANTA TERCERA EXPOSICIONES PERMANENTES
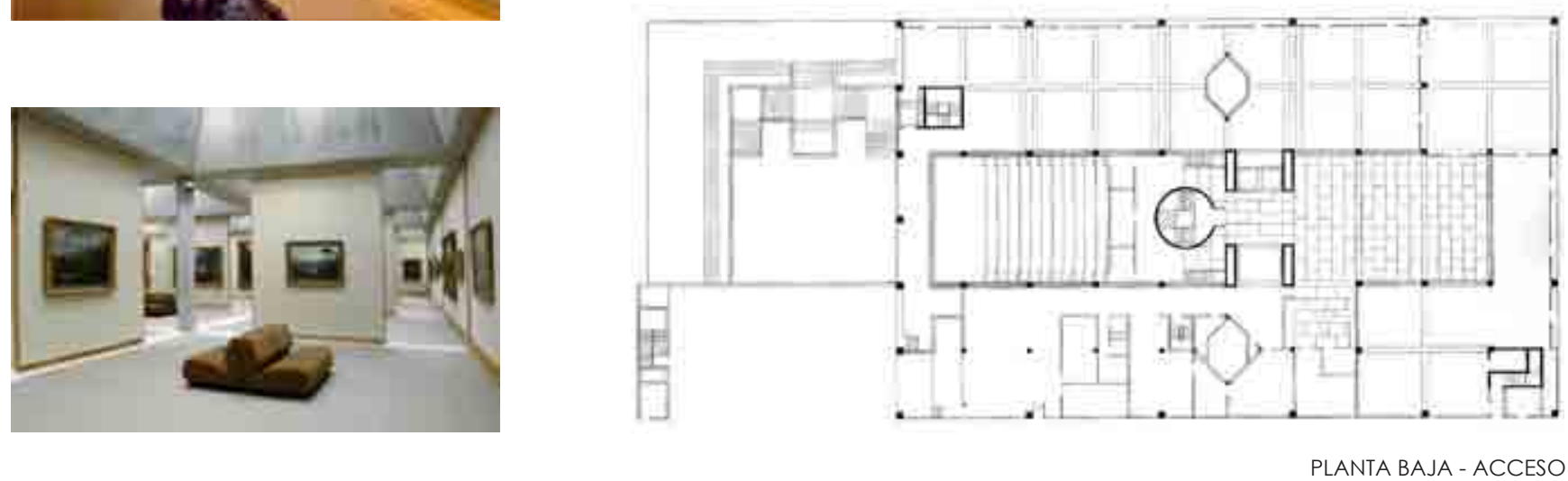
CENTRO POMPIDOU

París, Francia - Renzo Piano \& Richard Rogers, 1971
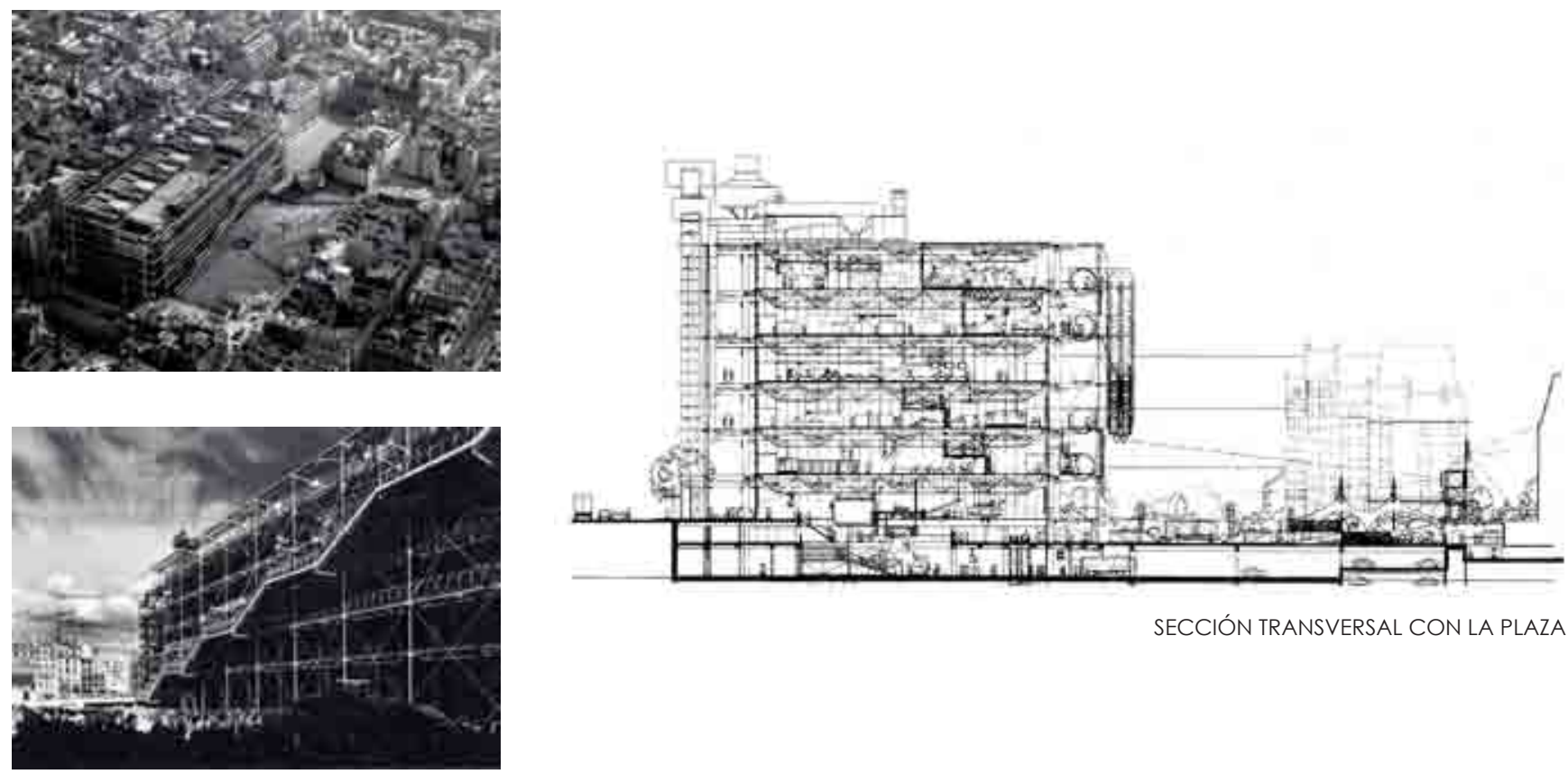

SECCIÓN TRANSVERSAL CON LA PLAZA
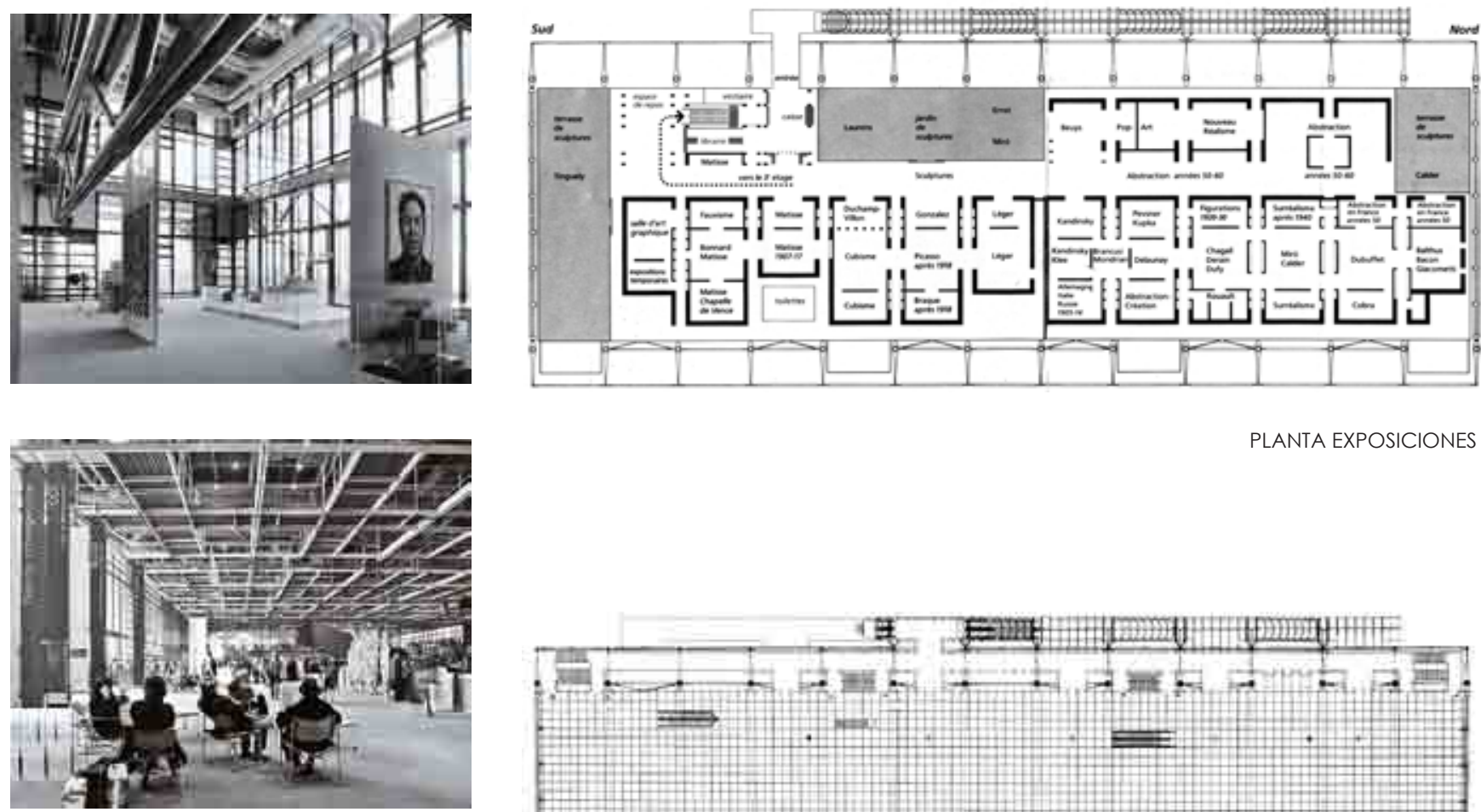

PLANTA EXPOSICIONES
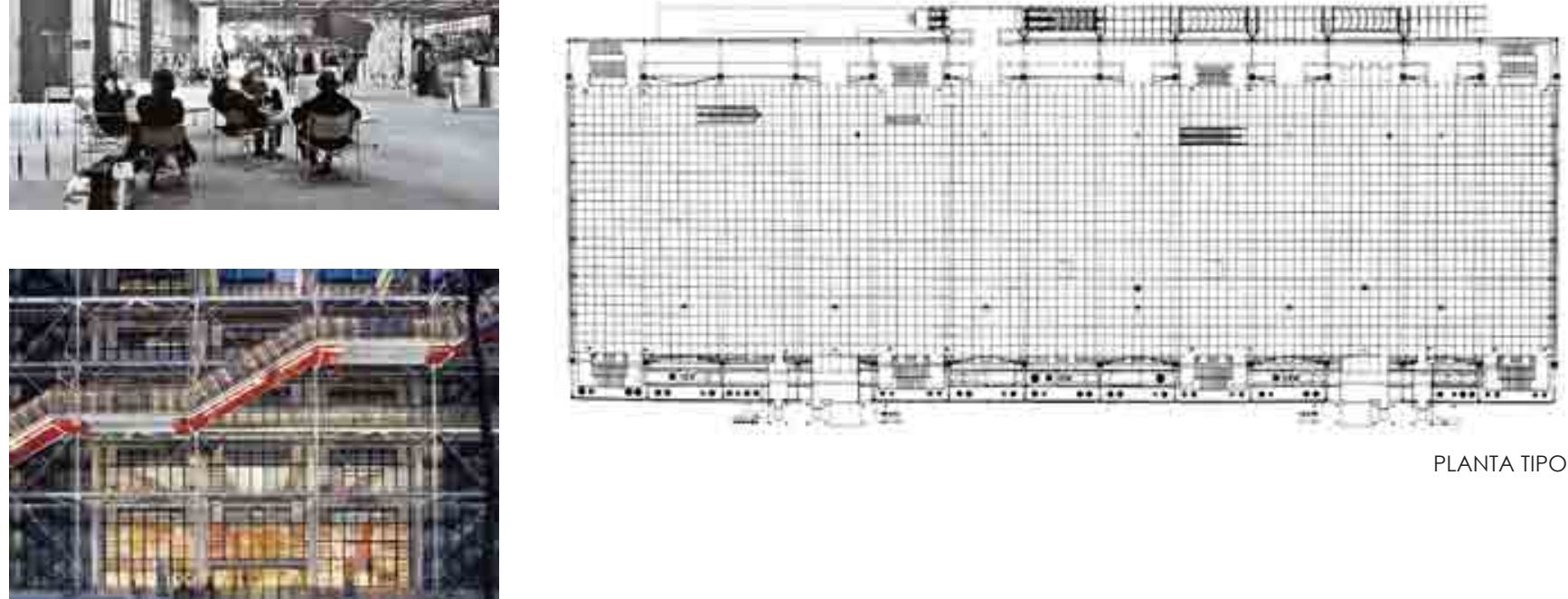

PLANTA TIPO 

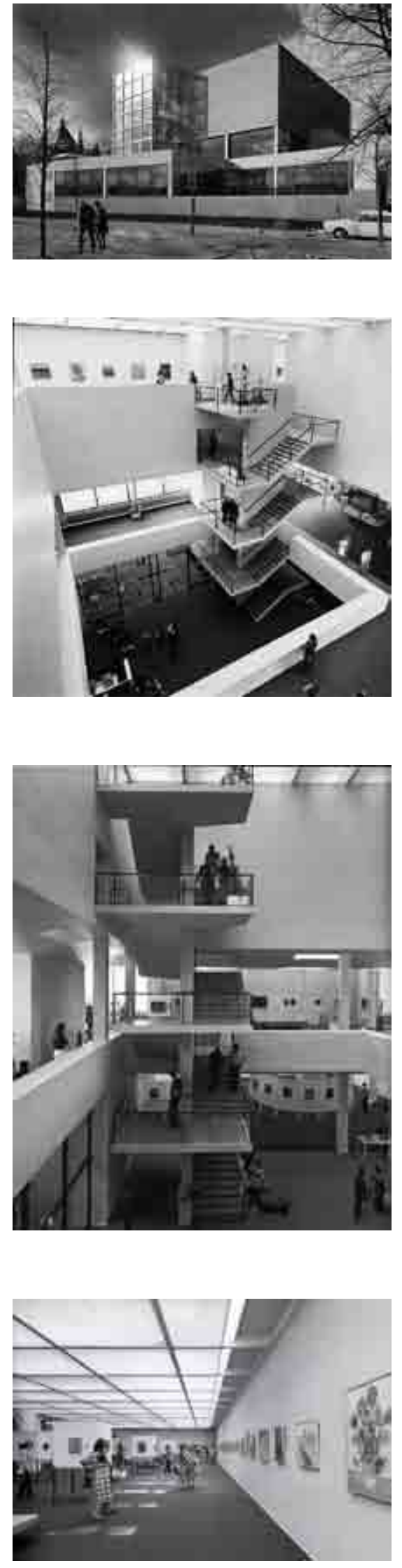
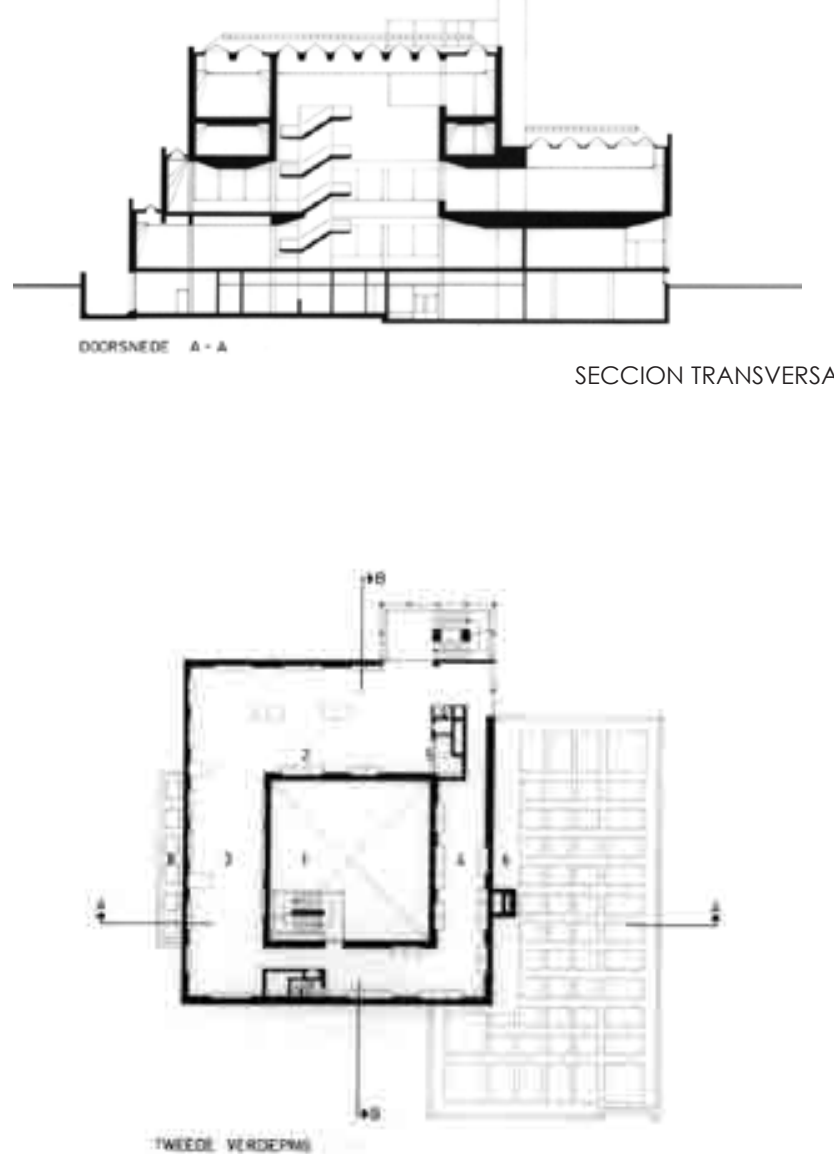

PLANTA SEGUNDA - EXPOSICIONES

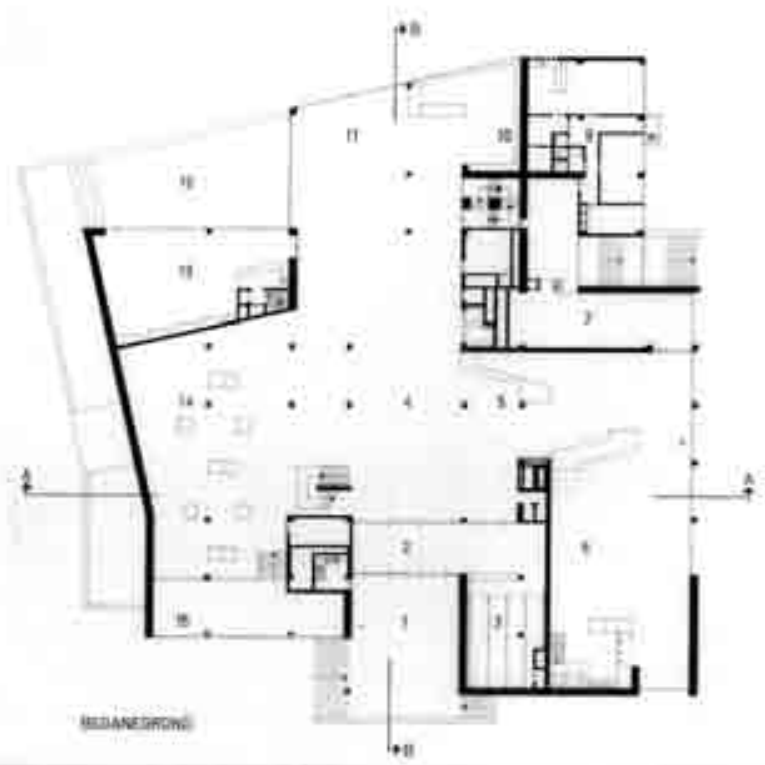

PLANTA BAJA 
AMPLIACIÓN DEL MUSEO WALLRAF-RICHARTZ

Colonia, Alemania - James Stirling, 1975
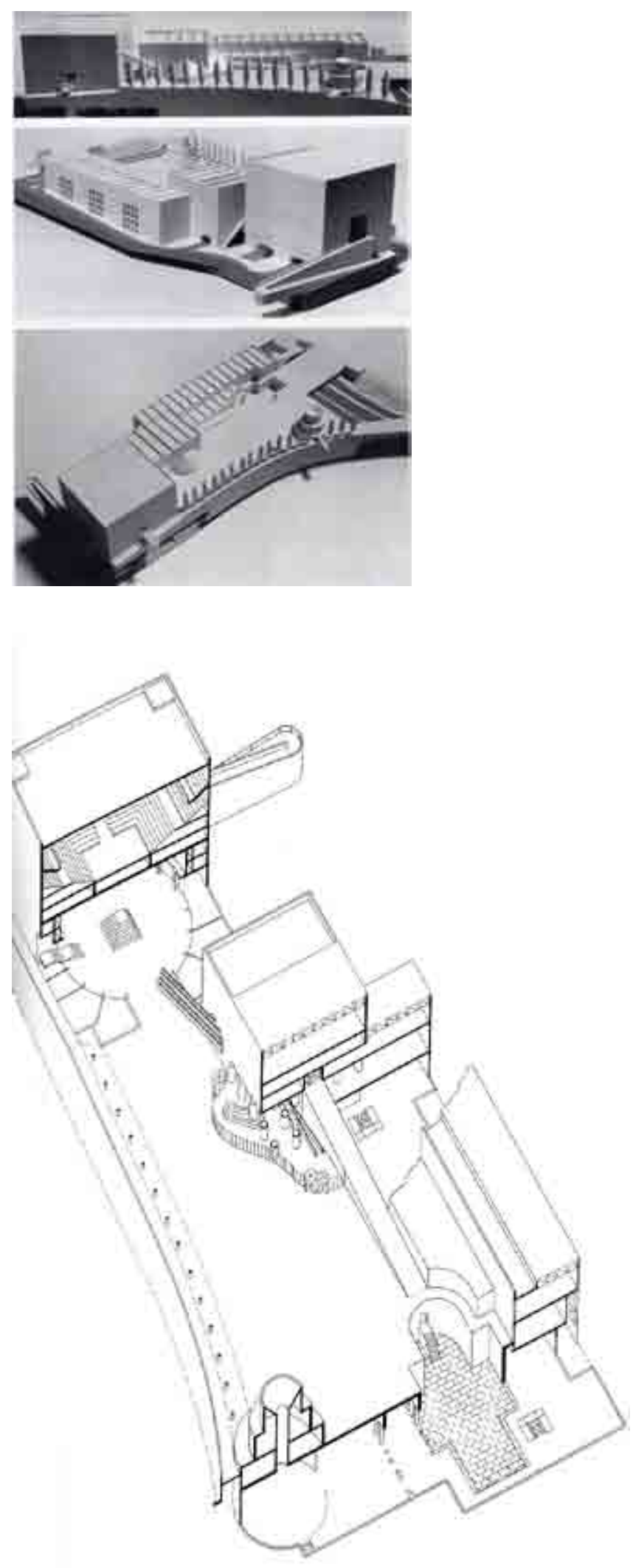
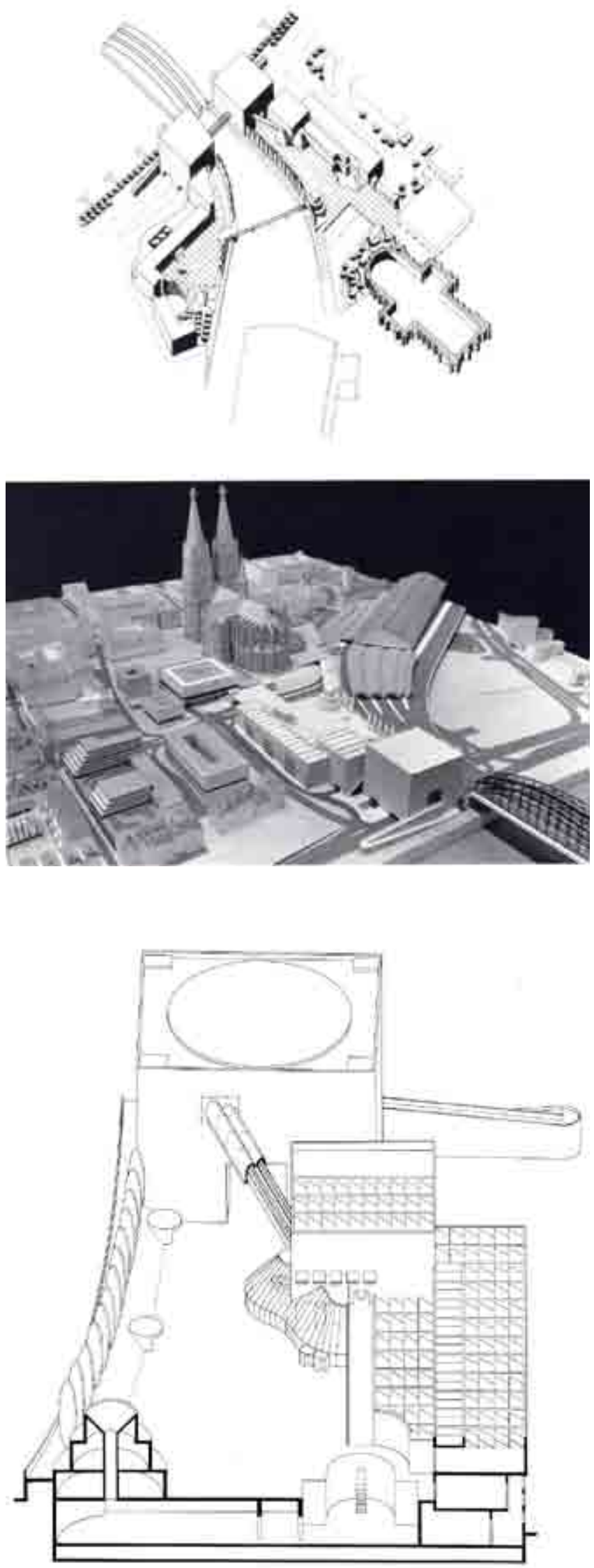
THE U.S. NATIONAL GALLERY OF ART (EDIFICIO ESTE) Washington, D.C. (USA) - I. M. Pei, 1978
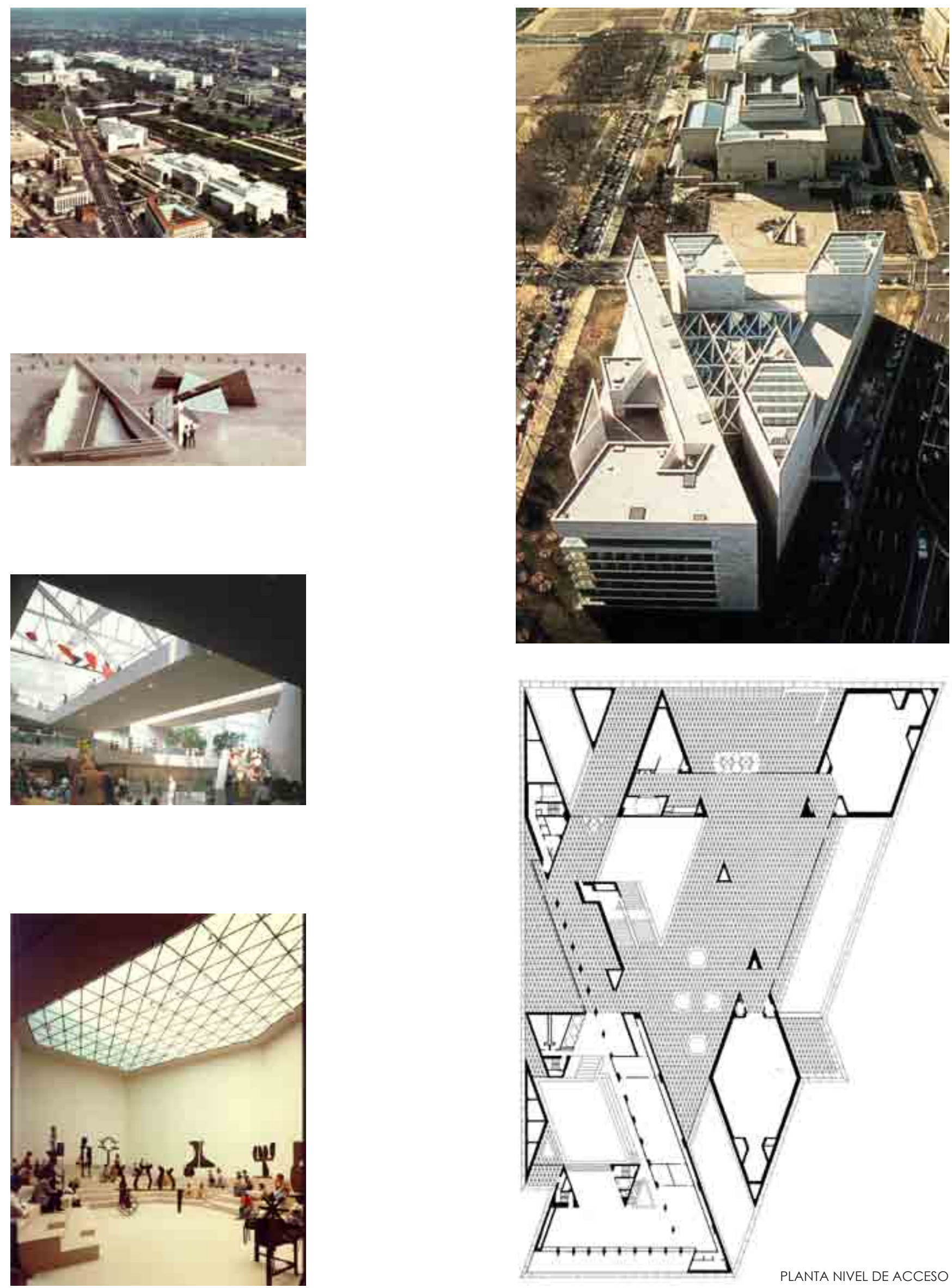
AMPLIACIÓN DEL MUSEO FOGG

Cambridge, Massachusetts (USA) - James Stirling, 1979
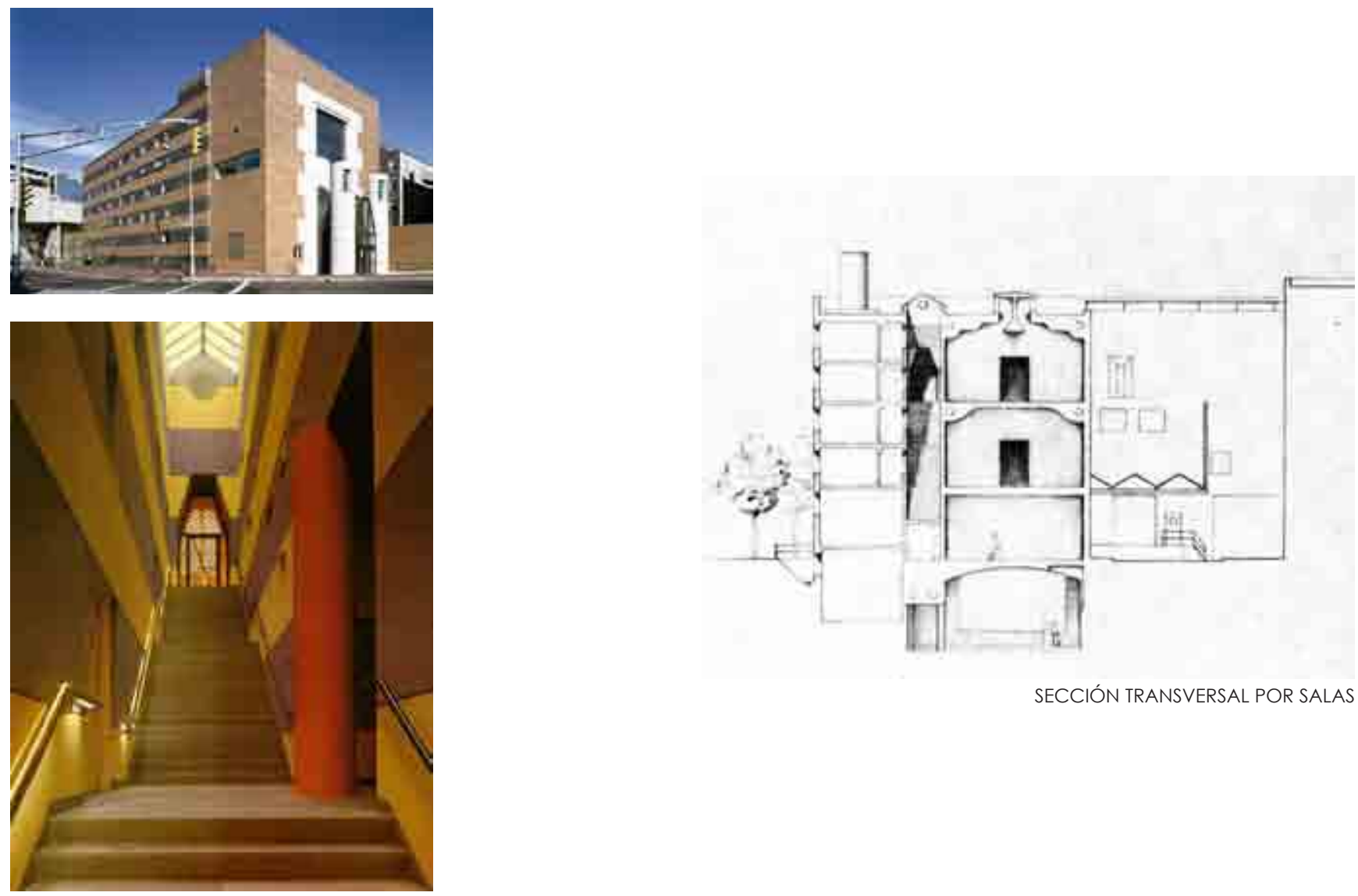

SECCIÓN TRANSVERSAL POR SALAS
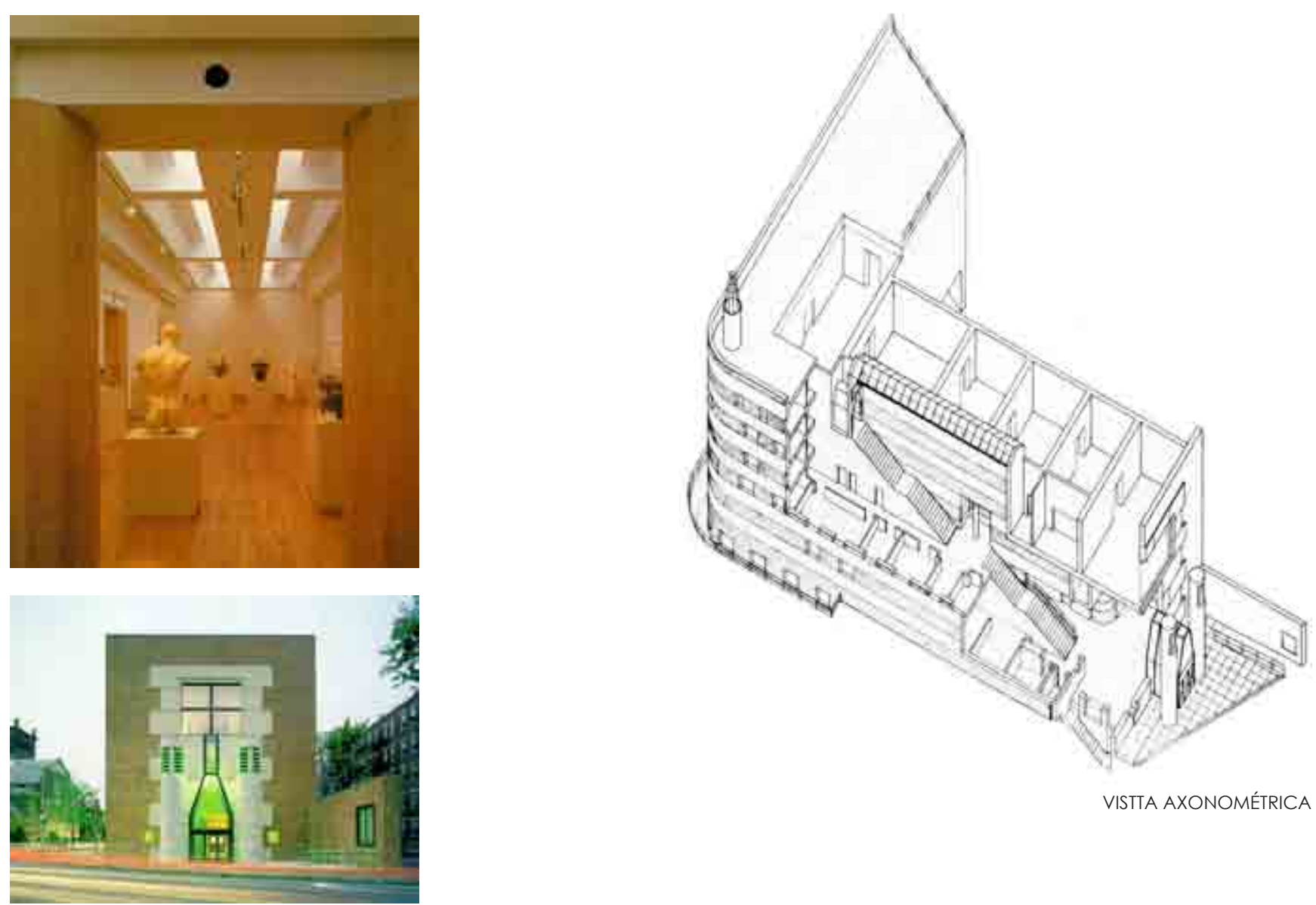

VISTTA AXONOMÉTRICA 
MUSEO DE ARTE ROMANO DE MÉRIDA

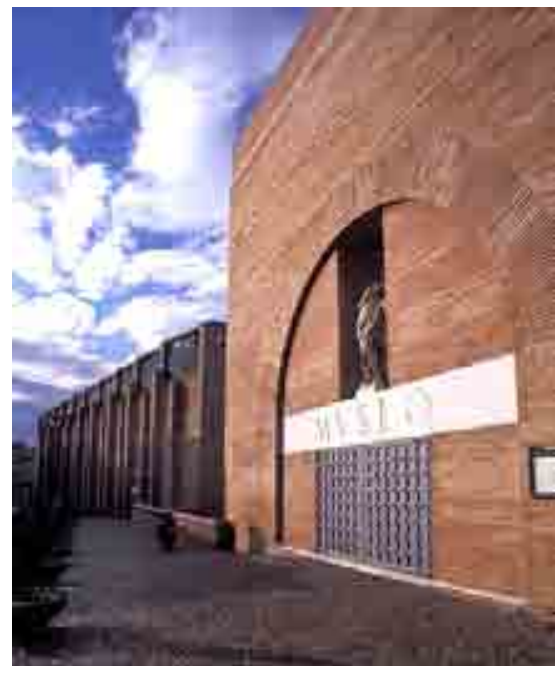

Mérida, España - Rafael Moneo, 1980
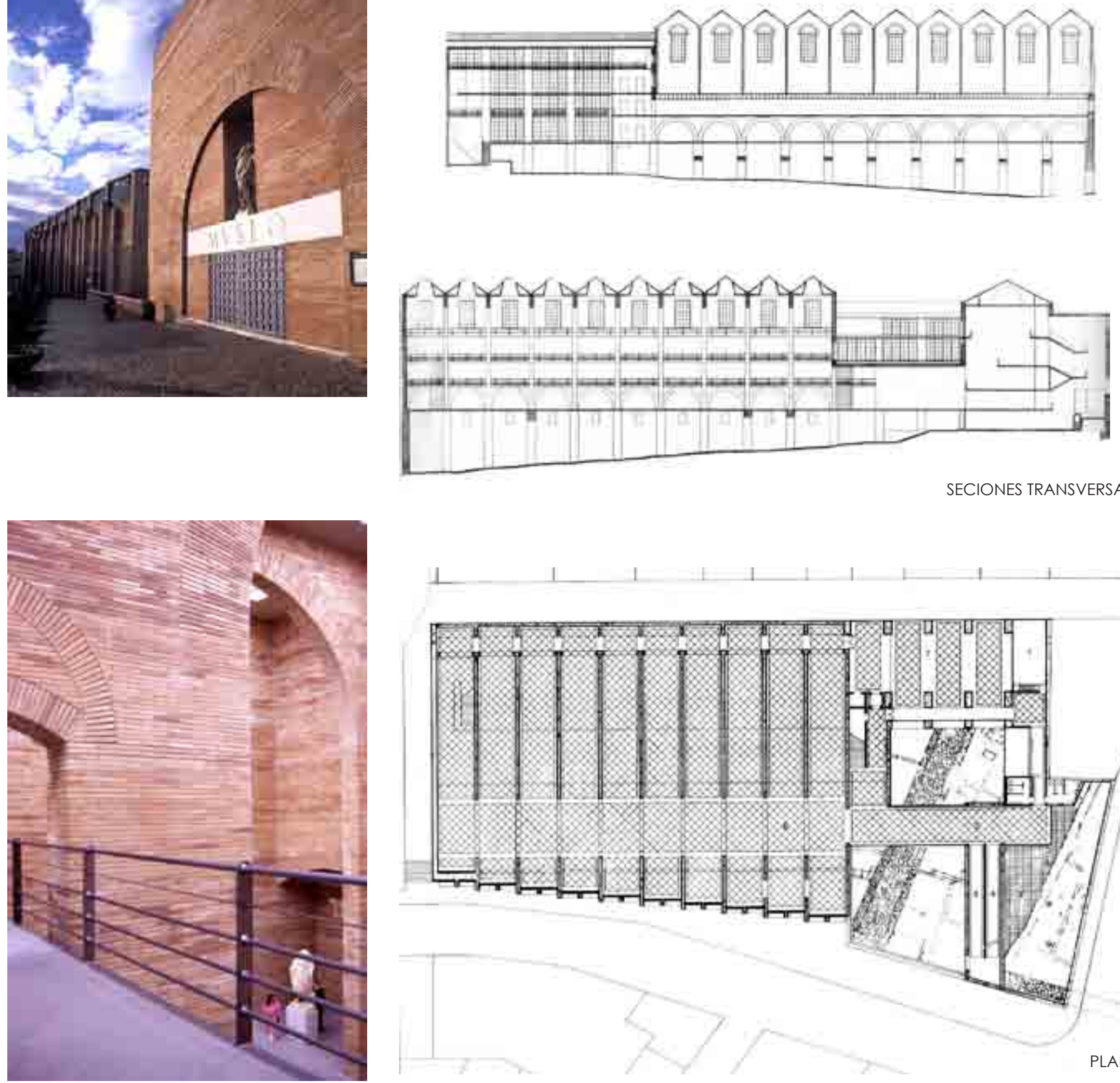

SECIONES TRANSVERSALES
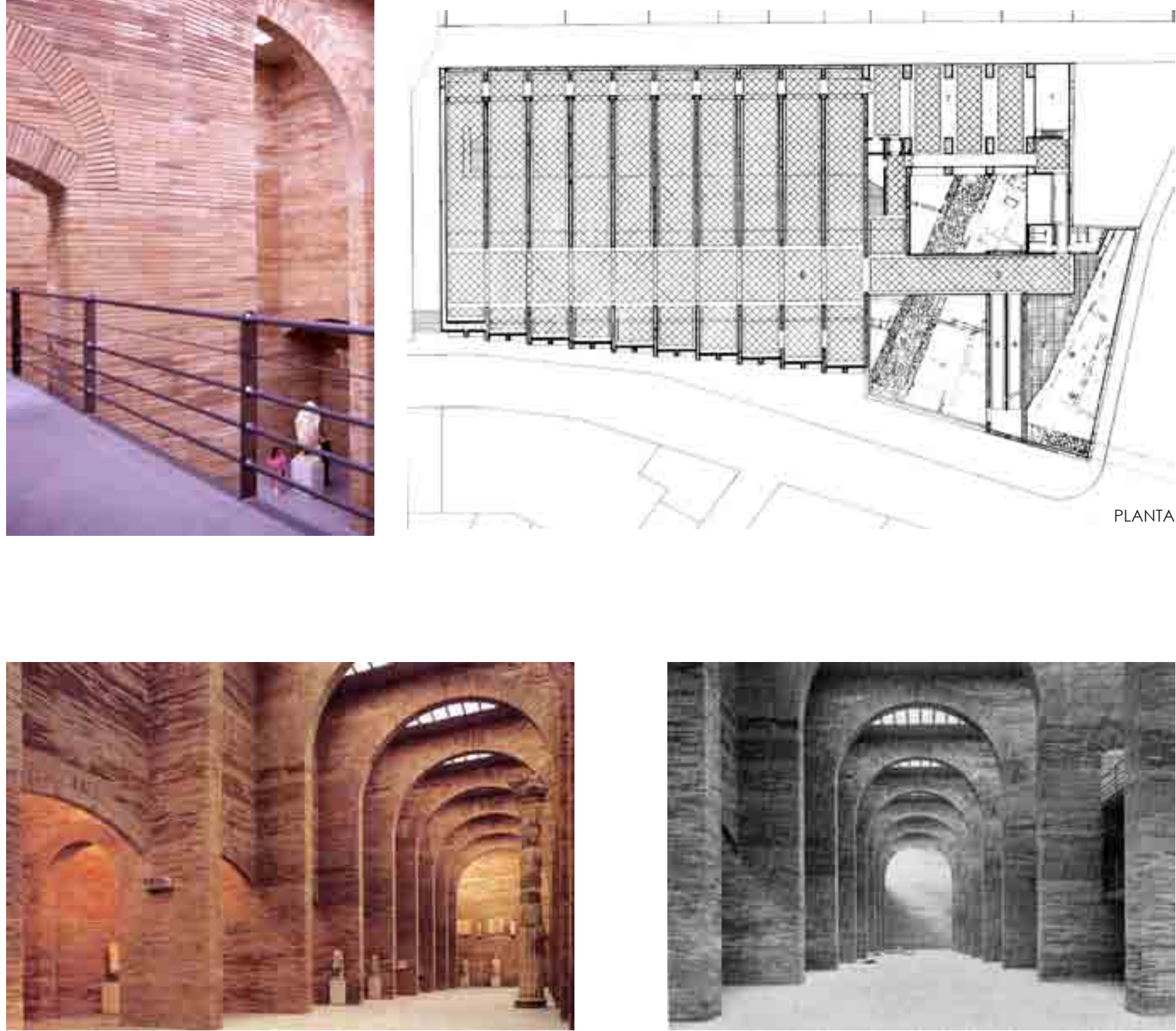
MUSEO DE ARTE MODERNO DE LOS ÁNGELES

Los Ángeles, California (USA) - Arata Isozaki, 1981
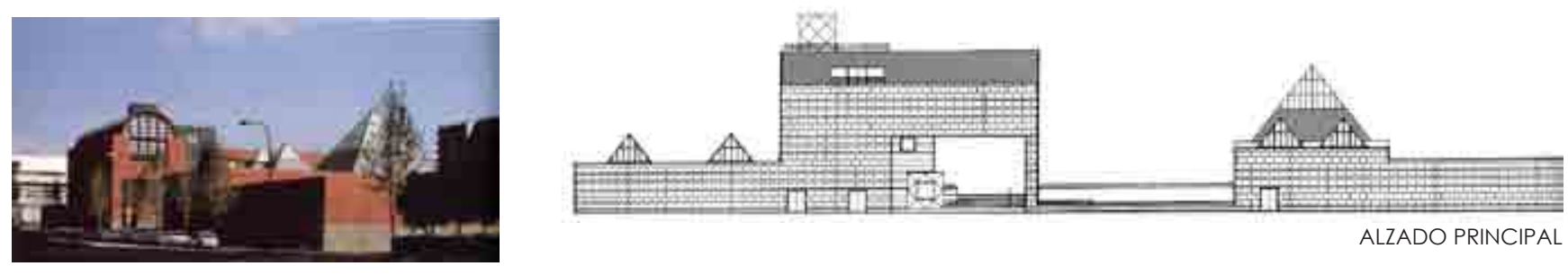

ALZADO PRINCIPAL
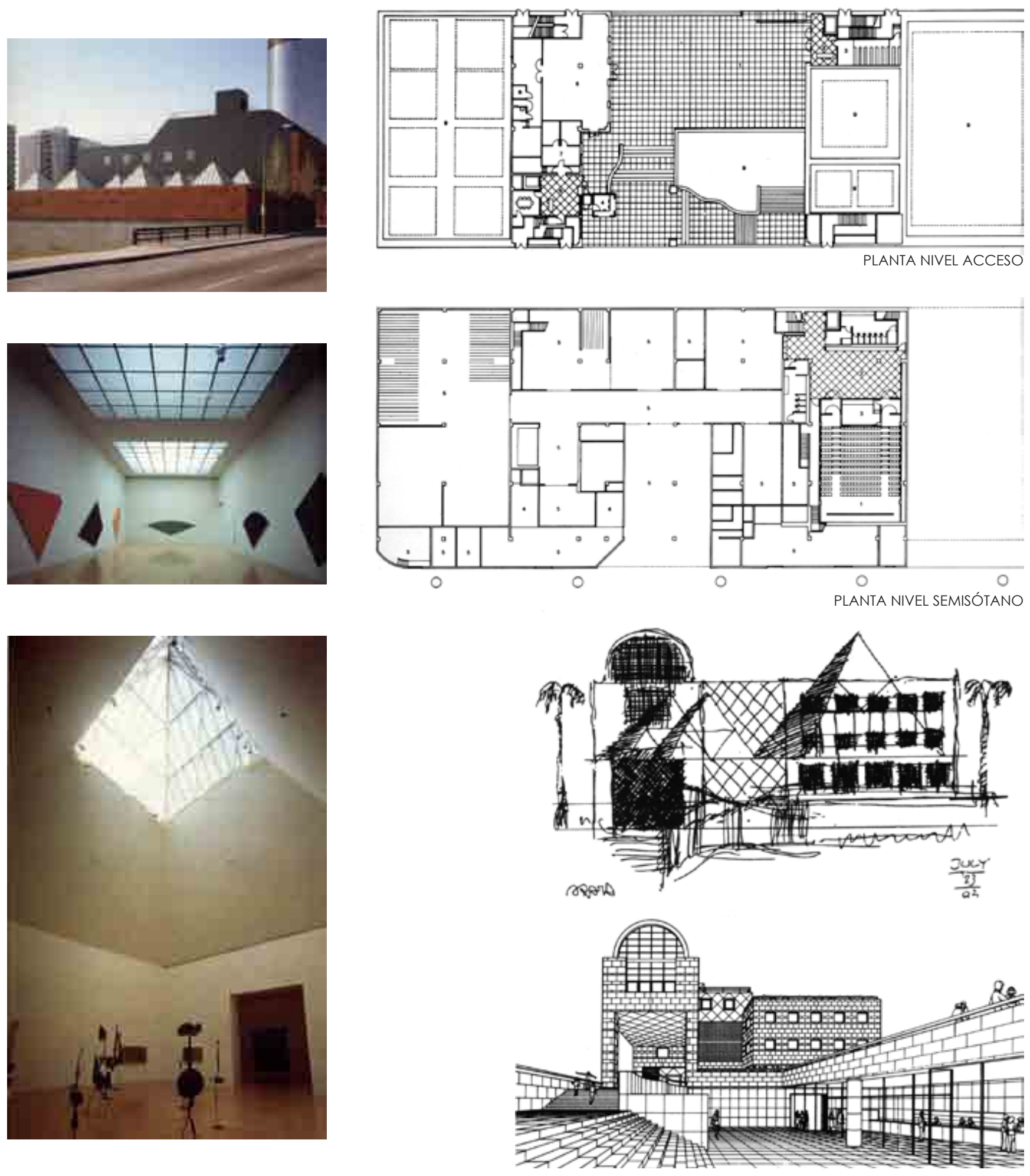
THE MENIL COLLECTION MUSEUM

Houston, Texas (USA) - Renzo Piano, 1982
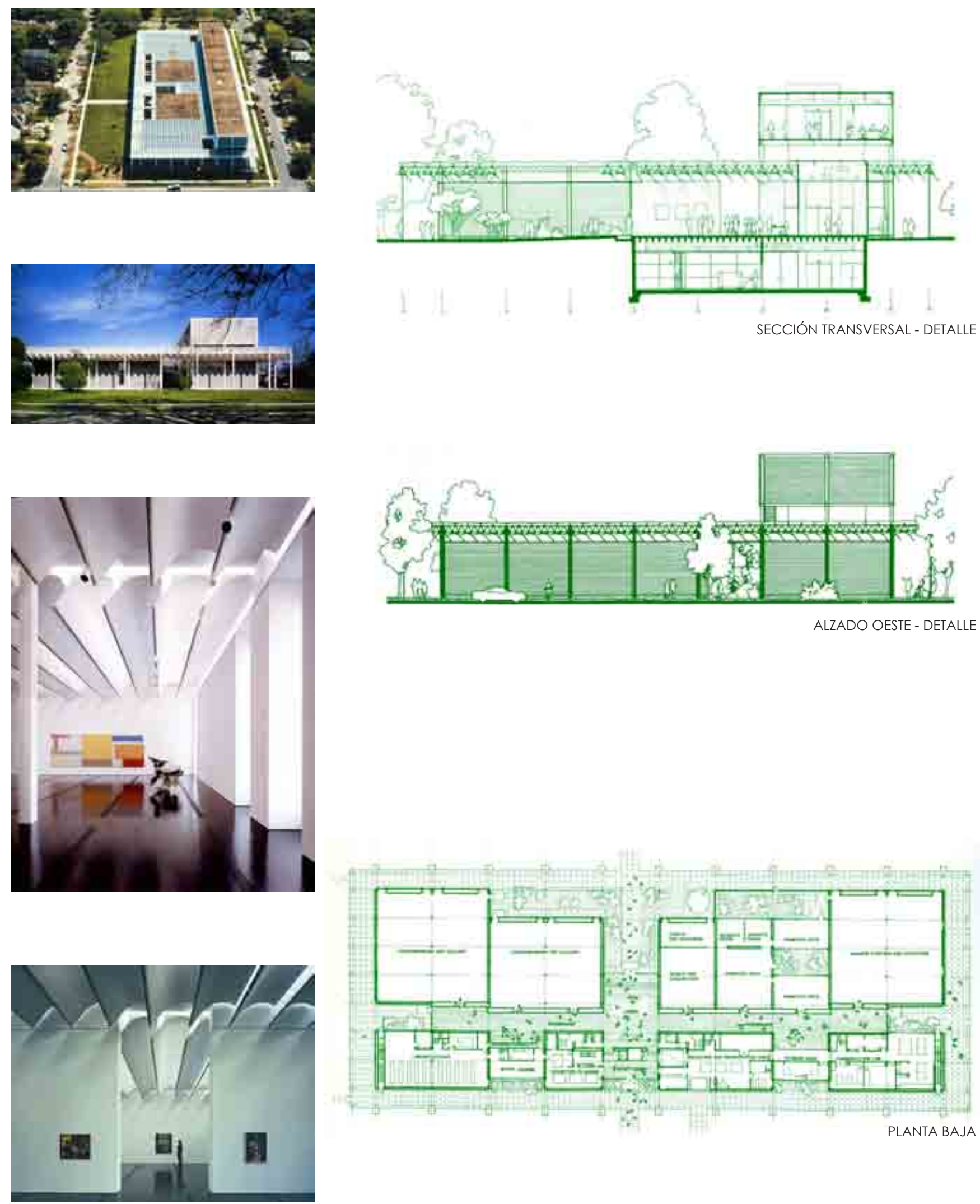

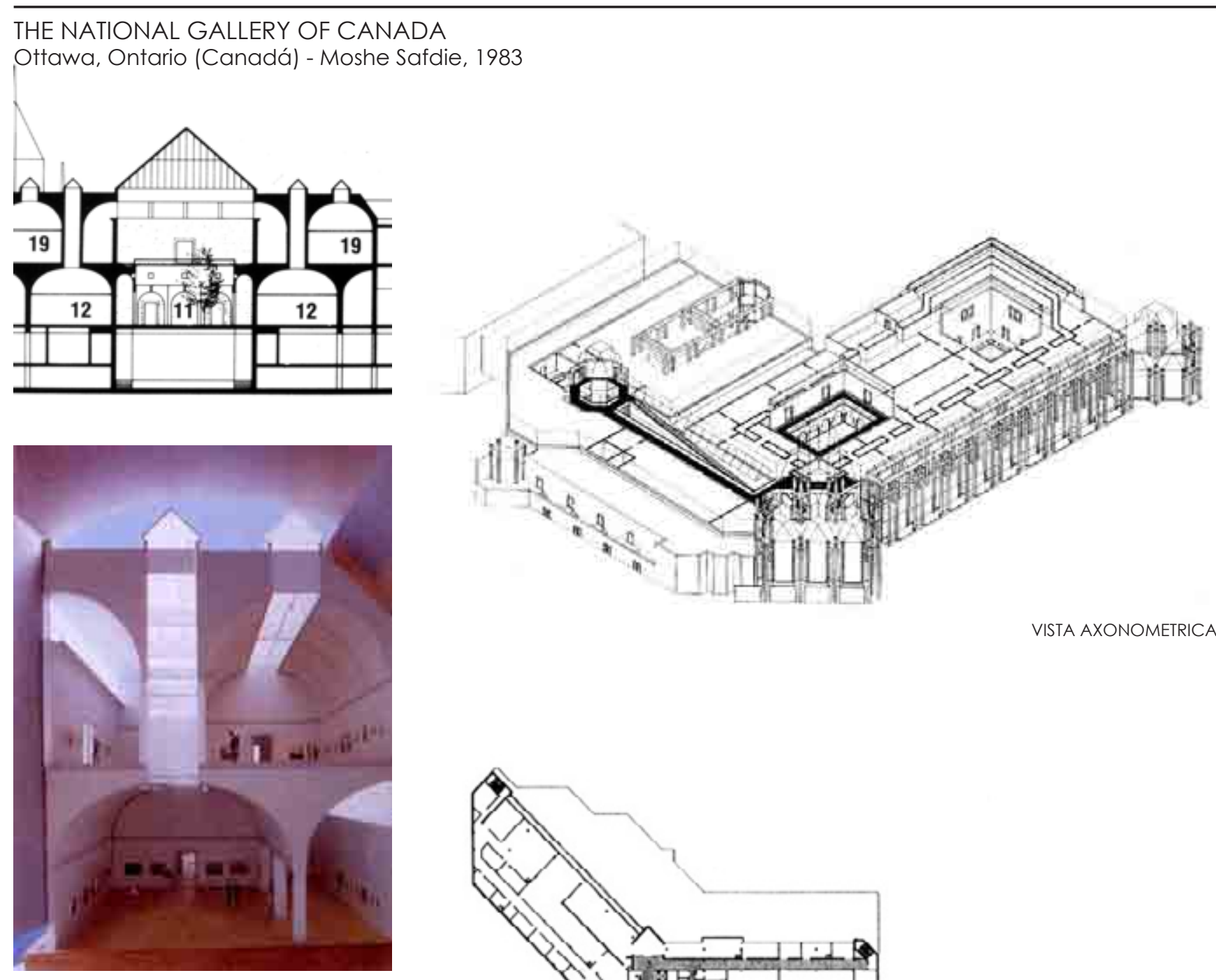

VISTA AXONOMETRICA
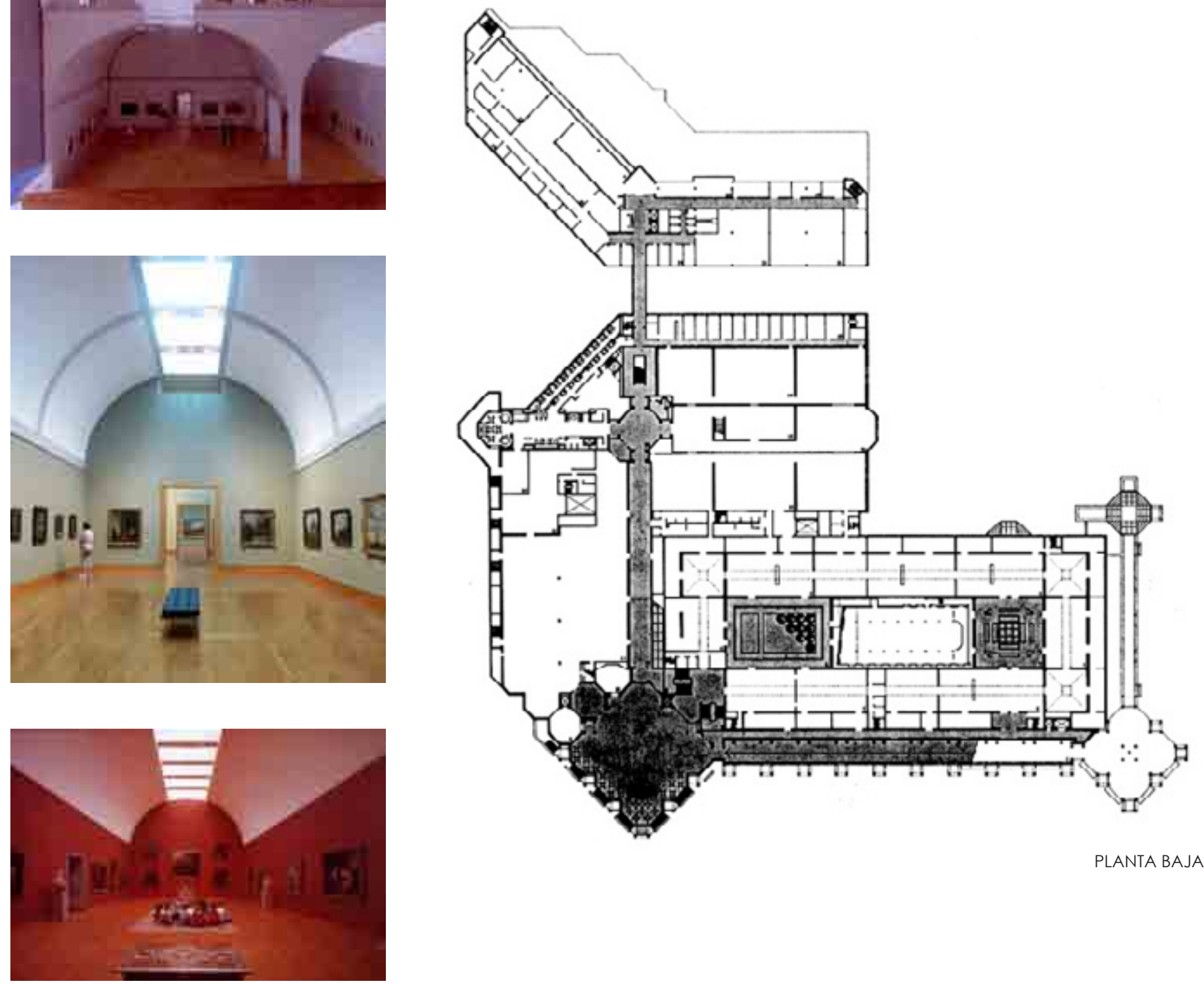
NEUE STAATSGALERIE

Stuttgart, Alemania - James Striling, 1984
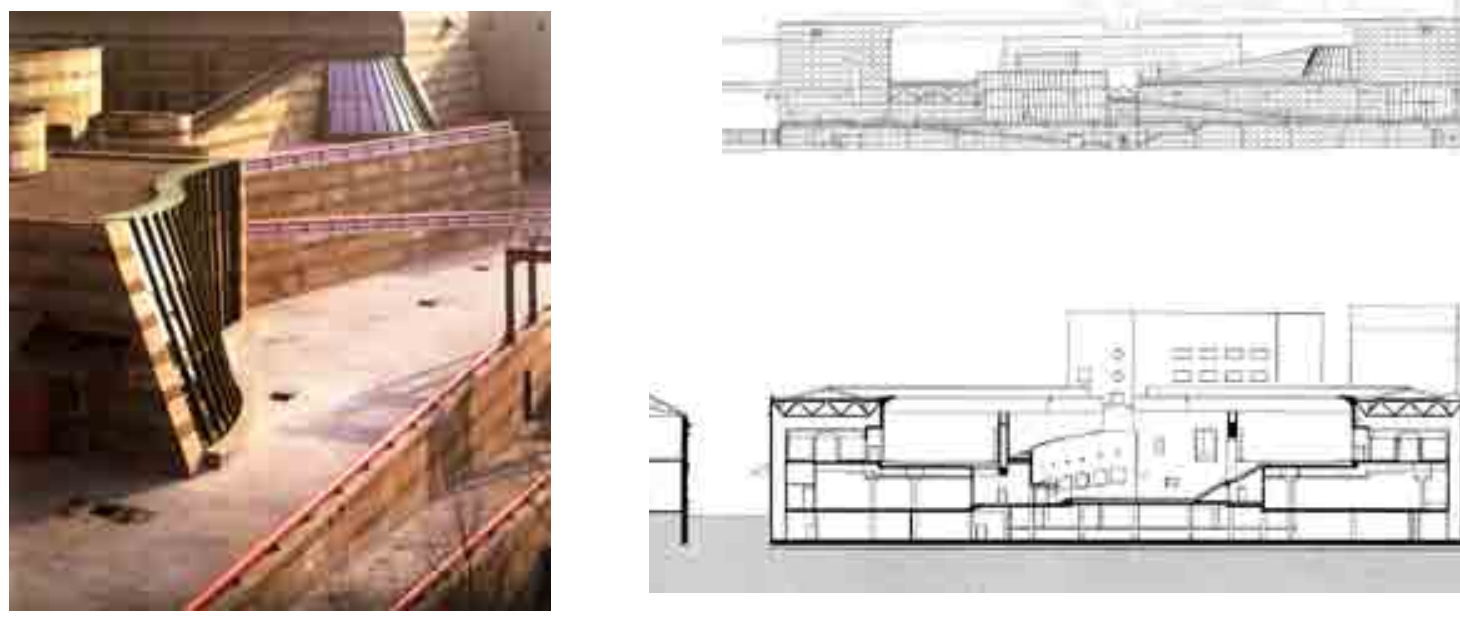

FACHADA PRINCIPAL

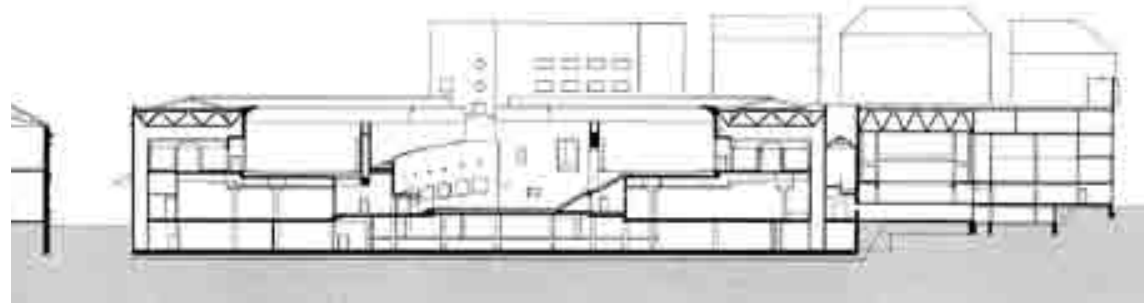

SECCIÓN LONGITUDINAL
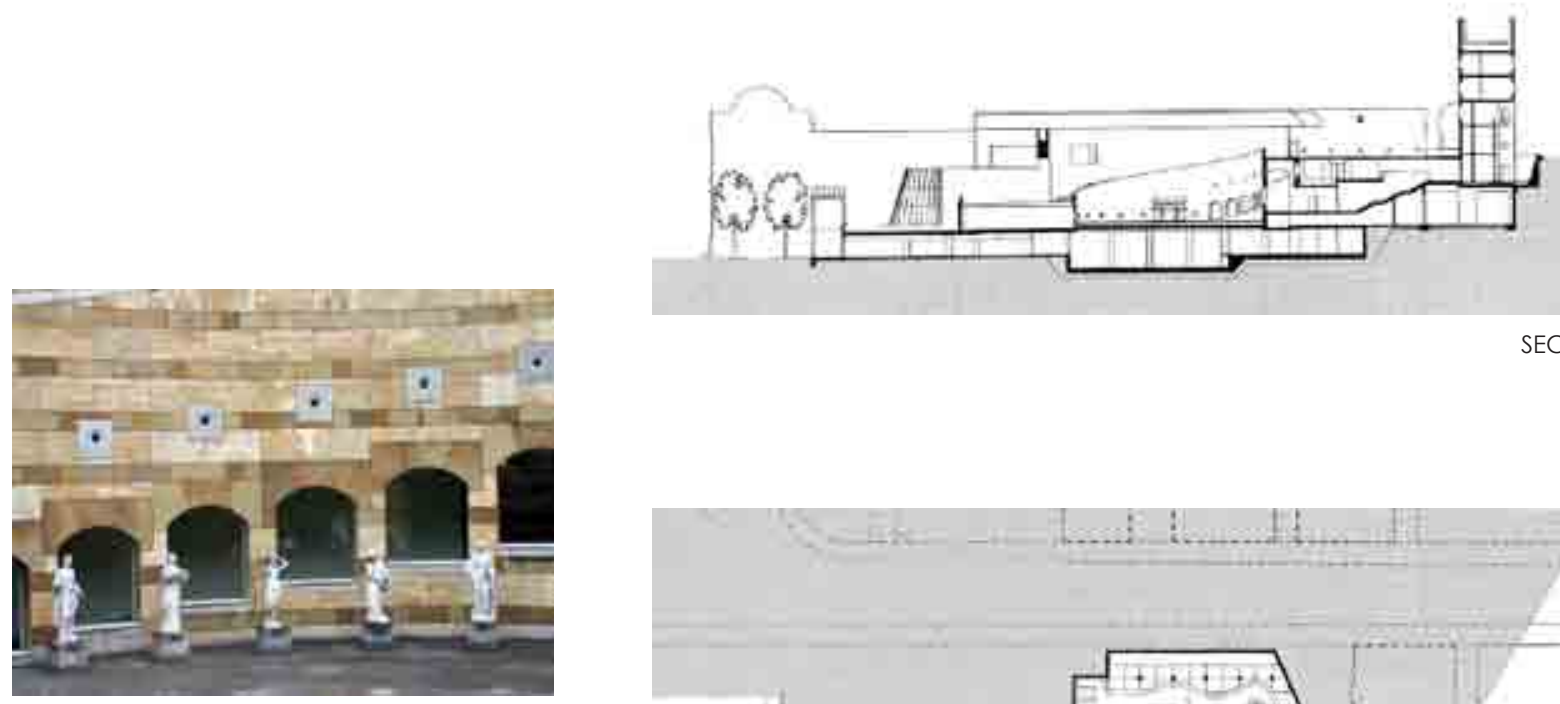

SECCIÓN TRANVERSAL
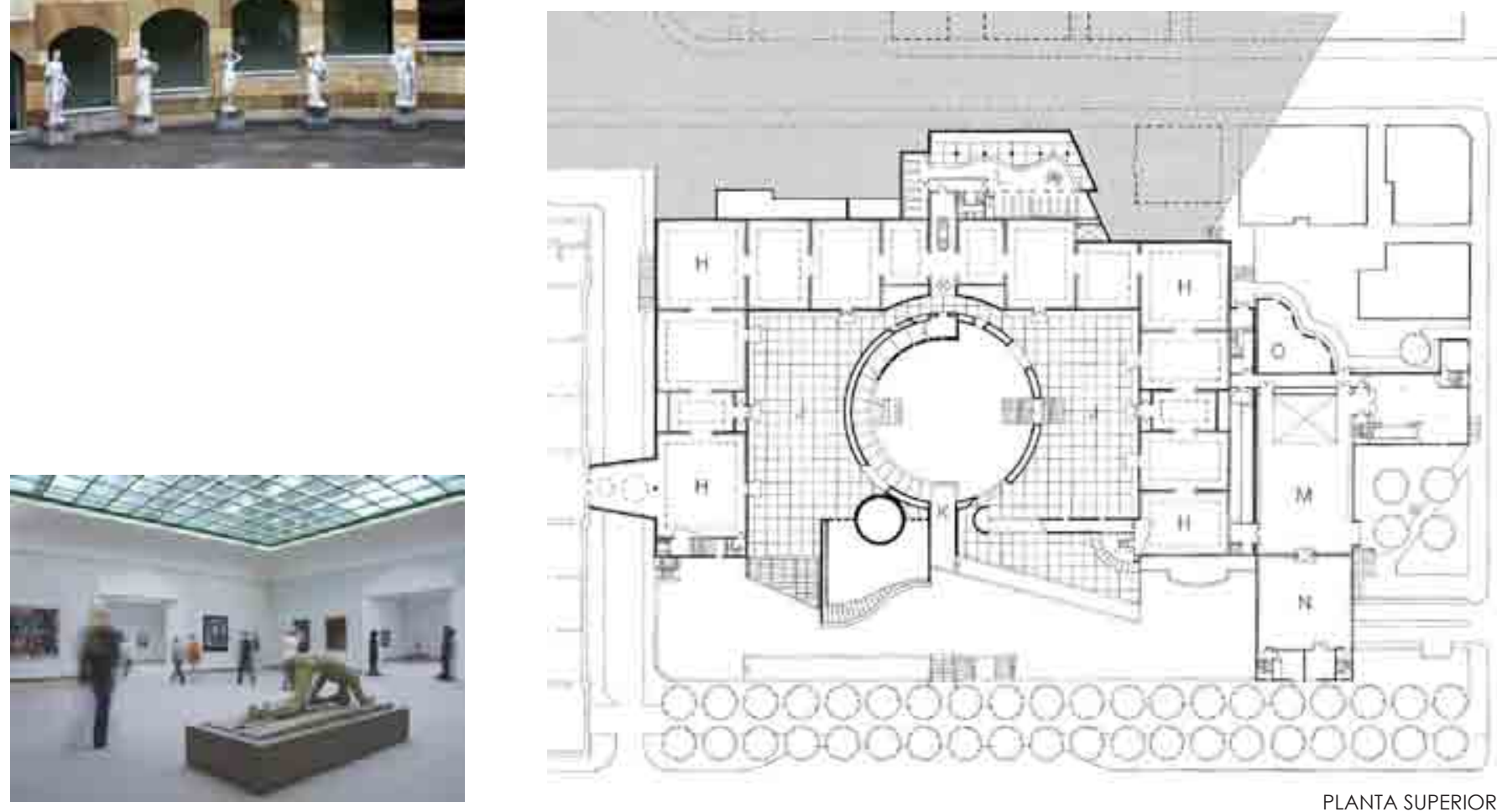

PLANTA SUPERIOR 
INSTITUT VALENCIÀ D'ART MODERN

Valencia, España - Emilio Giménez y Carlos Salvadores, 1986
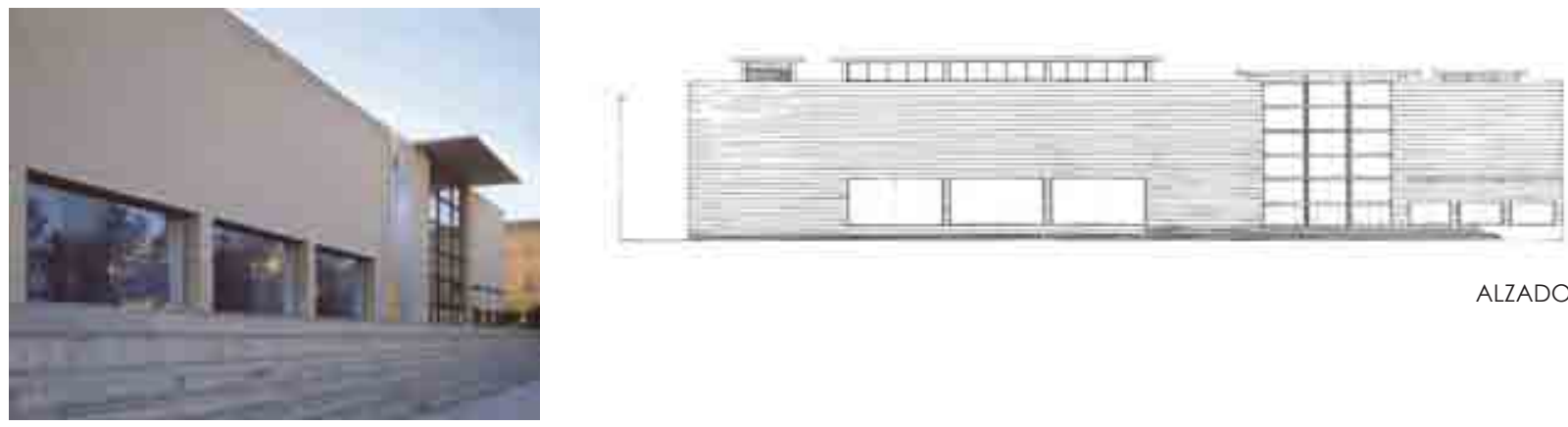

ALZADO PRINCIPAL
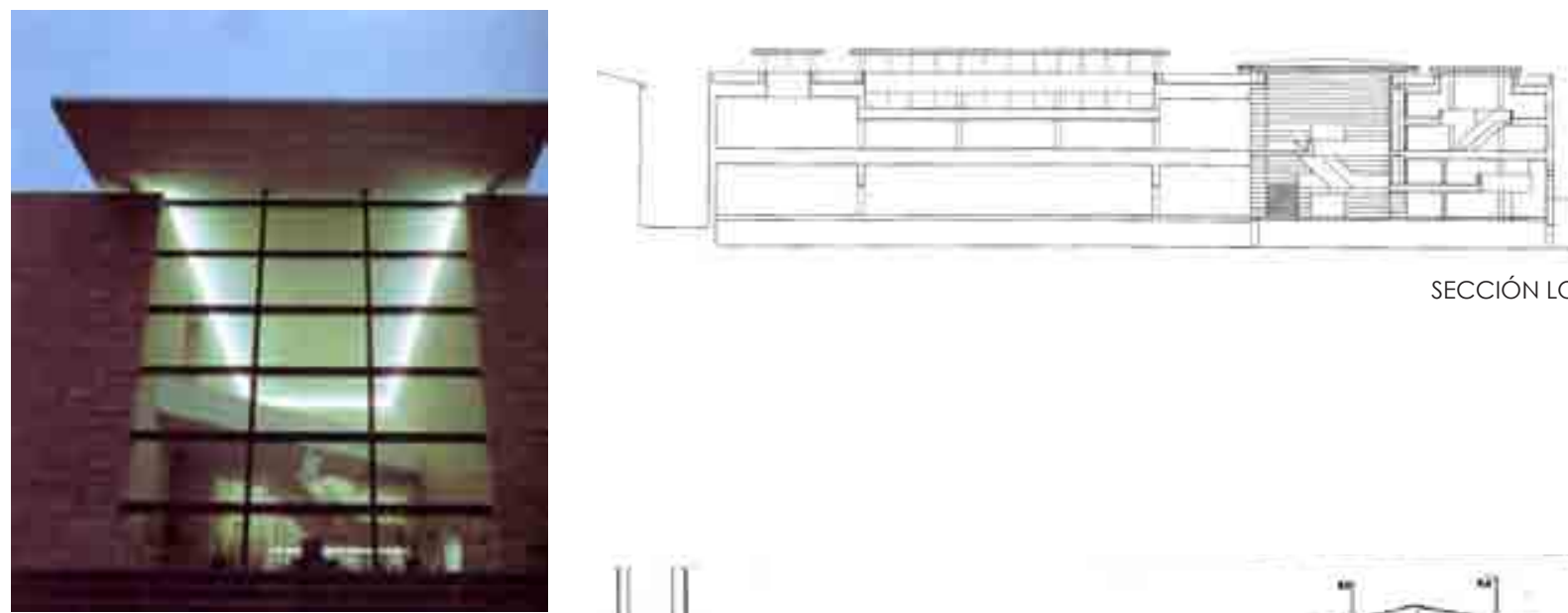

SECCIÓN LONGITUDINAL
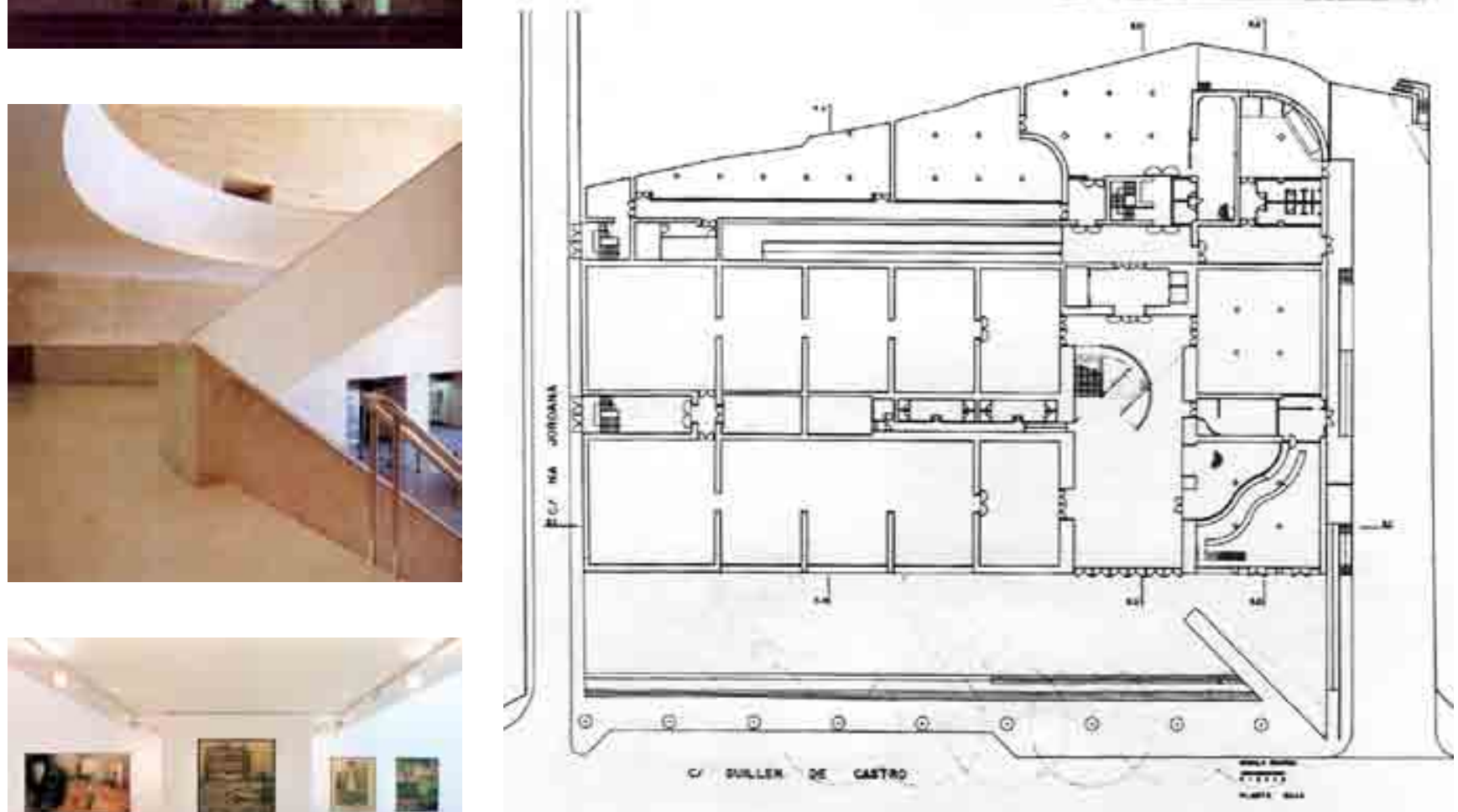

PLANTA BAJA - NIVEL DE ACCESO 

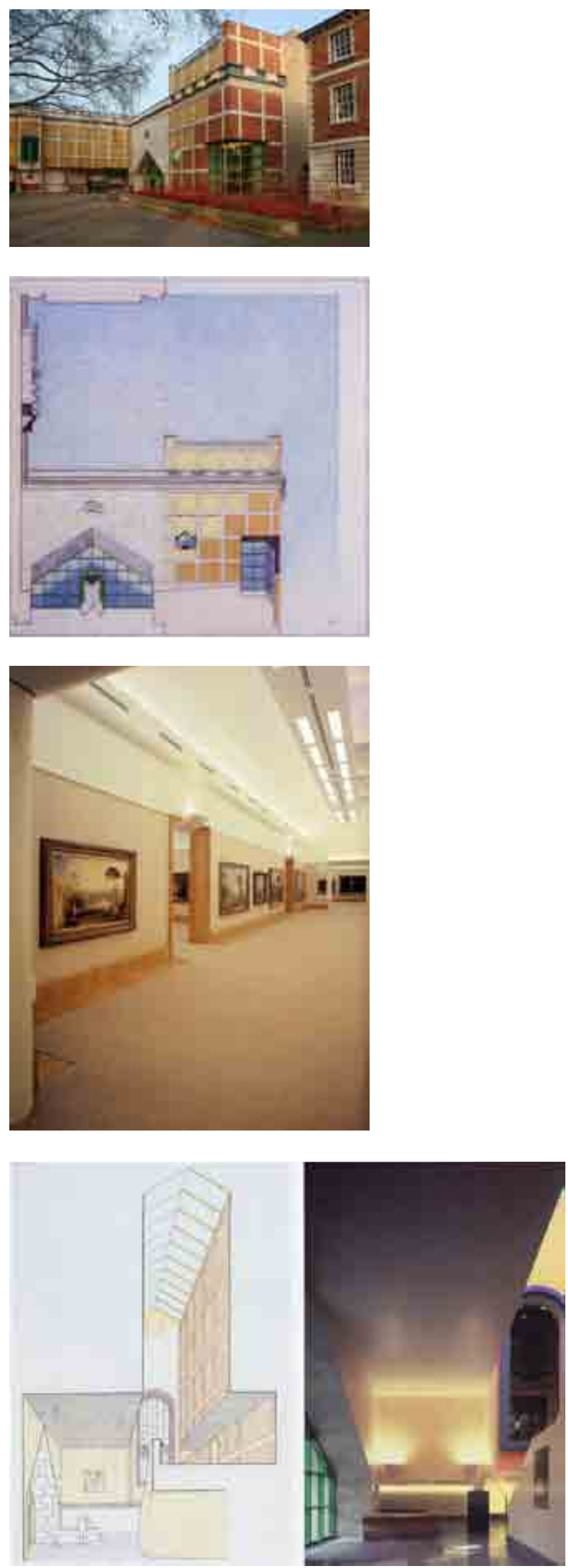
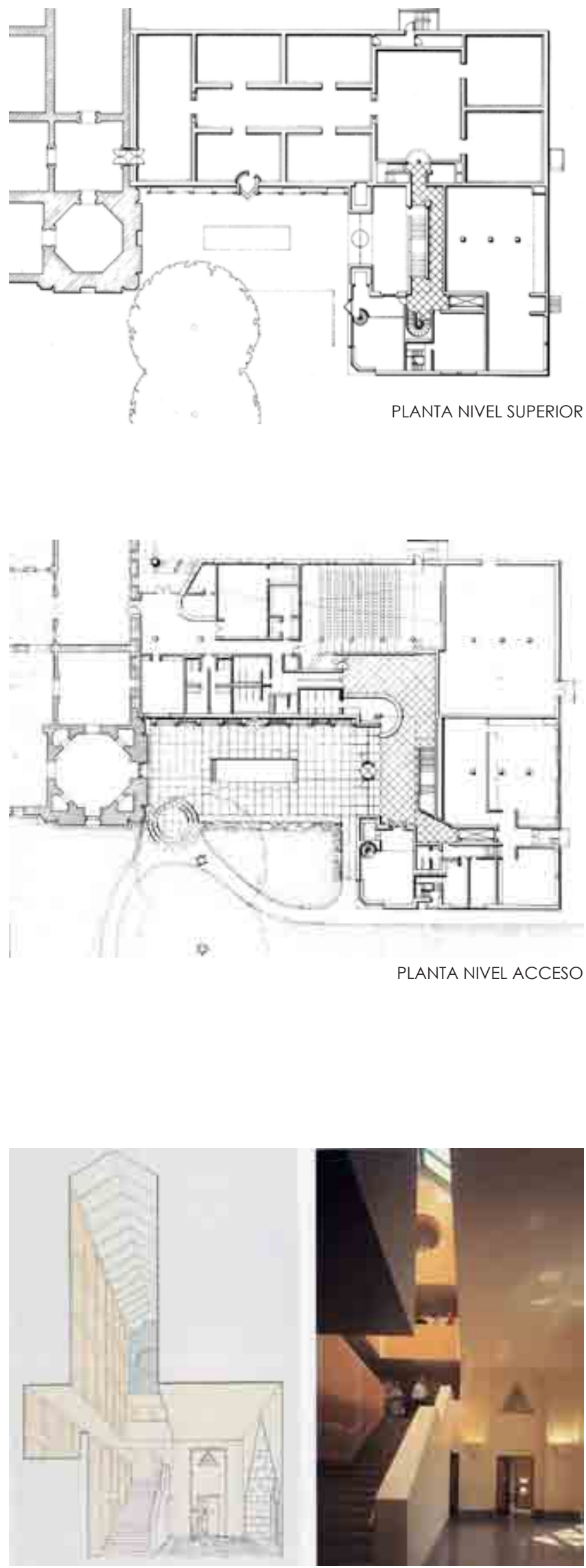
AMPLIACIÓN DE LA NATIONAL GALLERY - ALA SAINSBURY

Londres, Reino Unido - James Stirling, 1986
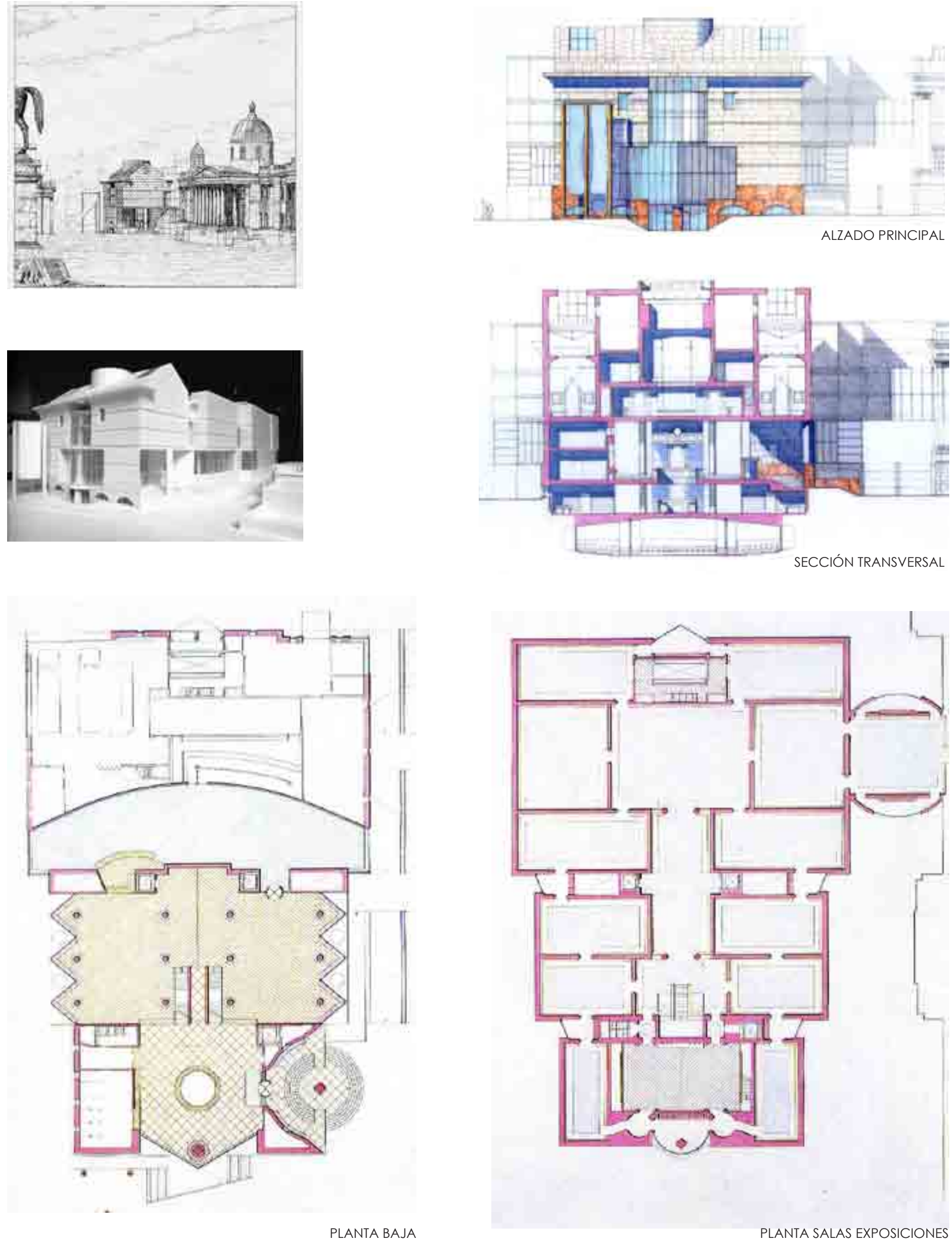
THYSSEN MUSEUM EN LUGANO Lugano, Suiza - James Stirling, 1986
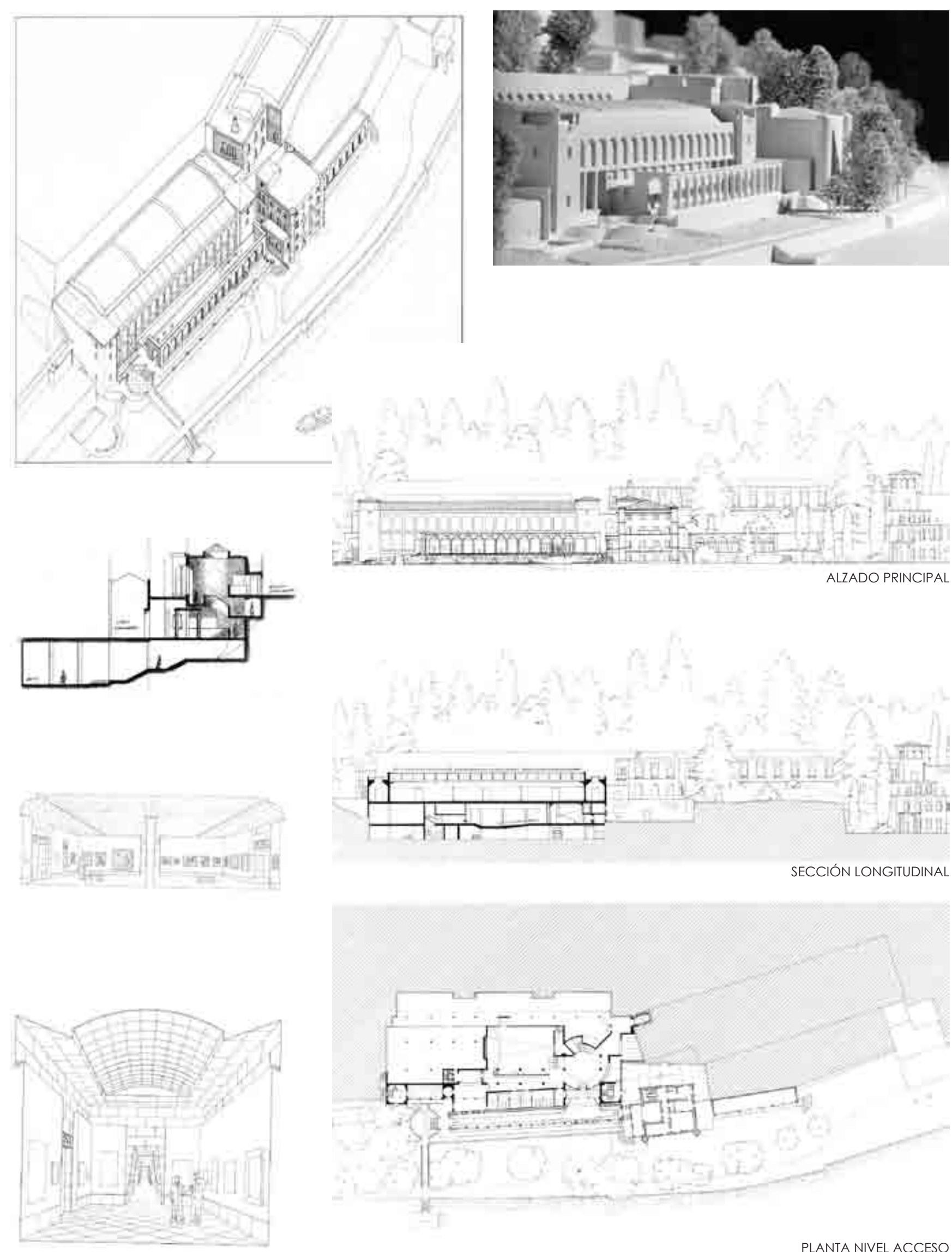
MUSEO DE ARTE CONTEMPORÁNEO (MACBA)

Barcelona, España - Richard Meier, 1987
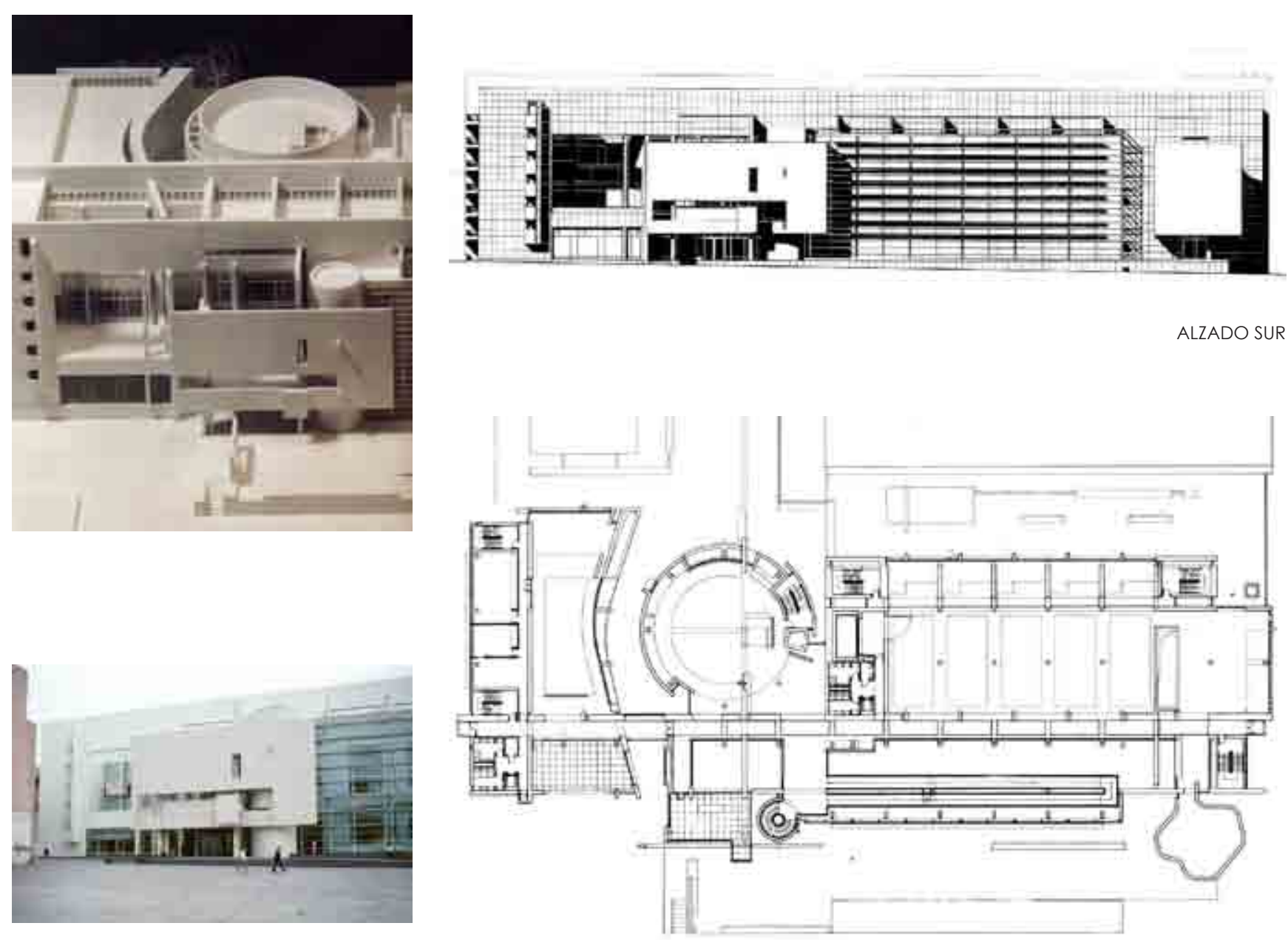

PLANTA PRIMERA
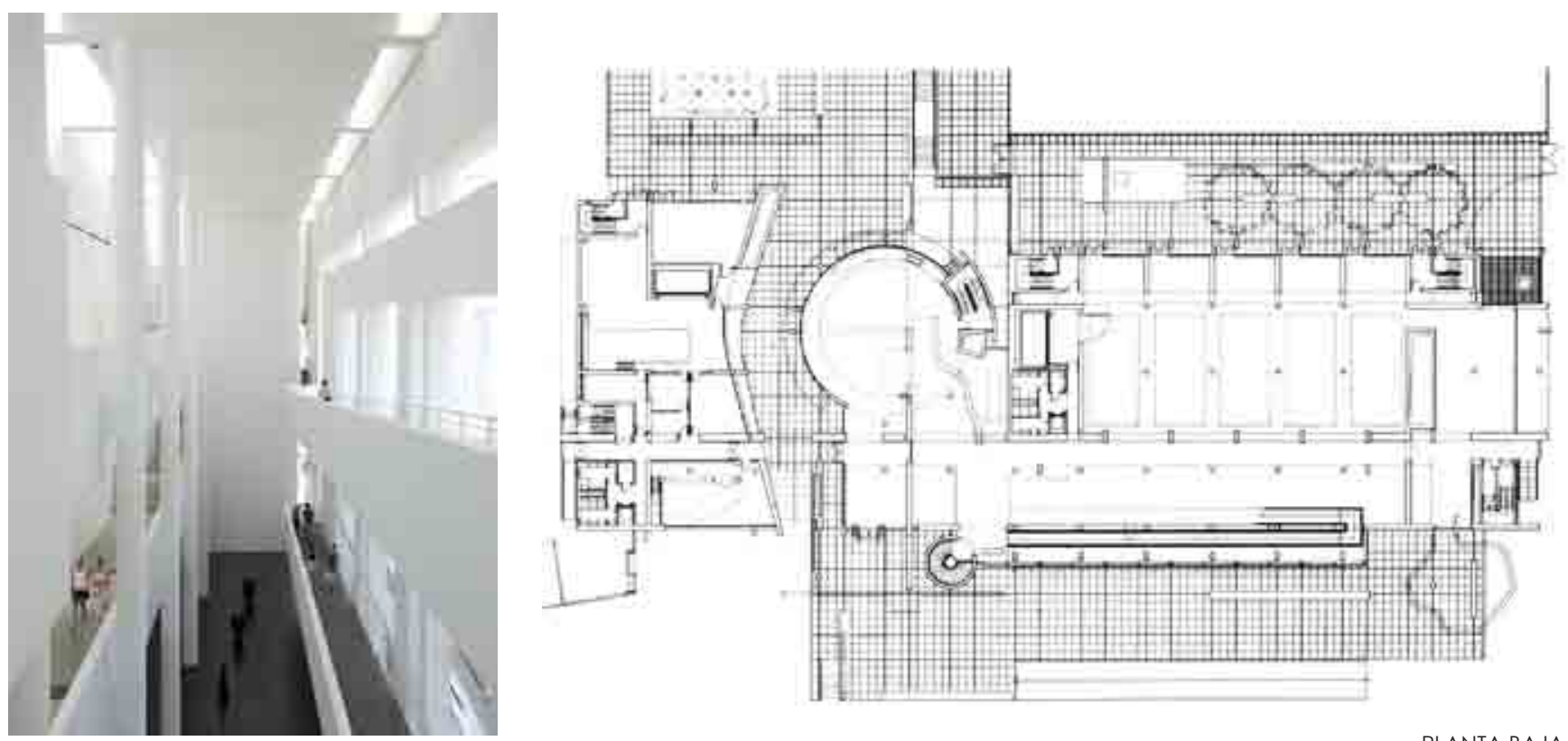

PLANTA BAJA 
MUSEO DE BELLAS ARTES DE CORUÑA La Coruña, España - Manuel Gallego, 1988
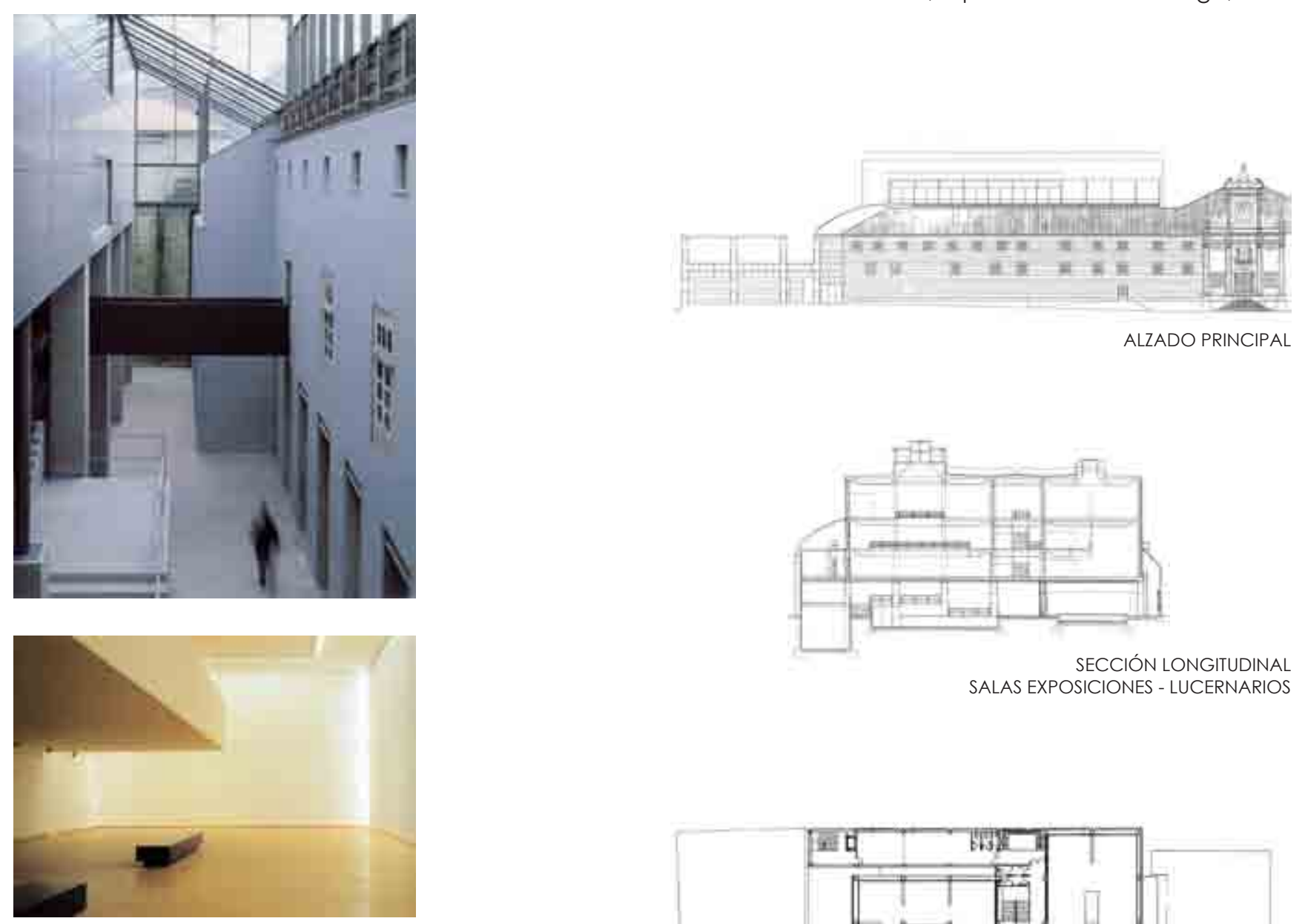

SECCIÓN LONGITUDINAL SALAS EXPOSICIONES - LUCERNARIOS
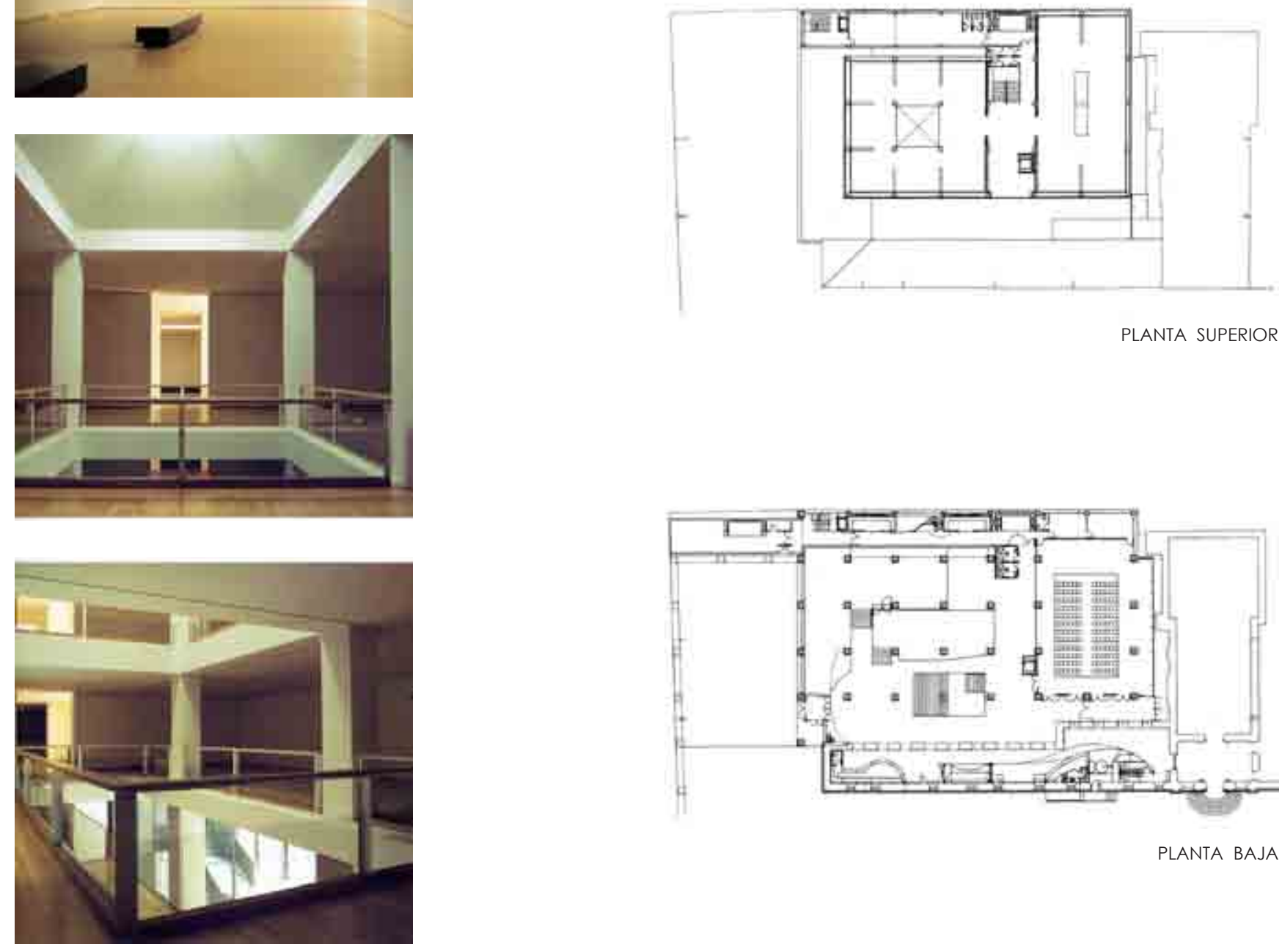
CENTRO GALLEGO DE ARTE CONTEMPORÁNEO

Santiago de Compostela, España - Álvaro Siza, 1988
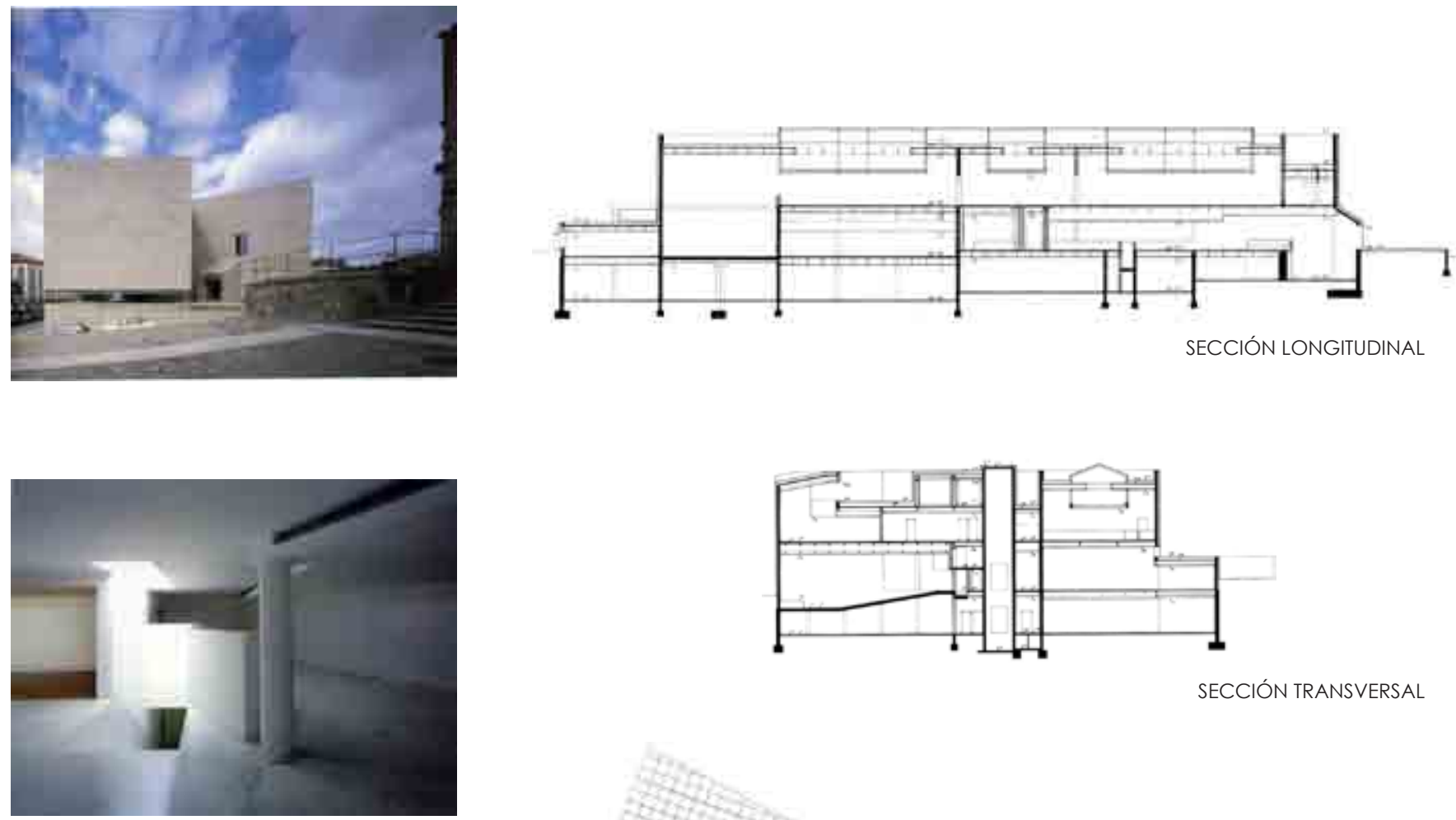

SECCIÓN TRANSVERSAL
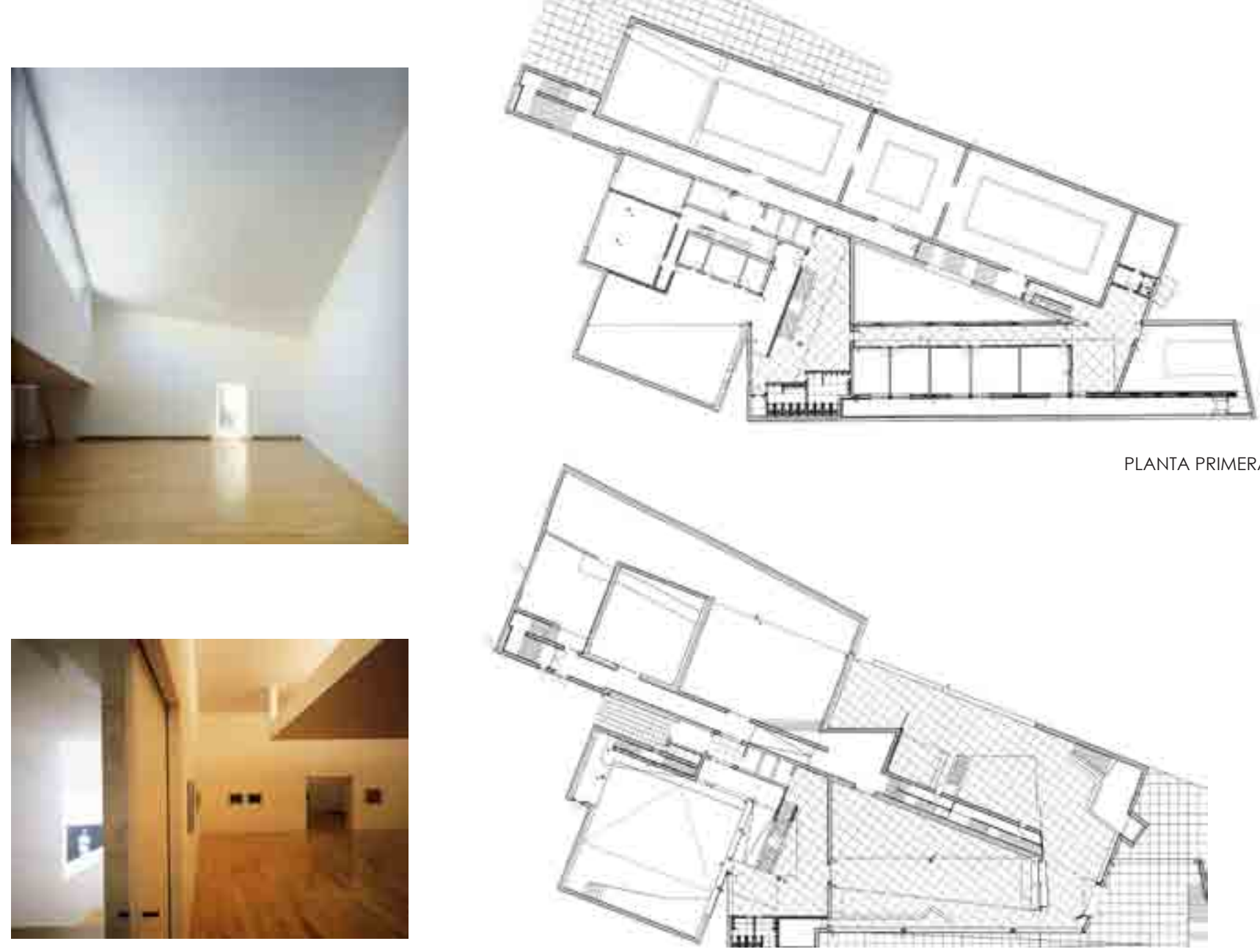

PLANTA BAJA 
GOETZ ART GALLERY

Munich, Alemania - Herzog \& De Meuron, 1989
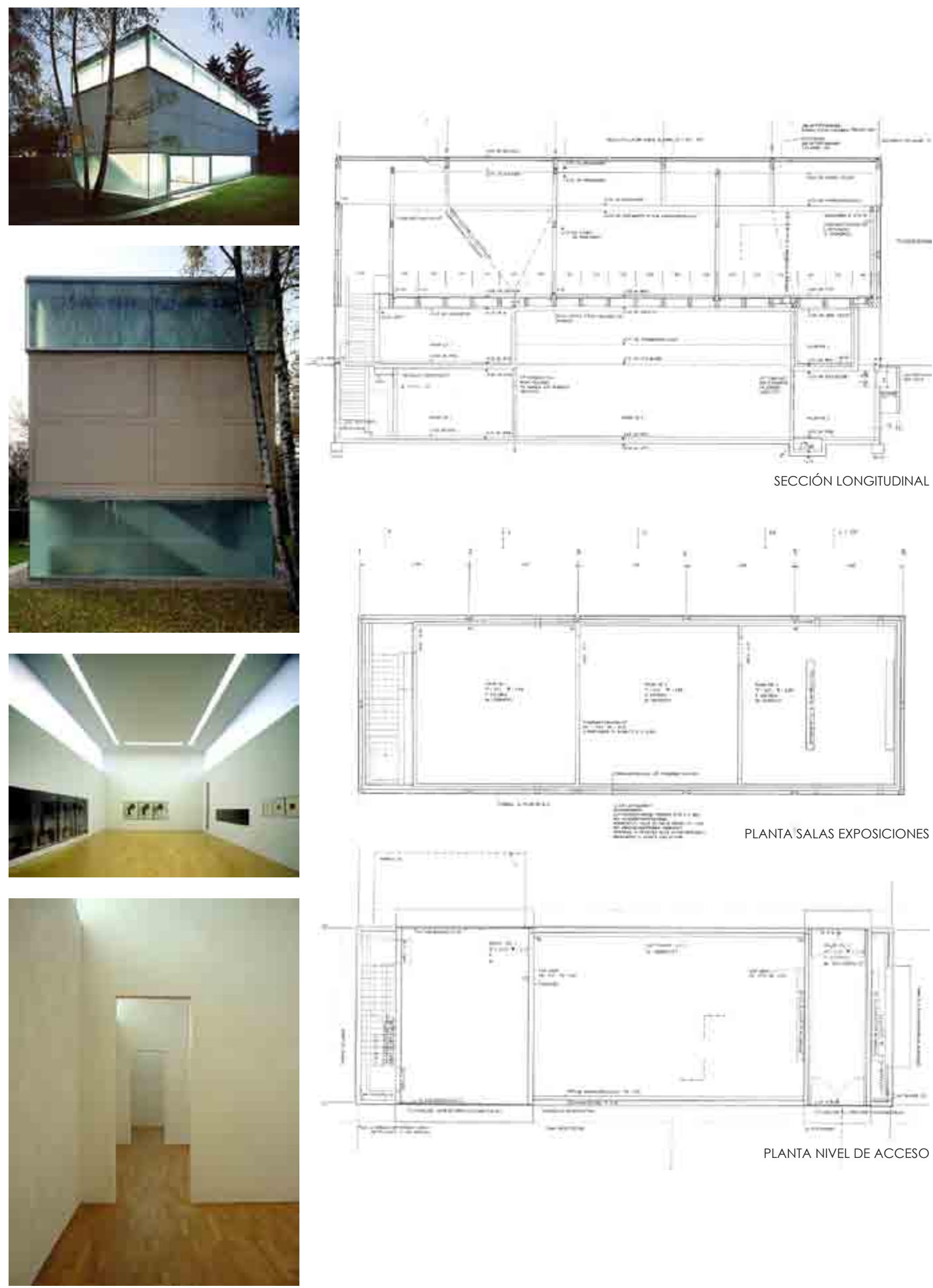

PLANTA SALAS EXPOSICIONES

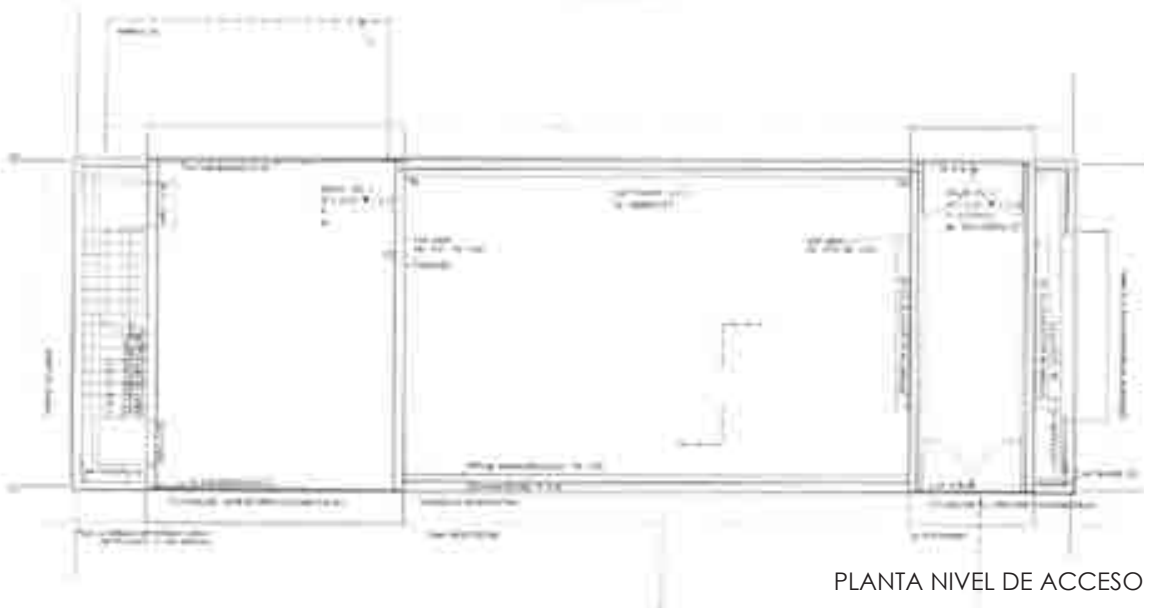


MUSEO KIRCHNER EN DAVOS

Davos, Suiza - Gigon \& Guyer, 1989
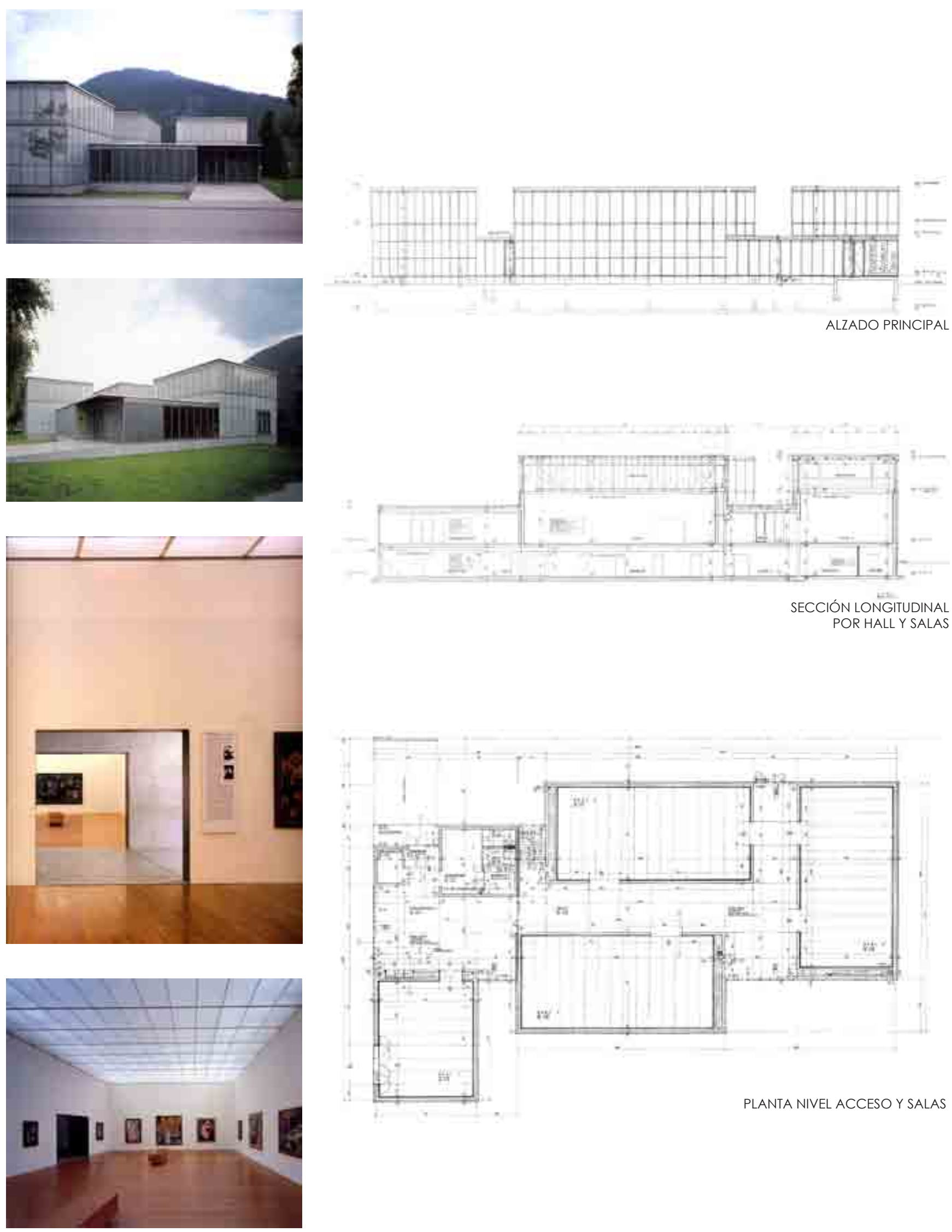
MUSEO DE ARTE BREGENZ

Bregenz, Austria - Peter Zumthor, 1990
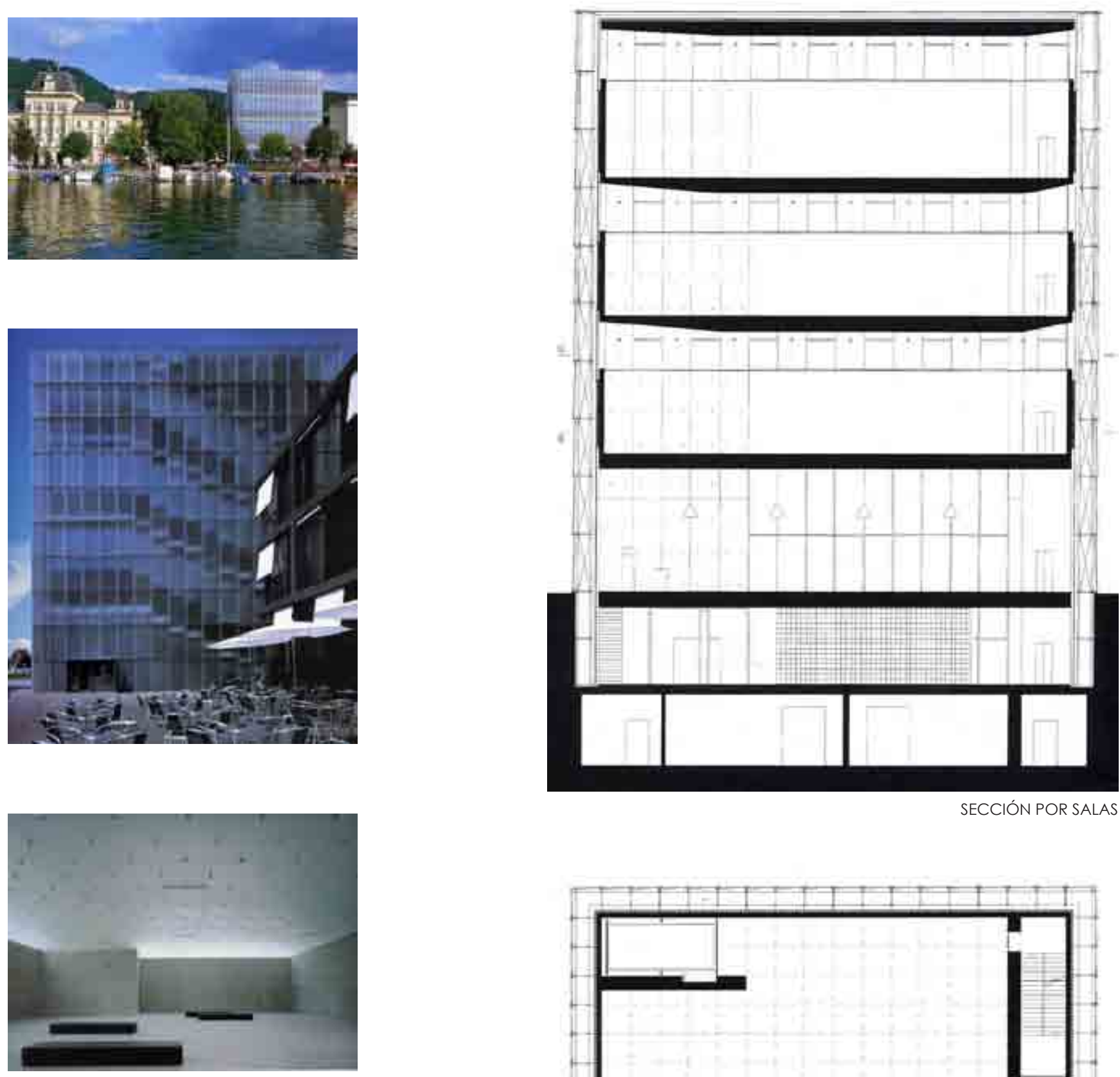

SECCIÓN POR SALAS
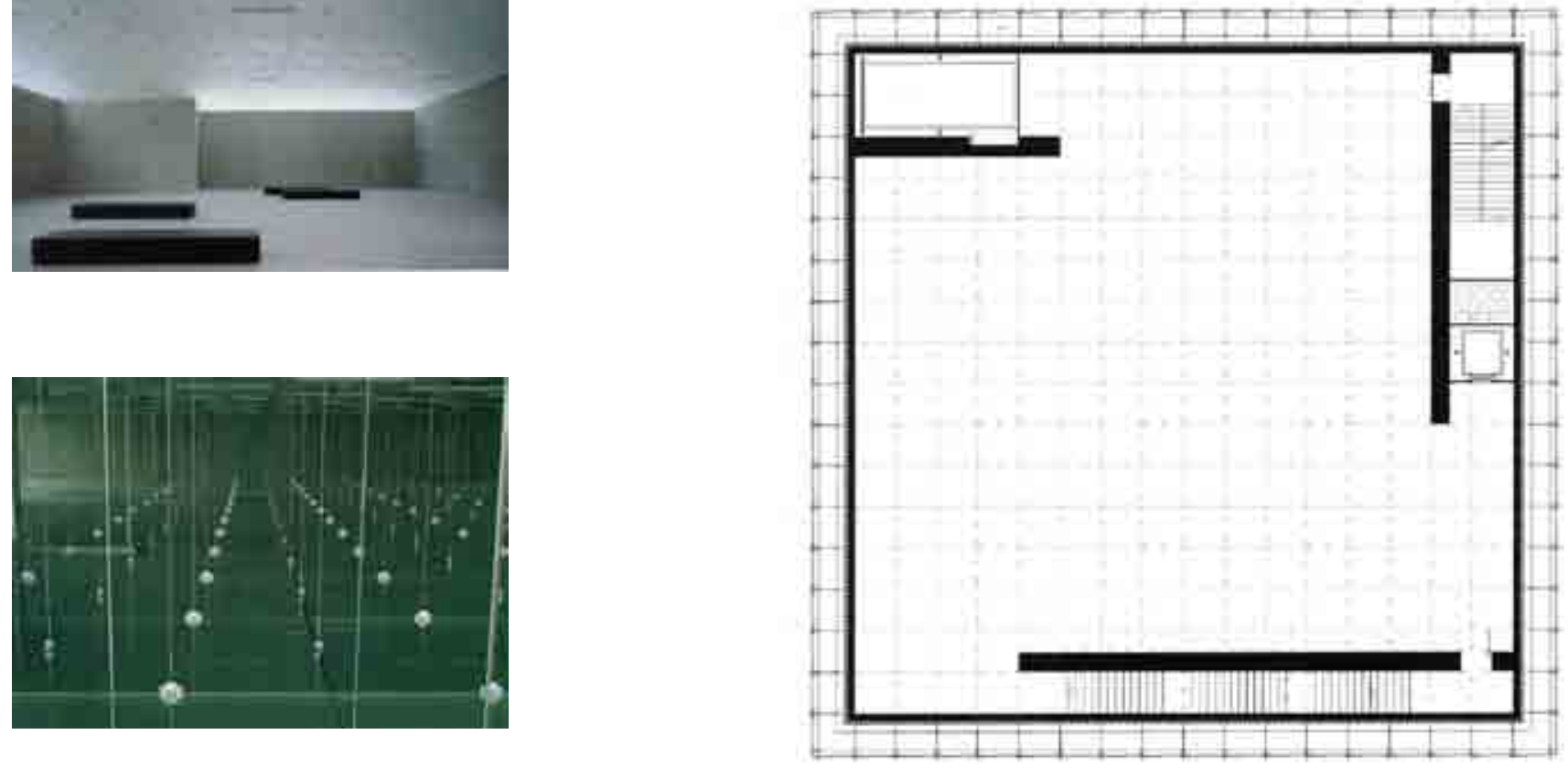

PLANTA NIVELES 1-3 - SALAS DE EXPOSICIONES 
MUSEO DEL BOSQUE DE LAS TUMBAS

Kumamoto, Japón - Tadao Ando, 1990
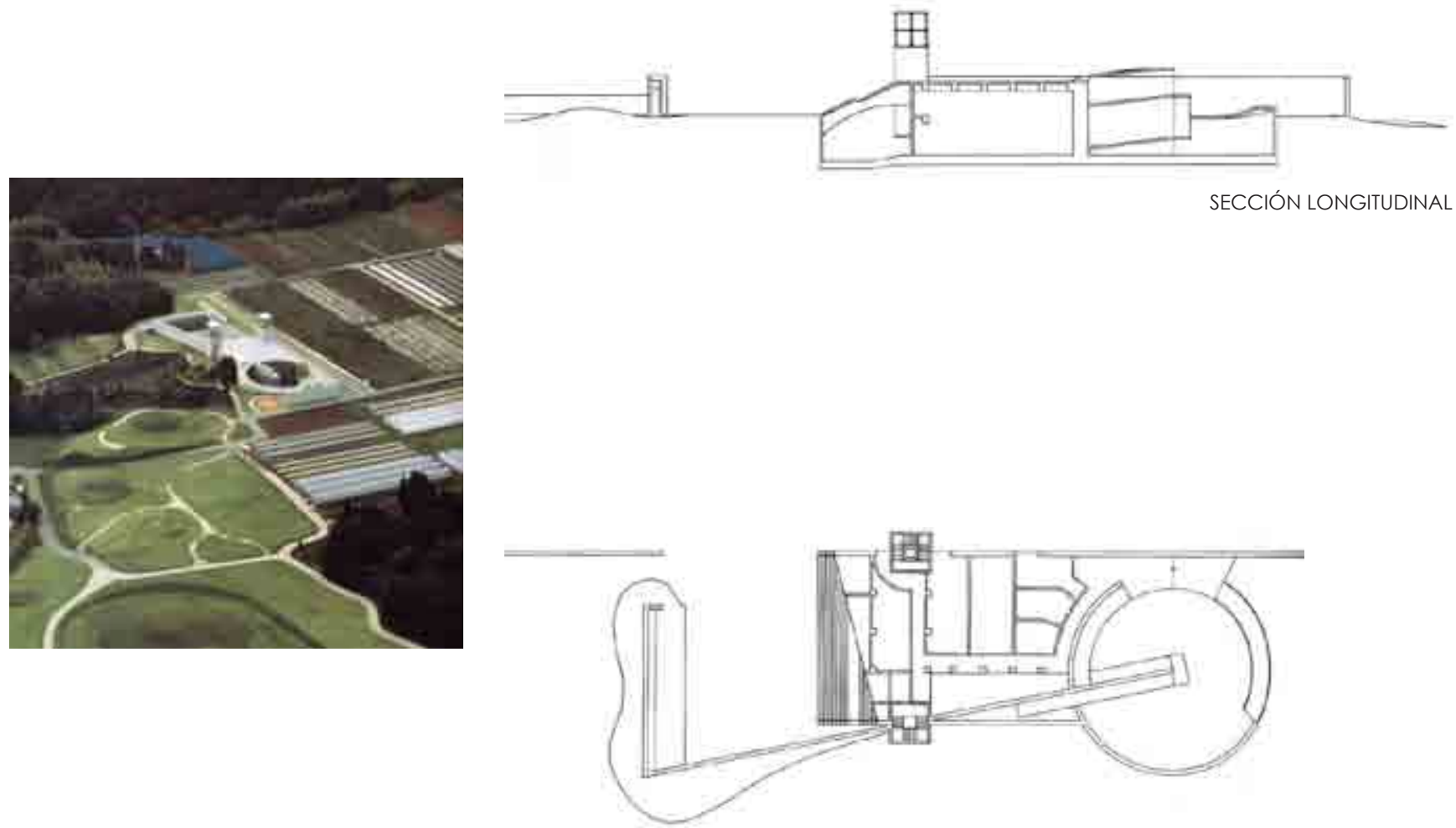

PLANTA NIVEL INFERIOR
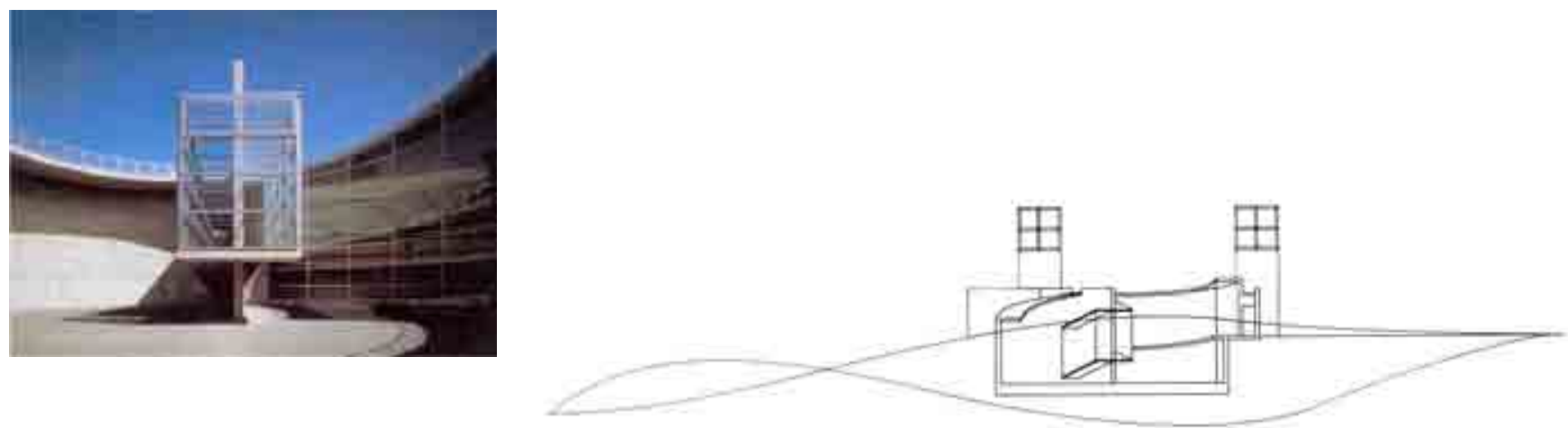

SECCIÓN TRANSVERSAL 
SEATTLE ART MUSEUM

Seattle, Washington, (USA) - Robert Venturi, 1990
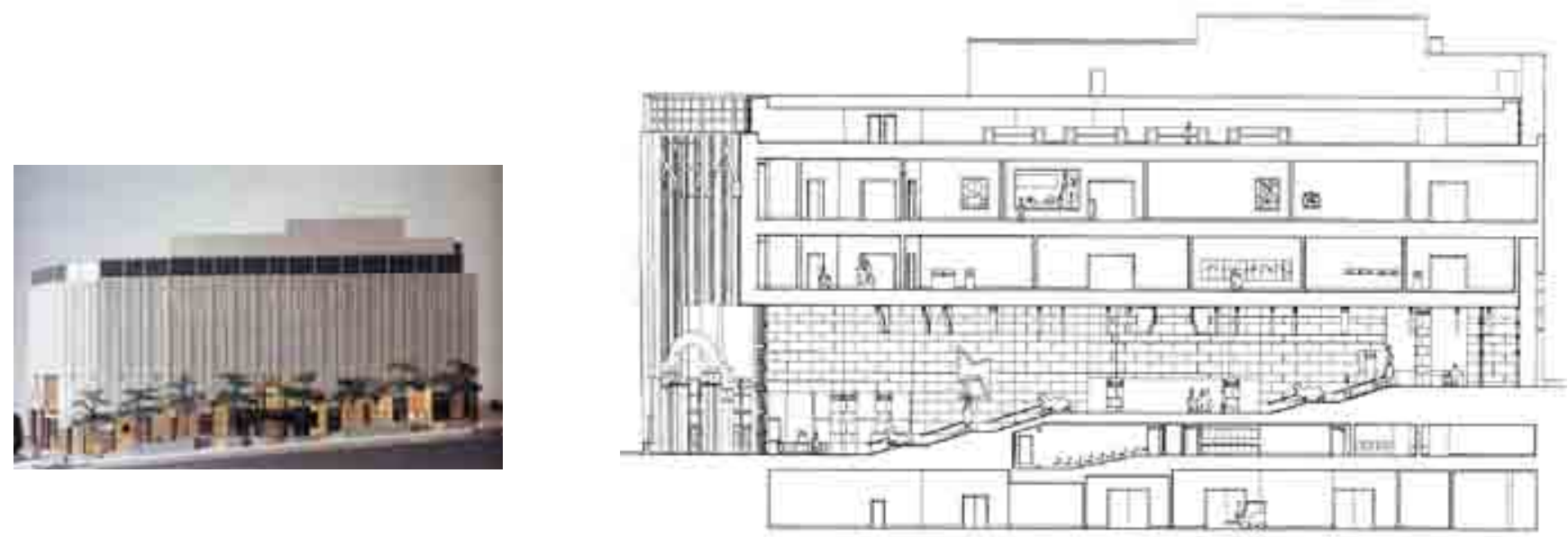

SECCIÓN POR ESCLAERA
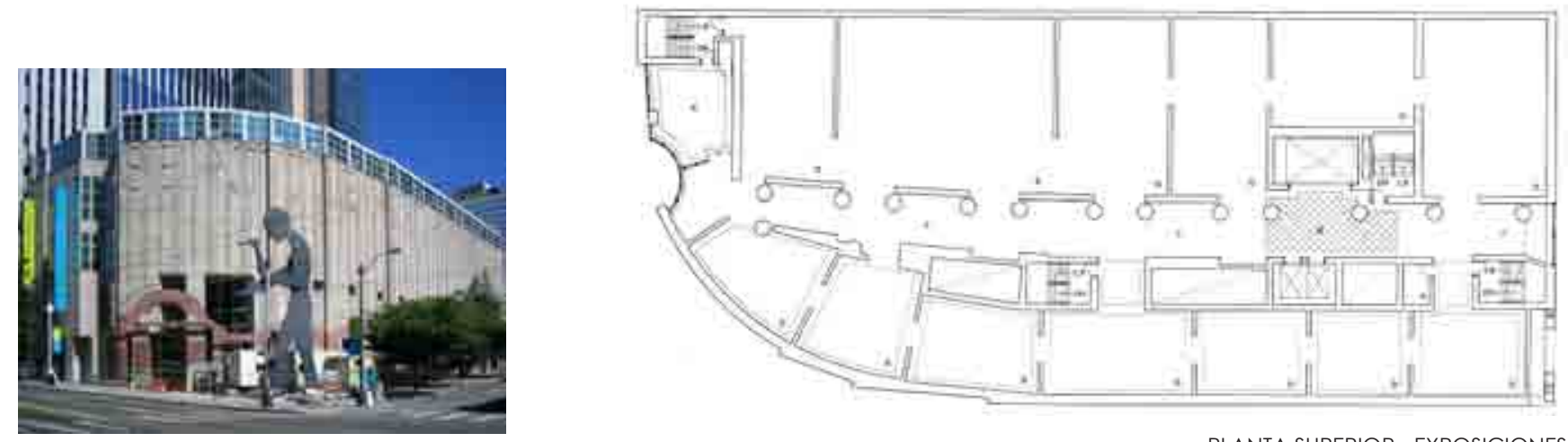

PLANTA SUPERIOR - EXPOSICIONES
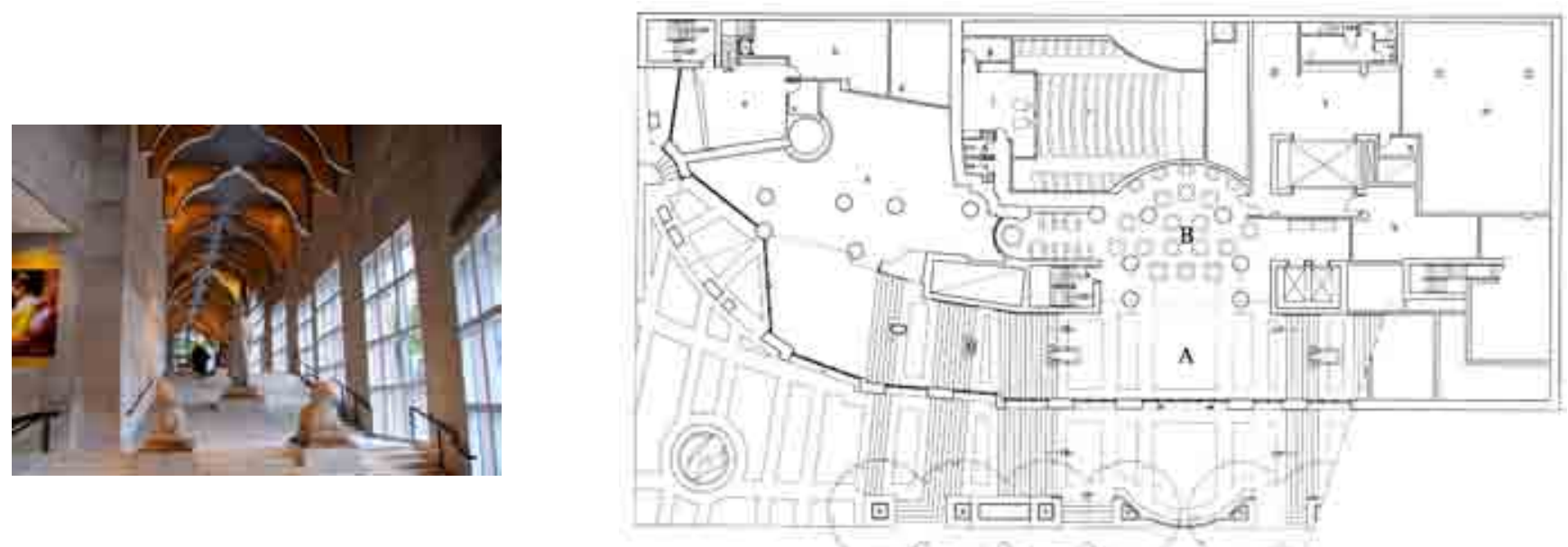

PLANTA BAJA - ACCESO 
MUSEO DE ARTE MODERNO DE ESTOCOLMO

Estocolmo, Suecia - Rafael Moneo, 1991
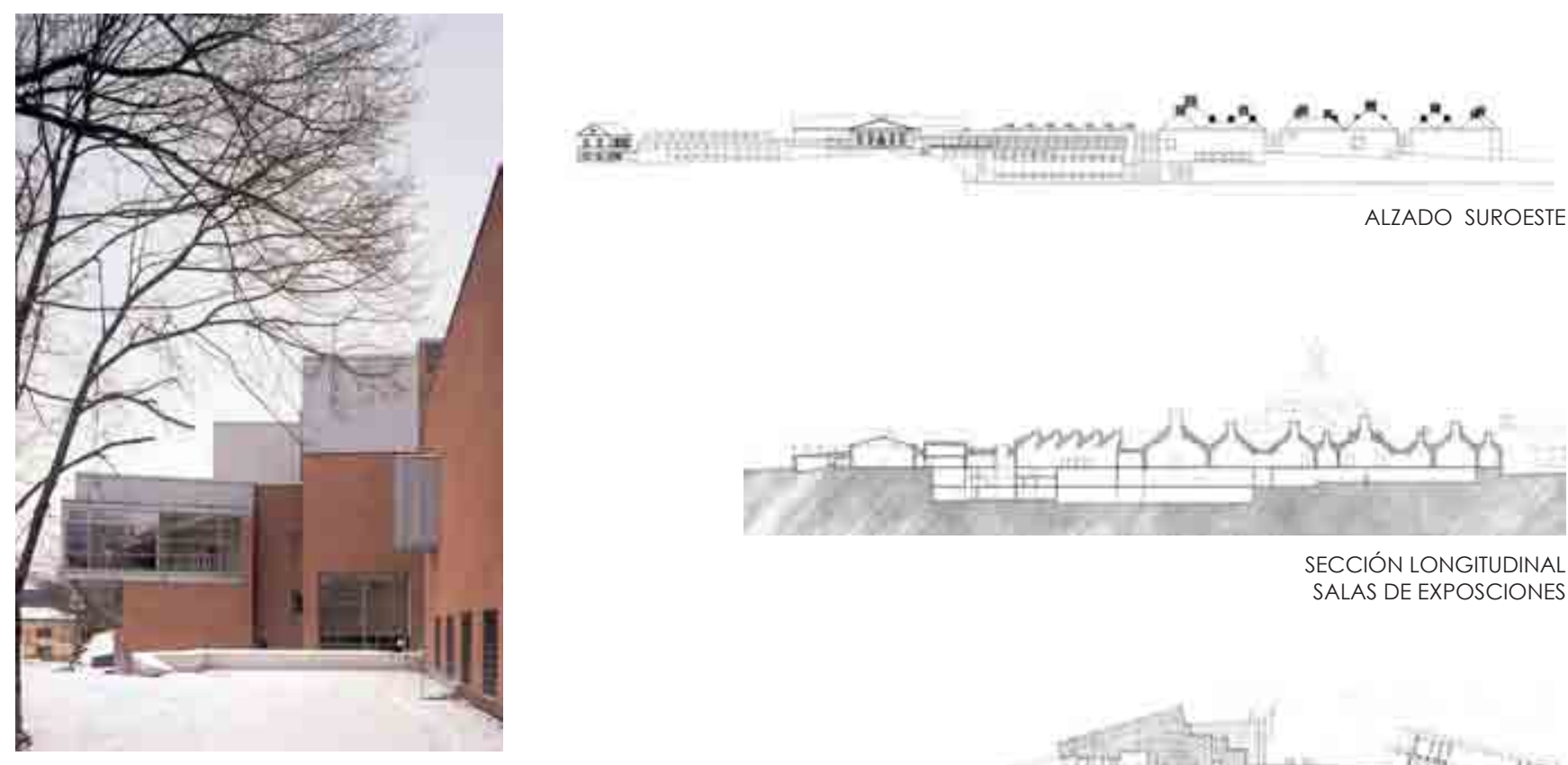

ALZADO SUROESTE

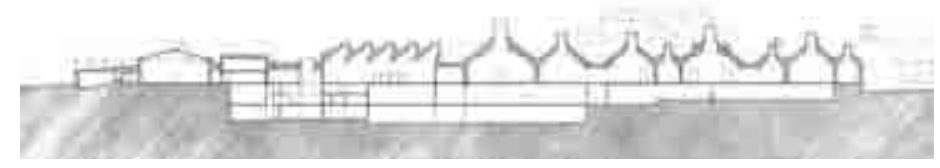

SECCIÓN LONGITUDINAL SALAS DE EXPOSCIONES
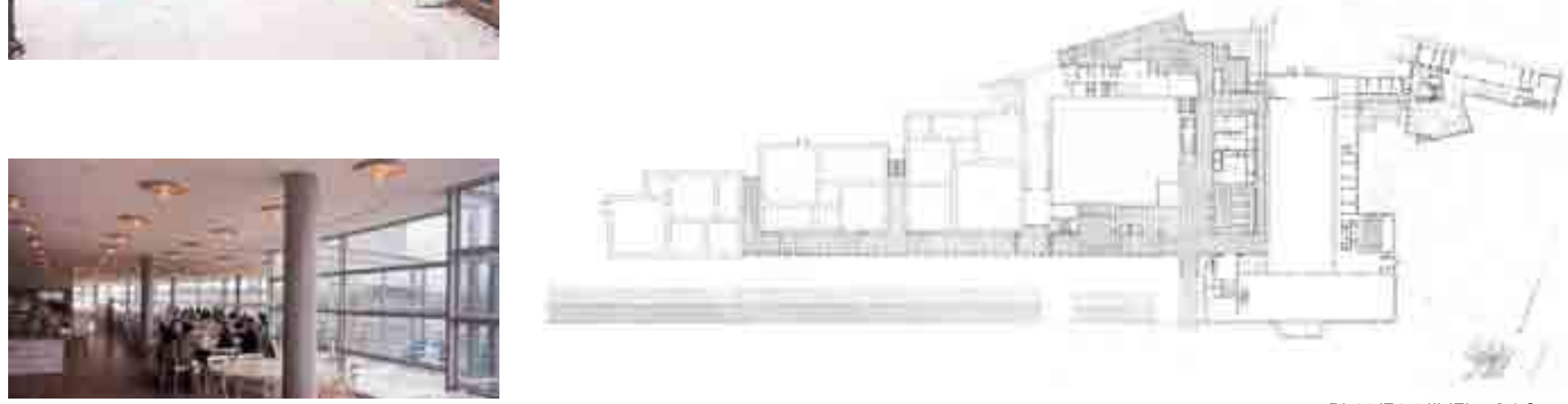

PLANTA NIVEL +14.3 m. ACCESO Y SALAS DE EXPOSICIONES
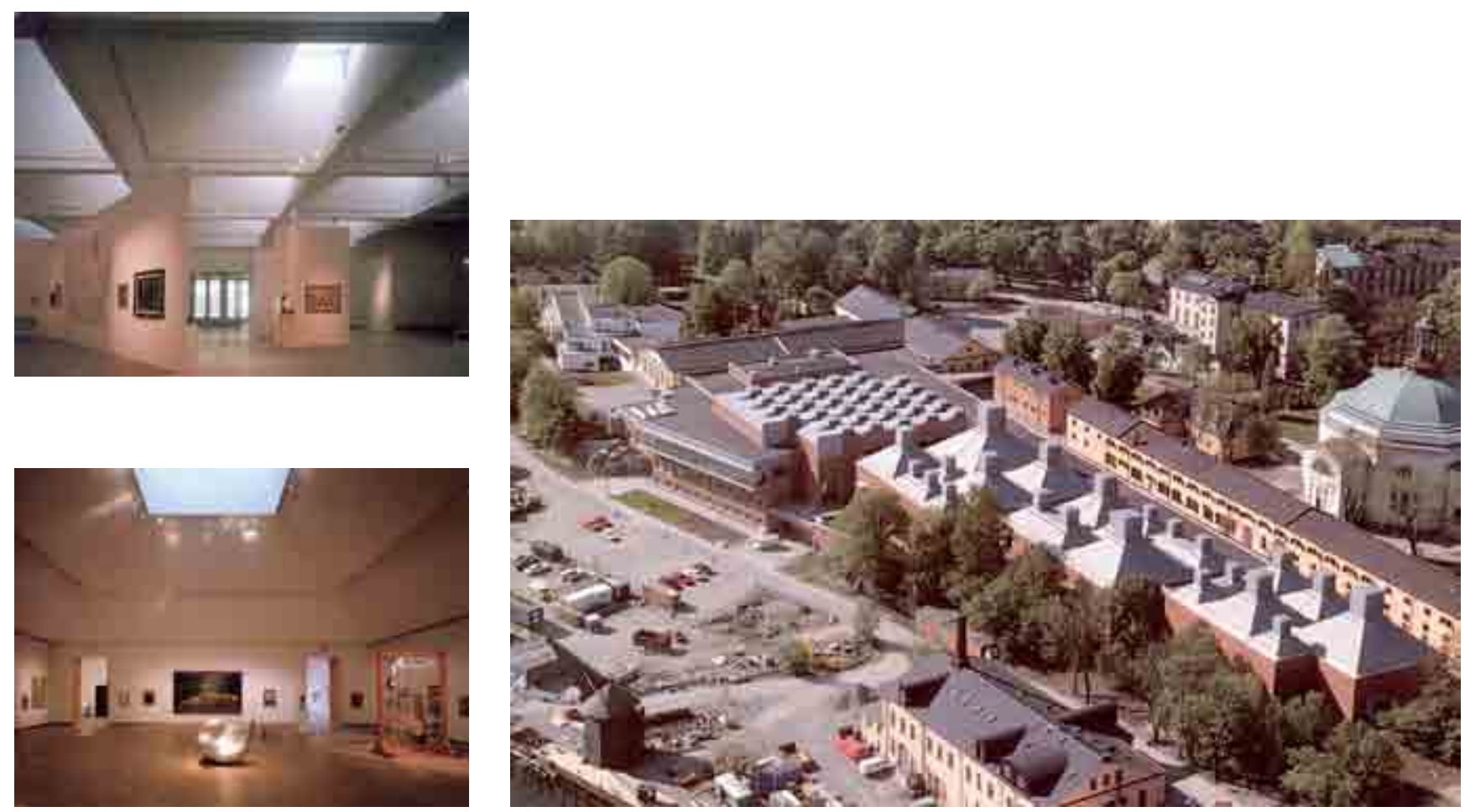
AMPLIACIÓN DE LA NATIONAL GALLERY - ALA SAINSBURY

Londres, Reino Unido - Venturi \& Scott Brown, 1991
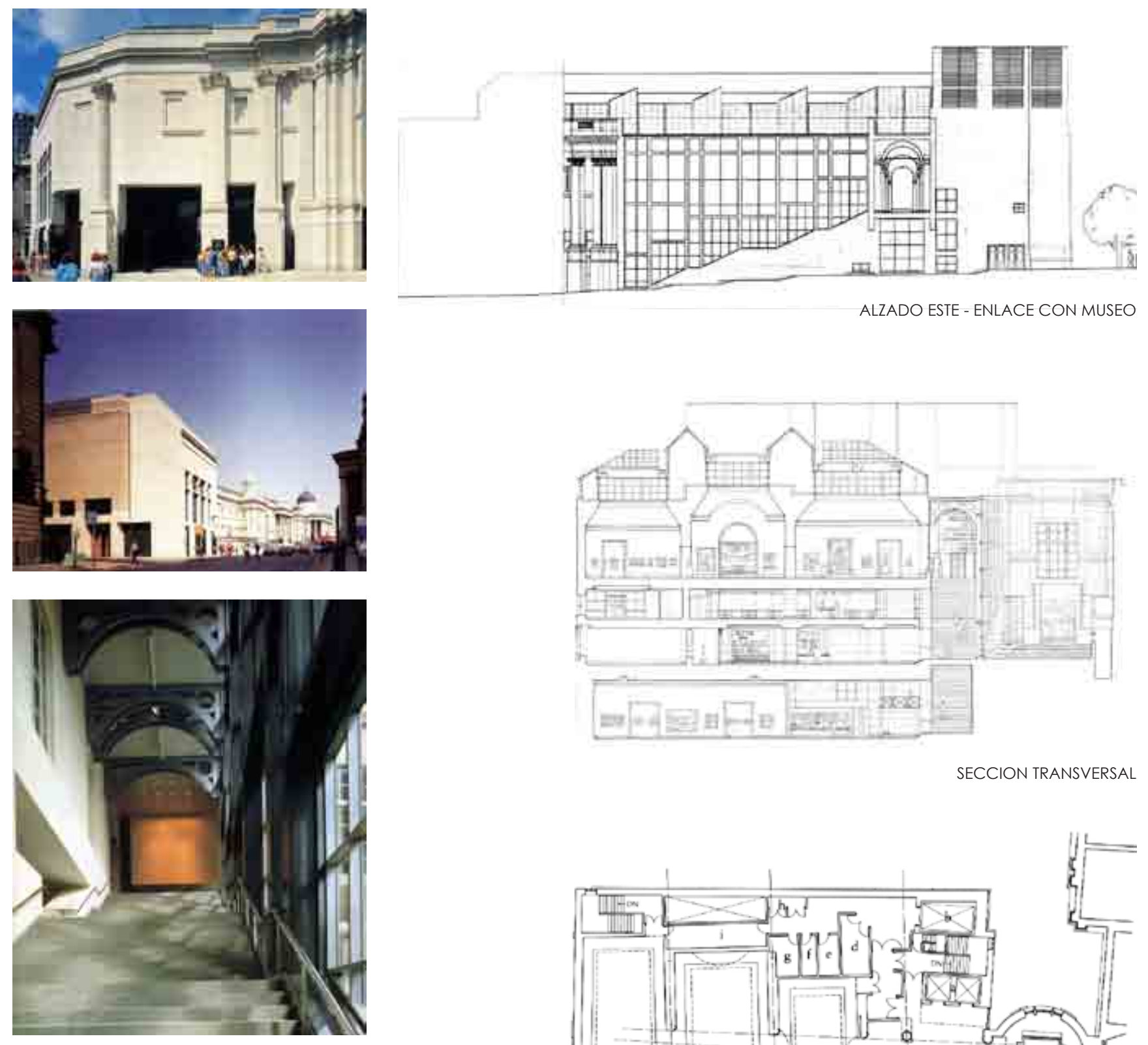

SECCION TRANSVERSAL
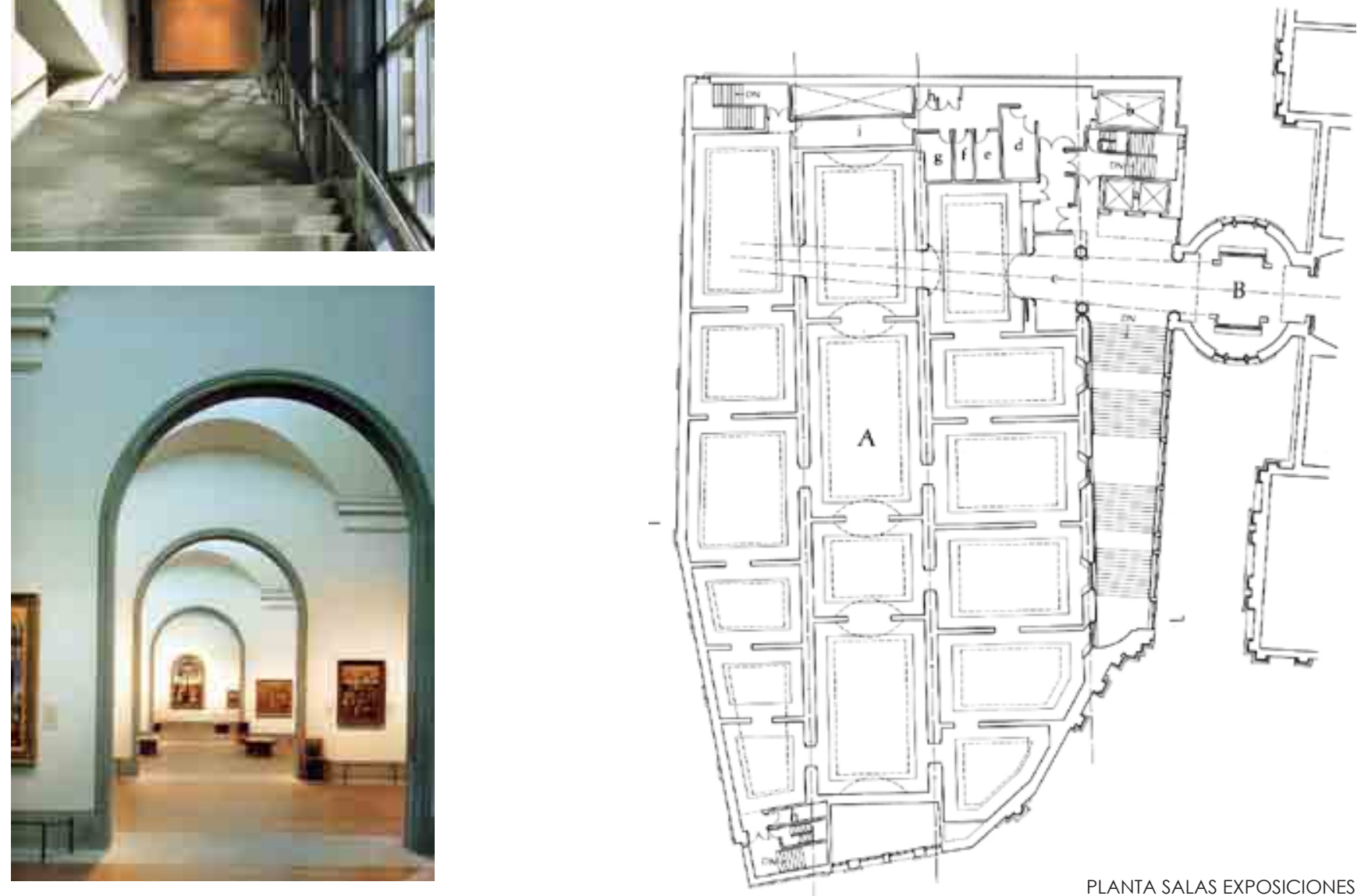
MUSEO PARA LA COLECCIÓN BEYELER

Basilea, Suiza - Renzo Piano, 1991
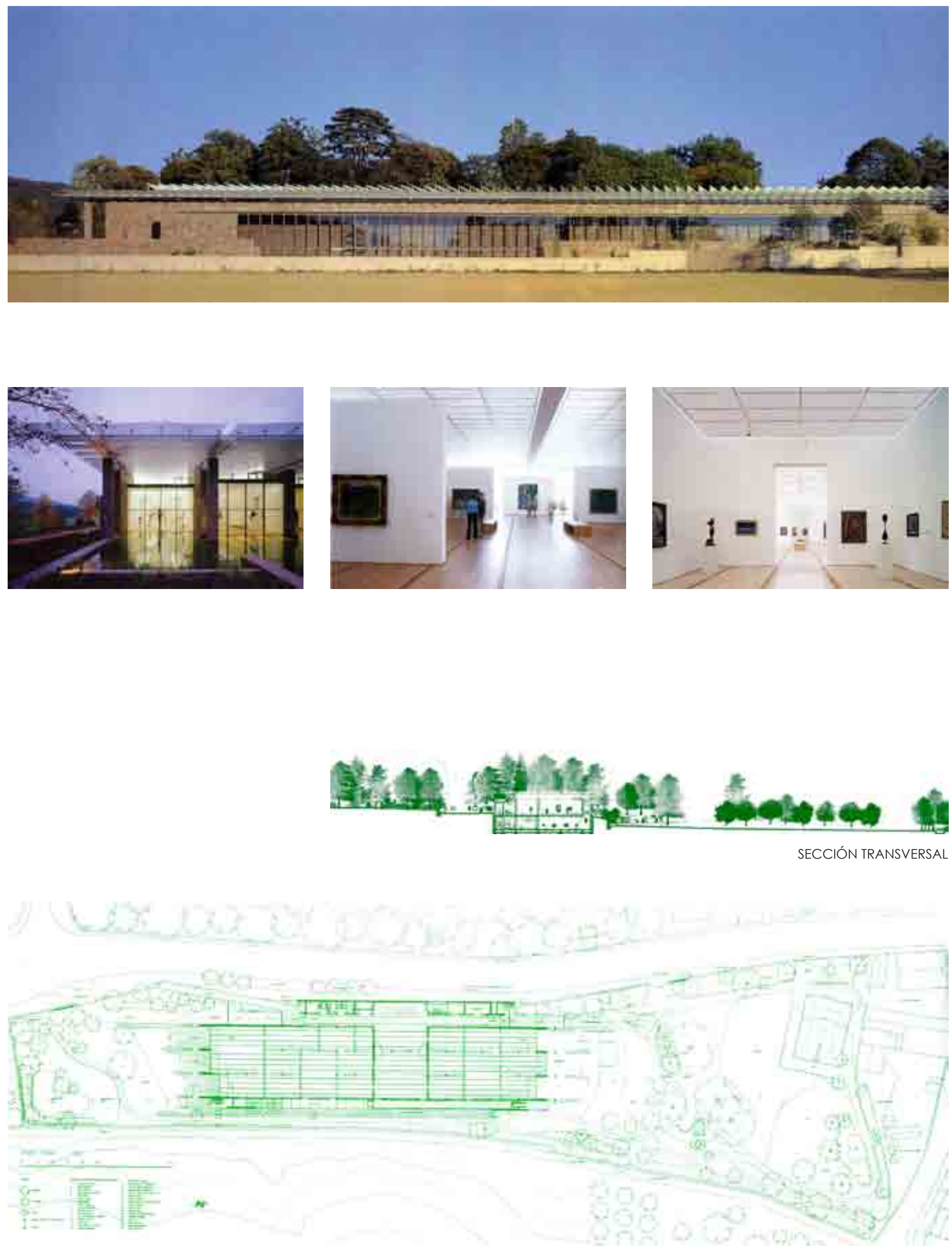

PLANTA BAJA EN ENTORNO 
MUSEO DE BELLAS ARTES DE HOUSTON - EDIFICIO AUDREY JONES BECK

Houston, Texas (USA) - Rafael Moneo, 1992
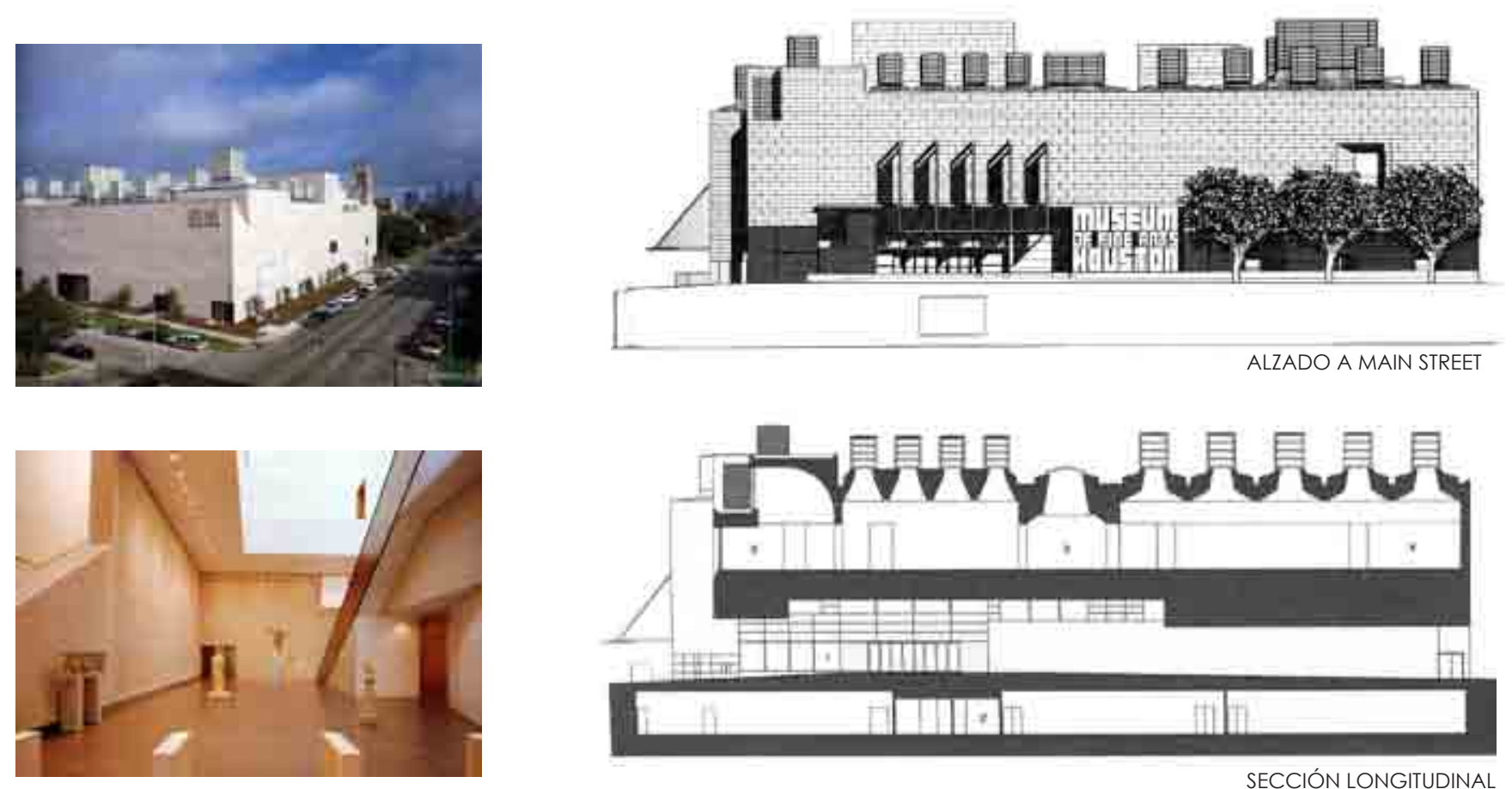

SECCIÓN LONGITUDINAL POR HALL Y SALAS
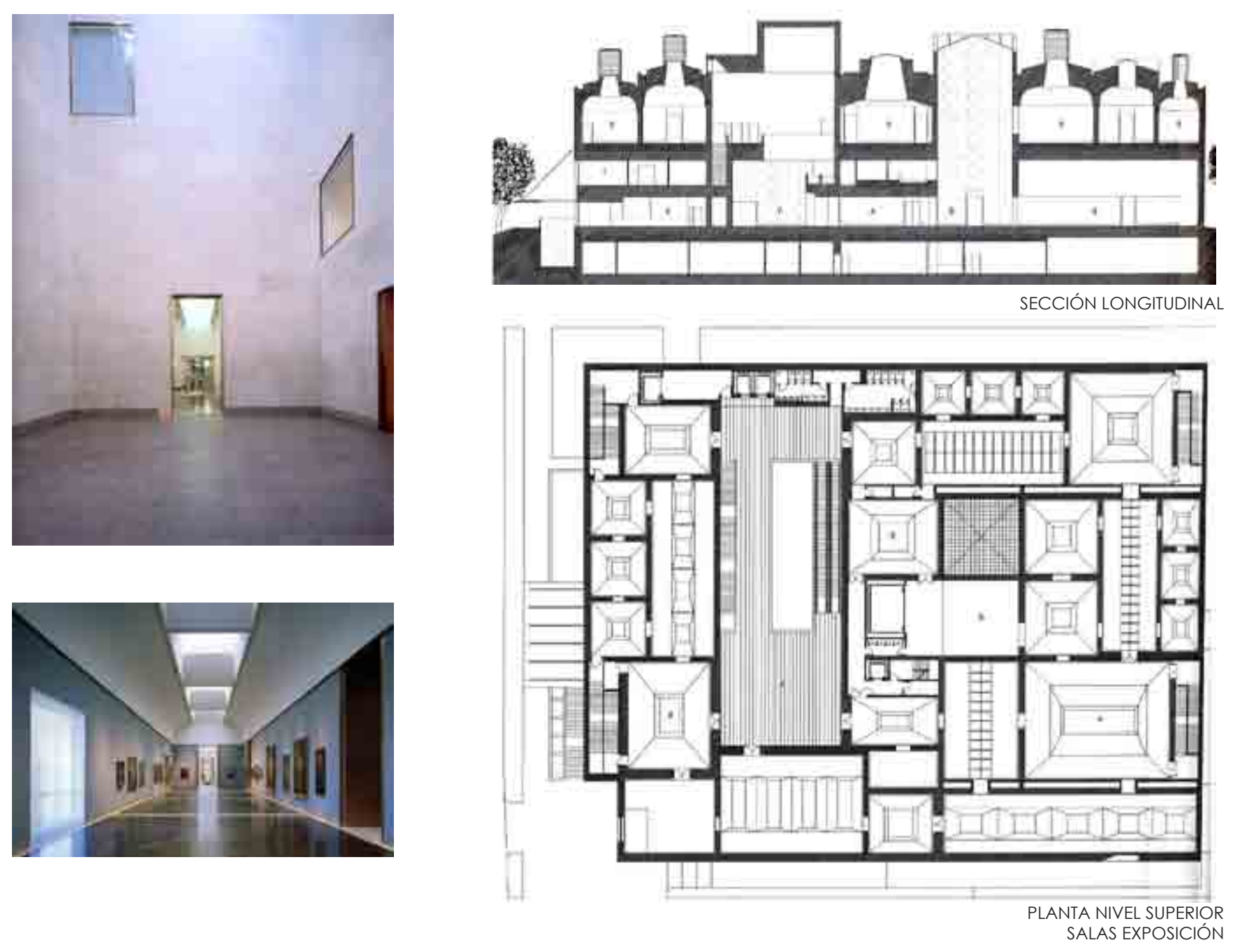
MUSEO EN HELSINKI

Helsinki, Finlandia - Álvaro Siza, 1993

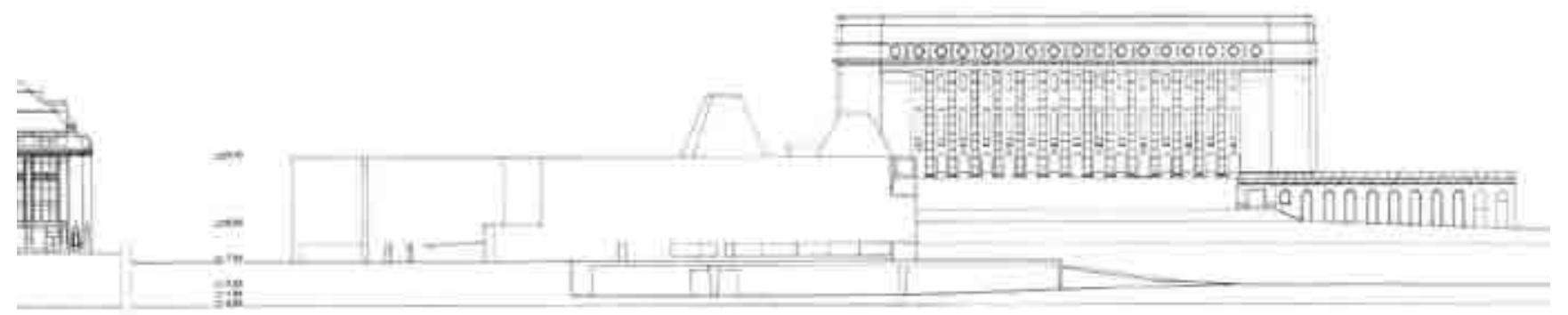

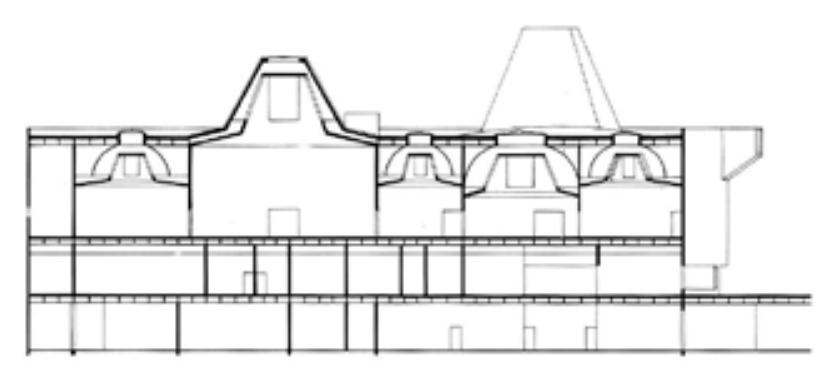

SECCIÓN POR SALAS
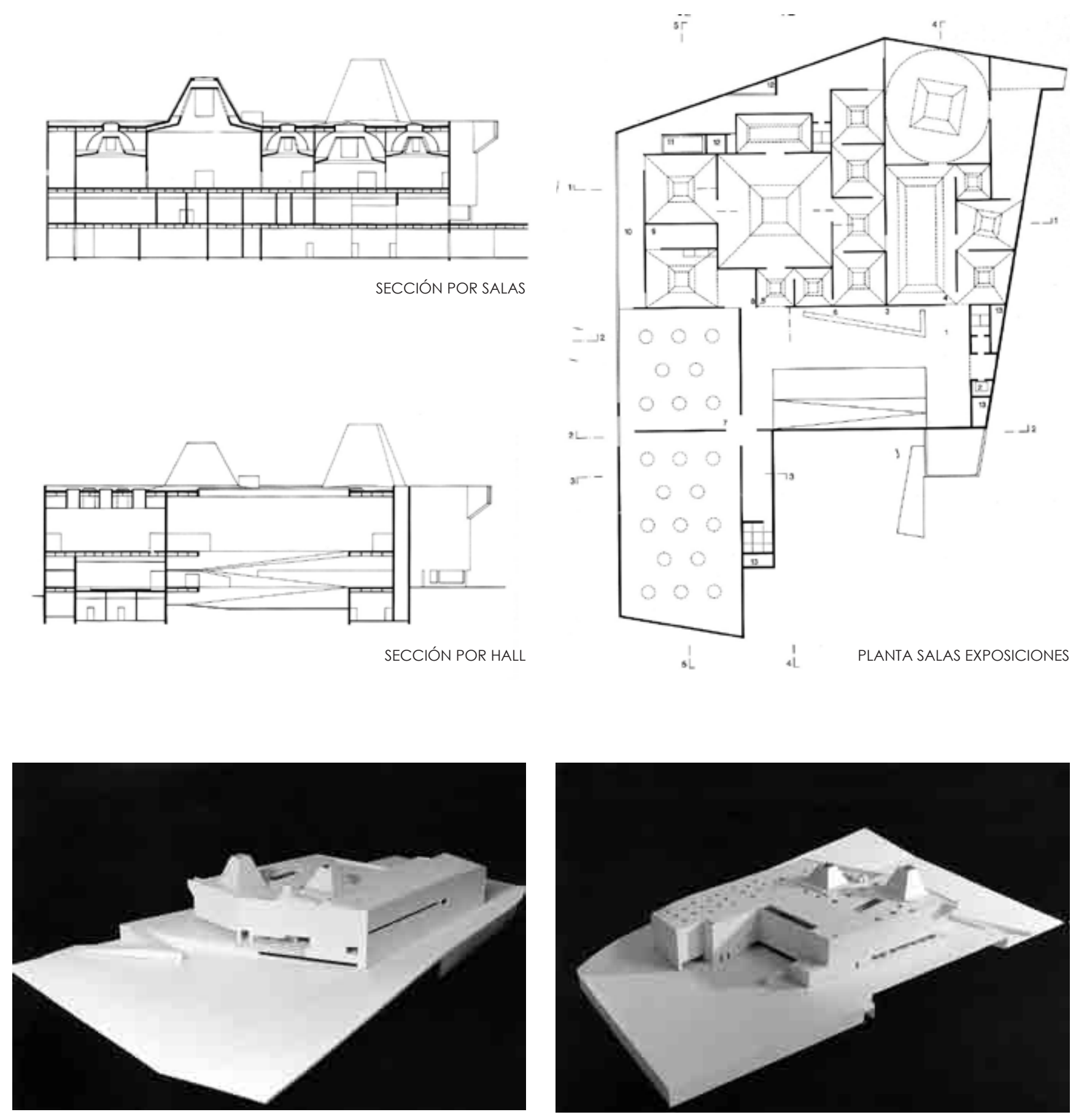

INDEX-66 
COLECCIÓN AM RÖMERHOLZ

Winterthur, Suiza - Gigon \& Guyer, 1993
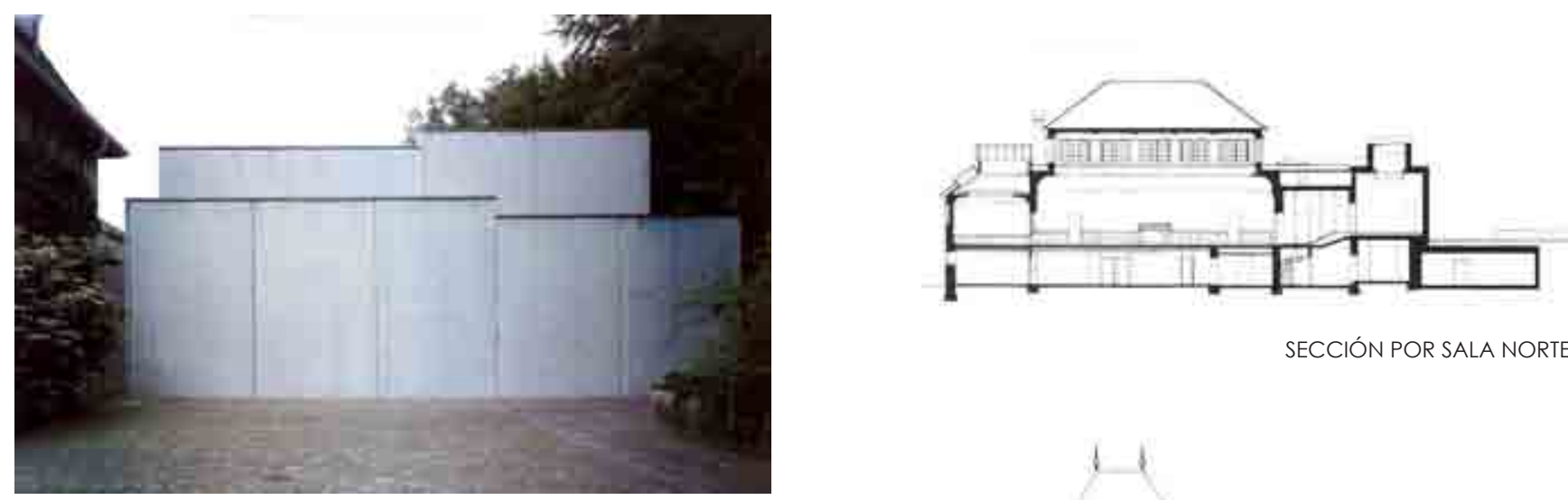

SECCIÓN POR SALA NORTE
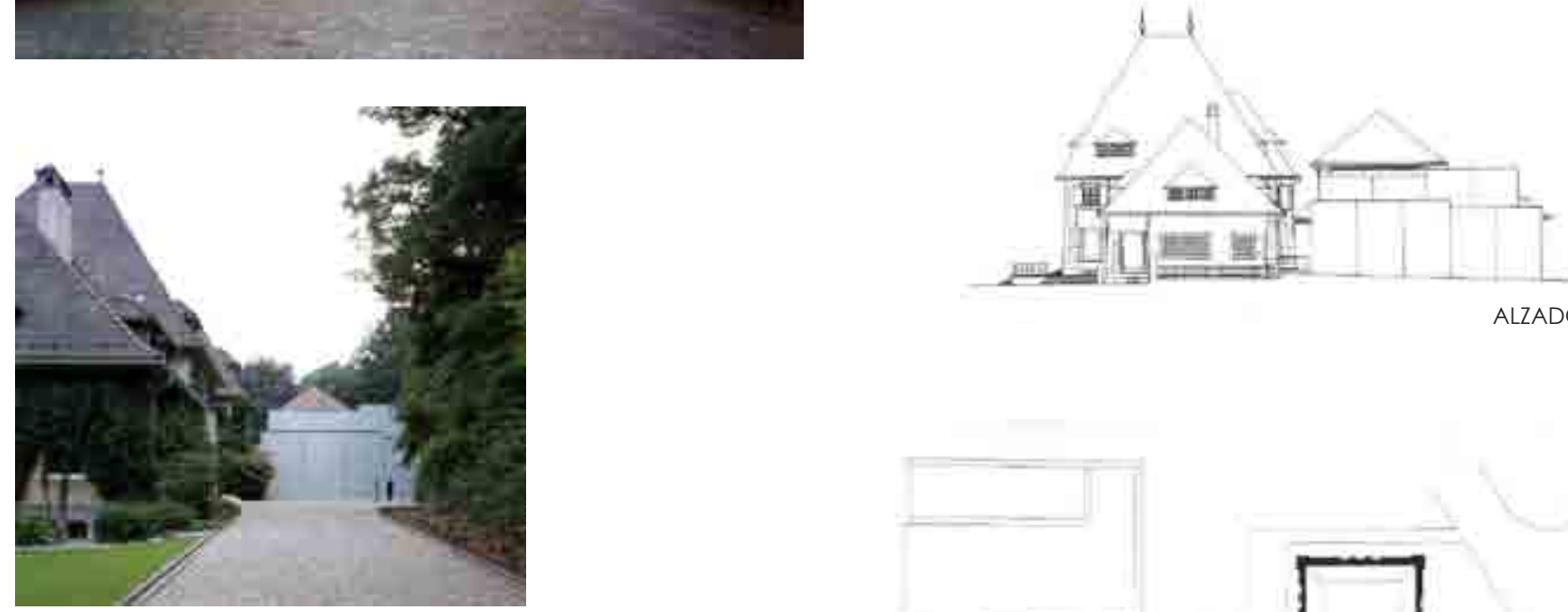

ALZADO ESTE
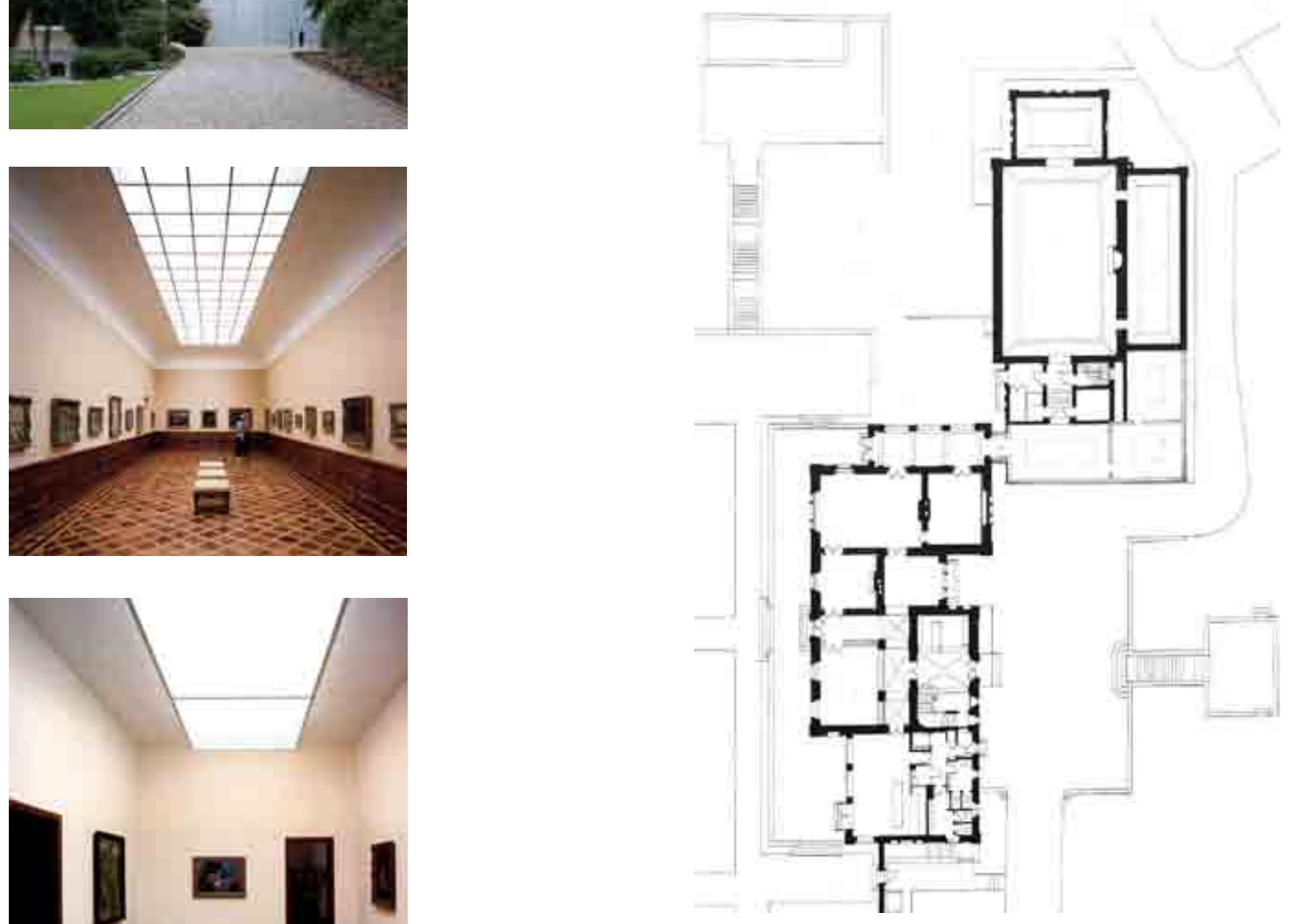

PLANTA GENERAL

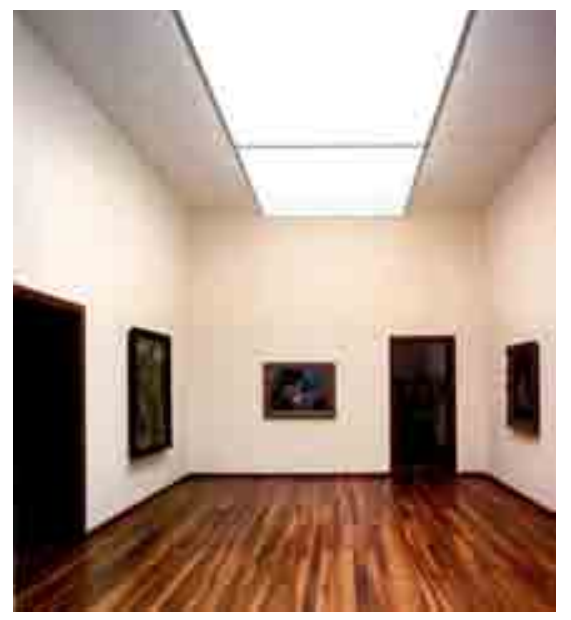


AMPLIACIÓN DEL MUSEO DE ARTE DE WINTERTHUR

Winterthur, Suiza - Gigon \& Guyer, 1993
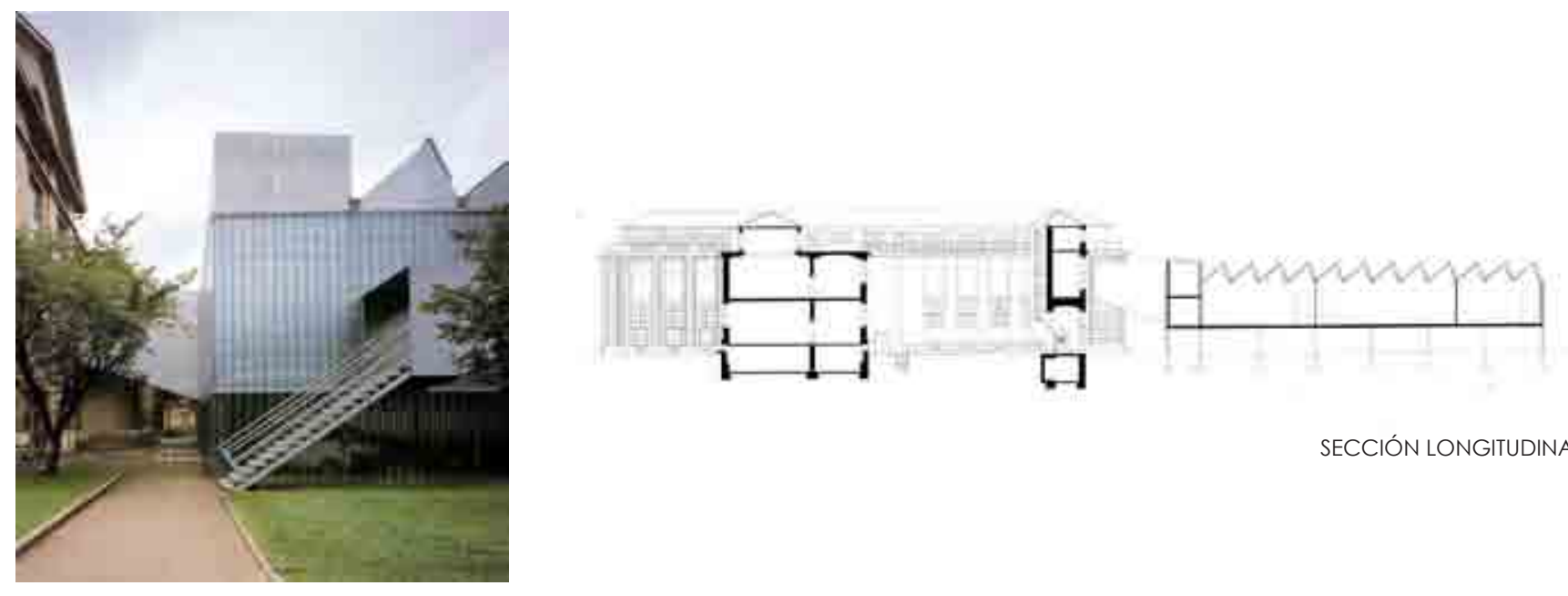

SECCIÓN LONGITUDINAL
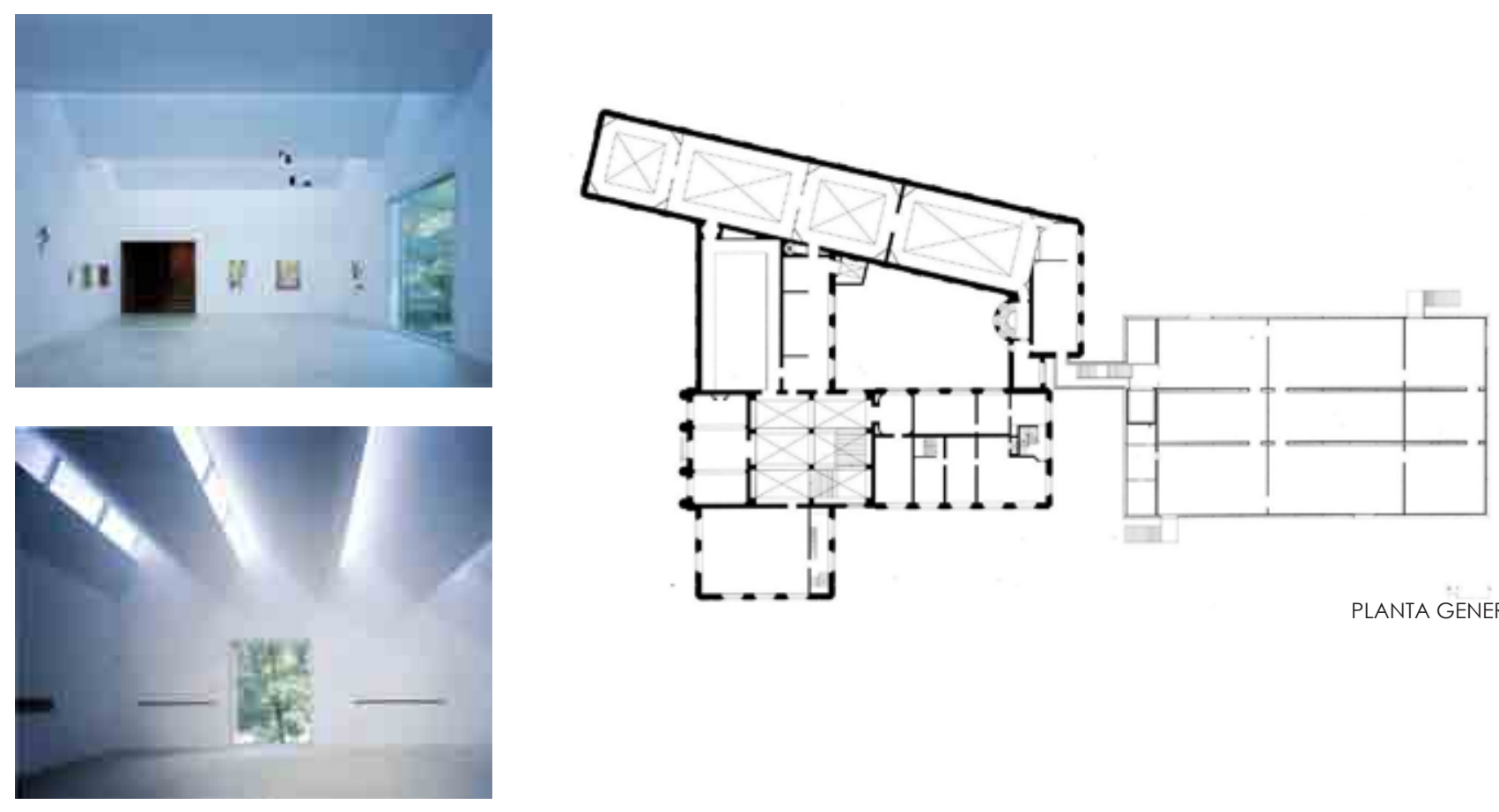

PLANTA GENERAL
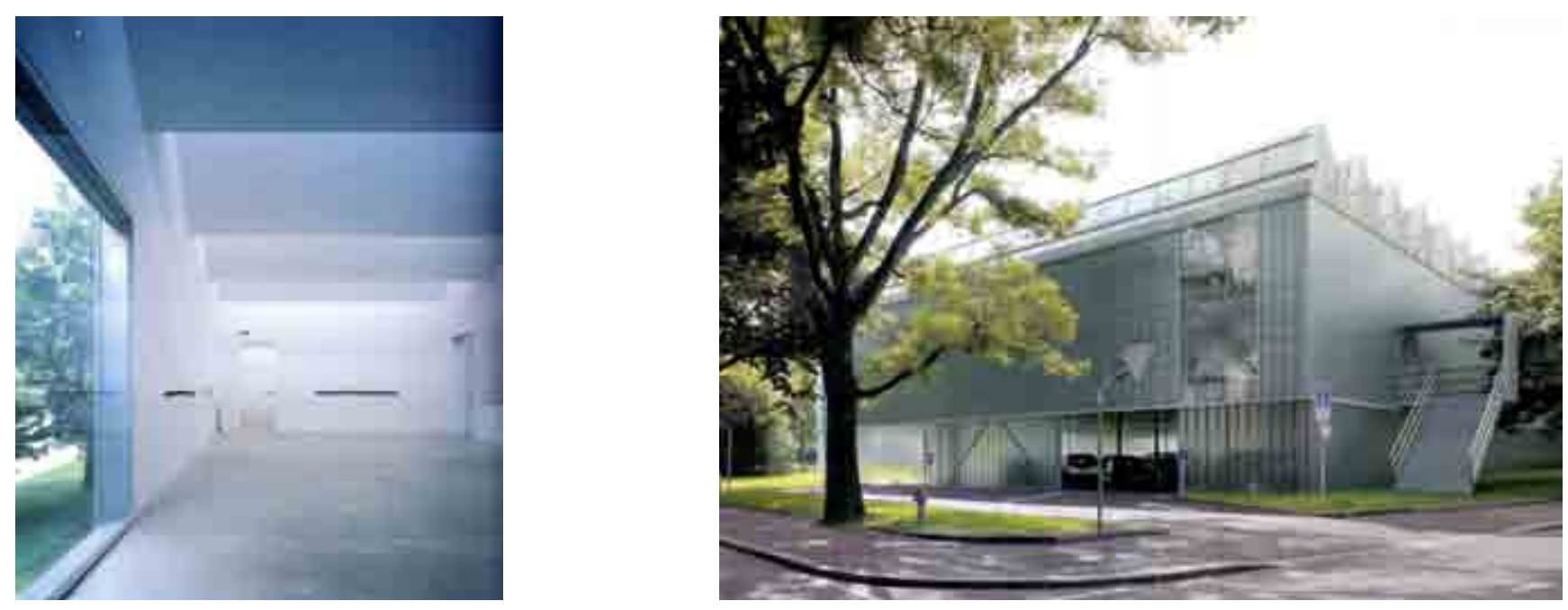

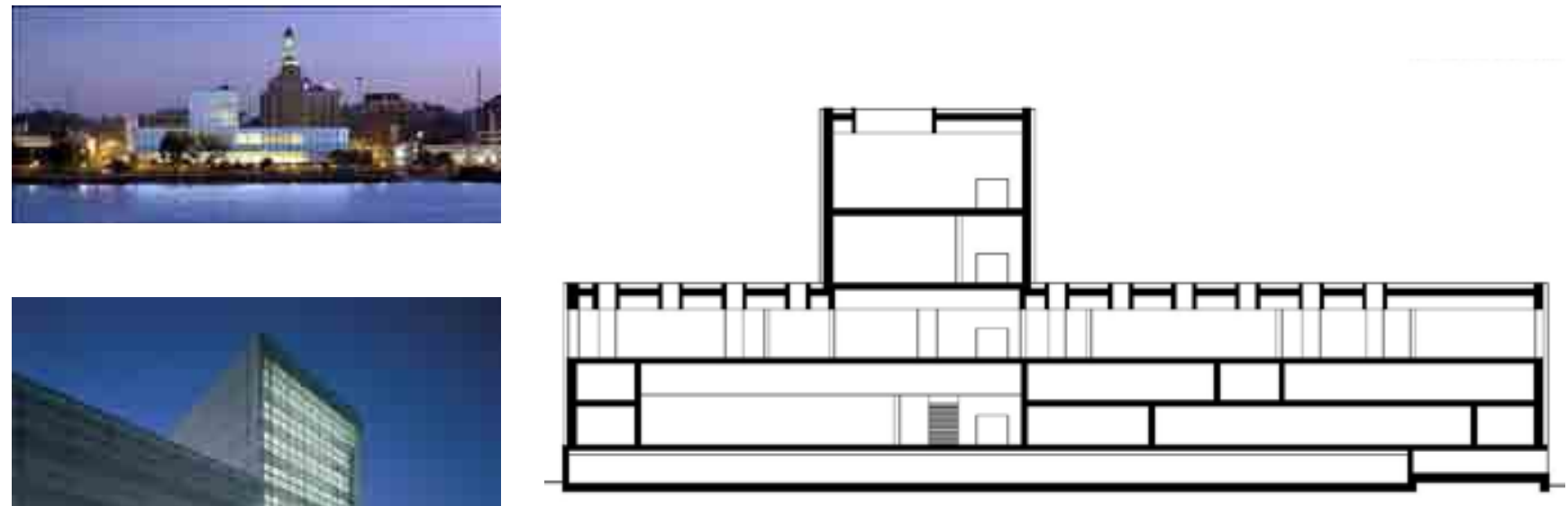

SECCIÓN TRANSVERSAL
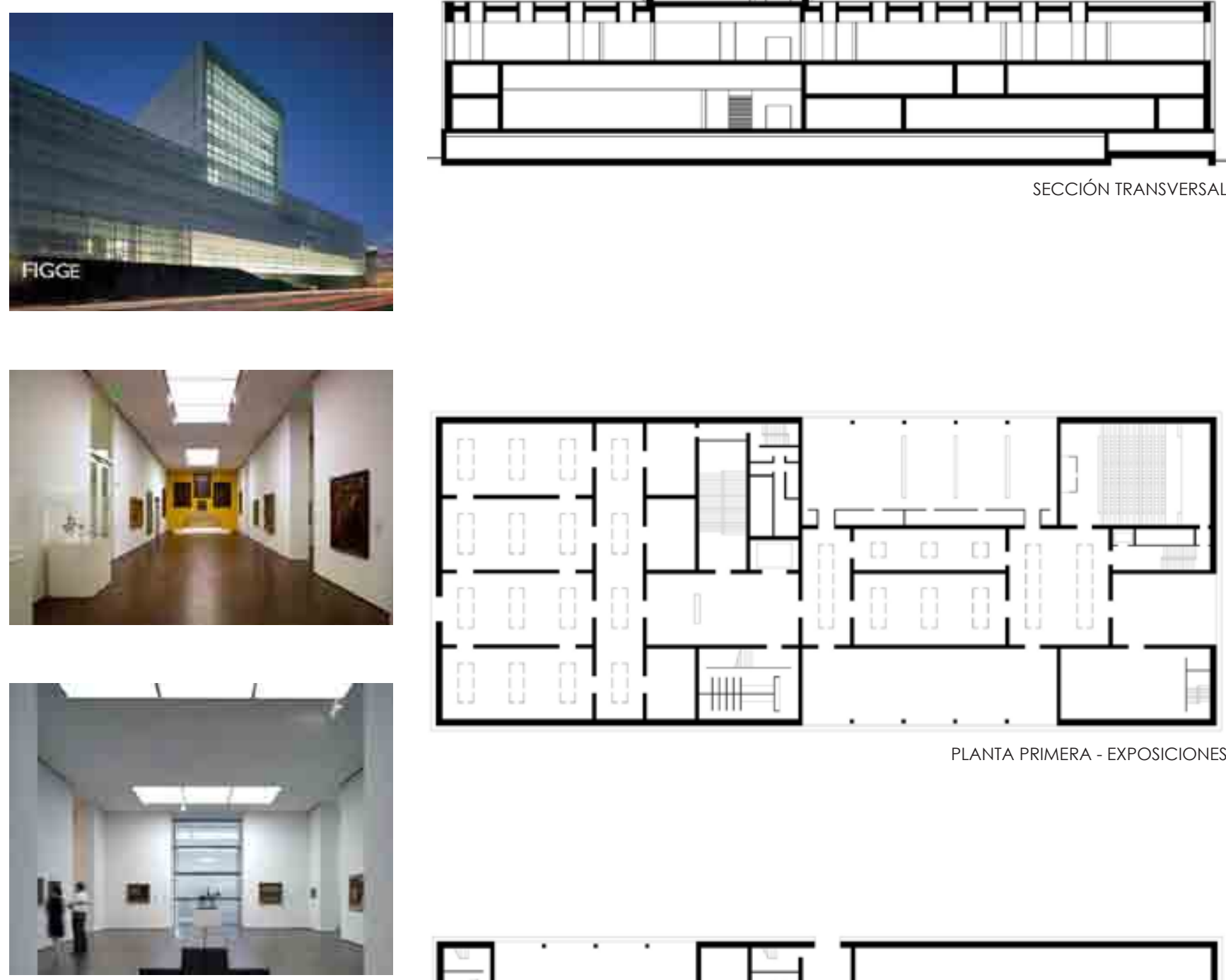

PLANTA PRIMERA - EXPOSICIONES
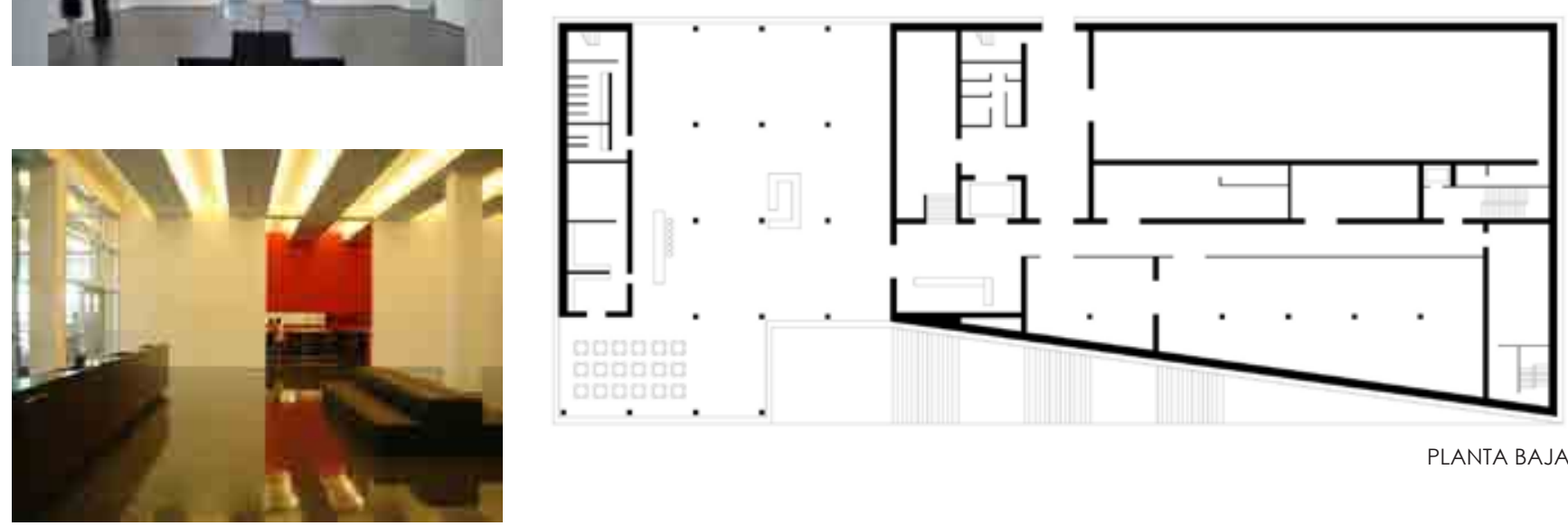
AMPLIACIÓN DEL MUSEO DEL PRADO

Madrid, España - Rafael Moneo, 1996
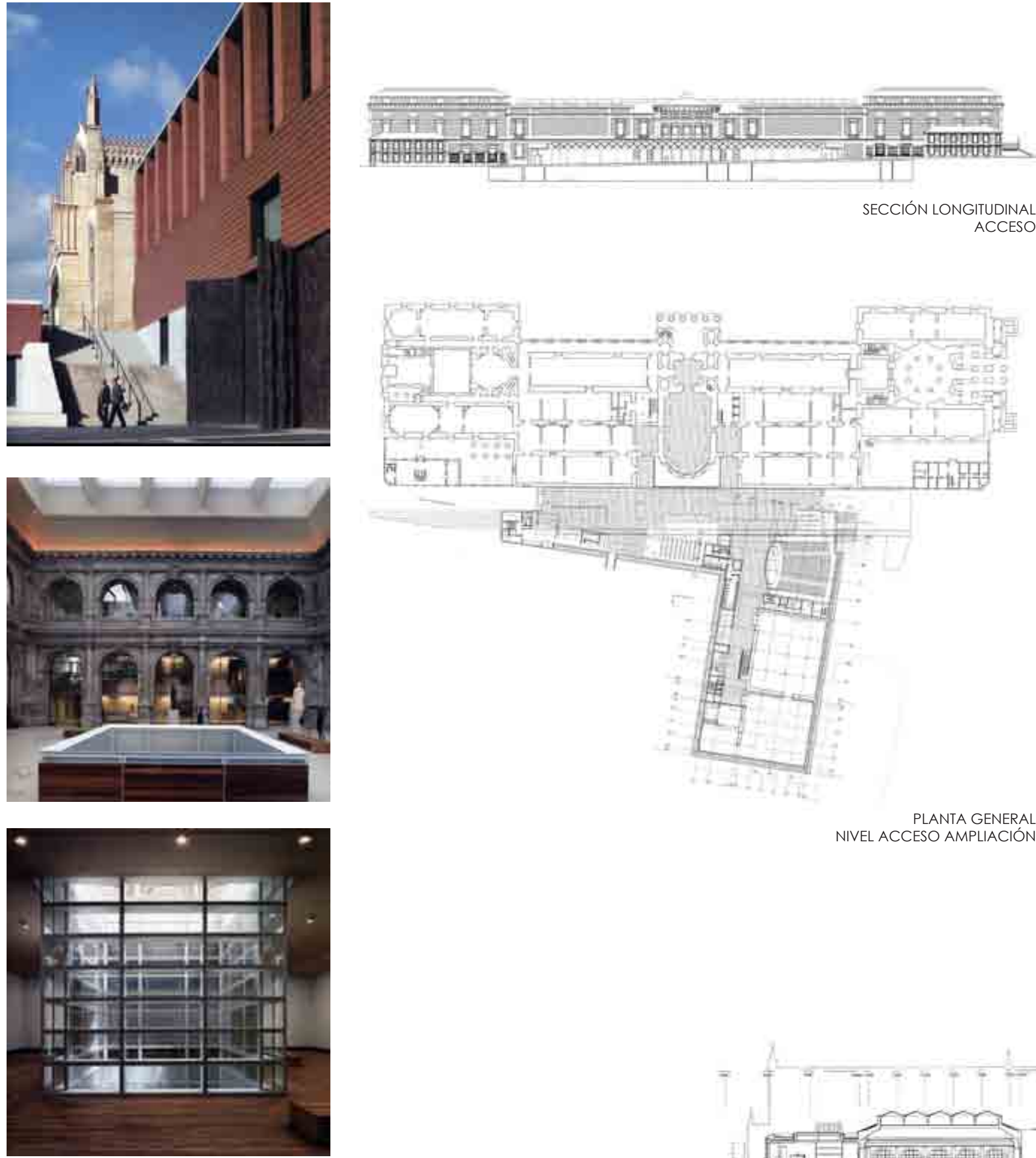

NIVEL ACCESO AMPLIACIÓN
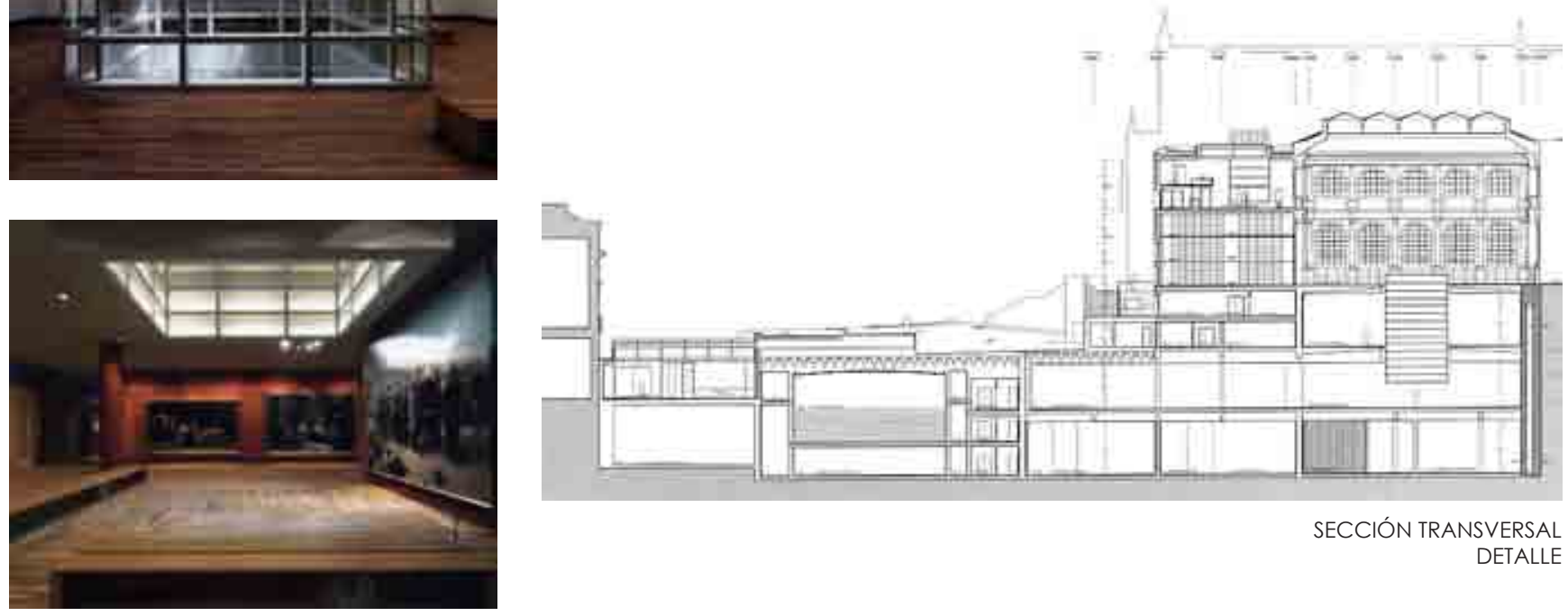

SECCIÓN TRANSVERSAL DETALLE 

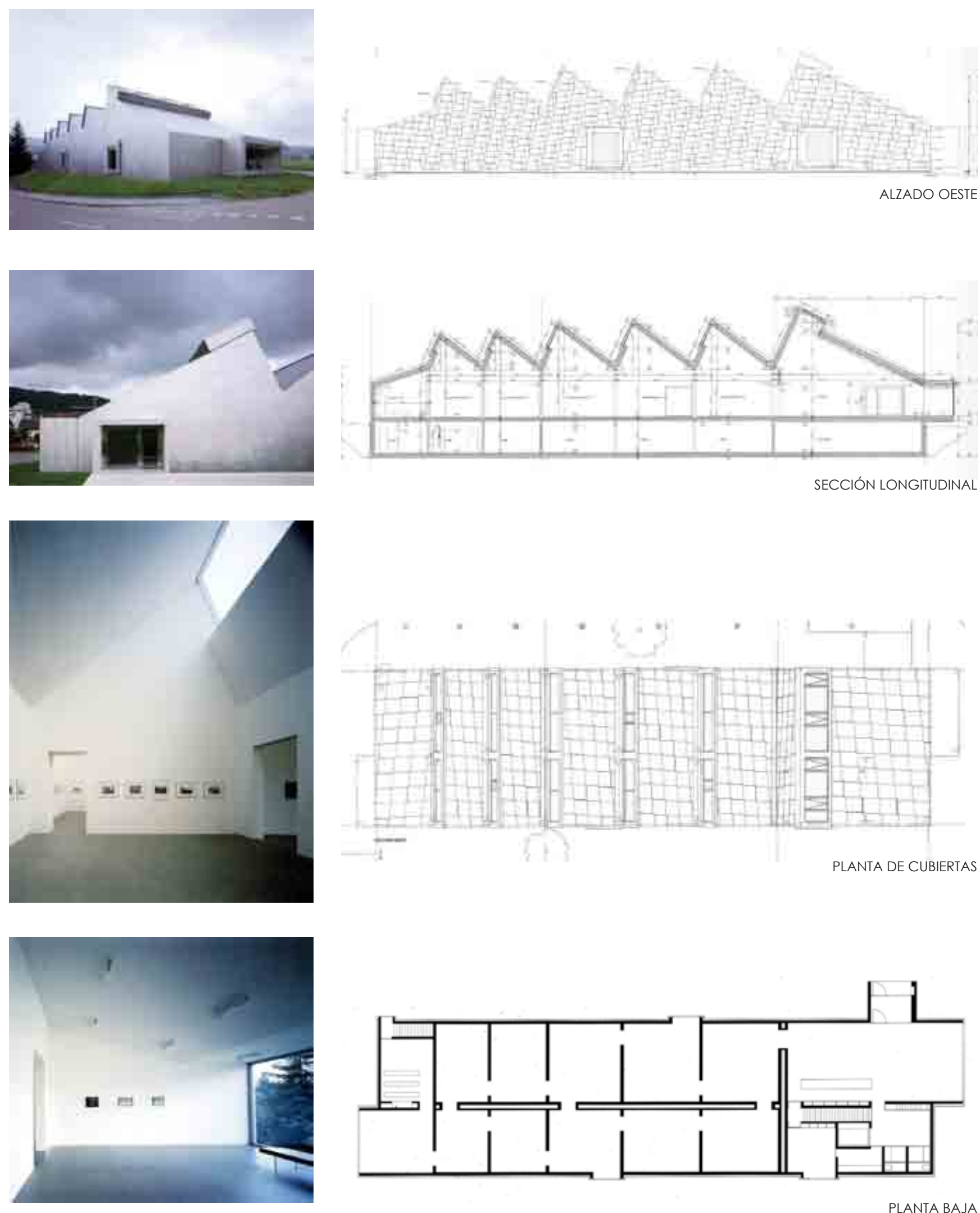
MUSEO DE BELLAS ARTES DE CASTELLÓN

Castellón de la Plana, España - Tuñón y Mansilla, 1997
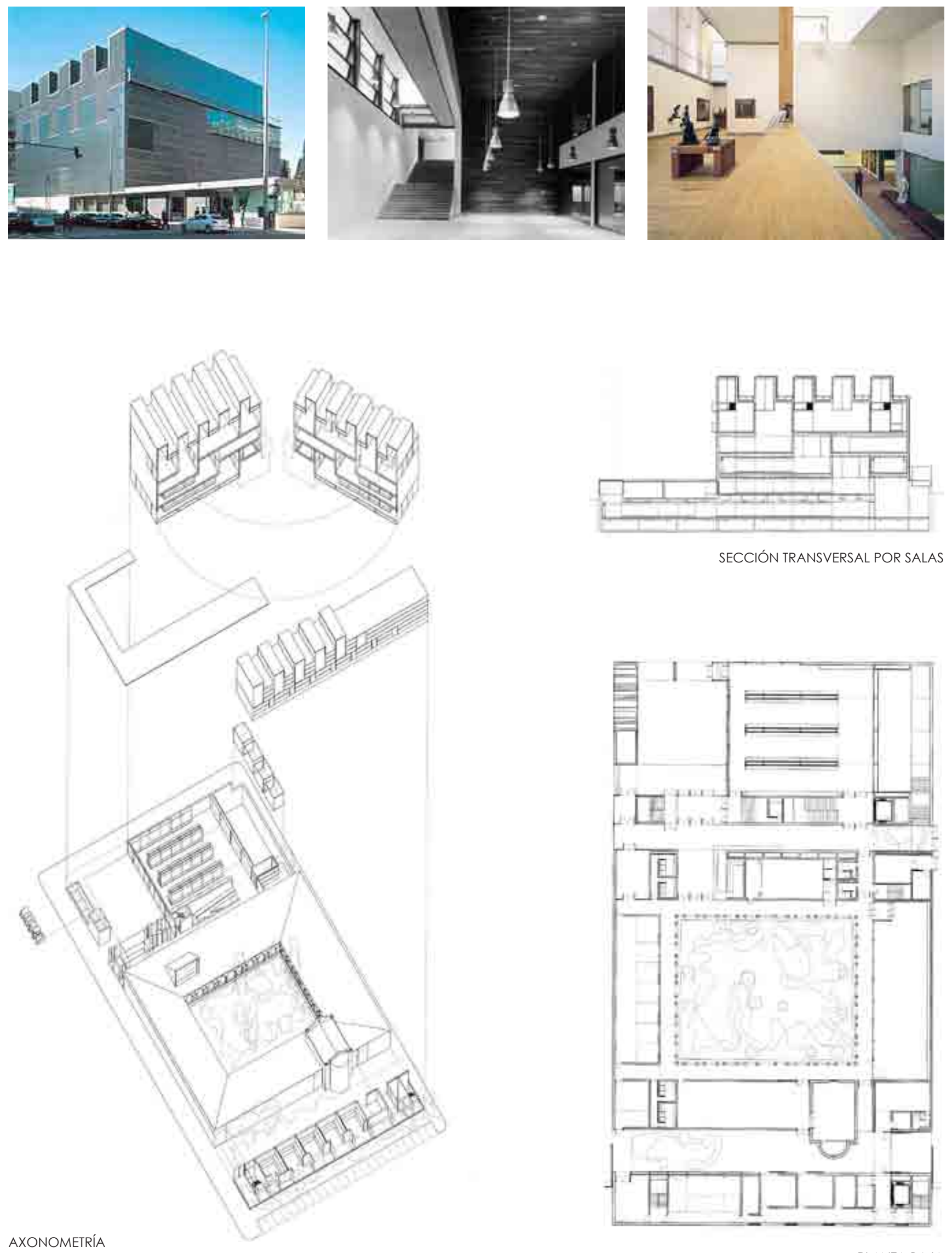

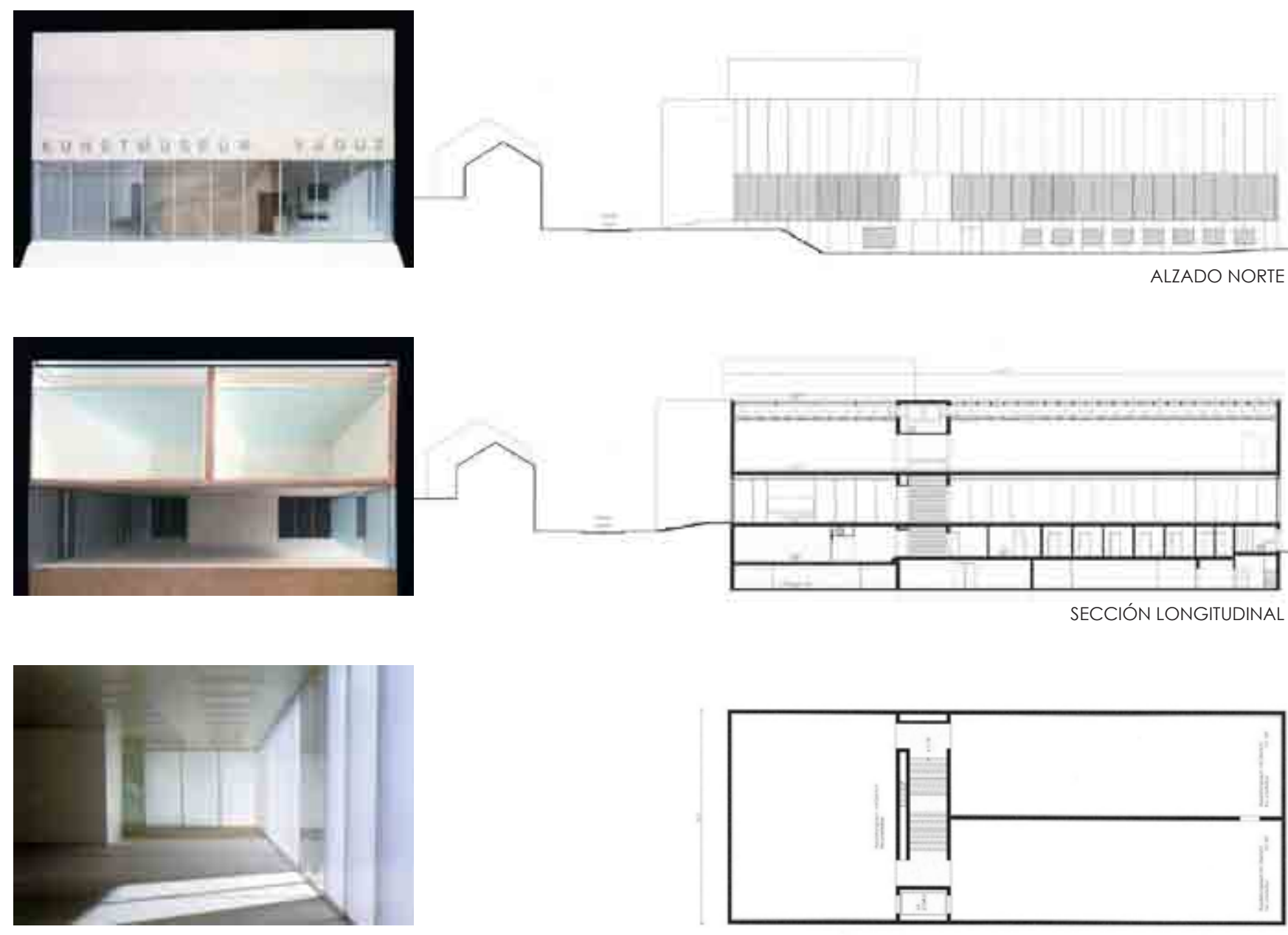

PLANTA PRIMERA
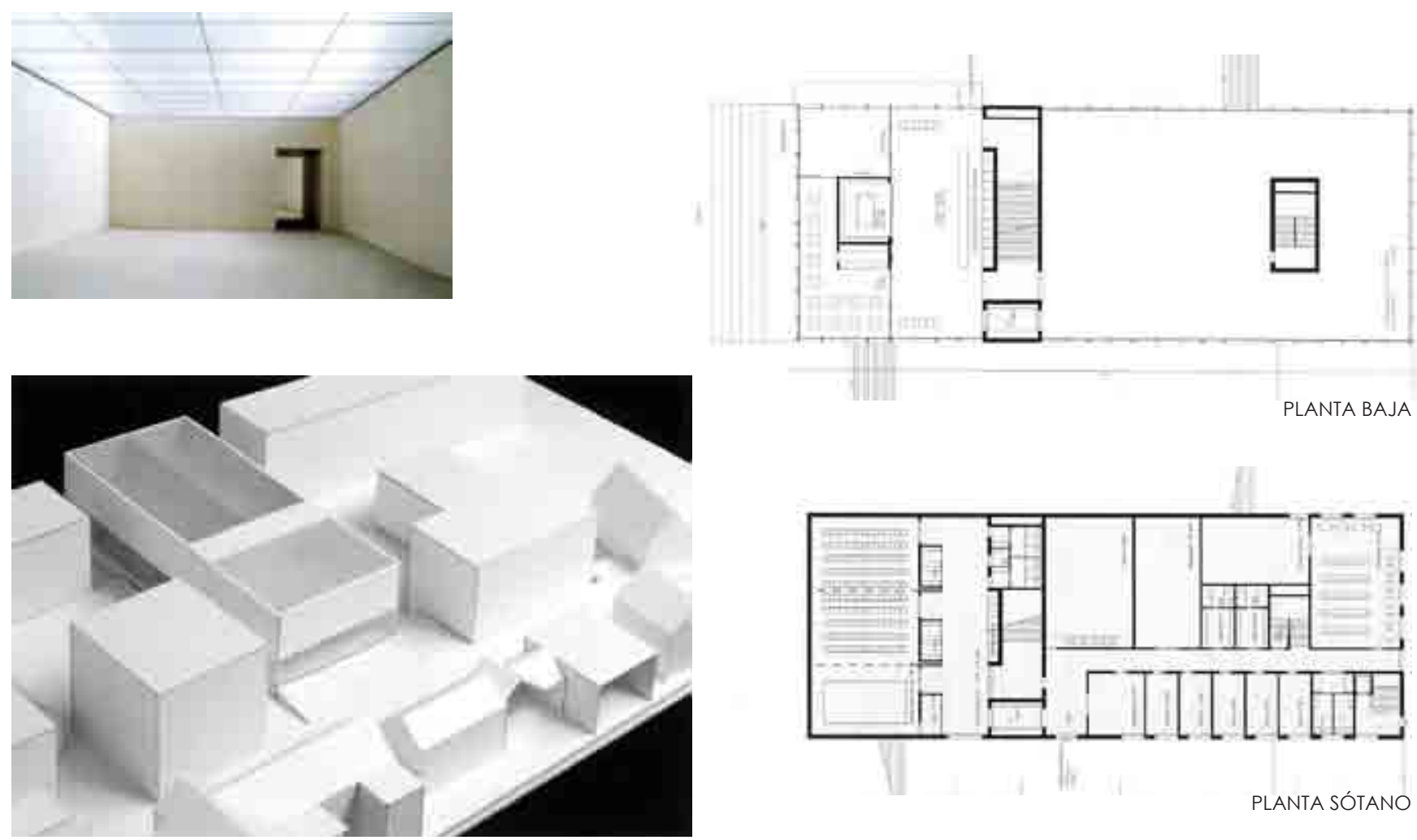

PLANTA BAJA
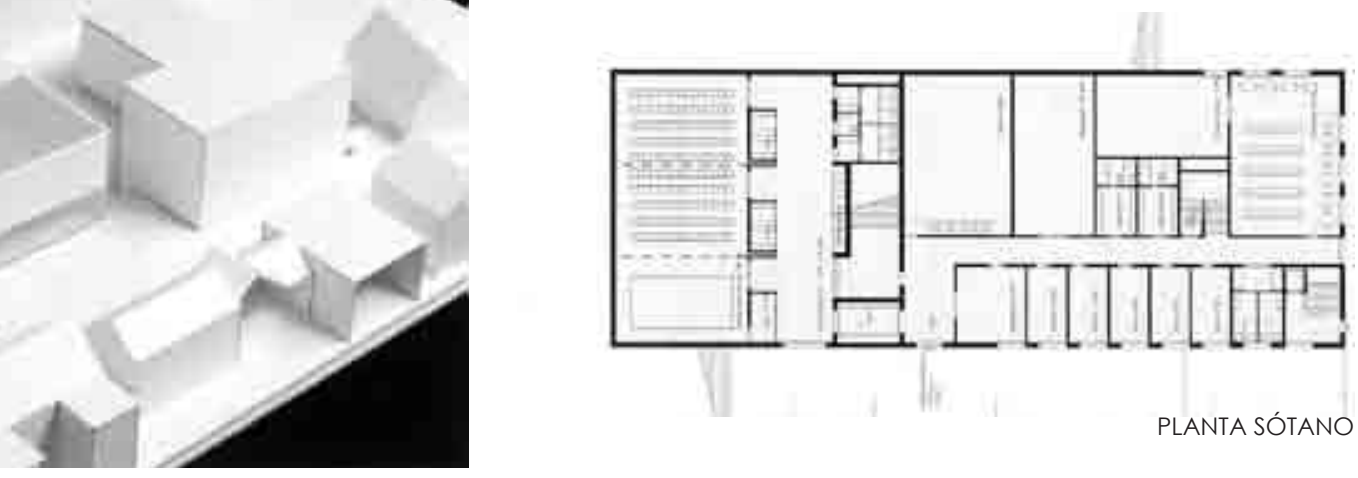
TATE MODERN GALLERY

Londres, Reino Unido - Herzog \& de Meuron, 1998
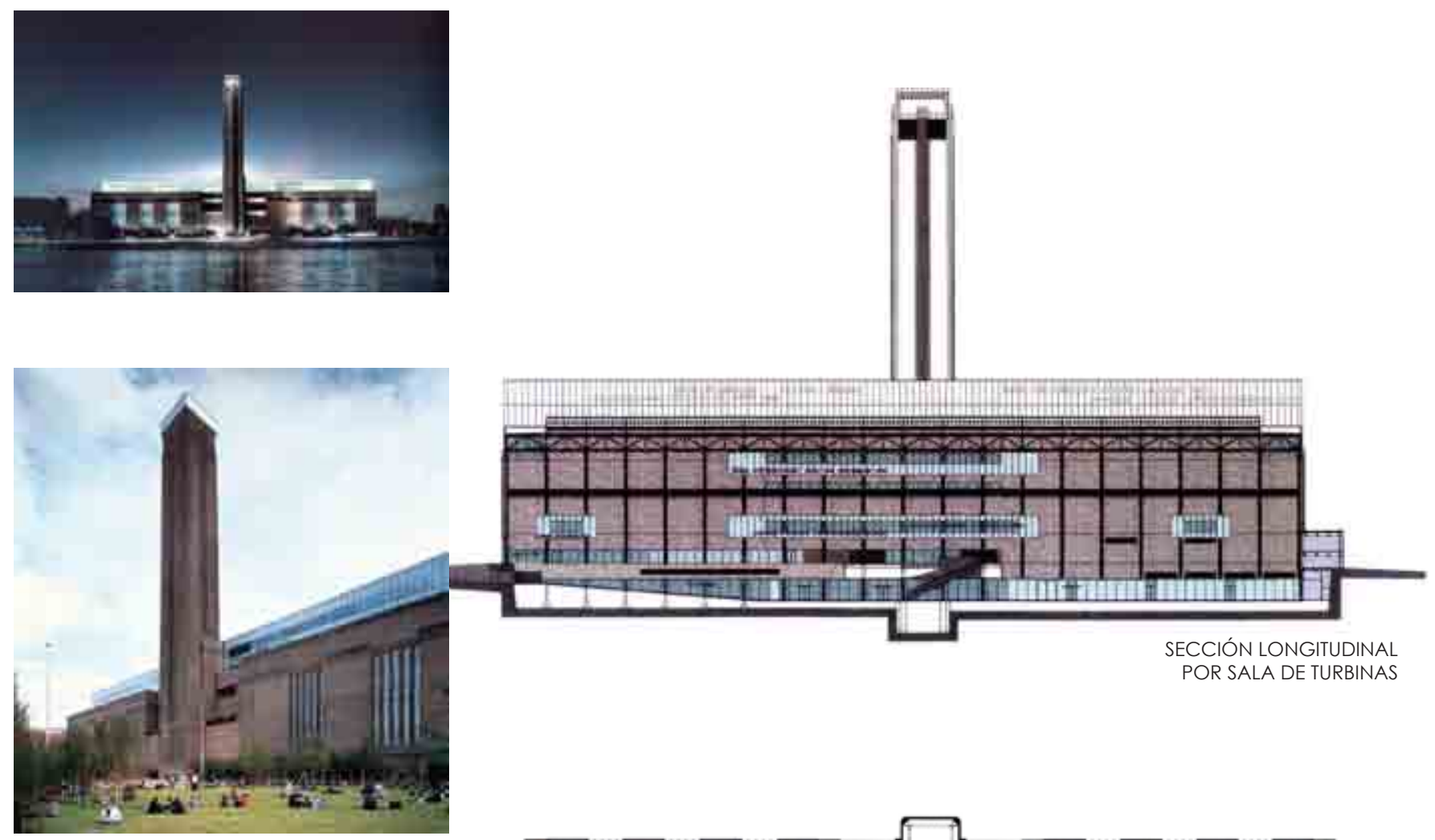

POR SALA DE TURBINAS
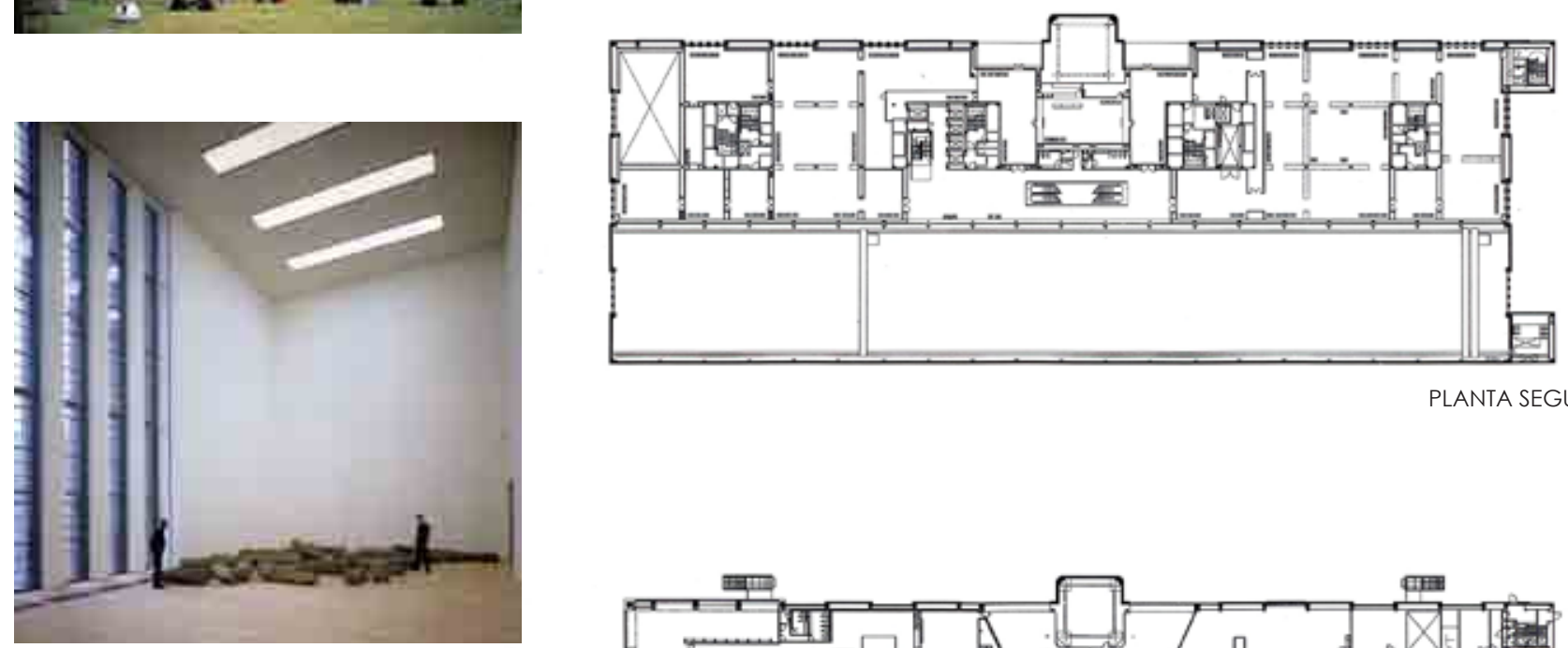

PLANTA SEGUNDA
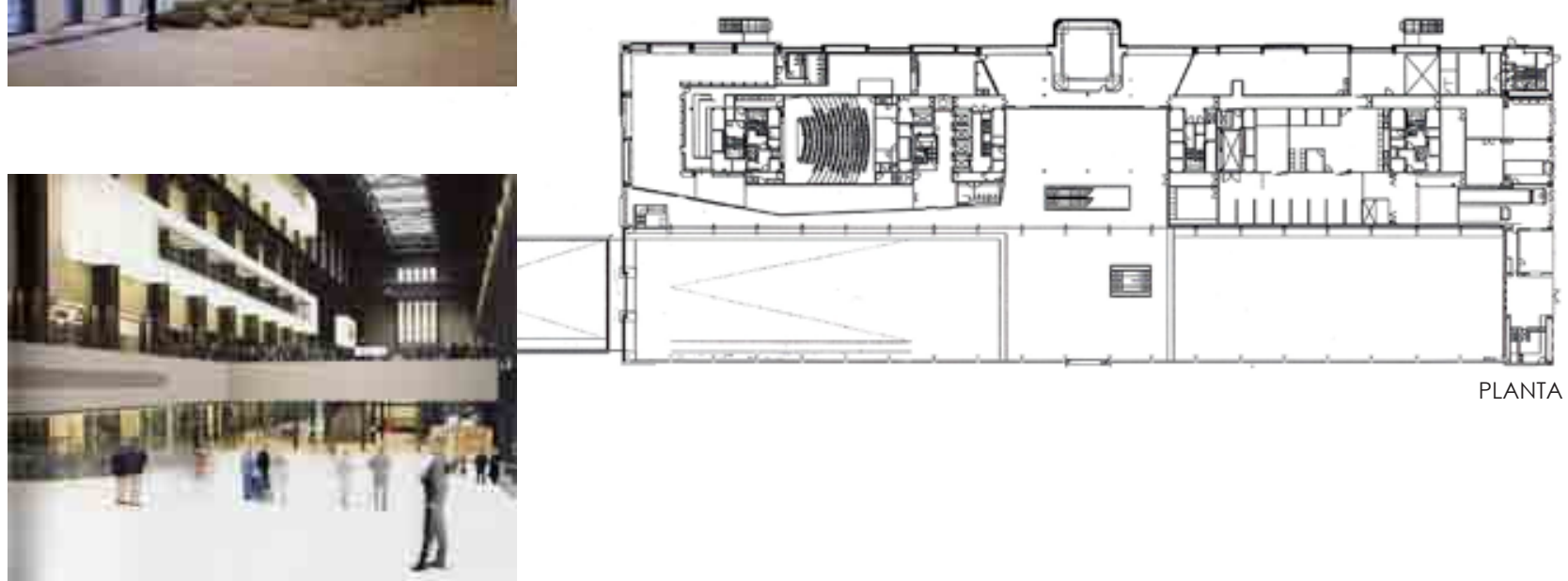

PLANTA BAJA 

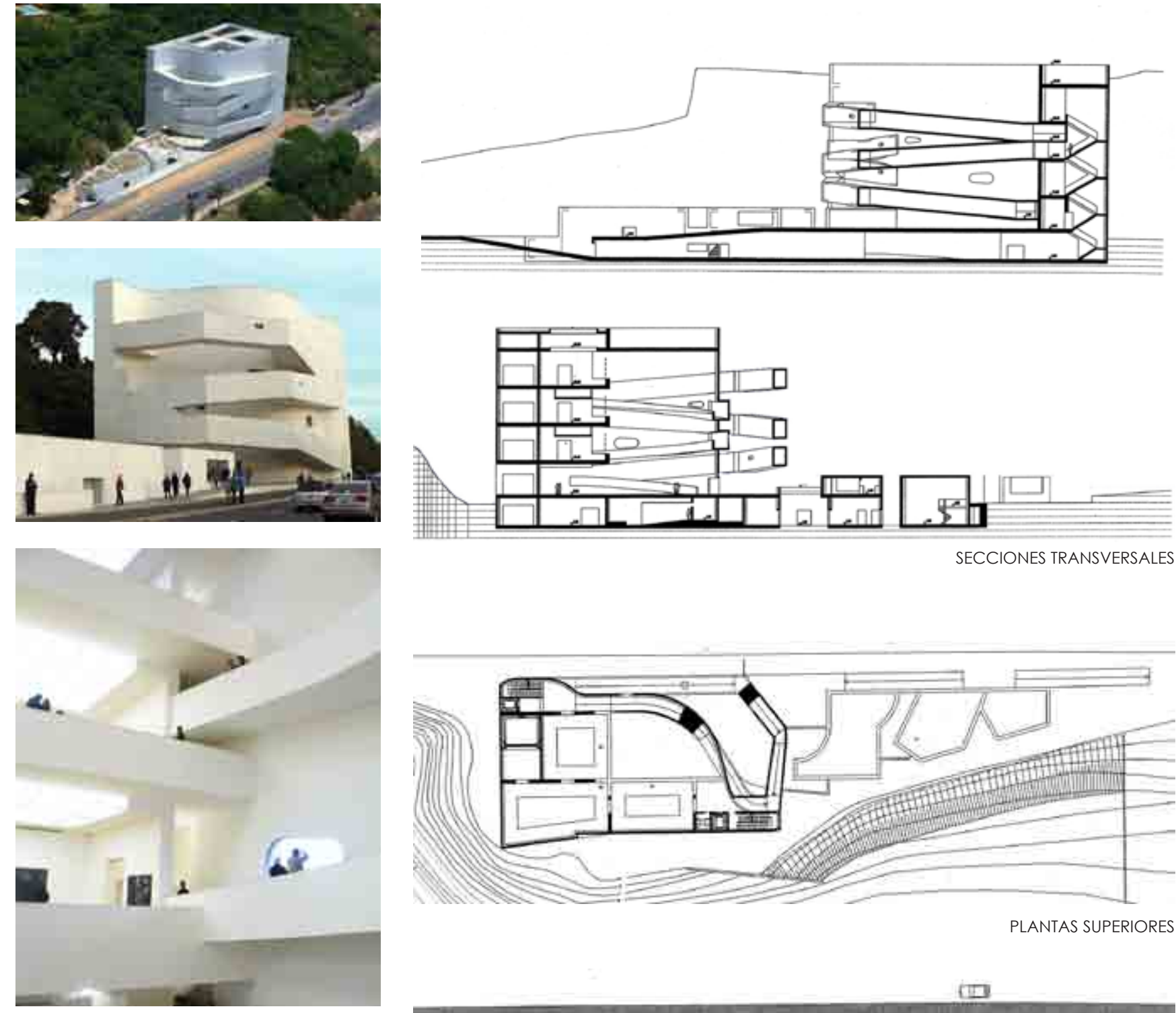

PLANTAS SUPERIORES
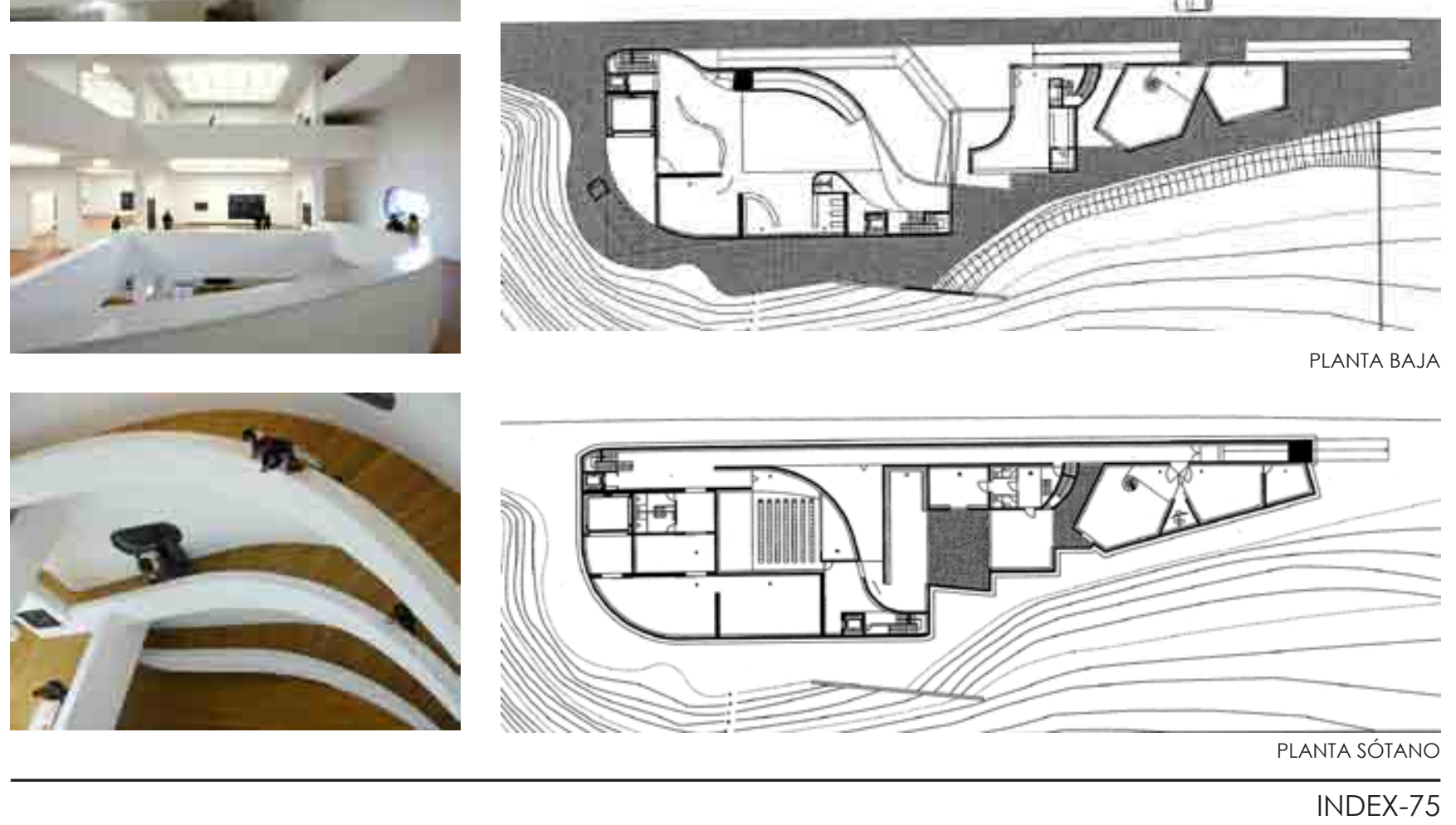
MUSEO ARTE MODERNO DE FORT WORTH

Fort Worth, Texas (USA) - Tadao Ando, 1999
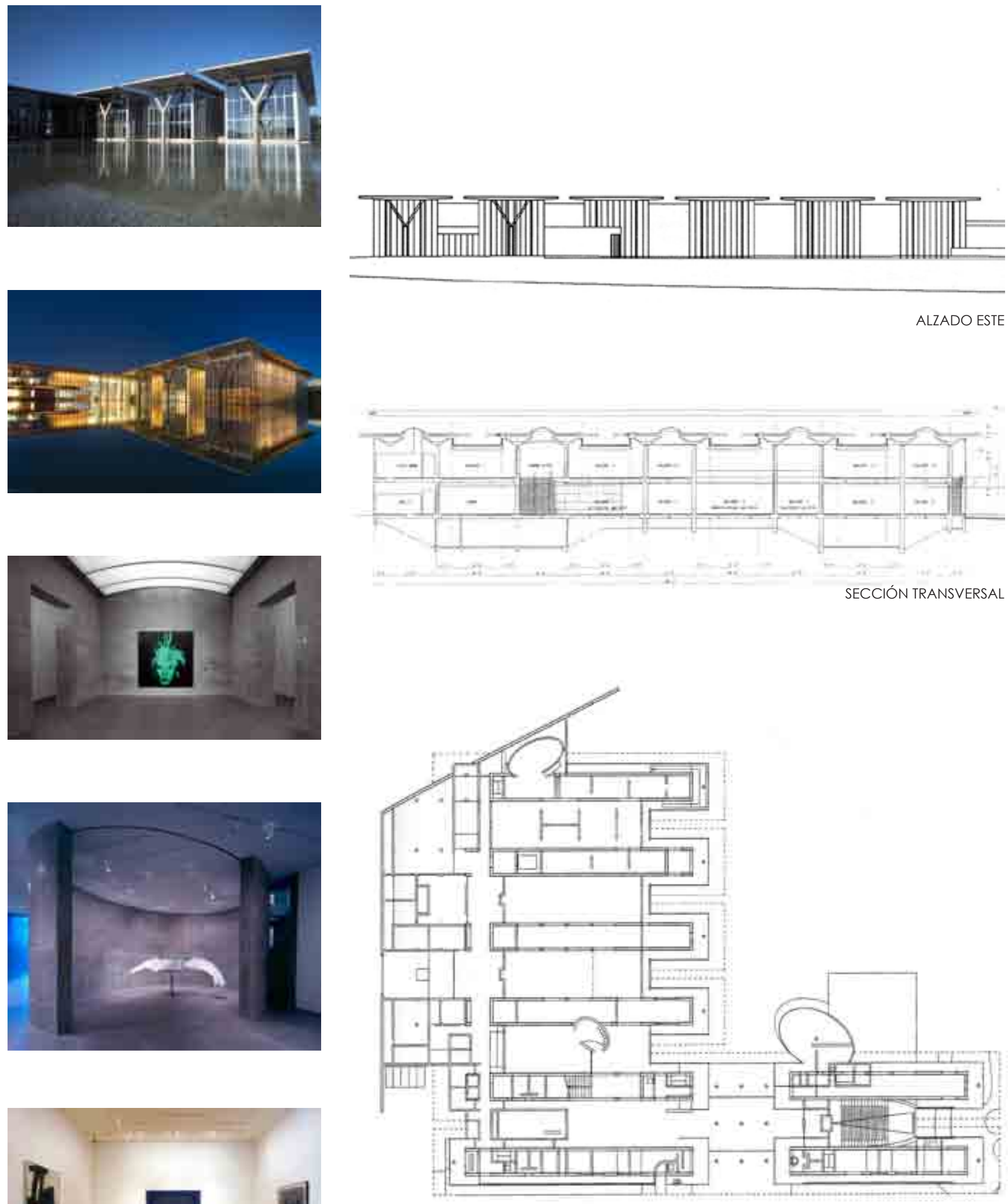

PLANTA BAJA 
NASHER SCULPTURE CENTER

Dallas, Texas, (USA) - Renzo Piano, 1999

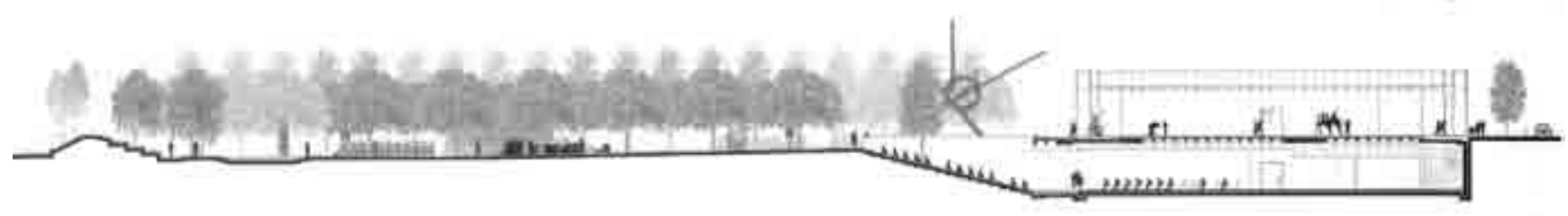

SECCIÓN LONGITUDINAL
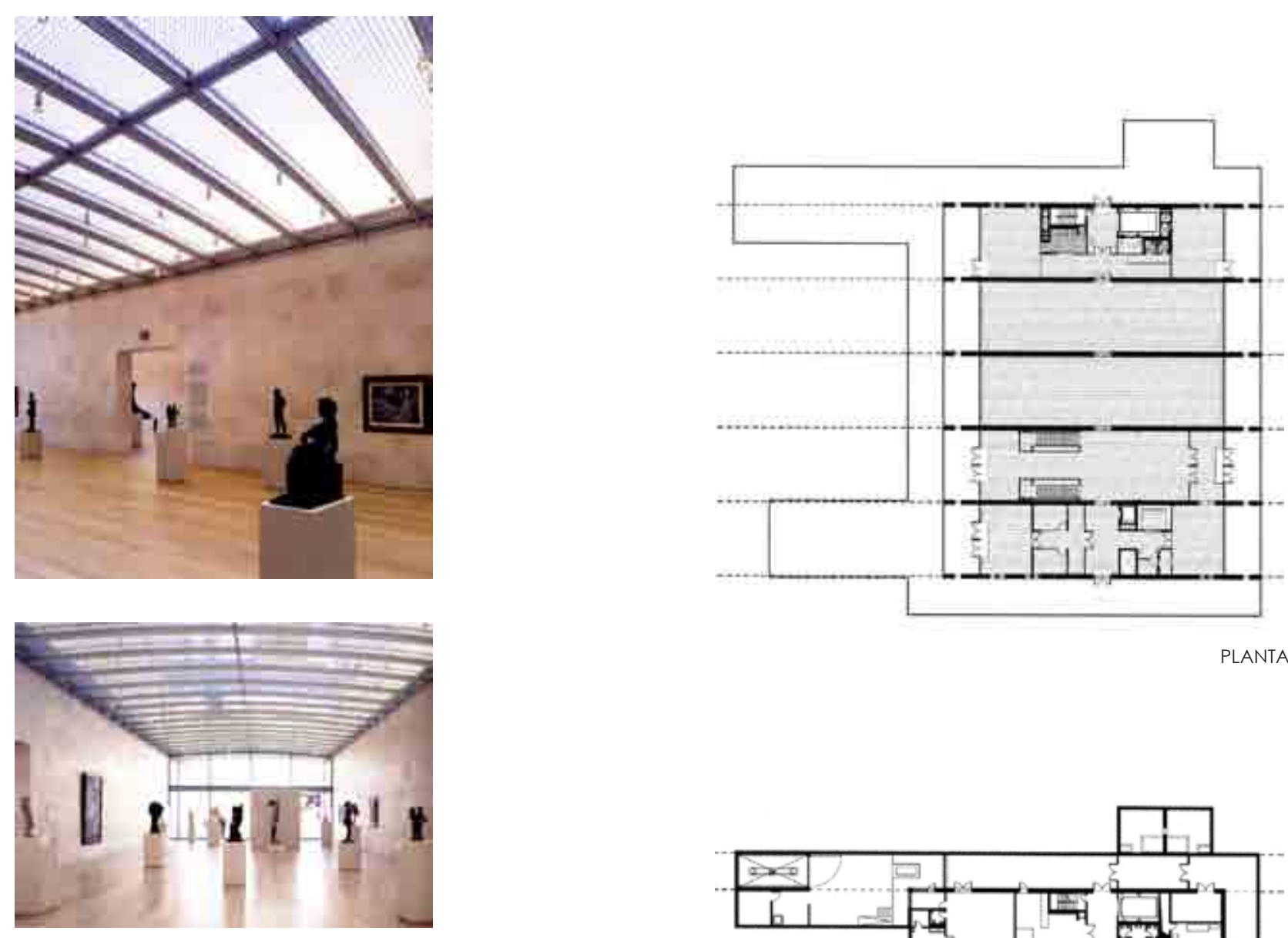

PLANTA BAJA
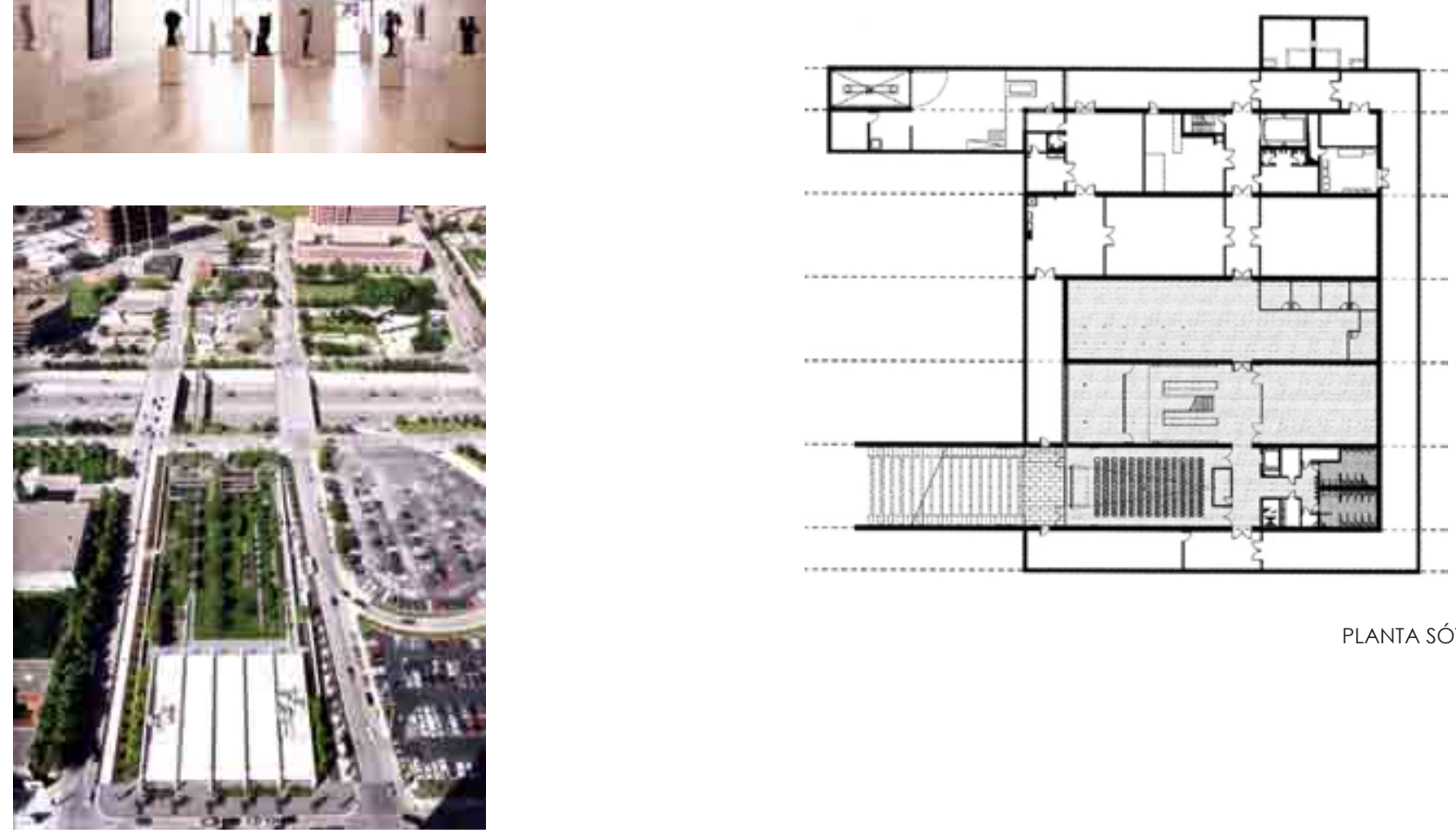

PLANTA SÓTANO 
ART INSTITUTE OF CHICAGO

Chicago, Illinois (USA) - Renzo Piano, 1999
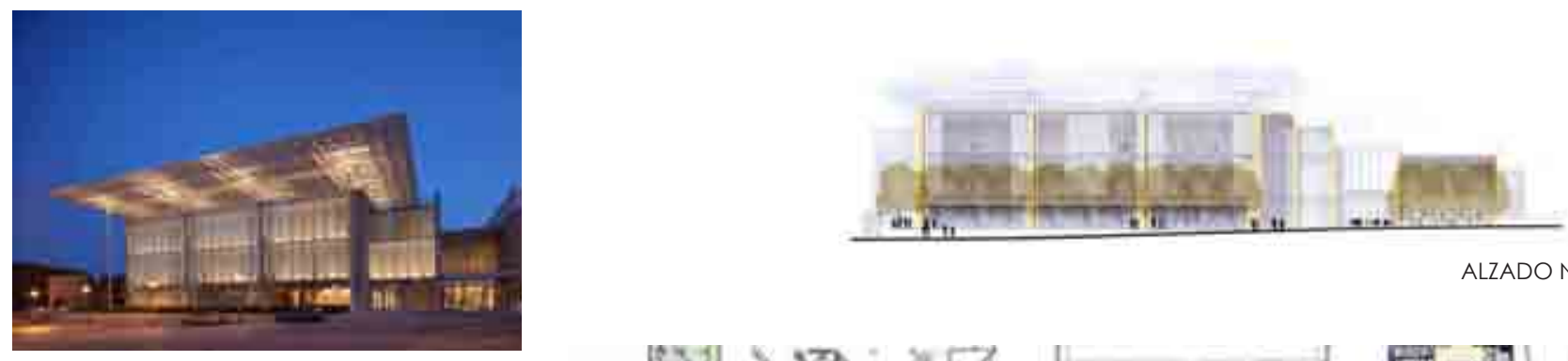

ALZADO NORTE
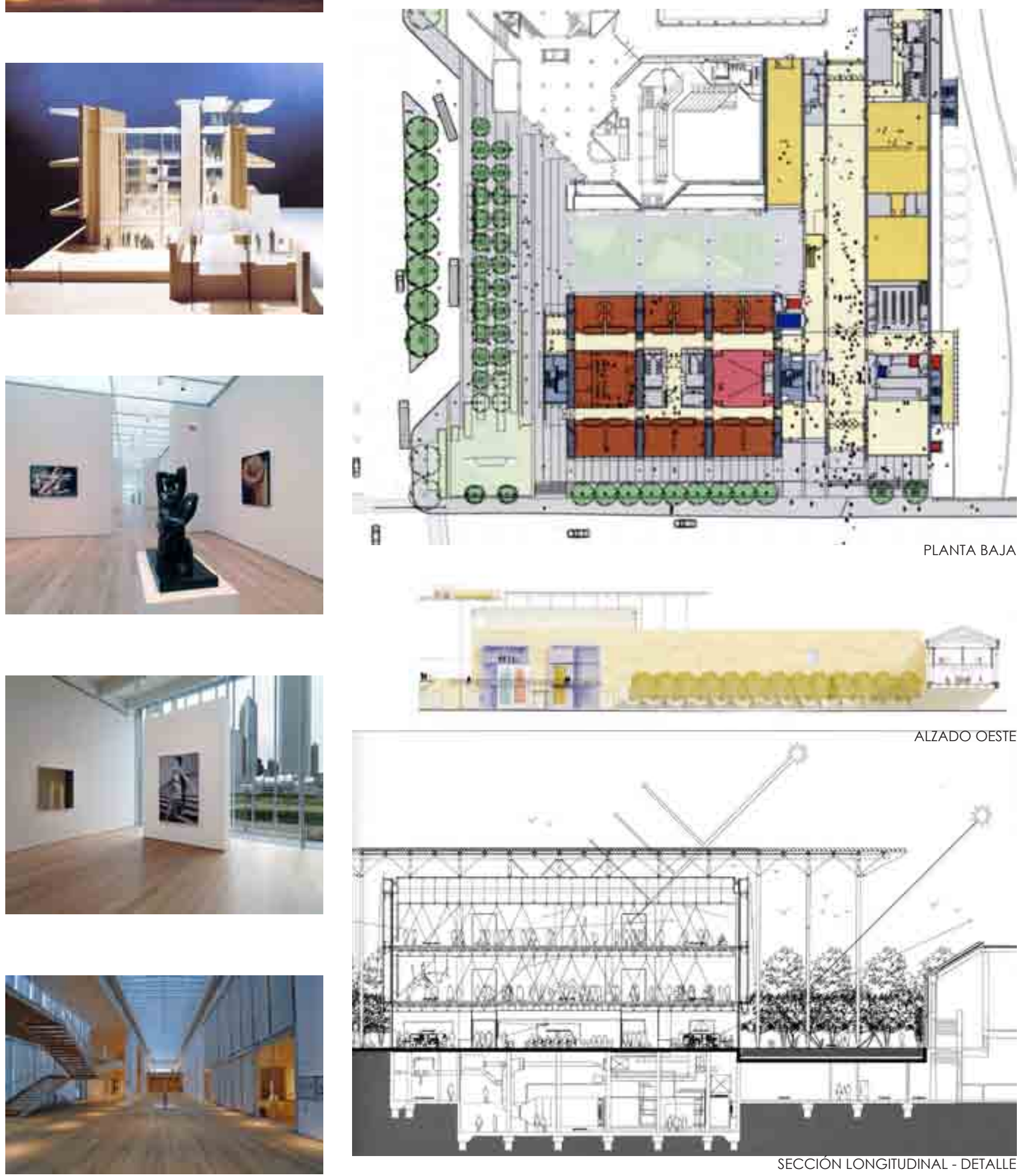

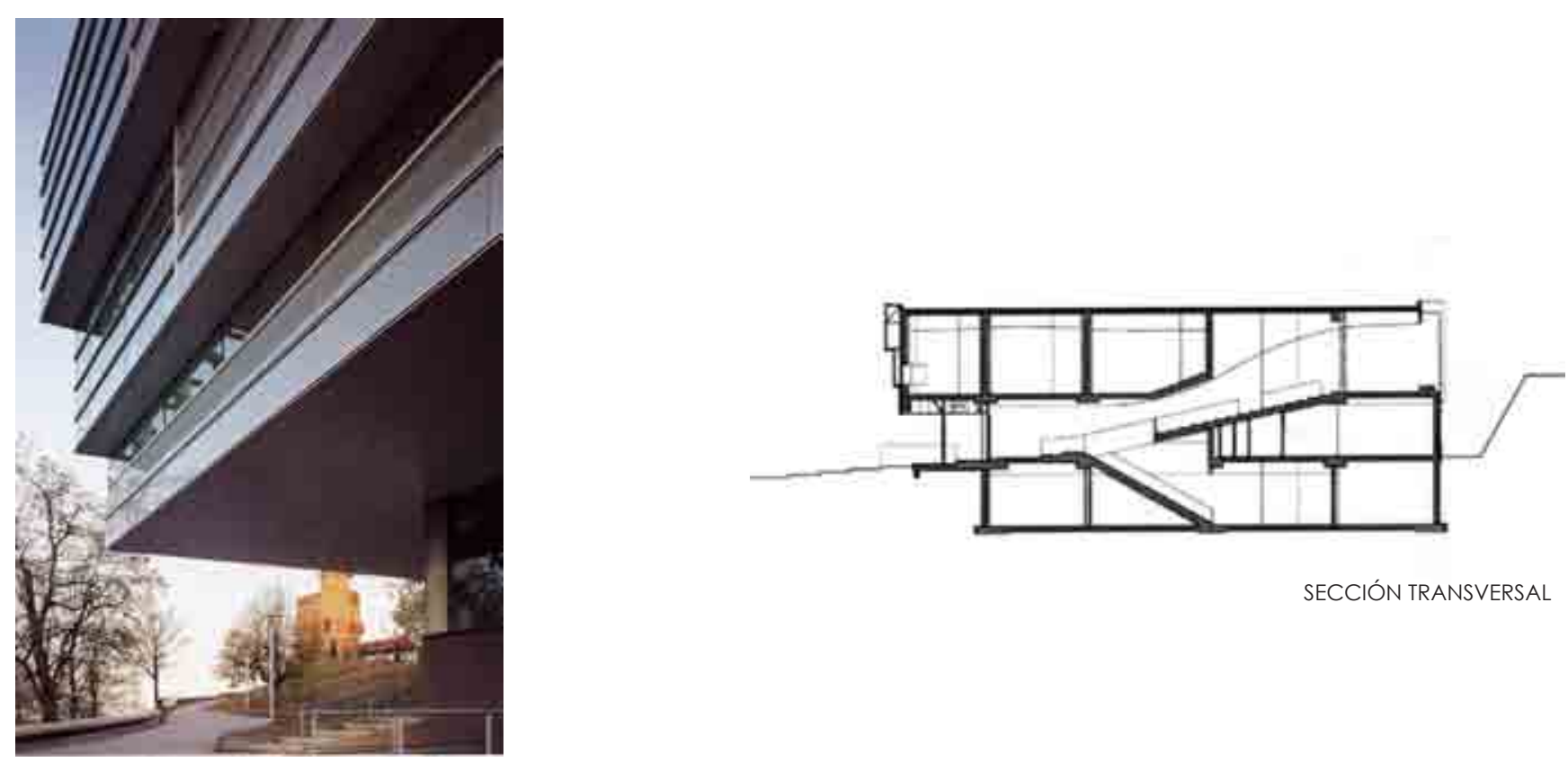

SECCIÓN TRANSVERSAL
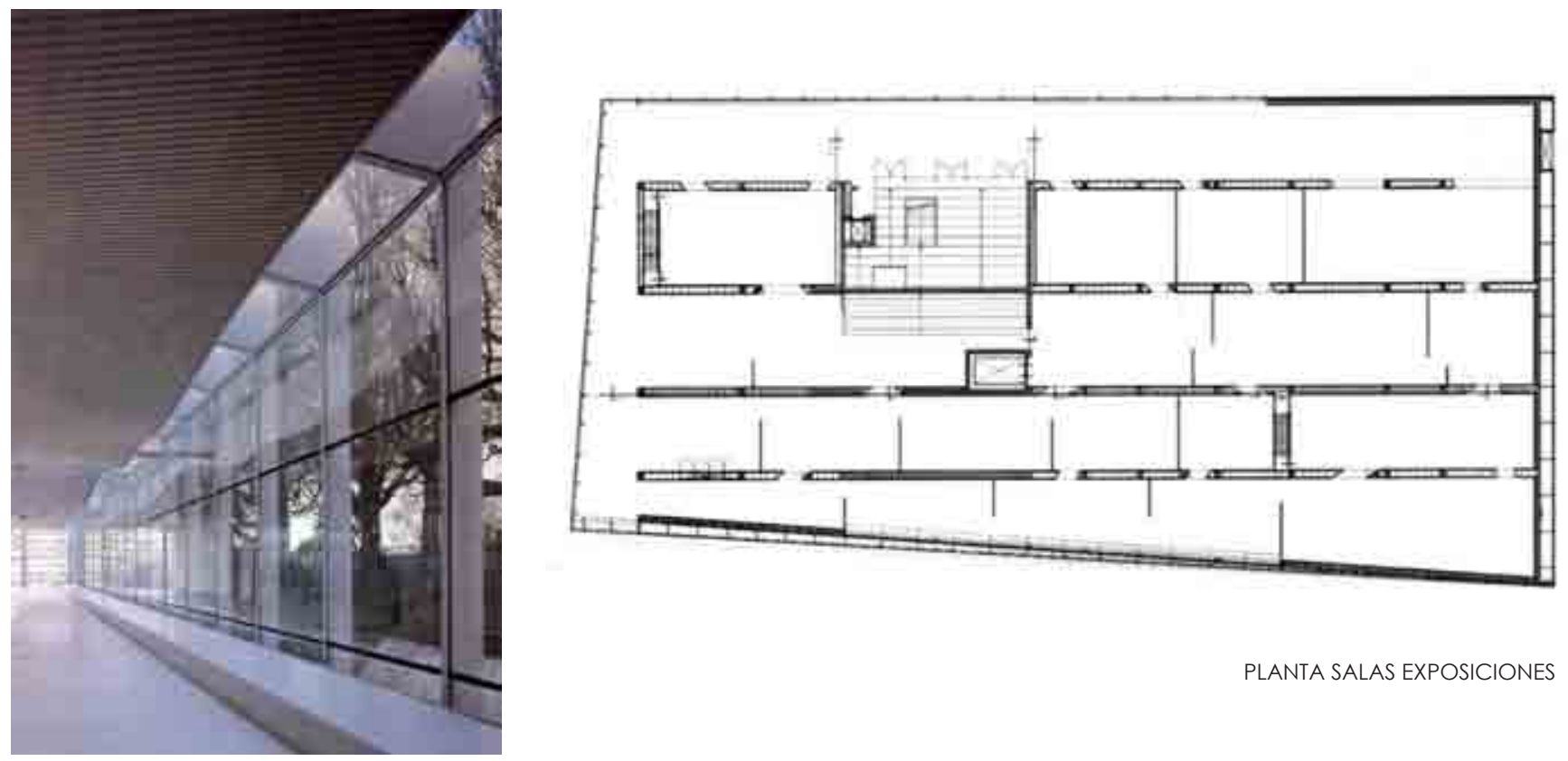

PLANTA SALAS EXPOSICIONES

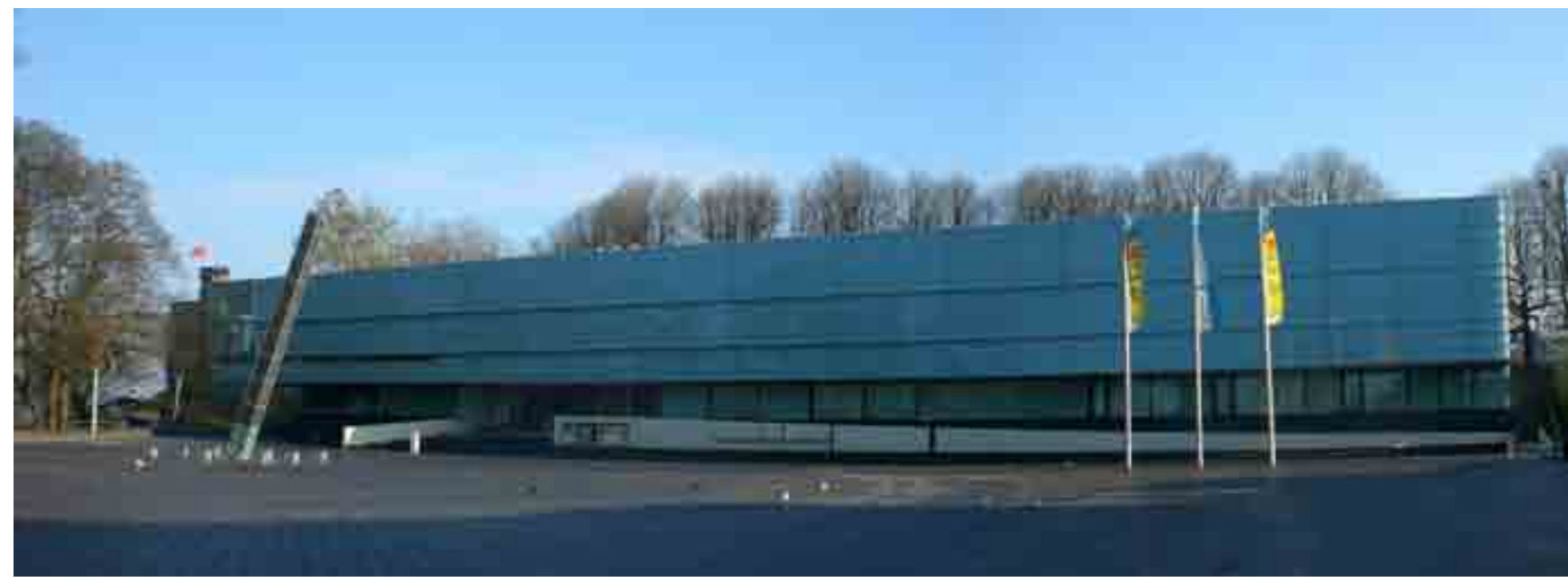


CENTRE PASQUART

Biel, Suiza - Diener \& Diener, 2000
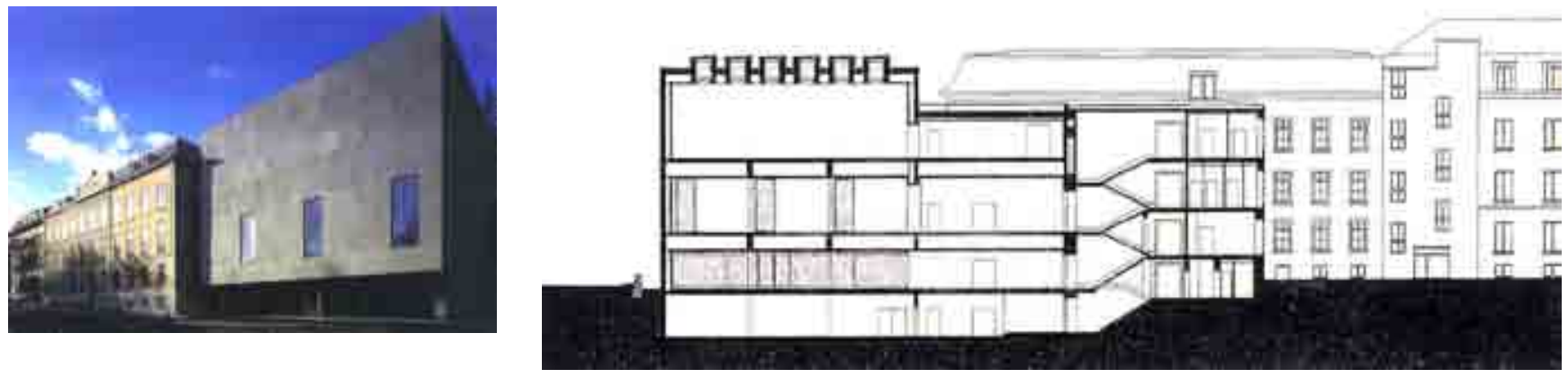

SECCIÓN LONGITUDONAL POR AMPLIACIÓN
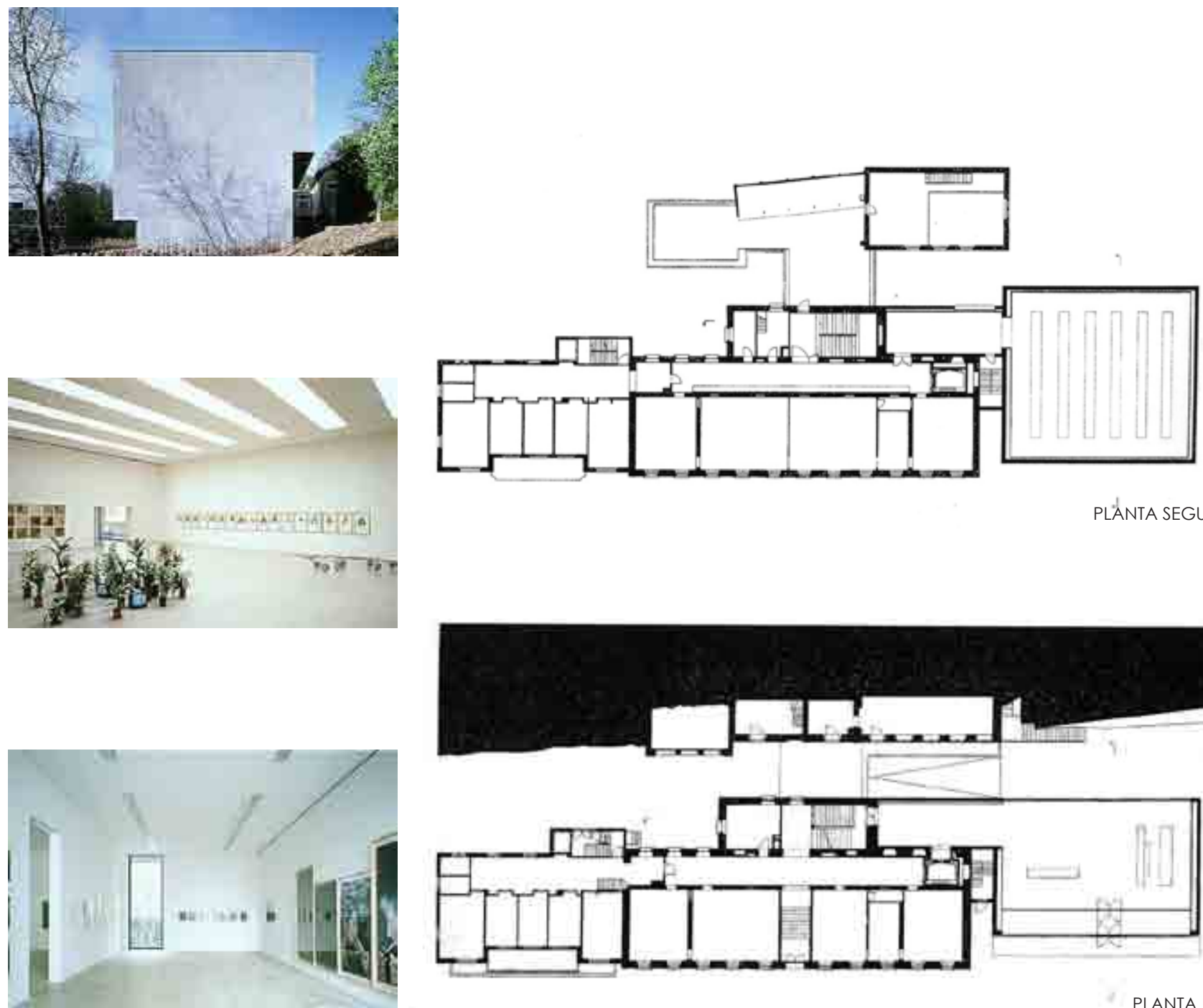

PLANTA SEGUNDA

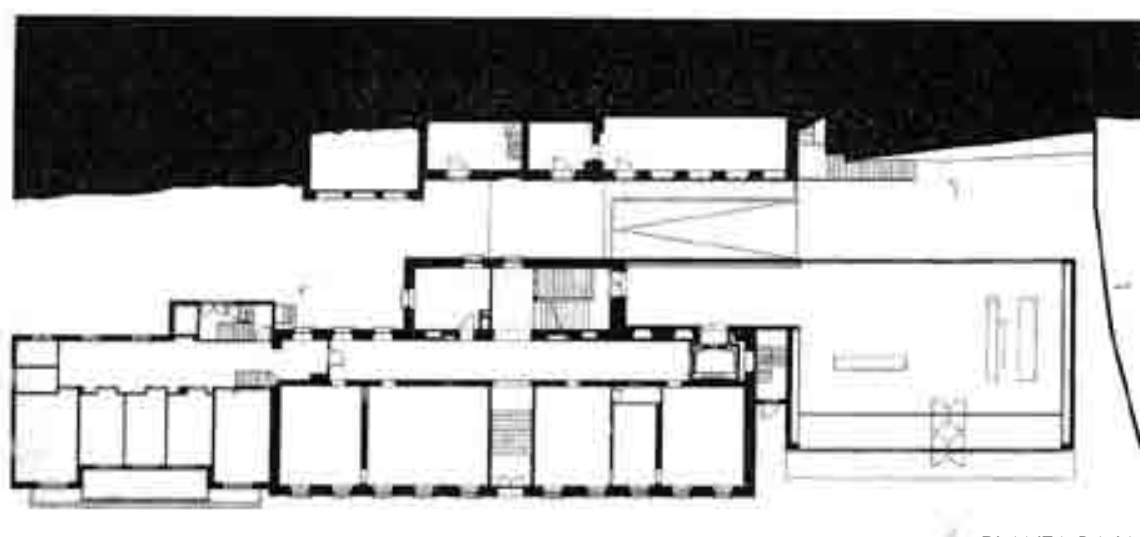

PLANTA BAJA 

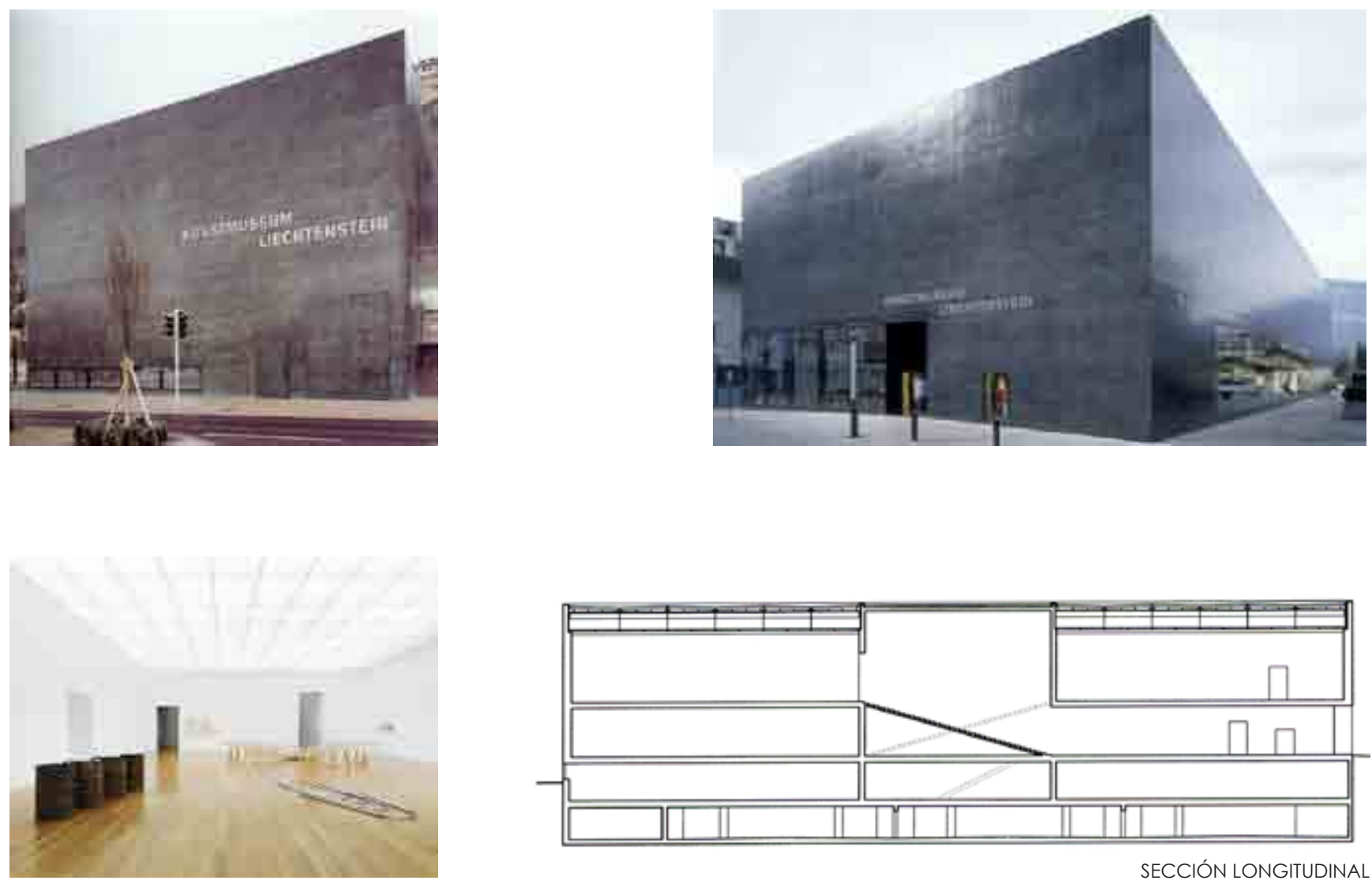

SECCIÓN LONGITUDINAL POR HALL Y SALAS
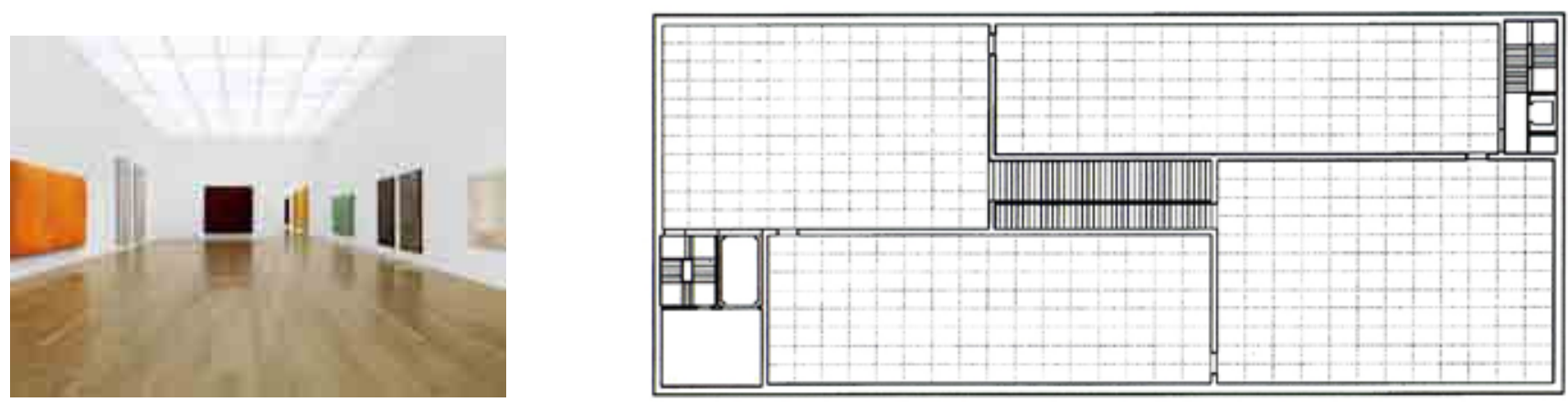

PLANTA PRIMERA EXPOSICIONES PERMANENTES
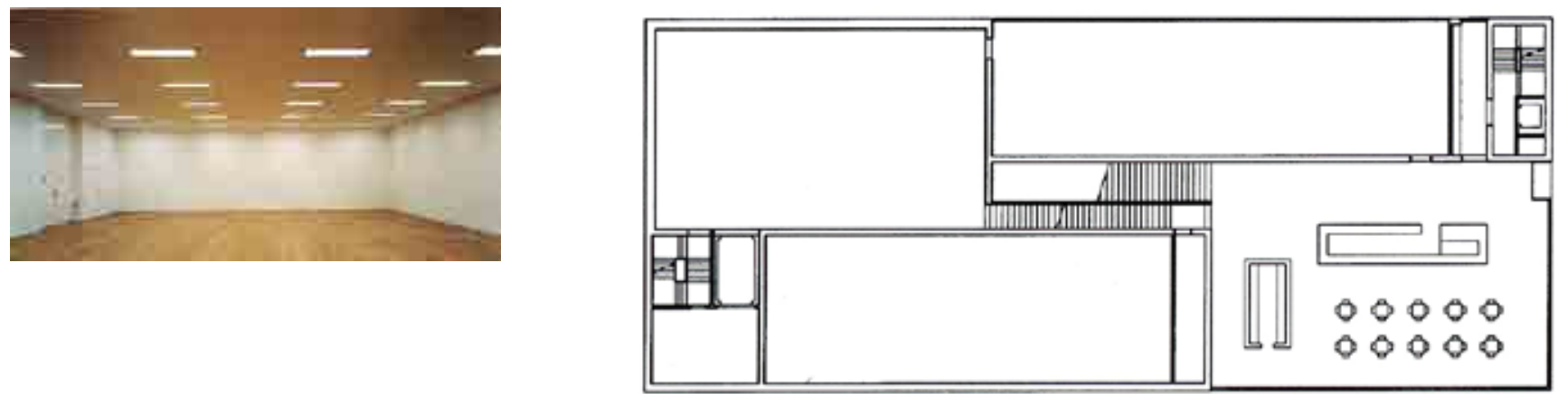
CONCURSO PARA EL MUSEO DE ARTE Y DISEÑO DE INGOLSTADT

Ingolstadt, Alemania - Gigon \& Guyer, 2000
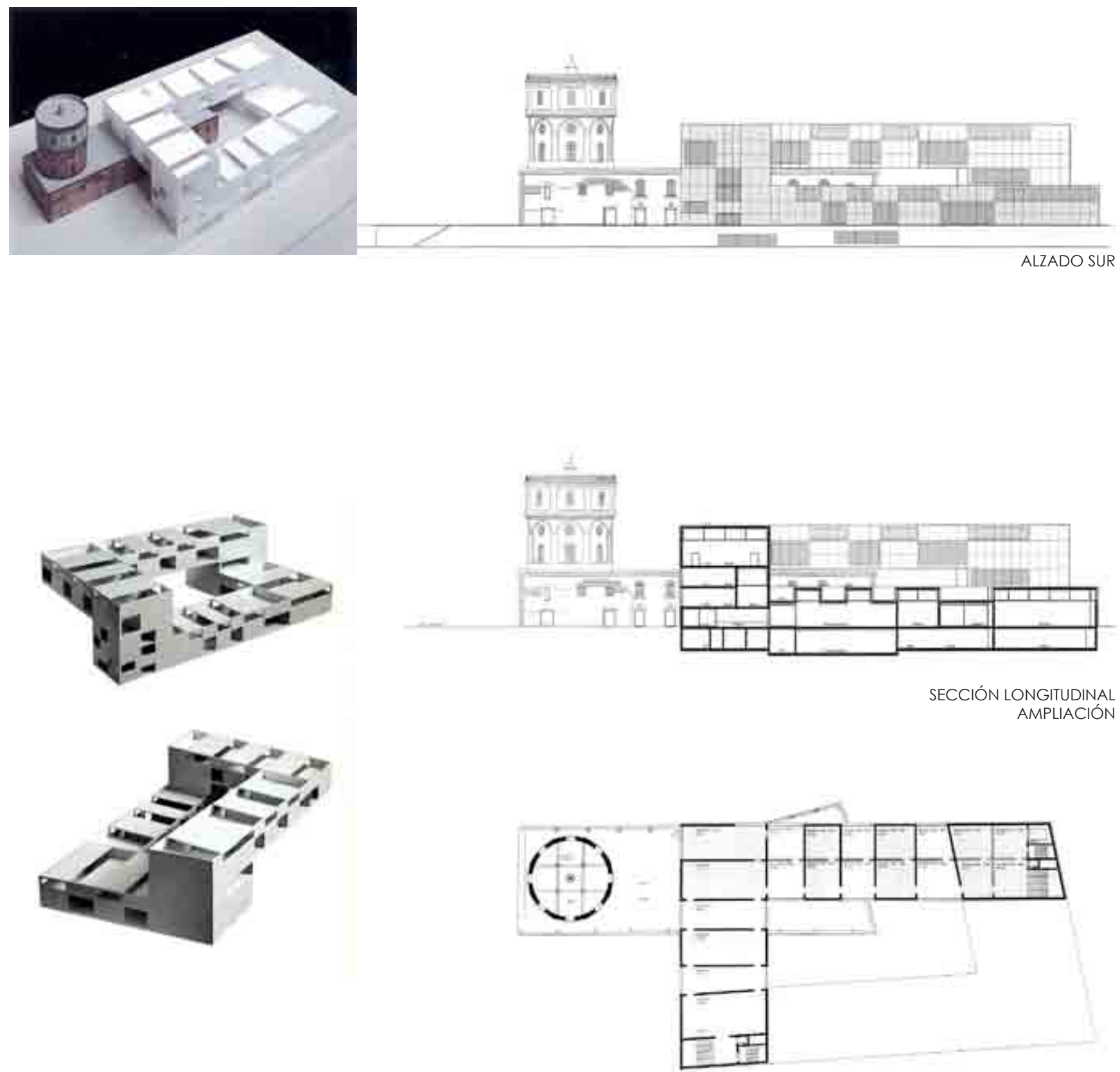

PLANTA NIVELES SUPERIORES

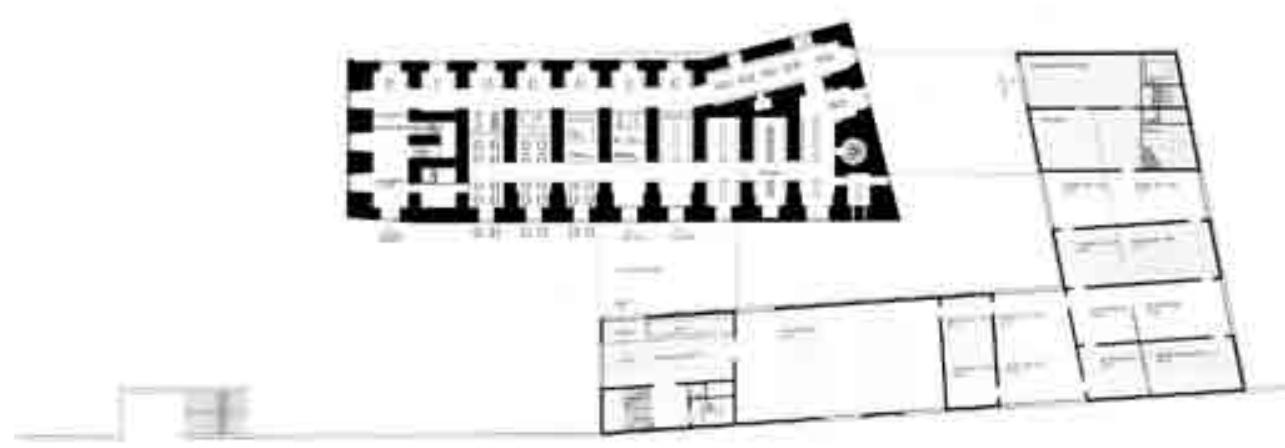

PLANTA BAJA 

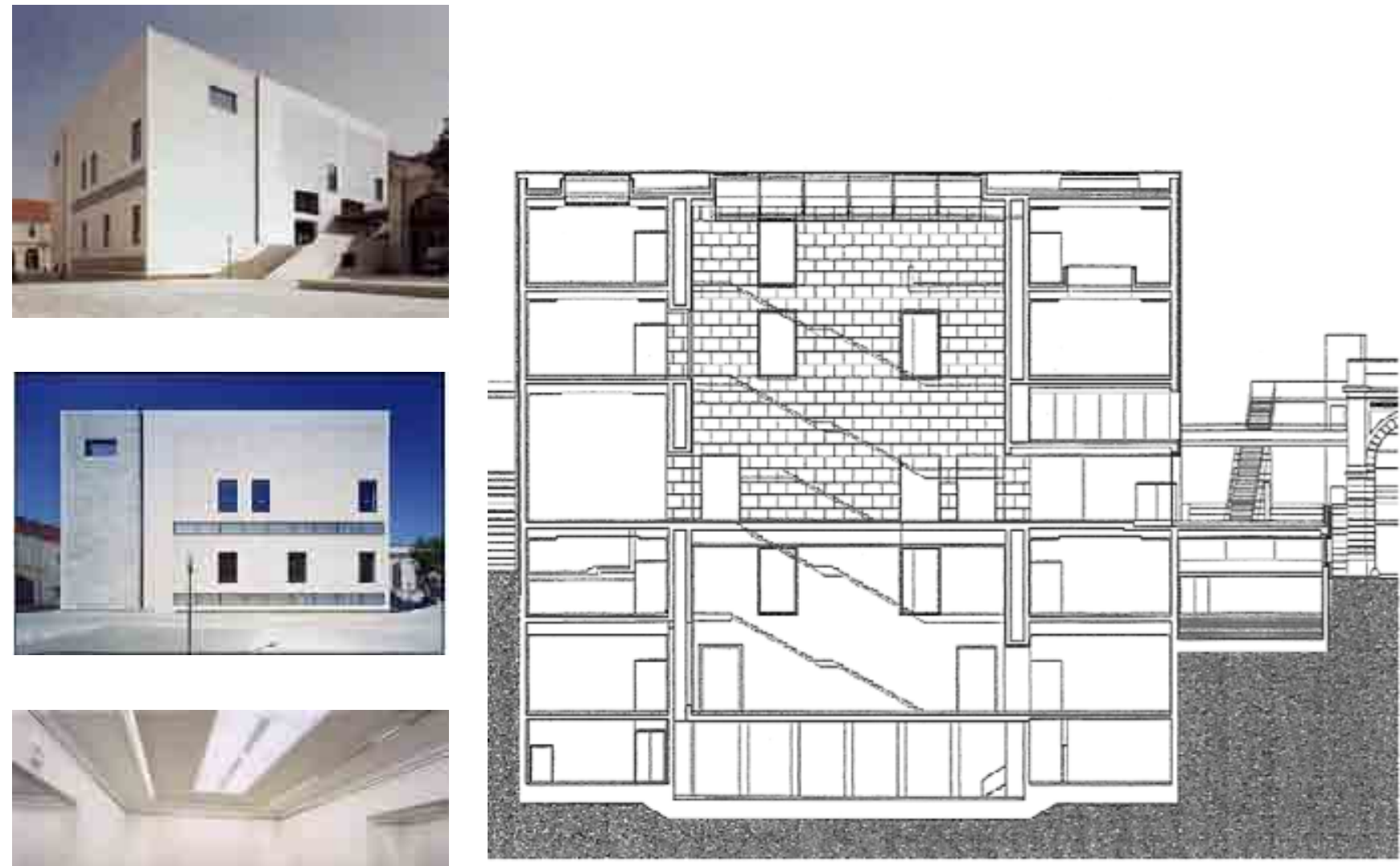

SECCIÓN POR PATIO CENTRAL
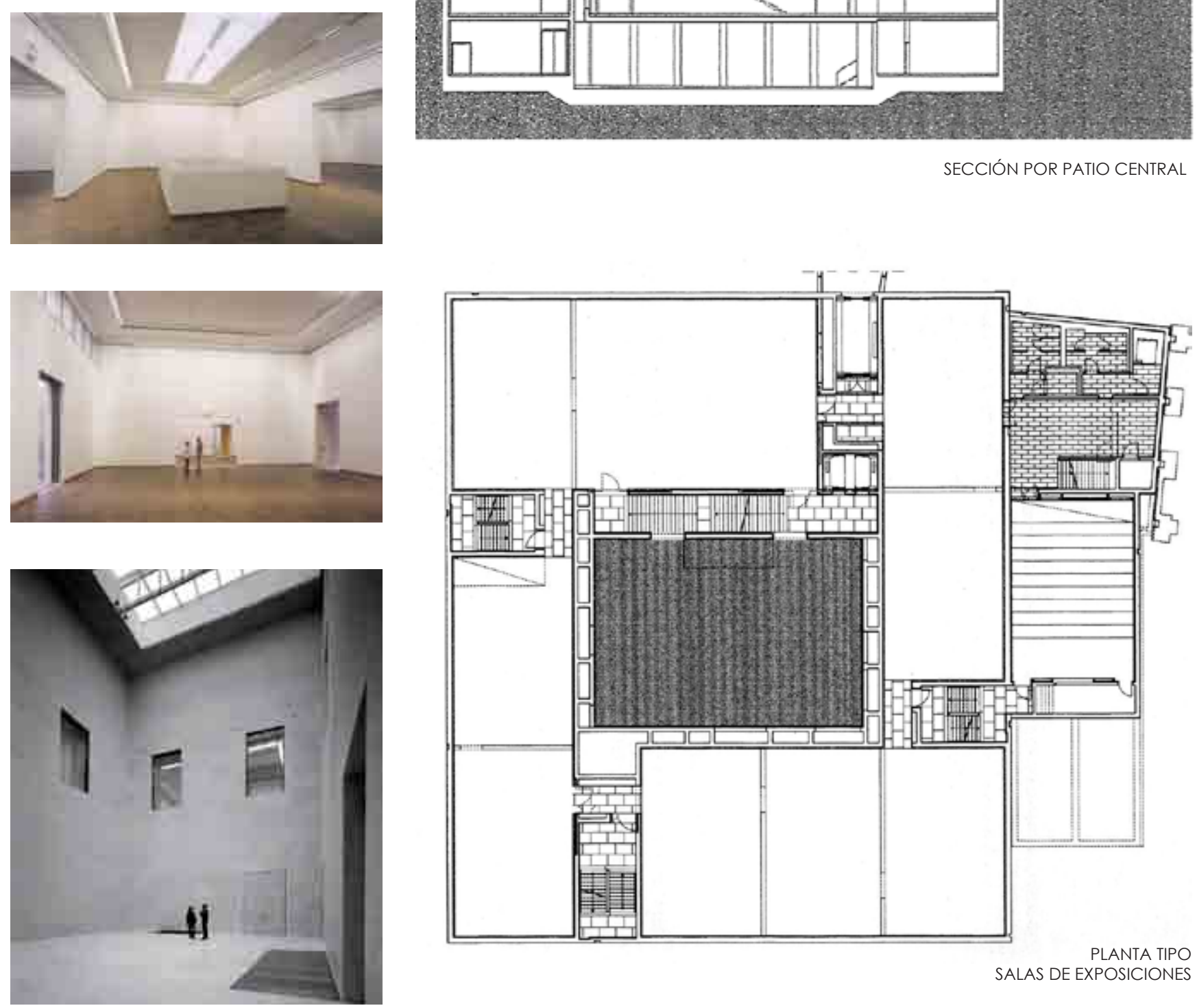
MUSEUM MODERNER KUNST STIFTUNG LUDWIG (MUSEUMSQUARTIER)

Viena, Austria - Ortner \& Ortner, 2000
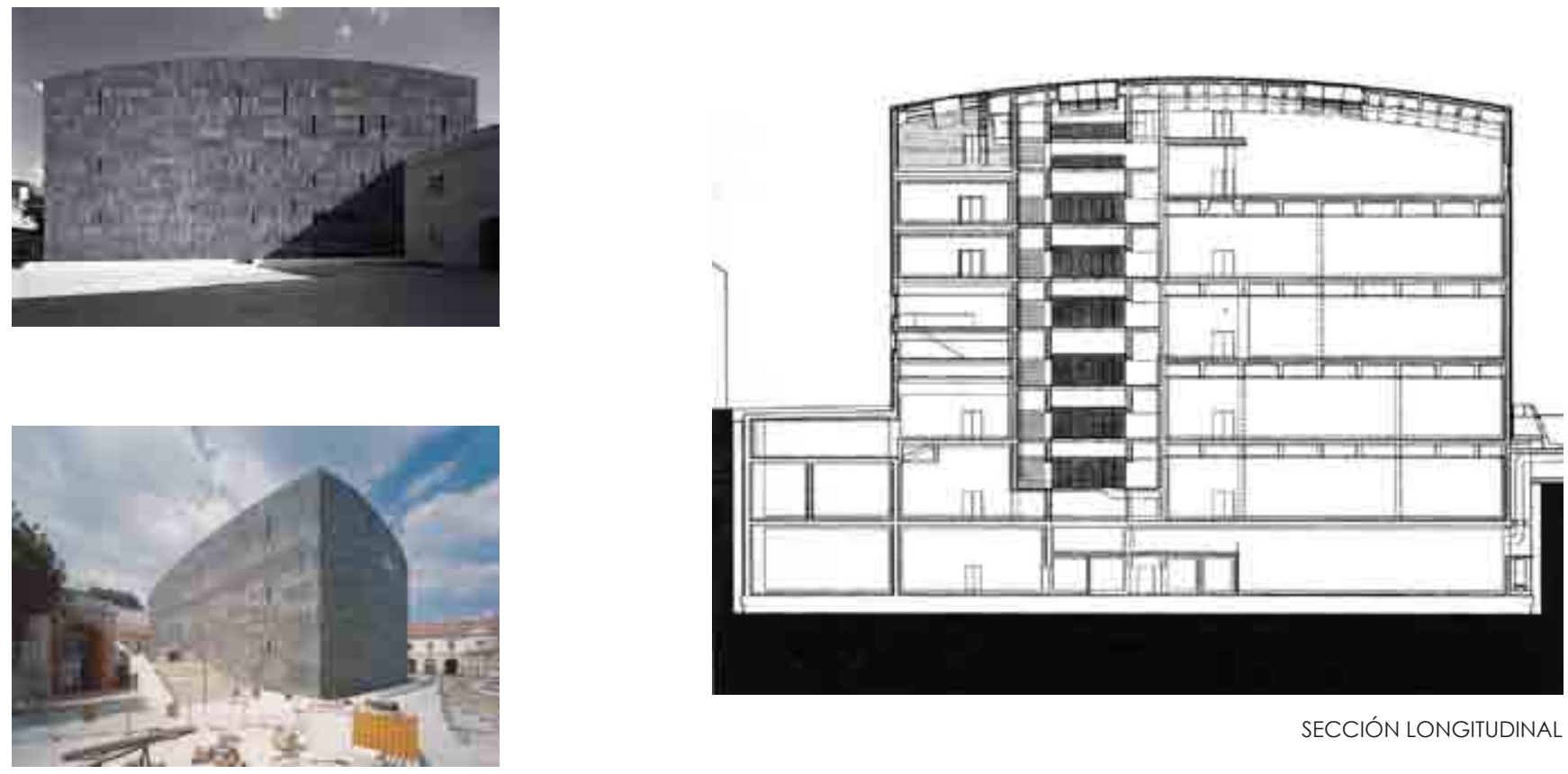

SECCIÓN LONGITUDINAL
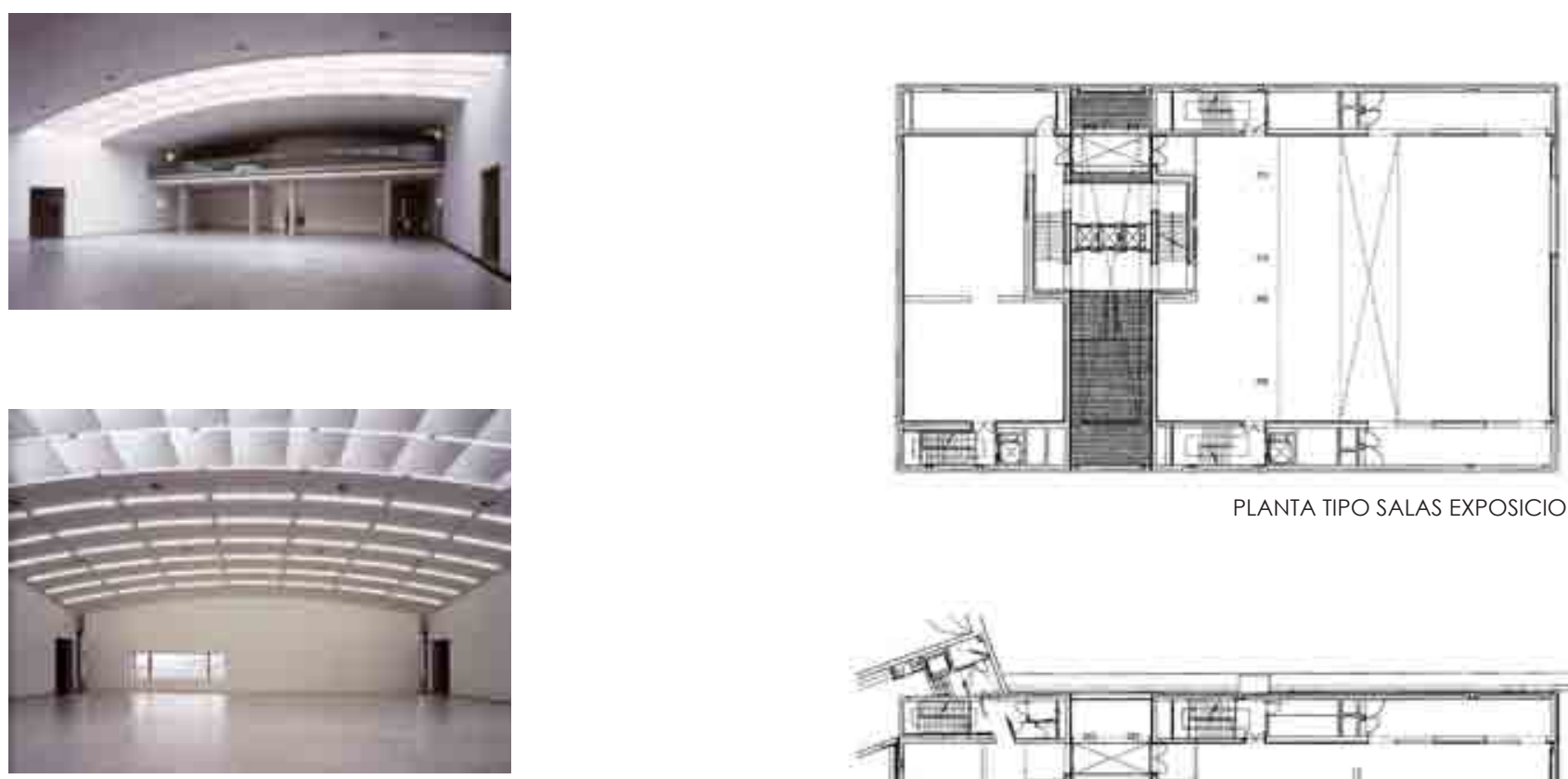

PLANTA TIPO SALAS EXPOSICIONES
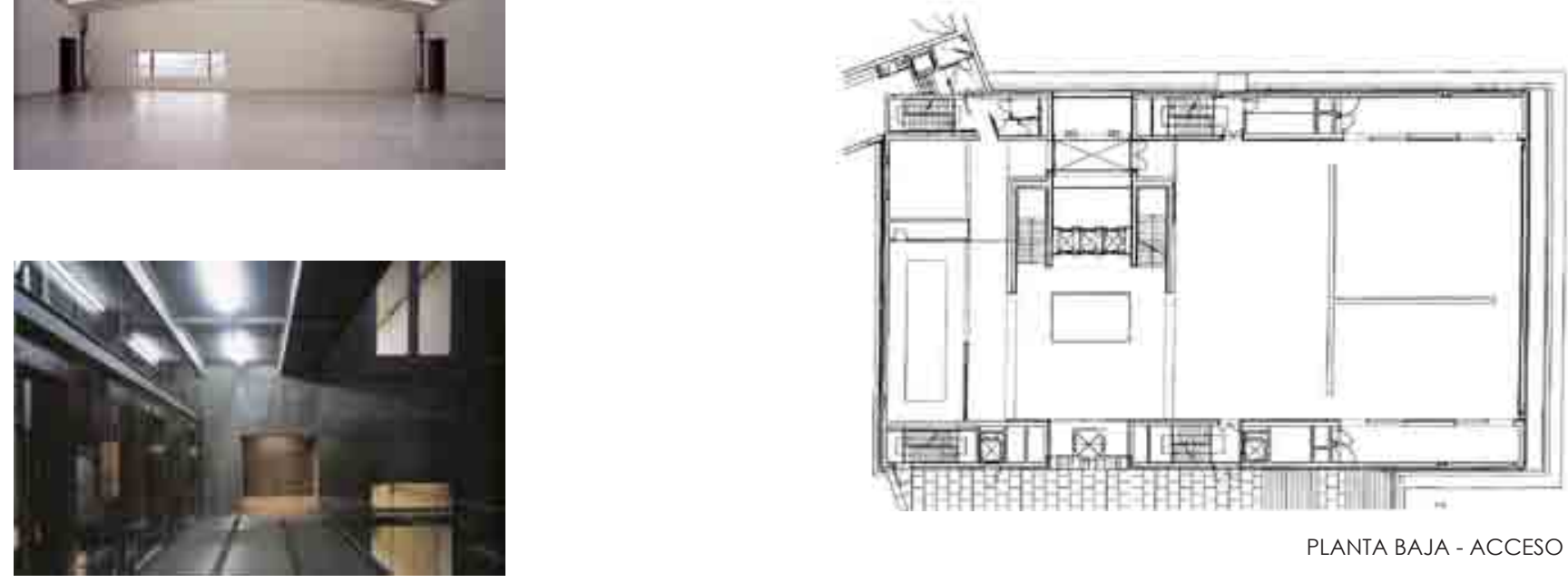

PLANTA BAJA - ACCESO 

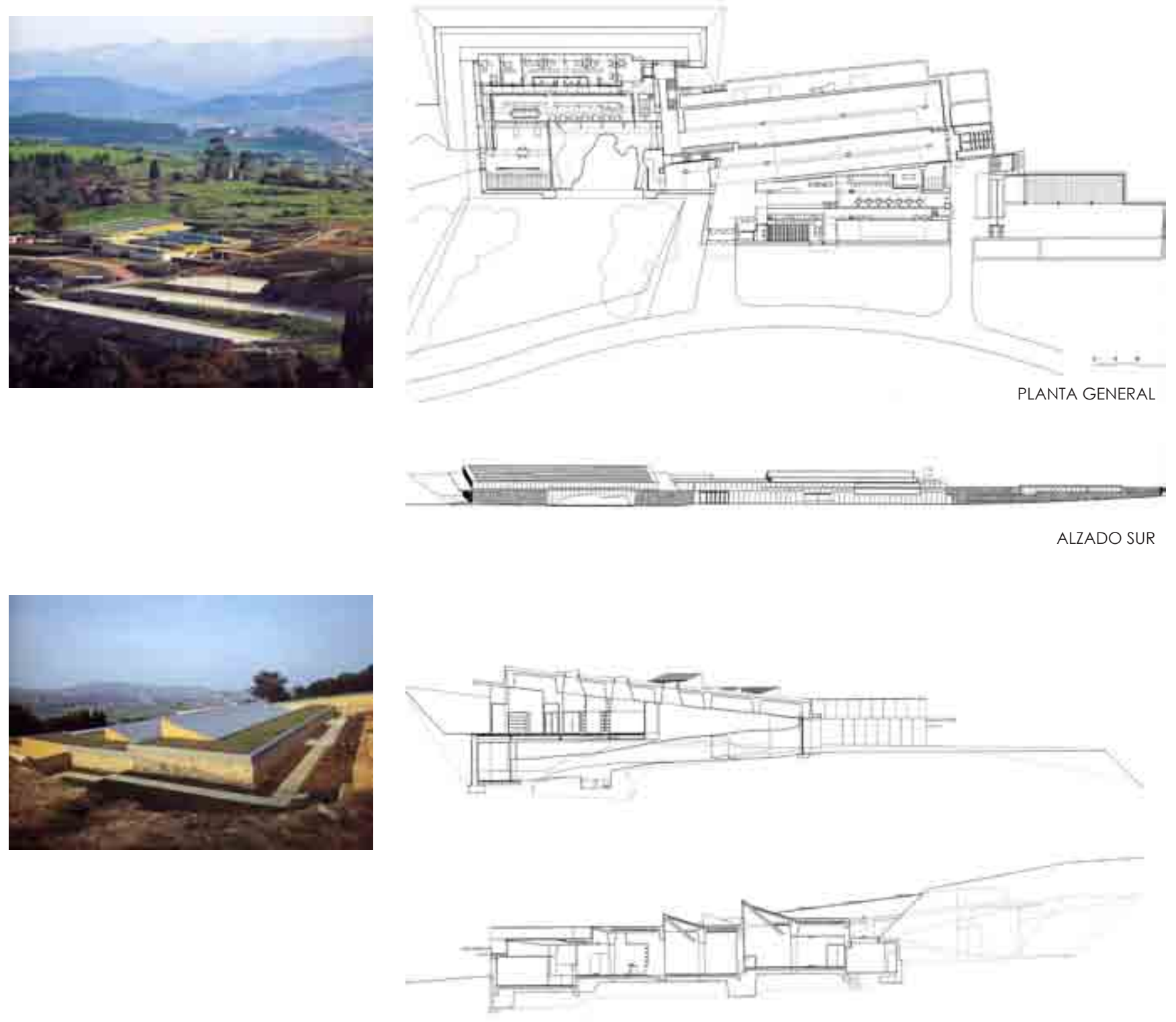

SECCIONES TRANSVERSALES

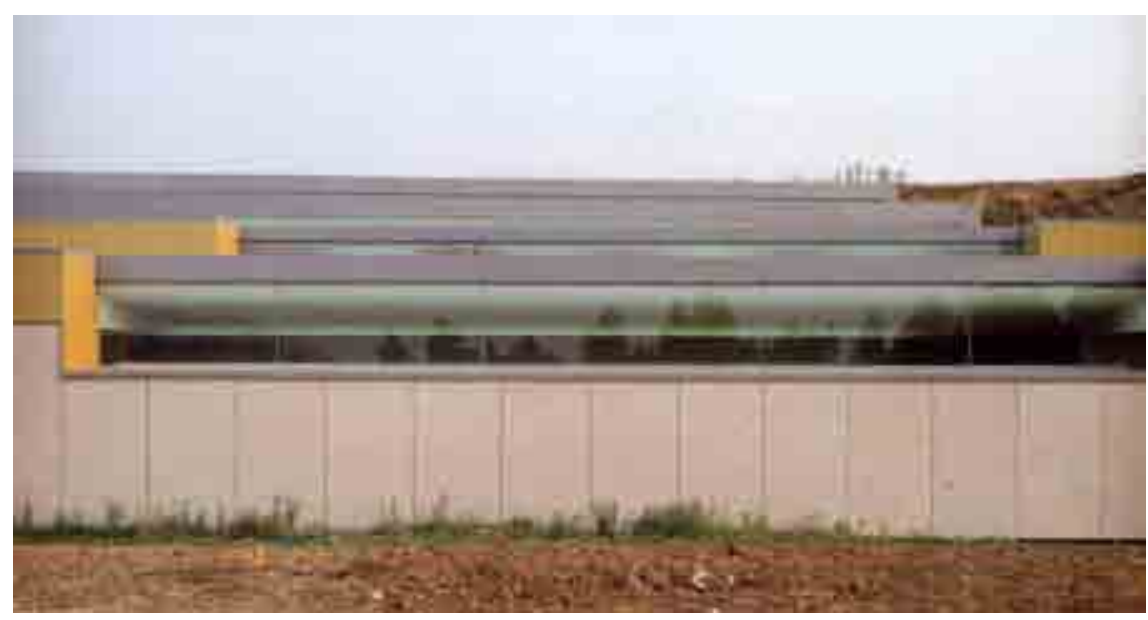

DETALLE 
AMPLIACIÓN DE LA GALLERIA NAZIONALE D'ARTE MODERNA E CONTEMPORANEA

Roma, Italia - Diener \& Diener - 2000
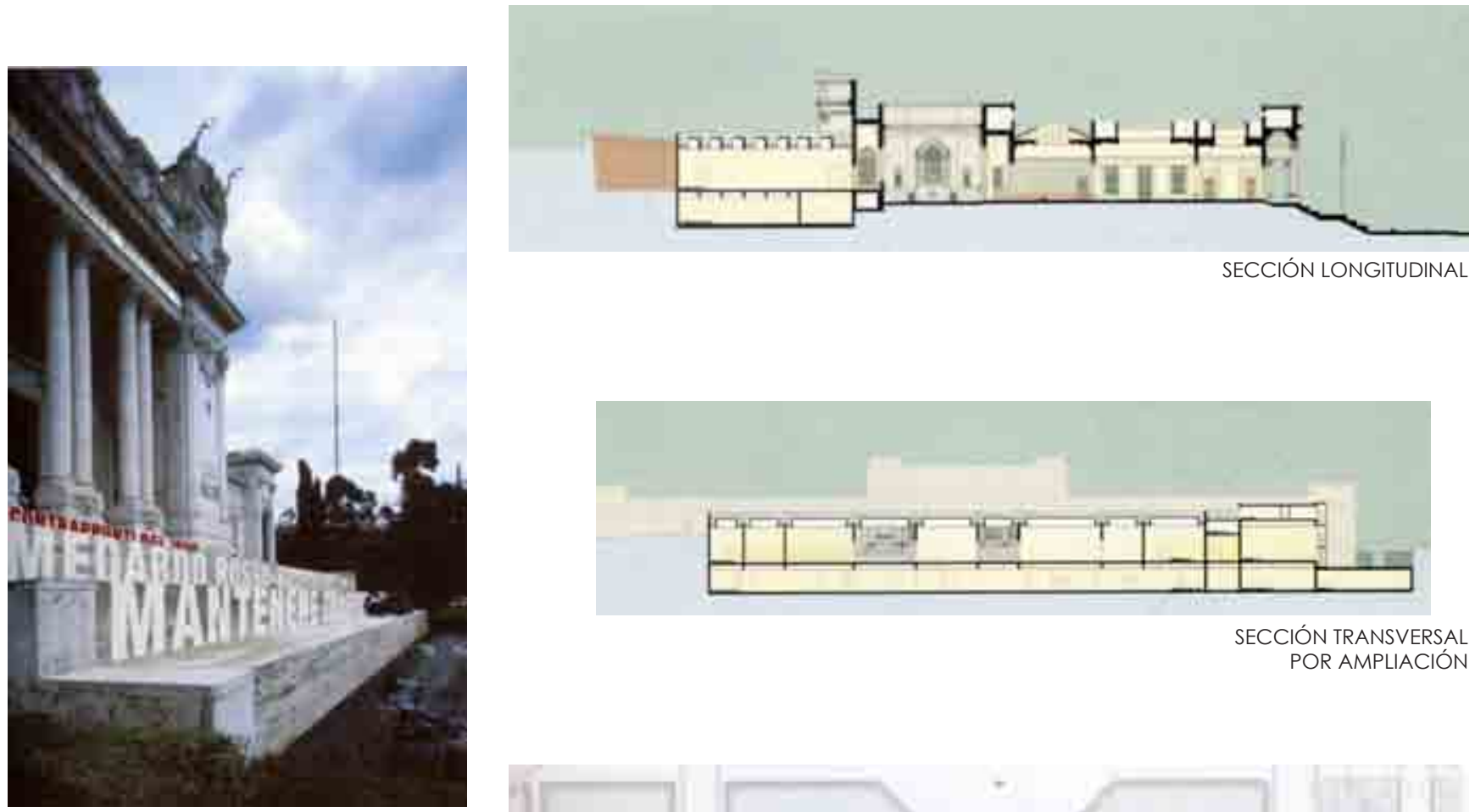

SECCIÓN LONGITUDINAL
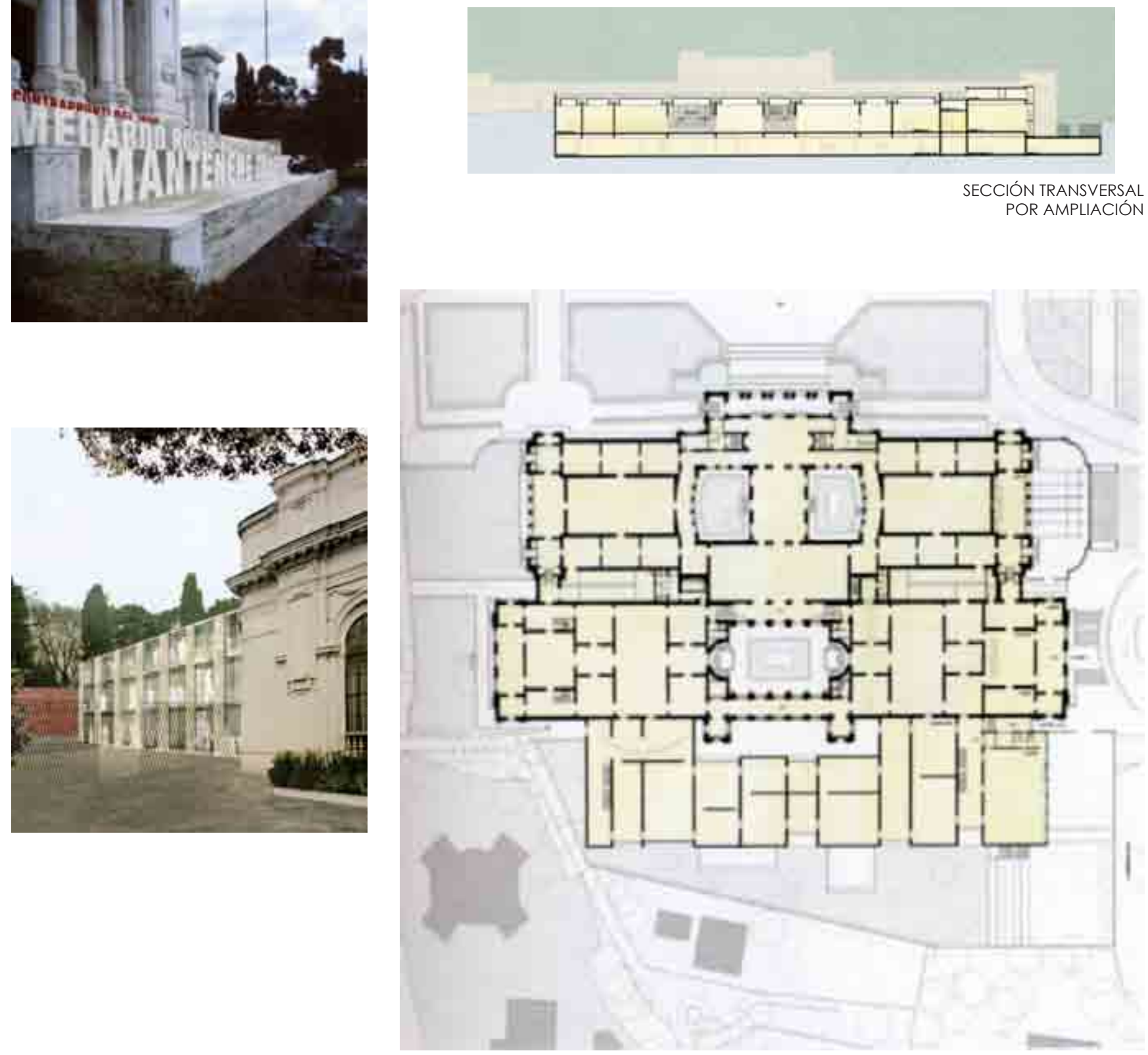

PLANTA BAJA 

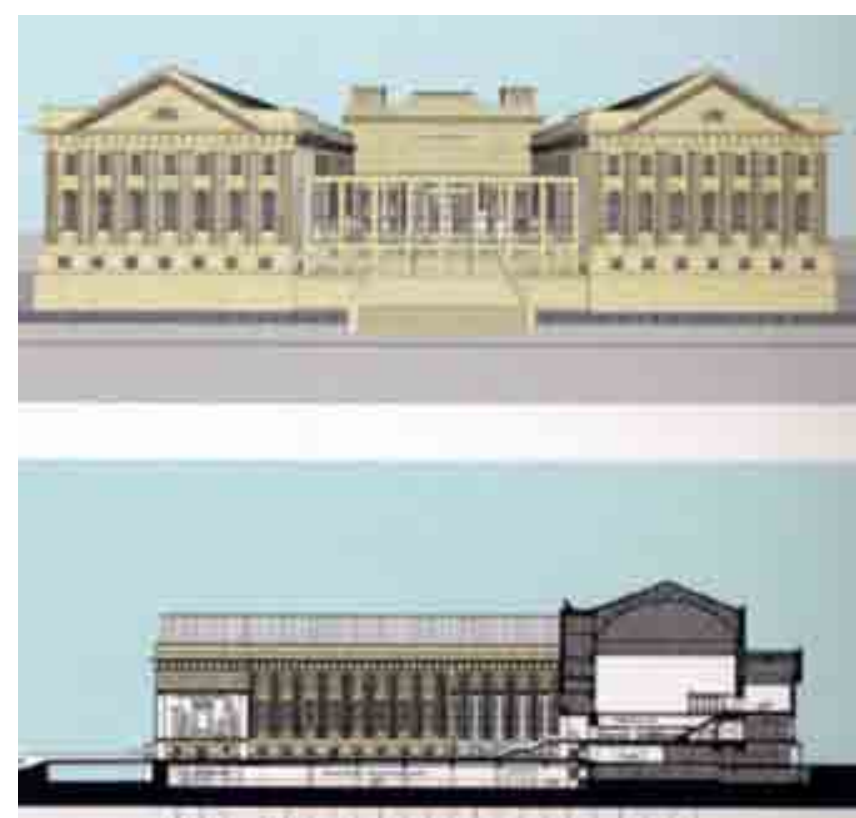

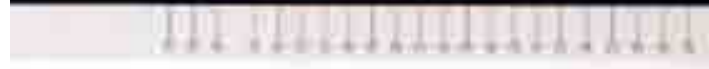

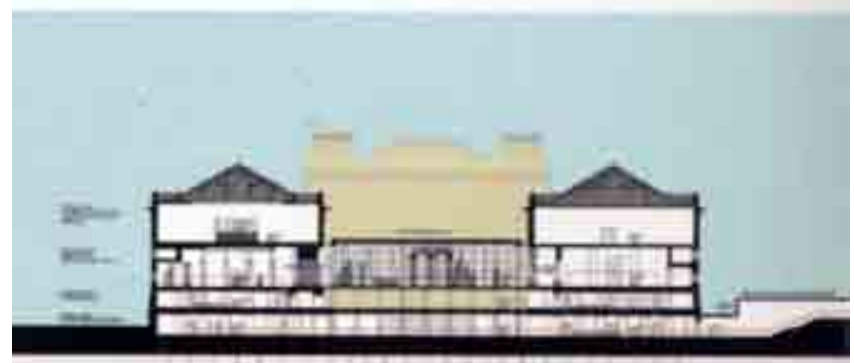

SECCIONES
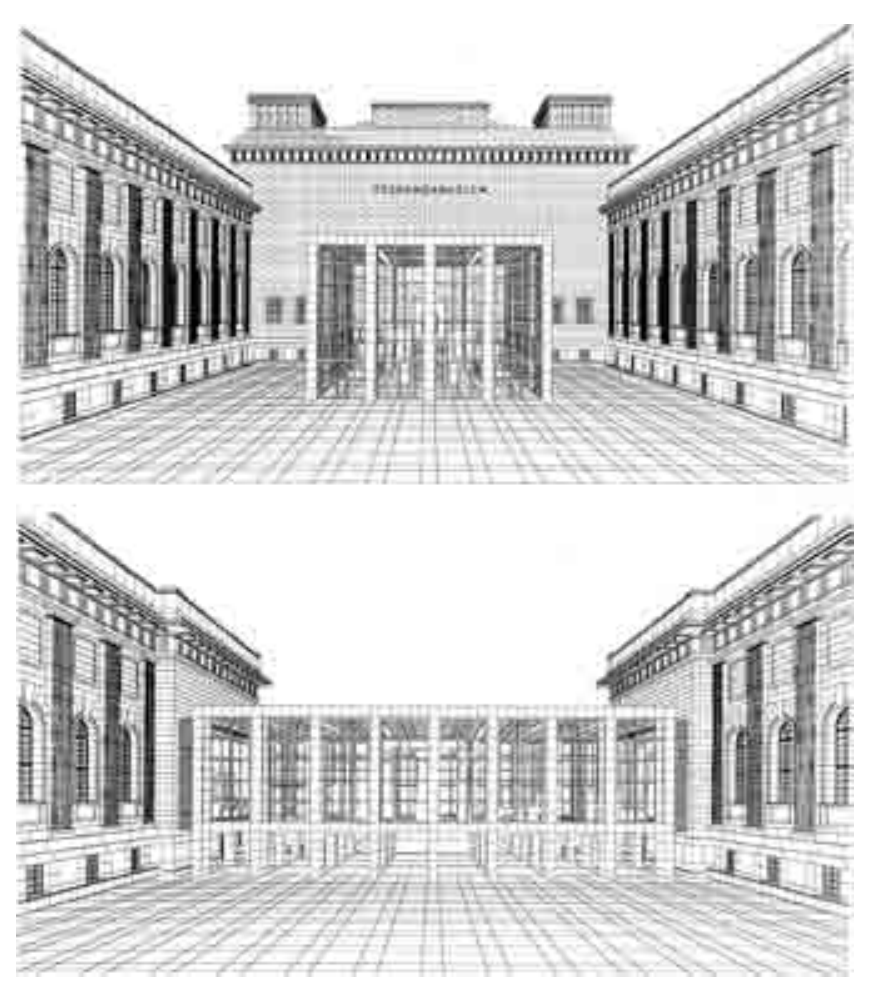

VISTAS DEL PATIO
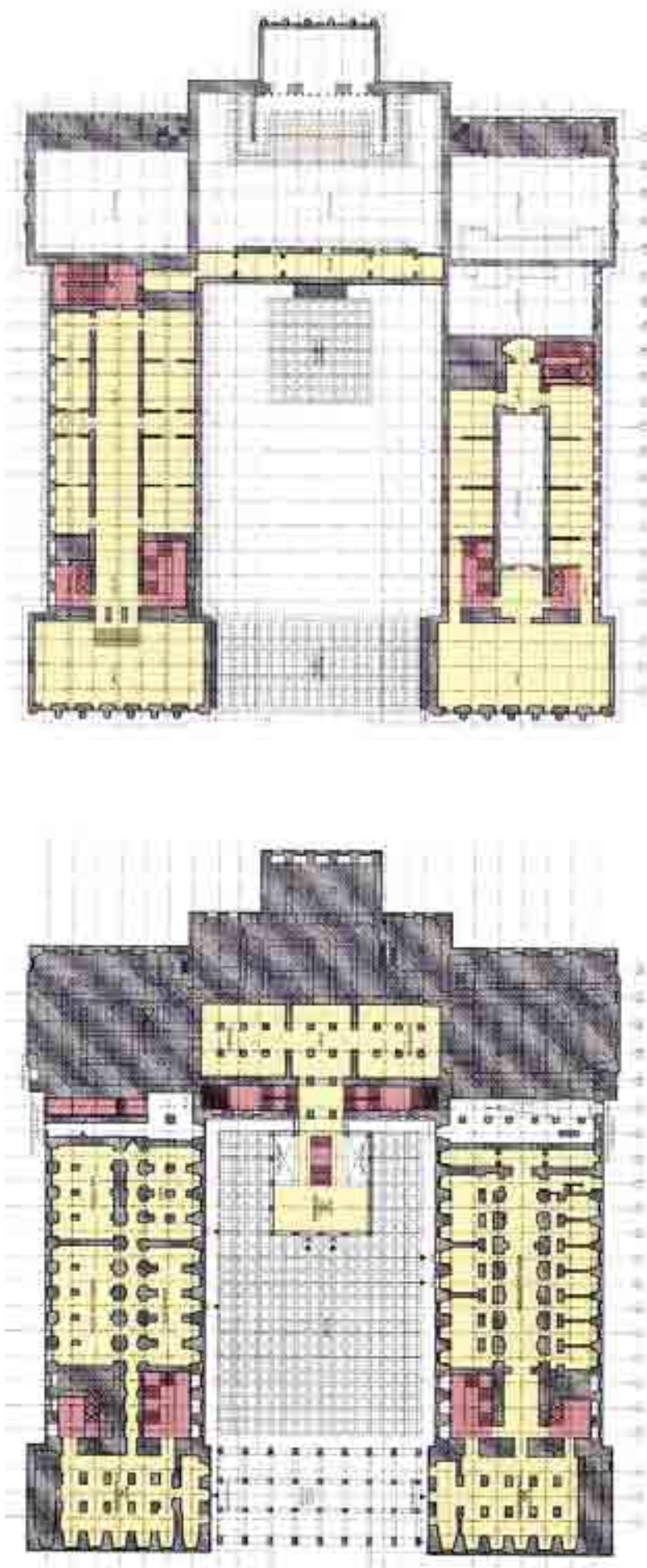

PLANTAS CON ESQUEMA DE USOS 
MUSEUM DER BILDENDEN KÜNSTE

Leipzig, Alemania - Hufnagel, Pütz \& Rafaelian - 2000
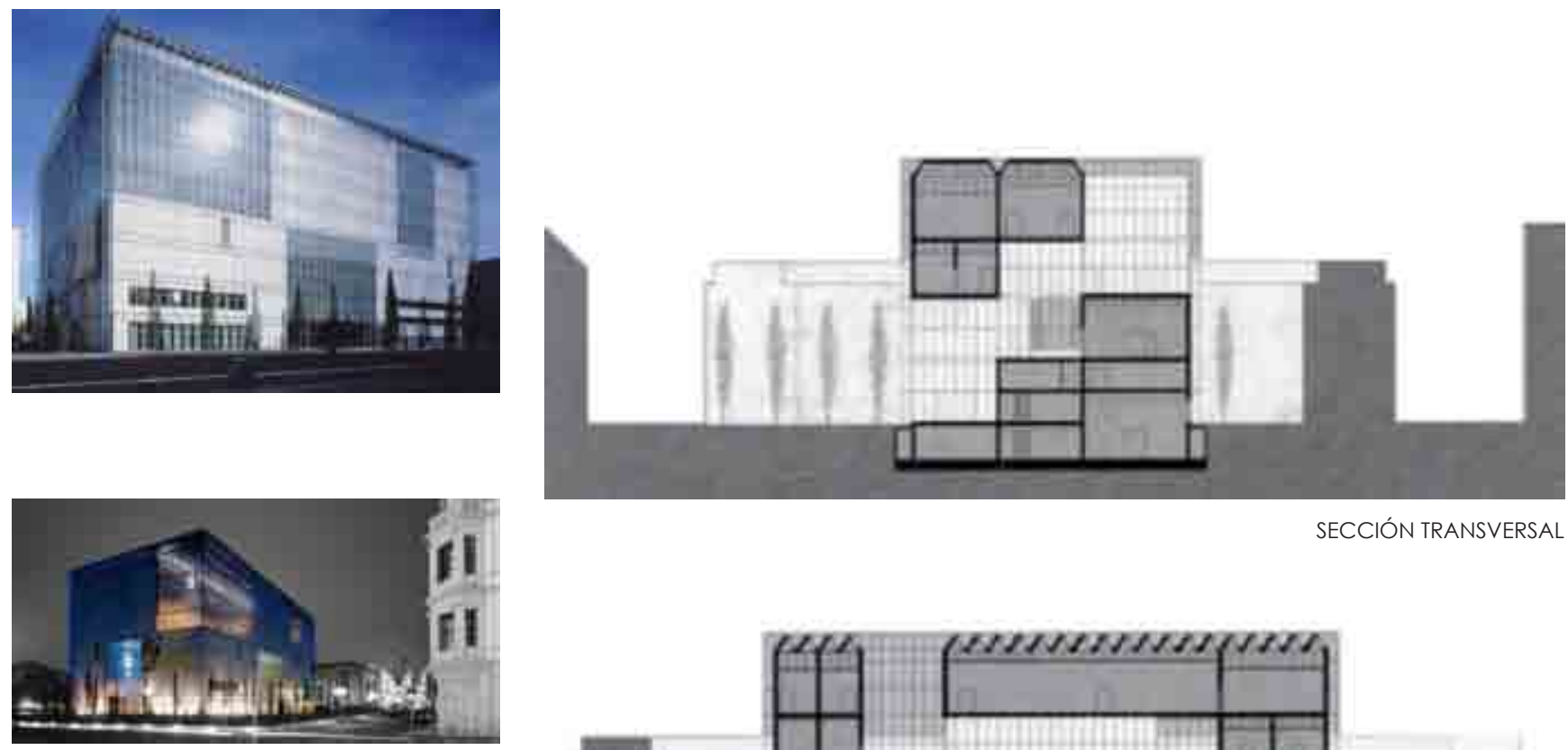

SECCIÓN TRANSVERSAL
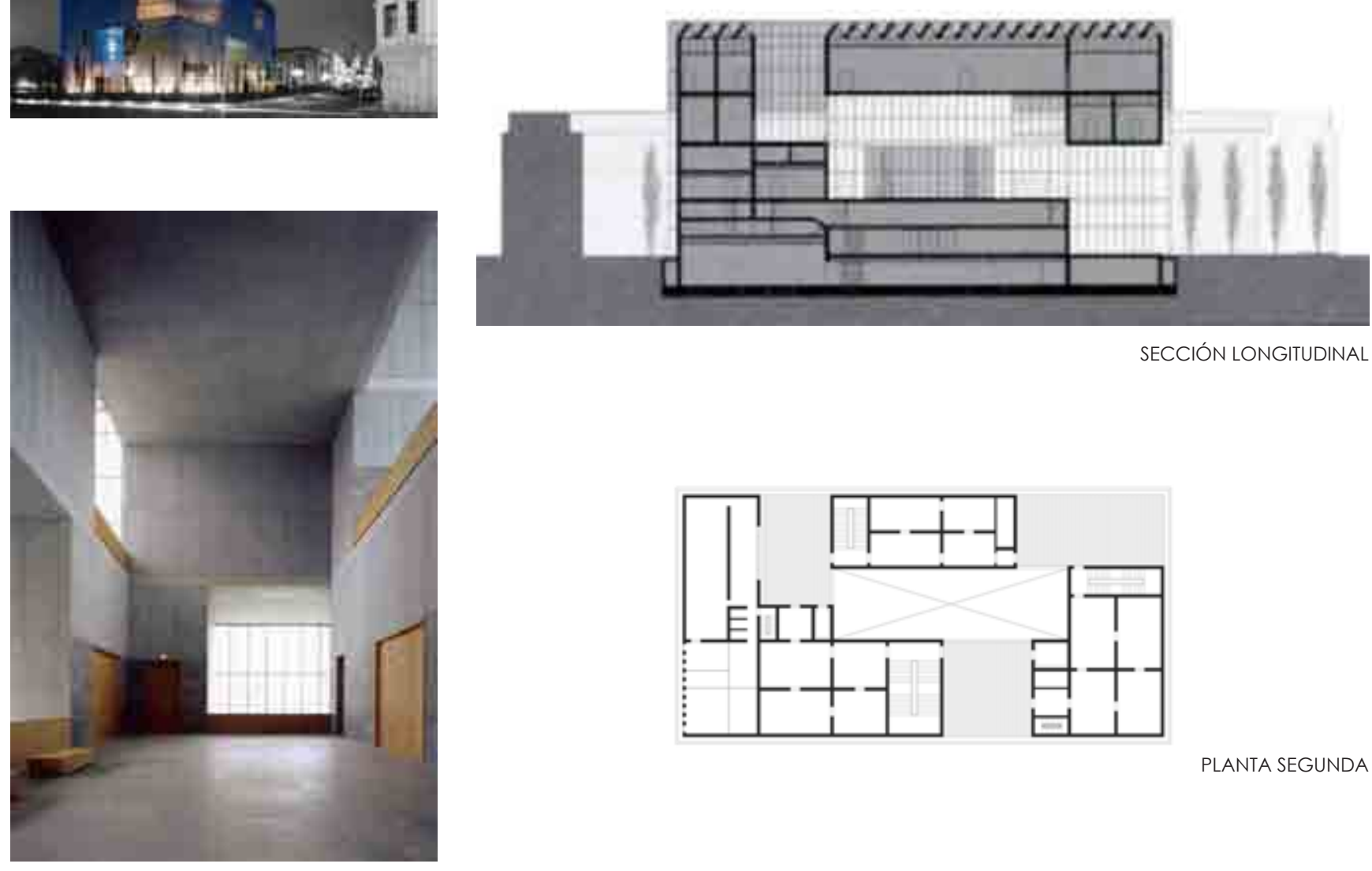

SECCIÓN LONGITUDINAL

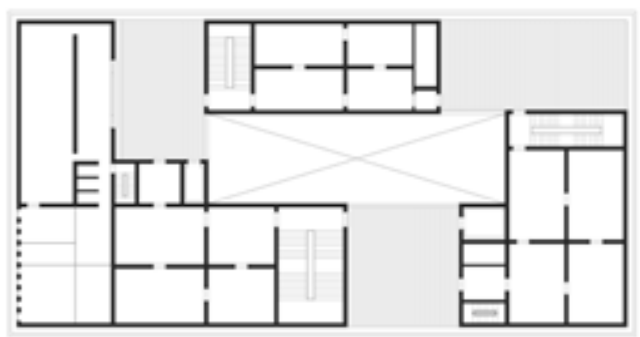

PLANTA SEGUNDA
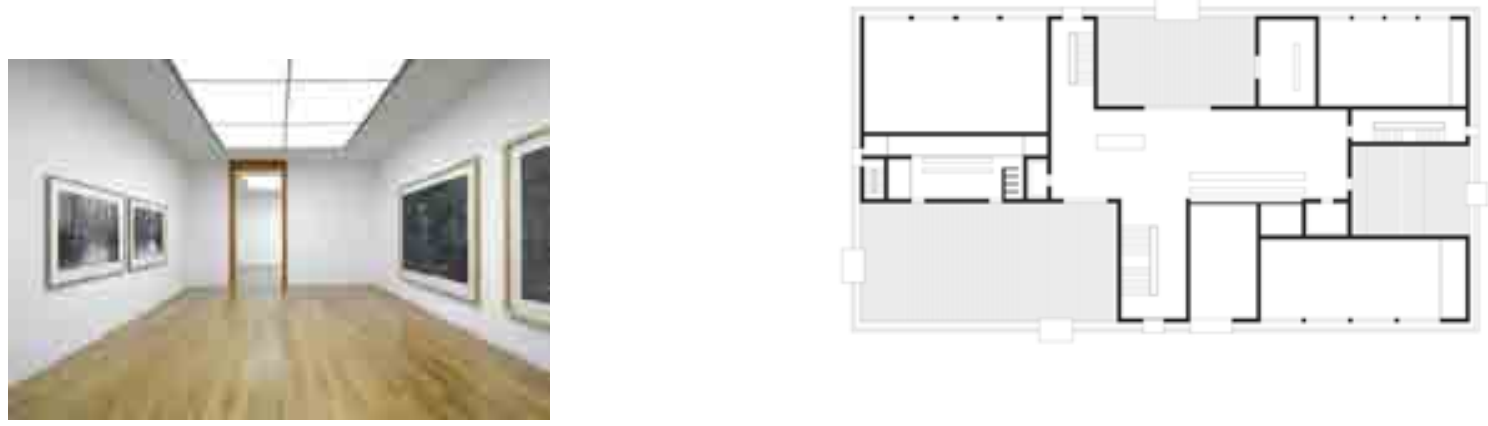

PLANTA BAJA 
ALBERS-HONEGGER DONATION, ESPACE DE L'ART CONCRET

Mouans-Sartoux, France - Gigon \& Guyer, 2000
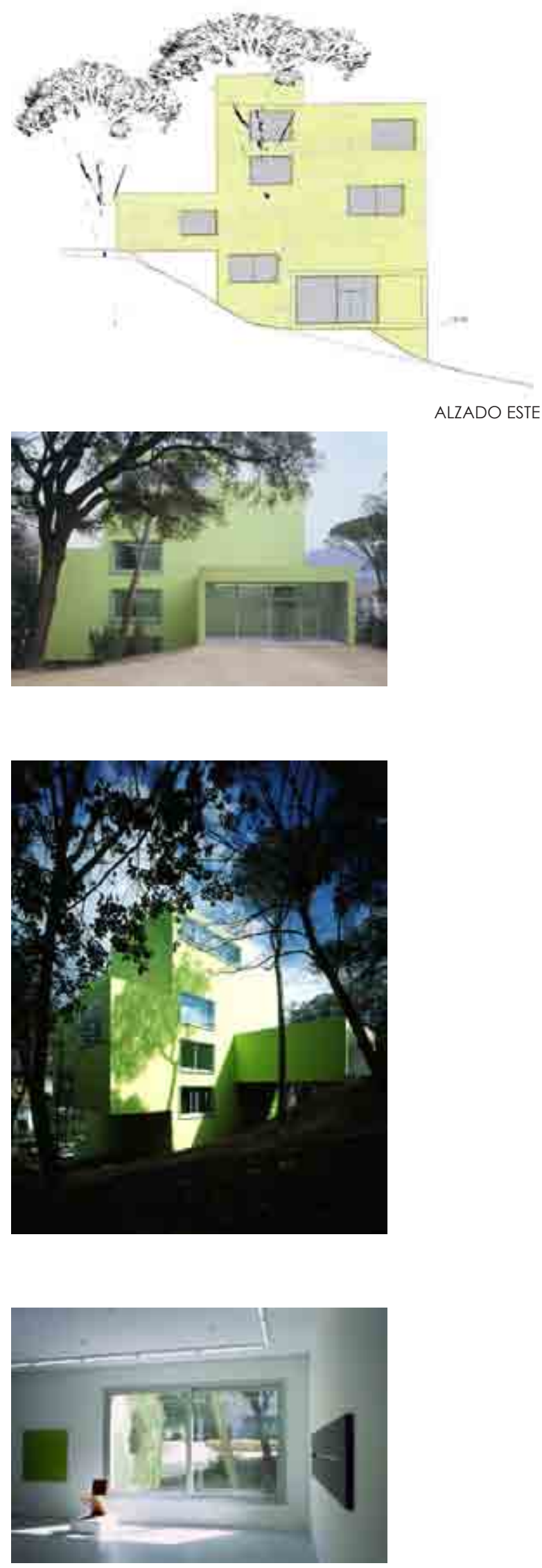

ALZADO ESTE
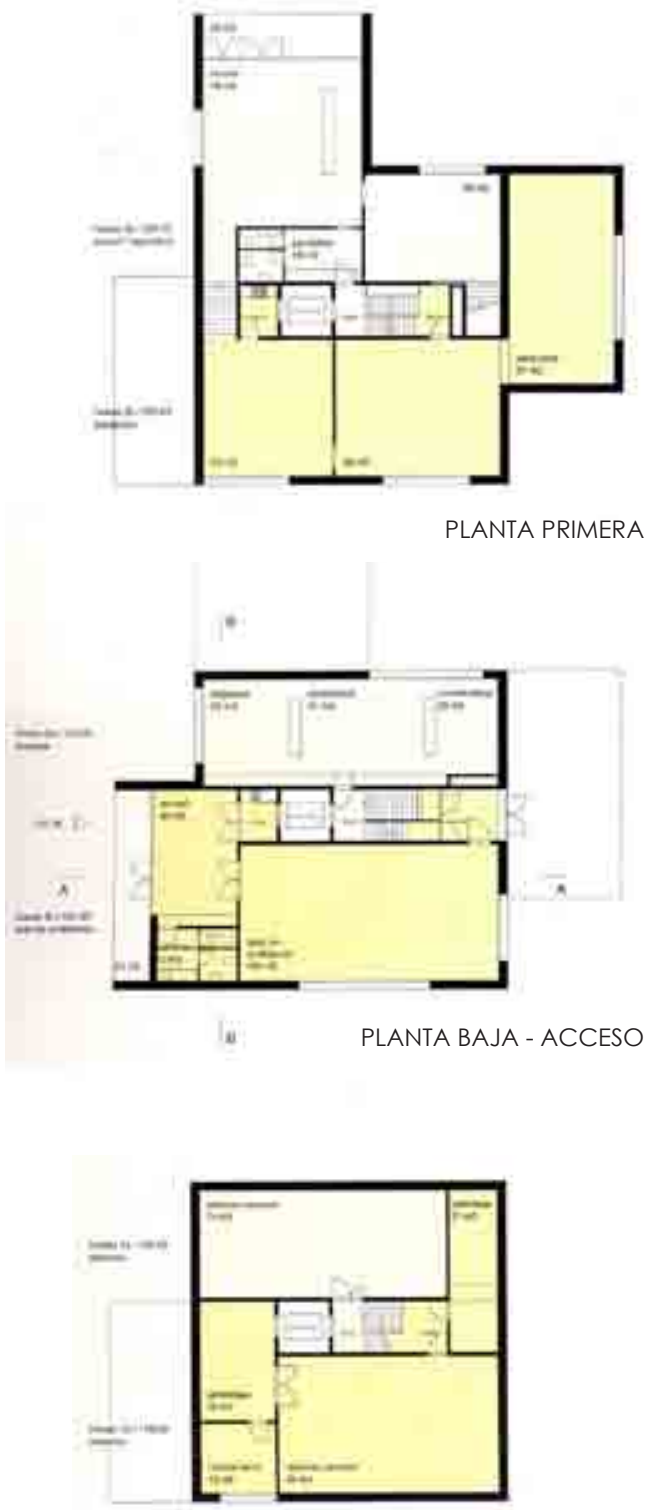

PLANTA SÓTANO 1 
PINACOTECA GIOVANNI \& MARELLA AGNELLI, EDIFICIO LINGOTTO

Turín, Italia - Renzo Piano - 2000
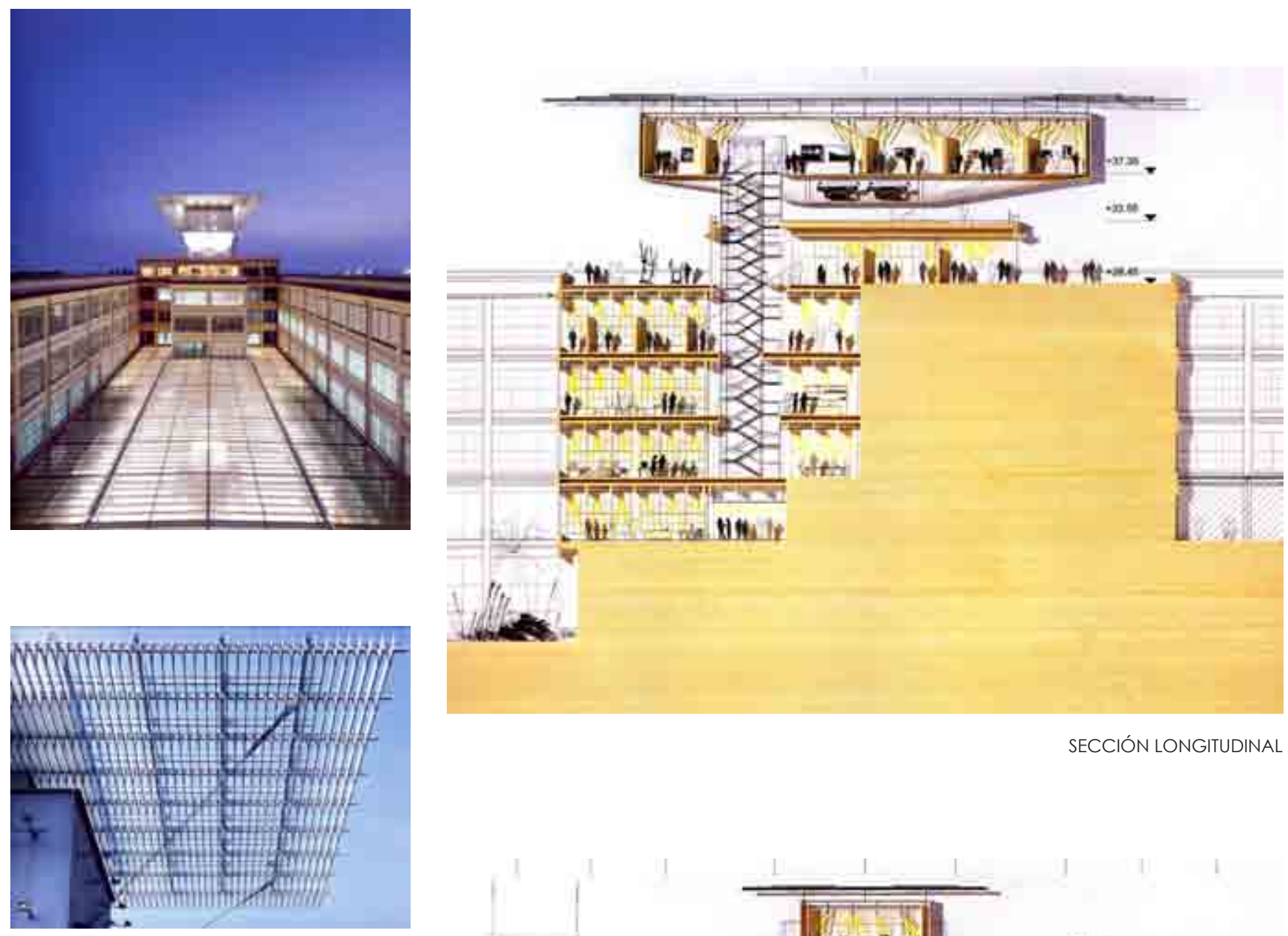

SECCIÓN LONGITUDINAL
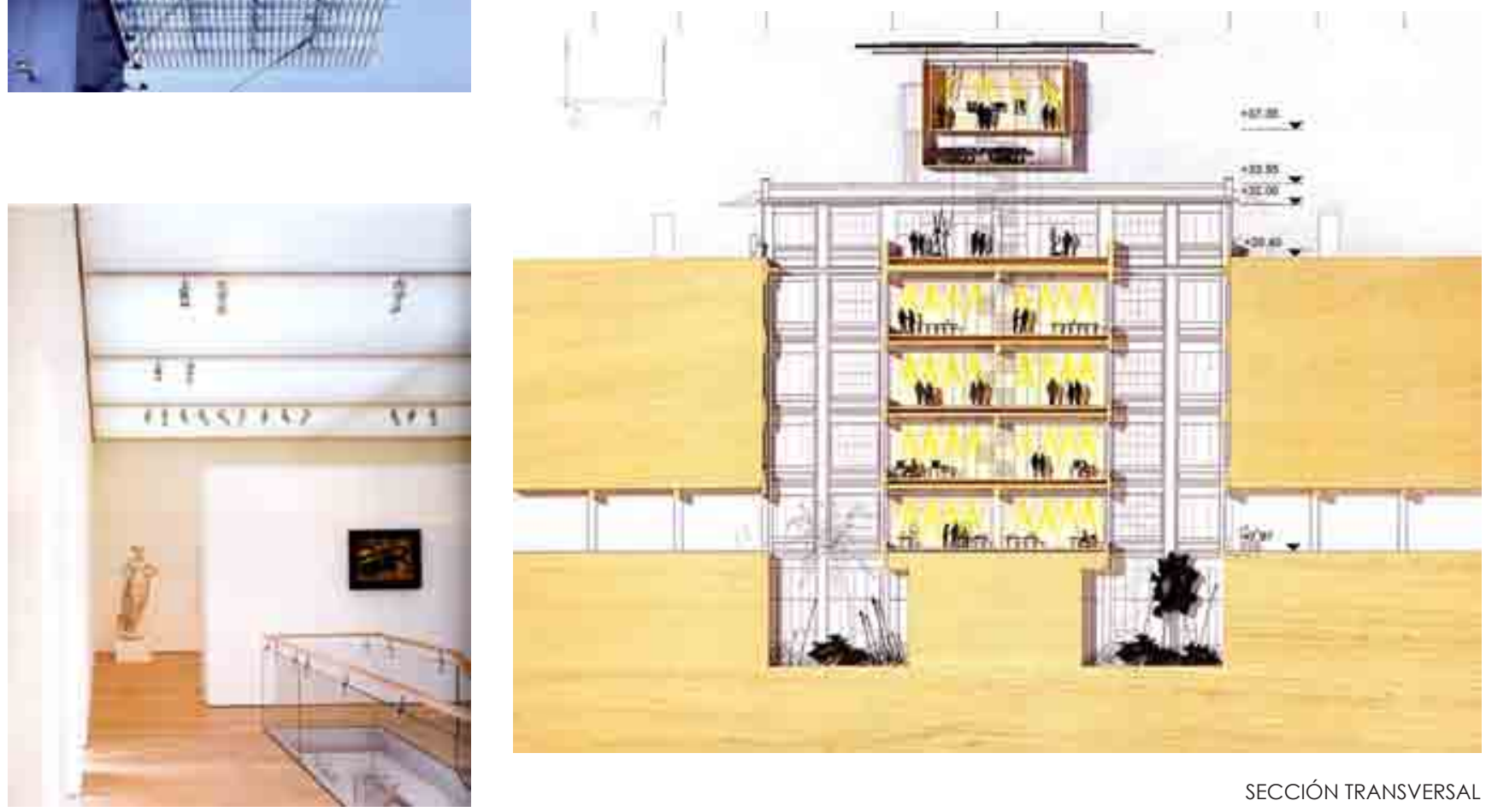

SECCIÓN TRANSVERSAL 

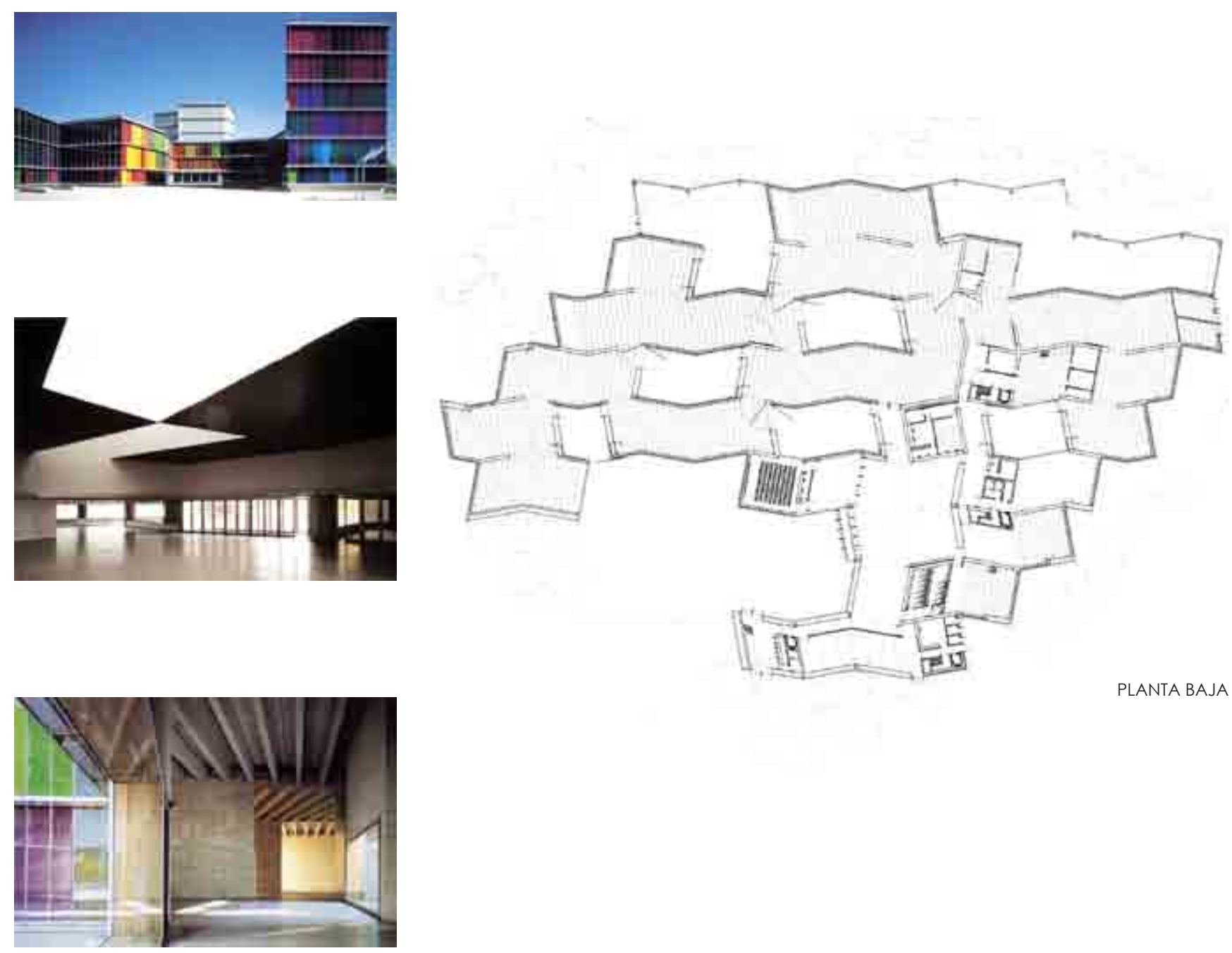

PLANTA BAJA
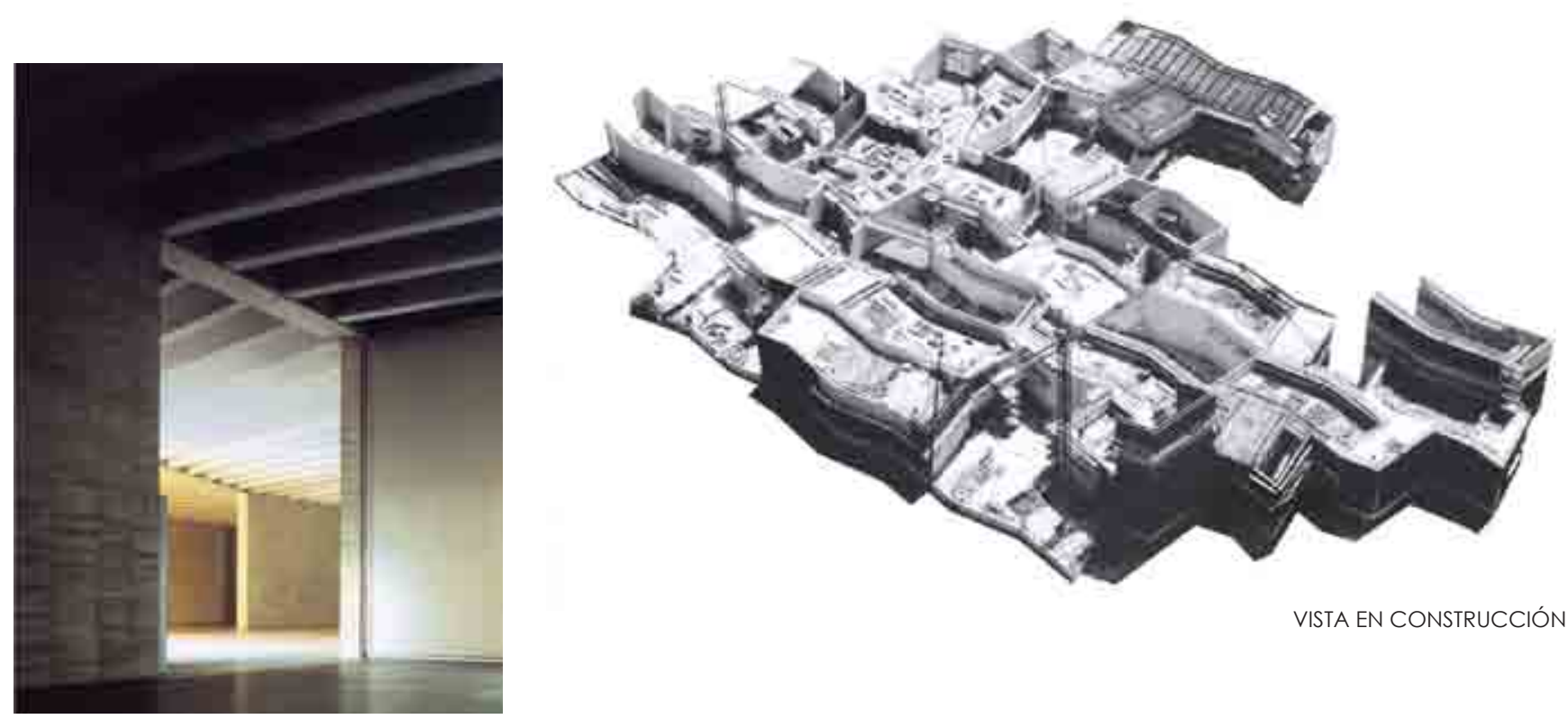

VISTA EN CONSTRUCCIÓN 
PATIO HERRERIANO. MUSEO DE ARTE CONTEMPORÁNEO ESPAÑOL

Valladolid, España - Juan Carlos Arnuncio, Clara Aizpún y Javier Blanco, 2001
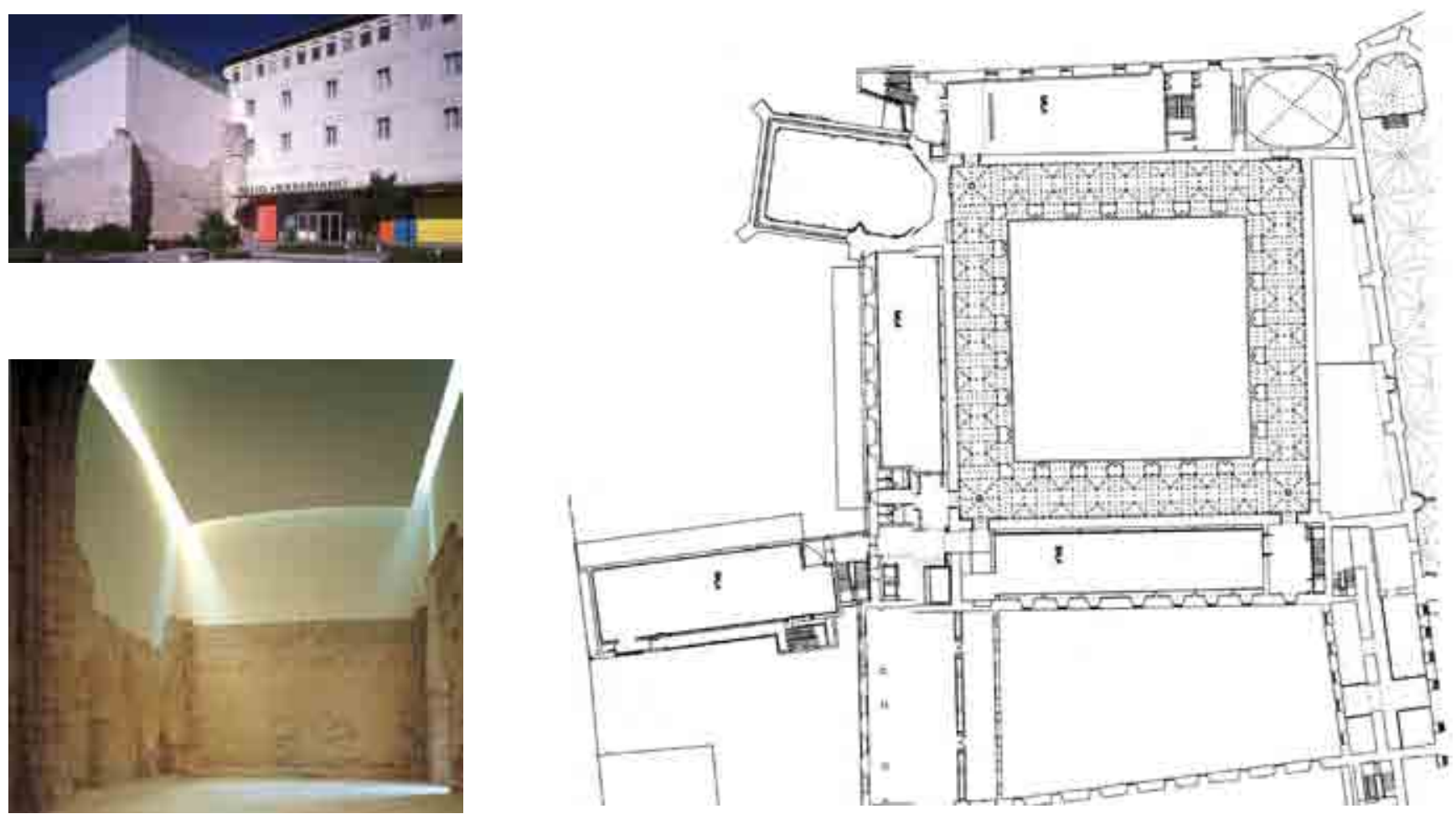

PLANTA SEGUNDA Y TERCERA
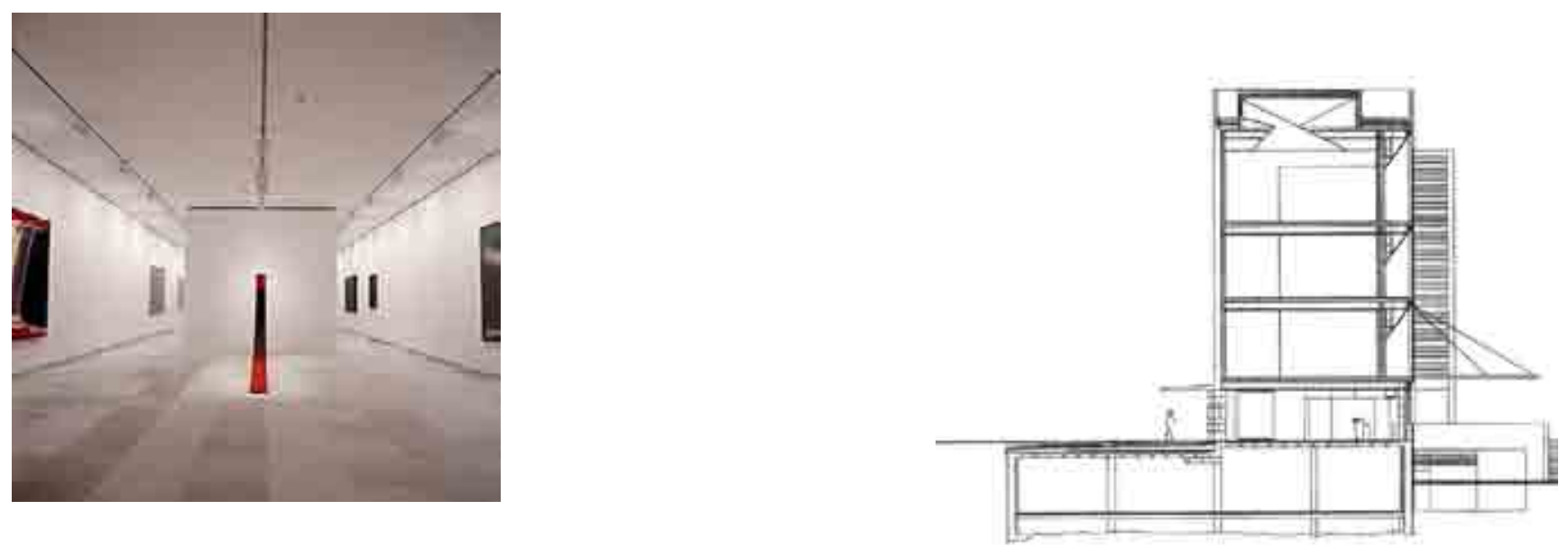

SALAS EXPOSICIONES TEMPORALES

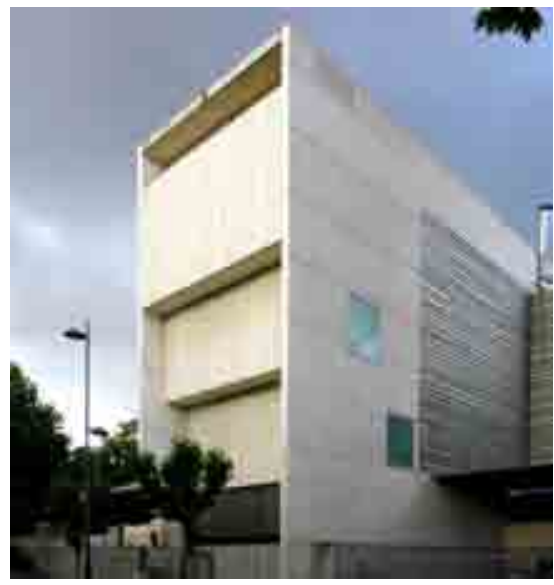
SECCIÓN TRANSVERSAL - DETALLE

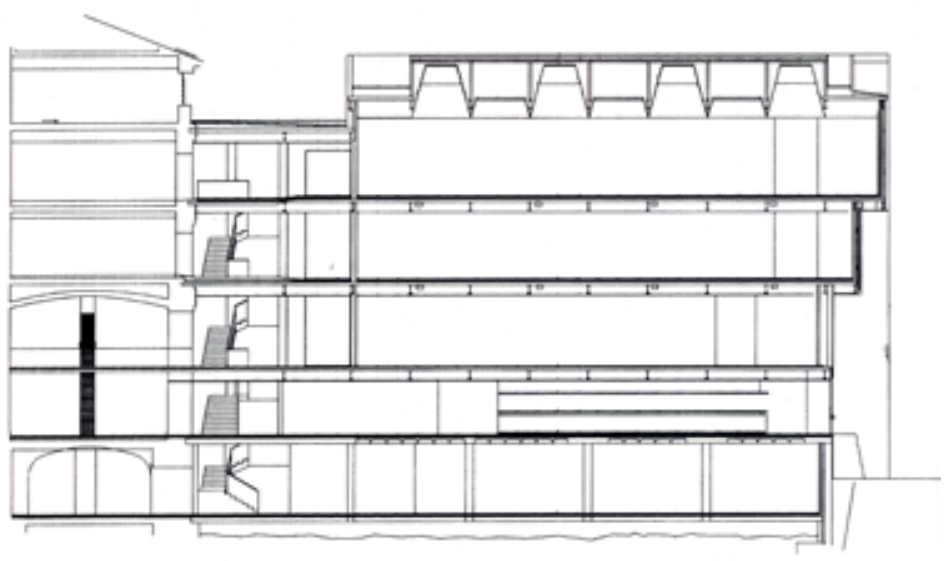

SALAS EXPOSICIONES TEMPORALES SECCIÓN LONGITUDINAL - DETALLE 

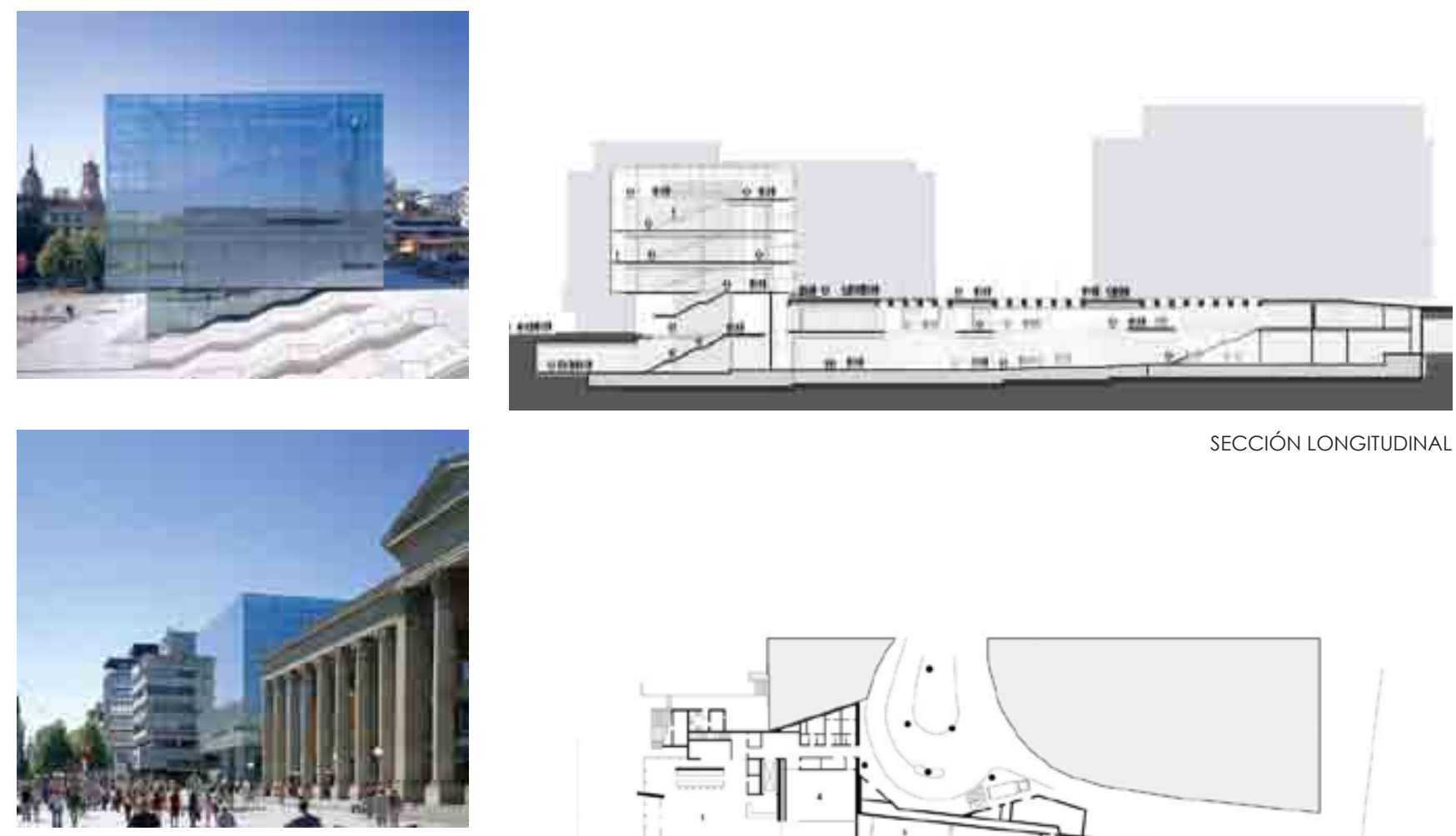

SECCIÓN LONGITUDINAL
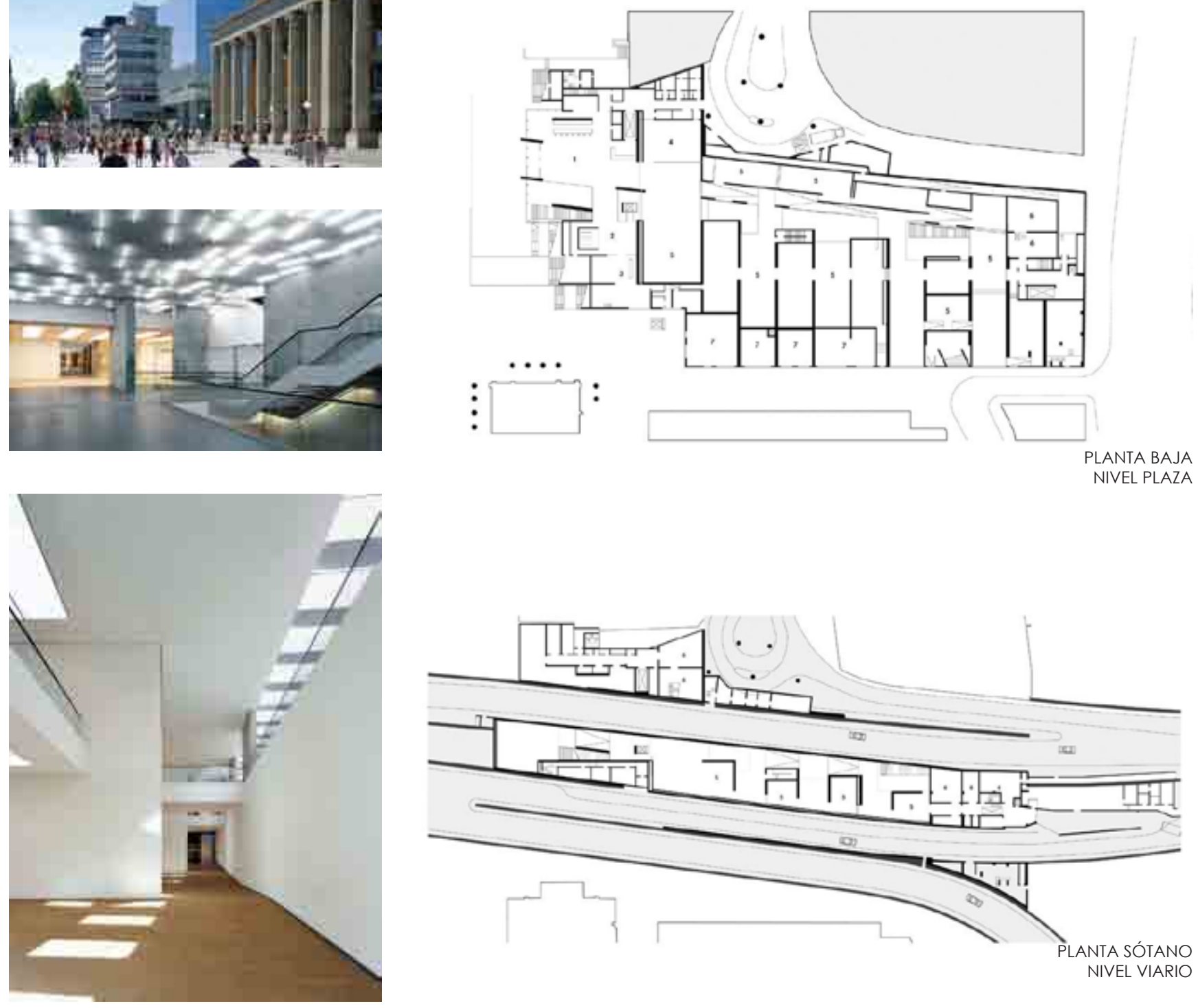
AMPLIACIÓN DEL MOMA

New York City, New york (USA) - Yoshio Taniguchi, 2004
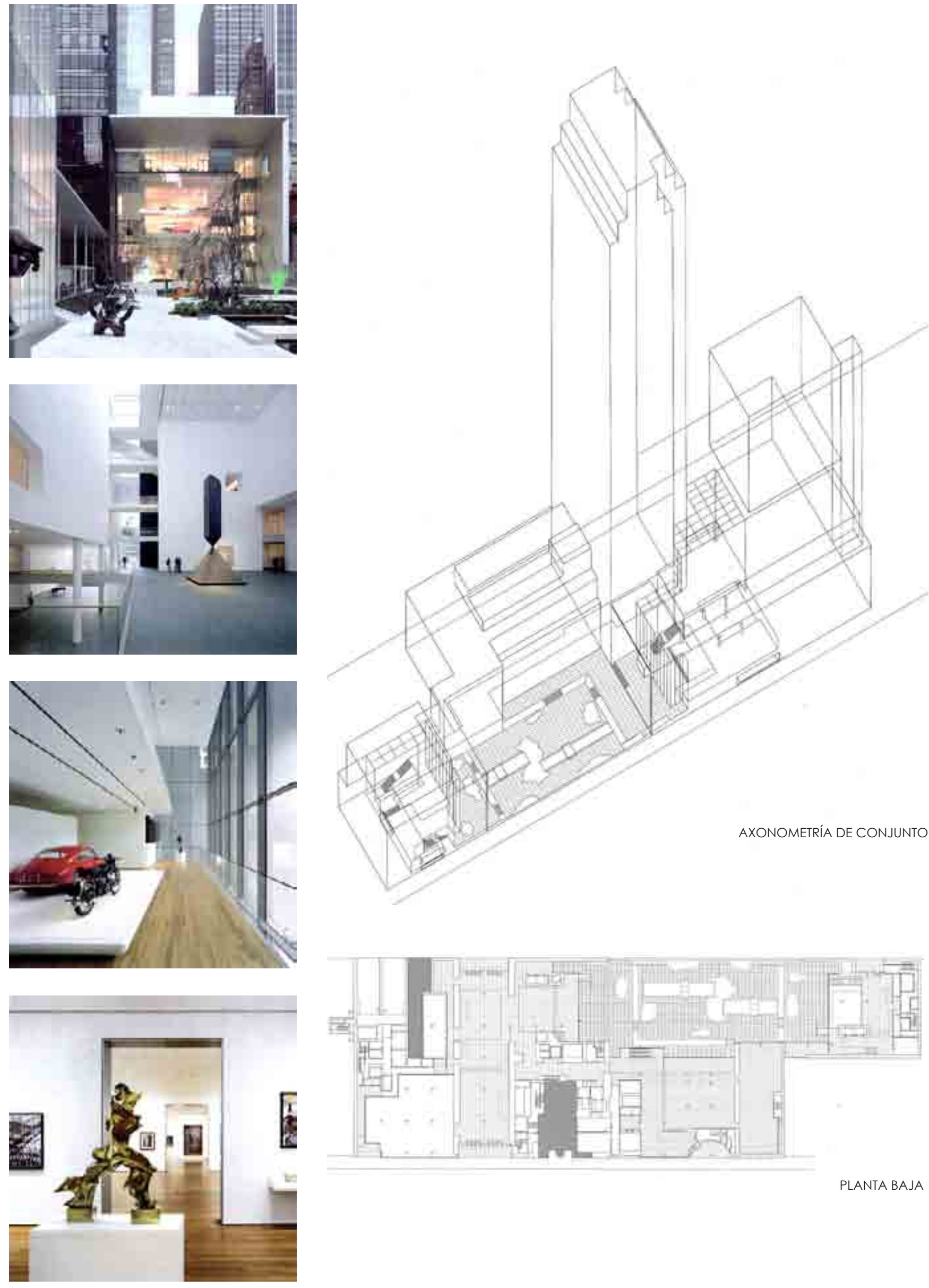

PLANTA BAJA 
MUSEO DE ARTE NELSON-ATKINS

Kansas City, Missouri (USA) - Steven Holl - 2007

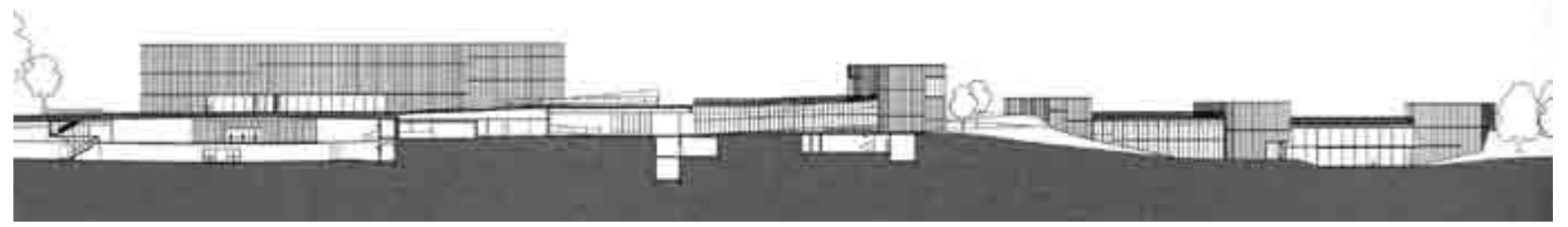

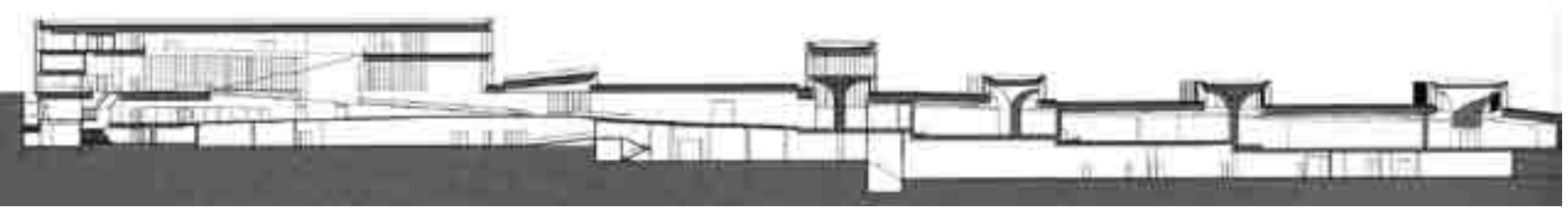

SECCIÓN POR GALERÍAS
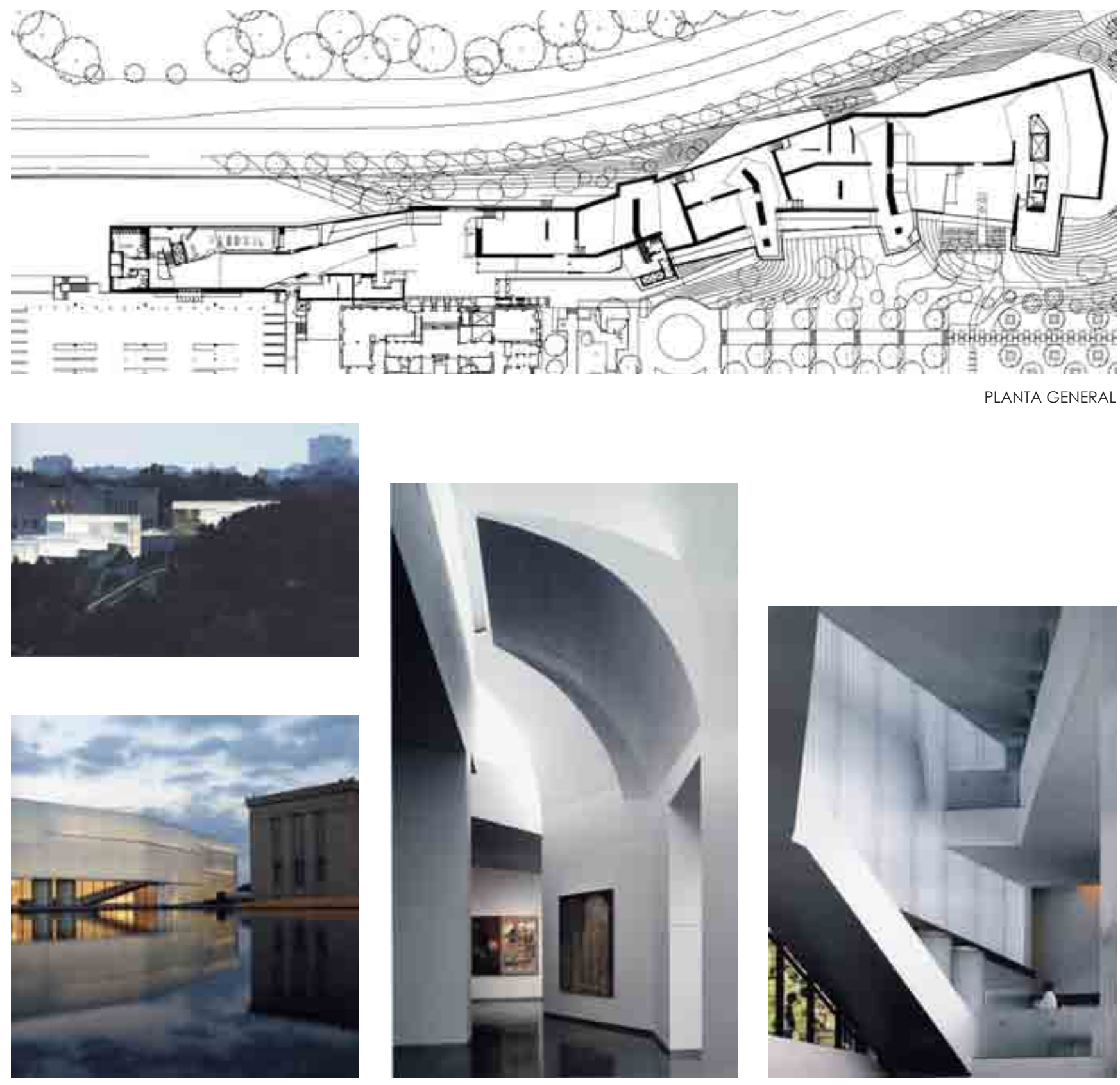


\section{BIBLIOGRAFÍA}

\subsection{BIBLIOGRAFÍA ACERCA DE LOS CINCO MUSEOS}

\subsubsection{Museo de la Ciudad: Restauración y Rehabilitación del Palacio del Marqués de Campo}

AAVV, Palacio del Marqués de Campo. Museo de la Ciudad. Valencia. Excmo. Ayto. de Valencia,1989.

AAVV, "Palacio del Marqués de Campo", Habitar, Valencia, Noviembre 1989.

Noguera, J. F., "La Restauración de un Palacio", Territorio, Noviembre 1989.

AAVV, "Restauración Palacio Marqués de Campo", ON Diseño, no 111, 1990, Barcelona, pp. 122

Ginés, E., "Las claves de la Escuela Valenciana. Un repaso sin militancias sobre las arquitecturas de aquí", Habitar, Valencia, Julio 1990.

AAVV, "Palacio del Marqués de Campo", A propósito de Arquitectura y Pintura, Sevilla, Junta de Andalucía. Colegio Oficial de Arquitectos de Granada, 1990

AAVV, "Palacio del Marqués de Campo", Arquitectura y Vivienda n 26. Monográfico. Madrid 1990.

AAVV, "Palacio del Marqués de Campo", A propósito de arquitectura y pintura, Madrid, MOPU, 1991. pp.147

AAVV, "A través del tiempo. Palacio del Marqués de Campo", Especial Comunidad Valenciana. Nuevo Estilo,

Madrid. 1990, pp.52-57.

Insausti, P. Vetges tu i Mediterrània, Archivo de la Comunidad Valenciana.1970 1990, Valencia, Colegio Oficicial de Arquitectos de la Comunidad Valenciana. 1991.

AAVV, "Palacio del Marqués de Campo", Arquitectura Valenciana. La Década de los Ochenta. IVAM Centre del Carme. Valencia. Edición a cargo de: Pilar Insausti y Amando Llopis, 1991. pp. 302.

AAVV, "Palacio del Marqués de Campo", Domus nº 724 XXIII, 1991.

AAVV, "Palacio Marqués de Campo. Premio Arquitectura 1988-89". Arquitectura Comunidad Valenciana. Colegio Oficial de Arquitectos de la Comunidad Valenciana, 1991. pp. 98-101.

AAVV, "Restauración y Rehabilitación Palacio Marqués de Campo", ON Diseño n 150. Especiales XV Aniversario cinco años de Arquitectura, Barcelona, Noviembre 1993.

AAVV, "Palacio del Marqués de Campo", Guía Arquitectura de España 1929/1996, Barcelona, Fundación Caja de Arquitectos, 1996, pp. 291

AAVV, "Palacio del Marqués de Campo. Museo de la ciudad", Guía de Museos de la Comunidad Valenciana, Valencia, Consellería de Cultura, Educación y Ciencia. Generalitat Valenciana, 1996. pp. 237

AAVV, Edicion a cargo de Llopis, Amando y Dauksis, Sonia, Arquitectura del S.XX en Valencia, Colección Formas Plásticas, Institució Alfons el Magnànim, Diputació de València, Valencia, 2001.

Portaceli, Manuel, "Palacio del Marqués de Campo", Manuel Portaceli: Arquitecturas 1971-2001, TC Cuadernos n० 50, Valencia 2002, pp. 90

Portaceli, Manuel, "El museo se adapta a la ciudad. La ciudad cambia con sus museos", Amigos de los museos, Madrid, Marzo, 2007. pp. 10-14 


\subsubsection{Museo del Almudín}

Grassi, G. y Portaceli, M., "El Museo del Almudín de Xátiva", Arquitectura nº 263, Madrid, 1986.

Grassi, G. y Portaceli, M., "Museo di Xátiva", Domus n 677, 1986.

Grassi, G. y Portaceli, M., "El Museo del Almudín de Xátiva", Premios de Arquitectura COACV 1985, Valencia, Colegio Oficial de Arquitectos de la Comunidad Valenciana, 1987.

Ros, J. LI., "Arquitectura: nova imatge amb sintaxi antiga", Batlia n 6, 1987

Grassi, G. y Portaceli, M., "El Museo del Almudín de Xátiva", Habitar, Enero 1988.

Grassi, G.: "L'Almudi di Xativa", en Architettura, Lingua Morta, Quaderni di Lotus n’ 9, 1988, pp.64-71

AAVV, "El Museo del Almudín de Xátiva", Arquitectura y Vivienda n¹6, Monográfico, 1988.

Grassi, G. y Portaceli, M., "El Museo del Almudín de Xátiva", Restauración y Análisis Arquitectónico, Sevilla 1989.

Ginés, E. "Las claves de la escuela valenciana. Un repaso sin militancias sobre las arquitecturas de aquí". Habitar 7, VII, 90.

Grassi, G. y Portaceli, M., "El Museo del Almudín de Xátiva" Monumentos y Proyectos, Madrid, Ministerio de Cultura, Dirección de Bellas Artes y Archivos 1990, pp. 198.

Insausti, P. Vetges Tu i Mediterrània, "El Museo del Almudín de Xátiva", Archivo de la Comunidad Valenciana. 1970 1990, Valencia, Colegio Oficial de Arquitectos de la Comunidad Valenciana,1991.

AAVV, Edición a cargo de Insausti, Pilar y Llopis, Amando, "El Museo del Almudín de Xátiva", Arquitectura Valenciana. La década de los ochenta. IVAM, Valencia Centre del Carme, 1991. pág. 278

AAVV, "El Museo del Almudín", Guía de Museos de la Comunidad Valenciana, Valencia, Generalidad Valenciana, Consellería de Cultura, Educación y Ciencia, 1991, pág. 277.

Urrutia, A. Arquitectura Española Siglo XX. Madrid. Cátedra, 1997, pág: 709

Portaceli, M., "El Museo del Almudín de Xátiva", Manuel Portaceli: Arquitecturas 1971-2001". TC Cuadernos n 50. 2002. pág. 84-89.

AAVV, Museos de España, Tomo II, Summa Artis, Madrid, Ed. Espasa Calpe, 2006, pp. 381

\subsubsection{Museo de las Atarazanas}

Portaceli, Manuel, "Las Atarazanas de Valencia", Rehabilitación no 1.1994, pp.4.

Portaceli, Manuel, "Restauración de las Atarazanas de Valencia", Muestra de Arquitectura Española 1991-1993,Madrid, M.O.P.U., 1994, pp. 97.

Portaceli, Manuel, "Rehabilitación del edificio de las Drassanes de València", ON Diseño n 167, 1995, pp.188.

Portaceli, Manuel, "Rehabilitación de las Atarazanas de Valencia", TC Cuadernos n 27, 1995, pp.74-76.

AAVV, Guía de Arquitectura España 1920-2000, Madrid. Ed. Ministerio de Fomento y Tanais, 1998, pp. 321 AAVV, Edicion a cargo de Llopis, Amando y Dauksis, Sonia, Arquitectura del S.XX en Valencia, Colección Formas Plásticas, Institució Alfons el Magnànim, Diputació de València, Valencia, 2001.

Portaceli, Manuel, "Las Atarazanas de Valencia", Manuel Portaceli: Arquitecturas 1971-2001, TC Cuadernos n 50. 2002. pp. 74

Portaceli, Manuel, "Las Atarazanas de Valencia", Vía Construcción, n 43 Abri, 2007, pp. 52

Portaceli, Manuel, "El museo se adapta a la ciudad. La ciudad cambia con sus museos", Amigos de los museos, Madrid, Marzo, 2007. pp. 10-14 


\subsubsection{Neues Museum de Berlin}

Stüler, August, Das Neues Museum in Berlin, Berlin, Ed. Riedel, 1862

Behne, Adolf, "L'isola del Museo, Una tragedia dell urbanistica di Berlino", en Grassi, Giorgio, Das Neue Frankfurt 1926-1931, Bari, Dedalo Libri, 1975

Petras, Renate, Die Bauten der Berliner Museumsinsel, Berlin, 1. a ed., Verlag für Bauwesen, 1987, pp. 227

Beltran, Adolf, "Grassi y Portaceli ganan el concurso del Neues Museum de Berlín”, El País, 18 de marzo de 1994

Grassi, Giorgio, I progetti, le opere e gli scritti, Milan, Ed. Electa, 1996, pp. 324-337

Grassi, Giorgio, Opere e progetti, Edición a cargo de Crespi, Giovanna y Dego, Nunzio, Milan, Ed. Electa, 2004, pp. 330-343

\subsubsection{Museo de Bellas Artes de San Pío V}

Portaceli, Manuel, "El nuevo museo de San Pío V", Papers n 17, 1986, pp.27.

Llorens i Serra, Tomás, "El museo de San Pío V", Tribuna no 21.1986, pp.26.

Gámez, C, "Un museu per als 90", El Temps n² 250, 1989, pp.69.

AA.V., "Restauración y ampliación del Museo de Bellas Artes de Valencia", Arquitectura Recuperada, Cuenca, Universidad Menendez y Pelayo, Ministerio Obras Públicas y Urbanismo, 1989, pp.114.

AAVV, "Restauración y Rehabilitación Museo de Bellas Artes San Pío V", El Temps n 308, 1990, pp. 4.

Baztán, Carlos, "Museos a media luz", Arquitectura y Vivienda n 26.1990, pp.8.

AA.V , "Rehabilitación y ampliación del Museo Bellas Artes San Pío V de Valencia", Restauración Arquitectónica, Universidad de Valladolid,1992, pp. 149

AA.V, "Intervención en Patrimonio Histórico Artístico", Monumento y Lugar, Logroño, Colegio Oficial de Arquitectos de la Rioja, 1991.

Insausti, Pilar y Vetges Tu i Mediterrània, Archivo de Arquitectura de la Comunidad Valenciana, 1970-1990, Valencia, Colegio Oficial de Arquitectos de la Comunidad Valenciana,1991.

AAVV, "Museo de Bellas Artes de San Pío V", Guía de Museos de la Comunidad Valenciana, Valencia, Conselleria de Cultura Educación y Ciencia, Generalidad Valenciana,1991, pp.207.

Portaceli, Manuel, "Intervención en el Museo de Bellas Artes de San Pío V en Valencia", On Diseño n 167, 1995, pp.178.

Portaceli, Manuel, "Vestíbulo y Biblioteca del Nuevo Museo de San Pío V", TC Cuadernos n² 27., 1995, pp.41-49 AAVV, "Testigo Histórico", Nuevo Estilo n 218. 1996, pp.253.

Portaceli, Manuel, "Rehabilitación y Ampliación Museo de Bellas Artes de San Pío V de Valencia", Equipamientos Culturales n³, Diciembre1996, pp. 37.

AAVV, Museos Españoles, La renovación arquitectónica. Museos, Espacios y Patrimonio, Madrid, Ministerio de Cultura, 1997, pp.29.

Portaceli, Manuel, "Museo de San Pío V", Nueva Arquitectura, n 6, Octubre 1997. pp. 85

AAVV, "Museo de Bellas Artes de San Pío V", Guía de Arquitectura. España 1920-2000, Ed. Ministerio de Fomento y Tanais ediciones, 1998, pp. 329.

AAVV, Edicion a cargo de Llopis, Amando y Dauksis, Sonia, Arquitectura del S.XX en Valencia, Colección Formas Plásticas, Institució Alfons el Magnànim, Diputació de València, Valencia, 2001. 
Portaceli, Manuel, "El Museo de Bellas Artes de San Pío V", Manuel Portaceli, Arquitecturas 1971-2001, TC

Cuadernos n 50. 2002. pp. 100

Portaceli, Manuel, "El Museo de Bellas Artes de San Pío V", Cultura Visual y Contemporánea, Valencia. Fundación Mainel, 2004. pp 77

Portaceli, Manuel, "El museo se adapta a la ciudad. La ciudad cambia con sus museos", Amigos de los museos, Madrid, Marzo, 2007. pp. 10-14

AAVV, Museos de España, Tomo II, Summa Artis, Ed. Espasa Calpe, Madrid, 2006, pp. 359.

\subsection{BIBLIOGRAFÍA ACERCA DEL MUSEO DE ARTE}

AAVV, Llorens, Tomás, Mira, Rafael, Portaceli, Manuel, Sanchez-Robles, J. Cecilio, (Editores), Arquitectura y Ciudad, vanguardia y continuidad, Valencia, Ed. Colegio Oficial de Arquitectos de Valencia y Murcia, 1980 AAVV, Neue Staatsgalerie und Kammertheater Stuttgart, Stuttgart, Finanzministerium Baden-Würtemberg, 1984

AAVV, München 5 Architekten, Sevilla, Ed. Junta de Andalucía, 1994

Abrams, Janet Y., "Contemplazione e rituale nel museo d'arte per il gran pubblico. Due progetti di Venturi, Rauch \& Scott-Brown ", Lotus International 55, Nouvi Musei, Ed. Electa, Milano, 1988

Aloi, R., Musei-Architettura-Tecnica. Hoepli, Milano, 1957

Ando, Tadao, El Croquis n 44 y n58, Madrid 1990

Annoni, Ambrogio, Scienza e Arte del Restauro Architettonico, Milano, Ed. Artistiche Framar, 1946

Argan, Giulio Carlo, El concepto del espacio arquitectónico. Desde el Barroco hasta nuestros días, Nueva Visión, Buenos Aires, 1966.

Argan, Giulio Carlo, Sobre el concepto de tipología arquitectónica, E.T.S.A.B., 1974.

Argan, Giulio Carlo, "L'architettura del museo", Casabella, n²02. Sept 54

Argan, Giulio Carlo, "La galleria di Palazzo Bianco a Genova", Architecture d'Aujourdhui, n48, Julio 53

Baker, Geoffrey, "The Sainsbury at the Nacional Gallery by Venturi, Scott Brown and Associates", Architectural Design, n० 94, 1991

Banham, Reyner. La Arquitectura del entorno bien climatizado, Buenos Aires, Ed. Infinito, 1957.

Barthes, Roland. El grado cero de la escritura. Siglo XXI. Buenos Aires, 1973.

Baudulaire, Charles, Salones y otros escritos sobre arte, Madrid, Visor, 1999.

Baztán, Carlos, Museos españoles. La renovación arquitectónica, Madrid, Ministerio de educación y Cultura, 1997

Behne, Adolf, La architettura funzionale, Florencia, 1968.

Benévolo, Leonardo, Historia de la Arquitectura Moderna, Barcelona, Ed. Gustavo Gili, 1998

Benjamin, Walter. Discursos ininterrumpidos, Madrid, Taurus, 1973.

Brandi, Cesare, Teoria del Restauro, Torino, Piccola Biblioteca Einaudi, 1977.

Brandi, Cesare, Struttura e architettura, Turín, Einaudi, 1967.

Brawne, Michael, The New Museum, Architecture and Display, Nueva York, Praeger, 1965

Brawne, Michael, The Museum Interior. Temporary and Permanent Display Techniques, Londres, Thames and Hudson, 1982

Berlage,H.P, "Museo de La Haya", Casabella 33, año1935.

Brawne, M., I/ museo oggi, Roma, Comunità, 1965. 
Bonfanti,Ezio y Porta, Carlo, Città, Museo e Architettura, Firenze, 1973

Calvino, Italo, Seis propuestas para el próximo milenio, Madrid, Ed. Siruela, 1998

Chastel, André, L'uso della Storia dell'Arte, Roma, Bari, 1982

Collins, Peter, "Arquitectura Revolucionaria", Los Ideales de la Arquitectura Moderna; su evolución

(1750-1950),Barcelona, Editorial Gustavo Gili, 1970

Colquhoun, Alan, "Un monumento para la ciudad", Los Museos de James Stirling, Michael Wilford y Asocia-

dos, Milán, Ed. Electa, Colección de Arquitectura, 1992

Colqhoun, Alan, Arquitectura moderna y cambio histórico. Ensayos, 1962-1976, Barcelona, Gustavo Gili, 1978.

Colquhoun, Alan, Modernidad y tradición clásica, Madrid, Ed. Júcar, 1991.

Colquhoun, Alan, El simbolisme cultural de l'arquitectura i la crisi del movimente modern,Introducción a cargo de Llorens, Tomás, Valencia, Ed. L’Estel, 1974.

Cortés, Juan Antonio, "La repetición en la arquitectura moderna y Modernidad y arquitectura. Una idea alternativa de modernidad en el arte moderno", Escritos sobre arquitectura moderna, Madrid, COAM, 1991.

Dal Co, Francesco, Los Museos de James Stirling, Michael Wilford y Asociados, Milán, Ed. Electa, Colección de Arquitectura, 1992

Debord, Guy, La sociedad del espectáculo, Valencia, Pre-textos, 1999.

Deleuze, Gilles, Repetición y diferencia, Anagrama, Barcelona, 1981.

Durand J.N.L., Compendio de Lecciones de Arquitectura, Parte Gráfica de los Cursos de Arquitectura, Prólogo de Moneo, Rafael, Madrid, Editorial Pronaos, año 1981,

Eliot, T.S. Función de la poesía y función de la crítica, Barcelona, Ed. Tusquets, 1999.

Frampton, Kenneth, Historia crítica de la arquitectura moderna, Barcelona Editorial Gustavo Gili, 1987

Gadamer, Hans-Georg, La actualidad de lo bello, Barcelona, Paidós/ ICE-UAB, 1996

Gadamer, Hans-Georg, La educación es educarse, Barcelona, Paidós, 2000.

Gombrich, E.H, Arte e ilusión, Barcelona, Gustavo Gili, 1980

Gigon \& Guyer, El croquis, n 102, Madrid, 2000

Grassi, Giorgio, Das Neue Frankfurt 1926-1931, Bari, Dedalo Libri, 1975

Grassi, Giorgio, Arquitectura lengua muerta y otros escritos, Barcelona, Ed. del Serbal, 2003

Grassi, Giorgio, La arquitectura como oficio y otros escritos, Barcelona, Gustavo Gili, 1980.

Grassi, Giorgio, La construcción lógica de la arquitectura, Barcelona, Publicaciones del Colegio Oficial de Arquitectos de Cataluña y Baleares, 1973

Grassi, Giorgio, Giorgio Grassi. Obras y proyectos 1962-1993, Edición a cargo de Insausti, Pilar y Llopis, Amando, Valencia, Ed IVAM- Electa, 1994

Guadet, J., Elements et théorie de l'architecture, París, Librarie de la Construction Moderne, 1894.

Habermas, Jürgen, La modernidad inconclusa, Madrid, "El Viejo Topo", 1981.

Hartvig, Hans, Kunstens Huse fra Thorvaldsens til Trapholt, Copenague, Dansk Arkitectur \& Byggeeksport Center Gammel Dok, 1989

Heidegger, Martin, Conferencias y artículos, Barcelona, Ediciones del Serbal, 1994.

Heidegger, Martin, El concepto de tiempo, Madrid, Ed. Trotta, 2001.

Herzog \& De Meuron, El croquis, 1983/1993, n 60, Madrid, 1993

Hitchcock, Henry-Russell, Frank Lloyd Wright. Obras 1887-1941, Barcelona, Gustavo Gili. 1978.

Hitchcock, Henry-Rusell, L'Architettura dell'Ottocento e del Novecento, Torino, Giulio Einaudi Ed., 1971

Hosbawm, E., Industria e Imperio, Barcelona, Ariel Historia, 1977. 
Iñiguez, Manuel, La columna y el muro. Fragmentos de un diálogo, Barcelona, Fundación caja de Arquitectos, 2001.

Jiménez, Juan Ramón, Antología Poética 1917-1935, Volumen 2, Madrid, Alianza Editorial, 1984

Kaufmann, E., De Ledoux a Le Corbusier, Barcelona, Ed. G. Gili, 1982.

Kaufmann, E., La arquitectura de la Ilustración, Barcelona, Ed G.Gili, 1974.

Klotz, Heinrich, New Museum Buildings in the Federal Republic of Germany, Nueva York, Rizzoli, 1985

Marí, Antoni, La vida de los sentidos. Fragmentos de una unidad perdida, Barcelona, Ed Tusquets, 2006.

Linazasoro, José Ignacio, El Proyecto clásico en arquitectura, Barcelona, Gustavo Gili, 1981.

Linazasoro, José Ignacio, Permanencias y arquitectura urbana, Barcelona, Gustavo Gili, 1978.

Le Corbusier, El espíritu nuevo en Arquitectura. En defensa de la arquitectura. Murcia, C.O.A.A.T. 1983.

Le Corbusier, Hacia una arquitectura, Buenos Aires, Poseidón, 1964.

Loos, Adolf, Ornamento y delito y otros escritos, Barcelona, Ed G. Gili,1971.

Magnago Lampugnani, Vittorio, Architettura moderna. L'avventura delle idee 1750-1980, Milano, Ed.Electa, 1985.

Mies van der Rohe, Ludwig, Escritos, diálogos y discursos, Murcia, Colegio Oficial de Aparejadores y Arquitectos Técnicos, 1983.

Moneo, Rafael, "Paradigmas fin de siglo. Los noventa, entre la fragmentación y la compacidad", Arquitectura Viva n $^{\circ}$ 66. Madrid, mayo-junio 1999. Pp. 17-24.

Moneo, Rafael, Inquietud teórica y estrategia proyectual en la obra de ocho arquitectos contemporáneos, Barcelona, Actar, 2004

Moneo, Rafael, Apuntes sobre 21 obras, Barcelona, Gustavo Gili, 2010,

Moneo, Rafael, El croquis n 64 y n 98, Madrid 1994 y 1999

Montaner, Josep Ma; Oliveras, Jordi, Los museos de la última generación, Barcelona, Editorial Gustavo Gili, 1986 Montaner, Josep Ma $\mathrm{M}^{\mathrm{a}}$ Nuevos Museos-Espacios para el arte y la cultura, Barcelona, Editorial Gustavo Gili, 1990 Naredi-Rainer, Paul, Museum buildings. A design manual, Basel, Ed. Birkhauser. 2004

Navarro Baldeweg, Juan, La habitación vacante, Pre-textos, Valencia, 1999.

Nietszche, Friedrich, Estética y teoría de las artes, Selección de textos de Izquierdo, Agustín, Madrid, Editorial Tecnos, 1999.

Ortega y Gasset, José, La deshumanización del arte, Madrid, Alianza Editorial, 1981.

Ortega y Gasset, José, Carta a un alemán pidiendo un Goethe desde dentro, Madrid, Biblioteca Nueva SL, 2004

Panofsky, Erwin. El significado en las artes visuales, Madrid, Alianza Forma, 1979

Panofsky, Erwin, Idea, Cátedra, Madrid, 1981

Pardo, José Luis, Las formas de la exterioridad, Valencia, Pre-textos. 1992.

Parkinson-Bailey, John J., Manchester, an architectural history, Manchester, Manchester University Press, 2000 Patetta, Luciano, La monumentalitá nell'architettura moderna, Milano, Ed. CLUP, 1982.

Perret, Auguste, "Le musée moderne", Mouseion n9, Paris, 1929

Pergam, Elizabeth A., Manchester Art Treasures Exhibition of 1857, Entrepreneurs, Connoisseurs and the public, Surrey, Ashgate Publishing Limited, 2011

Pevsner, Nikolaus, Historia de las Tipologías Arquitectónicas, Barcelona, Ed. Gustavo Gili, 1979 
Piano, Renzo, Renzo Piano y el Building Workshop, obras y proyectos 1971-1989, Barcelona, Editorial Gustavo Gili, 1990

Petras, Renate, Die Bauten der Berliner Museumsinsel, Berlin, Verlag für Bauwesen, 1987, pp. 227

Piva, Antonio, La costruzione del museo contemporaneo, Milan, Jaca book, 1983

Piva, Antonio, La fabbrica di cultura. La questione dei musei in Italia dal 1945 a oggi, Milano, II formichiere, 1978

Piva Antonio y Prina, V., Franco Albini, 1905-1977, Milano, Electa, 1998

Posener, Julius, Schinkel, Arquitecturas 1781-1841, Madrid, Ed. Ministerio de Obras Públicas, 1989

Premoli, Fulvia, Museopoli, Per un museo della cultura poltécnica. Dossier 2, Milan, Politécnico di Milano, 1985 Ryan, Raymund, Building Tate Modern- Herzog \& De Meuron Transforming Giles Gilbert Scout, Londres, The Trustees of the Tate Gallery, 2000

Riegl, Alois, El culto moderno a los monumentos, Madrid, Visor, 1987

Rogers, Ernesto N., Editoriali di architettura, Turín, Giulio Einaudi Editore., 1968.

Rogers, Ernesto N., Experiencia de la arquitectura, Buenos Aires, Nueva Visión. 1965.

Rogers, Ernesto N., Gli elementi del fenomeno architettonico, Nápoles, Guida editori, 1990.

Rossi, Aldo, Para una arquitectura de tendencia. Escritos, 1956-1972, Barcelona, Gustavo Gili, 1977.

Rowe, Colin, Manierismo y arquitectura moderna y otros ensayos, Barcelona, Editorial Gustavo Gili, 1978.

Rubert de Ventós, Xavier, Teoría de la sensibilidad, Barcelona, Ediciones Península, 1968.

Ryckwert, Joseph, The Dancing Column. On Order in Architecture, London, The MIT Press, Cambridge, 1996. Ryckwert, Joseph, La casa de Adán en el Paraíso, Barcelona, Gustavo Gili. 1974.

Ryckwert, Joseph, "El culto al museo, del tesoro al templo", en Arquitectura y Vivienda (AV) 18, Mayo-Junio1998 Samonà, Giuseppe, Un contributo alla museografía, Milano, Casabella, 211, junio-julio 1956.

Searing, Helen, New American Art Museums, Nueva York, Whitney Museum of American Art/ University of California Press, 1982

Searing, Helen, Art Spaces, The Architecture of four Tates, London, Tate Publishing, 2004

Searing, Helen, "Ipotesi sullo sviluppo delle tipologia del museo", Lotus International 55, Nouvi Musei, Milano, Ed. Electa, 1988

Semino, Gian Paolo, Schinkel, Bologna, Ed. Zanichelli, 1997

Sheppard, Francis Henry Wollaston, Survey of London: volumes 29 and 30, London, Francis Henry Wollaston Sheppard Editor, 1960

Snodin, Michael, Karl Friedrich Schinkel: A universal Man, New Haven and London, Yale University Press, 1991

Solá-Morales, Ignasi de, Eclecticismo y vanguardia, Barcelona, Editorial Gustavo Gili, 1980.

Solá-Morales, Ignasi, Exposició Conmemorativa del Centenari de L'Escola d'Arquitectura de Barcelona 187576/1975, Barcelona, ETSAB,1976

Solà-Morales, Ignasi, Diferencias. Topografía de la arquitectura contemporánea, Barcelona, Ed. Gustavo Gili, 2003

Steiner, George, Gramáticas de la creación, Madrid, Siruela. 2001.

Stephens, Suzanne, Building the New Museum, Nueva York, The architectural League of New York, Princeton Architectural Press, 1986

Streidt, Gert, Potsdam, Köln, Editorial Könemann, 1996

Stüler, August, Das Neues Museum in Berlin, Berlin, Ed. Riedel, 1862

Summerson, John, El lenguaje clásico de la arquitectura, Barcelona, Editorial Gustavo Gili, 1963. 
Summerson, John, Architecture in Britain 1530-1830, London, Penguin Books,

Tafuri, Manfredo, Teorie e storia dell 'architettura, Roma-Bari, Laterza. 1968.

Szambien, Werner, Simetría, gusto, carácter, Madrid, Ed. Akal, 1993

Tafuri, Manfredo \& Dal Co, Francesco, Arquitectura Contemporánea, Madrid, Aguilar, 1978.

Tafuri, Manfredo, Progetto e utopia, Laterza, Roma-Bari, 1979.

Torres, Jorge, "Realismo y Arquitectura", Annals n. 5, Barcelona. E.T.S.A.B. 1991.

Torres Cueco, Jorge, Le Corbusier, Visiones de la técnica en cinco tiempos, Barcelona, Colecció Arquithemas No 13, Ed. Fundacion Caja de Arquitectos, 2004

Trillo de Leyva, Juan Luis, Argumentos sobre la contigüidad en la Arquitectura, Sevilla, Universidad de Sevilla

I.U.C.C. 2001

Ustárroz, Alberto, La lección de las ruinas, Barcelona, Fundación Caja de Arquitectos, 1997.

Valéry, Paul, Piezas sobre arte, Madrid, Ed. Visor, 1999

Valéry, Paul, Eupalinos o el arquitecto, Murcia, C.O.A.A.T., Galería Yerba, 1993

Valéry, Paul, Tel quel 1. Barceona, Ed.Labor, 1977

Valéry, Paul, Teoría poética y estética, Madrid, La balsa de la Medusa, Visor,1998.

Venturi, Robert, "From invention to convention in architecture", Londres, Royal Society of Arts, RSJ Journal, Enero 1988

Venturi, Robert; Vaughan, David; Jencks, Charles, "National Gallery-Sainsbury Wing. An interview", Architectural Design, n० 91, 1991

Viollet le Duc, Eugène, ¿Qué es el arte?, Valencia, Ed. Fernando Torres, 1976

Viollet le Duc, Eugène, Dictionaire Raisonné de l'architecture française du XI au XVI siècle, París, V.A. Morel, 1875.

Viollet le Duc, Eugène, París, Entretiens sur l'architecture, Ed. A. Morel. 1863.

Virilio, Paul, Un paisaje de acontecimientos, Barcelona, Paidós, 1997.

Waterfield, Giles, Palaces of Art, Art Galleries in Britain 1790-1990, London, Ed. Dulwich Picture Gallery, 1991

Weiss, Barbara, "American museums: three examples-From the cloisters to Michael Graves", Lotus n 35. Ed. Electa, Milano, 1982

Worringer, Wilhem, Abstracción y naturaleza, México, Fondo de Cultura Económica, 1997

\subsection{BIBLIOGRAFÍA RELATIVA A LA CIUDAD DE VALENCIA}

Aldana, Salvador, La Lonja de Valencia, Valencia, Ed. Biblioteca Valenciana,1988

Almela y Vives, Francisco, El Marqués de Campo, Capdavanter de la burguesia valenciana (1814-1889), Valencia, Ajuntament de València, 1989

Almela y Vives, Francisco, Las Atarazanas del Grao, Valencia, Revista Feriario Valencia, 1953

Boira, Josep Vicent, Serra, Amadeu, El Grau de València. La construcció d'un espai urbà, Valencia, Institució Valenciana d'Estudis i Investigació, Generalitat Valenciana, 1994

Boira Maiques, Josep Vicent, Coordinador, El Palau Reial de València : els plànos de Manuel Cavallero (1802), Valencia, Ayuntamiento de Valencia, 2006

Boix, Vicente, Valencia histórica y topográfica. Relación de sus calles, plazas y puertas, origen de sus nombres, hechos célebres ocurridos en ellas, y demás noticias importantes relativas á esta capital, Tomo I, Valencia, Imprenta de J. Rius, Editor, 1862 
Boix, Vicente, Manual del viagero y Guia de los forasteros en Valencia, Valencia, Imprenta de J. Rius, Editor, 1849

Cavanilles, Antoni Joseph, Observaciones sobre Historia Natural, Geografía, Agricultura, Población y Frutos del Reyno de Valencia, Madrid, Imprenta Real, 1795

Cruilles, Marqués de, Guía Urbana de Valencia, Valencia, Imprenta de José Rius, 1876

Espinos Dias, Adela, Museo de Bellas Artes de Valencia, Catálogo de Dibujos I (Siglos XVI-XVII), Madrid, Ministerio de Cultura, 1979

Espinos Dias, Adela, Museo de Bellas Artes de Valencia. Catálogo de Dibujos II (Siglo XVIII), Madrid, Ministerio de Cultura, 1984

Francia, Carlos, "Grabado de la Naumacchia", en: Serrano Pérez, Tomás, Fiestas seculares, con que la coronada ciudad de Valencia celebró el feliz cumplimiento del tercer siglo de la canonizacion de su esclarecido hijo, y angel protector S. Vicente Ferrer, Apostol de Europa / escribialas el R.P. Thomas Serrano, de la Compañia de Jesus, Valencia, Imprenta de José de Orga, 1762

Garín Llombart, Felipe V., Breve visita al Museo de Bellas Artes de Valencia, Valencia, 1977

Garín Ortiz de Taranco, Felipe Mª, Catálogo-Guía del Museo Provincial de Bellas Artes de San Carlos, Valencia, Institución Alfonso el Magnánimo, 1955

Giménez, Emilio Y Llorens, Tomàs, "La imagen de la ciudad, Valencia", Hogar y Arquitectura n 86. Enero-Febrero 1970.

Giménez, Emilio Y Llorens, Tomàs, "Notas sobre la arquitectura valenciana durante la segunda república”, Hogar y Arquitectura no 99. Marzo-Abril 1972.

Llopis Alonso, Amando y Perdigón Fernández, Luis, Cartografía de la Ciudad de Valencia, 1608-1944, Valencia, Universidad Politécnica de Valencia, 2010

Llorens, Tomàs, "El moviment modern i el racionalisme a l'arquitectura i l'urbanisme valencians", Separata d'Arguments 1, Valencia, 1974.

Portaceli, Manuel, Arquitecturas 1971-2001, Cuadernos TC nº 50, Valencia, Ediciones Generales de la Construcción, 2001

Roca Traver, Francisco, El Colegio de San Pío V de Valencia, Valencia, Inédito, Copia del original en la Biblioteca del Colegio Territorial de Arquitectos de Valencia, 1969

Saralegui, Leandro de, "El Museo Provincial de Bellas Artes de San Carlos, Tablas de las Salas $1^{a}$ y $2^{a}$ de Primitivos Valencianos", Cuadernos de Arte, n॰8, Valencia, Institución Alfonso el Magnánimo, 1954

Solà-Morales, Ignasi, "Una restitución, un riesgo", Palacio del Marqués de Campo, Museo de la Ciudad, Valencia, Ajuntament de València, 1989

Tomás Sanmartín, Antonio, Silvestre Visa, Manuel, Estampas y planchas de la Real Academia en el Museo de Bellas Artes de Valencia, Madrid, Ministerio de Cultura, 1982

Tormo, Elías, Levante (Guía regional), Madrid, Espasa Calpe, 1923.

Tormo, Elias, Valencia: Ios Museos, Madrid, 1932

Tramoyeres Blasco, Luis, Guía del Museo de Bellas Artes de Valencia, Valencia, 1915 